\title{
WILDERNESS MINERAL POTENTIAL Assessment of Mineral-Resource Potential in U.S. Forest Service Lands Studied $1964-1984$
}

Edited by S. P. MARSH, S. J. KROPSCHOT, and R. G. DICKINSON

GEOLOGICA L S U R VEY PROFES I O N A L P A P E R 1300

Volume 2

Prepared in cooperation with the

U.S. Bureau of Mines

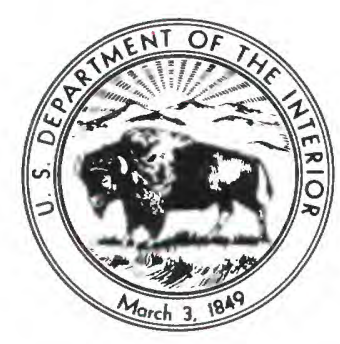




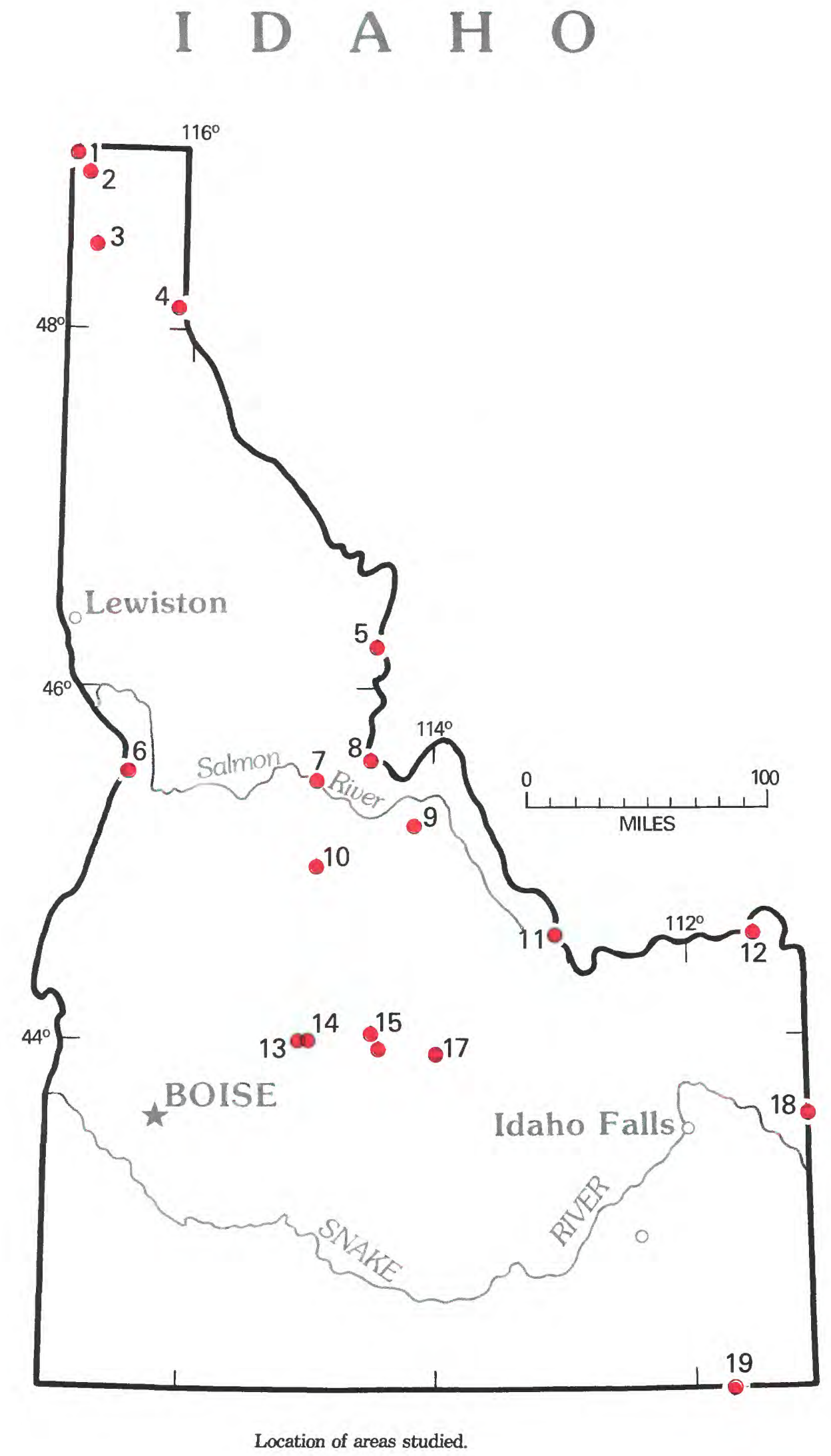




\section{IDAHO}

8 Blue Joint Wilderness study area, Montana, and Blue Joint Roadless Area, Idaho-See Montana

17 Boulder-Pioneer Wilderness study area

12 Centennial Mountains Wilderness study area, Montana and Idaho-See Montana

6 Hells Canyon Study Area, Oregon and Idaho-See Oregon

10 Idaho Wilderness

11 Italian Peak and Italian Peak Middle Roadless Areas, Idaho and Montana

19 Mount Naomi Roadless Area, Utah and Idaho-See Utah

1 Salmo Priest Wilderness study area, Washington and Idaho-See Washington

7 Salmon River Breaks Primitive Area and vicinity

16 Sawtooth National Recreation Area, eastern part

14 Sawtooth Wilderness

4 Scotchman Peak Wilderness study area, Montana and Idaho-See Montana

3 Selkirk Roadless Area

5 Selway-Bitterroot Wilderness, Idaho and Montana

9 Special Mining Management Zone-Clear Creek

13 Ten Mile West Roadless Area

2 Upper Priest Roadless Area

18 West and East Palisades Roadless Areas, Idaho and Wyoming

15 White Cloud-Boulder Roadless Area 

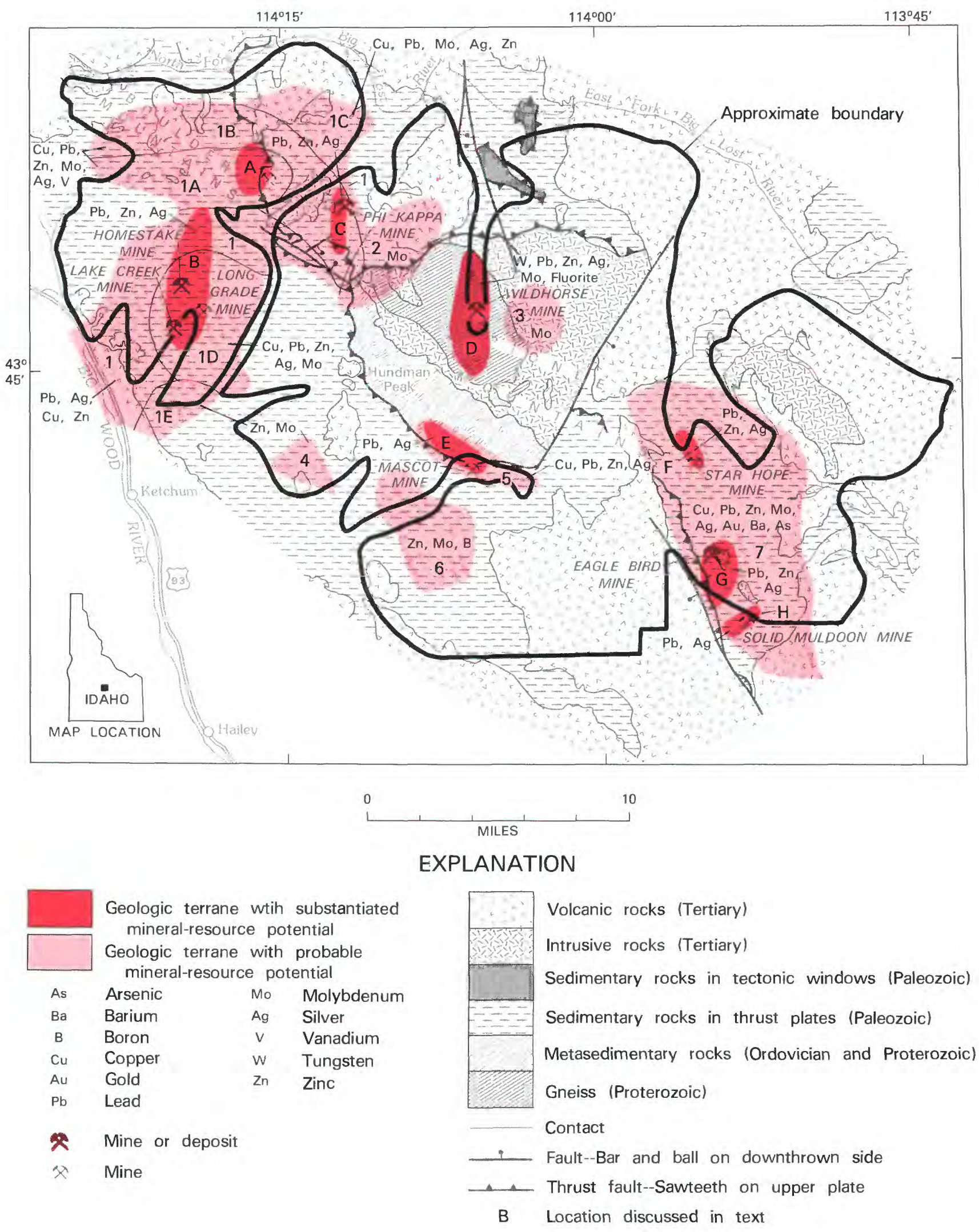

Figure 161.-Boulder-Pioneer Wilderness study area, Idaho. 


\title{
BOULDER-PIONEER WILDERNESS STUDY AREA, IDAHO
}

\author{
By Frank S. Simons, ${ }^{1}$ U.S. GeOlogical SurVey, and \\ ERNEST T. TUCHEK, U.S. BUREAU OF MINES
}

\begin{abstract}
SUMMARY
A mineral-resource survey of the Boulder-Pioneer Wilderness study area in the Pioneer and Boulder Mountains of south-central Idaho, was made in 1974-75. The area has demonstrated resources of about 1.7 million tons of leadzinc-silver ore, mostly in the Phi Kappa mine, and an additional 2.5 million tons of demonstrated resources in areas of substantiated potential for these metals and for tungsten, molybdenum, and fluorite. The survey indicates substantiated resource potential in eight areas and probable mineral-resource potential in seven. Mineral commodities of greatest interest include tungsten, copper, lead, zinc, silver, gold, molybdenum, vanadium, and barite. There is little likelihood for the occurrence of oil, gas, coal, or geothermal resources.
\end{abstract}

\section{CHARACTER AND SETTING}

The Boulder-Pioneer Wilderness study area is just northeast of the town of Ketchum in central Idaho. It is a northwest-trending, roughly oval shaped mountainous area $35 \mathrm{mi}$ long and $20 \mathrm{mi}$ wide, and covers about $450 \mathrm{sq}$ mi exclusive of corridors along access roads. The northeastern half of the area is drained by the Big Lost River, the southwestern half by the Big Wood River. The nearest highways are U.S. 93 on the west side of the study area along the Big Wood River and U.S. 93 Alternate northeast of the study area. The study area is crossed by a road and branches of this road go up East Fork Big Lost River into Copper Basin, Star Hope Creek, and Muldoon Canyon; up North Fork Big Lost River; and up Wildhorse Creek. Other access roads lead from U.S. Highway 93 up East Fork Wood River and Hyndman Creek, from Hailey to the Porcupine Creek area, and from Bellevue into Muldoon and Copper Creeks.

Access to most of the area is by trails, only a few of which are maintained and regularly used. Except for Trail Creek summit, the crest of the Pioneer Mountains is extremely rugged, and no trail crosses it anywhere in the 15 air mile distance between Trail Creek summit and the head of Little Wood River.

The topography of the study area is rugged and characterized by steep slopes and very narrow ridge crests. Altitudes range from about $6000 \mathrm{ft}$ along the southwest

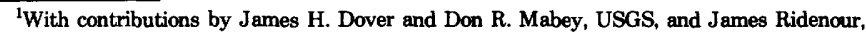
USBM. border of the area and 7000 to $8000 \mathrm{ft}$ along the northeast border, to $12,009 \mathrm{ft}$ on Hyndman Peak, the third highest point in the state. Local relief is commonly 3000 $\mathrm{ft}$ and in places is as much as $4000 \mathrm{ft}$. Canyons on the northeast side of the mountain crest have been glaciated for their entire length, and those on the southwest side were glaciated to at least as low as $7000 \mathrm{ft}$.

The most scenic part of the study area is along the crest of the Pioneer Mountains, particularly the part extending from Devil's Bedstead $(11,151 \mathrm{ft})$ to Standhope Peak (11,878 ft) and Pyramid Peak (11,628 ft), a distance along the crest of about $5 \mathrm{mi}$. This region is one of knife-edge ridges (aretes), jagged horn peaks, and numerous small cirque lakes, and bears the imprint of vigorous alpine glaciation.

The bedrock of the study area consist of granitic gneiss and associated rocks of Precambrian age; metasedimentary rocks, mainly quartzite, schist, and marble, of Proterozoic(?) and Ordovician age; Paleozoic sedimentary rocks of varied lithologies and ranging in age from Ordovician to Permian; intrusive quartz monzonite and associated silicic dikes, and intermediate to silicic volcanic rocks, all of Tertiary age. Bedrock is locally concealed beneath glacial and lake deposits, alluvium, and talus, all of Quaternary age. Paleozoic rocks make up two units on the geologic map, rocks in tectonic windows beneath thrust faults, and rocks in the overlying thrust plates.

The Paleozoic rocks are complexly folded and are cut by east- to northeastward-directed thrust faults of great displacement and by normal faults, some of which are 
large. The Pioneer Mountains are broadly anticlinal and consist of a northwest-trending core of gneiss, metasedimentary rocks, and plutonic rocks tectonically overlain by a succession of thrust sheets of sedimentary rocks, some of which are slightly metamorphosed. The youngest sedimentary rock unit involved in major thrust faulting is the Wood River Formation of Pennsylvanian to Permian age. Thrust faulting was essentially completed before emplacement of most of the intrusive rocks and deposition of the volcanic rocks; the volcanics are broken by normal faults but are not otherwise much disturbed.

A geochemical study was based on analyses of stream-sediment, rock, and soil samples, and samples from mines and prospects. Mines, prospects, and mining records were examined. Aeromagnetic and gravity surveys were done to aid in interpretation of geologic structure and evaluation of mineral-resource potential.

The study area includes parts of 5 mining districts-Alta, Copper Basin, Little Wood River, Lava Creek, and Warm Springs-and adjoins 2 others, Mineral Hill and Alder Creek (or Mackay). Production from these seven districts totals about $\$ 65$ million, of which about $\$ 870,000$ was produced from mines within the study area. Mines within or close to the study area that have produced $\$ 50,000$ or more are shown on the map. About 80 percent of the production in the study area has come from lead-zinc-silver deposits of the Homestake and Lake Creek mines $(\$ 340,000)$, the Phi Kappa mine $(\$ 174,000)$, the Eagle Bird mine $(\$ 130,000)$ and the Star Hope mine $(\$ 50,000)$. Mines outside of but close to the study area that have had appreciable production are the Wildhorse $(\$ 459,000$ in tungsten ore), Mascot (\$200,000 in lead-silver ore), and Solid Muldoon $(\$ 200,000$ in lead-silver ore). Mining has been intermittent from about 1885 to 1975 . More than 2600 lode claims and 11 placer claims have been located within the study area, and hundreds more near the boundary.

\section{MINERAL RESOURCES}

The study area has geologic terranes with probable and substantiated mineral-resource potential. Eight areas of substantiated resource potential are shown on the map: Little Fall Creek (area A), Phi Kappa Creek (area C) and Wildhorse Creek (area D) in the Alta district; Lake Creek (area B) and East Fork Wood River (area E) in the Warm Springs district; Star Hope Creek (area F) in the Copper Basin district; and Garfield Creek (area G) and Muldoon Creek (area H) in the Little Wood River district. Mines in these terranes that contain 25,000 tons or more of demonstrated or inferred resources of known or estimated grade are shown.

556
Demonstrated resources at specific mines in the areas of substantiated resource potential total about 1.7 million tons of lead-zinc-silver ore, most of which is in the Phi Kappa mine (Alta district). Resources of a few thousand tons are in the Homestake and Lake Creek mines in the Warm Springs district and in the Eagle Bird mine in the Little Wood River district.

Additional demonstrated and inferred resources total about 2.5 million tons in areas of substantiated mineralresource potential. The largest, about 1.4 million tons of tungsten-bearing rock averaging 0.32 percent tungsten trioxide, is in the Pine Mouse group of prospects on Wildhorse Creek in the Alta district. Other resources are mainly in areas of substantiated lead, zinc, and silver resource potential and consist of about 106,000 tons in the Alta district, 880,000 tons in the Warm Springs district $(730,000$ tons in the Homestake mine alone), and 107,500 tons in the Little Wood River district. The Alta district also has a resource of about 50,000 tons of molybdenum-bearing rock averaging 0.22 percent molybdenum sulfide and 1000 tons of fluoriterich rock containing from 49 to 95 percent calcium fluoride (fluorite). Past production from the Star Hope mine in the Copper Basin district suggests that the district has substantiated mineral-resource potential but data are not adequate to estimate demonstrated resources.

Analytical data from stream-sediment and rock samples indicate seven areas that have probable mineral-resource potential. These areas are interpreted to have only probable potential because the size of known deposits in the study area is small, the area lacks extensive zones of alteration, and most of the geochemical anomalies are weak and widely scattered.

The first area of probable resource potential is about $10 \mathrm{mi}$ long and 4-6 mi wide in the southeast part of the study area in which many samples contain anomalous amounts of copper, lead, zinc, and silver (area 7). In the southern part of this area, many samples have anomalous amounts of barium, and a small tonnage of barite has been produced from the nearby Solid Muldoon mine. The northwestern part of the area contains slightly anomalous amounts of molybdenum. The most favorable part of this anomalous area is along the ridge common to Argosy, Muldoon, and Left Fork Iron Bog Creeks and Muldoon Canyon, where several rock samples contain anomalous amounts of arsenic and, locally, anomalous amounts of gold. The southeastern part of area 7 includes two occurrences of Tertiary intrusive rock, which aeromagnetic data indicate to be parts of a much larger northwesterly-trending body.

The second area of probable potential is an easttrending area about $10 \mathrm{mi}$ long and 3-4 mi wide that contains anomalous amounts of copper, lead, molybdenum, silver, and zinc (areas 1A, 1B, 1C). The central 
parts of areas $1 \mathrm{~A}$ and $1 \mathrm{~B}$ are also anomalous in vanadium. The largest mine in the study area, the Phi Kappa, is on the eastern edge of this anomalous area. Other parts of this area have not been prospected.

The third area of probable potential is a large area on the west side of the study area where numerous samples contain anomalous amounts of lead, silver, copper, and zinc (area 1) and a few in the south part of the area contain anomalous amounts of molybdenum (areas 1D, 1E). Most of the area has been thoroughly prospected, but a molybdenum-zinc anomaly (area $1 \mathrm{E}$ ) near the southwest end of the ridge between Lake and Trail Creeks has not been prospected and would appear to merit study.

The fourth area of probable potential (area 6) is in the southwest part of the study area in Paleozoic sedimentary rocks. It is an area of probable resource potential for zinc, molybdenum, and boron based on samples anomalous in these metals.

Four other areas of probable resource potential are shown on the map; areas 2 and 3 are anomalous in molybdenum, area 4 in zinc and molybdenum, and area 5 in copper, lead, zinc, and silver.

\section{SUGGESTIONS FOR FURTHER STUDY}

Much of the Boulder-Pioneer Wilderness study area has been thoroughly prospected, in particular the areas designated as geologic terrane with substantiated mineral-resource potential. Among less prospected areas, areas $1 \mathrm{~A}, 1 \mathrm{~B}$, and $1 \mathrm{C}$ merit more detailed geologic and geochemical study because of their polymetallic geochemical anomalies and the high-metal content of many samples. Area 7 is of interest for more detailed study because of polymetallic anomalies (including gold and arsenic) and its proximity to a possibly large Tertiary intrusive; access to much of this area is difficult. Finally, numerous stream-sediment samples from area 6 have high to very high contents of zinc and molybdenum; little if any prospecting has been done in the area and a more thorough geochemical study seems warranted.

\section{REFERENCE}

U.S. Geological Survey and U.S. Bureau of Mines, 1981, Mineral resources of the Boulder-Pioneer Wilderness study area, Blaine and Custer Counties, Idaho: U.S. Geological Survey Bulletin 1497,303 p. 

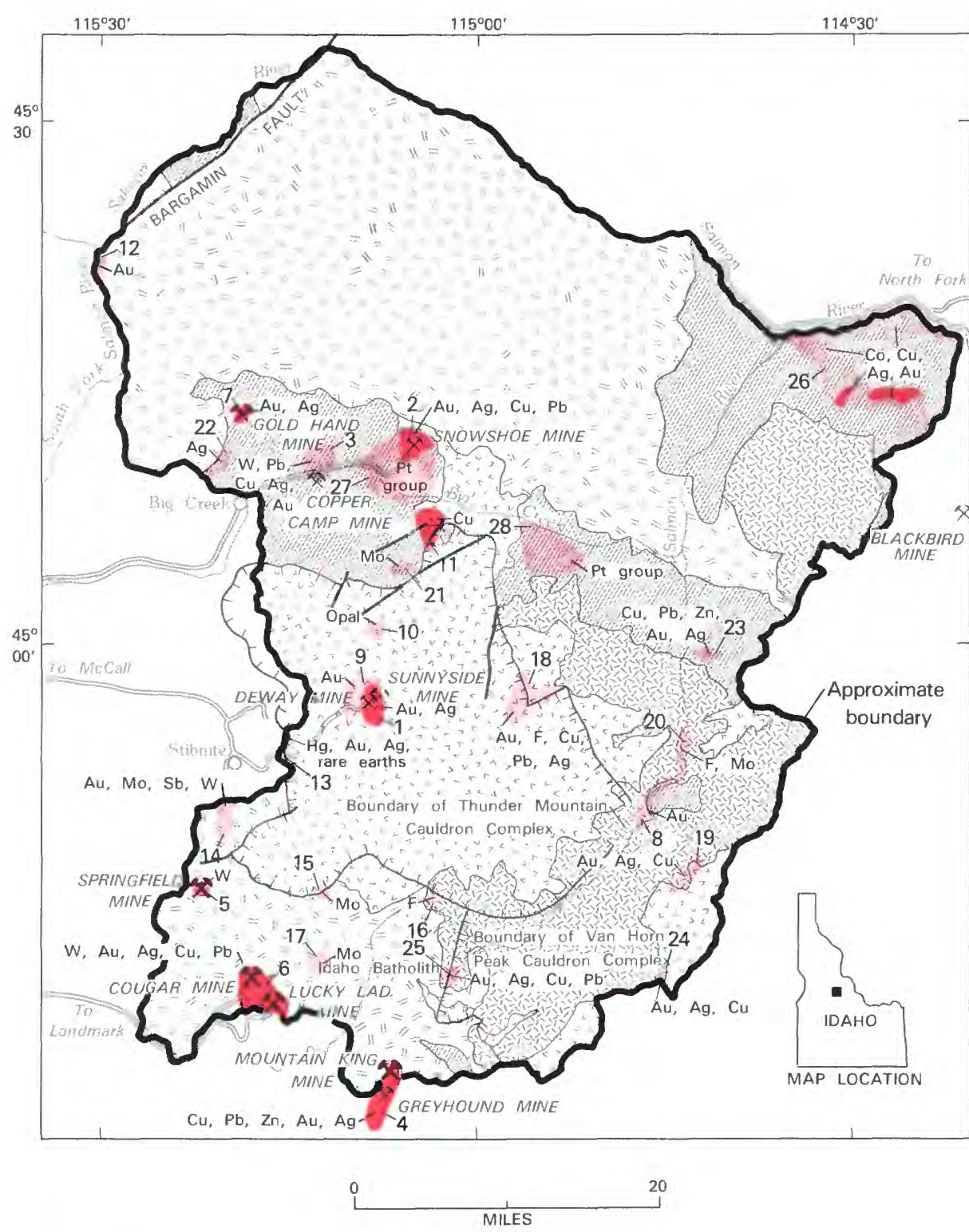

\section{EXPLANATION}

Geologic terrane with substantiated mineral-resource potential

Geologic terrane with probable mineral-resource potential

$\begin{array}{llrl}\text { Sb } & \text { Antimony } & \mathrm{Hg} & \text { Mercury } \\ \mathrm{Co} & \text { Cobalt } & \mathrm{Mo} & \text { Molybdenum } \\ \mathrm{Cu} & \text { Copper } & \mathrm{Pt} & \text { Platinum } \\ \mathrm{F} & \text { Fluorine } & \mathrm{Ag} & \text { Silver } \\ \mathrm{Au} & \text { Gold } & \mathrm{W} & \text { Tungsten } \\ \mathrm{Pb} & \text { Lead } & \mathrm{Zn} & \text { Zinc } \\ \mathrm{X} & \text { Mine or deposit } & \\ \text { X } & \text { Mine } & \\ 2 & \text { Area discussed in text }\end{array}$

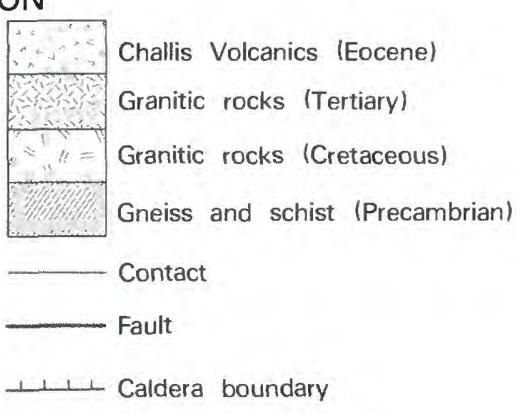

Figure 162.-Idaho Wilderness, Idaho. 


\title{
IDAHO WILDERNESS, IDAHO
}

\author{
By Fred W. CATER, U.S. GeOlOGical Survey, and \\ R. D. WELDin, U.S. BUREAU OF MiNES
}

\begin{abstract}
SUMMARY
Mineral surveys conducted between 1966 and 1972 in the Idaho Wilderness identified 28 areas with probable or substantiated mineral-resource potential, and 5 mines with demonstrated or inferred resources. Metals valued at about $\$ 1,671,500$, including gold, silver, copper, lead, zinc, and tungsten, have been extracted from deposits inside the wilderness. Current studies indicate additional areas of probable mineral-resource potential for gold, tungsten, mercury, rareearth elements, and base metals related to intrusive rocks that follow structures formed by cauldron subsidence. These on-going studies also indicate that there is probable and substantiated resource potential for cobalt with copper, silver, and gold in the Precambrian rocks in the northeastern part of the wilderness in a geologic environment similar to that of the Blackbird mine that lies outside the area. The nature of the geologic terrane precludes the potential for organic fuels.
\end{abstract}

\section{CHARACTER AND SETTING}

The Idaho Wilderness occupies about $2200 \mathrm{sq} \mathrm{mi}$ in the rugged mountainous area of central Idaho. The wilderness is cut by spectacular canyons, including those of the Middle Fork and main Salmon Rivers, that in places are more than $6000 \mathrm{ft}$ deep. The wilderness is remote from paved roads; the east side is about $60 \mathrm{mi}$ by rough USFS road from U.S. Highway 93 between Salmon and Challis; the west side is $40-70 \mathrm{mi}$ by USFS road from McCall and Cascade, which are on Idaho State Highway 55. A graded road down the north side of the Salmon River from North Fork parallels the north border to a point a few miles below the mouth of the Middle Fork Salmon River, but it is not feasible to cross the Salmon River except by boat or by the footbridge at the mouth of the Middle Fork.

Most of the Idaho Wilderness was an established Primitive Area when the Wilderness Act was passed in 1964. As provided by that Act, a mineral survey was made in 1966, 1967, and 1968; the Clear Creek-Upper Big Deer Creek addition was examined in 1972. The mineral survey included geologic mapping and sampling and analysis of altered rocks and stream sediments. An aeromagnetic survey was also made. All known mines and prospects were mapped and sampled in detail.

The wilderness is underlain by Precambrian gneiss and schist, Cretaceous granitic rocks of the Idaho batholith, Eocene granitic rocks, and Tertiary volcanic rocks (Challis Volcanics). The volcanic rocks occupy most of the central part of the wilderness. The rocks are cut by numerous faults, most of which trend either northeast or northwest. Most conspicuous is the large northeast-trending strike-slip Bargamin Creek fault that cuts the northwestern part of the wilderness.

\section{MINERAL RESOURCES}

The Idaho Wilderness contains about 5400 mining claims and would seem to be a likely region for mineral deposits. The wilderness is in a region that has yielded millions of dollars of metals and has a large potential for future yield. The wilderness itself has yielded about $\$ 1,671,500$ worth of metals. Favorable geologic structures and rock types occur throughout the wilderness. An evaluation of the ore deposits related to volcanic systems then, hinges in large measure in determining the former presence of ore-bearing solutions. The former presence or passage of ore-bearing solutions in a rock mass is indicated by such features as altered rock, leached rocks that may have formerly contained ore minerals, and geochemical halos.

Most productive of the mining areas is the Thunder Mountain area ( 1 on map) in the Thunder Mountain 
cauldron, which was one of the main sources of the Challis Volcanics and has a substantiated preciousmetal resource potential. Most of the gold came from two mines, the Dewey and the Sunnyside. The Dewey mine is in a black volcanic breccia that averaged $0.11 \mathrm{oz}$ gold/ton and $0.25 \mathrm{oz}$ silver/ton. The black breccia probably was the source of the gold-rich charred logs and wood fragments found during the boom days of the district. The Sunnyside deposit is in argillized and silicified rhyolite. No gold is visible in recently sampled ore from the district, but in a sample donated to the U.S. National Museum in 1902, probably from the Dewey mine, particles of gold are readily visible. No veins occur in the Thunder Mountain district, and no significant gold strikes were reported as a result of company prospecting in 1968 in areas underlain by altered rocks. The Monumental Creek area (9) is adjacent to area 1, yielded a few ounces of gold many years ago, and is an area of probable gold resource potential.

The Snowshoe area (2) of substantiated mineralresource potential has yielded $\$ 270,063$ worth of gold, silver, copper, and lead ore, mostly from veins at the Snowshoe mine. Veins in the Copper Camp area (3) are composed mostly of quartz and magnetite containing small quantities of copper minerals. Although the veins are low grade and discontinuous, the area has a probable resource potential for copper, lead, zinc, silver, and gold.

The Greyhound Ridge area (4) has a recorded production of nearly $\$ 325,000$ of precious- and base-metal ore, mostly from the Mountain King mine, but deposits just south of the mine outside the wilderness have yielded about $\$ 1,000,000$ worth of ore. Demonstrated resources of about 100,000 tons of rock containing small quantities of valuable minerals are estimated to be present in this area of substantiated mineral-resource potential.

The Springfield and Cougar areas (5 and 6, respectively) have substantiated mineral-resource potential and have yielded $\$ 465,226$ worth of metal; more than half of this total was tungsten ore taken in the early 1960's from the Springfield Scheelite mine. The ore deposit at the Springfield Scheelite mine consists of an irregular body at the contact of the Idaho batholith and country rock. Available demonstrated resources are estimated to contain several times as much tungsten as already produced, but the grade is much lower. Gold, silver, copper, and lead were produced from the Lucky Lad and Cougar mines (6) between 1935 and 1941. Inferred resources around the Lucky Lad and Cougar mines are estimated to total about 100,000 tons of low-grade rock.

The Golden Hand area (7) yielded a recorded production of gold and silver from lode deposits of about $\$ 44,000$ all from the Golden Hand mine. Placer gold recovered from the district is between $\$ 70,000$ and $\$ 100,000$. Remaining demonstrated resources include 560 lode deposits of about 200,000 tons of low-grade material and about $17,000,000 \mathrm{cu}$ yds of gravel containing $0.002 \mathrm{oz} \mathrm{gold} / \mathrm{cu} \mathrm{yd}$ in an area of substantiated mineral-resource potential.

The Middle Fork area (8) has yielded a small but unknown amount of gold from both lode and placer deposits. Lode deposits are scattered and consist mostly of thin, discontinuous quartz veins with a little gold and other metals. Only traces of gold occur in the gravel deposits along the Middle Fork Salmon River and the area has a probable gold resource potential.

The Wiles area produced about $\$ 1000$ worth of opal (10). The opal deposit continues to produce small amounts of material. Placer deposits have a very low average gold content. Demonstrated resources of 200,000 to 300,000 tons of material contaming 0.6 percent copper occur in the Copper Mountain area of substantiated copper resource potential (11). A small amount of placer gold was produced from the South Fork area of probable gold resource potential (12). All, however, contain known vein deposits that have been prospected for precious and base metals.

Since the publication of the results of the study conducted between 1966 and 1972, further geologic and geochemical studies conducted in parts of the Idaho Wilderness have identified additional areas of probable or substantiated mineral potential. Although these studies are as yet unpublished, preliminary results are briefly summarized here and incorporated into the map.

Of particular importance, two major cauldron complexes have been discovered; the older, the Van Horn Peak has margins largely invaded by intrusive rocks in the wilderness, the younger, the Thunder Mountain, is mostly within the wilderness. Areas of probable mineral-resource potential probably related to cauldron margin structures and late intrusive activity include: the Monumental Summit area (13), with rareearth elements, mercury, gold(?), silver(?); Big Chief Creek (14) with gold, molybdenum, antimony, tungsten(?); Virginia Beth (15) with molybdenum; Pungo Creek (16) with fluorine; RDG (17) with molybdenum; Shell Rock Peak (18) with gold, fluorine, copper, lead, silver; Wood Tick Summit (19) with gold, silver, copper; Aparejo Creek (20) with fluorine, molybdenum; Paint Creek Divide (21) with molybdenum; Werdenhoff (22) with silver; Yellow Jacket (23) with copper, lead, zinc, gold, silver; Falconberry Ranch (24) with gold, silver, copper; Thomas Creek (25) with gold, silver, copper, lead.

Resource potential has also been found in Precambrian rocks in the northern and northeastern parts of the wilderness. Particularly important are areas of probable and substantiated mineral-resource potential in Upper Big Deer Creek (26) where high-grade metamorphic rocks of the metasedimentary Yellowjacket Formation host cobalt-copper mineralization related to the 
deposition of this sedimentary unit. Gold and silver locally accompany the other metals. This geologic environment and the nature of the mineralization closely resemble those of the Blackbird cobalt mine, southeast of the Upper Big Deer Creek area. Gabbroic Precambrian rocks in the Acorn Butte (27) and Rush Creek (28) area have a probable resource potential for metals of the platinum group.

\section{SUGGESTIONS FOR FURTHER STUDIES}

Rocks and structures favorable for the occurrence of metallic mineral deposits occur throughout the Idaho Wilderness. Detailed geologic mapping based on the developing concepts of cauldron complexes in the region and on the stratigraphic control of cobalt deposits, and supporting geochemical and geophysical studies are needed to refine knowledge of the mineral potential of the region and identify new areas of resource potential. Such studies will be very difficult and costly because of the size of the wilderness, its geologic complexity, the heavy timber cover, and difficulties of access and terrain.

\section{REFERENCES}

Cater, F. W., Pinckney, D. M., Hamilton, W. B., and Parker, R. L., Weldin, R. D., Close, T. J., and Zilka, N. T., 1973, Mineral resources of the Idaho Primitive Area and Vicinity, Idaho, with a section on the Thunder Mountain district by B. F. Leonard, and a section on Aeromagnetic interpretation by W. E. Davis: U.S. Geological Survey Bulletin 1304, 431 p.

Cater, F. W., and Pinckney, D. M., Stotelmeyer, R. B., 1975, Mineral resources of the Clear Creek-Upper Big Deer Creek study area, contiguous to the Idaho Primitive Area, Lemhi County, Idaho: U.S. Geological Survey Bulletin 1391-C, 41 p. 

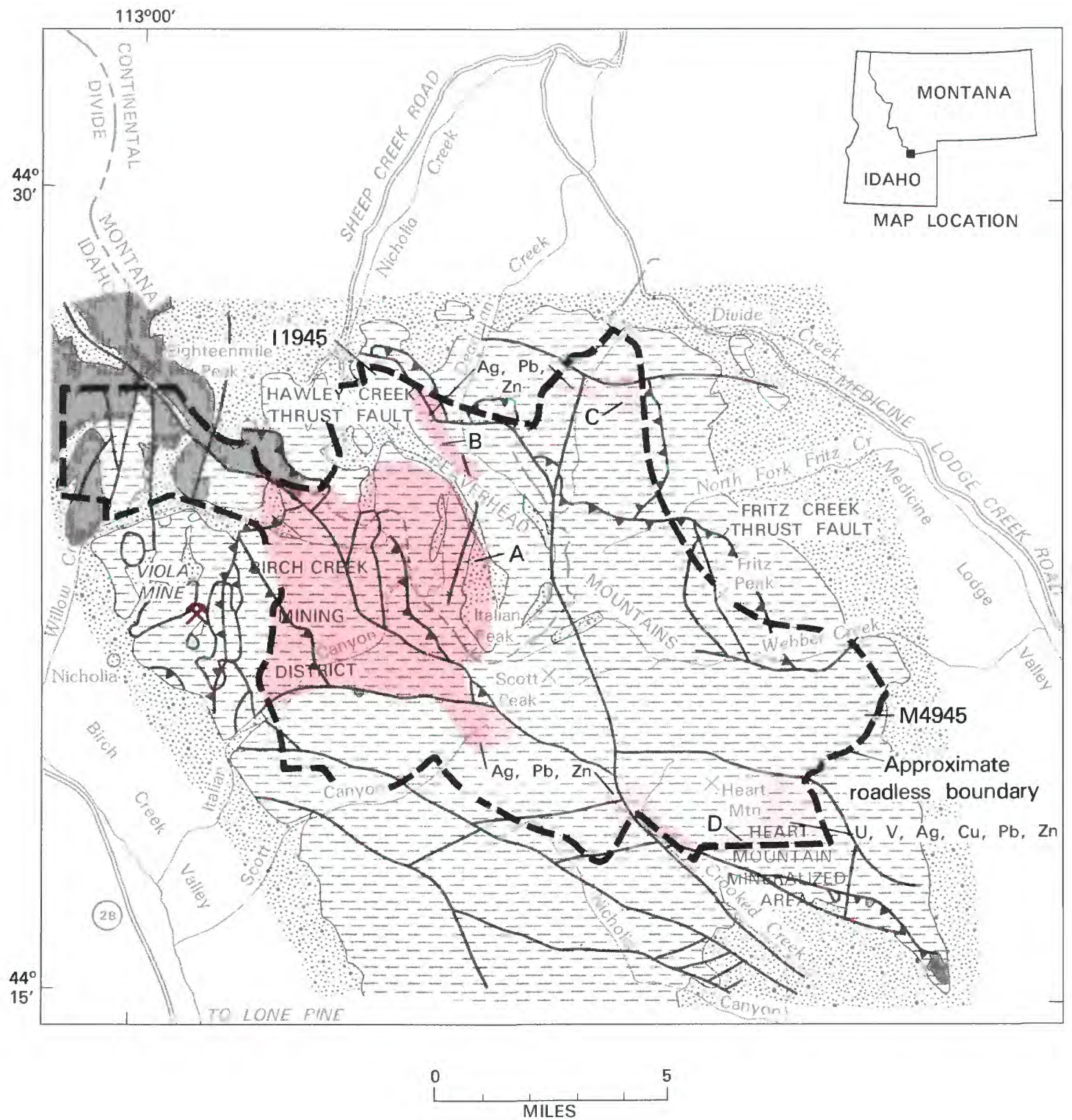

\section{EXPLANATION}

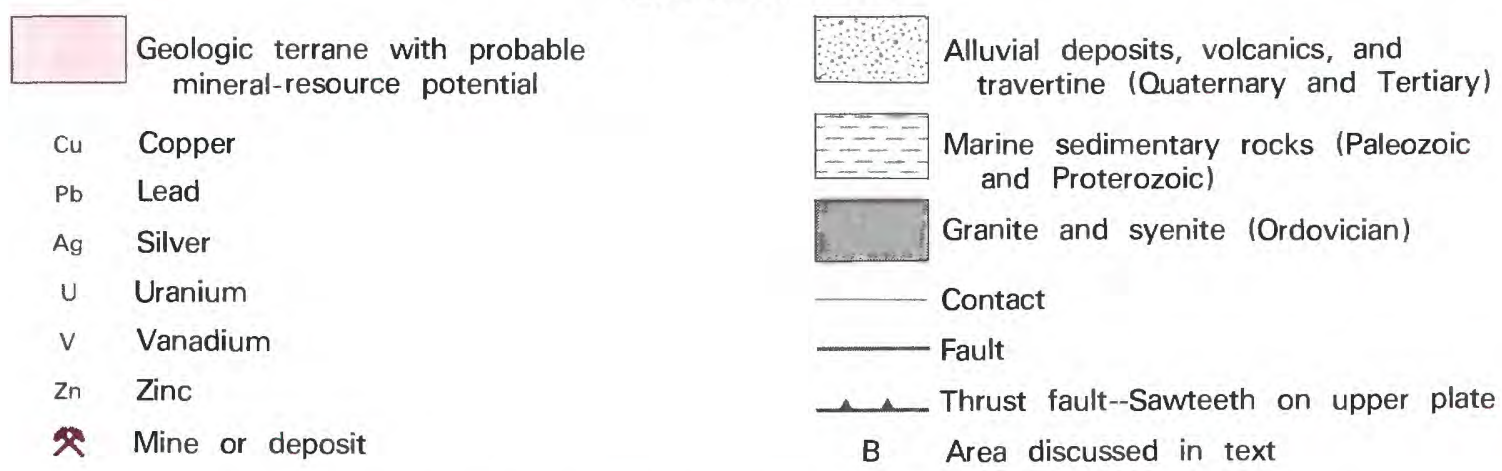

Figure 163.-Italian Peak and Italian Peak Middle Roadless Areas, Idaho and Montana. 


\title{
ITALIAN PEAK AND ITALIAN PEAK MIDDLE ROADLESS AREAS, IDAHO AND MONTANA
}

\author{
By BetTy Skipp, U.S. GeOlogiCal SuRVEY, and \\ ROBERT H. LAMBETH, U.S. BUREAU OF MINES
}

\begin{abstract}
SUMMARY
The Italian Peak and Italian Peak Middle Roadless Areas, in southwestern Montana and east-central Idaho, contain areas of probable mineral-resource potential based on combined geologic, geophysical, and geochemical studies and prospect examination conducted during 1980-82. Small areas along the western, southern, and northeastern boundaries of the roadless areas have probable mineral resource potential for zinc, lead, silver, and uranium. An area of probable resource potential just east of and including a part of the Birch Creek mining district, may contain stratabound and fault-controlled silver and base metals, even though geochemical anomalies are low, and extensive prospecting has not identified any significant mineralization. The roadless areas are a part of the overthrust belt, and oil and gas possibilities must be assessed, as rock units in the underlying thrust plates have characteristics favorable for gas accumulation. No hydrocarbons have yet been produced from these rocks in southwestern Montana, however, and there is little likelihood of the occurrence of hydrocarbons in these areas. There is little promise for the occurrence of other energy resources because of the nature of the geologic terrane.
\end{abstract}

\section{CHARACTER AND SETTING}

The Italian Peak and Italian Peak Middle Roadless Areas, referred to collectively as the study area, are contiguous and are located along the Continental Divide, which is also the Idaho-Montana State boundary. The study area consists of about $90 \mathrm{sq} \mathrm{mi}$ in the southern Beaverhead Mountains, 30 percent in Beaverhead County, southwesternmost Montana, and the remainder in Clark and Lemhi Counties, east-central Idaho, and is located about $17 \mathrm{mi}$ southwest of Lima, Montana, and $25 \mathrm{mi}$ northwest of Dubois, Idaho. Dubois is 50 mi north of Idaho Falls on Interstate 15. Scott Peak $(11,393 \mathrm{ft})$, the highest point in the study area, and Heart Mountain $(10,422 \mathrm{ft})$ can be seen from Idaho State Highway 22 looking north on a clear day. Eighteenmile Peak $(11,141 \mathrm{ft})$ in the northwestern corner of the study area is visible on the east side of Idaho State Highway 28 in Birch Creek Valley. Other peaks, including Italian Peak (10,998 ft), along the Continental Divide are not visible from major roads. Fritz Peak $(9,738 \mathrm{ft})$ can be seen on the west side of an improved dirt road in Medicine Lodge Valley. Maximum relief in the study area is about $4600 \mathrm{ft}$. Timberline is at about $9600 \mathrm{ft}$, and average annual rainfall ranges from 16 in. in the lower valleys to 32 in. near the Continental Divide.

The study area is an extension of the Idaho-Wyoming thrust belt north of the Snake River Plain, and consists of Precambrian (Proterozoic) and Paleozoic rocks that have been faulted and folded and moved from west to east (thrust) at least several miles. Thrusting is thought to have taken place about 70-65 million years ago. Two major thrust plates, the Hawley Creek and the Fritz Creek make up most of the study area (Skipp and others, 1983). Rocks of the Hawley Creek thrust plate, the upper plate, consist of relatively thick Proterozoic shallow-water marine sandstone, relatively thick Ordovician marine sandstone and quartzite, Ordovician granite and syenite, Devonian marine carbonate rocks, siltstone and shale, and relatively thin Mississippian marine limestone, siltstone and shale. Rocks of the Fritz Creek thrust plate, the lower plate, differ from those of the Hawley Creek plate in that Ordovician sandstone and quartzite are thin or missing; only small outcrops of Ordovician granite and syenite are present; and the 
Mississippian and younger Paleozoic carbonate rocks are very thick, about $5500 \mathrm{ft}$, and make up most of the outcrops of the Fritz Creek thrust plate in the study area.

Rocks of the study area, which overlie the thrust plates include young (about 47 million years and younger) volcanic rocks, fresh-water limestone or travertine, and thick sections of gravel, sand, and silt. Most of the old gravel and sand originated as alluvialfan deposits. The thrust plates and the post-thrust deposits have been broken by younger normal faults along which parts of the mountain range have been raised and slightly tilted eastward or northeastward, as along the west side bordering Birch Creek Valley, and in the central and southwestern parts of the study area. Movement along these faults appears to have been episodic. Along the western margin of the Beaverhead Mountains, west of the study area, irregular masses of Mississippian limestone from the Fritz Creek plate slid westward from old eastern topographic highs to rest on parts of the Hawley Creek thrust sheet.

All of the rocks and deposits described above have been eroded by small Pleistocene alpine glaciers, meltwaters, and steep gradient, fast-moving streams that sculptured the deep valleys and canyons, now either dry or occupied by small perennial or intermittent streams.

\section{MINERAL RESOURCES}

The Nicholia or Birch Creek mining district adjacent to the study area on the west was a significant leadsilver producing district for about 10 years (1881-90); $\$ 2.5$ to $\$ 5$ million in lead, silver, and zinc was recovered from the Viola mine and a few adjacent properties. Production was primarily from long, relatively thin, sandy lead carbonate ore bodies located in the Hawley Creek thrust plate in dolomite or magnesian limestone of the Devonian Jefferson Formation. Recent investigations by the USBM (Lambeth and Mayerle, 1983) suggest that the ore probably was stratabound and of basinmargin carbonate-hosted origins, rather than of hydrothermal origins as suggested by earlier workers who envisioned magmatic hydrothermal mineralizing fluids migrating up the normal faults that bound the range on the west, from an igneous source below. The igneous rock early workers thought might have been the source of metals is the Beaverhead Mountains pluton that 20 years ago was dated radiometrically as early Paleozoic, more than 100 million years older than the mineral deposits. Geochemical studies of the study area (Antweiler and others, 1983), show that outcrops of Devonian Jefferson Formation are mineralized in base metals throughout the study area, to one degree or another, and thus support the concept that mineralization within this formation may be stratabound. Although most observed geochemical anomalies are weak, a probable resource potential for stratabound deposits of lead, silver, and zinc in areas of the Devonian Jefferson Formation in the central part of the study area (A, on map) is assigned here.

Some prospecting in the study area along the western margin has been done along young normal faults. These structures, weakly mineralized in silver, copper, and base metals, have had no production, however, and no evidence was found indicating that resources might occur.

A small area (D) regarded as having probable mineral resource potential for uranium-vanadium, and silver and base metals is a northern extension of the Heart Mountain mineralized area which lies mainly south of the study area. This mineralized area has been prospected and drilled since the early 1950's, but no production has resulted. The low-grade occurrences, including silver and base metals in addition to uranium and vanadium, are in brecciated and (or) sheared zones in black shales and siltstones of the Devonian Sappington Member of the Three Forks Formation and the Mississippian McGowan Creek Formation.

Another area (B and $\mathrm{C}$ ) classed as having probable mineral-resource potential is an untested segment of the northeast part of the study area near the headwaters of Divide Creek where secondary dolomite is present locally in limestone of the Mississippian Scott Peak Formation, and a single analyzed sample of weakly mineralized ferrodolomite indicates the possible presence of stratabound silver-lead-zinc.

Granites and syenites of the Ordovician Beaverhead Mountains pluton have been prospected for uranium, silver, and base metals. Gravity and aeromagnetic (U.S. Geological Survey, 1981) surveys suggest that rocks of the pluton underlie much of the northwest part of the area at shallow depths (Skipp and others, 1983), but geochemical anomalies are weak, and there is little likelihood of the occurrence of resources.

The eastern part of the study area probably is underlain at several thousand feet by rocks of the Medicine Lodge and underlying thrust plates; these may contain reservoirs suitable for gas accumulation; no hydrocarbons have been produced to date (1982), however, from these rocks where they have been tested in southwesternmost Montana. Limestones at the surface on the Fritz Creek and Cabin thrust plates have been heated to temperatures of more than $190^{\circ} \mathrm{C}$ and any petroleum in these rocks would have been driven off; dry gas is the only possible shallow hydrocarbon resource. The fact that dense limestones are at the surface throughout the area makes present seismic explora- 
tion techniques used to identify deeper structures ineffective, and random drilling is very costly. For these reasons, no potential for the occurrence of oil or gas in this area was identified.

The study area was examined for evidence of placer gold and geothermal resources, but no potential for these resources was identified.

\section{SUGGESTIONS FOR FURTHER STUDIES}

Further study of most of the Italian Peak and Italian Peak Middle Roadless Areas for the identification of hidden mineral deposits seems unwarranted, except for the small areas of dolomite and magnesian limestone that may contain stratabound silver-lead-zinc deposits. These rocks were identified in the northern part of the area, but not fully evaluated, in this study. Carbonate hosted deposits of the variety described here, however, seldom have surface expression. The Viola mine and the
Birch Creek mining district, in general, would benefit from studies that would delineate the most favorable horizons or facies for mineralization and refine this resource assessment.

\section{REFERENCES}

Lambeth, R. H., and Mayerle, R. T., 1983, Mineral investigations of the Italian Peak RARE II Area (No. I-1945), Beaverhead County, Montana, and Italian Peak Middle RARE II AREA (No. M-4945), Clark and Lemhi Counties, Idaho: U.S. Bureau of Mines Open-File Report MLA 53-83, 26 p.

Skipp, Betty, Antweiler, J. C., Kulik, D. M., Lambeth, R. H., and Mayerle, R. T., 1983, Mineral resource potential map of the Italian Peak and Italian Peak Middle Roadless Areas, Beaverhead County, Montana, and Clark and Lemhi Counties, Idaho: U.S. Geological Survey Miscellaneous Field Studies Map MF-1601-A, scale 1:62,500.

U.S. Geological Survey, 1981 [1982], Aeromagnetic map of the Italian Peak area, Idaho and Montana: U.S. Geological Survey Open-File Report 81-1162, scale 1:62,500. 

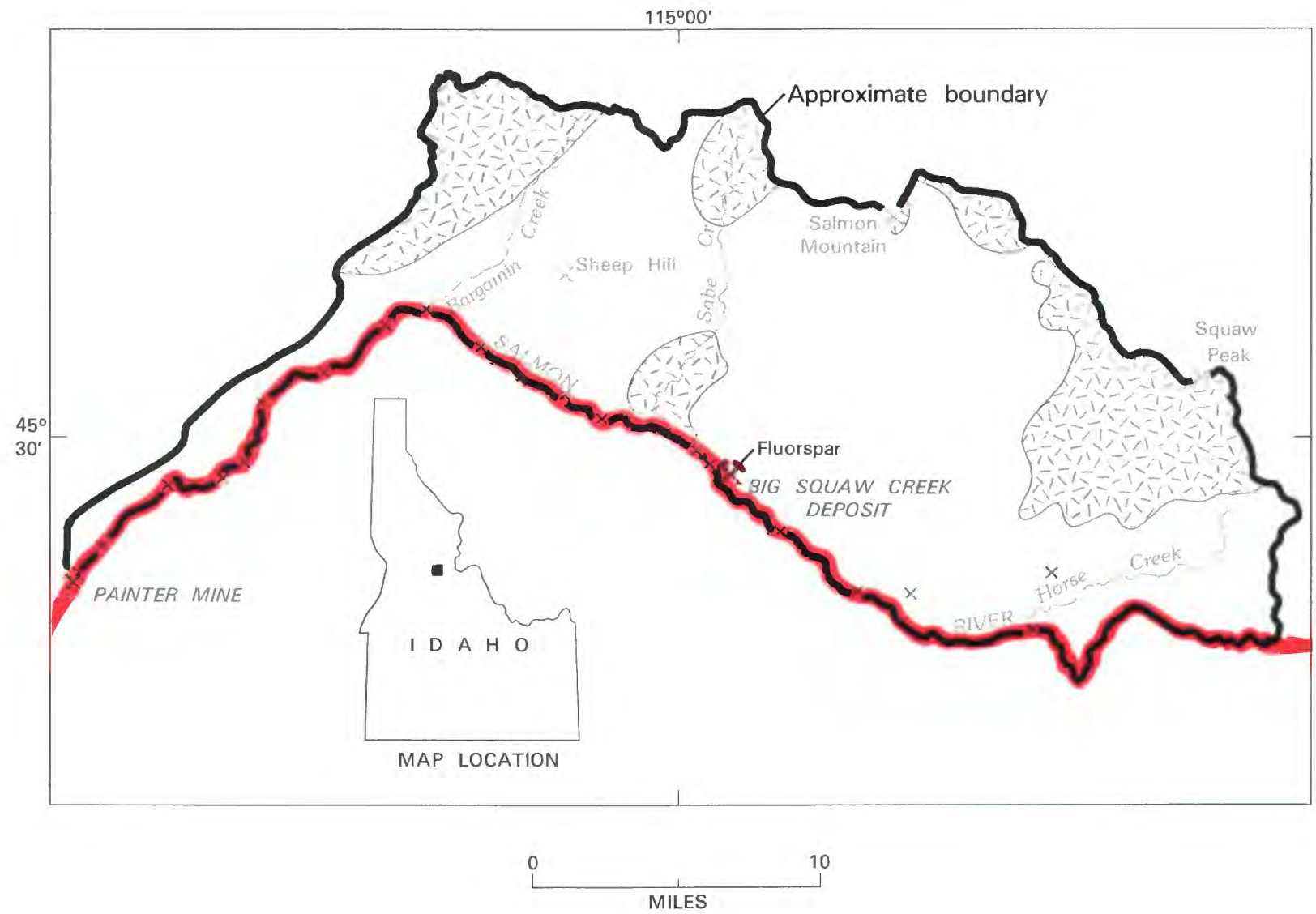

EXPLANATION

$\begin{array}{cll}\begin{array}{l}\text { Geologic terrane with substantiated } \\ \text { placer gold resource potential }\end{array} & \begin{array}{l}\text { Intrusive rocks (Cretaceous) } \\ \text { Metamorphosed rocks } \\ \text { (Precambrian) }\end{array} \\ \times \quad \text { Mine or deposit } & \text { Contact } \\ \times & \text { Mineral occurrence } \\ \times & \text { Mine }\end{array}$

Figure 164.-Salmon River Breaks Primitive Area and vicinity, Idaho. 


\title{
SALMON RIVER BREAKS PRIMITIVE AREA AND VICINITY, IDAHO
}

\author{
By ThOR H. KiILSGaARD, U.S. GeOlOGICAL SuRVEy, and \\ ERNEST T. TUCHEK, U.S. BUREAU OF MINES
}

\section{SUMMARY}

A mineral survey of the Salmon River Breaks Primitive Area and vicinity by the USGS and USBM in 1968-1970 confirmed a substantiated gold resource potential in placer deposits along the Salmon River but determined that largescale mining of the deposits probably would not be feasible. Except for demonstrated fluorspar resources at the Big Squaw Creek deposit, no other mineral resources were found in the area. The geologic environment, geochemical findings, and geophysical data all suggest little likelihood for the occurrence of additional mineral resources in the area. No energy resources were identified in this study.

\section{CHARACTER AND SETTING}

The Salmon River Breaks Primitive Area and vicinity consists of $420 \mathrm{sq} \mathrm{mi}$ of rugged mountainous terrane that forms the north side of the precipitous Salmon River canyon in central Idaho. Creeks draining into the river from the north have incised steep-gradient canyons. Topographic relief, from river level to ridge crests within $3 \mathrm{mi}$ of the river, often exceed $6000 \mathrm{ft}$. The area can be reached by unimproved roads from the southeast, north and southwest but principal access is by way of float trips down the Salmon River, the "River of No Return," which forms the southern boundary of the area. Business in the area consists predominantly of tourist float trips during the summer season; however, a few permanent residents live on small alluvial terraces along the river.

The mineral survey of the primitive area and an additional area along Horse Creek, contiguous to the primitive area, was made in 1968-1970 and the results published in 1972 (Weis and others, 1972). Scattered gold placers along the river and one small fluorspar deposit comprise the mineral resources identified in the area. On July 23, 1980, the area studied was incorporated into the National Wilderness Preservation System as part of the River of No Return Wilderness.

The area studied is underlain by older metamorphosed rocks of Precambrian age, which have been intruded by younger (Cretaceous) granitic rocks of the Idaho batholith. The youngest rocks are a variety of igneous dikes that range from dacite to rhyolite in composition, and which intrude the older rocks. A northerly trending fault passes along part of Bargamin Creek canyon, extending southwest into the Salmon River canyon.

\section{MINERAL RESOURCES}

Since the discovery of gold along the Salmon River in the 1860's all of the Salmon River valley in the primitive area and vicinity has been held by placer location at one time or another. More than 200 mining claims have been located in the area, nearly all of them within $1 \mathrm{mi}$ of the river.

The largest and most explored prospect in the area is the Big Squaw Creek fluorspar deposit, also known as the Smothers property. Large quartz veins with associated fluorspar were discovered in 1860 , investigated during World War II, and explored by diamond drilling and trenching in 1957. The latter work was done under a Defense Mineral Exploration Administration (DMEA) contract. Exploratory work at the deposit shows that it contains demonstrated resources of about 100,000 tons of material that averages 70 percent $\mathrm{CaF}_{2}$.

The Painter mine in the southwest corner of the area consists of a concentrating mill and a few prospect workings; the more intensive mine workings are east of the river outside the primitive area. The mill operated only a few months before being closed by restrictions 
brought on by World War II. Neither the mine nor the mill have operated since then and the small discontinuous amounts of mineralized material seen in the deposit are not indicative of significant resources.

Other prospects examined consist of small pits dug to test quartz veins, dikes, and pegmatites, none of which are indicative of mineral resources.

Many alluvial terraces and low-lying gravel bars along the Salmon River contain gold and have been worked as placers. Poor accessibility has limited development of the placers, consequently most of the work has been done by hand methods. The last period of active mining was during the 1930's and those operations were small, employing as many as 4 men per individual operation. Gold was priced at $\$ 35 / \mathrm{oz}$ and the placer operators tried to maintain ore grade of mined material at an average gold value of $\$ 3$ to $\$ 6 / \mathrm{cu}$ yd, but at times they mined material valued at only a few cents per cubic yard. About one-third of the placer deposits had been withdrawn from mineral entry by the USFS at the time of the mineral survey.

Gold was found to be concentrated in the placers, the values varying from zero to $\$ 2.70 / \mathrm{cu}$ yd of placer material, as determined at a gold price of $\$ 42.19 / \mathrm{oz}$. Richer concentrations of gold are in river bar deposits, known locally as skim-bar deposits, but these commonly are small in size, some containing only a few cubic yards of material. Skim-bar gravels along the north bank of the river, over the $52 \mathrm{mi}$ stretch of the river that was studied, are estimated to total 25,000 to $50,000 \mathrm{cu}$ yds and the area along the north bank is considered to have substantiated resource potential for gold.

The mineral survey confirmed the occurrence of measurable quantities of gold in placers along the Salmon River, but indications are that large-scale placer mining in the area probably is not feasible. Except for the Big Squaw Creek fluorspar deposit, no other indications of significant mineral resources were uncovered by mapping and sampling efforts of the mineral survey.

\section{SUGGESTIONS FOR FURTHER STUDY}

Further studies of the mineral-resource potential of the Salmon River Breaks part of the present River of No Return Wilderness are not recommended.

\section{REFERENCE}

Weis, P. L., Schmitt, L. J., Jr., and Tuchek, E. T., 1972, Mineral resources of the Salmon River Breaks Primitive Area, Idaho: U.S. Geological Survey Bulletin 1353-C, 91 p. 


\title{
EASTERN PART OF THE SAWTOOTH NATIONAL RECREATION AREA, IDAHO
}

\author{
By Thor H. KillsgaARd, ${ }^{1}$ U.S. GeOlogical Survey, and \\ Ronald M. VAN NOY, U.S. BUREaU OF MineS
}

\section{SUMMARY}

The eastern part of the Sawtooth National Recreation Area contains several hundred prospects and mines, some of which have produced substantial quantities of ore. An intensive investigation in 1971-72 by the USGS and the USBM indicated that much of the area has a probable or substantiated mineralresource potential for many metallic minerals. Because of recorded past production, known deposits, and the likelihood of finding additional deposits, much of the area, particularly that part underlain by structurally contorted, undifferentiated metasedimentary rocks, has a probable or substantiated mineral-resource potential. The geologic terrane precludes the occurrence of fossil fuel resources.

\section{CHARACTER AND SETTING}

The Sawtooth National Recreation Area consists of the Sawtooth Wilderness, which is described separately (Kiilsgaard and Coffman, this volume), and a much larger eastern part that aggregates about $820 \mathrm{sq} \mathrm{mi}$, and which is the subject of this report. Mountainous terrane of the area is strikingly scenic, particularly the White Cloud Peaks and the Boulder Mountains. Access to the area is by way of State Highway 75, which follows along the Salmon River, and State Highway 21, which enters from the northwest and connects with State Highway 75 at the picturesque town of Stanley.

A mineral survey of the eastern part of the Sawtooth National Recreation Area was made by the USGS and USBM in 1971 and 1972, and the results were released in 1974 (Tschanz and others, 1974). Parts of the area have long been recognized as some of the most mineralized localities in Idaho. Several mines have produced ore, but unmined mineral resources undoubtedly far exceed the value of recorded production. More than 3800 mining claims, including 930 placer claims, were found to be recorded in the area. The area was incorporated into the Sawtooth National Recreation Area in August, 1972 and the lands withdrawn from mineral entry.

Because of the known mineralized localities and recorded mining activity, an extensive mineral survey of the area was conducted. Special attention was given

\footnotetext{
${ }^{1}$ With contributions by James Ridenour, USBM.
}

236 mines and prospects. Abundant samples from existing mines and many stream-sediment samples were found to contain quantities of metals, including those not previously recognized in the area, such as tin and cadmium.

Geology of the area is complex. Paleozoic metamorphosed sedimentary rocks form an arcuate belt trending northerly through the central part of the area. The metasedimentary rocks have been deformed by folding and faulting, intruded by granitic rocks of Cretaceous and Tertiary ages and, near intrusive contacts, commonly are altered. Overlying the older rocks are the Eocene Challis Volcanics that are exposed extensively in the eastern part of the area. Moraines scoured from the mountains by glaciers and alluvium eroded by streams cover wide expanses of the region, particularly along the western side.

\section{MINERAL RESOURCES}

A large part of the area contains terranes with probable or substantiated mineral-resource potential for several metals including gold, silver, molybdenum, tungsten, lead, and zinc.

Several hundred prospects and mines are known in the area, only a few of which are shown on the map. The mineral deposits are chiefly in metasedimentary rocks, most of them beneath but near thrust faults and intrusive rocks. The deposits are largely polymetallic 


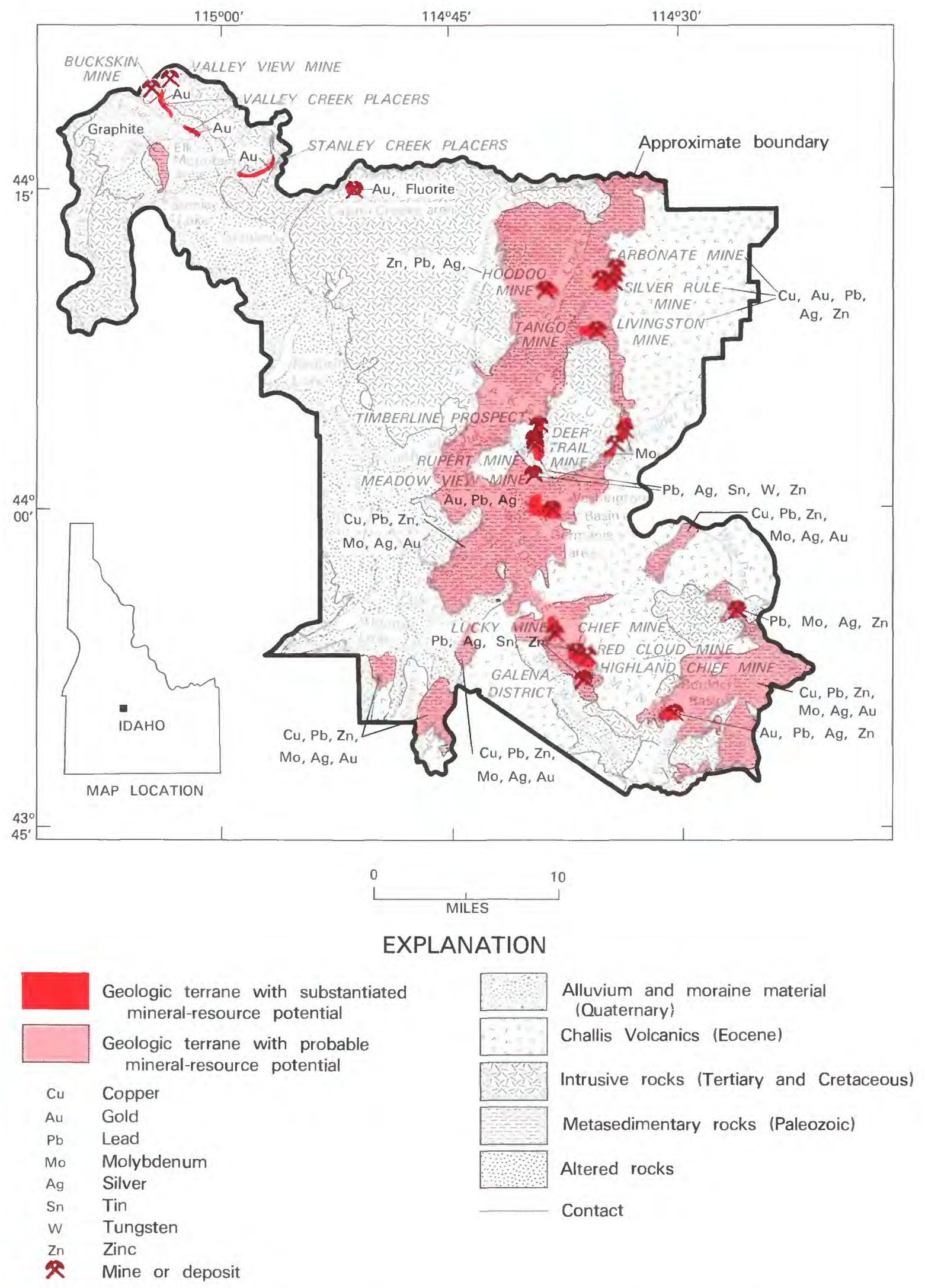

Figure 165.-Eastern Part of the Sawtooth National Recreation Area, Idaho. 
veins, replacement bodies, and disseminations in metasedimentary host rocks.

The largest and best known mineral resources in the area are molybdenite deposits at the head of Little Boulder Creek, which contain resources of national importance. Mineral exploration has outlined two mineralized zones that contain demonstrated molybdenum resources. Samples taken from the north zone during the mineral survey ranged from 0.01 to 0.33 percent $\mathrm{MoS}_{2}$ and gave a weighted average of 0.16 percent $\mathrm{MoS}_{2}$. Demonstrated and inferred resources of 100 million tons have been calculated for the north zone. Samples from the south zone yielded a weighted average of 0.12 percent $\mathrm{MoS}_{2}$ and demonstrated and inferred resources in the zone are estimated at 35 million tons. Sediment samples anomalous in molybdenum were obtained from many streams that drain the area of intrusive rocks immediately west of the Little Boulder Creek deposits, from streams in the Slate Creek district, and from streams in the vicinity of West Pass Creek. Further search might reveal additional molybdenite deposits in these areas.

The Livingston mine has produced more metals than any mine in the recreation area. The ore contained gold, silver, copper, lead, and zinc in veins and replacement bodies in metasedimentary rocks and intrusive dikes. Jamesonite, a lead-antimony sulfide, was the principal mineral mined but antimony apparently was not recovered from the ore. Demonstrated resources at the mine are estimated at 50,000 tons of material that averages $0.005 \mathrm{oz}$ gold/ton, $4 \mathrm{oz}$ silver/ton, 4 percent lead, and 5 percent zinc.

Several mines in the vicinity of Slate Creek have produced silver, lead, and zinc, all from deposits in metasedimentary rocks. The Hoodoo mine is the largest known deposit. Demonstrated resources at the mine total 870,000 tons. Weighted samples from the deposit average 11 percent zinc, 0.47 percent lead, and $0.35 \mathrm{oz}$ silver/ton; zinc concentrates from the ore contained about 0.46 percent cadmium. Past production and selected samples from Silver Rule mine dumps suggest resources may be present in the inaccessible workings. Inferred resources of the nearby Carbonate mine amount to 20,000 tons, the average grade of which is $1.6 \mathrm{oz}$ silver/ton, 2.7 percent lead, and 1.4 percent zinc. Inferred resources of 20,000 tons of vein material at the nearby Tango mine average $5.6 \mathrm{oz}$ silver/ton, 3.3 percent lead, and 0.8 percent zinc. Stream-sediment and rock samples containing anomalous concentrations of zinc and tin were obtained in the Slate Creek area.

Four mineral deposits in metasedimentary rocks in the headwaters area of Fourth of July Creek, have demonstrated resources and are surrounded by areas of substantiated mineral-resource potential. Two major zones of mineralization have been explored at the Deer
Trail mine. Of these the western zone is estimated to contain 270,000 tons of demonstrated resources that average 3.66 percent zinc, 0.17 percent lead, and $0.26 \mathrm{oz}$ silver/ton, whereas the eastern zone contains 200,000 tons averaging 3.84 percent zinc, 1.62 percent lead, and $0.6 \mathrm{oz}$ silver/ton. Lenses in the zones contain higher grade ore. Demonstrated resources at the Rupert mine are estimated to be 18,000 tons, averaging $1.05 \mathrm{oz}$ silver/ton, 3.13 percent lead, and 1.30 percent zinc. Two veins at the Meadow View mine, contain 51,000 tons of demonstrated resources that average $0.20 \mathrm{oz}$ silver/ton, 3.92 percent zinc, and 0.15 percent $\mathrm{WO}_{3}$. Demonstrated resources at the Timberline prospect are estimated at 27,000 tons, averaging $9.3 \mathrm{oz}$ silver/ton, 1.96 percent lead, 2.28 percent zinc, and 0.48 percent tin. One sample from the Timberline prospect contained 6 percent tin. An area of additional prospects, including the Confidence and Silver Dollar, has a substantiated mineralresource potential.

More than 45 mines and prospects are known in the Germania area. Notable quantities of silver, lead, and gold have been produced from several of the deposits. Some of these and other deposits are known to contain tungsten, bismuth, antimony, and tellurium. The Germania area of substantiated mineral-resource potential is estimated to contain demonstrated mineral resources of 25,000-100,000 tons, the grade of which is 0.2 to $0.11 \mathrm{oz}$ gold/ton, 5.8 to $12.6 \mathrm{oz}$ silver/ton, and 3.38 to 4.27 percent lead. Several million tons of lower grade material are present. There is also substantiated potential for the occurrence of additional mineral resources, particularly in Washington basin.

The Galena area, which extends along the crest of the Boulder Mountains, contains mines in metasedimentary rocks that have produced notable amounts of silver, lead, and zinc. Areas of probable and substantiated mineral-resource potential for these and other metals are present. Four deposits at the Red Cloud, Chief, Highland Chief, and Lucky mines contain demonstrated resources that total 19,000 to 27,000 tons averaging $4 \mathrm{oz}$ silver/ton and 5 percent lead. The Highland Chief mine contains an additional 180,000 tons of lower grade material. Samples from these and other deposits in the Galena area also have contained tin, with some containing as much as 2.25 percent.

Mines in the Boulder basin have yielded substantial amounts of gold, silver, lead, and zinc. Demonstrated resources of 4000 tons, averaging $0.05 \mathrm{oz}$ gold/ton, $21.7 \mathrm{oz}$ silver/ton, 8.7 percent lead, and 1.5 percent zinc are estimated for the mines, as well as several thousand additional tons of resources of silver- and lead-bearing material. Past production, known resources, and favorable geologic setting makes the area one of substantiated resource potential. Quartz-fluorite veins and goldbearing quartz veins crop out in granite in an area of 
substantiated resource potential in the Casino Creeks vicinity. Demonstrated resources of fluorite-bearing rock are estimated to be at least 200,000 tons. Tactite deposits near the head of West Pass Creek contain disseminated galena and sphalerite. Inferred resources are estimated at 10,000 tons that contain as much as $1.43 \mathrm{oz}$ silver/ton, 5.86 percent lead, and 5.48 percent zinc. Other areas of interest include Elk Mountain, southeast of Elk Creek, where an area of probable potential for flake graphite in metasedimentary rock is present.

Gold has been mined from mineralized shear zones in a broad zone of altered granitic rock that is several hundred feet wide and thousands of feet long, in the northwestern part of the recreation area. Two mines, the Valley Creek and the Buckskin have been worked, the Valley Creek mine being the more productive. Combined demonstrated resources of the two mines total 376,000 tons, averaging $0.15 \mathrm{oz}$ gold/ton, $2.31 \mathrm{oz}$ silver/ton, and 2 percent lead.

Forty-five placer deposits were identified in the mineral survey, of which demonstrated resources of two of the larger ones, Valley Creek and Stanley Creek, aggregate 10 million cu yd at an average gold content of $0.003 \mathrm{oz} / \mathrm{cu} \mathrm{yd}$, and 5.9 million cu yd at an average gold content of $0.0017 \mathrm{oz} / \mathrm{cu} \mathrm{yd}$, respectively.

\section{SUGGESTIONS FOR FURTHER STUDIES}

The recreation area warrants extensive additional studies. The metasedimentary rocks need to be mapped in detail and at large scales in order to gain information on the complicated stratigraphy and geologic structure. Stream-sediment anomalies should be studied and attempts made to locate their sources. Geology and metallurgy of tin-bearing deposits should be investigated. Tertiary intrusive rocks should be differentiated and their association to mineral deposits ascertained. Cost analysis of placer mining and measures needed to protect the environment should be determined. The mineral potential of favorable targets should be explored.

\section{REFERENCES}

Tschanz, C. M., Kiilsgaard, T. H., Seeland, D. A., Mabey D. R., Frischknecht, F. C., Van Noy, R. M., Ridenour, James, Zilka, N. T., Federspiel, F. E., Evans, R. K., Tuchek, E. T., and McMahan, A. B., 1974, Mineral resources of the eastern part of the Sawtooth National Recreation Area, Custer and Blaine Counties, Idaho: U.S. Geological Survey Open-file report, $667 \mathrm{p}$. 


\title{
SAWTOOTH WILDERNESS, IDAHO
}

\author{
By THOR H. KillsGaARD, U.S. GeOlOgical SuRVeY, and
}

JOSEPH S. COFFMAN, U.S. BUREAU OF MiNES

\begin{abstract}
SUMMARY
The Sawtooth Wilderness consists of the former Sawtooth Primitive Area and certain contiguous tracts of land. A survey of the mineral-resource potential of the entire area in 1966-68 disclosed hydrothermally altered and mineralized rocks at several localities, some of which have been prospected to a limited extent but none of which have produced significant quantities of ore. Sediment samples from many of the streams that drain the wilderness contained anomalous quantities of metals. At some sample sites the source of the anomalous concentrations of metals may be related to known mineralized outcrops but the source at many of the sites is unknown. The significant geochemical data, the extent of altered and mineralized rocks, and the proximity to other productive mineral districts in similar geologic environs indicate that substantial parts of the wilderness have probable mineral-resource potential. A placer deposit, in the northern part of the wilderness, has substantiated potential for rare-earth elements; an area in the southern part of the wilderness has substantiated potential for precious metals; and several mines in the wilderness have demonstrated resources of base and precious metals. The geologic setting precludes the presence of fossil fuels.
\end{abstract}

\section{CHARACTER AND SETTING}

The Sawtooth Wilderness is a scenic mountainous area of about $339 \mathrm{sq} \mathrm{mi}$ in central Idaho. The wilderness covers most of the spectacular Sawtooth Mountains, perhaps the most majestic mountain range in Idaho. Viewed from the eastern side, especially from the vicinity of Stanley, about $3 \mathrm{mi}$ east of the eastern border of the wilderness, the rugged mountains are particularly striking. Access to the wilderness is by way of State Highway 75, which passes through Sawtooth valley along the eastern edge of the wilderness and connects at Stanley with State Highway 21, which extends around the north end of the wilderness and continues southwest to Boise.

The mineral survey of the Sawtooth Primitive Area and certain contiguous tracts of land was made in 1966, 1967, and 1968 and the results were published in 1970 (Kiilsgaard and others, 1970). The primitive area and parts of the contiguous lands that were studied were incorporated into the National Wilderness Preservation System as the Sawtooth Wilderness in 1972 and the lands were withdrawn from mineral entry.
Biotite schist and various other interlayered metamorphic rocks of Precambrian(?) age crop out in the vicinity of Thompson Peak and are the oldest rocks in the Sawtooth Wilderness. The metamorphic rocks have been intruded by Cretaceous granitic rocks of the Idaho batholith. Biotite granodiorite is the principal rock type of the batholith, which underlies vast areas of central Idaho and is the common "granite" seen along roads that pass through the region. Intruding both the older metamorphosed rocks and granitic rocks of the Idaho batholith is a Tertiary pink granite, which underlies most of the wilderness and has been identified as the Sawtooth batholith (Reid, 1963). Crosscutting all of these rocks are a vast number of younger dikes of igneous rock. The eastern foothills of the Sawtooth Mountains and lower parts of valleys leading from them are underlain by morainal debris that has been scoured from the mountains by alpine glaciers. Major northwest-trending faults flank the northeast and southwest sides of the Sawtooth Mountains, which may be considered as a large block of the Earth's crust that has been uplifted above adjacent blocks of rock.

Central Idaho is a highly mineralized region and four 


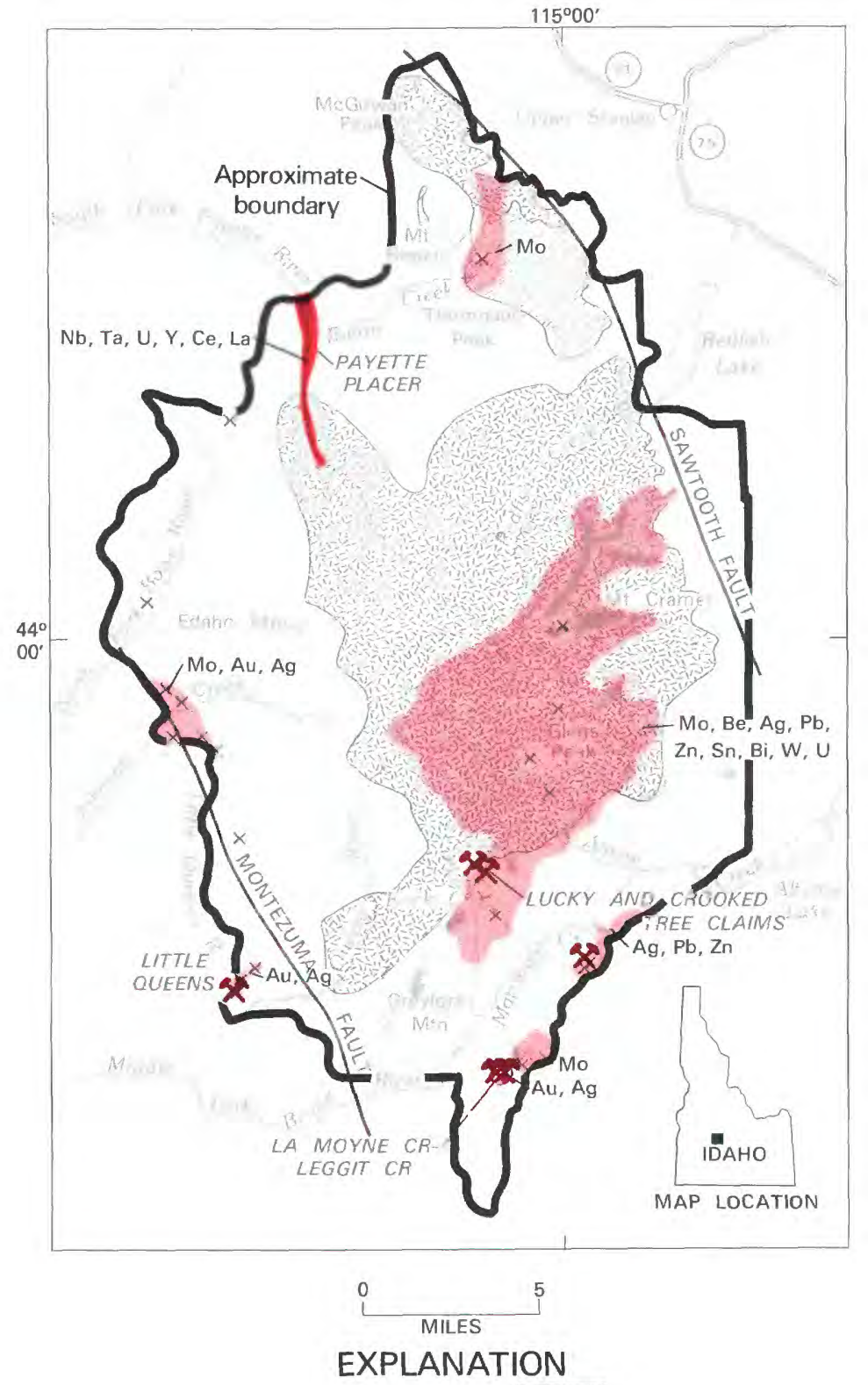

Geologic terrane with substantiated mineral-resource potential

Geologic terrane with probable mineral-resource potential

$\begin{array}{llllll}\text { Be } & \text { Beryllium } & \text { Mo } & \text { Molybdenum } & \text { W } & \text { Tungsten } \\ \mathrm{Bi} & \text { Bismuth } & \mathrm{Nb} & \text { Niobium } & \text { U } & \text { Uranium } \\ \mathrm{Ce} & \text { Cerium } & \mathrm{Ag} & \text { Silver } & \text { V } & \text { Vanadium } \\ \mathrm{Au} & \text { Gold } & \mathrm{Ta} & \text { Tantalum } & \text { Y } & \text { Yttrium } \\ \mathrm{La} & \text { Lanthanum } & \mathrm{Sn} & \text { Tin } & \text { Zn } & \text { Zinc } \\ \mathrm{Pb} & \text { Lead } & & & \\ \mathrm{X} & \text { Mine or deposit } & & \\ \times & \text { Mineral occurrence } & & \end{array}$

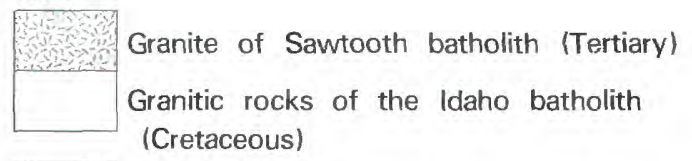

Figure 166.-Sawtooth Wilderness, Idaho. 
mining districts adjoin or extend into the wilderness. Three of these districts, Atlanta, Vienna, and Sawtooth have produced notable amounts of gold and silver. Ten other mining districts within $20 \mathrm{mi}$ of the wilderness have produced gold, silver, and other metals.

\section{MINERAL RESOURCES}

Mineralized quartz veins, iron-stained altered country rock and nearby productive mines in similar geologic environs have long made the Sawtooth Wilderness and contiguous areas an attractive region for prospecting. The mineral survey noted the existence of nearly 700 mining claims in the area studied. Extensive localities of altered granitic rocks trend northeasterly across the wilderness, and the mineralized character of some of these was confirmed by analysis of samples of the rock. Many stream sediments derived from erosion of upstream rocks contained anomalous quantities of metals and dispersement of the sample sites indicates a wider spread distribution of mineralized outcrops than was found by the mineral survey. Of the many mineralized occurrences prospected in the wilderness, only one, the Little Queens mine, is known to have been productive; it produced gold valued at about $\$ 10,000$.

Stream-sediment samples that were collected over widespread areas in the Sawtooth Wilderness contained anomalous quantities of molybdenum, particularly those from streams draining terrane underlain by the Sawtooth batholith (Kiilsgaard and others, 1970, fig. 8). The best known molybdenum prospects are near the mouth of Rock Creek, where molybdenite coats fractures and is disseminated in the fractured rock. Two prospect areas, the Lucky and the Crooked Tree groups of claims, are more than $0.5 \mathrm{mi}$ apart and molybdenite may be traced for several hundred feet on each group. Rock samples from the two sites contained as much as 0.7 percent molybdenum and $3.2 \mathrm{oz}$ of silver per ton. Stream-sediment samples taken below the prospects were anomalous in molybdenum.

Large areas of altered granite of the Sawtooth batholith crop out in the vicinity of Mt. Cramer and sediment samples from streams draining these areas were anomalous in molybdenum, beryllium, silver, lead, and zinc. Samples of the altered rock showed enrichment in silver, molybdenum, tin, lead, zinc, bismuth, and tungsten. None of the samples were of ore grade but they contained quantities of metal significant enough to warrant further investigation. Molybdenum was obtained from samples of quartz taken southeast of $\mathrm{Mt}$. Regan and from a sediment sample in that area. A sample of hillside float, taken along North Fork of Baron Creek, west of the above-mentioned quartz sample site, yielded 0.2 percent molybdenum and indicates more widespread mineralization than can be explained by the Mt. Regan occurrence alone. More significantly, sediment samples taken along more than $2 \mathrm{mi}$ of the upper reaches of Iron Creek, northeast of Mt. Regan and on the opposite side of the Sawtooth Mountains, are anomalous in molybdenum. One of these samples contained $50 \mathrm{ppm}$ molybdenum. The analyses were received after completion of field work thus there was no opportunity to search for the source of the molybdenum, but the unusually enriched sediment samples indicate far more extensive molybdenum deposits in the area than are now known. Quartz veins in the vicinity of Johnson Creek and the La Moyne Creek-Leggit Creek area also contain molybdenum but those occurrences are believed of minor significance.

A placer deposit that contains several hundred million cubic yards of demonstrated resources of rareearth elements lies along the South Fork Payette River in an area of substantiated potential, extending from beyond the wilderness boundary to about $4.5 \mathrm{mi}$ into the wilderness. Niobium, tantalum, and uranium have been the principal elements searched for in the deposit. Exploration through 1968 consisted of 17 churn drill holes ranging from 40 to $177 \mathrm{ft}$ deep and several bulldozer trenches. All but one of the holes were drilled within the present wilderness. Analytical results on holes 1 through 12, which span about a $4.2 \mathrm{mi}$ length of the placer, show the placer to average $11.16 \mathrm{lbs}$ of black sand and $4.02 \mathrm{lbs}$ of heavy but nonmagnetic material per cubic yard. The nonmagnetic fraction was analyzed for niobium, tantalum, and uranium and contained average values for $\mathrm{Nb}_{2} \mathrm{O}_{5}, \mathrm{Ta}_{2} \mathrm{O}_{5}$ and $\mathrm{U}_{3} \mathrm{O}_{8}$ of $0.320,0.0015$ and $0.0004 \mathrm{lb} / \mathrm{cu}$ yd, respectively. Significant quantities of the rare earths yttrium, cerium, and lanthanum have been identified by spectrographic analysis of the placer concentrate. At 1968 prices, value of the several hundred million cubic yards of demonstrated placer resources, based on niobium alone, ranged from about $4 \$ / \mathrm{cu} y d$ at the north end of the deposit to $19 \$ / \mathrm{cu}$ yd at the south end in the wilderness. About half the niobium was nonrecoverable by technology of 1968 , but total contained niobium and rare earths of the placer had a calculated value of more and 40\$/cu yd at 1968 prices.

Quartz veins that contain gold and silver occur at several localities in the wilderness and several of these have been explored to a limited extent. The most extensively worked deposit is the Little Queens gold mine, which is just inside the southwestern border of the wilderness and contains demonstrated resources. The deposit is developed by several hundred feet of mine workings on several different levels plus several hundred feet of bulldozer trenches. Mining in 1966 was from a quartz vein in a stope off a winze beneath the lowest 
adit level. A panned sample of crushed quartz from the vein being mined yielded fragments of gold as much as $1 / 8$ in. in diameter and a chip sample across an 8-in. thickness of vein contained $1 \mathrm{oz}$ of gold/ton and $4.4 \mathrm{oz}$ silver/ton. The area around the Little Queens mine has a probable gold and silver potential. Several quartz veins crop out on the Basin mining claims in the Leggit Creek area. The veins range from a few inches to more than 17 $\mathrm{ft}$ in thickness and some may be traced for several hundred feet on the surface. Exploration of the veins consist of a short adit only $15 \mathrm{ft}$ long and few prospect pits. The veins are estimated to contain demonstrated resources of 10,000 tons of material that ranges from 2.6 to 24.6 oz of silver/ton and 0.4 to 0.9 percent lead, and additional demonstrated resources of 100,000 tons of material that contains about $2 \mathrm{oz}$ of silver/ton. Quartz veins that contain low grade amounts of gold and silver crop out at the Pilot Knob prospect at the head of La Moyne Creek. The Leggit-LaMoyne Creek area has a substantiated resource potential for gold and silver. Several large quartz veins crop out on the divide at the head of Mattingly Creek. One of these veins on the This Is It claim is 4 to $6 \mathrm{ft}$ thick and may be traced more than $1000 \mathrm{ft}$ on the surface. A 16-in. sample across part of the vein contained $43.8 \mathrm{oz}$ of silver/ton, 3 percent lead, 0.3 percent zinc, and 0.3 percent bismuth. Several hundred feet to the southeast, on what may be a continuation of the This Is It vein, a dump sample at a prospect pit contained $58.4 \mathrm{oz}$ of silver/ton, 3 percent lead, 0.7 percent zinc, and 0.5 percent bismuth. Other quartz veins crop out in the Johnson Creek area and some of these have been explored for gold and silver by small prospect pits and limited underground workings.

An unexpected discovery from the stream-sediment sampling program was the content of uranium in many stream sediments, particularly from streams draining areas underlain by pink granite of the Sawtooth batholith. Values of more than 0.2 percent uranium were obtained from the samples but the volume of alluvial material at the higher-grade sample sites is too small to constitute a viable resource. Radiometric testing of the pink granite country rock shows those rocks to contain more uranium than normal granite. Two samples of the granite show it to contain about 8 parts per million uranium, an amount adequate to account for uranium in the stream sediments. Although it is not considered as having energy resource potential, the radioactive Sawtooth batholith is of scientific interest and likely will be the topic of further investigation.

Beryllium in the form of blue beryl (aquamarine) is widespread throughout rocks of the Sawtooth batholith particularly in the vicinity of Glens Peak. Beryl is found in discrete crystals in the host rock, in narrow veinlets, pods, and as fine-grain spherical concentrations, but no mineral-resource potential was identified.

\section{SUGGESTIONS FOR FURTHER STUDY}

Large areas of the Sawtooth Wilderness warrant further study and some areas warrant subsurface exploration. Particular attention should be given to terrane favorable for the occurrence of molybdenum. The entire drainage of Iron Creek deserves detailed examination as does the area in the vicinity of Rock Creek, and all altered or mineralized rocks, particularly those near $\mathrm{Mt}$. Cramer and east of the headwaters of Redfish Creek. Mineralized quartz veins in the vicinity of upper Mattingly Creek, Leggit Creek-La Moyne Creek, Little Queens River and along the Montezuma fault require further surface study and possible subsurface exploration before reliable estimates of their mineral-resource potential can be made. Metallurgical studies on the recovery of niobium and rare earths, cost analysis of placer mining and of measures that would be needed to protect or restore the ecologic environment would aid in determining the net value of the Payette Placer.

\section{REFERENCES}

Kiilsgaard, T. H., Freeman, V. L., and Coffman, J. S., 1970, Mineral resources of the Sawtooth Primitive Area: U.S. Geological Survey Bulletin 1319-D, $174 \mathrm{p}$.

Reid, R. R., 1963, Reconnaissance geology of the Sawtooth Range: Idaho Bureau of Mines and Geology Pamphlet 21, $17 \mathrm{p}$. 


\title{
SELKIRK ROADLESS AREA, IDAHO
}

\author{
By Fred K. Miller, U.S. Geological Survey, and \\ JOHN R. BENHAM, U.S. BUREAU OF MINES
}

\begin{abstract}
SUMMARY
On the basis of mineral-resource surveys conducted in 1979-80 and in 1982, the Selkirk Roadless Area has little promise for the occurrence of mineral or energy resources. Molybdenum, lead, uranium, thorium, chromium, tungsten, zirconium, and several rareearth elements have been detected in panned concentrates from samples of stream sediment, but no minerals containing the first five elements were found in place, nor were any conditions conducive to their concentration found. Zirconium, thorium, and the rare earths occur in sparsely disseminated accessory minerals in granitic rocks and no resource potential is identified. There is no history of mining in the roadless area and there are no oil, gas, mineral, or geothermal leases or current claims.
\end{abstract}

\section{CHARACTER AND SETTING}

The Selkirk Roadless Area, about 109 sq mi, is in the Kaniksu National Forest, Boundary County, Idaho, about $70 \mathrm{mi}$ north-northeast of Spokane, Washington. It lies in the high mountainous terrane between the Priest River and Kootenai River drainages. All of the roadless area has been glaciated and much of it is near or above timberline. Altitudes range from 2000 to 7600 $\mathrm{ft}$; much of the roadless area forms a high divide that averages about $7000 \mathrm{ft}$ in altitude. The stream canyons and lower altitudes are heavily forested, and although most timber is second growth, much is mature or nearly mature. Access to the area is provided by U.S. 95 on the east. Numerous USFS trails provide access within the roadless area.

Most of the Selkirk Roadless Area is underlain by the igneous complex of Selkirk Crest, two mica granitic rock units that contain abundant inclusions of metamorphic wallrock. The complex intrudes Proterozoic Prichard Formation, older Precambrian gneiss, and Triassic(?) monzonite and appears to be bounded by large faults on its east and west sides. A detailed account of the geology may be found in Miller (1983a).

A porphyroblastic gneiss unit appears to be the oldest rock in the roadless area. The Proterozoic Y Prichard Formation of the Belt Supergroup overlies the porphyroblastic gneiss in the northeast part of the area, but because of intense deformation, it is not pessible to determine whether the contact was originally deposi- tional or intrusive. The Prichard Formation in the roadless area consists of about equal parts of argillite, siltite, and quartzite intruded by numerous diabase sills. Almost everywhere in the roadless area, metamorphism has converted these rocks to sillimanite-grade schist, quartzite, and amphibolite. Alkalic monzonite of Triassic(?) age intrudes the porphyroblastic gneiss and is, in turn, intruded by two-mica granitic rocks of the igneous complex of Selkirk Crest.

Glacial and glacio-fluvial material mantle all older units. Recent alluvium occupies modern stream drainages, but much of this material is derived from glacial deposits.

Other than a concealed fault outside the roadless area in the Purcell Trench (Kootenai River valley), almost no faults occur in the area. Considerable movement distributed across zones between individual units of the Selkirk complex probably occurred during emplacement of the complex, but these zones do not constitute faults as such. Cataclastic deformation, probably related to emplacement of the complex and the fault in the Purcell Trench, are well developed along the northeast edge of the roadless area.

Geologic mapping and geochemical sampling were conducted by the USGS in 1979-80. A ground scintillometer survey was carried on concurrently with the geologic mapping. The USBM examined all recorded mining claims and prospects in the roadless area during the summer of 1982 . Although intermittent prospecting has occurred since 1903, there are no mines or workings in the roadless area. 

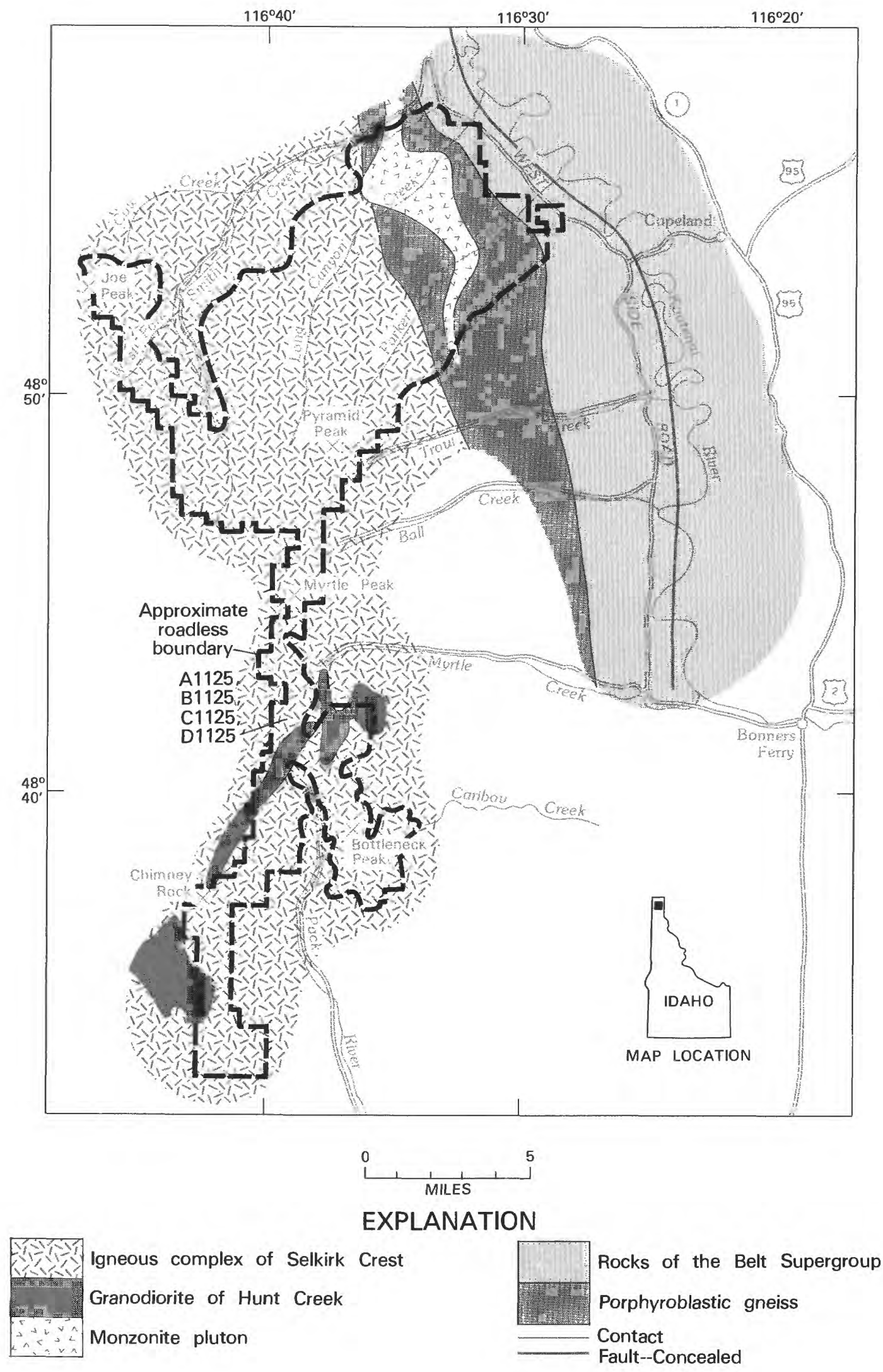

Figure 167.-Selkirk Roadless Area, Idaho. 


\section{MINERAL RESOURCES}

No mineralization of any significance was observed during the geologic or geochemical studies or during examination of the claims and prospects. The igneous complex of Selkirk Crest which underlies most of the roadless area appears to be relatively barren with regard to mineral resources. The only nearby mine having any history of production, the Continental mine about $6 \mathrm{mi}$ northwest of the roadless area, is developed in the Wallace Formation, which does not occur in the roadless area.

Analyses of most samples taken during the geochemical survey fall well within the expected limits for the rock types underlying areas drained by the respective streams. A few samples and (or) areas show anomalous amounts of molybdenum, lead, chromium, uranium, and thorium, and individual samples show anomalous silver, copper, and tungsten.

Molybdenum is restricted to samples taken from streams draining the alkalic monzonite of Triassic(?) age. Although virtually all samples from streams draining this body have small amounts of molybdenum, no molybdenite was observed in the rock during the geologic mapping and no resource potential for molybdenum in the area was identified.

Anomalous lead values in five stream-sediment samples may represent localized areas of mineralization or they may define a $6 \mathrm{mi}$-long belt of mineralization just east of the headwaters of the Pack River. The streams from which the samples with anomalous lead were collected drain four different rock units, none of which are rock types with which lead mineralization is normally associated. No lead-bearing minerals or concentration of veins of any type were observed in these four units during the stream-sediment sampling or geologic mapping.

Uranium appears to be associated with the alkalic monzonite pluton and with the granodionite of Hunt Creek, the latter one of the granitic units of the Selkirk Crest complex. Both bodies exhibit higher than normal radioactivity, and panned concentrates of sediment from streams that drain the bodies contain anomalous amounts of uranium and thorium. Careful examination of these two granitic bodies revealed no concentrations of uranium or thorium minerals. These elements occur chiefly in zircon and allanite which are abundant in both granitic units and no uranium resource potential was identified.

Anomalous chromium occurs in several samples of stream sediment and appears to have been derived from the diabase sills in the Proterozoic Y Prichard Formation or from xenoliths of these sills in the younger granitic rocks. Chromium is concentrated in the diabase, but nowhere is it identified as a resource.

Tungsten (200 parts per million) was detected in a stream-sediment sample from the upper reaches of Long Canyon. Although tungsten mineralization was not observed in place during stream-sediment sampling and geologic mapping, the most likely source is pegmatite dikes or metamorphic inclusions in a granitic unit of the Selkirk Crest complex.

Lanthanum, yttrium, and thorium are abundant in almost all samples. The high values for these elements are undoubtedly due to the high concentration of allanite in almost all granitic rocks in the region. Zirconium values are also high because of the abundance of zircon. Nowhere in the roadless area, however, do any of these elements occur in concentrations and no resource potential was identified.

\section{SUGGESTIONS FOR FURTHER STUDIES}

Additional studies within the roadless area would probably reveal no new mineral resources.

\section{REFERENCES}

Miller, F. K., 1983a, Geologic map of the Selkirk study area (A1-125, B1-125, C1-125, D1-125) Boundary County, Idaho: U.S. Geological Survey Miscellaneous Field Studies Map, MF-1447-A, scale $1: 48,000$.

$1983 \mathrm{~b}$, Geochemical map of the Selkirk study area (A1-125, B1-125, C1-125, and D1-125), Boundary County, Idaho: U.S. Geological Survey Miscellaneous Field Studies Map, MF-1447-B, scale 1:48,000.

Miller, F. K., and Benham, J. R., 1983, Mineral resource potential of the Selkirk Roadless Area, Bonner County, Idaho: U.S. Geological Survey Miscellaneous Field Studies Map, MF-1447-C, scale 1:48,000 (in press). 

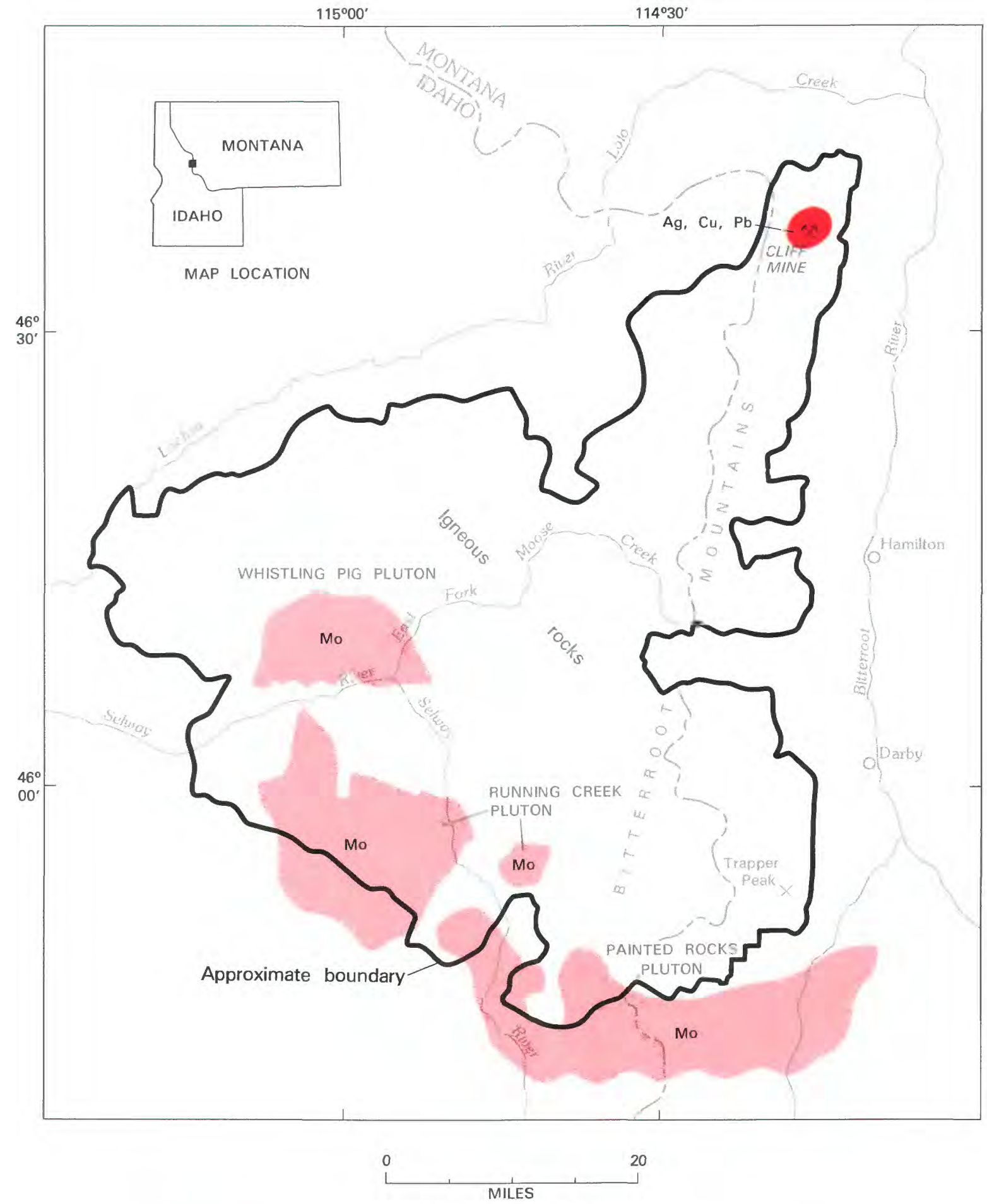

EXPLANATION

Geologic terrane with substantiated mineral-resource potential

Geologic terrane with probable mineral-resource potential

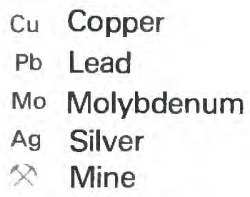

Figure 168.-Selway-Bitterroot Wilderness, Idaho and Montana. 


\title{
SELWAY-BITTERROOT WILDERNESS, IDAHO AND MONTANA
}

\author{
By Margo I. TOTh, ${ }^{1}$ U.S. GeOlOGical Survey, and \\ NiCHOlas T. ZILKa, U.S. BUREAU OF MiNES
}

\begin{abstract}
SUMMARY
Mineral-resource studies of the Selway-Bitterroot Wilderness in Idaho County, Idaho, and Missoula and Ravalli Counties, Montana, were carried out in 1976 and from 1978 to 1981 . Four areas with probable and one small area of substantiated mineral-resource potential were recognized. The areas of the Running Creek, Painted Rocks, and Whistling Pig plutons of Tertiary age have probable resource potential for molybdenum, although detailed geochemical sampling and surface investigations failed to recognize mineralized systems at the surface. Randomly distributed breccia zones along a fault in the vicinity of the Cliff mine have a substantiated potential for small silver-copper-lead resources.
\end{abstract}

\section{CHARACTER AND SETTING}

The Selway-Bitterroot Wilderness covers approximately $1950 \mathrm{sq} \mathrm{mi}$ in east-central Idaho and western Montana. The wilderness lies across the Bitterroot Range, which forms the boundary between Idaho and Montana, and includes large portions of the drainage basins of the Selway, Lochsa, and Bitterroot Rivers. Altitudes range from $1800 \mathrm{ft}$ on the Selway River near the western boundary to $10,157 \mathrm{ft}$ at Trapper Peak in Bitterroot Mountains. Cities within $50 \mathrm{mi}$ of the wilderness include Missoula, Hamilton, and Salmon on the east, and Orofino and Grangeville on the west. Access to the wilderness is limited to trails which are accessible by dirt roads.

The Selway-Bitterroot Wilderness was established as a primitive area in 1932 and was designated a wilderness in 1964. A mineral survey was made of the wilderness in 1976 and from 1978 to 1981 and the results of the study were published (Toth and others, 1983; Coxe and Toth, 1983).

The Magruder Corridor (165 sq mi), located to the southwest of the wilderness, was added to the SelwayBitterroot Wilderness in 1980 . The mineral-resource potential of that area is not included in this report.

The wilderness encompasses most of the northern part of the Idaho batholith, a large composite body of

${ }^{1}$ With contributions from Berton W. Coxe, USGS, and Mike M. Hamilton, USBM. granitic rocks (Toth, 1983). It consists of rocks that vary in age from Cretaceous (about 100 to 110 m.y. (million years)) to Tertiary (about 40 to $50 \mathrm{~m} . \mathrm{y}$.) and have compositions that vary widely but systematically with age. Older metamorphic rocks (Precambrian) encircle the wilderness and occur as small isolated bodies between the granite plutons. Widespread glaciation in Pleistocene time carved the stream valleys into U-shapes to the east and west of the crest of the Bitterroot Mountains, in The Crags area, and in some of the other higher altitudes in the wilderness.

A detailed geochemical survey was carried out in the wilderness by sampling and analyzing stream sediments and rocks. All samples were analyzed for 30 elements and some selected stream sediments were also analyzed for uranium and thorium (Coxe and others, 1982). Analyses of selected rocks for majorelements were also performed (Koesterer and others, 1982). The results of the geochemical survey indicate that with the exception of the three Tertiary plutons and the small area around the Cliff mine, the Selway-Bitterroot Wilderness lacks concentrations of metals.

Aeromagnetic and gravity reconnaissance surveys were carried out in the wilderness area but failed to yield any evidence of mineralized systems (Kleinkopf and Bankey, written commun., 1982). A mineral survey of claims, prospects, and mines was done as part of this investigation to determine the mineral-resource potential of the area (Zilka and Hamilton, 1982). 


\section{MINERAL RESOURCES}

Although major mining activity has occurred on the periphery of the Selway-Bitterroot Wilderness, none is known within it; ninety-three lode and five placer claims have been located in the wilderness. Regional geochemical, tectonic, and petrologic studies suggest that the three Tertiary granitic plutons on the south and southwest sides of the wilderness have characteristics favorable for molybdenum resources. Their composition is similar to that of other plutons genetically related to molybdenite deposits. Chemical data from streamsediment samples taken from the areas of the plutons indicate enrichment in molybdenum, and associated tin, niobium, beryllium, yttrium, lead, and zinc. However, molybdenum was detected in only two rock samples, both from the Whistling Pig pluton, and detailed surface mapping failed to locate alteration patterns characteristic of molybdenite mineralization. Therefore, there is little liklihood for near-surface molybdenum concentrations. Based on the favorable environment and geochemistry, the areas of these plutons have a probable molybdenum resource potential.

A deposit containing silver, lead, zinc, and copper was identified at the Cliff mine near the northeastern corner of the wilderness. These metals occur in randomly distributed breccia zones along a fault. Although the area has substantiated potential, the occurrences are small in size and erratically distributed.

There is no known geological evidence for oil, gas, coal, geothermal resources, or other energy-related commodities within the wilderness.

\section{SUGGESTIONS FOR FURTHER STUDIES}

Further study of the wilderness probably would not locate any hidden or concealed mineral deposits, with the exception of a drilling program in the Tertiary plutons that could explore the possibility of molybdenite deposits at depth.

\section{REFERENCES}

Coxe, B. W., and Toth, M. I., 1983, Geochemical maps of the SelwayBitterroot Wilderness, Idaho County, Idaho, and Missoula and Ravalli Counties, Montana: U.S. Geological Survey Miscellaneous Field Studies Map MF-1495-C, scale 1:125,000.

Coxe, B. W., Mosier, E. L., and McDougal, C. M., 1982, Analyses of rocks and stream sediments from the Selway-Bitterroot Wilderness Area, Idaho County, Idaho, and Missoual and Ravalli Counties, Montana: U.S. Geological Survey report; available from the U.S. Department of Commerce, National Technical Information Service, Springfield, VA 22161, as Report PB 82-253386.

Koesterer, M. E., Bartel, A. J., Elsheimer, H. N., Baker, J. W., King, B. S., and Espos, L. F., 1982, Major-element XRF spectroscopy analyses from the Selway-Bitterroot Wilderness, Idaho County, Idaho, and Missoula and Ravalli Counties, Montana: U.S. Geological Survey Open-File Report 82-1023, 36 p.

Toth, M. I., 1983, Reconnaissance Geologic Map of the SelwayBitterroot Wilderness, Idaho County, Idaho and Missoula and Ravalli Counties, Montana: U.S. Geological Survey Miscellaneous Field Studies Map MF-1495-B, scale 1:125,000.

Toth, M. I., Coxe, B. W., Zilka, N. T., and Hamilton, M. M., 1983, Mineral resource potential of the Selway-Bitterroot Wilderness, Idaho County, Idaho and Missoula and Ravalli Counties, Montana: U.S. Geological Survey Miscellaneous Field Studies Map MF-1495-A, scale 1:125,000.

Zilka, N. T., and Hamilton, M. M., 1982, Mineral investigation of the Selway-Bitterroot Wilderness, Idaho County, Idaho and Missoula and Ravalli Counties, Montana: U.S. Bureau of Mines Mineral Land Assessment Report MLA 102-82, 14 p. 


\title{
SPECIAL MINING MANAGEMENT ZONE-CLEAR GREEK, IDAHO
}

\author{
Karen Lund, U.S. GeOloGical Survey, and \\ LEON E. EsParZa, U.S. BUREAU OF MineS
}

\section{SUMMARY}

On the basis of mineral-resource surveys conducted by the USGS and USBM in 1981 and 1982, a substantiated resource potential for sediment-hosted cobaltcopper-gold-silver deposits has been identified in the Elkhorn and upper Garden Creek areas of the Special Mining Management Zone-Clear Creek, Idaho. Evidence supporting this identification includes the nature of the host rocks which are correlatives of the Yellowjacket Formation, anomalously high cobaltcopper values, tourmaline breccia, and cobalt and copper oxides in outcrop. Areas of favorable host rock, but with less strong evidence of mineralization, were classified as having probable resource potential for the same kind of deposit. A probable resource potential for porphyry-type copper-molybdenum deposits is assigned to areas along Clear Creek and upper Squaw Gulch based on the presence of extensive stockwork fracturing and alteration of the nonporphyritic granite, introduced disseminated magnetite, and the close proximity of known Tertiary plutons. The nature of the geologic terrain makes the occurrence of organic fuels on geothermal resources extremely unlikely.

\section{CHARACTER AND SETTING}

The Special Mining Management Zone-Clear Creek, Lemhi County, Idaho, includes $61 \mathrm{sq} \mathrm{mi}$ and is located in the Salmon River Mountains $24 \mathrm{mi}$ west of Salmon, Idaho. The area is about $6 \mathrm{mi}$ north of the Blackbird cobalt mine, the largest mine in the United States worked primarily for cobalt. This triangular-shaped area has rugged topography with alpine ridges on the southwest side and the deeply incised canyons of Panther Creek and the Salmon River on the east and north sides. The northeast-flowing streams, Clear Creek and Garden Creek, are the major drainages within the area. Maximum relief is from Dome Mountain, $9316 \mathrm{ft}$ in altitude, to the mouth of the Middle Fork of the Salmon River at an altitude of $3027 \mathrm{ft}$, across a distance of $5.6 \mathrm{mi}$.

Geologically, the area is underlain by Proterozoic metasedimentary rocks which lie south of the main mass of the Bitterroot lobe of the Idaho batholith and east of the main mass of the Atlanta lobe of the Idaho batholith. Rocks of the Bighorn Crags pluton are immediately southwest. Most of the Proterozoic metasedimentary rocks within the area correlate with the Yellowjacket Formation and are part of a northwest-trending zone continuous with rocks of the Yellowjacket Formation observed at the Blackbird mine.

Biotite-feldspar metagraywacke and garnet-biotite schist underlie most of the area. Recognized within these units are tourmaline breccias, possible chert beds, and possible metamorphosed mafic tuffaceous layers. In the northwestern part of the area, primary sedimentary features have been obliterated by intense deformation; the rocks of lowest metamorphic grade in the southern and eastern parts of the area retain fine laminations, possible graded bedding, and crossbedding, although a foliation parallel to bedding may indicate more structural complexity than is apparent in outcrop. These rocks are correlated with the Yellowjacket Formation, which is the host for all known cobalt mineralization in the region.

Multiple phases of deformation affected the metagraywacke and schist. The first event created primary foliation parallel to bedding, which was subsequently folded into tight to isoclinal folds and overprinted by a secondary foliation. This is especially pervasive in the northwestern part of the area where intrafolial folds are common. Finally, a gently northward plunging series of folds is superimposed on the earlier foliations and folds.

Biotite granite occurs as two phases. One is a 

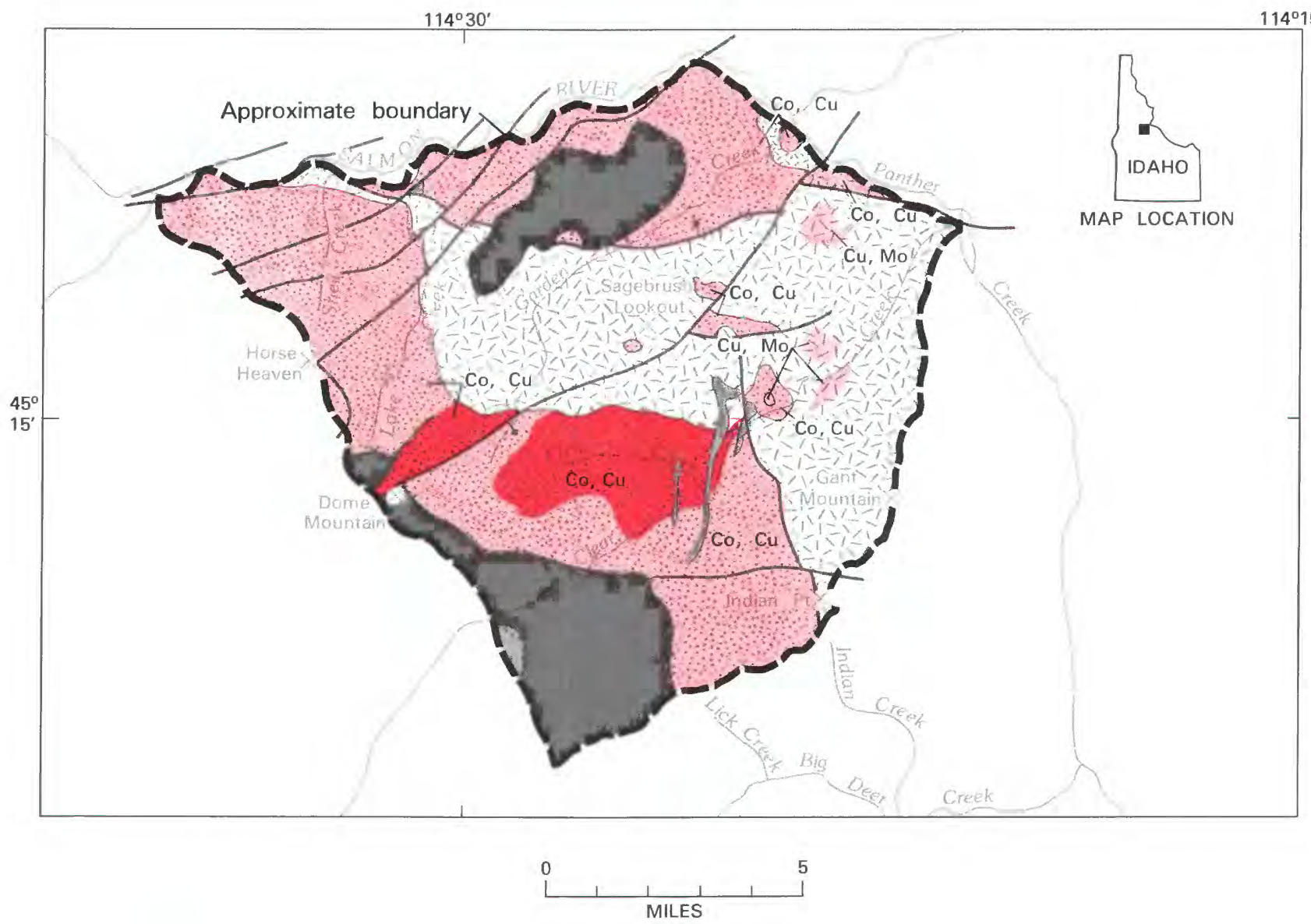

\section{EXPLANATION}

Geologic terrane with substantiated mineral-resource potential

Geologic terrane with probable mineral-resource potential

Co Cobalt

$\mathrm{Cu}$ Copper

Mo Molybdenum

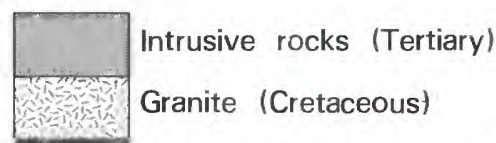

Big Creek Formation (Middle Proterozoic)

1 1 Granite (Middle Proterozoic)

Yellowjacket Formation (Middle Proterozoic)

Contact

- Fault--Bar and ball on downthrown side

Thrust fault--Sawteeth on upper plate

Figure 169,-Special Mining Management Zone-Clear Creek, Idaho. 
medium- to coarse-grained, weak to strongly foliated, porphyritic variety with large (commonly 5-15 cm), gray or pink potassium-feldspar phenocrysts often rimmed with plagioclase; the other is a nonporphyritic, medium- to coarse-grained, strongly foliated phase. These comagmatic granites are part of intrusions which have been dated at 1370 million years (Evans and Zartman, 1981). Contacts with the host Yellowjacket rocks are both intrusive and faulted; and a thrust fault places a metaquartzite unit on the granite.

Fine- to coarse-grained, slightly feldspathic, white or $\tan$ metaquartzite occurs as allochthonous plates which have been moved over the Yellowjacket Formation and Proterozoic granite along a thrust or low-angle normal fault, as evidenced by brecciation and greatly disparate attitudes of foliation and bedding across the contact. The metaquarzite is correlated to the Middle Proterozoic Big Creek Formation. Bedding is generally massive, with sparse crossbedding and finely laminated, biotitic layers. Analysis of the geologic map is suggestive of thrusting, but post-thrust steeply dipping faults, which make up all other Big Creek-Yellowjacket contacts in the area, have probably modified the dip of the basal fault surface.

Tan, medium-grained, nonfoliated to weakly foliated, two-mica granite, possibly an outlier of the main phase of the Idaho batholith, is exposed in Owl Creek several miles north of the area. The two-mica granite intrudes metagraywacke and schist near the mouth of Panther Creek and is partly truncated by steep faults.

Scattered dikes and small stocks of pink, mediumgrained, biotite granite, porphyritic rhyolite, and porphyritic dacite occur in the area and are related to the Tertiary Bighorn Crags pluton which crops out on Clear Creek at the southwestern edge of the management zone.

Quaternary alluvial and colluvial deposits are found in the Salmon River and Panther Creek canyons. Valleyglacier moraine and outwash are found in Clear Creek.

Generally, northeast-southwest and east-west trending, steep faults control the exposure of the allochthonous Proterozoic metaquartzite and the Proterozoic granite. In the northwestern part of the area, the higher-grade metasedimentary rocks may have been uplifted along the steep faults; an original increase in metamorphic gradient in that direction is likely. Movement on some of the faults has probably been recurrent, but a partial sequence of fault movements can be established. Hughes (1983) suggests that some of these faults may have been syndepositional with the Yellowjacket Formation and may have controlled sedimentation, volcanism, and ore deposition within the Yellowjacket basin. The youngest evidence of faulting is indicated by offset Cretaceous and Tertiary intrusive rocks.
Although there is no history of mining activity in the management zone, production records indicate mining activity occurred in the adjacent Mineral Hill, Mackinaw (Leesburg), and Blackbird districts. Nearly all production from the Blackbird mining district is from the vicinity of the Blackbird mine. Gold, silver, copper, and lead were mined mainly from the late 1800's and prior to the 1940's; cobalt was mined from the Blackbird district mainly in the early 1900's and in the 1950's. Mining activity in the Mackinaw and Mineral Hill mining districts is currently active.

As of 1982, at least 40 mining claims had been recorded in the management zone; few claims had been located prior to 1960 . Mills and facilities for processing the cobalt and copper ores mined near the management zone exist at the Blackbird mine. Other mills, for copper, gold, silver, and lead, exist in the Mackinaw and Mineral Hill mining districts.

\section{MINERAL RESOURCES}

Based on mapping and geochemical sampling integrated with the regional geology and known mineral systems in east-central Idaho, potential was found in the management zone for sediment-hosted cobaltcopper and porphyry-type copper-molybdenum deposits.

The Elkhorn and upper Garden Creek areas in the management zone have substantiated potential for the occurrence of cobalt-copper resources. Both have anomalous values of cobalt, copper, and boron in stream-sediment samples, and outcrops near Elkhorn Creek have visible cobalt mineralization. Of the features coincident with ore at the Blackbird mine (Hughes, 1983; Karen Lund, unpub. data, 1983), both areas in the management zone have the appropriate stratigraphy, possible mafic volcanics and exhalative(?) cherts, and tourmaline breccias. In addition, the Garden Creek area is cut by amphibolites which were probably originally mafic dikes. Syndepositional faulting through the region is postulated by Hughes (1983), although this study cannot confirm this. The combination of these factors suggests a substantiated potential for cobalt resources. All areas underlain by Yellowjacketequivalent rocks are assigned a probable potential based on the geologic environment and regional patterns consistent with the favorable factors mentioned above.

A probable potential for porphyry-type coppermolybdenum mineralization is assigned to an area along Clear Creek below Rancherio Creek and in upper Squaw Gulch, where bright-reddish-orange gossans are developed in the Proterozoic foliated, nonporphyritic granite. Extensive stockwork fracturing, quartz and limonite 
veining, alteration (possibly potassic), disseminated magnetite, and the bleaching of originally dark gray metasedimentary rocks to white "quartzites" are all features attributable to a major hydrothermal system and suggest the presence of a buried Tertiary(?) pluton. A small exposure of what appears to be epizonal, Tertiary pink granite in a fault block at the mouth of Rancherio Creek provides added credence to this interpretation. The intersection of major regional structural trends inferred from aeromagnetic data and mapping may indicate some structural control. Molybdenum mineralization similar to that inferred here probably is present a few miles east of Panther Creek near the headwaters of Beaver Creek (Bennett, 1977) and at the Napolean Ridge prospect yet farther east near North Fork, Idaho (Bennett, 1980).

\section{SUGGESTIONS FOR FURTHER STUDIES}

Further studies on the regional geology, stratigraphy of the Yellowjacket Formation, age and nature of the in- trusive rocks, and age and origin of mineralization are currently being conducted.

\section{REFERENCES}

Bennett, E. H., 1977, Reconnaissance geology and geochemistry of the Blackbird Mountain-Panther Creek region, Lemhi County, Idaho: Idaho Bureau of Mines and Geology Pamphlet No. 167, $108 \mathrm{p}$.

1980, Granitic rocks of Tertiary age in the Idaho batholith and their relation to mineralization: Economic Geology, v. 75, p. 278-288.

Evans, K. V., and Zartman, R. E., 1981, U-Th-Pb zircon geochronology of Proterozoic $\mathrm{Y}$ granitic intrusions in the Salmon area, east-central Idaho: Geological Society of America Abstracts With Programs, v. 13, no. 4, p. 195.

Hughes, G. B., 1983, The basinal setting of the Blackbird District cobalt deposits, Lemhi County, Idaho: Denver Regional Exploration Geologists Society Symposium, p. 21-28.

Lund, Karen, Evans, K. V., and Esparza, L. E., 1983, Mineral resource potential map of the Special Mining Management Zone-Clear Creek, Lemhi County, Idaho: U.S. Geological Survey Miscellaneous Field Studies Map MF-1576-A, scale $1: 50,000$. 


\title{
TEN MILE WEST ROADLESS AREA, IDAHO
}

\author{
By THOR H. KillsgaARD, ${ }^{1}$ U.S. GeOlOGical SuRVEY, and \\ JOHN R. BENHAM, U.S. BUREAU OF MiNES
}

\begin{abstract}
SUMMARY
A mineral survey of the Ten Mile West Roadless Area, Idaho, conducted from 1979 to 1982 disclosed the presence of a northwest-trending mineralized belt that extends completely across the area. The belt has probable resource potential and field evidence indicates that smaller parts of it, at the head of Grouse Creek, on the ridge south of Johnson Creek, in Bayhouse Pass, near Graham Peak, near the mouth of Johnson Creek, northwest of Big Silver Creek, and south of Crooked River have substantiated resource potential for one or more of the metals silver, gold, and molybdenum. Further studies and mineral exploration are needed to determine the extent and grade of these deposits. There is also an area of probable resource potential for gold, silver, and copper at the head of Chapman Creek in the northeast part of the area. The nature of the geologic terrain precludes the occurrence of oil and gas or coal resources.
\end{abstract}

\section{CHARACTER AND SETTING}

The Ten Mile West Roadless Area, Boise and Elmore Counties, Idaho, includes about $133 \mathrm{sq}$ mi of terrain that adjoins the western side of the Sawtooth Wilderness. It can be reached by traveling northeast from Idaho City on State Highway 21 to the junction with the gravel road that leads to Atlanta. The gravel road is followed to the mouth of Banner Creek, where an unimproved road leads to the old mining camp of Graham in the center of the roadless area. Drainage of the area is principally by way of the North Fork Boise River and its tributaries, although the northern part is drained by Ten Mile Creek, which empties into the South Fork Payette River about 12 mi east of Lowman.

The entire roadless area is underlain by granitic rocks, most of which belong to the Cretaceous Idaho batholith, an enormous body of granitic rock that underlies most of central Idaho. In addition, there are two varieties of younger or Tertiary granitic rock in the roadless area: hornblende granodiorite and other mafic rocks that have intruded the Idaho batholith and extend southeast from Jackson Peak, and younger red granite that is part of the Sawtooth batholith and is well exposed in the vicinity of Wolf Mountain. Intruding all three of the different types of granitic rock are countless younger igneous dikes. All of the rocks are offset along faults,

\footnotetext{
${ }^{1}$ With contributions by Dale W. Avery, USBM.
}

some of which are of regional extent. The Deer Park fault is at least $30 \mathrm{mi}$ long, and, in the vicinity of Deer Park, forms an escarpment the base of which marks the southwestern border of the roadless area. Rocks east of the fault are displaced upward with respect to those on the west and account for the location of Swanholm Peak, Goat Mountain, and other high ridges in the upthrown block. The Montezuma fault has been traced more than $15 \mathrm{mi}$ southeast, to beyond the Atlanta mining district, but it has not been found northwest of North Fork Boise River. The Bear River fault may represent the faulted extension of the Montezuma fault, in which case the extension has been offset by a fault inferred to extend northeast along the North Fork Boise River. The Montezuma fault is of particular significance because of the number of known mineral deposits, including the formerly productive Atlanta gold district, that occur along the western or downthrown side of the fault (Kiilsgaard and others, 1970). Field work for the survey reported here was done in 1979, and in parts of 1980, 1981, and 1982 and results have been released (Kiilsgaard, 1983a, b, c; Benham and Avery, 1983).

\section{MINERAL RESOURCES}

The Ten Mile West Roadless Area is crossed by a northwest-trending belt of faulted and altered rocks that has probable potential for silver, gold, and molybdenum resources. A smaller area at the head of 


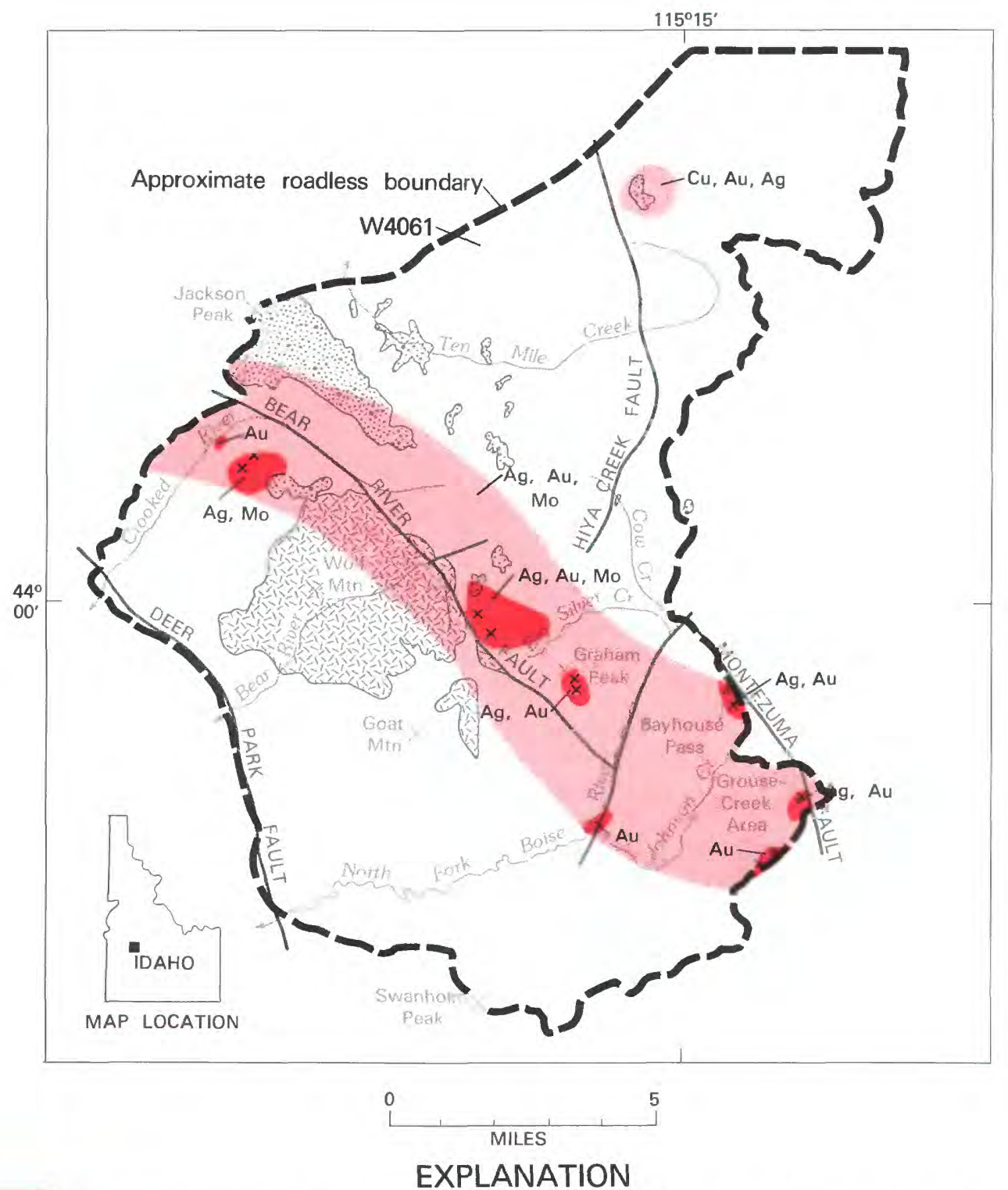

Geologic terrane with substantiated mineral-resource potential

Granite of Sawtooth batholith (Tertiary)

Geologic terrane with probable mineral-resource potential

Granodiorite of Jackson Peak (Tertiary)

$\begin{array}{ll}\text { Cu } & \text { Copper } \\ \text { Au } & \text { Gold } \\ \text { Mo } & \text { Molybdenum } \\ \text { Ag } & \text { Silver } \\ \text { X } & \text { Mineral occurrence }\end{array}$

Granitic rocks of the Idaho batholith (Cretaceous)

Contact

Fault

Figure 170.-Ten Mile West Roadless Area, Idaho. 
Chapman Creek, near the northern boundary of the area, also has a probable potential for mineral resources, although evidence of mineralization here is weaker than in the main belt. Placer gold has been found in terrace gravels and alluvium along North Fork Boise River and Crooked River.

The northwest-trending mineralized belt is about $2 \mathrm{mi}$ wide and extends more than 15 mi southeast of the Ten Mile West Roadless Area to and beyond the goldproducing district at Atlanta. Numerous quartz veins and hydrothermally altered and mineralized rocks crop out in the belt. Many of the mineralized sites have been prospected and some mined. Within the roadless area several areas of substantiated resource potential occur in the mineralized belt and include silver-gold deposits in the Grouse Creek area, gold-silver deposits on the ridge above Johnson Creek on the southern border of the roadless area, silver deposits in Bayhouse Pass, silver prospects in the vicinity of Graham Peak, silvergold quartz veins on ridges above Big Silver Creek, and a silver-molybdenum locality south of Crooked River. Two areas of substantiated placer gold resource potential occur within the belt, one along the Crooked River and one along the North Fork Boise River.

Exploration for silver and gold in the roadless area dates from the early 1880 's, when activity began at the old mining camp of Graham. Mine workings were excavated near the ridge top south of Graham Peak, and an aerial tramway was built from the mine to a mill which was built at the former town of Graham. At least 10 adits were driven near Graham Peak but only 4 were open in 1982. Assays from 43 samples taken in and near the workings ranged from 0.2 to $5.0 \mathrm{oz}$ silver/ton and 0.005 to $0.62 \mathrm{oz}$ gold/ton.

Several mine workings in highly altered granitic rock in the Bayhouse Pass area are on the southwest side of the Montezuma fault. Assays from 10 samples taken from workings and outcrop contained as much as 14.6 oz silver/ton, 1.0 percent zinc, 0.7 percent lead, 0.3 percent copper, and 0.07 percent bismuth. Sediment samples from the area were anomalous in silver, molybdenum, lead, and copper.

Caved adits, trenches, and pits in the upper Grouse Creek area, in altered granite southwest of the Montezuma fault, explore a vein more than $1000 \mathrm{ft}$ long (Kiilsgaard and others, 1970). Ten samples taken from the vein outcrop and prospect workings contained as much as $3.5 \mathrm{oz}$ gold/ton, $4.4 \mathrm{oz}$ silver/ton, 2.0 percent lead, and 0.15 percent zinc. A stream-sediment sample from a small stream north of the prospected area was anomalous in silver and lead, which suggests the possibility of other mineralized occurrences in the area.

Southwest of the Grouse Creek mine workings, on the ridge top between Black Warrior and Johnson Creeks, are some prospect pits and a short adit that explore an altered and mineralized zone. Samples from the dumps gave high gold values, one sample containing $3.2 \mathrm{oz}$ gold/ton (Kiilsgaard, 1982c).

Several northwest-striking quartz veins that range from 6 in. to $2 \mathrm{ft}$ in thickness cross the ridge immediately northwest of Big Silver Creek. Chip samples across these veins contained from 0.9 to $1.3 \mathrm{oz}$ silver/ton and from 0.001 to $1.2 \mathrm{oz}$ gold/ton. On the ridge $2500 \mathrm{ft}$ northwest, a sample taken across what probably is a continuation of one of the quartz veins, also was enriched in silver and gold. Erosion of these veins probably accounts for the anomalous amounts of silver detected in stream-sediment samples taken from streams that drain the area.

A number of 160-acre placer claims have been located in the area. Seven claims are located along Crooked River, 4 along North Fork Boise River and 11 along Cow Creek. Gravel was sampled for placer gold at 57 sites along the Crooked and North Fork Boise Rivers and gold was found at 27 of the sites. One locality along Crooked River contains $3400 \mathrm{cu}$ yds in which the gold content is valued at $\$ 0.32 / \mathrm{cu}$ yd (at a gold price of $\$ 400 /$ oz). Three localities along the North Fork Boise River, above the mouth of Johnson Creek, contain $434,000,75,000$ and $32,000 \mathrm{cu}$ yds in which the gold content is valued at $\$ 0.58, \$ 0.89$ and $\$ 1.22 / \mathrm{cu}$ yd, respectively. These areas have substantiated gold resource potential.

Stream-sediment samples anomalous in molybdenum are clustered in two areas of probable resource potential in the mineralized belt in the Ten Mile West Roadless Area: in the vicinity of Big Silver Creek and at streams draining into Crooked River near the western boundary of the belt. Molybdenum in the Silver Creek sediments could have been derived from the quartz veins that crop out on the ridges between Big and Little Silver Creeks; however, samples from those veins are low in molybdenum content. Granodiorite making up the ridge immediately north of Big Silver Creek is intensely altered and is cut by many small quartz veins. It is possible that concentrations of molybdenum occur in those rocks but more sampling and exploration would be needed to verify its occurrence.

Near the western boundary of the roadless area, south of the bend in Crooked River, are two molybdenum occurrences that have been tested by prospect pits. The two localities are on separate ridges about $1500 \mathrm{ft}$ apart. Both sets of workings appear to explore the same mineralized zone. Fragments of quartz as much as 1-ft thick litter the dumps and suggest that a fairly thick vein was explored. Two samples of quartz from the dumps contained low values in silver and molybdenum; however, sediment samples from streams that drain the mineralized area and from streams that drain an area west of the known mineralized locality were anomalous in 
molybdenum. The clustering of anomalous streamsediment samples indicates wider spread mineralization than was seen at the outcrop and the area is assessed a probable resource potential.

Several stream-sediment samples, collected from tributary streams at the head of Ten Mile Creek, in an area of probable mineral-resource potential in the northern part of the area, were anomalous in one or more of the elements lead, fluorine, copper, and uranium. The anomalies suggest mineralized outcrops in the area but only one was found. Sample localities suggest that the mineralized sources may be related to an exposure of hornblende granodiorite of the Jackson Peak stock.

\section{SUGGESTIONS FOR FURTHER STUDIES}

The Ten Mile West Roadless Area warrants further study to better define its mineral-resource potential. In particular, the altered rocks in the northwest-trending mineralized belt warrant large-scale mapping and more intensive rock and stream-sediment sampling, the objectives of which should be to more adequately outline the known mineralized localities and to better define other localities where field evidence suggest other mineral deposits may occur.

\section{REFERENCES}

Benham, J. R., and Avery, D. W., 1983, Mineral investigation of the Ten Mile West RARE II Area (No. 4061), Boise and Elmore Counties, Idaho: U.S. Bureau of Mines Open-File Report MLA 63-83.

Kiilsgaard, T. H., 1983a, Geologic map of the Ten Mile West Roadless Area, Boise and Elmore Counties, Idaho: U.S. Geological Survey Miscellaneous Field Studies Map MF-1500-A.

1983b, Geochemical map of the Ten Mile West Roadless Area, Boise and Elmore Counties, Idaho: U.S. Geological Survey Miscellaneous Field Studies Map MF-1500-B.

1983c, Analytical determinations from samples taken in the Ten Mile West Roadless Area, Boise and Elmore Counties, Idaho: U.S. Geological Survey Open-File Report 82-1099.

Kiilsgaard, T. H., Benham, J. R., and Avery, D. W., 1983, Mineral resource potential map of the Ten Mile West Roadless Area, Boise and Elmore Counties, Idaho: U.S. Geological Survey Miscellaneous Field Studies Map MF-1500-C, scale 1:62,500.

Kiilsgaard, T. H., Freeman, V. L., and Coffman, J. S., 1970, Mineral resources of the Sawtooth Primitive Area: U.S. Geological Survey Bulletin 1319-D, 174 p. 


\title{
UPPER PRIEST ROADLESS AREA, IDAHO
}

\author{
By F. K. Miller, U.S. Geological Survey, and \\ D. K. Denton, JR., U.S. Bureau of Mines
}

\begin{abstract}
SUMMARY
A mineral survey of the Upper Priest Roadless Area in northern Idaho, completed in 1979 indicates that the roadless area has little promise for the occurrence of metallic mineral or energy resources. Small amounts of zinc, lead, silver, tin, and tungsten were detected in pan concentrates of stream-sediment samples, but these metals probably were derived from weathering of scattered, sparsely mineralized quartz veins common to the region and no resource potential was identified.
\end{abstract}

\section{CHARACTER AND SETTING}

The Upper Priest Roadless Area is located north of Priest Lake in Bonner County, Idaho. This area is about 75 mi northeast of Spokane, Washington and lies completely in the Kaniksu National Forest. The area coincides with the Upper Priest Lake Scenic Area established on May 25, 1967, and covers most of Plowboy Mountain on the west side of the lake. A small noncontiguous area is located on the east side of the lake. Upper Priest Lake is about $2 \mathrm{mi}$ north of Priest Lake, and is reached by trail or boat on the navigable portion of Priest River that connects the two lakes. Trail head and boat-launching facilities at Priest Lake are accessible by a paved side road from Idaho State Highway 57. The roadless area contains $6 \mathrm{sq} \mathrm{mi}$, ranges in altitude from $2438 \mathrm{ft}$ to $5130 \mathrm{ft}$, and is all heavily timbered. Based on the results of the geologic and geochemical studies (Miller 1983), a geophysical study was considered unnecessary. A portable scintillometer with an audio alarm was carried throughout the geologic work to detect the presence of radioactive minerals.

The Upper Priest Roadless Area is underlain chiefly by the Prichard Formation of the Belt Supergroup, and by several diabase sills that intrude the Prichard. The Prichard Formation is about equal parts quartzite, siltite, and argillite. Both the sedimentary rock and the sills are more than 1.4 billion years old. The Granite Pass and Tango Creek granitic plutons, each about 100 million years old, intrude the 1.4 billion year old rocks. The granodiorite of Trapper Creek, between 50 and 100 million years old, is faulted against the older sedimentary unit. Young glacial deposits mantle all bedrock units at lower altitudes.
The Upper Priest Roadless Area straddles two fundamentally different geologic terranes that are separated by the Newport fault. East of the Newport fault are two-mica granitic rocks and high-rank metamorphic rocks; west of the fault are relatively unmetamorphosed rocks of the Belt Supergroup and hornblende-biotite and two-mica granitic plutons. Most of the roadless area lies west of the fault, and structurally consists of open north-northeast trending folds in the Prichard Formation.

Prospecting activity around Upper Priest Lake began in 1886 , and by 1908,30 prospects were located on the shores and in the surrounding hills. Bonner County mining-claim records indicate 105 lode claims were located in the roadless area between 1886 and 1967, but no production is recorded for any of them. The roadless area is in the Priest Lake mining district.

\section{MINERAL RESOURCES}

Trace amounts of silver and lead mineralization occur in widely scattered quartz veins in the Prichard Formation. Most prospects in the area are located on or near these quartz veins; a few are on fracture zones in quartzite, or on diabase sills. Analysis of panned-concentrate and bulk-sediment samples from streams show slightly anomalous amounts of zinc, lead, tin, tungsten, and silver in one or both sample types, but these concentrations probably reflect sparse mineralization in the widely scattered quartz veins. Tin and tungsten, along with detectable amounts of bismuth, in the panned concentrates probably occur in heavy resistant minerals derived from weathering of the Granite Pass pluton. No 


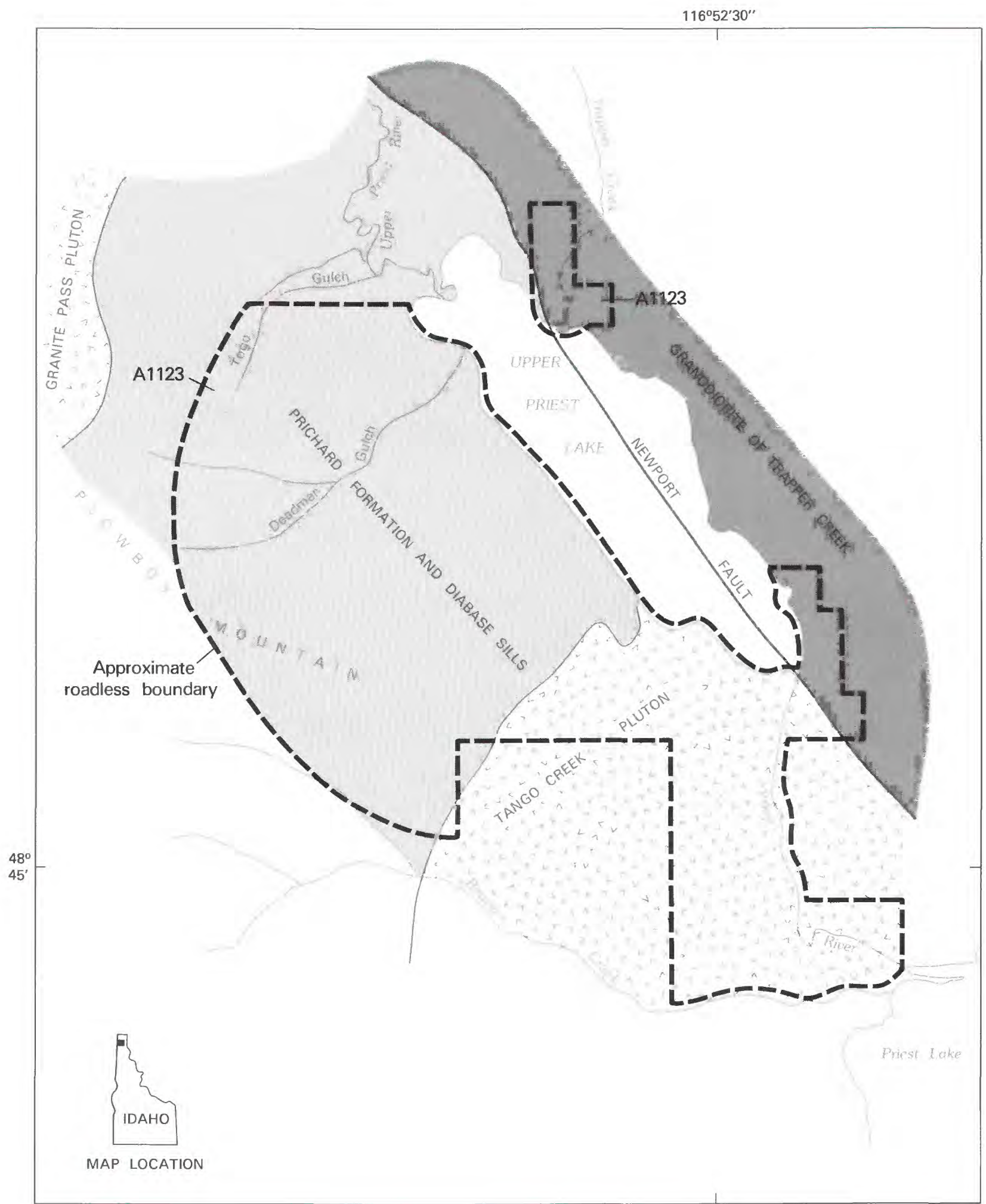

No Quaternary deposits shown

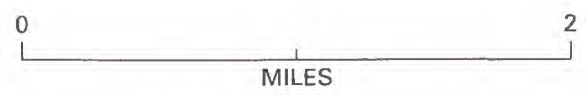

Figure 171.-Upper Priest Roadless Area, Idaho. 
tungsten mineralization was seen in outcrop, and the dearth of carbonate minerals in the Prichard Formation precludes large-scale skarn-type tungsten mineralization. Greater than average amounts of cobalt, chromium, copper, nickel, and vanadium in panned concentrates reflect the contribution of heavy mafic minerals derived from the diabase sills.

No mineral-resource potential for these metals was identified in the Upper Priest Roadless Area. Scintillometer readings indicate that the background radioactivity of both the Granite Pass and Tango Creek plutons is higher than most granitic rocks in the region, but there is no indication of any significant concentrations of uranium or thorium in, or immediately adjacent to, the roadless area. No potential for fossil fuels was identified.

\section{SUGGESTIONS FOR FURTHER STUDIES}

Further study of the Upper Priest Roadless Area offers little promise for identification of hidden mineral deposits.

\section{REFERENCES}

Miller, F. K., 1983, Geology and Geochemistry of the Upper Priest Roadless Area (A1-123), Bonner County, Idaho: U.S. Geological Survey Miscellaneous Field Studies Map MF-1448-A, scale $1: 48,000$.

Miller, F. K., Denton, D. K., Jr., 1983, Mineral resource potential map of the Upper Priest Roadless Area (A1-123), Bonner County, Idaho: U.S. Geological Survey Miscellaneous Field Studies Map MF-1448-B, scale 1:48,000. 


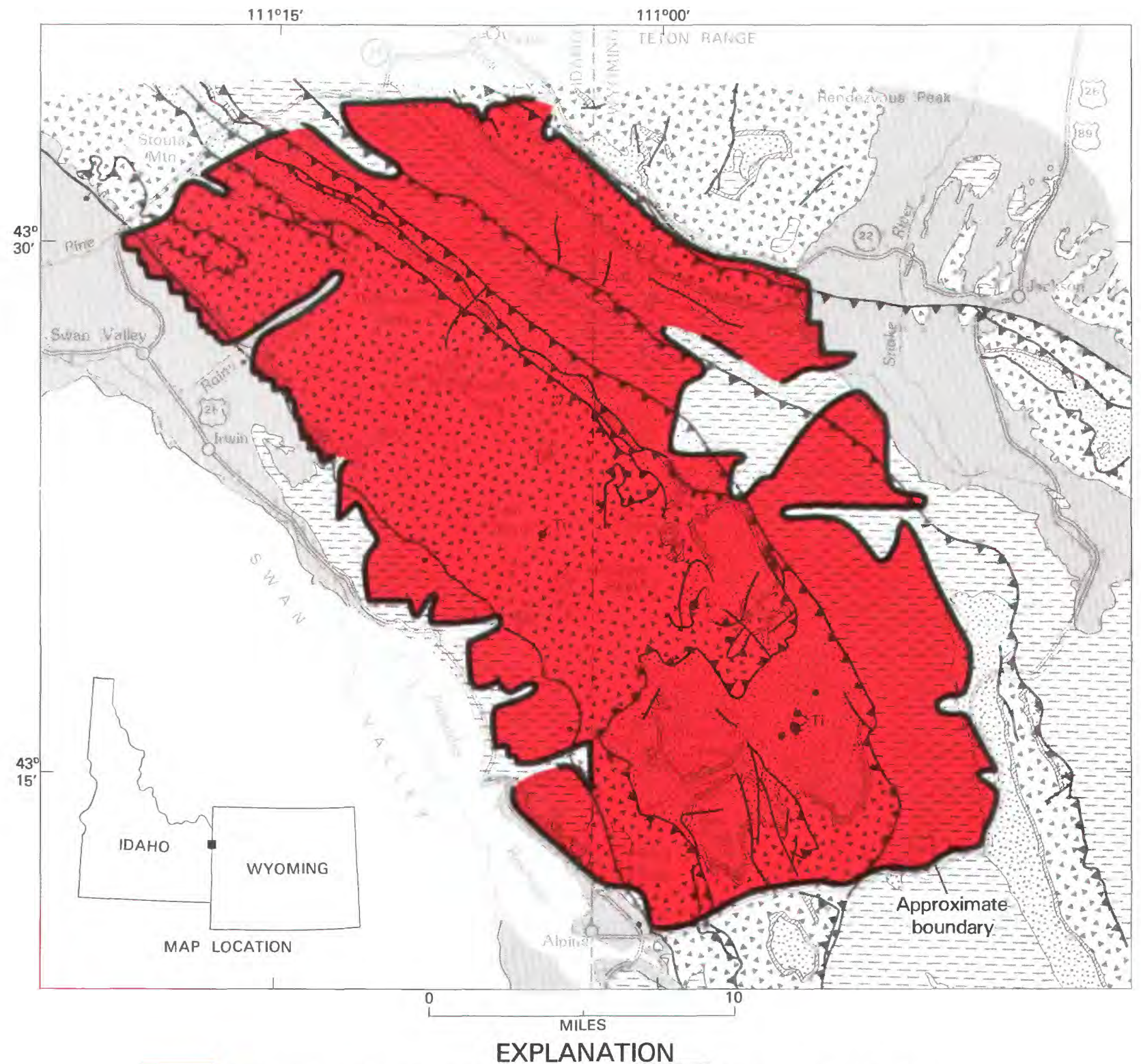

Geologic terrane with substantiated oil and gas resource potential

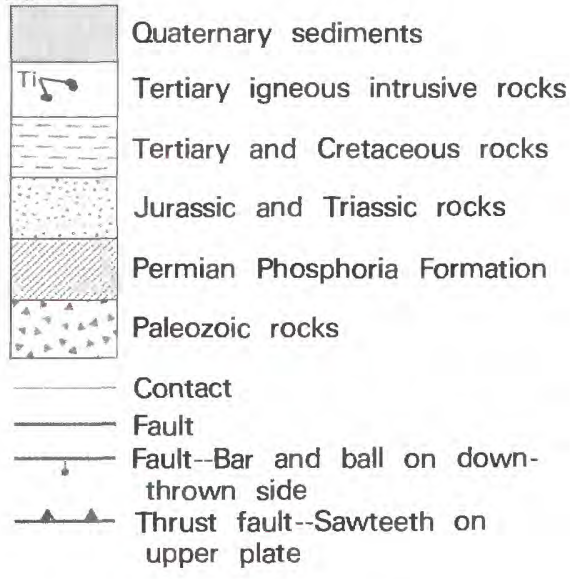

Figure 172.-West and East Palisades Roadless Areas, Idaho and Wyoming. 


\title{
WEST AND EAST PALISADES ROADLESS AREAS, IDAHO AND WYOMING
}

\author{
Steven S. Oriel, ${ }^{1}$ U.S. GeOlogical Survey, and \\ JOHN R. BENHAM, U.S. BUREAU OF MINES
}

\begin{abstract}
SUMMARY
Studies from 1979 to 1982 of the West and East Palisades Roadless Areas, which lie within the Idaho-Wyoming thrust belt, document structures, reservoir formations, source beds, and thermal maturities comparable to those in producing oil and gas fields farther south in the belt. Therefore, the areas are highly favorable for the occurrence of oil and gas. Phosphate beds of appropriate grade within the roadless areas are thinner and less accessible than those being mined from higher thrust sheets to the southwest; however, they contain 98 million tons of inferred phosphate rock resources in areas of substantiated phosphate resource potential. Sparsely distributed thin coal seams occur in the roadless areas. Although moderately pure limestone is present, it is available from other sources closer to markets. Geochemical anomalies from stream-sediment and rock samples for silver, copper, molydenum, and lead occur in the roadless areas but they offer little promise for the occurrence of metallic mineral resources. A possible geothermal resource is unproven, despite thermal phenomena at nearby sites.
\end{abstract}

\section{CHARACTER AND SETTING}

The West and East Palisades Roadless Areas encompass about $386 \mathrm{sq} \mathrm{mi}$ of the Snake River Range along the Idaho-Wyoming boundary. They lie within the Targhee and Bridger National Forests in Teton and Bonneville Counties, Idaho, and Teton and Lincoln Counties, Wyoming. The two roadless areas, considered here as one study area, extend from Alpine and the Grand Canyon of the Snake River in Wyoming, northward to Pine Creek and the Teton Basin near Victor, Idaho. Jackson, Wyoming, lies $7 \mathrm{mi}$ east of the northern part of the study area. The study area is bounded on the southwest by Swan Valley, in which lies the U.S. Bureau of Reclamation Palisades Reservoir, used for both irrigation and generation of electrical power.

Altitudes in the study area range from about $5600 \mathrm{ft}$ in Swan Valley to $10,025 \mathrm{ft}$ at Mount Baird. The flanks of the range, in contrast to its crest, are heavily forested. The sinuous east boundary of the study area excludes several logging trails to timbered areas, some of which have been clear-cut, as along Mosquito Creek, and only pack trails traverse the roadless areas.

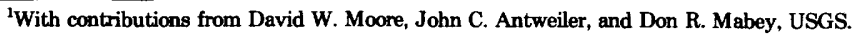

Investigations were begun by the USBM during the summer of 1979 , and by the USGS during the summer of 1980 , to assess the mineral-resource potential. These investigations, have included trenching and sampling of phosphate beds, geochemical sampling, and gravity and aeromagnetic surveys.

Bedrock of the study area consists overwhelmingly of westward thickening Paleozoic and Mesozoic layers of resistant limestone, quartzite, and dolomite, which form ridge crests, and weaker mudstone, claystone, and sandstone, which form valleys. These strata have been transported laterally tens of miles eastward and northeastward, in large thrust sheets which are folded and cut by imbricate thrust slices. The strata are locally intruded by igneous rocks exposed now in several small bodies. Strata in the thrust sheets are unconformably overlain locally by upper Cenozoic volcanic ashfalls and ashflows with interbedded terrestrial sediments, and by sediments of even younger, latest Cenozoic age. The rocks were deformed not only in response to the compressive stresses which produced thrusting and folding, but also by later uplift of the southwestern flank of the Snake River Range, as sediments in Swan Valley were tilted down. Very ancient Archean (older than 2500 million years) basement rocks present in the nearby Teton 
Range, to the north, are not exposed in the roadless areas.

\section{MINERAL RESOURCES}

The study area is highly favorable for petroleum exploration, the commodity of greatest interest. The study area lies in the northern part of the IdahoWyoming-Utah thrust belt. Numerous highly productive oil and gas fields have been found (Petroleum Information, 1981; Ver Ploeg and De Bruin, 1982) and continue to be found about $100 \mathrm{mi}$ southward within the belt in southwesternmost Wyoming and northern Utah. The same formations are present throughout the belt, including the same type of potential reservoirs, the same hydrocarbon source beds, and comparable thermal maturities. Comparable structures, including anticlines which may entrap oil and gas both above and below major thrust faults, are present throughout the belt. Some structures, like those that are buried and productive to the south, are now exposed to erosion in the study area, and hydrocarbons that may have been present have escaped. Nevertheless, comparable structures are also present at depth, beneath the several thrust sheets, as indicated by exposed structural relationships. Eastward thinning of most Paleozoic and Mesozoic units, which are inclined predominantly to the west, is favorable for the presence of numerous stratigraphic, as well as structural, traps.

The oil and gas potential we and others (Powers, 1978) recognize for the study area is based on the presence of favorable source beds, potential reservoirs, structural and stratigraphic traps, and thermal maturities, comparable to those in the already proven, highly productive southern part of the Idaho-Wyoming thrust belt.

Vanadium-bearing phosphate rock is present in the Meade Peak Phosphatic Shale Member of the Permian Phosphoria Formation. The formation crops out extensively in the roadless areas, but its continuity is disrupted by thrust faults. Sampling and analyses of the member in stratigraphic sections and trenches that represent $74 \mathrm{mi}$ of strike length revealed 98 million tons of inferred phosphate rock resources in areas of substantiated phosphate resource potential based on phosphate rock zones containing at least 14 percent $\mathrm{P}_{2} \mathrm{O}_{5}$.

Associated with these resources is an average of 2.39 percent fluorine that might be recovered as a byproduct, and lesser amounts of vanadium and uranium (Sheldon, 1963; Gere and others, 1966; Benham, 1983). Units of phosphate rock richer than 24 percent are thinner and less accessible in the the study area than those 20 to more than $30 \mathrm{ft}$ thick now being mined in the higher Meade thrust sheet in the Soda Springs and Pocatello areas to the southwest (U.S. Geological Survey, 1977, v. 1, p. 48 ).

The Phosphoria Formation contains small concentrations of silver, chromium, lead, vanadium, zinc, cadmium, copper, molybdenum, and nickel. Although no resource potential was identified, recovery of some of these metals could enhance the phosphate-mining potential at some sites.

Coal seams and beds occur in the Cretaceous Frontier and Bear River Formations, which trend northwest along the northeastern part of the Snake River Range. The seams and beds are thin, dip steeply, pinch out within short distances, and no potential for coal resources was identified.

The Mississippian Mission Canyon Limestone, exposed in the Jackson, Absaroka, and St. John thrust sheets, contains relatively pure limestone. The material is suitable as flux for smelters, and for use in glass, sugar-beet refining, and paper making, as well as for riprap. Other limestone sources closer to markets, make deposits in the study area useful only for local needs (Benham, 1983).

Analyses of samples of rocks, stream sediments, panned concentrates, and waters show geochemical anomalies for several elements. The anomalies occur in three different geologic settings: stratabound silver and copper in the mid-Mesozoic Nugget Sandstone; base metals and molybdenum associated with Tertiary igneous intrusive rocks; and several elements in the Phosphoria Formation. No mineral-resource potential was identified in any of these settings.

The Nugget Sandstone in the study area, as elsewhere in the thrust belt, hosts stratabound deposits of copper and silver locally accompanied by gold, zinc, lead, or other base metals. The metal concentrations are associated with local oil staining and bleached zones (Love and Antweiler, 1973). Gypsiferous beds in the basal part of the Twin Creek Limestone directly overlie the stratabound metal occurrences. At four localities in the study area, malachite- and azurite-stained sandstone or quartzite was found in the Nugget. Selected specimens contain as much as 2 percent copper and 150 parts per million silver; concentrations of other base metals, including zinc, are relatively minor. Because the observed mineralization is neither extensive nor continuous, no resource potential was identified for the areas having these occurrences.

Heat-flow data are not available for the study area but thermal phenomena are known from nearby localities. The study area lies close to the Eastern Snake River Plain and Yellowstone Park thermal anomaly, characterized by high heat-flow (Blackwell, 1978, p. 190). Although a geothermal resource is unproved in the study area, such a resource is possible. 


\section{SUGGESTIONS FOR FURTHER STUDIES}

Subsurface data from seismic-reflection surveys and from exploratory drilling are needed to define more precisely the oil and gas resource potential in the West and East Palisades Roadless Areas.

Detailed geochemical surveys may help define more precisely the extents of anomalies recorded in our investigations. Whether metalliferous mineral resources are present may also be ascertained by geophysical surveys and exploratory drilling.

\section{REFERENCES}

Benham, J. R., 1983, Mineral investigation of the Palisades RARE II areas (Nos. W4613 and E4613), Bonneville and Teton Counties, Idaho, and Lincoln and Teton Counties, Wyoming: U.S. Bureau of Mines Open-File Report MLA 46-83, 11 p.

Blackwell, D. D., 1978, Heat flow and energy loss in the western United States, in Smith, R. B. and Eaton, G. P., eds., 1978, Cenozoic tectonics and regional geophysics of the western Cordillera: Geological Society of America Memoir 152, p. 175-208.
Gere, W. C., Schell, E. M., and Moore, K. P., 1966, Stratigraphic sections and phosphate analyses of Permian rocks in the Teton Range and parts of the Snake River and Gros Ventre Ranges, Idaho and Wyoming: U.S. Geological Survey Open-file report, $71 \mathrm{p}$.

Love, J. D., and Antweiler, J. C., 1973, Copper, silver, and zinc in Nugget Sandstone, western Wyoming, in Wyoming Geological Association Guidebook, 25th Annual Field Conference: p. 139-147.

Oriel, S. S., and Benham, John, in press, Mineral resource potential map of the West and East Palisades Roadless Areas, Bonneville and Teton Counties, Idaho, and Lincoln and Teton Counties, Wyoming: U.S. Geological Survey Miscellaneous Field Studies Map MF-1619-A.

Petroleum Information, 1981, The Overthrust Belt-1981: Denver, Colorado, Petroleum Information Corporation, 251 p.

Powers, R. B., 1978, Map showing oil and gas resource potential of RARE II proposed roadless areas in National forests in the Idaho-Utah-Wyoming overthrust belt: U.S. Geological Survey Open-File Report 78-956, scale 1:500,000.

Sheldon, R. P., 1963, Physical stratigraphy and mineral resources of Permian rocks in western Wyoming: U.S. Geological Survey Professional Paper 313-B, p. 49-273.

U.S. Geological Survey, 1977, Development of phosphate resources in southeastern Idaho: U.S. Geological Survey Final Environmental Impact Statement Report 77-37.

Ver Ploeg, A. J., and De Bruin, R. H., 1982, The search for oil and gas in the Idaho-Wyoming-Utah salient of the Overthrust Belt: Wyoming Geological Survey Report Investigation 21, 108 p. 


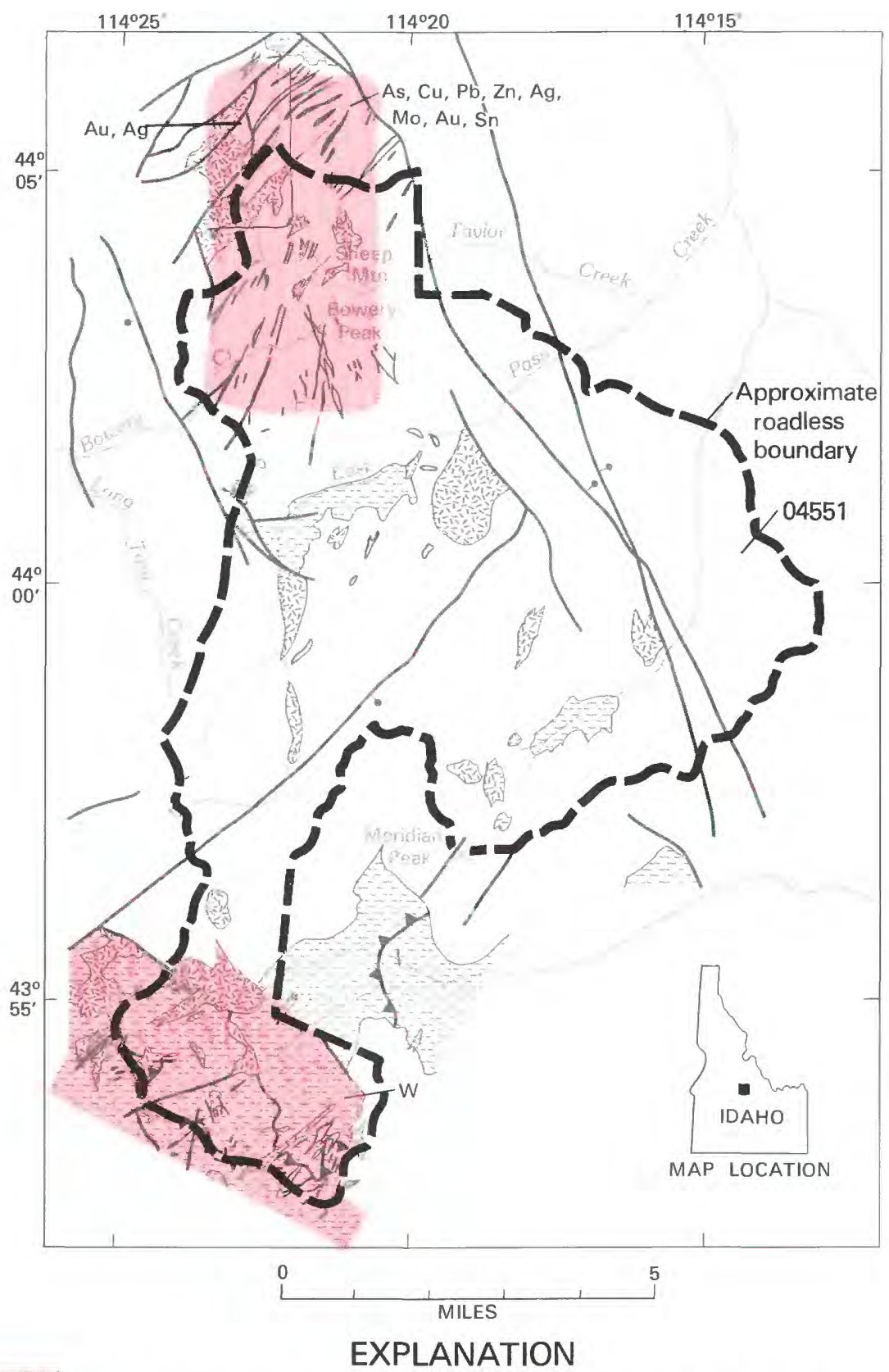

Geologic terrane with substantiated mineralresource potential

$\begin{array}{llll}\mathrm{As} & \text { Arsenic } & \mathrm{Ag} & \text { Silver } \\ \mathrm{Cu} & \text { Copper } & \mathrm{Sn} & \text { Tin } \\ \mathrm{Au} & \text { Gold } & \mathrm{W} & \text { Tungsten } \\ \mathrm{Pb} & \text { Lead } & \mathrm{Zn} & \text { Zinc } \\ \mathrm{Mo} & \text { Molybdenum } & & \end{array}$

Intrusive rocks (Tertiary)
Dikes (Tertiary)
Volcanic rocks (Tertiary)
Sedimentary rocks (Paleozoic)
Contact
Fault--Bar and ball on downthrown
side
Thrust fault-- Sawteeth on upper
plate

Figure 173.-White Cloud-Boulder Roadless Area, Idaho. 


\title{
WHITE CLOUD-BOULDER ROADLESS AREA, IDAHO
}

\author{
By Frederick S. FiSHER, U.S. GeOlogiCal SURVEY, and \\ FREDRICK L. JOHNSON, U.S. BUREAU OF MINES
}

\begin{abstract}
SUMMARY
There have been no minerals produced from, and there are no mines located within the White Cloud-Boulder Roadless Area, Idaho; however, based on mineral studies by the USGS and USBM in 1981, the southern part of the roadless area has a probable resource potential for tungsten and the northwestern corner a probable resource potential for gold and silver. The conclusions are based on the presence of favorable geologic environments for calc-silicate skarns in the southern part of the roadless area and the presence of gold-bearing quartzcarbonate veins in the northern part. The northern part of the area in the vicinity of Sheep Mountain-Bowery Peak has a probable resource potential for arsenic, copper, gold, lead, molybdenum, silver, tin, and zinc, on the basis of geologic and geophysical data that suggest the presence of a buried intrusive body which probably has associated ore deposits. No energy resources were identified in the study.
\end{abstract}

\section{CHARACTER AND SETTING}

The White Cloud-Boulder Roadless Area is located in Custer County approximately $30 \mathrm{mi}$ south of Challis, Idaho. It contains about $62 \mathrm{sq} \mathrm{mi}$ and is accessible by county roads along the East Fork of the Salmon River and then by foot and horse trails. The roadless area is on the eastern and southern sides of the White CloudBoulder Mountains and is characterized by very rugged topography with relief in excess of $4000 \mathrm{ft}$. Previous geologic work is limited to the northern third of the roadless area.

The White Cloud-Boulder Roadless Area includes two principal groups of rocks: sedimentary rocks of Paleozoic age, and volcanic rocks with associated intrusive rocks of Eocene age. The Paleozoic sedimentary rocks had been faulted, complexly folded, and eroded to form a rugged terrain prior to deposition of the volcanic rocks. Locally, especially in the southern part of the roadless area, the sedimentary rocks were contact metamorphosed by intrusive masses that were emplaced during the volcanism.

The structure within the northern part of the roadless area is closely related to two major regional structural features that occur to the west and east. To the west is the northeast-trending East Fork fault zone; to the east is the northwest-trending Herd Creek fault zone. North- east and northwest-trending faults bound the uplifted block centered on Sheep Mountain-Bowery Peak ridge. Uplift of the block most likely is due to buoyancy of an intrusive mass still concealed beneath the ridge. The presence of such an intrusive mass is suggested by the swarm of porphyry dikes on the ridge, the pervasive alteration of all rocks exposed on the ridge, and a strong positive aeromagnetic anomaly centered on the ridge (M. W. Webring, oral commun., 1982).

East- and northeast-directed thrust faults of considerable displacement characterize the structural geology of the Paleozoic rocks in the southern part of the roadless area. The allochthonous plates were emplaced during Paleozoic and Mesozoic deformation that affected wide areas of the western United States. The thrust plates have been broken by high-angle faults at various times and were intruded by numerous quartz porphyry plutons during Tertiary time.

\section{MINERAL RESOURCES}

In the southern part of the roadless area, skarns are commonly developed in carbonate-rich Paleozoic rocks adjacent to Tertiary plutons. Scheelite $\left(\mathrm{CaWO}_{4}\right)$ has been observed in some of these skarns, and panned concentrates collected from streams draining these areas 
contain visible scheelite grains. The skarn zones are commonly iron stained and contain garnet, epidote, and in places, pyrrhotite. Tungsten, molybdenum, and lead are all present in anomalous amounts in panned concentrates collected from streams draining the area of Paleozoic rocks. Although no skarn deposits have been identified in the roadless area, these types of ore bodies have been mined near the western and southern boundaries of the roadless area.

A probable resource potential for tungsten is assigned to the western and southern part of the roadless area because highly anomalous concentrations of tungsten were found in panned concentrates from all of the streams draining the area, scheelite has been observed both in the panned concentrates and in the skarn zones, and geologic relationships favorable to the formation of skarn deposits occur in the area.

In the northern part of the roadless area northwest of Sheep Mountain a series of quartz-carbonate veins cut rhyodacitic pyroclastic rocks and lava flows with predominantly northeast trends. Most of the veins are narrow (less than $1 \mathrm{ft}$ wide) and are exposed along strike for only a few tens to a few hundred feet. One vein, however, has a strike length of nearly $1 \mathrm{mi}$ and in places is as wide as $300 \mathrm{ft}$. The vein rocks are mostly breccias which consist mainly of a dense, white, fine-grained silica matrix surrounding subangular altered rock fragments about 1 to $2 \mathrm{in}$. in diameter. The veins are commonly crustiform, vuggy, and banded. Some clay occurs in small (less than 1 in.) pods, and carbonates are present both in thin veinlets and as vug fillings. The veins are usually iron stained, probably from the weathering of pyrite. The wallrocks a few inches away from the veins have been argillically altered and are bleached, somewhat iron-stained, and contain finegrained clay minerals. Propylitized rocks are widespread in the region and are characterized by the development of chlorite and epidote as replacements of biotite, hornblende, and plagioclase. Samples collected from the veins and adjacent rocks contain anomalous concentrations of zinc, arsenic, antimony, gold, molybdenum, and silver. A probable resource potential for gold and silver is assigned to the area of this vein zone because metalliferous quartz-carbonate veins are quite common in the area; gold was detected in approximately 25 percent of the rock samples from the area; and 50 percent of the rocks collected from the area contained anomalous concentrations of one or more metals.

Arsenic, copper, gold, lead, molybdenum, silver, tin, and zinc are all present in anomalous concentrations in rock and stream-sediment samples taken from the Sheep Mountain-Bowery Peak area. With the exception of the auriferous quartz-carbonate veins described above, no recognizable deposits were observed in the Sheep Mountain-Bowery Peak area. The most logical explanation for these widespread geochemical anomalies is the presence of a buried intrusive mass beneath Sheep Mountain-Bowery Peak ridge as suggested earlier. Copper or molybdenum porphyry-type ore deposits could be associated with such an intrusive and the observed geochemical anomalies would be explained as resulting from the hydrothermal events associated with the emplacement of the intrusive. If this is the case then deposits may be present, but not exposed, in the Sheep Mountain-Bowery Peak area and it is assigned a probable resource potential.

Sand, gravel, and stone could be produced from numerous localities within the roadless area, but there is a lack of good transportation routes and they are far from potential markets. Sedimentary rocks are present in the roadless area but have been extensively folded, faulted, metamorphosed, and intruded by igneous plutons; thus there is little likelihood for the occurrence of oil and gas.

\section{SUGGESTIONS FOR FURTHER STUDIES}

More detailed geologic mapping and geochemical sampling in the Sheep Mountain-Bowery Peak area would delineate areas that might be drilled to confirm the postulated presence of a buried intrusive with associated mineral deposits.

\section{REFERENCES}

Dover, J. H., Berry, W.B.N., and Ross, R. J., Jr., 1980, Ordovician and Silurian Phi Kappa and Trail Creek formations, Pioneer Mountains, central Idaho-stratigraphic and structural revisions and new data and graptolite faunas: U.S. Geological Survey Professional Paper 1090, $54 \mathrm{p}$.

Fisher, F. S., May, G. D., McIntyre, D. H., Johnson, F. L., 1983, Mineral resource potential, geologic and geochemical maps of part of the White Cloud-Boulder Roadless Area, Custer County, Idaho: U.S. Geological Survey Miscellaneous Field Studies Map MF-1580.

U.S. Geological Survey and U.S. Bureau of Mines, 1981, Mineral resources of the Boulder-Pioneer Wilderness study area, Custer and Blaine Counties, Idaho: U.S. Geological Survey Bulletin $1497,303 \mathrm{p}$. 

$\begin{array}{llllllll}I & L & L & I & N & O & I & S\end{array}$

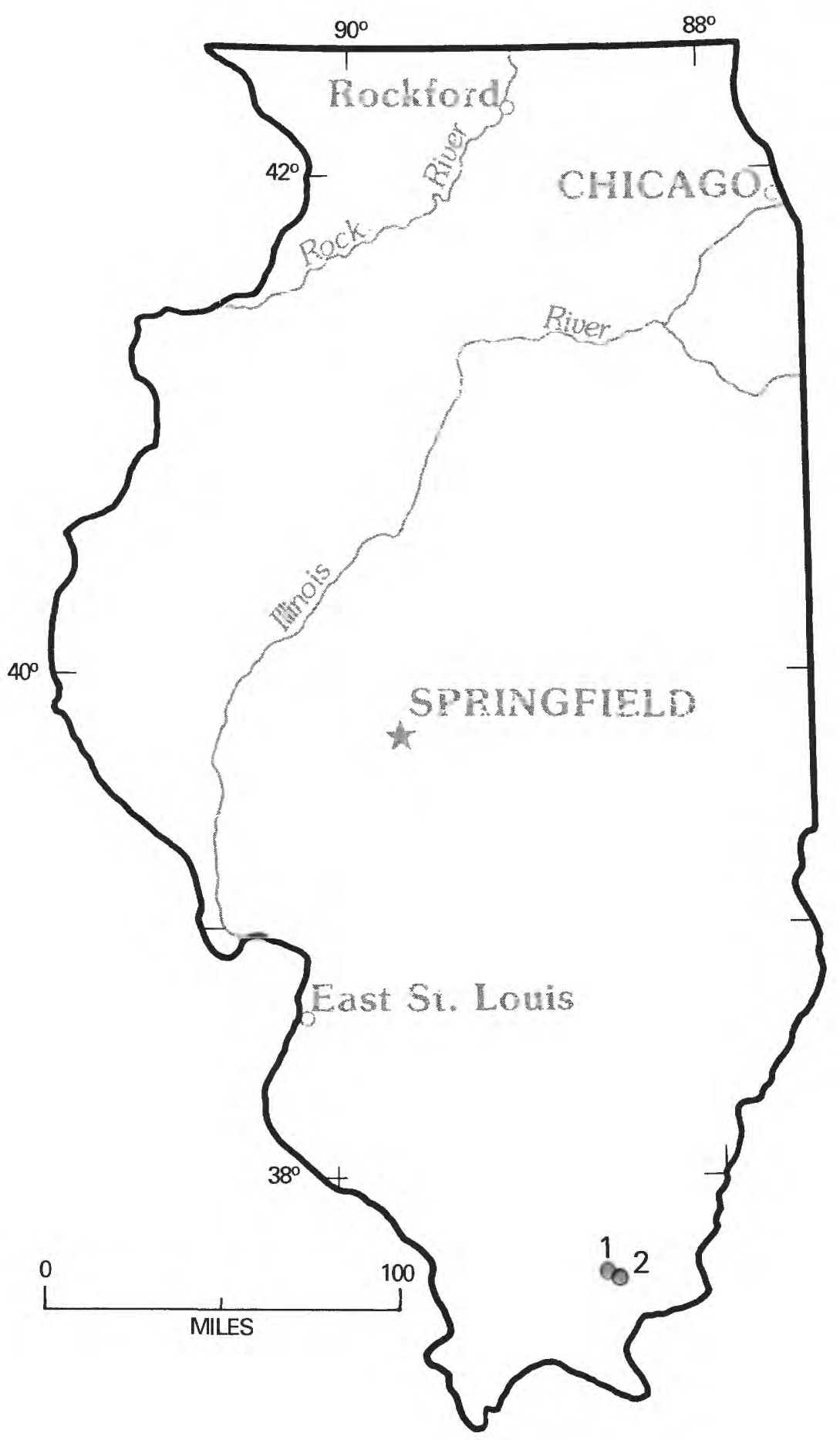

Location of areas studied. 


\title{
ILLINOIS
}

\author{
Map
No. \\ Name of Area \\ 1 Burden Falls Roadless Area \\ 2 Lusk Creek Roadless Area
}




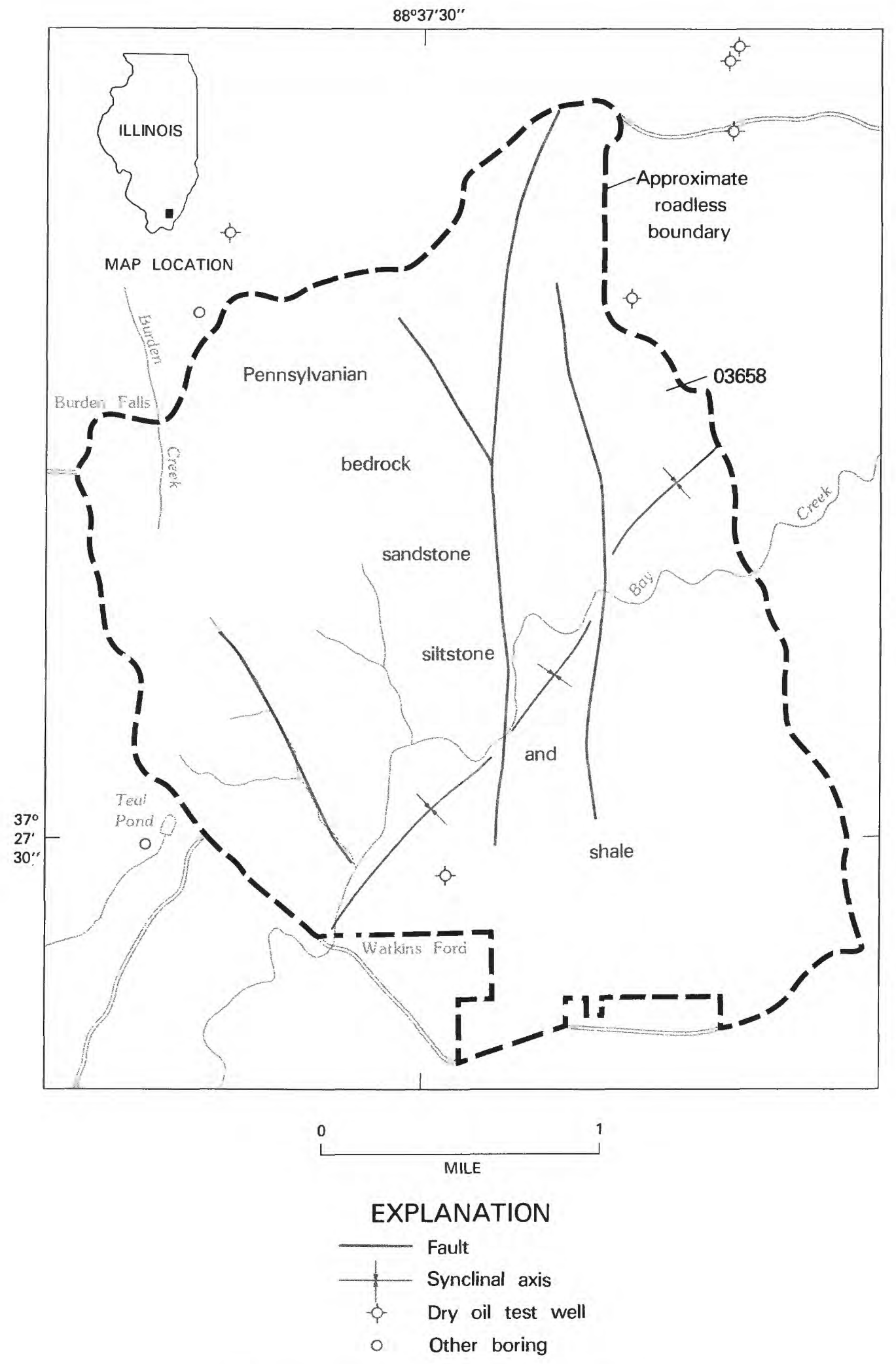

Figure 174.-Burden Falls Roadless Area, Illinois. 


\title{
BURDEN FALLS ROADLESS AREA, ILLINOIS
}

\author{
By JOHn S. Klasner, U.S. GeOlOGical SuRVEY, and \\ ROBERT M. THOMPSON, U.S. BUREAU OF MINES
}

\begin{abstract}
SUMMARY
The Burden Falls Roadless Area lies in the Shawnee National Forest of southern Illinois, about $5 \mathrm{mi}$ west of the western edge of the Illinois-Kentucky fluorspar district. Geologic mapping and geochemical surveys done in 1980 indicate that the area has little promise for the occurrence of fluorspar and associated minerals; other special studies also indicate little promise for oil and gas and construction materials. Traces of gold and silver were detected in some geochemical samples but follow-up studies indicate little promise for the occurrence of resources of these metals within the Burden Falls Roadless Area.
\end{abstract}

\section{CHARACTER AND SETTING}

The 5.75 sq mi Burden Falls Roadless Area lies within the Shawnee National Forest of southern Illinois, about $4 \mathrm{mi}$ northwest of Eddyville. USFS records indicate Federal ownership of roughly 82 percent of the surface rights and 62 percent of the mineral rights; oil and gas applications, filed in 1972 , include about 36 percent of the roadless area.

The roadless area lies at the southern edge of the Illinois Basin and about $5 \mathrm{mi}$ west of the western edge of the Illinois-Kentucky fluorspar district, the major fluorspar producing district in the United States. Geologic mapping (Klasner, 1983) shows that beds of conglomerate, sandstone, siltstone and shale, all of Pennsylvanian age, are exposed in the area, and are gently dipping, generally less than $10^{\circ}$. A northeasterly trending syncline (downwarp) transects the area and at least two northerly trending faults exist in the area. The faults, which are fracture zones along which movement has taken place, locally disrupt the otherwise nearly flat lying beds.

\section{MINERAL RESOURCES}

Mineral commodities evaluated for their occurrence in the Burden Falls Roadless Area include fluorspar, coal, oil and gas, and construction materials such as sandstone and shale. Inasmuch as gold and silver were detected in geochemical analyses of stream sediment and soil samples, the area was also evaluated for their occurrence.
Geologic mapping did not reveal the presence of fluorspar or commonly associated minerals such as barite, galena, or sphalerite. Geochemical analyses of bedrock samples (Klasner and Day, 1983) indicate that fluorine and associated elements such as barium, beryllium, lead, and zinc all occur at concentrations that are about the same as or lower than average concentrations of these elements for the rock types sampled. In addition, geochemical analyses of stream-sediment and soil samples generally do not show elevated concentrations of fluorine and other elements associated with fluorspar deposits. For these reasons the roadless area is considered to have little promise for the occurrence of fluorspar.

Geologic mapping as well as a special coal reconnaissance study did not reveal the presence of coal within the roadless area. Well-log data indicate that only thin lenses of coal of unminable thickness may occur in the general area and no resource potential was identified.

Analyses of Lower Pennsylvanian sandstone samples do not indicate that the sandstone is a source of highsilica sand. Sandstone from this area could be utilized as construction fill for local projects, but numerous sources are available elsewhere in the region. Evaluation of ceramic properties of exposed shale indicates possible use for structural clay products, but limited exposures and limited thickness of shale beds restrict this possiblity.

There is little promise for the occurrence of oil and gas. As shown on the map, several oil and gas tests have been drilled around the roadless area and one within it. A test hole, $1962 \mathrm{ft}$ deep, was drilled into Mississippian limestone near the northwest edge of the roadless area. 
It penetrated an anticline that marks the most favorable place structurally for oil and gas to occur in the area, but it was dry. Rocks other than Mississippian strata have not been tested but Weller $(1940$, p. 44) points out that older beds contain fresh water, suggesting that "***underground circulation may have been effective enough to flush out any oil that may have existed in some structurally favorable localities.'

Anomalous concentrations of gold and silver were detected in 3 stream-sediment samples and silver was detected in 2 soil samples (Klasner and Day, 1983). Because of suspected contamination either in sampling or instrumental analysis, the areas were resampled and reanalyzed by two different techniques, atomic absorption and semiquantitative spectrographic analyses, for gold and silver. Only a trace of gold was found in one of the recollected samples. In addition, several bedrock samples were analyzed, primarily for gold and silver, with negative results. Thus we conclude that the area has little promise for the occurrence of gold and silver.

\section{SUGGESTIONS FOR FURTHER STUDIES}

Because mineral-resource potential studies (Thompson, 1982, and Klasner and others, 1983) indicate that the Burden Falls Roadless Area has little promise for the occurrence of metallic, nonmetallic, and energy resources, we do not recommend further studies in this area.

\section{REFERENCES}

Klasner, J. S., 1983, Geologic map of the Burden Falls Roadless Area, Pope County, Illinois: U.S. Geological Survey Miscellaneous Field Studies Map MF-1565-A.

Klasner, J. S. and Day, G. W., 1983, Geochemical survey of the Burden Falls Roadless Area, Pope County, Illinois: U.S. Geological Survey Miscellaneous Field Studies Map MF-1565-B.

Klasner, J. S., Kehn, T. M., and Thompson, R. M., 1983, Mineral Resource Potential Map of the Burden Falls Roadless Area, Pope County, Illinois: U.S. Geological Survey Miscellaneous Field Studies Map MF-1565-C, scale 1:24,000.

Thompson, R. M., 1982, Mineral resource investigation, Burden Falls RARE II Further Planning Area, Pope County, Illinois: U.S. Bureau of Mines Open File Report MLA 32-81, 13 p.

Weller, J. M., 1940, Geology and oil possibilities of extreme southern Illinois: Illinois State Geological Survey Report of Investigation $71,71 \mathrm{p}$. 


\title{
LUSK CREEK ROADLESS AREA, ILLINOIS
}

\author{
By JOHn S. KLASNER, U.S. GeOlOGiCAL SURVEY, and \\ ROBERT M. THOMPSON, U.S. BUREAU OF MINES
}

\begin{abstract}
SUMMARY
Geologic mapping and geochemical sampling during 1980 show that the eastern third of the Lusk Creek Roadless Area has a substantiated resource potential for fluorspar, lead, zinc, and barite, and other parts of the area have a probable resource potential for fluorspar. Fluorspar, which occurs along fault zones in the eastern part of the area, has been produced in the adjacent IllinoisKentucky fluorspar district. There is little promise for the occurrence of other mineral or energy resources.
\end{abstract}

\section{CHARACTER AND SETTING}

The $9.5 \mathrm{sq}$ mi Lusk Creek Roadless Area is about 12 mi south of Harrisburg and 2 mi northeast of Eddyville. Approximately 89 percent of the surface rights and 58 percent of the mineral rights are under Federal ownership. Applications have been filed for lease of oil and gas rights on about 36 percent and for mineral prospecting on 14 percent of the area. These applications account for about 70 percent of the Federally owned mineral rights.

The roadless area lies in the Shawnee National Forest, near the southern edge of the Illinois basin and at the western edge of a major, roughly $35 \mathrm{mi}$ wide, north trending zone of faulting and fracturing in the Earth's crust. The Illinois-Kentucky fluorspar district, the major fluorspar producing district in the United States, lies within this broad fracture zone. Geologic mapping (Klasner, 1982) shows that the eastern third of the roadless area overlies the Shawneetown-Lusk Creek fault zones, which in turn lie at the western edge of the broad fracture zone. Within the Shawneetown-Lusk Creek fault zones, beds of sandstone and limestone are highly fractured and tilted. West of these fault zones, sandstone and limestone beds are nearly flat lying and generally unfaulted. Past studies by Grogan and Bradbury (1967) and by Trace (1974) show that most deposits of fluorspar occur as veins within the fault zones or in beds adjacent to fault zones, generally within $1 / 2 \mathrm{mi}$ of the faults. Thus, the presence of faults is an important geologic criteria in evaluation of fluorspar resource potential.

Resources evaluated for their occurrence in the Lusk Creek Roadless Area include fluorite, coal, oil and gas, and construction materials, specifically limestone, sandstone, and shale (Thompson, 1982; Klasner and others, 1982). Inasmuch as fluorspar deposits may have associated barite, galena, and sphalerite mineralization, these are considered collectively. Samples of bedrock, soils, and stream sediments were analyzed chemically (Klasner and Day, 1982).

Exposed geologic strata in the roadless area can be divided into two major units: (1) mostly sandstone and conglomerate of Pennsylvanian age, and (2) mostly limestone and siltstone of Mississippian age.

\section{MINERAL RESOURCES}

The presence of fluorite and associated mineralization, anomalous concentrations of elements associated with fluorite mineralization, and the presence of fault zones indicate that the eastern third of the Lusk Creek Roadless Area has a substantiated mineral potential for fluorspar and associated deposits of galena (lead), sphalerite (zinc), and barite. Other parts of the roadless area have a probable mineral-resource potential for fluorspar.

As a result of this study, the area was found to offer little or no promise for the occurrence of organic fuels. Geologic mapping, prospect studies, and a special coal reconnaissance investigation undertaken during this study revealed little evidence for coal occurrences in the roadless area. Although strata with known oil producing potential elsewhere in Illinois exist beneath the roadless area, available data suggests that the potential for structural or stratigraphic entrapment of oil is poor. 

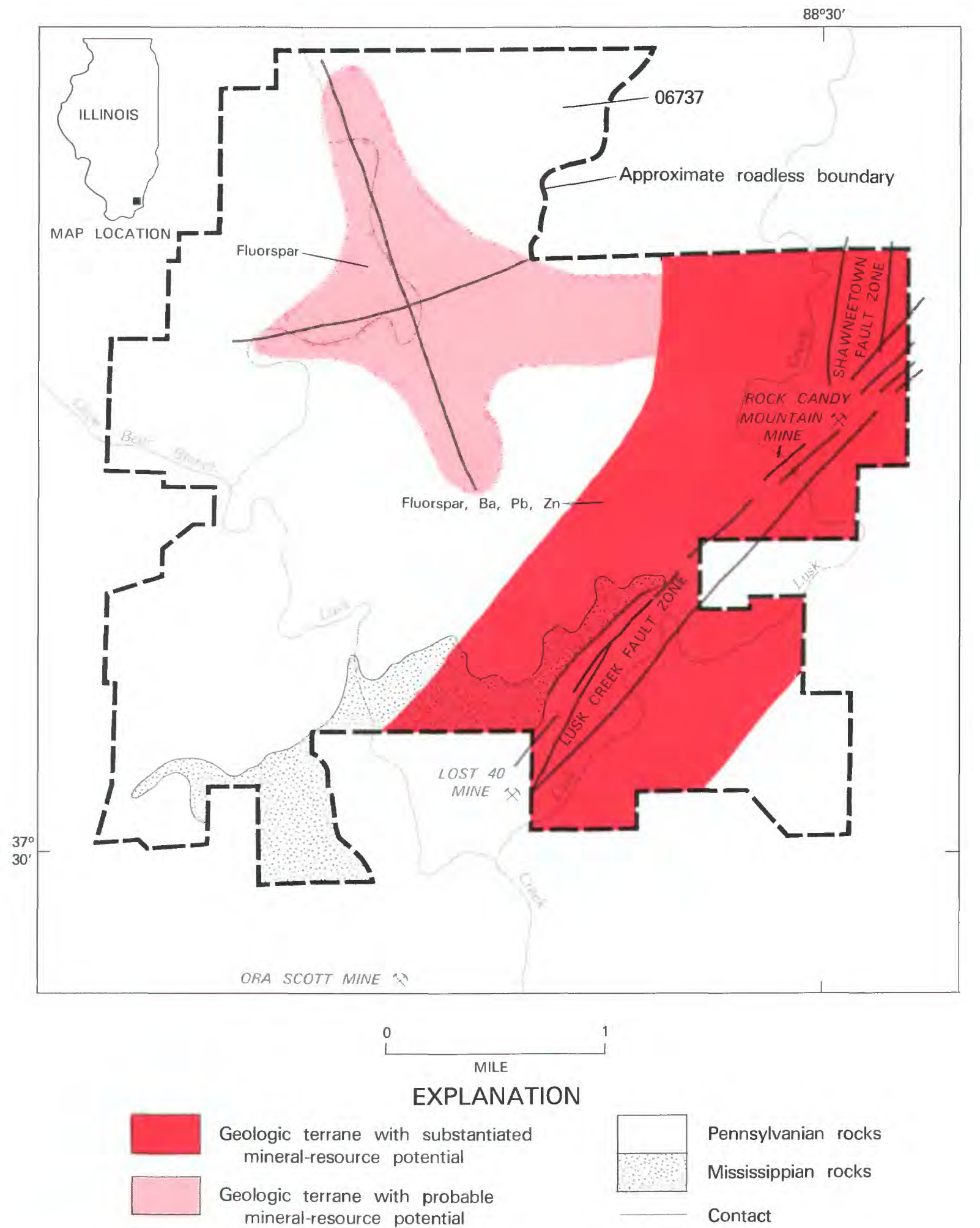

Geologic terrane with substantiated mineral-resource potential

Geologic terrane with probable mineral-resource potential

Pennsylvanian rocks

Mississippian rocks

Barium

Lead

Zinc

Mine

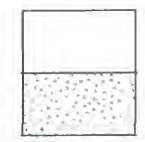

Mississippian rocks

Contact

Fault

Figure 175.-Lusk Creek Roadless Area, Illinois. 
Because hydrocarbons are known to have leaked along the faults, and because oil was not discovered in wells drilled on a nearby anticline that has a structurally higher position than the Lusk Creek Roadless Area, it is highly unlikely that deposits of oil exist beneath the area.

Possible construction materials in the roadless area include limestone, shale, and sandstone, but other areas outside of the roadless area contain similar materials that are more readily obtainable.

\section{SUGGESTIONS FOR FURTHER STUDY}

Fluorspar has been produced within the roadless area at Rock Candy Mountain mine and adjacent to the roadless area at the Lost 40 and Ora Scott mines. These mines were worked intermittently between 1941 and 1952. Physical data on mine workings indicate that the deepest known workings are more than $1100 \mathrm{ft}$ above the most productive geologic strata. Because the most productive horizons have not, to the best of our knowledge, been sampled, we suggest that the area be core drilled to further test for deposits of fluorspar and, if found to exist, to delineate their extent.

\section{REFERENCES}

Grogan, R. M., and Bradbury, J. C., 1967, Origin of stratiform fluorite deposits of southern Illinois: Economic Geology Monograph 3, p. 40-50.

Klasner, J. S., 1982, Geologic map of the Lusk Creek Roadless Area, Pope County, Illinois: U.S. Geological Survey Miscellaneous Field Studies Map MF-1405-A, scale 1:24,000.

Klasner, J. S. and Day, G. W., 1982, Geochemical Survey of the Lusk Creek Roadless Area, Pope County, Illinois. U.S. Geological Survey Miscellaneous Field Studies Map MF-1405-B, scale $1: 24,000$.

Klasner, J. S., Thompson, R. M., and Kehn, R. M., 1982, Mineral resource potential map of the Lusk Creek Roadless Area, Pope County, Illinois: U.S. Geological Survey Miscellaneous Field Studies Map MF-1405-C, scale 1:24,000.

Thompson, R. M., 1982, Mineral resource investigation of Lusk Creek RARE II Further Planning Area, Pope County, Illinois: U.S. Bureau of Mines Open File Report MCA 6-82, 28 p.

Trace, R. P., 1974, Illinois-Kentucky fluorspar district in a symposium on the geology of fluorspar: Forum on geology of industrial minerals, 9th Proceedings, Kentucky Geological Survey, series X, Special Publication 22, p. 58-76. 


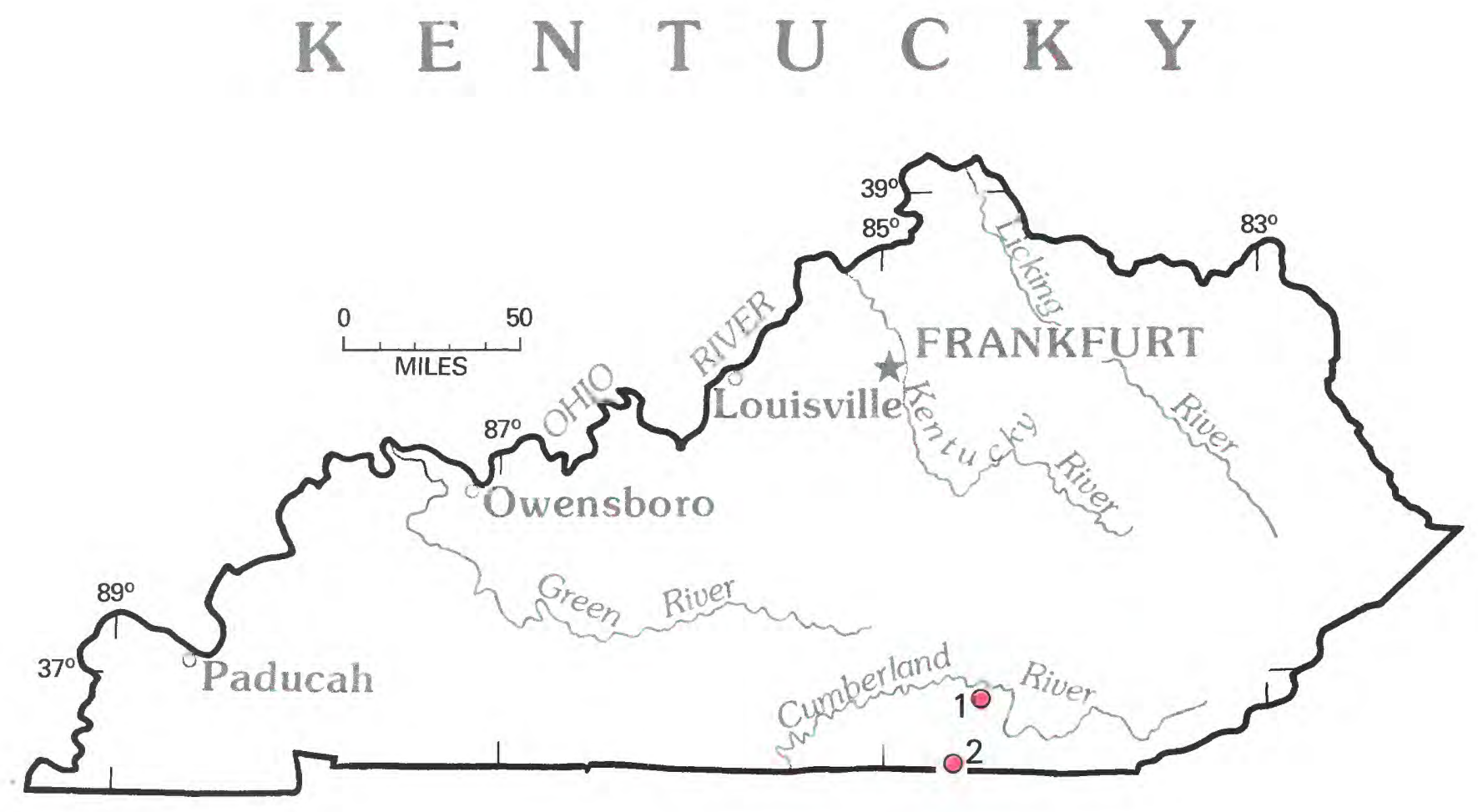

Location of areas studied. 


\title{
KENTUCKY
}

\author{
Map
No. Name of Area \\ 1 Beaver Creek Wilderness \\ 2 Troublesome Roadless Area
}




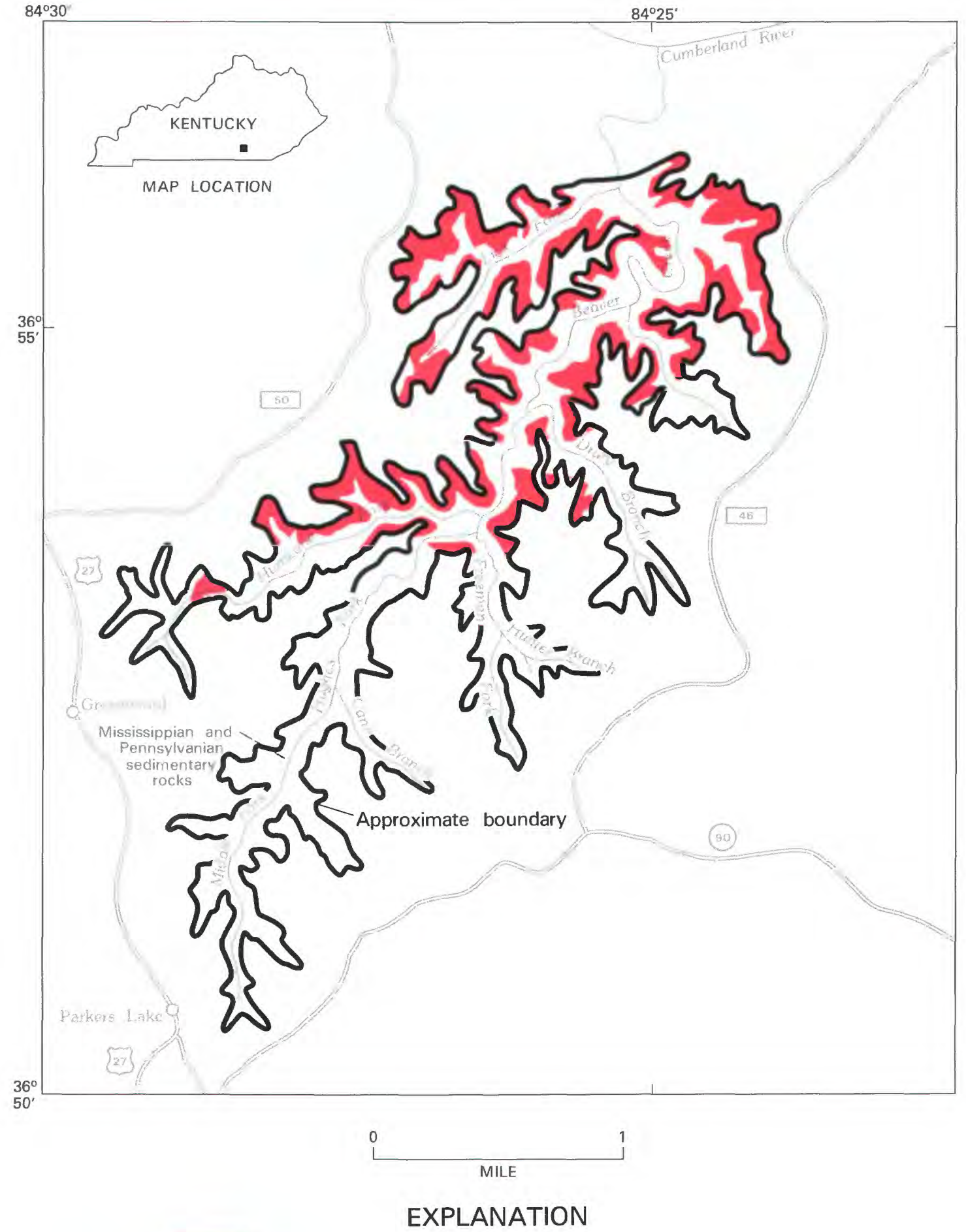

Geologic terrane with substantiated coal resource potential

Figure 176.-Beaver Creek Wilderness, Kentucky. 


\title{
BEAVER CREEK WILDERNESS, KENTUCKY
}

\author{
By K. J. Englund, U.S. Geological SuRVey, and \\ R. W. Hammack, U.S. BUREaU of Mines
}

\begin{abstract}
SUMMARY
The Beaver Creek Wilderness, Kentucky, was studied in 1980 by the USGS and USBM. Coal is the most important mineral resource in the Beaver Creek Wilderness. The coal is tentatively ranked as high-volatile A bituminous, and like coal of this rank in nearby mining areas, it is primarily suitable for use as steam coal. The coal resources are estimated to total 8.31 million short tons in beds greater than $14 \mathrm{in}$. thick. Nonmetallic minerals present in the Wilderness include limestone, shale, clay, and sandstone; these commodities are abundant outside the wilderness. The information available is not adequate for the assessment of the oil and gas resource potential of the Beaver Creek Wilderness. There is little likelihood for the occurrence of metallic mineral resources.
\end{abstract}

\section{CHARACTER AND SETTING}

The Beaver Creek Wilderness contains about $7.5 \mathrm{sq}$ $\mathrm{mi}$ in the Daniel Boone National Forest, Kentucky. The area is in McCreary County, about 11 mi southeast of Burnside, Kentucky, and is principally within the cliffline bordering the Beaver Creek drainage basin. The western edge of the wilderness is accessible from the north and south via U.S. Highway 27 and USFS Road 50. From the east the area can be reached via Kentucky State Route 90 and USFS Road 46. The interior is accessible by foot along an abandoned USFS Road and by several primitive trails that extend along the major streams.

Almost all surface rights in Beaver Creek Wilderness are in U.S. Government ownership; however, almost all mineral and oil and gas rights are privately owned.

The Beaver Creek Wilderness is located at the western edge of the Appalachian coal region and is within the highly dissected Cumberland Plateau section of the Appalachian Plateaus physiographic province. It is drained by Beaver Creek and its tributaries, which flow northeastward into Lake Cumberland, a reservoir on the Cumberland River about $1 \mathrm{mi}$ north of the wilderness. Altitudes range from about $730 \mathrm{ft}$ on the lower part of Beaver Creek to about $1200 \mathrm{ft}$ at its headwaters.

About $555 \mathrm{ft}$ of sedimentary rocks of Late Mississippian to Middle Pennsylvanian age crop out in the wilderness, and as much as $8000 \mathrm{ft}$ of older Paleozoic rocks may be in the subsurface. The lowermost part of the exposed section consists of marine rocks assigned to the Newman Limestone of Late Mississippian age. The remainder of the exposed stratigraphic section consists mostly of coal-bearing continental rocks assigned to the Mississippian and Pennsylvanian Lee Formation and the Pennsylvanian Breathitt Formation, which also contains several thin brackish-water and marginal marine beds. These formations underlie broad upland areas and crop out extensively along the upper valley slopes of the Beaver Creek drainage. Unmapped Quaternary deposits consist of colluvium on lower valley slopes and alluvium along the valley floors.

The Beaver Creek Wilderness is underlain by relatively flat lying rocks on the eastern flank of the Cincinnati arch. Structure contour lines drawn on the top of the Rockcastle Sandstone Member of the Lee Formation show that the regional dip is easterly less than $1^{\circ}$, and is modified locally to the northeast. Evidence of faulting has not been observed in the wilderness.

\section{MINERAL RESOURCES}

Mineral resources that must be considered in the evaluation of the resource potential in the Beaver Creek Wilderness include coal, oil and gas, shale, sandstone, and limestone. High-volatile A bituminous coal has been prospected extensively and mined on a small scale in and near the wilderness. In this report, coal resources are separately estimated for coal beds more than 28 in. 
thick and for coal in beds 14 to 28 in. thick. Areas underlain by coal beds more than 28 in. thick are shown on the map as areas of substantiated coal-resource potential.

Coal occurs in five beds in and near the wilderness: the Hudson, Stearns No. 1 1/2 (?), Beaver Creek, Beaver Creek rider, and Barren Fork. Of these, only the Hudson, Beaver Creek, and Beaver Creek rider contain coal of sufficient thickness, extent, and quality to meet the definition of resources.

The Beaver Creek coal, the thickest and most persistent bed, contains slightly more than 6.1 million short tons of coal. The Hudson coal bed is generally too thin (less than 28 in. thick) to be shown on the map, but the bed thickens in the north-central part of the area where about 1.96 million short tons of coal is estimated. The Beaver Creek rider coal bed is estimated to contain about 0.25 million short tons of coal. The total coal contained in the wilderness in beds more than 14 in. thick is about 8.31 million short tons; 4.258 million short tons of this total is contained in beds more than 28 in. thick and is shown on the map as substantiated coal resources.

Nonmetallic minerals in the wilderness include himestone, high-silica sandstone, clay, and shale; these commodites are abundant outside of the wilderness in other more favorably located areas.

Metallic mineral deposits have not been reported in the area and none were observed during the field investigation. The rock units exposed in the wilderness do not normally host metallic deposits in this region, and no major geochemical anomalies indicative of mineralization were identified in the geochemical survey (Grosz and Siems, 1982). Sedimentary rocks underlying the Beaver Creek Wilderness are similar to those in nearby areas that contain oil and gas resources. The oil and gas potential of the Beaver Creek Wilderness cannot be adequately determined from available information; most exploration drill holes in nearby areas are too shallow (less than $1100 \mathrm{ft}$ ) or widely spaced to adequately test this sedimentary sequence.

\section{SUGGESTIONS FOR FURTHER STUDIES}

Seismic studies and drilling are needed to determine the existence of traps for hydrocarbon accumulation and test the nature of the sedimentary strata beneath the Beaver Creek Wilderness if a proper assessment of the oil and gas potential of this area is to be attained.

\section{REFERENCES}

Englund, K. J., and Teaford, N. K., 1981, Geologic map of the Beaver Creek Wilderness, McCreary County, Kentucky: U.S. Geological Survey Miscellaneous Field Studies Map MF-1348-A, scale $1: 50,000$.

Englund, K. J., and Johnson, P. L., Hammack, R. W., and Ross, R. B., Jr., 1983, Mineral resource potential maps of the Beaver Creek Wilderness, McCreary County, Kentucky: U.S. Geological Survey Miscellaneous Field Studies Map MF-1348-D, scale 1:50,000.

Grosz, A. E., and Siems, D. F., 1982, Geochemical survey of the Beaver Creek Wilderness, McCreary County, Kentucky: U.S. Geological Survey Miscellaneous Field Studies Map MF-1348-B, scale 1:50,000.

Hammack, R. W., 1983, Map showing mines, prospects, and exposures in the Beaver Creek Wilderness, McCreary County, Kentucky: U.S. Geological Survey Miscellaneous Field Studies Map MF-1348-C, scale 1:50,000. 


\title{
TROUBLESOME ROADLESS AREA, KENTUCKY
}

\author{
By W. R. Sigleo, ${ }^{1}$ U.S. Geological Survey, and \\ R. W. Hammack, U.S. Bureau of Mines
}

\begin{abstract}
SUMMARY
A mineral-resource survey made in 1979-80 identified resources of coal, oil and gas, sandstone, and shale in the Troublesome Roadless Area. Demonstrated resources of approximately 429,100 short tons of coal in an area of substantiated resource potential are contained in two major coal beds more than 28 in. thick and the area also contains an additional 483,900 short tons of coal in beds between 14 and 28 in. thick. A probable potential for oil and gas is assigned to the entire area as these fuels may be present in underlying rocks of Mississippian age. Sandstone for silica sand, construction sand, and dimension stone, and shale for structural clay products occur in the area, but these commodities also occur in abundance outside the roadless area. A geochemical survey indicates that there is little promise for the occurrence of metallic mineral resources in the roadless area.
\end{abstract}

\section{CHARACTER AND SETTING}

The Troublesome Roadless Area, McCreary County, Kentucky is composed of six individual tracts of land containing a total of about $4.6 \mathrm{sq} \mathrm{mi}$. The largest tract is located about $13 \mathrm{mi}$ southwest of Stearns, Kentucky, and is accessible via State Route 92 to Hill Top, Kentucky, and then southwestward along country roads. Unimproved USFS roads, abandoned logging roads, and primitive trails provide access by foot or horseback into the interior of each tract.

The Federal Government owns all surface and mineral rights in the Troublesome Roadless Area. Mineral rights on about $2.6 \mathrm{sq} \mathrm{mi}$ previously held by Stearns Coal and Lumber Company were purchased by the Federal Government in July 1979 for implementation of the Big South Fork of Cumberland National River and Recreation Area.

Physiographically, the Troublesome Roadless Area is in the Cumberland Plateau section of the Appalachian Plateaus Province and is near the western edge of the Appalachian coal region. The topography, typical of the Cumberland Plateau, is characterized by irregular, narrow-crested ridges, deep narrow canyons, and dendritic drainage. Altitudes range from about $1600 \mathrm{ft}$ on ridge tops to less than $800 \mathrm{ft}$ along the South Fork of

${ }^{1}$ With contributions from A. H. Randall, USGS, and R. B. Ross, USBM. the Cumberland River. Troublesome Creek, a small tributary of the South Fork of the Cumberland River, is the source of the area's name.

About $800 \mathrm{ft}$ of sedimentary rocks of Late Mississippian to Middle Pennsylvanian age crop out in and adjacent to the roadless area, and as much as $8000 \mathrm{ft}$ of older Paleozoic rocks may be in the subsurface. The basal part of the exposed section, the Newman Limestone of Late Mississippian age, crops out along the South Fork of the Cumberland River and its major tributaries east of the area. Overlying rocks of the Lee and Breathitt Formations of Early and Middle Pennsylvanian age are mostly continental and coal bearing, but the sequence may also contain marine deposits. Deposits of colluvium mantle many valley slopes, and deposits of alluvium, consisting of sand, coarse gravel, and large boulders, cover the valley floors.

The area is situated on the western limb of a small north-trending anticline near the western margin of the Cumberland escarpment. Structure contour lines drawn on the base of the Rockcastle Sandstone Member of the Lee Formation show a low west-southwest dip, generally less than $1^{\circ}$. No evidence of faulting was observed in the area.

\section{MINERAL RESOURCES}

Coal is the principal mineral resource in the 


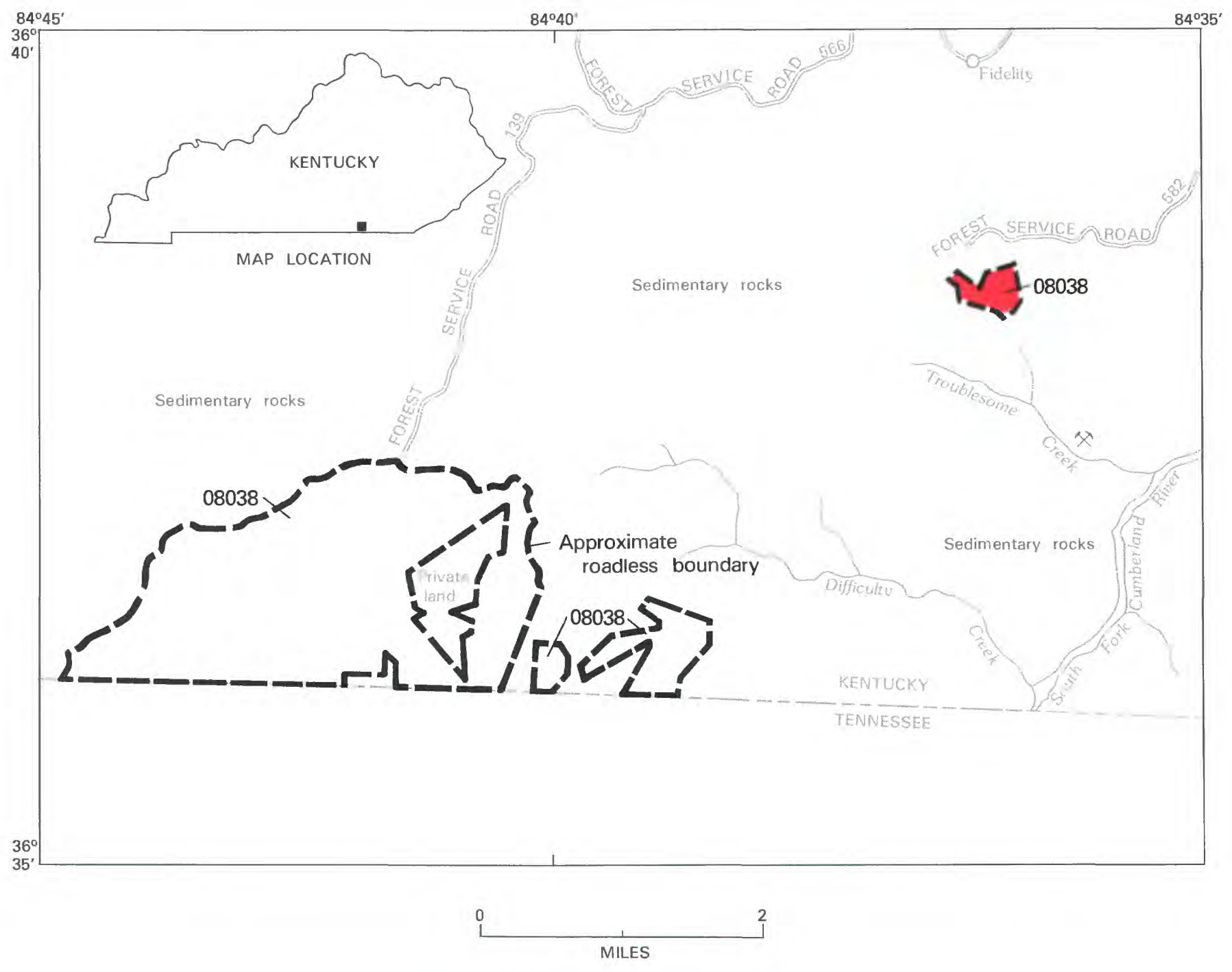

\section{EXPLANATION}

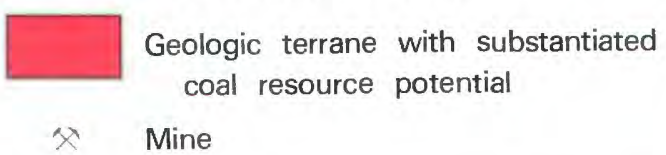

Figure 177.-Troublesome Roadless Area, Kentucky. 
Troublesome Roadless Area (Sigleo and others, 1981). The coal is apparently of high-volatile A bituminous rank, and it occurs in at least 13 beds of which two, the Stearns No. 1 1/2(?) and the Barren Fork(?), contain coal resources. In this report, demonstrated coal resources are separately estimated for coal beds more than $28 \mathrm{in}$. thick and for coal in beds between 14 and 28 in. thick. Areas underlain by coal beds more than 28 in. thick are shown on the map as areas of substantiated coal resource potential. Areas containing beds less than 28 in. thick are not shown, despite their contained coal, as development is considered unlikely. Other than for local use, there has not been commercial development of the coal resources in the Troublesome area. Coal has been produced from several mines north of the area near Fidelity, and to the southeast on a tributary of the South Fork of the Cumberland River. All adits in and adjacent to the roadless area are abandoned and most are caved.

Demonstated coal resources of approximately 913,000 short tons, in beds more than 14 in. thick and under less than $1000 \mathrm{ft}$ of overburden, have been identified in the Stearns No. 1 1/2(?) and Barren Fork(?) coal beds. Of the estimated total resources, 53 percent, or 483,900 short tons, is in beds $14-28$ in. thick, and 47 percent, or 429,100 short tons, is contained in beds 28-42 in. thick which are shown on the map as occurring in areas of substantiated coal resource potential. The Stearns No. $11 / 2$ (?) coal bed is the thicker and more persistent of the two beds, and is estimated to contain a combined total of 747,000 short tons of coal or 82 percent of the total calculated for the entire roadless area.

Sandstone in the Troublesome Roadless Area occurs in the Lee Formation as cliff-forming orthoquartzites and in the Breathitt Formation as poorly exposed subgraywacke and quartzose sandstone. The Rockcastle Sandstone Member of the Lee Formation contains 95 percent or greater $\mathrm{SiO}_{2}$ and is suitable for a variety of uses as silica sand. Possible uses of other area sandstones include filter, furnace, and abrasive sand. Shale occurs in both the Lee and Breathitt Formations and preliminary tests suggest that it may be suitable for structural clay products. These materials occur in abundance outside the roadless area.

Producing and abandoned oil and gas wells in the surrounding region indicate that oil and gas resources may exist in the subsurface of the Troublesome Roadless Area. Exploratory drilling has not yet been conducted in the study area; however, about $0.6 \mathrm{sq} \mathrm{mi}$ were included in an oil and gas lease (ES-7925) issued by the U.S. Bureau of Land Management in 1971. The entire area is classified as having a probable resource potential for oil and gas.

Metallic mineral deposits have not been reported in the area and none were observed during the field investigations. The rocks exposed in the area do not normally host metallic deposits and there is little promise for their occurrence. Geochemical anomaties indicative of metallic mineralization were not detected by a geochemical survey.

\section{SUGGESTIONS FOR FURTHER STUDIES}

Additional exploration, particularly deep drilling, is necessary to evaluate the area's potential for oil and gas resources.

\section{REFERENCES}

Grosz, A.E., and Siems, D. F., 1981, Geochemical survey of the Troublesome Roadless Area, McCreary County, Kentucky: U.S. Geological Survey Miscellaneous Field Studies Map MF-1341-B.

Sigleo, W. R. and Randall, A. H., 1981, Geologic map of the Troublesome Roadless Area, McCreary County, Kentucky: U.S. Geological Survey Miscellaneous Field Studies Map MF-1341-A, scale 1:50,000.

Sigleo, W. R., Randall, A. H., Ross, R. B., and Hammack, R. W., 1981, Mineral resource potential of the Troublesome Roadless Area, McCreary County, Kentucky: U.S. Geological Survey Miscellaneous Field Studies Map MF-1341-C. 
$\begin{array}{lllllllll}L & O & U & I & S & I & A & N & A\end{array}$

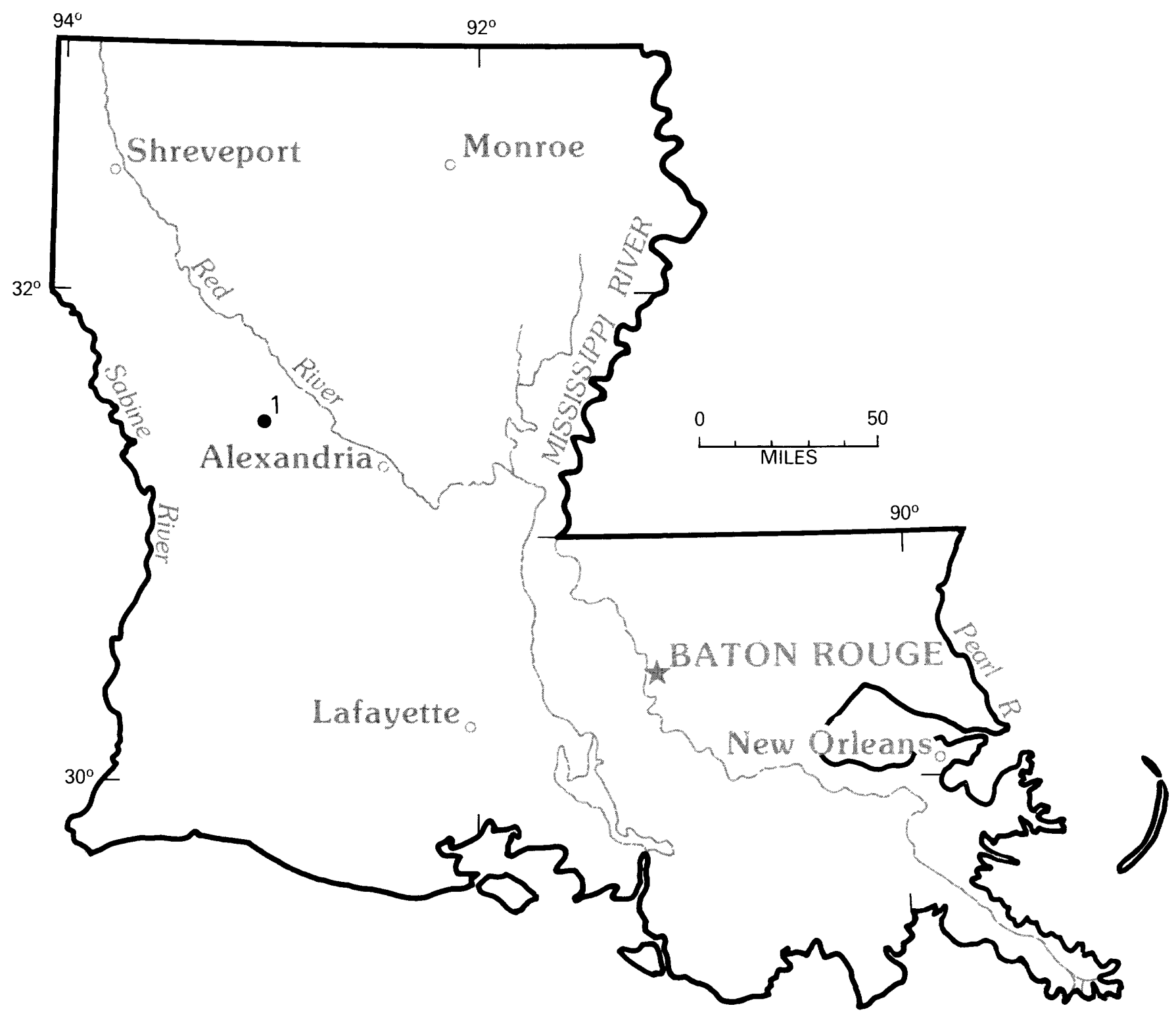

Location of areas studied.

618 


\section{LOUISIANA}

Map

Map
No.

Name of Area

1 Kisatchie Hills Wilderness 


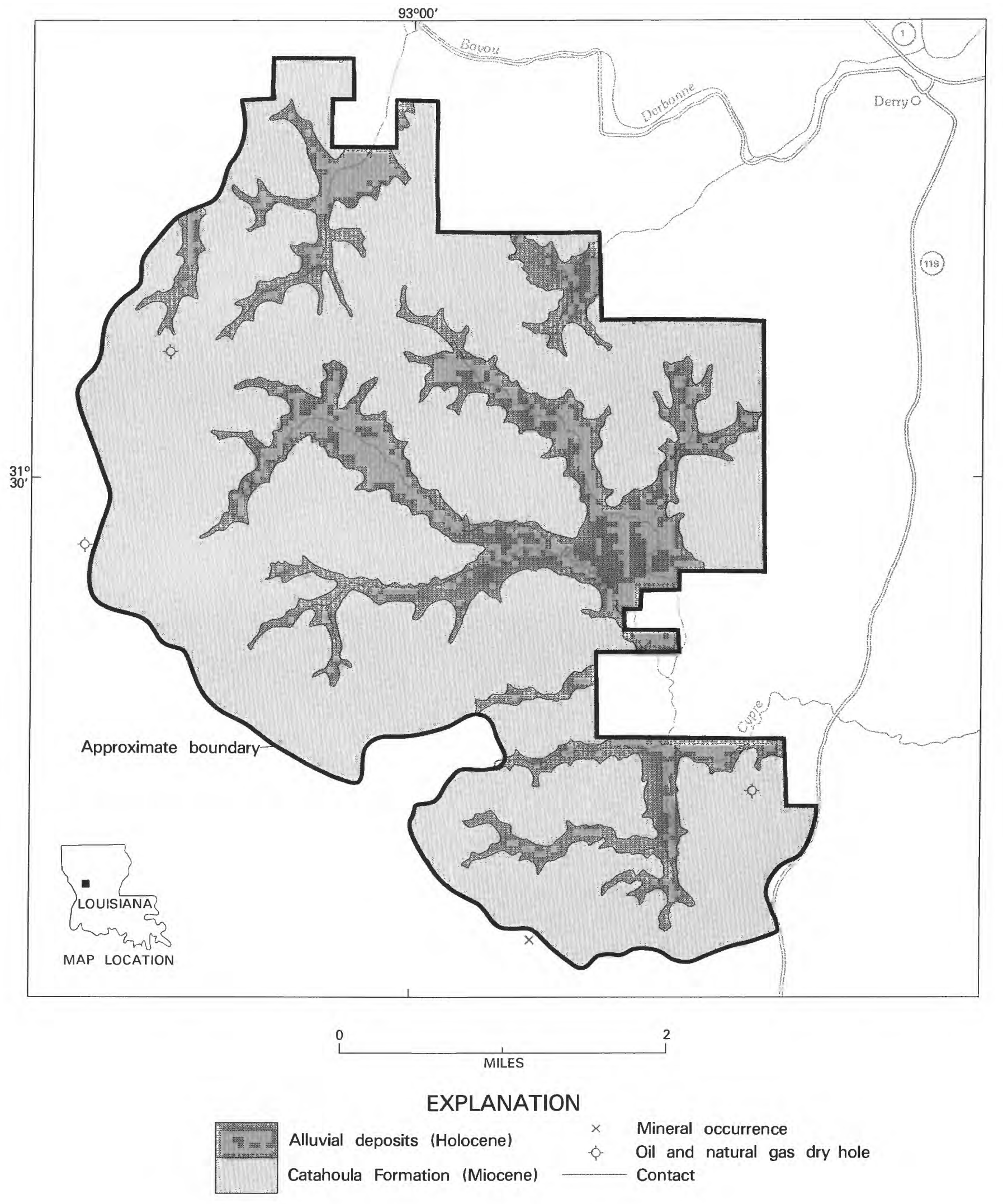

Figure 178.-Kisatchie Hills Wilderness, Louisiana. 


\title{
KISATCHIE HILLS WILDERNESS, LOUISIANA
}

\author{
By Boyd R. Haley, U.S. GeOlOGiCal Survey, and \\ GEORGE S. RYAN, U.S. BUREAU OF Mines
}

\begin{abstract}
SUMMARY
A mineral-resource survey conducted by the USGS and USBM in 1982 of the Kisatchie Hills Wilderness indicated little promise for the occurrence of mineral resources. There is insufficient data on oil and gas producing formations that underlie the area to evaluate the oil and gas resource potential.
\end{abstract}

\section{CHARACTER AND SETTING}

The Kisatchie Hills Wilderness, an area of about 13 sq mi in the southeastern part of Natchitoches Parish, is forested with a mixture of pine and hardwood trees. Bayou Cypre is an eastward-flowing stream that drains all but about $5 \mathrm{sq} \mathrm{mi}$ of the northern part of the wilderness. Altitudes range from about $375 \mathrm{ft}$ above sea level in the western part of the wilderness to about $110 \mathrm{ft}$ in the northeastern part. A relative relief of $165 \mathrm{ft}$ in such a small area is unique when compared to the generally flat surface of the rest of Louisiana.

Two lithologic units are present in the wilderness. The older unit (Catahoula Formation of Miocene age) consists of interbedded clay, silt, and sand, and crops out on the hillsides. The younger unit consists of Holocene alluvial deposits of silt and sand along the streams. The sediments in the Catahoula Formation dip southeastward at about $70 \mathrm{ft} / \mathrm{mi}$.

\section{MINERAL RESOURCES}

A clayey and silty sand has been taken from a pit in the NW1/4 sec. 33 , T. 6 N., R. 6 W., and used as a "binder clay" in asphalt for roads. Some of the sand at the surface has been cemented with silica so that it is now a rock. Some of this rock has been used as decorative stone in picnic areas, parks, flower beds, and building exteriors. The "binder clay" and the decorative stone are present elsewhere in the hills of the surrounding Kisatchie National Forest. Other nonmetallic min- erals are not known to be present in the wilderness nor are any metallic minerals known to be present.

Oil and natural gas have been produced from a reservoir of Wilcox (Paleogene) age in the Gorum Field (now abandoned) which is about $2 \mathrm{mi}$ southeast of the wilderness. However, oil and natural gas have not been reported from any of the other wells drilled within $6 \mathrm{mi}$ of the wilderness. Only six wells in the vicinity of the wilderness have been drilled deep enough to penetrate all of the sediments of Wilcox age and no oil or natural gas was found.

\section{SUGGESTIONS FOR FURTHER STUDIES}

All the oil fields of Wilcox age are less than 40 acres in extent; therefore, closer spaced deeper wells might find additional fields in sediments of Wilcox age. Oil and natural gas have been produced from older reservoirs (Cretaceous age) to the northwest of the wilderness, and deeper wells might find oil and natural gas in sediments of Cretaceous and older age in the vicinity of the wilderness.

\section{REFERENCES}

Haley, B. R., and Ryan, G. S., 1983, Mineral resource potential map of the Kisatchie Hills Wilderness, Natchitoches Parish, Louisiana: U.S. Geological Survey Open-File Report 83-495.

Ryan, G. S., 1982, Mineral investigation of the Kisatchie Hills Wilderness, Natchitoches Parish, Lousiana: U.S. Bureau of Mines Open-File Report MLA 135-82, 4 p. 
$\begin{array}{llllllll}M & \text { I } & C & H & \text { I } & G & A & N\end{array}$
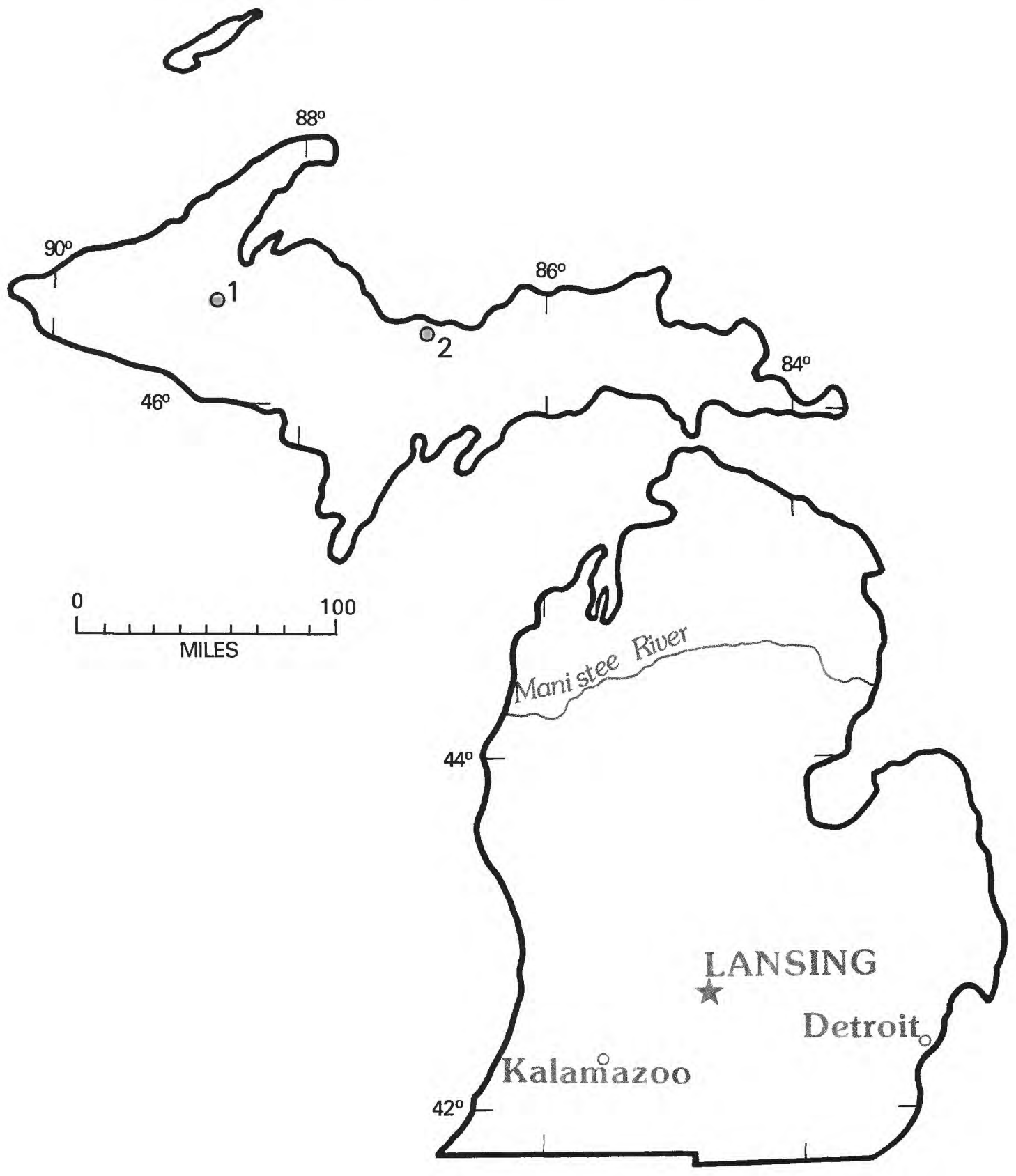

Location of areas studied. 


\section{MICHIGAN}

Map

No.

Name of Area

2 Rock River Canyon Wilderness Study Area

1 Sturgeon River Wilderness Study Area 


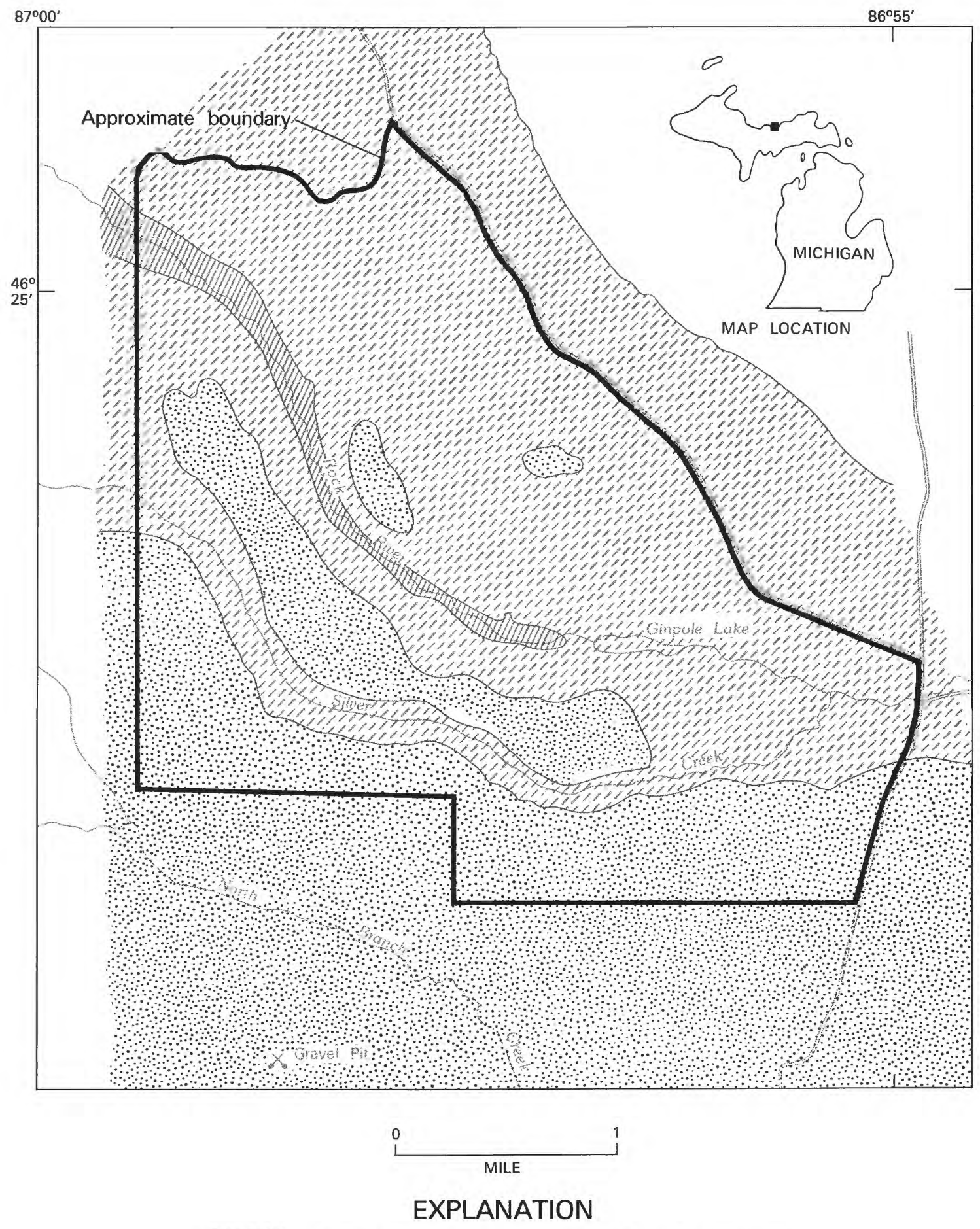

Au Train Formation (Lower and Middle Ordovician)
Munising Formation (Upper Cambrian)
Cacobsville Sandstone (Proterozoic Y)
Contact

Figure 179.-Rock River Canyon Wilderness Study Area, Michigan. 


\title{
ROCK RIVER CANYON WILDERNESS STUDY AREA, MICHIGAN
}

\author{
By Jesse W. Whitlow, ${ }^{1}$ U.S. GeOlOGICAl SuRVEY, and \\ Peter C. MOREy, U.S. Bureau of Mines
}

\section{SUMMARY}

\begin{abstract}
A mineral survey of the Rock River Canyon Wilderness study area, Alger County, Michigan, in 1975 by personnel of the USGS and the USBM concluded that there is little promise for the occurrence of metallic mineral resources in the study area. High silica sand and crushed rock from quartzose sandstone that is bedrock for much of the area occur but are available in more accessible areas outside of the wilderness.
\end{abstract}

\section{CHARACTER AND SETTING}

The Rock River Canyon Wilderness study area in the Upper Peninsula of Michigan is an area of approximately $8.6 \mathrm{sq} \mathrm{mi} \mathrm{located} 12 \mathrm{mi}$ west of Munsing, $2 \mathrm{mi}$ north of the towns of Eben Junction and Chatham, and in the Hiawatha National Forest. Only foot trails and logging roads furnish access into the area; USFS road number 2279 is the east boundary for approximately $1.2 \mathrm{mi}$. An unnumbered service road is the northeast boundary for $3.8 \mathrm{mi}$.

The Rock River Wilderness study area was established on January 3,1975. A mineral-resource survey of the area was made in the fall of 1975 and preliminary results were released in 1978 (Whitlow and others, 1978). The survey consisted of geologic mapping, geochemical sampling, and mine and prospect evaluation.

Geochemical studies indicate little promise for discovery of metallic minerals in bedrock in the study area. Soil samples collected are from glacier-transported debris and the significance of the variation in amount of contained elements is unknown. However, no group of samples from this small area contained a significantly large amount of any single metal.

Geophysical data for the study area indicate that Lake Superior-type iron ores are either absent or too deeply buried to be detected.

One or more glaciers crossed the study area modifying the existing topography by filling stream valleys with glacier-transported rock debris during the Pleistocene Epoch. The present topography is a result of postglacier erosion; however, the valleys of Rock River and

\footnotetext{
${ }^{1}$ With contributions from Elizabeth R. King.
}

Silver Creek follow filled preglacier valleys. Except for the valleys, the study area has relatively low relief.

Rocks exposed in the study area are almost flat-lying sandstone of Proterozoic $\mathrm{Y}$ and one of Late Cambrian age, and sandy dolomite, dolomitic sandstone, and quartzose sandstone of Middle and Late Ordovician age. The dolomite is thin and overlies older sandstone in the southern part of the study area.

\section{MINERAL RESOURCES}

Commodities in the study area are high-silica sand, stone, sand and gravel, and glauconite. The sandstone that is bedrock for much of the study area contains enough aluminum, iron, and other impurities to prevent it being used as a high-quality glass sand without beneficiation. Dimension sandstone is available near and probably from within the study area, but there is little promise for developing the stone. Sand and gravel are present mostly in glacier-deposited debris; a minor amount is in Holocene alluvium along Rock River and Silver Creek. No sand and gravel pits are in the study area, but pits near the area indicate substantial resources in the region. There is no local market for the sand and gravel. The thin sandy dolomite, and dolomitic sandstone that are at and near the top of high ground in the southern part of the study area contain as much as 7 percent glauconite; the glauconite has little promise as a resource.

\section{REFERENCE}

Whitlow, J. W., Geraci, P. J., Morey, P. C., and King, E. R., 1978, Mineral resources of the Rock River Canyon Wilderness study area: U.S. Geological Survey Open-File Report 78-527, 45 p. 

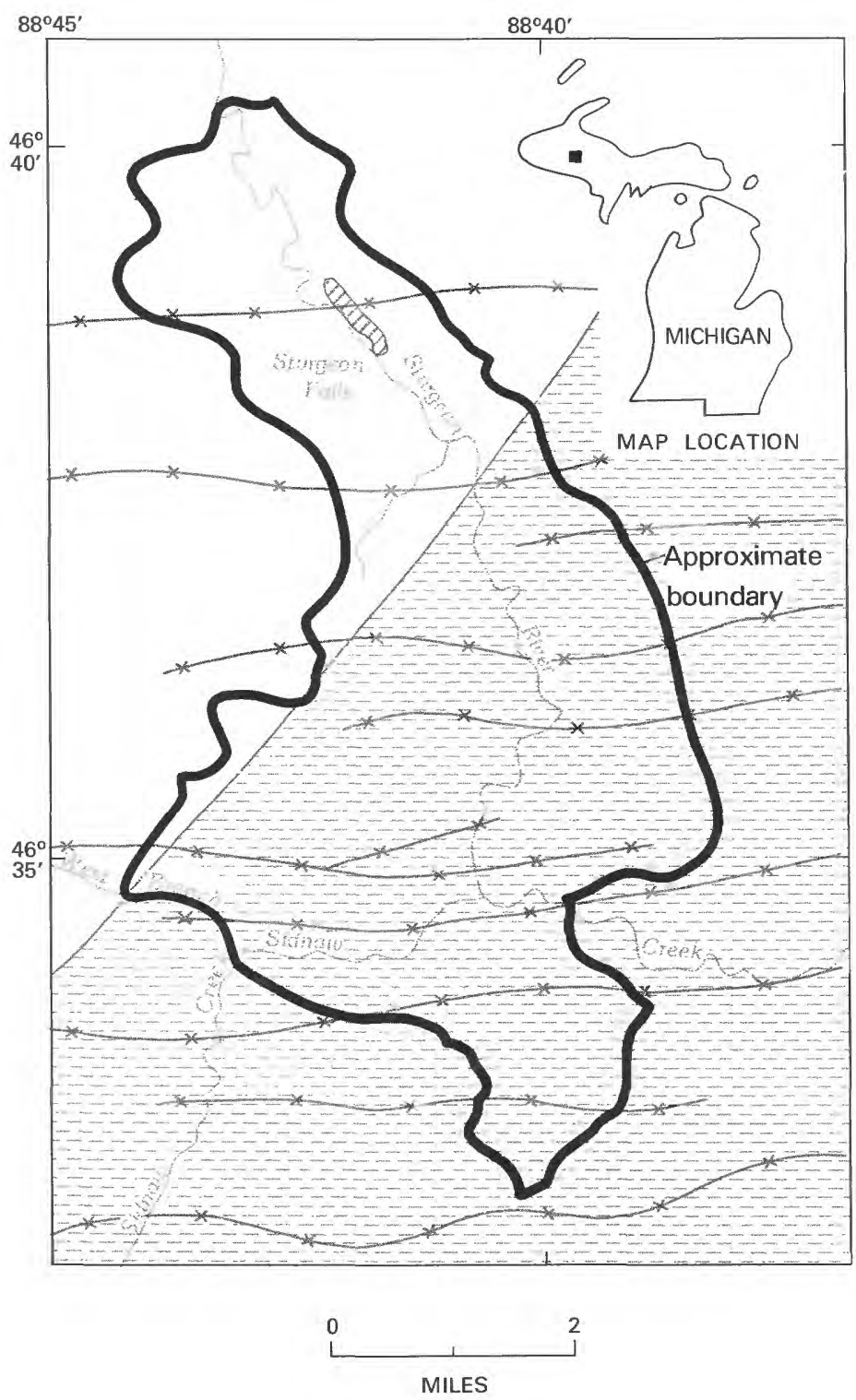

\section{EXPLANATION}

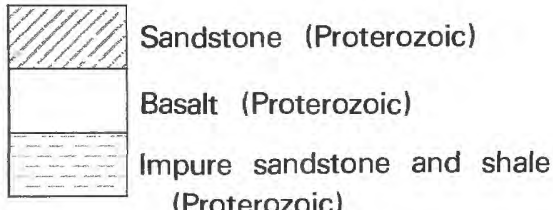
(Proterozoic)

Contact

$\rightarrow \quad *$ Dikes of basalt

Figure 180.-Sturgeon River Wilderness Study Area, Michigan. 


\title{
STURGEON RIVER WILDERNESS STUDY AREA, MICHIGAN
}

\author{
By W. F. Cannon, U.S. Geological Survey, and \\ James J. Hill, U.S. Bureau of Mines
}

\begin{abstract}
SUMMARY
A mineral survey of the Sturgeon River Wilderness study area was made in 1975 by the USGS and USBM using geologic mapping and geochemical techniques. Previous geophysical studies were incorporated in the mineral assessment. After our investigations in 1975, which found no indications for the occurrence of mineral resources, the area and surroundings became the focus of intense uranium exploration as the result of major discoveries of a newly recognized type of deposit found in Australia and Canada in rocks very similar to those in the study area. The exploration, to our knowledge, was unsuccessful and by 1982 exploration activity had nearly ceased. We still judge the area to have little promise for the occurrence of mineral or energy resources.
\end{abstract}

\section{CHARACTER AND SETTING}

The Sturgeon River Wilderness study area consists of flat upland surfaces underlain by sand and gravel deposited about 10,000 years ago by streams near the south margin of a northward receding glacier. The Sturgeon River has cut a steep-sided gorge through that sand and gravel and into underlying bedrock. The youngest bedrock unit is a sandstone probably about 1 billion years old which is in nearly flat lying beds. The sandstone lies on volcanic basalt flows that were erupted about 1.1 billion years ago. The flows were tilted northward and partly eroded before the sandstone was deposited. The oldest rocks present are impure sandstone and shale, about 2 billion years old. These rocks were folded and recrystallized, and then partly eroded prior to eruption of the basalt flows. Numerous vertical dikes of basaltic composition cut these rocks and probably were the lava conduits which fed the basalt flows. Because the only exposures of bedrock in the area are along the Sturgeon River, the overall geologic pattern in the area is not known in detail but was inferred from geophysical data (Cannon and others, 1980).

\section{MINERAL RESOURCES}

The Sturgeon River Wilderness study area is in the heart of the mineral-rich northern peninsula of Michigan and is less than $50 \mathrm{mi}$ from major copper and iron districts. However, the bedrock units in the area are not those that are mineralized in nearby mineral districts. No indications of mineral or energy resources were found in our study of the area.

In the late 1970's, after our study was completed, parts of the western northern peninsula, including the Sturgeon River Wilderness study area, were the focus of much uranium exploration. This resulted from some major discoveries of a newly recognized type of deposit in Australia and Canada in rocks and geologic environments very similar to those in part of the Sturgeon River Wilderness study area. The basal parts of the billion-year-old sandstone and immediately underlying rocks were the zone of interest. To our knowledge, the large amount of industry exploration done was not successful in finding uranium concentrations and by the early 1980's exploration activity had nearly ceased. Thus, although for a short period the area was judged by many geologists to have a good possibility for uranium resources, the failure of considerable exploration effort to find indications of mineralization leads us to conclude that the area has little promise for the occurrence of mineral or energy resources.

\section{REFERENCE}

Cannon, W. F., King, E. R., Hill, J. J., and Mory, P. C., 1980, Mineral resources of the Sturgeon River Wilderness study area, Houghton and Baraga Counties, Michigan: U.S. Geological Survey Bulletin $1465,49 \mathrm{p}$. 


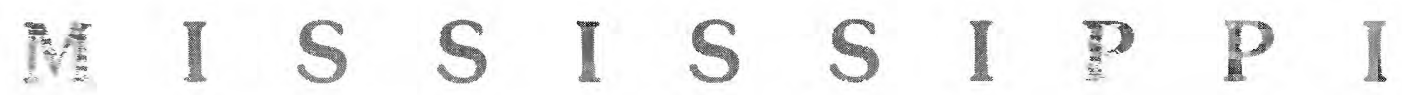

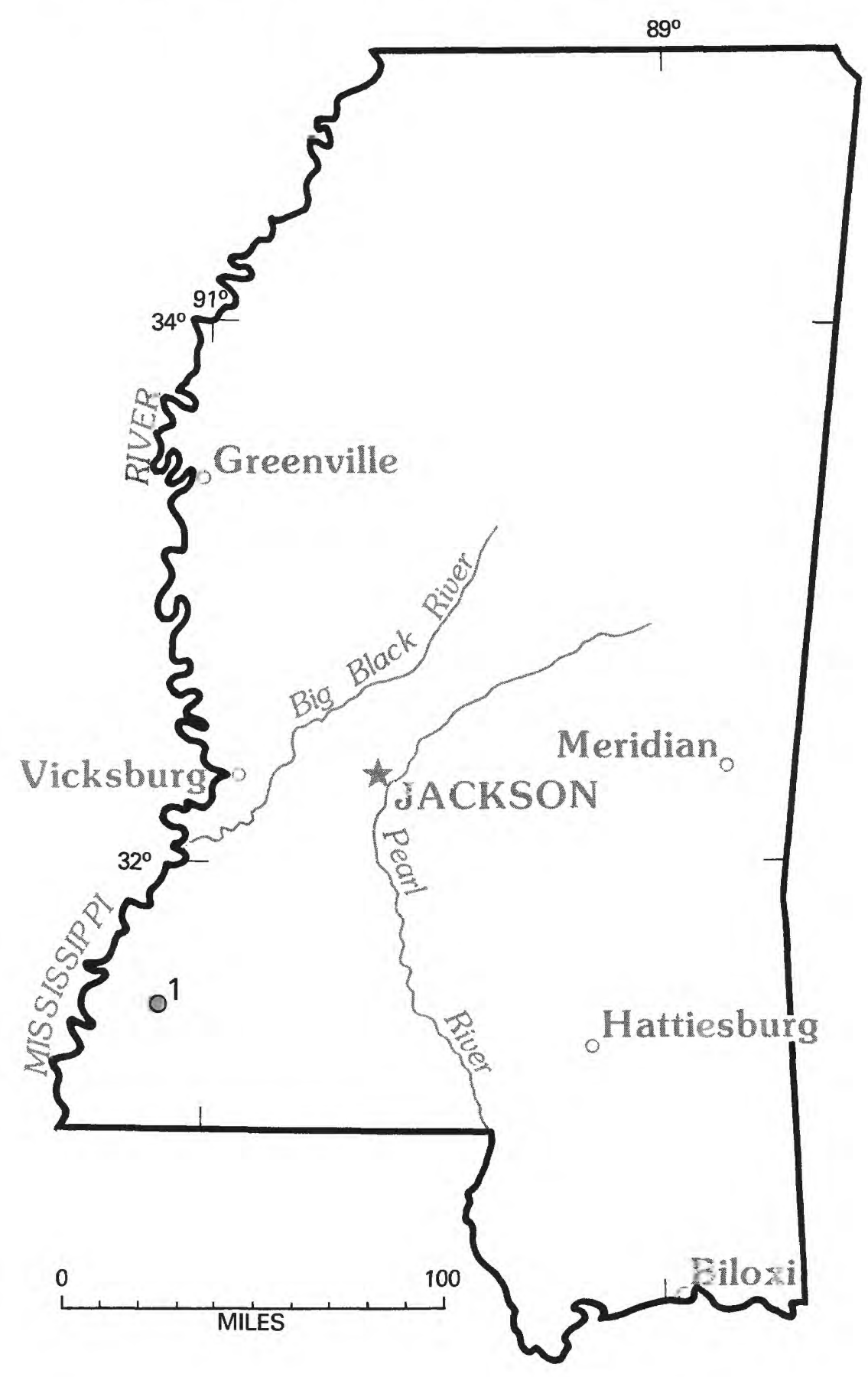

Location of areas studied. 


\section{MISSISSIPPI}

Map

Name of Area

1 Sandy Creek Roadless Area 

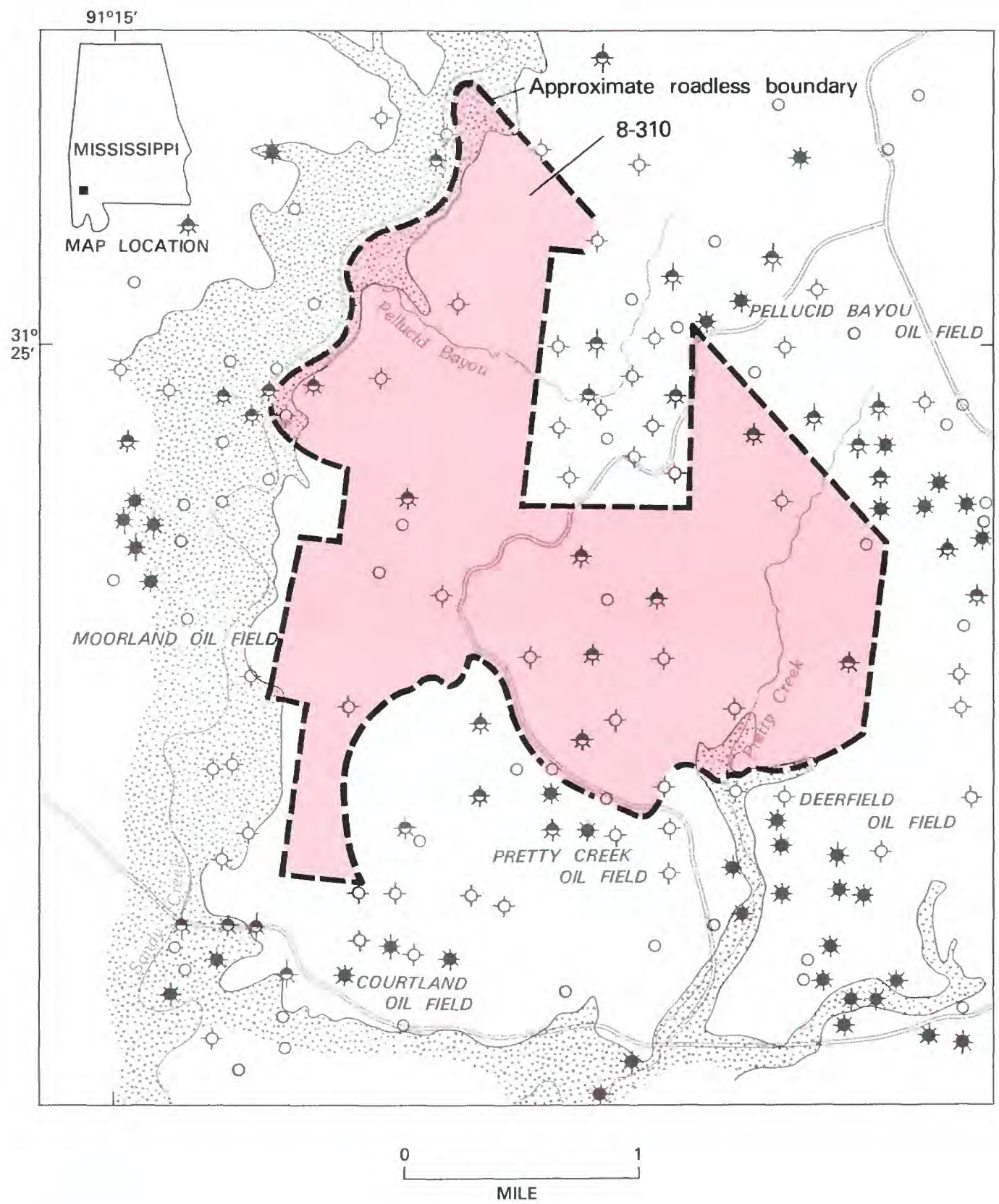

\section{EXPLANATION}

Geologic terrane with probable potential for oil and gas

Well symbols

Reported oil producing

\& Reported show of oil

b- Reported dry hole

- Production data not available

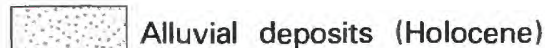

Alluvial deposits (Pleistocene)

Figure 181.-Sandy Creek Roadless Area, Mississippi. 


\title{
SANDY CREEK ROADLESS AREA, MISSISSIPPI
}

\author{
By BOYD R. Haley, U.S. GeOlOGical SuRvey, and \\ RichaRd F. BITAR, U.S. BUREAU OF MineS
}

\begin{abstract}
SUMMARY
On the basis of a mineral survey of the Sandy Creek Roadless Area by the USGS and USBM in 1981, the area offers little promise for the occurrence of metallic mineral resources but has a probable resource potential for oil and natural gas.
\end{abstract}

\section{CHARACTER AND SETTING}

The Sandy Creek Roadless Area includes about $3.7 \mathrm{sq}$ $\mathrm{mi}$ in the southeastern part of Adams County, Mississippi. Sandy Creek, Pellucid Bayou and Pretty Creek, the major streams, have eroded the area into gently rolling hills and narrow steep-walled valleys. Surface altitudes range from 130 to $290 \mathrm{ft}$ above sea level in the area.

Consolidated bedrock is not exposed in the roadless area, but alluvium of two ages, Pleistocene and Holocene, is present. The alluvium is composed of gravel, sand, silt, and clay.

\section{MINERAL RESOURCES}

The Sandy Creek Roadless Area has a probable resource potential for oil and natural gas, but offers little promise for the occurrence of metallic minerals. The roadless area lies within the oil and gas producing region known as the Western Gulf Basin (Mason, 1971, fig. 1), but no producing wells are present in the roadless area. Since 1948, oil and natural gas has been produced from 14 different reservoirs of the Eocene Wilcox Group or in younger rocks in the vicinity of the roadless area. According to Craft (1966, p. 124), most of the Wilcoxage oil and natural gas has been found in channel sands with lithologic entrapment and some local structural entrapment; the remainder of the oil and natural gas has been found in sheet sands that are draped over underlying channel sands. Most of the oil fields in Wilcox and younger strata have (1) structural closure of less than 20 $\mathrm{ft},(2)$ an oil column of less than $15 \mathrm{ft}$, (3) less than six producing wells, (4) an area of less than 160 acres, (5) oil production of less than 600,000 barrels, and (6) more than one reservoir in many of them.
The depositional environment and structural setting are favorable for the occurrence of oil and natural gas in the Wilcox and younger rocks in the roadless area, particularly when consideration is given to the following facts: (1) less than half the area is drilled on a 40 -acre spacing, (2) a show of oil has been reported from 9 of the 23 wells drilled in the roadless area, and (3) oil has been produced from 3 wells and reported as a show in four wells, all drilled within $500 \mathrm{ft}$ of the roadless area.

Wells sited in or near the roadless area were drilled to test reservoirs of Wilcox or younger age rocks, and as they are less than $7200 \mathrm{ft}$ deep, they did not penetrate the deeper reservoirs. Oil and natural gas are being produced from reservoirs of Late Cretaceous age in one oil field and two gas fields in western Adams County to the west, in four oil fields and two gas fields in Jefferson County to the north, and in four oil fields and one gas field in Franklin County to the east. Oil and natural gas are also being produced from reservoirs of Late Jurassic age in Franklin County. Because the roadless area is bracketed on three sides by commerical production of oil and natural gas, it is possible that wells drilled deep enough to penetrate the older reservoirs will encounter significant quantities of oil and natural gas in the roadless area.

The deposits of gravel, sand, and clay present in the area could be utilized in the construction industry, but similar deposits elsewhere are much closer to available markets.

\section{REFERENCES}

Craft, W. C., 1966, Channel sands are the key to Wilcox oil: Oil and Gas Journal, v. 64, no. 15, p. 124-130.

Haley, B. R., Bitar, R. F., and Crandall, T. M., 1983, Mineral resource potential map of the Sandy Creek Roadless Area, Adams County, Mississippi: U.S. Geological Survey Open-File Report 83-496. 
Mason, B. B., 1971, Summary of possible future petroleum potential of region 6, Western Gulf Basin: in Future petroleum provinces of the United States-their geology and potential: American Association of Petroleum Geologists, Memoir 15, p. 805-812. 

$\begin{array}{llllllll}M & \text { I } & S & S & O & U & R & \text { I }\end{array}$

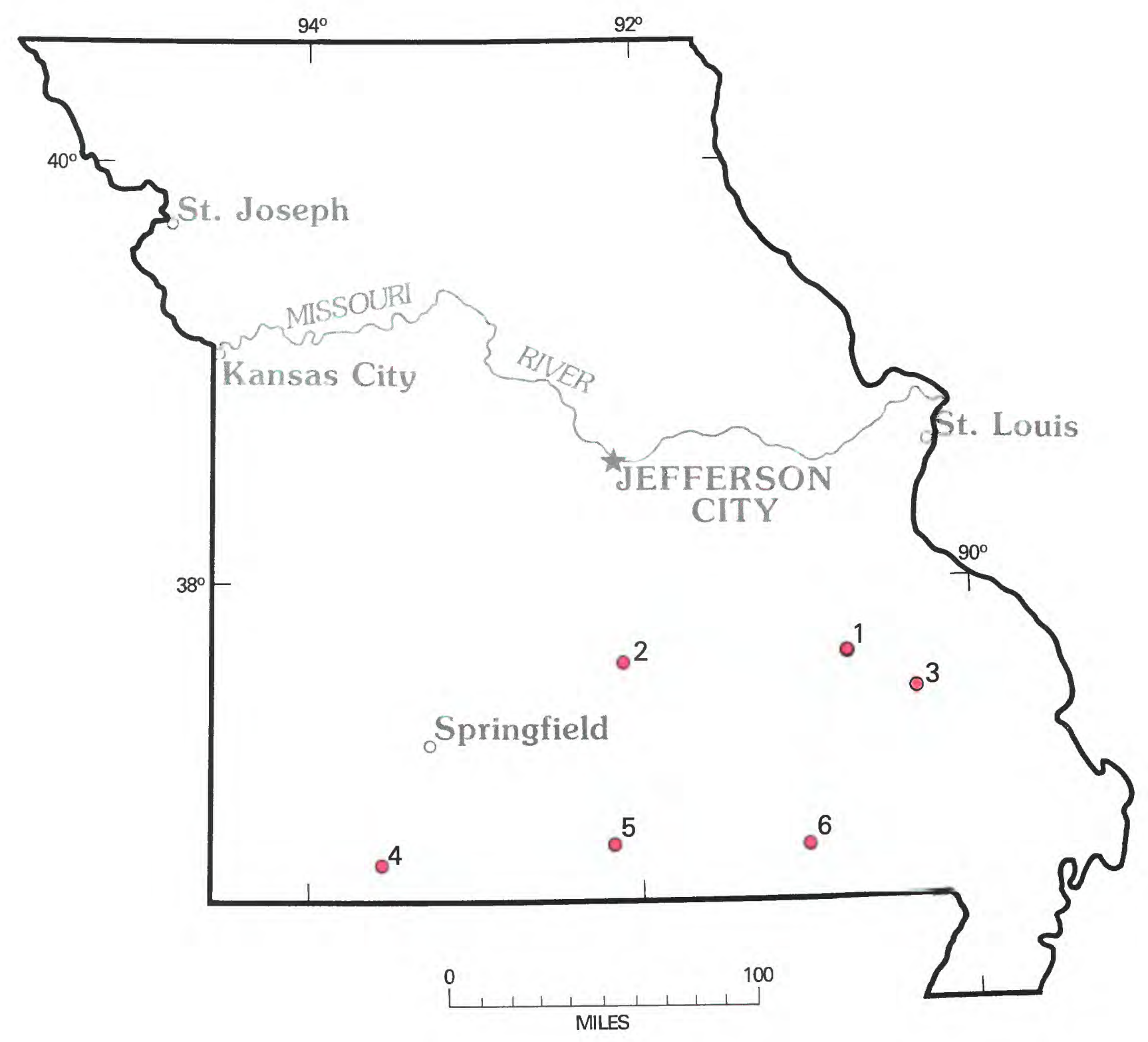

Location of areas studied. 


\section{MISSOURI}

Map
No.

Name of Area

1 Bell Mountain Wilderness Study Area

5 Hercules Glades Wilderness

6 Irish Wilderness Roadless Area

2 Paddy Creek Wilderness Study Area

4 Piney Creek Wilderness

3 Rock Pile Mountain Wilderness Study Area 

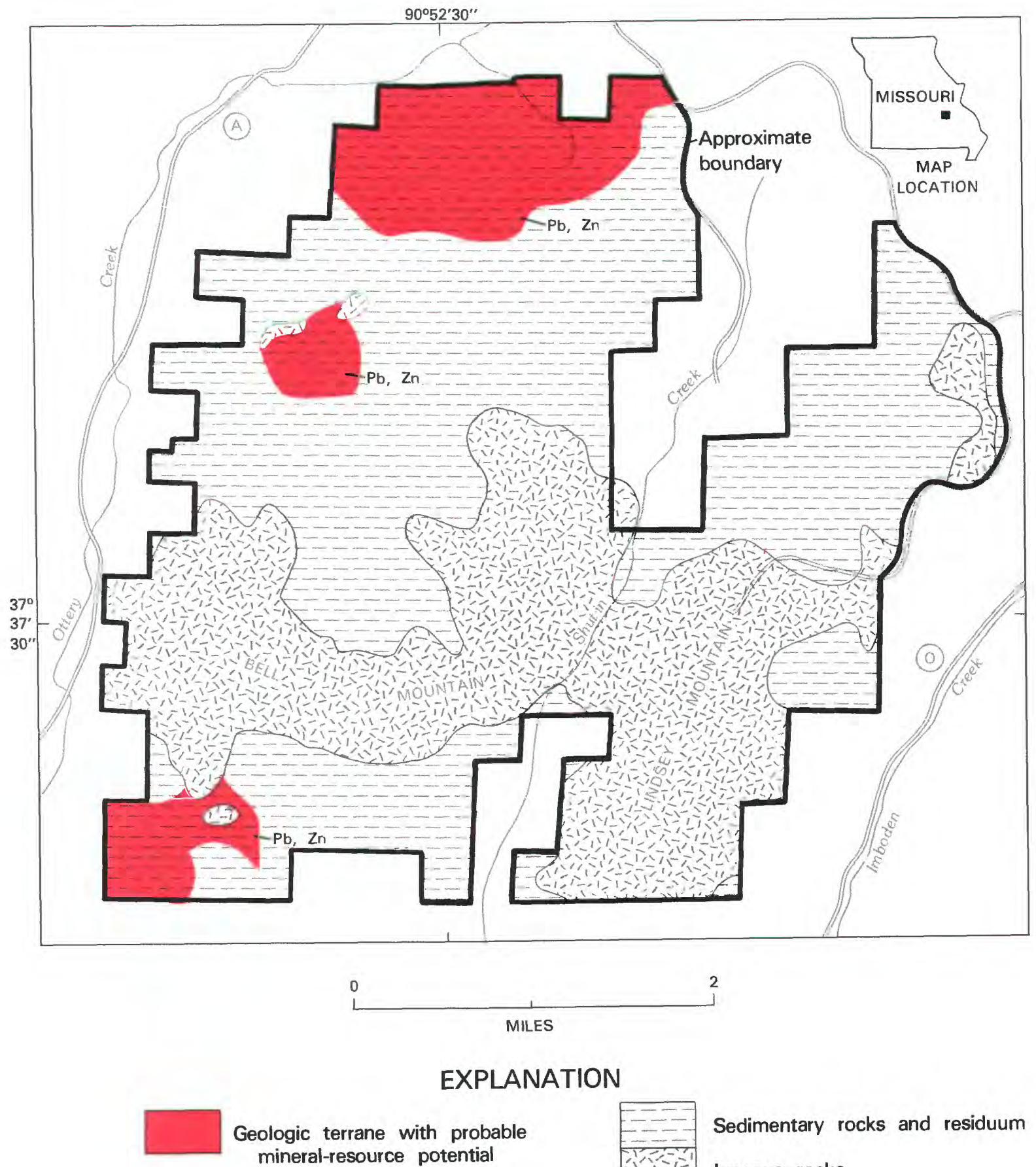

Geologic terrane with probable mineral-resource potential

$\begin{array}{cc}\mathrm{Pb} & \text { Lead } \\ \mathrm{Zn} & \text { Zinc }\end{array}$

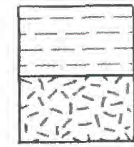

Sedimentary rocks and residuum Igneous rocks

Contact

Figure 182.-Bell Mountain Wilderness study area, Missouri. 


\title{
BELL MOUNTAIN WILDERNESS STUDY AREA, MISSOURI
}

\author{
By Walden P. Pratt, ${ }^{1}$ U.S. GeOlogical SuRvey, and \\ Clarence Ellis, U.S. Bureau of Mines
}

\section{SUMMARY}

\begin{abstract}
Geologic, geochemical, geophysical, and mineral-occurrence studies of the Bell Mountain Wilderness study area made in 1978-79 indicate little promise for the occurrence of major base-metal resources like those of the Viburnum Trend, which lies $12 \mathrm{mi}$ west of the study area. Abandoned prospects on the west side of Shut-in Creek were opened on narrow sulfide-bearing quartz veins in Precambrian volcanic rocks. These veins contain lead, copper, and trace amounts of silver, but they do not constitute a resource at present, and evidence from this study suggests little promise for resources at depth. Unusually high amounts of trace metals in panned concentrates from several drainages on the west side of the area indicate areas of probable resource potential for low-grade lead-zinc deposits buried at depths of a few hundred feet. There is little promise for the occurrence of energy resources in the area.
\end{abstract}

\section{CHARACTER AND SETTING}

The Bell Mountain Wilderness study area covers $13 \mathrm{sq}$ mi of the Mark Twain National Forest in Iron County, Missouri, about $110 \mathrm{mi}$ by highway southwest of St. Louis and $25 \mathrm{mi}$ west of Farmington. All sides of the study area are accessible by State, County, and USFS roads. The area is on the western flank of the St. Francois Mountains, and is dominated by Bell Mountain and Lindsey Mountain, two rounded ridges of Precambrian volcanic rocks. Flat to gently dipping Cambrian dolomites and minor sandstones flank the Precambrian rocks but are exposed only in small areas of some of the drainages; elsewhere these sedimentary rocks are covered by chert- and sandstone-bearing residuum of unknown thickness, derived by dissolution of the carbonates.

The Precambrian rocks that form Bell Mountain and Lindsey Mountain are mostly welded rhyolitic ash-flow tuffs. Porphyritic granite intrudes the rhyolite at the southeast corner of the area. The volcanic rocks are gently folded and faulted on a local scale; regionally, they form the northwest margin of a large volcanotectonic depression.

The exposed Cambrian rocks are mostly dolomites but include some shaly and silty units and a basal

${ }^{1}$ With contributions by R. L. Erickson, USGS. arkosic sandstone; from the base up, they include the Lamotte Sandstone, the Bonneterre and Davis Formations, and the Derby-Doerun (of the Missouri Geological Survey), Eminence, and Potosi Dolomites, all of Late Cambrian age. In much of the area underlain by these formations, the carbonate bedrock has been leached to considerable depths by percolating ground waters, which have dissolved and removed the carbonate minerals, leaving a residuum of poorly consolidated clay with fragments of chert, quartz, and sandstone.

The thickness of the Bonneterre Formation underneath the residuum north of Bell Mountain is pertinent to an appraisal of mineral-resource potential, because the Bonneterre is the principal ore host in the Old Lead Belt and Viburnum Trend. The few bedrock exposures of the sedimentary rocks indicate that the maximum thickness of the Bonneterre Formation in the study area is probably a few hundred feet, in the vicinity of Ottery Creek at the northwest edge of the area.

The only structures observed in the Paleozoic rocks are gentle dips away from the Precambrian knobs, reflecting initial depositional dips probably accentuated by diagenetic compaction. No faults have been identified or inferred.

A geochemical study of the area was made to augment surface observations. This study consisted of semiquantitative spectrographic and chemical analyses of stream sediments, panned concentrates of stream 
sediments, and outcropping volcanic rocks. Geochemical anomalies in the panned concentrates are discussed in the section "Mineral Resources". Analyses of rock samples from outcrops of Precambrian volcanic rocks showed no evidence of mineralization.

Regional gravity and aeromagnetic maps that include the study area do not show any anomalies considered to be significant in terms of mineral-resource potential.

\section{MINERAL RESOURCES}

The resource appraisal is based on interpretation of the local and regional geology, analyses of streamsediment and panned-concentrate samples representing all the drainages in the area, analyses of representative samples of Precambrian rocks, and examination of outcrops for visible metallic mineralization (Pratt and others, 1982). Several of the formations that underlie the study area are known to be the host rocks for mineral deposits in nearby areas, and therefore may have some potential for mineral resources in the study area.

The Viburnum Trend lead-zinc-silver-copper-nickelcobalt ore deposits are located about $12 \mathrm{mi}$ west of the west border of the study area and are mostly in the Bonneterre Formation. To our knowledge, no mineralization of economic importance has been discovered in the intervening area. Drilling for lead and zinc on USFS lands northeast of the study area yielded negative results. Much of the exposed Bonneterre Formation in the study area consists of the "white rock facies" of local usage, which is considered an unfavorable host rock for ores of this type. Therefore, although the mineral potential of the subsurface Bonneterre Formation can be tested only by drilling, the available geologic and geochemical data suggest that there is little promise in the study area for the occurrence of ore deposits of the magnitude of the Viburnum Trend deposits. However, the geochemical study showed three sites along the northwest side of the study area, in which the panned concentrates contained unusually high amounts of base metals. Although these concentrates were derived chiefly from formations higher in the stratigraphic section than the Bonneterre Formation, the high metal values may be leakage halos caused by the migration of metals from mineralized Bonneterre rocks in the sub- surface into overlying formations, which later were reduced to residuum through chemical weathering and dissolution of carbonate. Therefore these geochemical anomalies in concentrates of stream sediments derived from residuum are interpreted to be indirect indicators of probable resource potential for low-grade lead-zinc deposits in the Bonneterre Formation. If such deposits exist, they are probably within a few hundred feet of the surface.

Prospects on the west side of Shut-in Creek, in the south-central part of the study area, were opened on sulfide-bearing quartz veins in Precambrian rhyolitic ash-flow tuff; the principal contained metals are lead, copper, and traces of silver. The veins are exposed in only a limited area, are well below ore grade, and do not constitute a resource at present. They have not been explored at depth, but there is little promise for resources because they contain no trace elements indicative of a significant mineralizing system.

Coal is not found in Ordovician and older rocks. Occurrences of oil or gas are considered unlikely in the Ozark uplift. Evidence of geothermal energy is lacking.

Except for shaly parts of the Davis Formation, the rocks of the area are suitable for aggregate. The Bonneterre Formation is a major source of refractory dolomite in Missouri, and the Eminence Dolomite, which may be present beneath the residuum, is a potential source of pure dolomite in some areas. However, these formations are present over a wide area, and similar rocks are abundant in more accessible locations in the region.

\section{SUGGESTIONS FOR FURTHER STUDIES}

Drilling through the Bonneterre Formation in the three areas of probable potential on the west side of the study area, combined with geochemical studies of the drill samples, would permit a better appraisal of the potential for lead-zinc deposits in those areas.

\section{REFERENCE}

Pratt, W. P., Erickson, R. L., and Ellis, Clarence, 1982, Mineralresource potential map of the Bell Mountain Wilderness study area, Iron County, Missouri: U.S. Geological Survey Miscellaneous Field Studies Map MF-1178-B, scale 1:24,000. 


\title{
HERCULES GLADES WILDERNESS, MISSOURI
}

\author{
By Mary H. Miller, U.S. GeOlogical Survey, and \\ GEORGE S. Ryan, U.S. BUREAU OF MineS
}

\begin{abstract}
SUMMARY
Based on geologic, geochemical, geophysical, and mine and claim surveys in 1980 , Hercules Glades Wilderness has little promise for the occurrence of metallic-mineral or energy resources in formations exposed at and near the surface. Upper Cambrian formations, known to contain major deposits of lead, zinc, silver, copper, nickel, and cobalt in the Viburnum Trend and Southeast Missouri mining districts, occur in the subsurface within the wilderness. These formations are permissive for mineral resources of the Viburnum type, but the potential of the wilderness cannot be appraised without deep drilling.
\end{abstract}

\section{CHARACTER AND SETTING}

The Hercules Glades Wilderness comprises about 20 sq mi of the Mark Twain National Forest in east-central Taney County, Missouri, approximately $40 \mathrm{mi}$ southeast of Springfield. The area was studied in 1980 and the results published by Miller and others (1981) and Miller and Chesson (1982).

The principal access to the wilderness area is from Missouri State Highway 125, which passes along the eastern side of the area. U.S. Highway 160 and Blair Ridge Road provide access from the south.

Strata in southwestern Missouri are nearly horizontal; regional dip is about one-half degree west. No faults are known to occur within the wilderness. Formations exposed in the Hercules Glades Wilderness are carbonates of Ordovician and Mississippian age. Beds present in the subsurface include Ordovician and Upper Cambrian sandstones, dolomites, limestones, and shales. Precambrian rocks underlying this region are granitic.

\section{MINERAL RESOURCES}

There has been no mining activity or filing of claims within the wilderness, and there is little evidence of prospecting. All lead-zinc production from Taney County has been from occurrences $6 \mathrm{mi}$ or more outside the wilderness. One prospect pit in section 18, T. 23 N., R.
$18 \mathrm{~W}$. is said to have been opened in search of brown iron ore. Assays indicate that no iron resource is present.

Spectrographic analyses of stream-sediment and rock samples from the Hercules Glades Wilderness do not show anomalous amounts of metal in the formations exposed. Geochemical data available indicate that there is no significant surface mineralization within the wilderness.

Regional gravimetric and magnetic maps of Missouri show no anomalies in the wilderness. In July 1981, the USGS made an aeromagnetic survey of Hercules Glades Wilderness and adjacent areas. A preliminary study of these data do not show any significant magnetic anomalies (Ronny Martin, oral commun., 1982). Based on these studies it was determined that the area had little promise for the occurrence of metallic or energy resources at or near the surface.

Subsurface Upper Cambrian formations have some promise for lead-zinc-silver-copper deposits; however, existence of such deposits can neither be confirmed nor ruled out without exploratory drilling.

\section{SUGGESTIONS FOR FURTHER STUDIES}

Deep drilling to test the buried Cambrian formations for lithologic character and trace metals would be needed in order to permit appraisal of the potential of these formations for base-metal deposits. 


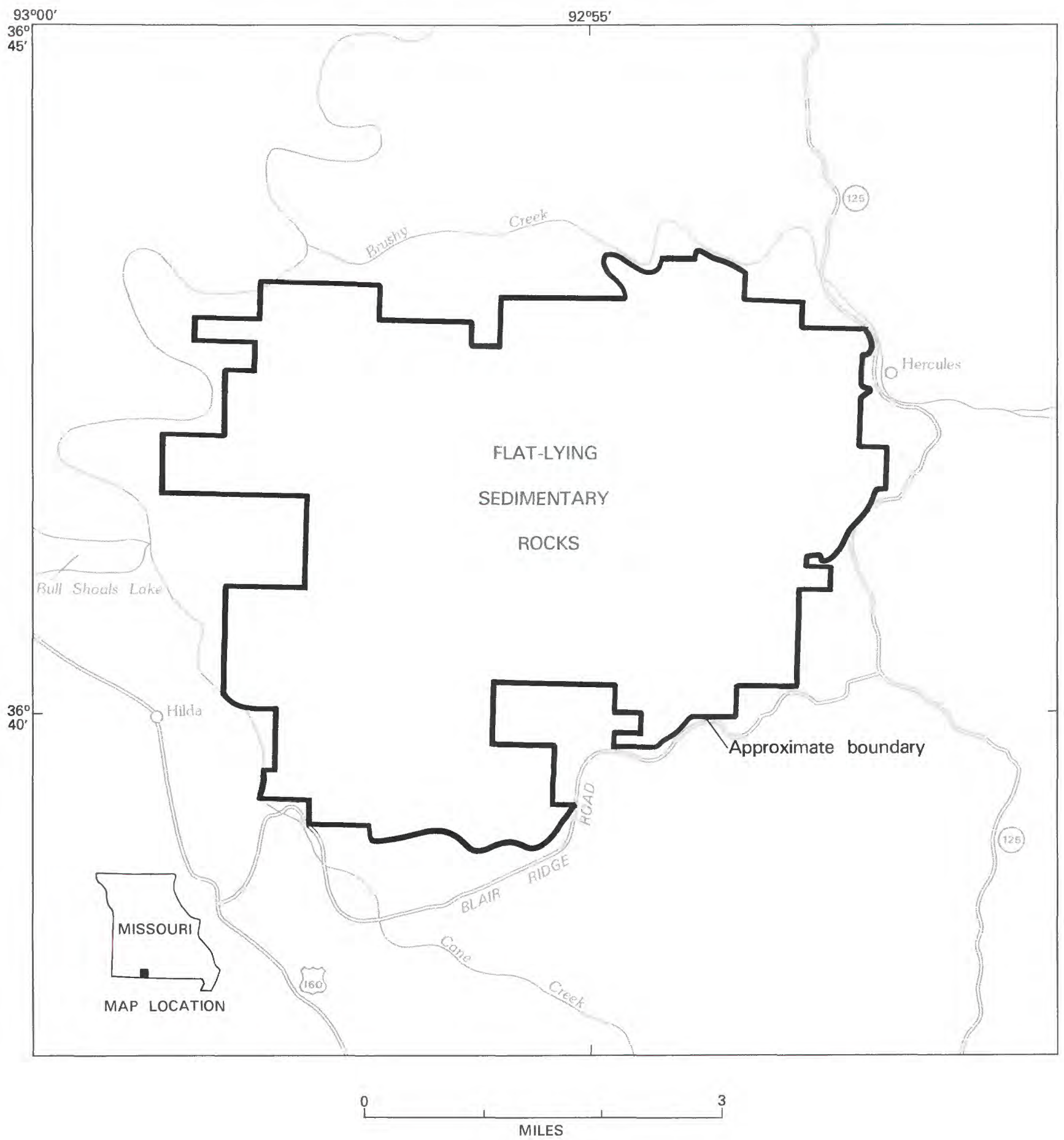

Figure 183.-Hercules Glades Wilderness, Missouri. 


\section{REFERENCES}

Miller, M. H., and Chesson, S. A., 1982, Geochemical map of Hercules Glades Wilderness, Taney County, Missouri: U.S. Geological Survey Miscellaneous Field Studies Map MF-1377-B, scale $1: 50,000$
Miller, M. H. Chesson, S. A., and Ryan, G. S., 1982, Mineral resource potential map of Hercules Glades Wilderness, Taney County, Missouri: U.S. Geological Survey Miscellaneous Field Studies Map MF-1377-C, scale 1:50,000.

Miller, M. H., Thompson, K. C., and Chesson, S. A., 1981, Geologic map of the Hercules Glades Wilderness and adjacent areas. Taney County, Missouri: U.S. Geological Survey Miscellaneous Field Studies Map MF-1377-A, scale 1:50,000. 


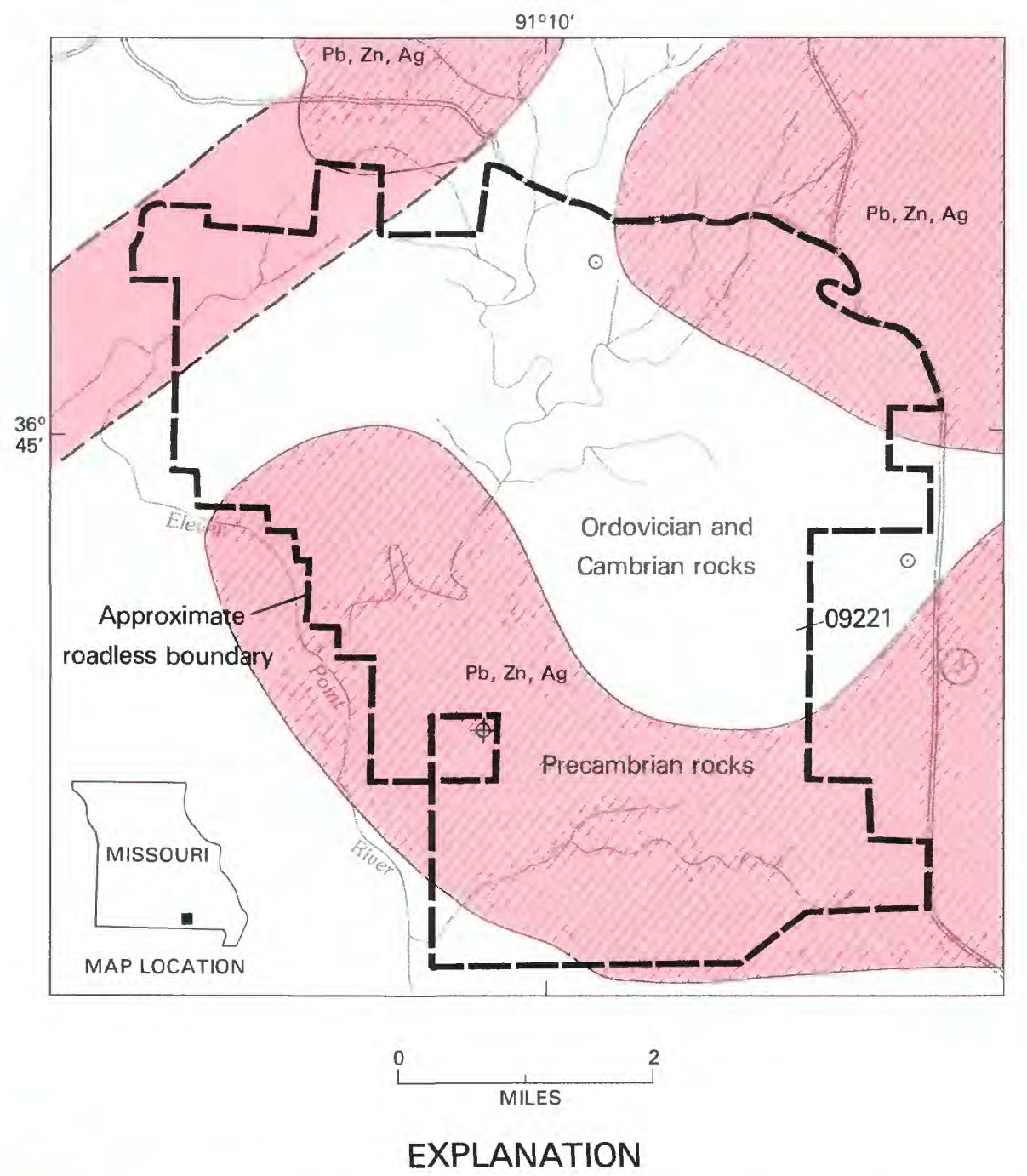

\begin{tabular}{|l|cll}
\hline & $\begin{array}{l}\text { Geologic terrane with probable } \\
\text { mineral-resource potential }\end{array}$ & $\$$ & U.S. Bureau of Mines sample locality \\
$\mathrm{Pb}$ & Lead & $\odot$ & Drill hole \\
$\mathrm{Ag}$ & Silver & - & Outer margins of buried fault zone \\
$\mathrm{Zn}$ & Zinc & & Contact
\end{tabular}

Figure 184.-Irish Wilderness Roadless Area, Missouri. 


\title{
IRISH WILDERNESS ROADLESS AREA, MISSOURI
}

\author{
By ALLEN V. Heyl, ${ }^{1}$ U.S. GeOlogical SuRVey, and \\ GEORGE S. RYAN, BUREAU OF MINES
}

\begin{abstract}
SUMMARY
Based on surveys by the USGS and the USBM during the years 1979-81, parts of the Irish Wilderness Roadless Area (hereafter called roadless area) are considered to have a probable mineral-resource potential for the occurrence of lead, zinc, and silver deposits. The same Upper Cambrian formations that contain economic deposits of lead, zinc, silver, copper, and, in places, cobalt and nickel in the Viburnum Trend of the Southeast Missouri mining district occur in the deep subsurface within the roadless area. Further, buried hills and wide fault zones, known to be unusually good host areas for deposits in the Southeast Missouri mining district, have been identified by geophysical surveys in the roadless area. There is little promise for the occurrence of other mineral and energy resources in the roadless area.
\end{abstract}

\section{CHARACTER AND SETTING}

The Irish Wilderness Roadless Area in southeast Missouri covers about $27 \mathrm{sq} \mathrm{mi}$ in the Mark Twain National Forest in northeastern Oregon County, just south of the village of Wilderness. The roadless area is accessible from County Highway $J$ which partly follows the Oregon and Ripley County line along the east side of the area. U.S. Highway 160 is about $3.1 \mathrm{mi}$ to the south of the roadless area boundary.

The roadless area is within the Salem Plateau region of the Ozark uplift. The heavily timbered, nearly flat uplands are dissected by narrow, entrenched branches of the Eleven Point River, forming narrow cliff-sided valleys. Numerous small sinkholes and caves exist in the roadless area.

Three rock formations, dolomites and sandstones of Ordovician age, are exposed at the surface in the roadless area. These rocks are underlain by sedimentary rocks of Ordovician and Cambrian age, beneath which are buried hills and valleys composed of Precambrian rocks, probably granite (Kisvarsanyi, 1975, p. 16). As the dips of the strata exposed at the surface are flat, only the meaningful buried Precambrian structures which are the controls for the probable base metal deposits are shown on the map. These buried hills and

${ }^{1}$ With contributions by S. K. Odland and C. K. Moss, USGS. valleys, which form an uneven land surface beneath the sedimentary rocks, are at a depth of about $1600 \mathrm{ft}$. A 1.4-mi-wide northeast-trending fault or shear zone in the Precambrian basement is expressed at the surface by weak shearing and brecciation in the Paleozoic sedimentary rocks. It has resulted from slight postPrecambrian movements along the Precambrian fault zone.

The deeply buried Precambrian hills extend into the roadless area from three sides (see map) as shown by the geophysical studies of C. K. Moss (unpub. data, 1982). The areas of these hills as well as the buried fault zone in the Precambrian, are shown on the map.

Geologic, geochemical, and geophysical studies of the roadless area were done during the interval 1979-81 (Heyl and others, 1983). Spectrographic analyses of minus-80-mesh stream sediments and their corresponding panned concentrates from streams within, or draining, the roadless area indicate only local and minor anomalously high metal concentrations in the surface formations of the roadless area. No successful mining activity has taken place in the roadless area and there is no record of production or development within it.

\section{MINERAL RESOURCES}

Extrapolation of available data, especially from many drill holes north of the roadless area to within a few 
miles of it, plus the buried, irregular surface of the Precambrian rocks which provide favorable traps for ore deposits, suggest that there is a probable mineralresource potential for lead-zinc-silver deposits of the type known from the Viburnum Trend in parts of the roadless area (Erickson and others, 1978). The Viburnum Trend, which is located $45 \mathrm{mi}$ north of the roadless area, is the major subdistrict of the Southeast Missouri lead district, which yielded 90 percent of the lead, 23 percent of the zinc, 5 percent of the silver, and 1 percent of the copper produced in the United States in 1980 (G. S. Ryan, USBM, written commun., 1982). Cobalt, nickel, and cadmium are also byproducts of this ore. The probable potential for deeply buried metallic deposits cannot be confirmed or ruled out without information by drilling deep test holes within the roadless area, especially near or above the buried hills and the fault zone. The roadless area has little promise for the occurrence of nonmetallic mineral and energy resources; such nonmetallic resources are more readily available elsewhere in the region.

\section{SUGGESTIONS FOR FURTHER STUDIES}

A deep drilling program, with the holes spaced a minimum of about $2000 \mathrm{ft}$ apart, on the flat uplands of a large part of the roadless area is suggested as the best means to determine if deeply buried metallic deposits exist in the area. By using the many available old lumber trails in the area, a minimum of damage would result. The emphasis in this further study program would be to drill those areas above or near the buried Precambrian hills found by the geophysical study and the fault zone in the northwest part.

\section{REFERENCES}

Erickson, R. L., Mosier, E. L., Viets, J. G., 1978, Generalized geologic and summary geochemical maps of the Rolla $1^{\circ} \times 2^{\circ}$ quadrangle, Missouri: U.S. Geological Survey Miscellaneous Field Studies Map MF-1004-A, scale 1:250,000.

Heyl, A. V., Odland, S. K., Moss, C. K., and Ryan, G. S., 1983, Mineral resource potential map of the Irish Wilderness Roadless Area: U.S. Geological Survey Miscellaneous Field Studies Map MF-1151, scale 1:24,000.

Kisvarsanyi, E. B., 1975, Data on Precambrian in drill holes of Missouri including rock types and surface configuration: Missouri Division of Geology and Land Survey Report of Investigations $56,20 \mathrm{p}$. 


\title{
PADDY CREEK WILDERNESS STUDY AREA, MISSOURI
}

\author{
By Walden P. Pratt, ${ }^{1}$ U.S. GeOlogical SuRVEy, and \\ Clarence Ellis, U.S. Bureau of Mines
}

\begin{abstract}
SUMMARY
The Paddy Creek Wilderness study area was investigated by geologic and mineral surveys in 1978-79 by the USGS and USBM. There is no known record of mineral production, development, or prospecting in the area. Several rock units that underlie the study area are known to be the host rocks for important lead-zinc-silver-copper-nickel-cobalt deposits and magnetic iron-ore deposits of the Southeast Missouri district, about $52 \mathrm{mi}$ east of the study area. Similar occurrences may exist in the Paddy Creek Wilderness study area, but the mineralresource potential cannot be adequately evaluated without further study. The available data suggest that there is little promise for the occurrence of mineral resources, but their existence cannot be confirmed or ruled out without additional information. There is little promise for the occurrence of energy resources in the area.
\end{abstract}

\section{CHARACTER AND SETTING}

The Paddy Creek Wilderness study area in southcentral Missouri covers $11 \mathrm{sq}$ mi of the Mark Twain National Forest in northern Texas County, and is located about $32 \mathrm{mi}$ south-southwest of Rolla. The area is within the Salem Plateau, a physiographic subdivision of the Ozark Mountains. The heavily timbered, rolling uplands are dissected by Big and Little Paddy Creeks, forming narrow, bluff-lined valleys. Paddy Creek flows into Big Piney River just east of the study area. Numerous caves and sinkholes, typical of karst topography, exist in and near the study area. Maximum elevation in the study area is $1430 \mathrm{ft}$ on the west edge, and relief is $530 \mathrm{ft}$.

The study area is located on the northwest flank of the Ozark uplift. The rock units exposed are about $530 \mathrm{ft}$ of dolomites and sandstones of Ordovician agefrom the top down, the Jefferson City Dolomite, Roubidoux Formation, and Gasconade Dolomite-which through most of the area appear to be flat lying but actually have a very gentle southwesterly regional dip. These units are underlain by about $1200 \mathrm{ft}$ of essentially flat lying sedimentary rocks of Cambrian age, and basement igneous rocks of Precambrian age. Although the Precambrian and Cambrian rocks are not exposed at the

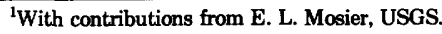

surface in the Paddy Creek area, they are exposed in the surrounding region and have been identified in drill holes several miles outside the study area.

The geologic structure in most of the area appears fairly simple; the strata have the very gentle regional southwesterly dip of this part of the Ozark uplift. Minor faults at the northeast edge of the area are thought to be due to solution collapse and not of tectonic origin; however, studies of regional Precambrian basement trends and LANDSAT imagery suggest that the study area is at the intersection of northeast- and northwest-trending lineaments that may reflect major structures at depth in the sedimentary section or in the Precambrian basement.

\section{MINERAL RESOURCES}

The resource appraisal of the Paddy Creek Wilderness study area is based on interpretation of the local and regional geology, analyses of stream-sediment and panned-concentrate samples representing all the drainages in the area, and examination of outcrops for visible metallic mineralization (Pratt and others, 1981), and in part on a recent appraisal of the resource potential of the Rolla $1^{\circ} \times 2^{\circ}$ quadrangle whose western boundary is just $3 \mathrm{mi}$ east of the study area (Pratt, 1981). No detailed magnetic or gravity surveys of the study area are available. 


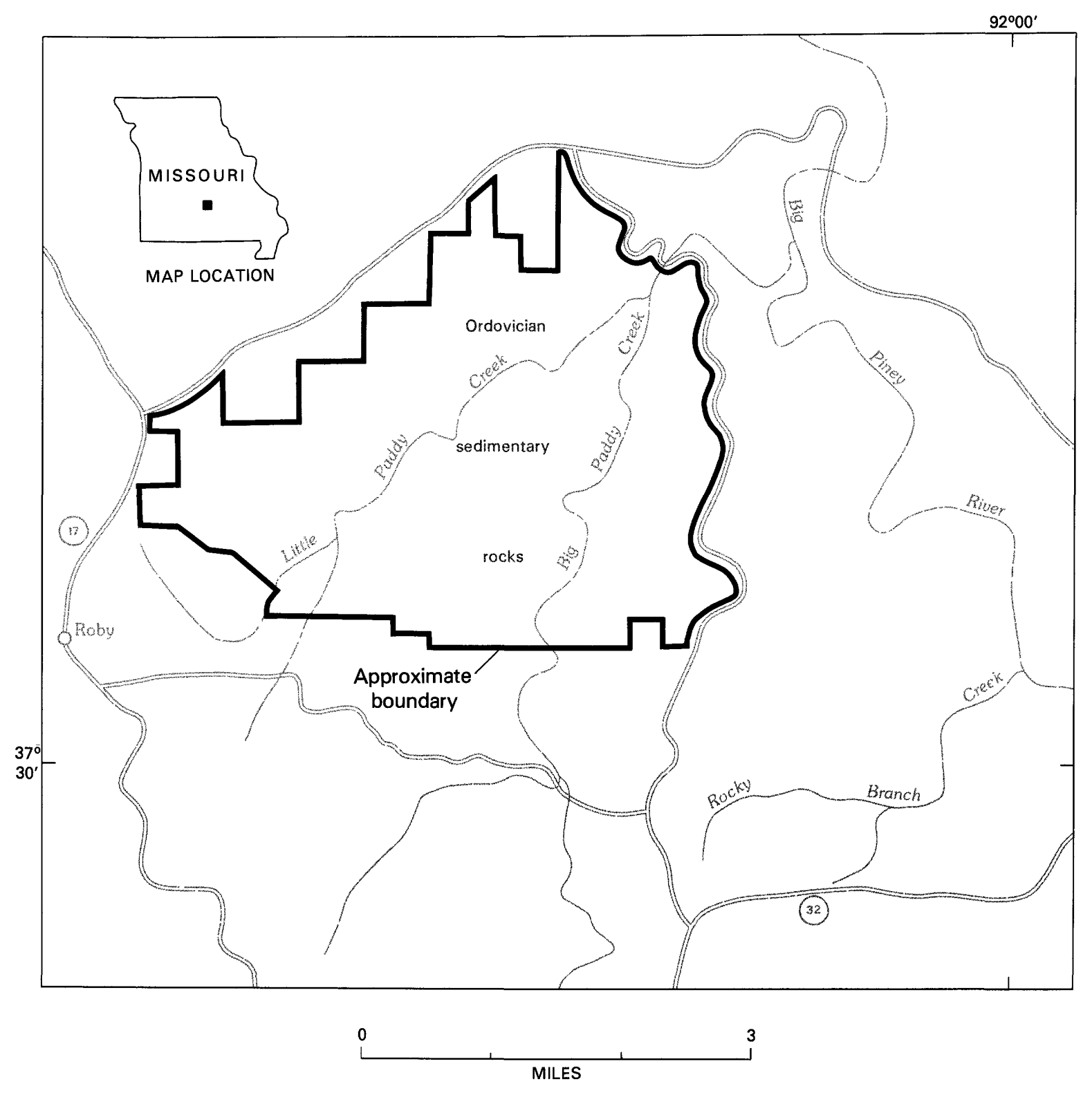

Figure 185.-Paddy Creek Wilderness study area, Missouri. 
Several of the formations that underlie the study area are known to be the host rocks for mineral deposits in nearby areas. The most important of these formations are the Cambrian dolomites, which contain the leadzinc-silver-copper-nickel-cobalt deposits and barite-lead (-zinc) deposits of the Southeast Missouri district, and the Precambrian igneous rocks, which contain magnetic iron-ore deposits.

The major lead-zinc-silver-copper-nickel-cobalt deposits of the Southeast Missouri district, whose western border lies about $52 \mathrm{mi}$ east of the study area, are sulfide disseminations and fracture fillings occurring in the Bonneterre Formation and to a lesser extent in the Lamotte, Potosi, Eminence, Gasconade, and Jefferson City Formations. In addition, large barite-lead, barite, and barite-zinc deposits are common in the Potosi and Eminence Dolomites in southeast and central Missouri. Thus in a general sense, sedimentary carbonate rocks anywhere in this region constitute "favorable geologic terrane" for ore deposits of this type. More specifically, the most important known ore trends in the Southeast Missouri district (1) occur in dolomite and are closely parallel to limestone-dolomite interfaces in the Bonneterre Formation, (2) tend to be localized close to algal reefs in the Bonneterre or (3) close to buried hills on the Precambrian surface, and (4) are in some cases spatially related to major faults. The existence of any of these features in the Paddy Creek area would indicate a potential for undiscovered ore deposits. Most of these features, however, cannot be detected at the surface, and no subsurface information is available on the Bonneterre Formation within the study area. All that we know or can infer as to the existence of the four features listed is that (1) on the basis of drill holes several miles east of the area, the Bonneterre within the study area is more probably limestone than dolomite; (2) algal reefs may or may not be present; (3) the presence or absence of buried Precambrian hills is not known, but could probably be inferred from a closely spaced aeromagnetic survey; and (4) major faults are not present at the surface but could be present at depth.

In a recent report on resource potential of the Rolla $1^{\circ} \times 2^{\circ}$ quadrangle (Pratt, 1981) "high" potential for small base-metal deposits in the Potosi and Eminence Dolomites was assigned to a northwest-trending elliptical area centered on a drill hole $3 \mathrm{mi}$ southeast of the Paddy Creek Wilderness study area. Although the apparent northwest extension of that elliptical area would include the study area, this assessment of high potential is no longer considered valid because it was based largely on "anomalous" amounts of molybdenum and arsenic in drill-hole samples, and subsequent studies in southwestern Missouri have shown that large trace amounts of these metals are not as anomalous as was originally believed (Erickson and others, 1981).
In summary, several formations potentially favorable for base-metal deposits underlie the study area; the most favorable of these, the Bonneterre Formation, can be inferred to be present at depths of about 1200$1450 \mathrm{ft}$ below the floor of Big Paddy Creek. The resource potential for base metals below the area cannot be adequately determined at this time.

The known magnetic iron-ore deposits in the Southeast Missouri district are in Precambrian silicic volcanic rocks and syenite. The surface of the Precambrian rocks in the Paddy Creek area is estimated to be about $1500-1600 \mathrm{ft}$ below the floor of Big Paddy Creek. The Precambrian rocks underlying the area are thought to be gneiss and granite, and the nearest known silicic volcanic rocks are those exposed in the Eminence area, some $45 \mathrm{mi}$ to the southeast. Precambrian volcanic rocks or a magnetite ore body within them would not be indicated by any visible features at the surface. However, a magnetite ore body comparable in size to those known in the Southeast Missouri district would be readily detectable at or above the ground surface by a ground or airborne magnetometer; the use of a magnetometer would be the most practical way to test for such a deposit.

Although the study area is underlain by several formations that contain deposits of barite in nearby areas, the evidence from this study indicates there is little promise for the occurrence of barite resources. The most important barite deposits in the region are in the clayey residuum of the Potosi and Eminence Dolomites formed by weathering at the surface. As the Potosi and Eminence are deeply buried beneath the surface in the study area, there is no Potosi or Eminence residuum and hence no potential for this type of barite deposit. The low barium values in the panned-concentrate samples rule out the possibility that barite deposits of commercial interest occur in the Gasconade, Roubidoux, or Jefferson City Formations in the study area.

There is some potential for "filled-sink" iron-ore deposits (marcasite-pyrite-hematite) in sedimentary rocks in the study area, but such deposits are generally so small, and the physical properties of the iron minerals so unsuitable to present standards for iron ores, that they would not constitute a resource.

Both the Roubidoux Formation and Gasconade Dolo mite have been quarried in the region for building stone and crushed rock. Both formations are widely exposed in Missouri and can be quarried at more desirable locales outside the study area. Although sand and gravel deposits occur in the lower reaches of the major streams, they are abundantly available outside the study area.

There is little promise for the occurrence of energy resources in the area. The Ozark uplift is considered to be geologically unfavorable for oil and gas occurrence. 
The abundant plant life necessary for coal formation did not exist until after Ordovician time and no evidence for deposits of radioactive minerals or for geothermalenergy sources was found in the study area.

\section{SUGGESTIONS FOR FURTHER STUDIES}

The potential for important mineral resources in the study area cannot be confirmed or ruled out without additional information-specifically, deep drilling within or close to the area to test the potential for base-metal mineralization, and detailed magnetic surveys of the area to test for magnetic anomalies.

\section{REFERENCES}

Erickson, R. L., Mosier, E. L., Odland, S. K., and Erickson, M. S., 1981, A favorable belt for possible mineral discovery in subsurface Cambrian rocks in southern Missouri: Economic Geology, v. 76, no. 4, p. 921-933.

Pratt, W. P., ed., 1981, Metallic mineral-resource potential of the Rolla $1 \times 2^{\circ}$ quadrangle, Missouri, as appraised in September 1980: U.S. Geological Survey Open-File Report 81-518, 77 p.

Pratt, W. P., Mosier, E. L., and Ellis, Clarence, 1981, Geology and mineral resources of the Paddy Creek Wilderness Study Area, Texas County, Missouri: U.S. Geological Survey Miscellaneous Field Studies Map MF-1286, scale 1:24,000. 


\title{
PINEY CREEK WILDERNESS, MISSOURI
}

\author{
By Walden P. Pratt, ${ }^{1}$ U.S. Geological Survey, and \\ Clarence Ellis, U.S. Bureau of Mines
}

\begin{abstract}
SUMMARY
The Piney Creek Wilderness in southwest Missouri was investigated by geologic, geochemical, and mineral-occurrence surveys in 1978-80. There is no evidence of metallic mineral deposits in the rock units exposed at the surface in the wilderness, but the entire area has a probable potential for significant zinclead deposits at depths of several hundred feet. A probable potential also exists for a small to moderate-sized iron ore deposit at a depth of at least $2100 \mathrm{ft}$ along the northwest side of the wilderness. Evaluation of these potentials would require deep drilling, and in the case of the possible iron ore deposit, a detailed magnetic survey. No energy resource potential was identified within this area.
\end{abstract}

\section{CHARACTER AND SETTING}

The Piney Creek Wilderness covers about 13 sq mi in Stone and Barry Counties, southwest Missouri, about $40 \mathrm{mi}$ southwest of Springfield, and immediately west of Table Rock Reservoir. The north, south, and west sides of the area are readily accessible by good State and USFS roads. There is a jeep trail along the bottom of Piney Creek, and most ridge tops have drivable roads. The narrow ridges of the area are the remnants of a maturely dissected upland, and are heavily timbered with oak, hickory, and pine. Piney Creek, which drains the wilderness, flows into the James River arm of Table Rock Reservoir. Grassy meadows along Piney Creek were once farms. Maximum altitude is $1447 \mathrm{ft}$ at the head of Piney Creek, and relief is $547 \mathrm{ft}$.

The wilderness is on the southwest flank of the Ozark uplift. The rock units exposed are limestones of Mississippian age and dolomites of Ordovician age, which dip very gently northeast. These units are underlain by some $1700 \mathrm{ft}$ of dolomites and minor sandstones of Ordovician and Cambrian ages, which rest upon basement igneous rocks of Precambrian age.

The geologic structure of the area is simple, consisting of a uniform northeasterly dip of about $50 \mathrm{ft} / \mathrm{mi}$. The Shell Knob fault just west of the wilderness has a vertical displacement of about $120 \mathrm{ft}$, east side down; it is delineated by the displacement of the Mississippian

\footnotetext{
${ }^{1}$ With contributions by R. L. Erickson, USGS, and K. C. Thomson, Southwest Missouri State University.
}

Compton Limestone bench as observed on aerial photographs. No faults have been mapped or observed on aerial photographs within the wilderness.

Stream-sediment samples and panned-concentrate samples from eleven drainages tributary to Piney Creek were collected and analyzed for 30 elements by semiquantitative spectrographic analysis. The analyses show a remarkably uniform content for each metal and indicate that anomalous concentrations of metals probably are not present in the surface formations of the area. Enhanced metal values detected in the pannedconcentrate samples reside in limonitic iron oxide derived from the ubiquitous sparsely disseminated pyrite in the surface rocks of the area.

The magnetic map of Missouri shows a crescentshaped high-amplitude positive magnetic anomaly along the northwest side of the wilderness. The high amplitude and apparently steep gradient of this anomaly indicate a source at or near the surface of the Precambrian basement, which is about $2100 \mathrm{ft}$ below the upland surface. However, this anomaly is based on magnetic readings at $2-\mathrm{mi}$ intervals along highways, and a more detailed magnetic survey of the area is needed to delineate the anomaly accurately before further inferences can be made as to its significance.

\section{MINERAL RESOURCES}

The resource appraisal is based on mapping and interpretation of the local and regional geology, analyses of 


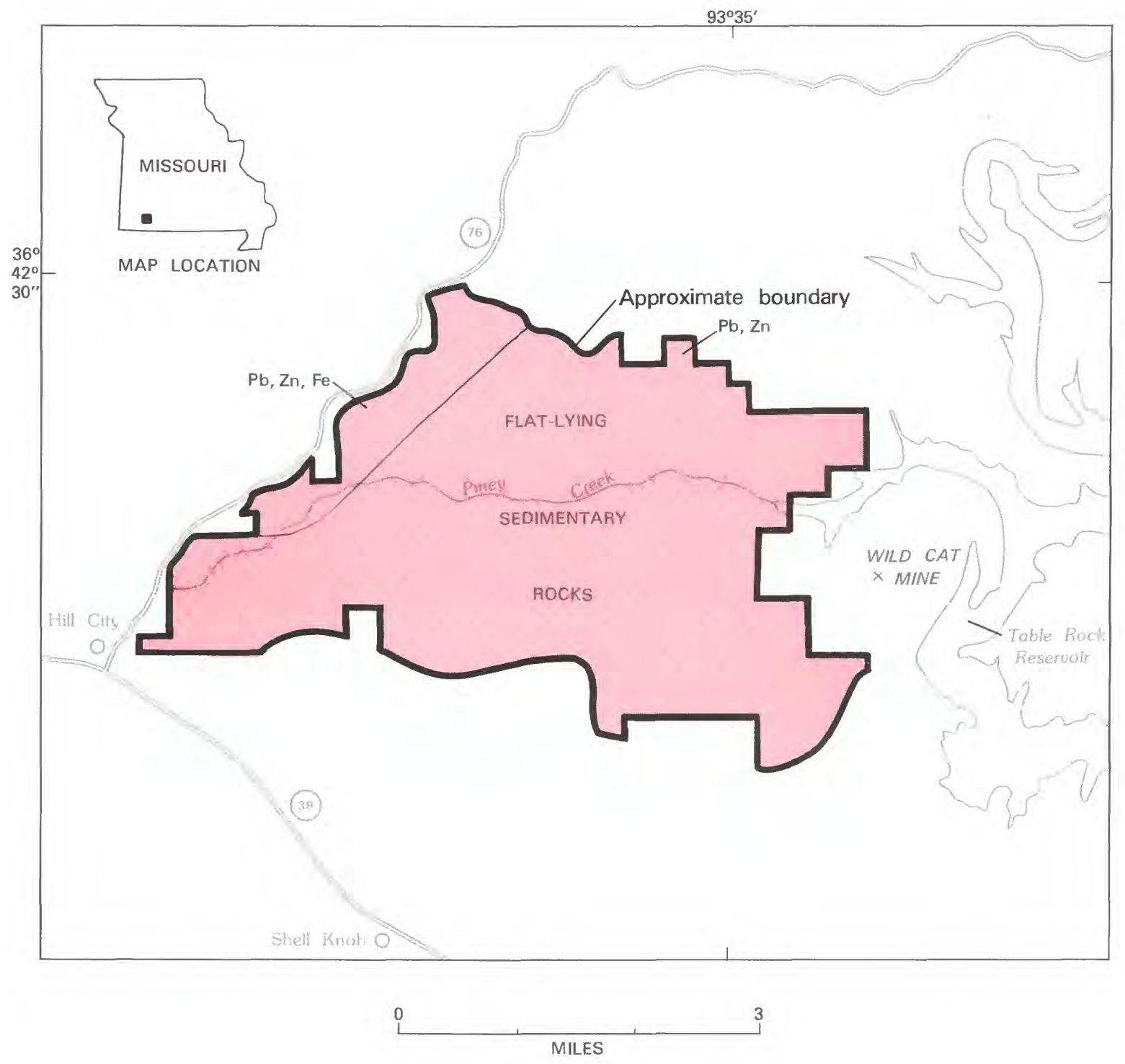

\section{EXPLANATION}

Geologic terrane with probable mineral-resource potential

$$
\begin{array}{ll}
\mathrm{Fe} & \text { Iron } \\
\mathrm{Pb} & \text { Lead } \\
\mathrm{Zn} & \mathrm{Zinc} \\
\times & \text { Mineral occurrence }
\end{array}
$$

Figure 186.-Piney Creek Wilderness, Missouri. 
stream-sediment and panned-concentrate samples representing all the drainages in the wilderness, examination of outcrops for visible metallic mineralization, and regional studies of subsurface geochemical patterns (Pratt and others, 1982).

There is no mining activity within the wilderness at present, no production has been reported, there is no evidence of prospecting, and no mineralized rocks were found at the surface. The area is about $12 \mathrm{mi}$ from the McDowell deposit, the nearest known deposit of basemetal sulfides. A small prospect named the Wild Cat mine was opened on a show of galena in the Ordovician Cotter Dolomite about $0.5 \mathrm{mi}$ east of the wilderness. Only sand, gravel, and limestone have been produced near the area; some quarries are within $2 \mathrm{mi}$. Except for 100 acres in the NW1/4 sec. 28 , T. 23 N., R. 25 W., all mineral rights in the wilderness have been held by the U.S. Government since 1975. No prospecting permits are on record.

Although the southern limit of the Tri-State zinc-lead district lies several miles to the northwest, there is no evidence of Tri-State type (stratabound) mineral deposits within the wilderness. The stream-sediment samples and panned-concentrate samples collected within the area indicate that anomalous concentrations of metals probably are not present in the surface formations. Analyses of galena and altered dolomite from a small prospect just east of the area showed strikingly low amounts of trace metals, suggesting that an extensive mineralized system is not present in the area.

The foregoing observations apply to the Ordovician and Mississippian formations that are exposed at the surface, which represent the lowermost of the units known to be mineralized in the Tri-State district. In the Southeast Missouri district, some $150 \mathrm{mi}$ northeast of the study area, mineral deposits of the same type are concentrated in the Bonneterre Dolomite of Cambrian age, and theoretically, the Bonneterre and other carbonate units that underlie the Cotter Dolomite in the study area could be favorable for zinc-lead mineralization. Analyses of insoluble residues of subsurface Cambrian formations, from drill holes along a traverse that passes about $15 \mathrm{mi}$ south of the wilderness, showed anomalous amounts of several metals in the DerbyDoerun (of the Missouri Geological Survey), Potosi, and Eminence Dolomites at depths of about $1500-1850 \mathrm{ft}$ below the surface (Erickson and others, 1981). This indicates that metal-bearing fluids passed through these formations over a large area, and in the light of recent studies in the Rolla $1^{\circ} \times 2^{\circ}$ quadrangle, suggests that these Cambrian units, as well as the subsurface Ordovician carbonate units, have a probable potential for basemetal mineral deposits in the Piney Creek area. Further evaluation of this potential, however, cannot be accom- plished without deep drilling to provide information on the lithology and anomalous metal content of these formations within or close to the study area.

In the Southeast Missouri mining district, several major magnetic iron ore deposits of past or potential importance occur in Precambrian rhyolitic volcanic rocks, and each of these major deposits is marked by a positive magnetic anomaly of at least several hundred gammas. The high-amplitude magnetic anomaly along the northwest side of the Piney Creek Wilderness, together with the inferred presence of rhyolitic volcanic rocks in the Precambrian basement, suggests the possibility of a buried magnetite deposit. Because the magnetic anomaly is not well defined and there is no specific data on the lithology of the basement in this area, the only interpretation now possible is that a probable potential exists. Further evaluation of this potential requires a detailed magnetic survey and physical (drilling) evidence of the basement lithology. If the anomaly is indeed caused by a magnetite deposit, the deposit is probably at a depth of at least $2100 \mathrm{ft}$ below the upland surface, and is probably at least partly outside the boundaries of the wilderness.

The wilderness contains industrial minerals like those readily available elsewhere in the region. Dolomite and limestone occur within the area, but abundant supplies are available nearby. Sand, gravel, and limestone have been produced near the area, and at the time of this investigation, quarries about $2 \mathrm{mi}$ south of the wilderness were producing crushed stone from the Cotter Dolomite.

There is no known potential for energy resources in the area. The Ozark uplift is considered to be geologically unfavorable for oil and gas occurrence. All the known coal-bearing strata in Missouri are of Pennsylvanian age; rocks as young as Pennsylvanian are not present in or near the study area, and in general southwestern Missouri is considered unfavorable for coal resources. No evidence for deposits of radioactive minerals or for geothermal-energy sources was found in the wilderness.

\section{SUGGESTIONS FOR FURTHER STUDIES}

Core-drilling one or two holes from the valley of Piney Creek to the Precambrian basement, a depth of about 1700-1900 ft, would obtain samples for lithologic and trace-element analysis, which would make possible a more specific evaluation for zinc-lead resources in the subsurface sedimentary rocks. The possibility for magnetite (iron ore) resources also can be definitively tested only by drilling, but in this case the drilling should be preceded by a detailed magnetic survey. 


\section{REFERENCES}

Erickson, R. L., Mosier, E. L., Odland, S. K., and Erickson, M. S., 1981, A favorable belt for possible mineral discovery in subsurface Cambrian rocks in southern Missouri: Economic Geology, v. 76, no. 4, p. 921-933.
Pratt, W. P., Thomson, K. C., Erickson, R. L., and Ellis, Clarence, 1982, Geologic, geochemical, and mineral-resource-potential map of the Piney Creek Wilderness, Stone and Barry Counties, Missouri: U.S. Geological Survey Miscellaneous Field Studies Map MF-1494, scale 1:24,000. 


\title{
ROCK PILE MOUNTAIN WILDERNESS STUDY AREA, MISSOURI
}

\author{
By WALDEN P. PratT, ${ }^{1}$ U.S. GeOlogical Survey, and \\ Clarence Ellis, U.S. BuREaU of Mines
}

\begin{abstract}
SUMMARY
A geologic and mineral-occurrence survey in 1977-78 of the Rock Pile Mountain Wilderness study area in southeastern Missouri indicates the area has little promise for the occurrence of energy and mineral resources. Exploratory drill holes on private land along the west side of the area encountered no mineralization, and none of the rocks or sediments exposed in the area contain any detectable evidence of significant mineralization.
\end{abstract}

\section{CHARACTER AND SETTING}

The Rock Pile Mountain Wilderness study area covers $6.5 \mathrm{sq}$ mi of the Mark Twain National Forest in Madison County, southeastern Missouri, about $100 \mathrm{mi}$ south of St. Louis and $15 \mathrm{mi}$ southwest of Fredericktown. The study area is within the St. Francois Mountains, and is centered on a northerly trending forested ridge made up of several rounded knobs of igneous rock. The area of Paleozoic sedimentary rocks that flank the igneous knobs has been eroded into valleys and low bluffs. Maximum elevation is $1305 \mathrm{ft}$ on Little Grass Mountain at the north boundary; relief is $780 \mathrm{ft}$. Captain Creek and the St. Francis River flank the west side of the area, and Trace Creek the east side. The St. Francis River and private land restrict access from the south and west sides. The north and east boundaries are readily accessible by good USFS roads which connect with County Highway C.

The study area is on the southeast flank of the Ozark uplift, and is centered on a northerly trending ridge of Precambrian rhyolite, part of a widespread volcanic complex that underlies most of the St. Francois Mountains. Reconnaissance mapping shows that the volcanic rocks appear to be flat lying at the extreme north end of the area and on the south slope of Rock Pile Mountain, but locally near the north end a sequence of lava flows several hundred feet thick dips about $50^{\circ} \mathrm{S}$. Cambrian dolomite and minor sandstone lap up onto the Precambrian rocks on all sides, but are well exposed at only a few places on the west side of the study area. The Cambrian rocks are divided into the Bonneterre Formation below and the Elvins Group above. The Bonneterre is massive fine- to coarsely crystalline dolomite, and

${ }^{1}$ With contributions by R. L. Erickson, USGS. grades upward into thin-bedded mostly finely crystalline and locally silty dolomite of the Elvins Group. Throughout most of the study area the surface is underlain by chert and drusy quartz-bearing residuum of unknown thickness, derived by dissolution of carbonate sedimentary rocks.

Geologic structures are limited to the erosional and depositional features of the rocks. The Paleozoic rocks either are flat lying or dip gently away from nearby Precambrian knobs, reflecting initial depositional dips which probably have been accentuated by diagenetic compaction. No faults have been identified or inferred in either the Precambrian or the Paleozoic rocks. With the exception of sparsely disseminated pyrite in Precambrian rhyolite and quartz latite at several localities, no signs of mineralization were seen in any of the exposed rocks in the area.

A geochemical study was made to augment field observations. This study consisted of the collection and chemical analysis of stream sediments from all streams draining the area, of pan concentrates from stream sediments from the same sites, and of representative outcropping volcanic rocks. Results show no metal values of unusual concentrations.

Regional gravity and aeromagnetic maps that include the study area do not show any anomalies that indicate mineral-resource potential.

\section{MINERAL RESOURCES}

The resource appraisal is based on interpretation of the local and regional geology, the geochemical survey, and examination of outcrops for visible metallic mineralization (Pratt and others, 1982). 


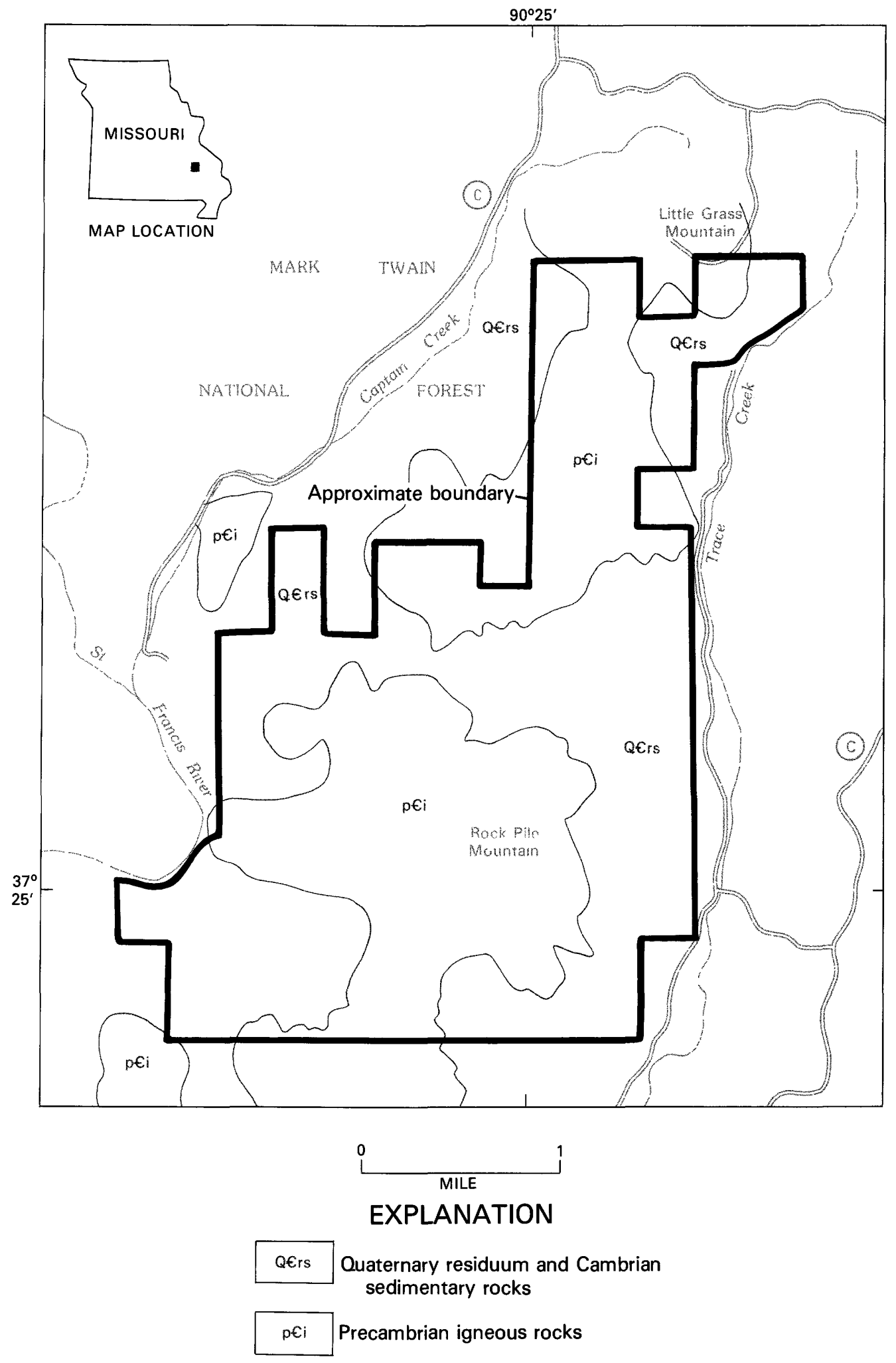

Figure 187.-Rock Pile Mountain Wilderness study area, Missouri. 
There is no record of mining activity or mineral production in the study area or its immediate vicinity, and the rocks contain no evidence of significant mineralization. Neither surface observations nor the geochemical analyses show any significantly anomalous metal content. Available geophysical data show no anomalies that suggest mineral-resource potential. Although nearly 40 percent of the area is known or presumed to be underlain at depths of a few hundred feet or less by the Cambrian Bonneterre Formation, which is the principal host rock for lead sulfide ore deposits elsewhere around the St. Francois Mountains, drill-hole information from adjacent areas suggests that the Bonneterre Formation in this area is not favorable for mineral discovery. However, the possibility of lead mineralization in coarsetextured dolomite close to the contact with Precambrian rocks cannot be entirely ruled out.

The study area has little promise for the occurrence of resources of metallic, industrial, or energy minerals. Precambrian rocks like those in the study area have been quarried elsewhere in the region for use as crushed stone ("felsite"), but abundant supplies of these rocks are available in more favorable locations outside the study area. The Bonneterre Formation is a major source of refractory dolomite in Missouri, but is widely exposed and can be quarried at more desirable locations outside the study area. No evidence exists for oil and gas. Missouri coal deposits are in rocks of Pennsylvanian age, which do not occur near the study area. No evidence exists that geothermal energy could be developed in the study area.

\section{SUGGESTIONS FOR FURTHER STUDIES}

Drilling through the Bonneterre Formation, supplemented by geochemical studies of the drill-hole samples, would test the remote possibility of lead mineralization close to the contact with Precambrian rocks.

\section{REFERENCE}

Pratt, W. P., Erickson, R. L., and Ellis, Clarence, 1982, Mineralresource potential map of the Rock Pile Mountain Wilderness Study Area, Madison County, Missouri: U.S. Geological Survey Miscellaneous Field Studies Map MF-1339-B, scale 1:24,000. 


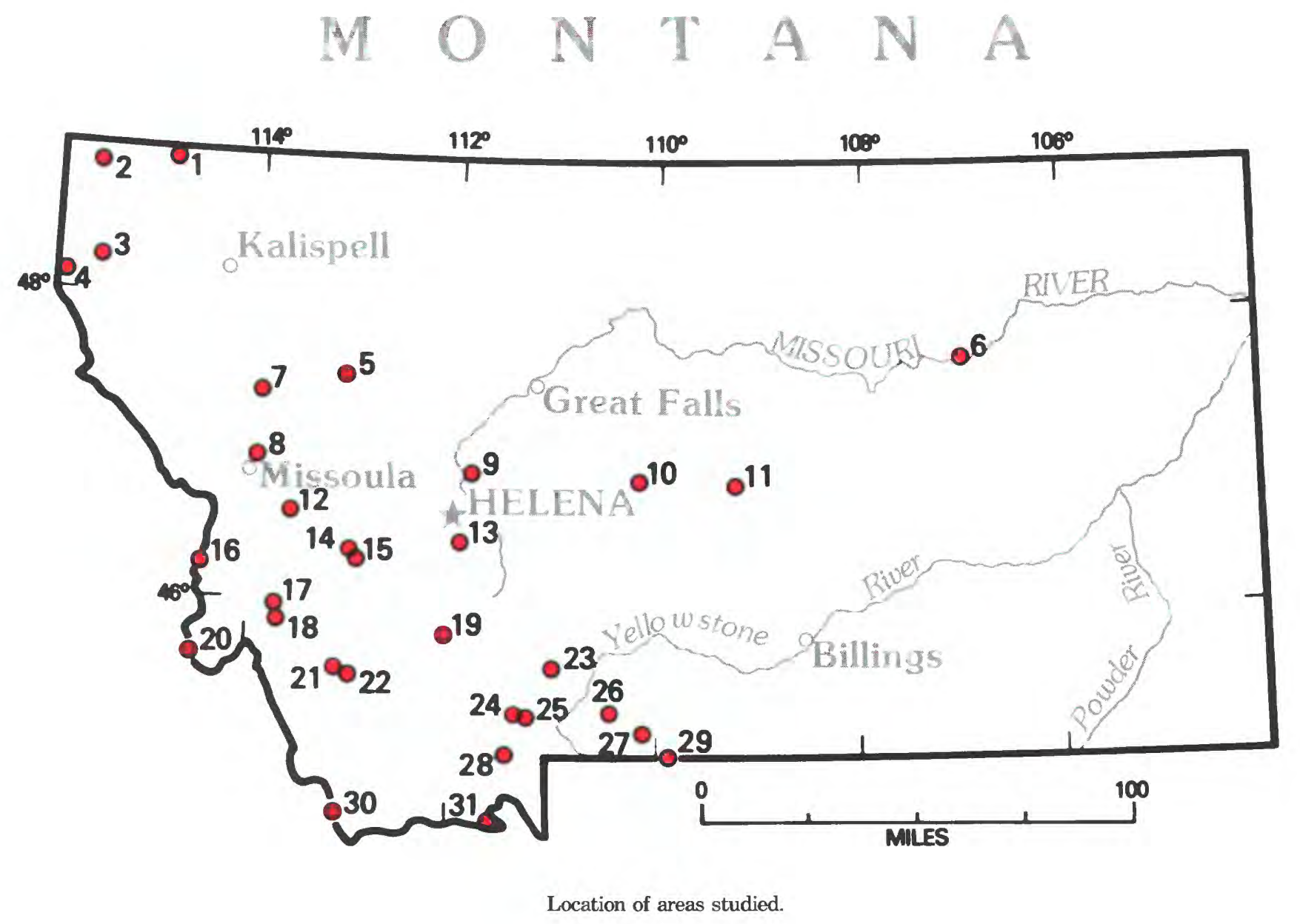




\section{MONTANA}

27 Absaroka Primitive Area and vicinity

18 Anaconda-Pintlar Wilderness

29 Beartooth Primitive Area and vicinity, Montana and Wyoming

11 Big Snowies Wilderness Study Area and contiguous roadless areas

20 Blue Joint Wilderness Study Area, Montana, and Blue Joint Roadless Area, Idaho

3 Cabinet Mountains Wilderness

31 Centennial Mountains Wilderness study area, Montana and Idaho

6 Charles M. Russell Wildlife Refuge

14 Dolus Lakes Roadless Area

22 Eastern Pioneer Mountains

13 Elkhorn Wilderness Study Area

15 Flint Creek Range Wilderness study area

23 Gallatin Divide Roadless Area

9 Gates of the Mountains Wilderness and additions

30 Italian Peak and Italian Peak Middle Roadless Areas, Idaho and Montana-See Idaho

24 Jack Creek basin

28 Madison Roadless Area

10 Middle Fork of the Judith River Wilderness Study Area

19 Middle Mountain-Tobacco Root Roadless Area

7 Mission Mountains Wilderness

2 Mount Henry Roadless Area

26 North Absaroka study area

8 Rattlesnake Roadless Area

17 Sapphire Wilderness Study Area and contiguous roadless areas

5 Scapegoat Wilderness and additions, Bob Marshall and Great Bear Wildernesses, and adjacent study areas

4 Scotchman Peak Wilderness study area, Montana and Idaho

16 Selway-Bitterroot Wilderness, Idaho and Montana-See Idaho

25 Spanish Peaks Primitive Area

1 Ten Lakes Wilderness Study Area

12 Welcome Creek Wilderness

21 West Pioneer Wilderness Study Area 

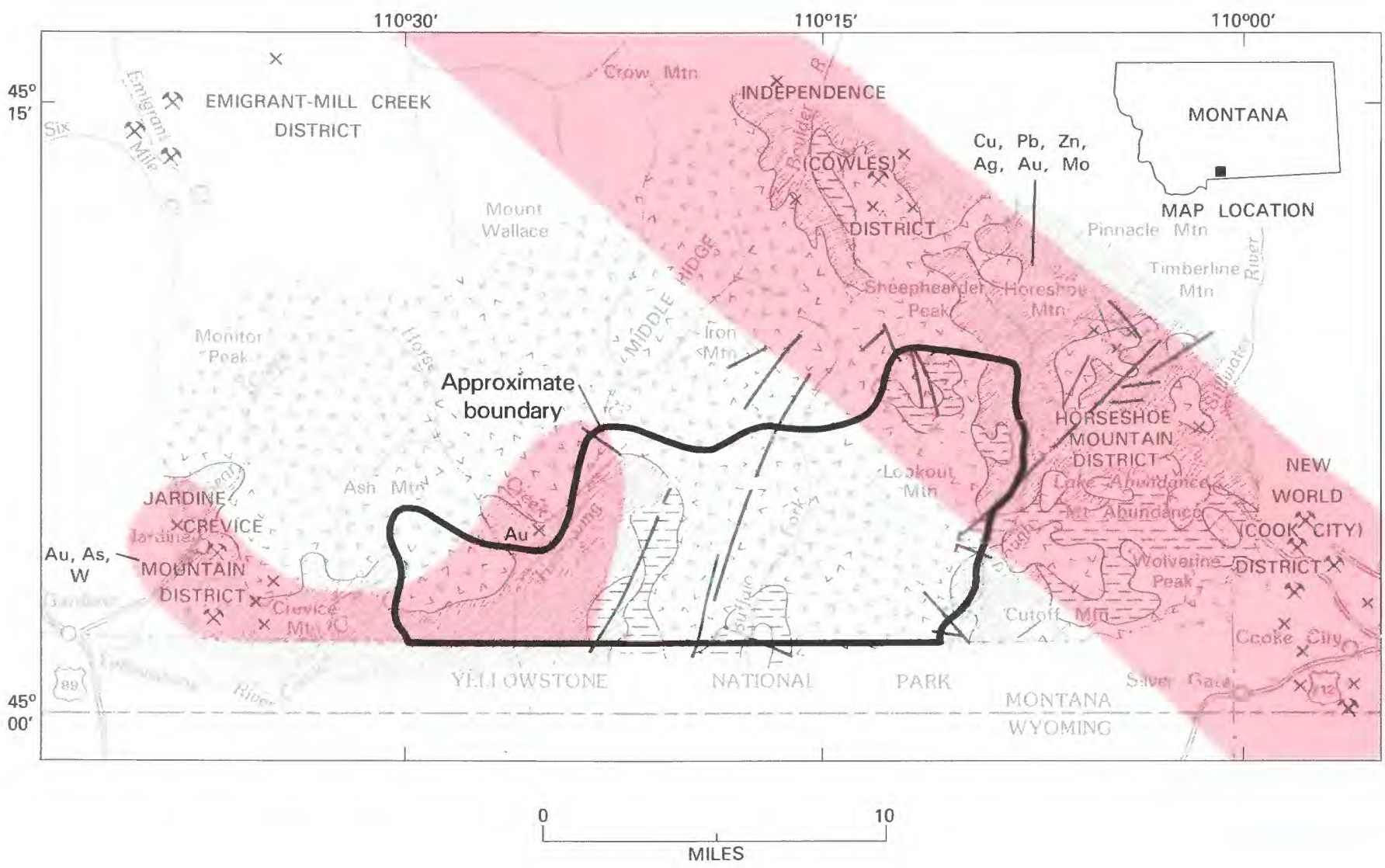

\section{EXPLANATION}

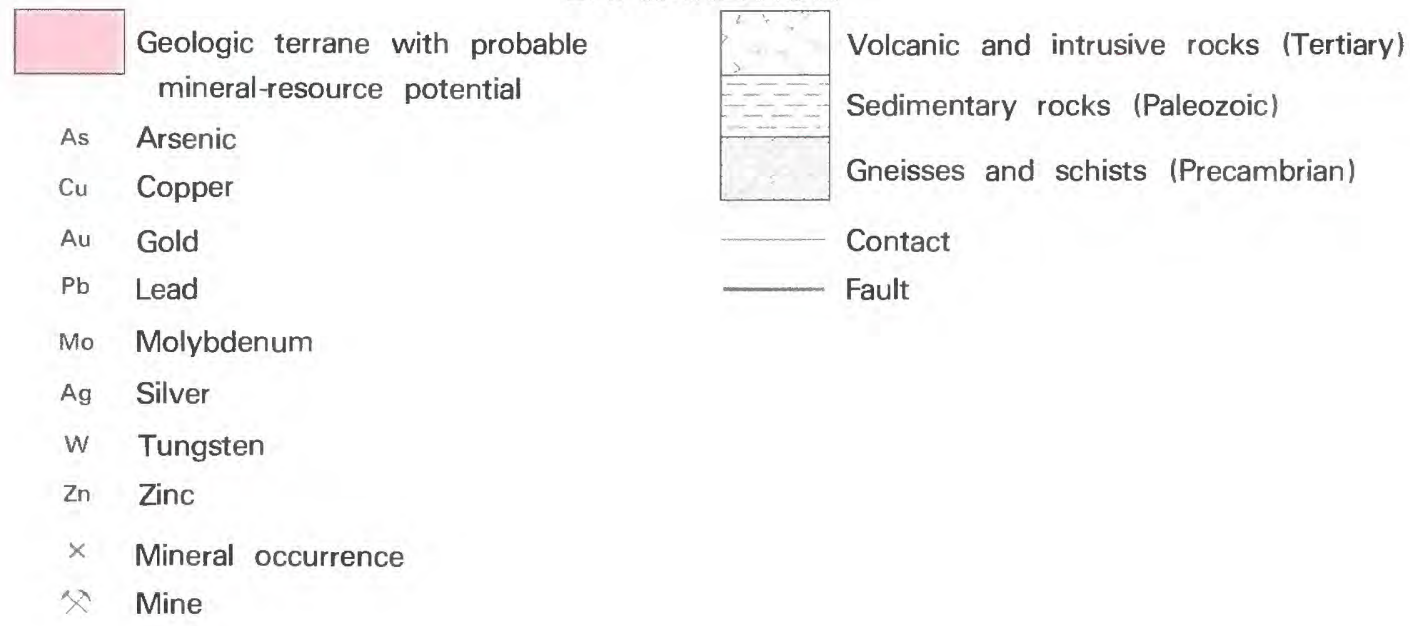

Figure 188. - Absaroka Primitive Area and vicinity, Montana. 


\title{
ABSAROKA PRIMITIVE AREA AND VICINITY, MONTANA
}

\author{
By Helmuth Wedow, JR., ${ }^{1}$ U.S. GeOlogical SuRVEY, and \\ D'ARGy P. Bannister, U.S. Bureau of Mines
}

\begin{abstract}
SUMMARY
A mineral-resource appraisal of the Absaroka Primitive Area, now a part of the Beartooth Wilderness, during 1970-71 indicates a probable resource potential for copper-molybdenum and gold in parts of the area. An area favorable for the occurrence of early Tertiary porphyry-type copper-molybdenum and associated gold deposits lies northwest of Cooke City, along the Cooke City structural sag in the Beartooth uplift. An area favorable for stratabound gold deposits of the Homestake type is in the western part of the area, in and around the Jardine-Crevice Mountain mining district and in lower Hellroaring Creek valley. There is little promise for the occurrence of energy resources in the primitive area.
\end{abstract}

\section{CHARACTER AND SETTING}

The Beartooth Wilderness of Montana and Wyoming was created by joining the Absaroka and Beartooth Primitive Areas and most of their surrounding study areas with a large contiguous wilderness study area that extended northward to the vicinity of Livingston Peak. This wilderness thus includes most of the northern part of the Absaroka Range. Geologic studies and mineral-resource assessment of the Absaroka Primitive Area and adjacent terrain was conducted in 1970-71; the results were published in 1975 (Wedow and others, 1975).

The Absaroka Primitive Area comprises an area of about $320 \mathrm{sq} \mathrm{mi}$ of which about $105 \mathrm{sq} \mathrm{mi} \mathrm{was} \mathrm{an}$ original officially established primitive area in the Gallatin National Forest. The primitive area lies in the northern part of the Absaroka Range along the northern border of Yellowstone National Park. All of its major streams flow southward into the Yellowstone River from peaks that attain altitudes of nearly $11,000 \mathrm{ft}$. On the west, north, and east are small mining districts that have been mined and prospected for gold, silver, lead, copper, zinc, molybdenum, tungsten, and arsenic since the 1880's. Within the primitive area some gold was mined at Horseshoe Mountain before the turn of the century; claims in that area have been restaked and prospected periodically.

\footnotetext{
${ }^{1}$ With contributions by David L. Gaskill, USGS, and Eldon C. Pattee, USBM.
}

Precambrian gneisses and schists, Paleozoic sedimentary rocks, and igneous rocks-both extrusive and intrusive-of Tertiary age comprise the bedrock of the Absaroka Primitive Area. Locally extensive deposits of various types of Quaternary debris partly conceal the bedrock. During Precambrian time an early sequence of sedimentary rocks was intensely folded and warped while undergoing metamorphism. Later, Paleozoic shales and carbonate strata, interrupted by minor unconformities, were deposited by shallow, intermittent, transgressive seas. In Late Cretaceous and early Tertiary time the primitive area was elevated as part of the Beartooth uplift, a major regional structural element. As a consequence, thick sequences of upper Paleozoic and Mesozoic rocks, found in nearby areas, are missing because of extensive erosion and structural denudation. Most Tertiary volcanic vents, associated intrusive rocks, and related mineral deposits in and near the primitive area are along the northwest-trending Cooke City structural sag, across the middle part of the uplift.

Several strong positive magnetic anomalies, found by geophysical surveys, appear to coincide with the larger Tertiary stocklike intrusive masses and several Precambrian intrusives. Contrasts in gravity data delineate the Gardiner fault along the southwest side of the Beartooth uplift and the contacts of the Precambrian crystalline core of the uplift with peripheral Tertiary volcanics. A significant gravity high in the valley of Hellroaring Creek, near the center of the primitive area, suggests a mass of dense Precambrian rock, possibly 
metamorphosed iron-carbonate formation, cut off along the Gardiner fault. A gravity low in the vicinity of Ash Mountain, in the western part of the primitive area, is most likely related to a volcanic vent and its associated intrusive plug.

\section{MINERAL RESOURCE POTENTIAL}

The Absaroka Primitive Area and vicinity has a probable potential for porphyry-type copper-molybdenum and associated gold resources in a wide zone across the northeast part of the area, and for stratabound gold resources in metamorphosed Precambrian iron-formation in the southwest part of the area.

Many of the attributes of the empirical porphyry model (Cox, 1982) are present in, along, or near the Cooke City structural depression, a zone about $10 \mathrm{mi}$ wide trending northwest from the vicinity of Cooke City and Independence Peak to the Mill Creek area. Abundant fracturing and numerous Laramide porphyry intrusive rocks are prominent features of the Cooke City sag. The sag zone also is the locus of the large eruptive feature of Eocene age, postulated by Rubel (1971) as the Independence stratovolcano. The Independence volcano conduit and its associated intrusive plugs, as described by Rubel (1971), is a particularly favorable area for mineralized-porphyry targets. Eruptive centers with associated mineralized alteration zones and breccia pipes are known elsewhere along the sag-zone trend, namely, in the New World (Cooke City) and EmigrantMill Creek districts and in the Horseshoe Mountain area. Anomalously high metal values occur in the zone in both stream-sediment and rock samples associated with the intrusive bodies and altered rocks. The lack of any significant supergene enrichment, so common to many of the porphyry deposits of the Southwest, can be ascribed to the extremely recent deglaciation of the region.

The association of gold with metamorphosed Precambrian iron-formation, particularly with rocks derived from the iron-carbonate facies, has long been considered geochemically feasible (Sawkins and Rye, 1971). In the type example at the Homestake mine, in the Black Hills of South Dakota, gold occurs in cummingtonite or sideroplesite schist in veins and masses of quartz and sparse pyrrhotite, pyrite, and arsenopyrite. The presence of quartz-cummingtonite schist in the western part of the wilderness and the occurrence of arsenopyrite in the gold-arsenic-tungsten ores of the Jardine-Crevice Mountain district are indicative of a setting resembling that at the Homestake mine. Thus, the area encompassing the Jardine-Crevice Mountain district and part of the valley of Hellroaring Creek are considered to have a probable resource potential for gold, arsenic, and tungsten. The attendant clusters of geochemically anomalous gold, arsenic, and boron support this classification of the area.

\section{SUGGESTIONS FOR FURTHER STUDIES}

Further studies of the area could include detailed mapping and sampling to analyze the potential for the occurrence of Homestake-type gold in the Hellroaring Ranger Station and the Jardine-Crevice Mountain areas. Selected ground geophysical studies should follow along with spot short-hole geologic drilling where outcrops are few. Detailed geologic mapping, geochemical sampling, and geophysical studies are needed along the Cooke City structural sag, with particular emphasis on the search for the study of the classic alteration zoning associated with copper-molybdenum porphyry ores.

\section{REFERENCES}

Cox, D. P., 1982, A generalized empirical model for porphyry copper deposits, in Erickson, R. L., compiler, Characteristics of mineral deposit occurrences: U.S. Geological Survey Open-File Report 82-795, p. 27-32.

Rubel, D. N., 1971, Independence volcano-A major Eocene eruptive center, northern Absaroka volcanic province: Geological Society of America Bulletin, v. 82, no. 9, p. 2473-2494.

Sawkins, F. J., and Rye, D. M., 1971, On the relationship of certain Precambrian gold deposits to iron formation [abs.]: Economic Geology, v. 66, no. 6, p. 981 .

Wedow, Helmuth, Jr., Gaskill, D. L., Bannister, D'A. P., and Pattee, E. C., 1975, Mineral resources of the Absaroka Primitive Area and vicinity, Park and Sweet Grass Counties, Montana, with a section on Interpretation of geophysical data, by D. L. Peterson: U.S. Geological Survey Bulletin 1391-B, p. B1-B115. 


\title{
ANACONDA-PINTLAR WILDERNESS, MONTANA
}

\author{
By J. E. Elliott, U.S. Geological Survey, and \\ T. J. Close, U.S. Bureau of Mines
}

\begin{abstract}
SUMMARY
A mineral survey of the Anaconda-Pintlar Wilderness, an area of about $250 \mathrm{sq}$ mi in southwestern Montana, was conducted by the USBM in 1978-80 and by the USGS in 1980-82. Results of this survey indicate that parts of the area have probable and (or) substantiated resource potential for silver, copper, molybdenum, lead, tungsten, tin, gold, and zinc. Based on the nature of the geologic terrain, there is little likelihood of the occurrence of geothermal, coal, oil, or gas resources.
\end{abstract}

\section{CHARACTER AND SETTING}

The Anaconda-Pintlar Wilderness is located in southwestern Montana and covers much of the Anaconda Range, a rugged northeasterly trending range of mountains that forms the continental divide 30 to $40 \mathrm{mi}$ west of Butte. Covering parts of Granite, Deer Lodge, Beaverhead, and Ravalli Counties, this impressive linear range of high alpine peaks and ridges cut by numerous deep valleys is best seen from the south near Wisdom along Montana State Highway 43 or from the north along U.S. Highway 10A near Philipsburg. The boundary of the wilderness is accessible by dirt and gravel roads and numerous trails cross the area. The wilderness includes parts of the Beaverhead, Bitterroot, and Deer Lodge National Forests.

The area is one of rugged relief throughout; from a low of $5400 \mathrm{ft}$ to $10,793 \mathrm{ft}$ on West Goat Peak, the highest point in the area. Streams that drain the range originate in glacial cirques that commonly contain alpine lakes and drain to the north, south, and west along linear to slightly curved valleys sculptured by glacial ice. The southeast side of the range is drained by tributaries of the Big Hole River and the west, northwest, and north sides are drained by tributaries of the Clark Fork River.

The core of the Anaconda Range is composed of two major rock types: sedimentary rocks of Proterozoic and Paleozoic age and plutonic igneous rocks of Cretaceous to Tertiary age. In the wilderness the relative abundance of plutonic rocks increases to the south and west. Proterozoic rocks are part of the Belt Supergroup and include middle Belt carbonate rocks and younger clastic rocks of the overlying Missoula Group. Sedimentary rocks of Paleozoic age are mostly carbonates with lesser amounts of quartzite, sandstone, siltstone, and shale. They are typical of the Paleozoic succession in westcentral Montana and include representatives of the Cambrian, Devonian, Mississippian, and Pennsylvanian Periods. Granitic rocks, mainly granodiorite and monzogranite, are the predominant plutonic rock type and occur as several stocks and one batholith. Dikes, ranging in composition from andesite to rhyolite, are common in the area. The intrusion of plutonic rocks caused contact metamorphism in adjacent wall rocks and was accompanied by regional metamorphism in the southwestern part of the wilderness.

Tertiary sedimentary rocks are uncommon in the wilderness, occurring principally on the southeast side on the downthrown side of a high-angle fault that marks much of the southeast margin of the Anaconda Range. Quaternary deposits are mainly of glacial origin but also include more recent alluvial stream deposits and large landslide deposits.

The sedimentary rocks of Proterozoic and Paleozoic age, which were deposited in a shallow marine environment during a long period of crustal stability, are present in the wilderness as a series of thrust plates. This thrusting took place during the Cretaceous and before intrusion of the plutonic rocks. A series of high-angle, northeast-trending faults and shear zones post-date the thrust faulting and cross the wilderness in a regular pattern. These must, in part, pre-date at least some of the igneous activity because they appear to have influenced the placement and orientation of some of the plutons and certainly controlled the orientation and distribution of rhyolitic to rhyodacitic dikes, especially in the 


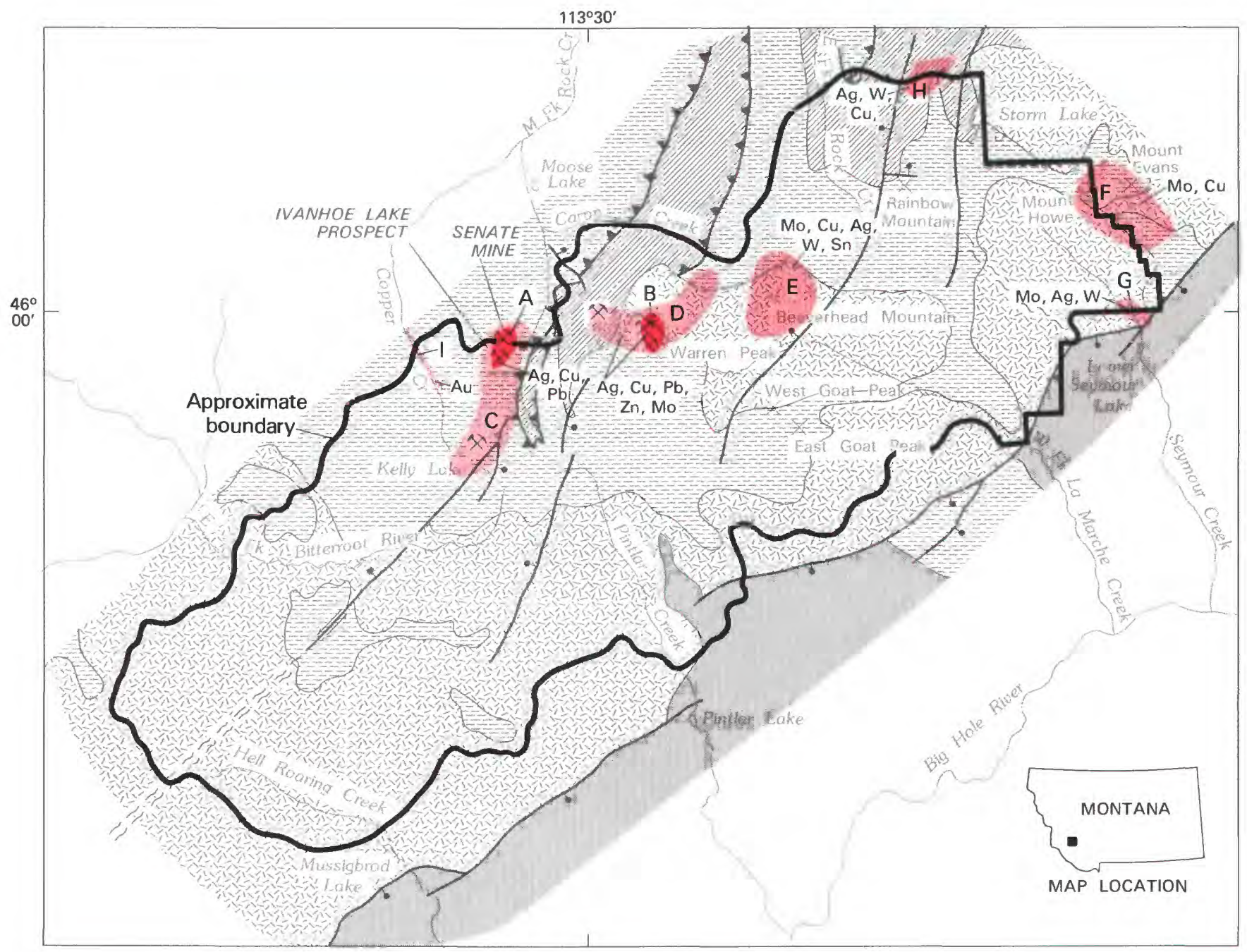

0 10

MILES

\section{EXPLANATION}

Geologic terrane with substantiated mineral-resource potential

Geologic terrane with probable mineral-resource potential

$\begin{array}{llll}\mathrm{Cu} & \text { Copper } & \text { Ag } & \text { Silver } \\ \mathrm{Au} & \text { Gold } & \text { Sn } & \text { Tin } \\ \mathrm{Pb} & \text { Lead } & \text { W } & \text { Tungsten } \\ \mathrm{Mo} & \text { Molybdenum } & \mathrm{Zn} & \text { Zinc } \\ \text { 父 } & \text { Mine } & & \end{array}$

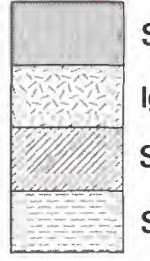

Sedimentary and volcanic rocks (Tertiary) Igneous rocks (Tertiary-Cretaceous)

Sedimentary rocks (Paleozoic)

Sedimentary rocks (Proterozoic)

\section{Contact}

Fault--Bar and ball on downthrown side

A Thrust fault--Sawteeth on upper plate

Shear zone

B Location discussed in text

Figure 189.-Anaconda-Pintlar Wilderness, Montana. 
southwest part of the wilderness. Other high-angle northeast-trending faults were active during uplift of the range in Tertiary time and some such as the range front-faults on the southeast side of the wilderness continued to be active in late Tertiary and Quaternary time when the range attained its present height.

The mineral-resource evaluation of the wilderness is based on results of geologic mapping, a geochemical survey, remote sensing techniques, geophysical surveys, and the investigation of prospects (Elliott and others, in press). In the geochemical survey samples of rocks, stream sediments, and panned concentrates of stream sediments were collected and analyzed. The application of remote sensing techniques included limonite "mapping" and the analysis of linear features. The geophysical work consisted of gravity and aeromagnetic surveys. A total of 40 prospects were examined for the mineral survey of the wilderness.

\section{MINERAL RESOURCES}

Located in one of the most mineral-rich regions of the Northern Rocky Mountains, the wilderness is situated near many highly productive mining districts which have geologic settings grossly similar to that of the wilderness. The next range to the north, the Flint Creek Range, contains many mining districts, including the Philipsburg district with production of about $\$ 100$ million. The "richest hill on Earth", Butte, with multibillion dollar production is about $35 \mathrm{mi}$ to the east of the wilderness, and the Pioneer Mountains, the next range to the southeast of the wilderness, has many productive districts and is currently the focus of much exploration for deposits of molybdenum, tungsten, gold, and other metals. Despite its location in a mineral-rich region, previous exploration and prospecting in the wilderness has resulted only in meager finds. The Barbara Ann prospect is the only one with a record of production, three tons of ore with a value of about $\$ 150$, mainly in silver.

Three mining districts with minor to moderate production are situated within a few miles of or overlap the wilderness; these are the Frogpond Basin, Moose Lake, and Silver Lake districts. The Frogpond Basin district, located about $5 \mathrm{mi}$ northwest of the Senate mine and west of Copper Creek, produced an estimated $\$ 23,100$ mainly of lead and silver from mesothermal quartz veins in Cretaceous granodiorite and Belt quartzite. The Moose Lake district includes mines near Moose Lake, the Senate mine, and about 30 prospects in the wilderness which are concentrated mainly near Warren Peak and in a belt trending south from the Senate mine. Mines near Moose Lake have produced about $\$ 65,000$, mainly of gold, from mesothermal quartz veins in Belt quartzite. The Silver Lake district, the center of which is located about $6 \mathrm{mi}$ north of Storm Lake at the northeast edge of the area, has an estimated production of about $\$ 490,000$ mainly in tungsten and silver from mesothermal fissure vein, replacement vein, and tabular replacement bodies in Paleozoic carbonate rocks.

Areas of mineral-resource potential in the AnacondaPintlar Wilderness are all located in the northern twothirds of the area; they include two areas with substantiated potential and seven with probable potential.

The two areas with substantiated resource potential are around the Senate mine (A, on map) and the Warren Peak area (B). At the Senate mine a structurally controlled zone of shearing, quartz veins, and replacement of quartzite by ankerite, barite, and sulfide minerals is present. Sparse sulfide minerals, mainly chalcopyrite, pyrite, and galena, occur in veins and disseminated in the wall rocks and constitute a demonstrated resource of silver and copper. This zone extends southward into the wilderness, and includes the Ivanhoe Lake prospects where resources of silver and lead have been identified. The area has substantiated resource potential for silver, copper, and lead. It is coincident with geochemical anomalies of copper, silver, lead, antimony, molybdenum, and tungsten in rock samples and a zone of highly fractured Belt quartzite. This fracturing has promoted a high degree of secondary permeability and permitted access by ore-forming hydrothermal fluids. In the Warren Peak area, mesothermal fissure quartz veins occur in a granodiorite stock and in quartzite or carbonate rocks which border the stock. This area has substantiated resource potential for silver, lead, copper, zinc, and molybdenum. Two deposits with resources of silver, lead, and copper and several prospects occur in the area. The area coincides with a positive magnetic anomaly. Both the Senate mine and Warren Peak areas are enclosed by mineralized areas of probable mineralresource potential. Area $\mathrm{C}$ encloses the Senate mine area and extends to the vicinity of Kelly Lake and has probable resource potential for silver, copper, and lead in deposits similar to those in the Senate mine area. Area $D$ extends west and noriheast from the Warren Peak area and has probable resource potential for silver, lead, copper, zinc, and molybdenum in deposits similar to those in area B.

Other areas with probable potential for mineral resources are the Beaverhead Mountain (E), Mount Howe-Mount Evans (F), Lower Seymour Lake (G), One Hundred Acre Meadow (H), and Copper Creek (I) areas. The Beaverhead Mountain area (E) has probable resource potential for molybdenum, copper, silver, tungsten, and tin in stockwork or porphyry, vein, skarn, and greisen deposits. The core of the area has a concentration of quartz veins with altered envelopes and several altered rhyolite dikes, all of which cut granodiorite. The 
area is geochemically anomalous, has widespread limonite staining related to hydrothermal alteration, and is situated on the flank of a positive magnetic anomaly. The Mount Howe-Mount Evans area $(F)$ has probable resource potential for molybdenum and copper in vein and stockwork or porphyry deposits. Geochemical anomalies in many elements occur in contact metamorphosed Belt quartzite and argillite adjacent to monzogranite and granodiorite stocks. The area has an abundance of porphyry dikes, several quartz veins, and locally intense limonite staining and is situated on the flank of a positive magnetic anomaly. In the Lower Seymour Lake area $(G)$ a poorly exposed zone of shearing, alteration, and veining in granodiorite is geochemically anomalous in many elements. This area is on the flank of a positive magnetic anomaly. It has probable resource potential for molybdenum, silver, and tungsten in stockwork or porphyry deposits. The One Hundred Acre Meadow area $(\mathrm{H})$ has probable resource potential for silver, tungsten, and copper in vein and replacement deposits in Paleozoic carbonate rocks. This area contains prospects in the wilderness and known deposits outside, but near the boundary. Favorable factors include the occurrence of highly fractured host rocks and location on flank of positive magnetic anomaly. The Copper Creek area (I) has probable resource potential for gold in placer deposits in alluvium, glacial till, and outwash along a stream valley. The stream drains an area with metal-bearing veins and several panned concentrate samples from the stream bed contain anomalous gold values.

\section{SUGGESTIONS FOR FURTHER STUDIES}

Further studies are recommended for three areas; the Warren Peak (B) and surrounding area (D) and the Lower Seymour Lake area (G). The Warren Peak area and area extending out from it are recommended for detailed geochemical studies and geologic mapping. The presence of several zones of limonitic staining needs to be investigated further. In the Lower Seymour Lake area, glacial till surrounds and partially covers the mineralized zone. Drilling is required to assess the resource potential of this promising zone.

\section{REFERENCE}

Elliott, J. E., Wallace, C. A., O'Neill, J. M., Hanna, W. F., Rowan, L. C., Segal, D. B., Zimbelman, D. R., Pearson, R. C., Close, T. J., Federspiel, F. E., Causey, J. D., Willett, S. L., Morris, R. W., and Huffsmith, J. A., in press, Mineral resource potential map of the Anaconda-Pintlar Wilderness, Granite, Deer Lodge, Beaverhead, and Ravalli Counties, Montana: U.S. Geological Survey Miscellaneous Field Studies Map-1633-A. 


\title{
BEARTOOTH PRIMITIVE AREA AND VICINITY, MONTANA AND WYOMING
}

\author{
By Frank S. Simons, ' U.S. Geological Survey, and \\ Ronald M. VAN NOY, U.S. BUREAU OF MineS
}

\section{SUMMARY}

A mineral-resource survey of the Beartooth area, which comprised the Beartooth Primitive Area and large contiguous areas, was done in 1969-72; the area studied became part of the Absaroka-Beartooth Wilderness in 1978. The survey concluded that one area of probable and one of substantiated mineral-resource potential are present in the Beartooth area. Three small mining districts (Red Lodge, Stillwater, and Independence) and one possibly major district (Cooke City) adjoin the Beartooth area but lie almost entirely outside it; the northern part of the Cooke City mining district, around Goose Lake, is within the area. This area has substantiated resource potential for copper, silver, gold, and platinum-group elements. The Red Lodge mining district extends into the eastern part of the area and has a probable chrome resource potential. There is little promise for the discovery of energy resources in the area.

\section{CHARACTER AND SETTING}

The Beartooth area comprises about $600 \mathrm{sq} \mathrm{mi}$ in the central part of the Beartooth Mountains in southcentral Montana and northwestern Wyoming just northeast of Yellowstone National Park. All but about $40 \mathrm{sq} \mathrm{mi}$ is in Montana. The area discussed in this report includes all of the former Beartooth Primitive Area of $365 \mathrm{sq} \mathrm{mi}$ together with surrounding areas aggregating $235 \mathrm{sq} \mathrm{mi}$. The Montana part of the area is now combined with the former Absaroka Primitive Area and contiguous terrain to form the Absaroka-Beartooth Wilderness Area of about 1400 sq mi established by Congress in March 1978. The area was studied in 1969-72 and the results were published in 1979 (Simons and others, 1979).

The Beartooth Mountains trend northwest and in the area studied are characterized by a gently sloping southwest flank dotted with countless rock-basin lakes mostly less than $0.5 \mathrm{mi}$ across and a very rugged northeast flank dominated by high broad rocky plateaus surmounted by jagged alpine peaks and dissected by widely spaced steep-walled deep canyons. Granite Peak,

\footnotetext{
${ }^{1}$ With contributions from Theodore J. Armbrustmacher and Lennart A. Anderson, USGS and Nicholas T. Zilka, Frank E. Federspeil, and James Ridenour, USBM.
}

the highest point in Montana $(12,799 \mathrm{ft})$ is located near the middle of the area. Access to the area is limited to foot or stock trails but a panoramic view southward toward the region is afforded from Interstate Highway 10 between Columbus and Livingston, Montana; a closer view is provided from U.S. Highway 212 between Red Lodge and Cooke City, Montana, which skirts the east and south edges of the area as it crosses the Beartooth Mountains and offers superb vistas of spectacular alpine scenery.

Virtually all of the Beartooth area consists of hard and resistant metamorphic rocks-granitic gneiss and amphibolite-of Precambrian age, mostly more than 2.7 billion years old. These rocks are cut by innumerable dark-colored dikes as much as $14 \mathrm{mi}$ long and $500 \mathrm{ft}$ thick. The Stillwater Complex, composed of mafic and ultramafic rocks (mainly dark colored, magnesium- and iron-rich rocks) extends for $30 \mathrm{mi}$ along the northeast side of the Beartooth area, but only a small part is within the area.

The Precambrian metamorphic rocks constitute a huge northwest-trending block uplifted 15,000$20,000 \mathrm{ft}$ along its east and northeast edges and tilted toward the southwest. Faulting occurred during Late Cretaceous and early Tertiary time (approximately 70 to 50 million years ago). Sedimentary rocks about $10,000 \mathrm{ft}$ thick that formerly covered the ancient rocks 

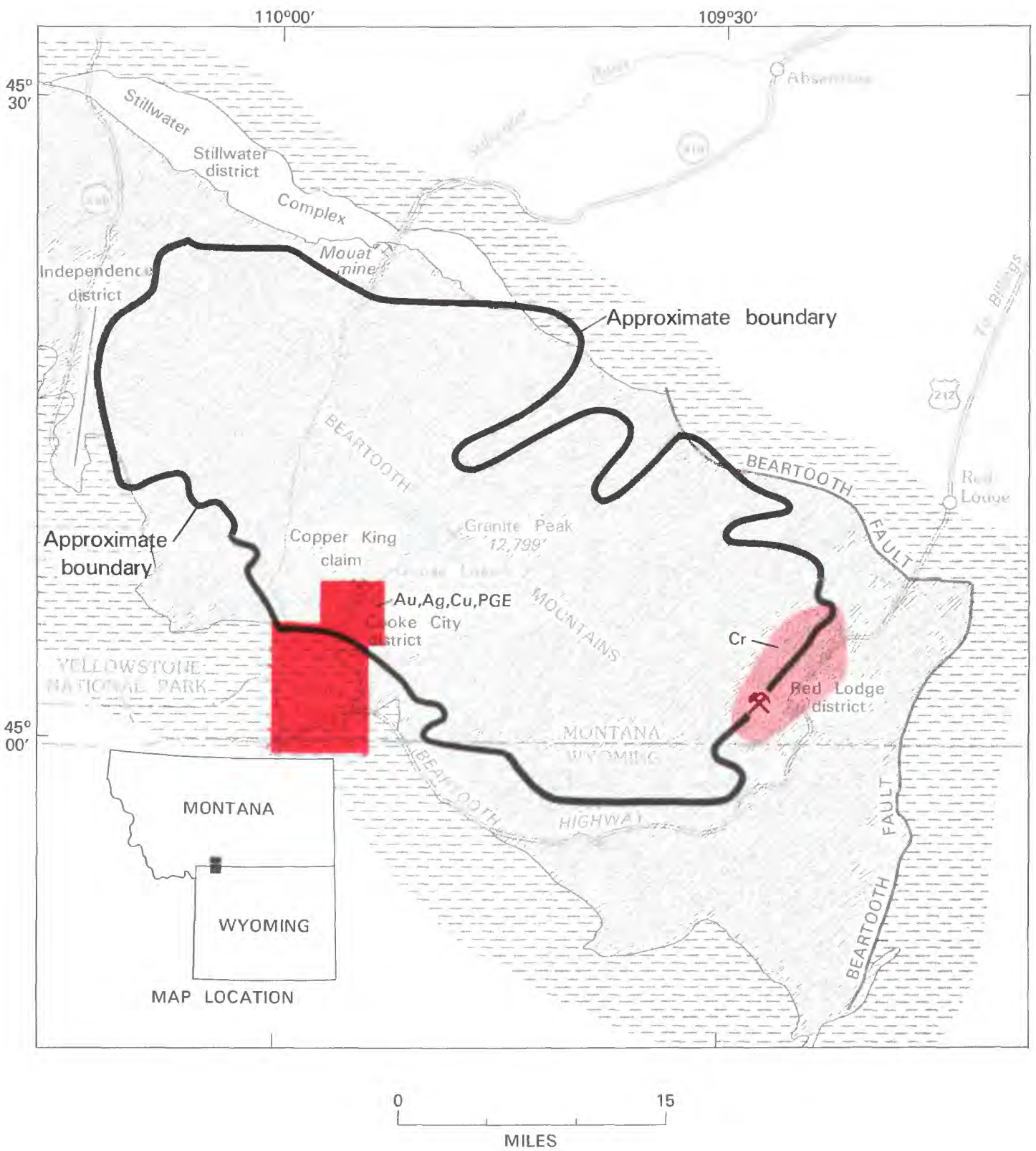

\section{EXPLANATION}

Geologic terrane with substantiated mineral-resource potential

Geologic terrane with probable mineral-resource potential

$\mathrm{Cr}$ Chromium PGE Platinum-group

$\mathrm{Cu}$ Copper

Au Gold elements

\section{Silver}

a Mine or deposit

× Mine

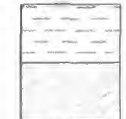

Sedimentary and volcanic rocks

Metamorphic rocks

Contact

Fault

Figure 190-Beartooth Primitive Area and vicinity, Montana and Wyoming. 
have been eroded from most of the uplifted block within the Beartooth area but occur around the borders where they locally are upturned steeply against the boundary faults. Subsequent regional uplift, perhaps a few million years ago, initiated the erosion period during which the present rugged topography was carved by streams and glaciers.

A geochemical study of the Beartooth area was based on spectrographic and chemical analysis of samples of rocks and stream sediments by the USGS, and on examination and sampling of prospects, mining claims, or mineral occurrences by the USBM. An aeromagnetic survey provided additional information on the geology and mineral resources.

Except for a few hundred tons of chromite ore from the Red Lodge district and possibly a few tons of copper ore from the Cooke City district, no minerals have been produced from the Beartooth area. Mineral production from districts adjoining the area comprises about $\$ 4$ million in gold, silver, copper, lead, and zinc from the Cooke City district; about $\$ 600,000$ in chromite ore from the Red Lodge district; 1 million tons of lowquality chromite concentrate from the Stillwater district; and a small amount of gold, silver, copper, and lead from the Independence district.

\section{MINERAL RESOURCES}

Most of the prospects, mining claims, or mineral occurrences that were examined are in the Goose Lake basin part of the Cooke City district and in the Red Lodge district. The rest are widely scattered and are mainly narrow veins or shear zones containing quartz, iron oxide, and traces of copper, gold, lead, or silver.

In the Goose Lake basin part of the Cooke City district, the Copper King claim has a deposit of copper, silver, gold, and platinum-group elements. This deposit, at the north end of Goose Lake, is in and near a body of syenite (quartz-poor granite) 4000 to $5000 \mathrm{ft}$ across that intrudes gneiss. It has been explored by a shaft 60 $100 \mathrm{ft}$ deep (now flooded to the level of the surface of Goose Lake), at least 11 diamond-drill holes, and numerous small surface workings, but no work is currently being done. At least one drill hole found mineralized rock containing copper, gold, and silver, and some rock removed from the shaft contains gold, silver, copper, and platinum-group elements (platinum and palladium) disseminated and in veinlets. This area has a substantiated mineral-resource potential.

The Red Lodge mining district extends a short way into the eastern edge of the study area where chromite in small masses of ultramafic rock occur in granitic gneiss. Several prospect pits and trenches have exposed a chromite-bearing zone that is estimated to contain 25,000 tons of demonstrated chromite resources averaging 11.3 percent $\mathrm{Cr}_{2} \mathrm{O}_{3}$. From data collected in this study it was determined that the area around the Red Lodge district has a probable resource potential for chrome.

Elsewhere in the Beartooth area, little evidence of mineral deposits was found. Although anomalous amounts of one or more elements were found in many samples (particularly chromium, cobalt, copper, gold, lead, molybdenum, nickel, and silver), most of the samples appear to represent only very local concentrations of that element rather than extensive mineralization. In certain stream-sediment samples, anomalous amounts of various elements reflect the presence in the corresponding drainage basins of metal-rich rocks of the Stillwater Complex (chromium, cobalt, copper, and nickel) and of the Cooke City district (copper, lead, molybdenum, silver, and zinc).

Except for mafic dikes, few intrusive rocks younger than the metamorphic rocks were recognized, nor were any large areas or volumes of altered rock seen; both of these features are typically associated with mineral deposits in the Rocky Mountains. In many places, rock outcrops are iron stained and appear to be altered, but upon examination the rusty color seen is the result of very thin films of iron oxide apparently derived largely from the oxidation of biotite, an iron-rich mica contained in the rocks.

The lack of sedimentary rocks in the Beartooth area precludes the existence of mineral deposits typically associated with them, such as clay, gypsum, limestone, and phosphate rock. No coal-, petroleum-, or natural gas-bearing rocks are known within the area, and the likelihood of their occurrence at accessible depth anywhere beneath the area is very remote. No indicators of potential geothermal energy-hot springs or geysers, or very young volcanic rocks-are found in the area.

\section{SUGGESTIONS FOR FURTHER STUDIES}

The Copper King deposit at Goose Lake has been explored repeatedly both on the surface and underground, but the extent and grade of the mineralized rocks are still not well known. Inasmuch as little new information can be gained by further surface studies, additional exploration would require subsurface methods, such as diamond drilling. However, the area is remote, access is difficult, Goose Lake basin is free from snow for only about 2 months in the summer, and the water table is shallow, about at the level of the surface of Goose Lake; these combined factors apparently have discouraged exploration in recent years. 


\section{REFERENCE}

Simons, F. S., and Armbrustmacher, T. J., U.S. Geological Survey, Van Noy, R. M., Zilka, N. T., Federspiel, F. E., and Ridenour, James, U.S. Bureau of Mines, 1979, Mineral resources of the Beartooth Primitive Area and vicinity, Carbon, Park, Stillwater, and Sweet Grass Counties, Montana, and Park County, Wyoming: U.S. Geological Survey Bulletin 1391-F, 125 p. 


\title{
BIG SNOWIES WILDERNESS STUDY AREA AND CONTIGUOUS ROADLESS AREAS, MONTANA
}

\author{
By DAVID A. Lindsey, U.S. GeOlogical SuRVEY, and \\ Francis E. FEDERSPIEL, U.S. BUREAU OF Mines
}

\section{SUMMARY}

A mineral survey published in 1982 determined that the Big Snowies Wilderness study area had little promise for the occurrence of mineral or fossil fuel resources. This assessment was based on consideration of geologic environments where minerals and fossil fuels might be expected, on geochemical and geophysical surveys of the study areas, and on examination of claims and prospects.

\section{CHARACTER AND SETTING}

The Big Snowies Wilderness study area and contiguous roadless areas cover about $195 \mathrm{sq} \mathrm{mi}$ of Lewis and Clark National Forest in the Big Snowy Mountains in central Montana. Rising to an elevation of more than $8000 \mathrm{ft}$, the crest of the range is broad, near timberline, and sparsely forested; the flanks of the range are deeply dissected by valleys that resemble those cut by glaciers, but probably owe their origin to landslides and erosion by streams. The study area can be reached by auto via gravel roads. From the north, it is about $25 \mathrm{mi}$ by road from Lewiston; from the west, about $10 \mathrm{mi}$ from Judith Gap; and from the southwest about $30 \mathrm{mi}$ from Harlowton. Trails enter the area from both sides and are connected by a trail that runs along the crest of the range.

Four areas were studied in the Big Snowy Mountains; these are (1) the Big Snowies Wilderness study area; (2) the Snowies Roadless Area; (3) the Half Moon Roadless Area; and (4) the Green Pole Canyon Roadless Area.

The Big Snowy anticline is the dominant geologic structure of the study areas in the Big Snowy Mountains. A small area of Precambrian sedimentary rocks is exposed in the anticlinal core, large areas of Paleozoic sedimentary rocks crop out high in the mountains, and Mesozoic sedimentary rocks encircle the mountains. The steep south limb of the anticline is broken by a fault where it descends into the Wheatland syncline south of the mountains, and the anticline is traversed by a northwesterly trending zone of faults interpreted to overlie a deep shear zone. The anticline was formed by regional tectonic stress and does not contain intrusive rocks.
None of the geologic features of the study areas is known to be associated with significant mineral or fuel deposits. Geophysical and geochemical anomalies that might indicate buried deposits were not found in the study areas.

\section{MINERAL RESOURES}

There are only a few claims and prospects in the study areas. No patented claims and no production has been reported from the areas. Geochemical analyses of sparse veins from prospects showed virtually no values for any metals. Various geologic settings were investigated for potential for base and precious metals, uranium, gypsum, high-calcium hmestone, oil and gas, oil shale, and coal; based on available evidence, there is little or no promise for deposits of any of these resources within the study area (Lindsey and others, 1982). Metalliferous shales reported recently from central Montana (Desborough and others, 1981) are located mostly outside the study areas.

\section{SUGGESTIONS FOR FURTHER STUDIES}

Seismic-reflection studies across the Big Snowy anticline are recommended to better assess the nature and magnitude of offset along the faulted southern flank of the anticline. In geologic and geophysical studies of the areas, it was concluded that the magnitude of fault offset was small (Lindsey, 1980; Long, 1981). The degree to 


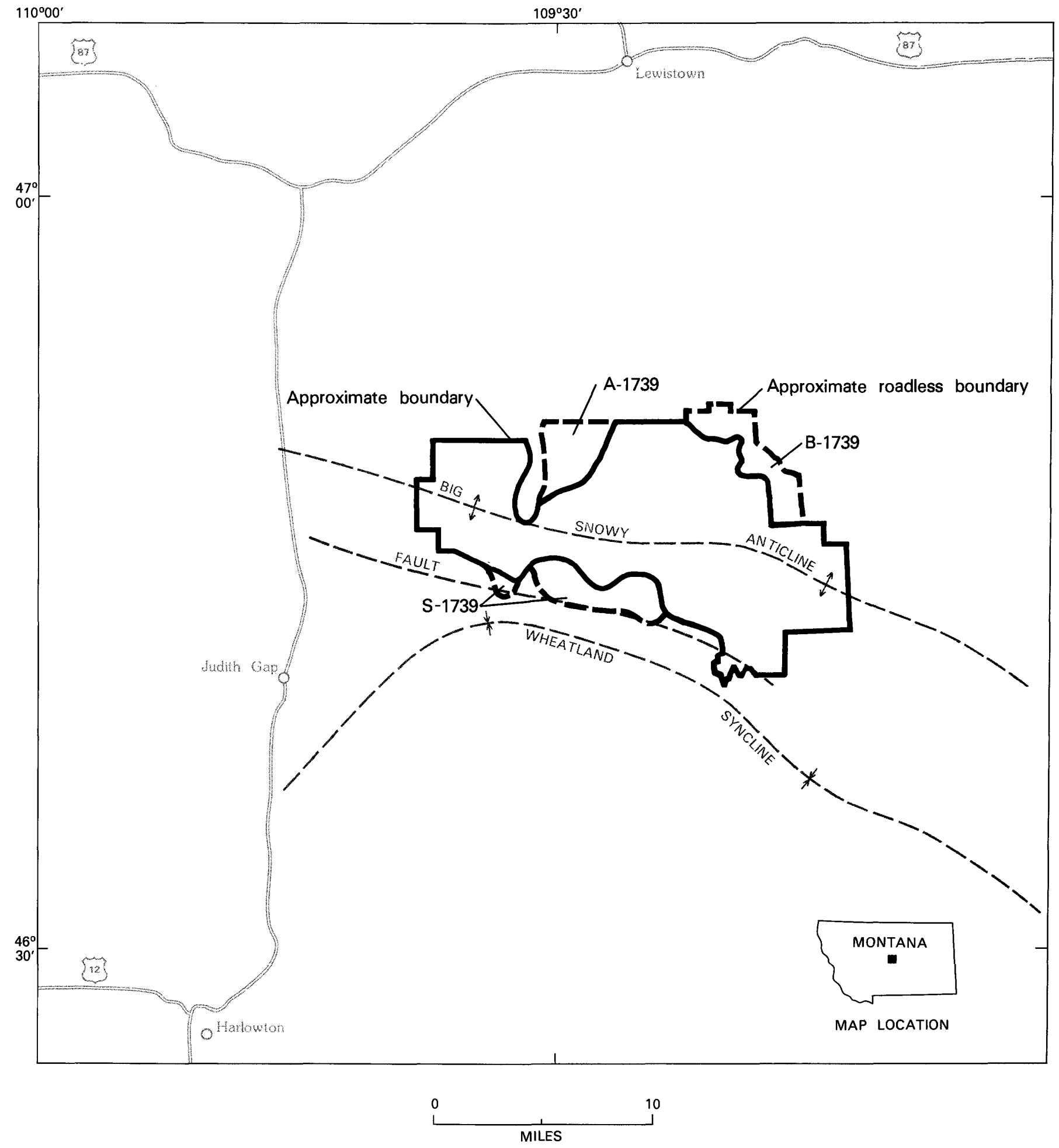

Figure 191.-Big Snowies Wilderness Study Area and contiguous roadless areas, Montana. 
which this structure overrides the Wheatland syncline to the south affects the favorability for occurrence of oil and gas in the study areas. Discovery of a large offset, although considered a remote possibility, would place strata and structures favorable for oil and gas beneath the southern part of the study areas.

\section{REFERENCES}

Desborough, G. A., Poole, F. G., and Green, G. N., 1981, Metalliferous oil shales in central Montana and northeastern Nevada: U. S. Geological Survey Open-File Report 81-121, $14 \mathrm{p}$.
Lindsey, D. A., 1980, Reconnaissance geologic map and sections of the Big Snowies Wilderness and contiguous RARE II study areas, Fergus, Golden Valley, and Wheatland Counties, Montana: U. S. Geological Survey Miscellaneous Field Studies Map MF-1243-A, scale 1:100,000.

Lindsey, D. A., Federspiel, F. E., and Huffsmith, J. D., 1982, Mineral potential of the Big Snowies Wilderness and contiguous (RARE II) study area, Fergus, Golden Valley, and Wheatland Counties, Montana: U. S. Geological Survey Miscellaneous Field Studies Map MF-1243-E, scale 1:100,000.

Long, C. L., 1981, Complete Bouguer gravity map of the Big Snowies Wilderness and contiguous RARE II study areas, Fergus, Golden Valley, and Wheatland Counties, Montana: U.S. Geological Survey Miscellaneous Field Studies Map MF-1243-C, scale 1:100,000. 

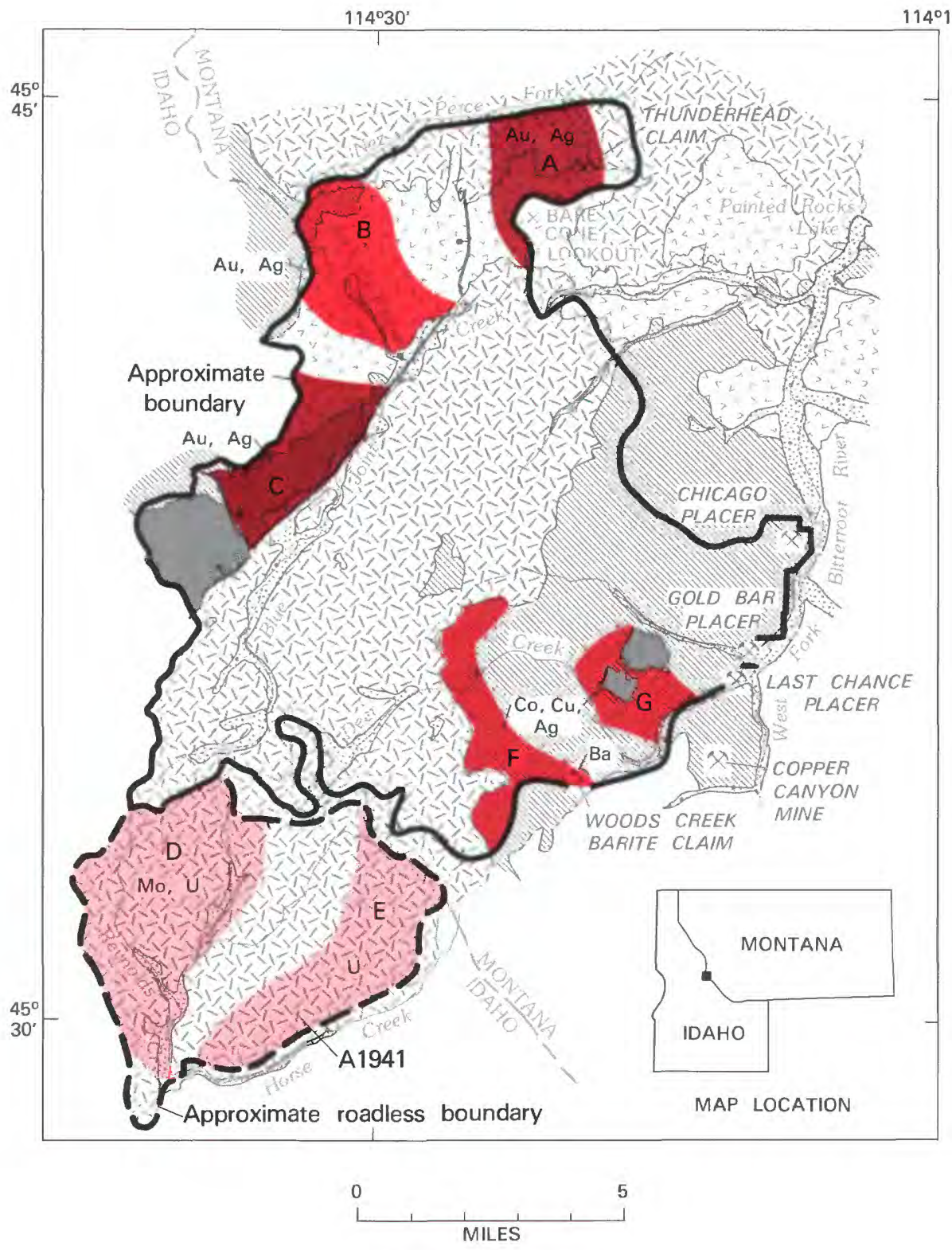

\section{EXPLANATION}

Geologic terrane with substantiated mineralresource potential and probable molybdenum resource potential

Geologic terrane with substantiated mineralresource potential

Geologic terrane with probable mineralresource potential

$\begin{array}{ll}\mathrm{Ba} & \text { Barium } \\ \mathrm{Co} & \text { Cobalt } \\ \mathrm{Cu} & \text { Copper } \\ \mathrm{Au} & \text { Gold } \\ \mathrm{Mo} & \text { Molybdenum } \\ \mathrm{Ag} & \text { Silver } \\ \mathrm{U} & \text { Uranium } \\ \times & \text { Mine }\end{array}$

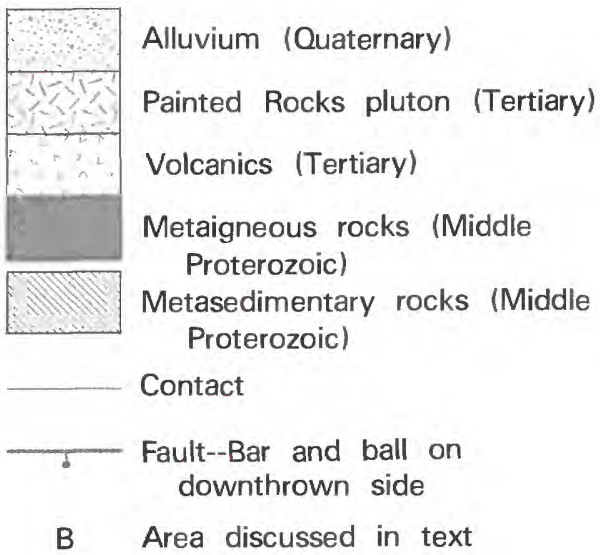

Figure 192.-Blue Joint Wilderness Study Area, Montana, and Blue Joint Roadless Area, Idaho. 


\title{
BLUE JOINT WILDERNESS STUDY AREA, MONTANA, AND BLUE JOINT ROADLESS AREA, IDAHO
}

\author{
By Karen Lund, U.S. GeOlOgical Survey, and \\ JOHN R. BENHAM, U.S. BUREAU OF MineS
}

\section{SUMMARY}

During field studies of the Blue Joint Wilderness Study Area, Montana, and the Blue Joint Roadless Area, Idaho, in 1979, areas of substantiated resource potential for epithermal precious-metal vein deposits were identified in areas of hydrothermal alteration and fossil hot springs activity in the Eocene volcanic rocks. Areas with substantiated resource potential for cobalt, copper, silver, and barite resources of the sediment-hosted type were identified in the Proterozoic quartz schist of the eastern part of the area. Probable potential exists for molybdenum in a porphyry system; anomalously high molybdenum values are coincident with high values for precious and base metals and uranium in some places. The geologic terrane precludes the occurrence of fossil fuel resources.

\section{CHARACTER AND SETTING}

The study area is located in the southern Bitterroot Mountains $90 \mathrm{mi}$ south of Missoula, Montana, and contains the Blue Joint Wilderness Study Area (96 sq mi), Ravalli County, Montana, and the Blue Joint Roadless Area (31 sq mi), Lemhi County, Idaho. Both areas were examined by the USGS but only the Montana portion has been studied by the USBM.

The study area is located in the southeastern part of the Bitterroot lobe of the Idaho batholith. Most of the area is underlain by the Painted Rocks pluton (Eocene) which intrudes the Idaho batholith (Cretaceous) and its metasedimentary and metaigneous roof rocks. Middle Proterozoic metasedimentary rocks are made up of pure to feldspathic quartzite, phyllite, and quartz schist. Bedded copper sulfides, bedded barite, and banded ironformation locally occur within the quartz schist. These metasedimentary rocks are tentatively correlated with the Big Creek and Yellowjacket Formations of eastcentral Idaho. Metaigneous complexes of amphibolite, granodiorite gneiss, and granite augen gneiss intrude some of the Middle Proterozoic metasedimentary rocks. Tertiary volcanic and volcaniclastic rocks include rhyolite-rhyodacite and andesite. Volcaniclastic rocks include conglomerates with volcanic and quartzite cobbles and tuffaceous lake sediments. Hydrothermal activity has affected most of the volcanic rocks; there is a widespread, weak alteration of rocks and local hot springs deposits can be recognized. The Painted Rocks pluton of Eocene age is predominantly granite, and is cut by slightly younger rhyolite porphyry, granite porphyry, and andesite dikes. Pink granite occurs north of Blue Joint Creek and may be genetically related to the overlying volcanic rocks. Gray granite occurs south of Blue Joint Creek. Quaternary alluvium and older glacial moraine and minor glacio-lacustrine deposits are found along the major streams within the study area.

Folded and thrusted stacks of Middle Proterozoic metasedimentary and metaigenous rocks are broken by predominent north-northeast trending normal faults associated with uplift of the Idaho batholith and intrusion of the Painted Rocks pluton. These fault offsets allowed preservation of Tertiary volcanic rocks in downdropped blocks and formed the north-northeast fracture system along which Eocene dikes were intruded.

There have been $\mathbf{4 0}$ mining claims located in the study area; of these, 15 were lode, 23 were 160 -acre placer, and 2 were 20 -acre placer. Only one claim, the Woods Creek Barite No. 1 was active at the time of the survey. There are no patented claims or mineral or energy leases in the study area.

The Blue Joint district along Blue Joint Creek is the only mining district extending into the study area. Activity in the district began in 1898 when a group of ten prospectors located seven 160 -acre placer claims. From 1898 to 1934,15 or more 160 -acre placers were located along Blue Joint Creek. Examination of these claims 
revealed only a few prospect trenches and pits. There is no record of production.

Other placer workings and prospects outside the Blue Joint placer district but inside the study area are the Chicago, Last Chance, and Gold Bar placer claims. Examination of lode claims revealed only a few prospect pits and trenches with no evidence of production.

\section{MINERAL RESOURCES}

Five areas within the study area have substantiated mineral-resource potential. Area A, near Bare Cone Lookout, is underlain by pink granite of the Painted Rocks pluton and is characterized geologically by hydrothermal pyrite-sericite alteration, quartz veining, and brecciation. A fluorite prospect (Thunderhead claim) in the Bare Cone alteration area opened fluorite veins in a rhyolite dike. An anomalous element suite was detected and includes beryllium, silver, molybdenum, zinc, arsenic, gold, tungsten, mercury, uranium, bismuth, and fluorine. The last 10 elements of the suite have anomalously high values in this area and represent a favorable association for precious-metal deposits. The element assemblage and geologic environment indicate that this area has a substantiated mineral-resource potential for gold-silver deposits of the epithermal, hot springs type. The first five elements of the anomalous element suite, the fluorite veins, and the pyrite-sericite alteration of the granitic host rock indicate a probable mineral-resource potential in area $\mathrm{A}$ for a stockwork molybdenum system.

Area B, in the drainage of Jack the Ripper Creek, is underlain by Eocene rhyolitic to dacitic flows and tuffs. Sinter deposits are evident, and quartz veining and hydrothermal alteration are also present. Gold, silver, molybdenum, tungsten, zinc, mercury, uranium, arsenic, bismuth, and fluorine have anomalously high values in this geologic environment and indicate a substantiated resource potential for epithermal precious-metal hot spring-type deposits.

Area C, at Steep Hill, is also in Eocene rhyolitic to dacitic flows and tuffs. This area is characterized by quartz veining, intense zones of pyrite-sericite alteration, and brecciation. An anomalous element suite of gold, silver, molybdenum, arsenic, mercury, uranium, zinc, tungsten, bismuth, fluorine, lead, and lithium was detected. The first 10 elements of this suite, and the geologic setting indicate a substantiated resource potential for precious metals. This element suite and notably high molybdenum values from rock samples, the alteration mineralogy, and the quartz veining present suggest that this area also has a probable mineralresource potential for molybdenum in a fluorine-poor stockwork system.
Although no precious-metal lode prospects have been located in the study area, placer claims are present in Blue Joint Creek and near the mouths of Deer, Chicken, and West Creeks (Last Chance, Gold Bar, and Chicago placers). The fine flakes of gold recovered from these placers probably come from mineralized rock in the Eocene volcanics and Tertiary granites. The placers provide indications of mineralization in the source areas $(\mathrm{A}$, $\mathrm{B}$, and $\mathrm{C}$ ); but the areas of the placers are not themselves regarded as having resource potential.

In area $\mathrm{D}$, in the middle fork of Reynolds Creek, high values for molybdenum and associated tin, tungsten, uranium, and fluorine in a zone of pyrite-sericitecarbonate alteration indicate probable mineral-resource potential for molybdenum in a stockwork system, even though no younger mineralizing intrusive has yet been recognized in this area. Coincident high gold values are most likely associated with the base-metals assemblage. Anomalous uranium values in stream-sediment and water samples spatially coincide with the areas of high base- and precious-metal values and suggest a probable resource potential for uranium.

Area E, on the north side of Horse Creek, also has anomalous uranium values in stream-sediment and water samples in areas of high base- and preciousmetals values, and a probable resource potential for uranium is inferred.

Two outcrop areas of Middle Proterozoic quartz schist $(F, G)$ in the southeastern part of the Blue Joint Wilderness Study Area, Montana, have high copper, silver, cobalt, and barium values. Regional correlations indicate that the quartz schist may be part of the Middle Proterozoic Yellowjacket Formation which hosts the cobalt-copper-silver deposit at Blackbird, Idaho. The Copper Canyon mine north of Woods Creek and $1.5 \mathrm{mi}$ outside of the study area is characterized by stratiform and remobilized chalcopyrite and bornite. A bedded iron-formation is associated with it. Bedded tourmalime quartzite and tourmalime breccia are found within the quartz schist between Chicken and Deer Creeks. The geochemical and geological evidence indicate these areas have substantiated resource potential for sediment-hosted deposits of the Blackbird cobaltcopper-silver type.

An area of substantiated bedded barite resource potential (of drilling mud quality) occurs at the southern edge of the study area near the Woods Creek barite claim.

\section{SUGGESTIONS FOR FURTHER STUDIES}

More detailed mapping and geochemical sampling in the areas with potential for mineralization are warranted by the positive indications found in this study. 
Regional investigations of the Middle Proterozoic Yellowjacket Formation and lower Belt Supergroup are needed to refine assessments of the potential for sediment-hosted copper-cobalt deposits in the quartz schist. Further studies of the Eocene volcanic rocks would be useful for indicating the nature and extent of gold mineralization.

\section{REFERENCE}

Lund, Karen, Rehn, W. M., and Benham, J. R., 1983, Mineral resource potential map of the Blue Joint Wilderness Study Area, Ravalli County, Montana, and the Blue Joint Roadless Area, Lemhi County, Idaho: U.S. Geological Survey Miscellaneous Field Studies Map MF-1557-A, scale 1:50,000. 

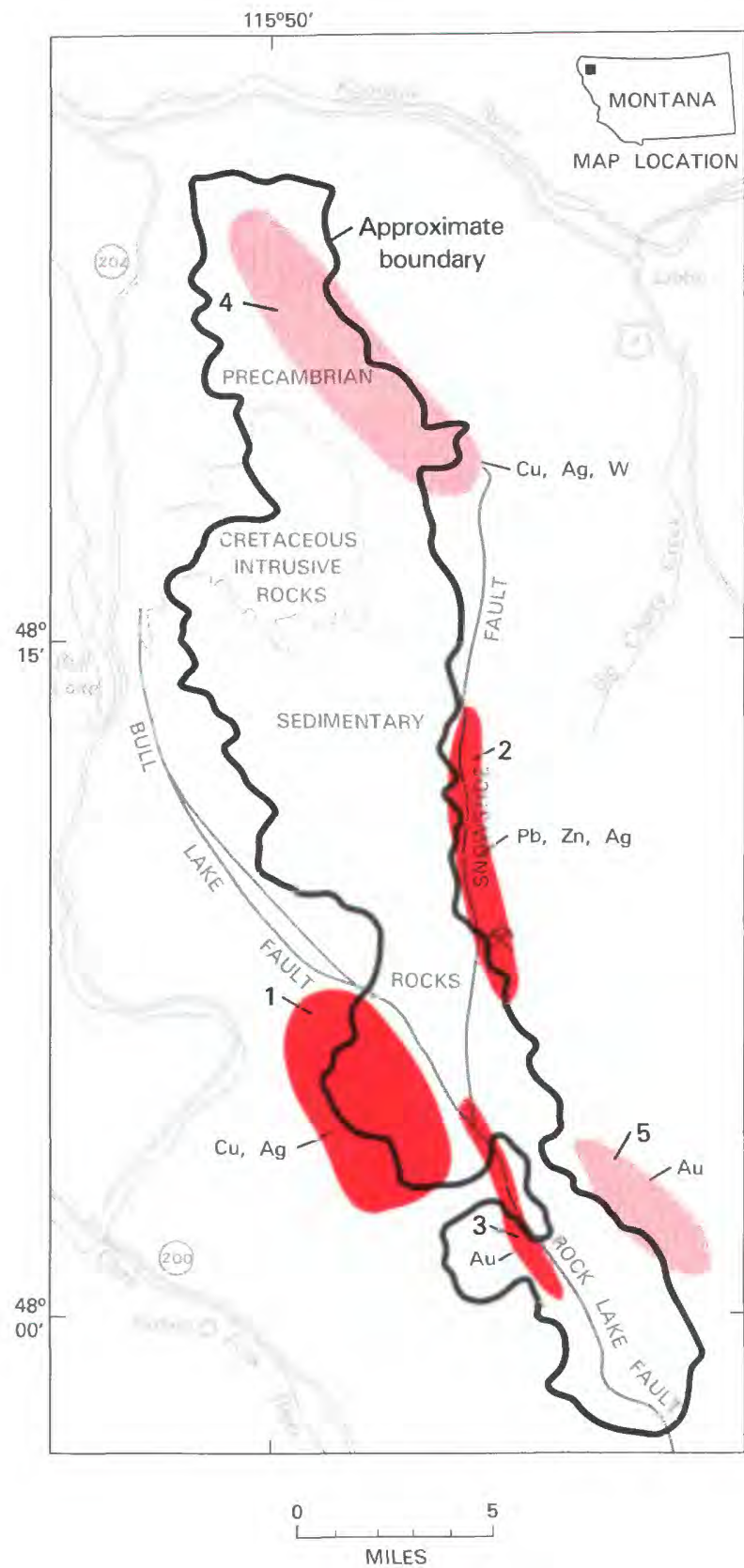

\section{EXPLANATION}

Geologic terrane with substantiated mineral-resource potential

Geologic terrane with probable mineral-resource potential

$\begin{array}{ll}\mathrm{Cu} & \text { Copper } \\ \mathrm{Au} & \text { Gold } \\ \mathrm{Pb} & \text { Lead }\end{array}$

\author{
Ag Silver \\ W Tungsten \\ Zn Zinc \\ X Mine or deposit \\ 2 Locality discussed in text
}

Figure 193.-Cabinet Mountains Wilderness, Montana. 


\title{
CABINET MOUNTAINS WILDERNESS, MONTANA
}

\author{
By DaVid A. LindSey, ${ }^{1}$ U.S. GeOlogical SurVey, and \\ D'ARCY P. BANister, U.S. BUREAU OF Mines
}

\begin{abstract}
SUMMARY
The results of a mineral survey published in 1981 of the Cabinet Mountains Wilderness indicate areas of probable and substantiated resource potential for copper, silver, lead, zinc, and gold. No potential for other metals or energy res Jurces was identified in this survey. The mineral-resource potential of the area was evaluated by interpretation of geologic mapping, geochemical, geophysical, and gravity surveys, and by examination of mines and prospects; these studies were conducted from 1972 to 1974 . Exploration by private industry since 1960 has resulted in discovery of significant copper-silver deposits in and adjacent to the wilderness.
\end{abstract}

\section{CHARACTER AND SETTING}

The Cabinet Mountains Wilderness covers about $150 \mathrm{sq} \mathrm{mi}$ in the Kootenai and Kaniksu National Forests, Lincoln and Sanders Counties, northwestern Montana. The wilderness extends $34 \mathrm{mi}$ along the crest of the eastern part of the Cabinet Mountains; its average width is about $4 \mathrm{mi}$. The crest of the range has an altitude of more than $7000 \mathrm{ft}$ and is extremely rugged and scenic. It contains many high basins and deep valleys carved by glaciers during the ice age. Timberline is at about $7000 \mathrm{ft}$, and forests are dense below that altitude. Access to the wilderness is by U. S. Highway 2 , which passes through the town of Libby, by State Highway 200 along the Clark Fork River, and by State Highway 202 along the Bull River. Good gravel roads extend along some streams nearly to the wilderness boundary. Many trails extend over the crest of the range where they connect with trails from the other side.

Most of the wilderness is underlain by more than $27,000 \mathrm{ft}$ of Precambrian Belt sedimentary rocks according to studies conducted in 1972-74 (U.S. Geological Survey and U.S. Bureau of Mines, 1981). The Revett Formation, a thick quartzite unit in the middle of the sequence of sedimentary rocks, crops out extensively in the southwestern part of the area, where it is an important host for copper-silver deposits (area 1 on map). Stocks and minor dikes of igneous rock of Cretaceous age intrude the sedimentary rocks. Although

${ }^{1}$ With contributions from John D. Wells, USGS. similar intrusions are mineralized in other areas, the igneous rocks of the Cabinet Mountains Wilderness do not appear to contain mineral deposits. The Precambrian rocks have been folded and faulted along a northnorthwest trend. Some of the faults, particularly the Snowshoe and Rock Lake faults, were important in localizing mineralization.

\section{MINERAL RESOURCES}

Five areas of mineral potential in and adjacent to the Cabinet Mountains Wilderness have been identified by geologic mapping, geophysical and geochemical surveys, and detailed examination of mines and known mineral occurrences. These are (1) an area of copper- and silver-bearing beds in the Revett Formation, (2) an area of lead, zinc, and silver veins and geochemical anomalies along the Snowshoe fault, (3) an area of gold-bearing quartz veins along the Rock Lake fault, (4) an area of small mineral occurrences and low-level silver anomalies in soil in the northern part of the wilderness, and (5) an area of scattered gold- and sulfide-bearing quartz veins southeast of but adjacent to the wilderness. The first three of these areas have substantiated mineralresource potential, whereas the last two areas are considered to have probable mineral-resource potential, based on mineral occurrences and other features. No mineral production has been recorded from the Cabinet Mountains Wilderness, although much has been produced nearby. County records show that about 300 mining claims have been located within and along the 
boundary of the wilderness; there are no patented claims within the wilderness.

Exploration by private industry since 1960 has resulted in the discovery of deposits of disseminated copper and silver in quartzite beds of the Revett Formation at several localities in northwestern Montana. One of these is along the wilderness boundary (area 1 on map). Exploratory drilling just outside the wilderness boundary has revealed that an area of about $0.5 \mathrm{sq} \mathrm{mi}$ contains 4 million tons of demonstrated resources with an average grade of 0.86 percent copper and $1.8 \mathrm{oz}$ silver/ton, and demonstrated resources of 20.6 million tons averaging 0.29 percent copper and $0.4 \mathrm{oz}$ silver/ton. Projection of the copper-bearing strata into adjacent terrane indicates that there is an area of approximately $10 \mathrm{sq}$ mi that contains a substantiated mineral-resource potential for copper and silver, much of it in the wilderness.

Mines along the east side of the wilderness are associated with generally narrow and discontinuous veins in and near the north-trending Snowshoe fault (area 2 on map). Geochemical anomalies outline an area of mimeralized rock located mostly just outside the wilderness that has substantiated lead, zinc, and silver resource potential. One part of the area, located astride the wilderness boundary, has demonstrated resources of 500,000 tons of rock containing lead, zinc, and silver.

An area of gold-bearing veins with substantiated mineral-resource potential associated with the Rock Lake fault (area 3 on map), such as those at the Heidelberg mine, may extend into the wilderness. There is a possibility of finding such veins in the wilderness.

An area of small mineral occurrences (copper, silver, and tungsten) and widespread low-level silver anomalies is located in the northwestern part of the wilderness (area 4 on map). This area is tentatively rated as having probable mineral-resource potential. The low-level anomalies there are probably derived from small copper-silver occurrences in Precambrian sedimentary rocks; such occurrences belong to a class of deposits known to be of small size.

Gold is widespread in veins and placers southeast of the wilderness (area 5 on map), but this area does not extend far into the wilderness. The volume of goldbearing rock in most veins is probably small and the area has a probable mineral-resource potential.

Neither petroleum nor coal nor any evidence of geothermal energy exists in or near the wilderness; the geologic terrane is not favorable for the occurrence of these resources.

\section{SUGGESTIONS FOR FURTHER STUDIES}

Further studies of value in assessing the resource potential of the Cabinet Mountains Wilderness should be concentrated on understanding the processes that form and localize the copper-silver deposits found in Precambrian sedimentary rocks there. Such deposits occur throughout a large area of northwestern Montana adjacent to the Cabinet Mountains Wilderness; studies of their origin are needed both for assisting exploration and for assessing their liklihood of occurrence.

\section{REFERENCES}

U. S. Geological Survey and U. S. Bureau of Mines, 1981, Mineral resources of the Cabinet Mountains Wilderness, Lincoln and Sanders Counties, Montana, U. S. Geological Survey Bulletin 1501,77 p. 


\title{
CENTENNIAL MOUNTAINS WILDERNESS STUDY AREA, MONTANA AND IDAHO
}

\author{
By IRVING J. WiTKIND,${ }^{1}$ U.S. GEOLOGICAL SURVEY, and \\ JAMES RIDENOUR, U.S. BUREAU OF MINES
}

\begin{abstract}
SUMMARY
A mineral survey conducted in 1979 within the Centennial Mountains Wilderness study area showed large areas of probable and substantiated resource potential for phosphate. Byproducts that may be derived from processing the phosphate include vanadium, chromium, uranium, silver, fluorine, and the rare earths, lanthanum and yttrium. Results of a geochemical sampling program suggest that there is little promise for the occurrence of base and precious metals in the area. Although the area contains other nonmetallic deposits, such as coal, building stone, and pumiceous ash they are not considered as mineral resources. There is a probable resource potential for oil and gas and significant amounts may underlie the area around the Peet Creek and Odell Creek anticlines.
\end{abstract}

\section{CHARACTER AND SETTING}

The Centennial Mountains Wilderness study area consists of about $150 \mathrm{sq} \mathrm{mi}$ that occupy parts of Beaverhead County, Montana, and Clark and Fremont Counties, Idaho. Four contiguous parcels of land make up the study area: (1) the U.S. Bureau of Land Management's Centennial Mountains Instant Study Area, occupying $72 \mathrm{sq}$ mi wholly in Montana, (2) the USFS's Management Unit 1, some $61 \mathrm{sq}$ mi within Idaho, (3) the Mt. Jefferson area, a USFS roadless area occupying about $7 \mathrm{sq} \mathrm{mi}$ in Montana, and (4) the Mt. Jefferson West area, a second roadless area of about $10 \mathrm{sq} \mathrm{mi}$ wholly in Idaho.

The Centennial Mountains are uncommon in that they trend eastward in a region dominated by northand northwest-trending mountain ranges. The Centennial Mountains form a long, narrow forested mass between Centennial Valley on the north, and the broad, sweeping, arid expanse of the Snake River Plain on the south. In all, the range is about $40 \mathrm{mi}$ long, and about $8 \mathrm{mi}$ wide. The area proposed for wilderness status includes the central more scenic and heavily forested part of the range. In the study area, average altitudes along

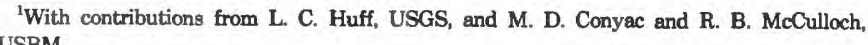
USBM. the crest of the mountains range from about $7000 \mathrm{ft}$ to as much as $9000 \mathrm{ft}$.

The mountains are divided into two almost equal parts, the Eastern and Western Centennial Mountains, by northeast-flowing Odell Creek. The Eastern Centennial Mountains, composed chiefly of well-indurated, southward-tilted sedimentary rocks, are very rugged and majestic. The Western Centennial Mountains are underlain by softer sedimentary rocks that erode easily and are very unstable; landslides and earthflows are common and widespread. These softer rocks form high mountains only because they are capped by resistant volcanic rocks.

The mountains are an effective barrier to all vehicular travel. U.S. Highway 20-191, leading to Yellowstone National Park, skirts their east end. Interstate Highway 15 , the main route northward to Dillon and Butte, Montana from Idaho Falls, Idaho bypasses them on the west via Monida Pass. Graveled roads, north and south of the mountains, connect these two major highways.

The north margin of the Centennial Mountains is delineated by the Centennial fault, one of the major active faults zones in southwestern Montana. The fault is normal, trends almost due west, and dips northward; Centennial Valley is downdropped relative to the mountains.

The geology of the mountains was mapped by Witkind $(1972,1976)$ and Witkind and Prostka (1980). The 

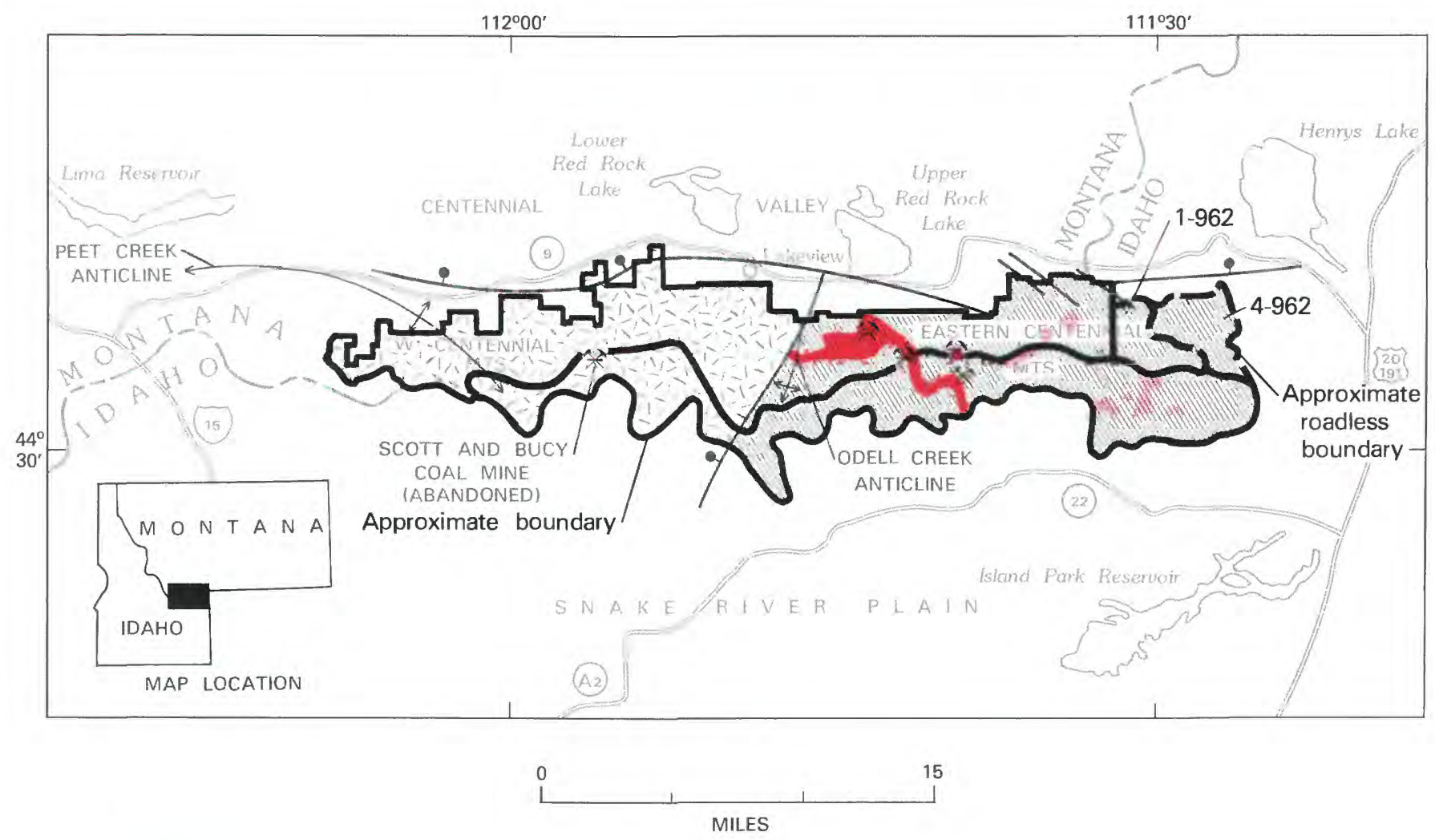

EXPLANATION

Geologic terrane with substantiated phosphate potential

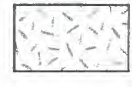

Beaverhead Formation (?)

sedimentary rocks (Cretaceous and Tertiary)

Geologic terrane with probable phosphate potential

Sedimentary rocks

(Paleozoic and Mesozoic)

Abandoned phosphate mine

Fault--Bar and ball on downthrown side

Figure 194.-Centennial Mountains Wilderness study area, Montana and Idaho. 
inineral-resource potential of the study area was determined in a joint USGS/USBM investigation (Witkind and others, 1981). Geophysical surveys were made and published by Martin (1982).

\section{MINERAL DEPOSITS}

Almost all mineral deposits of interest are in the Eastern Centennial Mountains; structures favorable for the accumulation of oil and gas may underlie the Western Centennial Mountains and the west edge of the Eastern Centennial Mountains.

As no known base or precious-metal deposits occur in the area, it was decided that the most feasible way to assess the inineral potential of the mountains was to conduct a geochemical survey by sampling stream sediments. The results of the sampling suggest that there is little promise for the occurrence of base or precious metals at or near the surface within the study area. Semiquantitative spectrographic analyses of the sediment samples did not detect any gold or silver, and although chromium, copper, lead, molybdenum, nickel, tin, vanadium, and zinc were detected, the amounts were not above those expected in the rocks of the area.

Placer gold reportedly was found near the mouth of Odell Creek (Lyden, 1948). Sampling during this investigation did not find any gold at this locality.

Deposits of nonmetallic minerals occur in the area, but phosphate is the only nonmetallic mineral of interest. Although about 296,000 tons of phosphate was mined from open pits during the period 1956 to 1958 , the mines have been closed for many years. Large amounts of phosphate, contained within the Phosphoria Formation of Permian age, still underlie the area.

In the Centennial Mountains, the phosphate-bearing Phosphoria Formation consists of a complex series of interfingering units. Of these, only two contain phosphate, the Meade Peak Member and the Retort Shale Member, and of these only the Meade Peak Member contains minable amounts. The Meade Peak Member ranges in thickness from 0 to $15 \mathrm{ft}$, but it averages $14 \mathrm{ft}$. At a few localities, the entire member is a single bed composed of phosphatic pellets, nodules, and shell fragments. More commonly, it consists of two beds of bluish-white (the so-called "phosphate bloom") phosphate rock separated by a lenticular bed of light-brown calcareous silty dolomite. The lower phosphate bed is extremely lenticular; its thickness changes abruptly, ranging from about $0.5 \mathrm{ft}$ to as much as $7 \mathrm{ft}$, but it generally averages 3-4 ft. It consists of oolitic to pisolitic pellets and nodules of phosphate cemented by carbonate-fluorapatite. The upper phosphate bed closely resembles the lower phosphate bed in appearance and composition. This upper phosphate bed ranges in thickness from about 1.5 to $5 \mathrm{ft}$, but commonly, is about $3 \mathrm{ft}$ thick. Both the upper and lower phosphate beds have been inined in the past.

The Retort Shale Member is dark-gray to black and ranges in thickness from 15 to $20 \mathrm{ft}$. It consists of a basal, thin-bedded, carbonaceous shale and shaly siltstone rich in phosphatic oolites, overlain by a darkbrown, thin-bedded, banded siltstone with some shale interbeds. The phosphate in the basal phosphate-rich carbonaceous shale is contained in several very thin oolite-rich beds; each oolite, composed of carbonatefluorapatite, is embedded in a matrix of phosphatic siltstone. The overlying dark-brown siltstone is virtually barren of phosphate.

Demonstrated phosphate resources within the areas of subtantiated phosphate potential are estimated to be $395,012,000$ tons of acid-grade (greater than 31 percent $\mathrm{P}_{2} \mathrm{O}_{5}$ ) rock, or $635,595,000$ tons of furnace-grade (greater than 24 percent $\mathrm{P}_{2} \mathrm{O}_{5}$ ) rock, or $828,543,000$ tons of beneficiation-grade (greater than 18 percent $\mathrm{P}_{2} \mathrm{O}_{5}$ ) rock. It is important to recognize that in the determination of the furnace-grade and the beneficiation-grade resources a cumulative method has been used. In essence, resources of furnace-grade rock include acid-grade amounts; resources of beneficiation-grade rock include both acid-grade and furnace-grade amounts. Probable byproducts derived from processing the phosphate include vanadium, chromium, uranium, silver, fluorine, and the rare earths, lanthanum and yttrium.

A thin bed of coal is found in the Western Centennial Mountains. Its grade, lenticularity, difficulty of access, and distance from railheads suggests that it cannot be considered a resource. Sources of building stone are in the study area, but localities are difficult to reach and are far from railheads. Pumiceous ash is near the west end of the Western Centennial Mountains, but here, too, access is difficult and railheads are distant. Geothermal springs are not known to occur in the area.

Two areas of probable resource potential for oil and gas are present and two structures are of interest: the Peet Creek anticline, a structure buried beneath a thrust(?) plate at the west end of the Western Centennial Mountains, and the Odell Creek anticline at the west end of the Eastern Centennial Mountains.

\section{SUGGESTIONS FOR FURTHER STUDIES}

Additional exploration work can better delineate the extent of the concealed phosphate deposits. 


\section{REFERENCES}

Lyden, C. J., 1948, The gold placers of Montana: Montana Bureau of Mines and Geology, Memoir 26.

Martin, R. A., 1982, Geophysical survey of the Centennial Mountains Wilderness Study Area and contiguous areas, Beaverhead County, Montana, and Clark and Fremont Counties, Idaho: U.S. Geological Survey Miscellaneous Field Studies Map MF-1342C, scale 1:100,000.

Witkind, I. J., 1972, Geologic map of the Henrys Lake quadrangle, Idaho and Montana: U.S. Geological Survey Miscellaneous Investigation Series I-781-A, scale 1:62,500.

1976, Geologic map of the southern part of the Upper Red Rock Lake quadrangle, southwestern Montana and adjacent
Idaho: U.S. Geological Survey Miscellaneous Investigations Series I-943, scale 1:62,500.

1982, Geologic map of the Centennial Mountains Wilderness Study Area and contiguous areas, Beaverhead County, Montana, and Clark and Fremont Counties, Idaho: U.S. Geological Survey Miscellaneous Field Studies Map MF-1342-A, scale 1:50,000.

Witkind, I. J., and Prostka, H. J., 1980, Geologic map of the southern part of the Lower Red Rock Lake quadrangle, Idaho and Montana: U.S. Geological Survey Miscellaneous Investigations Series I-1216, scale 1:62,500.

Witkind, I. J., Huff, L. C., Ridenour, James, Conyac, M. D., and McCulloch, R. B., 1981, Mineral resource potential map of the Centennial Mountains Wilderness Study Area and contiguous areas, Idaho and Montana: U.S. Geological Survey Miscellaneous Field Studies Map MF-1342-B, scale 1:50,000. 


\title{
CHARLES M. RUSSELL WILDLIFE REFUGE, MONTANA
}

\author{
By Dudley D. Rice, ${ }^{1}$ U.S. Geological Survey, and \\ MichaEl S. MilleR, U.S. BUREAU OF Mines
}

\begin{abstract}
SUMMARY
A mineral survey of the Charles M. Russell Wildlife Refuge was initiated in 1975 and completed in 1978. The results of the investigation indicate that parts of the area have demonstrated resources of low-rank coal and bentonite in areas of substantiated potential and all of the area is assigned a probable resource potential for oil and gas because it is underlain by sedimentary strata known to contain hydrocarbons in other areas.
\end{abstract}

\section{CHARACTER AND SETTING}

The refuge comprises $1530 \mathrm{sq} \mathrm{mi}$ along the Missouri River in central Montana. Fort Peck Dam impounds the water of the Missouri River to form Fort Peck Lake. At present, 15 subareas within the refuge, totaling $245 \mathrm{sq}$ $\mathrm{mi}$, are under consideration for wilderness inclusion.

The topography of the refuge is varied. The western part, locally called the "Missouri Breaks," consists of deeply eroded coulees and steep, rounded hills. The central part is composed of broad flat benches which have been carved into sheer, inaccessible bluffs along the Missouri River channel. The eastern part of the refuge consists primarily of steep-sided hills and badlands topography. Hummocky terrain resulting from mudflows and slumping of soft bedrock is common throughout the refuge. Away from the deeply incised Missouri River channel, the topography changes to broad rolling, glaciated plains. Fort Peck Lake covers $390 \mathrm{sq} \mathrm{mi}$, or about one fourth of the refuge, and has a maximum depth of $220 \mathrm{ft}$.

Access via two-lane paved highways is limited to U.S. Highway 191, which crosses the Missouri River at Robinson Bridge in the western part of the refuge and State Highway 24 which crosses Fort Peck Dam. Gravel roads provide good access to many parts of the refuge when dry. Areas immediately adjacent to the river and lake are best reached by boat.

The Charles M. Russell Wildlife Refuge is part of the northern Great Plains. The refuge contains a succession of nearly flat lying marine, brackish, and fresh-water

\footnotetext{
${ }^{1}$ With contributions from Claudia W. Frahme, USGS, and Otto L. Schumacher and James G. Rigby, USBM.
}

rocks ranging in age from Late Cretaceous to early Tertiary. About $1700 \mathrm{ft}$ of sandstone, siltstone, shale, and coal are exposed, which are locally overlain by unconsolidated Pleistocene glacial and glacial-related deposits and Holocene alluvium. The dip of the strata in the refuge rarely exceeds $3^{\circ}$, and the overall dip directions reflect nearby structural features including Bowdoin Dome to the north, the Bearpaw and Little Rocky Mountains to the northwest, the Blood Creek Syncline to the south, and the Williston Basin to the east.

\section{MINERAL RESOURCES}

The refuge has demonstrated resources of 11 million tons of low-rank coal in 3 small areas of substantiated resource potential. The coal has a thickness of greater than $5 \mathrm{ft}$, depth of burial less than $60-90 \mathrm{ft}$ (10-to-1 stripping ratio) and an ash content of $25-30$ percent. An additional 279 million tons of low-rank coal $1.5-10 \mathrm{ft}$ thick is estimated to occur at depths greater than $90 \mathrm{ft}$ elsewhere in the area, but are not shown.

Demonstrated resources of bentonite are estimated at 3 billion tons in an area of substantiated resource potential. The highest quality bentonite beds are in the Cretaceous Bearpaw Shale; impure montmorillonite beds are present in the Cretaceous Fox Hills Sandstone and Hell Creek Formation and the Tertiary Fort Union Formation. Easily accessible bentonite would be limited to relatively small areas on gently sloping valley sides and benches where the overburden to bentonite ratio is favorable.

Most tested samples of the Bearpaw Shale indicate the shale is a possible source of lightweight aggregate, however, large similar deposits exist in adjacent areas. 


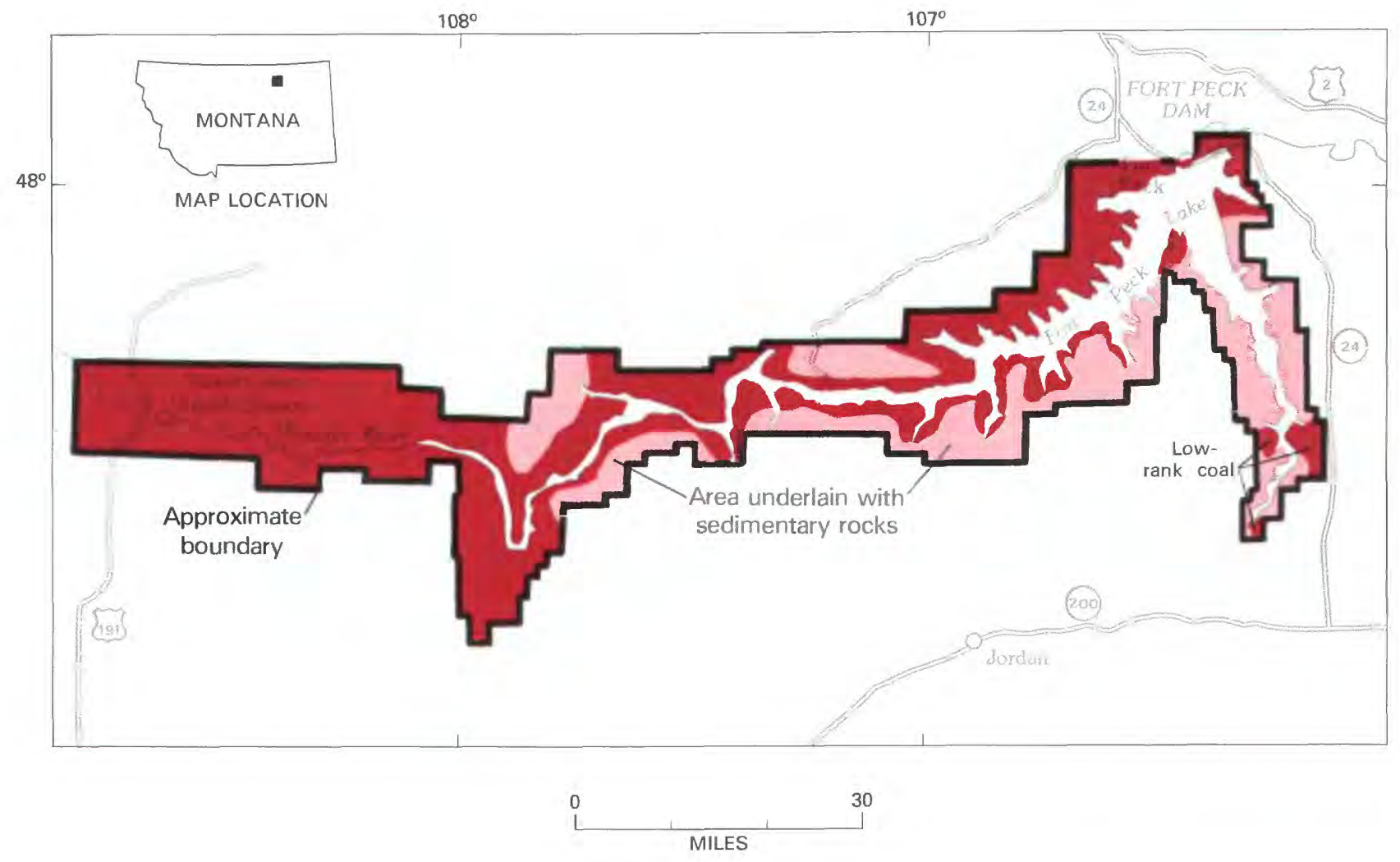

\section{EXPLANATION}

Geologic terrane with probable oil and gas resource potential and substantiated bentonite or low-rank coal resource potential (Areas of low-rank coal labeled)

Geologic terrane with probable oil and gas resource potential

Figure 195.-Charles M. Russell Wildlife Refuge, Montana. 
The entire refuge has a probable potential for oil and gas accumulations. Liquid hydrocarbons (oil) have been generated in Mississippian and older Paleozoic rocks and could have accumulated in the area in predominantly stratigraphic traps locally enhanced by structure. It is not possible to identify oil and gas resources in the area because no exploratory wells have been drilled in the wildlife refuge and no geophysical data are available.

There is also a probable potential for shallow, biogenic gas accumulations in Upper Cretaceous marine shale at depths less than $2000 \mathrm{ft}$. These accumulations would be similar to the Bowdoin field to the north.

\section{SUGGESTIONS FOR FURTHER STUDIES}

Potential hydrocarbon accumulations, including both oil and gas, are difficult to delineate because of the absence of subsurface control points within the refuge. Geophysical surveys and directional drilling along the fringes of the wildlife refuge would aid in refining resource estimates for organic fuels.

\section{REFERENCE}

Frahme, C. W., Rice, D. D., Miller, M. S., Schumacher, O. L., and Rigby, J. G., 1979, Mineral resources of the Charles M. Russell Wildlife Refuge, Fergus, Garfield, McCone, Petroleum, Phillips, and Valley Counties, Montana: U.S. Geological Survey Open-File Report 79-1204, 178 p. 

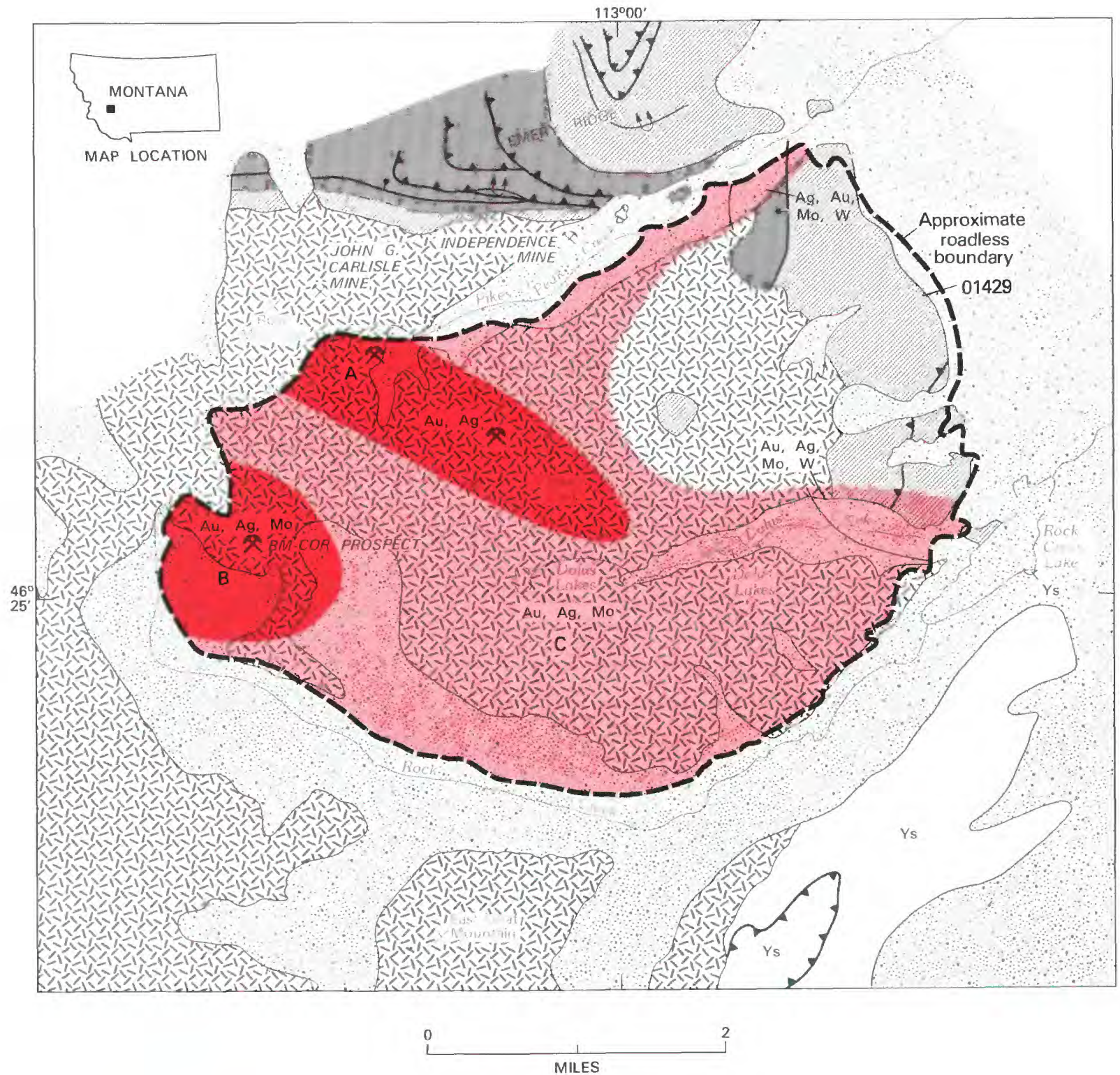

\section{EXPLANATION}

Geologic terrane with substantiated mineral-resource potential

Geologic terrane with probable mineral-resource potential

Au Gold

Mo Molybdenum

Ag Silver

W Tungsten

R Mine or deposit

Mine

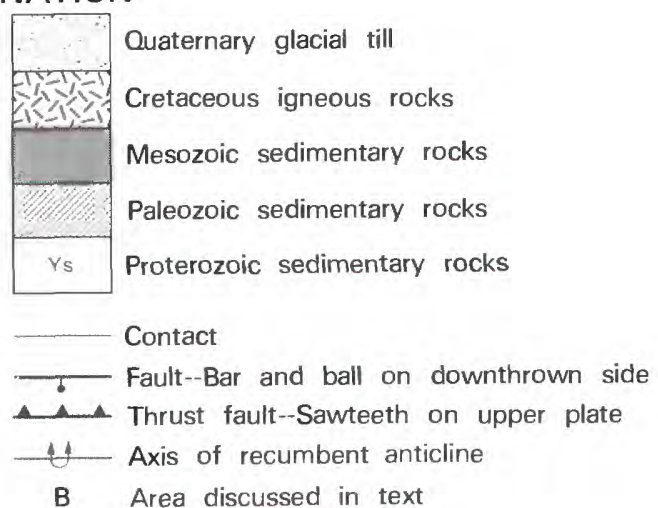

Figure 196,-Dolus Lakes Roadless Area, Montana 


\title{
DOLUS LAKES ROADLESS AREA, MONTANA
}

\author{
By James E. Elliott, U.S. GeOlogical SuRVey, and \\ Dale W. AVery, U.S. BuREAU Of Mines
}

\begin{abstract}
SUMMARY
A mineral survey of the Dolus Lakes Roadless Area in southwestern Montana, was conducted by the USGS and USBM in 1981-82. Much of the roadless area has probable and substantiated potential for resources of gold, silver, molybdenum, and tungsten. The nature of the geologic terrain indictates that there is little promise for the occurrence of coal, oil, gas, or geothermal resources.
\end{abstract}

\section{CHARACTER AND SETTING}

The Dolus Lakes Roadless Area is located in mountainous terrain of southwestern Montana, about $35 \mathrm{mi}$ northwest of Butte and $12 \mathrm{mi}$ west of Deer Lodge. The area is about $14 \mathrm{sq} \mathrm{mi}$ in Powell and Granite Counties and is part of the Deer Lodge National Forest. The roadless area lies adjacent to the Flint Creek Range Wilderness study area and is separated from it by a narrow corridor along Rock Creek, and forms the northeastern part of the Flint Creek Range, an impressive range of mountains on the west side of Deer Lodge valley that can be viewed by the traveler from Interstate 90 between Deer Lodge and Butte. Altitudes in the roadless area range from 6200 to $9359 \mathrm{ft}$. The topography of the roadless area is dominated by a horseshoe-shaped mountain mass, open to the east, that includes Pikes Peak, the highest point in the area. The center of this horseshoe is occupied by a valley containing the eastflowing Dolus Creek and the three Dolus Lakes. Peaks and ridges in the roadless area are above timberline but the lower slopes and stream valleys are tree and brush covered.

The southern part of the roadless area is drained by Rock Creek and the northern part is drained by Pikes Peak Creek. Gravel and dirt roads provide access to the eastern and northern borders of the roadless area and rough jeep trails follow the southern border and provide access to the western boundary.

Biotite granodiorite of the Royal stock is the principal rock type exposed in the roadless area. This pluton, of probable Cretaceous age, is in contact with sedimentary rocks of Paleozoic and Mesozoic age in the eastern part and to the north of the roadless area. To the south, contacts between the Royal stock and granite of the Mount Powell batholith and the stock and Helena Formation, a carbonate sequence of Proterozoic age, are concealed by glacial till in the valley of Rock Creek. Paleozoic sedimentary rocks that are exposed in or adjacent to the roadless area are mostly carbonates with lesser amounts of quartzite, siltstone, and shale that were deposited during the Cambrian, Mississippian, Pennsylvanian, and Permian Periods. Mesozoic rocks of the Jurassic and Cretaceous Periods also occur and consist of sandstone, siltstone, shale, limestone, and conglomerate. In many parts of the roadless area, particularly in valleys and along the mountain front on the east side the igneous and sedimentary rocks are concealed by deposits of glacial till, the product of two stages of glaciation.

The roadless area lies within the Sapphire thrust system, a major structural element of western Montana, in which the sedimentary rocks are strongly deformed by folding and thrust faulting. This deformation occurred during the Cretaceous Period just prior to the intrusion of igneous rocks such as the Royal Stock. Structures typical of this deformation are exposed on Emery Ridge to the north of the roadless area where five thrust faults and a recumbent anticline have been mapped. Thrust faults in the sedimentary section are also exposed in the eastern part and just to the south of the roadless area. A normal fault is also exposed in the east where Jurassic rocks have been faulted down against Mississippian limestone. Prominent jointing accompanied by minor shearing along a northwesterly trend and dipping to the southwest is evident in the Royal stock. 


\section{MINERAL RESOURCES}

The mineral-resource evaluation of the roadless area is based mainly on geologic mapping, a geochemical survey, and investigation of prospects (Elliott and others, in press). Little geophysical work was done; the area is covered by a regional gravity survey $(\mathrm{J}$. H. Hassemer, unpub. data) and an aeromagnetic survey (Douglas, 1973). The geochemical survey of the area consisted of the collection and analysis of rocks, stream sediments, and panned concentrates from stream sediments. A total of 30 mines and prospects were investigated including 22 within the boundaries of the area and 8 located within $1 \mathrm{mi}$ of the roadless area boundary.

The roadless area is situated in one of the richest mineral producing regions of Montana. There are about 15 mining districts in the Flint Creek Range with an aggregate production estimated to be approximately $\$ 120$ million; the richest of these is the Philipsburg district with a production of about $\$ 100$ million. Many of the districts are located in sedimentary rocks near or at contacts with plutonic igneous rocks.

Two districts either overlap or lie close to the northern boundary of the roadless area; these are the Pioneer and Rose Mountain (Gold Creek) districts. The lower section of Gold Creek, a part of the Pioneer district, is credited with having the first discovery of placer gold in Montana, in 1852 by Francois Finlay (Lyden, 1948). The Pioneer district which also includes Pioneer Creek and the lower part of Pikes Peak Creek eventually produced about $\$ 7$ million in gold. Presumably much of the gold occurring in placer deposits in Pikes Peak Creek had its source in veins in the roadless area which were weathered and eroded from a higher level than that presently exposed.

The majority of mines and prospects studied are along the northern border of the roadless area and are part of the Rose Mountain district that extends to the northwest. This district has produced about $\$ 100,000$, about half of which was of gold from placers in the upper sections of Gold Creek. The remainder was from lode deposits, principally narrow gold- and silver-bearing quartz veins. Two mines adjacent to the roadless area, the John G. Carlisle and Independence mines had small production, mostly in gold and silver. The value of production from both was about $\$ 12,500$.

Two areas (A and B, on map) have substantiated mineral-resource potential. Area A includes several prospects and small mines, two of which have 57,000 tons of demonstrated or inferred resources of gold and silver. The deposits are northwesterly trending narrow quartz veins and mineralized shear zones that parallel the principal attitude of joints and minor faults in the granodiorite. The mineralized zones and veins are nar- row and discontinuous. Anomalously high amounts of gold and silver in rock samples and the occurrence of favorable faults and quartz veins indicate substantiated potential for the occurrence of more deposits of the same type. Anomalously high values of molybdenum, copper, tungsten, and bismuth in several rock samples suggests the possible occurrence of stockwork molybdenum deposits at depth in this area.

Area B includes the BM-COR prospect, where drilling in 1976 has indicated the presence of a 6 million ton inferred molybdenum resource in a quartz-pyrite stockwork vein system. The area was held by Houston International Minerals Corporation in 1981 and exploration was continuing. To the southeast and outside of the roadless area, another stockwork molybdenum zone was being investigated in 1981 (Erickson and others, 1981). Area B has substantiated potential for stockwork molybdenum and quartz vein gold-silver deposits based on the occurrence of demonstrated or inferred resources, prospects, favorable geology, and anomalously high amounts of molybdenum, gold, silver, and other metals in rock, stream sediment, and panned concentrate samples from the area.

Based on the occurrence of prospects, geochemical anomalies, and favorable geology, area $\mathrm{C}$ has probable potential for the occurrence of mesothermal gold-silver veins and stockwork molybdenum deposits similar to those in areas A and B. In addition, area C has a probable potential for skarn tungsten resources similar to prospects in Finlay Basin, approximately $4 \mathrm{mi}$ to the southwest of the roadless area, where exploration has identified about 1 million tons of tungsten resources (Erickson and others, 1981). The skarn tungsten deposits are found in the contact zone between the Royal stock and Paleozoic carbonate rocks. A geologic setting very similar to that in Finlay Basin occurs in two parts of area $\mathrm{C}$, at the northeast corner of the roadless area in the valley of Pikes Peak Creek and at the eastern edge along the lower part of Dolus Creek. A favorable contact zone is projected in both these areas but is almost entirely concealed beneath glacial till. One rock sample from near Rock Creek Lake contained anomalous amounts of tungsten and other metals. Area $\mathrm{C}$ also has potential for placer gold deposits along Pikes Peak and Rock Creeks.

\section{SUGGESTIONS FOR FURTHER STUDIES}

Detailed geologic and geochemical studies are suggested for areas A and B to delineate exploration targets that could be tested by drilling. In area C, drilling is suggested to test for skarn tungsten deposits at contacts between granodiorite and carbonate rocks where these contacts are concealed beneath glacial till. 


\section{REFERENCES}

Douglas, J. K., 1973, Geophysical investigations of the Montana Lineament: University of Montana, unpublished M.S. thesis.

Elliott, J. E., Waters, M. R., Campbell, W. L., and Avery, D. W., in press, Geologic and mineral resource potential map of the Dolus Lakes Roadless Area, Granite and Powell Counties, Montana: U.S. Geological Survey Miscellaneous Field Studies Map MF-1640-A.
Erickson, G. E., Leinz, R. W., and Marks, L. Y., 1981, Mineral resources of the Flint Creek Range Wilderness study area, Granite and Powell Counties, Montana: U.S. Geological Survey Open-File Report 81-1095, 6 p.

Lyden, C. J., 1948, The gold placers of Montana: Montana Bureau of Mines and Geology Memoir 26, 152 p. 

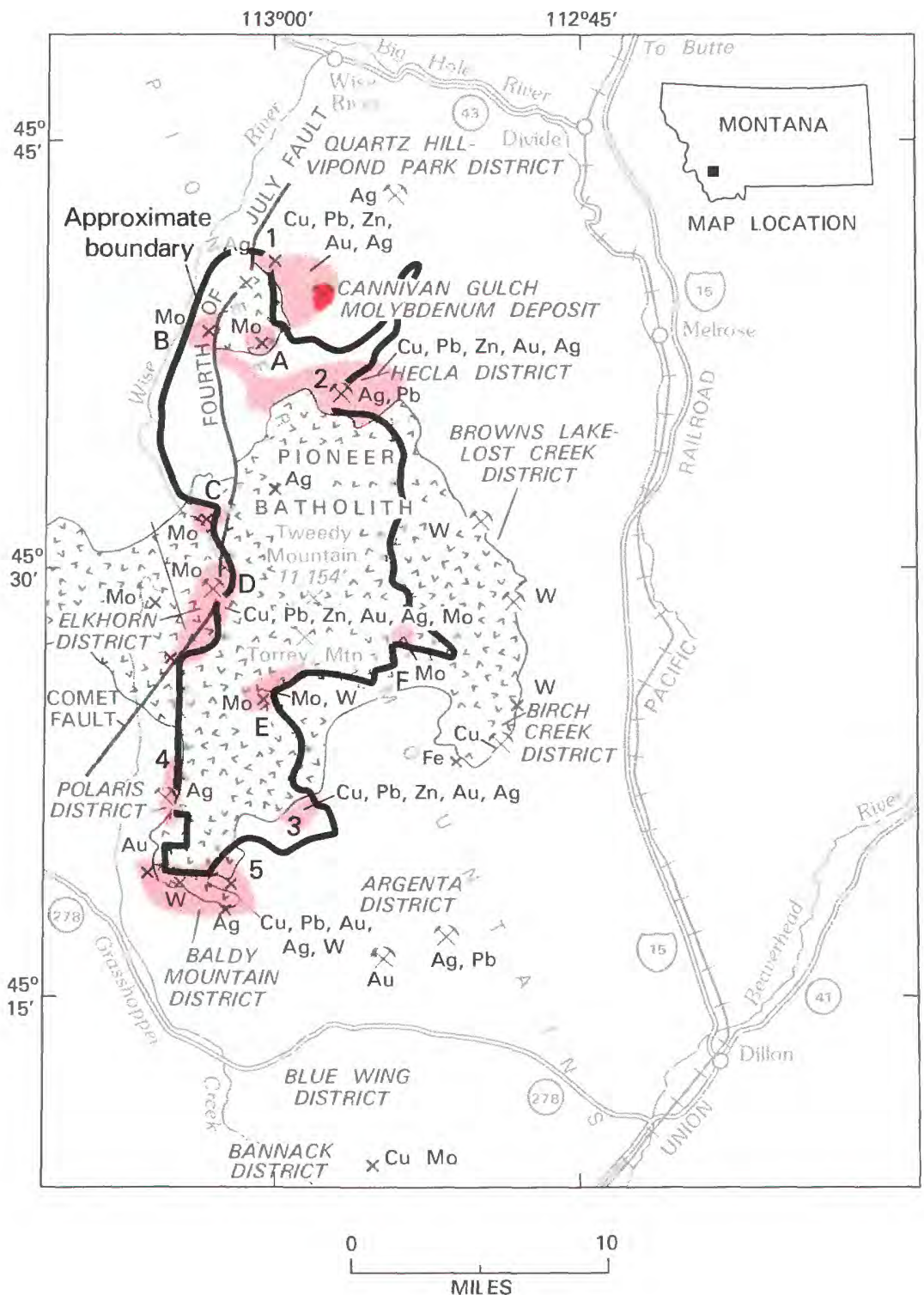

\begin{tabular}{|c|c|c|c|}
\hline & $\begin{array}{l}\text { Geologic terrane with substantiated } \\
\text { mineral-resource potential }\end{array}$ & 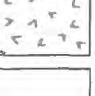 & $\begin{array}{l}\text { Intrusive igneous rocks (Shown only } \\
\text { in and near roadless area) }\end{array}$ \\
\hline & Geologic terrane with probable & & Sedimentary rocks \\
\hline $\mathrm{Cu}$ & Copper & & Contact \\
\hline Au & Gold & - & Fault \\
\hline $\mathrm{Pb}$ & Lead & & \\
\hline Mo & Molybdenum & 2 & Location discussed in text \\
\hline $\mathrm{Ag}$ & Silver & & \\
\hline w & Tungsten & & \\
\hline $\mathrm{Zn}$ & Zinc & & \\
\hline$x$ & Mineral occurrence & & \\
\hline 父 & Mine & & \\
\hline
\end{tabular}

Figure 197.-Eastern Pioneer Mountains, Montana. 


\title{
EASTERN PIONEER MOUNTAINS, MONTANA
}

\author{
By Robert C. PEarson, ${ }^{1}$ U.S. GeOlogical Survey
}

\begin{abstract}
SUMMARY
Eight mining districts and numerous individual mines ring the eastern Pioneer Mountains, Beaverhead County, Montana, and are within $4 \mathrm{mi}$ of the boundary of the eastern Pioneer area. Mineralized ground peripheral to these districts extends into the area at several places. Three of 12 molybdenum prospects in the Pioneer Mountains are within the eastern Pioneer area. Several areas of Paleozoic carbonate rocks are mineralized or favorably situated with respect to the Pioneer batholith. All such areas have probable resource potential. Interest in exploration for molybdenum and possibly for base and precious metals is likely to continue.
\end{abstract}

\section{CHARACTER AND SETTING}

The Pioneer Mountains in southwestern Montana are a subcircular mountain mass almost completely surrounded by broad alluviated valleys of the Big Hole and Beaverhead Rivers. The structurally controlled valleys of Wise River and Grasshopper Creek divide the Pioneer Mountains into two lobes. The eastern lobe contains the area studied, here termed the eastern Pioneer area, which is the more rugged and contains high peaks and deep valleys. The area is located about $25 \mathrm{mi}$ southwest of Butte and $20 \mathrm{mi}$ northwest of Dillon. It is $4-8 \mathrm{mi}$ wide, $25 \mathrm{mi}$ long, (approximately $150 \mathrm{sq} \mathrm{mi}$ ) and is elongated northerly. The area is drained radially by glacially eroded stream valleys.

The eastern Pioneer area is within that part of the overthrust belt of southwest Montana in which numerous bodies of Mesozoic igneous rocks were intruded into folded and faulted sedimentary rocks. During folding and faulting, a great sheet of old Proterozoic quartzite was thrust eastward over complexly folded younger (Paleozoic and Mesozoic) strata. One of the larger of the intrusive masses-the Late Cretaceous Pioneer batholith-occupies most of the area; it and associated satellitic intrusive masses are the foci of the widespread mineralization. Volcanism accompanied the intrusion of the batholith, though no volcanic rocks of this age remain uneroded within the area. Minor volcanism continued sporadically for the next several tens of millions

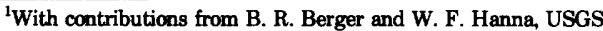

of years, but only small remnants of these younger lava flows remain.

Interpretations of the mineral-resource potential have been assisted by geochemical and geophysical studies. Stream-sediment and rock-chip samplings have shown that many parts of the area are anomalous in base metals, precious metals, and molybdenum, as well as "pathfinder" elements (easily detected mobile elements associated with mineralization) such as antimony, arsenic, tungsten, bismuth, and tin. Aeromagnetic surveys outline the plutonic rocks, give a clue to the subsurface configurations of the plutons, and show a response locally to hydrothermal iron oxide.

The eastern Pioneer Mountains figure prominantly in the mining history of Montana. The Bannack district, a few miles south of the area, was the first significant mining district in what is now the State of Montana. After the discovery of gold near Bannack in 1862, the several other base- and precious-metal districts in the eastern Pioneer Mountains were discovered in the 1860 's and 1870's. Gold, silver, and lead were the principal products in the early years, but tungsten, produced from mines at the southern boundary and a few miles east of the study area, became important in the 1950's. Thus, the area has a rich and varied mining history. With the discovery of molybdenum in the 1960's, renewed interest in mineral exploration developed in the Pioneer Mountains.

The most productive district in the eastern Pioneer Mountains is the Hecla district along the northeast edge of the roadless area. Some of the most productive mines of the Hecla district extend below the surface of the eastern Pioneer area. 


\section{MINERAL RESOURCES}

Recent exploration activity in the Pioneer Mountains has concentrated on a search for molybdenum as a result of the impetus provided by the discovery of the Cannivan Gulch deposit, located 2 mi outside the study area. Base and precious metals have also been searched for principally in the formerly productive districts. The productive tungsten mines east of the area, which are being actively explored and contain substantial new reserves, are in a geologic formation that is unlikely to be found in the area.

Structural trends, favorable host rocks, and associated intrusive rocks suggest that mineralized rock in the peripheral mining districts may continue into the study area although surface indications of such extentions are meager. The following areas (on map) are interpreted as having probable mineral-resource potential for base and precious metals, molybdenum, and tungsten:

The Quartz Hill-Vipond Park base- and precious-metal district (area 1) north of the area trends north-northeast and is composed of numerous north-northeast-trending veins. A projection of this district to the southwest includes the Blue Bell mine, just outside the area, and the Atlas mine within the area. Both mines are in carbonate sedimentary rocks adjacent to a body of granite although the favorable contact zone is largely covered by glacial deposits. The granite locally contains pyrite near the contact.

The Hecla district (area 2) produced silver, lead, gold, copper, and zinc from mines, the largest of which extend from surface openings outside the eastern Pioneer area westward into the area in the subsurface and thus represent the principal mining activity that has taken place within the area. The folded and fractured carbonate sedimentary rocks that are favorable hosts for ore at Hecla continue westward for $4 \mathrm{mi}$ in a belt about 1 mile wide adjacent to the north edge of the Pioneer batholith. Farther west, the favorable rocks become buried progressively more deeply beneath a thrust sheet of less favorable rocks; they also become farther away from the batholith and farther from the mineralizing center at Hecla. Thus, the potential for the occurrence of resources is greatest in the Hecla district and decreases from east to west across the area.

Near the southeast corner of the area, the same or a similar sequence of favorable carbonate sedimentary rocks is inferred to be in contact with the Pioneer batholith and to occupy more than 1 sq mi (area 3). The contact itself and virtually all these sedimentary rocks are covered by glacial deposits. The presence of geochemical anomalies and of favorable rocks and their relationship to the batholith are sufficient reasons to infer probable resource potential for copper, lead, zinc, gold, and silver.

692
Mineral production from the Polaris district (area 4) has been chiefly of silver from the Polaris mine. The deposit is in veins in carbonate sedimentary rock similar to, if not stratigraphically the same as, those in other nearby districts. A narrow belt of these favorable rocks within the eastern Pioneer area has a probable mineralresource potential for silver although surface evidence of mineralization is sparse.

The Baldy Mountain district (area 5) at the southern tip of the area contains numerous mines that produced small amounts of base- and precious-metal and tungsten ores from deposits in carbonate rocks adjacent to the Pioneer batholith and in veins within the batholith. The area has a probable resource potential for additional deposits of base and precious metals and tungsten.

Six areas contain molybdenum prospects that are considered to have probable mineral-resource potential. A quartz-vein stockwork in granite at Black Lion Lake (area A, on map) contains molybdenite and ferrimolybdite in outcrop. It was explored by drilling in 1977 and 1982. This appears to be the most significant prospect in the area. A quartz-vein stockwork in Precambrian quartzite on Moose Creek (area B) is separated from granite by the Fourth of July fault. This prospect is poorly exposed but seems to occupy an area at least $2000 \mathrm{ft}$ long and an unknown width. A quartz-vein stockwork along the Comet fault in Jacobson Meadows (area C) contains molybdenite locally in outcrop. It extends into the roadless area and is partly covered by glacial deposits. Molybdenite-bearing veins at deep levels in the Elkhorn mine within the Elkhorn district (area D) indicate metal zoning from silver, lead, zinc, tungsten at the surface to molybdenum, $1000 \mathrm{ft}$ below. This zoning indicates a probable mineral-resource potential for molybdenum beneath the Elkhorn district that extends eastward barely into the area. The district and nearby areas also have probable potential for silver and base metals in veins. Molybdenum and tungsten in quartz and quartz-muscovite veins in granite near Pear Lake (area E) extends in a northeast-trending belt to the lower slopes of Torrey Mountain. The presence of a breccia pipe suggests the possibility of deep mineralization. A body of weakly mineralized intrusion breccia within the Pioneer batholith along Dubois Creek (area F) is about $0.5 \mathrm{mi}$ in diameter and contains some geochemical anomalies for molybdenum.

\section{SUGGESTIONS FOR FURTHER STUDIES}

Detailed studies of structural and stratigraphic controls of ore deposition and its association with intrusive rocks of particular types and ages may be useful in providing the basis for a more precise resource assessment. 


\section{REFERENCES}

Berger, B. R., Breit, G. N., Siems, D. F., Welsch, E. P., and Speckman, W. S., 1979, A geochemical survey of mineral deposits and stream deposits in the East Pioneer Wilderness Study Area, Beaverhead County, Montana: U.S. Geological Survey Open-File Report 79-1079, 128 p.

Pearson, R. C., Berger, B. R., and Hanna, W. F., 1983, Mineral resources of the Eastern Pioneer Mountains, Beaverhead County, Montana: U.S. Geological Survey Open-File Report 83-507. 

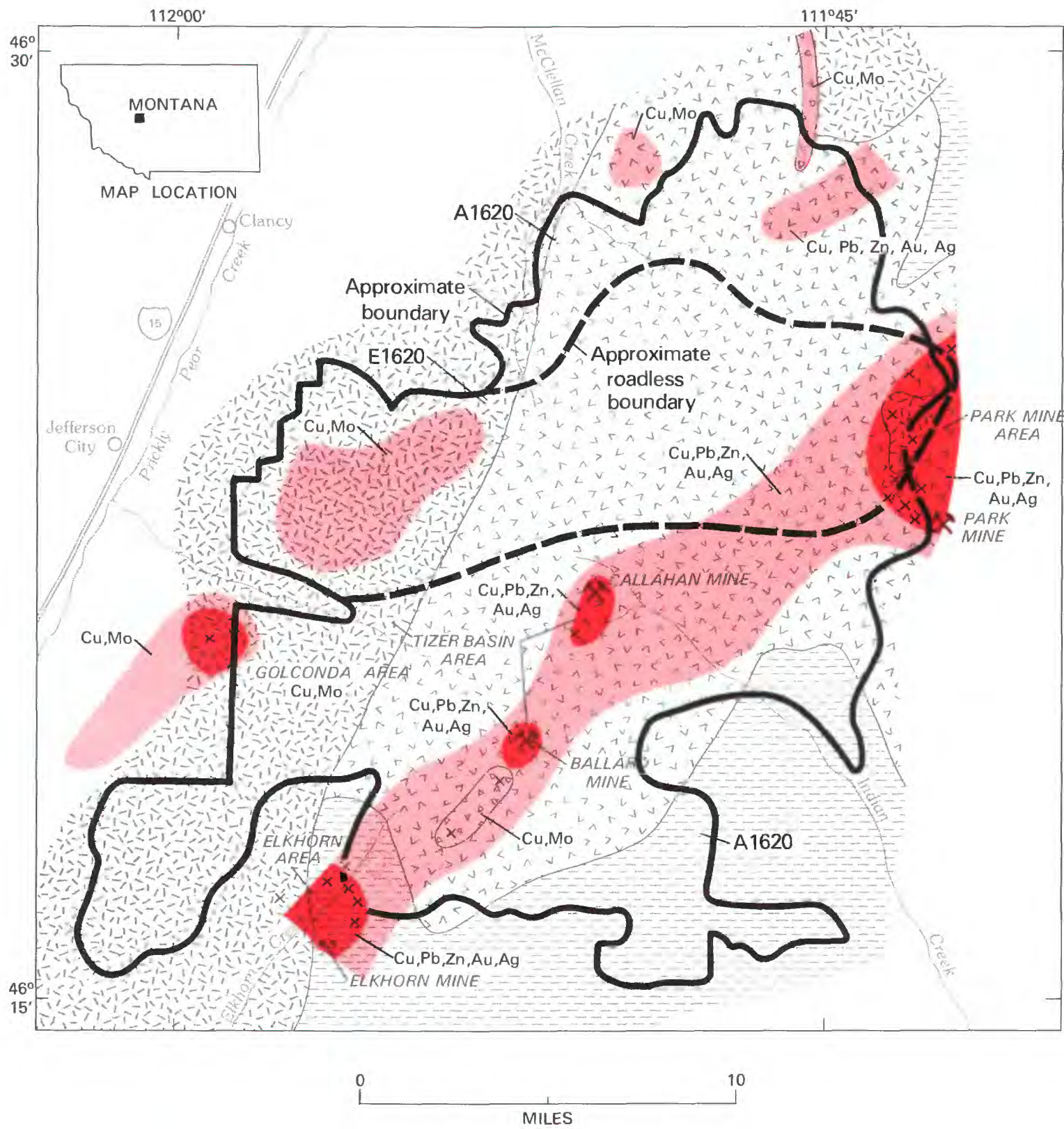

\section{EXPLANATION}

Geologic terrane with substantiated mineral-resource potential

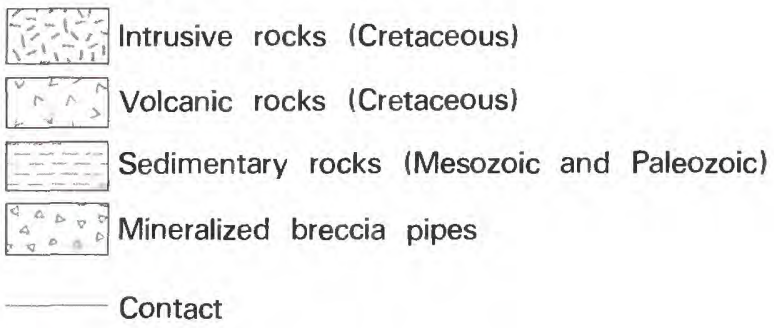

Geologic terrane with probable mineral-resource potential

$\begin{array}{llll}\mathrm{Cu} & \text { Copper } & \mathrm{Mo} & \text { Molybdenum } \\ \mathrm{Au} & \text { Gold } & \mathrm{Ag} & \text { Silver } \\ \mathrm{Pb} & \text { Lead } & \mathrm{Zn} & \text { Zinc }\end{array}$

M Mine or deposit Contact

$\times \quad$ Mineral occurrence

Figure 198.-Elkhorn Wilderness Study Area, Montana. 


\title{
ELKHORN WILDERNESS STUDY AREA, MONTANA
}

\author{
By W. R. GREENWOOD, ${ }^{1}$ U.S. GeOlOGiCAl SuRveY, and \\ TERRY J. Close, U.S. BUREAU OF MineS
}

\begin{abstract}
SUMMARY
The Elkhorn Wilderness study area, near Helena, Montana, was studied by the USGS and the USBM in 1976 and 1977. Substantiated resource potential for gold, silver, copper, lead, zinc, and iron was identified in three areas and a copper-molybdenum porphyry deposit exists in a fourth area of substantiated resource potential. Several broad areas with probable mineral-resource potential for all the above metals except iron were also identified.
\end{abstract}

\section{CHARACTER AND SETTING}

The Elkhorn Wilderness study area occupies an area of about $128 \mathrm{sq} \mathrm{mi}$ in a mountainous region to the southeast of Helena, Montana. Access is by secondary roads leading from Interstate 15 on the west, Montana State Highway 281 on the south, and U.S. Highways 12 and 287 on the north and east.

The area is underlain primarily by the Elkhorn Mountains Volcanics, and by the Boulder batholith and related stocks, all of which are Cretaceous in age. Older rocks, ranging in age from Mesozoic to Precambrian (Belt Supergroup), underlie the volcanics in nearby areas and are presumed to be present at depth beneath much of the study area. Because parts of the volcanic sequence consist of thick sections of welded ash-flow tuff, the study area probably contains a volcanotectonic depression, or caldera.

The mountain range containing the study area is a tectonically uplifted block, bounded on the east and north, and probably on the south and west, by major faults. This block has been eroded to its present form by glaciers and running water.

\section{MINERAL RESOURCES}

Three areas, in and immediately contiguous to the study area, have substantiated mineral potential for gold and (or) silver, copper, lead, and zinc. From northeast to southwest, they are the Park mine area, the Tizer Basin area, and the Elkhorn area.
Within the Park mine area, numerous mines and prospects have demonstrated resources of about $33,000 \mathrm{oz}$ of gold, $370,000 \mathrm{oz}$ of silver, 400 tons of copper, and 2000 tons of lead. However, this estimate does not include three large deposits which were not studied and are a few hundred feet beyond the study area boundary. There are also many other prospects on base- and precious-metal veins which are not exposed and thus it was not feasible to sample them. Heavy-mineral concentrate samples from this area are anomalous in base and precious metals and the area is shown as having substantiated resource potential.

Two areas of substantiated resource potential occur in the Tizer Basin area around the Ballard and Callahan mines. Deposits in these areas are estimated to contain demonstrated resources of about $1500 \mathrm{oz}$ of gold. This estimate does not include two deposits for which lack of access and exposure prevent a meaningful estimate. The Ballard and Callahan mines in this area have produced nearly $9000 \mathrm{oz}$ of gold and $15,000 \mathrm{oz}$ of silver.

In the Elkhorn area, production from mines within the study area boundary totals more than $10,000 \mathrm{oz}$ of silver. Many prospects appear to be in replacement deposits similar to the Elkhorn mine, a major silver producer which is about $2000 \mathrm{ft}$ beyond the study area boundary. No resources were estimated for the Elkhorn area because of the lack of exposure of mineralized rock and because the Elkhorn mine was not studied. In addition to silver and base metals, iron has been produced from a small skarn deposit in this area.

These three areas all lie within an elongate region which is judged to have probable resource potential for further discoveries of base and precious metals on the basis of scattered small mines, prospects, and heavymineral concentrate geochemical anomalies. 
The Golconda area has substantiated resource potential for copper and molybdenum. On the basis of surface studies of alteration and mineralization, it contains a copper-molybdenum porphyry deposit. Though it has been drilled and explored by a major minerals company, the deposit has not been developed.

Several other areas along the western edge of the study area have probable potential for the same type of deposit, and are characterized by scattered mineralization and by heavy-mineral concentrate geochemical anomalies similar to those in the Golconda area.

Two areas with mineralized breccia pipes, possibly related to the rim of a large volcano-tectonic subsidence structure, have probable mineral potential for buried copper and (or) molybdenum porphyry deposits.

\section{SUGGESTIONS FOR FURTHER STUDIES}

Detailed studies aimed at identification of the source rocks for the Golconda deposit would be useful in further understanding of the potential for coppermolybdenum porphyry deposits in the region. The significance of the breccia pipes could be clarified by deep drilling. A detailed stratigraphic study of the volcanics, which would better delineate the probable caldera, would also be helpful in understanding the overall setting of the ore deposits of the region.

\section{REFERENCE}

U.S. Geological Survey and U.S. Bureau of Mines, 1978, Mineral resources of the Elkhorn Wilderness study area, Montana: U.S. Geological Survey Open-File Report 78-235, 342 p. 


\title{
FLINT CREEK RANGE WILDERNESS STUDY AREA, MONTANA
}

\author{
By George E. Ericksen, U.S. Geological Survey, and \\ LAWRENCE Y. MARKS, U.S. BUREAU OF MineS
}

\begin{abstract}
SUMMARY
A mineral survey of the Flint Creek Range Wilderness study area, carried out in 1975 with supplemental studies in 1980 and 1981, shows the presence of mineral deposits. By far the most important are low-grade, potentially large, contact-metamorphic tungsten deposits along the contact of the Royal stock of the Finley Basin-Thompson Lake areas. These deposits, were discovered and explored by Union Carbide Corporation during the 1970's. A large stockwork molybdenum deposit at East Goat Mountain is probably low in grade. The areas of these tungsten and molybdenum deposits have substantiated mineralresource potential. A multimillion ton phosphate-rock deposit occurs in an area of substantiated resource potential in the Permian Phosphoria Formation in the south-central part of the study area. Deposits of massive quartz, perhaps suitable for smelter flux, are on the northeastern side of Deer Lodge Mountain and are a demonstrated resource. Small scattered silver- and gold-bearing veins are present, but no resource potential was identified.
\end{abstract}

\section{CHARACTER AND SETTING}

The Flint Creek Wilderness study area extends over an area of $82 \mathrm{sq} \mathrm{mi}$ in the central part of the Flint Creek Range, central western Montana. The range is a domelike, deeply dissected, glaciated uplift showing typical radial drainage and marked by moderately rugged topography. It has many U-shaped glacial valleys and steep-sided cirque basins in which are many small glacial lakes. The highest peak in the Flint Creek Range, Mount Powell $(10,168 \mathrm{ft})$, is in the eastern part of the study area. The area is accessible from Interstate Highway 90 in the Deer Lodge valley to the east and U.S. Highway $10 \mathrm{~A}$ in the Philipsburg valley to the west. The principal nearby towns are Philipsburg, Deer Lodge, and Anaconda. Mines in the vicinity of Philipsburg are famous for their production of rich silver ores during the latter part of the 19th century. The city of Butte, the center of one of the richest mining districts of the world, is about $20 \mathrm{mi}$ southeast of Anaconda.

The dominant rocks of the central Flint Creek Range are three small plutons of Late Cretaceous to early Tertiary age that intrude a sequence of intensely folded and faulted sedimentary rocks of late Precambrian (Late Proterozoic) to Cretaceous age. The three plutons have been dated radiometrically by the potassium-argon method as being $77 \mathrm{~m} . \mathrm{y}$. (million years) to $56 \mathrm{~m} . \mathrm{y}$. old, the Philipsburg batholith being oldest, the Royal stock being of intermediate age, and the Mount Powell batholith being youngest. The plutons were injected forcefully, causing some deformation and widespread thermal metamorphism of the enclosing sedimentary rocks. The plutons also were the sources of the mineralizing fluids that formed most of the mineral deposits in the central Flint Creek Range.

Investigations of the study area included geologic mapping, geochemical sampling, study and sampling of known mineral deposits, search of courthouse records for mining claims, and field search for recorded claims. An aeromagnetic map was prepared from published maps. Results of these investigations and subsequent laboratory determinations are presented in a report by Ericksen and others (1981), which is the source of information for this summary report.

\section{MINERAL RESOURCES}

Mines in the Flint Creek Range have produced silver, gold, manganese oxide, lead, zinc, copper, iron ore, and phosphate rock. With the possible exception of a small amount of silver and gold, none of this production came 


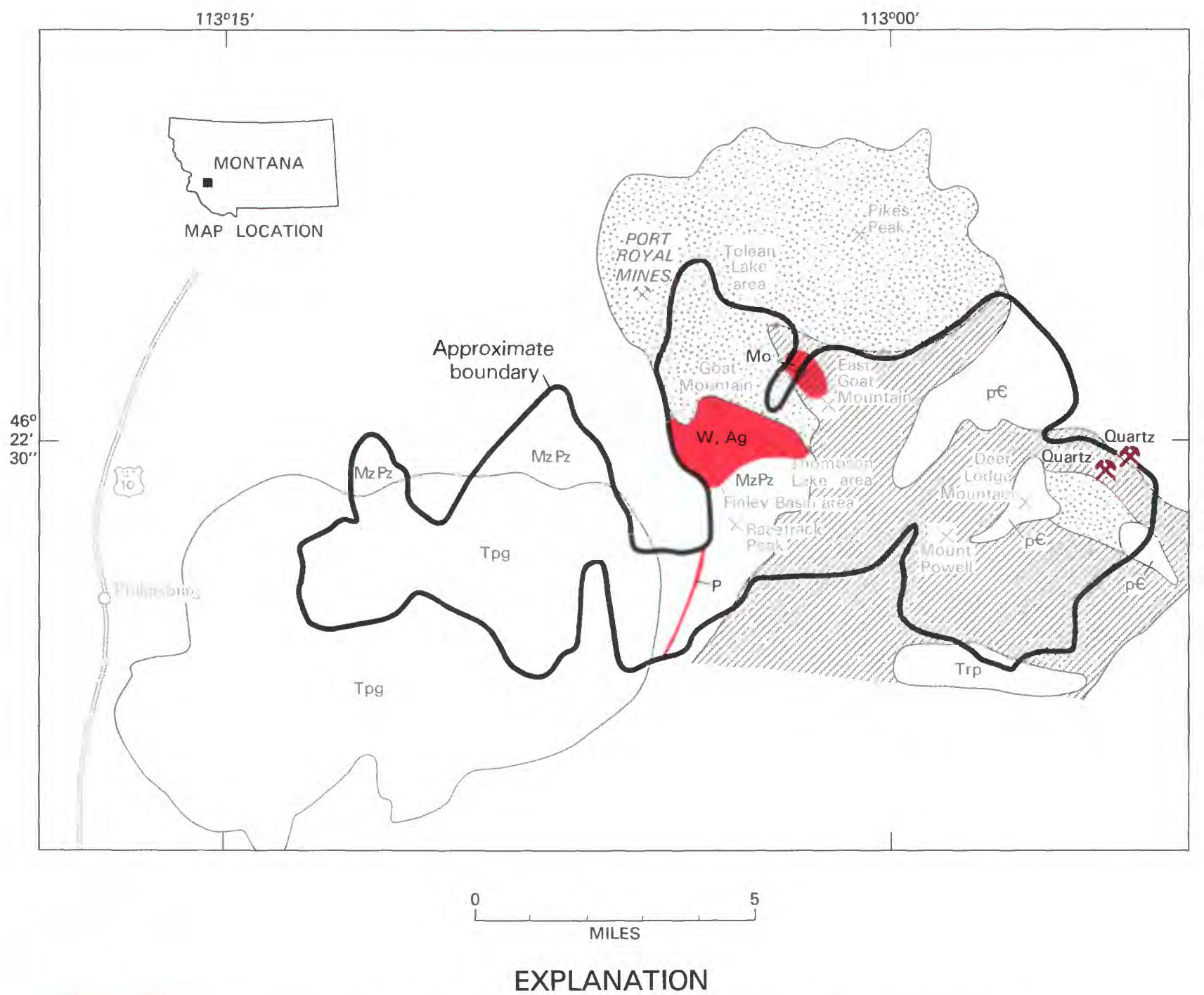

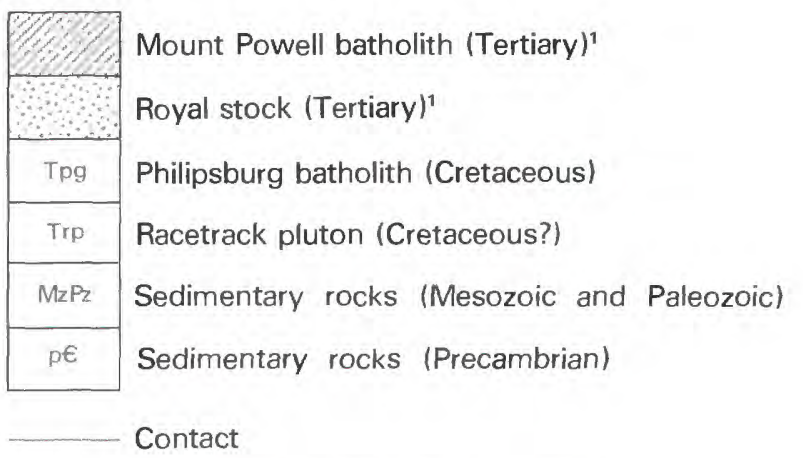

'Tertiary units of same general age

Figure 199.-Flint Creek Range Wilderness study area, Montana. 
from within the wilderness study area. It has been estimated that production from mines in the Philipsburg quadrangle, which includes nearly all the major mines in the Flint Creek Range, totaled about $\$ 60$ million between 1864 and 1954. Of this production, $88,500 \mathrm{oz}$ was gold and $21,200,000 \mathrm{oz}$ silver; copper, lead, iron ore, and manganese oxide were also produced. Silver-rich ore produced from the Philipsburg district during the period 1904-1962 had an estimated total value of nearly $\$ 30$ million, again, chiefly silver. The district has been a major producer of battery-grade manganese oxide, and 450,000 tons of concentrates of 65-72 percent $\mathrm{MnO}_{2}$ were shipped during the period 1921-1962. An additional 260,000 tons of manganese ore was shipped for metallurgical use during the period 1916-1921. Placer gold from the Flint Creek Range had an estimated total value of about $\$ 2$ million. However, total production of placer gold from chiefly outside the Flint Creek Range, was estimated to have been $\$ 7 \mathrm{mil}-$ lion for the period 1860-1945.

Production from other mines near the study area has been much smaller than that of mines in the Philipsburg district. To judge from descriptions by Emmons and Calkins (1913), and the size of workings as can be seen today, the dozen or so small mines and placers that are within a mile or two of the study area have yielded silver, gold, and small amounts of byproduct lead, zinc, and copper having a total value of less than $\$ 1.5$ million. By far the most important were the Port Royal mines which produced about $\$ 1$ million in gold, chiefly during the late 1890's. Small mines and placers accounted for most of the remaining production from near the study area.

No records exist of mineral production from within the study area, but small amounts of rich silver ore presumably were recovered from workings at Thompson Lake and Goat Mountain.

From the mid-1960's to the early 1980's four companies undertook mineral exploration in the Flint Creek Wilderness study area. Cominco American, Inc., opened bulldozer trenches and pits to explore for phosphate rock in the Phosphoria Formation in the south-central part of the study area. The Union Carbide Corporation discovered tungsten in the Finley Basin area in the early 1970's during a geochemical exploration program, and did core drilling in this area and in the Thompson Lake area from 1975 to 1980 . AMAX Exploration, Inc., discovered molybdenum in 1974 , also by geochemical sampling, and did core drilling north of the study area in the Tolean Lake area in 1976 and 1977. Noranda Exploration, Inc., did core drilling for molybdenum in the East Goat Mountain area in 1979 and 1980.

The exploration for tungsten in the Finley Basin area has identified about 1 million tons of demonstrated tungsten resources in tactite along the contact of the
Royal stock and additional resources have been identified in a similar tactite zone in the Thompson Lake area. The geologic terrane including these prospects is an area of substantiated tungsten potential.

The molybdenum occurrences in the East Goat Mountain area probably contain large tonnages of molybdenum-bearing rock. The grades of material encountered in four core-drill holes at East Goat Mountain, by Noranda Exploration, Inc., are not known, but ore-grade material was evidently not encountered because this company abandoned its claims in this area in 1982.

The molybdenum occurrences consist of stockworks of molybdenum-bearing quartz veinlets and sparse quartz veins a few inches to several feet thick in the Mount Powell batholith at East Goat Mountain. To judge from surface exposures, the grades of molybdenum-bearing rock at East Goat Mountain are low although the area is one of substantiated molybdenum resource potential.

Cominco American, Inc., found that an area of substantiated phosphate resource potential extends for about $10,000 \mathrm{ft}$ along the strike length of the Phosphoria Formation in the south-central part of the study area. Samples collected by Cominco from its pits and trenches show an average thickness of the phosphate rock layer to be $5.9 \mathrm{ft}$ and grade to be 20 percent $\mathrm{P}_{2} \mathrm{O}_{5}$. Core drilling would be required to determine the total phosphate resources in this area, but the sedimentary rocks in this area are in a roof pendant over the contact zone between the Philipsburg and Mount Powell batholiths, which lies at a depth of not more than $2000 \mathrm{ft}$ below the surface. It can be estimated that resources of phosphate rock here are not more than 10 million tons, and could be less because of intense folding and faulting of the sedimentary sequence.

Small amounts of silver resources may exist in scattered veins in the study area. To judge from samples on mine dumps, silver is associated with sulfide minerals of copper, lead, and zinc in quartz veins. Veins from which these samples came generally have maximum dimensions of only a few feet thick and a few hundred feet in length. Specimens collected in this study commonly show silver values of only a few ounces per ton, but some show $10 \mathrm{oz} /$ ton or more, and the richest sample, from a vein near the top of Goat Mountain, contains $30.7 \mathrm{oz} / \mathrm{ton}$. It is evident that the silver in veins of the study area occurs sporadically in small shoots in the otherwise barren or nearly barren veins. Other than the area of substantiated silver resource potential at Goat Mountain these small and isolated occurrances are not shown on the map and no resource potential was identified for the areas in which they occur.

Irregular bodies of massive quartz were prospected at two localities on the northeastern side of Deer Lodge 
Mountain. Chemical analyses of chip samples of quartz from these localities show values of 90.5 to 97.2 percent $\mathrm{SiO}_{2}$ and 1.7 to 2.7 percent iron. The deposits are estimated to contain demonstrated silica resources of nearly 2 million tons of quartz, which may be suitable for smelter flux. No resource potential for coal, oil, gas, uranium, or geothermal energy was identified in this study.

\section{SUGGESTIONS FOR FURTHER STUDIES}

Future mineral-resource studies in the Flint Creek Range Wilderness study area would be concerned chiefly with determining the extent and grade of mineral deposits already known to exist. Such studies would include core drilling to determine the resources of tungsten ore in the Finley Basin-Thompson Lake area, and to determine the tonnage and grade of phospate rock in the south-central part of the area.

\section{REFERENCES}

Emmons, W. H., and Calkins, F. C., 1913, Geology and ore deposits of the Philipsburg quadrangle, Montana: U.S. Geological Survey Professional Paper 78, 271 p.

Ericksen, G. E., Leinz, R. W., and Marks, L. Y., 1981, Mineral resources of the Flint Creek Range Wilderness study area, Granite and Powell Counties, Montana: U.S. Geological Survey Open-File Report 81-1095, 6 p. 


\title{
GALLATIN DIVIDE ROADLESS AREA, MONTANA
}

\author{
By Frank S. Simons ${ }^{1}$, U.S. GeOlogical SurVey, and \\ TERry J. Glose, U.S. Bureau of Mines
}

\section{SUMMARY}

A mineral-resource survey of the Gallatin Divide Roadless Area in the Gallatin Range of southwestern Montana was made in 1978-80. The area has probable and substantiated mineral-resource potential for phosphate rock, but most of the phosphate beds are thin, discontinuous, low grade, and deeply buried. Petrified wood is abundant but is scattered and of poor quality. Oil and gas resources are unlikely because possible productive structures are small and deeply eroded. The roadless area has little promise for the occurrence of other mineral or energy resources.

\section{CHARACTER AND SETTING}

The Gallatin Divide Roadless Area is in southwestern Montana just north of the northwest corner of Yellowstone National Park. It extends northeast along the crest of the Gallatin Range for about $35 \mathrm{mi}$ and covers an area of about $242 \mathrm{sq} \mathrm{mi}$. The Gallatin Range lies between the Yellowstone River to the east and the Gallatin River to the west. Access to the area is provided by U.S. Highway 191 along the Gallatin River and U.S. Highway 89 along the Yellowstone River. Unimproved roads extend up all the main canyons but access to the area itself is limited to foot and stock trails.

The entire roadless area except for the lowermost parts of Fridley and Big Creeks is above $6000 \mathrm{ft}$; the highest altitude, 10,333 ft, is shared by Mt. Bole and Mt. Chisholm in the northern part of the roadless area. Both flanks of the Gallatin Range are incised by deep steep-walled canyons, many of which head in small glacial cirques. Evidences of glaciation-cirques, rockbasin lakes, U-shaped valleys, and glacial deposits-are found throughout the area. Among the scenic attractions of the area-jagged alpine peaks in the northern part, grass-carpeted glacial basins and small lakes in the headwaters of many streams, and a striking plateau as much as $1 \mathrm{mi}$ wide along much of the range crest-only a few peaks can be seen from any road.

The Gallatin Range is geologically part of a Tertiary structural block that also includes the Madison Range

\footnotetext{
${ }^{3}$ With contributions from Richard E. Van Loenen, Samuel L. Moore, William F. Hanna, and Harold E. Kaufmann, USGS, and J. Douglas Causey, Spencee L. Willett, and Clayton M. Rumsey, USBM.
}

to the west. The two ranges are separated geographically but not geologically by the Gallatin River. The Gallatin-Madison block consists of a basement of Precambrian metamorphic rocks $3000-4000 \mathrm{ft}$ thick and a sequence of dominantly clastic Mesozoic sedimentary rocks, mainly Cretaceous, perhaps $10,000 \mathrm{ft}$ or more thick. Volcanic rocks mostly of Eocene age are widespread in the Gallatin Range and underlie nearly 75 percent of the roadless area.

Prevolcanic rocks of the Gallatin-Madison block were folded and faulted along northerly and northwesterly trends during Laramide deformation. The principal structures formed at this time in the Gallatin Range in or near the roadless area are the west-northwesterly trending Squaw Creek fault, which dips steeply and has a displacement of at least $4500 \mathrm{ft}$, and the northwesterly trending Spanish Peaks fault, which dips steeply northeast and has a minimum displacement of $10,000 \mathrm{ft}$. The uplifted rocks were then eroded and in Eocene time were buried by lava flows and volcaniclastic rocks of the Absaroka volcanic field. The Gallatin-Madison block subsequently was tilted gently southeastward during late Cenozoic uplift of the block along a range-front fault that defined the west flank of the Madison Range. The present topography of the Gallatin Range resulted from erosion by water and ice following tilting.

The geology of the area was mapped by the USGS in 1978-80. Geochemical evaluation of the Gallatin Divide Roadless Area is based on stream-sediment samples, rock samples, and panned concentrates of stream sediments collected by the USGS and the Los Alamos Scientific Laboratory. Phosphate rock was sampled at four localities by the USBM and petrified wood was cut 

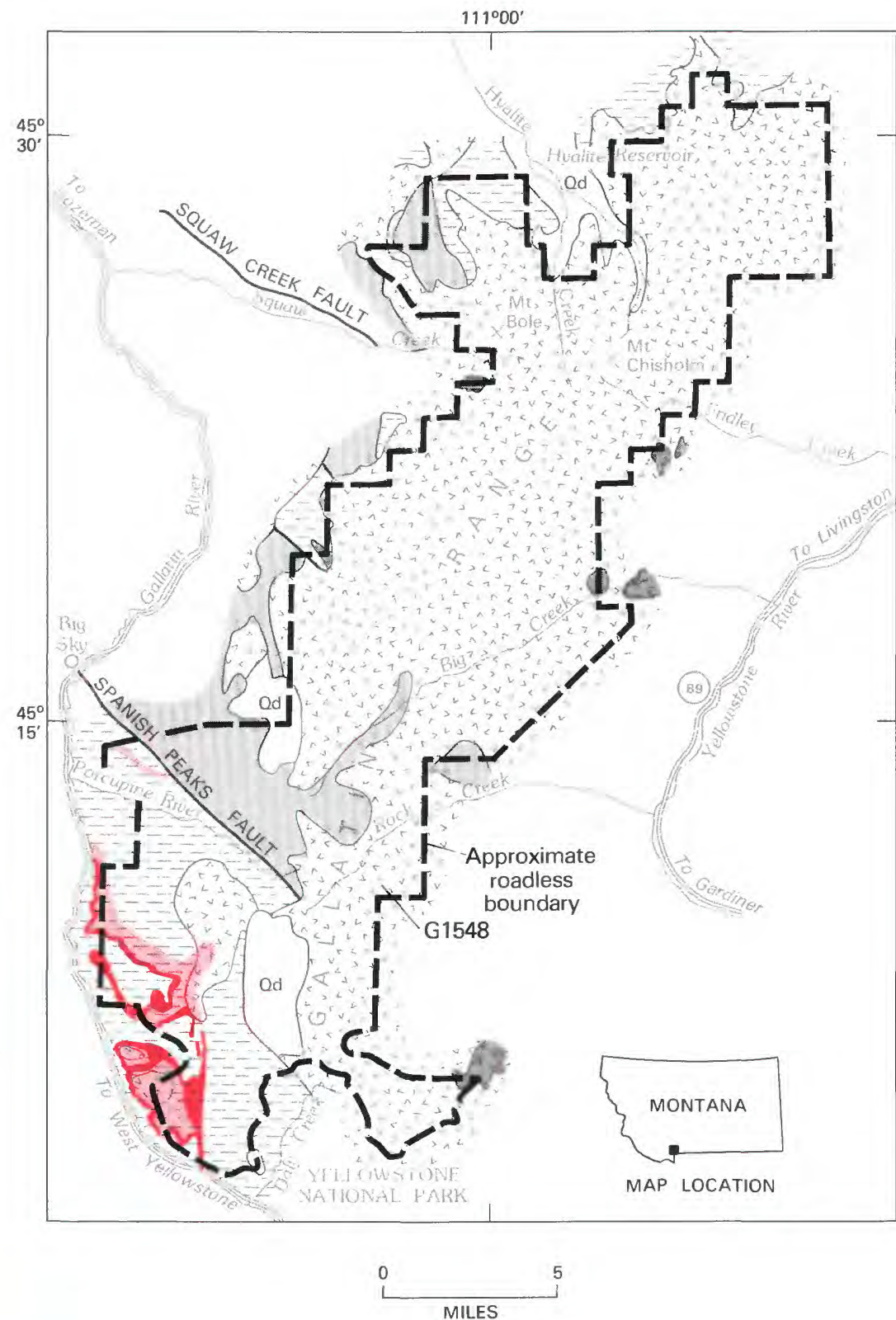

EXPLANATION

Geologic terrane with substantiated phosphate resource potential

Geologic terrane with probable phosphate resource potential

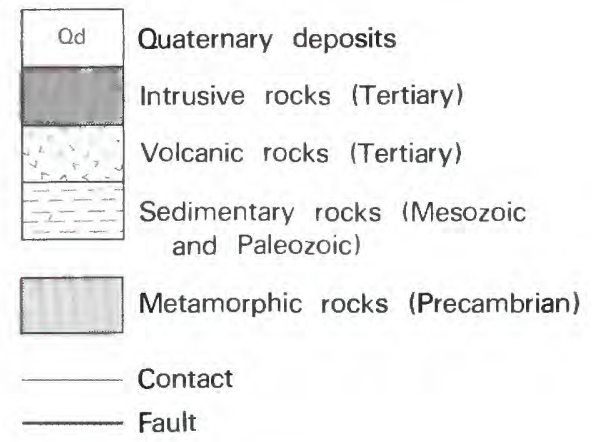

Contact 
and polished to determine its quality. Geophysical investigations of the area comprised aeromagnetic and gravity surveys and were made to obtain information on subsurface geology that would assist in evaluation of mineral resources (Simons and others, 1983).

\section{MINERAL RESOURCES}

No minerals have been produced from the Gallatin Divide Roadless Area, and no prospects or mining claims were found during this study. The nearest mineral deposits are the Thumper Lode mica mine in the Squaw Creek drainage about $3.5 \mathrm{mi}$ west of the area and the Karst asbestos mine just west of the Gallatin River and $4 \mathrm{mi}$ west of the area. Some prospecting was done in the 1880's for copper near the head of Levinski Creek and for calcite near Almart, both $1 \mathrm{mi}$ or so west of the roadless area. A few small showings of copper minerals have been reported along the Spanish Peaks fault on both sides of the Gallatin River. Placer gold deposits discovered along the Gallatin River in the 1860's were small and low grade and yielded only a few hundred ounces of gold. Coal deposits of the Livingston field, 6 mi northeast of the roadless area, were discovered in the 1870's and mined until 1943, and small amounts of coal are reported to have been mined on the Taylor Fork and West Fork Gallatin River, several miles west of the roadless area. Phosphate rock within the roadless area was investigated in 1928 and $1947-48$ by the USGS. The Gallatin and Yellowstone valleys were prospected for oil and gas in the 1920's but no exploratory drilling has been done in the roadless area, and the nearest test hole (dry) is in Carrot Basin about 9.5 mi southwest of the roadless area. Oil and gas lease applications were filed in the 1960's and 1970's, mainly in the northeastern part of the roadless area, but none have been granted to date. Petrified wood has been collected from deposits in the area. Terrace gravels and talus along the Gallatin River have been utilized extensively for road building, and welded tuff has been quarried on a small scale on the ridge between Porcupine Creek and Gallatin River; none of the localities are within the roadless area.

Mineral commodities in the roadless area are phosphate rock, petrified wood, and construction materials (Simons and others, 1983). Anomalous amounts of 20 elements were detected in samples collected during the geochemical study, but no significant geochemical anomaly was found for any element, and the area lacks both the plutonic igneous rocks and the altered rocks that commonly are associated with mineral deposits in the Rocky Mountains; indeed, samples of the most highly altered rocks seen contain with a few minor exceptions only ordinary amounts of any element.
Analyses of panned concentrates of stream sediments from all major drainages in the area revealed no concentrations of minerals indicative of mineral resources. No oil or gas, geothermal energy sources, or other mineral deposits are known to exist within the roadless area.

A probable and substantiated resource potential for phosphate exists in the southwest part of the area, where Shedhorn Sandstone of Permian age, containing minor phosphate rock, occurs over an area of several square miles and underlies a much larger area in the subsurface. Phosphatic rock was sampled at four localities during this study. A 64-ft-thick exposure of phosphate-bearing rock between Buffalo Horn and Tepee Creeks has 4.1 percent $\mathrm{P}_{2} \mathrm{O}_{5}$, and a 14 -ft-thick part of the exposure contains 13.1 percent $\mathrm{P}_{2} \mathrm{O}_{5}$. Other sampled exposures contain less than 2 percent $\mathrm{P}_{2} \mathrm{O}_{5}$. No other elements of interest were detected in the phosphate samples. Data at hand suggest that phosphatic rock in the area is thin, discontinuous, and low grade, and most of it is deeply buried.

About $15 \mathrm{sq}$ mi of the Gallatin Petrified Forest is in the southern part of the roadless area. Petrified wood occurs in Eocene volcanic rocks and is contained in at least 15 beds. Samples of the best quality petrified wood available were cut and polished to determine whether an attractive product could be made. The wood was found to be fractured, leached, and discolored, and no slab larger than 3 in. across could be cut. Similar petrified wood occurs outside the roadless area.

Many of the major drainages of the area, particularly Hyalite, Squaw, and Porcupine Creeks, have small deposits of sand and gravel. However, access to these deposits except those of Hyalite and Porcupine Creeks is difficult, and extensive and more accessible deposits of suitable material are available along the Gallatin River outside the roadless area.

Limestone is abundant in the southwest part of the roadless area, but it is equally abundant and much more accessible in areas outside of the roadless area.

Possible oil- or gas-bearing structures within the roadless area are concealed over about 75 percent of the area by Tertiary volcanic rocks, and the possible existence of such structures cannot be determined by surface geologic observations. Another 8 percent of the area is underlain by Precambrian metamorphic rocks which are not permissive for the occurrence of oil and gas. Within areas underlain by Paleozoic and Mesozoic sedimentary rocks, folds that could contain traps are too small and deeply eroded to be of any significance. No coal was seen in the roadless area but some may occur in the poorly exposed Cretaceous strata in the southwest part of the area. It is unlikely that coal beds of sufficient thickness and quality to be classified as resources are present in the roadless area. No hot 
springs were seen in the roadless area, and the nearest hot spring is Bozeman Hot Springs about $15 \mathrm{mi}$ northwest of the area; this spring is reported to have a temperature of $137^{\circ} \mathrm{F}$ and a flow of $250 \mathrm{gal} / \mathrm{min}$. No volcanic or intrusive rocks younger than Pliocene(?) occur in the roadless area. The Eocene volcanic rocks that make up so much of the area would be excellent reservoirs for geothermal fluids, but the lack of heat sources indicates that there is little likelihood for geothermal energy in the area.

\section{SUGGESTIONS FOR FURTHER STUDIES}

Further study of the Gallatin Divide Roadless Area appears unlikely to identify concealed or otherwise unrecognized mineral resources. The lack of intrusive igneous rocks and of extensive areas of altered rocks militate against the occurrence of metallic mineral deposits. Known mineral deposits in stratified rocks in or near the area-phosphate rock, coal, and petrified wood-are of poor quality and it is improbable that better quality material will be found with additional exploration. Over most of the area, possible oil- or gasbearing structures are concealed by volcanic rocks and can be sought only by geophysical methods; the known structures are unfavorable because they are small and deeply eroded.

\section{REFERENCE}

Simons, F. S., Van Loenen, R. E., Moore, S. L., Close, T. J., Causey J. D., Willett, S. L., and Rumsey, C. M., 1983, Mineral resource potential map of the Gallatin Divide Roadless Area, Gallatin and Park Counties, Montana: U.S. Geological Survey Miscellaneous Field Studies Map MF-1569-A, scale 1:126,720 (in press). 


\title{
GATES OF THE MOUNTAINS WILDERNESS AND ADDITIONS, MONTANA
}

\author{
Mitchell W. ReynoldS, U.S. GeOlogical Survey, and \\ TERRY J. Close, U.S. BUREAU OF MineS
}

\section{SUMMARY}

The Gates of the Mountains Wilderness and Additions, Montana, have little promise for the occurrence of metallic mineral or fossil fuel resources. This conclusion is based on detailed investigation of the geology and mineral and fossil fuel resources conducted in 1976 by the USGS and USBM. Geologic structures of the area, although similar to potential petroleum-bearing structures in other parts of the Rocky Mountains overthrust belt, are open to the surface and probably could not have trapped or held hydrocarbons. Rocks that potentially could have generated petroleum have higher levels of thermal maturity than the range of oil generation but are within the range of dry natural gas generation.

\section{CHARACTER AND SETTING}

The Gates of the Mountains Wilderness was established as a wilderness in 1964. In 1976 new areas on the south and west margins of the wilderness were designated for mineral-resource study. Inclusion of the new areas into the wilderness would increase the wilderness by about 20 percent. Mineral and fossil fuel resource potential of both the nucleus and additions was assessed during our investigation in 1976.

The Gates of the Mountains Wilderness is at the north end of the Big Belt Mountains in west-central Montana, about $30 \mathrm{mi}$ north-northeast of the capital city of Helena. The area encompasses about $45 \mathrm{sq} \mathrm{mi}$, and the additions total about $10 \mathrm{sq} \mathrm{mi}$. Jagged limestone peaks rise above an irregular surface eroded in shale across the high reaches of the wilderness. Narrow canyons incised in limestone dissect the lower reaches of the southern and western margins of the wilderness. Canyons of the western margin join the canyon of the Missouri River, made famous as the Gates of the Rocky Mountains by the Lewis and Clark expedition in 1805 . Altitudes generally rise east across the area from about $3585 \mathrm{ft}$ on the Missouri River to $7980 \mathrm{ft}$ at Moors Mountain. Access to the southern margin of the wilderness is by an improved gravel road from Canyon Ferry and York, Montana, to Beaver Creek. Trails into the wilderness which head on the Missouri River can be reached by boat from Holter dam or Upper Holter Lake; the northwest corner on Willow Creek can be reached by an unimproved dirt road from Holter dam about $10 \mathrm{mi}$ northwest of the area.
The wilderness lies at the south end of the Montana disturbed belt, a narrow belt of folds and imbricate thrust faults along the east edge of the Rocky Mountains overthrust belt. Highly complicated geologic structure has juxtaposed contorted sequences of rocks that range in age from Proterozoic (1400-1100 million years old) to Cretaceous (about 85 million years old). These rocks are dominantly siltstone, mudstone, and sandstone or their low-grade metamorphosed equivalents, but the most conspicuous rocks are paleyellowish-brown to white limestone and dolostone of Mississippian and Devonian age which form the rugged peaks and cliffs of the wilderness. Very thin diorite sills, probably of latest Mesozoic age (about 70 million years old), have intruded siltstone and mudstone beds of Cambrian age or, uncommonly, Devonian carbonate rocks.

The geologic structure of the wilderness is complex. Strata exposed at the surface across the northern and western parts form a great sheet of rock that broke at depth from crystalline and low-grade metamorphic rocks to ride east and northeast along the Moors Mountain thrust fault over contorted rocks of equivalent and younger ages. The thrust fault broke from the substrate and emerges over folded strata between Cottonwood Creek north of the wilderness and Willow Creek. Southeast of the wilderness the thrust sheet has travelled at least $15 \mathrm{mi}$ over strongly folded beds. Between Moors and Candle Mountains and Elkhorn Creek, rocks above the leading edge of the thrust plate are strongly folded and broken internally by thrust faults of small displacement. Along and west of the Missouri River at the west edge of the wilderness, a structurally higher sheet of 


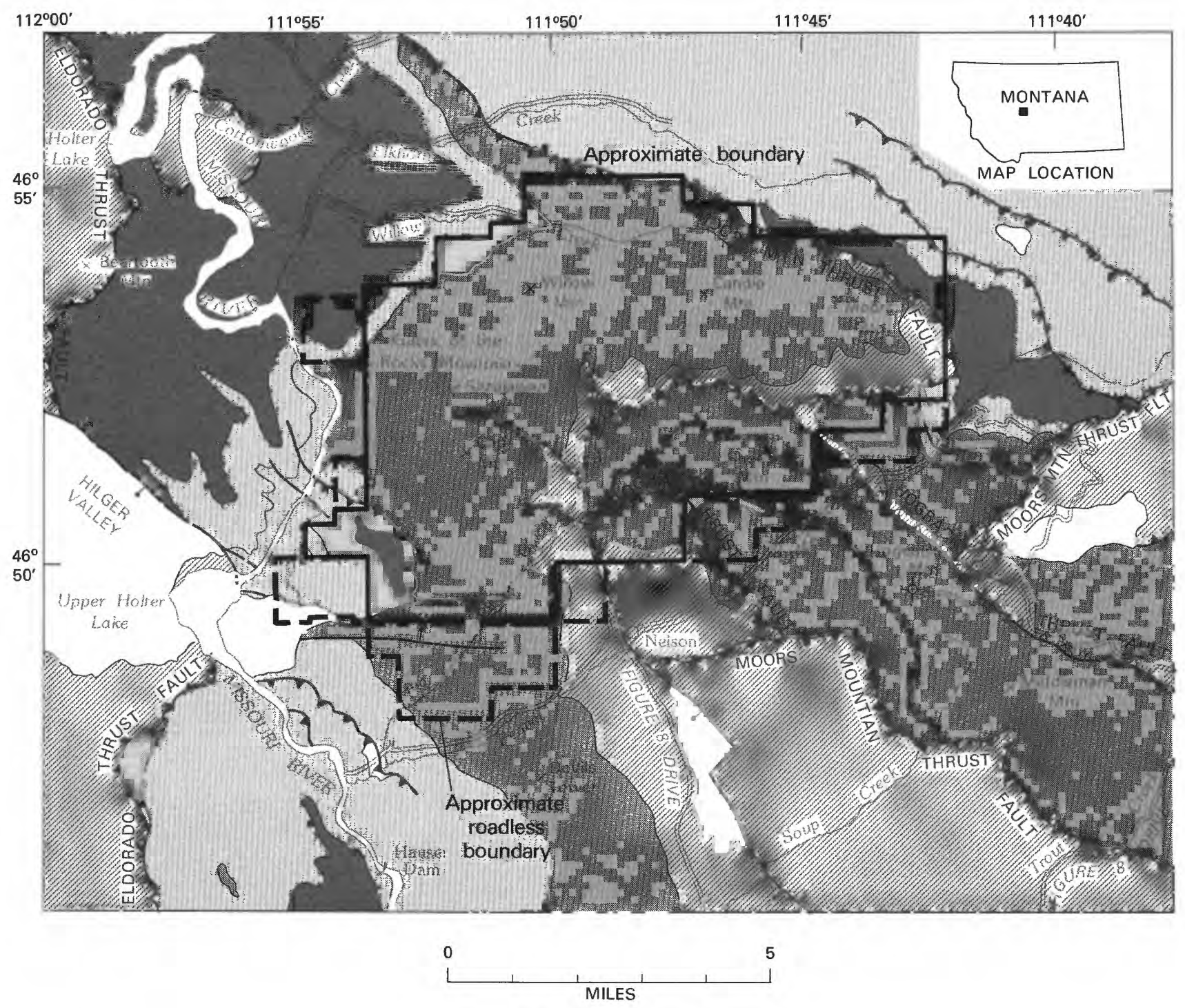

\section{EXPLANATION}

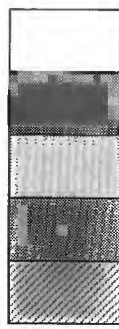

Quaternary alluvium and Tertiary rocks

Cretaceous and Jurassic rocks

Permian, Pennsylvanian, and Mississippian rocks

Mississippian, Devonian, and Cambrian rocks

Precambrian rocks

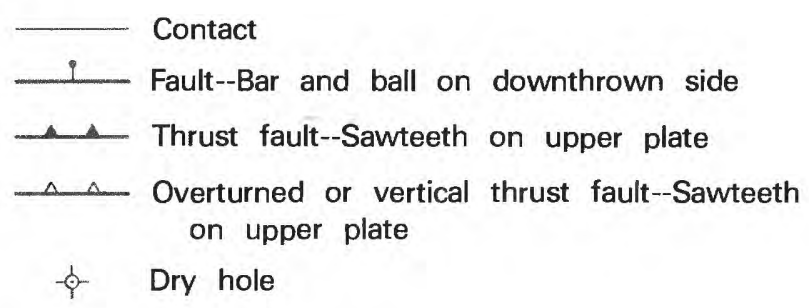

Figure 201.-Gates of the Mountains Wilderness and additions, Montana. 
deformed rocks on the Eldorado thrust fault has overridden strata of the wilderness.

Rocks beneath the Moors Mountain thrust fault are spectacularly exposed along the southern margin of the wilderness in the canyon of Beaver Creek. These rocks are folded in a major syncline and anticline, and those folds are, in turn, refolded under a thrust fault (Hogback thrust fault), that is older than the Moors Mountain thrust fault. Movement on the latter fault has folded and truncated both the Hogback thrust fault and folded rocks beneath it. Smaller scale thrust faults repeat sequences of carbonate rocks in refolded folds beneath the Hogback fault. Folds beneath the Moors Mountain thrust fault can be traced continuously $18 \mathrm{mi}$ southeast from the wilderness. Progressively older beds are exposed at higher altitudes southeast until Precambrian rocks crop out in the core of the principal fold. Those Precambrian rocks, in turn, rest on older Precambrian strata; younger strata which could be sources or reservoirs for hydrocarbons are absent within the core or at the base of the principal fold.

Basalt flows were extruded from fissures east and southeast of the wilderness about 30 million years ago. An episode of major faulting displaced the western part of the mountain range relatively down to the west from the south-central part of the wilderness south to Nelson and York. Faults along which Hilger Valley has dropped relative to adjacent mountains extend from Upper Holter Lake east into the wilderness. Young sedimentary rocks, including sandstone, siltstone, and volcanic tuff, are preserved along young faults that bound the valleys.

The field and laboratory investigations of the wilderness consisted of detailed geologic mapping, analysis of rock and stream-sediment samples, thermal pyrolysis and vitrinite reflectance exaunination of potential petroleum source rocks, and sampling of stream and river gravels for potential placer deposits. Magnetic and gravity anomaly maps from older geophysical surveys were exainined but proved to be of little value to the appraisal. No mineral prospect pits could be definitely located in the wilderness although early claims had been recorded near the southeast edge of the wilderness. About $1 \mathrm{mi}$ southeast of Nelson outside the wilderness, prospect pits in quartz veins cutting Proterozoic siltites were examined and sampled, but similar veins were not observed in equivalent or younger strata within the wilderness. During 1981-82, a hole, Getty Oil Company Federal No. 3-10, was drilled on Hogback Mountain, 2 mi outside the wilderness, to explore for petroleum in the refolded fold beneath the Moors Mountain and Hogback thrust faults. The hole was plugged and abandoned without significant shows of hydrocarbons.

\section{MINERAL RESOURCES}

No mining claims were found within the boundary of the wilderness and adjacent roadless areas, no mineral deposits are known to be present, and no anomalous occurrences of metallic elements were identified in our study. Sampling of gravel deposits in streams draining the wilderness or on terraces adjacent to the Missouri River on the west edge of the wilderness did not identify any placer occurrences of gold, sapphire, or tin. Careful visual inspection of rocks and fractures on outcrop identified no occurrences of metallic minerals and no significant mineralized alteration in or adjacent to very thin diorite sills or fault zones. All rock samples were scanned with a scintillometer to detect abnormal radioactivity, but none was found.

Dark-gray to dark-grayish-brown carbonaceous mudstone units at the top of the Devonian and Jurassic successions and at the base of Mississippian strata have higher concentrations of elements such as copper, chromium, nickel, and vanadium than other rocks in the wilderness. Similar rocks elsewhere, however, have equal or higher concentrations of those elements, so that the observed concentrations are not anomalous for carbonaceous mud rocks.

Limestone of quality adequate for use in cement or as smelting flux is present locally in the wilderness, but larger deposits more accessible to Montana markets exist outside of the wilderness.

Because segments of the Rocky Mountains overthrust belt either contain economic accumulations of hydrocarbons or have high potential for the presence of such accumulations, careful evaluation of the rocks and structure of the wilderness was made for their fossil fuel resource potential. Close exaunination of potential reservoir rocks, including sandstone, limestone, and dolostone units, identified no residual oil in pores or fractures. Unaltered and unweathered samples of potential hydrocarbon source rocks of Devonian, Mississippian, Jurassic, and Cretaceous age were analyzed for organic carbon content, thermal pyrolysis levels, and vitrinite reflectance properties, where possible, at all structural levels exposed in the wilderness. Carbonaceous mudstone at the top of the Devonian succession contains as much as 15 percent organic carbon and Lower Mississippian dark-gray calcareous mudstone contains as much as 5 percent organic carbon; both rock intervals could serve as source beds for hydrocarbon generation. Other possible source rocks contain less than 1 percent organic carbon and thus are not probable source rocks. Regardless of the structural position of the samples, however, analyses suggest that the potential source rocks have passed through temperatures of oil and wet 
gas generation and have been in the temperature range of dry gas generation.

Potential reservoir rocks exposed at the surface are strongly deformed; fractures are numerous and, in many cases, wide throughout the rocks. Structural closure necessary to trap hydrocarbons has not been identified in the wilderness, and potential trapping structures are open to the surface at higher altitudes southeast of the wilderness. Projection of structures into the wilderness suggests that Precambrian strata are in the cores of folds and that those strata are in fault contact with underlying Precambrian strata. Nowhere in the region are Precambrian strata demonstrable reservoirs for hydrocarbon accumulation. All factors investigated, together with the unsuccessful exploration test hole, drilled adjacent to the wilderness on the major fold that plunges beneath the surface of the wilderness, suggest that hydrocarbons, if present, would be dry natural gas, but that the possibility for accumulation is very remote.

\section{SUGGESTIONS FOR FURTHER STUDY}

Further study of the mineral and fossil fuel resource potential of the wilderness seems unwarranted. Folds in Pennsylvanian and Mississippian rocks at the surface east-northeast of the wilderness could be drilled to investigate possible structural entrapment of hydrocarbons in Mississippian carbonate rocks at depth; but the up-plunge exposure of the potential reservoir rocks markedly reduces the likelihood of successful exploration.

\section{REFERENCE}

Reynolds, M. W., and Close, R. J., in press, Mineral resource potential map of the Gates of the Mountains Wilderness, Lewis and Clark County, Montana: U.S. Geological Survey Miscellaneous Field Studies Map MF-1642-A. 


\title{
JACK CREEK BASIN, MONTANA
}

\author{
By Thor H. KiIlsgaARd, U.S. GeOlogical SurVey, and \\ Ronald M. VAN NOY, U.S. BUREaU OF Mines
}

\begin{abstract}
SUMMARY
A mineral survey of the Jack Creek basin area made in 1968 revealed that phosphate rock underlies the basin. The phosphate rock is in thin beds that dip steeply and are broken and offset by faults. These features plus the rugged topography of the region would make mining difficult; however, this study finds the area to have a probable mineral-resource potential for phosphate. Sedimentary rock formations favorable for oil and gas also underlie the basin. No oil or gas has been produced from the basin or from nearby areas in southwestern Montana, but oil and gas have been produced from the same favorable formations elsewhere in Montana. The possibility of oil and gas being produced from the basin is slight but it cannot be ignored.
\end{abstract}

\section{CHARACTER AND SETTING}

Jack Creek basin area is in the Beaverhead National Forest, Madison County, Montana. It adjoins the southwest border of the Spanish Peaks Primitive Area and contains about $41 \mathrm{sq} \mathrm{mi}$. The basin is bordered on the north by glaciated peaks of the Madison Range, on the west by a high ridge of upturned sedimentary rocks and on the south by an irregular ridge of intrusive and sedimentary rocks. The area is dominated by two majestic peaks, Lone Mountain and Fan Mountain, which rise along the southern border. Most of the basin is drained by Jack Creek, which flows west and leaves the basin through a sharply incised canyon.

The mineral survey of Jack Creek basin area was made in 1968, at the request of the USFS, who were studying the suitability of the Spanish Peaks Primitive Area for possible inclusion into the National Wilderness Preservation System, and who were interested in obtaining information on contiguous lands in the basin that might be added to those already in the designated primitive area. Results of the study were published in 1970 (Becraft and others, 1970).

The entire Jack Creek basin lies within the area studied and most of the bedrock is relatively soft sandstone and shale. In the northern part of the basin these rocks have been folded upward and offset along the Spanish Peaks fault. North of the fault are uplifted, resistant older schist and gneiss that form the core of the Madison Range. Rocks in the western part of the basin have been contorted by folding and faulting, and older gneiss and schist has been thrust along faults over the younger and softer sedimentary rocks. In the vicinity of Fan Mountain and Lone Mountain thick layers of igneous rocks have been intruded into sandstone and shale, forming resistant rocks that have been eroded to form the spectacular peaks. Younger glacial deposits, scoured from the higher mountains to the north and south, cover large areas of the basin.

Folded and faulted sandstone and shale crop out along the northern side of the basin, south of the Spanish Peaks fault, and dip to the southwest thereby passing beneath the basin in the form of a broad syncline or trough. One of these is the Phosphoria Formation, which is well known for its phosphate rock content. The same formations reappear along the western side of the basin, near faults in that area, thus indicating that they underlie the basin.

\section{MINERAL RESOURCES}

Jack Creek basin has been prospected for mineral deposits, but no commercial-grade material has been mined from the basin or is known to occur in it. Phosphate rock of the Phosphoria Formation underlies the basin, but the phosphate beds of acceptable grade are thin and unlikely to be mined by underground 


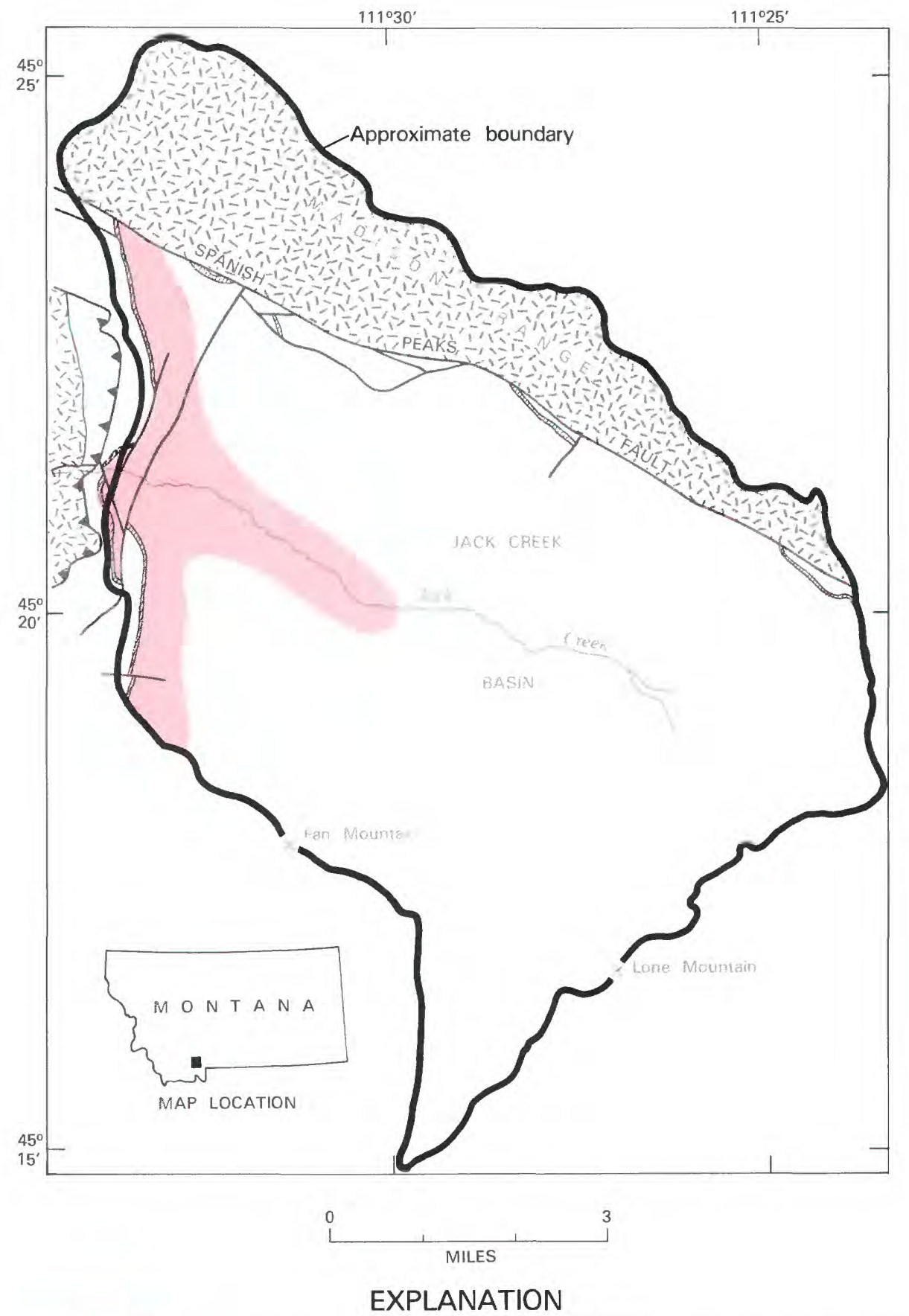

Geologic terrane with probable potential for phosphate rock

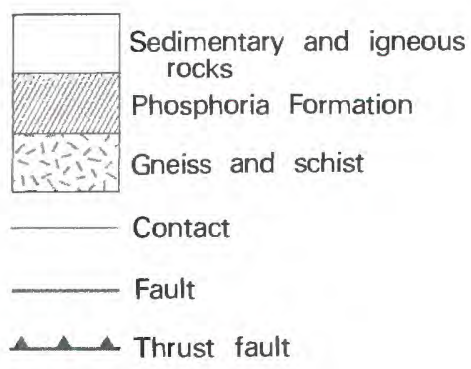

Figure 202.-Jack Creek basin, Montana. 
methods. The steep dip of the beds make strip mining unfeasible. Nevertheless, the phosphate must be considered as a resource that could be mined should future need for phosphate become great enough. Depth of the phosphate rock varies depending on location in the basin and topography; in the south-central part it may be more than $2000 \mathrm{ft}$ deep. In the west-central part, along Jack Creek, rocks immediately overlying the phosphate crop out, indicating relatively shallow depths to the phosphate. In recognition of the phosphate potential, much of the area in which phosphate rock crops out has been withdrawn under phosphate classification and the phosphate rights retained in Federal ownership. The withdrawn land forms a strip that extends roughly $1 \mathrm{mi}$ to the north and 2-1/2 mi south of Jack Creek.

Oil and gas have not been produced from the basin or from nearby areas. As of 1969 , no indications of oil and gas had been obtained in 9 test wells drilled at distances ranging from 4 to $25 \mathrm{mi}$ south and southeast of the basin. Some of the same sedimentary rocks that underlie the basin, however, have produced oil and gas elsewhere in Montana. The possible existence of oil and gas beneath the basin cannot be disregarded.

Coal was reported in the Jack Creek basin and most of the coal-bearing basin lands were withdrawn many years prior to this study and the coal rights retained in Federal ownership. Anthracite coal is reported to have been mined about $6 \mathrm{mi}$ south of the basin, from the same rock formation that crops out over much of the basin, but there is no evidence that coal has been mined from the basin and field work in 1968 failed to find any coal in the basin. Coal prospect pits were found at several places, most of them dug in black noncumbustible shale that was found to be too low in volatile matter and fixed carbon to be of value as coal. Individual coal beds tend to be disc shaped, tapering gradually from thicker centers to thinner edges. Therefore, it is possible that coal could exist in the basin but simply has not been found at the outcrop.

Several prospect workings have been dug along the Spanish Peaks fault in search for mineral deposits. Samples from the workings, from nearby rocks, and sediments from streams that drain the prospected areas failed to produce any evidence of mineral deposits.

\section{SUGGESTIONS FOR FURTHER STUDIES}

Further studies of the Phosphoria Formation on both the north and west sides of the Jack Creek basin would give more conclusive information on the grade, thickness, and extent of the phosphate rock and would contribute to a better understanding of the geologic structure of the area.

\section{REFERENCES}

Becraft, G. E., Kiilsgaard, T. H., and Van Noy, R. M., 1970, Mineral resources of the Jack Creek basin, Madison County, Montana: U.S. Geological Survey Bulletin 1319-B, 24 p. 


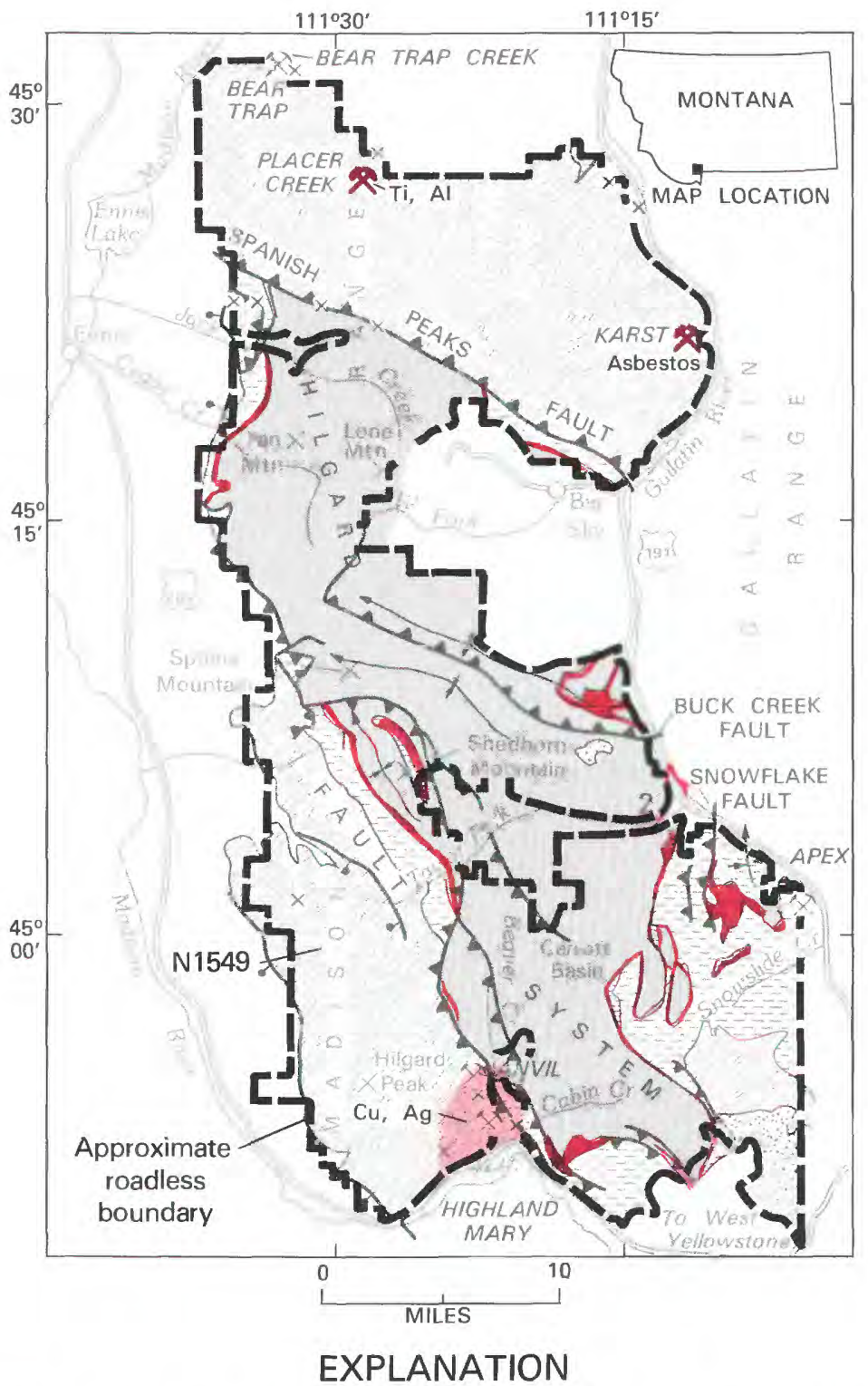

Geologic terrane with substantiated phosphate resource potential

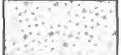

Pleistocene and Pliocene Yellowstone Group volcanic rocks

Geologic terrane with probable mineral-resource potential

$\begin{array}{cl}\mathrm{Al} & \text { Aluminum } \\ \mathrm{Cu} & \text { Copper } \\ \mathrm{Ag} & \text { Silver } \\ \mathrm{Ti} & \text { Titanium } \\ \times & \text { Mine or deposit } \\ \times & \text { Mineral occurrence } \\ \times & \text { Mine }\end{array}$

2 Location discussed in text

Figure 203.-Madison Roadless Area, Montana. 


\title{
MADISON ROADLESS AREA, MONTANA
}

\author{
By Frank S. Simons, ${ }^{1}$ U.S. Geological Survey, and \\ RoberT H. LAMBETH, U.S. BUREAU OF Mines
}

\begin{abstract}
SUMMARY
A mineral-resource survey of the Madison Roadless Area in the Madison Range of southwestern Montana was made by the USGS and USBM in 1978-82; some preliminary work was done in 1968 and 1970. The Madison Roadless Area has demonstrated resources of about 93,000 tons of sillimamite rock at the Placer Creek deposit and of about 83,000 tons of asbestos rock at the Karst deposit. The roadless area also has areas of substantiated phosphate resource potential; much of the phosphate is in thin deeply buried beds. An area near the south edge of the roadless area has a probable resource potential for copper and silver. There seems little promise for the occurrence of oil and gas because known possible oil- and gas-bearing structures are small and deeply eroded.
\end{abstract}

\section{CHARACTER AND SETTING}

The Madison Roadless Area is in southwestern Montana immediately west and northwest of Yellowstone National Park. It extends north-northwestward along the crest of the Madison Range from Hebgen Lake on the Madison River to the Madison River about $5 \mathrm{mi}$ north of Ennis Lake, a distance of $50 \mathrm{mi}$ and covers an area of approximately $576 \mathrm{sq} \mathrm{mi}$. The west flank of the Madison Range is in the Beaverhead National Forest, the east flank within the Gallatin National Forest. The area is about equally divided between Madison and Gallatin Counties, Montana.

General access to the roadless area is provided by U.S. Highway 287 along the Madison River and U.S. Highway 191 along the Gallatin River. Unimproved roads extend up most of the main drainages and some penetrate short distances into the roadless area, but access to most of the area is only by trail.

Most of the roadless area is above $6000 \mathrm{ft}$ in altitude; the highest point is Hilgard Peak, $11,316 \mathrm{ft}$, and several other peaks exceed $11,000 \mathrm{ft}$. The western part of the Madison Range is rugged, characterized by jagged ridges and deep narrow canyons and rises steeply as much as $5000 \mathrm{ft}$ above the Madison River valley. The eastern part of the range has gentle slopes and open valleys, and the highest peaks are around $10,000 \mathrm{ft}$ in

\footnotetext{
${ }^{1}$ With contribution from R. G. Tysdal and R. E. Van Loenen, USGS, and S. W. Schmauch, R. T. Mayerle, and M. M. Hamilton, USBM.
}

altitude. Evidence for alpine glaciation-cirques, rock basin lakes, U-shaped valleys, glacial deposits-is particularly well displayed in the southern part of the roadless area. Landslides and earthflows, some of enormous size, are abundant; the best known is the Madison River slide on the southern edge of the roadless area, which resulted from the Hebgen Lake earthquake of August 17, 1959, and dammed the Madison River canyon to produce the present Earthquake Lake.

The Madison Range is geologically part of a Tertiary structural block that also includes the Gallatin Range to the east; the two ranges are separated geographically but not geologically by the Gallatin River. The Madison-Gallatin block consists of a basement of Precambrian metamorphic rocks overlain by a sequence of dominantly carbonate Paleozoic rocks 3000 to $4000 \mathrm{ft}$ thick and a sequence of dominantly clastic Mesozoic sedimentary rocks, mainly Cretaceous, about 5000 to $7000 \mathrm{ft}$ thick. Volcanic and volcaniclastic rocks of Late Cretaceous age, 1500 to $2500 \mathrm{ft}$ thick, and conglomerate of Late Cretaceous age, $2000 \mathrm{ft}$ or more thick, occur in the central part of the roadless area. A few square miles in the southeast corner of the roadless area is underlain by Pliocene volcanic rocks. Porphyritic igneous rocks of Late Cretaceous age intrude sedimentary rocks at Lone Mountain and Fan Mountain and along the Gallatin River at Snowslide Creek. Bedrock is concealed locally by Holocene glacial deposits, landslide deposits, talus, and alluvium. 
Pre-Tertiary rocks of the Madison Range were folded and faulted along northerly to northwesterly trends during Laramide deformation. The principal structures formed during this deformation are, from north to south, the Spanish Peaks fault, which trends northwest across the range and has a displacement of 10,000 to $15,000 \mathrm{ft}$; the Buck Creek fault and its associated folds, which for most of its length trends northwest across the middle of the roadless area and has a displacement of as much as $2500 \mathrm{ft}$; the Snowflake fault-fold zone, which trends north in the southeastern part of the roadless area and has a displacement of $2000 \mathrm{ft}$ or less; and the Hilgard fault system, which trends north-northwest for about $30 \mathrm{mi}$ from Hebgen Lake to the Spanish Peaks fault, has a displacement of many thousands of feet, and in general forms the boundary between Precambrian rocks to the west and younger rocks to the east in the central and southern parts of the Madison Range. Rocks uplifted during Laramide deformation were subsequently eroded, and in Pliocene and Pleistocene time a large part of the present range was blanketed by volcanic rocks of the Yellowstone Group. The MadisonGallatin block was tilted gently southeastward during late Cenozoic uplift in the block along a system of faults that define the west flank of the Madison Range. The present topography of the range resulted from erosion by water and ice following tilting.

\section{MINERAL RESOURCES}

No minerals have been produced from the Madison Roadless Area, and no active mining claims exist. Several small mining districts and mineral deposits adjoin or are near the area; these include the Boaz mine in the Lower Hot Springs district near the northwest corner of the area, which has produced about 62,000 tons of goldsilver-lead ore, and the Karst mine just inside the northeast border of the area (loc. 4), which has produced a few thousand tons of asbestos ore. A few hundred ounces of gold are reported to have been produced from placer deposits on West Fork Gallatin River and Taylor Fork near the east edge of the roadless area, and small amounts of coal are reported to have been mined on the Taylor Fork and West Fork Gallatin River. A little prospecting has been done for corundum and sillimanite around the north end of the roadless area. Copper and silver have been sought at a few places along the Spanish Peaks fault and near the south end of the area, and a dozen or so prospects were found during this study. Phosphate rock resources in Permian rocks in the roadless area were studied by the USGS in 1928 and 1947-48. The Gallatin and Yellowstone Valleys were prospected for oil and gas in the 1920's, but the only exploratory drilling in the roadless area was a dry hole in Carrot Basin in the southern part of the area. Lease applications for oil and gas exploration have been made for about $105 \mathrm{sq} \mathrm{mi}$ of the roadless area, mainly in the drainage basins of West Fork Gallatin River, Jack Creek, Taylor Fork, Indian Creek, and Beaver Creek. Terrace gravels and talus along the Gallatin River near the Madison Roadless Area have been utilized extensively for road building.

Geochemical evaluation of the mineral potential of the Madison Roadless Area is based on stream-sediment, rock, and panned concentrates of stream-sediment samples collected by the USGS, and stream-sediment samples collected by Los Alamos Scientific Laboratory. The USBM sampled possible copper-silver-bearing material, coal, phosphate rock, and sillimanite, mica, and uranium occurrences. Aeromagnetic and gravity geophysical surveys were made to obtain information on subsurface geology that would contribute to mineralresource evaluation.

Mineral commodities in the roadless area are phosphate rock, asbestos, and sillimanite. Traces of copper, silver, molybdenum, gold, lead, and zinc were found at several prospects.

Anomalous amounts of 21 elements were detected in samples collected during the geochemical study, but no significant geochemical anomaly was found for any element. Very low level anomalies were recognized for molybdenum in two areas and for uranium in one region. The area lacks both the kinds of plutonic igneous rocks and the altered rocks that commonly accompany metallic mineral deposits and the few apparently altered rocks that were sampled were not geochemically anomalous. No oil or gas, geothermal energy sources, or other mineral deposits are known to exist within the roadless area.

The Shedhorn Sandstone of Permian age contains layers of phosphate rock at many places along its outcrop. Phosphate rock was sampled at four localities during this study. At Indian Creek (loc. 1), the phosphatic bed is about $6 \mathrm{ft}$ thick; at Pulpit Rock (loc. 2) on the Gallatin River it is $1.7 \mathrm{ft}$ thick; at Shedhorn Mountain it is 3.5 to $6.2 \mathrm{ft}$ thick and contains 0.14 to 12 percent $P_{2} 0_{5}$; and at Taylor Falls it is $2.6 \mathrm{ft}$ thick and contains 7.3 percent $\mathrm{P}_{2} \mathrm{O}_{5}$. Resources were calculated by Swanson (1970, p. 737) for areas that include all the potentially phosphate bearing part of the roadless area. Most of the phosphate rock of the Cedar Creek-Jack Creek area, and much of it in the Indian Creek-Taylor Fork block, is probably too deeply buried to be minable, and that of the Beaver Creek-Cabin Creek area is less than $4 \mathrm{ft}$ thick. Nevertheless, the roadless area has areas of substantiated resource potential for phosphate rock.

The Placer Creek sillimanite deposit (loc. 3) is a lens of 
sillimanite-rich Precambrian gneiss at least $150 \mathrm{ft}$ long and $20 \mathrm{ft}$ wide. The deposit is estimated to have demonstration resources of about 93,000 tons of rock containing 84 percent sillimanite (aluminum silicate), as well as 2 percent rutile (titanium dioxide).

The Karst asbestos deposit (loc. 4) contains anthophyllite asbestos in fractures in Precambrian mafic rocks; that part of the deposit within the roadless area contains demonstrated resources of about 83,000 tons of rock averaging 18 percent asbestos.

The Bear Trap Creek sillimanite prospect (loc. 5) consists of lenses of gneiss that contains small amounts of sillimanite. An occurrence of sillimanite-corundum gneiss about $1 \mathrm{mi}$ southeast at the Bear Trap prospect (loc. 9) has small lenses that contain as much as 15 percent corundum (aluminum oxide) and 68 percent sillimanite.

The Apex copper prospect (loc. 6) has a lens of copperand iron-bearing altered limestone about $550 \mathrm{ft}$ long and $3 \mathrm{ft}$ wide that contains a little copper and traces of gold.

The Anvil mica claim (loc. 7) is on a Precambrian pegmatite about $10 \mathrm{ft}$ across that contains crystals of biotite (dark mica) 2 in. across and 0.5 in. thick.

Several small copper prospects occur in an area of probable copper-silver resource potential northwest of the confluence of Beaver Creek and the Madison River at the southern edge of the roadless area. The main prospect, Highland Mary (loc. 8), is on thin lenticular sulfide veins in a shear zone that cuts Precambrian gneiss. The zone is $400 \mathrm{ft}$ long and 1.4 to $3 \mathrm{ft}$ wide. Samples from 5 localities contain 0.29 to 0.77 percent copper and as much as $0.4 \mathrm{oz}$ silver per ton. Other prospects in the area contain similar or smaller amounts of copper and silver.

Stream-sediment samples containing more than a few parts per million of uranium come almost entirely from drainages underlain wholly or mainly by Precambrian metamorphic rocks; all streams that drain dominantly Precambrian rocks, except for some in the northwesternmost part of the roadless area, yield sediment samples high in uranium. Samples containing exceptionally high uranium contents -100 parts per million or more-are concentrated in the southwest corner of the roadless area around and south of Hilgard Peak. The area is entirely underlain by Precambrian rocks and contains 19 of the 24 samples from the roadless area that have 100 parts per million or more uranium. It is likely that these samples reflect a relatively high background uranium content in the Precambrian source rocks, that is, the uranium is dispersed rather than being concentrated into deposits. There seems little likelihood for the presence of uranium resources.

\section{SUGGESTIONS FOR FURTHER STUDY}

The concentration of uranium-rich stream-sediment samples in the southwest part of the roadless area suggests that a further attempt to identify the source rocks might be justified, although the presence of resources seems unlikely, based on existing information. Elsewhere in the roadless area, additional study seems unlikely to identify concealed or otherwise unrecognized mineral resources.

\section{REFERENCES}

Lambeth, R. H., Schmauch, S. W., Mayerle, R. T., and Hamilton, M. W., 1982, Mineral investigations of the Madison RARE II Areas (No. 1549, Parts E, J, N, R, and S), Madison and Gallatin Counties, Montana: U.S. Bureau of Mines Open-File Report MLA 81-82, 32 p.

Simons, F. S., Van Loenen, R. E., Tysdal, R. G., Lambeth, R. H., Schmauch, S. W., Mayerle, R. T., and Hamilton, M. M., 1983, Mineral resource potential map of the Madison Roadless Area, Gallatin and Madison Counties, Montana: U.S. Geological Survey Miscellaneous Field Studies Map MF-1605-A.

Swanson, R. W., 1970, Mineral resources in Permian rocks of southwest Montana: U.S. Geological Survey Professional Paper 313-E, p. 661-777. 

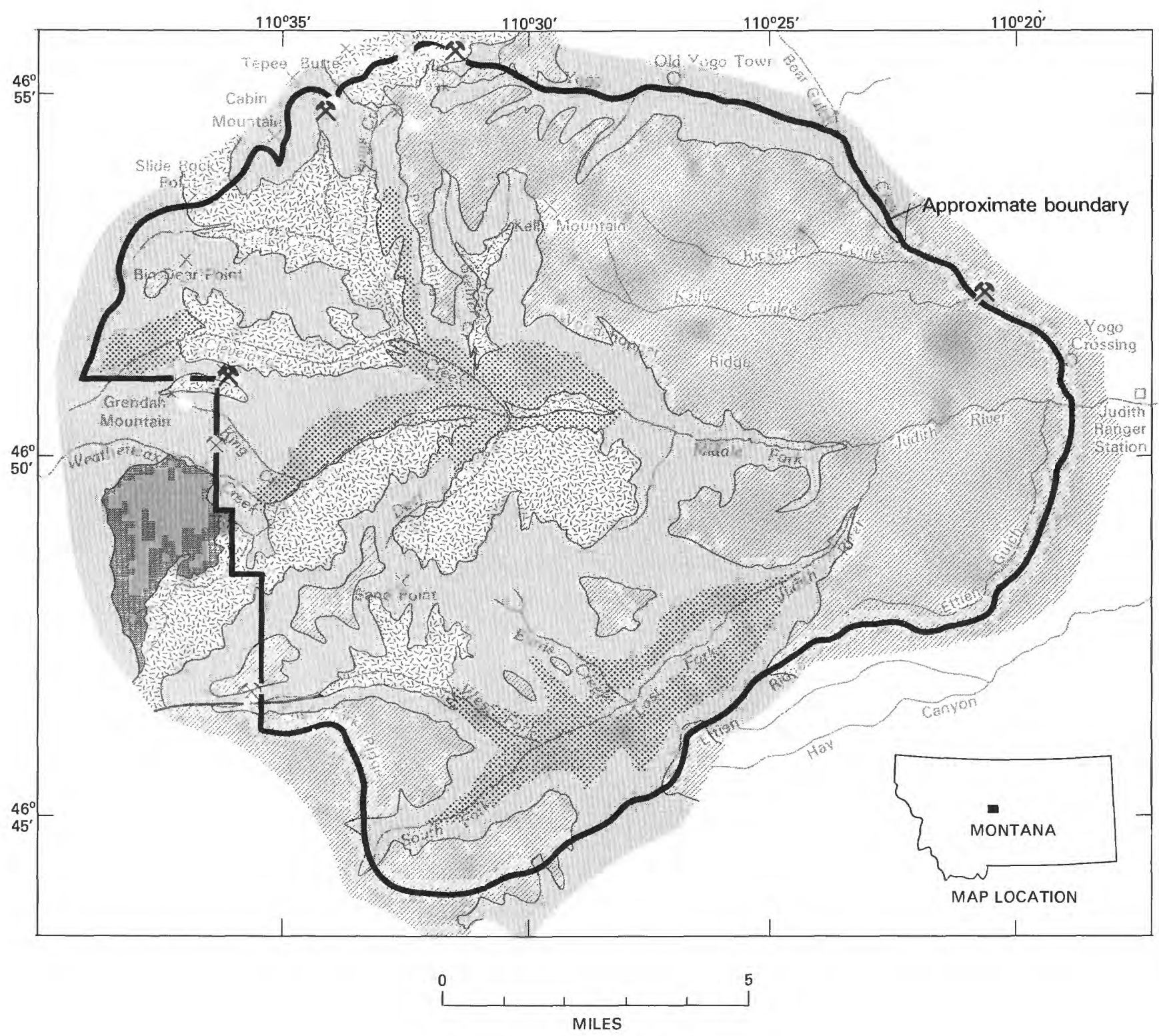

\section{EXPLANATION}

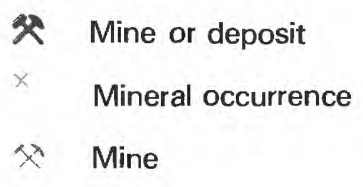

Mine or deposit

父 Mine

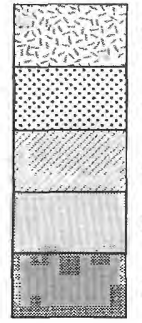

Igneous rocks (Tertiary)

Area of bedrock which contains abundant sills of Tertiary igneous rocks

Carbonate rocks (Mississippian)

Sedimentary rocks (Devonian and Cambrian)

Siltite and argillite (Precambrian)

Contact

Fault

Figure 204.-Middle Fork of the Judith River Wilderness Study Area, Montana. 


\title{
MIDDLE FORK OF THE JUDITH RIVER WILDERNESS STUDY AREA, MONTANA
}

\author{
Mitchell W. Reynolds, ${ }^{1}$ U.S. GeOlOGiCAl SuRVEy, and \\ Michael Hamilton, U.S. Bureau of Mines
}

\begin{abstract}
SUMMARY
The Middle Fork of the Judith River Wilderness Study Area has several prospects containing local small inferred resources and several exposed mineral occurrences bearing silver, lead, copper, and gold along its north and west edges with no identified resource potential. Geologic, geophysical, and geochemical studies, conducted during 1979 to appraise the mineral resources of the study area, identified no other anomalous concentrations of metallic elements. A gemquality sapphire resource, present near the east boundary, cannot be identified within the study area. The area holds little promise for the occurrence of other mineral or energy resources.
\end{abstract}

\section{CHARACTER AND SETTING}

Assessment of the mineral-resource potential of lands designated as the Middle Fork of the Judith River Wilderness Study Area was authorized under the Montana Wilderness Study Act of 1977 . The area includes about $129 \mathrm{sq} \mathrm{mi}$ in the upper drainage basin of the Middle Fork of the Judith River along the east-central crest of the Little Belt Mountains in west-central Montana. The area is about $65 \mathrm{mi}$ southeast of Great Falls and $32 \mathrm{mi}$ northeast of White Sulphur Springs. Access to ridges overlooking the area or to its center along the Middle Fork of the Judith River is by rough unimproved dirt road from U.S. Highway 89 about 4 mi west of the area or from Utica, about $18 \mathrm{mi}$ to the northeast.

Uneven ridges slope generally east across the study area from altitudes of about $8200 \mathrm{ft}$ on the western divide to $5400 \mathrm{ft}$ at the eastern border. On the northern boundary Yogo Peak $(880 \mathrm{lt})$ rises above the area. Timbered steep-walled valleys of the Middle and Lost Forks of the Judith River and their tributaries are incised as deeply as $2000 \mathrm{ft}$; the major streams in the eastern third of the area flow through narrow winding canyons eroded in limestone.

Rocks exposed are of contrasting origins and ages. Sedimentary rocks, dominantly limestone and dolostone with thinner exposed sequences of siltstone, mudstone, and quartzite, form the framework of the area.

${ }^{1}$ With contributions from M. D. Kleinkopf, USGS, and Ronald Mayerle, USBM.
These strata range in age from Precambrian to Mississippian. Igneous rocks of Tertiary (Eocene) age are intruded into the sedimentary strata as thin tabular bodies (sills) parallel or nearly parallel to bedding, or as a thick more coarsely crystalline pluton (laccolith) which domes the strata. The igneous rocks were generally intruded into weak siltstone, mudstone, and silty limestone units of Precambrian and Cambrian age, but along the north and locally west margins, they intruded carbonate rocks of Devonian and Mississippian age. Rocks of the pluton are quartz monzonite in composition, whereas the sills are more alkaline (monzonite) or basic (diorite and minette). Some sills were intruded before the pluton and were domed by it; others are thin tongues of the pluton that extend into adjacent strata. Clay alteration is present locally in and adjacent to sills along Cleveland Creek, but most sills and the pluton are unaltered. Sedimentary rocks are metamorphosed within a few feet of the sills and generally within 300 to $1000 \mathrm{ft}$ of the pluton. Rare quartz or pegmatite veins or dikes that developed during late stages of intrusion were observed near Yogo Peak.

Paleozoic sedimentary rocks are generally tilted east across the area so that the oldest are exposed along the west boundary. The igneous pluton has deformed strata in a broad dome which has an undulatory crest. Igneous rocks or older sedimentary rocks are exposed in centers of the undulations. Beds on Yogo Peak were tilted south at high angles and locally strongly contorted during intrusion of the pluton there. Gravity and magnetic 
anomalies identified in our investigation generally coincide with crests of undulations on the broader intrusive dome. Other anomalies coincide with the sill exposed at the surface on Grendah Mountain. Limestone beds in the eastern part of the area are folded in small easttrending folds, and strata in the upper reaches of Lost Fork of the Judith River are broken and displaced downward on the south by an east-trending normal fault.

Our mineral-resource assessment is based on new geologic mapping, on geochemical sampling and analysis of samples of fresh rock, mineral occurrences, and altered rock, and on geophysical investigations including gravity and magnetic surveys (Reynolds and others, in press). All known adits and prospect pits were exaunined, and rocks and minerals exposed in them were sampled for analysis of their metal content.

\section{MINERAL RESOURCES}

Prospecting for precious and base metals has been conducted for a century along the north and west edges of the study area, and gem-quality sapphire has been mined just east of it. The Neihart and Barker mining districts, about 8 to $10 \mathrm{mi}$ northwest and north of the study area, produced precious metals during the $1890 \mathrm{~s}$ and intermittantly since. Prospecting extended from those districts into the study area to terranes which had similar intrusive igneous relations. Despite the prospecting and proximity of the areas, significant mineral resources have not been identified in the study area. Widely scattered low-level anomalous concentrations of metallic elements identified in this study are not associated with alteration, extensive veining, or brecciation and are not regarded as indicative of unexposed resources in the area.

Mining records show that 200 to 300 claims were located in the study area between the 1880 s and the present. Only nine claims, however, mainly in the vicinity of Yogo Peak were patented. Most claims were located in carbonate rocks of Cambrian, Devonian, and Mississippian age, at or near the contacts with intrusive igneous rocks along the north and west edges of the study area. Gold placer claims were located along Yogo Creek at the north edge of the study area. A few other claims were located for building stone or sapphire. Placer production on Yogo Creek was small and placer deposits essentially exhausted by 1900 . Our sampling and analysis for placer metals along the boundary or within the study area identified no occurrences of such metals.

Known bedrock occurrences of metallic minerals in the study area have several characteristics in common.
The occurrences are mostly in carbonate rocks of limited stratigraphic range-Upper Cambrian, Devonian, and Lower Mississippian-generally coincident with the highest observed intrusion of thin sills and dikes or the pluton that underlies much of the western part of the area. The inferred mineral resources are spatially near the major intrusive bodies, generally at or adjacent to thin intervals of siltstone and mudstone which bound Devonian carbonate strata. Regionally these intervals contain higher background concentrations of metallic elements than the adjacent carbonate rocks. Careful exaunination and geochemical sampling identified no anomalous concentration of metallic elements within the igneous bodies or at contacts of those bodies with siltstone, mudstone, or quartzite of Cambrian age. It seems possible that the anomalous concentrations might have resulted locally from "sweating out" of the metallic elements from Devonian shale units into host carbonate rocks adjacent to the hottest parts of igneous intrusions in the north and western part of the area; but nowhere were quantities of the metals concentrated.

In the vicinity of Yogo Peak, several properties developed with adits or prospect pits have small inferred resources of silver and copper or silver, copper, and lead. The properties are located primarily on very thin veins of igneous rock intruded into carbonate rock or in thin inclusions of the carbonate rock in igneous plutons. Quantities of sulfide ore minerals observed or inferred are small and the ore grade is low. Mineral production of record has been limited generally to hand-picked small quantities.

At the west edge of the study area on Grendah Mountain and in the upper reaches of the West Fork of Lost Fork of the Judith River, adits or prospect pits have been excavated in Devonian rocks. On Grendah Mountain sulfide and oxide minerals containing lead, zinc, copper, silver, and traces of gold occur beneath a sill intruded into basal Mississippian strata. Mineral occurrences on West Fork of Lost Fork are in calcareous siltstone and limestone at the contact between Mississippian and Devonian rocks. Metallic minerals at these localities seem confined to single fractures, bedding surfaces or presumed veinlets a fraction of an inch wide. The lateral continuity of the mineralized surfaces could not be demonstrated in our study either by detailed exaunination or by geochemical sampling. The presence of base- or precious-metal resources at these localities seems unlikely.

At the junction of Yogo Creek and Kelly Coulee on the east boundary of the study area, gem-quality sapphire crystals have been mined from a basic igneous dike. The dike extends $3 \mathrm{mi}$ east from the boundary. Once a principal source of sapphire gems in the nation, the mines 
have been worked only intermittently since 1929 and have been inactive since 1977 . Westward projection of the trend of the dike suggests that it could be present in Kelly Coulee within the study area, but if so, it is buried by alluvium along part of the projected trend. Our examination of rock outcrops that cross the trend failed to identify either an extension of the dike or clay seams characteristic of deeply weathered dike rock; panned concentrates of the alluvium were barren. The likelihood that a sapphire gemstone resource exists in the Middle Fork of the Judith River Wilderness Study Area is remote.

\section{SUGGESTIONS FOR FURTHER STUDY}

Two limited areas within the study area could be investigated in greater detail to reassess the possibility for the occurrence of mineral resources which our study could not demonstrate. Altered rock adjacent to thin sills exposed on valley walls of Cleveland Creek from its junction with Hell Creek to $2 \mathrm{mi}$ upstream should be sampled more closely and analyzed for metallic elements. A small-scale exploration program could be conducted on Grendah Mountain to better define the extent and resource potential of silver and gold mineral occurrences known there. Additional study of the remainder of the study area would seem to hold little prospect for identification of other resources.

\section{REFERENCE}

Reynolds, M. W., Kleinkopf, M. D., Hamilton, Michael, and Mayerle, Ronald, in press, Mineral resource potential map of the Middle Fork of the Judith River Wilderness Study Area, Judith Basin and Cascade Counties, Montana: U.S. Geological Survey Miscellaneous Field Studies Map MF-1641-A. 


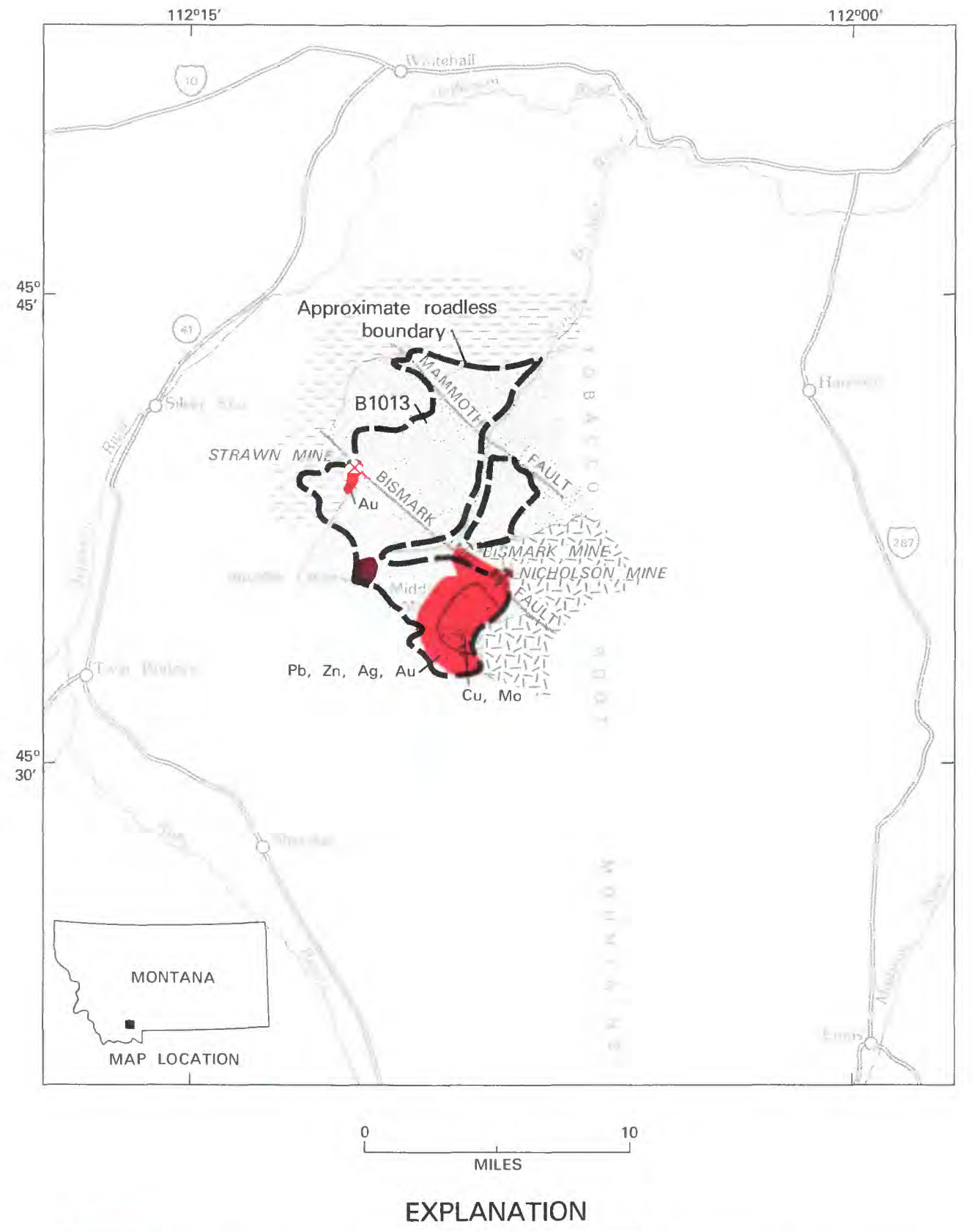

Geologic terrane with substantiated
resource potential for gold and silver
and probable resource potential for
copper, lead, and zinc
Geologic terrane with substantiated
mineral-resource potential

Figure 205.-Middle Mountain-Tobacco Root Roadless Area, Montana. 


\title{
MIDDLE MOUNTAIN-TOBACCO ROOT ROADLESS AREA, MONTANA
}

\author{
By J. Michael O’Neill, ${ }^{1}$ U.S. Geological Survey, and \\ Eric E. Cather, U.S. Bureau of Mines
}

\begin{abstract}
SUMMARY
A mineral-resource survey, made during 1979, 1980, and 1982 of the northern part of the Tobacco Root Mountains, determined that the area included in or enclosed by the Middle Mountain-Tobacco Root Roadless Area contains several areas of probable or substantiated mineral-resource potential. Most of the mineralized areas are located in or adjacent to intrusive rocks of Late Cretaceous age. Mineral resources are probably of three types: disseminated and stockwork copper and molybdenum in porphyry-type deposits; gold-silverquartz veins; and gold-bearing silicified zones. No energy resources were identified in this study.
\end{abstract}

\section{CHARACTER AND SETTING}

The Middle Mountain-Tobacco Root Roadless Area is located in the northern part of the Tobacco Root Mountains of southwestern Montana. The area encompasses about $62 \mathrm{sq} \mathrm{mi,} \mathrm{mainly} \mathrm{within} \mathrm{the} \mathrm{Deer} \mathrm{Lodge} \mathrm{National}$ Forest. The Tobacco Root Mountains are a linear, northtrending range; the combined lower Ruby and Jefferson River valleys bound the range on the west and north sides and the Madison River valley is located east of the range. The highest peaks of the Tobacco Root Mountains are located within the roadless area and reach a maximum altitude of $10,604 \mathrm{ft}$ on Mt. Jefferson. Topographic relief is nearly $5000 \mathrm{ft}$ along the western part of the range. The roadless area encompasses nearly all of the headwaters of the South Boulder River, marked by a ring of north-facing cirques along the formidable southern boundary of the area. Middle Mountain is the prominent peak that projects northward into the center of the cirque complex.

Three major rock types are exposed in the roadless area: layered Archean gneiss and schist are exposed over much of the central and southern parts; dioritic to granitic batholithic igneous rocks of Late Cretaceous age occupy lobes in the southeast part; and sedimentary rocks, mainly Paleozoic in age, are present along the west and north sides. The range was strongly glaciated in the Pleistocene and contains many cirques, tarns and ice-carved valleys. Quaternary deposits, mainly glacial

${ }^{1}$ With contributions by J. M. Linné, USBM. in origin, commonly blanket the floors of the larger mountain valleys.

The rocks of the roadless area are deformed to various degrees. Archean rocks, the most strongly deformed, were folded, faulted and strongly attenuated during metamorphism at least 2.7 billion years ago (James and Hedge, 1980). During Late Cretaceous and early Tertiary time, the Paleozoic sedimentary rocks were intensely faulted and folded along the western and northern sides of the roadless area (Schmidt and O'Neill, 1983; O'Neill, 1983a). On the west, west-dipping, high-angle reverse and thrust faults of small horizontal displacement are associated with folds overturned to the east. These faults merge to the north with oblique slip reverse and thrust faults associated with the overthrust belt structures of west-central Montana.

Two major northwest-trending, high-angle faults that cross the Tobacco Root Mountains are present in the roadless area. These faults, the Bismark and the Mammoth, first formed in Precambrian time (Reid, 1957) and have been recurrently active (Schmidt, 1975); they appear to have exerted a degree of structural control over the position and orientation of the part of the northwest-trending Tobacco Root batholith that is present in the roadless area.

\section{MINERAL RESOURCES}

The Middle Mountain-Tobacco Root Roadless Area encloses or contains 12 patented mining claims and 
about 240 current unpatented claims. Several of these claims are in areas that have probable or substantiated mineral-resource potential (O'Neill, 1983c). Most of these areas are located in or adjacent to intrusive rocks of Late Cretaceous age.

Disseminated and stockwork copper and molybdenum sulfides are present in the southern part of the roadless area at Granite Peak in that part of the batholith that extends into the roadless area. The batholithic rocks have been intruded by north-trending, finecrystalline granitic dikes. Exposures on the north face of Granite Peak reveal strongly altered and fractured rocks peripheral to these dikes characterized by alteration of hornblende to chlorite, locally abundant thin quartz veins, thin stockwork fractures filled with sulfides, and disseminated copper and, less commonly, molybdenum sulfides. Similar veins are also locally abundant south of Granite Peak near Rossiter Lake. Pyrite is present throughout the altered zone. Sulfidebearing breccia pipes, exposed about $1 \mathrm{mi}$ north of Granite Peak on the north side of Middle Mountain, are composed of coarse, angular fragments of Precambrian gneiss. The pipes are moderately stained yellow-orange and contain abundant veinlets of sulfide minerals. Rockchip samples collected from the pipe contain silver, arsenic, molybdenum and zinc (O'Neill, 1983b). The pipes are probably related to the hydrothermal mineralization at Granite Peak, and may represent an important subsurface extension of the mineralized zone. Thus, Granite Peak and part of Middle Mountain are regarded as having substantiated mineral-resource potential for copper and molybdenum.

The Nickelson and Bismark mines, located directly north of Granite Peak and Middle Mountain, are geologically similar; both are located along the northwesttrending Bismark fault zone, are peripheral to the Granite Peak mineralized area, and are completely surrounded by the roadless area. The Bismark mine is presently inactive; it yielded 58,549 lb of copper, $7143 \mathrm{lb}$ of lead, $1189 \mathrm{oz}$ of silver, and $12 \mathrm{oz}$ of gold in 1916-71 from quartz veins and zones of disseminated minerals along the Bismark fault zone. Stream-sediment samples collected from this area locally show anomalously high base-metal values (O'Neill, 1980, 1983b). Gold resources at the Nickelson mine appear to be restricted to the area of the present mining claims; approximately $420 \mathrm{oz}$ of gold has been produced from the mine, and additional gold resources were identified at the mine during this study. Additional resources, if present, would most probably be found along the northwestward or southeastward trace of the Bismark fault zone. Several small, known gold-quartz veins are located within $0.25 \mathrm{mi}$ of the fault zone. Thus the area adjacent to the fault zone and principally between the Bismark and Nickelson mines must be considered to have substantiated potential for base and precious metals.

Satellitic intrusive bodies of the Tobacco Root batholith are present in the Boulder Lakes area, partly within the roadless area. All of these bodies are felsic in composition and most contain minor disseminated or weakly developed stockwork sulfides. One small porphyritic latite plug adjacent to Lower Boulder Lake contains disseminated fluorite and pyrite. A weakly mineralized breccia pipe located on the ridge directly east of Lower Boulder Lake contains sparce pyrite. Biotite gneiss adjacent to this pipe is locally strongly bleached and chloritization of biotite in brecciated igneous rocks in the pipe is common. Prospects and mines in this area have been dug along gold-bearing vein systems concentrated at the margins of the plutonic rocks. The probable hydrothermal origin of the gold-bearing fissure veins (Johns, 1961), the presence of numerous sulfidebearing stocks with locally abundant fluorite and lesser tourmaline, and the nearby, weakly mineralized breccia pipe may indicate that this area is underlain by a major hydrothermal system. Alternatively, this area may represent an extension of the hydrothermal system that mineralized the Granite Peak area. Most mines in this area explored precious-metal veins. Almost all of these mines are outside the roadless area (Tansley and others, 1933; Johns, 1961), but some, such as those in the Boulder Lakes area are directly adjacent to the roadless area boundary. Several of these mines were closed at the beginning of World War II and may have gold resources at depth. The Boulder Lakes area is considered to have a substantiated resource potential for gold and silver and a probable resource potential for base metals.

The Strawn mine on the west side of the roadless area is an active gold mine that is nearly surrounded by the roadless area boundaries; the mine has yielded at least $1600 \mathrm{oz}$ of gold since 1921 . The main vein carries free gold in a thin, silicified zone in limestone adjacent to a thin granitic sill. The vein has been traced several thousand feet southward into the roadless area. This area is considered to have substantiated mineral-resource potential for gold.

\section{REFERENCES}

James, H. L, and Hedge, C. E., 1980, Age of basement of southwestern Montana: Geological Society America Bulletin, v. 91 , pt. 1, p. 11-15

Johns, W. J., 1961, The geology and mineraldeposits of the Tidal Wave Mining District, Madison County, Montana: Montana Bureau of Mines and Geology Memoir, $53 \mathrm{p}$.

O'Neill, J. M., 1983a, Geologic map of the Middle Mountain-Tobacco Root Roadless Area, Madison County, Montana: U.S. Geological Survey Miscellaneous Field Studies Map MF-1590-A, scale 1:50,000. 
1983b, Geochemical map of the Middle Mountain-Tobacco Root Roadless Area, Madison County, Montana: U.S. Geological Survey Miscellaneous Field Studies Map MF-1590-B, scale 1:50,000.

1983c, Mineral resource potential map of the Middle Mountain-Tobacco Root Roadless Area, Madison County, Montana: U.S. Geological Survey Miscellaneous Field Studies Map MF-1590-C, scale 1:50,000.

O'Neill, J. M., Siems, D. F., Welsch, E. P., and Speckman, W. W., 1980 , Geochemical analyses of stream sediments of the Middle Mountain-Tobacco Root Further Planning Area (RARE II), Madison County, Montana: U.S. Geological Survey Open-File Report 80-720,6 p.
Reid, R. R., 1957, Geology of the Tobacco Root Mountains: Montana Bureau of Mines and Geology Memoir, $27 \mathrm{p}$.

Schmidt, C. J., 1975, An analysis of folding and faulting in the northern Tobacco Root Mountaions, southwestern Montana: University of Indiana, unpublished Ph.D. thesis, 480 p.

Schmidt, C. J., and O'Neill, J. Michael, 1983, Structural evolution of the central Montana transverse zone in R. Powers, editor, Rocky Mountain Association Geologists Symposium, Powers, R. ed., in press.

Tansley, W., Schafer, P. A., and Hart, L. H., 1933, A geological reconnaissance of the Tobacco Root Mountains, Madison County, Montana: Montana Bureau of Mines and Geology Memoir 9, $57 \mathrm{p}$. 


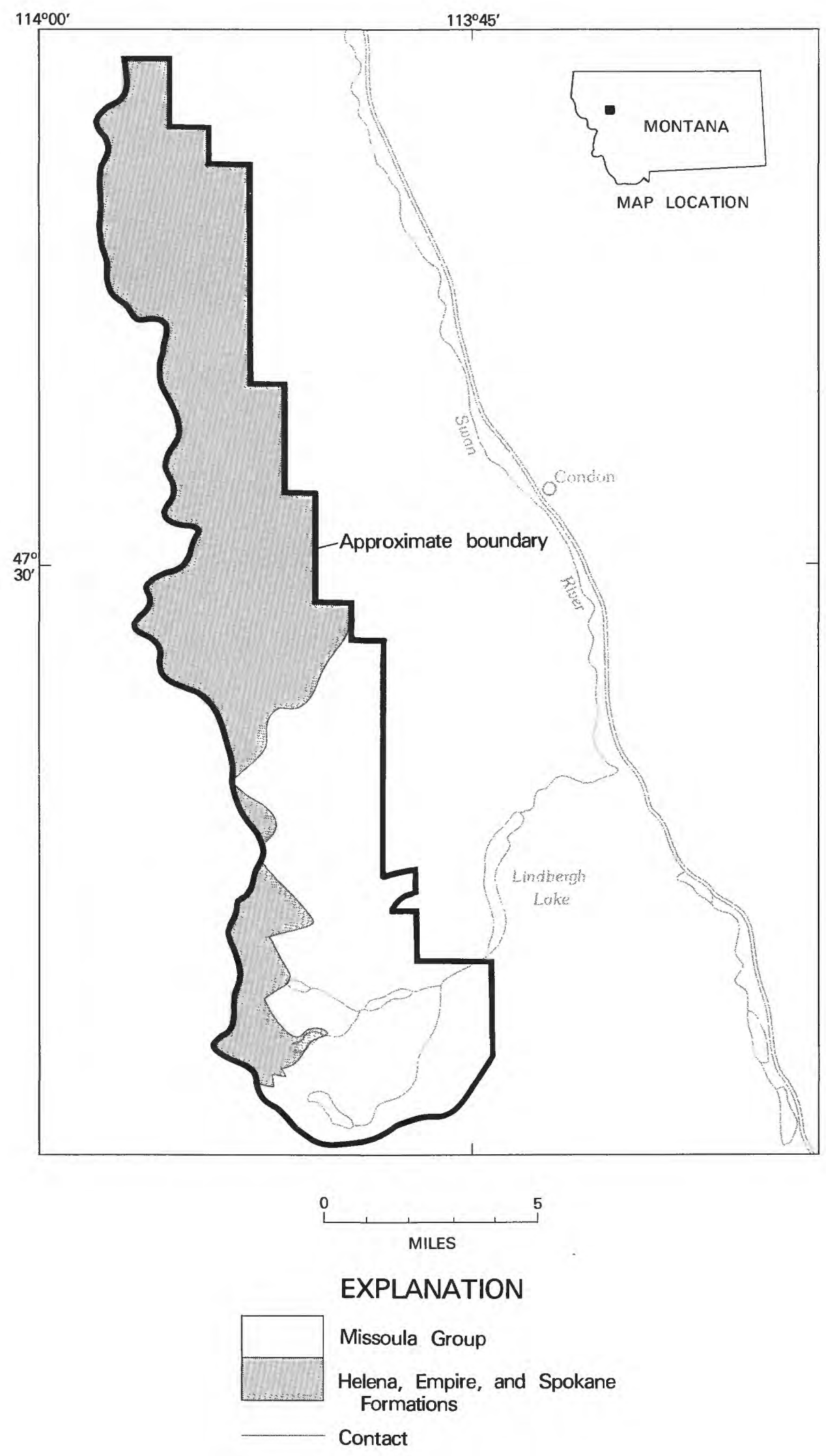

Figure 206.-Mission Mountains Wilderness, Montana. 


\title{
MISSION MOUNTAINS WILDERNESS, MONTANA
}

\author{
By JACK E. HARrison, U.S. GeOloGiCal Survey, and \\ Eldon C. Pattee, U.S. Bureau of Mines
}

\begin{abstract}
SUMMARY
A mineral survey of the Mission Mountains Primitive Area was conducted in 1967. No evidence of metallic or energy resources was identified during the course of this study. The primitive area was formally established as a wilderness in 1975.
\end{abstract}

\section{CHARACTER AND SETTING}

The Mission Mountains Wilderness occupies an area from the crest of the Mission Range eastward toward the valley of the Swan River in western Montana about $40 \mathrm{mi}$ north of Missoula. The wilderness, about $4 \mathrm{mi}$ wide and $30 \mathrm{mi}$ long, was studied in 1967 and the results were published by Harrison and others (1969). The west boundary coincides with part of the boundary of the Flathead Indian Reservation. Rugged peaks of the Mission Range rise sharply from the Mission Valley and present a spectacular view to travellers on U.S. Highway 93 as they traverse the valley between St. Ignatius and Polson. The valley is about $3000 \mathrm{ft}$ in altitude, and the crestline of the peaks is at 8000 to $9800 \mathrm{ft}$.

Bedrock in the wilderness consists almost entirely of low-grade metasedimentary strata of the Belt Supergroup of Middle Proterozoic age. Lowest exposed strata are purple and green argillites and siltites of the Spokane Formation that are overlain by dolomitic green argillites of the Empire Formation, dolomite and dolomitic fine-grained clastic rocks of the Helena Formation, purple and green siltites interbedded with argillite of the Snowslip Formation, thinly laminated dolomitic green argillites and gray dolomitic beds of the Shepard Formation, and red siltite, argillite, and quartzite of the Mount Shields Formation. These strata all dip gently eastward and strike northerly; this simple homoclinal structure is disrupted only slightly by a few faults of small stratigraphic offset. A quartz diorite sill and silldike as thick as $200 \mathrm{ft}$ of probable Tertiary age are intruded into the Belt strata.

\section{MINERAL RESOURCES}

The geologic setting of the wilderness is not favorable for mineral resources when compared with mineralized areas of western Montana. The nearest mining districts, tens of miles away, are associated with granitic intrusive rocks, volcanic centers, highly faulted and fractured rocks, or with stratabound (confined to certain strata) sulfides in Belt rocks. Of these kinds of characteristics, only the possibility for stratabound coppersilver sulfides applies to the wilderness, and even then the most favorable zones are thousands of feet below the rocks exposed in the wilderness. An intensive search for stratabound copper-silver sulfides in the area found only sporadic and insignificant occurrences in surface strata. Rocks of the Belt Supergroup are not favorable for oil and gas or coal resources.

\section{SUGGESTIONS FOR FURTHER STUDIES}

No further studies can be recommended at this time, as the growing bank of data for western Montana on stratabound sulfides in Belt rocks reinforces the original evaluation of an unfavorable geologic setting for ore deposits in the wilderness.

\section{REFERENCE}

Harrison, J. E., Reynolds, M. W., Kleinkopf, M. D., and Pattee, E. C., 1969. Mineral resources of the Mission Mountains Primitive Area, Missoula and Lake Counties, Montana: U.S. Geological Survey Bulletin 1261-D, 48 p. 

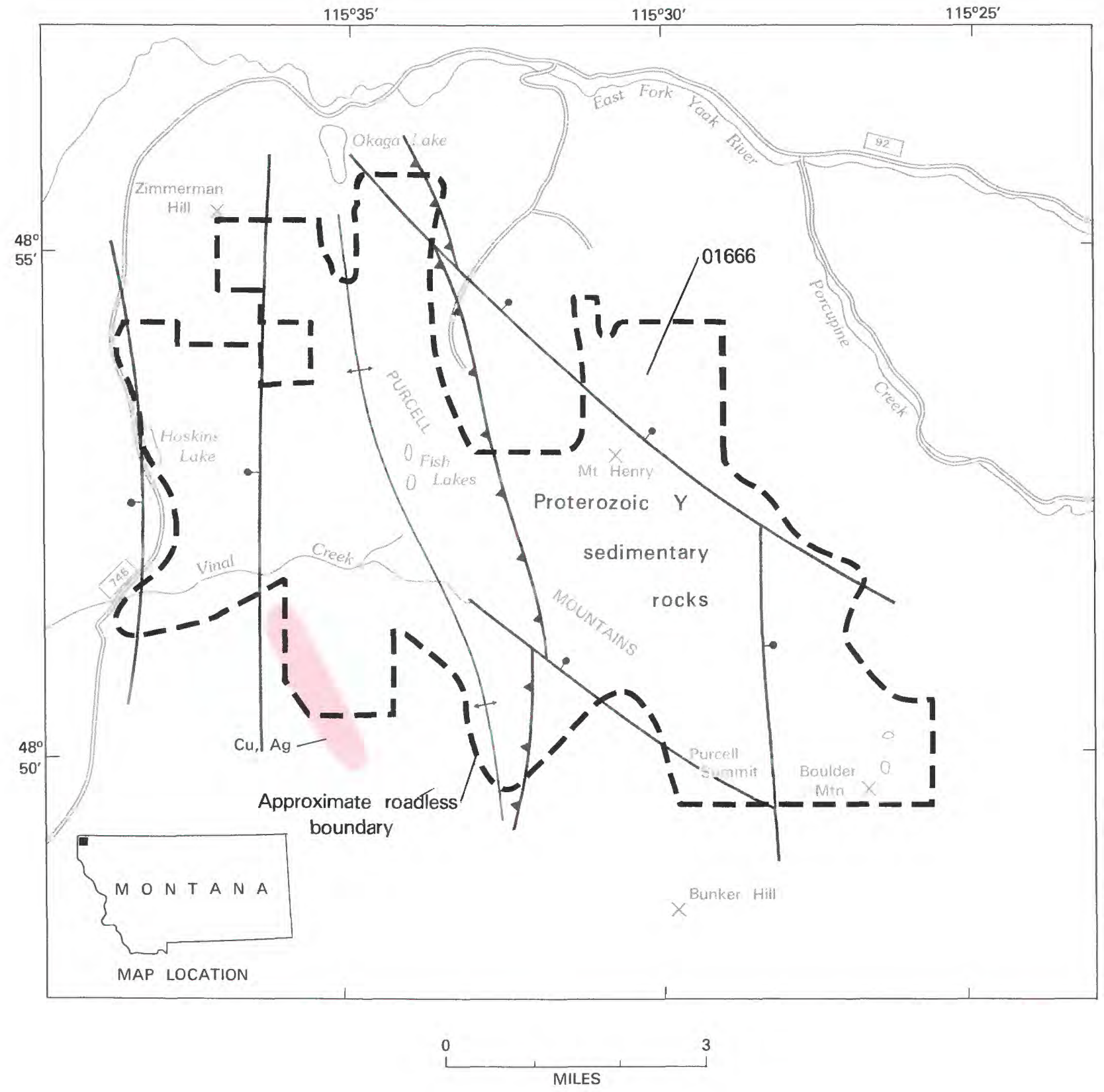

\section{EXPLANATION}

Geologic terrane with probable mineral-resource potential

\section{$\mathrm{Cu}$ Copper \\ Ag Silver}

- Fault--Bar and ball on downthrown side

A Thrust fault--Sawteeth on upper plate

! Anticline

Figure 207.-Mount Henry Roadless Area, Montana. 


\title{
MOUNT HENRY ROADLESS AREA, MONTANA
}

\author{
By Richard E. VAn LOENEn, ${ }^{1}$ U.S. GeOlogical Survey, and \\ Martin D. CONYAC, U.S. BurEaU OF MineS
}

\section{SUMMARY}

\begin{abstract}
A mineral survey of the Mount Henry Roadless Area, Lincoln County, Montana, was conducted in 1980 and 1981 . A small area located along the southwest boundary was determined to have a probable mineral-resource potential for lowgrade deposits of stratabound copper and silver. There is little possibility for locatable mineral, coal, oil, gas, and geothermal resources in the remainder of the area. There are no mines, prospects, or records of mineral production within the roadless area.
\end{abstract}

\section{CHARACTER AND SETTING}

The USGS and the USBM conducted studies in the Mount Henry Roadless Area including geologic mapping (Van Loenen, 1983), geochemical sampling (Seims and others, 1983), geophysical studies (Bankey and others, 1983), a courthouse record search and on-site inspection of nearby mining properties by M. D. Conyac in 1980, and the compilation of a mineral-resource potential map by Van Loenen and others (1983).

The Mount Henry Roadless Area lies within the Kootenai National Forest in Lincoln County, Montana, and is approximately $36 \mathrm{mi}$ north of Libby, Montana. The area covers $36 \mathrm{sq} \mathrm{mi}$ of the heavily forested Purcell Mountains in the drainage basin of the Kootenai River. Altitudes range from $3400 \mathrm{ft}$ along the Yaak River to $7200 \mathrm{ft}$ on Mount Henry. Thick accumulations of glacial debris cover much of the area. Bedrock is exposed mostly on the high ridges, along some stream drainages, and in recent logging roadcuts. Extensive logging operations have taken place adjacent to the roadless area, causing the very irregular boundary. Many of the roads constructed for these operations are maintained, providing easy access to most of the area. Trails are limited within the area; many shown on 1963 topographic maps are in poor condition and difficult to locate. This remote area is accessible from Highway 508 north of Troy, Montana, or by the Pipe Creek road north of Libby, Montana.

The Mount Henry Roadless Area is underlain by rocks of the Belt Supergroup, a thick sequence of metasedimentary rocks of Proterozoic age (850-1400 million

\footnotetext{
${ }^{1}$ With contributions from David F. Siems, Reinhard W. Leinz, Viki Bankey, M. Dean Kleinkopf, and Donald Hoover, USGS.
}

years old). In Proterozoic time sediments (muds, silts, fine sand, and carbonates) accumulated to over $40,000 \mathrm{ft}$ in thickness in a large basin known as the Belt basin of western Montana, Idaho, and southern Canada. Lithification of these sediments was later followed by lowgrade regional metamorphism resulting in the present rock types, argillites, siltites, quartzites, and recrystallized limestones of various drab shades of gray, green, and red. Folding, faulting, and erosion have exposed nearly $16,000 \mathrm{ft}$ of this section within the roadless area.

The structural history of the region probably began during Proterozoic time when tectonism was hited to faulting associated with subsidence and downwarping as the basin was filled by great thicknesses of sediments. Major tectonic deformation began about 200 million years ago and continued throughout the Laramide orogeny (50-60 million years ago). The rocks of this region are thought to be an allochthonous part of an extensive fold and thrust belt that has been transported eastward many miles across coeval autochthonous rocks in the Cordillera of Idaho, Montana, and southern Canada.

The structural setting of the Mount Henry Roadless Area is a broad anticline with a north-trending axis located near the center of the area. Erosion along the axis of the anticline has exposed the oldest rocks in the roadless area. A northerly trending thrust fault with movement from west to east nearly bisects the anticline. Also transecting the roadless area are north-northwesttrending high-angle faults, some with as much as 2000 $\mathrm{ft}$ of displacement.

Many of the physiographic features present today in the Mount Henry Roadless Area result from erosion 
and deposition of glacial deposits by Cordilleran ice sheets and alpine glaciers during Pleistocene time.

The U.S. Government owns all surface and mineral rights in the Mount Henry Roadless Area. No mines or evidence of prospecting were seen in the roadless area during this investigation, although the area is on the periphery of the Yaak (Sylvanite) district, which is centered $25 \mathrm{mi}$ to the southwest, and the Ural district, which lies $15 \mathrm{mi}$ to the southeast. Reported production from the Yaak district totaled 22,500 tons of ore valued at the time at $\$ 251,600$ from iron-copper-lead sulfides and native gold. Nearly all production was from one mine that operated prior to 1937 . The Ural district has about seven lode and three placer properties. Production is unreported or reported only as small, possibly only a few hundred tons.

\section{MINERAL RESOURCES}

The Mount Henry Roadless Area is underlain by at least two formations (Revett and Prichard Formations of the Belt Supergroup) that elsewhere in the Belt basin host deposits of copper-silver and lead-zinc. These deposits are stratabound in nature and probably originated during early diagenesis; seemingly other deposits should exist, given the same favorable conditions, in rocks of the same age and same stratigraphic position. Special attention was given to identifying these types of deposits within the Mount Henry Roadless Area, but none were found. Several prospects and a few productive mines are located on fault structures in adjacent areas, and some of these structures extend into the Mount Henry Roadless Area. Only a few randomly scattered samples contaiming slightly anomalous concentrations of metals were found along these structures. Geophysical studies which included gravity and aeromagnetic surveys, and audiomagnetotelluric soundings did not define any unusual or anomalous areas.

The Revett Formation (quartzite) hosts stratabound occurrences of copper and silver at several localities in the western part of the Belt basin. One mine in the Spar Lake district south of Troy, Montana, and $55 \mathrm{mi}$ south of the roadless area is currently producing copper-silver ore which averages 0.7 percent copper and $1.5 \mathrm{oz}$ of silver/ton. The Mount Henry Roadless Area lies just north of a "Western sulfide belt" (which includes the Spar Lake district) identified as an area favorable for stratabound deposits of copper and silver. The Revett Formation is well exposed on prominent ridges in the roadless area where it was carefully studied and sampled. No indications of mineralization were seen in outcrop and samples collected and analyzed were largely barren.

Minor indications of copper- and silver-bearing minerals occur in rocks of the Burke Formation of the Belt Supergroup just below the Revett Formation southwest of the roadless area. This occurrence is only a few inches thick and probably is not extensive laterally. Channel samples collected several feet above and below the copper zone contain only trace amounts of copper. Small stratabound copper and silver occurrences such as this are not uncommon in most formations throughout the Belt basin. This area and its extension into the roadless area are shown as having probable copper and silver resource potential.

Stratabound lead-zinc mineral occurrences are known in lower Belt rocks approximately $60 \mathrm{mi}$ north of the Mount Henry Roadless Area near Kimberley, British Columbia. High-grade lead-zinc ore is being mined from the lower middle part of the Aldridge Formation (Canadian equivalent to the lower part of the Prichard) at the Sullivan mine. This stratigraphic horizon is exposed a few miles west of this roadless area, where it contains no known deposits of lead and zinc minerals. In the Mount Henry Roadless Area, the same horizon would occur several thousand feet below the surface and well below the lowermost Prichard exposures.

Gold was not found in any stream-sediment samples or concentrates collected from the area of the early placer claims.

The oil and gas potential of the Mount Henry Roadless Area is unknown. Phanerozoic source rocks could be present beneath the thrust fault that underlies the allochthonous Proterozoic rocks of the area, but this possibility is considered unlikely. No drilling has been done anywhere in the region.

\section{SUGGESTIONS FOR FURTHER STUDIES}

The Revett and Prichard Formations of the Belt basin have been the focus of attention of many exploration companies in recent years for deposits of copper-silver and lead-zinc. Exploration also continues in a search for younger (Phanerozoic) rocks beneath older (Proterozoic) rocks which might contain oil and gas. Many formations throughout the Belt basin are poorly understood, and their potential for oil and gas and base metals probably is not yet realized. A better understanding of the ore controls in Belt rocks and tectonic structures of the Belt basin on a regional scale could conceivably indicate favorable ground in the Mount Henry Roadless Area; however, until then, further studies are probably not warranted. 


\section{REFERENCES}

Bankey, Viki, Kleinkopf, M. D., and Hoover, Donald, 1983, Geophysical studies of the Mount Henry Roadless Area, Lincoln County, Montana: U.S. Geological Survey Miscellaneous Field Studies Map MF-1534-C, scale 1:50,000.

Siems, D. F., Leinz, R. W., Van Loenen, R. E., Wadsworth, Gail, and McDougal, C. M., 1983, Reconnaissance geochemical map of the Mount Henry Roadless Area, Lincoln County, Montana: U.S. Geological Survey Miscellaneous Field Studies Map MF-1534-B, scale 1:50,000.
Van Loenen, R. E., 1983, Geologic map of Mount Henry Roadless Area, Lincoln County, Montana: U.S. Geological Survey Miscellaneous Field Studies Map MF-1534-A, scale 1:50,000.

Van Loenen, R. E., Siems, D. F., Bankey, Viki, and Conyac, M. D., 1983, Mineral resource potential map of the Mount Henry Roadless Area, Lincoln County, Montana: U.S. Geological Survey Miscellaneous Field Studies Map MF-1534-D, scale 1:50,000. 

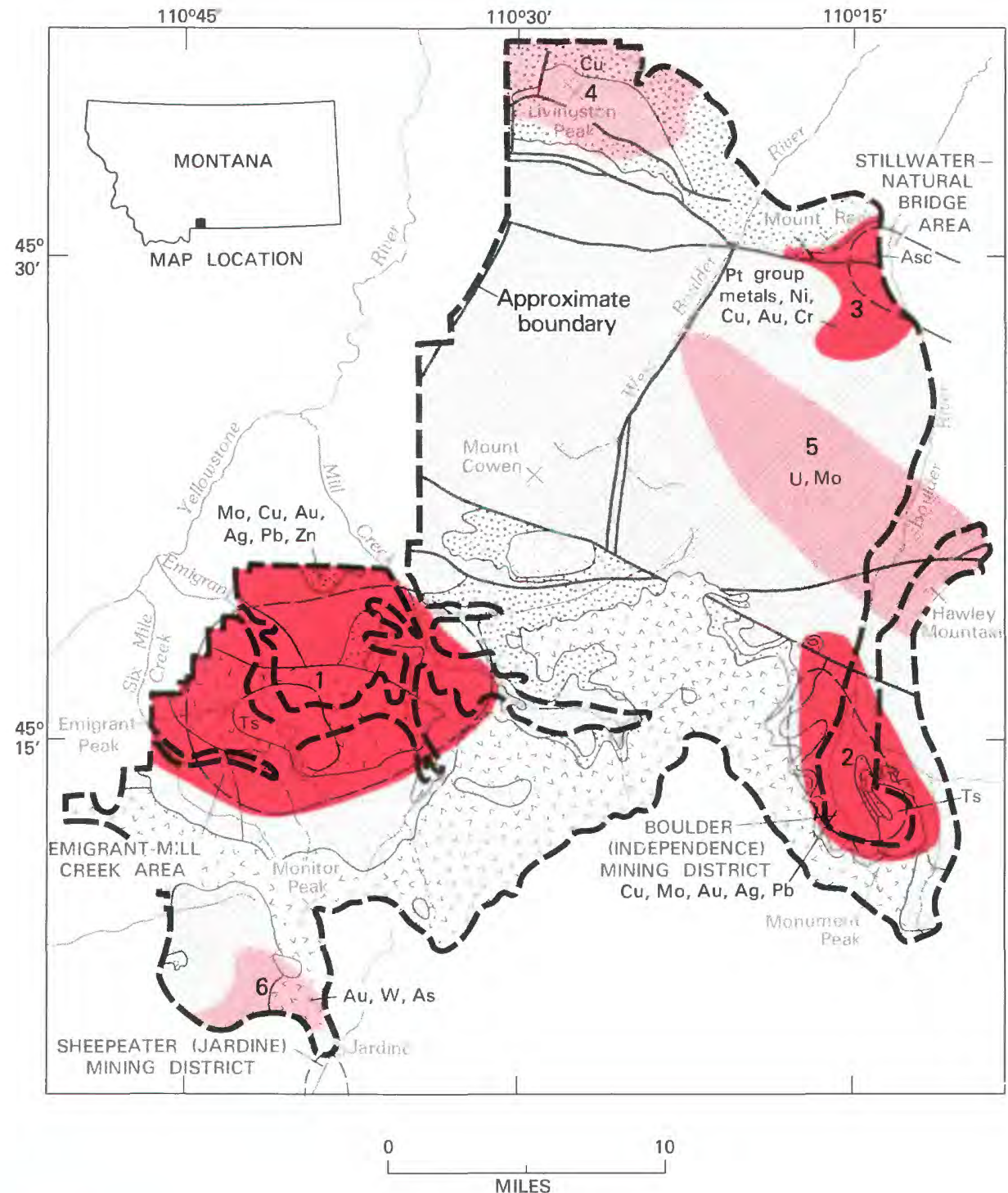

EXPLANATION

Geologic terrane with substantiated mineral-resource potential

Geologic terrane with probable mineral-resource potential

Arsenic

Chromium

Copper

Gold

Lead

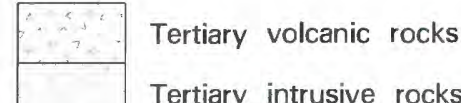

Molybdenum

Nickel

Platinum

Silver

Tungsten

Uranium

Tertiary stocks

Mesozoic and Paleozoic rocks

Precambrian rocks

Archean Stillwater Complex

Zinc

Figure 208.-North Absaroka study area, Montana. 


\title{
NORTH ABSAROKA STUDY AREA, MONTANA
}

\author{
By J. E. Elliott, U.S. GeOlogical Survey, and \\ R. B. Stotelmeyer, U.S. Bureau of Mines
}

\section{SUMMARY}

A mineral survey of the North Absaroka study area was conducted during 1973 and 1974. The results of this survey indicate that parts of the area are extensively mineralized and that the area has potential for resources of gold, silver, copper, molybdenum, nickel, lead, zinc, platinum-group metals, uranium, iron, manganese, chromium, tungsten, and arsenic. Six areas of probable and substantiated mineral-resource potential were identified. The nature of the geologic terrain indicates that there is little likelihood for occurrence of oil, gas, coal, or geothermal resources.

\section{CHARACTER AND SETTING}

The purpose of this mineral survey was to evaluate the mineral-resource potential of the North Absaroka study area, an area of approximately $540 \mathrm{sq} \mathrm{mi}$ in the Gallatin National Forest, Park and Sweet Grass Counties, Montana. This area was proposed as an addition to the Beartooth and Absaroka Primitive Areas studied previously (Simons and others, 1973; Wedow and others, 1975). Most of these three areas have been combined to form the Absaroka-Beartooth Wilderness. This report has been summarized from reports by Elliott and others (1983) and Stotelmeyer and others (1983).

The North Absaroka study area is located in southcentral Montana just north of Yellowstone National Park. On the southwest, west, and north sides the area is bordered by the valley of the Yellowstone River and on the northeast side it is bordered by the Boulder River. Nearly all of the area has extremely high relief and rugged topography. More than 25 peaks have altitudes in excess of $10,500 \mathrm{ft}$ with the highest being Mt. Cowen $(11,206 \mathrm{ft})$ in the west-central part of the area.

The North Absaroka study area spans two major geologic provinces; the western part of the Beartooth uplift and the northeastern part of the Absaroka-Gallatin volcanic province. The Beartooth uplift is a broad faultbounded structural block that rises abruptly from the Great Plains province to the north and east. The uplift is bounded on the north by the Crazy Mountain basin, a northwesterly trending structural basin filled with sedimentary and volcaniclastic rocks and on the west by the alluvium-filled valley of the Yellowstone River. No sharp topographic break exists along much of the southern part of the uplift where it merges into the Absaroka-Gallatin volcanic province.

Metamorphic and igneous rocks of Precambrian age constitute the core of the Beartooth uplift and make up about 60 percent of the bedrock of the study area. Tertiary igneous rocks of the Absaroka-Gallatin volcanic province cover the southern part of the study area and make up about 30 percent of the bedrock. Sedimentary rocks of Paleozoic and Mesozoic age cover half the remaining area, and the rest consists of surficial deposits of Quaternary age (glacial deposits, alluvium, landslides, and talus that conceal bedrock in many places).

This region has had a long and complex geologic history. During the period of about 3500 to 1000 million years (m.y.) ago sedimentation and volcanism were followed by several periods of folding, faulting, metamorphism and igneous intrusion. The region was covered by shallow seas during the Paleozoic and Mesozoic Eras, about 570 to 63 m.y. ago; during this time a thick pile of carbonate and clastic sedimentary rocks were deposited. Following this lengthy period of crustal stability, the Laramide orogeny began in the late Mesozoic and continued into the early Tertiary, about 60 to $40 \mathrm{~m} . y$. ago. During this orogeny, the Beartooth uplift was formed, many intrusives were emplaced, and volcanic rocks of the Absaroka-Gallatin volcanic province were formed. In late Tertiary time ( 25 to $2 \mathrm{~m} . \mathrm{y}$. ago) the region was uplifted to approximately its present altitude. Glaciation and erosion during Quaternary time developed the present topography.

The geologic structure of the study area is complex 
and is the cumulative result of two periods of major deformation. Precambrian deformation produced a complex series of structures and included several periods of folding. Laramide deformation consisted of the development of several high-angle normal and reverse faults which bound major structural blocks of the Beartooth uplift. A major zone of structural downwarping, the Cooke City zone, which trends southeastward from Mill Creek to the Clarks Fork canyon in Wyoming may be a control for Tertiary volcanic vents, plutons, dikes, and mineralized areas. Paleozoic and Mesozoic rocks were also folded during the Laramide.

\section{MINERAL RESOURCES}

The mineral survey by the USGS and the USBM included geologic mapping, geochemical sampling, geophysical surveys, a search of courthouse records, examination of claims and mineralized areas, and a compilation of production records. During the geochemical survey samples of rocks and stream sediments were collected and analyzed. Geophysical studies consisted of aeromagnetic and gravity surveys.

The study area includes all or parts of seven organized and unorganized mining districts and subdistricts. More than 3500 lode and 580 placer claims have been recorded within the study area or the excluded corridors. Geothermal lease applications for about $40 \mathrm{sq} \mathrm{mi}$ have been made on two tracts in the southwest part of the area.

Recorded and estimated production from the study area and excluded corridors has been about $50,000 \mathrm{oz}$ of gold and minor amounts of silver, copper, lead, and zinc. Production from the Sheepeater (Jardine) district adjacent to the southwestern corner of the study area has been $180,000 \mathrm{oz}$ of gold, $778,000 \mathrm{lbs}$ of tungsten trioxide, 12.6 million lbs of arsenic trioxide, and minor amounts of copper, lead, and silver.

The only active mining operations in the study area during 1973-74 were a small placer and development at a small lode mine. However, several mining companies were conducting exploration programs in different parts of the area.

A variety of metallic mineral deposits occur in and adjacent to the study area. The majority of these are clustered in four areas: the Emigrant-Mill Creek area, the Boulder (Independence) mining district, the Stillwater-Natural Bridge area, and the Sheepeater (Jardine) mining district.

In the Emigrant-Mill Creek area and the Boulder mining district the mineralization is related to igneous rocks of early Tertiary age. Both areas contain vein, replacement, and disseminated types of deposits containing base and precious metals and molybdenum. The Emigrant-Mill Creek area also has stockwork and breccia pipe deposits within the Emigrant stock. In both areas, there is an apparent zonation of metals and alteration facies centered on eruptive centers of Tertiary age. These areas have produced significant amounts of gold and minor amounts of silver, copper, lead, and zinc. Other metals known to occur in these two areas are molybdenum, tungsten, bismuth, manganese, and iron. Both areas (areas 1 and 2, on map) have a substantiated resource potential for porphyry-type copper and molybdenum deposits.

Two other areas with known deposits are the Sheepeater (Jardine) mining district and the StillwaterNatural Bridge area. The mineral deposits are in rocks of Precambrian age, but, the metal suites and types of deposits are very different in each of the areas. In the Sheepeater district, gold-tungsten-arsenic deposits occur in Archean banded ironstone and carbonaceous metasedimentary rocks and are similar to those of the Homestake mine at Lead, South Dakota (Seager, 1944; Hallager, 1982; Rye and Rye, 1974). These are stratabound deposits genetically related to ironstone beds which have been remobilized and folded during metamorphism and plutonism. This geologic terrane extends into the study area (area 6) and geochemical anomalies indicate that there is a probable resource potential for similar types of deposits. The Stillwater-Natural Bridge area encloses several types of mineral deposits located in or near the lower part of the Archean Stillwater Complex, a mafic and ultramafic stratiform igneous body that outcrops along the northeast edge of the Beartooth uplift. The area of substantiated mineral-resource potential (area 3) includes the Stillwater Complex that contains a substantiated resource potential for stratiform magmatic deposits of chromium, nickel, copper, and platinum group metals and also includes small quartz-gold veins in Precambrian hornfels near the base of the Stillwater Complex.

Two additional areas within the study area have probable mineral resource potential: the Livingston Peak area for copper (area 4) and Hawley Mountain-West Boulder for uranium and molybdenum (area 5). This assessment was based on favorable geology, geochemical and geophysical anomalies, and recent exploration activity.

\section{SUGGESTIONS FOR FURTHER STUDIES}

Further studies are recommended for the Emigrant intrusive center, the Livingston Peak area, and for the areas of occurrence of Precambrian iron formation. 
Studies in the Emigrant intrusive center should include detailed mapping, geochemical sampling, and petrographic and fluid inclusion studies. The Livingston Peak area needs detailed mapping and geochemical and ground geophysical surveys to better define the potential of this anomalous area. In addition, there are several occurrences of iron-formation in Precambrian terrane in the study area. These should be examined and sampled in detail to better evaluate their potential for Homestake-type gold mineralization.

\section{REFERENCES}

Elliott, J. E., Gaskill, D. L., Raymond, W. H., and Peterson, D. L., 1983, Chapter A-Geological, geochemical, and geophysical investigations of the North Absaroka study area, Park and Sweet Grass Counties, Montana, in Mineral Resources of the North Absaroka study area, Park and Sweet Grass Counties, Montana: U.S. Geological Survey Bulletin 1505 (in press).

Hallager, W. S., 1982, Geology of an Archean stratiform gold deposit near Jardine, Montana [abs.]: Proceedings of Symposium on the genesis of Rocky Mountain ore deposits by Denver Region Exploration Geologists Society, November 4-5, Denver, Colorado.
Rye, D. M., and Rye, R. O., 1974, Homestake Gold Mine, South Dakota, I. Stable isotope studies: Economic Geology, v. 69, no. 3, pp. 293-317.

Seager, G. F., 1944, Gold, arsenic, and tungsten deposits of the Jardine-Crevasse Mountain district, Park County, Montana: Montana Bureau of Mines and Geology Memoir 23, 111 p.

Simons, F. S., Armbrustmacher, T. J., Van Noy, R. M., Zilka, N. T., Federspiel, F. E., and Ridenour, James, 1973, Mineral resources of the Beartooth primitive area and vicinity, Carbon, Park, Stillwater, and Sweet Grass Counties, Montana, and Park County, Wyoming, with a section on Interpretation of aeromagnetic data, by L. A. Anderson: U.S. Geological Survey Bulletin 1391-F, $125 \mathrm{p}$.

Stotelmeyer, R. B., Johnson, F. L., Lindsey, D. S., Ridenour, James, and Schmauch, S. W., 1983, Chapter B-Economic appraisal of the North Absaroka study area, Park and Sweet Grass Counties, Montana in Mineral resources of the North Absaroka study area, Park and Sweet Grass Counties, Montana: U.S. Geological Survey Bulletin 1505 (in press).

Wedow, Helmuth, Jr., Gaskill, D. L., Banister, D. P., and Patte, E. C., 1975, Mineral resources of the Absaroka primitive area and vicinity, Park and Sweet Grass Counties, Montana, with a section on Interpretation of geophysical data by D. L. Peterson: U.S. Geological Survey Bulletin 1391-B, 115 p. 

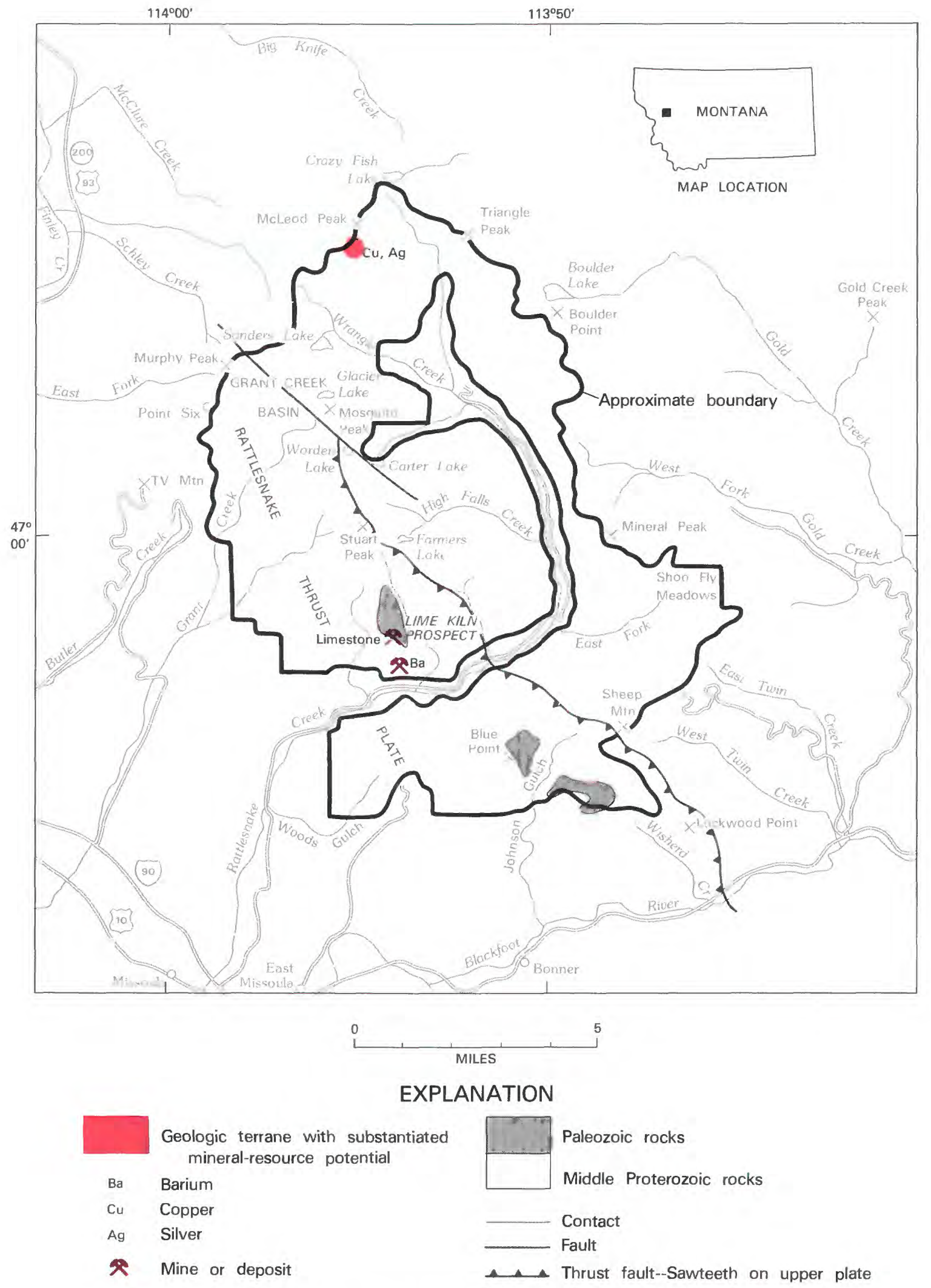

Figure 209.-Rattlesnake Roadless Area, Montana. 


\title{
RATTLESNAKE ROADLESS AREA, MONTANA
}

\author{
By C. A. Wallace, U.S. Geological Survey, and \\ Ronald T. MAYERLE, U.S. BuREAU of Mines
}

\section{SUMMARY}

Geologic, geochemical, and geophysical surveys of the Rattlesnake Roadless Area by the USGS in 1979 and USBM in 1982 identified a small area of substantiated resource potential for a low-grade stratabound copper occurrence along the northwest border of the area. A demonstrated barite $\left(\mathrm{BaSO}_{4}\right)$ resource of 45 tons and a demonstrated limestone resource suitable for cement production are present in the southern part of the roadless area. Limestone, silica in quartz veins, and sand and gravel deposits are known in the southern part of the area but similar deposits occur widely outside the study area. There is little promise for the occurrence of energy resources in the Rattlesnake Roadless Area.

\section{CHARACTER AND SETTING}

The Rattlesnake Roadless Area encompasses a mountainous area of about $71 \mathrm{sq} \mathrm{mi}$ in the southern part of the Jocko Mountains, western Montana. The roadless area is about $3 \mathrm{mi}$ north of Missoula and is bordered on the north and northwest by the Flathead Indian Reservation. Paved and gravel roads provide access to the roadless area from the south and east. The upper reaches of Grant, Rattlesnake, and Wrangle Creeks flow through the rugged topography of sharp ridges and peaks, and deep, steep-sided canyons typical of glacially sculptured terranes. Numerous small lakes occupy glacial valleys in the roadless area. McLeod Peak, along the north border of the roadless area, is $8280 \mathrm{ft}$ high, and nearby Missoula is at about $3200 \mathrm{ft}$ at the east end of a broad valley.

The approximate boundaries of the Rattlesnake Roadless Area shown on the map are those established in 1979 when the geologic, geophysical, and geochemical studies were conducted. In 1980 the northern part of the roadless area was proposed as wilderness, and the south part of the area was proposed as a national recreation area. The original study area is a patchwork of private land ownership interspersed with land administered by the USFS.

Most of the Rattlesnake Roadless Area is underlain by hard and resistant weathering sedimentary rock of the Belt Supergroup, which is older than about 950 million years. The oldest exposed rock unit contains some limestone and dolomite that is interbedded with fine-grained sandstone and mudstone. Rock units above this oldest unit are mainly red and green mudstone, interbedded with fine-grained sandstone, and cleanly washed sandstone and conglomerate of the Missoula Group. After deposition of these units, a period of uplift, faulting, folding, and intrusion of dikes and sills occurred. About 600 million years ago this region was again inundated by the sea; sandstone, shale, and limestone of early Paleozoic age were deposited on an eroded surface. Presumably younger Paleozoic sedimentary rocks were deposited in the region after deposition of the early limestone, but later erosional events may have removed these rocks. Before approximately 80 million years ago large plates of rock were pushed eastward as thrust plates, which eventually formed the Montana segment of the thrust belt. The Rattlesnake thrust plate, the leading edge of which trends southeast across the roadless area, is only one part of the larger Montana thrust belt. Rocks of Belt age and of early Paleozoic age were transported to their present position an unknown distance from the southwest or west. After emplacement of the Rattlesnake thrust plate, vertical faulting occurred and later glacial sculpting formed the present rugged topography of the roadless area.

Geochemical studies included sampling and analysis of rocks, stream sediments, and panned concentrates. Geophysical interpretations are based on an aeromagnetic survey and a gravity survey of the roadless area.

A survey of mining records and field study of prospects and mining claims indicates that there was no mineral production from the roadless area. At least 99 lode claims have been located since 1866 , but none of the claims are current within the roadless area. 


\section{MINERAL RESOURCES}

The Rattlesnake Roadless Area does not contain sedimentary rocks that are traditionally associated with large mineral deposits. Granitic plutons that might contain mineralization systems similar to that of Butte, are absent. Older rocks of the Belt Supergroup that contain copper-silver or lead-zinc-silver elsewhere are absent.

Geologic, geochemical, and geophysical surveys located four areas that showed evidence of mineralization or had suggestive high geochemical anomalies. Three of those four areas contain dikes and sills that are exposed at the surface or that are thought to be buried at shallow depth. The dikes and sills contain anomalously high amounts of titanium, manganese, chromium, zirconium, cobalt, vanadium, niobium, and zinc, but they have little promise for the occurrence of resources because the concentrations of commodity elements in the rocks are relatively low and because dikes and sills containing this suite of elements occur at numerous other locations in western Montana. The fourth area located during this survey, south of McLeod Peak, contains a small low-grade stratabound copper occurrence. The mineralized rock occurs in a zone that contains dispersed thin beds of dolomitic, fine-grained sandstone. Beds that contain copper and some silver minerals are thin, low grade, and discontinuous. About 35,000 tons of inferred resources containing about 0.55 percent copper and $0.2 \mathrm{oz}$ silver/ton occur and the area is considered to have substantiated resource potential.

Numerous, isolated, single-element geochemical anomalies occur locally in the roadless area, but none of these could be related to specific systems of mineralization using geologic, geochemical, or geophysical interpretations.

A barite vein is located on land controlled by Montana Power Company. The barite vein contains demonstrated barite resources of about 45 tons but the full extent of the vein is not known. Industrial-grade limestone occurs at the Lime Kiln prospect. Two other areas of similar limestone occur in the roadless area and these are shown as outcrops of Paleozoic rocks. The occurrence at the Lime Kiln prospect contains an estimated 500,000 tons of demonstrated limestone resources suitable for cement production.

Although limestone, quartz veins, and sand and gravel deposits are known in the roadless area, similar deposits occur widely in the region outside the area.
Barite resources occur in numerous deposits 25 mi east of the roadless area in the Garnet Range.

The roadless area has little promise for the occurrence of coal, radioactive mineral, or geothermal resources. Although the Hellgate coal mine, located south of the roadless area, was active intermittently until 1944, young valley-fill deposits that contain the coal do not extend into the roadless area. The potential for the occurrence of oil and gas in the roadless area is unknown. The rocks exposed at the surface typically do not produce oil or gas, but thrust faulting may have pushed these older rocks over younger rocks that do have potential for oil and gas. However, based on regional knowledge of rock types and thrust faulting, it is considered unlikely that oil and gas resources exist in the area.

\section{SUGGESTIONS FOR FURTHER STUDIES}

No further studies on the potential for the occurrence of mineral resources are suggested for the Rattlesnake Roadless Area. The potential for the occurrence of oil and gas resources depends mainly on the possibility that oil-bearing strata may be present below the Rattlesnake thrust plate, and that regional thermal gradients have remained low enough during the last 225 million years to preserve oil or gas; that possibility remains to be studied.

\section{REFERENCES}

Campbell, W. L., McDanal, S. K., and Hopkins, R. T., 1981, Analytical results for 130 rock, 135 stream sediment and soil, and 110 panned concentrate samples from the Rattlesnake Wilderness study area, Missoula County, Montana: U.S. Geological Survey Open-File Report 81-1219, 32 p.

Kulik, Dolores, M., 1983, Interpreted complete Bouguer gravity and aeromagnetic maps of the Rattlesnake Wilderness study area, Missoula County, Montana: U.S. Geological Survey Miscellaneous Field Studies Map, MF-1235-B, scale 1:50,000.

Wallace, C. A., and Lidke, D. J., 1980, Geologic map of the Rattlesnake Wilderness study area, Missoula County, Montana: U.S. Geological Survey Miscellaneous Field Studies Map, MF-1235-A, scale 1:50,000.

Wallace, C. A., Lidke, D. J., Kulik, D. M., Campbell, W. L., Antweiler, J. C., and Mayerle, R. T., 1983, Mineral resource potential map of the Rattlesnake Roadless Area, Missoula County, Montana: U.S. Geological Survey Miscellaenous Field Studies Map MF-1235-D. 


\title{
SAPPHIRE WILDERNESS STUDY AREA AND CONTIGUOUS ROADLESS AREAS, MONTANA
}

\author{
By C. A. Wallace, ${ }^{1}$ U.S. GeOlogical Survey, and \\ D'ARCY P. BANNISTER, U.S. BUREAU OF MiNES
}

\section{SUMMARY}

Geologic and mineral studies done in 1978-80 by the USGS and USBM located sulfide-bearing quartz veins with demonstrated metallic mineral resources in granitic and metasedimentary rocks in several parts of the Sapphire Wilderness Study Area and contiguous roadless areas, Montana. Mines and prospects contain demonstrated resources of gold, silver, lead, copper, and zinc. Gold-bearing placers occur downstream from each of these vein occurrences; most of the gold placers have a probable mineral-resource potential. A replacement body of sulfide minerals is present at the Senate mine adjacent to the Sapphire Wilderness Study Area. Around the Senate mine is an area of probable mineral-resource potential that extends into the study area. There is little promise for the occurrence of energy resources in the study area.

\section{CHARACTER AND SETTING}

The Sapphire Wilderness Study Area and contiguous roadless areas, Montana, is an area of about $150 \mathrm{sq} \mathrm{mi}$ and together is referred to as the study area. The study area straddles the crest of the southern Sapphire Mountains, is about $21 \mathrm{mi}$ east of Hamilton and about $24 \mathrm{mi}$ west of Philipsburg. Montana, and adjoins the Anaconda-Pintlar Wilderness on the southeast. At the headwaters of most drainages, moderately rugged terrane was formed where glaciers developed along the topographic crest of the range and most valleys show the effects of glaciation. The area is accessible from USFS roads 16 and 80.

Bedrock in the study area is mainly metamorphosed Middle Proterozoic strata (older than 900 million years) of the middle and upper Belt Supergroup, and 73 million year old granitic rocks that form the Sapphire batholith (Wallace and others, 1982). Paleozoic and Mesozoic rocks are not present at the surface in the study area. The Proterozoic rocks were deposited an estimated 60 mi west of their present location. Before 73 million years ago, thrust faults moved thick plates of rock eastward to their present locations, forming the Sapphire thrust plate, which is one element of the Montana thrust belt. After thrust faulting ceased, granitic magma intruded the thrust-faulted terrane at depth and

\footnotetext{
${ }^{1}$ With contributions from D. J. Lidke, USGS, and T. J. Close, USBM.
}

heated the adjacent sedimentary rocks to temperatures of $400^{\circ}$ to $600^{\circ} \mathrm{C}$. Precipitation of minerals in veins or in replacement bodies occurred locally during final stages of magma crystallization, or during a later faulting and intrusive event that opened pathways for mineralizing fluids. Uplift and erosion dominated this region for the last 50-60 million years, bringing granitic and metamorphosed rocks, and mineralized rocks to the surface. During Pleistocene time, glaciers formed in the headwaters of many drainages and accelerated erosion along the topographic crest of the study area. Erosion and glaciation of mineralized areas were important factors for occurrence of placers in the study area.

Geochemical studies included sampling of rocks, veins and mine dumps, stream sediments, and panned concentrates over the entire study area. Geophysical interpretations were based on an aeromagnetic survey and on gravity measurements made throughout the study area.

Most of the documented mineral production has been from the southern part of the Sapphire Wilderness Study Area, in the Frogpond basin district (A, on map). The first claims were located in Frogpond basin in 1898; most activity occurred between 1907 and the late 1930's, resulting in production of gold, silver, lead, copper, and zinc. Two other mines that are adjacent to the study area boundary, the Banner and Senate mines, also had production in the early 1900's. Numerous prospects are concentrated in the southern part of the study area. 

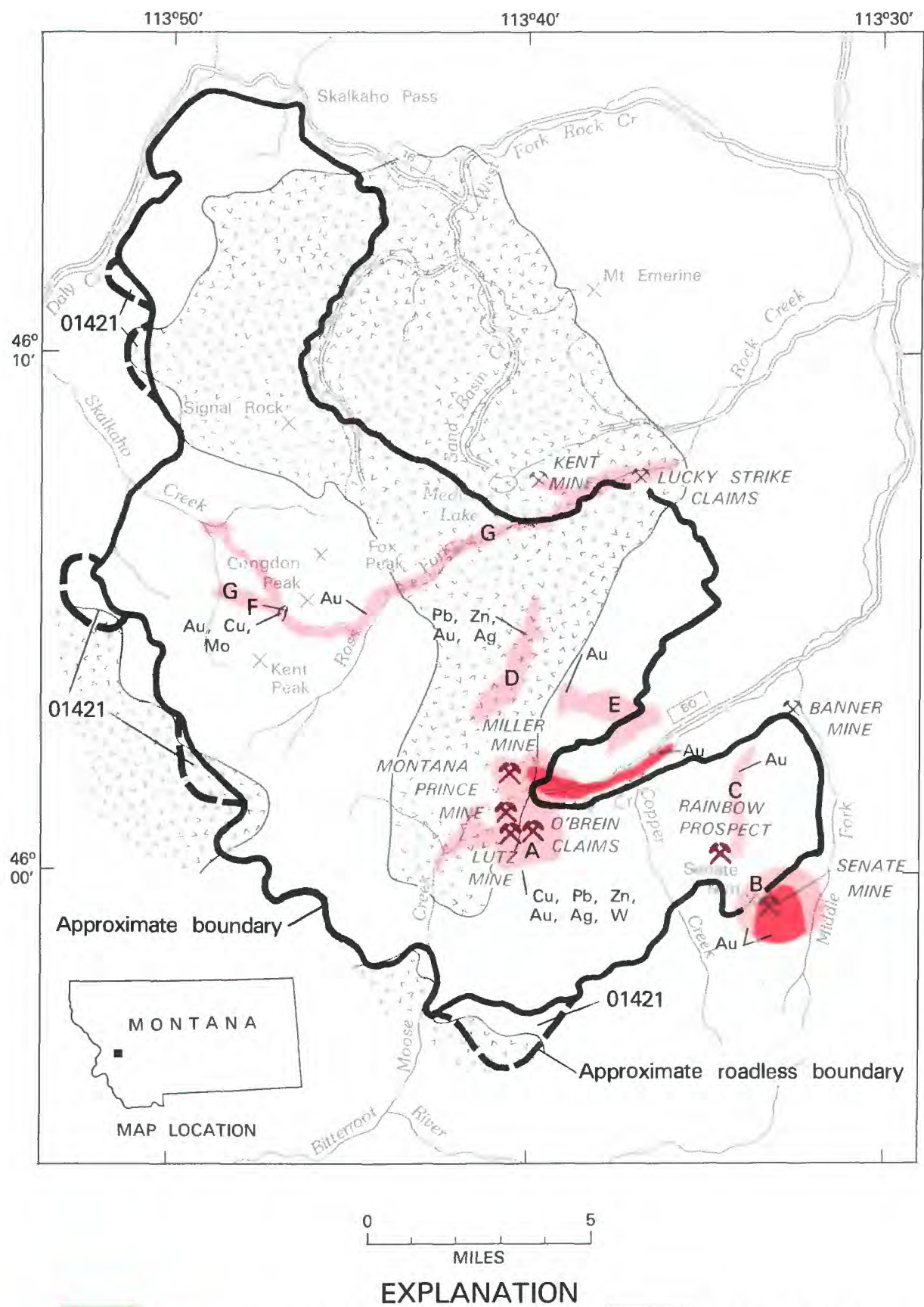

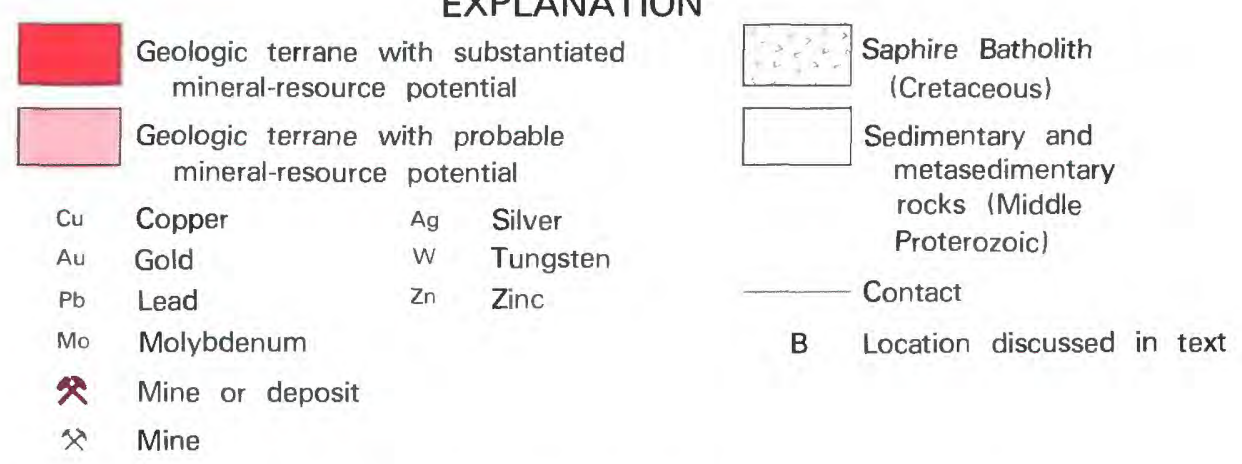

Figure 210.-Sapphire Wilderness Study Area and contiguous roadless areas, Montana. 


\section{MINERAL RESOURCES}

Mineralized areas occur along and adjacent to the margins of the Sapphire batholith in the study area, and these geologic terranes have probable mineral-resource potential for gold, silver, lead, copper, and zinc. Additional areas of probable or substantiated mineralresource potential exist for gold in placers derived from the bedrock deposits.

The Frogpond basin area (A) is a large area of probable resource potential in the southern part of the study area. Demonstrated and inferred resources occur in sulfide-bearing quartz veins at the Miller and Lutz mines and inferred resources occur in sulfide-bearing quartz veins at the Montana Prince claim group. Demonstrated gold-placer resources occur at the Gold Bar prospect in an area of substantiated placer gold resource potential along Lutz Creek and areas of probable gold-placer resources occur elsewhere in Lutz Creek, in Cuba Creek, and in tributaries to Moose Creek. Commodities in the Frogpond basin are gold, silver, lead, copper, zinc, and possibly tungsten. There may be a potential for the occurrence of gold in placers in glacial deposits (till and outwash) that blanket the valleys and form meadows in the Frogpond basin area.

The Senate mine, which is located adjacent to the study area, contains demonstrated and inferred resources of copper, silver, and a trace of gold. Sulfide minerals replace quartzite and occur in veins in shear zones; mineralized rocks may extend into the study area and into the adjacent Anaconda-Pintlar Wilderness and the area has a probable potential for copper, silver, and gold (B). Gold was detected in stream deposits downstream from the Senate mine, therefore glacial and modern stream deposits, and the area around the mine are also assigned a probable potential for the occurrence of a placer gold resource.

The Rainbow prospect is on a sulfide-bearing quartz vein that contains demonstrated resources of gold and silver. A probable gold placer resource occurs in Meyers Creek, which drains the area of the Rainbow prospect (C).

At the Banner mine, now inaccessible, a sulfidebearing vein system adjacent to the boundary of the study area had production of gold, silver, copper, and minor lead. Prospects of the Lucky Strike claims (Bentz mine) contain resources of molybdenum and tungsten in sulfide-bearing quartz veins in granitic rocks.

In the South Fork of Ross Fork (D) an area of sulfidebearing quartz veins occurs in several prospects in granitic rocks; this area has a probable mineral-resource potential for gold, silver, lead, and zinc. Gold-bearing placers, apparently derived from the nearby veins, are classed as areas of probable mineral-resource potential.
Green Canyon Creek (E) contains glacial and modern stream deposits that have a probable potential for a small resource of gold. The source of the gold in placers could be sulfide-bearing veins in the headwaters of Green Canyon Creek, or gold could have been transported from Frogpond basin with glacial deposits where the glacier spilled over the ridge into Green Canyon Creek.

In the west-central part of the study area, a small, weakly mineralized area has probable mineral-resource potential (F). Sulfide-vein minerals and sulfide replacement minerals contain gold, copper, and molybdenum. The main importance of this occurrence is that these deposits may be the source of gold that occurs to the west in the headwaters of Skalkaho Creek and to the east in Ross Fork of Rock Creek (G).

In the west and northwest parts of the Sapphire batholith, a suite of rarearth and related elements is found in rock samples, and appears to be related to the minerals allanite, sphene, and zircon in granitic rocks. Rock samples contain anomalously high amounts of vanadium, scandium, cobalt, yttrium, lanthanum, titanium, and niobium. Stream deposits in the West Fork of Rock Creek derived from these granitic rocks contain anomalously high amounts of tin, thorium, niobium, and some gold. These anomalously high values are not indicative of resource potential. This area shows little promise for the occurrence of rareearth and related metal resources.

Numerous small areas were located during this study that had high geochemical anomalies, some small vein occurrences, or prospect pits, but these areas lack evidence to suggest occurrence of resources.

Although the northern part of the Sapphire batholith shares some geologic, geochemical, and geophysical affinities with known copper and tin porphyry-type deposits, available data do not identify a resource potential for these deposits.

There is little promise for the occurrence of oil and gas, coal, geothermal resources, and radioactive minerals in the Sapphire Wilderness Study Area. Rocks that have potential as sources for hydrocarbons do not occur at the surface in the southern Sapphire Mountains. The probability that potential source rocks could exist at depth beneath thrust sheets in the study area cannot be evaluated from existing data. However, because intrusion of the Sapphire batholith produced temperatures of $400^{\circ}$ to $600^{\circ} \mathrm{C}$ in rocks now exposed at the surface, it is doubtful that oil or methane-bearing gas would have survived in rocks near the surface or at depth. Coal is unlikely to occur because Tertiary rocks that typically contain coal beds in this region are absent in the study area. Hot springs, young volcanic rocks, and other surface evidence of possible geothermal 
resources are absent from the study area. A reconnaissance survey with a hand-carried scintillometer produced no evidence that radioactive minerals occur in significant amounts in the intrusive rocks of the study area.

\section{SUGGESTIONS FOR FURTHER STUDIES}

Detailed study of the Frogpond basin area offers the greatest possibility for establishing the occurrence of additional resources. Undiscovered vein systems may be present in this area. The relations of vein systems to gold placers remains to be established, and placers should be evaluated using modern scientific methods.

\section{REFERENCES}

Bannister, D. P., Close, T. J., McColloch, R. B., and Mayerle, R. T., 1983, Mineral investigation of the Sapphires RARE II Area (No. 1421), Granite and Ravalli Counties, Montana: U.S. Bureau of Mines Open-File Report 69- 83, 19 p.

Campbell, W. L., Hopkins, R. T., Lee, G. K., and Antweiler, J. C., 1983, Analytical results and sample locality map for 340 rock, 322 stream-sediment and soil, and 263 panned concentrate samples from the Sapphire Wilderness Study Area, Granite and Ravalli Counties, Montana: U.S. Geological Survey Open-File Report 83-196, 74 p.

Wallace, C. A., Lidke, D. J., Elliott, J. E., Antweiler, J. C., Campbell, W. L., Hassemer, J. H., Hanna, W. F., Bannister, D. P., and Close, T. J., 1983, Mineral resource potential map of the Sapphire Wilderness Study Area and contiguous roadless areas, Granite and Ravalli Counties, Montana: U.S. Geological Survey Miscellaneous Field Studies Map MF-1469- B, scale 1:50,000.

Wallace, C. A., Lidke, D. J., and Obradovich, J. D., 1982, Geologic map of the Sapphire Wilderness and contiguous roadless areas, Granite and Ravalli Counties, Montana: U.S. Geological Survey Miscellaneous Field Studies Map MF-1469-A. 


\title{
SCAPEGOAT WILDERNESS AND ADDITIONS, BOB MARSHALL AND GREAT BEAR WILDERNESSES, AND ADJACENT STUDY AREAS, MONTANA
}

\author{
By ROBERT L. EARHART, U.S. GEOLOGICAL SURVEY, and \\ LAWRENCE Y. MARKS, U.S. BUREAU OF MiNES
}

\begin{abstract}
SUMMARY
Hydrocarbon and non-fuels mineral surveys, conducted between 1969 and 1978 indicate that parts of the Bob Marshall and Great Bear Wildernesses and several of the adjacent study areas have probable and substantiated mineralresource potential for hydrocarbon accumulations, especially natural gas; the Scapegoat and Great Bear Wildernesses have a substantiated resource potential for copper and silver. The Bob Marshall Wilderness has a substantiated potential for barite and a probable potential for copper and silver. Lead, zinc, coal, and limestone occur locally within the study areas but such occurrences are small and low grade and no resource potential is identified.
\end{abstract}

\section{CHARACTER AND SETTING}

The mineral surveys covered the $375 \mathrm{sq} \mathrm{mi}$ of the Scapegoat Wilderness, the $84 \mathrm{sq} \mathrm{mi}$ of the Scapegoat Additions, and the $2587 \mathrm{sq} \mathrm{mi}$ of the Bob Marshall and Great Bear Wildernesses and adjacent Deep Creek and Reservor-North Roadless Areas in northwest Montana. The Scapegoat Wilderness and Additions, Bob Marshall and Great Bear Wildernesses and adjacent study areas are geologically divisible into two parts: thrust faulted and folded strata of Paleozoic and Mesozoic ages in the eastern third of the Bob Marshall and Great Bear Wildernesses, and broadly folded and faulted Precambrian rocks and some Paleozoic rocks in the western two-thirds of the Bob Marshall and Great Bear Wildernesses and all of the Scapegoat Wilderness and the Scapegoat Additions. The studies in these contiguous areas which straddle the Continental Divide consisted of geologic, geochemical, and geophysical investigations, and the investigation of mines and prospects.

\section{MINERAL RESOURCES}

The eastern parts of the areas contain hydrocarbon source and reservoir rocks and are inferred to have structural traps formed at depth, primarily by thrustfault stacking of the Paleozoic strata. Traps of this type contain gas in shut-in or abandoned wells near the eastern border of the area, and are common in the highly productive Albertan gas fields to the north. These eastern parts of the areas have substantiated hydrocarbon resource potential. The geologic terrane favorable for hydrocarbons is inferred to underlie the Precambrian rocks below a westerly dipping thrust fault throughout most of the western two-thirds of the areas. The depth to the thrust fault and thus to the areas favorable for hydrocarbons in the western parts of the areas may be as much as $30,000 \mathrm{ft}$. The hydrocarbon potential diminishes westward because of the increasing depth as well as uncertainty about the character of the rocks and structure beneath the thrust fault. For these reasons, a probable hydrocarbon resource is assigned to only the eastern part of the western two-thirds of the areas. The potential for hydrocarbons diminishes to the southeast in the Scapegoat Wilderness and in the Scapegoat Additions; this is because of the presence of large areas of igneous intrusive rocks to the east and southeast of the areas. Only a small eastern part of these areas is assigned a probable mineral-resource potential.

Four hundred ninety-two mining claims have been located in or adjacent to the areas studied. Of these, 297 were located in or near the Bob Marshall Wilderness and adjacent study areas and the Great Bear Wilderness, 131 were in the Scapegoat Wilderness, and 64 were located in or near the Scapegoat Additions. A small amount of gold has been produced from claims within the Scapegoat Additions but, none of the claims in or near the Bob Marshall have a record of production.

The most widespread type of mineral occurrence is 

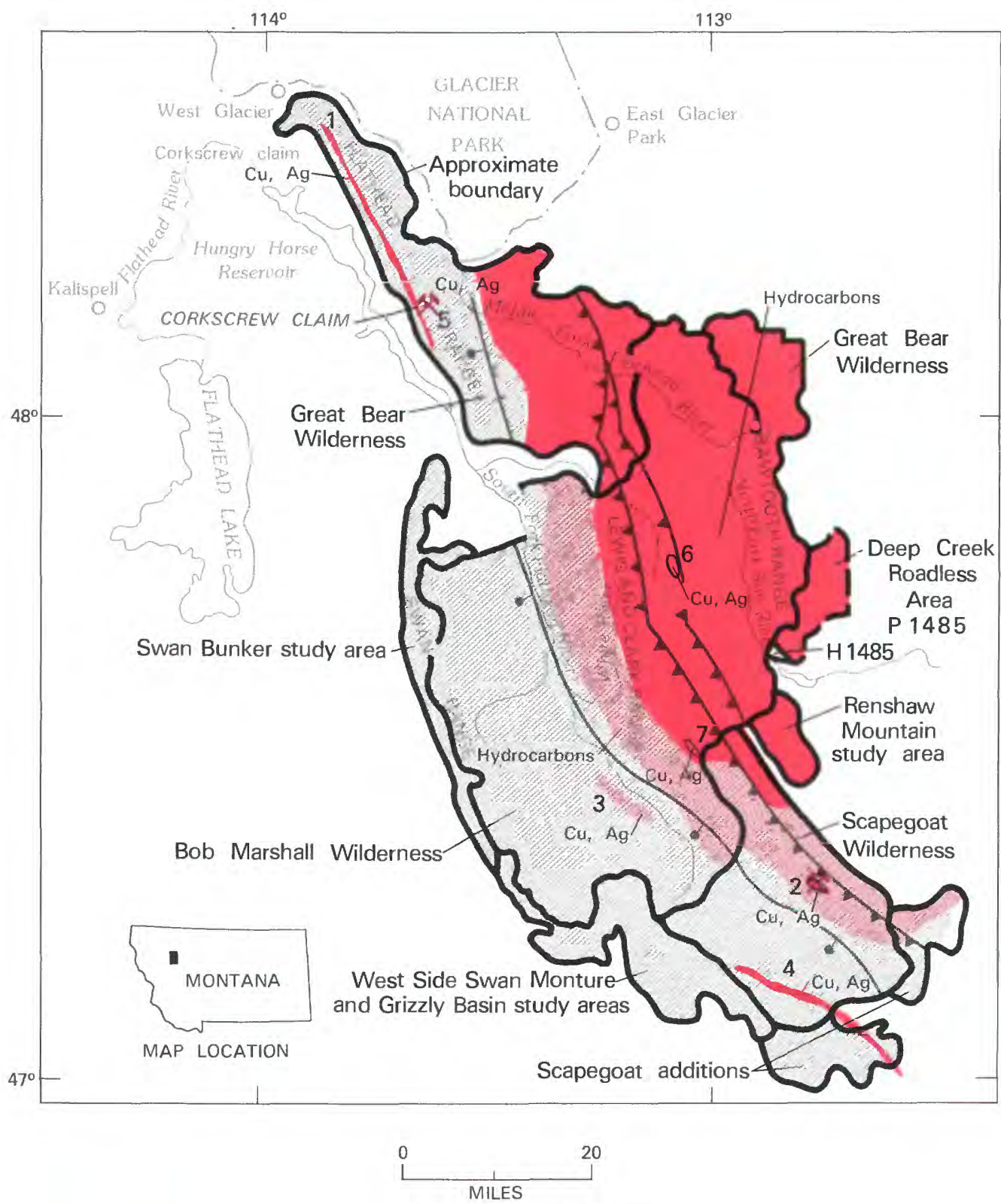

EXPLANATION

Geologic terrane with substantiated mineral-resource potential

Geologic terrane with probable mineral-resource potential

$\begin{array}{ll}\mathrm{Ba} & \text { Barium } \\ \mathrm{Cu} & \text { Copper } \\ \mathrm{Pb} & \text { Lead } \\ \mathrm{Ag} & \text { Silver } \\ \mathrm{Zn} & \text { Zinc } \\ \text { X } & \text { Mine or deposit }\end{array}$

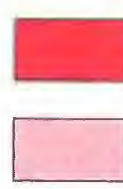

Mine or deposit
20

1

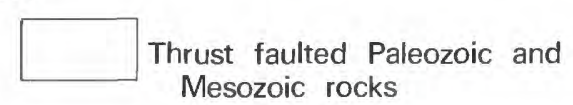
Mesozoic rocks

Proterozoic Belt Supergroup rocks locally includes some Paleozoic rocks

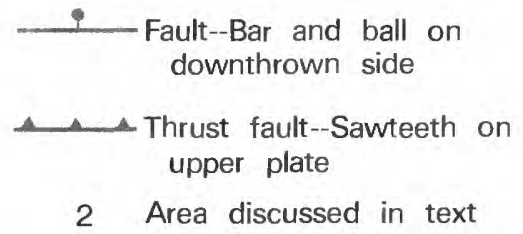

Figure 211.-Scapegoat Wilderness and additions, Bob Marshall and Great Bear Wildernesses, and adjacent study areas, Montana. 
stratabound copper and silver in green beds of Precambrian rocks that contain both red (oxidized) and green (reduced) beds. The copper minerals follow sedimentary structures in the rocks and are concentrated along fractures. The largest known green bed occurrences are at map areas 1 and 2 and have substantiated mineralresource potential and area 2 contains a small deposit with demonstrated resources averaging about 0.15 percent copper and less than $0.1 \mathrm{oz}$ silver/ton. Area 3 may also contain similar mineralization and is shown as having a probable mineral-resource potential for copper and silver. Numerous other green-bed type copper-silver occurrences were noted in the areas, but they are not shown on the map because of their low grade and small size. In addition, these deposits and occurrences contain minor amounts of lead, zinc, and molybdenum.

Copper and silver occur in quartz-calcite stockwork veins at areas 4, 5, 6, and 7. A substantiated resource potential for copper and silver minerals concentrated in a quartz-calcite vein stockwork exists in an area that extends about $15 \mathrm{mi}$ through the southern part of the Scapegoat Wilderness and into the Scapegoat Additions (area 4). At places the stockwork is as much as 110 $\mathrm{ft}$ wide; however, the width is highly variable and concentrations of the metallic minerals are localized. A deposit at the Corkscrew claim (5) contains a demonstrated resource of an estimated 660,000 tons of rock that averages about 0.15 percent copper and $0.1 \mathrm{oz}$ silver/ton. Similar vein stockworks exist in areas 6 and 7 and have localized concentrations of copper and subordinate amounts of silver. The vein stockworks in these areas are considered to have small substantiated copper- and silver-resource potential.

Stratabound occurrences of lead, zinc, and copper sulfide minerals occur locally in the eastern part of the Bob Marshall Wilderness in limestones and in calcareous quartzites. All these occurrences are of small size and low grade and no resource potential is identified.

Nearly pure barium sulfate (barite) occurs in a vein near the center of the Bob Marshall Wilderness. The vein is as much as $10 \mathrm{ft}$ wide and $400 \mathrm{ft}$ long, and may contain 100,000 tons of rock with a content of 92 percent barite. Although this barite vein constitutes a demonstrated resource it is not shown on the map because readily accessible barite resources occur in abundance elsewhere outside the wilderness.

Other nonmetallic resources in the areas studied are not identified as having resource potential. Subbituminous coal as much as $3.5 \mathrm{ft}$ thick occurs over a small area near Teton Pass in Cretaceous beds, but the occurrences are small and low grade. The Paleozoic rock terrane contains deposits of high-purity limestone and dolomite, and sand and gravel deposits occur at numerous localities in the study area; however, these resources occur in abundance in more accessible parts of northwest Montana. No potential for geothermal resources was identified in this study.

\section{SUGGESTIONS FOR FURTHER STUDIES}

Seismic surveys would help to locate structural traps for hydrocarbon accumulations in the study areas.

\section{REFERENCES}

Mudge, M. R., Earhart, R. L., Kleinkopf, M. D., Rice, D. D., Claypool, G. E., and Marks, L. Y., 1978, Mineral resources of the Bob Marshall Wilderness and study area, Lewis and Clark, Teton, Pondera, Flathead, Lake, Missoula, and Powell Counties, Montana: U.S. Geological Survey Open-File Report 78-295, 268 p.

Mudge, M. R., Earhart, R. L., and Marks, L. Y., 1982, Mineral resource potential of the Reservoir-North and Deep Creek Roadless Areas, Teton County, Montana: U.S. Geological Survey Open-File Report 82-988, 13 p.

Mudge, M. R., Earhart, R. L., Watts, K. C., Tuchek, E. T., and Rice, W. L., 1974, Mineral resources of the Scapegoat Wilderness, Powell and Lewis and Clark Counties, Montana with a section on Geophysical surveys by Donald L. Peterson: U.S. Geological Survey Bulletin 1385-B, 82 p.

Earhart, R. L., Grimes, D. J., Leinz, R. W., and Marks, L. Y., 1977, Mineral resources of the proposed additions to the Scapegoat Wilderness, Powell and Lewis and Clark Counties, Montana: U.S. Geological Survey Bulletin 1430,62 p. 


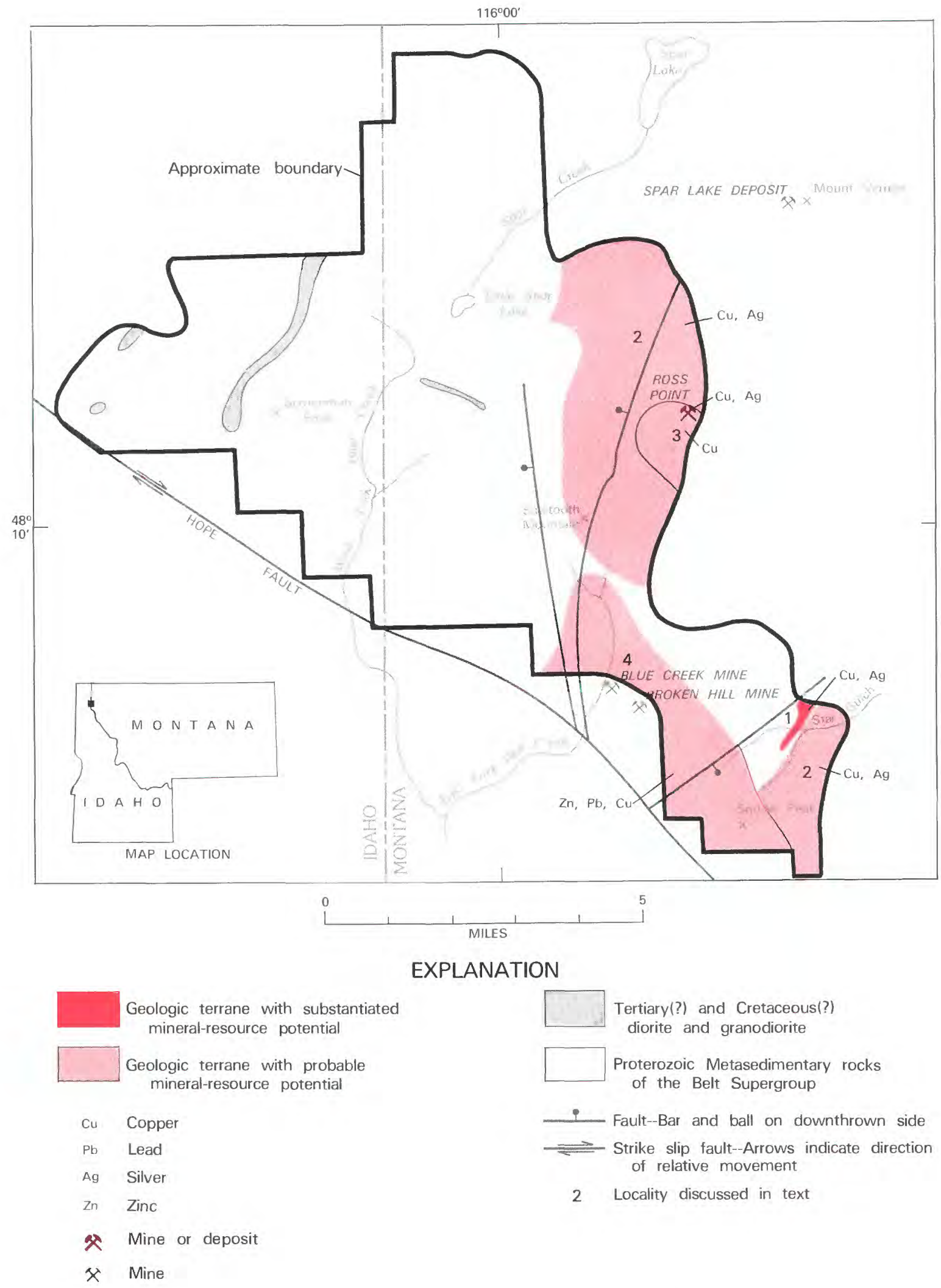

Figure 212.-Scotchman Peak Wilderness study area, Montana and Idaho. 


\title{
SCOTCHMAN PEAK WILDERNESS STUDY AREA, MONTANA AND IDAHO
}

\author{
By R. L. EARHART, U.S. GeOlogical SURVey and \\ N. T. ZiLKa, U.S. BUREAU OF MiNES
}

\section{SUMMARY}

\begin{abstract}
A geologic and mineral survey of the Scotchman Peak Wilderness study area in northwestern Montana and northeastern Idaho was completed in 1975. The mineral-resource potential was evaluated by geological, geochemical, and geophysical studies and by the examination of mining claims. The results of the investigations indicated that the eastern part of the area has a substantiated mineral-resource potential for copper and silver. As a result of this study it was determined that there is little promise for the occurrence of energy resources in the area.
\end{abstract}

\section{CHARACTER AND SETTING}

The area covers about $58 \mathrm{sq} \mathrm{mi}$ in the Cabinet Mountains. It is mostly underlain by fine-grained metasedimentary rocks of the Belt Supergroup of Proterozoic age that are locally intruded by granodiorite and diorite plutons, sills, and dikes of Cretaceous(?) and Tertiary(?) age. The eastern half of the area is highly faulted and folded. The Hope fault, a major strike-slip structure, trends northwest along the southwest boundary of the area.

\section{MINERAL RESOURCES}

Approximately 439 claims were located in and near the study area. Mines south of the southern boundary of the area have produced nearly 300,000 tons of gold, silver, copper, lead, and zinc ores, and the area near these mines may contain additional undiscovered metallic ores.

The Star Gulch area (locality 1 on map) contains highly anomalous amounts of copper and silver in a zone about $10,000 \mathrm{ft}$ long and $100 \mathrm{ft}$ wide. The anomaly reflects a stratabound occurrence of disseminated copper and silver minerals in quartzite of the lower part of the Revett Formation of the Belt Supergroup. The geologic setting of the mineralized zone is similar to that of the Spar Lake deposit 2 mi northeast of the study area, which contains an estimated 58 million tons of disseminated ore with an average grade of 0.79 percent copper and $1.67 \mathrm{oz}$ silver/ton. The geochemical results from the
Star Gulch area indicate a substantiated mineralresource potential for a deposit at shallow depth and of similar size and grade to the Spar Lake deposit.

A broad area in the eastern part of the Scotchman Peak area (locality 2), contains scattered occurrences of stratabound copper, small copper and silver geochemical anomalies, and a few copper-bearing quartz veins in the Revett Formation. The widespread occurrences indicate that this part of the study area has a probable mineral-resource potential for larger deposits too deep to detect by surface sampling methods.

The Ross Point area (locality 3 ) contains several basemetal-bearing quartz veins in the Revett Formation that have been explored by means of small adits and pits. One vein with small amounts of bornite and chalcopyrite has a maximum thickness of $16 \mathrm{ft}$ and contains 430,000 tons of demonstrated silver and copper resources that average $0.07 \mathrm{oz}$ silver/ton and 0.13 percent copper. The area has been partially explored by diamond drilling for stratabound copper-silver deposits. Additional subsurface exploration may possibly reveal higher-grade material in either vein or stratabound occurrences.

The Blue Creek and Broken Hill mines, just outside the Scotchman Peak study area (locality 4) have produced 675 tons of zinc-lead-silver ore and are inferred to contain additional resources. The ore minerals are concentrated in the shear zones of faults that trend northerly into the study area. These unexplored extensions of the shear zones have a probable mineral-resource potential for small additional resources of zinc, lead, and silver. 
Mineralized quartz veins in the area west of Scotchman Peak contain highly localized concentrations of lead, copper, and zinc minerals. The veins are near granodiorite intrusive rocks and the Hope fault. Because the base metal occurrences are small and of low grade, this part of the area has little promise for the discovery of mineral resources.

As a result of this study it was determined that there is little promise for the discovery of energy resources in the area.

\section{SUGGESTIONS FOR FURTHER STUDIES}

Additional detailed studies would help to define the resource potential of localities 1,2 , and 3 of the study area. Such studies should consist of detailed mapping and sampling of mineralized or geochemically anomalous sites, and detailed geophysical work, such as induced polarization surveys.

\section{REFERENCES}

Earhart, R. L., Kleinkopf, M. D., Wilson, D. M., Grimes, D. J., and Zilka, N. T., 1981, Mineral resources of the Scotchman Peak Wilderness study area, Lincoln and Sanders Counties, Montana and Bonner County, Idaho: U.S. Geological Survey Bulletin $1467,73 \mathrm{p}$. 


\title{
SPANISH PEAKS PRIMITIVE AREA, MONTANA
}

\author{
By James A. Calkins, ${ }^{1}$ U.S. Geological Survey, and \\ Eldon C. Pattee, U.S. Bureau of Mines
}

\section{SUMMARY}

A mineral survey in 1965 of the Spanish Peaks Primitive Area, Montana, disclosed a small low-grade deposit of demonstrated chromite and asbestos resources. The chances for discovery of additional chrome resources are uncertain and the area has little promise for the occurrence of other mineral or energy resources. As of 1965 , no prospecting was underway within the primitive area and no production of minerals had taken place.

\section{CHARACTER AND SETTING}

The Spanish Peaks Primitive Area occupies an elongate, tear-drop shaped area of about $102 \mathrm{sq}$ mi near the northern end of the Madison Range in southwestern Montana. The area is centered around a series of rugged peaks and ridges, collectively called the Spanish Peaks. Drainage flows generally northeast and east into the Gallatin River. Altitudes range from $6000 \mathrm{ft}$ above sea level near the Gallatin River to $11,015 \mathrm{ft}$ on Gallatin Peak. Alpine glaciation has produced a rugged topography with many knife-edge ridges and cirques, and the highlands are dotted with many small lakes at the foot of the cirques. The area is heavily forested to timberline, which is near $9000 \mathrm{ft}$, and is within the Gallatin National Forest. U.S. Highway 191 follows the Gallatin River and skirts the eastern end of the primitive area. Bozeman, the nearest town, is $23 \mathrm{mi}$ to the northeast and Yellowstone National Park $25 \mathrm{mi}$ to the south.

The mineral survey of the primitive area was made in 1965 by USGS and USBM personnel. It included reconnaissance geologic mapping, spectrographic and chemical analyses of rock and mineral samples, examination of recorded mining claims and of prospect diggings and mineral occurrences in the area, and assays, mineral dressing tests, and concentration tests relating to chromite and asbestos showings on Table Mountain.

At the time of the 1965 survey there were no operating mines within the primitive area. The only mine in the immediate vicinity of the primitive area is the Karst asbestos deposit located on the west side of Gallatin Canyon near the eastern edge of the primitive area. This mine was closed and abandoned at the time of the 1965

\footnotetext{
${ }^{1}$ With contributions from George E. Becraft, USGS.
}

survey; earlier sporadic production by various operators who mined a total of $1800-2600$ tons of asbestos ceased about 1948.

Nearly the entire primitive area consists of hard and resistant metamorphic rocks of Precambrian age. The predominant rock type is granite gneiss (banded granite). Other rock types are dark-green amphibolite, garnet- and kyanite-bearing schist, sillimanite-bearing quartzite, and pegmatite.

Situated on top of these old rocks are a few small patches of volcanic rocks, remnants of once extensive lava flows that poured out of fissures or nearby volcanoes in early Tertiary time, some 50 million years ago.

The metamorphic rocks occupying the primitive area are part of an uplifted block that was raised thousands of feet relative to the adjacent terrane. The Spanish Peaks fault marks the southern border of the uplifted block. The northern limits of the uplifted block are not known.

In contrast to the hard metamorphic rocks north of the Spanish Peaks fault, those south of the fault are younger, relatively soft, sedimentary rocks (limestone, dolomite, sandstone, shale) totaling about $5000 \mathrm{ft}$ in thickness and representing a time span of some $500 \mathrm{mil}-$ lion years (Paleozoic and Mesozoic Eras).

\section{MINERAL RESOURCES}

A small chrome and asbestos resource was identified during the course of the study of the Spanish Peaks Primitive Area. Although, at the time of the 1965 survey, 25 mining claims were located within the primitive area, there had been no production of minerals. 


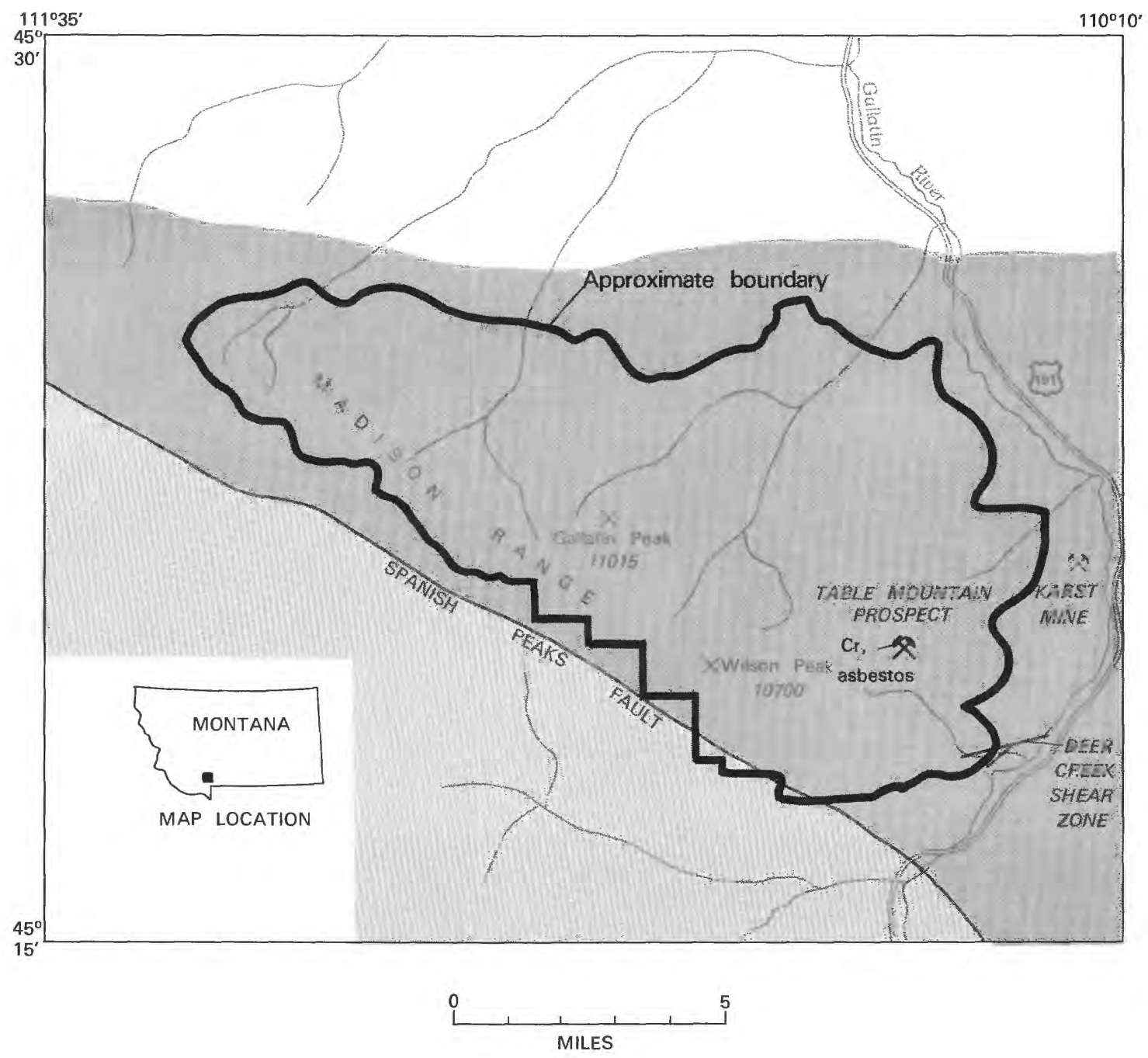

EXPLANATION

x Mine or deposit

$\mathrm{Cr}$ Chromium

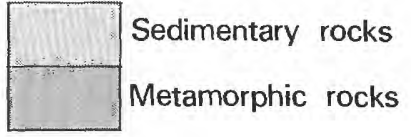

Fault

Figure 213.-Spanish Peaks Primitive Area, Montana. 
Altered zones localized along the Spanish Peaks fault and the Deer Creek shear zone contained little evidence of mineralization. Numerous prospect holes were dug long ago along these altered zones. Two narrow quartz veins south of Gallatin Peak contained small amounts of copper minerals but the veins are small and no resource potential was identified. The several occurrences of kyanite within the primitive area were assessed to have no resource potential.

The asbestos prospect on Table Mountain in the eastern part of the area is interesting in that it contains chromite in addition to amphibole asbestos. This locality has small demonstrated resources of chrome and asbestos and is discussed briefly here because of new thoughts as to its origin and the need for further fieldwork.

The USGS team concluded in 1965 that the asbestos and chromite on Table Mountain occurred in a metamorphosed and altered mafic dike. As a result of recent interpretation of the geologic environment furnished by T. P. Thayer (oral commun., 1982), it appears that the Table Mountain prospect could be a metamorphosed ultramafic roof pendant consisting of layered, metamorphosed peridotite and pyroxenite, the layers containing accessory chromite. As with the chromite locality at Red Lodge, Montana, the Table Mountain locality likely contains occasional chromite-rich layers and lenses in which the chromite content may reach 20-25 percent.

Samples collected in 1965 by the USBM contained an average of 10 percent $\mathrm{Cr}_{2} \mathrm{O}_{3}$. In as much as little bedrock is exposed at the site, the samples collected for analysis were composed partly of residual fragments. Composited samples ranged from 17 to 26 percent chromite and concentration tests produced a concentrate of chemical grade chromite ranging from 42 to 48 percent $\mathrm{Cr}_{2} \mathrm{O}_{3}$. Demonstrated resources were estimated at 140,500 tons of rock averaging 11 percent $\mathrm{Cr}_{2} \mathrm{O}_{3}$, and 900 tons of amphibole asbestos. Mineral dressing tests showed that it was technically possible to concentrate the chromite ore. As a result of this study, the USBM concluded that the exposed deposit is small and low in grade. Trenching or drilling would be required to more accurately determine the grade and size of the deposit.

\section{SUGGESTIONS FOR FURTHER STUDIES}

Although further study of the primitive area is unlikely to reveal major mineral deposits, additional work on specific topics would extend and refine the information gained during the 1965 survey. A reevaluation, sampling at depth, and testing for possible extensions of the Table Mountain asbestos and chromium deposit should be undertaken in the light of recent interpretations regarding its geologic setting.

\section{REFERENCE}

Becraft, G. E., Calkins, J. A., Pattee, E. C., Weldin, R. D., and Roche, J. M., 1966, Mineral resources of the Spanish Peaks Primitive Area, Montana: U.S. Geological Survey Bulletin 1230-B, 45 p. 


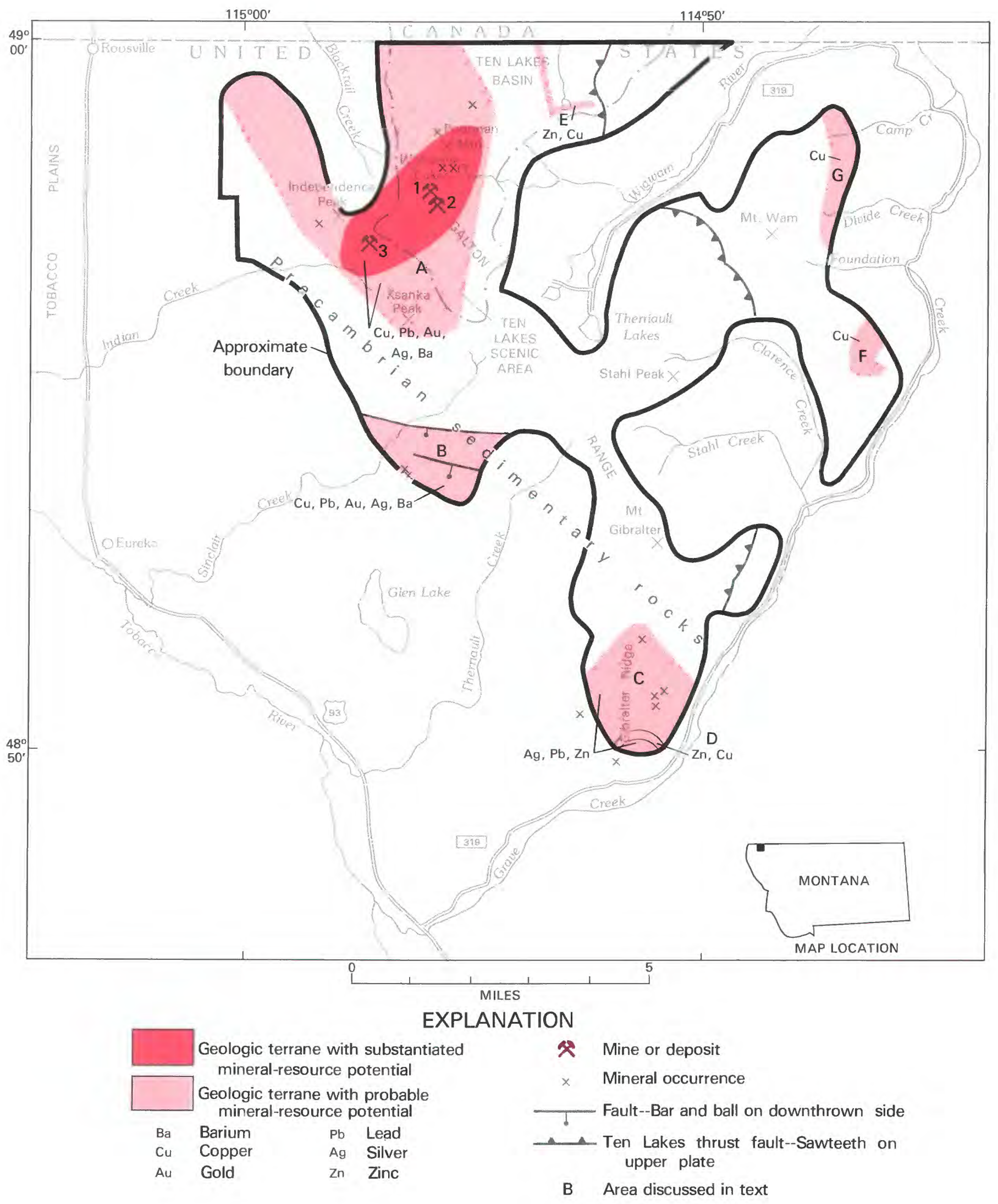

Figure 214.-Ten Lakes Wilderness Study Area, Montana. 


\title{
TEN LAKES WILDERNESS STUDY AREA, MONTANA
}

\author{
By James W. Whipple, ${ }^{1}$ U.S. GeOlOGiCal SurVey, and \\ Michael M. Hamilton, U.S. BuREaU of Mines
}

\begin{abstract}
SUMMARY
A mineral-resource survey of the Ten Lakes Wilderness Study Area, Montana, was conducted by the USGS and USBM in 1980-82. Areas of probable or substantiated mineral potential were found surrounding zones of past mining activity east of Independence Peak where copper-bearing veins are hosted by basaltic lava flows. Three mines contain demonstrated or inferred resources, and there are numerous prospects. Other areas of probable resource potential include an area on Sinclair Creek with copper occurrences similar to those of the Independence Peak area, an area including Gibralter Ridge where lead and zinc veins are hosted by sedimentary rocks, two areas where zinc-copper occurrences are related to metadiorite sills, and two areas that contain stratabound copper occurrences. The areas with copper and lead-zinc veins may also be of interest for deeply buried mineralized systems, as the veins may be the surface expression of plutons at relatively shallow depths. Although there is current interest in oil and gas in this area, there seems little likelihood for the occurrence of these resources, or for other energy resources, on the basis of available information.
\end{abstract}

\section{CHARACTER AND SETTING}

The Ten Lakes Wilderness Study Area contains about $53 \mathrm{sq}$ mi mostly in the Kootenai National Forest, Lincoln County, Montana. This study area spans the southern end of the Galton Range and its northern limit coincides with the boundary between the United States and Canada. Around Ten Lakes Basin, in the north part of the area, approximately $10 \mathrm{sq} \mathrm{mi}$ are presently designated the Ten Lakes Scenic Area. Much of the study area is forested; however, above $6600 \mathrm{ft}$, the forest cover changes to alpine meadows, rock-floored basins, and rocky crags. A compliment of small alpine lakes dot the Ten Lakes Scenic Area; most are near $6800 \mathrm{ft}$ in altitude. Poorman Mountain, which overlooks Wolverine Lakes, is the highest peak and reaches an altitude of $7832 \mathrm{ft}$. Primary access to the study area is provided by USFS Road 319 that begins at Montana State Highway 93, $8 \mathrm{mi}$ south of Eureka, Montana, and passes up Grave Creek and the Wigwam River to Therriault Lakes. Numerous secondary timber-access roads and

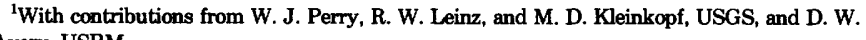
Avery, USBM.
}

pack trails furnish access to the interior of the Ten Lakes Wilderness Study Area.

Precambrian sedimentary rocks of the Belt Supergroup underlie all of the Ten Lakes Wilderness Study Area and consist of varicolored argillite, siltite, arenite, limestone, and dolomite. Sedimentary rocks are approximately $10,000 \mathrm{ft}$ thick, and were deposited in shallow, near-shore marine and conjugate fluvial environments. Igneous rocks of the study area include the Purcell Lava which is dominantly basalt and intertongues with sedimentary rocks. The Purcell consists of several thin (less than $7 \mathrm{ft}$ thick) flows, most of which were extruded in a subaerial environment. A Precambrian(?) metadiorite sill is also interlayered with the sedimentary rocks.

All rocks in the study area were transported eastward by thrust faults and are now probably several miles from their original site of deposition. This setting is typical of Rocky Mountain Thrust Belt terranes. Bordering the study area on the west and forming the eastern edge of the geologic and geographic feature called the Rocky Mountain trench is a large fault that separates the Tobacco Plains from the Galton Mountains. This fault is estimated to have about $10,000 \mathrm{ft}$ of vertical displacement. 


\section{MINERAL RESOURCES}

Prospecting, claim staking, and mining began in the 1890 's when miners developed base- and precious-metal veins in the area. County mining records indicate that 117 claims have been located within or adjacent to the study area from the 1890's to 1981. Many of the records are of relocations; six claims were patented. There is no indication of any mineral production having occurred in the study area except possibly from the Independence claim group. Current activity consists primarily of prospecting and minor claim staking.

Geologic, geochemical, and geophysical investigations have identified four kinds of resources in the study area: copper occurs in well-developed vein systems and shear zones, is hosted by the Purcell Lava, and has been the most developed; veins that contain lead, zinc, silver, and barite are present at the south end of the study area, on the nose of Gibralter Ridge, and are hosted by the sedimentary rocks (some of these veins were being prospected at the time of this study); small isolated occurrences of mineralized rock are associated with a thin metadiorite sill; and copper in stratabound occurrences was found in calcareous arenite beds in some of the sedimentary rock units.

Most of the mines and prospects in the study area are in the northwest part and are located on copper-bearing, quartz-barite-siderite veins that are hosted by the Purcell Lava. Although copper is the principal metal in the veins, silver, gold, and lead occur in sparse amounts. Aeromagnetic anomalies in the vicinity of Independence Peak (area A, on map) suggest small, near-surface granitic intrusions, and analysis of stream sediments indicates anomalous copper in most drainages. Parts of this area are assigned a substantiated resource potential; other parts are classified as having a probable resource potential.

Most of the copper-bearing veins in the Purcell Lava also contain barite as gangue. The percentage of barite varies, but this mineral is reported to make up as much as 60.6 percent $\mathrm{Ba} 0$ (Johns, 1970, p. 152) in some veins. There has been no known production of barite from any of the vein systems (R. G. Berg, Montana Bureau of Mines and Geology, oral commun., 1983); however, if certain of the copper-bearing veins were to be mined, it is possible that barite might be recovered as a byproduct. Three mines or claims in the Independence Peak area have demonstrated resources of copper, silver, and barite. The Red Bird, Midnight, Copper Kettle, and Eureka claims (loc. 1) have resources of 440,000 tons of rock averaging 0.64 percent copper and $0.33 \mathrm{oz}$ silver/ ton. The Green Mountain mine (loc. 2) has resources of 2900 tons of rock averaging 0.67 percent copper and 32.9 percent barite. The Independence mine (loc. 3) has resources of 18,000 tons of rock averaging 2.9 percent 752 copper and additional resources of $1,300,000$ tons of rock averaging 0.5 percent copper. A smaller area (area B) south of Independence Peak has a similar geologic setting. This area is assigned a probable resource potential for copper and associated metals; the grades of the resources and the expected tonnages are small.

In the south end of the study area, on Gibralter Ridge (area C), several prospects explore argentiferous leadzinc-bearing veins. The area containing these veins has a probable resource potential for silver and base metals. Dolomite host rocks are locally silicified and pyritic and suggest some hydrothermal alteration; and although no geophysical anomalies are centered over Gibralter Ridge, small aeromagnetic highs are present on the east and west sides of the ridge. If a shallow-buried pluton is present, there exists the possibility that additional mineralization could be present at depth.

Zinc-copper veins associated with metadiorite sills are common in the Belt rocks of the Whitefish Range and elsewhere in Montana; however, only small isolated vein occurrences are present in the Ten Lakes Wilderness Study Area (areas D, E). A probable mineral-resource potential is assigned to the areas of these occurrences; the sills are relatively thin, laterally discontinuous, and relatively devoid of metal-bearing veins. Zinc and copper concentrations in vein and in stream-sediment samples have probably been derived from occurrences related to the sills.

Stratabound copper mineralization was found to be disseminated primarily in some beds of the lower McNamara Formation, over a widespread area, as shown on the map (areas F, G). The observed interval of mineralized strata is thin and the occurrences are low in grade, however, the areas are regarded as having probable mineral-resource potential.

The presence of stratiform seismic reflections at depth, obtained by surveys in northwestern Montana, west of Glacier Park, and rumors of hydrocarbon seepages in this region, have led to numerous applications for oil and gas leases in the region. No hydrocarbon seepages have been located in or near the Ten Lakes Wilderness Study Area. Reports of oil-saturated limestone along Trail Creek and Thoma Creek east of the Ten Lakes Wilderness Study Area could not be substantiated. Every limestone exposure along these creeks was examined and sampled, but none contained significant hydrocarbons. Neither the Belt rocks or the inferred underlying crystalline rocks would have oil or gas potential unless they rest in fault contact above hydrocarbon source beds, with structural closures such that hydrocarbons would be trapped in the subsurface. Such may be the case farther east, near the western margin of Glacier Park, but this structural configuration is considered to be highly unlikely beneath the Ten Lakes Wilderness Study Area. Narrow belts of Phanerozoic 
sedimentary rocks, examined both east and west of the study area do not extend into the study area and are erosional remnants on the downthrown side of large vertical faults. Therefore these rocks cannot be projected to extend beneath the Ten Lakes Wilderness Study Area. On the basis of present information, there seems little likelihood for the occurrence of oil and gas resources in the Ten Lakes Wilderness Study Area.

\section{REFERENCES}

Johns, W. M., 1970, Geology and mineral deposits of Lincoln and Flathead Counties, Montana: Montana Bureau of Mines and Geology Bulletin 79, 182 p.

Whipple, J. W., Perry, W. J., Leinz, R. W., Hamilton, M. M., and Avery, D. W., 1983, Mineral resource potential map of the Ten Lakes Wilderness Study Area, Lincoln County, Montana: U.S. Geological Survey Miscellaneous Field Studies Map MF-1589-A. 


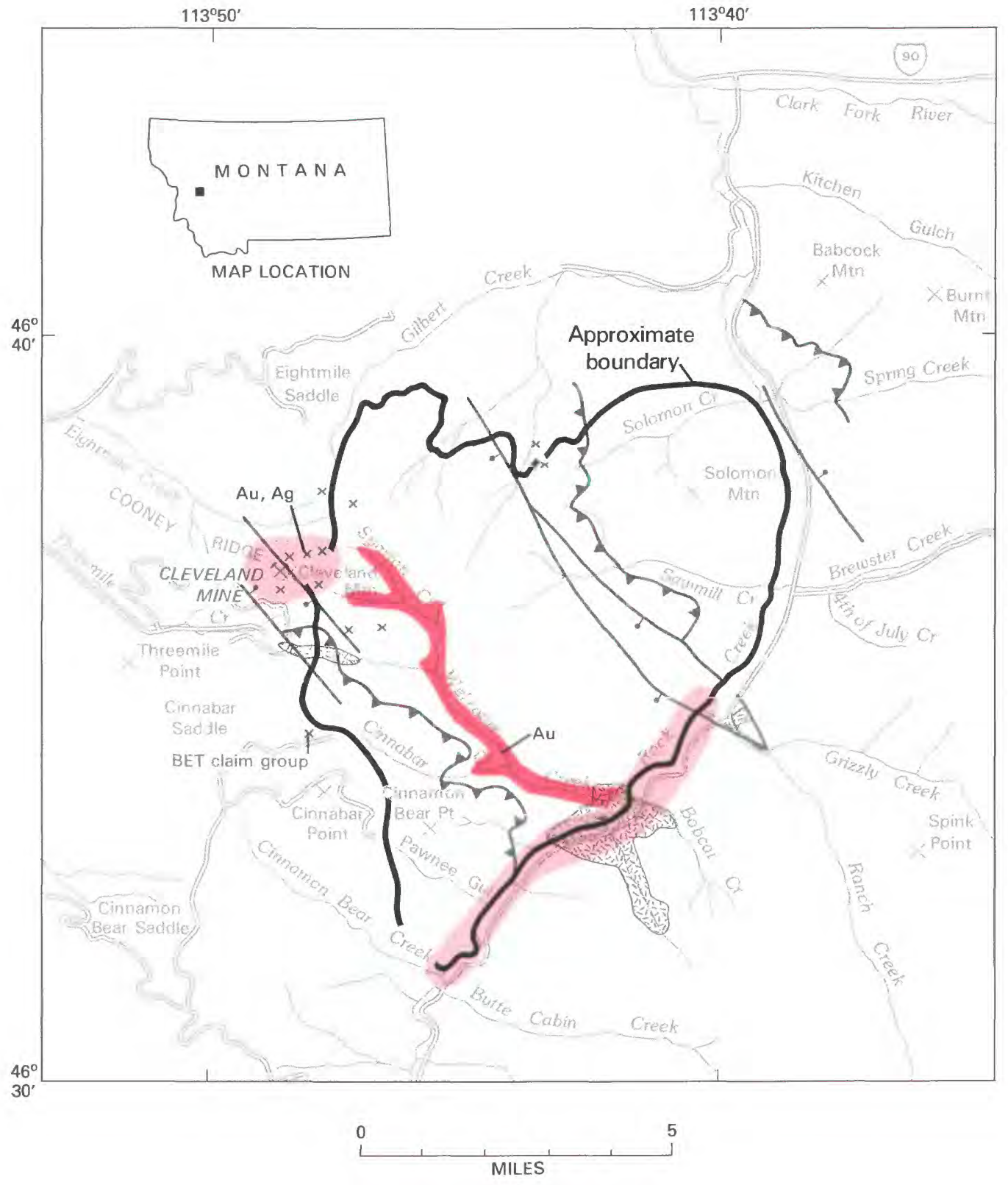

\section{EXPLANATION}
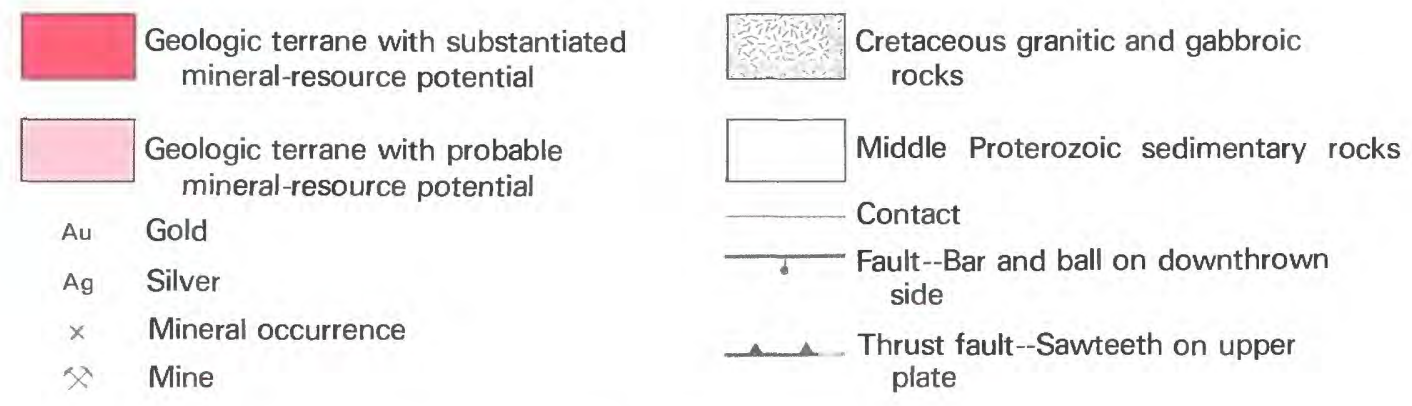

Figure 215.-Welcome Creek Wilderness, Montana. 


\title{
WELCOME CREEK WILDERNESS, MONTANA
}

\author{
By D. J. LidKe, U.S. GeOlogical SuRVEY, and \\ T. J. Close, U.S. BUREAU of Mines
}

\begin{abstract}
SUMMARY
Mineral-resource surveys conducted by the USGS and USBM in 1979-82 indicate probable or substantiated mineral-resource potential for small amounts of gold and other metals in and near two areas mined in the later 1800's and early 1900's. Areas of alluvium in Welcome Creek and in part of Rock Creek are classed as having probable and substantiated mineral-resource potential for small quantities of gold in small and scattered placers and in placer tailings. A small area which contains the Cleveland mine, on Cleveland Mountain, near the west border of the wilderness was classed as having probable mineral-resource potential for silver and gold in veins. Although green mudstone strata that often are favorable hosts for stratabound copper occurrences were found in the northeast part of the wilderness, no copper deposits were found and these studies indicate little likelihood for the occurrence of copper resources. The nature of the geologic terrain indicates that there is little likelihood of the occurrence of energy resources.
\end{abstract}

\section{CHARACTER AND SETTING}

The Welcome Creek Wilderness is located about $18 \mathrm{mi}$ southeast of Missoula and encompasses a densely forested mountainous area of about $44 \mathrm{sq} \mathrm{mi}$ in the north part of the Sapphire Mountains. The north, south, and west sides of the wilderness are accessible by unpaved USFS roads from Highway 93 approximately $12 \mathrm{mi}$ south of Missoula. The east side is accessible by the unpaved road that follows Rock Creek south from Interstate 90 , approximately $18 \mathrm{mi}$ southeast of Missoula. Travel along the east wilderness boundary, on the unpaved road along Rock Creek provides scenic views of the wilderness. Steep-sided valleys are flanked by precipitous ridges that rise abruptly from Rock Creek (approximate altitude $3700 \mathrm{ft}$ ) toward the Bitterroot Divide (approximate altitude $7700 \mathrm{ft}$ ), which forms part of the west boundary of the wilderness.

The Welcome Creek Wilderness is underlain by a thick sequence of sedimentary rocks of Middle Proterozoic age (approximately 900-1450 million years) that consist mainly of interbedded sandstone, mudstone, and claystone; the bottom part contains limestone interbedded with carbonate-bearing mudstone and sandstone. Sedimentary rocks younger than Middle Proterozoic age are not present in the wilderness. After deposition of ancient sedimentary rocks and before approximately 80 million years ago, two faulting events occurred. The sedimentary rocks were first faulted along high-angle faults and later were broken by lowangle thrust faults. The greatest disruption of the rocks resulted from the thrust faulting. The thrust faulted rocks in the wilderness comprise only a small part of the Sapphire Thrust Plate, a plate that apparently moved great distances to the east during thrust faulting. After thrust faulting, probably about 60-80 million years ago, small granitic and gabbroic intrusive bodies intruded the ancient sedimentary rocks. Heat from these intrusive rocks has locally metamorphosed the intruded sedimentary rocks. After this event the rocks were again offset along high-angle faults. Geologically recent erosion, primarily erosion by streams carved the steep valleys, and the streams deposited alluvium along their courses.

The Welcome Creek Wilderness encompasses most of the Welcome Creek mining district, and includes the historic gold placer deposits along Welcome Creek and some sulfide-bearing veins and vein prospects. Placer mining of alluvium in Welcome Creek began in the late 1800 's and has been the dominant mining activity in the wilderness. Lyden $(1948$, p. 36$)$ reported that $\$ 30,000$ in placer gold was produced from placer deposits in 
Welcome Creek from 1890 to 1911 . USBM records list $\$ 500$ in gold production between 1912 and the present time. Recently there has been intermittent small-scale placer mining along upper Welcome Creek. The Cleveland mine, located about $0.25 \mathrm{mi}$ west of the wilderness on Cleveland Mountain, probably yielded ore during the late 1800 's to early 1900 's, but there are no records of production and there was little development. Other lode prospects in the Welcome Creek Wilderness have not been developed.

Studies conducted in the wilderness consisted of geologic mapping, sampling and analysis of rock, mineralized rock, and alluvium; examination of mines and prospects; and interpretation of gravity and aeromagnetic data in terms of the known geology and mineral occurrences.

\section{MINERAL RESOURCES}

Alluvium of Welcome Creek was classed as having substantiated resource potential for small quantities of gold because gold has been produced from placer deposits in this area and because sampling of the alluvium indicates that gold may be present in small and scattered deposits in both placered and in unplacered alluvium. Alluvium of Rock Creek between Cinnamon Bear Creek and Ranch Creek was classed as having probable potential for some placer gold because sampling indicates that the essentially unplacered alluvium along this part of Rock Creek might also contain small and scattered placers. The remaining alluvium of Rock Creek, along the eastern wilderness boundary, also contains gold. However, samples taken from this part of Rock Creek contained significantly lower concentrations of gold than did samples taken south of Ranch Creek.

The Cleveland Mountain area is classed as having probable mineral-resource potential for silver and gold in veins because the Cleveland mine on Cleveland Mountain apparently produced some ore from veins during the late 1800's to early 1900's and because a concentration of base and precious metal bearing veins occurs in the area. Except for the BET claim group, all mines and mineral occurrences shown on the map are located in vein occurrences. Veins are most numerous near the west boundary of the wilderness. Examination of these veins and analyses of vein material suggests that the veins are thin, discontinuous, and low grade.

In the northeast part of the wilderness anomalous concentrations of copper were found in a few stream- sediment samples. Green mudstones that are favorable hosts for stratabound copper deposits are present in this area. However, based on regional trends for this type of deposit, and because no stratabound deposits or other types of copper-bearing deposits were found in the area, there seems little promise for the occurrence of copper resources.

The BET claim group, approximately $0.5 \mathrm{mi}$ outside the southwest wilderness boundary, is apparently located in a weakly mineralized replacement deposit. Although examination of the BET claims suggests the deposit may contain a small resource of gold and tungsten, no evidence of similar occurrences was found in the wilderness.

Little likelihood exists for the occurrence of radioactive minerals, coal, geothermal, and oil and gas resources in the Welcome Creek Wilderness. The sedimentary rocks exposed in the wilderness do not commonly contain oil and gas resources; information is lacking on the younger sedimentary rocks that are often more favorable host rocks for oil and gas that might lie below regional thrust sheets. Radioactive minerals and coal were not found during these studies, and these resources are not common in rock types exposed in the area. The geologic setting and lack of favorable signs indicate little promise for geothermal resources.

\section{SUGGESTIONS FOR FURTHER STUDIES}

The Cleveland Mountain area coincides with some prominent northeast-trending gravity and magnetic anomalies that have not been related to mineralized systems present in the area. Detailed geophysical surveys and geologic study in this area might permit a better understanding of the mineralization, and its resource potential.

\section{REFERENCES}

Close, T. J., 1982, Mineral resources of the Welcome Creek Wilderness, Granite County, Montana: U.S. Bureau of Mines Open-File Report MLA 17-82, 14 p.

Hassemer, J. H., 1981, Principal facts and complete Bouguer gravity anomaly map for the west half of the Butte $1^{\circ}$ by $2^{\circ}$ quadrangle, Montana: U.S. Geological Survey Open-File Report 81-949, 39 p.

Lidke, D. J., Wallace, C. A., Close, T. J., Antweiler, J. C., Campbell, W. L., Hassemer, J. H., and Hanna, W. F., in press, Mineral resource potential map of the Welcome Creek Wilderness, Granite County, Montana: U.S. Geological Survey Miscellaneous Field Studies Map MF-1620-A, scale 1:50,000.

Lyden, C. J., 1948, The gold placers of Montana: Montana Bureau of Mines and Geology Memoir 26, v. 15, 99 p. 


\title{
WEST PIONEER WILDERNESS STUDY AREA, MONTANA
}

\author{
By Byron R. Berger, U.S. Geological Survey, and \\ JOHN R. BENHAM, U.S. BUREAU OF MiNES
}

\begin{abstract}
SUMMARY
The West Pioneer Wilderness Study Area is in the Pioneer Mountains, Beaverhead County, Montana. A mineral-resource study of the area in 1978-81 identified eight areas with molybdenum potential, four areas with gold-silver potential, one area with tungsten potential, and one area with barite potential. Several small mines were encountered, but none were accessible for the purposes of resource evaluation. No energy resources were identified in the study.
\end{abstract}

\section{CHARACTER AND SETTING}

The study area consists of $231 \mathrm{sq} \mathrm{mi}$ in the western one-half of the Pioneer Mountains in southwestern Montana, about $30 \mathrm{mi}$ northwest of the town of Dillon. The western Pioneer Mountains constitute a northerly trending $30 \mathrm{mi}$ long and $13 \mathrm{mi}$ wide mountain block between the north-flowing Wise River and south-flowing Grasshopper Creek on the east and the Big Hole valley on the west. The mountains rise abruptly from broad, flat valleys at about $7000 \mathrm{ft}$ altitude to peaks from 9000 to above $9400 \mathrm{ft}$. Access to the area is from State Highway 43 on the north and west and from an access road on the east along the Wise River.

Multidisciplinary studies by the USGS and USBM commenced in 1978, and included reconnaissance geochemical sampling of stream sediments and rocks, an aeromagnetic survey of the area, a study of the geology by the USGS, and a study of known mines and prospects by the USBM. The studies by the USBM included a mining-claim records search, on-site claim, mine, and prospect investigations, and mapping and sampling of known mines.

Since 1869, numerous claims have been located in the study area. Three hundred of these are lode claims, with only five 20-acre placer claims staked along the eastern boundary of the study area. Two hundred ninety claims are currently active.

The western Pioneer Mountains contain rocks of many ages. Precambrian gneisses and metavolcanic rocks occur in the northwestern part of the study area. Proterozoic metasedimentary rocks are exposed extensively throughout the area and consist of quartzite, siltite, argillite, and calc-silicate hornfels. Paleozoic sedimentary rocks are exposed only beneath a thrust fault on the east side of the study area and as roof pendants in batholithic rocks in the northern part of the study area. Upper Mesozoic to Tertiary plutonic rocks intrude all of the older rocks and make up the Pioneer batholith. Batholithic rocks ranging in composition from diorite to granite are extensively exposed in the study area. Quaternary glacial and alluvial deposits are found throughout the study area.

\section{MINERAL RESOURCES}

Evidence of mineralization is widespread within the study area and immediately adjacent to the proposed boundaries. Numerous precious- and base-metal-bearing quartz veins and porphyry-type molybdenum deposits occur in the area. Minor tungsten-bearing skarn occurrences were found, and a single barite vein is located near the southern boundary of the study area. All of these mineral occurrences appear to be related to late phases of the batholitic rocks.

The present study has identified several areas of substantiated mineral-resource potential as well as several terranes with probable mineral-resource potential. Those areas with substantiated mineral-resource potential were delineated on the basis of an assemblage of favorable geologic data including observable alteration and metallization as well as positive indications from private exploration and (or) development. Areas with probable mineral-resource potential are delineated on the basis of data consistent with modern concepts on the presence of undiscovered mineral deposits.

One area of gold-silver mineralization, three areas of molybdenum mineralization, and one area of barite have substantiated mineral-resource potential. The areas are 


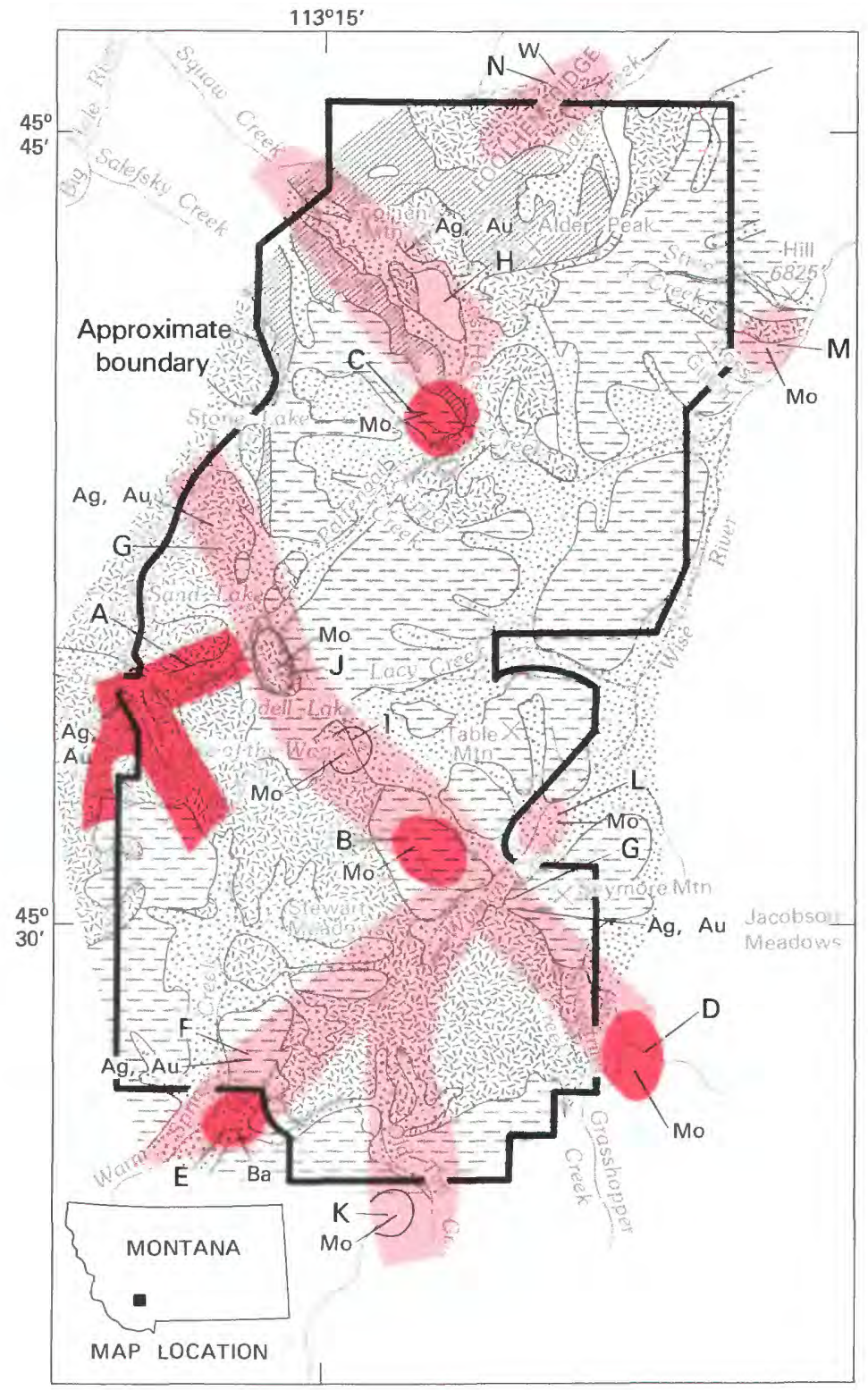

0 5 MILES

\section{EXPLANATION}

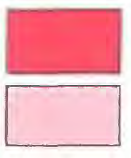

$\mathrm{Ba}$
$\mathrm{Au}$
$\mathrm{Mo}$
$\mathrm{Ag}$
$\mathrm{W}$
Geologic terrane with substantiated mineral-resource potential

Geologic terrane with probable mineral-resource potential

\section{Barium}

Gold

Molybdenum

Silver

Tungsten

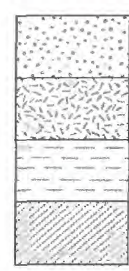

Quaternary deposits

Tertiary and Mesozoic intrusions

Proterozoic metasedimentary rocks

Precambrian gneiss and metavolcanics

Contact

B Area discussed in text

Figure 216.-West Pioneer Wilderness Study Area, Montana. 
discussed below according to the principal commodity of economic interest.

Gold and silver mineralization occurs in area $\mathrm{A}$ (on map) which contains quartz veins along faults, fractures, and joints. The vein widths vary from a few inches to several feet. The veins occur along northwestand northeast-trending structures, and appear to be localized at the intersection of a through-going northwesterly fault trend that transects the entire study area with a more subtle northeastern trend. The deposits contain oxidized and primary ores of silver, gold, lead, and zinc with minor associated concentrations of molybdenum, tungsten, and bismuth.

Molybdenum mineralization occurs in areas B, C, and $\mathrm{D}$ and these areas have been explored extensively. Area $B$ is a large area of multiple episodes of brecciation with associated quartz-molybdenite veining. Molybdenum occurs in quartz veins in drill core, as do multiple injections of altered porphyritic granitic rocks.

Area $\mathrm{C}$ is an area of intense quartz-sericite-molybdenite veining in Precambrain quartzite associated with altered porphyritic granitic dikes. Exploration drilling has found multiple episodes of mineralization to a considerable depth.

Area D contains zones of intense quartz-sericite alteration with some localized areas of stockwork veining with molybdenite. The mineralization occurs in porphyritic granitic rocks. Exploration drilling has confirmed the continuation at depth of quartz-molybdenite veins in association with sericite and potassium feldspar alteration.

A vein several feet wide of relatively pure barite occurs near the southern boundary of the study area, and strikes northerly towards it. An area of substantiated barite resource potential $(\mathrm{E})$ occurs around the vein and extends into the study area. Some development work has been done on the vein.

Three areas of gold-silver mineralization, five areas of molybdenum mineralization, and one area of tungsten mineralization have probable mineral-resource potential. The areas are discussed below according to the principal commodity of economic interest.

Areas $\mathrm{F}, \mathrm{G}$, and $\mathrm{H}$ contain sporadic quartz veins along northeast- and northwest-trending fault zones that have probable gold and silver resource potential. Visible sulfides, particularly pyrite, are observable in the veins. Stream-sediment geochemical anomalies are persistent along mapped fault trends, and some of the veins are in close proximity to extensive areas of hydrothermal alteration of the porphyry type. Some re cent prospecting activity of a minor variety is evident, and old, caved underground workings may be found at a few localities along each of the trends.
Areas I through $\mathbf{M}$ contain probable molybdenum resource potential. Area $I$ is an occurrence of sulfidebearing intrusive breccia with associated quartz-sericite alteration. Sulfide-bearing quartz veins occur in the vicinity of the breccia pipe. These veins contain molybdenum-bearing minerals including molybdenite and wulfenite. The veins have been explored, but the breccia shows no evidence of recent exploration.

Area $\mathrm{J}$ is an intrusive breccia with sulfide minerals and associated quartz-sericite alteration. Sulfidebearing quartz veins radiate away from the breccia pipe. Geochemical sampling of the breccia shows anomalous concentrations of molybdenum with associated copper, silver, lead, and zinc. There is no evidence of recent exploration.

Area $\mathrm{K}$ consists of several breccia pipes with quartzsericite alteration and altered porphyritic granitic dikes. Exploration activity has been high, and the breccia pipes are known to persist to several hundred feet depth.

Area L consists of scattered outcroppings of quartzsericite veins in Precambrian quartzite with minor amounts of visible molybdenite. The outcrops occur sporadically over a large area which is mostly covered by alluvium and talus.

Area $M$ consists of an extensive area of pervasively altered batholithic rocks with sericite, quartz, and disseminated molybdenite. Aplitic granitic dikes are spatially associated with the mineralization. There is no evidence of exploration.

Tungsten occurs as scheelite in altered carbonate rocks, called skarn. These skarns occur as roof pendants in batholithic rocks in area N. Immediately north of the study area there has been extensive exploration, and it is likely that some exploration will continue.

\section{SUGGESTIONS FOR FURTHER STUDIES}

Geochemical evidence of a copper-zinc anomaly was detected in the southwestern corner of the study area. No corroborative geologic indications of mineralization were found. A limited electrical geophysical survey in the area defined an anomaly at depth beneath the surface outcrops. Further study is needed to define the source of the anomaly. Another area warranting additional study is the region in the northern part of the study area where mixed gneisses and metavolcanic rocks occur. Similar rocks elsewhere in the region contain precious-metal deposits, and more detailed study is needed to evaluate the resource potential of these rocks. 


\section{REFERENCE}

Berger, B. R., Snee, L. W., Hanna, William, and Benham, J. R., 1983, Mineral resource potential map of the West Pioneer Wilderness Study Area, Beaverhead County, Montana: U.S. Geological Survey Miscellaneous Field Studies Map MF-1585-A, scale $1: 48,000$ 



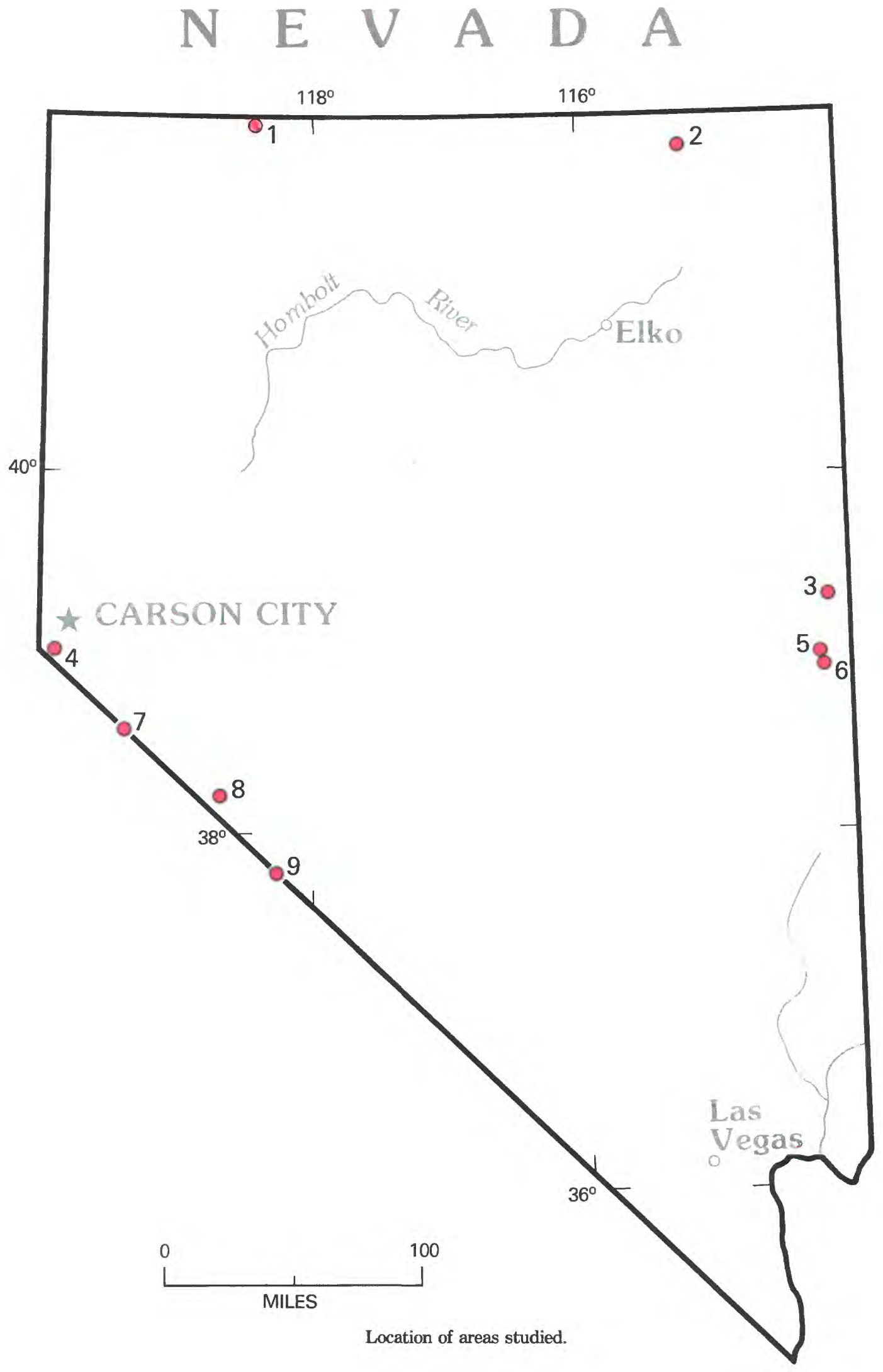




\section{NEVADA}

Map

No.

1 Charles Sheldon Antelope Range and Sheldon National Antelope Refuge, Nevada and Oregon

6 Highland Ridge Roadless Area

2 Jarbidge Wilderness

4 Lincoln Creek Roadless Area

3 Mount Moriah Roadless Area

8 Sugarloaf Roadless Area

7 Sweetwater Roadless Area, California and Nevada-See California

5 Wheeler Peak Roadless Area

9 White Mountains and Birch Creek Roadless Areas, California and Nevada-See California 

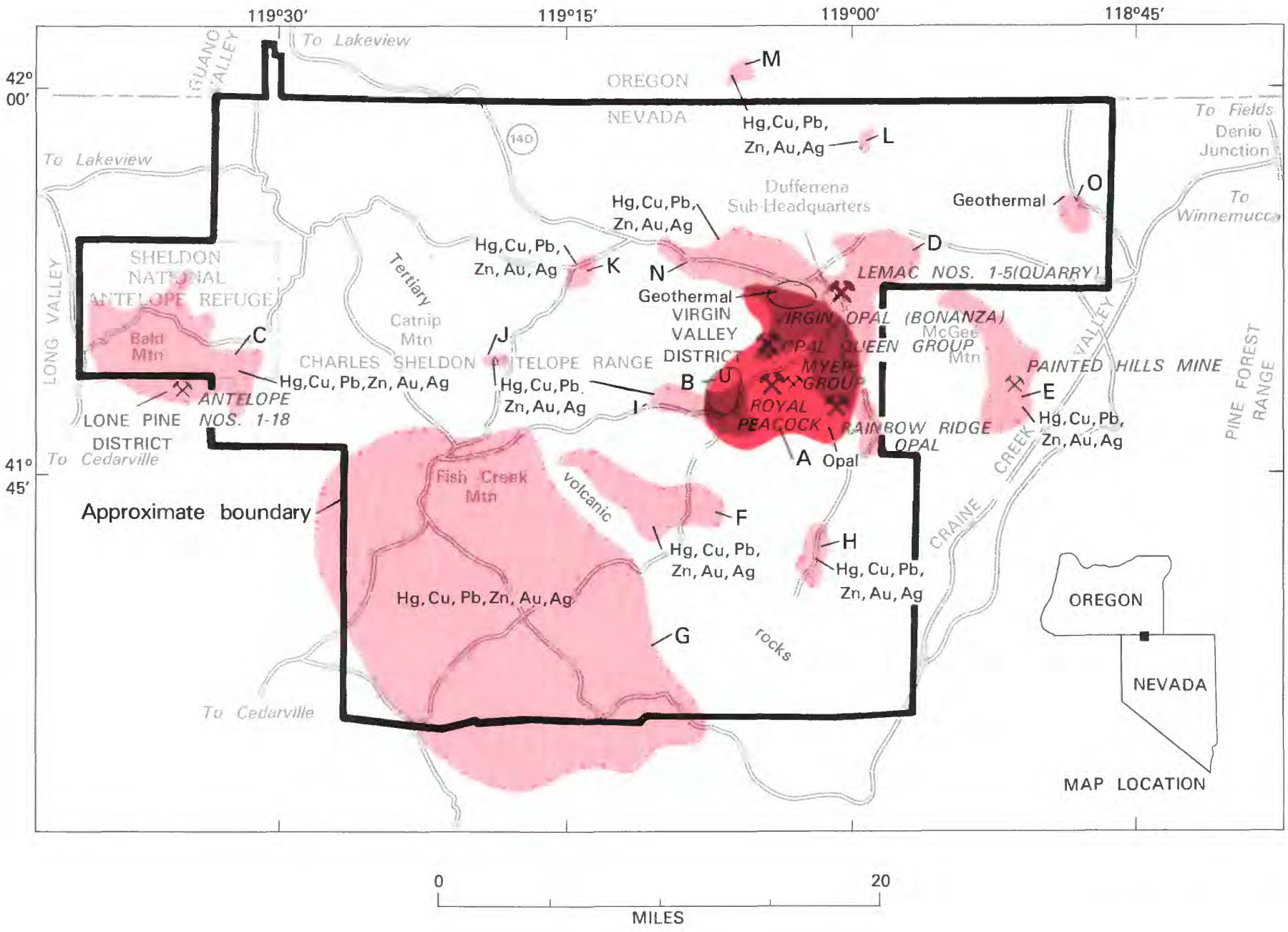

\section{EXPLANATION}

Geologic terrane with substantiated uranium and (or) opal resource potential and probable mineral-resource potential

Geologic terrane with substantiated mineral-resource potential

Geologic terrane with probable mineral-resource potential

$\begin{array}{cl}\mathrm{Cu} & \text { Copper } \\ \mathrm{Au} & \text { Gold } \\ \mathrm{Pb} & \text { Lead } \\ \mathrm{Hg} & \text { Mercury } \\ \mathrm{Ag} & \text { Silver } \\ \text { u } & \text { Uranium } \\ \mathrm{Zn} & \text { Zinc } \\ \text { a } & \text { Mine or deposit } \\ \text { \& } & \text { Mine } \\ \text { B } & \text { Location discussed } \\ & \text { in text }\end{array}$

Figure 217.-Charles Sheldon Antelope Range and Sheldon National Antelope Refuge, Nevada and Oregon. 


\title{
CHARLES SHELDON ANTELOPE RANGE AND SHELDON NATIONAL ANTELOPE REFUGE, NEVADA AND OREGON
}

\author{
By J. B. Cathrall, ${ }^{1}$ U.S. Geological Survey, and \\ E. T. TUChEK, U.S. BurEaU of Mines
}

\begin{abstract}
SUMMARY -
A mineral survey of the Charles Sheldon Antelope Range and Sheldon National Antelope Refuge, in Humboldt and Washoe Counties, Nevada, and Lake and Harney Counties, Oregon, was conducted in 1974-75. The investigation identified areas of mineral-resource potential within the range and refuge. The range and refuge have areas of substantiated resource potential for precious opal and uranium, a demonstrated resource of decorative building stone, and areas with probable resource potential for mercury and for base- and preciousmetal sulfide deposits. Reservoir temperatures, estimated from the analysis of thermal springs, indicate that a probable potential for geothermal resources exists in two areas in the range. No other energy resources were identified in the area.
\end{abstract}

\section{CHARACTER AND SETTING}

The Charles Sheldon Antelope Range and Sheldon National Antelope Refuge are located in the vicinity of the junction of California, Oregon, and Nevada and cover approximately $820 \mathrm{sq} \mathrm{mi}$; the two areas will be referred to as the study area in this paper. The study area is far from any town, the nearest being Denio Junction, $10 \mathrm{mi}$ east by road. Access to the study area is provided by Nevada-Oregon Route 140; a network of gravel and dirt roads, some requiring four-wheel drive vehicles, provide access within the study area.

The study area is in the northwestern part of the Great Basin section of the Basin and Range province. Topographically, it consists mostly of flat plateaus and rounded mountains, locally broken by steep scarps or cut by canyons. High fault scarps adjacent to flat alluvial valleys, a characteristic feature of the Great Basin, are present on both the east and west sides of the study area. Total relief in the study area is just over $3000 \mathrm{ft}$ with several peaks reaching altitudes slightly over $6800 \mathrm{ft}$.

The study area is on the southeast flank of a broad basin filled with sedimentary and volcanic rocks of Tertiary and Quaternary age that occupy northwestern-

\footnotetext{
${ }^{1}$ With contributions from R. C. Greene, D. Plouff, D. F. Siems, G. L. Crenshaw and E. F Cooley, USGS, and F. J. Johnson and M. D. Conyac, USBM.
}

most Nevada, northeastern California, and southcentral Oregon. This broad basin is dominated by northwest-trending normal faults. The structural break between this broad basin area and the northeasttrending fault-block ranges to the east occurs at the Pine Forest Range. Outcrops within the study area consist entirely of volcanic and continental sedimentary rocks of late Tertiary and Quaternary age. These rocks rest on a buried basement that probably comprises Permian, Triassic, and Jurassic metavolcanic and sedimentary and Jurassic and Cretaceous granitic rocks. The thickness of the Tertiary and Quaternary rocks is variable and they are flat lying or gently dipping and show much interfingering in local basins.

Volcanic rocks are andesite lava flows, rhyolite ashflow tuffs, and basalt flows. The andesitic rocks are the oldest and are middle Miocene in age. The ash-flow tuffs are slightly younger and are parts of widespread tuff sheets recognized elsewhere in northwestern Nevada. Basalt flows that cap much of the study area are varied in age. Tuffaceous sedimentary strata are lenticular units at many horizons in the section and are especially thick in ancient valleys such as Virgin Valley.

Basin and range faults in the study area are fewer in number, have less offset, and have a different trend than in surrounding regions of the Great Basin. The general trend of the faults in the study area is northwest, while the trend of faults in adjacent regions is 
northeast. There are no major mountains of block-fault origin in the study area.

The mineral-resource potential was evaluated by geologic, geochemical, and geophysical studies by the USGS, and by the examination of mines, prospects, and other mineralized localities by the USBM (Cathrall and others, in press).

\section{MINERAL RESOURCES}

The study area contains two mining districts, the Virgin Valley near the eastern edge of the Charles Sheldon Antelope Range, and the Lone Pine near the southern part of the Sheldon National Antelope Refuge. Production from the study area is estimated to have been several million dollars, nearly all of it coming from the Virgin Valley district. Precious opal accounted for more than 75 percent of the total. Within the study area, 1656 lode and 98 placer claims have been located; 393 claims were being actively worked at the time of this investigation.

Part of the Virgin Valley district (area A, on map) has a substantiated resource potential for precious opal. Demonstrated resources of precious opal are at the Rainbow Ridge Opal, Royal Peacock, and Virgin Opal (Bonanza) mines in the Virgin Valley district and are estimated at several million dollars. Demonstrated resources of ornamental dimension stone at the Lemac quarry in the Virgin Valley district are estimated to be more than 250,000 tons of poor-quality stone; more than 18,000 tons of ornamental dimension stone have been produced. About 15 tons of fluorescent opalite have also been produced from the Virgin Valley district.

An area of substantiated uranium resource potential in tuffaceous sediments, exposed or beneath younger volcanics (area B) in the Virgin Valley district, contains demonstrated resources of 15-20 million tons of uranium-bearing rock. Anomalous concentrations of some of the elements discussed, anomalous element ratios, and detectable gold are associated with the known uranium occurrences.

Geochemical sampling during this investigation identified anomalous concentrations of gold, mercury, antimony, arsenic, tungsten, molybdenum, manganese, and barium, as well as anomalous cadmium-to-zinc ratios, which together form dispersion patterns that with geophysical data delineate target areas for possible exploration for concealed mineral deposits (areas C-M).

Fault zones or major geologic contacts are indicated by the occurrence of approximately linear magnetic contours near the east and northeast edges of the study area. The rather linear zones of high gravity or magnetic gradients are considered possible sites for future mineral exploration. The occurrence of four gravity maxima in or along the edge of the study area suggest the presence of concealed intrusive centers. The westernmost gravity anomaly occurs at a structurally uplifted location near the Lone Pine mining district at the west edge of the study area. Three gravity maxima that occur near thermal springs along the east edge of the study area seem too broad to be explained wholly as an effect of local densification of the underlying tuffaceous sedimentary rocks by compaction and filling of pre-existing pore space with precipitates from mineralrich thermal waters.

Three prominent closed gravity minima along the south edge of the study area may indicate underlying calderas masked by younger Tertiary rocks. The largest possible caldera is 27.2 by $40 \mathrm{mi}$ in size and extends to a depth of about $4.3 \mathrm{mi}$, if the assumed underlying tuffaceous sedimentary rocks are less dense than the surrounding volcanic rocks. The areas (areas F, G, H) along the edges of the postulated calderas have probable mineral potential for mercury and base and precious metals and are considered sites for possible future mineral exploration.

The south part of the Sheldon National Antelope Refuge (area C) has probable potential for mercury deposits and for concealed base-metal and complex precious-metal sulfide deposits. A mercury anomaly occurs over a large part of the area. In addition, the anomalous concentrations of the other elements mentioned above and anomalous cadmium-to-zinc ratios form dispersion patterns that are contiguous with normal faults and with magnetic and (or) gravity highs.

Additional areas that may contain mercury and concealed base-metal and complex precious-metal sulfide deposits are the areas encompassing the Dufferrena Subheadquarters (area D) and Painted Hills mine (area E). The geochemical dispersion patterns in these areas and their relationship to geologic structures, geophysical anomalies, and alinement of thermal springs suggests that the mineralized areas $\mathrm{D}$ and $\mathrm{E}$ may be joined at depth and may extend northwestward beneath younger volcanic rocks.

Area $\mathrm{F}$ has a probable potential for similar metallic resources. Most of this area is fault controlled and is contiguous with a gravity minimum anomaly. Anomalous amounts of mercury, arsenic, antimony, molybdenum, barium, gold, manganese, and anomalous cadmium-to-zinc ratios, as well as several mercury prospects, seem to be associated with faults as well as the geophysical anomaly.

In the southwestern part of the study area, a gravity minimum anomaly of substantial size suggests the possible existence of a caldera or buried pluton. The widespread geochemical anomalies in this area are similar in 
size and magnitude to the mineralized McDermitt caldera approximately $82 \mathrm{mi}$ to the northwest in the Opalite mining district. Whether a caldera or buried pluton is present in the area, the geochemical data suggest that area $\mathrm{G}$ has a probable mineral-resource potential for concealed mercury and complex precious-metal sulfide deposits.

Areas $\mathrm{H}$ through $\mathrm{M}$ are other localities where anomalous concentrations of some of the elements discussed, anomalous cadmium-to-zinc ratios, and detectable gold occur in either stream sediments or rocks. These areas have probable mineral-resource potential for mercury and complex base and precious metals.

Surface data from the principal thermal springs and adjacent cold springs indicates the areas around the springs have probable potential for geothermal resources (areas $\mathrm{N}, 0$ ). If mixed waters are involved, the estimated minimum thermal-reservoir temperatures may be low.

The apparent low level of magnetization of rocks within the postulated calderas suggests destruction of former magnetization by rock alteration that would be associated with mineralization.

\section{SUGGESTIONS FOR FURTHER STUDIES}

If calderas underlie the study area, faulting associated with caldera collapse might have provided channels for warm, ore-bearing solutions to migrate upward. Geochemical data show high concentrations of elements in the same location as the postulated calderas. The localities of gravity or magnetic maxima are considered possible sites for future mineral exploration, and additional geophysical studies are needed to verify these sites that may outline concealed calderas.

\section{REFERENCE}

Cathrall, J. B., Greene, R. C., Plouff, Donald, Siems, D. F., Crenshaw, G. L., and Cooley, E. F., Tuchek, E. T., Johnson, F. J., and Conyac, M. D., in press, Mineral resources of the Charles Sheldon Wilderness study area, Humboldt and Washoe Counties, Nevada, and Lake and Harney Counties, Oregon: U.S. Geological Survey Bulletin 1538. 

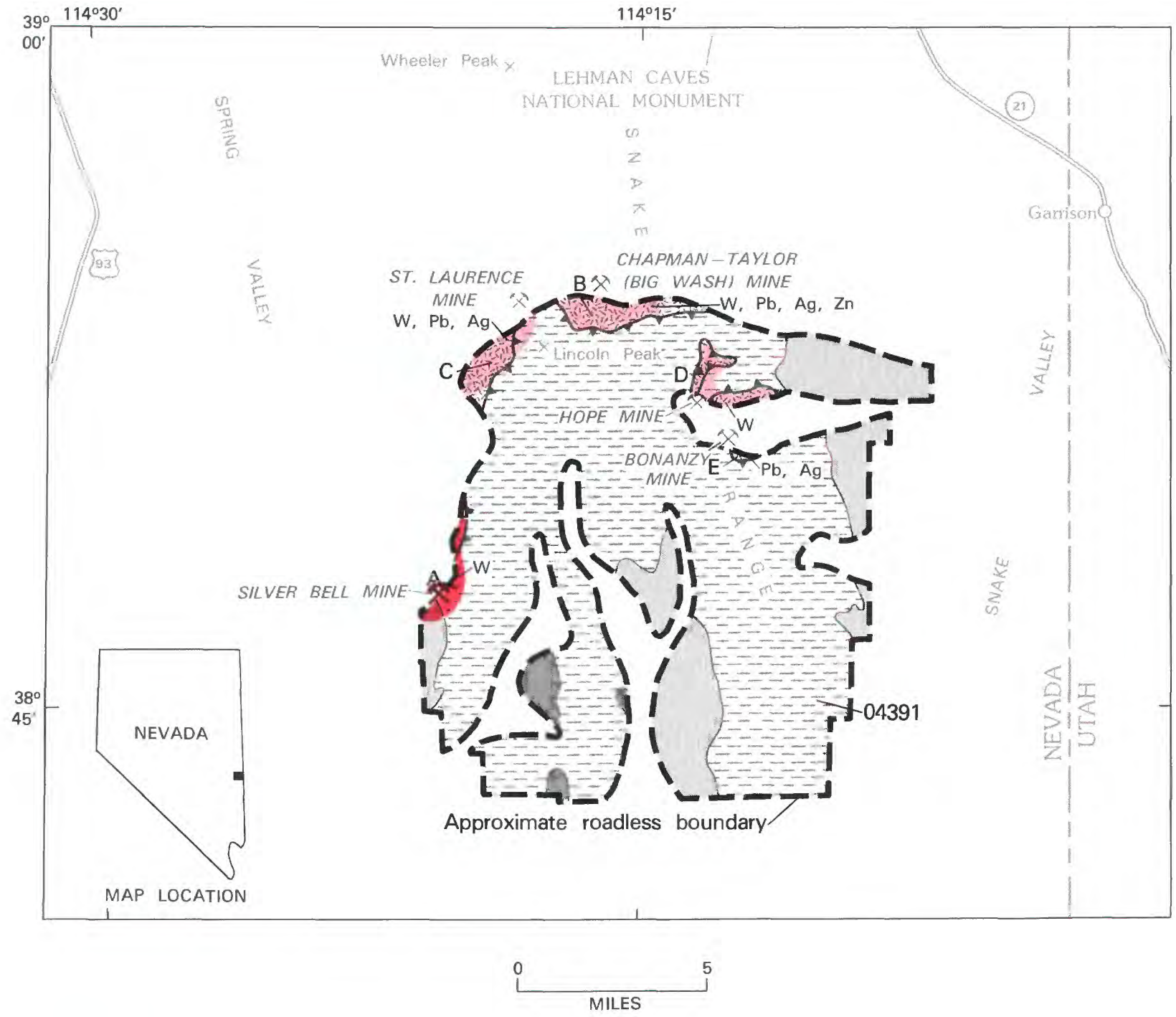

\section{EXPLANATION}

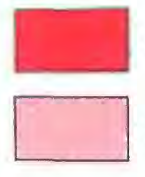

Geologic terrane with substantiated mineral-resource potential

Geologic terrane with probable mineral-resource potential

$\begin{array}{ll}\mathrm{Pb} & \text { Lead } \\ \mathrm{Ag} & \text { Silver } \\ \mathrm{W} & \text { Tungsten } \\ \mathrm{Zn} & \text { Zinc } \\ \text { × } & \text { Mine or deposit } \\ \text { 爻 } & \text { Mine }\end{array}$

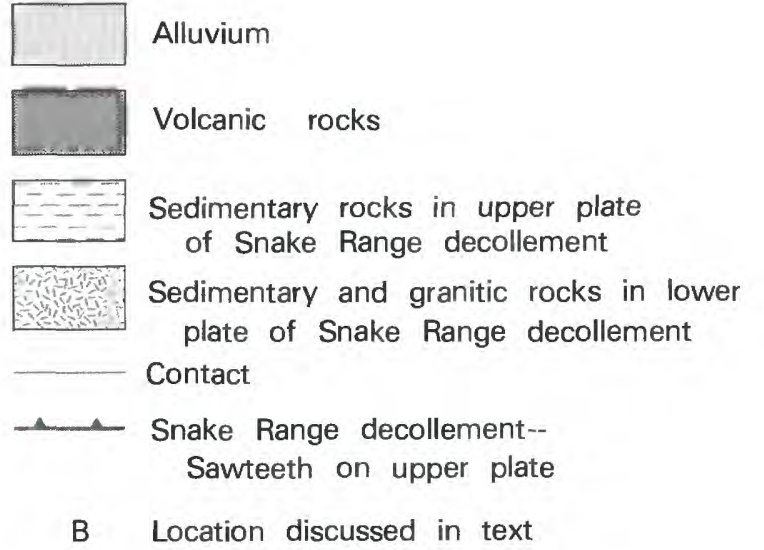

Figure 218.-Highland Ridge Roadless Area, Nevada. 


\title{
HIGHLAND RIDGE ROADLESS AREA, NEVADA
}

\author{
By Donald H. Whitebread, U.S. GeOlogical Survey, and \\ S. DON BROWN, U.S. BurEaU OF MineS
}

\begin{abstract}
SUMMARY
The mineral-resource potential of the Highland Ridge Roadless Area was evaluated on the basis of results from field investigations conducted in 1980 and 1981. One area along the west border of the Highland Ridge Roadless Area has substantiated mineral-resource potential for tungsten. Several other areas are classed as having probable mineral-resource potential, based mainly upon anomalously high values of tungsten, lead, silver, and zinc in concentrates of stream sediments. Most of the roadless area is underlain by rocks in the upper plate of the Snake Range decollement, and is considered to have little promise for the occurrence of mineral resources. No energy resource potential was identified in the area.
\end{abstract}

\section{CHARACTER AND SETTING}

The Highland Ridge Roadless Area includes $118.8 \mathrm{sq}$ $\mathrm{mi}$ in the southern Snake Range in eastern White Pine County, Nevada. Lincoln Peak (11,597 ft) is the highest point in the roadless area. Spring Valley borders the area on the west and Snake Valley borders it on the east. The Nevada-Utah State boundary is about $4 \mathrm{mi}$ east. Garrison, Utah, on Utah State Highway 21 about $6 \mathrm{mi}$ northeast, is the nearest permanent community. Ely, Nevada, about $40 \mathrm{mi}$ northwest, is the nearest main population center. U.S. Highway 50 crosses the Snake Range at Sacramento Pass about $17 \mathrm{mi}$ north, and U.S. Highway 93 is about $11 \mathrm{mi}$ west of the area. The Wheeler Peak Roadless Area is less than $1 \mathrm{mi}$ north of the area.

Most of the Highland Ridge Roadless Area is underlain by Paleozoic carbonate rocks that are in the upper plate of the Snake Range decollement, a low-angle fault that emplaced younger rocks over older rocks. Cambrian carbonate and clastic rocks and Mesozoic granitic rocks in the lower plate of the decollement are locally exposed along the north and west borders and in the northeast part of the area. The rocks above the decollement are cut by abundant high-angle normal faults and younger-on-older low-angle faults. Tertiary conglomerate and volcanic rocks that overlie these rocks are younger than the decollement and associated faults. Quaternary alluvial material and landslide debris are the youngest deposits in the area.
Mines immediately west of the Highland Ridge Roadless Area are the largest producers of tungsten in the southern Snake Range, and the easternmost workings of the Silver Bell mine extend into the roadless area. A small amount of lead and silver also has been produced from other mines west of the area. In the northeast part of the Highland Ridge Roadless Area, several prospects contain small amounts of tungsten or silver, lead, copper, and zinc, and the Bonanzy and Hope mines a short distance outside the boundaries of the area, have produced a small amount of tungsten.

The field studies included geologic mapping, geochemical sampling, and geophysical surveys by the USGS, and a survey of mines and prospects by the USBM. Stream-sediment sampling within and adjacent to the roadless area has shown anomalously high values of tungsten, lead, zinc, silver, beryllium, barium, and thorium in panned concentrates of some samples. Both gravity and aeromagnetic data were compiled as part of the geophysical studies in the area.

\section{MINERAL RESOURCES}

Based on observed mineral occurrences in prospects, proximity to known mineral occurrences, the structural and stratigraphic setting, and geochemical data from rock or stream-sediment samples, small parts of the Highland Ridge Roadless Area are considered to have probable and substantiated mineral-resource potential. 
Most of the roadless area is underlain by rocks in the upper plate of the Snake Range decollement, and is considered to have little promise for the occurrence of mineral resources, although favorable host rocks concealed beneath the decollement may possibly contain mineral occurrences. Within the roadless area, the rocks in the lower plate of the decollement are exposed only along the northern and western borders and locally in the northeast part.

One area (area A, on map) has substantiated mineralresource potential for tungsten. The easternmost workings of the Silver Bell mine extend into this area, and demonstrated and inferred resources of more than 1000 units of $\mathrm{WO}_{3}$ are estimated to be present on the basis of exposures in the mine workings (U.S. Bureau of Mines files, Denver, Colo.). Other east-trending quartz veins that have been mined for tungsten west of the roadless area also may extend into the area.

Along the northern border of the roadless area, an area (B) has probable potential for mineral resources on the basis of anomalously high values of tungsten, silver, lead, and zinc in panned concentrates of stream sediments. Another area of probable potential (area C) has been delineated because of anomalous values of tungsten in concentrates of stream sediments and the stratigraphic and structural setting. Both areas B and C are unexplored by prospects, but the Chapman-Taylor (Big Wash) tungsten mine is about 1/4 mi north of area $B$ and the St. Lawrence mine is less than $1 \mathrm{mi}$ from both areas. The fault along which the lead-silver ore of the St. Lawrence mine occurs, projects southward into area C, but is concealed by rocks in the upper plate of the Snake Range decollement. The probable potential for mineral resources in areas $\mathrm{D}$ and $\mathrm{E}$ is based mainly on anomalous values in geochemical samples and the proximity to tungsten mines outside the area. A prospect pit in area $D$ contains sparse tungsten minerals in a quartz vein, and the tungsten-bearing veins at the Hope mine may extend into the roadless area, although analyses of samples from several pits and trenches do not support this. Samples from prospects along a quartz vein in area $E$ contain anomalous amounts of lead, zinc, silver, and copper.

Anomalous barium values in panned concentrates of stream sediments are apparently related to small veinlets or beds of barite in the Paleozoic rocks in the upper plate of the Snake Range decollement. No resource potential for deposits of barite was identified.

Limestone, sand, and gravel resources occur but they are readily available at more accessible sites outside the roadless area. Several square miles of land along the borders of the Highland Ridge Roadless Area are leased for oil and gas exploration, but the occurrence of oil and gas in the roadless area is believed to be unlikely.

\section{SUGGESTIONS FOR FURTHER STUDIES}

Additional geochemical sampling, probably followed by physical exploration, would be required to determine the sources of the metals causing anomalous values in the geochemical samples.

\section{REFERENCES}

Whitebread, D. H., 1982, Geologic map of the Wheeler Peak and Highland Ridge Further Planning Areas, White Pine County, Nevada: U.S. Geological Survey Miscellaneous Field Studies Map MF-1343-A, scale 1:62,500.

Whitebread, D. H., Carlson, R. R., Moss, C. K., Kluender, Steve, Brown, Donald, 1983, Mineral resource potential map of the Wheeler Peak and Highland Ridge Roadless Areas, White Pine County, Nevada: U.S. GeologicalSurvey Miscellaneous Field Studies Map MF-1343-B, scale 1:62,500. 


\title{
JARBIDGE WILDERNESS, NEVADA
}

\author{
By ROBERT R. COATS, U.S. GeOlogical SuRvey, and \\ L. Y. MARKS, U.S. BUREAU OF MINES
}

\begin{abstract}
SUMMARY
A geologic, geochemical, geophysical, and mines and mineral study of the Jarbidge Wilderness was made in 1972 by the USGS and USBM. A demonstrated resource of barite consisting of an estimated 90,000 tons of rock averaging 90 percent $\mathrm{BaSO}_{4}$ was identified and is exposed in prospects in the southern part of the wilderness. Similar amounts of barite may occur in the same area and might be discovered by additional exploration. This area has a substantiated potential for barite. To the west, a much larger area is classed as having probable potential for barite resources. The northwest part of the wilderness has a probable potential for gold and silver resources in veins that extend into the area from the nearby Jarbidge mining district. No energy-resource potential was identifed in the course of this study.
\end{abstract}

\section{CHARACTER AND SETTING}

The Jarbidge Wilderness comprises an isolated highland area of about $100 \mathrm{sq}$ mi that sits astride the divide between the Snake and Humboldt River drainages, in north-central Elko County, Nevada. Altitudes range from 6000 to more than $10,000 \mathrm{ft}$. The oldest rocks exposed in the area are sedimentary rocks of Ordovician age; other marine sedimentary rocks are as young as Triassic. The Paleozoic sedimentary rocks are cut by thrust faults of Mesozoic age, and are intruded by small dioritic stocks of Jurassic(?) age. All of these rocks have been eroded to a surface of low relief, on which Tertiary volcanic rocks and associated sediments have been deposited. The area was uplifted and tilted to the north, intruded, mineralized, and faulted in Tertiary time. The principal faults trend a little west of north, and define a series of horsts and grabens; many of the faults of this trend have been mineralized in the Jarbidge mining district that adjoins the wilderness on the west for part of its length.

The USGS study of the area consisted of geologic mapping, sampling and analysis of bedrock and streamsediment samples, and interpretation of a 1967 aeromagnetic survey of the Jarbidge Mountains (Coats and others, 1977). The USBM personnel examined known prospects and mining claims and sampled them for evaluation.

\section{MINERAL RESOURCES}

The Jarbidge mining district extends into the northwest part of the Jarbidge Wilderness. More than $\$ 10$ million worth of gold and silver production is recorded between 1910 and 1949 for the district. All of this production was from veins of the west vein system, which crop out on the west slope of the Jarbidge Range. The veins of the east system, which crop out within what is now the wilderness, near the crest of the Jarbidge Range, have produced little to no gold. Sampling of prospects in the east veins disclosed some gold at the outcrop level and these veins might be significantly richer in gold and silver at depth. In at least one mine in part of the west vein system, the lower limit of workable ore was at about $7350 \mathrm{ft}$ elevation. As the country has been dissected by many faults that strike more or less parallel to the veins, and that are generally downthrown on the west, the possibility of finding ore closer to the level of the East Fork Jarbidge River has not been entirely eliminated, although any ore bodies that exist are not likely to be of great extent. The area of the east vein system is considered to have a probable mineral potential for gold and silver resources.

Barite veins occur locally as fault fillings in Paleozoic sedimentary rocks in the southeastern part of the wilderness. During 1957 more than 1000 tons of barite ore was produced from the Wildcat mine, a few hundred 

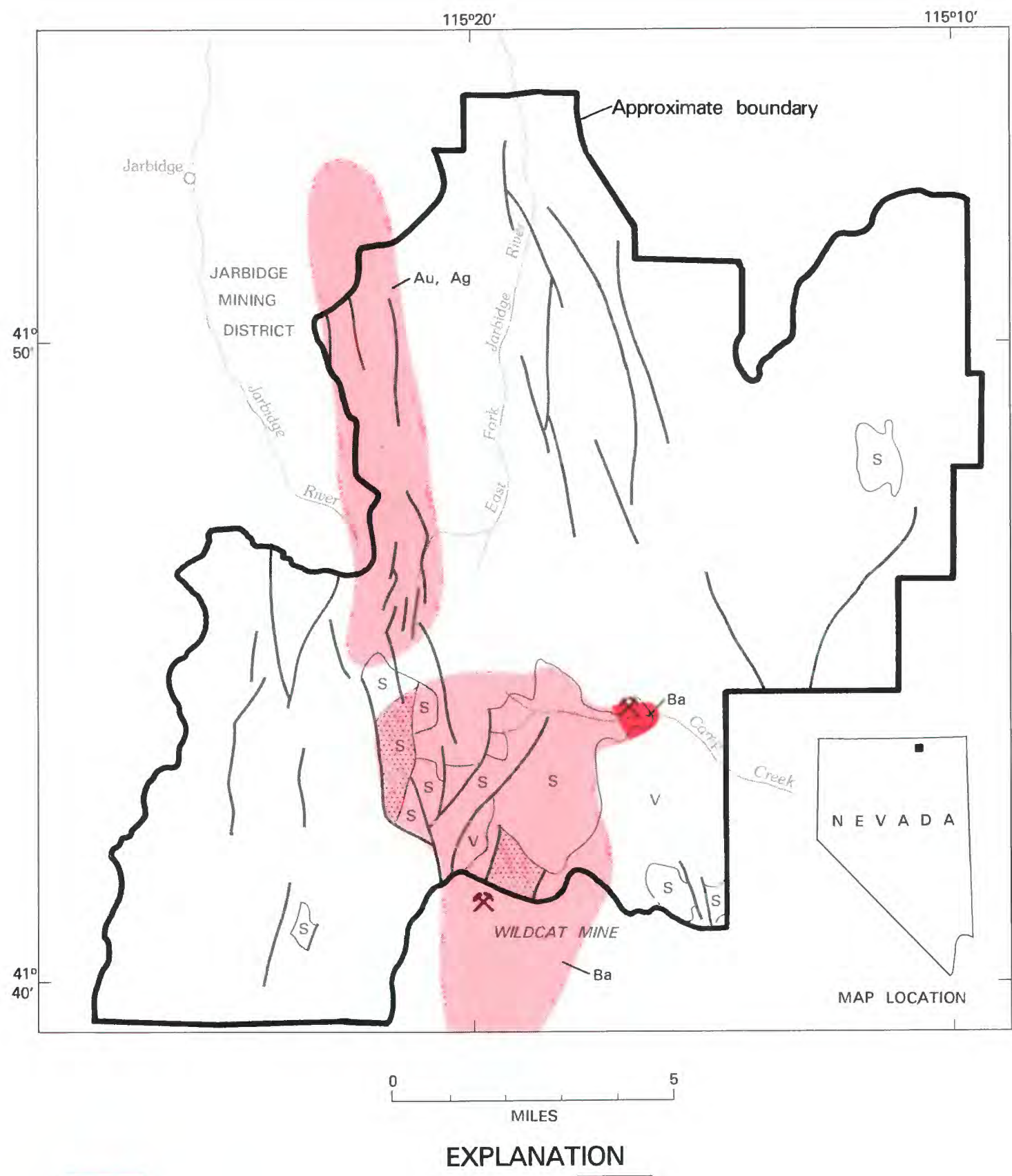

\begin{tabular}{|c|c|c|c|}
\hline & $\begin{array}{l}\text { Geologic terrane with substantiated } \\
\text { mineral-resource potential }\end{array}$ & V & $\begin{array}{l}\text { Volcanic rocks (Cretaceous) } \\
\text { and alluvium }\end{array}$ \\
\hline & $\begin{array}{c}\text { Geologic terrane with probable } \\
\text { mineral-resource potential }\end{array}$ & S & $\begin{array}{l}\text { Sedimentary rocks (Mesozoic and } \\
\text { Paleozoic) }\end{array}$ \\
\hline $\mathrm{Ba}$ & Barium & & Complexly faulted rocks \\
\hline $\mathrm{Au}$ & Gold & & (Upper Paleozoic) \\
\hline $\mathrm{Ag}$ & Silver & & Contact \\
\hline st & Mine or deposit & 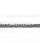 & Fault \\
\hline
\end{tabular}

Figure 219.-Jarbidge Wilderness, Nevada. 
feet south of the wilderness boundary, and a demonstrated resource of about 90,000 tons of rock averaging about 90 percent $\mathrm{BaSO}_{4}$ is estimated to occur within the wilderness in the vicinity of prospects near the confluence of Camp Creek and its north fork. Similar volumes of barite rock might be found in this area by additional exploration. These identified and undiscovered resources together account for the area of substantiated resource potential for barite shown on the map. Although much of this material as mined would be slightly below ore grade (92 percent $\left.\mathrm{BaSO}_{4}\right)$, hand sorting or jigging might raise the grade of the product to 92 percent or better.

More widespread occurrences of barite indicate that the entire area of exposed Paleozoic limestones in the south-central part of the wilderness has a probable resource potential for barite. Within this area, the two smaller areas of complexly faulted Paleozoic rocks, (shown on the map) are the most promising targets for prospecting.

\section{SUGGESTIONS FOR FURTHER STUDIES}

More extensive sampling and mapping are needed in the east vein system to establish whether any substantiated resource potential for gold and silver exists and the same is true for the area of barite mineralization in the southeast part of the wilderness.

\section{REFERENCE}

Coats, R. R., Green, R. C., and Cress, L. D., and Marks, L. Y., 1977, Mineral resources of the Jarbidge Wilderness and adjacent areas, Elko County, Nevada: U.S. Geological Survey Bulletin 1439, $79, \mathrm{p}$. 


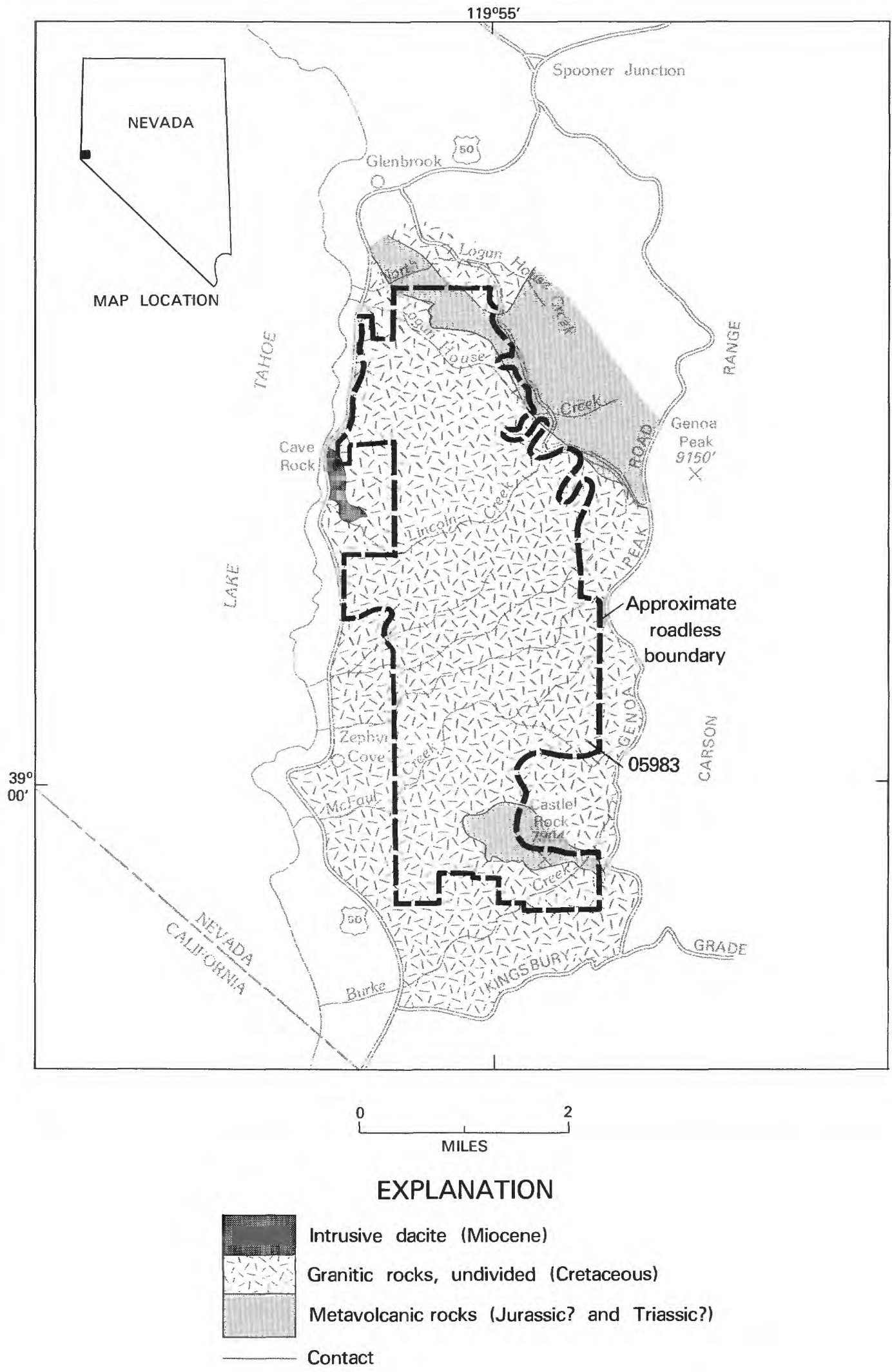

Figure 220.-Lincoln Creek Roadless Area, Nevada and California. 


\title{
LINCOLN GREEK ROADLESS AREA, NEVADA
}

\author{
By DaVid A. John, U.S. GeOlogical Survey, and \\ SCOTt A. STEbBins, U.S. BureaU OF Mines
}

\section{SUMMARY}

\begin{abstract}
On the basis of a mineral survey by the USGS and USBM in 1981-82, the Lincoln Creek Roadless Area was determined to have little likelihood for the occurrence of mineral resources. Geologic terrane favorable for the occurrence of contact-metasomatic tungsten deposits exists, but no evidence for this type of mineralization was identified. The geologic setting precludes the occurrence of fossil fuels and no other energy resources were identified.
\end{abstract}

\section{CHARACTER AND SETTING}

The Lincoln Creek Roadless Area comprises $10.3 \mathrm{sq}$ mi on the western slope of the Carson Range overlooking the southeast shore of Lake Tahoe in Douglas County, Nevada. The Carson Range is an eastern spur of the Sierra Nevada that trends north along the eastern side of Lake Tahoe. Altitudes range from about $6400 \mathrm{ft}$ at Cave Rock to $8433 \mathrm{ft}$ near the east boundary, and spectacular views of the Lake Tahoe basin are possible from the higher parts of the roadless area. The area is bounded by U.S. Highway 50 on the north and west, by Nevada Highway 19 (Kingsbury Grade) on the south, and by a USFS road on the east.

Most of the rocks exposed in the Lincoln Creek Roadless Area are Upper Cretaceous granitic rocks of the Sierra Nevada batholith. Parts of five plutons are exposed in the area, although more than three-quarters of the area is underlain by a single pluton that is about 92 million years old. The granitic rocks intrude two pendants or septa of metavolcanic rocks of probable Triassic and Jurassic age. Castle Rock near the southern end of the roadless area is composed of highly siliceous metavolcanic rock that is more resistant to weathering than the surrounding granitic rocks and thus stands above them.

Late Tertiary age volcanic rocks are common throughout much of the nearby Sierra Nevada, but a small body of intrusive dacite near Cave Rock is the only evidence of this volcanism in the roadless area. The tunnel at Cave Rock is cut through this volcanic rock.

Exploration and mining activity began in the Sierra Nevada as early as 1850 , with the first recorded activity near the Lincoln Creek Roadless Area in 1901. The Genoa mining district, $3 \mathrm{mi}$ east of the roadless area, was organized in 1860 , but results of prospecting for gold, silver, and copper in this district were disappointing. No claims have been located within the roadless area, and no visible signs of mining activity were observed during field investigations.

This mineral-resource potential report is based on studies conducted by the USGS and USBM during 1981-82. Studies included geologic mapping of the area, geochemical sampling of stream sediments, examination of prospects and mineralized areas, and searches of literature and county claim records. The results of these studies are summarized in John and others (1983).

\section{MINERAL RESOURCES}

No mineral-resource potential was identified in the Lincoln Creek Roadless Area, and little evidence of mineral deposits was found. No mineralized areas or prospects were noted in the area. Two principal types of mineral deposits are known in the Sierra Nevada in geologic settings similar to that of the Lincoln Creek Roadless Area. These are contact-metasomatic tungsten deposits, found near contacts between granitic rocks and calcareous metasedimentary rocks; and base- and precious-metal deposits, occurring in Tertiary volcanic rocks. Tungsten deposits occur in metasedimentary rocks about 20 mi southwest of the Lincoln Creek Roadless Area in the Hope Valley district; zinc, copper, and silver sulfide minerals also occur in veins and as replacements of fractures near the tungsten deposits; and silver and gold deposits occur in Tertiary volcanic rocks in the Monitor district about $25 \mathrm{mi}$ southeast of the area. 
There is little likelihood that of any of these types of mineral deposits occur in the Lincoln Creek Roadless Area. Tertiary volcanic rocks are virtually absent in the area except for small exposures near Cave Rock. Also, these volcanic rocks are both unaltered and of different composition than the mineralized rocks in the Monitor district. No evidence for the existence of base- and precious-metal-bearing sulfide veins was found during geologic mapping or in geochemical studies of streamsediment samples.

The only hint of possible mineralization in the Lincoln Creek Roadless Area occurs in the extreme northern part of the area, where stream-sediment samples from North Logan House Creek give very weak geochemical anomalies. Anomalous elements in these samples are compatible with contact-metasomatic tungsten mineralization. However, the generally weak nature of these anomalies, the lack of known suitable host rocks (limestone) for this type of mineralization, the lack of observed tungsten mineralization, and the lack of prospects and claims in this area suggest that there is little likelihood for the occurrence of tungsten resources in the roadless area.

\section{REFERENCE}

John, D. A., Chaffee, M. A., and Stebbins, S. A., 1983, Mineral resource potential map of the Lincoln Creek Roadless Area, Douglas County, Nevada: U.S. Geological Survey Miscellaneous Field Studies Map MF-1545, scale 1:62,500. 


\title{
MOUNT MORIAH ROADLESS AREA, NEVADA
}

\author{
By Robert R. CARlson, U.S. GeOlOgical Survey, and \\ ROBERT H. WOOD II, U.S. BUREAU OF MineS
}

\begin{abstract}
SUMMARY
A mineral survey conducted in 1979-81 identified the northeastern part of the Mount Moriah Roadless Area in extreme east-central Nevada as an area of probable potential for the occurrence of small, isolated deposits containing lead and zinc. Many active quarries in a unique high-quality decorative building stone occur in the area and have substantiated mineral-resource potential.
\end{abstract}

\section{CHARACTER AND SETTING}

The Mount Moriah Roadless Area covers $152 \mathrm{sq}$ mi of the Humbolt National Forest in eastern White Pine County, Nevada. Located in the rugged northern Snake Range, the area is $1.5 \mathrm{mi}$ from the Utah border, $4 \mathrm{mi}$ north of U.S. Highway 6 and 50, and 35 mi east of Ely, Nevada. The Mount Moriah massif, the only named peak in the area, ranges in altitude from $6000 \mathrm{ft}$ on its flanks to $12,050 \mathrm{ft}$ on its summit. The topography changes from a high plateau in the northwest, through transitional shallow valleys, to deep canyons flanked by towering cliffs for most of the roadless area. Most streams are intermittent, exhibiting signs of cyclical flash flooding. Vegetation ranges from desert shrubs and scrub trees to thick stands of conifers and tall deciduous trees where water is continuously available.

Geologically, the area is divided into two major terranes separated by the Snake Range décollement, a slightly warped, low-angle to flat-lying fault. Rocks below the fault consist of Precambrian and Cambrian age metamorphic quartzite, schist, phyllite, and marble. These rocks were intruded by granitic magmas of Cretaceous or Tertiary age. The intrusion by the magmas produced the metamorphism in the pre-existing rocks. The upper-plate rocks (rocks above the Snake Range décollement) are slightly younger than the lower-plate rocks and range from Cambrian to the Permian in age. They consist of unmetamorphosed limestone, dolomite, siltstone, shale, and quartzite (Hose, 1981).

The upper-plate rocks are complexly faulted by both high-angle (vertical) and low-angle (flat-lying) faults, while the lower-plate rocks are almost devoid of identified high-angle faulting. The entire package of faulted upper-plate rocks was thrust into position over the lower-plate rocks sometime after the Cretaceous/ Tertiary granitic intrusion of the lower-plate rocks (Hose, 1981).

In general, the resources of the lower-plate rocks are related to, and confined by, metamorphism of specific sedimentary units. The resources of the upper-plate rocks are, in general, related to the movement and concentration of minerals along high-angle faults, an event which occurred elsewhere, before the package was emplaced in the roadless area. These mineral occurrences, therefore, are limited to zones above the Snake Range décollement.

\section{MINERAL RESOURCES}

The appraisal of the mineral-resource potential of the Mount Moriah Roadless Area is based on geochemical data from stream-sediment, rock, and placer samples; observed mineral occurrences in mines, prospects, and placers; current and historical quarrying; and geologic controls as defined by the structural and stratigraphic setting. Geophysical evidence indicates the existence of additional granitic intrusive bodies in the lower plate, hidden below the upper-plate rocks, but it appears that no mineralization is associated with these bodies.

The most valuable commodity in the roadless area is a high-quality quartzite building stone, which is currently quarried from claims in the southeastern portion of the roadless area. This unique decorative building stone is in the metamorphosed Prospect Mountain Quartzite; current claims on this unit cover over $3 \mathrm{sq} \mathrm{mi}$ of the roadless area and contain an estimated half-trillion tons of stone. Adjacent to this area of claims, and outside the roadless boundary on the east, is an area of over $2 \mathrm{sq} \mathrm{mi}$ 


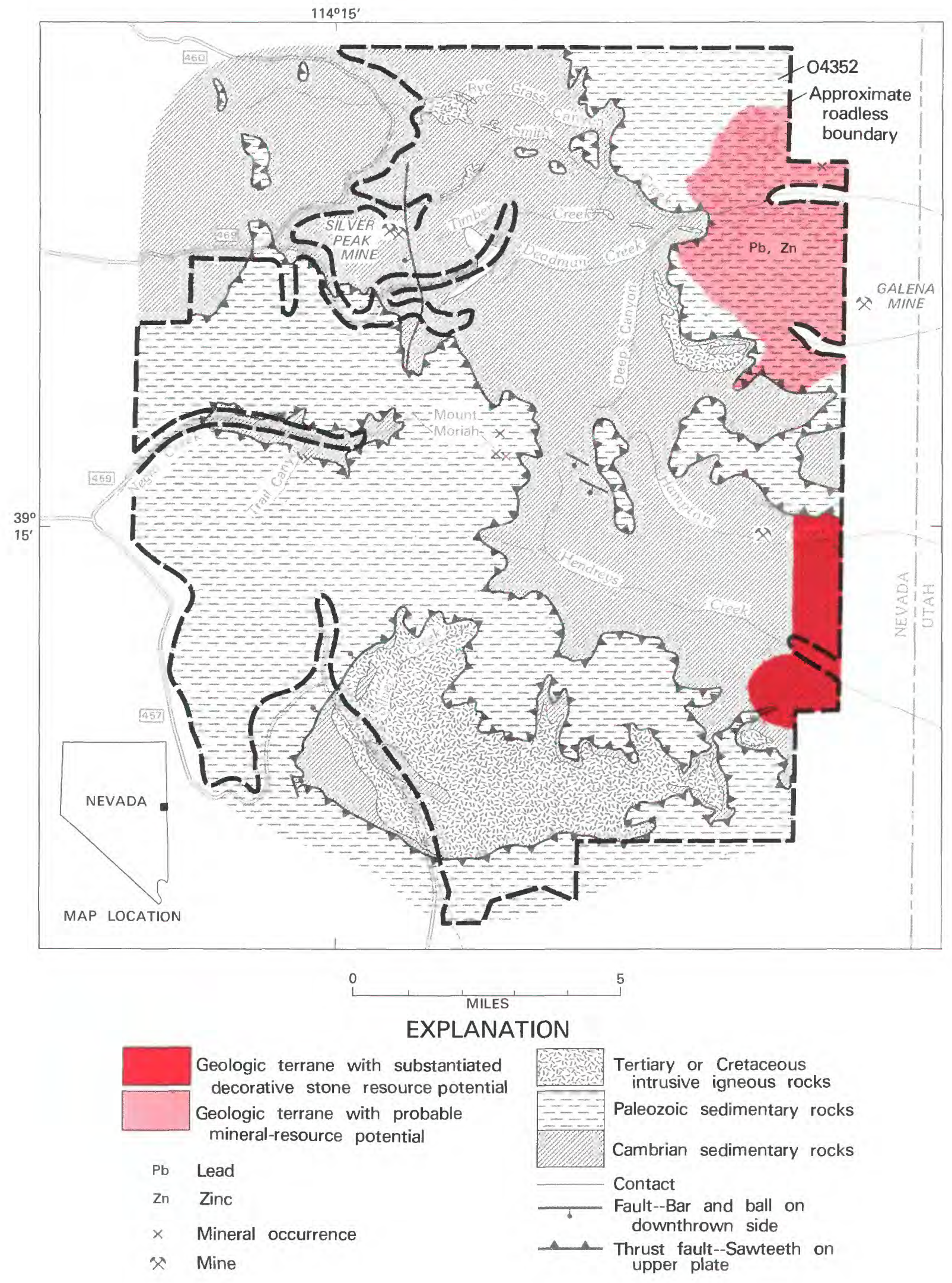

Figure 221.-Mount Moriah Roadless Area, Nevada. 
that contains additional resources of decorative stone of lower quality. A large area of exposed lower-plate rocks in the roadless area also contains quantities of this quartzite, but because there is insufficient data from this study, they are not shown as having resource potential.

Garnet-bearing schists in the Prospect Mountain Quartzite are the source for garnet placer deposits mined in Hampton Creek in the 1960's (Hose and others, 1976). High garnet content in panned concentrates, coupled with the mapped surface geology (Hose, 1981), broadens the picture for additional placer and lode occurrences in the lower-plate rocks. However, the high content of magnetite inclusions within the garnet crystals, together with the low grade (4 to 20 percent of total rock or placer concentration), could negate this area as a garnet abrasives resource.

A probable potential for base-metal resources exists in the northeastern portion of the roadless area. Thirtythree tons of lead-zinc ore containing minor silver and copper were extracted from the Galena mine, just outside the roadless area south of lower Smith Creek, and an equal amount of ore is estimated to be present in the mine. The proximity of the Galena mine, geochemical evidence, and mineralization in a small adit north of lower Smith Creek indicate that the mineralizing system extends into the roadless area. However, mineralization probably occurs as small, isolated concentrations of lead and zinc along fault zones, and it is thought to not extend at depth below the Snake Range décollement.

Three caved prospect pits on Mount Moriah showed high values of copper, lead, zinc, antimony, silver, and barium, but they are not considered to indicate the presence of resources. The same is true for one adit in Trail canyon that showed very limited amounts of high copper, lead, and silver mineralization.
The Silver Peak mine on upper Smith Creek is unusual for the roadless area in that its lead and silver mineralization (19 tons of lead and $275 \mathrm{oz}$ of silver (Hose and others, 1976)) occurs in a low-angle fault in lowerplate rocks. The mine appears to be played-out and no resource potential was identified.

There is little promise for the occurrence of oil and gas resources within the roadless area. As of June, 1981, no oil and gas lease applications had been filed within the roadless area, although several leases were current in valleys on either side of the area (Wood, 1983).

\section{SUGGESTIONS FOR FURTHER STUDIES}

Further studies in the roadless area might include detailed mapping of exposed Prospect Mountain Quartzite building stone units and notation of their suitability for quarrying. More detailed geochemical studies in the area of probable base-metal resource potential might include additional stream-sediment sampling and sampling along fault zones.

\section{REFERENCES}

Carlson, R. R., Martin, R. A., and Wood, R. H., in press, Mineral resource potential map of the Mount Moriah Roadless Area, White Pine County, Nevada: U.S. Geological Survey Miscellaneous Field Studies MF-1244-B, scale 1:62,500.

Hose, R. K., 1981, Geologic map of the Mount Moriah Further Planning (RARE II) Area, Eastern Nevada: U.S. Geological Survey Miscellaneous Field Studies Map MF-1244-A, scale 1:62,500.

Hose, R. K., Blake, M. C., and Smith, R. M., 1976, Geology and mineral resources of White Pine County, Nevada: Nevada Bureau of Mines and Geology Bulletin 85, 105 p.

Wood, R. H., 1983, Mineral investigation of the Mt. Moriah Roadless Area, White Pine County, Nevada: U.S. Bureau of Mines, Open-File Report MLA 50-83. 


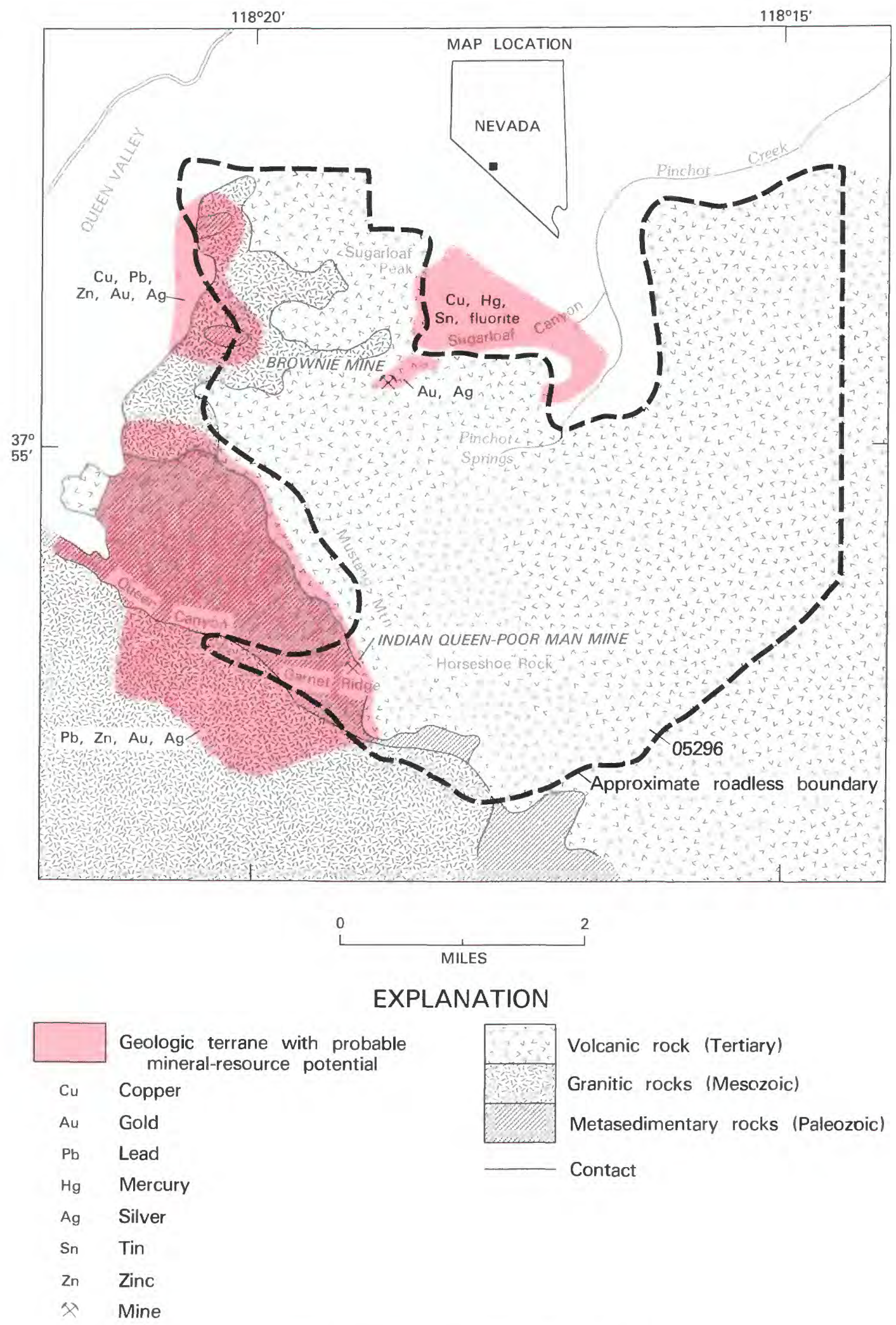

Figure 222.-Sugarloaf Roadless Area, Nevada. 


\title{
SUGARLOAF ROADLESS AREA, NEVADA
}

\author{
By EDWin H. MCKeE, ${ }^{1}$ U.S. GEOlOGICAL SURVEY, and \\ STEVEN W. SchmaUCh, U.S. BUREaU of MineS
}

\section{SUMMARY}

On the basis of a mineral survey in 1980-81, local areas in and near the western edge of the Sugarloaf Roadless Area, in particular near Queen Canyon and Garnet Ridge, have probable resource potential for silver and small amounts of associated lead, zinc, and gold.

\section{CHARACTER AND SETTING}

The Sugarloaf Roadless Area covers about $17.5 \mathrm{sq} \mathrm{mi}$ in the northern part of the White Mountains in Esmeralda and Mineral Counties, Nevada. It is $44 \mathrm{mi}$ north of Bishop California via U.S. Highway 6. Perimeter access is by an unpaved road leading eastward into Queen Canyon. The highest point in the roadless area is Mustang Mountain, which is $10,288 \mathrm{ft}$ above sea level located in the southwestern part of the area. Queen Valley, on the west edge of the roadless area at the north end of Owens Valley, has an altitude of $6400 \mathrm{ft}$ above sea level.

Rocks of the northern White Mountains, in the area that includes the Sugarloaf Roadless Area, range from Paleozoic to Holocene in age (Crowder and others, 1972; McKee, 1982). The oldest rocks are metamorphosed strata, now phyllite, slate, and marble that are correlated with Cambrian strata from the southern part of the White Mountains. Limestone, shale, and chert of the Ordovician Palmetto Formation are in thrust contact with these Cambrian rocks. Mesozoic plutonic rocks of the Inyo batholith, an eastern part of the Sierra Nevada batholith, intrude the Paleozoic rocks. Lying unconformably on the Mesozoic granitic and Paleozoic metasedimentary rocks are upper Cenozoic volcanic rocks mainly rhyolites and andesites and unconsolidated sedimentary deposits. Structures in the northern White Mountains can be classified into three groups on the basis of style and age. The oldest are thrust faults, thought to have been emplaced during the middle Paleozoic Antler orogeny, which brought the Ordovician rocks into the White Mountain region from as much as $40 \mathrm{mi}$ to the northwest. The next oldest are

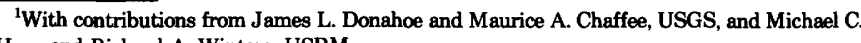
Horn and Richard A. Winters, USBM.
}

small and large folds, high-angle faults, local shearing, and some contact metamorphism related to emplacement of granitic rocks of the Inyo batholith the final phases of which took place during Cretaceous time. The youngest structures are Late Tertiary to Holocene highangle normal faults that uplifted the range. This basinand-range faulting is still active today.

\section{MINERAL RESOURCES}

The Sugarloaf Roadless Area has several areas with probable mineral-resource potential including the southwestern edge of the area, in particular near Queen Canyon and Garnet Ridge; two localities in the northcentral part of the area; and an area in and adjacent to the western edge of the area.

Most of the stream-sediment and panned-concentrate samples from drainage basins in the western half of the roadless area contain significant anomalous concentrations of many of the elements that indicate hydrothermal mineralization and alteration (Donahoe and Chaffee, 1983). This element association is characteristic of hydrothermal activity which often forms baseand precious-metal vein and replacement-type deposits peripheral to granitic intrusions. Anomalies in the western part of the Sugarloaf Roadless Area seem to be primarily related to mineralization in Paleozoic metasedimentary rocks near their contacts with Mesozoic plutonic rocks.

Geochemical anomalies in the eastern half of the roadless area consist predominantly of the element mercury. These anomalies are spacially and probably genetically related to the Tertiary rhyolite that covers most of this part of the area, but, no resource potential was identified. Gold is found locally in panned-concentrate 
samples from this area and gold has been mined from quartz-bearing shear zones in the rhyolite units that are the host for the mercury. Immediately south of Sugarloaf Peak, the Brownie mine produced $393 \mathrm{oz}$ of gold and $327 \mathrm{oz}$ of silver from a quartz-bearing shear zone (S. W. Schmauch, unpub. data, 1983) and an area of probable mineral-resource potential extends around this mine. Directly north of the roadless area, in Sugarloaf Canyon and around Sugarloaf Peak, anomalous concentrations of iron, probably in pyrite, and copper, fluorite, mercury, and tin indicate alteration, mineralization, and probable mineral-resource potential that may extend into the roadless area. A number of small mines and prospects in this area are additional evidence of mineralization adjacent to, and probably within this part of the roadless area.

\section{SUGGESTIONS FOR FURTHER STUDY}

Specific areas with probable mineral-resource potential should be studied in detail to determine the source of the geochemical anomalies within each area. Addi- tional stream-sediment panned-concentrate, or soil samples might pinpoint mineralized areas causing anomalies. Compilation of this data and information on the limits and extent of mineralized structures in accessable mines could provide targets for shallow drilling.

\section{REFERENCES}

Crowder, D. F., Robinson, P. T., and Harris, D. L., 1972, Geologic map of the Benton Quadrangle, Mono County, California and Esmeralda and Mineral Counties, Nevada: U.S. Geological Survey Quadrangle Map, GQ-1018, scale 1:62,500.

Donahoe, J. L., and Chaffee, M. A., 1983, Geochemical anomaly map of the Sugarloaf Roadless Area, Esmeralda and Mineral Counties, Nevada: U.S. Geological Survey Miscellaneous Field Studies Map MF-1400-B, scale 1:62,500.

McKee, E. H., 1982, Geologic map of the Sugarloaf Roadless Area, Esmeralda County, Nevada: U.S. Geological Survey Miscellaneous Field Studies Map MF-1400-A, scale 1:62,500.

McKee, E. H., Donahoe, J. L., Chaffee, M. A., Schmauch, S. W., Horn, M. C., Winters, R. A., 1983, Mineral resource potential map of the Sugarloaf Roadless Area, Esmeralda and Mineral Counties, Nevada: U.S. Geological Survey Miscellaneous Field Studies Map MF-1400-C, scale 1:62,500. 


\title{
WHEELER PEAK ROADLESS AREA, NEVADA
}

\author{
By Donald H. Whitebread, U.S. Geological SuRvey, and \\ Steven E. KLUENDER, U.S. BuREAU OF Mines
}

\begin{abstract}
SUMMARY
Field investigations to evaluate the mineral-resource potential of the Wheeler Peak Roadless Area in east-central Nevada were conducted during the summers of 1980-81. The field studies included geologic mapping, geochemical sampling, geophysical surveys, and a survey of mines and prospects. Several areas in the sedimentary and granitic rocks in the lower plate of the Snake Range decollement have probable mineral-resource potential for tungsten, beryllium, and lead. A small area of gravels near the north border of the area has a probable mineral-resource potential for placer gold. The geologic setting is not conducive for the occurrence of energy resources.
\end{abstract}

\section{CHARACTER AND SETTING}

The Wheeler Peak Roadless Area covers $96.7 \mathrm{sq} \mathrm{mi} \mathrm{in}$ the southern Snake Range of eastern Nevada, about 35 mi southeast of Ely. The area includes Wheeler Peak $(13,063 \mathrm{ft})$, the second highest peak in Nevada, and many other peaks higher than $11,000 \mathrm{ft}$. The rugged north-trending Snake Range is bounded on the west by Spring Valley and on the east by Snake Valley. Baker, Nevada, and Garrison, Utah, the only permanent communities in the immediate area, are on Nevada State Highway 487 and Utah State Highway 21, about $6 \mathrm{mi}$ east of the area. U.S. Highway 50 crosses the Snake Range at Sacramento Pass about $4 \mathrm{mi}$ north of the roadless area. Nevada State Highway 488 extends from Baker to Lehman Caves National Monument, which is on the northeast border of the roadless area. A narrow strip of land separates the Wheeler Peak Roadless Area from the Highland Ridge Roadless Area to the south.

Most of the Wheeler Peak Roadless Area is underlain by a thick succession of clastic and carbonate rocks of Late Proterozoic and Cambrian age that are intruded by granitic rocks. Radiometric ages obtained from the granitic rocks suggest intrusive episodes mainly in Mesozoic time, but probably also in Tertiary time. Wheeler Peak and several other peaks along the crest of the range consist of quartzite, but to the south limestone forms bold gray to white outcrops and local cliffs. In the southeast corner of the area, carbonate rocks of Cambrian to Devonian age are separated from the underlying rocks by a low-angle fault, known as the Snake Range decollement, which has displaced younger rocks over older rocks. The decollement locally truncates the granitic rocks. The rocks in the upper plate of the decollement are cut by both high-angle normal faults and younger-on-older low-angle faults. Glacial deposits that formed during Pleistocene time cover the floors and sides of some canyons in the higher parts of the roadless area, and alluvial material is deposited in other parts of canyons and along the flanks of the range.

The roadless area contains a small placer gold deposit, several tungsten mines, and scattered prospects that contain small amounts of tungsten, lead, and zinc minerals. Mines adjacent to the roadless area have produced tungsten, beryllium, gold, silver, and lead. The ore deposits occur in veins in Cambrian sedimentary rocks and Mesozoic granitic rocks in the lower plate of the Snake Range decollement.

A geochemical survey conducted by sampling stream sediments within and adjacent to the roadless area disclosed anomalously high values of tungsten, beryllium, lead, zinc, and thorium in panned concentrates of some samples. Many of the samples from mines and prospects within the Wheeler Peak Roadless Area contain tungsten, lead, silver, or zinc.

Aeromagnetic and gravity data show a correlation with the geology in the area, but no geophysical anomalies can be directly related to known ore deposits. Many of the magnetic anomalies are associated with the granitic rocks. 

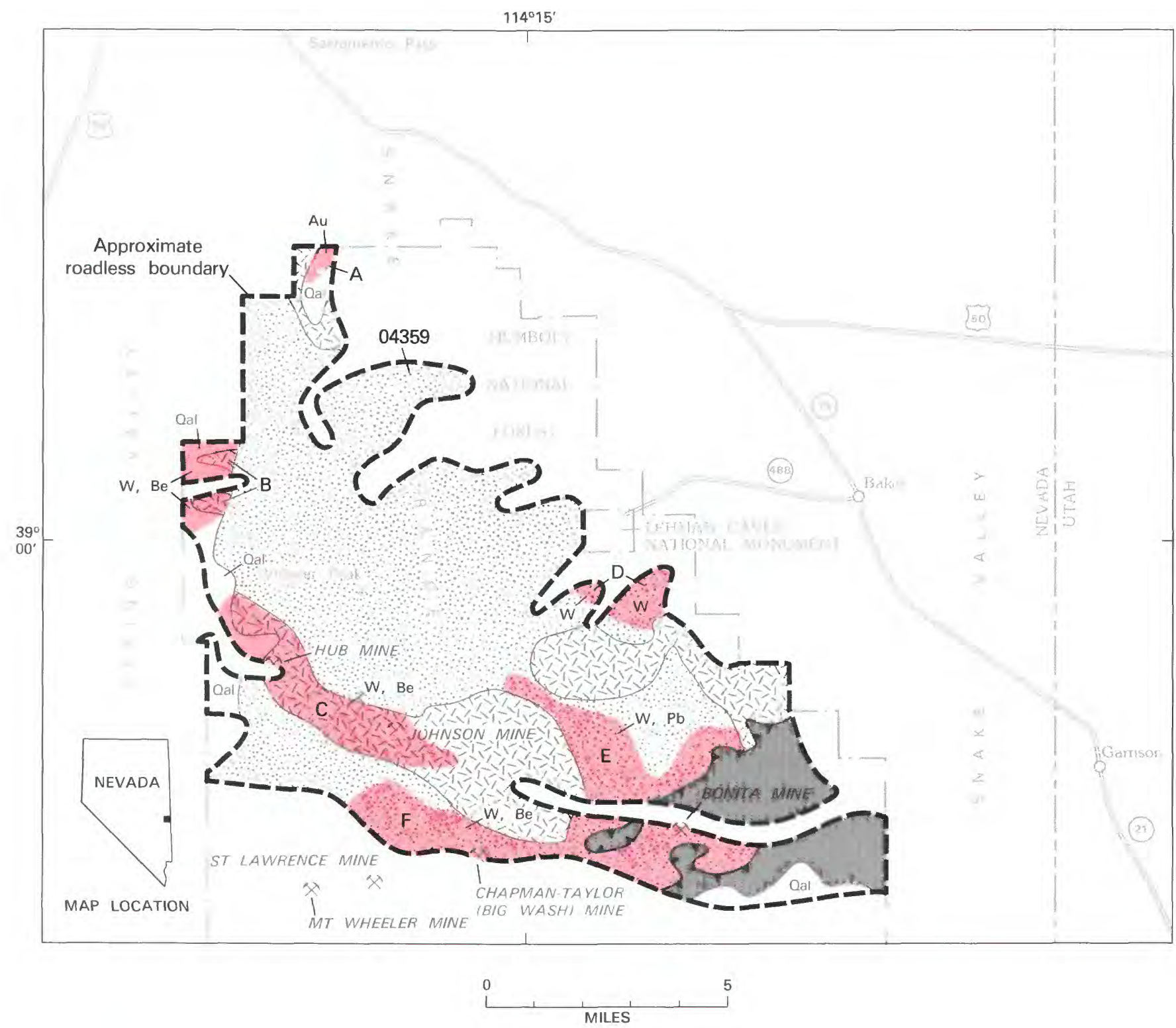

\section{EXPLANATION}

Geologic terrane with probable mineral-resource potential

Be Beryllium

Au Gold

$\mathrm{Pb} \quad$ Lead

W Tungsten

\& Mine

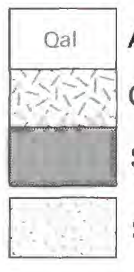

Alluvium (Quaternary)

Granitic rocks (Tertiary, Cretaceous, and Jurassic)

Sedimentary rocks in upper plate of Snake Range decollement (Devonian to Middle Cambrian)

Sedimentary rocks in lower plate of Snake Range decollement (Middle Cambrian to Proterozoic)

B Location discussed in text

- Snake Range decollement--Sawteeth on upper plate

Figure 223.-Wheeler Peak Roadless Area, Nevada. 


\section{MINERAL RESOURCES}

The assessment of the potential for mineral resources in the Wheeler Peak Roadless Area is based on observed mineral occurrences in mines and prospects, proximity to known mineral occurrences, the stratigraphic and structural setting, and geochemical data from rock or stream-sediment samples. On the basis of these criteria, several areas are considered to have probable mineralresource potential.

A small amount of placer gold has been recovered from gravels that extend into the north edge of the area (area A, on map), and these alluvial deposits have a probable potential for additional gold. Quartz veins in Cambrian rocks contain gold in deposits a few miles northwest of the roadless area, and probably are the source of the placer gold.

Tungsten minerals have been mined from the Hub, Johnson, Bonita, and Chapman-Taylor (Big Wash) mines, which are within or on the border of the Wheeler Peak Roadless Area. The tungsten deposits at the Hub and Johnson mines are in quartz veins in granitic rocks. There is little likelihood for the occurrence of additional resources at these mines, but other veins in the granitic rocks adjacent to and between the mines (area $\mathrm{C}$ ) and about $2 \mathrm{mi}$ north (area B), have had little exploration and have probable potential for additional small resources of tungsten. Area F, along the south edge of the roadless area, includes the Bonita and Chapman-Taylor (Big Wash) mines. There is little likelihood for the occurrence of additional resources at these mines, but area $\mathrm{F}$ is considered to have probable potential for small tungsten resources because the Cambrian sedimentary rocks are favorable host rocks, and concentrates of some stream sediments contain anomalously high values of tungsten. The probable potential for mineral resources in areas $\mathrm{D}$ and $\mathrm{E}$ is based on the stratigraphic setting and the analysis of stream sediments that show the areas anomalously high in tungsten; area $\mathrm{E}$ also had anomalously high values of lead. Additional geochemical sampling and field studies of the favorable host rocks are required to provide firm evidence of resources.

Beryllium minerals have been mined at the Mt. Wheeler mine about $2 \mathrm{mi}$ southwest of the Wheeler Peak Roadless Area, and anomalous values of beryllium were detected in concentrates of stream sediments from several drainages along the west side of the roadless area. The source of beryllium in drainages crossing areas $\mathrm{B}$ and $\mathrm{C}$ is unknown, but probably is beryllium minerals in small veins or dikes in the granitic rocks. The western part of area $\mathrm{F}$ has probable potential for beryllium because of the proximity of the Mt. Wheeler mine and the presence of the same host rock as that at the mine.

Concentrates of stream-sediment samples from area $\mathrm{F}$ contain anomalous values of lead and zinc. The lead and zinc minerals, however, are apparently confined to small veins, and no resource potential was identified, although lead and silver were produced from the St Lawrence mine about $1 \mathrm{mi}$ south.

Anomalous thorium values were noted in panned concentrates of stream sediments in many drainages that include granitic rocks. The thorium occurs in allanite and monazite, which also contain rare-earth elements. The allanite and monazite, which occur as accessory minerals in the granitic rocks, are concentrated as placer deposits in alluvium. Most of the favorable sites for placers are in canyons outside the roadless area and no resource potential for thorium and rare-earth elements was identified in this study.

Limestone, building stone, and sand and gravel occur in the area, but similar deposits that are closer to markets exist outside of the roadless area. There is little promise for the occurrence of energy resources.

\section{SUGGESTIONS FOR FURTHER STUDIES}

The known ore deposits in the area are in Cambrian clastic and carbonate rocks and in granitic rocks that are in the lower plate of the Snake Range decollement. The limestone unit that is the host rock for the tungsten and beryllium deposits at the Bonita and Mt. Wheeler mines is exposed over a length of several miles within the roadless area, but apparently has been only slightly explored. More detailed geochemical sampling along the outcrop trace of this unit might reveal small veins containing tungsten or beryllium minerals. Little is known of the size and grade of the placer deposits containing thorium and rareearth elements, and additional studies are needed to better assess their resource potential.

\section{REFERENCES}

Whitebread, D. H., 1982, Geologic map of the Wheeler Peak and Highland Ridge Further Planning Areas, White Pine County, Nevada: U.S. Geological Survey Miscellaneous Field Studies Map MF-1343-A, scale 1:62,500.

Whitebread, D. H., Carlson, R. R., Moss, C. K., Kluender, Steve, Brown, Donald, 1983, Mineral resource potential map of the Wheeler Peak and Highland Ridge Roadless Areas, White Pine County, Nevada: U.S. Geological Survey Miscellaneous Field Studies Map MF-1343-B, scale 1:62,500. 


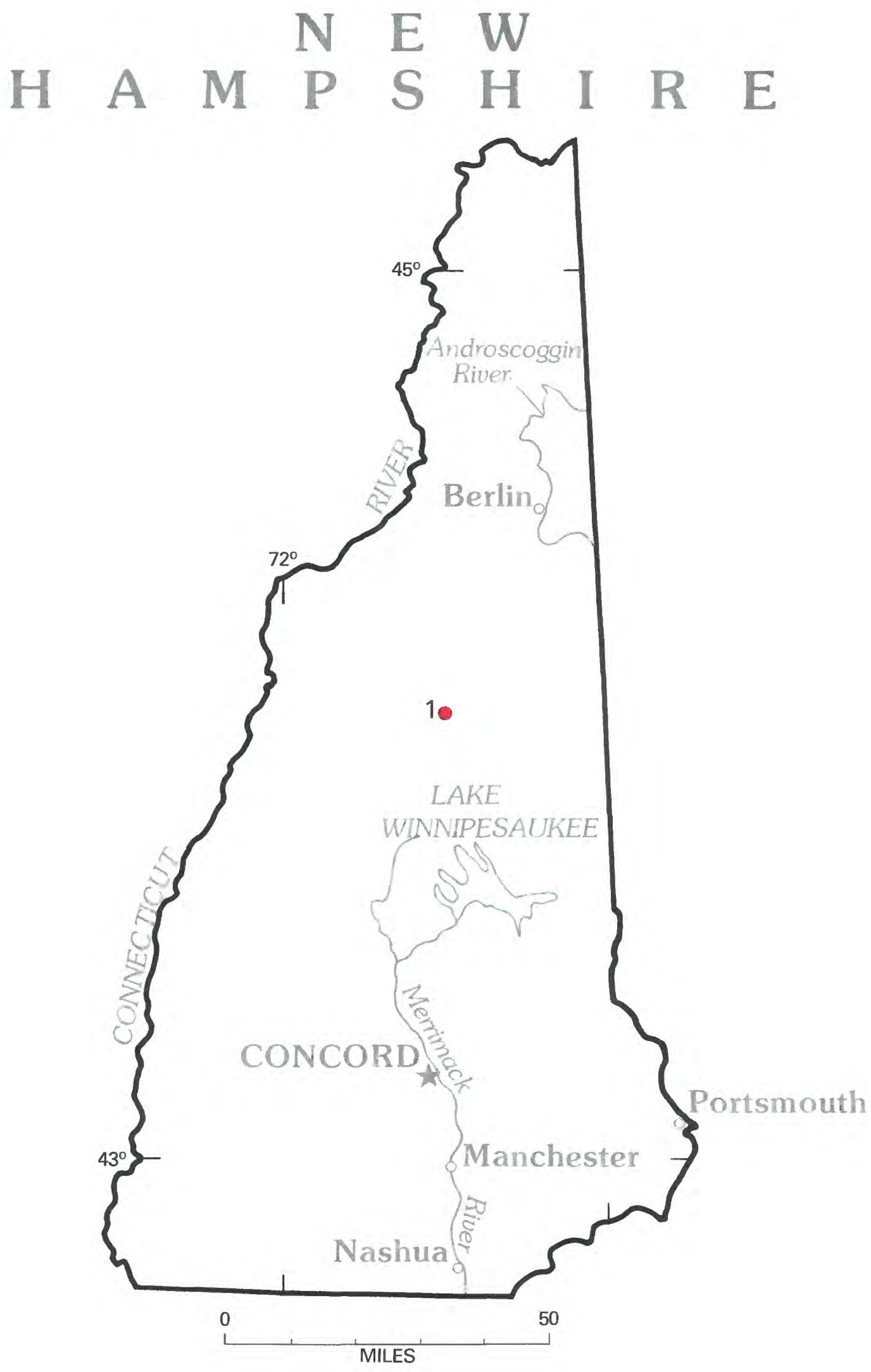

Location of areas studied. 


\section{NEW HAMPSHIRE}

Map

No.

1 White Mountain National Forest, wilderness and roadless areas 


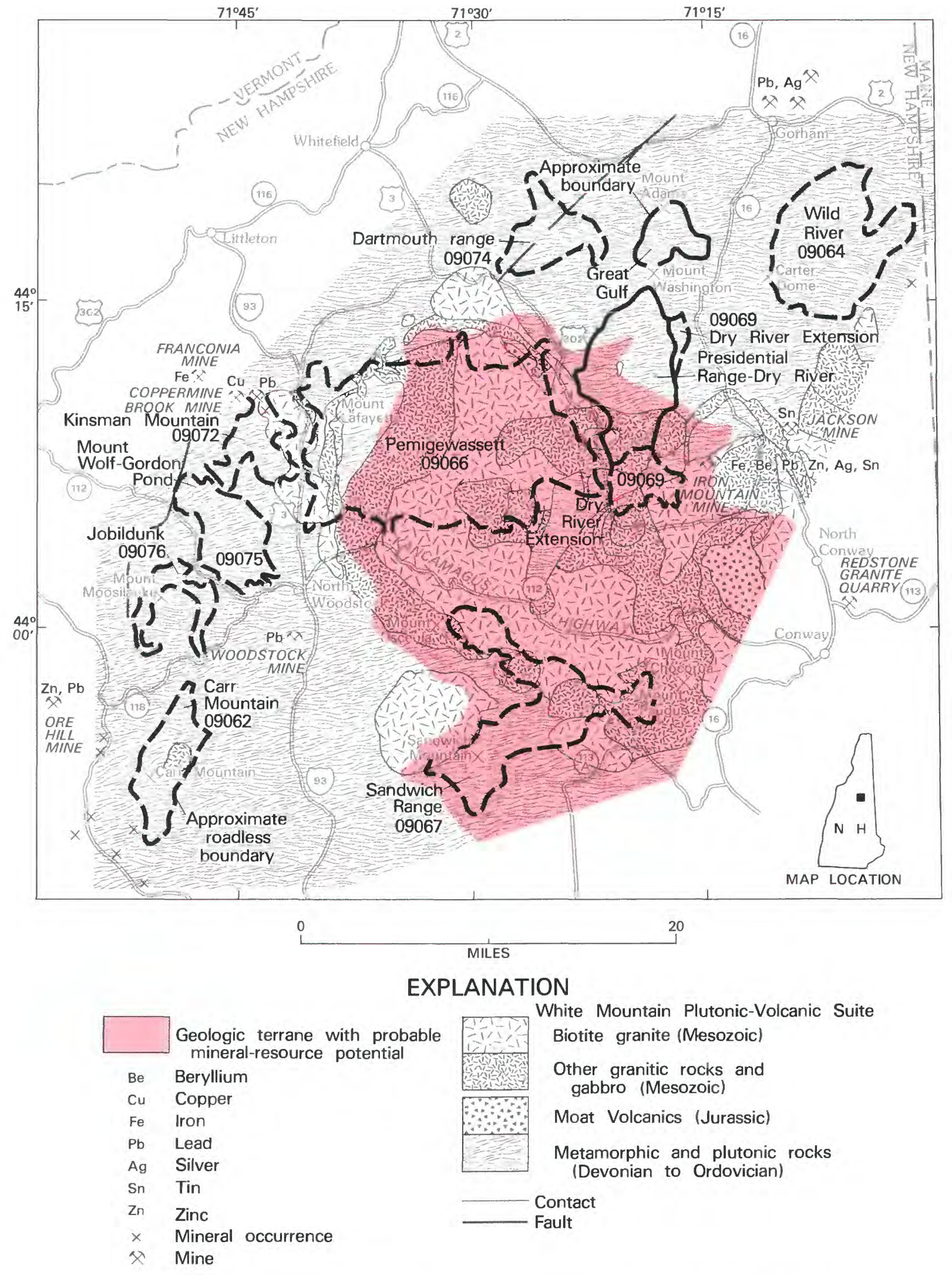

Figure 224.-Wilderness and roadless areas in White Mountain National Forest, New Hampshire. 


\title{
WILDERNESSES AND ROADLESS AREAS IN WHITE MOUNTAIN NATIONAL FOREST NEW HAMPSHIRE
}

\author{
By ROBERT H. MOENCH, ${ }^{1}$ U.S. GEOLOGICAL SURVEY, and \\ Gertrude C. GaZdiK, U.S. Bureau OF MineS
}

\begin{abstract}
SUMMARY
On the basis of a mineral survey conducted in 1980-82, a geologic terrane in north-central New Hampshire having an area of at least $300 \mathrm{sq}$ mi has probable potential for the occurrence of tin resources. This terrane covers all of the Sandwich Range Roadless Area, approximately the eastern two thirds of the Pemigewasset Roadless Area, a large part of the Presidential Range-Dry River Wilderness, and the southern part of the Dry River Extension Roadless Area. If major tin deposits occur in New Hampshire, they are probably associated with the Mesozoic Conway Granite. Tin resources in the New Hampshire terrane may also occur in small but high-grade veins, as at the old Jackson tin mine; and in iron-beryllium deposits that are low grade with respect to tin but richer in iron, beryllium, lead, zinc, and silver, as at the old Iron Mountain mine. The resource potential for uranium, tungsten, and niobium in the same and other parts of the area investigated cannot be evaluated from present data. The nature of the geologic terrain indicates little likelihood of the occurrence of organic fuels.
\end{abstract}

\section{CHARACTER AND SETTING}

The White Mountain National Forest contains two established wildernesses and ten roadless areas, covering a total of about $315 \mathrm{sq} \mathrm{mi}$. In order to treat all the separate areas as a single geologic entity, they were combined into a single study area of nearly $1300 \mathrm{sq} \mathrm{mi}$.

The study area is mountainous and includes several of the highest peaks in the northeastern United States. The highest, Mt. Washington $(6288 \mathrm{ft}$ ) rises far above treeline; most of the area below treeline is heavily forested. Most points within the study area can be reached by a network of hiking trails maintained by the USFS and the Appalachian Mountain Club.

The most conspicuous feature of the study area's bedrock geology is the White Mountain batholith, the largest and most complex body in a belt of many igneous plutons and locally related volcanic rocks of Mesozoic age that extends slightly west of north across New Hampshire. These rocks are mostly varieties of granite, but they include mildly alkalic syenites, mon-

${ }^{1}$ With contributions by Frank C. Canney, Wallace A. Bothner, Norman L. Hatch, Jr., and Howard A. Pohn, USGS; and Lyle E. Harris, Robert A. Welch, Jr., and Vaughn P. Girol, USBM. zonites, gabbro, and other types. They constitute the White Mountain Plutonic-Volcanic Suite (Billings, 1956; name is current usage). In the study area most of the magmas were emplaced about 155-190 million years ago in the uppermost 2 or $3 \mathrm{mi}$ of the Earth's crust. The area is one of complex overlapping ringshaped dikes and steep-walled plutons. Associated rhyolitic volcanic rocks are preserved locally in downdropped cauldrons.

The plutons and ring dikes sharply truncate the structural grain of a far older Paleozoic metamorphic terrane of schist and gneiss injected by many large and small bodies of granite, pegmatite, and related rocks. The central part of the metamorphic terrane is characterized by a great thickness of complexly deformed and intensely metamorphosed sedimentary rocks about 400 to 430 million years old that have been separated into the Devonian Littleton Formation and several underlying formations of Silurian age (Hatch and Moench, 1983). The Ammonoosuc Volcanics (Ordovician; about 440460 million years old) are exposed in a belt along the western side of the study area. A volcanic member of the Littleton Formation lies just to the southeast of the Ammonoosuc belt. These metavolcanic rocks are host to known metalliferous sulfide deposits. 
The study area has no active mines and only minor past mineral production. The cluster of prospects in the extreme southwestern part of the study area are on the edge of the Grafton pegmatite district; they have yielded only mica and feldspar. The Rumford-Paris pegmatite area, which contains several famous mineral collecting localities, lies just east of the study area. The largest nearby metal mine developed a stratabound zinc-lead massive sulfide deposit in the Ammonoosuc Volcanics, at Ore Hill about 2 mi west of the study area.

Investigations by the USBM were conducted in the fall of 1980, and in the spring of 1981. Reports on mines and prospects in the study area are summarized by Gazdik and others (1983).

Investigations by the USGS were conducted in the summers of 1980-82. The geochemical survey in the study area and adjacent parts of the Lewiston $1^{\circ} \times 2^{\circ}$ quadrangle, New Hampshire was conducted in 1980 through the office of the New Hampshire State Geologist, Robert I. Davis. Stream-sediment and heavymineral concentrate samples were collected and analyzed by Domenico and others (1982).

\section{MINERAL RESOURCES}

The bedrock tin deposits in Nigeria are associated with biotite granite that is remarkably similar to the Conway Granite, the principal suspected host for possibly important tin deposits in New Hampshire. Some 35 years ago H. H. Read (1948, p. 8) observed: "So noteworthy is the identity of the Nigerian and New Hampshire rocks and structures that I suggest you have another look for tin in the Eastern States." In fact, a recent summary description of the Nigerian tin district by Olade $(1980$, p. 72$)$ is almost interchangeable with one that might be written for the White Mountain PlutonicVolcanic Suite. Both the New Hampshire and Nigerian rocks are mainly Jurassic. The granites are so-called specialized types, shown by recent studies to be consistently richer in silica and potassium and poorer in magnesium, calcium, and titanium than normal granites, and richer in trace elements such as lithium, fluorine, rubidium, tin, and others. The Conway Granite is well known for its high radioactivity and high average uranium and thorium contents (about 11 parts per million uranium and 53 parts per million thorium).

On the basis of the geochemical survey combined with the geologic characteristics of the White Mountain batholith, a large geologic terrane with probable resource potential for tin is defined in the central and southeastern part of the study area. This terrane covers a total of $300 \mathrm{sq}$ mi that indicates all of the Sandwich Range Roadless Area, approximately the eastern two thirds of the Pemigewasset Roadless Area, a large part of the Presidential Range-Dry River Wilderness, and the southern part of the Dry River Extension Roadless Areas. The boundary of the most promising tin-bearing terrane is drawn to enclose an area where analyses of almost all heavy-mineral concentrates yielded 2000 parts per million (ppm) or more tin, and where analyses of stream sediments yielded more than $20 \mathrm{ppm}$ tin. Topaz (characteristic of tin-bearing greisen deposits), and sharply angular grains of cassiterite (tin oxide) as much as $2 \mathrm{~mm}$ across were identified in some of the concentrates. Abundant lead and zinc also were detected in many of the same tin-rich heavy-mineral and stream sediment samples, and abundant niobium, beryllium, thorium, and rareearth elements were detected in many of the tin-rich concentrates.

The area of the tin anomaly centers on the White Mountain batholith, and it relates most closely to the Conway Granite. However, the anomaly overlaps other rocks of the batholith and parts of the older metamorphic-plutonic terrane. Small tin-bearing areas occur outside the principal anomaly; they probably have sources in isolated tin-bearing veins that would be difficult to find.

It seems likely that a tin anomaly having an areal extent of $300 \mathrm{sq} \mathrm{mi}$ is an expression of many centers of mineralization, some of which undoubtedly have been destroyed by erosion. Although abundant tin was not identified in bedrock, exposed bedrock sources are indicated by the sharp angularity of the grains of cassiterite.

Several types of tin deposits can be expected in the study area. Cassiterite veins of the type mined in the mid-1800's at the Jackson tin mines may occur in areas underlain by the older gneisses and granites. Such deposits, though high grade are likely to be small and difficult to find. The magnetite-phenacite replacement body at Iron Mountain has a low tenor of tin but is high grade in beryllium, zinc, lead, and silver. Barton and Goldsmith (1968, p. 67) suggest that the Conway Granite and its contacts should be explored for other occurrences of this type of deposit. The Conway Granite also needs to be investigated for occurrences similar to those in Nigeria where cassiterite is extracted from placers, and occurs in low-grade bedrock disseminations in the margins and roof zones of individual plutons, and in smaller but richer greisen veins and replacements in the roof zones (Olade, 1980; Taylor, 1979).

The probable tin resource potential far overshadows the likelihood of the occurrence of resources of other commodities. The Conway Granite-long recognized for its high radioactivity-has been investigated as a lowgrade source of uranium and thorium, and as a geothermal energy resource. Uranium might occur locally as 
primary concentrations in the Conway Granite, or as secondary concentrations in young fractures that cut the Conway and adjacent rocks (Page, 1980). Values of tungsten in the range of $200-3000 \mathrm{ppm}$ were detected in many heavy-mineral concentrates, but in patterns that do not relate obviously to specific geologic features. A poor correlation can be seen between tungsten and the Devonian and Ordovician metavolcanic rocks in the western part of the study area, suggesting an ancient volcanic source for some of the tungsten. The metavolcanic rocks contain known sulfide deposits, such as the copper deposit at Coppermine Brook and the massive zinc-lead deposit at Ore Hill, west of the study area. Other deposits of the same type are likely to occur within the same belts of metavolcanic rocks, which are barely included at the western edge of the study area. Argentiferous lead-bearing veins of the type developed by the Mascot mine and others may occur elsewhere in the study area. Despite these noted occurrences there seems little likelihood for additional metallic resources in the study area.

Although possible sources for refractory minerals, industrial pegmatite minerals, silica, peat, and diatomaceous earth exist in these areas, interest in nonmetallic materials is confined to gemstone collecting. Sand and gravel, dimension stone, and decorative stone occur within these areas, but such materials are found more conveniently located elsewhere in the region.

\section{SUGGESTIONS FOR FURTHER STUDIES}

The tin resource potential of the study area is of paramount interest and further effort should be directed toward delineating the most favorable specific geologic settings. The work should include detailed mapping and petrographic and chemical studies to find possible altered facies of the Conway Granite, possible roof zones of plutons, and possible greisens and low-grade disseminations of cassiterite; fracture and lineament analysis to detect evidence of fracture control of mineralization, which is particularly conspicuous in some other tin districts; and geophysical studies to detect the presence of plutons whose tops have not yet been eroded. Further study of other commodities also is needed, particularly the geologic setting of tungsten, and the possible occurrence of uranium, niobium, beryllium, and other elements in relation to the Conway Granite or other members of the White Mountain Plutonic-Volcanic Suite.

\section{REFERENCES}

Barton, W. R., and Goldsmith, C. E., 1968, New England beryllium investigations: U.S. Bureau of Mines Report of Investigations 7070, p. 51-122.

Billings, M. P., 1956, The geology of New Hampshire, Part II, Bedrock geology: Concord, New Hampshire State Planning and Development Commission, $203 \mathrm{p}$.

Domenico, J. A., Howd, F. A., Hall-Santalla, P. A., and Gerstel, W. J., 1982, Spectrographic analyses and statistical summaries of nonmagnetic-heavy-mineral-concentrate samples from northcentral New Hampshire: U.S. Geological Survey Open-File Report 82-866.

Gazdik, G. C., Harris, L. E., Welsh, R. A., Jr., and Girol, V. P., in press, Mines, prospects, and mineral sites in and near the wildernesses and roadless areas of the White Mountain National Forest: U.S. Geological Survey Miscellaneous Field Studies Map MF-1594-C.

Hatch, N. L., Jr., and Moench, R. H., 1983, Bedrock geologic map of the wildernesses, proposed wildernesses, and roadless areas of the White Mountain National Forest, Coos, Carroll and Grafton Counties, New Hampshire: U.S. Geological Survey Miscellaneous Field Studies Map MF-1594-A.

Moench, R. H., Canney, F. C, and Gazdik, G. C., in press, Mineral resource potential map of the wildernesses and roadless areas in the White Mountain National Forest, New Hampshire: U.S. Geological Survey Miscellaneous Field Studies Map MF-1594-B.

Olade, Moses, 1980, Geochemical characteristics of tin-bearing and tin-barren granites, northern Nigeria: Economic Geology, v. 75, no. 1, p. 71-82.

Page, L. R., 1980, Guides to prospecting for uranium and thorium in New Hampshire and adjacent areas: U.S. Geological Survey Open-File Report 80-657.

Read, H. H., 1948, Granites and granites: Geological Society of America Memoir 28, p. 1-19.

Taylor, R. G., 1979, Geology of tin deposits: Elsevier, New York, $543 \mathrm{p}$. 


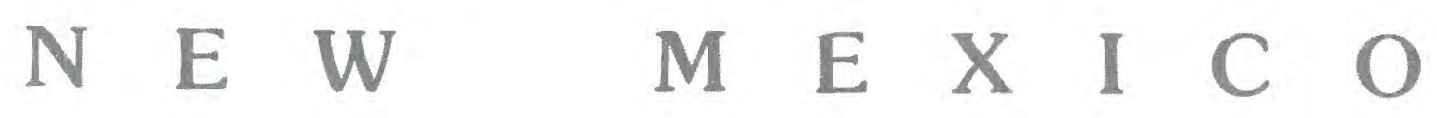

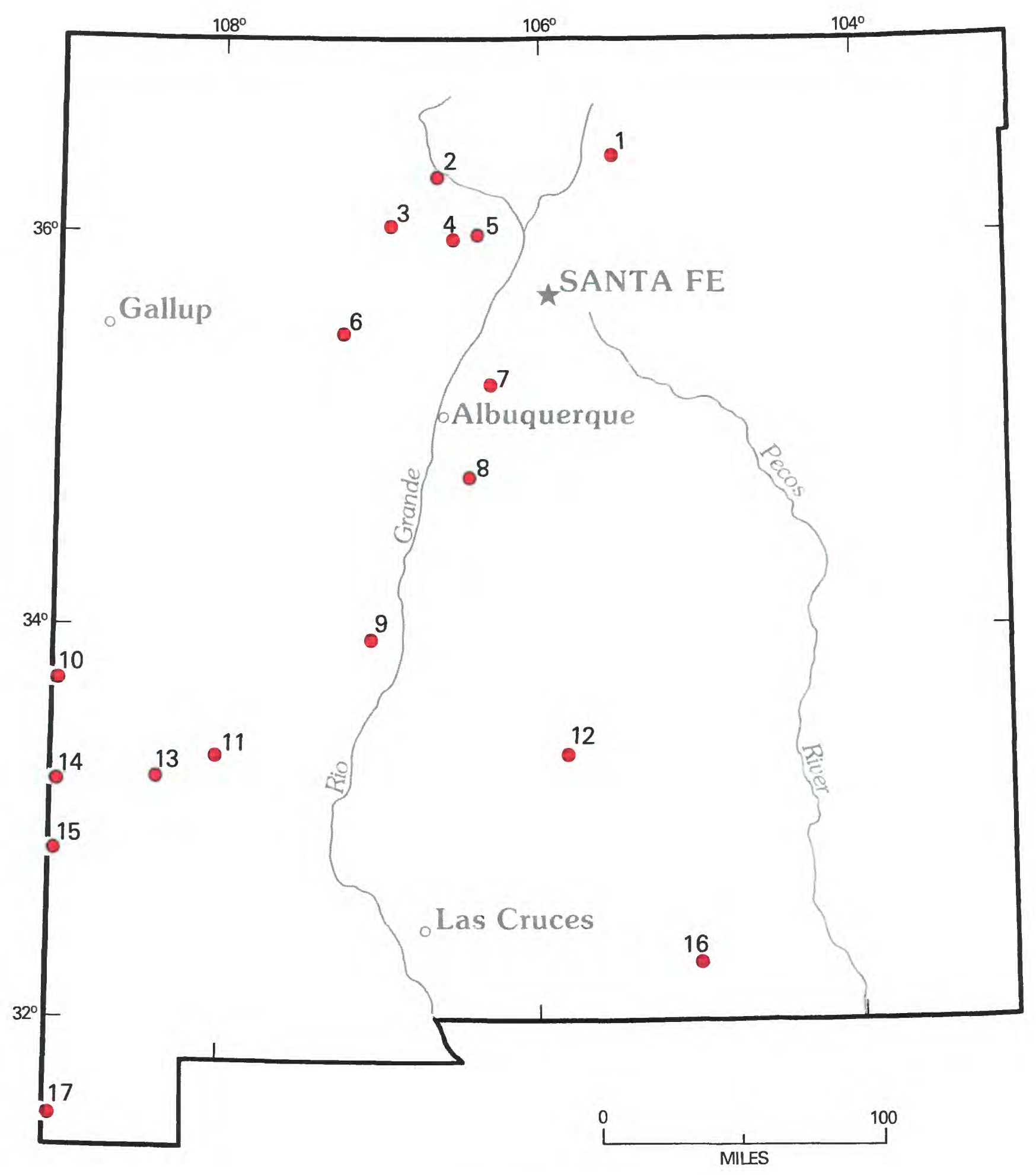

Location of areas studied. 


\section{NEW MEXICO}

Map

No.

Name of Area

11 Black Range Primitive Area

10 Blue Range Wilderness, Arizona and New Mexico-See Arizona

17 Bunk Robinson Peak and Whitmire Canyon Roadless Areas, New Mexico and Arizona

5 Caballo and Polvadera Roadless Areas

2 Chama River Canyon Wilderness and contiguous roadless area

1 Columbine-Hondo Wilderness study area and Wheeler Peak Wilderness

13 Gila Wilderness

6 Guadalupe Escarpment Wilderness Study Area

15 Hells Hole Roadless Area, Arizona and New Mexico-See Arizona

16 Little Dog and Pup Canyons Roadless Area

14 Lower San Francisco Wilderness study area and contiguous roadless areas, Arizona and New Mexico-See Arizona

8 Manzano Wilderness

4 Pecos Wilderness

9 Ryan Hill Roadless Area

3 San Pedro Parks Wilderness

7 Sandia Mountain Wilderness

12 White Mountain Wilderness 


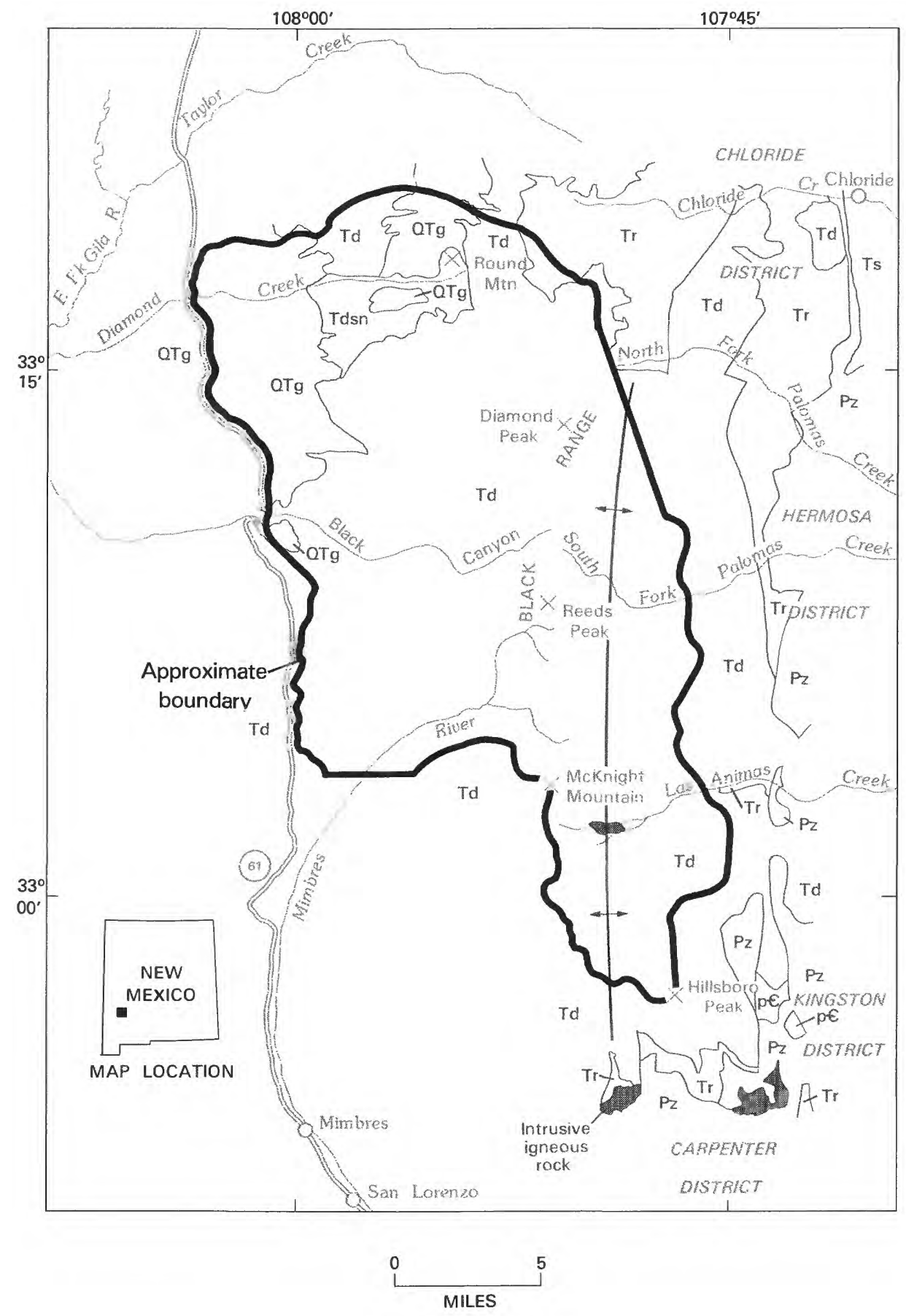

\section{EXPLANATION}

Gila conglomerate (Quaternary and Tertiary)

Ts Santa Fe Formation (Tertiary)

Td Volcanic rocks of the MogollonDatil volcanic field (Tertiary)

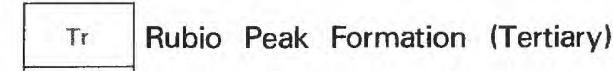

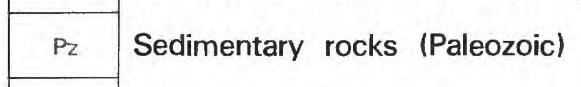

p€ Granitic and metamorphic rocks (Precambrian)

Tdsn Tin-bearing rhyolite (Tertiary)

Contact

Approximate crest of broad dome

Figure 225.-Black Range Primitive Area, New Mexico. 


\title{
BLACK RANGE PRIMITIVE AREA, NEW MEXICO
}

\author{
By George E. ERICKSEN, U.S. GeOlOGiGal SuRVEY, and \\ GeORGE R. LELAND, U.S. BuREAU OF MineS
}

\section{SUMMARY}

A study of the Black Range Primitive Area during the period 1967-69 indicated that the area had little promise for the occurrence of mineral resources. A few miles north of the area, a unit of rhyolite in the otherwise barren volcanic rocks of the Mogollon-Datil volcanic field contains local concentrations of the tin mineral cassiterite, and streams draining outcrop areas of this rhyolite within the primitive area may contain very small cassiterite placer deposits. None were observed in this study and no resource potential was identified. Paleozoic sedimentary rocks and Precambrian granitic and metamorphic rocks exposed just east and south of the primitive area contain small polymetallic deposits with varying amounts of silver, lead, zinc, copper, and gold. These same rocks lie beneath the volcanic cover within the primitive area and are likely to contain similar deposits, but no resource potential was identified.

\section{CHARACTER AND SETTING}

The Black Range Primitive Area extends over 265.6 sq $\mathrm{mi}$ in the central part of the Black Range, a northtrending mountain range in southwestern New Mexico. The principal nearby towns are Silver City, about $30 \mathrm{mi}$ to the southwest, and Truth or Consequences, a similar distance to the east. New Mexico State Highway 90 crosses the Black Range at the southern margin of the primitive area, and State Highway 59 crosses the range several miles north of the area. State Highway 61, a graded dirt road, extends along the western side of the area between State Highways 90 and 59. The eastern side of the area is accessible by unimproved roads. The primitive area itself is crisscrossed by well-maintained horse trails.

The Black Range forms the eastern mountainous rim of the Mogollon Plateau, and the crest of the range, which in the primitive area is a sinuous sharp ridge generally ranging from 9000 to $10,000 \mathrm{ft}$ in altitude, is part of the Continental Divide. Streams on the eastern side of the range drain into the Rio Grande whereas those on the west drain into the Gila River, a tributary of the Colorado River. The highest peak in the range is McKnight Mountain at an altitude of $10,165 \mathrm{ft}$. The Black Range shows an asymmetrical profile, having a relatively steep eastern slope and gentle western slope. The eastern side of the range is marked by many deep valleys separated by sharp ridges whereas the western side has few valleys separated by broad ridges. Valley bottoms along the eastern margin of the primitive area range from about 6000 to $6400 \mathrm{ft}$ in altitude; those on the western margin are somewhat higher, generally 6700 to $7000 \mathrm{ft}$.

The primitive area is covered largely with volcanic rocks of early to late Tertiary age which attain a maximum thickness of about $7500 \mathrm{ft}$, and which from oldest to youngest are: (1) the Rubio Peak Formation, (2) volcanic rocks of the Mogollon-Datil volcanic field, and (3) basaltic andesite of Hodge Canyon. The Rubio Peak Formation, which is equivalent to the "early andesite" volcanic sequence of Ericksen and others (1970), is the only volcanic formation of Tertiary age known to contain exploitable mineral deposits in the vicinity of the Black Range Primitive Area. It crops out within the northeasternmost part and just outside the southern part of the area, and has a maximum thickness of about $2000 \mathrm{ft}$. The most widespread rock sequence in the primitive area-the rocks of the Mogollon-Datil fieldconsists of many discontinuous units of rhyolite and quartz latite ash-flow tuffs and lava flows and andesite to latite lava flows. The maximum aggregate thickness of the volcanic pile is about $14,000 \mathrm{ft}$, but no single unit is continuous over the whole area in which it outcrops, and the maximum thickness in the primitive area is estimated to be less than $5000 \mathrm{ft}$. The youngest volcanic 
sequence, the basaltic andesite of Hodge Canyon, crops out locally in the western part of the primitive area where it attains a maximum thickness of about $600 \mathrm{ft}$; this unit is included with the volcanic rocks of the Mogollon-Datil volcanic field on the figure.

The youngest formation exposed in the primitive area is a semiconsolidated conglomerate of late Tertiary and Quaternary age called the Gila Conglomerate. It crops out in the northwestern part of the primitive area where it attains maximum thicknesses of $600-1000 \mathrm{ft}$. The equivalent of the lower part of this formation is exposed to the east of the primitive area where it is called the Santa Fe Formation.

Paleozoic sedimentary rocks and Precambrian metamorphic and granitic rocks crop out to the east and south of the primitive area and probably lie beneath the volcanic cover throughout the primitive area. The Paleozoic rocks are by far the most widespread and are the principal host rocks of the mineral deposits in the nearby Hermosa, Kingston, and Carpenter mining districts. The Paleozoic formations have an aggregate thickness of about $2400 \mathrm{ft}$, range in age from Cambrian to Permian, and consist chiefly of limestone and dolomite and lesser amounts of sandstone and shale.

The volcanic rocks of the primitive area have been folded and faulted and intruded by dikes and irregularly shaped masses of rhyolite porphyry, flow-banded rhyolite, and andesite. The primitive area is the center of an elongate dome that marks the resurgent Emory Cauldron. Many north-trending faults in the area have displacements ranging from a few feet to a few hundreds of feet. The Paleozoic sedimentary rocks along the eastern side of the Black Range show gentle folding and intense block faulting.

Field investigations of the primitive area included geologic mapping, geochemical sampling of stream sediments and rocks, investigation and sampling of mineral occurrences and hydrothermal alteration zones, an aeromagnetic survey, and search of courthouse records for mining claims (Ericksen and others, 1970).

\section{MINERAL RESOURCES}

Although few indications of exposed mineral deposits were found in the Black Range Primitive Area, it is probable that "blind" or buried deposits are present, chiefly in the Paleozoic and Precambrian rocks and the Rubio Peak Formation of Oligocene age that underlie the volcanic rocks of the Mogollon-Datil volcanic field. Such deposits would be expected to be similar to those that occur in these rocks in the four mining districts shown on the map. These districts are, from north to south, the Chloride, Hermosa, Kingston, and Carpenter districts. The mines in these districts were active chiefly during the late 19 th and early 20 th centuries. At the time of our investigations in the late 1960's, the only activity was prospecting for silver ores in the Chloride district and mining of a small lead-zinc deposit in the Carpenter district. During early mining, silver was the principal metal recovered from deposits in the Chloride, Hermosa, and Kingston districts where it occurs in association with varying amounts of lead, zinc, copper, and gold. Lead and zinc ores, low in silver, were mined in the Carpenter district. The deposits consist chiefly of veins in the Paleozoic rocks and the andesite of the Rubio Peak Formation, and replacement bodies in $\mathrm{Pa}$ leozoic limestone units near some of these veins. The deposits are small, and total production from all four districts probably had a value of about $\$ 9$ million, chiefly from secondarily enriched silver ores. Although it is likely that the Black Range Primitive Area contains hidden or buried silver-bearing base-metal mineral deposits, it would be expected that most deposits be small, as are most known deposits along the eastern side of the Black Range. Because of these uncertainties nobase- and precious-metal resource potential was identified. Small amounts of cassiterite (tin oxide) have been recovered from veins in a tinbearing rhyolite of the Mogollon-Datil field along Taylor Creek and from placers resulting from erosion of these rocks, north of the primitive area. It is possible that similar deposits could exist in the primitive area, however, cassiterite veins were not observed in the tinbearing rhyolite within the primitive area and although the geochemical samples from Diamond Creek show anomalously high tin values, these values are not sufficient to indicate a tin placer. The presence or absence of tin placers in this area could be determined only by a detailed drilling program.

In the Taylor Creek area, the cassiterite occurs as local concentrations of veinlets, blebs, and disseminated grains in the rhyolite, chiefly in zones of steeply dipping sheeting that may have been eruptive centers; most of the rhyolite is either barren or contains only traces of tin. The richest lode deposits in the Taylor Creek area reportedly do not exceed 0.02-0.06 percent tin, and the placer deposits averaged less than $0.05 \mathrm{lb} / \mathrm{cu}$ yd of tin. Recorded production of cassiterite from Taylor Creek was $325 \mathrm{lbs}$ of hand-picked vein material in 1937, and 1500 lbs of placer concentrates recovered in 1939-40. Additional but undisclosed small amounts of concentrates were produced during the periods 1941-44 and 1965-66. No potential for tin was identified in the area.

Sparse impure topaz crystals as much as 1 in. long and 0.25 in. in diameter occur in cavities in vuggy rhyolite at Round Mountain, in the northernmost part of the primitive area. The crystals consist of pale-yellow topaz enclosing mineral grains and fragments of the 
rhyolite that were incorporated as the crystals formed. The crystals are of mineralogical interest only, not being of gem quality and occurring in quantities too small for recovery as refractory material.

\section{SUGGESTIONS FOR FURTHER STUDIES}

Deposits of base and precious metals might be present in the primitive area. A search for such deposits would require detailed geochemical and geophysical investigations to delineate target areas in which buried mineral deposits might occur, followed by core drilling to test these areas.

The tin-bearing rhyolite in the northern part of the primitive area might contain hidden zones of cassiterite- bearing rock and tin placers may be present along Diamond Creek, but the potential for tin here is probably less than that of the Taylor Creek area to the north. As a consequence, exploration for tin in the primitive area should be made only after it had been demonstrated that lode and placer tin deposits in the Taylor Creek area are exploitable.

\section{REFERENCE}

Ericksen, G. E., Wedow, Helmuth, Jr., Eaton, G. P., and Leland, G. R., 1970, Mineral resources of the Black Range Primitive Area, Grant, Sierra, and Catron Counties, New Mexico: U.S. Geological Survey Bulletin 1319-E, 162 p. 

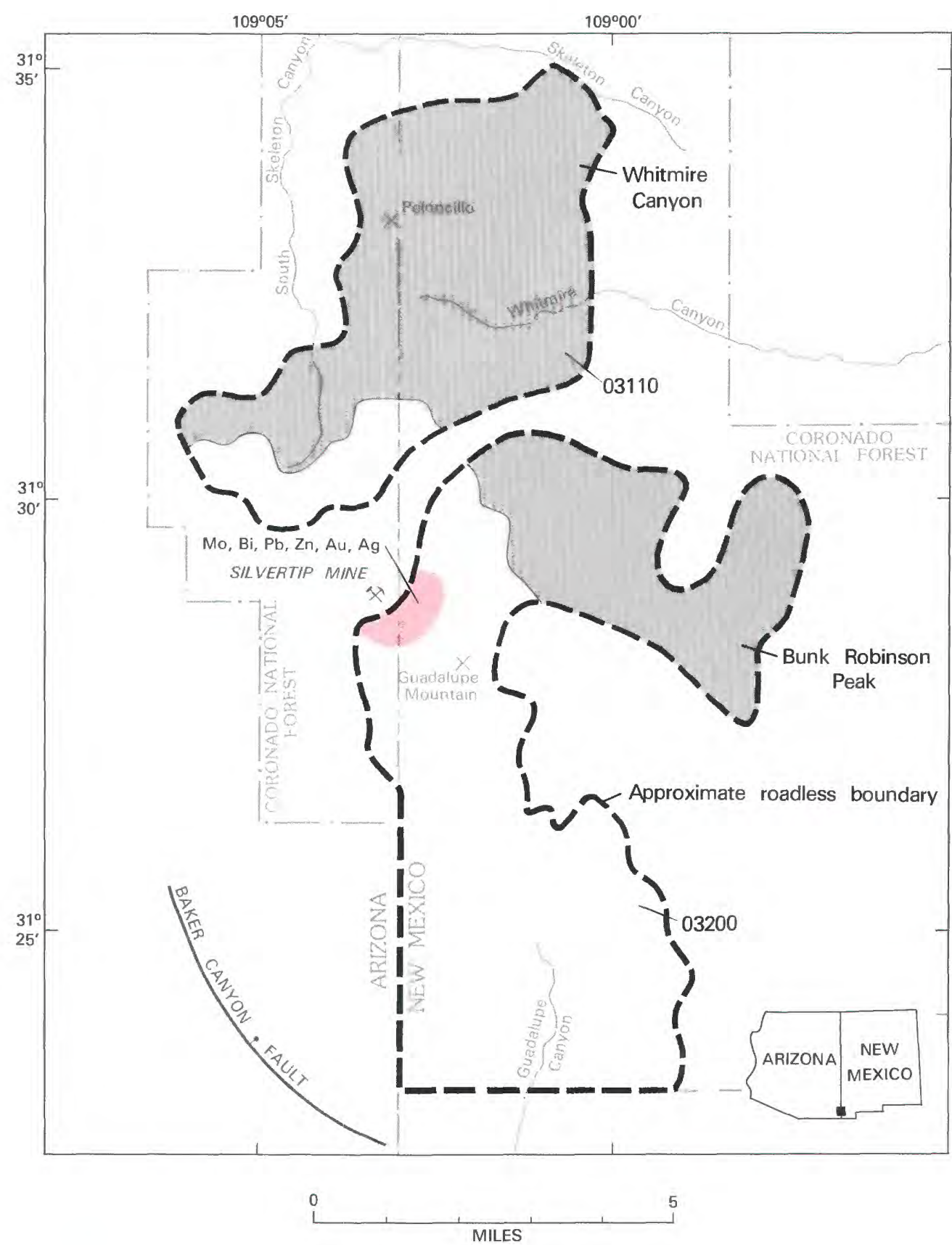

\section{EXPLANATION}

Geologic terrane with probable mineral-resource potential

Bismuth

Gold

Lead

Molybdenum

Silver

Zinc

Figure 226.-Bunk Robinson Peak and Whitmire Canyon Roadless Areas, New Mexico and Arizona. 


\title{
BUNK ROBINSON PEAK AND WHITMIRE CANYON ROADLESS AREAS, NEW MEXICO AND ARIZONA
}

\author{
By Philip T. Hayes, ${ }^{1}$ U.S. GeOlogical Survey, and \\ S. DON BROWN, U.S. BUREAU OF MINES
}

\begin{abstract}
SUMMARY
A mineral-resource survey of the Bunk Robinson Peak and Whitmire Canyon Roadless Areas in 1980 identified a 1-sq-mi area of probable resource potential for molybdenum, bismuth, lead, zinc, and precious metals in the northwest part of the Bunk Robinson Peak Roadless Area. This appraisal is based on the presence of hydrothermally altered rock and geochemical anomalies. Small deposits of perlite could be present locally, but none were seen. The possibility that resources of oil and (or) gas underlie the area is deemed to be very slight.
\end{abstract}

\section{CHARACTER AND SETTING}

The Bunk Robinson Peak and the Whitmire Canyon Roadless Areas straddle the Arizona-New Mexico State line in the southern Peloncillo Mountains and are separated by a $1 \mathrm{mi}$-wide zone containing a road that crosses the mountains. The Bunk Robinson Peak Roadless Area, the southerly one, comprises about $30 \mathrm{sq} \mathrm{mi}$ mostly in New Mexico but with a little more than 1 sq mi extending into Arizona. The Whitmire Canyon Roadless Area, the northerly one, comprises about $11 \mathrm{sq} \mathrm{mi}$ in New Mexico and about $7 \mathrm{sq} \mathrm{mi}$ in Arizona. The terrain in both areas is characterized by cliffs and steep slopes. The highest altitudes above sea level are $6450 \mathrm{ft}$ in the Bunk Robinson Peak Roadless Area and $6526 \mathrm{ft}$ in the Whitmire Canyon Roadless Area, and the lowest altitudes are about $4600 \mathrm{ft}$ in the Bunk Robinson Peak area and about $5100 \mathrm{ft}$ in the Whitmire Canyon area.

A mineral-resource survey of the roadless areas was made in 1980 by the USGS and the USBM. A geologic map was prepared, a thorough geochemical survey was made, and the rocks of the areas were examined for evidence of mineral deposits. In addition, a records search was made for mineral claims, and prospects in the vicinity of the roadless areas were examined. The results of these studies were presented by Hayes (1982), Watts and others (1983), Hayes and others (1983) and S. D. Brown (unpub. data, 1980).

\footnotetext{
${ }^{1}$ With contributions by Kenneth C. Watts, Jr., USGS.
}

About 80 percent of the surface rock in the two roadless areas is volcanic rhyolitic tuff and lava of Oligocene age; tuff is dominant in the Bunk Robinson Peak Roadless Area and lava in the Whitmire Canyon Roadless Area. Other rocks in the two areas consist of Oligocene dacitic lava, quartz latitic lava and tuff, volcanic breccias, and epiclastic sedimentary rocks. Some tuffaceous sandstone and conglomerate with interlayered tuff of probable Miocene age lies near the northeast corners of both roadless areas, and small remnants of Pleistocene or Pliocene olivine basalt cap some higher hills in both roadless areas. The rhyolitic lavas and tuffs and related rocks almost certainly were vented from one or more nearby volcanic centers, and there is some evidence that they came from a large volcanic cauldron centered near the middle of the study area. There are a dozen or so north-trending faults within the study area, most of which may be related to cauldron collapse but some of which have shown displacement since eruption of the Pleistocene or Pliocene basaltic lava. Paleozoic or Mesozoic sedimentary rocks that may underlie the volcanic rocks must have been somewhat shattered and baked by the volcanism.

There is no history of mining in either of the roadless areas, but there has been some recent prospecting and about 90 mining claims have been located in or very near the areas. Most of these are in a zone of altered rock that extends into the northwest part of the Bunk Robinson Peak Roadless Area. A small abandoned quarry, from which rhyolite tuff was taken for local use as building stone, lies between the roadless areas. 


\section{MINERAL RESOURCES}

Geologic and geochemical investigations did not find surface exposures of minable base- or precious-metal minerals within the roadless areas. However, kaolinized(?) surface rock, metal-rich acid waters, and anomalously high values of barium, lead, molybdenum, and arsenic in the northwest part of the Bunk Robinson Peak Roadless Area, indicate mineralizing hydrothermal activity in that area. It is possible that deposits of molybdenum, bismuth, lead, zinc, or possibly precious metals could be discovered by drilling, and the area is considered to have probable resource potential. Anomalously high values of tin, molybdenum, beryllium, and bismuth in areas underlain by rhyolitic lava in both roadless areas are not indicative of mineral deposits at the surface, but do suggest the possibility of mineralized igneous rock at depth. These data are insufficient to assess the areas as having resource potential.

No nonmetallic or energy resources were found in either roadless area. However, layers of obsidian as much as $8 \mathrm{ft}$ thick are locally present in the rhyolitic lava outcrops in both roadless areas. The presence of obsidian suggests that the area could also contain perlite deposits, but none were seen in this study.

Although sedimentary rocks of Mesozoic and Paleozoic age may underlie the volcanics in the roadless area, the potential for deposits of oil and gas in those rocks is deemed to be very slight. Natural gas in Permian rocks and dead oil in Ordovician rocks have been encountered in exploratory holes drilled about $30 \mathrm{mi}$ east of the roadless areas, but the volcanic activity that took place within the roadless areas would almost certainly have had a deleterious effect on any oil or gas that may once have been present.

\section{SUGGESTIONS FOR FURTHER STUDIES}

A limited core-drilling program in the area of altered rock that extends into the northwest part of the Bunk Robinson Peak Roadless Area might either reveal the presence of metallic deposits there or discourage further study.

An airborne magnetometer survey or other geophysical surveys of the roadless areas could help in locating possible buried stocks that might be the source of anomalously high metal values in the outcrop areas of rhyolitic lava. If such stocks were indicated by one or more geophysical surveys, they should be further evaluated by a core-drilling program.

\section{REFERENCES}

Hayes, P. T., 1982, Geologic map of Bunk Robinson Peak and Whitmire Canyon Roadless Areas, Coronado National Forest, New Mexico and Arizona: U.S. Geological Survey Miscellaneous Field Studies Map MF-1425-A, scale 1:62,500.

Hayes, P. T., Watts, K. C., Hassemer, J. R., and Brown, S. D., 1983, Mineral resource potential map of Bunk Robinson Peak and Whitmire Canyon Roadless Areas, Hidalgo County, New Mexico and Cochise County, Arizona: U.S. Geological Survey Miscellaneous Field Studies Map MF-1425-B, scale 1:62,500.

Watts, K. C., Hassemer, J. R., and Day, G. W., 1983, Geochemical maps of Bunk Robinson Peak and Whitmire Canyon Roadless Areas, Hidalgo County, New Mexico and Cochise County, Arizona: U.S. Geological Survey Miscellaneous Field Studies Map MF-1425-C, scale 1:62,500. 


\title{
CABALLO AND POLVADERA ROADLESS AREAS, NEW MEXICO
}

\author{
By Kim Manley, U.S. GeOlOGical SuRVeY, and \\ Michael E. LANE, U.S. BUREAU OF MineS
}

\section{SUMMARY}

A mineral-resource survey has been conducted for the Caballo and Polvadera Roadless Areas, Los Alamos and Rio Arriba Counties, New Mexico. These areas, consisting of $38 \mathrm{sq} \mathrm{mi}$ in the Jemez Mountains, are located in the Santa Fe National Forest north of the town of Los Alamos. The rocks in the study areas are chiefly volcanic with minor volcaniclastic sedimentary rocks. There is little promise for the occurrence of mineral or fossil fuel resources in the areas. There has been no mining activity within the roadless areas and chemical analyses of stream-sediment samples show no significant anomalous concentrations of metals. There has been some interest in geothermal resources near the Polvadera Roadless Area and a KGRA (Known Geothermal Resource Area) extends into the southwestern corner of the area. This area has been classified as having probable geothermal-resource potential.

\section{CHARACTER AND SETTING}

The Caballo and Polvadera Roadless Areas are separate areas in the Santa Fe National Forest, New Mexico, that were studied together for mineral-resource potential in 1980 (Manley and Lane, 1983). The Caballo Roadless Area, consisting of $14 \mathrm{sq} \mathrm{mi}$ is in the northwest part of Los Alamos County adjacent to the town of Los Alamos. The Polvadera Roadless Area, consisting of $24 \mathrm{sq} \mathrm{mi}$, is about $6 \mathrm{mi}$ north of the Caballo area in Rio Arriba County.

The study areas are in the Jemez Mountains, an isolated mountain range in north-central New Mexico. The areas are in large part heavily timbered and dissected by several steep-walled canyons that contain perennial streams. Altitudes range from 7300 to $11,232 \mathrm{ft}$.

The Jemez Mountains are remnants of a large, complex volcanic field that was active between 0.5 and 12 million years ago. Rocks in the roadless areas are chiefly mafic to felsic domes and flows, ash-flow tuffs, and volcaniclastic rocks derived from the volcanic highlands (Smith and others, 1970; Bailey and others, 1969). The rocks of the Jemez Mountains volcanic field were erupted along the western margin of the Rio Grande rift.

In 1980 the Caballo and Polvadera Roadless Areas were assessed for mineral potential. Although no additional geologic mapping or geophysical surveys were considered necessary, a geochemical stream-sediment investigation was conducted; stream-sediment samples were collected from major drainages in the Caballo Roadless Area and twenty-six from the Polvadera Roadless Area. Spectrographic analyses of the samples showed no significant anomalously high concentrations of metals.

\section{MINERAL RESOURCES}

No mining districts are located within the two areas. Courthouse records were examined at Los Alamos (Los Alamos County) and Tierra Amarilla (Rio Arriba County). No claim records were found in the Tierra Amarilla courthouse and claim records are absent in the Los Alamos courthouse as the county has been closed to mineral entry because of the classified nature of the Los Alamos Laboratory complex. There are no known mineralized areas and there is little promise for the occurrence of mineral resources in the Caballo and Polvadera Roadless Areas.

There has been some interest near the Polvadera Roadless Area for geothermal resources. A KGRA (Known Geothermal Resource Area) and several geothermal leases extend into the southwestern corner of the area and eight geothermal holes have been drilled adjacent to the roadless area. This portion of the area has been classified as having a probable geothermal resource potential. 

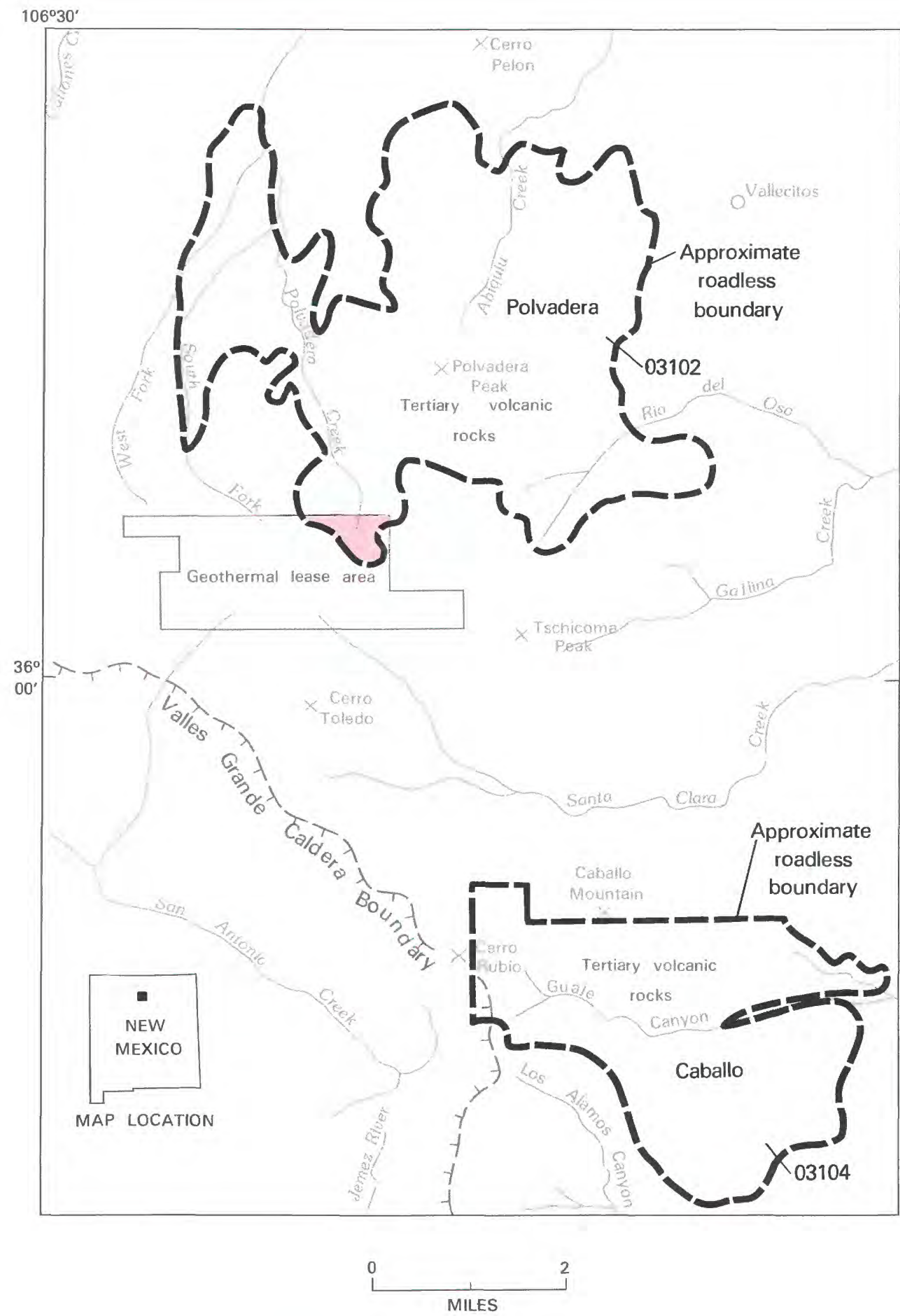

\section{EXPLANATION}

Geologic terrane with probable geothermal resource potential

Figure 227.-Caballo and Polvadera Roadless Areas, New Mexico. 


\section{REFERENCES}

Bailey, R. A., Smith, R. L., and Ross, C. S., 1969, Stratigraphic nomenclature of volcanic rocks in the Jemez Mountains, New Mexico: U.S. Geological Survey Bulletin 1274-P, 19 p.

Manley, Kim and Lane, M. E., 1983, Mineral resource potential and geologic map of the Caballo and Polvadera Roadless Areas, Los
Alamos and Rio Arriba Counties, New Mexico: U.S. Geological Survey Miscellaneous Field Studies Map MF-1516, scale $1: 62,500$.

Smith, R. L., Bailey, R. A., and Ross, C. S., 1970, Geologic map of the Jemez Mountains, New Mexico: U.S. Geological Survey Miscellaneous Geologic Investigations Series, I-571, scale 1:250,000. 


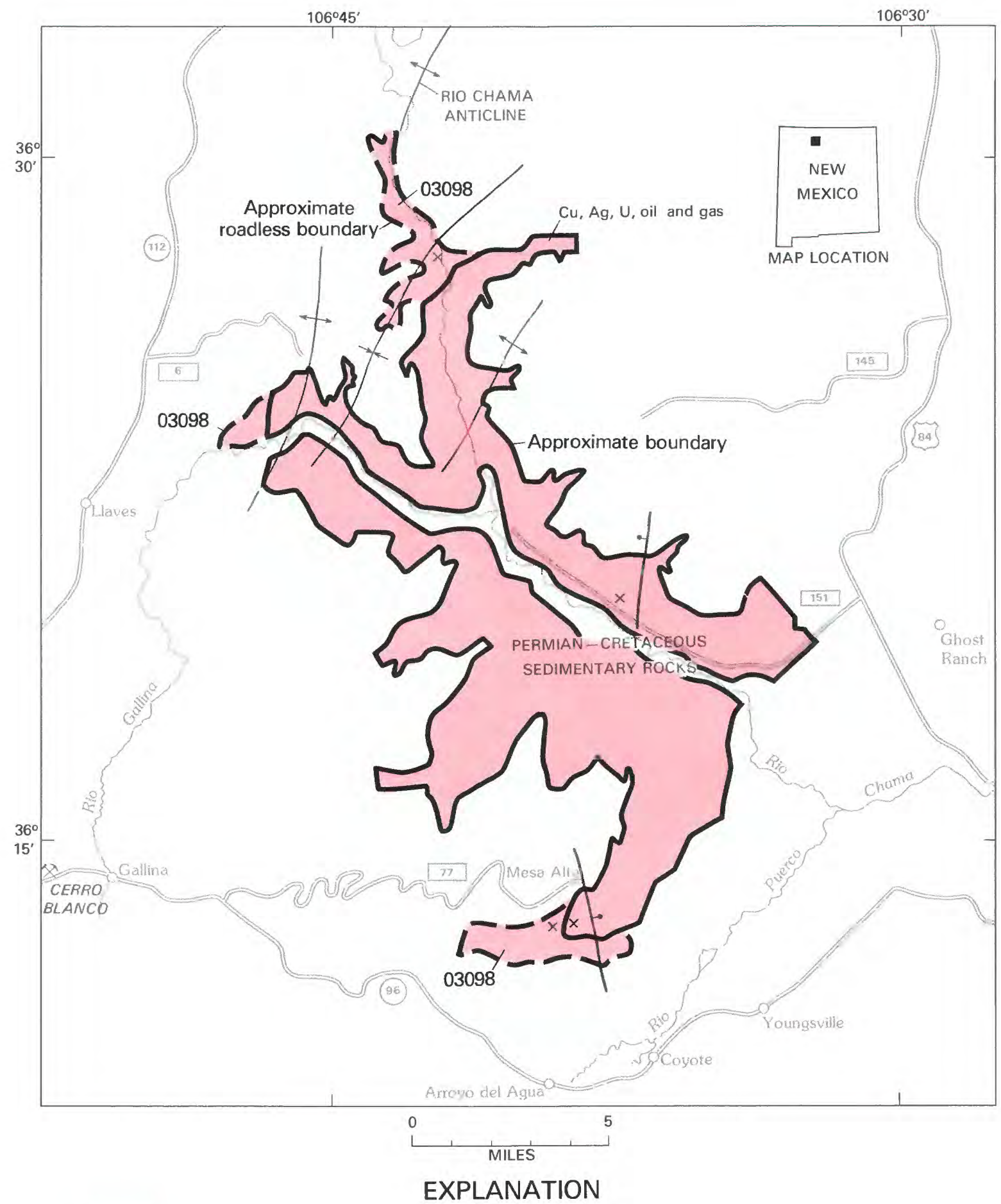

a Gypsum mine

Geologic terrane with probable mineral-resource potential

Copper

Silver

Uranium

Uranium occurrence

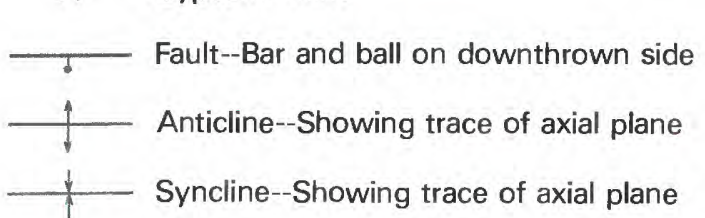

Figure 228.-Chama River Canyon Wilderness and contiguous roadless area, New Mexico. 


\title{
CHAMA RIVER CANYON WILDERNESS AND CONTIGUOUS ROADLESS AREA, NEW MEXICO
}

\author{
By JenNie L. Ridgley, U.S. GeOlogiCal SuRVEY, and \\ Thomas D. Light, U.S. Bureau of Mines
}

\begin{abstract}
SUMMARY
Results of mineral surveys conducted during 1980-81 indicate that the Chama River Canyon Wilderness and contiguous roadless area have a probable mineral-resource potential for copper with associated uranium and silver. Gypsum occurs throughout the area, exposed in the canyon walls. The possibility for the occurrence of oil and gas and uranium in limestone needs to be further tested.
\end{abstract}

\section{CHARACTER AND SETTING}

The Chama River Canyon Wilderness, in Rio Arriba County, north-central New Mexico, covers approximately $80 \mathrm{sq} \mathrm{mi}$ within the Santa Fe and Carson National Forests. In 1979, the USFS designated three contiguous areas, totaling $7.5 \mathrm{sq} \mathrm{mi}$, for further planning, but these areas were subsequently dropped from the program. In 1980-81 geologic, geochemical, and mineral surveys of the wilderness and contiguous roadless areas were conducted by the USGS and USBM (Light, 1983; Ridgley, 1983a,b; Ridgley and Light, 1983).

The Chama River Canyon Wilderness and contiguous roadless area are approximately $70 \mathrm{mi}$ northwest of Santa Fe and nearly $130 \mathrm{mi}$ north of Albuquerque. The areas are accessible by several USFS roads that join major highways in the vicinity.

The wilderness and contiguous roadless area consist of the very scenic steep canyons cut by the Rio Chama, Rio Gallina, and their tributaries. Altitudes range from $6300 \mathrm{ft}$ above sea level along the valley of the Rio Chama to $8900 \mathrm{ft}$ at Mesa Alta, in the southern part of the wilderness.

Rocks exposed in the wilderness consist entirely of sedimentary rocks that range in age from Permian to Quaternary. These rocks have an aggregate thickness of more than $2300 \mathrm{ft}$, and consist of conglomerate, sandstone, siltstone, mudstone, and limestone. Sediments that formed these rocks were deposited in fluvial, lacustrine, eolian, and marine environments. Formations present in the wilderness include the Permian Cutler Formation, Triassic Chinle Formation, Jurassic Entrada Sandstone, Todilto Limestone, and Morrison
Formation, and Cretaceous Burro Canyon(?) Formation and Dakota Sandstone. Quaternary units consist of unconsolidated to semiconsolidated deposits of sand, silt, and gravel and talus and landslide deposits.

The Chama River Canyon Wilderness and adjacent roadless area are in the southern part of the Chama basin, in the southeast part of the Colorado Plateau physiographic province. Major structual features in the wilderness were formed during the Laramide orogeny of Late Cretaceous and early Tertiary age. The wilderness is located in a structural transition zone. Rocks in the western part of the area are folded and faulted and form the southern part of the Archuleta anticlinorium, a series of faulted anticlines and synclines that separate the Chama basin from the San Juan basin to the west. Structural features that characterize the eastern part of the wilderness consist of gently north and northwest dipping strata, broad open folds or warps, and a few steep, normal faults. The gentle warps and folds occur at the southern margin of the Chama syncline, the principal structural feature that forms the Chama basin.

Most of the surface in the wilderness has been examined at some time in the past for the presence of mineral deposits. Mining claims have been staked in and around the wilderness for uranium, kaolinite, and rareearth elements. During the mid-1950's, when uranium exploration was at its peak, many mining claims were located throughout the area. Exploration for uranium was revived in the 1970's; additional claims were staked at this time. No production has been recorded from any of the properties in the wilderness.

Much of the land in and around the wilderness has been previously leased for oil and gas (Light, 1983), although no wells have been drilled in the wilderness. 


\section{MINERAL RESOURCES}

Results of geologic, unineral, and geochemical surveys during 1980 and 1981 indicate several types of inineral resources in the Chama River Canyon Wilderness and contiguous roadless area. Gypsum in the Jurassic Todilto Limestone is the principal resource in the area. Gypsum is presently being mined at San Ysidro, about $75 \mathrm{mi}$ south of the wilderness, and recent mining has begun on Cerro Blanco, near Gallina. Although gypsum exists within the wilderness, other areas outside the wilderness also contain resources of gypsum that are easier to obtain and closer to market.

The surveys also indicate a probable mineral-resource potential for copper with associated uranium and silver as red-bed stratiform deposits in the Cutler and lower part of the Chinle Formations. Stratiform copper deposits, present in the Chinle and Cutler Formations in the nearby Cuba, Gallina, and Coyote areas (Chenoweth, 1974), range in size from a few thousand to several hundred thousand tons. Chemical analyses from these deposits indicate the presence of several hundred parts per million (ppm) uranium and as much as $50 \mathrm{ppm}$ silver (Green and others, 1982).

In the wilderness only two stream-sediment samples contained anomalous concentrations of copper (Ridgley, 1983b). The samples were from drainages that, at some place, cut through lower Chinle sandstones. The occurrence of copper anomalies in stream sediments derived in part from lower Chinle sandstones could be fortuitous or might actually reflect the presence of buried or eroded copper deposits. Drilling would be necessary to adequately determine the resource potential for these metals.

The presence of one uranium anomaly and two prospects in the Todilto Limestone in the wilderness and contiguous roadless area (Ridgley and Light, 1983) and one small deposit that was inined outside the wilderness near Coyote (Chenoweth, 1974) is interpreted to indicate a probable inineral-resource potential for noncopperrelated uranium in the Todilto Limestone. The grade of the deposit near Coyote was 0.10 percent $\mathrm{U}_{3} \mathrm{O}_{8}$ (Chenoweth, 1974), similar to that reported for ore inined from the Todilto in the Grants uranium region (Hilpert, 1969).

One prospect and a nearby anomalous locality, at Mesa Alta in the southern part of the wilderness, are probably part of the same inineralizing system, as only $1 \mathrm{mi}$ separates the two. At both localities the uranium is associated with an increase in vanadium content. A similar association has been noted by Hilpert (1969) in the uranium ores in the Todilto Limestone in the Grants area. All of the surface area of the Todilto within the wilderness has probably been prospected at one time or another. No additional uranium prospects have been 806 reported in the literature. All the uranium anomalies and prospects in the Todilto occur where the overlying gypsum facies is absent; thus the best target areas would be where the gypsum member is not present.

The wilderness has a probable inineral-resource potential for oil and gas. Fitter (1958) reported shows of oil in Pennsylvanian strata in a drill hole several miles south of the wilderness. These strata, however, have not been drilled in the wilderness to determine the potential for favorable facies or the presence of structural or stratigraphic traps at depth. The best target areas for exploration would be the structurally complex western part of the wilderness (Ridgley, 1982).

\section{SUGGESTIONS FOR FURTHER STUDIES}

Further study of the wilderness should concentrate on exploratory drilling to test the oil and gas potential of Pennsylvanian strata and evaluate vanadium anomalies in the Todilto as a prospecting guide for locating uranium.

\section{REFERENCES}

Chenoweth, W. L., 1974, Uranium occurrences in the NacimientoJemez region, Sandoval and Rio Arriba Counties, New Mexico: New Mexico Geological Society, 25th Field Conference, Ghost Ranch, central-northern New Mexico, Silver Anniversary Guidebook, p. 309-314.

Fitter, F. L., 1958, Stratigraphy and structure of the French Mesa area, Rio Arriba County, New Mexico: Albuquerque, University of New Mexico, unpublished M.S. thesis, $71 \mathrm{p}$.

Green, M. W., and others, 1982, National uranium resource evaluation, Aztec Quadrangle, New Mexico and Colorado: U.S. Department of Energy Open-File Report PGJ/F-012(82), 88 p.

Hilpert, L. S., 1969, Uranium resources of northwestern New Mexico: U.S. Geological Survey Professional Paper 603, 166 p.

Light, T. D., 1983, Mines and prospect map of the Chama River Canyon Wilderness and contiguous roadless area, Rio Arriba County, New Mexico: U.S. Geological Survey Miscellaneous Field Studies Map MF 1523-A, scale 1:48,000.

Ridgley, J. L., 1982, Isopach and structure contour maps of the Burro Canyon(?) Formation in the Mesa Golondrino and Mesa de los Viejos areas, Chama Basin, New Mexico: U.S. Geological Survey Miscellaneous Field Studies Map MF-1496-A.

Ridgley, J. L., 1983a, Geologic map of the Chama River Canyon Wilderness and contiguous roadless area, Rio Arriba County, New Mexico: U.S. Geological Survey Miscellaneous Field Studies Map MF-1523-C, scale 1:48,000.

1983b, Geochemical map of the Chama River Canyon Wilderness and contiguous roadless area, Rio Arriba County, New Mexico: U.S. Geological Survey Miscellaneous Field Studies Map MF-1523-D, scale 1:48,000.

Ridgley, J. L., and Light, T. D., 1983, Mineral resource potential map of the Chama River Canyon Wilderness and contiguous roadless area, Rio Arriba County, New Mexico: U.S. Geological Survey Miscellaneous Field Studies Map MF-1523-B, scale 1:48,000. 


\title{
COLUMBINE-HONDO WILDERNESS STUDY AREA AND WHEELER PEAK WILDERNESS, NEW MEXICO
}

\author{
By Steve Ludington, ${ }^{1}$ U.S. Geological Survey, and \\ S. DON BROWN, U.S. BUREAU OF MiNES
}

\begin{abstract}
SUMMARY
The Columbine-Hondo Wilderness Study Area and the Wheeler Peak Wilderness, near Taos, New Mexico, were studied by the USGS and the USBM during 1979-82. Two areas within the study area and wilderness have substantiated mineral-resource potential for molybdenum and are surrounded by an area of probable molybdenum potential. A small area on the north side of the Columbine-Hondo Wilderness Study Area also has probable molybdenum potential; this area is peripheral to the Red River mining area, which includes the Questa mine. Two other areas within the study area and wilderness have probable mineral-resource potential for copper, lead, and zinc, and four areas have probable mineral-resource potential for gold and silver, as well as base metals.
\end{abstract}

\section{CHARACTER AND SETTING}

The Columbine-Hondo Wilderness Study Area (approximately $72 \mathrm{sq} \mathrm{mi}$ ) and the Wheeler Peak Wilderness (approximately $31 \mathrm{sq} \mathrm{mi}$ ) are in the Sangre de Cristo Range, an uplifted block of mountains on the east side of the Rio Grande rift. Access is by a series of secondary roads leading east from New Mexico Highway 3, north of Taos.

This part of the Sangre de Cristo Range is composed primarily of Precambrian rocks, partly mantled by midTertiary volcanic rocks. The Precambrian rocks and the Tertiary volcanic rocks are invaded by intrusive rocks of Tertiary age.

The Precambrian rocks, of volcanic, sedimentary, and intrusive origin, are of medium to high metamorphic grade and are believed to be of Early Proterozoic age (1.7 to 1.8 billion years). The Tertiary igneous rocks include parts of the Latir volcanic field and associated intrusive rocks. Rocks of the Latir field include lava flows of basalt to quartz latite composition lava flows that are overlain by a welded ash-flow sheet of rhyolite erupted during the collapse of the Questa caldera. These volcanic rocks are cut by mafic to felsic plutons, dikes, and sills.

${ }^{1}$ With contributions by John P. Briggs, USBM.

\section{MINERAL RESOURCES}

The Red River mining area, lies north of the Colombine-Hondo Wilderness Study Area and extends north northeast to south southwest nearly parallel to the Red River; it contains the Questa mine, a major molybdenum mine that has been in production since 1922. Molybdenum resources are also present in several other stockwork molybdenum deposits that are not being exploited at the present time. These deposits are found in or above the apical portions of plutons of a particular suite of mid-Tertiary granitic rocks that can be identified on the basis of texture, chemical composition, and age.

The presence of the same mid-Tertiary granitic rocks, coincident with an appropriate erosional level, and of scattered observed mineralized rock, defines the two areas of substantiated molybdenum resource potential, one near Gallina Peak in the Columbine-Hondo Wilderness Study Area, and another near South Fork Peak in the Wheeler Peak Wilderness. These areas of substantiated molybdenum resource potential are surrounded by an area of probable resource potential for molybdenum. Geochemical characteristics which contribute to the assignment of probable molybdenum potential to this surrounding area include stream-sediment anomalies for molybdenum, tin, tungsten, and bismuth. Geophysical techniques (gravity, magnetics, and electric 


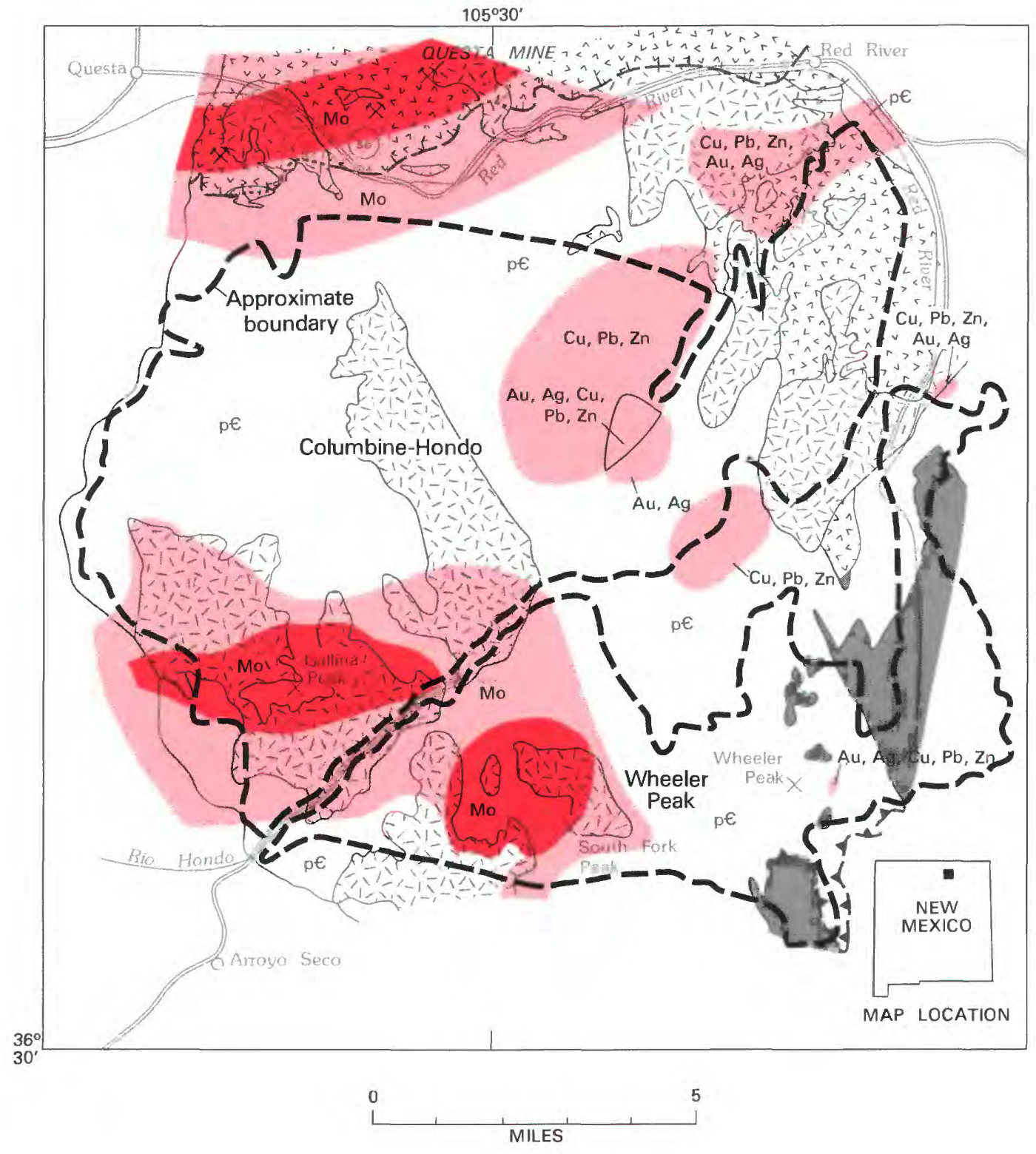

\section{EXPLANATION}

\begin{tabular}{|c|c|}
\hline & $\begin{array}{l}\text { Geologic terrane with substanti } \\
\text { mineral-resource potential }\end{array}$ \\
\hline & Geologic terrane with probable \\
\hline $\mathrm{Cu}$ & Copper \\
\hline $\mathrm{Au}$ & Gold \\
\hline $\mathrm{Pb}$ & Lead \\
\hline Mo & Molybdenum \\
\hline $\mathrm{Zn}$ & Zinc \\
\hline
\end{tabular}

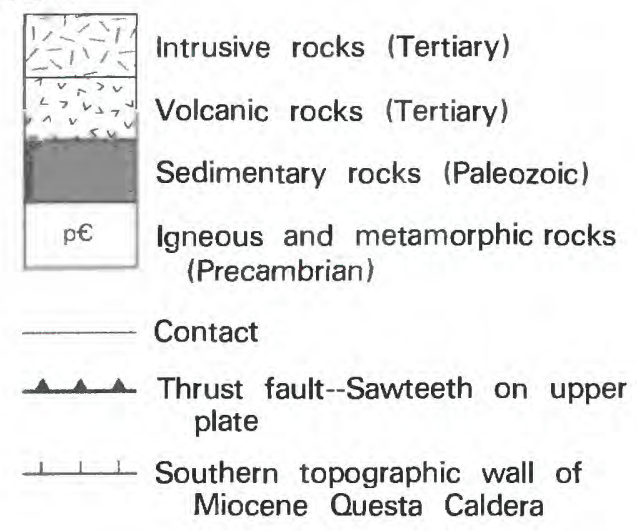

Figure 229.-Columbine-Hondo Wilderness study area and Wheeler Peak Wilderness, New Mexico. 
resistivity) show that this area of probable and substantiated potential is similar to the Red River mining area.

Two areas within and adjacent to the ColumbineHondo Wilderness Study Area have probable resource potential for copper, lead, and zinc in proximal volcanogenic massive sulfide deposits. These areas of probable resource potential are assigned on the basis of coincidence of felsic metavolcanic and metavolcaniclastic rocks with boron anomalies in stream-sediment samples.

Two moderate-sized areas within and adjacent to the Columbine-Hondo Wilderness Study Area and two small areas within and adjacent to the Wheeler Peak Wilderness have probable resource potential for small amounts of gold and silver in epithermal precious- and base-metal vein deposits. The classification of these areas is based on past production and (or) the presence of relatively high concentrations of gold and (or) silver in surface or underground samples.

\section{SUGGESTIONS FOR FURTHER STUDIES}

Detailed geochemical and petrologic study of the source rocks for the stockwork molybdenum deposits will refine the occurrence model for this type of deposit, resulting in increased utility of the model as a predictive tool. Further definition of the potential for massive sulfide deposits could be accomplished by detailed mineralogical studies designed to determine the source of the boron anomalies in stream-sediment samples.

\section{REFERENCE}

Ludington, Steve, Briggs, J. P., and Robertson, J. M., 1983, Mineral resource potential map of the Columbine-Hondo Wilderness Study Area, Taos County, New Mexico: U.S. Geological Survey Miscellaneous Field Studies Map MF-1570-A, scale 1:50,000. 


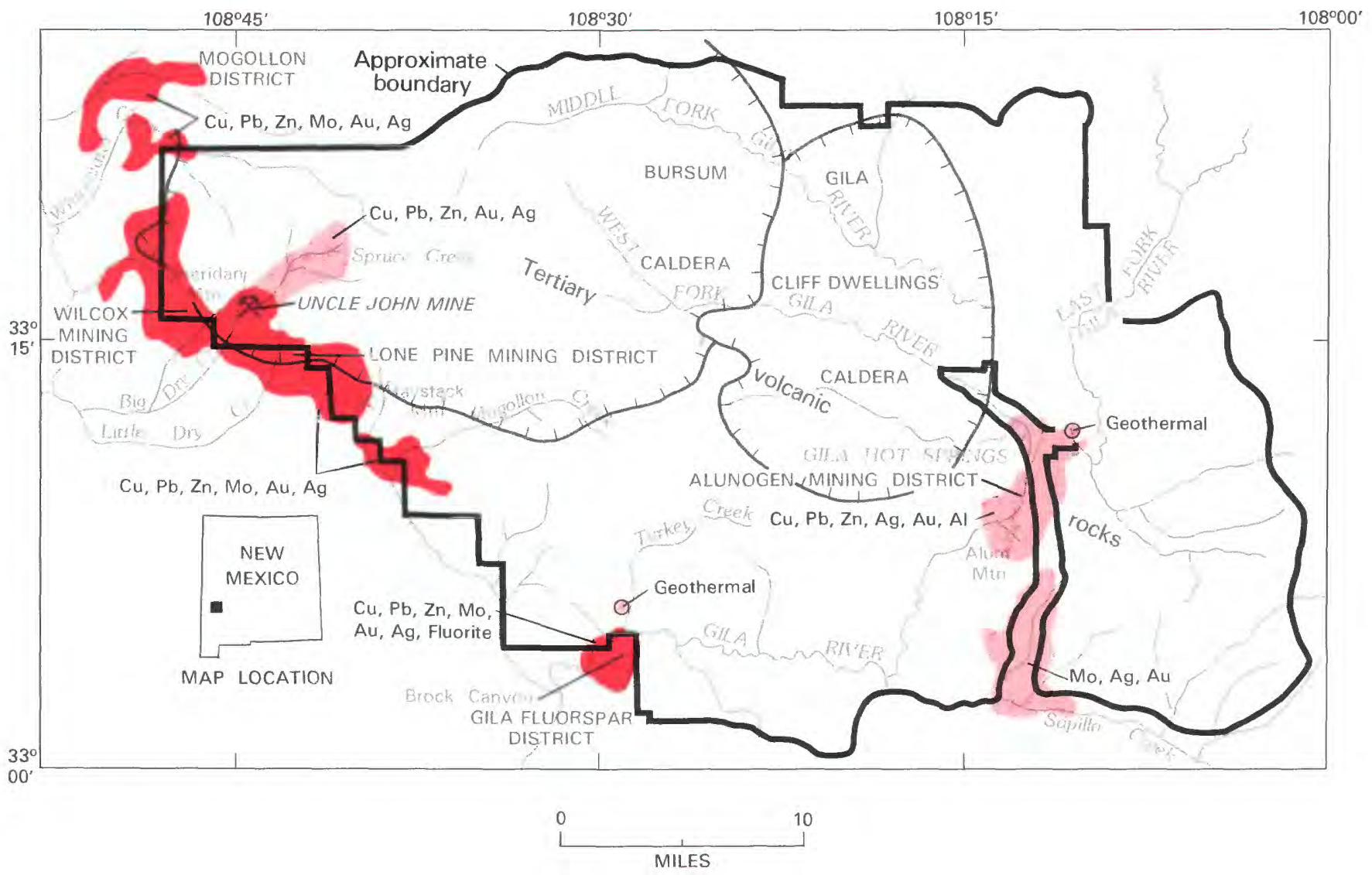

\section{EXPLANATION}

Geologic terrane with substantiated mineral-resource potential

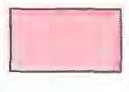

Geologic terrane with probable mineral-resource potential

$\begin{array}{ll}\mathrm{Al} & \text { Aluminum } \\ \mathrm{Cu} & \text { Copper } \\ \mathrm{Au} & \text { Gold } \\ \mathrm{Pb} & \text { Lead } \\ \mathrm{Mo} & \text { Molybdenum } \\ \mathrm{Ag} & \text { Silver } \\ \mathrm{Zn} & \text { Zinc } \\ \mathrm{X} & \text { Mine or deposit }\end{array}$

Figure 230.-Gila Wilderness, New Mexico. 


\title{
GILA WILDERNESS, NEW MEXICO
}

\author{
By James C. Ratté, U.S. Geological Survey, and \\ RONALD B. STOTELMEyER, U.S. BUREAU OF MineS
}

\begin{abstract}
SUMMARY
Geologic, geochemical, and geophysical indicators delineated during a study of the Gila Wilderness by the USGS and USBM from 1968 to 1971 indicate that there are areas of probable and substantiated mineral-resource potential for gold, silver, tellurium, molybdenum, copper, lead, zinc, and fluorite. The areas which have resource potential lie along both sides of the western and southwestern boundaries of the wilderness, and adjacent to the access corridor to the Gila Cliff Dwellings National Monument in the eastern part of the wilderness. Areas marked by geothermal springs along Turkey Creek and the Middle Fork of the Gila River have a probable potential for geothermal energy. No other energy-resource potential was identified within the study area.
\end{abstract}

\section{CHARACTER AND SETTING}

The Gila Wilderness in southwestern New Mexico (formerly the Gila Wilderness and the contiguous tracts of the Gila Primitive Area) was the first area in the United States to be administered as wilderness; it was established by the USFS in 1924. The original wilderness of approximately $685 \mathrm{sq} \mathrm{mi}$ was augmented by another $200 \mathrm{sq} \mathrm{mi}$ in the New Mexico Wilderness Act of 1980. The wilderness is in a rugged area of high mountains and deep canyons, and it includes the headwaters of the Gila River. Altitudes range from nearly $11,000 \mathrm{ft}$ on the crest of the Mogollon Mountains to less than $5000 \mathrm{ft}$ at the mouth of the canyon where the Gila River exits the wilderness, giving a maximum relief greater than $6000 \mathrm{ft}$. Access is mainly from the towns of Silver City and Cliff on the south, and Glenwood and Mogollon on the west.

The Gila Wilderness was studied from 1968-71 and its mineral potential was assessed. Samples of stream sediment, panned concentrates from stream sediments, and rocks were used for the assessment, and all known mines and prospects were evaluated.

Geologically, the wilderness is in the southern part of the Mogollon-Datil volcanic field, which covers approximately $10,000 \mathrm{sq} \mathrm{mi}$ at the southeastern corner of the Colorado Plateau in southwestern New Mexico and adjacent parts of Arizona. This mountainous part of the Mogollon-Datil volcanic field overlies the transition zone between the Colorado Plateau and the Basin and
Range structural and physiographic provinces. Except for extensive areas where the volcanic rocks are covered by streamlain sedimentary rocks (Gila Conglomerate) that were derived by erosion of the older volcanic rocks, the rocks exposed within the wilderness are almost entirely volcanic igneous rocks of middle Tertiary age. A minimum aggregate thickness of $6000 \mathrm{ft}$ of volcanic rocks underlies most of the wilderness, and the thickness may be twice that over large areas. These middle Tertiary volcanic rocks, largely Oligocene and Miocene in age, are the eruptive products of a large magma chamber, or chambers, that probably underlies most of the present wilderness and extends beneath adjacent areas. The first materials erupted from the magma reservoir formed numerous andesitic central volcanoes that built a foundation upon which later catatastrophic eruptions deposited a thick sequence of silicic ash-flow tuffs. The great volume of magma evacuated from the magma reservoir during these eruptions caused the chamber's roof to collapse, and large subsidence calderas such as the Bursum and Gila Cliff Dwellings calderas were formed as a consequence.

The ring-like faults that formed during caldera collapse, plus the faults of several regional fracture systems provided weak zones where volcanic activity continued, including the emplacement of subvolcanic intrusives and associated mineralizing fluids, particularly along the west and southwest boundaries of the wilderness. Dating of vein material in the Mogollon mining district indicates that silver-gold-copper ore probably 
was formed there about 17-18 million years ago (R. F. Marvin, written commun., 1981). However, there may also have been at least one earlier period of mineralization in the middle Tertiary rocks of this area.

\section{MINERAL RESOURCES}

The Gila Wilderness is within a major volcanic field of middle Tertiary age, near the intersection of regional tectonic trends and adjacent to major copper deposits of Laramide age and lesser but significant silver-goldcopper, lead-zinc-copper, and fluorite deposits of middle to late Tertiary age. The mineral-resource survey of the USGS and USBM (Ratté and others, 1979) furthermore has shown the presence of molybdenum anomalies in the area, and intensive exploration by major mining companies for molybdenum ore targets within the Gila Wilderness and along its boundaries continues at present.

Although past production of mineral commodities from within the wilderness has been negligible, abundant evidence of mining activities in and adjacent to the area dates back more than a century. Thousands of mining claims have been located, including 11 patented claims within the wilderness; another 61 patented claims in the Alum Mountain area were purchased by the USFS in 1969, and are now part of the Gila Wilderness. Most of the mines and prospects are concentrated in the wilderness boundary areas, but some mining has penetrated into the most rugged heart of the wilderness along Big Dry Creek. Several mining districts along the periphery of the protected area are the Mogollon, Wilcox, Lone Pine, Gila, and Alunogen districts. Activity within the districts has been sporadic, but the Mogollon district has produced more than 25 million dollars in silver, gold, and copper, and exploration for new ore bodies continues there today. The Wilcox district has been the site of concentrated exploration for gold, silver, fluorite, and base metals in the past, and more recently, intensive molybdenum exploration. The Gila fluorspar district has been the principal source of fluorspar in the area, although other fluorspar mines and prospects are scattered along the wilderness boundary from the Gila district to the Mogollon district. The Brock Canyon area within the Gila district is part of an elliptical halo of altered volcanic rocks about $2 \mathrm{mi}$ long that represents a major exploration target for molybdenum and other metals immediately adjacent to the wilderness.

The Alunogen district (Alum Mountain) is an area of probable resource potential for base- and preciousmetals and represents a prime exploration target; the area has aluminum resources as well.
Within the wilderness, small demonstated resources of lead-zinc-copper-cadmium ore have been identified at the Uncle John mine on Big Dry Creek, and goldbearing quartz veins have been mined near the head of Big Dry Creek, though there are no records of production.

Nearly 60,000 tons of fluorspar has been produced from mines near but largely outside the wilderness. Minor production of other nonmetallic industrial minerals includes 1000 tons of meerschaum clay, and minor other clays and aluminum salts.

Geothermal springs are used for local domestic hot water at Gila Hot Springs adjacent to the wilderness near the Gila National Monument, and geothermal springs occur along Turkey Creek.

The mineral-resource potential of the Gila Wilderness is directly related to the following: (1) Subvolcanic intrusives of middle Tertiary age that have been emplaced along major zones of faulting and fracturing that are concentrated in a northwest-trending belt along the southwest boundaries of the wilderness, and around the ring fracture zone of the Bursum caldera. Some of the intrusives are presently exposed and are known to have altered and mineralized rocks associated with them; others can be assumed to be buried at depth along the structurally weakened zones. The presence of exploitable ore deposits associated with the intrusives can only be ascertained by more detailed geologic studies and exploratory drilling. (2) Possible Laramide-age mineralized intrusives may occur beneath the middle Tertiary volcanic rocks. The evidence for such intrusives and possible associated mineral deposits is the presence of porphyry copper and base-metal vein or replacement deposits in similar terrain where the middle Tertiary volcanic cover has been partially removed-as at Morenci, Tyrone, and Santa Rita-all within $30 \mathrm{mi}$ of the Gila Wilderness. New techniques probably will be required before exploration targets of Laramide age can be identified with a reasonable chance of success beneath the thick middle Tertiary volcanic sequence that covers most of the Gila Wilderness.

In summary, much of the west and southwest boundary of the Gila Wilderness has a substantiated mineralresource potential for deposits of silver, gold, tellurium, copper, molybdenum, lead, zinc, and fluorite. The Alum Mountain-Copperas Creek area has a probable mineralresource potential for molybdenum, silver, gold, or other base and precious metals. A probable potential for base-metal deposits is present within the wilderness above the main forks of Big Dry Creek at the Uncle John mine, and gold- and silver-bearing quartz veins between Spruce Creek and Big Dry Creek also have a probable mineral-resource potential.

In addition, there could be vein and replacement 
deposits of copper and other base metals or disseminated porphyry copper deposits of Laramide age beneath the cover of middle Tertiary volcanic rocks.

Areas of probable geothermal energy potential are present near two hot springs within the wilderness along the Middle Fork of the Gila River and along Turkey Creek. Difficult access to the springs would probably inhibit their development in the foreseeable future.

\section{SUGGESTIONS FOR FURTHER STUDIES}

Continued geologic studies are necessary to provide a better evaluation of the mineral-resource potential of the Gila Wilderness and environs. Such studies should be concentrated in the northwest-trending zone of faulting and intrusion that lies along the southwest boundaries of the wilderness, and particularly where that zone intersects and becomes virtually coincident with the ring fracture zone of the Bursum caldera south of the Mogollon mining district. Dating of the various intrusives in this zone is needed to determine if any correspond in age to the mineralization at Mogollon, where $\mathrm{K}$-Ar dating of adularia from vein material indicates an age of about 17.5 m.y. (R. F. Marvin, written commun., 1981).

\section{REFERENCES}

Ratté, J. C., Gaskill, D. L., Eaton, G. P., and Peterson, D. L., Stotelmeyer, R. B., and Meeves, H. C., 1979, Mineral Resources of the Gila Primitive Area and Gila Wilderness, Catron and Grant Counties, New Mexico: U.S. Geological Survey Bulletin 1451,228 p. 

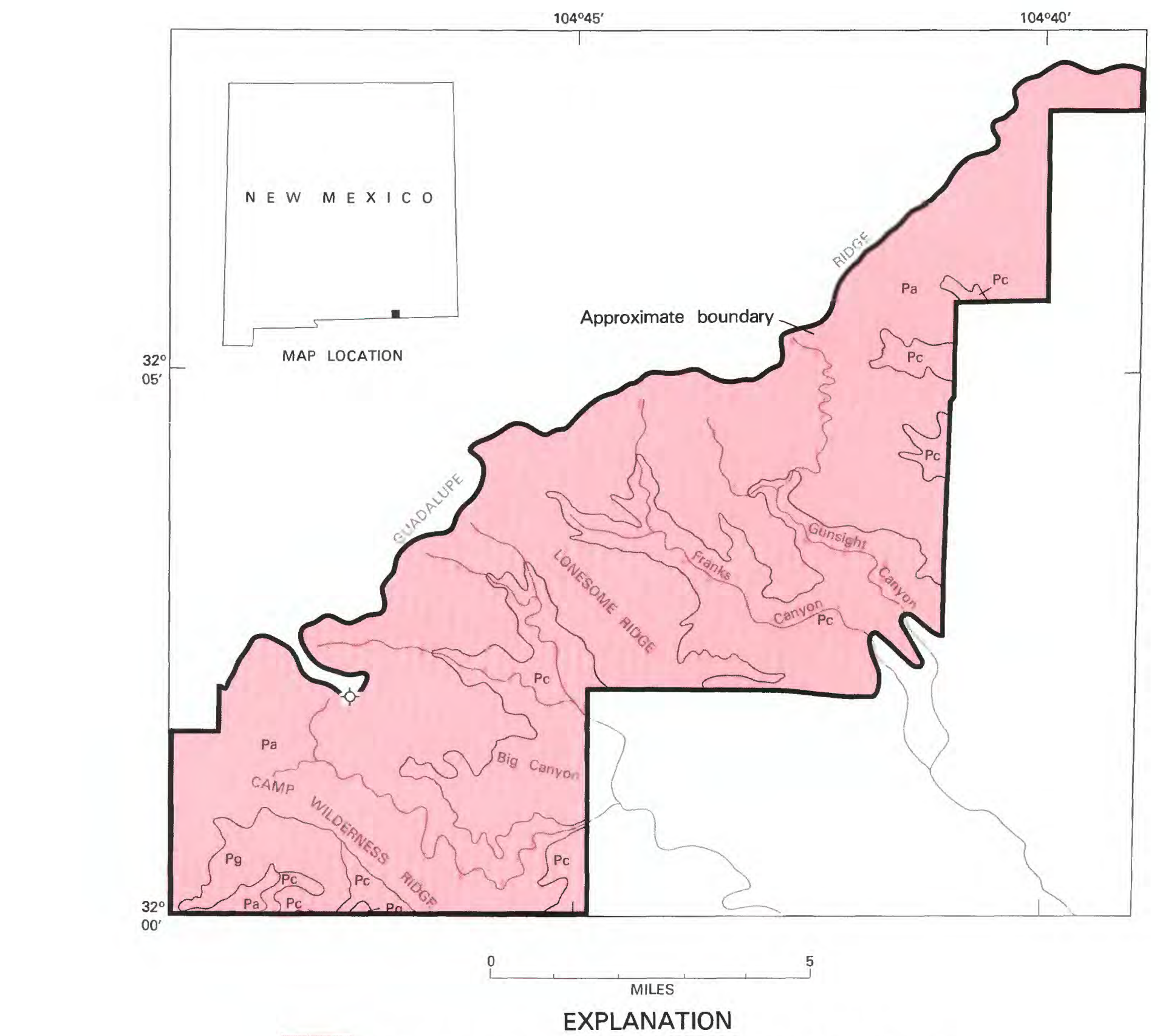

Geologic terrane with probable oil and gas resource potential

$\mathrm{Pa}$ Artesia Group (Permian)

- Abandoned oil and gas test hole

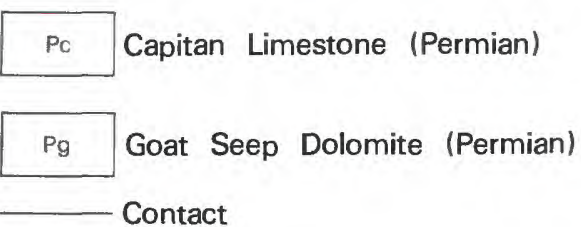

Figure 231.-Guadalupe Escarpment Wilderness Study Area, New Mexico. 


\title{
GUADALUPE ESCARPMENT WILDERNESS STUDY AREA, NEW MEXICO
}

\author{
By Philip T. Hayes, ${ }^{1}$ U.S. Geological Survey, and \\ JOHN R. THOMPSON, U.S. BUREAU OF MINES
}

\section{SUMMARY}

\begin{abstract}
A mineral-resource survey of the Guadalupe Escarpment Wilderness Study Area made by the USGS and the USBM in 1981 and 1982 indicates little possibility for the occurrence of metallic mineral resources. The area is underlain by thousands of feet of sedimentary rock that could contain either stratigraphic or structural oil and (or) gas traps. The oil and gas resource potential is assessed to be probable, but cannot be conclusively known before several exploratory holes have been drilled in the area. Limestone, gravel, and guano occur in the area but these commodities also occur elsewhere outside the area.
\end{abstract}

\section{CHARACTER AND SETTING}

The Guadalupe Escarpment Wilderness Study Area comprises about $34 \mathrm{sq}$ mi along the southeast escarpment of the Guadalupe Mountains in Eddy County, New Mexico. The escarpment is incised by deep, rugged canyons that drain eastward to tributaries of the Pecos River. The highest altitude above sea level in the study area is about $7480 \mathrm{ft}$ and the lowest altitude is about $4875 \mathrm{ft}$.

A mineral-resource survey of the area was made by the USGS and the USBM in late 1981 and early 1982. A geologic map was prepared (Hayes and others, 1983), a search was made for field evidence of mineralization, a survey and assessment of existing mines and prospects in and near the study area was done (Thompson, 1983), and a geochemical study of the area was made (Light and Domenico, 1983).

The area is known to geologists for its splendid exposures of the fossil barrier-reef or bank deposits of the Capitan Limestone and older Goat Seep Dolomite of Permian age and for the northwestward lateral facies changes of those formations into equivalent bedded dolomite, sandstone, and siltstone of the Artesia Group. The Capitan forms the face of the escarpment and holds up magnificent cliffs in the canyons whereas the Goat Seep is exposed in steep slopes in the bottom of the southernmost canyon of the area. The rocks of the Artesia Group are exposed to the northwest of the Capitan and Goat Seep and on the ridges between the

${ }^{1}$ With contributions by Thomas D. Light, USGS canyons. Alluvial gravel derived from the Permian formations is present in most canyon bottoms. On the basis of exposures elsewhere in the Guadalupe Mountains and on drilling information it is known that thousands of feet of older Permian and of Pennsylvanian and older rocks underlie the area in the subsurface. The rocks of the area are generally unfaulted but dip gently eastward to southeastward. The northwest boundary of the study area lies along a ridge that nearly coincides with the crest of an anticline.

\section{MINERAL RESOURCES}

There is no record of mining in the Guadalupe Escarpment Wilderness Study Area. However, some copper was mined before 1928 from veins in Capitanequivalent rocks of the Artesia Group about 2 mi southwest of the southwest corner of the study area and minor copper mineralization is present at a prospect in similar rocks within the bounds of the study area. Those occurrences combined with geochemically anomalous concentrations of zinc, arsenic, lead, cadmium, and molybdenum in sandstones of the Artesia Group and anomalous concentrations of lead, molybdenum, copper, and boron in stream sediments suggest the possibility for the occurrence of epigenetic base-metal resources in the Artesia Group. Although these data indicate a possibility for the occurrence of resources, they are insufficient to assess the area as having resource potential.

Some of the rock in the Capitan Limestone might be suitable as cement limestone but due to the massive 
nature of the rock and its general occurrence in cliffs, it would be difficult and expensive to quarry. Limestone gravel near the mouths of some of the large canyons might be exploitable at some time in the future when and if gravels closer to market areas have been exhausted. Guano that occurs in one cave and possibly in others is probably of academic interest only inasmuch as there are cheaper sources for the fertilizer nitrate for which guano was formerly mined.

Both oil and gas are presently being produced from Pennsylvanian rocks about $10 \mathrm{mi}$ east of the study area and oil has been discovered in Lower Permian rocks less than $5 \mathrm{mi}$ east of the area. About a dozen wildcat holes located in the Guadalupe Mountains within $10 \mathrm{mi}$ north of the study area have been drilled into or through Pennsylvanian rocks without success. Information from drill holes indicates that lithologic facies changes take place in Pennsylvanian and Lower Permian rocks beneath the study area with the possibility that stratigraphic traps suitable for oil and gas accumulation could exist beneath the area. The fact that the northwest boundary lies approximately on the axis of a surface anticline opens the possibility of structural traps as well. However, one unsuccessful hole has been drilled on that anticline on the edge of the study area. In spite of that hole, the study area itself can be said to be virtually untested, and valid cases could be made for drilling several exploratory holes in the area (Hayes and others,
1983). Based on these data the area has a probable potential for oil and gas.

\section{SUGGESTIONS FOR FURTHER STUDIES}

Although it is possible that epigenetic metal deposits may be present in the Artesia Group, the probability that such deposits would be exploitable is so low that no further search for them is recommended. The oil and(or) gas potential of the area cannot be conclusively known until several exploratory holes have been drilled at least through the Pennsylvanian strata known to underlie the area.

\section{REFERENCES}

Hayes, P. T., Light, T. D., and Thompson, J. R., 1983, Mineral resource potential and geologic map of Guadalupe Escarpment Wilderness Study Area, Eddy County, New Mexico: U.S. Geological Survey Miscellaneous Field Studies Map MF-1560-A, scale $1: 24,000$.

Light, T. D. and Domenico, J. A., 1983, Geochemical data for the Guadalupe Escarpment Wilderness Study Area, Eddy County, New Mexico: U.S. Geological Survey Open-File Report 83-7, $20 \mathrm{p}$.

Thompson, J. R., 1983, Mineral investigation of the Guadalupe Escarpment Wilderness Study Area, Eddy County, New Mexico: U.S. Bureau of Mines Open-File Report MLA 41-83. 


\title{
LITTLE DOG AND PUP CANYONS ROADLESS AREA, NEW MEXICO
}

\author{
By Philip T. hayes, U.S. Geological Survey, and \\ PHILIP R. BIGSBY, U.S. BUREAU OF Mines
}

\section{SUMMARY}

On the basis of a mineral survey conducted in 1979, the Little Dog and Pup Canyons Roadless Area is considered to have a probable potential for oil and (or) gas resources and little likelihood for the occurrence of other mineral or energy resources.

\section{CHARACTER AND SETTING}

The Little Dog and Pup Canyons Roadless Area comprises about $41 \mathrm{sq} \mathrm{mi}$ along the precipitous west escarpment of the Guadalupe Mountains in southeastern New Mexico. Altitudes above sea level range between $4360 \mathrm{ft}$ and $6715 \mathrm{ft}$. As part of a mineral-resource survey in 1979, a geologic map was prepared, an airborne magnetometer survey was made, alluvial-sediment samples were collected from the main drainage systems for geochemical analysis, and the rocks of the area were examined in the field for evidence of potential mineral deposits. In addition, records were searched for mining claims and a study was made of past oil and gas drilling activity in the surrounding region. The results of these studies were presented by Hayes and Bigsby (1983).

The Guadalupe Mountains escarpment can, in a general way, be described as a faulted monocline characterized by en echelon north- to northwest-trending faults that cut Lower Permian sedimentary rocks. The faults have stratigraphic displacements of a few tens to many hundreds of feet; most fault displacements are relatively down on the west or southwest sides, but several faults have an opposite displacement. The rocks forming the uplifted Guadalupe Mountains east of the fault zone dip $1-2^{\circ}$ eastward. The Permian rocks in the escarpment are made up almost entirely of dolomite and dolomitic limestone, but there is some siltstone and impure gypsum low in the northern part of the escarpment and some sandstone high in the southern part of the escarpment. Gravels and finer alluvial material derived from the rocks of the escarpment are present in canyon bottoms and in fans below the escarpment. On the basis of drilling information, it is probable that 3000 to 5000 $\mathrm{ft}$ of older Permian and pre-Permian sedimentary rocks lie beneath the area between the oldest exposed rocks and Precambrian basement rocks.

\section{MINERAL RESOURCES}

There is a probable resource potential for oil and (or) gas in the sedimentary rocks underlying the roadless area. At the time of writing this report, the closest production is from a group of gas wells about 12 mi northeast of this area. More than 20 unproductive test holes have been drilled in the mountains between this group of gas wells and the study area; on the basis of information from those wells, it is probable that the strata that contain gas to the northeast are thin or absent beneath the roadless area. However, at least $3000 \mathrm{ft}$ and possibly as much as $5000 \mathrm{ft}$ of sedimentary rocks lie between the lowest exposed strata and the Precambrian basement rocks beneath the roadless area, and several zones within these sedimentary rocks have proven to be productive for oil and (or) gas some tens of miles east of the area. It is possible that the gouge zones that occur along many of the faults in the area could have served as barriers to oil or gas migration and might have served as traps for hydrocarbons. Thus, the area is regarded as having probable resource potential even though the chances of a productive reservoir are low.

No visible signs of base- or precious-metal mineralization or hydrothermal alteration were found, and there are no mineral claims in the Little Dog and Pup Canyons Roadless Area. No anomalous metal values were found in the alluvial-sediment samples collected from the area, and the magnetic survey showed no evidence for shallow igneous intrusions. On the basis of the above, it is deemed highly improbable that any metallic resources underlie the area.

Dolomite is abundant in the area, but this commodity is found in abundance elsewhere in the region. The gypsum and alluvial gravel of the area are of inferior grade compared to similar deposits in nearby areas and are distant from potential markets. 

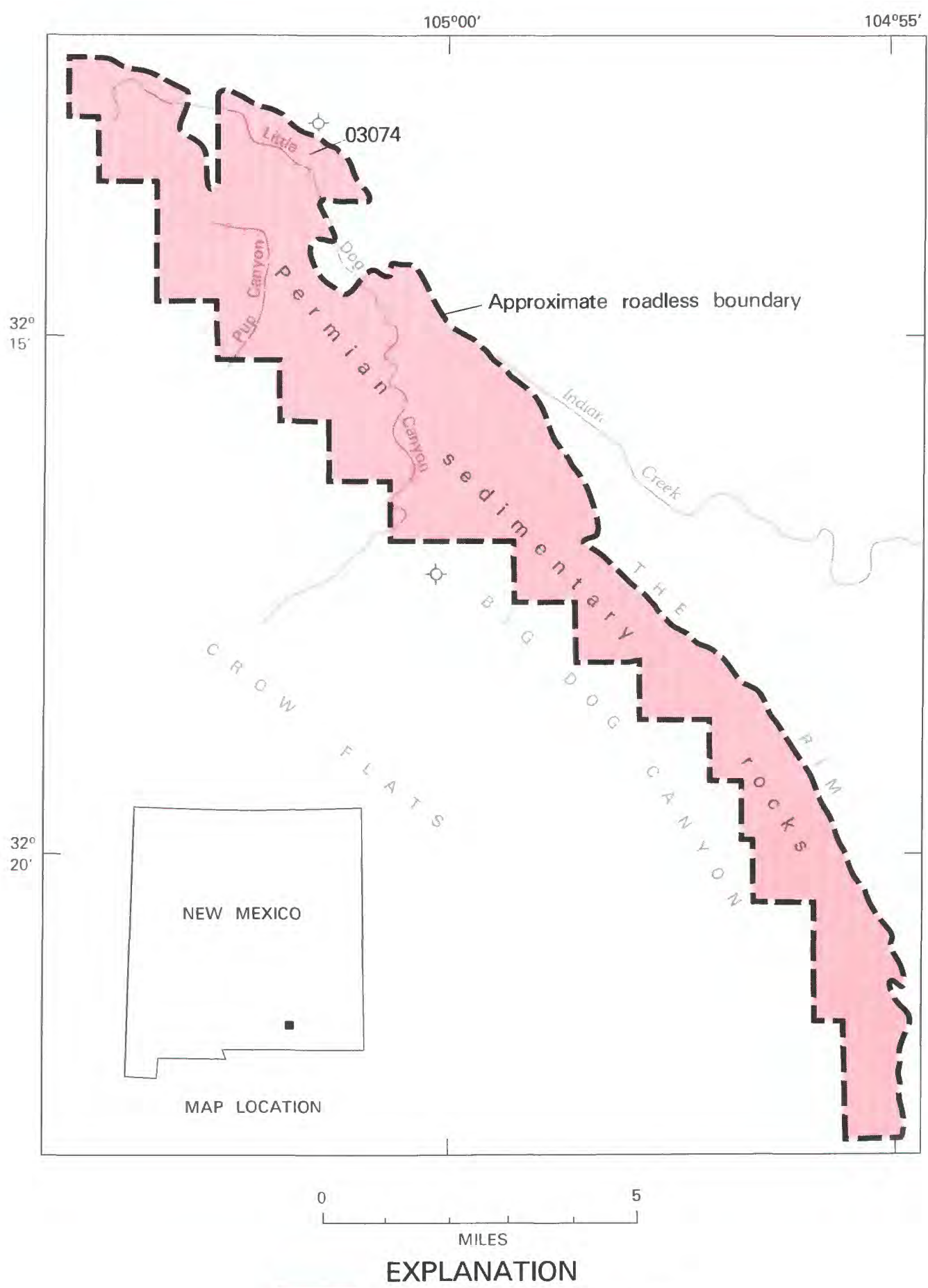

Geologic terrane with probable oil and gas resource potential

$-\quad$ Abandoned oil and gas test hole

Figure 232.-Little Dog and Pup Canyons Roadless Area, New Mexico. 
SUGGESTIONS FOR FURTHER STUDY

There is very little chance that further studies would lead to identification of metallic resources in the Little Dog and Pup Canyons Roadless Area. Only the drilling of exploratory holes in or near the roadless area could conclusively determine its resource potential for oil and (or) gas.

\section{REFERENCE}

Hayes, P. T., and Bigsby, P. R., 1983, Mineral resource potential and geologic map of the Little Dog and Pup Canyons Roadless Area, Otero County, New Mexico: U.S. Geological Survey Miscellaneous Field Studies Map MF-1468, scale 1:50,000. 


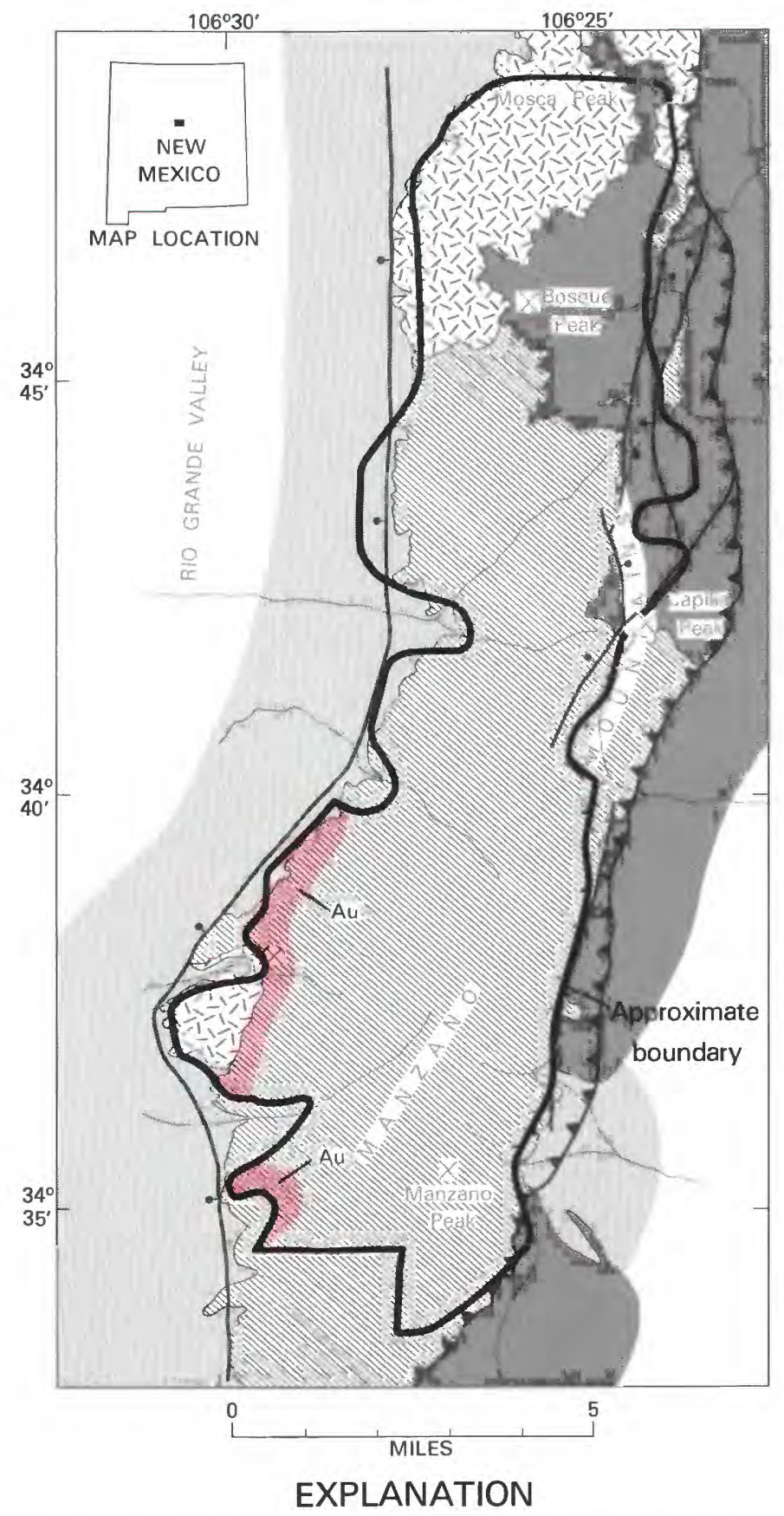

Geologic terrane with probable mineral-resource potential
Au Gold
父 Mine

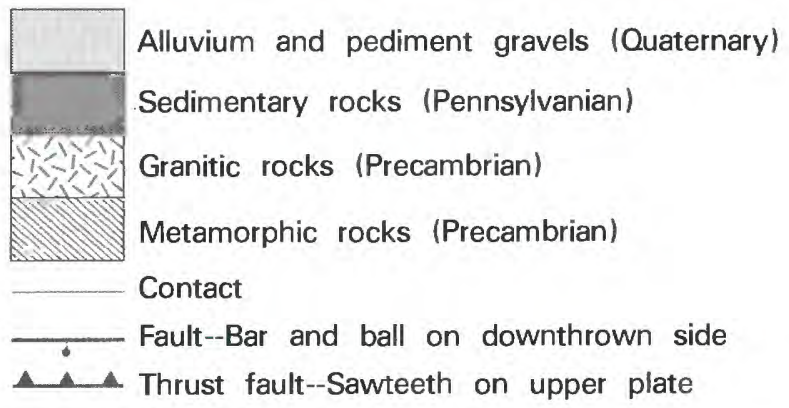

Figure 233.-Manzano Wilderness, New Mexico. 


\title{
MANZANO WILDERNESS, NEW MEXICO
}

\author{
By C. H. Maxwell, ${ }^{1}$ U.S. Geological Survey, and \\ Thomas D. Light, U.S. BureaU of MineS
}

\section{SUMMARY}

\begin{abstract}
On the basis of a mineral survey in 1979-80, the extreme southwestern part of the Manzano Wilderness has a probable mineral-resource potential for the occurrence of gold. A sample from one inactive mine in this area yielded concentrations of gold and silver. Other mines and prospects and associated geologic terrane have little promise for the occurrence of additional mineral resources. No other mineral or energy resource potential was identified in the study.
\end{abstract}

\section{CHARACTER AND SETTING}

The Manzano Wilderness occupies an area of about 55 sq $\mathrm{mi}$ along the crest and west slope of the Manzano Mountains about $30 \mathrm{mi}$ south-southeast of Albuquerque, along the boundary of Torrance and Valencia Counties. The western base of the mountains is about $6000 \mathrm{ft}$ above sea level and crest generally about $9000 \mathrm{ft}$, rising to a maximum of $10,098 \mathrm{ft}$ at Manzano Peak. The range is rugged and precipitous, with $1600 \mathrm{ft}$ to $2400 \mathrm{ft} / \mathrm{mi}$ relief over most of the range, with large talus fields and rock glaciers near the crest and numerous cliffs and steep rock faces throughout the area.

Access to the periphery of the wilderness is provided by unimproved dirt roads and jeep trails along most of the western and southeastern parts of the area and by improved dirt and gravel roads, one to the John F. Kennedy Camp Ground on the west-center boundary, one to Red Canyon Picnic Area on the southeast side, one to the top of Capilla Peak, and the Tarreon-Tajique loop road near the northeast boundary.

The Manzano Mountains, part of the uplifted eastern margin of the Rio Grande Trench, are an eastwarddipping, fault-block mountain range with a core of complexly deformed Precambrian rocks overlain by Pennsylvanian sedimentary rocks that dip gently eastward. The Manzano Wilderness is largely confined to the area underlain by Precambrian rocks, which includes the crest and steep west-facing slopes and some of the eastfacing slopes, mostly in the southern part of the area.

The major faults in the region occur along the eastern and western borders of the range. Those along the west

${ }^{1}$ With contributions by R. A. Wobus, USGS base of the mountains, near the western boundary of the wilderness, have projected displacements of at least $10,000 \mathrm{ft}$ down to the west, and as much additional displacement on other faults a short distance west of the wilderness. The faults are not well alined and are probably part of a wide zone of faults marking the east edge of the Rio Grande Trench.

The faults along the east base of the mountains are mostly westward dipping reverse faults with older rocks on the west upthrust against and over younger rocks on the east. Some segments of the faults are vertical or eastward dipping, probably indicating later vertical movement on the fault. Several prominent faults in the Precambrian rocks are parallel to the reverse faults and are probably related to the same period of deformation. Numerous occurrences of cataclastic rock and bull quartz veins in the Precambrian rocks probably represent fault and shear zones.

Folds in the Manzano Mountains are a minor part of the regional structure; the sedimentary rocks have only a few small and open folds plunging gently eastward. Bedding is locally steeply dipping or overturned adjacent to the reverse faults. The Precambrian rocks, however, have numerous small folds. Argillaceous rocks in the central part of the wilderness are characterized by tightly crenulated, nearly isoclinal folds, with amplitude to length ratios varying from $1: 1$ to as much as $4: 1$; chevron crenulations with amplitudes of a few centimeters occur on the limbs of chevron folds having three to several feet amplitude, which are part of an apparent fold with hundreds of feet amplitude.

The argillaceous rocks on the west side are composed largely of schist containing numerous lenses and layers of quartzite, and appear to have had a more complex 
deformational history than the overlying rocks to the east. Bedding or compositional layering is rarely observed except in the quartzite. Many of the quartzite layers appear to be lenticular, but they could be tectonically disjointed remnants of beds; some lenses of quartz cataclasite and quartz-sericite schist may also be disjointed remnants of beds. Some quartzite layers exhibit folding not seen in the overlying rocks. Most foliation in the argillaceous rocks near the contact with the overlying rocks is generally parallel to the contact but may be at a large angle a short distance from the contact.

The argillaceous metasedimentary rocks are interpreted to be the oldest of the Precambrian rocks. They were intruded by granodiorite of the Ojito stock, which has an isochron age of 1.57 billion years; the youngest of the metamorphic rocks have an isochron age of 1.7 billion years (Condie and Budding, 1979).

\section{MINERAL RESOURCES}

A small area in the southwest part of the Manzano Wilderness is considered to have probable mineralresource potential. Assays of samples from several mines and prospects on a small northwest-trending fault in this area revealed concentrations of gold. One sample, a 2-ft chip from a mine, contained $0.37 \mathrm{oz}$ of gold/ton and $4.0 \mathrm{oz}$ of silver/ton, and 0.65 percent copper and 1.45 percent lead. Other samples ranged from 0.01 to $0.1 \mathrm{oz}$ of gold/ton.

No significant mineral occurrences were found elsewhere in the wilderness. Small occurrences of secondary copper minerals and pyrite, an iron-sulfide mineral, in vein-like pods were prospected in the southwestern part of the wilderness. Bismuth was detected in two samples from erosional remnants of Mississippian rocks from the wilderness southeast of Mosca Peak. Zirconium occurred in anomalous amounts in many stream-sediment samples from drainages in an argillaceous metasedimentary rock unit, and probably represents an alluvial concentration of the mineral zircon from Precambrian formations, followed by a further concentration in the Quaternary alluvium of detritus derived from the Precambrian rocks.

Gold was detected in very small amounts in several stream-sediment and rock samples, but only four samples contained more than 1 part per million; silver was detected in several samples but in amounts less than 1 part per million; other elements were also found in anomalous amounts, but none indicate a likelihood for the occurrence of resources.

\section{SUGGESTIONS FOR FURTHER STUDIES}

Further study of the wilderness offers little promise for the identification of hidden mineral deposits.

\section{REFERENCES}

Condie, K. C., and Budding, A. J., 1979, Geology and geochemistry of Precambrian rocks, central and south-central New Mexico: New Mexico Bureau of Mines and Mineral Resources Memoir 35, $58 \mathrm{p}$.

Maxwell, C. H., and Wobus, R. A., 1982a, Geologic map of the Manzano Wilderness, Valencia and Torrance Counties, New Mexico: U.S. Geological Survey Miscellaneous Field Studies Map MF1464-A, scale 1:50,000.

1982b, Geochemical and geophysical maps of the Manzano Wilderness, Valencia and Torrance Counties, New Mexico: U.S. Geological Survey Miscellaneous Field Studies Map MF1464-B, scale 1:50,000.

Maxwell, C. H., Wobus, R.A., and Light, T. D., 1983, Mineral resource potential map of the Manzano Wilderness, Valencia and Torrance Counties, New Mexico: U.S. Geological Survey Miscellaneous Field Studies Map MF-1464-C, scale 1:50,000.

Myers, D. A., and McKay, E. J., 1971, Geologic map of the Bosque Peak quadrangle, Torrance, Valencia, and Bernalillo Counties, New Mexico: U.S. Geological Survey Geologic Quadrangle Map GQ-948, scale 1:24,000.

1972, Geologic map of the Capilla Peak quadrangle, Torrance and Valencia Counties, New Mexico: U.S. Geological Survey Geologic Quadrangle Map GQ-1008, scale 1:24,000.

1974, Geologic map of the southwest quarter of the Torreon 15-minute quadrangle, Torrance and Valencia Counties, New Mexico: U.S.Geological Survey Miscellaneous Investigations Map I-820, scale 1:24,000. 


\title{
PECOS WILDERNESS, NEW MEXICO
}

\author{
By ROBERT H. MOENCH, ${ }^{1}$ U.S. GeOlOGICAL SuRVEY, and \\ Michael E. LANE, U.S. BuREaU of Mines
}

\section{SUMMARY}

Mineral surveys conducted in 1976-77 and 1979-80 of the Pecos Wilderness identified probable mineral-resource potential within an area of about $3 \mathrm{sq} \mathrm{mi}$ at its southern boundary, in and near an area underlain by Precambrian metamorphosed volcanic and related sedimentary rocks. The mineral deposits, if they exist, probably are of the zinc-lead-copper stratabound massive sulfide type, possibly with by-product silver and gold, of the type mined previously just outside the wilderness. No fossil fuel resources were identified in this study.

\section{CHARACTER AND SETTING}

The Pecos Wilderness occupies nearly $350 \mathrm{sq} \mathrm{mi}$ at the southern end of the Sangre de Cristo Range in north-central New Mexico, centering about 15 mi northeast of Santa Fe. The axis of the range is alpine in character, with summits at altitudes of $12,000-13,000$ ft. The axial high peaks divide the wilderness into a western tract of densely wooded ridges and canyons, and an eastern high plateau dissected by deep canyons bordered on the east by a scarp of some $3000 \mathrm{ft}$. Lower grassy ranchland and forest and the Great Plains prairie extend east from the base of the scarp. The wilderness is bordered on the west by the wide semidesert Rio Grande valley, and beyond that to the west are the volcanic Jemez Mountains. Access to the Pecos Wilderness is provided by several roads that lead from Interstate 25 on the east and south, U.S. Highway 285 on the west, and New Mexico Routes 68 and 3 on the north.

The present boundary of the Pecos Wilderness incorporates several additions to the original wilderness. Mineral resources of the original wilderness and proposed additions were investigated in 1976-77 (U.S. Geological Survey, U.S. Bureau of Mines, and New Mexico Bureau of Mines and Mineral Resources, 1980). Several other additions proposed later were studied in 1979-80 (Moench and Erickson, 1980). This report incorporates the results of both surveys in the wilderness and additions and other recent work in the region.

The Sangre de Cristo Range is a huge uplifted block of Precambrian schist, gneiss, and igneous rocks that are

\footnotetext{
${ }^{1}$ With contributions by James M. Robertson, New Mexico Bureau of Mines and Mineral Resources, and Jeffrey A. Grambling, University of New Mexico.
}

partly covered by much younger nearly flat lying sedimentary rocks of Mississippian, Pennsylvanian, and Permian age. Within the past 20 million years or so the range was uplifted several miles relative to the Rio Grande depression on the west, by block faulting that occurred in a wide north-trending belt known as the Rio Grande rift. Master faults of the rift probably lie just west of the wilderness boundary.

The most conspicuous feature of the geologic map is the Pecos-Picuris fault, an ancient Precambrian feature that was reactivated at least twice, but most recently about 65 million years ago. The fault separates the Precambrian igneous and metamorphic rocks of the area into two blocks. The Garcia Ranch and Borrego faults are smaller features that probably have similar histories. The Jicarilla fault and others farther east probably were active about 65 million years ago.

Mineral resources of the Pecos Wilderness are contained mainly in the Precambrian basement rocks, which range in age from about 1.4 to 1.75 billion years old. Metamorphic rocks of the basement are divisible into two broad groups of contrasting origin, wellstratified quartz sandstone and shale, and complexly interstratified volcanic and related sedimentary rocks.

The metamorphosed volcanic and related sedimentary rocks accumulated in an ancient sea characterized by local volcanic centers and possible volcanic islands. At the centers, viscous rhyolitic magma (containing 70-75 percent silica) and much more fluid basaltic magma (containing about 50 percent silica) erupted possibly in alternating cycles and accumulated together under deep water. Some of these deposits were reworked by bottom currents, carried far from the volcanic centers, and mixed with fine-grained sediments from 


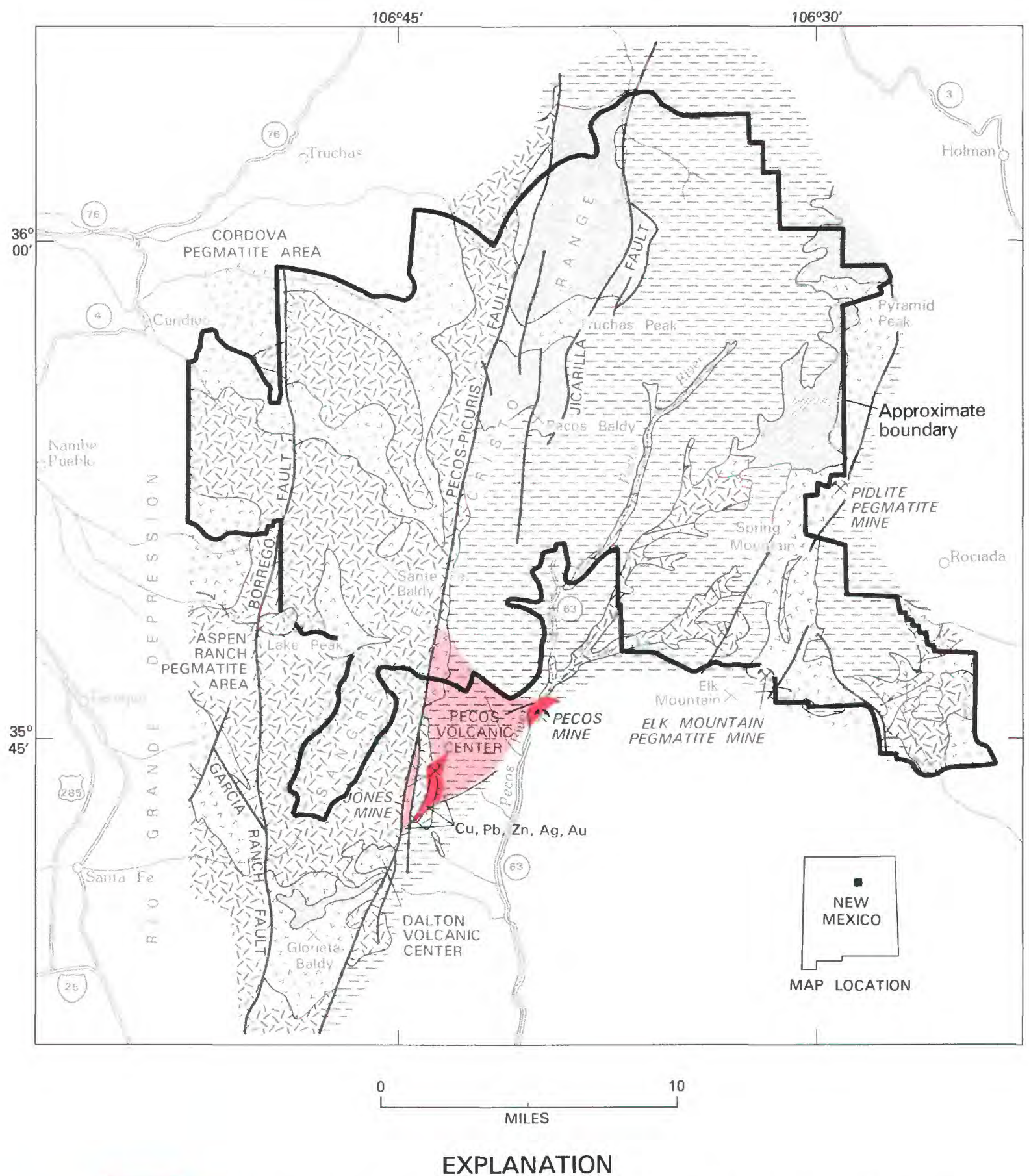

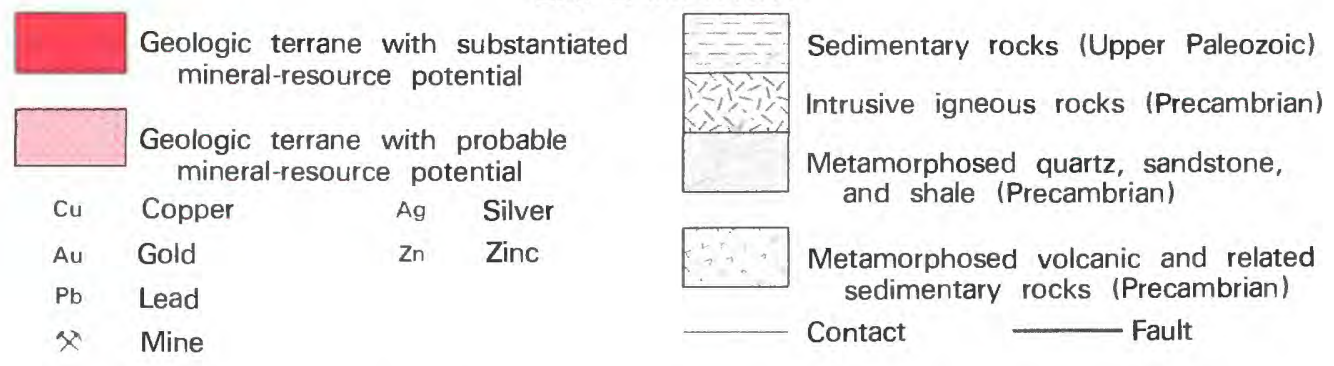

Figure 234.-Pecos Wilderness, New Mexico. 
other sources. At the fumaroles at or near the sites of the rhyolitic eruptions, metals precipitated on the sea floor. Such ore-forming processes are known to have occurred elsewhere from ancient to modern times. They produced the ore that was extracted from the Pecos mine, located approximately $1 \mathrm{mi}$ southeast of the wilderness boundary, clearly recognized by Riesmeyer (1978) as a nearly classic example of rhyolite-hosted volcanogenic massive sulfide deposits.

The principal mineral potential of the wilderness is closely related to the Pecos and Dalton volcanic centers (Moench and Erickson, 1980; Fulp, 1982; Riesmeyer, 1978). The Pecos center is the principal known source of the metamorphosed volcanic and related sedimentary rocks exposed east of the Pecos-Picuris fault. These deposits were erupted atop and were spread outward from an underlying large complex chamber of magma, now represented by some of the Precambrian intrusive igneous rocks exposed in the southeastern part of the wilderness. The assemblage of related volcanic and intrusive rocks, called the Pecos greenstone belt (Robertson and Moench, 1979), probably originated about 1.72 billion years ago. As volcanism waned, quartz sandstone and shale, now quartzite and schist, were shed from an unknown source and spread across the region.

The Dalton volcanic center west of the Pecos-Picuris fault may be younger (Fulp, 1982; about 1.65 to 1.70 billion years old) and unrelated to the Pecos center. Speculatively, the Dalton eruptions may have followed deposition of the quartz sandstone and shale, now represented by quartzite and schist north of Glorieta Baldy and inferred to lie below the volcanic rocks. The eruptions yielded potassium-rich rhyolite unlike that of the Pecos center (Fulp, 1982; Riesmeyer, 1978). Also, whereas tungsten as well as zinc, lead, copper, and silver are important resources at the Dalton center (Moench and Erickson, 1980), no appreciable evidence of tungsten mineralization is recognized at the Pecos center or elsewhere east of the Pecos-Picuris fault.

\section{MINERAL RESOURCES}

Two small areas just south of the Pecos Wilderness are classed as having substantiated mineral-resource potential for volcanogenic massive sulfide deposits associated with the Pecos volcanic center. One area contains the Pecos mine, a substantial past producer of zinc, lead, copper, silver and gold. The other contains the Jones mine, a prospect having no known production, but the approximate site of a recent major discovery by Conoco (World Mining, 1978).

The two areas of substantiated potential are within a larger area classed as having probable potential for similar deposits in the Precambrian basement, most of which is buried under sedimentary rocks. The covered rocks are assumed to belong to the same geologic terrane as that which contains the exposed mineralized rocks at the Pecos and Jones mines. The area of probable potential includes about $3 \mathrm{sq}$ mi within the wilderness. The Precambrian of this area shows geochemical evidence for copper, zinc, and silver occurrences, and contains several prospect pits and adits where sparse metalliferous minerals are exposed. However, the area does not contain rocks characteristic of a volcanic center, and the likelihood of the occurrence of a major deposit is small.

The geochemical data show evidence of scattered minor sulfide mineralization in the southeastern part of the wilderness, in areas underlain by metamorphosed volcanic and related sedimentary rocks. The scattered mineralization suggested by the geochemical data is regarded as "smoke" widely peripheral to some unrecognized main volcanic center.

Traces of zinc, antimony, and other elements were found by the geochemical survey along the Jicarilla fault, northeast of Truchas Peak where the fault is bordered on both sides by quartzite and minor schist. The zinc and antimony are accompanied by minor amounts of beryllium, and niobium, and perhaps by uranium, inferred from moderate amounts of radon detected in three springs. Two of the springs occur within the site of the zinc and antimony occurrence; the other is about $4 \mathrm{mi}$ to the south along the fault: Minerals containing these elements may have precipitated from hot ground water that circulated through broken rock along the fault. No potential can be defined from the available data.

Pegmatite dikes are abundant in and near the Pecos Wilderness, but they are not considered to constitute a mineral resource. Pegmatites of the Pidlite mine, to the east of the wilderness, have yielded some lithiumbearing mica. Similar bodies are not known to occur within the wilderness. Pegmatites at the Elk Mountain mine and in the Aspen Ranch and Cordova areas have been explored principally for mica, and locally for minor beryl. The Elk Mountain and nearby properties yielded several hundred tons of mica through 1955 . No significant production is reported elsewhere in or near the wilderness.

Data from the geochemical survey indicate that the upper Paleozoic sedimentary cover rocks contain rather high abundances of zinc, copper, and molybdenum, but they show no evidence for the occurrence of resources of these metals.

\section{SUGGESTIONS FOR FURTHER STUDY}

Although the setting and geochemical characteristics 
of volcanogenic massive sulfide deposits are well known and have served us well in this study, the occurrence of sulfide deposits of similar composition in more distal volcanic and sedimentary settings is poorly understood. Accumulating knowledge on the subject should be applied by continuing studies of Precambrian rocks in the area.

Further study of the occurrence of zinc and antimony along part of the Jicarilla fault may help to delineate vein deposits of uncommon but possibly significant type.

Pennsylvanian sedimentary rocks of a large area, probably far greater than the area of their exposure in the Pecos Wilderness, deserve study for possible occurrence of metals.

\section{REFERENCES}

Fulp, M. S., 1982, Precambrian geology of the Dalton Canyon volcanic center, Santa Fe County, New Mexico: University of New Mexico, unpublished M.S. thesis, 199 p.
Moench, R. H., and Erickson, M. S., 1980, Occurrence of tungsten in the Sangre de Cristo Range near Santa Fe, New MexicoPossible stratabound scheelite peripheral to favorable settings for volcanogenic massive sulfide deposits: U.S. Geological Survey Open-File Report 80-1162, 21 p.

Riesmeyer, W. D., 1978, Precambrian geology and ore deposits of the Pecos mining district, San Miguel and Santa Fe Counties, New Mexico: University of New Mexico, unpublished M.S. thesis, $215 \mathrm{p}$.

Robertson, J. M., and Moench, R. H., 1979, The Pecos greenstone belt-A Proterozoic volcano-sedimentary sequence in the southern Sangre de Cristo Mountians, New Mexico: New Mexico Geological Society Guidebook, 30th Field Conference, Santa Fe Country, p. 165-173.

U.S. Geological Survey, U.S. Bureau of Mines, and New Mexico Bureau of Mines and Mineral Resources, 1980, Mineral resources of the Pecos Wilderness and adjacent areas, Santa Fe, San Miguel, Mora, Rio Arriba, and Taos Counties, New Mexico: U.S. Geological Survey Open-File Report 80-382, 117 p.

World Mining, 1978, Conoco discovers massive sulphides in Pecos Mountains: World Mining, v. 31, no. 2, p. 76. 


\title{
RYAN HILL ROADLESS AREA, NEW MEXICO
}

\author{
By C. H. MAXwell, ${ }^{1}$ U.S. GeOlOGical SuRvey, and \\ C. E. ElLis, U.S. BuREAU OF MiNeS
}

\section{SUMMARY}

On the basis of a geochemical survey, the Ryan Hill Roadless Area, now the Langmuir Research Site, has both probable and substantiated resource potential for manganese deposits. The nature of the geologic terrane holds little likelihood for the occurrence of organic fuels.

\section{CHARACTER AND SETTING}

The Ryan Hill Roadless Area comprises about $57 \mathrm{sq}$ $\mathrm{mi}$ in the southern part of the Magdalena Mountains in southwestern New Mexico, at altitudes ranging from about $6400 \mathrm{ft}$ along the southern boundary to a maximum of $10,783 \mathrm{ft}$ at South Baldy Peak. Local relief is generally around 1000 to $2000 \mathrm{ft}$. The Langmuir Research Site occupies about $48 \mathrm{sq}$ mi within the roadless area. The Langmuir Laboratory area is situated in the northwestern corner of the research site, around South Baldy Peak at altitudes of 10,500 to $10,600 \mathrm{ft}$. The laboratory is engaged in research on lightning and other atmospheric conditions and on astronomical phenomena, with plans for future studies in conjunction with the National Radio Astronomy Observatory Very Large Array facility, $26 \mathrm{mi}$ to the west, on the Plains of San Augustin.

The southern part of the Magdalena Mountains comprises part of a deeply eroded composite volcano composed predominantly of intensely welded rhyolite ash-flow tuffs, rhyolite flows and flow domes, and a few quartz latite and dacite flows, overlying and interlayered with andesite flows and lahars. A few quartz monzonite intrusives occur in the northern part of the roadless area, and some Precambrian and Paleozoic rocks occur just outside the area in and north of Water Canyon. The volcanic rocks generally dip radially away from the area of South Baldy Peak. They are shown on the generalized geologic map as two map units, rhyolite and rocks of intermediate composition (andesite to latite). The rocks range in age from 38 to 26 million years for most of the area, and are about 14 million years old in the northwesternmost part and 11 million years old along the eastern side. The area is complexly

\footnotetext{
${ }^{1}$ With contributions by A. V. Heyl, USGS, and D. C. Scott, USBM.
}

faulted into a rectilinear pattern with both normal and reverse faults trending predominantly north-northwest or east-northeast. Most fault blocks dip eastward, some in the western part of the area dip westward.

Most of the faults in the region are mineralized to some extent and many contain mineral occurrences that have been prospected or mined. Numerous mines and prospects are in or adjacent to the roadless area, in three established mining districts. The two oldest are the Water Canyon or Silver Mountain and the Mill Canyon districts in the northern part and northeastern corner of the roadless area. Prospecting began in that region as early as 1868 and continued sporadically to the present. Active mining began soon after discovery and continued off and on until 1917 and again from about 1929 to 1946. Production records are not available for that area. The third, the Magdalena Mountains manganese district, was established about 1930 , with most of the mining activity between 1940 and 1959. Recorded production is more than 8000 tons of manganese.

All veins and mineralized areas encountered during the resource study were sampled and stream sediments were collected from all appropriate drainage basins throughout the roadless area. Rock, vein, mineralized rock, stream-sediment, and panned concentrate samples were analyzed.

Aeromagnetic maps for the region were compiled and released in 1973. Two audio-magnetotelluric profiles were made by D. L. Hoover in the eastern part of the roadless area, one along Sixmile Canyon and another from Madera Canyon southward.

\section{MINERAL RESOURCES}

Numerous mineral deposits and occurrences near the periphery of the Ryan Hill Roadless Area indicate a 

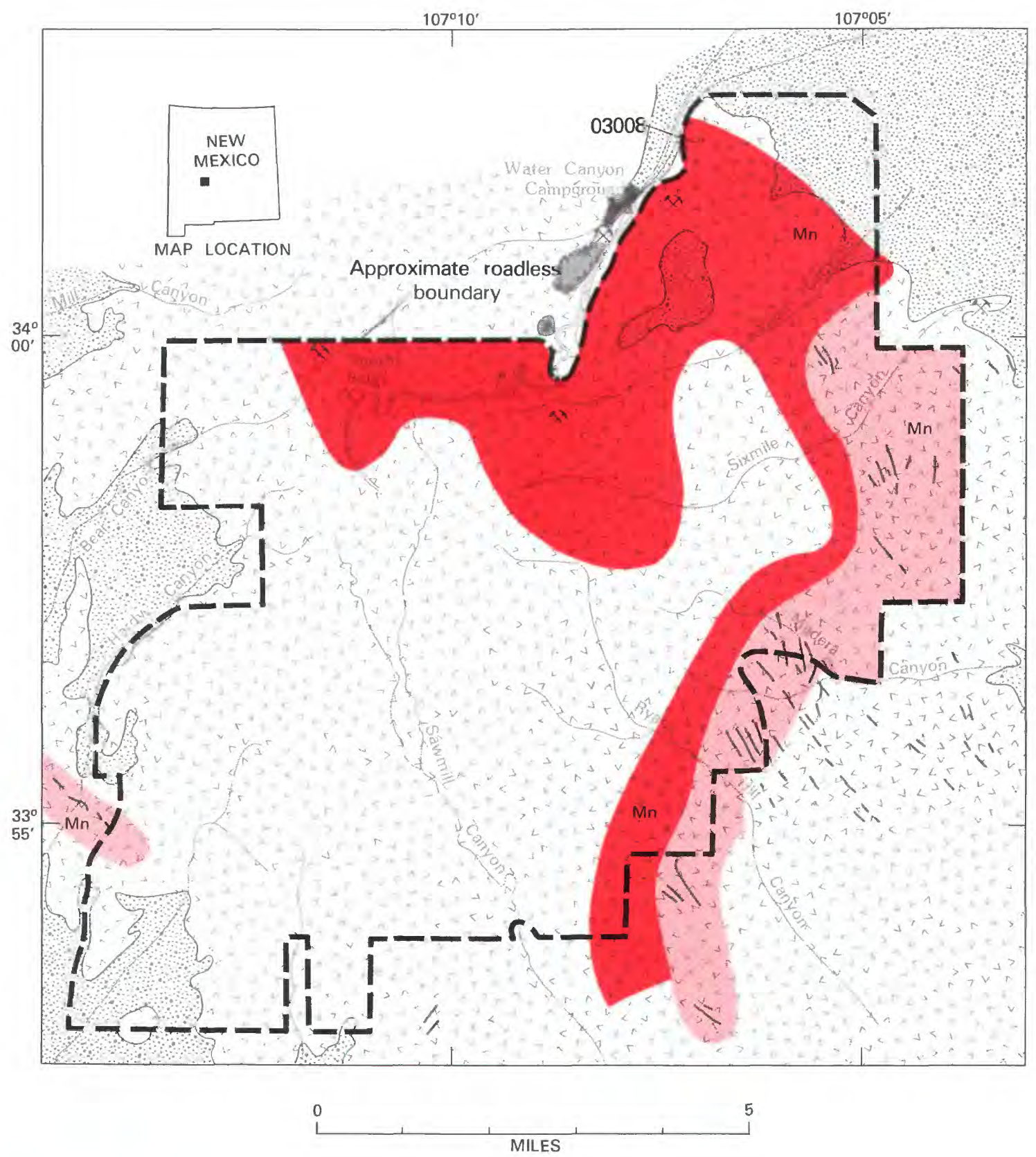

\section{EXPLANATION}

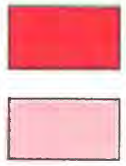

Geologic terrane with substantiated mineral-resource potential

Geologic terrane with probable mineral-resource potential

$\begin{array}{ll}\text { Mn } & \text { Manganese } \\ \text { SX } & \text { Mine } \\ & \text { Manganese vein }\end{array}$

Quaternary and Tertiary alluvium
and gravel deposits
Tertiary volcanics
Paleozoic rocks
Precambrian rocks
Contact

Figure 235.-Ryan Hill Roadless Area, New Mexico. 
probable resource potential for manganese deposits. An area of substantiated resource potential for manganese is located along the eastern, southeastern, and northern sides, extending to include an area around South Baldy Peak in the Magdalena Mountains manganese district.

The boundary of the roadless area was placed to exclude the largest or most productive manganese mines, but many smaller mines and prospects occur within the area, as well as many additional occurrences that are too small in surface expression to have been prospected.

The manganese deposits appear to be epithermal, formed in the uppermost levels of a hydrothermal system near the original surface, some as hot spring deposits. None have been developed for more than a few tens of feet in depth, but similar deposits in the Luis Lopez district, $6 \mathrm{mi}$ to the east, have been mined to depths of $450 \mathrm{ft}$ or more.

Most of the manganese deposits occur as veins along persistent north- and northwest-trending faults, in brecciated zones 1 to $30 \mathrm{ft}$ wide and as much as $2000 \mathrm{ft}$ long. The veins are made up of layers of manganese oxides as much as several inches thick that coat the walls and cement angular fragments of the rhyolite host rock. Jasperoid is locally prominent both in the veins and in the wallrock; black or white calcite is locally present in the veins.

The most abundant minerals in the manganese deposits are the barium manganates, hollandite, and psilomelane; pyrolusite and cryptomelane were also identified. Spectrographic analyses of 60 samples from manganese veins in the roadless area show that the deposits contain high amounts of lead, zinc, copper, and molybdenum. Tungsten is noteworthy, and commonly is 0.2 to 0.5 percent. Arsenic (as much as 0.3 percent) and antimony (as much as 1500 parts per million) are also present in anomalous amounts; other elements present also in anomalous amounts include beryllium, cobalt, lanthanum, strontium, and vanadium. Silver was not detected in most samples; gold was detected (trace to 1 part per million) in many of the samples.

The audio-magnetotelluric profiles show a zone of greatly reduced resistivity ( 1 or 2 orders of magnitude) from 300 to $900 \mathrm{ft}$ below the surface to a depth of 2400 to $3500 \mathrm{ft}$, in an area generally corresponding to ground containing numerous veins and mineral occurrences. The low resistivity could indicate, among other possibilities, the presence of sulfides in the rocks or of mineralized water. These data along with the unusually high concentrations of accessory elements in the manganese deposits suggest the possibility of the continuation of an extensive epithermal vein system at depth, possibly containing base-metal deposits.

The suite of elements in the mineralized rock samples from the northern part of the roadless area contrast markedly with those from the rest of the manganese district. Samples from the small veins around South Baldy Peak and from a mine on the northwestern boundary show as much as $10 \mathrm{oz}$ silver/ton, copper and manganese mineralization, and anomalous lead, zinc, and bismuth; notably absent in detectable amounts were molybdenum, tungsten, barium, arsenic, antimony, and cobalt. Other samples from veins in the Water Canyon district have similar values but in addition have anomalous molybdenum and gold.

\section{SUGGESTIONS FOR FURTHER STUDIES}

Additional geochemical studies of the manganese vein systems are desirable to better delineate the resource potential; mineralogical and metallurgical studies are needed to determine recoverability of potentially important byproducts, including tungsten and cobalt. Drilling into the vein system at depth would be required to test the continuity of the manganese deposits and evaluate the resource potential of the area for deeply buried base- and precious-metal resources.

\section{REFERENCE}

Maxwell, C. H., Heyl, A. V., Ellis, C. E., and Scott, D. C., in press, Mineral resource potential map of the Ryan Hill Roadless Area, Socorro County, New Mexico: U.S. Geological Survey Miscellaneous Field Studies Map MF-1634-A. 


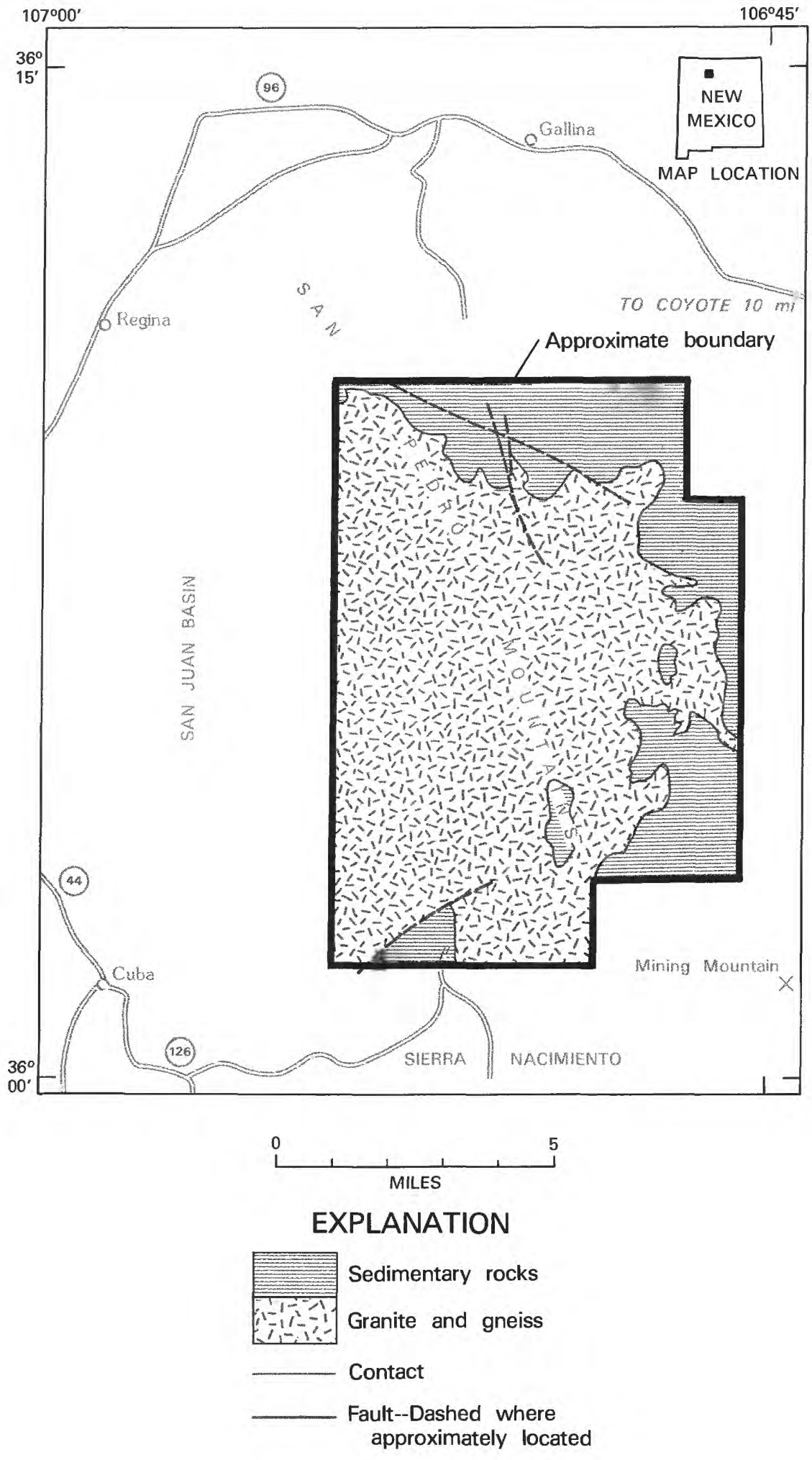

Figure 236.-San Pedro Parks Wilderness, New Mexico. 


\title{
SAN PEDRO PARKS WILDERNESS, NEW MEXICO
}

\author{
By Elmer S. SANTOS, ${ }^{1}$ U.S. GeOlogical SURVEY, and \\ ROBERT C. WEISNER, U.S. BUREAU OF MINES
}

\begin{abstract}
SUMMARY
The results of a mineral survey made from 1970 to 1972 indicate that there is little promise for the occurrence of mineral deposits, fossil fuel, or geothermal energy in the San Pedro Parks Wilderness.
\end{abstract}

\section{CHARACTER AND SETTING}

The San Pedro Parks Wilderness occupies $62.7 \mathrm{sq} \mathrm{mi}$ of the Santa Fe National Forest in north-central New Mexico; it was studied by the USGS and USBM and the results are published in a report by Santos and others (1975). The San Pedro Parks Wilderness is located at the north end of the granite-cored San Pedro MountainSierra Nacimiento range which is flanked by sedimentary rocks of Paleozoic to Tertiary age. The range is bounded on its west side by the Nacimiento fault; other north- and east-trending faults juxtapose granite and sedimentary rocks in the northern, southern, and southeastern parts of the wilderness.

Elevations range from 8400 to $10,600 \mathrm{ft}$ in the wilderness, which is easily reached from the villages of Cuba, Regina, and Gallina along New Mexico Highways 44, 96, and 126. Approaches to the wilderness boundaries are provided by numerous USFS roads; many hiking trails maintained by the USFS provide access to most of the wilderness.

A large, relatively flat, upland area at the summit of San Pedro Mountain drops off steeply to the north and west and less steeply to the south and east. The thick forest cover is interrupted locally by open grassy meadows or parks for which the wilderness is named.

Rocks exposed throughout 75 percent of the wilderness consist of hard and resistant red granite with minor amounts of gneiss, all of which are Precambrian in age. Sedimentary rocks overlying the granite along the north and east side of the range consist of interbedded limestone, shale, and sandstone about $800 \mathrm{ft}$ thick. Along the south and southeast sides of the wilderness, the rocks resting on granite are younger than

${ }^{1}$ With contributions by Robert B. Hall, USGS. those on the north side and consist of about $500 \mathrm{ft}$ of interbedded red mudstone and siltstone with minor beds of gray sandstone. Along the east side of the wilderness area Miocene strata lap across the older sedimentary rocks and onto the granite.

\section{MINERAL RESOURCES}

There is no recorded mineral production from within the San Pedro Parks Wilderness. Several copper mines, many copper prospects, and a few uranium prospects occur in sedimentary units in the vicinity of the wilderness. These units, where they extend into the wilderness, constitute only a small volume of rock and, judging from analyses of samples and from field observations, are devoid of copper and uranium concentrations. Prospects on several of about 65 mining claims within the wilderness revealed concentrations of manganese or barite but only in volumes too small to be considered a demonstrated resource.

No evidence of alteration other than that caused by weathering was observed in either the granite or sedimentary rocks. Analyses of stream-sediment and rock samples indicate that there is little promise for the discovery of mineral resources in the wilderness.

There is no evidence to indicate any fossil fuel or geothermal resources in the wilderness.

\section{SUGGESTIONS FOR FURTHER STUDIES}

Further study of the San Pedro Park Wilderness offers little promise for the identification of hidden mineral deposits. 


\section{REFERENCE}

Santos, E. S., Hall, R. B., and Weisner, R. C., 1975, Mineral resources of the San Pedro Parks Wilderness and vicinity, Rio Arriba and Sandoval Counties, New Mexico: U.S. Geological Survey Bulletin 1385-C, 29 p. 


\title{
SANDIA MOUNTAIN WILDERNESS, NEW MEXICO
}

\author{
By D. C. Hedlund ${ }^{1}$, U.S. Geological Survey, and \\ R. F. KNESS, U.S. BUREAU OF MiNES
}

\section{SUMMARY}

Geologic and mineral-resource investigations in the Sandia Mountains from 1980 through 1982 indicate that a small part of the area has a probable mineralresource potential. Most of the mineral occurrences are small barite-fluorite veins that occur along faults on the eastern slope of the range. The barite veins in the Landsend area and in the Tunnel Spring area are classed as having a probable mineral-resource potential. Fluorite veins which occur at the La Luz mine contain silver-bearing galena and the area near this mine is regarded as having a probable resource potential for silver. No energy resources were identified in this study.

\section{CHARACTER AND SETTING}

The Sandia Mountain Wilderness occupies an area of about $61 \mathrm{sq} \mathrm{mi}$ along the north-trending and eastwardtilted fault block of the Sandia Mountains about $12 \mathrm{mi}$ east of Albuquerque, New Mexico. The westward-facing range front is impressive and of great relief, varying from altitudes of 5800 to $6400 \mathrm{ft}$ at the base to $10,678 \mathrm{ft}$ at the crest. The rim with its limestone capping and verdant pine forest contrasts with the steep, bare, weathered slopes of pinkish granite. This reddened "core" and green-rim color contrast is especially enhanced at sunset and gave rise to the term "watermelon mountains" or Sandia Mountains in Spanish.

The physiographic limits of the range are defined by the Placitas fault to the north and the Tijeras fault or Tijeras-Gutierrez rift on the south. The west-facing fault scarp is slightly eroded back from the SandiaRincon range front faults that separate the Sandias from the Rio Grande Trough. The eastern limit of the range is less well defined but it is separated from Monte Largo by a structural sag formed by the merging of the Tijeras synclinal basin with the Hagan Basin. The Sandia Mountains, as thusly defined, are about $18 \mathrm{mi}$ long and 8 to $10 \mathrm{mi}$ wide.

Much of the steep and rugged west-facing part of the Sandia Mountains consists of Precambrian granite; biotitic gneiss crops out in the Rincon area, and an older greenstone belt follows Tijeras Canyon. A major uncon-

\footnotetext{
${ }^{1}$ With contributions from D. E. Hendzel, USGS.
}

formity separates the Precambrian crystalline rocks from the overlying Mississippian and Pennsylvanian limestone and sandstone strata. The limestones of the Madera Group (Pennsylvanian) are overlain by a thick Permian-Triassic red-bed sequence of strata that outcrop farther down along the dip-slope. The still younger Jurassic-Cretaceous strata are folded into synclinal basins near Cedar Crest, Tijeras, and Hagan, and also fill a structural sag near Placitas.

The east-tilted fault block of the Sandia Mountains was displaced upward as much as $30,000 \mathrm{ft}$ along the Sandia and Rincon faults during the Pliocene and Miocene. Numerous north-striking faults along the dip slope developed during this tilting and locally some of these back slope faults brought Precambrian rocks to present surface levels. A major Laramide fault system includes the Placitas, Tijeras, and Gutierrez faults that strike east-northeast to northeast along the north and south boundaries of the range. These faults have had recurring movements dating back to the late Precambrian and continuing into the Holocene. The major known displacement on these faults occurred in the Laramide; $3000 \mathrm{ft}$ of displacement of the Upper Cretaceous Mesaverde Formation can be established along the Tijeras fault. The Tijeras and Gutierrez faults are scissor faults that bound the Tijeras graben and syncline to the southwest and the Monte Largo horst of Precambrian rocks to the northeast.

Two mining districts include parts of the wilderness: the Tijeras Canyon mining district in the southern part and the Placitas district in the northern part. A 


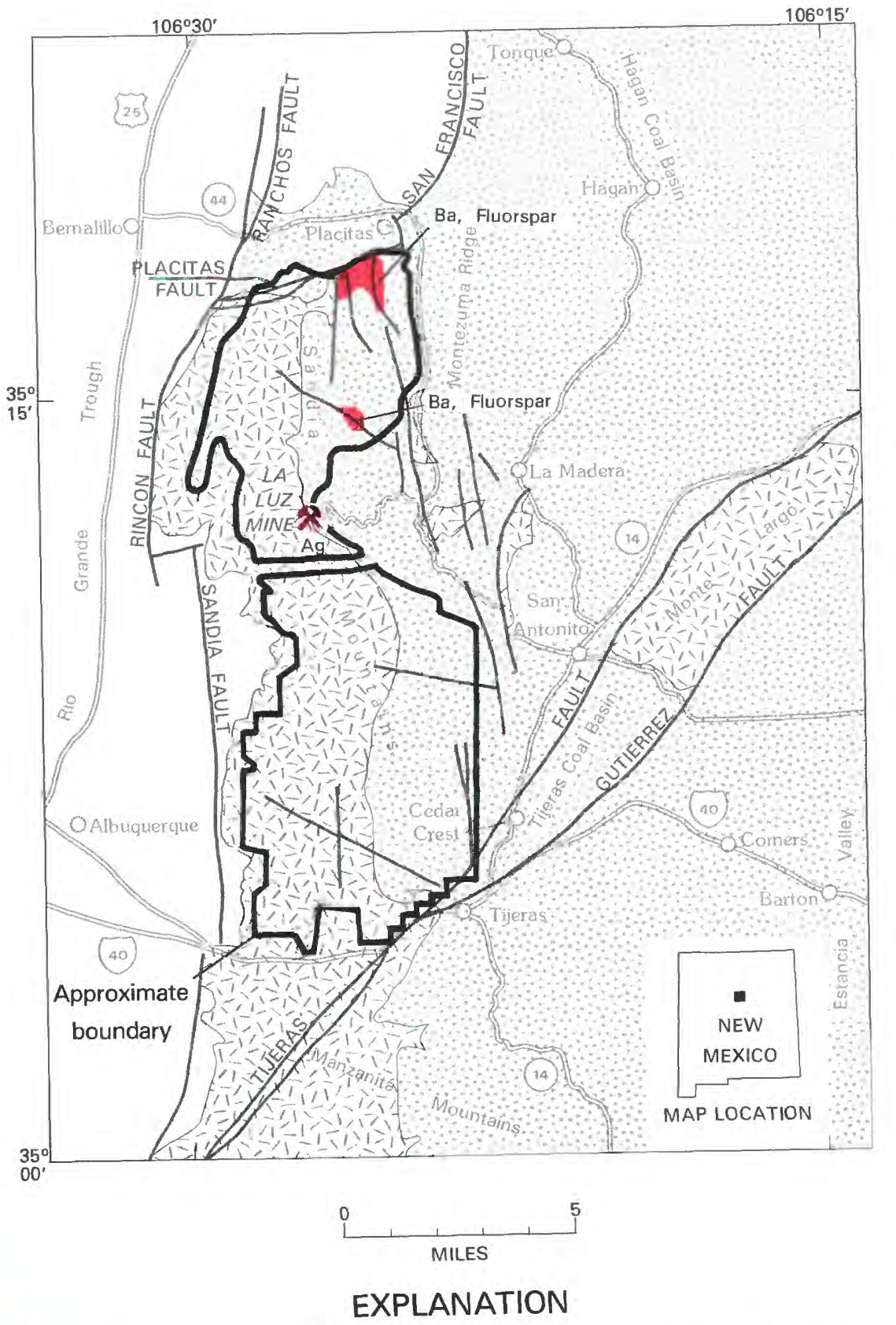

\begin{tabular}{|c|c|c|}
\hline & $\begin{array}{l}\text { Geologic terrane with substantiated } \\
\text { mineral-resource potential }\end{array}$ & $\begin{array}{l}\text { Unconsolidated sediments } \\
\text { (Quarternary) }\end{array}$ \\
\hline & $\begin{array}{l}\text { Geologic terrane with probable } \\
\text { mineral-resource potential }\end{array}$ & $\begin{array}{l}\text { Sediment rocks } \\
\text { (Mesozoic and Upper Paleozoic) }\end{array}$ \\
\hline $\mathrm{Ba}$ & Barite & $\begin{array}{l}\text { Granitic rocks, gneiss, and greenstone } \\
\text { (Precambrian) }\end{array}$ \\
\hline $\mathrm{Ag}$ & Silver & Contact \\
\hline x & Mine or deposit & Fault \\
\hline
\end{tabular}

Figure 237.-Sandia Mountain Wilderness, New Mexico. 
minimum of 520 claims have been recorded within the wilderness.

\section{MINERAL RESOURCES}

Numerous small fissure veins containing barite, fluorite, and silver-bearing base metals are known in the wilderness. The north-striking faults along the limestone beds of the eastern dip-slope have localized these veins, and many have been extensively prospected, for example the barite veins of the Tunnel Springs area and the Landsend barite prospect. The Landsend prospect can be traced over a length of about $450 \mathrm{ft}$ with a maximum width of about 3 to $4 \mathrm{ft}$. Some bedding replacement deposits occur along this barite vein system but most are not large and show numerous pinch-outs. The barite is intergrown with fluorite. As much as 1 percent strontium is contained in barite concentrates. The barite-fluorite fissure veins in the vicinity of Tunnel Springs occur along minor north-trending faults and at the intersections of these faults with the east-northeasttrending Placitas fault. Some of these veins are as much as $3 \mathrm{ft}$ wide, but have little continuity along the faults; bedded replacement ore bodies are lacking. Both of these areas are considered to have substantiated re- source potential for small resources of barite and fluorite. A probable silver resource potential occurs around the area of the La Luz mine in fluorite veins that, at the mine, contain pockets of argentiferous galena. Of five samples taken from various levels at the La Luz mine the highest value was about $0.43 \mathrm{oz}$ silver/ton. There is no current mining activity in the wilderness.

\section{SUGGESTIONS FOR FURTHER STUDIES}

Further studies to refine understanding of the mineral potential of this wilderness would require drilling or other physical exploration in the areas of barite veins to identify subsurface mineralization and decipher structural and stratigraphic controls.

\section{REFERENCES}

Hedlund, D. C., Hendzel, D. E., and Kness, R. F., in press, Mineral resource potential map of the Sandia Mountain Wilderness, Bernalillo and Sandoval Counties, New Mexico: U.S. Geological Survey Miscellaneous Field Studies Map MF-1631-A, scale 1:50,000.

Kelley, V. C., and Northrup, S. A., 1975, Geology of the Sandia Mountains and Vicinity, New Mexico: New Mexico Bureau of Mines and Mineral Resources Memoir 29, 136 p. 


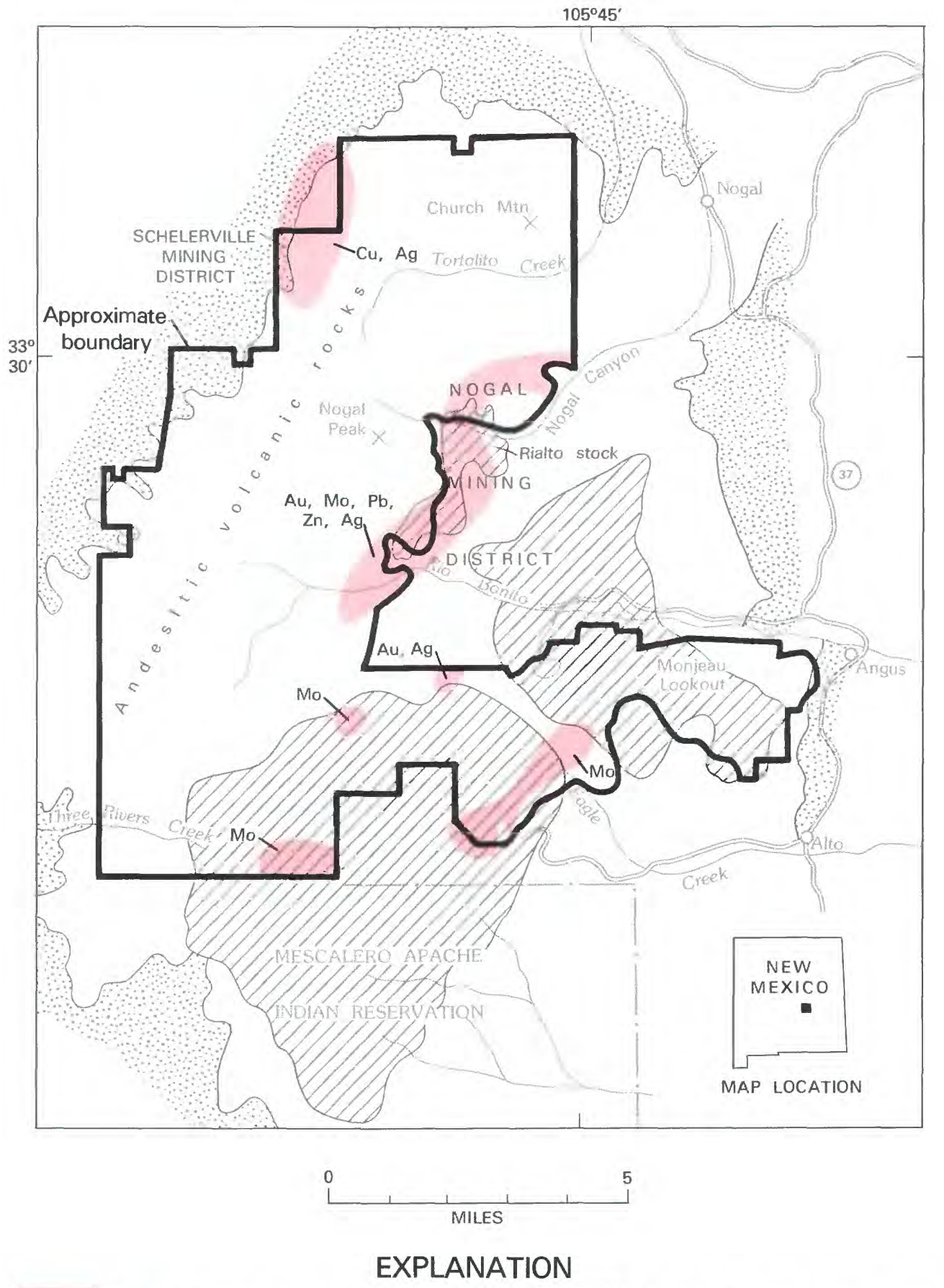

\begin{tabular}{|ll|l}
\hline & $\begin{array}{c}\text { Geologic terrane with probable } \\
\text { mineral-resource potential }\end{array}$ & $\begin{array}{c}\text { Alluvium, fanglomerates, and } \\
\text { sedimentary rocks }\end{array}$ \\
$\mathrm{Cu}$ & Copper & Syenite and monzonite \\
$\mathrm{Au}$ & Gold & Andesite and andesite \\
$\mathrm{Pb}$ & Lead & Contact \\
$\mathrm{Mo}$ & Molybdenum \\
$\mathrm{Ag}$ & Silver & \\
$\mathrm{Zn}$ & Zinc &
\end{tabular}

Figure 238.-White Mountain Wilderness, New Mexico. 


\title{
WHITE MOUNTAIN WILDERNESS, NEW MEXICO
}

\author{
By Kenneth Segerstrom, ${ }^{1}$ U.S. Geological Survey, and \\ R. B. STOTELmeyer, U.S. Bureau of Mines
}

\section{SUMMARY}

On the basis of a inineral survey made during 1971-73, the White Mountain Wilderness, which constitutes much of the western and northern White Mountains, New Mexico, is appraised to have six areas of probable mineral potential for base and precious metals. If inineral deposits exist in the wilderness, the potential is for small deposits of base and precious metals in veins and breccia pipes or, more significantly, the possibility for large low-grade disseminated porphyry-type molybdenum deposits. There is little promise for the occurrence of geothermal energy resources in the area.

\section{CHARACTER AND SETTING}

The White Mountain Wilderness occupies an irregular area of about $61 \mathrm{sq} \mathrm{mi}$ in the highest mountains of southeastern New Mexico, about $125 \mathrm{mi}$ southsoutheast of Albuquerque, and within a large triangle formed by U.S. Highways 54,70 , and 380 . The wilderness was studied in 1971-73 and the results were published by Segerstrom and others (1979). The wilderness includes part of the tremendous west escarpment of the White Mountains. Imposing views of this escarpment, which is $1 \mathrm{mi}$ high in places, are seen by travelers following U.S. Highway 54 from Tularosa to Carrizozo. The mountains descend more gradually to the east, where they are deeply cut by canyons along Nogal Creek, Tortolita Creek, Rio Bonito, and Eagle Creek.

The part of the White Mountains included in the wilderness consists mostly of flat-lying andesite flows and breccia; other volcanic rocks present are latite and trachyte, but they are minor. The lower part of the layered volcanic rocks is intruded by two large syenite stocks, a smaller monzonite stock, a large syenite dike, and swarms of minor andesite dikes. All these igneous rocks are relatively young (Tertiary). Around the east, north, and west edges of the study area are older sedimentary rocks, mostly sandstone (lower Tertiary and Cretaceous) and younger Quaternary gravels and sand. The White Mountains rise out of a relatively small structural depression on the crest of a major arch that forms the east border of the Basin and Range province.

\footnotetext{
${ }^{1}$ With contributions from F. E. Williams, USBM.
}

Extrusion of the volcanic rocks followed by intrusion of stocks has produced a topographic high on a structural low. Principal fractures are a few high-angle faults in the northeast and west-central parts of the wilderness; displacements are probably small.

\section{MINERAL RESOURCES}

Because of abundant surface shows of metallic minerals, the wilderness, and particularly a large area immediately to the east, is replete with prospect pits and inines; most of them, however, are very small. Most of these shallow exploratory workings tend to be concentrated in three areas, the Nogal mining district, extending into the wilderness along part of the east boundary, the Bonito district, east of and outside the wilderness, and the Schelerville district at the northwest corner of the wilderness.

Mineral discoveries were made in the Nogal and Bonito mining districts as early as 1865 for placer gold and 1868 for lode deposits. Most of the major veins in the White Mountain Wilderness were first discovered and located between 1880 and 1882, soon after the area was separated from the Mescalero Apache Indian Reservation. Total unineral production from the White Mountains is reported to have been about $\$ 1$ million. Most of this production was probably from a goldbearing fissure vein in the Helen Rae mine, about a half mile from the wilderness. Total production from the Parsons (Hopeful) inine, a quarter of a mile from the wilderness, is not known; however, it is believed that at 
least 68,000 tons of low-grade gold ore has been removed. The average grade during 1908 is said to have been $\$ 3.50 /$ ton, based on a gold price of $\$ 20 / \mathrm{oz}$. The only recorded production from the wilderness was about 145 tons of silver-copper-lead ore from a small vein in the Schelerville district.

Because the White Mountain Wilderness adjoins and includes parts of two mining districts and is near a third, careful study was made of geology, known mines and prospects, and other mineralized and altered areas. Numerous samples of stream sediment and rocks were collected and analyzed.

Known mineral occurrences in the Nogal mining district consist mainly of small deposits of lead-zincsilver minerals in simple fissure veins cutting andesitic volcanic rocks, spotty occurrences of gold in fissure veins and in breccia zones, and disseminated molybdenum mineralization in a monzonite stock. In the Schelerville district copper-lead-silver minerals occur in simple fissure fillings, commonly in east-trending veins, in part associated with dikes. Although prospecting has been carried on for many years in both these districts, it has failed to disclose encouraging indications for any major deposits. Nevertheless, base- and precious-metal occurrences are so widespread that it is probable that other small and spotty occurrences would be encountered with further prospecting.

Of more significance are occurrences of disseminated molybdenum in the stocks that suggest a probable potential for large low-grade molybdenum deposits. Thousands of feet of drill core, stored in the town of Nogal, and chiefly from the Rialto monzonite stock, just outside the wilderness, show the ubiquity of sulfides, including molybdenum sulfide, in subsurface. Four molybdenum anomalies were found within the wilderness by USGS sampling. Molybdenum occurs (1) as coatings on fracture seams and small grains in quartz veinlets; (2) disseminated in brecciated zones; and (3) within dense aphanitic high-silica rock. The molybdenum occurrences are associated with hydrothermal alteration.

The geologic, geochemical, and historic data referred to above suggest that the six areas indicated on the map have probable mineral-resource potential. The Schelerville district and two areas in the Nogal district have a probable potential for small base and (or) precious metal veins or breccia zones. The area in the Nogal district around the Rialto stock has a probable potential for disseminated molybdenum as well. Three areas in the southern part of the wilderness also have a probable potential for disseminated molybdenum.

Few indications of nonmetallic-mineral resources occur in the wilderness. Locally, fluorite crystals occur in cavities and fractures of the southern one of the two syenite stocks. It is extremely unlikely, however, that fluorite occurs in or near the area in concentrations sufficiently high to have resource potential. Specimenquality quartz crystals, as much as 6-8 in. long, have been found in the southernmost syenite stock along the crest of the White Mountains at the head of a south fork of the Rio Bonito. Corundum occurs along the northeast edge of the same stock; it is very fine grained and so sparsely distributed in the host rock (altered syenite) that it is not shown on the map. Lenses in the andesite layers contain carbonized remains of wood, but these lenses are not of high enough carbon content or extent to constitute a source of fuel. Sand and gravel deposits, although present in the wilderness, are much smaller and less accessible than those of adjacent areas. Massive syenite for building stone is plentiful but the combination of distance from markets and competition for cheaper materials makes it unlikely that this resource would ever be exploited.

There is little promise for the occurrence of a geothermal energy source in the area for no known thermal springs or very young igneous rocks occur in or adjacent to the wilderness.

\section{SUGGESTIONS FOR FURTHER STUDIES}

Judging from the results of considerable drilling activity in and near the wilderness during the last 20 years or so, the only metal that is even marginally worth targeting for exploration is molybdenum.

\section{REFERENCE}

Segerstrom, Kenneth, Stotelmeyer, R.B., and Williams, F. E., 1979, Mineral resources of the White Mountain Wilderness and adjacent areas, Lincoln County, New Mexico: U.S. Geological Survey Bulletin 1453, 135 p. 



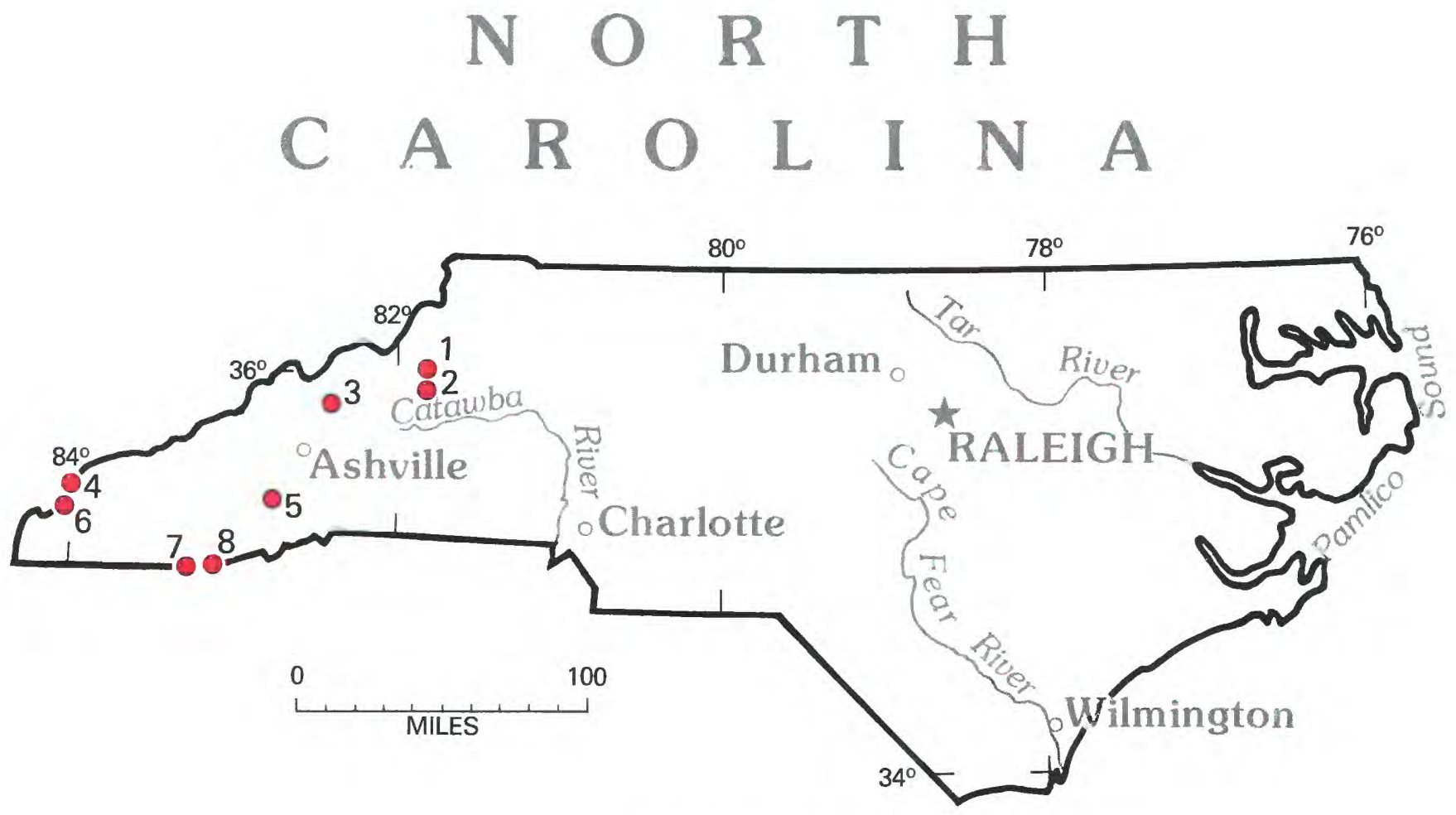

Location of areas studied. 


\section{NORTH CAROLINA}

Map

No.

3 Craggy Mountain Wilderness study area and Extension

8 Ellicott Rock Wilderness and Additions, South Carolina, North Carolina, and Georgia-See South Carolina

4 Joyce Kilmer-Slickrock Wilderness, North Carolina and Tennessee

2 Linville Gorge Wilderness and Additions

1 Lost Cove and Harper Creek Roadless Areas

7 Overflow Roadless Area, Georgia and North Carolina-See Georgia

5 Shining Rock Wilderness

6 Snowbird Roadless Area 


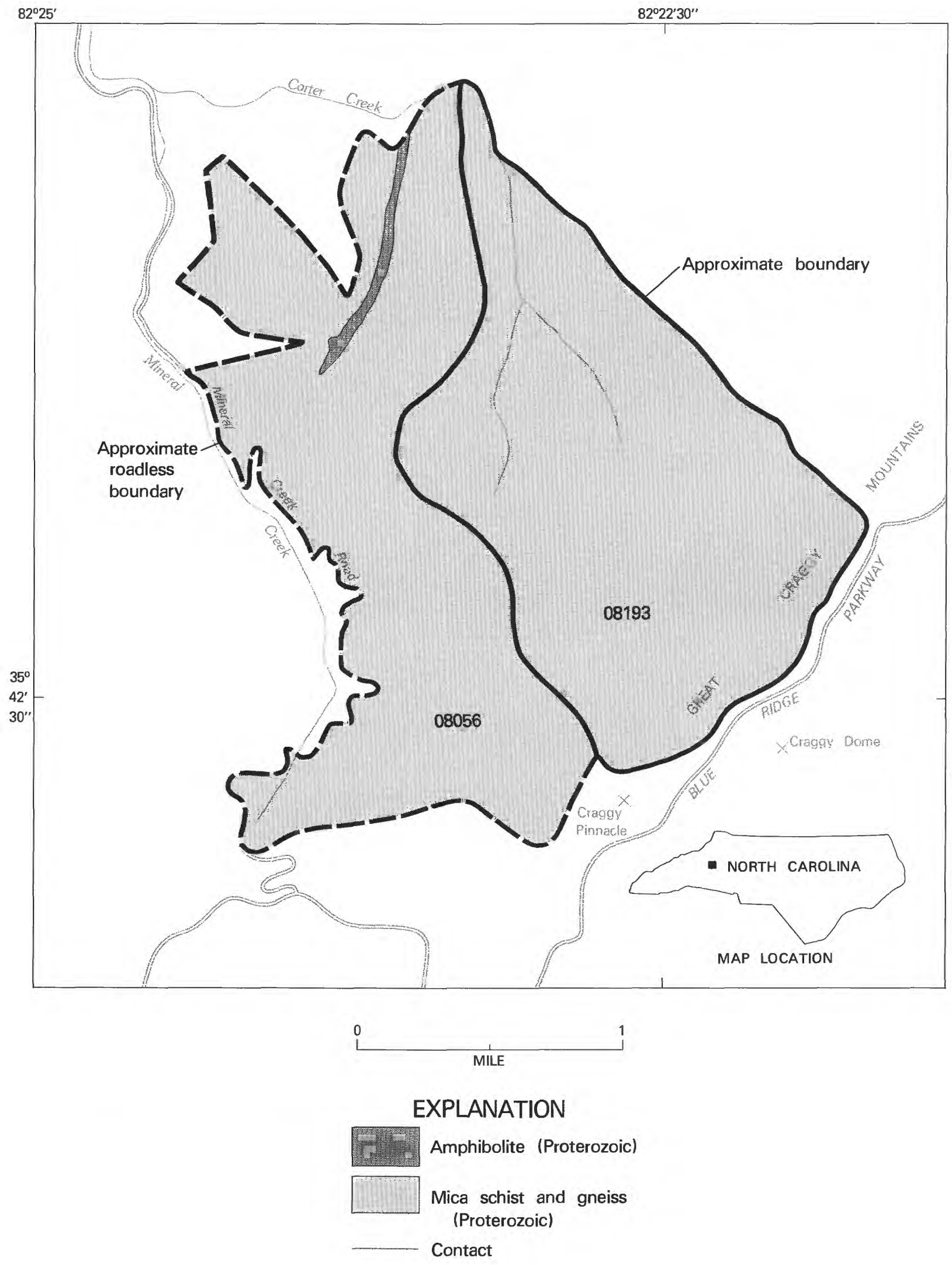

Figure 239.-Craggy Mountain Wilderness Study Area and Extension, North Carolina. 


\title{
CRAGGY MOUNTAIN WILDERNESS STUDY AREA AND EXTENSION, NORTH CAROLINA
}

\author{
By Frank G. Lesure, U.S. GeOlogical Survey, and \\ BRADFORD B. WILLIAMS, U.S. BUREAU OF MINES
}

\begin{abstract}
SUMMARY
Craggy Mountain Wilderness Study Area and the adjoining Craggy Mountain Extension consist of more than $4 \mathrm{sq}$ mi of steep wooded slopes on the west side of Great Craggy Mountain in the Blue Ridge of western North Carolina. A mineral-resource survey of the area done between 1976 and 1979 found no evidence for metallic mineral resources. Kyanite, garnet, and building stone are the only mineral resources in the study area, but large quantities of similar material are available outside the study area. Natural gas may possibly be present at great depth, but until some deep drilling is done in or near the area no estimate of the gas potential can be made.
\end{abstract}

\section{CHARACTER AND SETTING}

The Craggy Mountain Wilderness Study Area and Extension, totalling $4 \mathrm{sq} \mathrm{mi}$, is on the steep northwest slopes of Great Craggy Mountain, a south-trending extension of the Black Mountains of which Mount Mitchell is a part. The area is $13 \mathrm{mi}$ north of Asheville, Buncombe County, North Carolina, and $7 \mathrm{mi}$ southwest of Mount Mitchell, the highest point in eastern North America. The study area is bounded on the southeast by the Blue Ridge Parkway and on the west by the road along Mineral Creek. Altitudes range from a low of 2840 $\mathrm{ft}$ above sea level on Carter Creek at the northern end to $5892 \mathrm{ft}$ on Craggy Pinnacle at the southern edge. Access is by trails from the Blue Ridge Parkway, from the visitor center at Craggy Gardens, and from the Mineral Creek Road.

Craggy Mountain Extension is a roadless area adjoining the study area on the west side. All surface and mineral rights are owned by the Federal Government. No prospecting or mining-development permits have been issued for the study area.

As provided by the Wilderness Act of 1964 and related acts, a mineral-resource survey of the wilderness study area was done during a few days in the fall of 1976 and spring of 1977 , and the results were released in preliminary form in 1978 (Lesure and others, 1978). The area was revisited in 1979 to complete studies in the roadless extension. A combined report on both areas was published in 1982 (Lesure and others, 1982).
Analytical data on rock, stream-sediment, and soil samples were released separately (Motooka and others, $1978 ; 1980)$.

Bedrock in the study area is interlayered mica-garnet schist, quartz-biotite gneiss, and amphibolite. These rocks are part of the Great Smoky Group of Proterozoic age and were originally a series of sedimentary and igneous rocks that included interlayered fine-grained feldspathic sandstone and clay-rich shale intruded by basalt. Following deep burial in the crust, the combined heat and pressure, in part from deformation, altered the rocks to their metamorphic equivalents, gneiss, schist, and amphibolite. Minor amounts of vein quartz and granite pegmatite formed during the metamorphism and small masses of these rock types intrude the gneiss and schist. Some of the layers of shale were aluminum rich; these now contain aluminum minerals such as kyanite, sillimanite, and garnet.

\section{MINERAL RESOURCES}

Kyanite, garnet, and building stone are the only resources in the Craggy Mountain Wilderness Study Area and Extension; none are being exploited at this time. A possibility exists for the presence of natural gas. No metallic mineral deposits are known in the rocks of the study area. Traces of gold ranging from less than 0.002 parts per million (ppm) to $0.016 \mathrm{ppm}(0.0005 \mathrm{oz}$ 
gold/ton) in rock, soil, and stream-sediment samples are not considered to have resource potential.

The most significant mineral commodity in the study area is kyanite, an aluminum silicate used primarily as a high-quality refractory material in steel furnaces. The kyanite content of the mica-garnet schist layers ranges from a trace to as much as 21 percent. This area may contain some millions of tons of kyanite disseminated in schist that averages 15 percent kyanite and occurs in layers 3 to $10 \mathrm{ft}$ thick and 300 to $3000 \mathrm{ft}$ long. Similar kyanite-rich rock was mined at the Celo mine $2.5 \mathrm{mi}$ southeast of Burnsville, Yancey County, North Carolina, about $14 \mathrm{mi}$ northwest of the study area. Garnet, both of industrial-abrasive and gem quality, occurs as an accessory mineral in gneiss and schist throughout the region. Within the study area garnet is randomly disseminated and also concentrated in vein-like masses in the schistose rocks. Garnet content ranges from a trace to 28 percent and may average 5 to 10 percent. Garnet for abrasive use would be produced as a byproduct of kyanite mining. Great quantities of similar rocks containing kyanite and garnet are available outside the study area.

Gneiss and schist similar to those in the study area are used for crushed rock and rough building stone in the Asheville region. The abundance of similar material throughout the region means that rocks of the study area are not considered as having resource potential for the usual uses of stone.

Recent seismic studies (Cook and others, 1979) indicate that a sequence of sedimentary rocks 3000 to $15,000 \mathrm{ft}$ thick lies below metamorphic rocks 4500 to 45,000 $\mathrm{ft}$ thick in the Blue Ridge Mountains of North Carolina. These sedimentary rocks could contain oil and gas. The depths of these sedimentary rocks and the implied temperatures and pressures at these depths suggest that any hydrocarbons present would be in the form of natural gas and not oil. The chances of finding concentrations of gas are uncertain and until additional seismic studies and deep drilling are done no reasonable evaluation of the gas potential can be made.

\section{SUGGESTIONS FOR FURTHER STUDIES}

Further seismic work and some exploratory drilling are needed to evaluate the gas potential of this part of the Eastern Overthrust Belt. Beneficiation tests on the kyanite-bearing schists are needed to determine the mineral potential of the schists as a source of kyanite. If a usable kyanite product can be recovered from these schists, then more detailed mapping, drilling, and sampling would be necessary to determine the resources present.

\section{REFERENCES CITED}

Cook, F. A., Albaugh, D. S., Brown, L. D., Kaufman, Sidney, Oliver, J. E., and Hatcher, R.D., Jr., 1979, Thin-skinned tectonics in the crystalline southern Appalachians; COCORP seismic-reflection profiling of the Blue Ridge and Piedmont: Geology, v. 7, no. 12, p. $563-567$.

Lesure, F. G., Grosz, A. E., Williams, B. B., and Gazdik, G. C., 1978, Mineral resources of the Craggy Mountain Wilderness Study Area, Buncombe County, North Carolina: U.S. Geological Survey Open-File Report 78-1091, 23 p.

Lesure, F. G., Grosz, A. E., Williams, B. B., and Gazdik, G. C., 1982, Mineral resources of the Craggy Mountain Wilderness Study Area and Extension, Buncombe County, North Carolina: U.S. Geological Survey Bulletin 1515, 27 p.

Motooka, J. M., Meier, A. L., and Lesure, F. G., 1980, Analyses and descriptions of geochemical samples, Craggy Mountain Extension, Buncombe County, North Carolina: U.S. Geological Survey Open-File Report 80-1069, 10 p.

Motooka, J. M., Sharkey, J. D., and Lesure, F. G., 1978, Analyses and description of geochemical samples, Craggy Mountain Wilderness Study Area, Buncombe County, North Carolina: U.S. Geological Survey Open-File Report 78-856, 10 p. 


\title{
JOYCE KILMER-SLICKROCK WILDERNESS, NORTH CAROLINA AND TENNESSEE
}

\author{
By Frank G. Lesure, U.S. GeOlOGicAl SuRVeY, and \\ JAMES J. HILL, U.S. BUREAU OF MiNES
}

\begin{abstract}
SUMMARY
A mineral-resource survey in 1973 of the Joyce Kilmer-Slickrock Wilderness in the western part of the Blue Ridge Mountains along the border between North Carolina and Tennessee found trace amounts of such metals as copper, gold, lead, and zinc in rock, stream-sediment, and soil samples, but little promise for the occurrence of metallic-mineral resources was identified. The only apparent mineral resources are small amounts of sand and gravel and abundant rock suitable for construction materials. Oil and natural gas may be present in younger sedimentary rocks below a major thrust fault zone at depth below the wilderness, however the energy-resource potential cannot be evaluated.
\end{abstract}

\section{CHARACTER AND SETTING}

The Joyce Kilmer-Slickrock Wilderness consists of $23 \mathrm{sq}$ mi of steep forested ridges along the continuation of the main crest of the Great Smoky Mountains just south of the Little Tennessee River about $35 \mathrm{mi}$ south of Knoxville, Tennessee; $17 \mathrm{sq} \mathrm{mi}$ are in the Nantahala National Forest, Graham County, North Carolina and $6 \mathrm{sq} \mathrm{mi}$ are in the Cherokee National Forest, Monroe County, Tennessee. The area includes all of two watersheds: Little Santeetlah Creek which flows into Santeetlah Creek and drains the Joyce Kilmer Memorial Forest, and Slickrock Creek which flows into Calderwood Lake on the Little Tennessee River. Altitudes range from $1086 \mathrm{ft}$ above sea level at Calderwood Lake to $5341 \mathrm{ft}$ above sea level on Stratton Bald on the divide between the two watersheds.

Access to the Slickrock area is by trail and jeep road from U.S. Highway 129 along the Cheoah River east of the area and from unpaved USFS roads along Doublecamp Creek and Citico Creek to the west. Access to Joyce Kilmer Memorial Forest is by trail from the parking lot and visitor center at the lower end of Little Santeetlah Creek and from the unpaved USFS road up Santeetlah Creek to the southwest. The nearest metal mining was done before World War II at the Fontana and Hazel Creek copper mines about 10-14 mi northeast and in the Coker Creek gold area about $18 \mathrm{mi}$ southwest of the wilderness. The Ducktown mines, which currently produce sulfur, copper, and zinc, are $30 \mathrm{mi}$ southwest of the area. Several rock quarries opened for construction materials used locally are within a few miles of the wilderness. Although five prospecting permits have been issued for small areas within the wilderness, very little prospecting was done on any of the areas and only small amounts of disseminated ironsulfides were found.

A mineral-resource survey of the wilderness was made in the fall of 1973 and the results published in 1977 (Lesure and others, 1977). The survey consisted of geologic mapping, geochemical studies, and examination of mines and prospects near the area. Geochemical analyses for 30 elements by semiquantitative spectrographic analyses and for several elements by atomicabsorption methods were made on rock, soil, forest litter, and stream-sediment samples. The adjacent roadless areas proposed for wilderness after our work was finished have not been studied in detail; these areas contain the same rock units mapped in the wilderness and probably have the same resource potential as the wilderness.

Bedrock in the Joyce Kilmer-Slickrock Wilderness is a thick mass of old (Precambrian) interlayered fine- and coarser-grained clastic sedimentary rocks of probable marine origin. These have been folded, faulted, and metamorphosed. The coarse-grained rocks, sandstones, and conglomerates, are little altered, but the finegrained, siltstones and shales, have been changed to slate, phyllite, and schist; new minerals such as biotite mica and garnet have formed in rocks that have the 


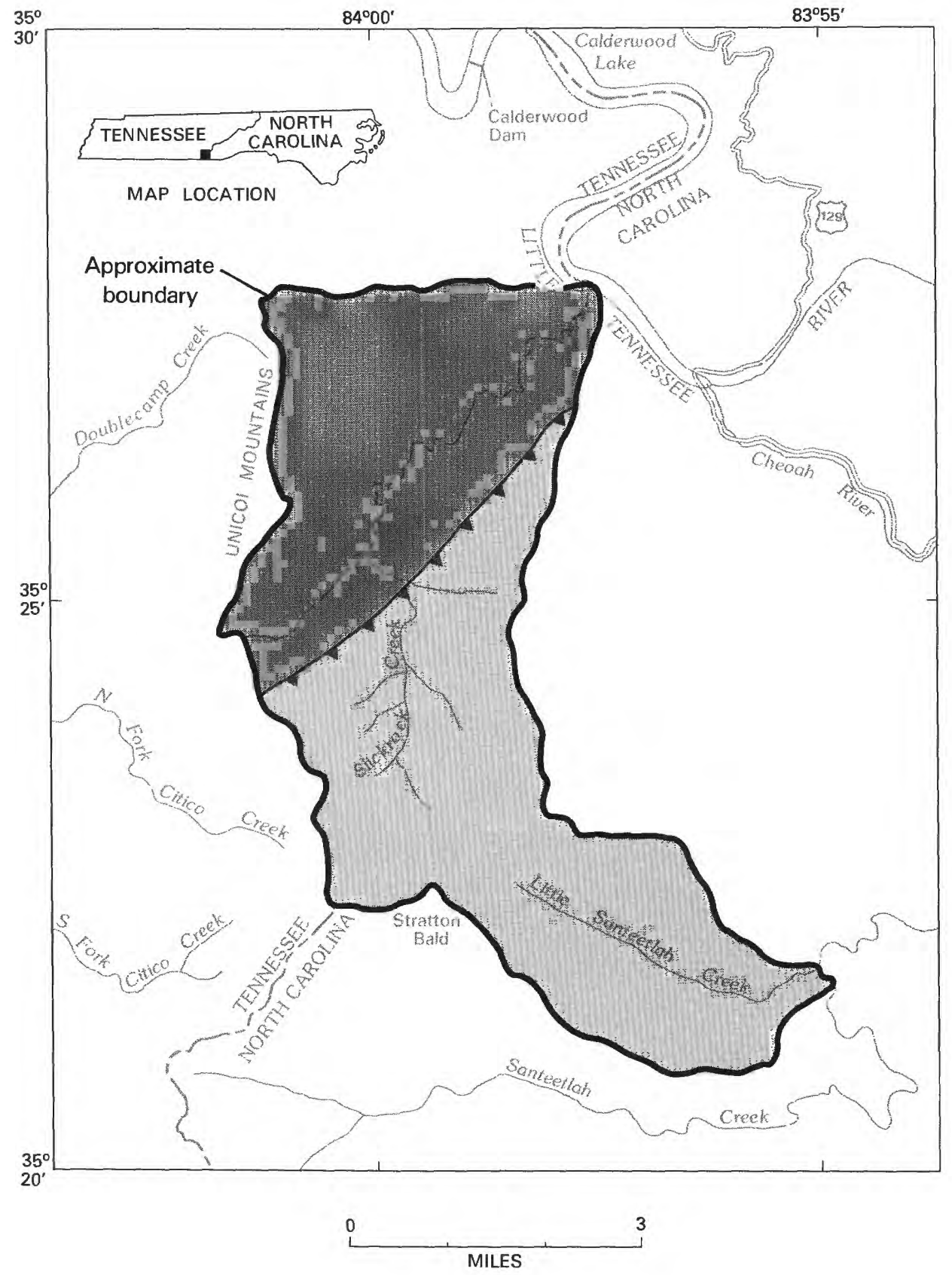

Metamorphosed sandstone containing interbeds of shale and minor conglomerate (Precambrian)

Metamorphosed shale containing interbeds of sandstone and conglomerate (Precambrian)

Thrust fault

Figure 240.-Joyce Kilmer-Slickrock Wilderness, North Carolina and Tennessee. 
appropriate chemical composition. Numerous veins and pods of quartz that intrude the layered rocks are presumably the result of the metamorphism. No evidence of rock alteration related to the formation of mineral deposits is present in the rocks studied. A major fault through the north half of the area separates the wilderness into a northern area of predominantly fine grained rocks such as shale with lesser amounts of sandstone and conglomerate and a southern area of predominately sandstone over shale.

\section{MINERAL RESOURCES}

The only known mineral resources in the Joyce Kilmer-Slickrock Wilderness are abundant rock suitable for construction materials and small deposits of sand and gravel. Extensive deposits of rock of equal or better quality are present in all the surrounding areas closer to markets.

No evidence for the presence of any metallic mineral deposits was found during the survey. Trace amounts of gold were found in 11 rock, 3 soil, and 5 streamsediment samples. These are not deemed significant and are not considered as resources. Only one quartz vein out of 30 sampled contained detectable gold. Areas of alluvium that might be a source of placer gold are small. The nearest gold mines in rock types similar to those in the wilderness are $18 \mathrm{mi}$ to the southwest in the Coker Creek area of Tennessee; these are small deposits that are not amenable to commercial mining (Hale, 1974, p. 1). Disseminated iron sulfides in several of the rock units in the wilderness contain only trace amounts of copper, lead, and zinc.

Recent seismic studies indicate that the Blue Ridge of North Carolina contains a thick sequence of younger sedimentary rocks below the overlying metamorphosed rocks at the surface (Cook and others, 1979). The resource potential for oil and gas of the area underlain by these sedimentary rocks cannot be evaluated.

\section{SUGGESTIONS FOR FURTHER STUDIES}

A few stream-sediment and rock samples from the wilderness contain $1000-2000 \mathrm{ppm}$ barium which is two to three times normal content of barium for these rock types. Recent work in Scotland has led to the discovery of bedded deposits of barium in rocks similar to those in the wilderness (Coats and others, 1980). Additional exploration may be warranted to look for similar deposits in the wilderness especially where high contents of barium were found in the reconnaissance sampling.

The Joyce Kilmer-Slickrock Wilderness is $4 \mathrm{mi}$ south of an exposure of younger sedimentary rocks in a window eroded through a thrust fault, and the wilderness is only $10 \mathrm{mi}$ southwest of the western edge of this thrust block of older rock. Further seismic work and exploratory drilling are needed to evaluate the resource potential of the whole overthrust belt in this area for oil and gas.

\section{REFERENCES}

Coats, J. S., Smith, C. G., Fortey, N. J., Gallagher, M. J., May, F., and McCourt, W. J., 1980, Strata-bound barium-zinc mineralization in Dalradian schist near Aberfeldy, Scotland: Institution of Mining and Metallurgy Transactions, v. 89, sec. B., p. B110-B122.

Cook, F. A., Albaugh, D. S., Brown, L. D., Kaufman, Sidney, Oliver, J. E., and Hatcher, R. D., Jr., 1979, Thin-skinned tectonics in the crystalline southern Appalachians; COCORP seismic-reflection profiling of the Blue Ridge and Piedmont: Geology, v. 7, no. 12, p. $563-567$.

Hale, R. C., 1974, Gold deposits of the Coker Creek district, Monroe County, Tennessee: Tennessee Division of Geology Bulletin 72, $93 \mathrm{p}$.

Lesure, F. G., Force, E. R., Windolph, J. F., and Hill, J. J., 1977, Mineral resources of the Joyce Kilmer-Slickrock Wilderness, North Carolina-Tennesee: U.S. Geological Survey Bulletin 1416, 89 p. 

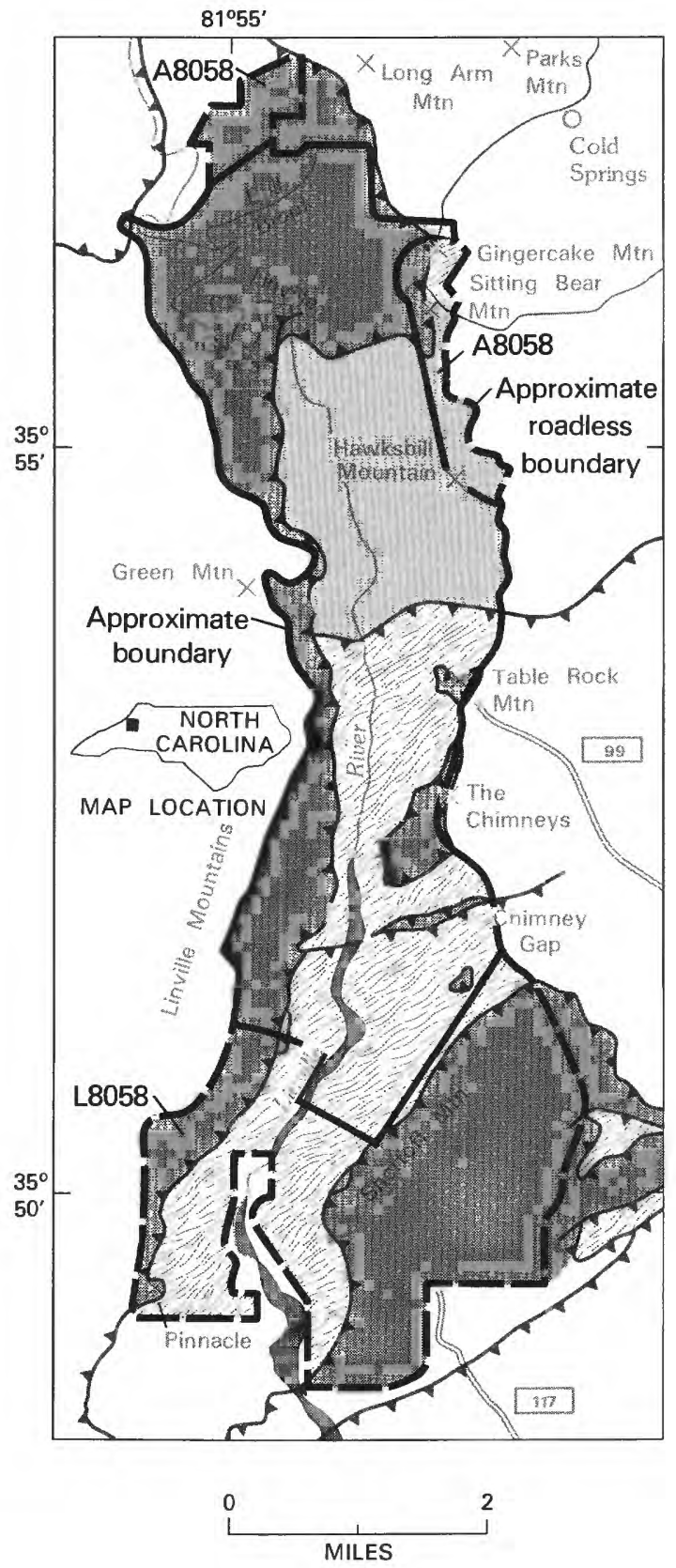

\section{EXPLANATION}

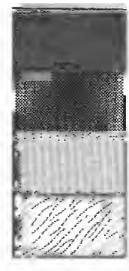

Alluvial deposits (Quaternary)

Chilhowee Group (Lower Cambrian)

Grandfather Mountain Formation (Proterozoic Z)

Gneiss (Proterozoic Y)

\section{Contact}

Thrust fault--Sawteeth on upper plate

Figure 241.-Linville Gorge Wilderness and Additions, North Carolina. 


\title{
LINVILLE GORGE WILDERNESS AND ADDITIONS, NORTH CAROLINA
}

\author{
By John P. D’Agostino, ${ }^{1}$ U.S. Geological Survey, and \\ Gertrude C. Gazdik, U.S. Bureau of Mines
}

\begin{abstract}
SUMMARY
During a mineral-resource survey of the Linville Gorge Wilderness and additions in 1977-80 little evidence for the occurrence of metallic mineral resources was identified. Rock suitable as small-size building stone and crushed aggregate for construction use is abundant, but similar material is more readily accessible outside the wilderness. Recent seismic data indicate that the Proterozoic and Cambrian metamorphic rocks exposed at the surface are underlain at a depth of about 8,000 to $10,000 \mathrm{ft}$ by Paleozoic sedimentary rocks 15,000 to $20,000 \mathrm{ft}$ thick which could have a resource potential for gaseous hydrocarbons and metallic sulfide ores, but further studies are needed to evaluate this potential.
\end{abstract}

\section{CHARACTER AND SETTING}

The Linville Gorge Wilderness and additions (here called study area) comprise approximately $17 \mathrm{sq} \mathrm{mi}$ of Pisgah National Forest, Burke and McDowell Counties, in the Blue Ridge Mountains of western North Carolina. The Linville Gorge additions are roadless areas at the north and south ends of Linville Gorge that are proposed extensions of the Linville Gorge Wilderness. The study area is $10 \mathrm{mi}$ north-northeast of Marion and $13 \mathrm{mi}$ west-northwest of Morganton, North Carolina. Kistler Memorial Highway is the western boundary of the study area. From this graveled road several good foot trails lead into the gorge to the Linville River Trail which follows the west bank of the river. Table Rock Mountain is accessible from the southeast by gravel USFS Road 99. Two foot trails lead into the gorge from the east rim, terminating at the river. There is no trail along the east side of the Linville River, and fording the river is extremely hazardous. The southeastern part of the study area is accessible by gravel USFS road 117. From the end of USFS road 117 an eroded timber trail extends north along the crest of Shortoff Mountain to Table Rock Mountain.

The study area is heavily forested with mixed hardwoods and softwoods. A dense understory of rhododendron and laurel make off-trail hiking very difficult. Cliffs, as much as $\mathbf{9 0 0} \mathrm{ft}$ high and several thousand feet

'With contributions from Jesse W. Whitlow, and David F. Siems, USGS, and Donald K. Harrison, USBM. long, occur throughout the gorge area and form most of the gorge rim. These create spectacular scenery but also restrict access. Altitudes range from $1240 \mathrm{ft}$ at river level at the southern boundary to $4120 \mathrm{ft}$ on the top of Gingercake Mountain resulting in maximum relief of nearly $2900 \mathrm{ft}$.

The gorge is in the middle course of the Linville River and is one of the deeper dissections on the eastern edge of the Blue Ridge. The Linville River flows south into Lake James, a reservoir on the Catawba River.

The Linville Gorge Wilderness and proposed extensions are within the Grandfather Mountain window (Bryant and Reed, 1970), an area eroded through several thrust sheets exposing underlying rocks of different ages. All the rocks exposed in the study area show strong evidence of being thrust to their present site; supposedly their original location was dozens of miles to the east. There are three recognized thrust sheets in the area. The lowest exposed thrust sheet is unnamed and contains the Proterozoic Y Wilson Creek Gneiss and the overlying Proterozoic Z Grandfather Mountain Formation (Reed, 1964). A hiatus separates the bedded arkosic Grandfather Mountain Formation from the massive granitic gneiss of the Wilson Creek Gneiss, which is the oldest bedrock cropping out in the study area. Overlying the unnamed thrust unit is the Tablerock thrust sheet which contains the Lower Cambrian Chilhowee Group. The Blue Ridge thrust sheet, the uppermost sheet, overlies the two lower thrust units. It appears in the extreme northwest corner of the area studied.

The total thickness of the three thrust sheets with 
rocks of Proterozoic $\mathrm{Y}$ to Early Cambrian age is about 8000 to $10,000 \mathrm{ft}$. The rocks overlie and conceal a younger Paleozoic sequence of unmetamorphosed sedimentary strata 15,000 to $20,000 \mathrm{ft}$ thick. Parts of this younger sequence also have been horizontally shoved dozens of miles from the east into the study area (Harris and others, 1981).

Rock chip, bulk soil, and bulk stream-sediment samples were collected from the Linville Gorge Wilderness by the USGS in 1977 and from the proposed extensions in 1979. The analytical results are reported by D'Agostino, Whitlow, and Siems (1983). The USBM collected random or continuous chip rock samples from the wilderness in 1978 and from the additions in 1980. The analytical results are reported by Gazdik and Harrison (1981).

The U.S. Government owns all of the surface rights and about 96 percent of the mineral rights in the study area. Although prospecting and mining development permits are granted in Pisgah National Forest, there is no record of any permit application nor any historical accounts of prospecting or mining in what is now Linville Gorge Wilderness and proposed extensions.

\section{MINERAL RESOURCES}

No minerals have been produced from the Linville Gorge Wilderness and proposed extensions, and no mineral-resource potential, other than stone and sand and gravel, was identified in the surface rocks during our study. Mining has taken place nearby, however. For more than 100 years, the large Spruce Pine district, $3 \mathrm{mi}$ west of the study area, has been a major producer of mica, feldspar, quartz, and clay from rocks in the Blue Ridge thrust sheet. Also near the study area are mineral occurrences of asbestos, uranium, zinc, gold, manganese, lead, fluorite, copper, and abrasive (garnet), rock quarries for construction stone and road metal, and sand and gravel pits. The greatest possibility of any mineral-resource potential is in the younger rocks, the faulted Paleozoic rocks that lie as much as $10,000 \mathrm{ft}$ below the surface rocks. These rocks are considered to constitute a geologic terrane that could have potential for both hydrocarbons and metallic minerals. The hydrocarbons would most probably be natural gas; the metallic minerals would most probably be sulfides of iron (pyrite), lead (galena), and zinc (sphalerite) which occur in similar rocks just west of the study area. Data from this study are insufficient to evaluate this potential.

There are no rock quarries or sand and gravel pits in the Linville Gorge Wilderness Area and proposed extensions. The bedrock is suitable for use as building stone and crushed rock and sand and gravel in limited amounts could be obtained along the gorge bottom from small irregularly spaced alluvial fans composed of silt to cobble size material. However, rock types better suited for quarrying, and of higher quality for construction stone, and abundant sand and gravel occur outside the wilderness.

\section{SUGGESTIONS FOR FURTHER STUDIES}

Analyses of samples did not identify any resource potential for near surface mineral occurrences. Only drilling can assess the gas and metallic resource potential of the 15,000 to $20,000 \mathrm{ft}$ of sedimentary rock that lies beneath the thrust faults.

\section{REFERENCES}

Bryant, Bruce, and Reed, J. C., Jr., 1970, Geology of the Grandfather Mountain Window and Vicinity, North Carolina and Tennessee: U.S. Geological Survey Professional Paper 615, 190 p.

D'Agostino, J. P., Whitlow, J. W., and Siems, D. F.,1983, Geologic and geochemical maps of Linville Gorge Wildereness and proposed extentions, Burke and McDowell Counties, North Carolina: U.S. Geological Survey Miscellaneous Field Studies Map MF-1610-A, scale 1:48,000.

D'Agostino, J. P., Whitlow, J. W., Gazdik, G. C., and Harrison, D. K., 1983, Mineral resource potential map of Linville Gorge Wilderness and proposed extentions, Burke and McDowell Counties, North Carolina: U.S. Geological Survey Miscellaneous Field Studies Map MF-1610-B, scale 1:48,000.

Gazdik, G. C., and Harrison, D. K., 1981, Mineral resources of the Linville Gorge Wilderness and additions, Burke and McDowell Counties, North Carolina: U.S. Bureau of Mines Open-File Report MLA 16-81, 1981, 34 p.

Harris, L. D., Harris, A.G., DeWitt, Wallace, Jr., and Bayer, K. C., 1981, Evaluation of Southern Eastern Overthrust Belt beneath Blue Ridge-Piedmont Thrust: American Association of Petroleum Geologists Bulletin v. 65, no. 12, p. 2497-2505.

Reed, J. C., Jr., 1964, Geology of the Linville Falls quadrangle, North Carolina: U.S. Geological Survey Bulletin 1161-B, 53 p. 


\title{
LOST COVE AND HARPER CREEK ROADLESS AREAS, NORTH CAROLINA
}

\author{
By W. R. GRIFFITTS, U.S. GEOlOGiCAL SURVEY, and \\ T. M. CRANDALL, U.S. BUREAU OF MiNES
}

\begin{abstract}
SUMMARY
An investigation in 1979 and 1980 indicated that a part of the Lost Cove and Harper Creek Roadless Areas, North Carolina has a probable mineral-resource potential for uranium, niobium, and beryllium. The study areas lie within the Blue Ridge physiographic province and are predominantly underlain by Precambrian plutonic and metasedimentary rocks of low metamorphic grade. The uranium occurs in vein-type deposits and in supergene-enriched foliated rocks. All surface and mineral rights are Federally owned. The geologic setting precludes the presence of fossil fuel resources.
\end{abstract}

\section{CHARACTER AND SETTING}

The Lost Cove and Harper Creek Roadless Areas, in North Carolina comprise 9 and $11 \mathrm{sq} \mathrm{mi}$, respectively, in Pisgah National Forest, Avery and Caldwell Counties, North Carolina. The areas are contiguous and have similar geology and mineral potential.

The study areas are on the eastern flank of the Blue Ridge Mountains and are characterized by rugged topography comprising a series of east-west-trending ridges interspersed with steep-sided valleys. Altitudes range from about 1500 to $4000 \mathrm{ft}$. Major drainages are Gragg Prong, Harper, North Harper, Lost Cove, and Craig Creeks. Access to the areas is provided by the Blue Ridge Parkway and USFS roads 464, 981, and 982. Well-traveled foot trails and abandoned logging roads provide interior access.

The Wilson Creek Gneiss of Proterozoic Y age underlies both roadless areas except the northwestern third of the Lost Cove Roadless Area. This gneiss consists of metamorphosed plutonic rocks of quartz monzonite to granodiorite composition (Bryant and Reed, 1970; Rankin and others, 1972). Some of these rocks resemble normal granites; others are coarse grained and pegmatitic in texture. Enclosed in these plutonic rocks are a variety of rocks ranging from amphibolite to feldspathic or biotitic gneisses and minor metavolcanic rocks (Wagener, 1979). Phyllonite zones in the Wilson Creek Gneiss are a result of Paleozoic low-grade metamorphism of the Precambrian granitic rocks (Reed,
1964) and are the hosts for nearly all the known occurrences of uranium minerals in the roadless areas.

Basal arkosic sandstone and siltstone of the Grandfather Mountain Formation of Proterozoic $\mathrm{Z}$ age nonconformably overlies the Wilson Creek Gneiss. The Grandfather Mountain Formation is exposed in the northwestern third of the Lost Cove Roadless Area.

\section{MINERAL RESOURCES}

Uranium has been sought intermittently in the area from 1955 to 1981 . Early trenching showed small discontinuous lenses of copper uranium phosphate in schist inclusions in granite. The North Harper Creek prospect has been explored several times, first in 1955 and most recently in 1977 . Uranium minerals were concentrated along three principal zones of shearing that produced mylonitic schist or phyllonite that is bounded by nonbrecciated schists and granites. Uranium minerals are associated with lenses and pods of quartzfeldspar-rich gneisses that were thoroughly transected by uraninite (uranium oxide) veins and veinlets. Uraninite veins trend dominantly east-west although paper-thin veinlets parallel to the northerly trending foliation were also observed.

A probable mineral-resource potential for uranium is assigned to the eastern part of the Lost Cove Roadless Area and the central and southeastern parts of the Harper Creek Roadless Area because some rocks have 

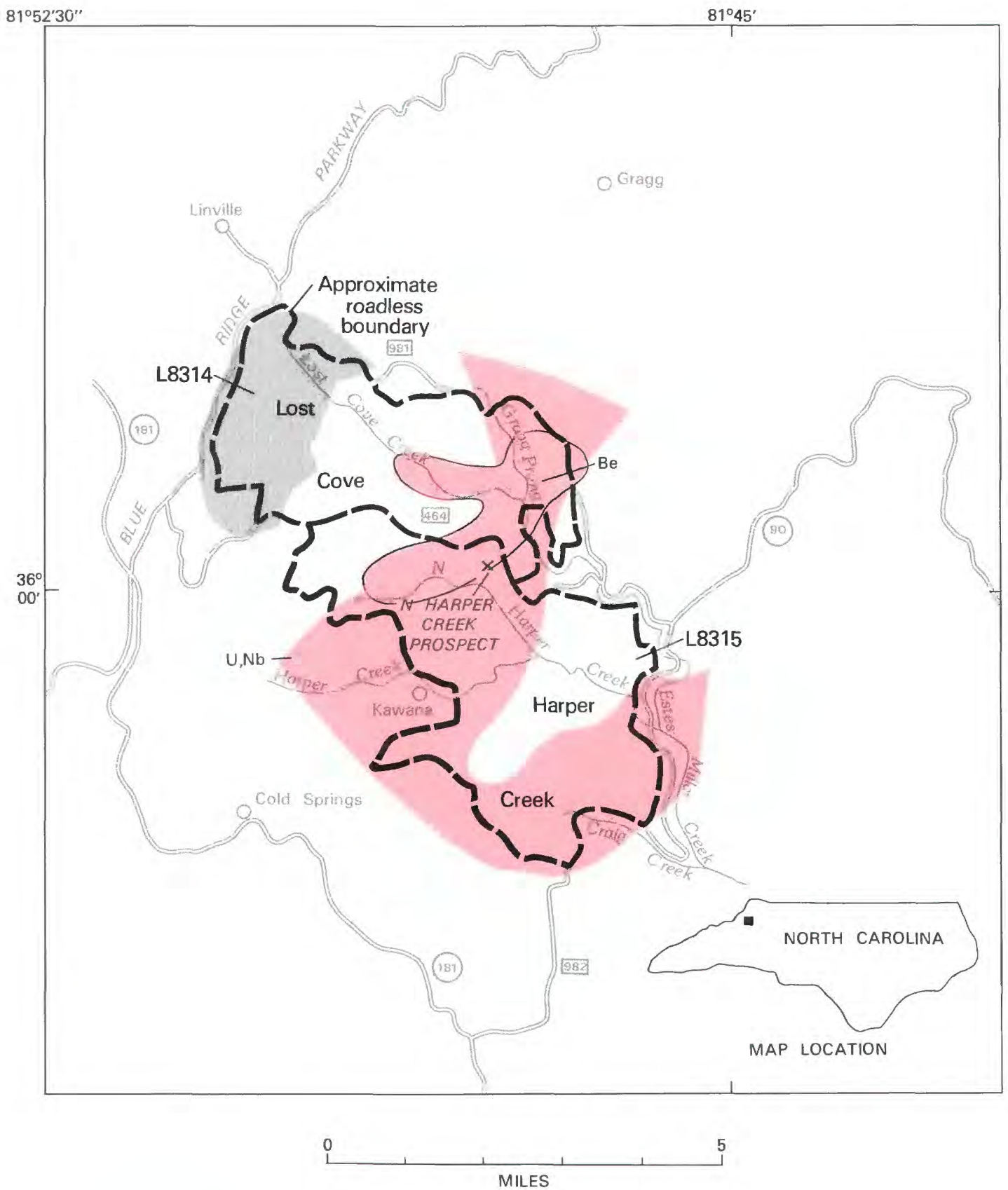

EXPLANATION

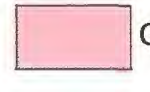

Geologic terrane with probable mineral-resource potential

Be Beryllium

$\mathrm{Nb} \quad$ Niobium

u Uranium

$\times \quad$ Mineral occurrence
Grandfather Mountain Formation (Proterozoic Z)

Wilson Creek Gneiss

(Proterozoic Y)

Contact

Figure 242.-Lost Cove and Harper Creek Roadless Areas, North Carolina. 
very high uranium contents, as was shown by high radiometric readings and high uranium values, determined chemically; anomalous uranium contents were found in stream sediments; uranium minerals are evident in trenches and drill holes at several prospects; and, phyllonite, related to uranium mineralization, is widespread (Reed, 1964).

A probable resource potential for niobium is indicated by niobium concentrations, as much as 5000 parts per million in heavy-mineral concentrates, but its bedrock source is unknown. The overlap of the niobium and uranium areas suggests that the niobium might be produced as a byproduct of uranium mining.

An area of probable beryllium resource potential is indicated by the very high beryllium content of 100 parts per million or more in heavy-mineral concentrates collected in the eastern part of the Lost Cove Roadless Area and the northern part of the Harper Creek Roadless Area. This probably reflects the presence of beryllium minerals in the bedrock.

The remainder of the roadless areas has little promise for the occurrence of fossil fuel or other mineral resources, especially the western part of the Lost Cove Roadless Area, which is underlain by the Grandfather Mountain Formation-a less favorable host rock than the Wilson Creek Gneiss.

\section{SUGGESTIONS FOR FURTHER STUDIES}

The wide distribution of uranium and the interesting concentrations found in the few places that have been explored are strong incentives for further work. Both regional and local radiometric surveys should be made with a gamma-ray spectrometer to distinguish uranium radiation from those of thorium and potassium. Studies of disequilibrium of radiogenic decay products may help to distinguish surficial concentrations from oxidized primary concentrations. Studies of deep-rooted trees can provide additional information about uranium in the lower part of the weathered zone. Then shallow drilling with light equipment could help determine which areas deserve thorough exploration.

\section{REFERENCES}

Bryant, Bruce, and Reed, J. C., 1966, Geology of the Grandfather Mountain window and vicinity: U.S. Geological Survey Professional Paper 615, p. 190.

Crandell, T. M., Ross, R. B., Jr., Whitlow, J. W., and Griffitts, W. R., 1982, Mineral resource potential of the Lost Cove and Harper Creek Roadless Areas, Avery and Caldwell Counties, North Carolina: U.S. Geological Survey Map MF-1391-A, scale 1:48,000.

Rankin, D. W., Espenshade, G. H., and Neuman, R. B., 1972, Geologic map of the west half of the Winston-Salem quadrangle, North Carolina, Virginia and Tennessee: U.S. Geological Survey Map I-709-A, scale 1:25,000.

Reed, J. C., 1964, Geology of the Linville Falls quandrangle, North Carolina: U.S. Geological Survey Bulletin 1161-B, p. 53.

Siems, D. F., Whitlow, J. S., Griffitts, W. R., Duttweiler, K. A., and Arbogast, Belinda, 1981, Preliminary report on the Lost Cove and Harper Creek Roadless Areas, North Carolina: U.S. Geological Survey Open-File Report 81-1245, p. 4.

Wagener, H. D., 1979, Petrology of the Wilson Creek Gneiss, western North Carolina and its relation to the Grandfather Mountain Formation, Cranberry Gneiss, and Inner Piedmont: South Portland, Maine, Chiasma Consultants, Inc., 57 p. 


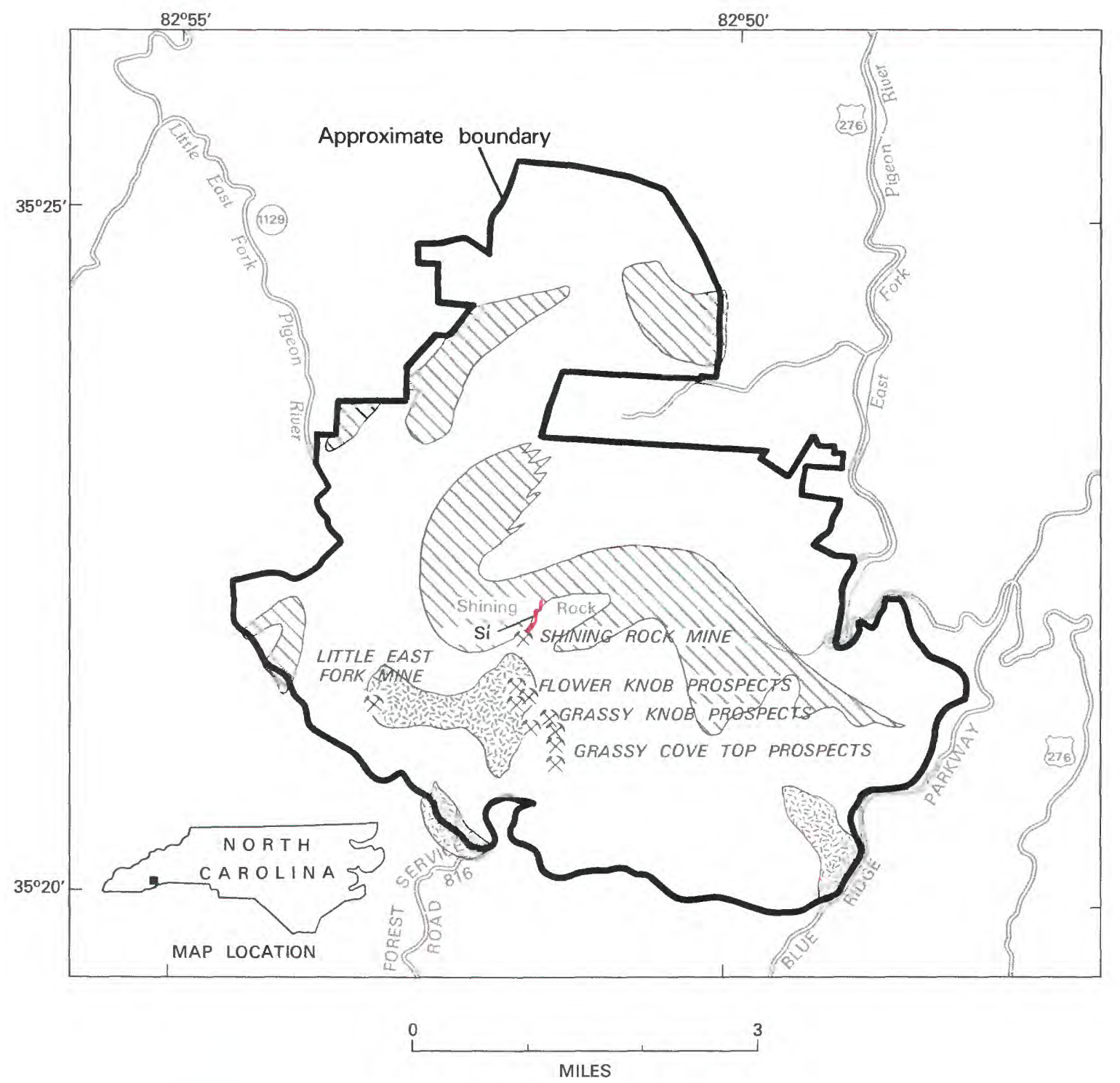

\section{EXPLANATION}

Geologic terrane with substantiated mineral-resource potential

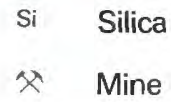

Migmatite (Paleozoic and (or) Precambrian!

\section{Garnet-mica schist}

(Precambrian)

Mica gneiss (Precambrian)

\section{Contact}

Figure 243.-Shining Rock Wilderness, North Carolina. 


\title{
SHINING ROCK WILDERNESS, NORTH CAROLINA
}

\author{
By Frank G. Lesure, U.S. GeOlogical Survey, and \\ Maynard L. DUnn, JR., U.S. BuREaU of MineS
}

\section{SUMMARY}

The Shining Rock Wilderness, in the Blue Ridge Mountains of Haywood County, North Carolina, is underlam by complexly folded mica gneiss and schist of Precambrian age. A mineral-resource survey in 1978 determined that two commodities, quartz as a source of silica $\left(\mathrm{SiO}_{2}\right)$ and gneiss and schist suitable for common building stone and crushed rock, are present in large quantities. Demonstrated resources of silica occur at Shining Rock Mountaim and small amounts of sheet muscovite (mica) and scrap mica are present at about 10 localities. Geochemical studies indicate little promise for the occurrences of additional mineral resources. A possibility exists for the presence of natural gas at depths greater than $5000 \mathrm{ft}$.

\section{CHARACTER AND SETTING}

The Shining Rock Wilderness contains about $21 \mathrm{sq} \mathrm{mi}$ within the Pisgah National Forest in the Blue Ridge Mountains of western North Carolina. The study area is in Haywood County, 9 mi southeast of Waynesville and $20 \mathrm{mi}$ southwest of Asheville. The Blue Ridge Parkway forms the southeast boundary. USFS road 816 from the parkway west of milepost 420 provides access to the southern part of the wilderness at Ivestor Gap. Access to the eastern part is from U.S. Highway 276 at the bridge over East Fork of the Pigeon River and from the road up Crawford Creek. On the west side, access is by North Carolina State Roads 215 and 1129 up Little East Fork. Altitudes range from about $6040 \mathrm{ft}$ at Grassy Cove Top to $3280 \mathrm{ft}$ near the parking lot on Little East Fork on the west side of the wilderness. Slopes are steep and generally overgrown with secondgrowth hardwoods and scattered pines and hemlock. Ridge tops have a few clearings or balds and some extensive rhododendron thickets. Several well-developed trails and old logging roads provide good access to the high ridges and major drainages.

A mineral-resource survey of the Shining Rock Wilderness was made in 1978 and the results published in 1982 (Lesure and Dunn, 1982). Several adjacent roadless areas were recommended for inclusion in the wilderness during the Second Roadless Area Review and Evaluation (RARE II) by the USFS, January 1979; these areas have not yet been studied and they are not included in this summary. This survey included reconnaissance geologic mapping (Lesure, 1981a), geochemical studies (Lesure, 1981b), and mine prospect examination (Dunn, 1981).
All surface rights in the wilderness are held by the Federal Government. The Government owns mineral rights on about $2 \mathrm{sq} \mathrm{mi}$ at the north end of the area; mineral rights are privately owned on the remaining acreage.

The bedrock in the Shining Rock Wilderness is regionally metamorphosed sedimentary rocks of probable Precambrian age. Most of the area is underlain by mica gneiss containing various amounts of interlayered mica schist, garnet-mica schist, granitic gneiss, amphibolite, and migmatite (Lesure, 1981a).

The gneiss and schist have been complexly folded and possibly faulted. Small folds, a few feet to more than $30 \mathrm{ft}$ in wavelength, plunge northeast, generally at angles of less than $40^{\circ}$. Larger folds are suggested by the outcrop patterns of garnet-mica schist, but were not completely identified in the reconnaissance mapping. No faults were observed, but the presence of sheared mica schist containing retrograde chlorite suggests at least local faulting.

A few quartz veins and small dikes or sills of mica pegmatite intrude the gneiss and schist. The largest mass of quartz is a complexly folded vein or series of veins about $1750 \mathrm{ft}$ long and 30-60 ft thick exposed on top of Shining Rock Mountaim. The white quartz can be seen from afar and consequently is the "shining rock" from which the mountain and in turn the wilderness take their names.

The pegmatites are medium- to coarse-grained mixtures of quartz, feldspar, and muscovite. They are generally tabular or lens shaped and small. The average size is $1-8 \mathrm{ft}$ wide and probably less than $100 \mathrm{ft}$ long. 


\section{MINERAL RESOURCES}

Analytical data from stream-sediment, soil, and rock samples (Seims and others, 1981) indicate little promise for the discovery of mineral-resources in the area. Quartz $\left(\mathrm{SiO}_{2}\right)$ and building stone are the only commodities found in large quantities in the Shining Rock Wilderness. Known deposits of mica pegmatite are small and low grade.

The large mass of quartz exposed on Shining Rock Mountain is a possible source of almost pure silica $\left(\mathrm{SiO}_{2}\right)$. The quartz is exposed above ground to a height of 3-20 ft and probably extends an equal or greater distance below ground. We estimate that at least 130,000 short tons and possibly as much as 500,000 short tons of quartz are present within $30-100 \mathrm{ft}$ of the surface on Shining Rock Mountain. No other masses of quartz of similar size are known to exist in the wilderness. Small pods and lenses of quartz a few inches to several feet thick and tens of feet long are widely scattered throughout the gneiss and schist but are not considered a resource. Quartz resources are available outside the wilderness. Large masses of quartz are common in the cores of zoned pegmatite bodies in the Franklin-Sylva pegmatite district, 5-40 mi southwest of the wilderness (Lesure, 1968, p. 94-121). Similar quartz cores in pegmatite in the Spruce Pine pegmatite district, $\mathbf{5 0}$ mi northeast, have been mined for quartz.

Most of the gneiss and schist in the study area is suitable for use as crushed rock or aggregate and rough building stone. The area, however, is far from large markets for aggregate, and similar stone is abundant throughout the region.

Within the wilderness, at least ten mica pegmatite deposits have been mined or prospected for sheet muscovite (mica). A small mica mine and several mica prospects in the wilderness were last operated during the 1950's. Total production of sheet mica from these deposits was less than 2000 lbs and scrap mica production was about $30,000 \mathrm{lbs}$. The value of this production was probably no more than $\$ 3000$ in 1952 dollars, and the average quality of mica produced was low. -

The largest workings are at the Little East Fork mine. This deposit was prospected during World War I, mined sporadically from 1942 to 1944 , and prospected again in 1952-53 (Lesure, 1968, p. 94-95). The last work was not successful. A small resource of mostly scrap quality mica is present.

The other known workings-the Shining Rock mine or prospect, three small prospects on Flower Knob, the Grassy Knob prospects, and three prospects north of
Grassy Cove Top-all contain small pegmatite dikes that range in thickness from 1 to $8 \mathrm{ft}$ and in length from 10 to $100 \mathrm{ft}$. They contain only small amounts of scrap quality muscovite. None of these muscovite occurrences are considered to have mineral-resource potential.

No additional mineral resources are known in the Shining Rock Wilderness and the geochemical survey indicated little promise for any discoveries.

\section{SUGGESTIONS FOR FURTHER STUDIES}

Recent seismic studies (Cook and others, 1979) indicate that the metamorphic rocks of the Blue Ridge Mountains in North Carolina, including the Shining Rock Wilderness, have been thrust at least $100 \mathrm{mi}$ up and over a thick sequence of younger sedimentary rocks, 3000-15,000 $\mathrm{ft}$ thick. At present the resource potential for hydrocarbons in the area underlain by these sedimentary rocks cannot be evaluated. The depths at which they occur-5000-45,000 ft-and the implied degree of metamorphism for rocks at such depths suggest that any hydrocarbons present would be in the form of natural gas (Cook and others, 1979, p. 566). Until deep drilling is done to test the results of the seismic studies, no estimate of the potential for gas can be made, but the presence of gas cannot be totally discounted.

\section{REFERENCES}

Cook, F. A., Albaugh, D. S., Brown, L. D., Kaufman, Sidney, Oliver, J. E., and Hatcher, R. D., Jr., 1979, Thin-skinned tectonics in the crystalline southern Appalachians; COCORP seismic-reflection profiling of the Blue Ridge and Piedmont: Geology, v. 7, no. 12, p. 563-567.

Dunn, M. L., Jr., 1981, Mineral resources of the Shining Rock Wilderness, Haywood County, North Carolina: U.S. Bureau of Mines Open-File Report MLA 13-81, 17 p.

Lesure, F. G., 1968, Mica deposits of the Blue Ridge in North Carolina: U.S. Geological Survey Professional Paper 577, 124 p. 1981a, Geology of the Shining Rock Wilderness, Haywood County, North Carolina: U.S. Geological Survey Miscellaneous Field Studies Map MF-1290-A, scale 1:48,000.

$1981 \mathrm{~b}$, Geochemical survey of the Shining Rock Wilderness, Haywood County, North Carolina: U.S. Geological Survey Miscellaneous Field Studies Map MF-1290-B, scale 1:48,000.

Lesure, F. G. and Dunn, M. L., Jr., 1982, Mineral resource potential map of the Shining Rock Wilderness, Haywood County, North Carolina: U.S. Geological Survey Miscellaneous Field Studies Map MF-1290-C, scale 1:48,000.

Siems, D. F., Meier, A. L., and Lesure, F. G., 1981, Analyses and descriptions of geochemical samples, Shining Rock Wilderness, Haywood County, North Carolina: U.S. Geological Survey OpenFile Report 81-595, 24 p. 


\title{
SNOWBIRD ROADLESS AREA, NORTH CAROLINA
}

\author{
By Frank G. LeSURE, U.S. GeOlogical Survey, and \\ MARK L. CHATMAN, U.S. BUREAU OF MineS
}

\begin{abstract}
SUMMARY
The Snowbird Roadless Area includes all the upper reaches of Snowbird Creek and the surrounding rugged ridges of the Unicoi Mountains, North Carolina. Mineral-resource surveys made in the fall of 1980 and spring of 1981 show that the area contains folded metasedimentary rocks of the Great Smoky Group of Late Proterozoic age and that the area has little promise for the occurrence of mineral resources. Abundant rock suitable for crushed rock and rough building stone is the only identified mineral resource, but extensive deposits of this commodity occur throughout the region outside the roadless area. Oil and gas and massive sulfide deposits are possible resources, but no evidence for them was discovered in this study and more detailed and expensive exploration methods would be necessary to evaluate the potential for their occurrence.
\end{abstract}

\section{CHARACTER AND SETTING}

The Snowbird Roadless Area contains about $13 \mathrm{sq} \mathrm{mi}$ of the Nantahala National Forest in the Unicoi Mountains, a southern extension of the Great Smoky Mountains in Graham County, North Carolina. The roadless area includes all the drainage basin of the upper part of Snowbird Creek and its tributaries and the surrounding rugged ridges. The highest point is Hooper Bald at the north end, $5429 \mathrm{ft}$ above sea level, and the lowest point is $2600 \mathrm{ft}$ along Snowbird Creek near the parking lot, called Junction, at the southeast end of the area. Access to Junction is by North Carolina State Road 1120 and USFS Road 75 that follow the road bed of an abandoned logging railroad along Snowbird Creek. Well-marked trails follow the old railroad grade up the creek and follow the ridges that rim the drainage basin from Junction to Hooper Bald.

The Federal Government owns all surface and mineral rights in the roadless area. The Ducktown mines, which currently produce sulfur, copper, and zinc, are $26 \mathrm{mi}$ to the southwest and the abandoned Fontana and Hazel Creek copper mines are 17 to $21 \mathrm{mi}$ to the northeast. Prospecting in and near the roadless area in the last 50 years has found only insignificant amounts of disseminated iron sulfides. A prospecting permit for base metals in the Big Junction area at the north end of the roadless area was relinquished in 1954 after the exploration company drilled two holes. Recently applications have been made for prospecting permits for base and precious metals on much of the southern end of the roadless area. Oil and gas lease applications have also been filed for much of the National Forest land in western North Carolina including the Snowbird Roadless Area.

Mineral surveys of the area made in the fall of 1980 and the spring of 1981 (Lesure and Chatman, 1983) included geologic mapping (Lesure, 1983a), geochemical sampling (Lesure, 1983b) and mine and prospect examination (Chatman, 1982).

The Snowbird Roadless Area contains metamorphosed sedimentary rocks of the Great Smoky Group of Late Proterozoic age. These rocks were mapped as three units (Lesure, 1983a). The oldest is a thick unit of metasandstone interlayered with lesser amounts of slate in several broad low folds in the central and northern part of the roadless area. These rocks may correlate with the rocks containing massive sulfide deposits at Ducktown, Tennessee. Above this unit is about 2000 to $3000 \mathrm{ft}$ of dark-gray graphitic slate that contains disseminated iron sulfide minerals and is interlayered with metagraywacke and metasandstone. This slate unit is exposed in several belts crossing the roadless area near the middle and at the northern end. The youngest rocks are interlayered garnet-mica schist and metasandstone forming the southern part of the roadless area.

The original sedimentary rocks have been progressively metamorphosed to garnet grade at the north and to staurolite grade at the south. Garnets, especially in 


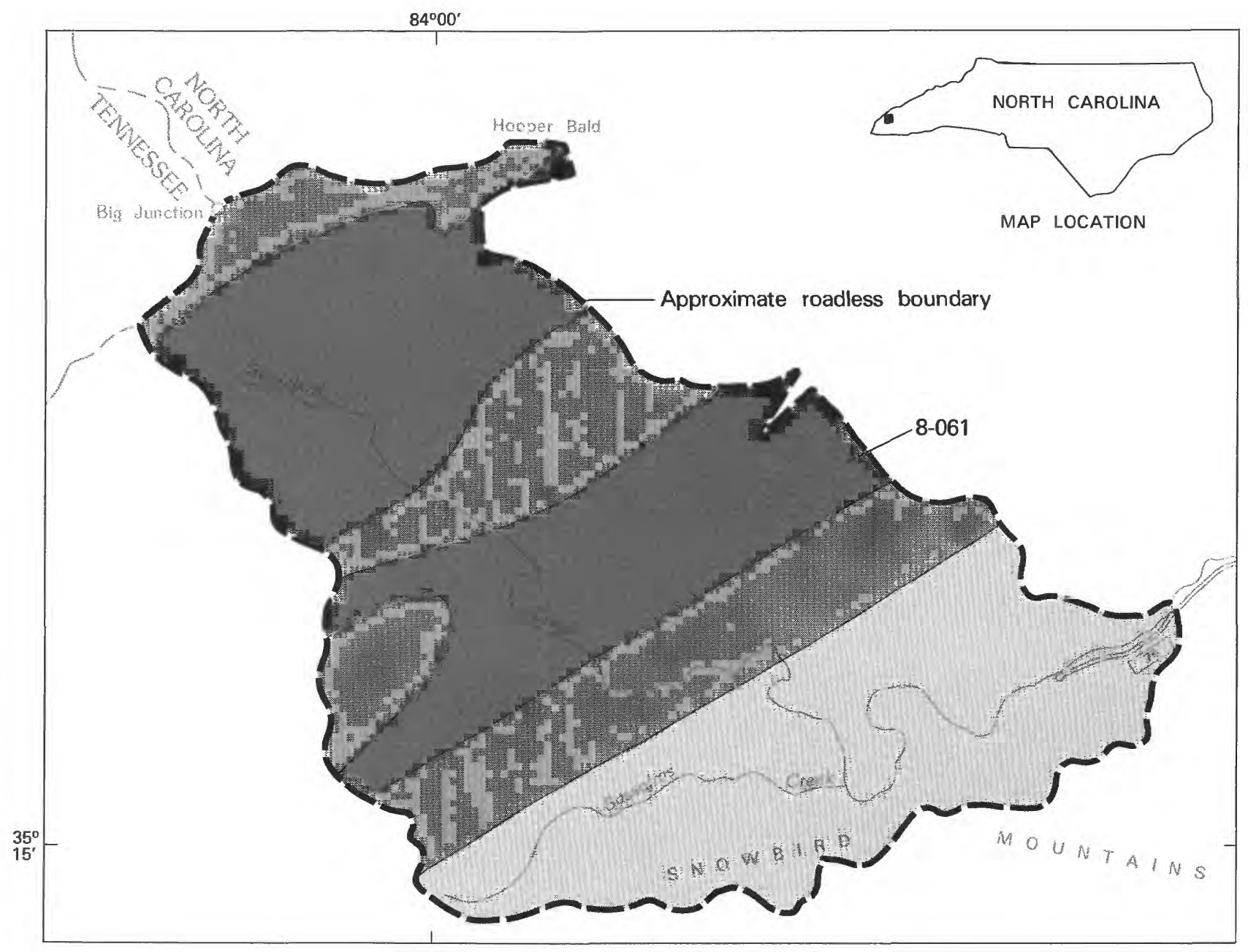

\section{0}

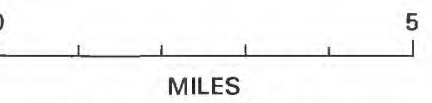

EXPLANATION

Garnet-mica schist (Proterozoic Z)

Wehutty Formation (Proterozoic Z)

Metasandstone (Proterozoic Z)

Contact

Figure 244.-Snowbird Roadless Area, North Carolina. 
slate and schist, become coarser and more abundant from north to south across the area.

\section{MINERAL RESOURCES}

The only known mineral resource in the Snowbird Roadless Area is abundant rock suitable for crushed stone and rough building stone. Extensive deposits of rock of equal or better quality are abundant throughout the region in areas where they are more readily available.

A potential for oil and gas exists but is untested. Recent seismic studies indicate that the Blue Ridge of North Carolina contains a thick sequence of younger sedimentary rock below the overlying metamorphosed rocks at the surface (Cook and others, 1979). The metamorphic surface rocks have been thrust $100 \mathrm{mi}$ up and over the younger rocks which have an unknown potential for oil and gas. The Snowbird Roadless Area is $14 \mathrm{mi}$ south of an exposure of some of the younger sedimentary rocks in a window or hole through the thrust block and $15 \mathrm{mi}$ southeast of the eroded western edge of the thrust block of older rock.

The Snowbird Roadless Area lies between the massive sulfide deposits of Ducktown, Tennessee, and the copper deposits of Fontana and Hazel Creek, Swain County, North Carolina. The metasandstone unit of the roadless area may correlate with the rocks of the Ducktown district that contain the ore deposits. Regional mapping (Hernon, 1968; Magee, 1968, p. 218-219) suggests that the Ducktown deposits are stratigraphically several thousands of feet below the contact between the metasandstone and the overlying rock unit. Analyses of rock, stream-sediment, and soil samples suggest that the rocks in the Snowbird Roadless Area contain generally normal amounts of the 32 elements for which they were tested. The metals cobalt, copper, lead, and zinc, commonly associated with massive sulfide deposits like those at Ducktown, Tennessee, are present in only normal concentrations. Only the upper part of the metasandstone unit is exposed in the roadless area so that although we found no evidence for massive sulfide deposits in the rocks exposed there is still a possibility for such deposits at depth.

\section{SUGGESTIONS FOR FURTHER STUDIES}

Detailed geophysical studies might be of use in evaluating the potential for massive sulfide deposits at depth. Further seismic work and deep exploratory drilling are needed to evaluate the oil and gas potential of the western edge of the overthrust belt in this part of North Carolina.

\section{REFERENCES}

Chatman, M. L., 1982, Mineral resources of Snowbird RARE II Further Planning Area, Graham County, North Carolina: U.S. Bureau of Mines Open-File Report MLA 42-82, 18 p.

Cook, F. A., Albaugh, D. S., Brown, L. D., Kaufman, Sidney, Oliver, J. E., and Hatcher, R. D., Jr., 1979, Thin-skinned tectonics in the crystalline southern Appalachians-COCORP seismic-reflection profiling of the Blue Ridge and Piedmont: Geology, v. 7, p. 563-567.

Hernon, R. M., 1968, Geology of the Ducktown, Isabella, and Persimmon Creek quadrangles, Tennessee and North Carolina: U.S. Geological Survey Open-File Report, 71 p.

Hurst, V. J., 1955, Stratigraphy, structure, and mineral resources of the Mineral Bluff quadrangle, Georgia: Georgia Geological Survey Bulletin 63, $137 \mathrm{p}$.

Lesure, F. G., 1983a, Geologic map of the Snowbird Roadless Area, Graham County, North Carolina: U.S. Geological Survey Miscellaneous Field Studies Map MF-1587-A, scale 1:48,000.

Lesure, F. G., 1983b, Geochemical survey of the Snowbird Roadless Area, Graham County, North Carolina: U.S. Geological Survey Miscellaneous Field Studies Map MF-1587-B, scale 1:48,000.

Lesure, F. G., and Chatman, M. L., 1983, Mineral resource potential map of the Snowbird Roadless Area, Graham County, North Carolina: U.S. Geological Survey Miscellaneous Field Studies Map MF-1587-C, scale 1:48,000.

Magee, Maurice, 1968, Geology and ore deposits of the Ducktown district, Tennessee, in J. D. Ridge, editor, Ore deposits of the United States, 1933-1967 (Graton-Sales Volume): American Institute of Mining and Metallurgy, New York, v. 1, p. 207-241. 


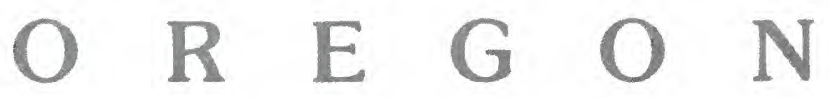

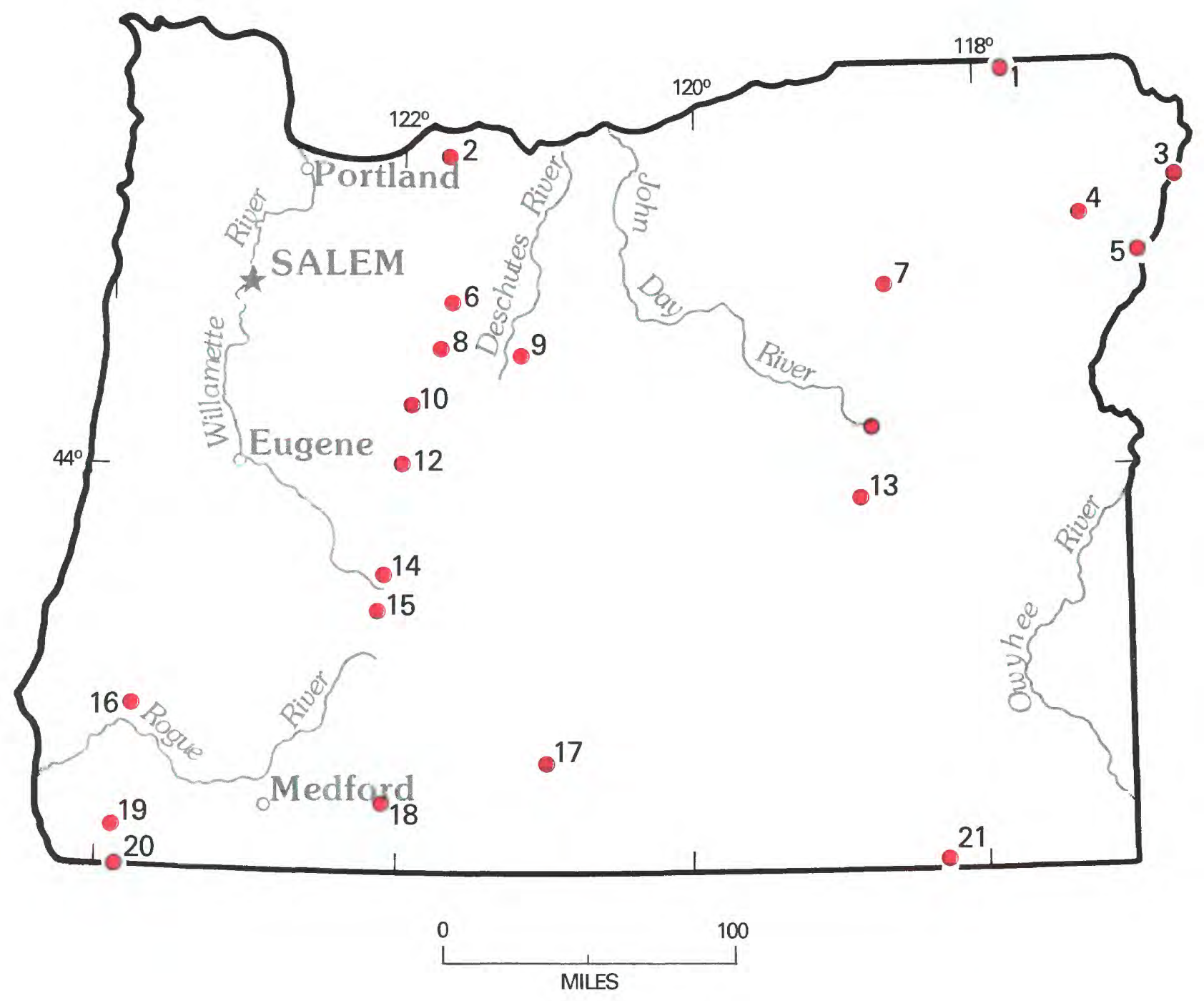

Location of areas studied. 


\section{OREGON}

21 Charles Sheldon Antelope Range and Sheldon Antelope Refuge, Nevada and Oregon-See Nevada

9 Deschutes Canyon Roadless Area

14 Diamond Peak Wilderness

4 Eagle Cap Wilderness and adjacent areas

17 Gearhart Mountain Wilderness and contiguous roadless area

3 Hells Canyon study area, Oregon and Idaho

5 Homestead, Lake Fork, and Lick Creek Roadless Areas

19 Kalmiopsis Wilderness

2 Mount Hood Wilderness and adjacent areas

8 Mount Jefferson Primitive Area

10 Mount Washington Wilderness

7 North Fork John Day River Roadless Area

20 North Fork Smith River Roadless Area, California and Oregon-See California

6 Olallie Roadless Area

13 Pine Creek Roadless Area

18 Sky Lakes Roadless Area and Mountain Lakes Wilderness

11 Strawberry Mountain Wilderness

12 Three Sisters Wilderness

1 Wenaha Tucannon Wilderness, Washington and Oregon-See Washington

16 Wild Rogue Wilderness

15 Windigo-Thielsen Roadless Area 


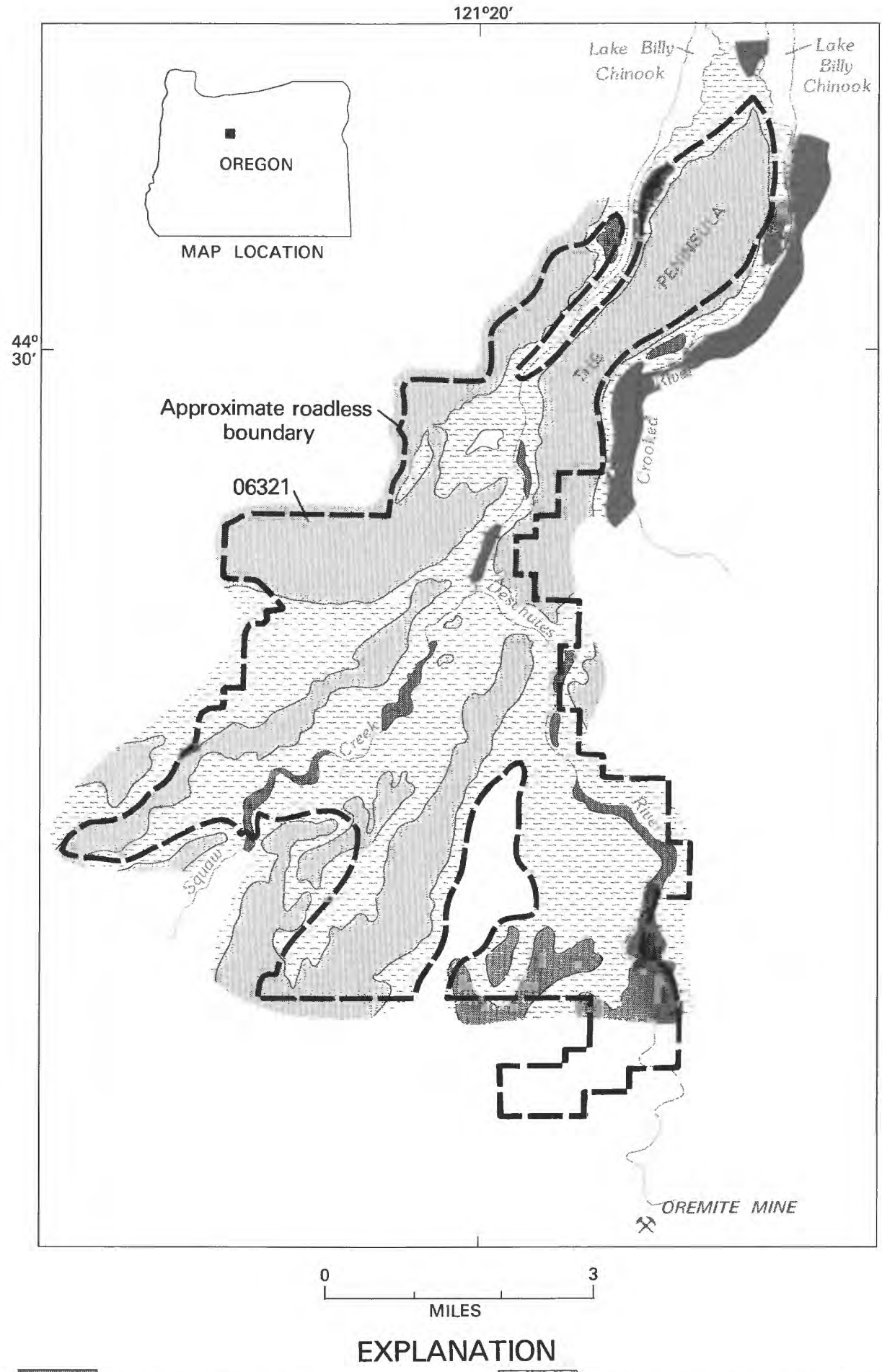

Basalt and basaltic andesite (Quaternary)

Olivine basalt flows, Madras Formation (Miocene and Early Pliocene)

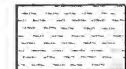

Tuffs and sedimentary rocks, Madras Formation (Miocene and Early Pliocene)

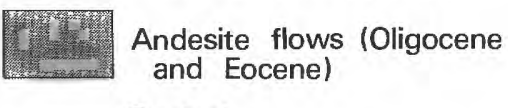

Contact

Figure 245.-Deschutes Canyon Roadless Area, Oregon. 


\title{
DESCHUTES CANYON ROADLESS AREA, OREGON
}

\author{
By GeOrge W. WAlker U.S. GeOlogical SurVey, and \\ RICHARD A. WINTERS, U.S. BUREAU OF MINES
}

\begin{abstract}
SUMMARY
An examination of the Deschutes Canyon Roadless Area, Oregon, in 1980 indicated that the area is devoid of mines and active mineral prospects or claims and that there is little likelihood for the occurrence of metallic or nonmetallic mineral resources. There is no evidence to indicate that mineral fuels are present in the roadless area. Nearby parts of central Jefferson County on the Warm Springs Indian Reservation are characterized by higher- than-normal heat flow and by numerous thermal springs, some of which have been partly developed. This may indicate that the region has some as yet undefined potential for the development of geothermal energy.
\end{abstract}

\section{CHARACTER AND SETTING}

The Deschutes Canyon Roadless Area is located in Jefferson and Deschutes Counties, Oregon, along a largely undeveloped section of the Deschutes River and includes the lower reaches of several tributary streams that drain areas to the west and southwest. The roadless area covers part of the Crooked River National Grassland, under the jurisdiction of the Ochoco National Forest. It is an irregular-shaped area of about $29 \mathrm{sq} \mathrm{mi}$ that is characterized by flat to gently sloping upland surfaces between steep canyon walls along the north- to northeast-trending major drainages. The most prominent upland surface, The Peninsula, is a large flattopped ridge or plateau between the Deschutes River on the west and the precipitous Crooked River canyon on the east. Arms of Lake Billy Chinook extend southward from the confluence of Deschutes and Crooked Rivers along both sides of The Peninsula.

All of the rock exposures in and near the Deschutes Canyon Roadless Area are of Cenozoic age (Walker, 1981) and include an older pile of porphyritic andesite that is overlapped by a sequence of volcanic, volcaniclastic, and sedimentary rocks representing part of the Madras Formation (Deschutes Formation of some geologists). Erosion of these volcanic and clastic rocks produced precipitous canyons along the major drainages; the drainages localized younger flows of basalt and andesite that erupted from vents in adjoining areas.

The oldest rocks are exposed in the southeast part of the area (Walker, 1981) in a steep-sided pile composed largely of porphyritic andesite flows. Most of the flows, which are poorly exposed, are comparatively unaltered and only slightly weathered; a few flows show slight alteration of hypersthene and clinopyroxene to a greenish-brown clay mineral, probably nontronite. No evidence was found to indicate that there is a local vent for these rocks within the boundaries of the roadless area.

The precise age of the porphyritic andesites is unknown, although Stensland (1970) considers them to be part of the Clarno Formation of late Eocene or Oligocene age, which is exposed extensively on Greys Butte about $9 \mathrm{mi}$ to the east (Robinson and Stensland, 1979).

Most of the Deschutes Canyon Roadless Area is underlain by sedimentary, volcanic, and volcaniclastic rocks of the Madras Formation of Miocene and early Pliocene age. In this area the formation rests unconformably on the Oligocene and Eocene porphyritic andesites; it consists largely of poorly bedded to moderately well bedded, coarse-to fine-grained clastic sediments composed entirely of basaltic, andesitic, and rhyodacitic debris derived from volcanic terranes to the south and west. Interstratified in this sedimentary sequence are basalt and basaltic andesite flows, which commonly form prominent rims or ledges, and a number of partly bedded pumice-rich layers representing ash flows and mudflows. In addition to abundant pumice fragments and lapilli as large as 1 in., most of these pumiceous layers contain some, and locally abundant, fragments, pebbles, and cobbles of basalt, andesite, and dacite or rhyolite. The pumice fragments are commonly hydrated and partly devitrified. 
Upper parts of the Madras Formation are exposed in the roadless area and here its total exposed thickness is about $670 \mathrm{ft}$. Lower parts of the formation are exposed in canyon walls of the Deschutes and Metolius Rivers, a few miles to the north, where it rests on Miocene basalt flows of the Columbia River Basalt Group.

Subsequent to deposition of the Madras Formation, erosion by the Deschutes and Crooked Rivers and by tributary streams developed precipitous canyons in the gently northward dipping, largely homoclinal sequence. Intracanyon flows erupted from vents to the south, southwest, and east, and poured down these canyons at different stages in the erosion cycle.

Poorly consolidated materials include chaotic mixtures of basalt rubble and sedimentary rocks in landslides at the north end of The Peninsula, along the shores of Lake Billy Chinook, and alluvium at Squaw Flat.

\section{MINERAL RESOURCES}

The Deschutes Canyon Roadless Area is in a region of little promise for the occurrence of metallic mineral resources, but lies about $2 \mathrm{mi}$ north of the large diatomite deposits at the Oremite mine. Also, near Bend, Oregon, about $20 \mathrm{mi}$ to the south, pumice deposits have been mined extensively since about 1940 for lightweight aggregate and pozzolanic additive to hydraulic cement. The roadless area contains no active mines, prospects, or claims, although 707 placer claims, located in the period 1906 to 1975 , virtually cover the roadless area; all but 6 of the claims were located prior to 1947. Two small prospects are present in the roadless area, but analyses of samples collected at these prospects indicate no significant metal concentrations.

Diatomaceous deposits that occur south of the roadless area were mined extensively (Peterson and others, 1976, p. 47). Examination of the geology in and near the deposit indicates that the diatomite, which is locally as much as $38 \mathrm{ft}$ thick, appears to be stratigraphically higher than any of the sedimentary rocks of the Madras Formation exposed in the roadless area. Only minor, thin diatomaceous beds were found in the sedimentary section exposed in the Deschutes Canyon Roadless Area.

Pumiceous ash-flow and mudflow deposits exposed on canyon walls of the Deschutes Canyon Roadless Area are superficially like some of the pumice beds that have been quarried since about 1940 near Bend and Tumalo. The commercial lump pumice is characterized by thick beds of fresh, glassy pumice fragments and few, if any, impurities. Most of this pumice has been used as lightweight aggregate in the manufacture of concrete building blocks and some has been used in acoustic plaster 864 and as a soil conditioner (Wagner, 1969b; Peterson and others, 1976); some apparently has been used as a pozzolanic additive to hydraulic cement. The pumiceous layers in the Deschutes Canyon Roadless Area are composed dominantly of rather poorly sorted pumice fragments, mostly less than 1 in. in diameter, in discontinuous lenslike or shoestring-shaped beds; generally the beds in the Deschutes Canyon Roadless Area are thinner and more highly indurated than those in the Bend and Tumalo areas. They differ significantly from the mined deposits in that they are older, late Miocene versus early Pleistocene or possibly latest Pliocene, are thinner and less continuous, and they commonly contain a comparatively large amount of extraneous fragments of andesite, basalt, or rhyodacite. The pumice fragments (or lumps) are also commonly hydrated and partly devitrified rather than glassy, which greatly reduces the usability. The presence of abundant rock fragments and the hydration and devitrification of pumice fragments, as well as the inaccessibility of these discontinuous thin beds on steep canyon walls, prohibits assessing these deposits in the Deschutes Canyon Roadless Area as a resource, particularly in light of the very large quantity of better quality and more accessible deposits near Bend and Tumalo.

Insofar as can be determined from surface geologic features, there is no evidence that the Deschutes Canyon Roadless Area contains mineral fuel resources and the potential for geothermal energy resources is undefined. There are no thermal springs within the roadless area, although hot springs are present about $22 \mathrm{mi}$ to the north on the Warm Springs Indian Reservation (Mariner and others 1974; Robison and Laenen, 1976). There, the hot spring waters (as hot as $182.3^{\circ} \mathrm{F}$ ) emerge directly from fractures in rhyolite or welded tuff of the Joln Day Formation near its contact with volcanic rocks of the underlying Clarno Formation. Although similar geologic conditions are not present in the roadless area, both areas occur in a region characterized by heat flow that is 2 to 3 times normal (Riccio, 1978). The significance, if any, of this higher-than-normal heat flows has yet to be determined.

\section{REFERENCES}

Mariner, R. H., Rapp, J. B., Willey, L. M., and Presser, T. S., 1974, The chemical composition and estimated minimum thermal reservoir temperatures of selected hot springs in Oregon: U.S. Geological Survey Open-file report, $27 \mathrm{p}$.

Peterson, N. V., Groh, E. A., Taylor, E. M., and Stensland, D. H., 1976, Geology and mineral resources of Deschutes County, Oregon: Oregon Department of Geology and Mineral Industries Bulletin 89,66 p.

Riccio, J. F., 1978, Preliminary geothermal resource map of Oregon: Oregon Department of Geology and Mineral Industries Geologic Map Series Map GMS-11, scale 1:500,000. 
Robinson, P. T., and Stensland, D. H., 1979, Geologic map of the Smith Rock area, Jefferson, Deschutes, and Crook Counties, Oregon: U.S. Geological Survey Miscellaneous Investigations Map I-1142, scale 1:48,000.

Robison, J. H., and Laenen, Antonius, 1976, Water resources of the Warm Springs Indian Reservation, Oregon: U.S. Geological Survey Water Resources Investigations 76-26, 85 p.

Stensland, D. E., 1970, Geology of part of the northern half of the Bend quadrangle, Jefferson and Deschutes Counties, Oregon: Corvallis, Oregon State University, M.S. thesis, 118 p.

Wagner, N. S., 1969a, Diatomite, in Mineral and water resources of Oregon: Oregon Department of Geology and Mineral Industries Bulletin 64, p. 205-210. 1969b, Perlite, pumice, pumicite, and cinders, in Mineral and water resources of Oregon: Oregon Department of Geology and Mineral Industries Bulletin 64, p. 222-228.

Walker, G. W., 1981, Geologic map of the Deschutes Canyon Further Planning Area, Oregon: U.S. Geological Survey Miscellaneous Field Studies Map MF-1303-A, scale 1:48,000.

Walker, G. W., and Winters, R. A., 1983, Mineral resource potential of the Deschutes Canyon Roadless Area, Jefferson and Deschutes Counties, Oregon: U.S. Geological Survey Open-File Report 83-375.

Winters, R. A., 1983, Mineral investigation of the Deschutes Canyon RARE II Area (No. 6321), Jefferson and Deschutes Counties, Oregon: U.S. Bureau of Mines Open-File Report MLA 6-83, 8 p. 

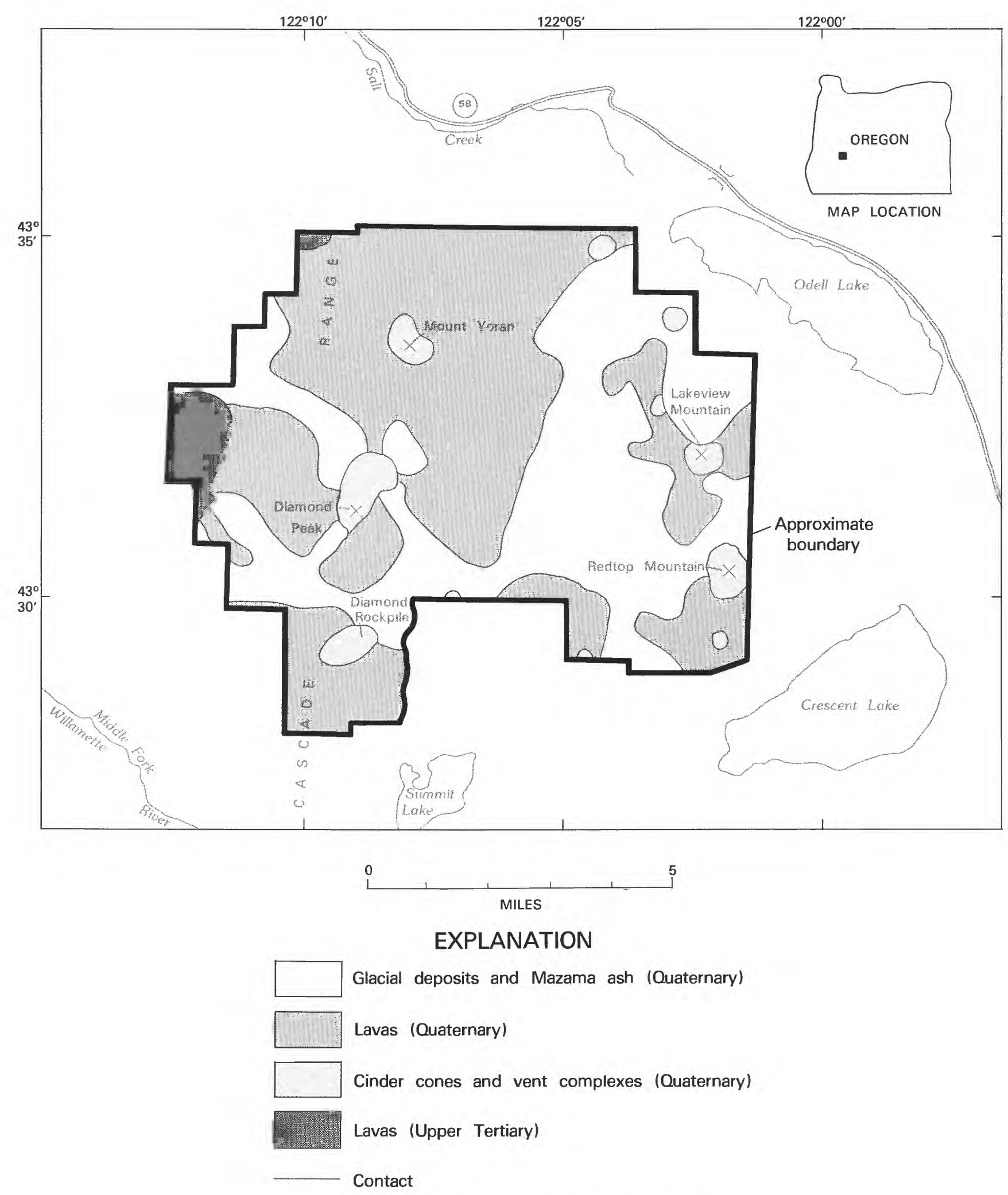

Figure 246.-Diamond Peak Wilderness, Oregon. 


\title{
DIAMOND PEAK WILDERNESS, OREGON
}

\author{
By DAVID R. SHERrod, U.S. GEOlogical SuRvey, and \\ PHILliP R. MOYLE, U.S. BUREAU OF MiNES
}

\section{SUMMARY}

\begin{abstract}
No metallic mineral resources were identified during a mineral survey of the Diamond Peak Wilderness in 1981-82. Cinder cones within the wilderness contain substantial cinder resources, but similar deposits that are more accessible occur outside the wilderness. The area could have geothermal resources, but available data are insufficient to evaluate their potential. The geologic terrane precludes the occurrence of fossil fuels.
\end{abstract}

\section{CHARACTER AND SETTING}

Diamond Peak Wilderness occupies an area of $57 \mathrm{sq}$ mi along the crest of the Cascade Range, 20 mi southeast of Oakridge, Oregon. The dominant geographic feature of the wilderness is 8748-ft-high Diamond Peak; total relief in the wilderness exceeds $4000 \mathrm{ft}$. The wilderness is in the High Cascade physiographic province of Oregon, which is an elongate belt of late Cenozoic lava flows and vents. The major Cascade peaks are Pleistocene stratovolcanoes built upon this belt. A mineral survey of the wilderness was made in 1981 and 1982 (Sherrod and others, in press).

Diamond Peak Wilderness is underlain entirely by young lava flows and the volcanoes from which they were derived. Diamond Peak stratovolcano is formed dominantly of basaltic andesite flows and pyroclastic rocks of late Pleistocene age. It has a youthful form, although glacially modified, and its lavas have normal remnant magnetization. As there is no indication of post-glacial volcanic activity (less than 10,000 years), the volcano is probably extinct. Adjacent stratovolcanoes at Mount Yoran and Lakeview Mountain are similar in composition to Diamond Peak, but are older and more deeply dissected. Flows from the Mount Yoran vent have a potassium-argon age of $0.33 \pm 0.07$ million years. These stratovolcanoes have central edifices built of poorly bedded pyroclastic rocks and minor interbedded flows, which are laced by dikes and sills that radiate from one or more high level plugs or volcanic necks. The flanks are formed of numerous lava flows. Several cinder cones and small mafic vent complexes also occur in the wilderness. Most of the lavas in the wilderness are fresh olivine basaltic andesite and basalt of Pleistocene age. Older flows and pyroclastic rocks of basaltic to andesitic or dacitic composition, which crop out along the western border, could be as old as late Miocene.

Repeated glaciations have dissected the volcanoes, scoured the upland surfaces, and deposited lateral and ground moraines over much of the middle and lower altitudes. A Holocene air-fall pumice deposit as much as 32 in. thick mantles the wilderness. This pumice is part of the extensive Mazama ash that erupted from the caldera at Crater Lake National Park in the Cascade Range south of Diamond Peak. No volcanic rocks in the wilderness are younger than the Mazama ash.

\section{MINERAL RESOURCES}

Metallic mineral resources are not known to occur in the High Cascade physiographic province in Oregon, and neither mining claims nor active mines are known in the Diamond Peak Wilderness. Samples of sediment from streams draining the wilderness contain only trace abundances of metallic elements, similar to those commonly found in unaltered volcanic rocks.

Although several of the volcanoes contain large volumes of material suitable for construction purposes, other voluminous sources of cinders and rock are available in the region, closer to markets.

Hydrocarbon deposits (oil, natural gas, coal) are not known to occur in the region and are highly unlikely in the Diamond Peak Wilderness, which is underlain by a very thick sequence of volcanic rocks.

The High Cascade physiographic province could locally contain high-temperature geothermal energy 
resources capable of producing electric power, but lower-temperature resources, which can be utilized for heating and other direct uses of hot water, are likely to be more abundant. Hot springs occur marginal to the province, mostly near the contact between the Western Cascades and High Cascades. They occur near valley bottoms, locally along faults, and are interpreted to represent lateral flow of hot water from sources beneath the High Cascades.

No thermal springs occur in the Diamond Peak Wilderness. The nearest are along Salt Creek (McCredie Springs, $163^{\circ} \mathrm{F}$ ), Salmon Creek (Wall Creek Springs, $106^{\circ} \mathrm{F}$ ), and Hills Creek (Kitson Hot Springs, $111^{\circ} \mathrm{F}$ ), 10 to $18 \mathrm{mi}$ northwest of the wilderness boundary. A warm spring occurs near Summit Lake, south of the boundary. The geochemistry of the waters from these springs does not indicate high-temperature sources, and cold meteoric water probably has diluted the thermal water during lateral subsurface flow.

Based on the geology of the wilderness, there is no reason to suspect that geothermal resources are more likely there than in other nearby parts of the High Cascades. If present, they probably are at substantial depth. At these depths the volcanic rocks may have very low porosity and permeability and fluids may not be present in sufficient quantity for geothermal electric power production. In summary, available evidence does not substantiate the presence of geothermal resources, and if they do occur they are likely deep beneath the wilderness.

\section{SUGGESTIONS FOR FURTHER STUDIES}

The geothermal potential of the High Cascades province cannot be realistically analyzed without data on the subsurface thermal and hydrologic regime that can only be provided by deep drill holes. Several deep holes could be drilled in areas of the High Cascades outside the wilderness, from which extrapolations of the geothermal potential of the several Cascade wildernesses could be made. Studies of other mineral resources do not seem warranted.

\section{REFERENCE}

Sherrod, D. R., Moyle, P. R., Rumsey, C. M., and MacLeod, N. S., in press, Geology and mineral resource potential map of the Diamond Peak Wilderness, Lane and Klamath Counties, Oregon: U.S. Geological Survey Open-File Report 83-661. 


\title{
EAGLE CAP WILDERNESS AND ADJACENT AREAS, OREGON
}

\author{
By THOR H. KiILSGAard, U.S. GeOlOgical SuRVey, and \\ ERnEST T. TUCHEK, U.S. BUREAU OF Mines
}

\begin{abstract}
SUMMARY
On the basis of a mineral survey of the Eagle Cap Wilderness and adjacent areas by the USGS and USBM in 1970-72, a probable mineral-resource potential was identified in five areas in the eastern part of the wilderness. Mineral resources are most likely to occur in tactite deposits in sedimentary rocks at or near contacts with intrusive granitic rocks that could contain copper and small amounts of other metals; however, there is little promise for the occurrence of energy resources.
\end{abstract}

\section{CHARACTER AND SETTING}

The Eagle Cap Wilderness and adjacent areas are in Baker, Union, and Wallowa Counties, northeastern Oregon. The area covers much of the Wallowa Mountains, a roughly dome shaped range drained mainly by the Minam, Lostine, and Wallowa Rivers, all of which head in the vicinity of Eagle Cap, a prominent peak for which the wilderness is named. The wilderness is readily accessible by various unsurfaced roads that lead into the mountains and extend to within short distances of the wilderness boundary. Principal towns near the area are Enterprise, LaGrande, and Baker.

A survey of the mineral potential of the wilderness and adjacent areas was made in 1970-72 and the results published in 1976 (Weis and others, 1976). The initial objective of the survey was the wilderness itself, a tract of about $345 \mathrm{sq} \mathrm{mi}$. In 1970 and 1971, ten adjoinin? parcels of land were proposed for inclusion into the wilderness, and in 1972 an additional 20 parcels of lard were proposed, all of which increased the area that was studied to about $557 \mathrm{sq} \mathrm{mi}$.

'The oldest rocks in the Eagle Cap Wilderness and vicinity are Triassic and Jurassic sedimentary and volcanic rocks that crop out in the eastern and southeastern parts of the area. These rocks have been intruded by Cretaceous granitic rocks that form the core of the area. Following uplift and erosion of the older and granitic rocks, the area was covered by flows of Columbia River Basalt Group of Miocene age. Further uplift resulted in erosion of the basalt from higher parts of the mountains, but leaving basalt lapping onto older rocks in peripheral parts of the area, particularly in the Minam
River area to the northwest. Alpine glaciation has shaped higher peaks and ridges and scoured the valleys.

More than 1500 mining claims have been located in the area that was studied. Many of the claims have been staked at the same localities at different times, thus records show more claims that actually exist on the ground. There is no recorded mineral production from any of the claims within the area that was studied. The nearest productive mines are in the Cornucopia district, which is immediately south of the wilderness.

\section{MINERAL RESOURCES}

Geologic mapping, analysis of geochemical samples, and site examinations at known prospects and mineralized outcrops disclosed that although no mineral production has been recorded from the area, a few areas have a probable mineral-resource potential. Metalliferous deposits are found in veins and in sedimentary rocks that have been thermally metamorphosed to tactite near contacts with intrusive granitic rocks. Extensive high-calcium limestone deposits occur in the sedimentary rocks of the eastern part of the wilderness, but deposits of high-calcium limestone also occur outside the area. The mineral-resource potential is in the southern, eastern, and northeastern parts of the area.

The Dotson and Rainbow prospects, in Copper Creek Basin in the southwestern part of the wilderness, contain demonstrated resources of copper-bearing material. The prospect workings explore quartz veins in granodiorite. Chalcopyrite, azurite, malachite, and molybdenite are the most abundant ore minerals, and 


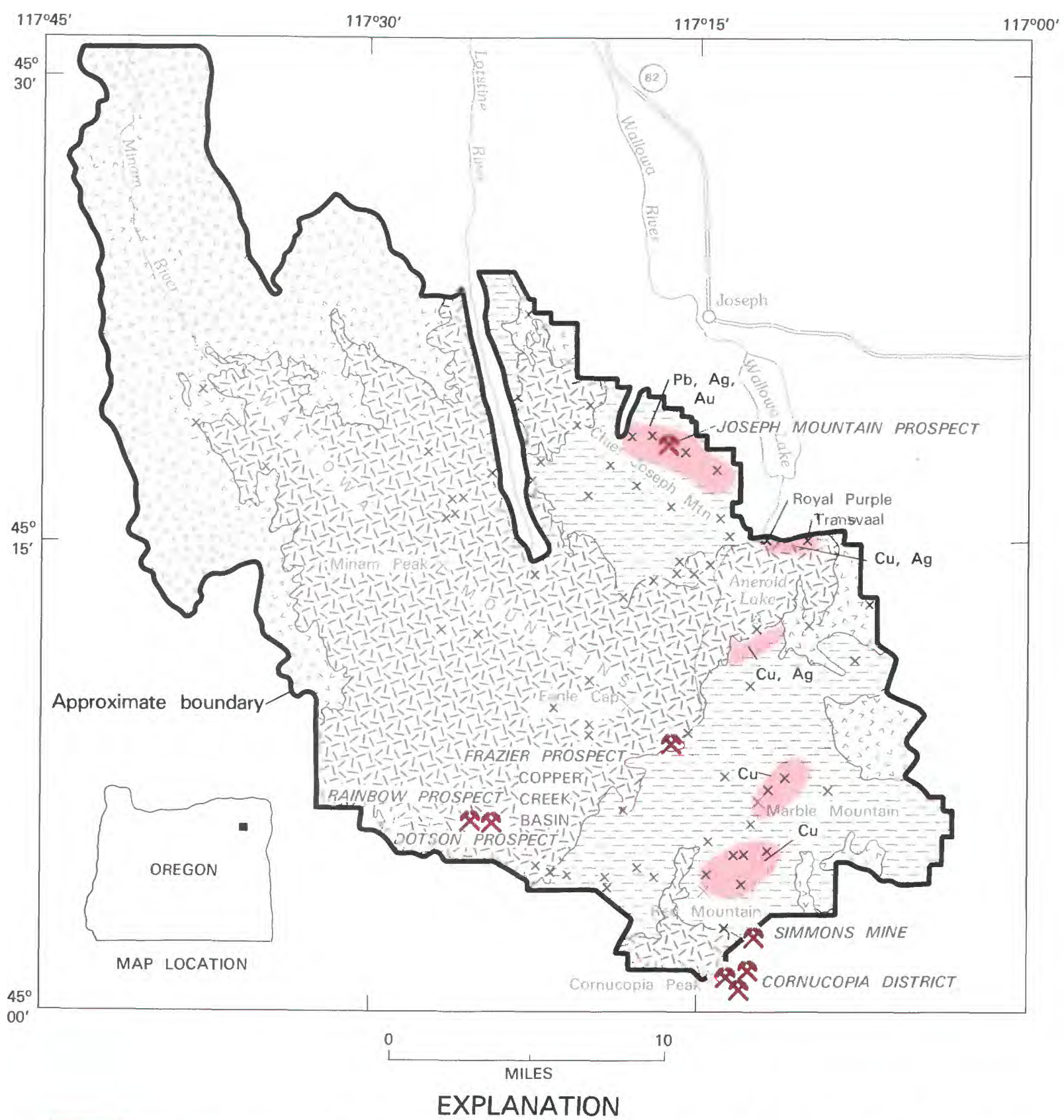

$\begin{aligned} & \text { Geologic terrane with probable } \\ & \text { mineral-resource potential }\end{aligned}$
$\mathrm{Cu}$ Copper $\quad \mathrm{Pb} \quad$ Lead
$\mathrm{Am} \quad \mathrm{Ag}$ Silver

Figure 247.-Eagle Cap Wilderness and adjacent areas, Oregon. 
the resources are estimated to exceed 100,000 tons of material containing from 1-2 percent copper, about 0.15 percent molybdenum, and about $0.60 \mathrm{oz}$ silver/ton. Five areas of probable mineral-resource potential occur in the eastern part of the area studied. The Joseph Mountain prospect, on the east slope of Chief Joseph Mountain and outside the wilderness boundary but within the adjacent study area, is in an area of probable resource potential for lead, silver, and gold. The prospect consists of adits and prospect pits that explore a quartz vein in sedimentary rocks that contains moderate amounts of gold, silver, and lead. Samples from the vein average $0.03 \mathrm{oz}$ gold/ton, $0.71 \mathrm{oz}$ silver/ton, 2.90 percent lead, and trace amounts of copper, molybdenum and zinc. The prospect is estimated to contain demonstrated resource of 68,000 tons of vein material of the abovequoted grade. The Frazier prospect, about $2 \mathrm{mi}$ southeast of Eagle Cap, is another tactite deposit in limestone with demonstrated resource of copper, molybdenum, tungsten, and silver. Prospect workings consist of several short adits and shallow prospect pits. The ore minerals occur as disseminated grains, small pods, and discontinuous veins. Twenty-eight samples of tactite were taken and analyzed, the best sample containing 2.44 percent copper and $0.20 \mathrm{oz}$ silver/ton. Potential resources at the deposit are estimated at 24,000 tons, the grade of which averages 0.84 percent copper, 0.06 percent molybdenum, 0.03 percent tungsten, and $0.10 \mathrm{oz}$ silver/ton. Exposures of tactite in the Aneroid Lake basin, south of Aneroid Lake, contain copper and silver minerals; however, the most mineralized tactite outcrops are on patented claims, which could not be examined by the field team. The sinuous mineralized zone crops out for about $4700 \mathrm{ft}$ along strike and ranges from 8 to $47 \mathrm{ft}$ in width. Other tactite deposits in an area of probable mineral-resource potential include the Royal Purple and Transvaal prospects southeast of Joseph Mountain.

Stream-sediment samples from streams draining the cirque on the northeast side of Red Mountain contained high amounts of copper. Volcanic and sedimentary rocks cropping out in the cirque are cut by many quartz veins, most of which are less than 1 in. thick and which contain minor amounts of copper minerals. A similar but smaller occurrence of copper minerals is at the west end of Boner Flat, about $1.5 \mathrm{mi}$ northeast of Marble Mountain. Other stream-sediment samples anomalous in copper were taken from streams draining the older sedimentary rocks but little evidence of significant deposits was found upstream from the sample sites.

Placer claim sites were sampled in the northwestern part of the area and along the Imnaha River, southwest of Marble Mountain, but concentrations of gold in the samples were negligible.

Mines and prospects in the Cornucopia district, adjacent to Cornucopia Peak, have produced substantial amounts of gold from workings south of the area studied. At least two of the productive gold-bearing veins extend into the area studied, and the down-dip extension of a third formerly productive vein, the Wallingford vein, could project across the boundary and into the area. The gold in these veins could be mined from workings the portals of which are located outside the wilderness boundary. The Simmons mine, about $2 \mathrm{mi}$ north of Cornucopia Peak and nearly $1 \mathrm{mi}$ southeast of the study area boundary contains demonstrated gold and silver resources of 175,000 tons, samples of which average $0.09 \mathrm{oz}$ gold, and $1 \mathrm{oz}$ silver/ton. The mine is connected by an aerial tram to the Queen of the West ore-treatment mill, which is within the study area.

\section{SUGGESTIONS FOR FURTHER STUDIES}

Additional study and large-scale geologic mapping of the older sedimentary and volcanic rocks would improve geologic knowledge on the stratigraphy and structures of the rocks, would yield information on the extent and content of the high-calcium limestone, and might identify additional tactite zones that could contain metalliferous deposits.

\section{REFERENCE}

Weis, P. L., Gualtieri, J. L., Cannon, W. F., Tuchek, E. T., McMahan, A.B., and Federspiel, F. E., 1976, Mineral resources of the Eagle Cap Wilderness and adjacent areas, Oregon: U.S. Geological Survey Bulletin 1385-E, 100 p. 


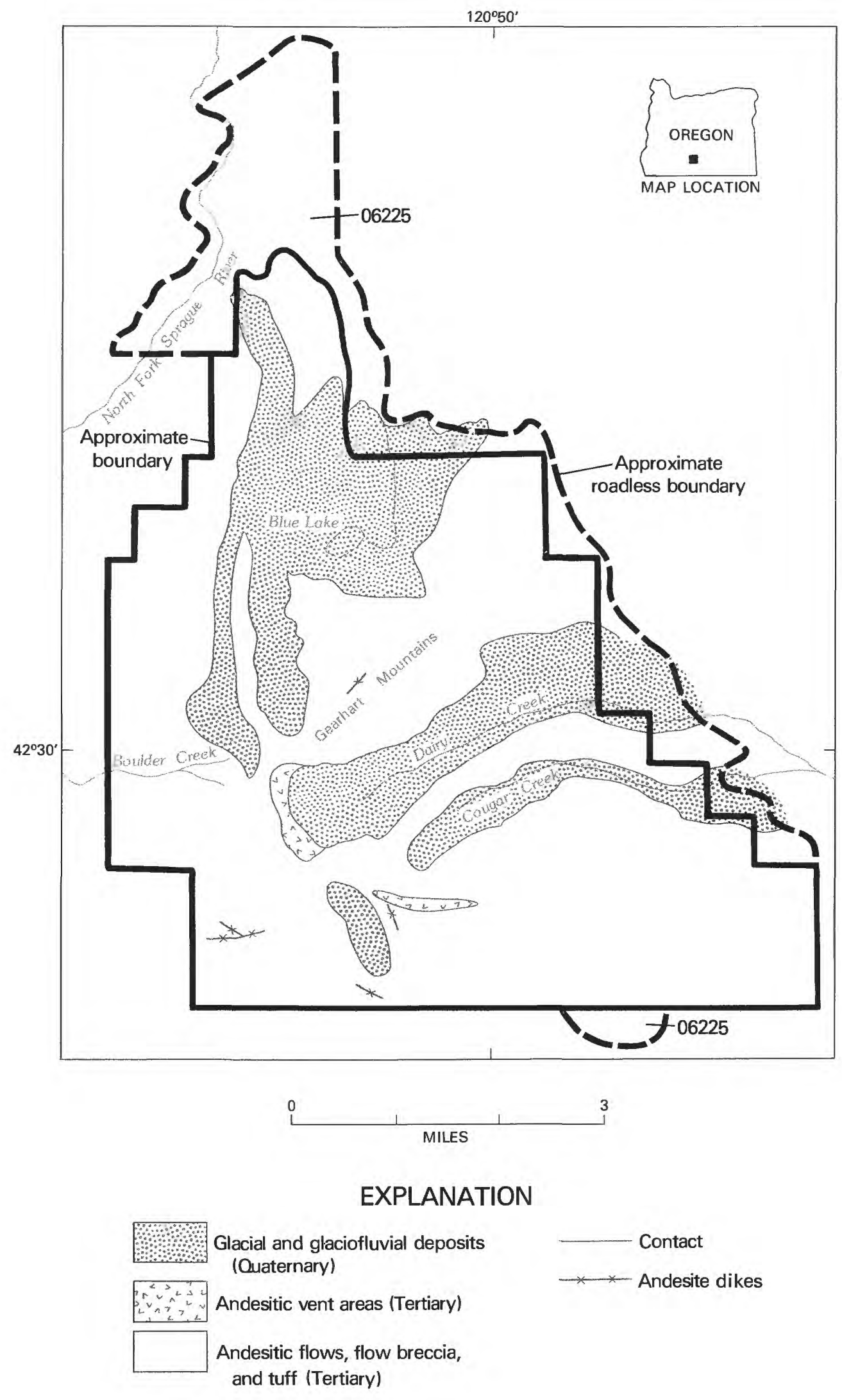

Figure 248.-Gearhart Mountain Wilderness and contiguous roadless area, Oregon. 


\title{
GEARHART MOUNTAIN WILDERNESS AND CONTIGUOUS ROADLESS AREA, OREGON
}

\author{
By George W. Walker, U.S. Geological Survey, and \\ JAMES RIDENOUR, U.S. BUREAU OF MINES
}

\section{SUMMARY}

\begin{abstract}
A mineral-resource appraisal of the Gearhart Mountain Wilderness and contiguous roadless area, made in August 1980, indicates that it is devoid of mines and mineral prospects and that there is little likelihood that metallic mineral resources occur in the area. Higher than normal heat flow characterizes the region containing Gearhart Mountain, indicating that it may have some potential, as yet undefined, for the occurrence of geothermal energy resources, but no geothermal resources were identified in this study.
\end{abstract}

\section{CHARACTER AND SETTING}

The Gearhart Mountain Wilderness incorporates a remote and undeveloped, partly forested, andesitic volcano within the Fremont National Forest, Lake and Klamath Counties, Oregon. The wilderness consists of about $29.7 \mathrm{sq}$ mi essentially all on Gearhart Mountain and about 6.3 additional sq $\mathrm{mi}$ of roadless area (area 6225 ) on and immediately adjacent to the lower flanks of Gearhart Mountain.

Prior to the present study (Walker and Ridenour, 1982), the geology of the Gearhart Mountain Wilderness was partially mapped in broad reconnaissance by Walker (1963) as part of a regional study of the eastern half of the Klamath Falls $1^{\circ} \times 2^{\circ}$ quadrangle. Subsequently, some additional reconnaissance was completed by Peterson and McIntyre (1970) in preparing an evaluation of the regional geology and mineral resources of eastern Klamath and western Lake Counties, Oregon. These studies indicate that the Gearhart Mountain Wilderness is confined mostly to a large andesitic volcano of late Cenozoic age.

Gearhart Mountain is a large volcanic edifice about $12 \mathrm{mi}$ in diameter and $3000 \mathrm{ft}$ high of late Miocene or Pliocene age. The edifice is built on a basement apparently locally consisting of olivine and pyroxene basalt flows of middle to late Miocene age. The exact geologic age of the volcanic pile that comprises Gearhart Mountain is not known but it is lapped on the north by basalt flows that appear to correlate with flows that cap several rims in the region; these capping flows have been dated by potassium-argon methods at about
6 to 8 million years old (Miocene). Deep glaciation and stream erosion, as well as local alteration and deep weathering of some of the rocks on Gearhart Mountain, also support a Pliocene or older age.

The rocks of Gearhart Mountain consist of extensive flows and flow breccias, agglomerate, numerous dikes and small intrusive bodies, and andesitic or basaltic tuff. Compositionally, these rocks range from olivine basalt or basaltic andesite with $\mathrm{SiO}_{2}$ contents of about 52.5 percent to highly porphyritic olivine and hypersthene-bearing flows and intrusions with $\mathrm{SiO}_{2}$ contents of about 61 percent. Depending on which rock classification is used, the most silicic rocks recognized on Gearhart Mountain probably would be identified as silicic hypersthene andesite, mafic hypersthene dacite, or possibly hypersthene tonalite porphyry.

Upper slopes of Gearhart Mountain are deeply scarred by glacial cirques, and several major drainages on the north and east side of the mountain follow extensive glaciated, U-shaped canyons. Glacial moraines are present in and adjacent to cirques and canyons; Blue Lake, in the northern part of the wilderness, appears to be partly confined by an end (or terminal) moraine. Several eroded end moraines in the canyons of Dairy and Cougar Creeks have been breached by subsequent stream action. The glacial deposits consist of poorly sorted blocks of andesite or basalt in a matrix of rock flour. Glacio-fluvial deposits, in which there has been some small amount of sorting and the development of crude bedding, are present in all canyons at lower altitudes on Gearhart Mountain. In places small outcrops of the underlying andesitic rocks project through 
the glacial and glacio-fluvial deposits. Alluvium, in the form of sand, silt, gravel, and boulders, is present along lower segments of all of the creeks originating on the mountain.

A veneer of moderately well sorted pumice sand is discontinuously present in the area, particularly on the north and east sides of Gearhart Mountain. It is mostly less than $4 \mathrm{ft}$ thick, but locally drifted into piles $10 \mathrm{ft}$ or more thick. Isolated outcrops of underlying andesitic bedrock project through the veneer in places, but where it rests on the poorly sorted glacio-fluvial deposits, as for example south and southwest of Blue Lake, it obscures all but the largest erosional blocks of andesite. Uniformity of particle size of the pumice sand suggests that it is an air-fall deposit most likely related to Mazama ash.

\section{MINERAL RESOURCES}

The Gearhart Mountain Wilderness and contiguous roadless area are in a region that has little promise for the occurrence of either metallic or nonmetallic mineral resources. There is no past record of either mining or quarrying in the area nor were any metallic mineral occurrences or prospect pits recognized during the present investigation. There are no known lode or placer claims. Analyses of stream-sediment and rock samples collected from areas in and immediately adjacent to the wilderness also indicate a low level of metal concentration. Panned concentrates of stream sediments from the area are composed almost entirely of common rockforming minerals, principally olivine, pyroxene, hornblende, hypersthene, and magnetite.

Although no prospects or mineralized or hydrothermally altered ground were recognized, the bedrock of the Gearhart Mountain area is somewhat similar to that found in nearby mineralized areas. However, there are important differences. All of the rocks in the region are Cenozoic in age and relate directly or indirectly to volcanic activity. Most of the mineralization is associated with areas that contain silicic intrusions, whereas the Gearhart Mountain Wilderness and contiguous roadless area contains no such intrusions. Evidence of hydrothermal alteration, including bleaching and the development of clays and secondary silica minerals, is present in the bedrock in all of the mineralized areas, whereas no such bleaching or alteration was found in the area. Furthermore, analyses of bedrock samples, and of stream-sediment samples taken downstream from major outcrops of the andesites and basalts that characterize the wilderness, show no anomalous amounts of any of the metals present in the adjoining mineralized areas.

Volcanic rock suitable for some construction purposes is present in parts of the Gearhart Mountain Wilderness, but better quality material is abundant elsewhere and is more readily accessible.

As far as can be determined from surface geologic features, there is no evidence that the Gearhart Mountain Wilderness and contiguous roadless area contains deposits of mineral fuels or a potential for the development of geothermal energy. There are no thermal springs within the area, although it lies in a region characterized by slightly higher than normal heat flow, and numerous thermal springs and wells are present in adjoining areas.

\section{REFERENCES}

Peterson, N. V., and McIntyre, J. R., 1970, The reconnaissance geology and mineral resources of eastern Klamath County and Western Lake County, Oregon: Oregon Department of Geology and Mineral Industries, Bulletin 66, 70 p.

Walker, G. W., 1963, Reconnaissance geologic map of the eastern half of the Klamath Falls (AMS) quadrangle, Lake and Klamath Counties, Oregon: U.S. Geological Survey Mineral Investigations Field Studies Map MF-260, scale 1:250,000.

Walker, G. W., and Ridenour, James, 1982, Mineral resource potential of the Gearhart Mountain Wilderness and Roadless Area (6225), Lake and Klamath Counties, Oregon: U.S. Geological Survey Miscellaneous Field Studies Map MF-1367, scale 1:48,000. 


\title{
HELLS CANYON STUDY AREA, OREGON AND IDAHO
}

\author{
By George C. Simmons, ${ }^{1}$ U.S. GeOlogical Survey, and \\ Terry J. Close, U.S. Bureau of Mines
}

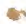

\begin{abstract}
SUMMARY
Geologic, geochemical, aeromagnetic, and mine and prospect investigations to determine the mineral-resource potential of the Hells Canyon study area were carried out during the years $1974-76$ and 1979 by the USGS and USBM. As a result, $42 \mathrm{sq} \mathrm{mi}$ or about 4 percent of the lands, in 21 separate areas, were classified as having probable or substantiated resource potential for base and precious metals, molybdenum, and tungsten. Most of the 21 areas are in the southern part of the study area; nine of the areas and parts of seven others are within the Hells Canyon Wilderness. No energy resource potential was identified in this study.
\end{abstract}

\section{CHARACTER AND SETTING}

The Hells Canyon study area occupies nearly 950 sq mi along and near Hells Canyon of the Snake River in northeast Oregon and west-central Idaho. The study area is at the junction of the Northern Rocky Mountains and the Columbia Plateau, and includes public lands of the Wallowa-Whitman National Forest in Wallowa County, Oregon, and the Nez Perce and Payette National Forests in Nez Perce and Adams Counties, Idaho. In December 1975 Congress created the Hells Canyon Wilderness, an area of about $300 \mathrm{sq}$ mi lying within the study area; the remaining $650 \mathrm{sq} \mathrm{mi}$ are classified as roadless areas.

The sequence of the major geologic events in the Hells Canyon region has been determined and much of the geologic history can be reconstructed. During Permian time (about 250 million years ago), volcanic and volcaniclastic rocks were deposited. Toward the end of that period or in the Early Triassic the rocks were uplifted, deformed, and intruded by plutonic rocks ranging in composition from gabbro to granite. Following this uplift, in the Middle and Late Triassic, more volcanic and volcaniclastic rocks interbedded with limestone were deposited; these Permian and Triassic rocks comprise the Seven Devils Group. Volcanism ceased in the Late Triassic and was followed by the deposition of a thick unit of limestone, the Martin Bridge Limestone.

${ }^{1}$ With contributions from James L. Gualtieri and Don R. Mabey, USGS, and Francis E. Federspiel and Andrew M. Leszcykowski, USBM.
After the deposition of the Martin Bridge Limestone, the Hells Canyon region was uplifted, plutonic rocks similar to the Early Triassic plutonic rocks were emplaced, and the region was extensively eroded. In the Middle and Late Jurassic, the Coon Hollow Formation, a black mudstone, was deposited on deformed Triassic rocks. A major orogeny followed; the pre-existing rocks were folded and faulted, the volcanic and volcaniclastic rocks were metamorphosed into greenstones, and another group of plutonic rocks was emplaced.

At the end of the Jurassic, plutonic rocks were thrust northwestward in the central part of the study area, and limestone and greenstone were thrust into the east part of the study area. The thrusting was succeeded in the Early Cretaceous by the intrusion of granitic plutons in the south part of the study area. Later, still during the Early Cretaceous, low- to high-grade metamorphism, most notable east of the study area, transformed volcanic and sedimentary rocks into slate, marble, schist, and gneiss, and shortly thereafter these foliated metamorphic rocks were thrust eastward in the southeast part of the study area.

The region was subsequently uplifted and an erosion surface of variable relief developed; the southeastern part was mountainous, and the northern part is known to have had several canyons cut into it. In the middle Miocene, basalt erupted from numerous fissures and covered much of the region, with the possible exception of the peaks in the south. These flows are part of the Columbia River Basalt Group. During the late Miocene and Pliocene the region was subjected to warping and 


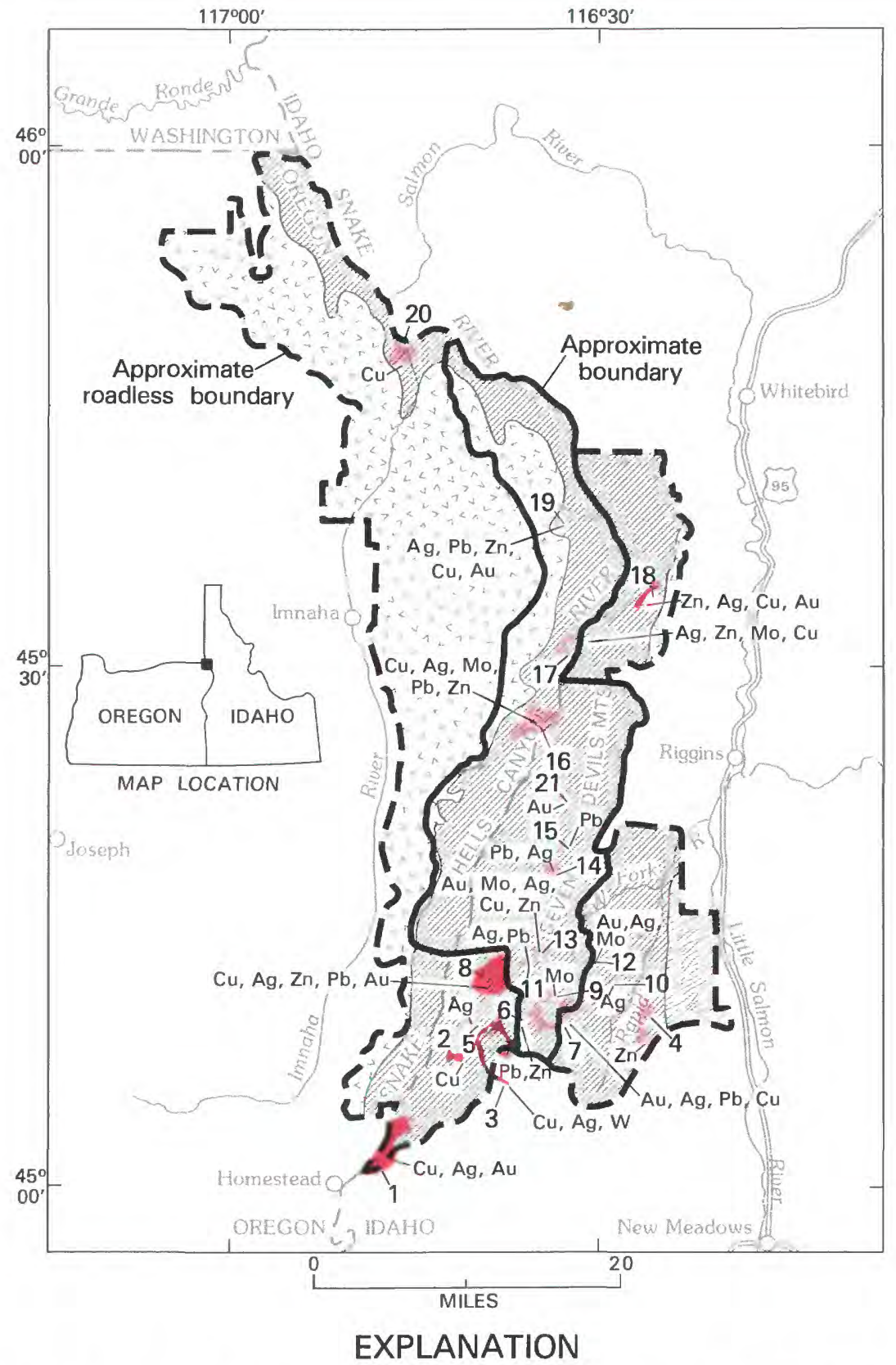

Geologic terrane with substantiated mineral-resource potential and probable tungsten resource potential

Geologic terrane with substantiated mineral-resource potential

Geologic terrane with probable mineral-resource potential

$\mathrm{Cu}$

Au Gold

$\mathrm{Pb} \quad$ Lead

Mo

$\begin{array}{ll}\text { Ag } & \text { Silver } \\ \text { W } & \text { Tungsten } \\ \mathrm{Zn} & \text { Zinc }\end{array}$

Molybdenum
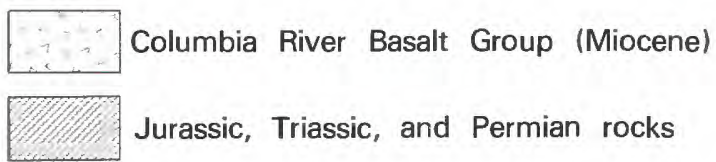

Schist and gneiss

Contact

2 Area discussed in text

Figure 249.-Hells Canyon study area, Oregon and Idaho. 
block faulting, and this was followed in late Pliocene and Pleistocene time by the erosion of the Hells Canyon gorge. During the Pleistocene, the mountainous part of the study area was glaciated, and morainal deposits and outwash gravels were deposited. During the Holocene, alluvium was deposited along the Snake River and its tributaries, and colluvium or landslide debris was formed at a few places.

Geochemical samples were collected throughout the study area and anomalous amounts of gold, silver, copper, molybdenum, lead, tungsten, and zinc were found. Aeromagnetic mapping shows a very complex pattern that principally reflects the strongly magnetized rocks and the high relief.

County records show that approximately 4100 mining claims have been located in the study area. About 1290 lode claims and 110 placer claims are held in Oregon, and about 2510 lode claims and 190 placer claims in Idaho. U.S. Bureau of Land Management records indicate 186 patented claims.

Much of the mining activity in the study area took place before complete records were maintained and the early history of mining is not well known. The first successful attempts were near White Monument where placer gold (area 21, on map) claims were staked in the 1870 's. When these deposits were nearly exhausted, gold-silver-tungsten bearing tactite deposits (area 3) were discovered and mined from the 1880's until 1906. During the latter part of this period and for a few years thereafter claims were staked in many parts of the study area: on mineralized shear zones, tactite deposits, and volcanogenic sulfides near the Rapid River, until 1900 (areas 4, 7, 10, 12); on magnetite-hematite fissure veins near the mouth of the Imnaha River, until 1915 (area 20); on elevated placer deposits, on quartz veins, on volcanogenic deposits until 1915, and at isolated places elsewhere.

The Iron Dyke mine, $3 \mathrm{mi}$ south of the study area, operated from 1914 until 1928 and is presently (1982) being developed. The discovery in 1965 of the Copper Cliff mine, $1 \mathrm{mi}$ east of the south end of the study area spurred exploration in nearby parts within the study area. The Copper Cliff mine is the only mine currently operating in the region.

\section{MINERAL RESOURCES}

The more important types of mineral deposits in the study area, from the point of view of past and future production, include replacement deposits in tactites, volcanogenic sulfide occurrences, quartz veins, magnetite-hematite fissure veins, and placers. The tactite deposits involve the replacement of limestone, particularly by copper minerals, and to a lesser extent by tungsten and other metals. The volcanogenic occurrences are widespread and include massive and disseminated syngenetic deposits, and structurally controlled deposits; the structurally controlled deposits may have formed as a result of partial remobilization during the emplacement of plutons or regional metamorphism. The volcanogenic deposits contain copper, silver, zinc, and lesser amounts of molybdenum, lead, and gold. Quartz veins bearing gold, small amounts of silver, and at a few places copper are associated with tabular granitic plutons in the southeast part of the study area. The magnetite-hematite fissure veins are localized in the gabbro-diorite-quartz diorite pluton near the mouth of the Imnaha River; the only metal of importance which they contain is copper. Three types of placer gold deposits are recognized: residual deposits overlying tactite deposits, elevated deposits on the pre-Columbia River Basalt Group erosion surface in the central part of the study area, and along or in the bed of the Snake River.

Recorded production from 17 lode deposits in the study area totals 55,785 tons of ore containing 9355 troy oz of gold, 225,530 troy oz of silver, 6109 tons of copper, 1 ton of lead, 40 tons of zinc, and 180 pounds of tungsten trioxide. Recorded production from placer deposits is 605 troy oz of gold. Demonstrated resources in the study area total $31,000,000$ tons containing copper, gold, silver, and zinc.

Twenty-one areas covering a total of $42 \mathrm{sq} \mathrm{mi}$ or about 4 percent of the study area are classified as having probable or substantiated resource potential on the basis of geologic, geochemical, aeromagnetic, past production, or present resource considerations. Five of these areas (areas $1,2,3,8,18$ ) have substantiated base and precious-metal resource potential. All contain demonstrated resources in known deposits and the classification is further supported by favorable geology, geochemical anomalies, and geophysical data. Four of these areas are areas of volcanogenic deposits, whereas one (3) has a substantiated resource potential for tactite deposits containing copper and silver and also has probable resource potential for tungsten in tactite, for volcanogenic copper, and for porphyry copper.

The remaining 16 areas are regarded as areas of probable mineral-resource potential. Ten of these areas $(5,6$, $9,10,11,14,15,16,17,19)$ are expected to contaim volcanogenic deposits of base and (or) precious metals. The identification of all these areas is supported by geochemical anomalies in the metals identified on the map; a few areas contain mines and prospects; several areas show hydrothermal alteration at the surface, others are interpreted to have rock alteration at depth based on analysis of magnetic data. 













slightly altered and deformed, and differ lithologically from those of the High Cascade Range; they are considered to be correlative with younger parts of the volcanics of the Western Cascade Range.

Numerous cinder cones associated with the Holocene flows are little modified by erosion and retain much of their constructional form. They are composed of differing amount of scoriaceous cinders, blocks of more massive material, spindle bombs, and irregular layers of partly agglutinated eruptive material; in some cones, massive flows and intrusive rocks are present.

Intrusive plugs are widely distributed throughout the Mount Jefferson Primitive Area. In places they occur as partly exhumed volcanic conduits forming the cores of large andesitic cones, such as Mount Jefferson and Three Fingered Jack; and in places they occur as almost completely exhumed rock masses. Some cones are little modified by erosion, only small parts of the intrusive plug or conduit being exposed through the mantle of eruptive flows and fragmental material.

Most of the plugs are texturally and mineralogically like the associated flows of the High Cascade Range, particularly in their chilled, more finely crystalline peripheral zones. Nearly all of these finer grained rocks are composed of various types of andesite or basaltic andesite. The cores of some plugs are more coarsely crystalline than the associated flows, contain little or no interstitial glass, and are classed as micronorite, microgabbro, or microdiorite, depending on the character and abundance of ferromagnesian minerals.

Dikes and stringers of andesite and basalt are prominantly exposed in some cirque walls and crisscross the tremendous piles of volcanic eruptive material that constitute Three Fingered Jack and Mount Jefferson. Elsewhere the cover of soil, talus, and vegetation so effectively mantles the slopes that the smaller dikes are concealed. Some of the large dikes acted as conduits and vents for widespread andesite and basalt flows. None of the dikes appear to have any associated alteration or sulfide mineralization.

Rocks that have been bleached and altered by fumarolic and solfateric processes during late stages of volcanism are present at several places, mostly close to the vents from which the andesites of the High Cascade Range erupted. Altered flows and pyroclastic rocks are lighter in hue than the fresh rocks, and locally are brightly stained with iron oxides. Many of the fractures and pore spaces in these rocks are filled with earthy to finely crystalline buff, white, or yellow encrustations, and in some localities with iron-stained clayey material. Analysis of these encrustations and pore fillings indicates the presence of alunite, native sulfur, and kaolinite(?). Inasmuch as alunite is a common constituent of metallic ore deposits in some volcanic terranes, a number of samples of the alunitized rocks were further analyzed for possible associated concentrations of base or precious metals, but none were found.

\section{MINERAL RESOURCES}

No metallic mineral deposits with resource potential were recognized in the Mount Jefferson Primitive Area during the investigation in 1965 , and evaluation of the geology and analyses of samples indicate that such deposits are not likely to be found.

Except for the discovery of weak alteration zones associated with some vent areas that are characterized by alunite, native sulfur, and kaolinite(?), the geologic examinations failed to reveal any evidence suggesting the presence of ore deposits with any resource potential. None of the faults or fracture zones either within or just outside the primitive area are mineralized, and there is no evidence of sulfide minerals or extensive alteration associated with any of the intrusive rocks. There are several claims in the area, presumably located for gold; analysis of samples collected from these claims failed to detect the presence of gold or anomalous amounts of other metals. To check further for exposed deposits of metallic minerals, the alluvial deposits were panned in a number of different places both within and just outside the border of the primitive area. No commercially valuable concentrations of metallic minerals were found.

The geologic and mineral appraisal of the primitive area indicates that the kinds of metallic ore deposits found to the west, associated with Miocene intrusive rocks and the mercury deposits in the Oak Grove area to the northwest, are not likely to occur except, possibly, at great depth. The structural downwarping and accompanying down-faulting of the central part of the Cascade Range, which depressed any sites geologically comparable to those that are mineralized in adjacent areas, and the very thick overlying pile of young andesitic and basaltic volcanic rocks, creates an environment highly unfavorable for any concentration of potentially valuable metallic minerals. The geology is typical of areas of young andesitic and basaltic volcanic rocks, none of which are known to contain commercial ore deposits in the entire Cascade Range.

The potential for thermal energy resources of the Mount Jefferson Primitive Area was investigated because of the occurrence of several groups of hot springs in nearby areas including one group at Breitenbush only a few miles to the northwest. Furthermore, the primitive area is located in a region dominated by late Cenozoic volcanism, which is geologically similar to some areas in other parts of the world that are being explored for thermal energy. Many springs are present within the 
area, some discharging large volumes of water; none of these springs, however, are thermal, and, because of their characteristically low temperature, most are thought to be fed only from snowmelt water. Also, no sinter or tufa deposits denoting ancient hot-springs sites are present. It may therefore be concluded that there is little promise for the discovery of thermal energy resourves.

\section{SUGGESTIONS FOR FURTHER STUDIES}

Further study of the primitive area offers little promise for the identification of hidden mineral deposits, but inasmuch as the area is within a region of abnormally high heat flow and is characterized by extensive young volcanism, some additional study of the potential for geothermal energy resources might be feasible.

\section{REFERENCES}

Callaghan, Eugene, 1933, Some features of the volcanic sequence in the Cascade Range in Oregon: Transactions of the American Geophysical Union, 14th Annual Meeting, p. 243-249.
Callaghan, Eugene, and Buddington, A. F., 1938, Metalliferous mineral deposits of the Cascade Range in Oregon: U.S. Geological Survey Bulletin 893, 141 p.

Peck, D. L., Griggs, A. B., Schlicker, H. G., Wells, F. G., and Dole, H. M., 1964, Geology of the central and northern parts of the western Cascade Range in Oregon: U.S. Geological Survey Professional Paper 449, 56 p.

Thayer, T. P., 1936, Structure of the North Santiam River section of the Cascade Mountains in Oregon: Journal of Geology, v. 44, no. 6, p. 701-716.

1937, Petrography of later Tertiary and Quaternary rocks of the north-central Cascade Mountains in Oregon, with notes on similar rocks in western Nevada: Geological Society of America Bulletin, v. 48, no. 11, p. 1611-1651.

Walker, G. W., Greene, R. C., and Pattee, E. C., 1966, Mineral resources of the Mount Jefferson primitive area, Oregon: U.S. Geological Survey Bulletin 1230-D, p. D1-D32.

Willams, Howel, 1944, Volcanoes of the Three Sisters region, Oregon Cascades: California University, Department of Geological Sciences Bulletin, v. 27, no. 3, p. 37-83.

1957, A geologic map of the Bend quadrangle, Oregon, and a reconnaissance geologic map of the central portion of the High Cascade Mountains: Oregon Department of Geology and Mineral Industries, in cooperation with U.S. Geological Survey, scale $1: 125,000$ and $1: 250,000$. 


\title{
MOUNT WASHINGTON WILDERNESS, OREGON
}

\author{
By EdWARD M. TAYlOR, U.S. GEOlOGiCAl SURVEY, and \\ J. Douglas Causey, U.S. Bureau of Mines
}

\section{SUMMARY}

On the basis of a mineral survey in 1980 and 1981, Mount Washington Wilderness has little promise for the occurrence of metallic mineral or fossil fuel resources. Abundant cinder resources occur in the wilderness, but other large volume cinder deposits are available outside the wilderness and closer to markets. Available data are insufficient to evaluate the geothermal resource potential of the wilderness.

\section{CHARACTER AND SETTING}

Mount Washington Wilderness occupies an area of 73 sq mi along the crest of the Cascade Range between McKenzie and Santiam Passes, 32 mi west of Bend, Oregon. The wilderness is the smallest of three nearly contiguous wildernesses that occupy most of a 65-milong north-south segment of the High Cascade physiographic province in central Oregon. The Pacific Crest National Scenic Trail extends north-south through these wilderness areas.

The nearest town is Sisters, 12 mi east of the wilderness. Hoodoo Butte, $3 \mathrm{mi}$ north of the wilderness, is the site of a small ski facility. Dee Wright Observatory at McKenzie Pass on the south margin of the wilderness is a popular tourist stop and provides a spectacular view of stark young lava flows and of Mount Washington and the Three Sisters stratovolcanoes.

Mount Washington is one of the smaller of the stratovolcanoes that form the prominent peaks of the Cascade Range in Oregon. It rises to an altitude of $7794 \mathrm{ft}$, but was once higher before being deeply glaciated. All other hills and small mountains in the wilderness are smaller volcanoes ranging from cinder cones a few tens of feet high to broad lava cones with summit vents. The lava platform on which they rest is mostly at an altitude of 4000 to $5000 \mathrm{ft}$. It slopes gently westward to the McKenzie River and merges eastward with the Deschutes Plateau.

Faults bound the High Cascade province east and west of the Mount Washington Wildernesss. The trough resulting from displacement on these faults has been filled by lava flows and related vent deposits that form the Mount Washington Wilderness. The oldest part of the sequence is dominantly basalt, and the younger rocks are basalt and basaltic-andesite.

All rocks within the Mount Washington Wilderness are of Quaternary age. With the exception of the oldest flows at the westernmost margin of the wilderness, all flows show normal magnetic polarity and thus likely formed during the last 0.7 million years. The flows and vents are readily divisible into Pleistocene and Holocene sequences.

The Pleistocene flows are glaciated and commonly covered by several feet of ground moraine or outwash deposits. These older flows were derived from cinder cones, fissure vents, and small composite volcanoes. The Pleistocene vents are modified by glacial scouring; in the cores of some the feeder dikes and plugs are now exposed.

Mount Washington belongs to this older group of volcanic rocks. It is a glacially gutted stratovolcano formed of basaltic andesite flows and pyroclastic rocks (cinders, scoria, palagonite tuff). A plug forms the summit and the upper flanks are cut by a north-southtrending swarm of basaltic andesite dikes. Mount Washington has no Holocene flows or pyroclastic rocks and is no longer active. It is similar in erosional form, and perhaps in age, to Mount Thielsen, farther south in the Cascade Range, which has yielded a potassiumargon age of 0.3 million years.

Holocene basalt and basaltic andesite flows cover approximately half of the Mount Washington Wilderness and extend beyond it several miles to the northwest and south. Few other areas in the Cascade Range have such areally extensive young flows. Carbon derived from beneath many of the flows has yielded ages of about 1500 to 3000 years based on carbon-14 dates. The 


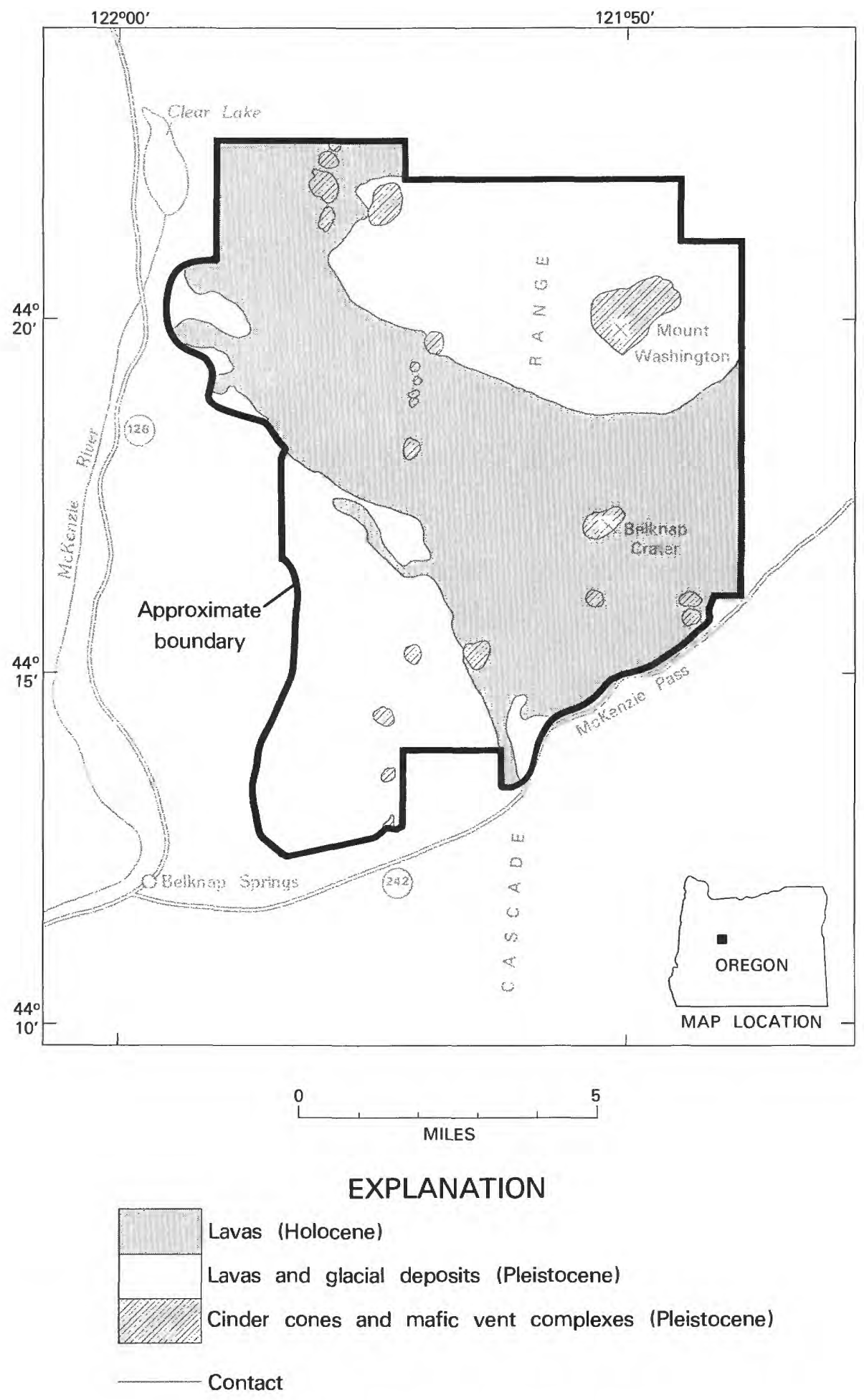

Figure 254.-Mount Washington Wilderness, Oregon. 
rugged surfaces of flows are mostly free of vegetation, but even the youngest ones, where covered by cinders from nearby vents, locally have trees growing on them. The flows are derived from a series of alined cinder cones and composite vents that probably were fed by en echelon fissures. The cinder cones are typically 150 to $300 \mathrm{ft}$ high. They are formed of grayish to reddish oxidized cinders, scoria, and welded spatter. The largest of the volcanic edifices is Belknap Crater, a lava shield with summit cinder cone, which rises $1600 \mathrm{ft}$ above the surrounding terrain.

\section{MINERAL RESOURCES}

Metallic mineral resources are not known within the High Cascade physiographic province of Oregon, of which the Mount Washington Wilderness is a part. Samples of stream sediment from the wilderness contain amounts of metallic elements similar to those commonly found in unaltered volcanic rocks.

Volcanic cinder is the only resource in the wilderness identified by this study. Large quantities of cinders outside the wilderness and closer to markets are more than adequate for regional needs.

Fossil fuel deposits, such as oil, gas, and coal, do not occur within the wilderness. A thick sequence of upper Eocene to Pliocene volcanic rocks with no hydrocarbon potential underlie the young flows and vents of the Mount Washington Wilderness.

The High Cascade physiographic province in Oregon is an area of interest for geothermal exploration, but the magnitude of the geothermal resource, if any, is not known. Hot springs are rare in the High Cascades, but occur locally along or just beyond the margins of the province, particularly on the west side. The springs emerge from valley bottoms and may occur along or near faults. They are interpreted to be the result of lateral flow of warm or hot water from heat sources beneath the High Cascades. Belknap Hot Spring, about $4 \mathrm{mi}$ southwest of the Mount Washington Wilderness, yields about 75 gallons of water per minute with a temperature of $180^{\circ} \mathrm{F}$. Within the High Cascades, the flows and interbedded breccias and other pyroclastic rocks are so permeable and porous that shallow lateral flow of cold ground water probably masks any deep geothermal anomalies that may exist.

The areally extensive Holocene basalt and basaltic andesite flows of the Mount Washington Wilderness may lead to falsely optimistic estimates of geothermal resources. These flows are derived mostly from alined vents that likely are the surface manifestations of buried fissures. In areas of intensive glaciation in the Cascade Range where surface rocks are deeply eroded, most exposed basaltic fissures (dikes) are only 3 to $10 \mathrm{ft}$ wide. The fissure feeders for the Holocene flows in the Mount Washington Wilderness likely did not contribute major amounts of heat to the shallow crust and much of this heat likely has been lost by conduction and ground water flow since they formed at least 1300 years ago.

\section{SUGGESTIONS FOR FURTHER STUDIES}

Analysis of the geothermal potential of the High Cascades province cannot be made without data on the subsurface thermal and hydrologic regimes which can only be provided by deep drill holes. Several deep holes could be drilled in areas outside the wildernesses of the High Cascades, from which extrapolations of the geothermal potential of the wildernesses could be made.

\section{REFERENGE}

Taylor, E. M., Causey, J. D., and MacLeod, N. S., in press, Geology and mineral resource potential map of the Mount Washington Wilderness, Deschutes, Lane, and Linn Counties, Oregon: U.S. Geological Survey Open-File Report 83-662. 

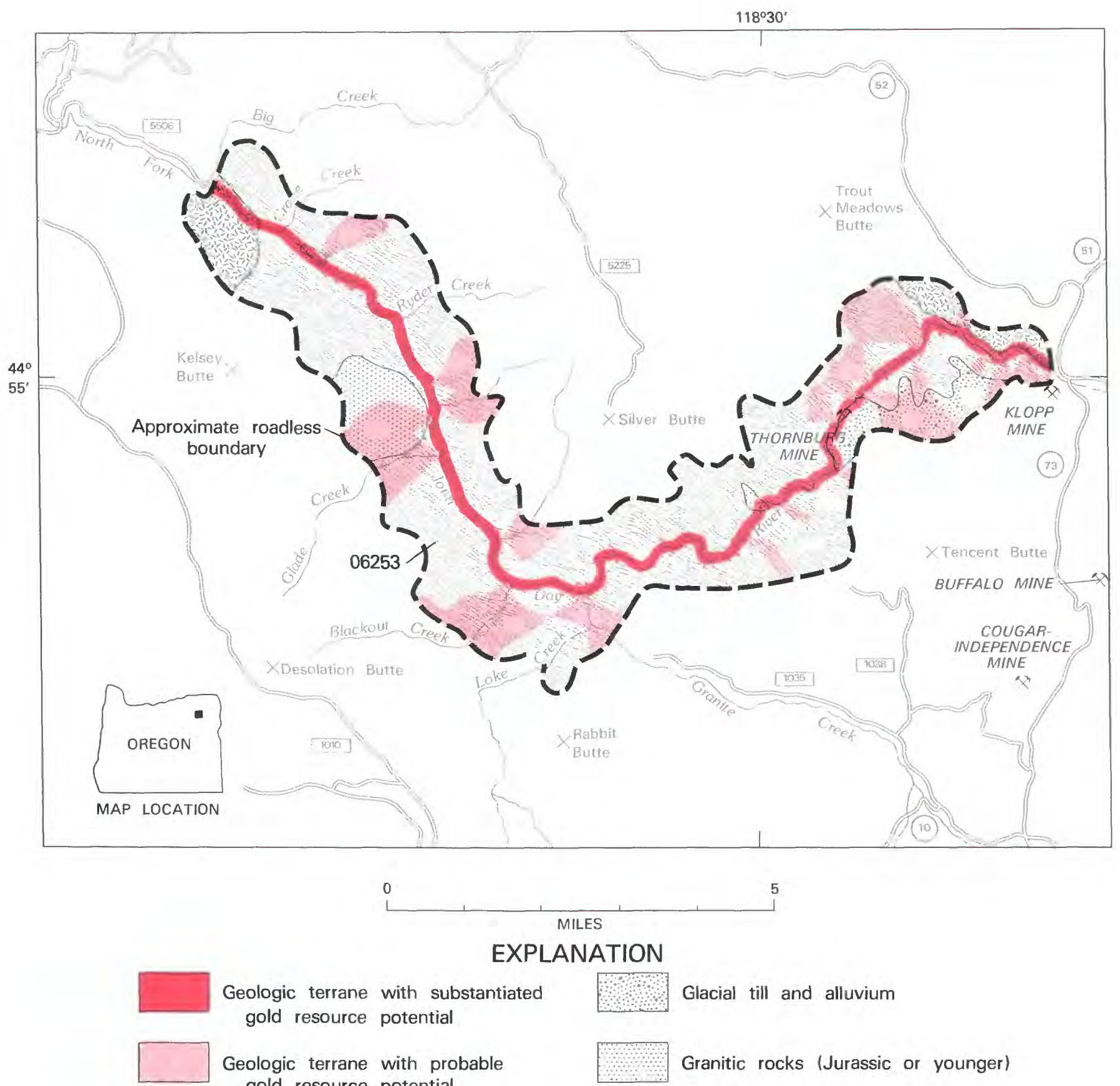

Geologic terrane with substantiated gold resource potential

Geologic terrane with probable gold resource potential

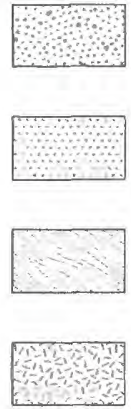

Glacial till and alluvium

Granitic rocks (Jurassic or younger)

a Mine

Argillite and volcanic rock (Late Paleozoic and Triassic)

Diorite (Paleozoic or Triassic)

Contact

Figure 255.-North Fork John Day River Roadless Area, Oregon. 


\title{
NORTH FORK JOHN DAY RIVER ROADLESS AREA, OREGON
}

\author{
By James G. Evans, U.S. Geological Survey, and \\ MarTin D. CONYAC, U.S. BUREAU OF MiNES
}

\begin{abstract}
SUMMARY
A mineral survey of the North Fork John Day River Roadless Area in 1980-82 indicates that a narrow belt along the river has a substantiated resource potential for placer gold, and several other drainages tributary to the North Fork have a probable resource potential for placer or lode gold.
\end{abstract}

\section{CHARACTER AND SETTING}

The North Fork John Day River Roadless Area covers $33 \mathrm{sq} \mathrm{mi}$ in the Blue Mountains, Grant County, Oregon. The irregularly shaped area is about $30 \mathrm{mi}$ west-northwest of Baker, and extends for about $1 \mathrm{mi}$ on either side of a 25-mi-long segment of the North Fork John Day River. The altitude of the river falls from about $5200 \mathrm{ft}$ at the east end of the area to about $3300 \mathrm{ft}$ at the west end. It is flanked by steep canyon walls and side ridges that rise 1000 to $2500 \mathrm{ft}$ above the river to a maximum altitude of $6100 \mathrm{ft}$. Due to the topographic configuration and the dense forest, panoramas of the canyon are available only from certain ridges located 0.5 to $1 \mathrm{mi}$ from the river. Access to the roadless area is by USFS roads. Road 73 provides access to the east end of the area; road 5225 to the north side; roads 10,1010 , and 1035 to the south side; and road 5506 to the west end.

Most of the roadless area is underlain by two distinct rock assemblages, which have been juxtaposed by faulting. The most widespread assemblage consists mainly of black argillite of late Paleozoic and Triassic age, representing deposits of marine mud. The other assemblage, consisting chiefly of green tuff and andesite, representing volcanic ash falls and flows of late Permian or older age, may be at least $2000 \mathrm{ft}$ thick. They were juxtaposed by faulting, approximately in the Triassic. A very broad zone of intensely faulted rock (melange) was developed in terrane to the south of the present North Fork John Day River, including the southern tip of the roadless area. Most of the melange in the roadless area was derived from the argillite assemblage. A diorite, possibly of Paleozoic or Triassic age with textures indicating a history of crystallization from magma, later deformation, recrystallization, and in- tense fracturing, was probably faulted contemporaneously against the argillite. Four Jurassic or younger granitic bodies were intruded after the faulting. A long period of uplift and erosion ended when the rocks described above were partly buried by a conglomerate (Eocene and Oligocene) derived from the older rocks and by a post-Oligocene assemblage of basalt, andesite and volcanic ash flows. Boulders and gravel carried by glaciers during the last glacial advance blanket parts of the eastern end of the roadless area. Other parts are covered by a thick mantle of rock and soil and by reworked volcanic ash, which may be younger than the glacial deposits.

The roadless area lies in the Granite and North Fork mining districts. Gold placer mining began in 1861 in the Granite district and in 1845 in the North Fork district, and has continued intermittently (Conyac, 1983). No lode mining is known from the roadless area. Lode mining was more important to the southeast in the Granite district. Claims in the roadless area numbered over 200 in 1980. Most are along the North Fork John Day River. Approximately one million cubic yards of placer gravel have been mined in the roadless area, mostly from four or five large deposits including the Thornburg mine. Production is unknown and an estimate of production is not possible due to lack of records.

Geochemical and resource studies of the area in 1980-82 included sampling of silt and collection of panned concentrates from streams, collecting alluvial samples from placer deposits, and sampling mineralized rock. The samples were analyzed for gold and other elements by the USGS and USBM. The results of these analyses along with discussions of the geology have been published (Conyac, 1983; Evans and Conyac, 1983). The mineral-resource evaluation of the roadless area is based on these analyses and the geology. 


\section{MINERAL RESOURCES}

Placer deposits containing gold resources exist in an area of substantiated resource potential along the North Fork John Day River. A probable resource potential for gold in lode or placer deposits exists in several other areas. One hundred fourteen auriferous placer deposits identified along the river within the roadless area, contain nearly 3 million cubic yards of gold-bearing material in fossil and present-day river gravels. Placer deposits in the central part of the roadless area contain the most gold per cubic yard, but the deposits are relatively small in volume. The area along the present river has a substantiated potential for gold resources.

A probable resource potential for gold is inferred for 21 drainages tributary to the North Fork John Day River. Gold resources would be in recent or Holocene stream gravels, pre-Holocene placer deposits, or mineralized bedrock underlying the drainage basins. Some small areas adjacent to gold-bearing drainages were not sampled, and it is possible that some of the unsampled ground may have gold resource potential.

\section{SUGGESTIONS FOR FURTHER STUDY}

Further study of the roadless area may reveal other areas with a potential for gold, and could help to delineate bedrock or additional placer resources. especially in drainages tributary to the North Fork. This work could also point to other mineral deposits near the roadless boundary.

\section{REFERENCES}

Conyac, M. D., 1983, Mineral investigations of the North Fork Johr Day River Rare II Area (No. B6253), Grant County, Oregon: U.S. Bureau of Mines Open-File Report MLA 34-83.

Evans, J. G., and Conyac, M. D., 1983, Mineral resource potentia' map of the North Fork John Day River Roadless Area, Gran', County, Oregon: U.S. Geological Survey Miscellaneous Field Studies Map MF-1581-A, scale 1:48,000. 


\title{
OLALLIE ROADLESS AREA, OREGON
}

\author{
By GeOrge W. Walker, U.S. Geological SuRvey, and \\ TERry R. NEUMANN, U.S. BUREAU OF Mines
}

\begin{abstract}
SUMMARY
The Olallie Roadless Area, Oregon, is devoid of mines and mineral prospects, and a mineral-resource evaluation of the area in 1981 did not identify any mineral-resource potential. There is no evidence that fossil fuels are present in the roadless area. Nearby areas in Clackamas, Marion, Jefferson, and Wasco Counties are characterized by higher-than-normal heat flow and by numerous thermal springs, some of which have been partly developed. This may indicate that the region has some, as yet undefined, potential for the development of geothermal energy. Lack of thermal springs or other evidence of localized geothermal anomalies within the roadless area may be the result of masking by young, nonconductive rock units and by the flooding out and dilution of rising thermal waters by cool meteoric water.
\end{abstract}

\section{CHARACTER AND SETTING}

The Olallie Roadless Area is in Mt. Hood National Forest, in northwest- to north-central Oregon along and immediately west of the crest of the Cascade Range; Mount Jefferson Wilderness lies adjacent to the south. The area is mostly in Marion County, but extends a short distance into Jefferson County.

The area is irregular in shape and consists of about $13 \mathrm{sq} \mathrm{mi}$ that is characterized by gently sloping upland surfaces surmounted by small volcanic cones mostly less than $300 \mathrm{ft}$ high. The southwest border of the roadless area is along the steep canyon wall of the North Fork of the Breitenbush River.

Prior to the present study, the geology of Olallie Roadless Area was mapped in broad reconnaissance by Thayer (1939) as part of a regional study of the geology and petrology of a large segment of the north-central Cascade Range in Oregon. Hammond and others (1980) prepared a "Guide to the geology of the upper Clackamas and North Santiam Rivers area, northern Oregon Cascade Range," which included the Olallie Butte area in broad reconnaissance, and White (1980) briefly discussed the geology of the Breitenbush Hot Springs quadrangle, which incorporates all of the roadless area.

All the rocks in and near the Olallie Roadless Area are of Cenozoic age, and principally include basaltic andesite and andesite flows and flow breccias, as well as volcanic vent accumulations, all part of the stratigraphic sequence generally referred to as "volcanic rocks of the High Cascade Range." Much of the roadless area is buried under a veneer of glacial till.

Most of the roadless area is underlain by fresh flows and flow breccias of light- to dark-gray hypersthene, clinopyroxene, or olivine basaltic andesite, or locally, platy, pyroxene or olivine andesite. Nearly all these rocks are porphyritic and contain phenocrysts of these varietal minerals as well as abundant phenocrysts of labradorite or calcic andesine and, rarely, magnetite. In a few places the olivine is only slightly altered to iddingsite on crystal margins, but otherwise these rocks show no evidence of alteration. Magnetic polarity measurements indicate that all these rocks are normally $(\mathrm{N})$ polarized and thus are most likely of Pleistocene age.

Vents for the flows and breccias occur both in and marginal to the roadless area and consist of cinder cones, small lava cones from which cinders have been largely removed by erosion, and dikes.

Domelike masses of unaltered hornblende dacite are exposed in several places in the roadless area. The dacite contains fairly abundant phenocrysts of andesine and dark reddish-brown basaltic hornblende, which, in thin section, is commonly shown to have been thermally baked and altered on crystal margins to magnetite, reddish iron-oxides, presumably mostly hematite, and other unidentified alteration products.

Glacial till composed of angular blocks of basaltic andesite and andesite suspended in a matrix of finegrained rock flour covers about 50 percent of the roadless area. In a few places this veneer is thin and small 


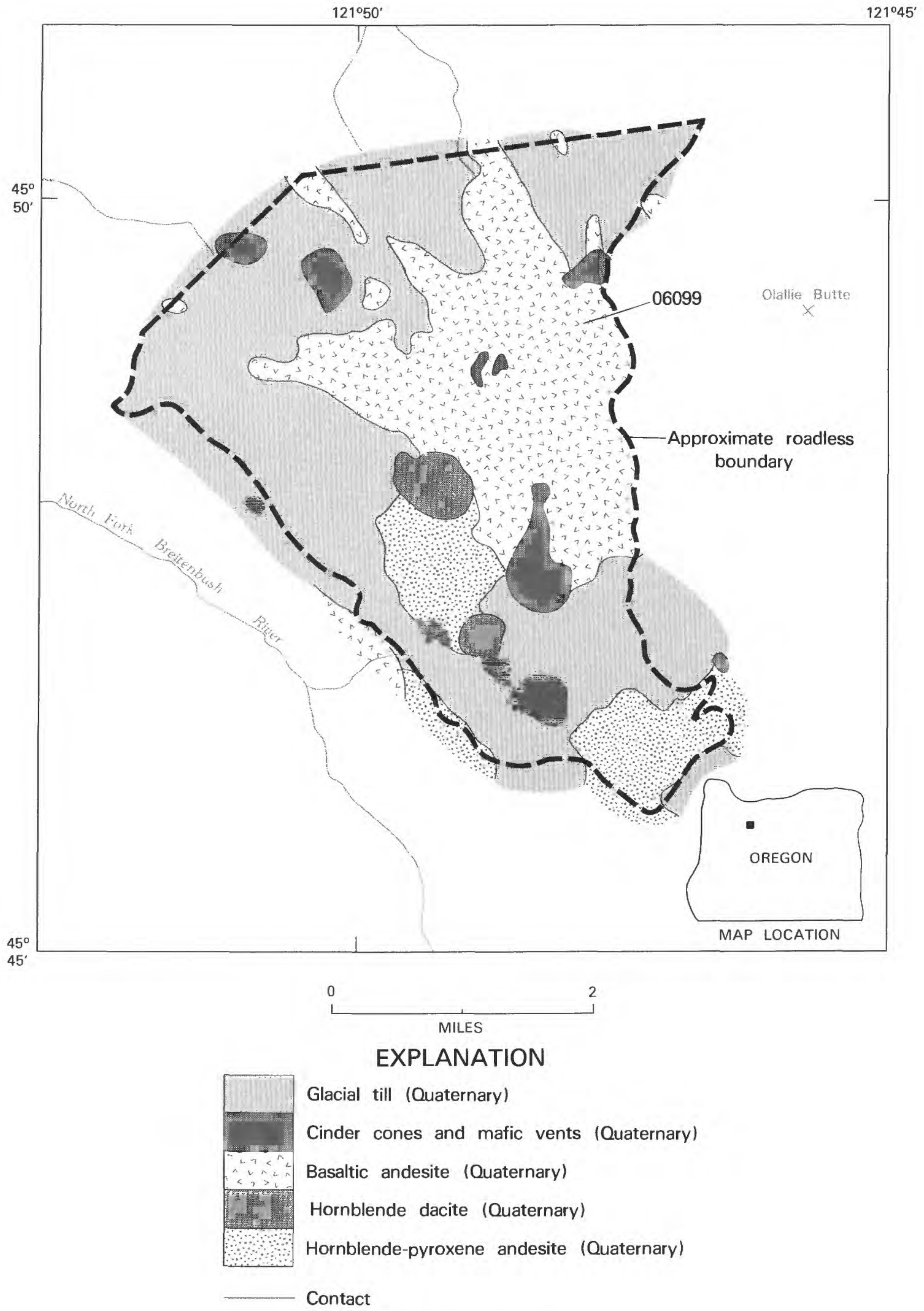

Figure 256.-Olallie Roadless Area, Oregon. 
bedrock outcrops project through it, but elsewhere it is several tens of feet thick, completely obscuring the underlying rocks. The source of the glacial till is not known, but presumably it is derived largely from areas of high altitude lying to the south along the crest of the Cascade Range near and north of Mt. Jefferson. On some slopes and in stream beds the fine-grained rockflour matrix of the till has been completely removed by erosion leaving a lag gravel of coarse blocks of basaltic andesite and andesite.

\section{MINERAL RESOURCES}

There is no past record of either mining or quarrying within the roadless area nor were any occurrences of metallic minerals, prospect pits, or claims recognized during the present investigation. Hot springs in areas adjacent to the roadless area suggest that there may be some undetermined potential for the development of geothermal energy.

The nearest metallic mineral occurrences include mercury deposits in the Oak Grove Fork area of the Clackamas River (Brooks, 1963), about 12 mi north- northwest of the roadless area. Mercury mineralization has been reported from hot-spring travertine terrace deposits at Breitenbush Hot Springs, about $6 \mathrm{mi}$ to the southwest, but there is no record of production from these occurrences.

Some of the volcanic cinders (scoria) within the Olallie Roadless Area are suitable for use as road ballast or surfacing and possibly as lightweight concrete aggregate, but similar rock material is abundantly present in more accessible deposits in nearby areas.

Insofar as can be determined from surface geologic features, there is no evidence that the Olallie Roadless Area has a potential for fossil fuels, although it may have a potential for geothermal energy. There are no thermal springs within the roadless area, but several hot springs are present in nearby areas. Breitenbush Hot Springs, on the North Fork of the Breitenbush
River, includes a group of about 40 springs that collectively discharge about 900 gallons of water per minute at a temperature of $198^{\circ} \mathrm{F}$ (Bowen and Peterson, 1970). Austin Hot Springs are located on the Clackamas River, about $16 \mathrm{mi}$ to the northwest of the Olallie Roadless Area; they discharge hot water $\left(196^{\circ} \mathrm{F}\right)$ at a rate of about 250-300 gallons per minute. Thermal springs also are present on the Warm Springs Indian Reservation about $28 \mathrm{mi}$ to the east (Robison and Laenen, 1976). The entire region along this part of the Cascade Range in Oregon is characterized by heat flow that is 2 to 3 times normal (Riccio, 1978). The potential significance of this higher-than-normal heat flow has yet to be determined.

\section{REFERENCES}

Bowen, R. G., and Peterson, N. V., 1970, Thermal springs and wells, in Oregon: Oregon Department of Geology and Mineral Industries Miscellaneous Paper 14.

Brooks, H. C., 1963, Quicksilver in Oregon: Oregon Department of Geology and Mineral Industries Bulletin 55, 223 p.

Hammond, P. E., Anderson, J. L., and Manning, K. J., 1980, Guide to the geology of the upper Clackamas and North Santiam Rivers area, northern Oregon Cascade Range: Oregon Department of Geology and Mineral Industries Bulletin 101, p. 133-167

Riccio, J. F., 1978, Preliminary geothermal resource map of Oregon: Oregon Department of Geology and Mineral Industries Geologic Map Series Map GMS-11, scale 1:500,000.

Robison, J. H., and Laenen, Antonius, 1976, Water resources of the Warm Springs Indian Reservation, Oregon: U.S. Geological Survey Water Resources Investigations 76-26, 85 p.

Thayer, T. P., 1937, Petrography of later Tertiary and Quaternary rocks of the north-central Cascade Mountains in Oregon, with notes on similar rocks in western Nevada: Geological Society of America Bulletin, v. 48, no. 6, p. 1611-1651.

1939, Geology of the Salem Hills and the North Santiam River basin, Oregon: Oregon Department of Geology and Mineral Industries Bulletin 15, $40 \mathrm{p}$.

Walker, G. W., 1982, Mineral resource potential of the Ollalie Roadless Area, Marion and Jefferson Counties, Oregon: U.S. Geological Survey Open-File Report 82-885.

White, Craig, 1980, Geology of the Breitenbush Hot Springs quadrangle, Oregon: Oregon Department of Geology and Mineral Industries Special Paper 9, 26 p. 


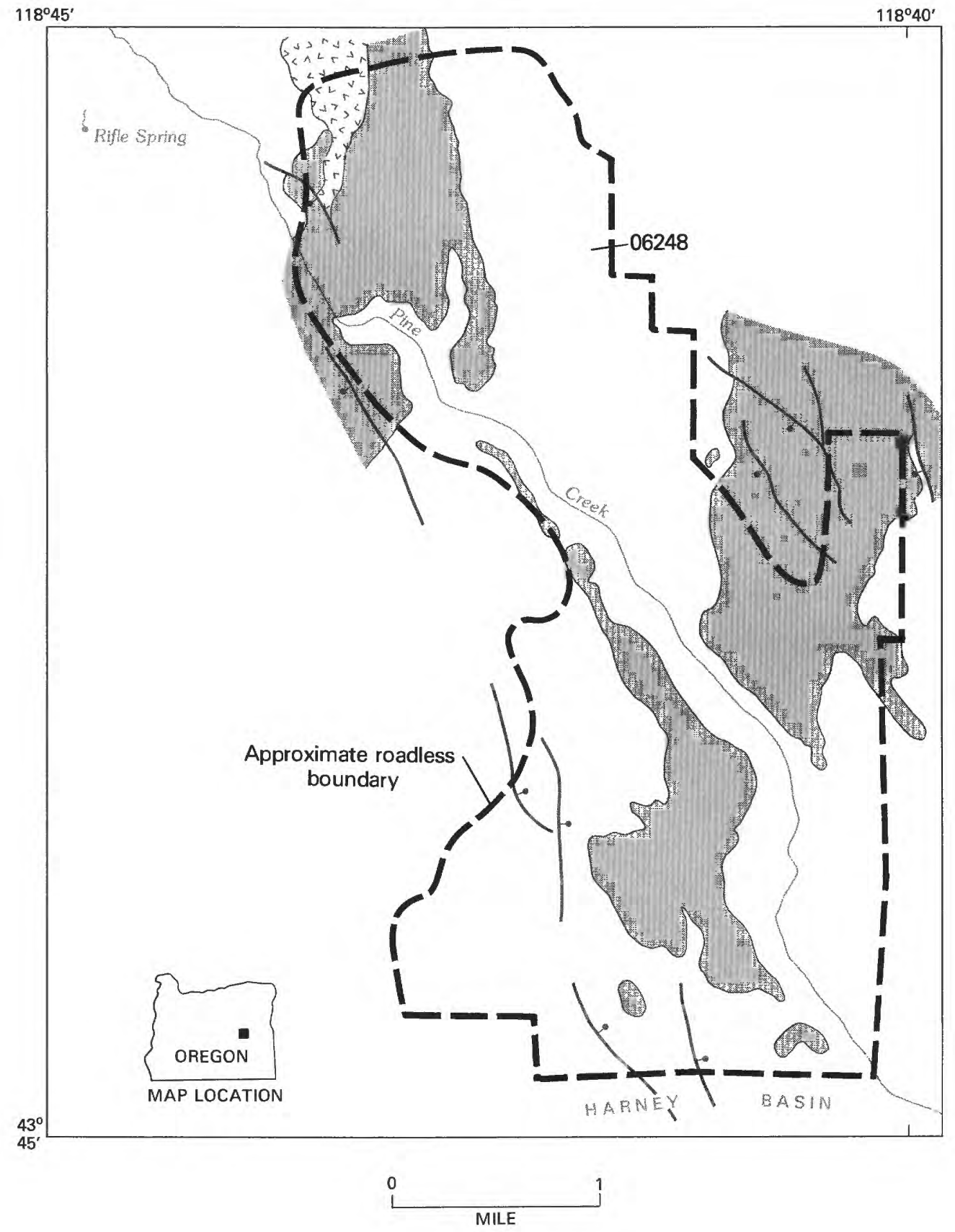

EXPLANATION

Ash-flow tuffs and tuffaceous sediments (Miocene)

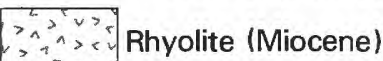

Basalt and andesite flows, breccias, and tuffs (Miocene)

Figure 257.-Pine Creek Roadless Area, Oregon. 


\title{
PINE CREEK ROADLESS AREA, OREGON
}

\author{
By George W. Walker, U.S. Geological Survey, and \\ David K. DENTON, JR., U.S. BUREAU of Mines
}

\begin{abstract}
SUMMARY
Examination of the Pine Creek Roadless Area, Oregon, in August 1979, indicates that there is little likelihood for the occurrence of energy or metallic mineral resources in the area. No mines or mineral prospects were identified during the investigation. Although nearby parts of Harney Basin are characterized by higher than normal heat flow, indicating that the region as a whole may have some as yet undefined potential for the occurrence of geothermal energy resources, no potential for this resource was identified in the roadless area.
\end{abstract}

\section{CHARACTER AND SETTING}

The Pine Creek Roadless Area is near the southern margin of the Malheur National Forest, northeastern Harney County, Oregon, about $22 \mathrm{mi}$ northeast of Burns. The area, about $8.5 \mathrm{sq} \mathrm{mi}$, lies along both sides of a 5-mi-long southeast-trending remote and undeveloped segment of Pine Creek and includes high-level bluffs along both sides of the creek. Although Pine Creek drains eastward into the Mallieur River, the western and southwestern margins of the roadless area are adjacent to the divide with Harney Basin, a large physiographic and structural basin with internal drainage (Piper and others, 1939; Walker, 1979). Rock units and structures present in the area are characteristic of those found in the northeastern part of Harney Basin.

Prior to this study, the geology of the Pine Creek Roadless Area was mapped in reconnaissance by Greene and others (1972) as part of a regional study of the Burns $1^{\circ} \times 2^{\circ}$ quadrangle. Lithologic units shown on their geologic map are readily equated with units shown on the geologic map prepared for this study (Walker, 1980a), although some terminology has been modified and $a$ few additional rock units have been delineated. A description of the petrography of a prominent and widespread ash-flow tuff (Devine Canyon) by Greene (1973) and a report on the stratigraphic section of Harney Basin (Walker, 1979) provide additional background information.

The rocks in and near the roadless area are of Miocene or younger age, and represent part of a faulted and warped monoclinal sequence that dips generally southward into the central part of Harney Basin. Restricted patches of late Pleistocene or Holocene surficial deposits occur locally.

The oldest rocks consist of an interlayered sequence of basalt and andesite flows and flow breccias, tuff, and minor interbeds of pumiceous and ashy tuffaceous sedimentary rocks. They are part of a regionally extensive unit, which is about 19 to 12 million years (middle? Miocene) old. The base of the sequence is not exposed so the total thickness of it is not known; however a stratigraphic section about $800 \mathrm{ft}$ thick is exposed within the area on the canyon walls of Pine Creek and as much as $3000 \mathrm{ft}$ is exposed in and marginal to Harney Basin. Rocks older than the basalt and andesite sequence, principally Jurassic volcanic sandstone and mudstone, are exposed many miles to the north and presumably some of these rocks are present at depth in the Pine Creek Roadless Area.

Rhyolite flows rest discordantly on the basalt and andesite flows and tuffs in the northern part of the roadless area, as well as west of the area on the ridge south of Rifle Spring. The rhyolite is a 100 or more feet thick, is flow banded, and shows little silicification or alteration. Locations of vents for the flows are not known, but must be nearby and probably buried by the flows. The rhyolite has not been isotopically dated, but it overlies rocks dated in the range of 19 to 12 million years and underlies an ash-flow tuff dated from material collected in adjacent areas at 9.2 to 9.3 million years (Greene, 1973; Walker, 1979).

Stratigraphically above the rhyolite is a discontinuous sheet of crystal-rich tuff that locally rests on a somewhat irregular surface on the basalt and andesite unit. The tuff includes either two separate crystal-rich 
ash flows or possibly one ash flow with mineralogically distinct zones, and is part of the Devine Canyon Ashflow Tuff (Walker, 1979). Samples collected in and marginal to Harney Basin have given an age of about 9.2 or 9.3 million years (Greene, 1973), and are late Miocene.

The youngest rock unit in the area, exclusive of the unconsolidated surficial deposits, is a pumiceous, rhyolitic ash-flow tuff that occurs in discontinuous patches and is generally less than $20 \mathrm{ft}$ thick. Locally it rests with slight discordance on the basalt and andesite unit, but throughout most of the area it lies either directly on the Devine Canyon Ash-flow Tuff or on a thin and discontinuous septum of poorly exposed tuff consisting partly of unwelded ash-flow material and partly of airfall pumice. From its stratigraphic position and lithologic character, it is correlated with the Prater Creek Ash-flow Tuff (Walker, 1979), which is about 8.4 million years old (Parker, 1974, p. 13; Parker and Armstrong, 1972).

Alluvium, in the form of sand, silt, gravel, and locally some boulders, is present along segments of Pine Creek, but occurs in patches sufficiently large to be mapped only at the northern end of the area.

The Pine Creek Roadless Area is on the northern margin of the Harney Basin, a broad, downwarp. The central part of the basin is located east and southeast of Burns in which most layered units generally dip gently toward the central part of the basin. In the area the rocks tend to dip gently to the south, toward the basin center, although northwest-trending normal faults and local small warps have locally disrupted some layered units. Where this disruption has occurred, both east and west dips of as much as about $10^{\circ}$ have been recognized, as well as fault displacements of $50 \mathrm{ft}$ or more. The fault zones are poorly exposed, and rarely exhibit evidence of extensive shearing or brecciation. Within the Pine Creek Roadless Area, the faults show no evidence of associated alteration or mineralization.

\section{MINERAL RESOURCES}

This study concluded that there is little likelihood for the occurrence of energy or metallic mineral resources in the Pine Creek Roadless Area. There is no past record of either mining or quarrying in the area and no metallic mineral occurrences or prospect pits were recognized during the present investigation. Volcanic rock suitable for construction purposes is present in parts of the roadless area, but better quality and more readily accessible material is abundant elsewhere. There is no evidence that the roadless area contains deposits of mineral fuels or a potential for development of geothermal energy. There are no thermal springs within the area, although it lies near the margin of a region characterized by slightly higher than normal heat flow and numerous thermal springs and wells.

\section{REFERENCES}

Greene, R. C., 1973, Petrology of the welded tuff of Devine Canyon, southeast Oregon: U.S. Geological Survey Professional Paper $797,26 \mathrm{p}$.

Greene, R. C., Walker, G. W., and Corcoran, R. E., 1972, Geologic map of the Burns quadrangle, Oregon: U.S. Geological Survey Miscellaneous Geologic Investigations Map I-680, scale 1:250,000.

Parker, D. J., 1974, Petrology of selected volcanic rocks of the Harney Basin, Oregon: Corvallis, Oregon State University, Ph. D. thesis, $110 \mathrm{p}$.

Parker, D. J., and Armstrong, R. L., 1972, K-Ar dates and Sr isotope ratios for volcanic rocks in the Harney Basin, Oregon: Isochron/West, no. 5, p. 7-12.

Piper, A. M., Robinson, T. W., and Park, C. F., Jr., 1939, Geology and ground-water resources of the Harney Basin, Oregon, with a statement on Precipitation and tree growth, by L. T. Jessup: U.S. Geological Survey Water-Supply Paper 841, 189 p.

Walker, G. W., 1979, Revisions to the Cenozoic stratigraphy of Harney Basin, southeastern Oregon: U.S. Geological Survey Bulletin 1475,35 p.

1980a, Maps showing geology and geochemical sample localities, Pine Creek (RARE II) area, Harney County, Oregon: U.S. Geological Survey Miscellaneous Field Studies Map MF-1237, scale 1:31,130.

$1980 \mathrm{~b}$, Mineral resource potential of the Pine Creek (RARE II) area, Oregon: U.S. Geological Survey Open-File Report 80-989, $7 \mathrm{p}$.

Walker, G. W., and Denton, D. K., Jr., 1982, Mineral resource potential of the Pine Creek Roadless Area, Harney County, Oregon: U.S. Geological Survey Open-File Report 82-822, 9 p. 


\title{
SKY LAKES ROADLESS AREA AND MOUNTAIN LAKES WILDERNESS, OREGON
}

\author{
By James G. Smith, U.S. Geological Survey, and \\ JOHN R. BENHAM, U.S. BUREAU OF MINES
}

\begin{abstract}
SUMMARY
Based on a mineral survey in 1978 of the Sky Lakes Roadless Area and the Mountain Lakes Wilderness, Oregon, the areas have little or no promise for the occurrence of metallic-mineral resources or geothermal energy resources. Nonmetallic resources exist in the areas, but other areas outside the roadless area and wilderness also contain resources of volcanic cinders, scoria, ash, breccia, and sand and gravel which are easier to obtain and closer to markets. The roadless area and wilderness are not geologically favorable for metallic deposits, or for coal, oil, or gas resources.
\end{abstract}

\section{CHARACTER AND SETTING}

The Sky Lakes Roadless Area and Mountain Lakes Wilderness lie along the crest of the Cascade Range in southern Oregon. Sky Lakes Roadless Area, which is adjacent to the south boundary of Crater Lake National Park, comprises some $112 \mathrm{sq} \mathrm{mi}$ in Rogue River National Forest and $69 \mathrm{sq} \mathrm{mi}$ in Winema National Forest. Access on the north is by State Highway 62, on the south by State Highway 140, and on the east and west by county and USFS roads. However, only foot trails provide access within the roadless area. Mountain Lakes Wilderness, $19 \mathrm{mi}$ northwest of Klamath Falls, Oregon, comprises $36 \mathrm{sq} \mathrm{mi} \mathrm{in} \mathrm{the} \mathrm{Winema} \mathrm{National}$ Forest. State Highway 140 passes just north of the area and a network of paved secondary and unpaved logging roads provide good access to the east, south, and west sides.

The Sky Lakes Roadless Area and Mountain Lakes Wilderness are underlain by volcanic rocks of late Miocene to Holocene age which are part of the sequence of volcanic rocks of the High Cascade Range. Extensive glacial deposits mantle large parts of both the roadless area and wilderness. Volcanic rocks of the High Cascade Range occur in andesite stratovolcanoes and less prominent basalt and basaltic-andesite shield volcanoes, as well as small generally monogenetic volcanoes of basalt, basaltic andesite or andesite, extensive valley-filling flows, and cinder cones. Constructional volcanic landforms predominate, although stream erosion and glacial action has considerably modified the symmetrical shapes of older volcanoes. Eroded lavas of Bessie Rock volcano exposed $3 \mathrm{mi}$ west of Sky Lakes Roadless Area are about 4.9 m.y. (million years) old and lavas of Burton Butte $2 \mathrm{mi}$ southwest of Mountain Lakes Wilderness are about 3.35 m.y. old; the latter age has a large analytical error. The oldest dated rock unit in either area is the pyroxene andesite found in the Mountain Lakes Wilderness. A sample collected a short distance west of the wilderness from a valley-filling flow near Lake of the Woods gave an age of about 3.6 m.y.

More than three-quarters of the individually mapped volcanic units in the roadless area and wilderness forned between 3.5 m.y. and 500,000 years ago. In addition, most of the vents mapped as the undifferentiated olivine phyric basalt of the High Cascade Range and the undifferentiated andesite of the High Cascade Range probably erupted in this interval as well. Volcanic units younger than 500,000 years include the stratovolcano of Mount McLoughlin, two small basaltic shield volcanoes, a chain of pyroxene andesite vents, numerous cinder cones, and pumice and ash deposits from the climactic eruptions of Mount Mazama. Surficial deposits consist of loose aggregates of boulders, cobbles, pebbles, gravel, sand, silt, and clay deposited as alluvium along stream valleys; alluvial fans at the mouths of streams; and glacial deposits in glacially carved canyons and along the broad crest of the Cascade Range.

Extensive ice sheets extended over most of the roadless area and wilderness more than once, covering the crest of the Cascades to a depth of hundreds of feet. 


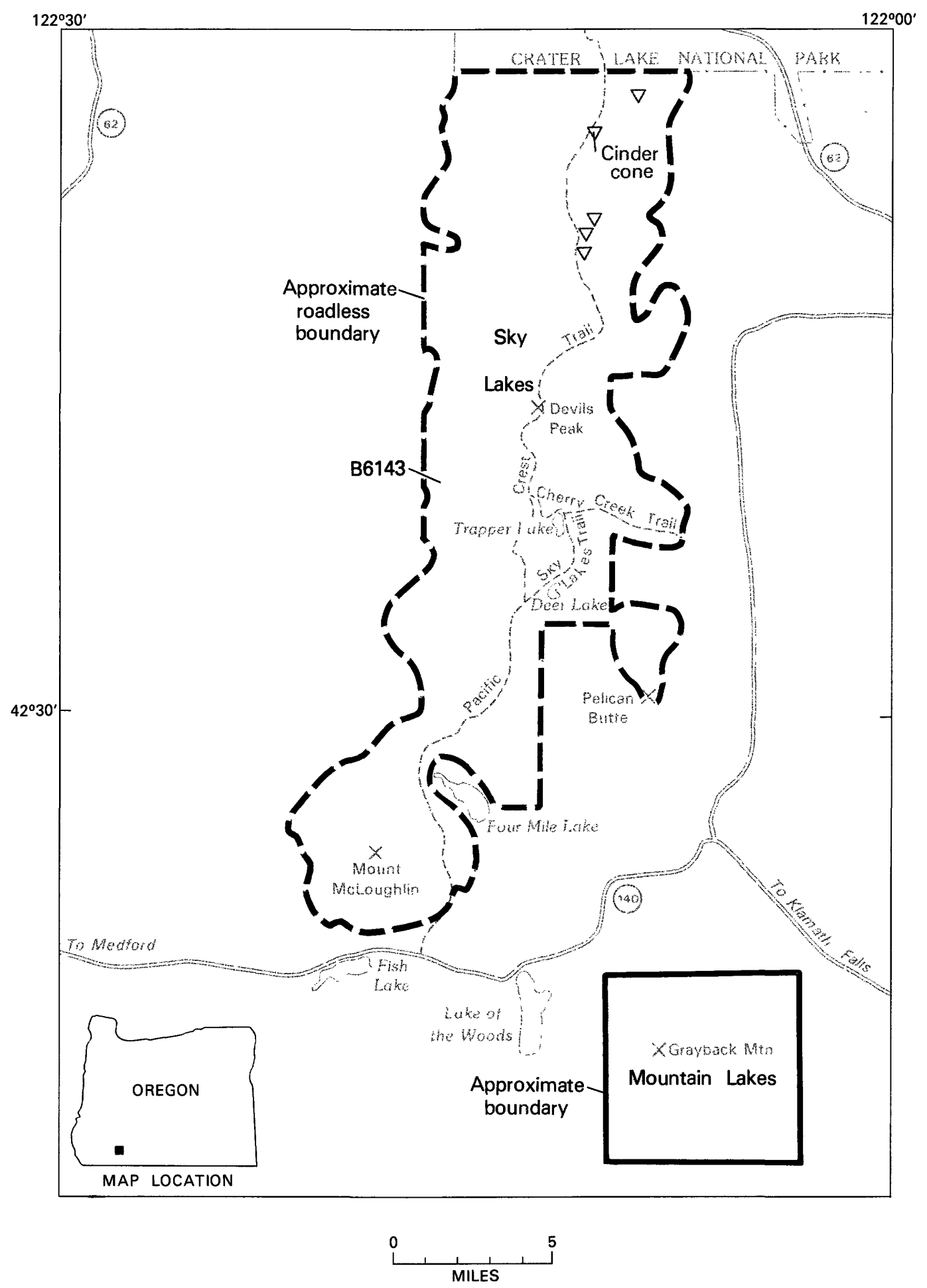

Figure 258.-Sky Lakes Roadless Area and Mountain Lakes Wilderness, Oregon. 
Valley glaciers spread eastward down canyons to altitudes as low as $4140 \mathrm{ft}$ at Upper Klamath Lake and westward to altitudes as low as $3600 \mathrm{ft}$ (Carver, 1972).

\section{MINERAL RESOURCES}

No mining districts occur within the Sky Lakes Roadless Area or Mountain Lakes Wilderness, and no mining claims have been recorded in either area. Geologic mapping, aeromagnetic surveys, and spectrographic analyses of rocks and stream sediments by the USGS and field observations, scintillation surveys, and assays of samples from the most likely sites within the area by the USBM failed to show any evidence of mineralization or hydrothermally altered areas (Smith and others, 1983). As a result of these studies the Sky Lakes Roadless Area and the Mountain Lakes Wilderness have little promise for the occurrence of metallic mineral or energy resources. Volcanic cinders, scoria, ash, and breccia which could be used in road construction, along with sand and gravel, occur in the area, but these deposits are remote, and larger deposits of equal or better quality occur at more accessible localities in nearby areas, outside the roadless area and wilderness boundaries.

In the United States, the only areas of development or active exploration for geothermal energy are associated with either young silicic volcanic rocks or regions of exceptionally high heat flow in extensional tectonic zones characterized by numerous normal faults. To date, the largest geothermal systems with the highest temperatures generally are those associated with very young volcanic fields (Smith and Shaw, 1975). Within the roadless area and wilderness, there are no young suitably silicic volcanic rocks exposed at the surface. Geologic mapping and aeromagnetic and gravity surveys likewise give no indication of buried silicic magma bodies of sufficient size to serve as sources of heat for geothermal systems.

\section{REFERENCES}

Carver, G. A., 1972, Glacial geology of the Mountain Lakes Wilderness and adjacent parts of the Cascade Range, Oregon: Seattle, University of Washington, Ph.D. thesis, 83 p.

Smith, J. G., Benham, J. R., and Johnson, F. L., 1983, Mineral resource potential map of the Sky Lakes Roadless Area and Mountain Lakes Wilderness, Jackson and Klamath Counties, Oregon: U.S. Geological Survey Miscellaneous Field Studies Map MF-1507-B, scale 1:62,500.

Smith, R. L., and Shaw, H. R., 1975, Igneous-related geothermal systems, in White, D. E., and Williams, D. L., eds., Assessment of geothermal resources of the United States-1975: U.S. Geological Survey Circular 726, p. 58-83. 

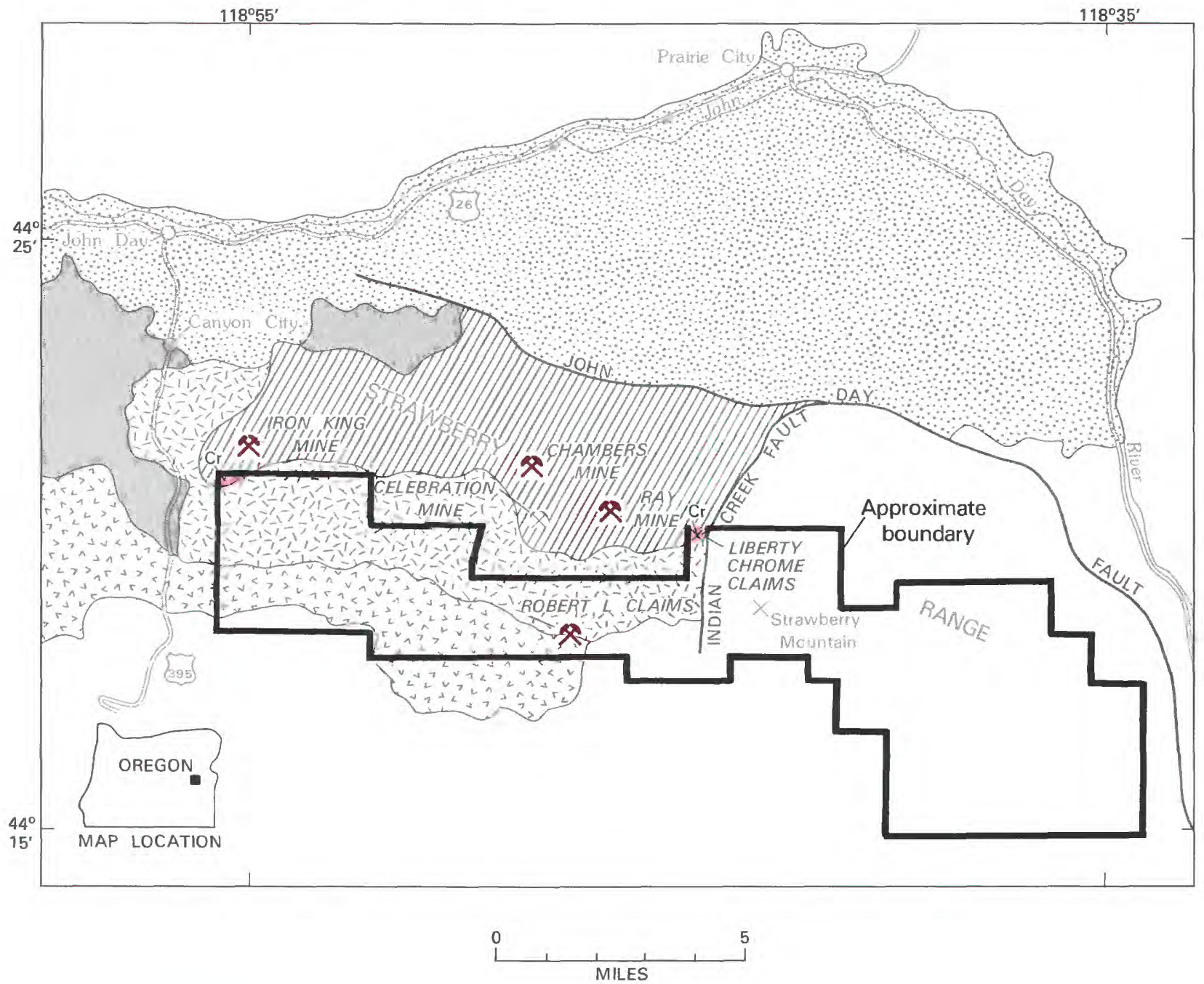

\section{EXPLANATION}

\begin{tabular}{ll}
\hline & $\begin{array}{l}\text { Geologic terrane with substantiated } \\
\text { mineral-resource potential }\end{array}$ \\
$\mathrm{Cr}$ & Chromium \\
$\times \quad$ Mine or deposit \\
$\times \quad$ Mineral occurrence \\
$\times \quad$ Mine
\end{tabular}

\begin{tabular}{|l|l}
\hline & Alluvial fans \\
\hline & Young volcanic rocks \\
\hline & Old volcanic rocks \\
\hline & Gabbro \\
\hline & Mixed rocks
\end{tabular}

Contact

Figure 259.-Strawberry Mountain Wilderness, Oregon. 


\title{
STRAWBERRY MOUNTAIN WILDERNESS, OREGON
}

\author{
By T. P. ThaYeR, ${ }^{1}$ U.S. GeOlOGICAL SurVEy, and \\ RONALD B. STOTELMEYER, U.S. BUREAU OF MiNeS
}

\begin{abstract}
SUMMARY
Systematic geologic mapping and geochemical sampling was done by the USGS and detailed sampling of prospect workings was done by the USBM during the summer of 1975. A demonstrated copper resource in small quartz veins averaging at most 0.33 percent copper with traces of silver occurs in shear zones in gabbro. Two small areas with substantiated potential for chrome occur near the northern edge of the wilderness. There is little promise for the occurrence of additional mineral or energy resources in the Strawberry Mountain Wilderness.
\end{abstract}

\section{GHARACTER AND SETTING}

The Strawberry Mountain Wilderness extends $18 \mathrm{mi}$ along the crest of the Strawberry Range and comprises about $53 \mathrm{sq} \mathrm{mi}$. The Strawberry Range is an east-west mountain block $20 \mathrm{mi}$ long by $8-10 \mathrm{mi}$ wide, whose crest is 7200-8000 ft in altitude except for Strawberry Mountain which reaches $9038 \mathrm{ft}$. The crest is about $5000 \mathrm{ft}$ above the Joln Day River valley. The wilderness is in the Malheur National Forest, Grant County, Oregon. The area is served by U.S. Highways 395 and 26 which meet in John Day, about $6 \mathrm{mi}$ northwest of the wilderness.

The Strawberry Range is divided into eastern and western segments by the north-south Indian Creek fault. The rocks in the western segment consist of three units, 225-250 m.y. (million years) in age, which occupy three east-west belts and as a group form the Canyon Mountain Complex. The oldest and lowest rocks are varieties of peridotite and its altered equivalent, serpentine, which form the northern slopes of the range. The peridotite contains chrome resources, however, only two small areas with substantiated potential for chromite, totalling about $0.25 \mathrm{sq} \mathrm{mi}$, extend into the northern part of the wilderness.

Gabbro, a rock that is intermediate in composition between granite and peridotite, occupies a central belt about $2 \mathrm{mi}$ wide and forms the high parts of the range. The southern slopes of the range are on a unit made up of hundreds of rhyolitic and basaltic dikes and elongate

${ }^{1}$ With contribution from James E. Case, USGS. granitic masses that are alined parallel to the belt of the gabbro. The eastern segment of the range, and 60 percent of the wilderness, comprise young (5-50 m.y. in age) basaltic to rhyolitic lava flows and other volcanic rocks. The principal center of volcanic eruptions was about 2.5 mi southeast of Strawberry Mountain.

The geologic structure of the Strawberry Range changes at the Indian Creek fault. The western segment is an east-west anticlinal fold whose north limb is cut off by the Joln Day fault. The southern limb is formed of southward sloping young lava flows. The eastern segment is a fault block that has been tilted southward by uplift along the John Day fault. Because the Indian Creek fault dies out at the crest of the range, southward tilted young lava flows extend continuously along the southern flank of the range.

\section{MINERAL RESOURCES}

Mining began in the region in 1862 when gold was discovered near Canyon City. Gold production from placers in Canyon Creek south of John Day and quartz veins in Little Canyon Mountain, southeast of Canyon City, is estimated at 600,000 oz to 1908 . Between 1916 and $1942,124,000 \mathrm{oz}$ of gold and $13,000 \mathrm{oz}$ of silver was recovered by dredges along the John Day river. A total of about 30,000 tons of chromite was mined from peridotite or serpentine in the north slopes of the Strawberry Range during World Wars I and II and the Korean war. A mine about $4.25 \mathrm{mi}$ south of the west end of the wilderness produced 8500 lbs (111 flasks) of mercury between 1963 and 1968 . 
Two kinds of mineral resources commonly occur in rocks of the type that make up the Canyon Mountain Complex (Thayer and others, 1981). Deposits of chromite, the ore of chromium, occur only in peridotite or serpentine, which also contain nickel and platinum metals in minor or trace amounts. The large area of peridotite and serpentine on the map has a substantiated chrome resource potential, but only two small areas inside the wilderness are shown in red. The chromite forms irregular lenses or pods, most of which contain a few hundreds or thousands of tons. Most of the identified chromite occurs at the Chambers and Iron King mines. The Iron King mine is $2000 \mathrm{ft}$ north of the wilderness boundary and the Chambers is $1.3 \mathrm{mi}$ from the nearest boundary. The peridotite and serpentine unit extends into a small portion of the wilderness and only one small chromite prospect (the Liberty chrome claims) is known to occur in the wilderness. Two mines which together have yielded about 1600 tons of chromite ore and 6 or 8 small prospects are present in proposed additions to the wilderness. One of the mines, the Celebration, has been mined out, and the other, the Ray, may contain about 5000 tons of demonstrated chromite resoures. In small prospects most of the possible ore has been mined out, and stockpiles give assays between 10 and 45 percent $\mathrm{Cr}_{2} \mathrm{O}_{3}$ and $0.2-0.3$ percent nickel. The nickel in serpentine occurs in the rockforming silicates and is not readily recoverable. The mode of occurrence of platinum-group metals in peridotite is not well known, but they appear to be concentrated in chromite ore. Platinum metals in peridotite vary between 5 and 50 parts per billion (ppb) but in chromite may be as much as $850 \mathrm{ppb}$. A USBM assay found $69 \mathrm{ppb}$ platinum, 0.17 percent nickel, and 0.14 percent copper in ore apparently mined from a chromite lens 2-3 in. wide. The small size of the deposit and low metal content make development unlikely and it is not classified as a resource. Some platinum was recovered from the gravels of the John Day River by gold dredges.

Copper minerals and traces of silver have been found at eight localities over a distance of about $5.5 \mathrm{mi}$ near the southern border of the gabbro. The mineralization consists of quartz veins containing pyrite and chalcopyrite in shear zones associated with basalt dikes. The most promising workings are the Robert $\mathrm{L}$. claims, in a shear zone about $350 \mathrm{ft}$ long, assayed 0.55 to 0.67 percent copper across widths of 2 to $3 \mathrm{ft}$, and total demonstrated resources are estimated to be 33,600 tons of rock averaging 0.31 percent copper.

No evidence of mineralization has been found in the young volcanic rocks. The upper flows in the group are fresh and unaltered, and geochemical sampling shows metal contents normal for such rocks. Although in places the lower flows are bleached and iron stained, assays indicate that the content of gold is below the limit of determination. No gold deposits have been found in volcanic rocks of similar age in eastern Oregon. No mercury was detected in the only prospect dug for that metal; the prospect, moreover, is in a landslide.

\section{SUGGESTIONS FOR FURTHER STUDY}

The small sizes and low grades of copper-bearing veins in the gabbro do not encourage more prospecting. A search for platinum metals would begin with investigation of the larger chromite deposits, all of which are outside the wilderness or proposed additions to it.

\section{REFERENCES}

Thayer, T. P., Case, J. E., and Stotelmeyer, R. B., 1981, Mineral resources of the Strawberry Mountain Wilderness and adjacent areas, Grant County, Oregon: U.S. Geological Survey Bulletin $1498,67 \mathrm{p}$. 


\title{
THREE SISTERS WILDERNESS, OREGON
}

\author{
By Norman S. MacLeod, ${ }^{1}$ U.S. GeOlogical Survey, and \\ J. Douglas Causey, U.S. Bureau of Mines
}

\begin{abstract}
SUMMARY
A mineral survey in 1978-80 of the Three Sisters Wilderness indicated little promise for the occurrence of metallic mineral resources. Block pumice suitable for commercial uses occurs at an undeveloped claim at Rock Mesa in the wilderness, but numerous other sources occur outside the wilderness closer to markets. A broad area centered around South Sister volcano is among the most favorable targets for geothermal resources in the Oregon Cascade Range, based on the very young age and large volume of silicic volcanic rocks that occur in this area, but no geothermal resource potential was identified inside the wilderness.
\end{abstract}

\section{CHARACTER AND SETTING}

The Three Sisters Wilderness occupies an area of about 312 sq mi straddling the crest of the Cascade Range in central Oregon. It is approximately $\mathbf{4 5}$ mi east of Eugene and $30 \mathrm{mi}$ west of Bend, Oregon.

The wilderness is mostly in the High Cascade physiographic province, a narrow belt of young (less than 2 million years) lava flows and volcanoes, typically at an altitude of about $6000 \mathrm{ft}$. The Three Sisters (South Sister, 10,358 ft; Middle Sister, 10,047 ft; and North Sister, 10,085 ft) and Broken Top (9179 ft) are four large contiguous Quaternary stratovolcanoes constructed on this highland. They are formed of interlayered thin flows, pyroclastic deposits, dikes and plugs, and they possess active glaciers and large areas of permanent snowfield. The western part of the wilderness is in the Western Cascade province, a deeply dissected terrane of gently dipping flows and pyroclastic rocks, about 8 to 12 million years old, overlain by a discontinuous sequence of epiclastic sediments capped by flat-lying basalt and andesite flows that are about 6 million years old.

Basalt and basaltic andesite flows are the dominant rock type in the wilderness. The flows are glaciated and commonly covered by glacial outwash and till. Vents, including cinder cones, small to large stratovolcanoes, and lava shields are abundant, especially near the axis of the range. Some vents retain most of their original

\footnotetext{
${ }^{\text {I}}$ With contributions from E. M. Taylor, D. R. Sherrod, and G. W. Walker, USGS.
}

form, others are deeply glaciated. Intermediate and silicic volcanic rocks of Pleistocene age are interlayered with and overlie the more widespread flows of basaltic andesite and basalt in a broad region surrounding South Sister volcano. They consist of andesite, dacite, and rhyodacite flows, domes, and pyroclastic rocks.

Considering the youthfulness of volcanic activity, the highlands around the four major stratovolcanoes likely will continue to have eruptions in the future. Three of the major stratovolcanoes have not erupted during the Holocene and may have no future activity, but South Sister is capable of future eruptions. The area which includes the Three Sisters and Broken Top has many geologic similarities to Mount Mazama before its climactic eruptions that produced Crater Lake.

Most of the rocks in the wilderness are not tectonically deformed. The older volcanic" rocks of the western part are locally faulted, but the displacement is not large. A large north-south-trending east-dipping normal fault that has been mapped near the junction of the High Cascades and Western Cascades provinces probably extends into the wilderness beneath Pleistocene basalt flows. Faults were not observed in the High Cascades part of the wilderness.

\section{MINERAL RESOURCES}

No evidence for the occurrence of metallic or energy mineral resources was found in the Three Sisters Wilderness. Chemical analyses of sediments from streams 

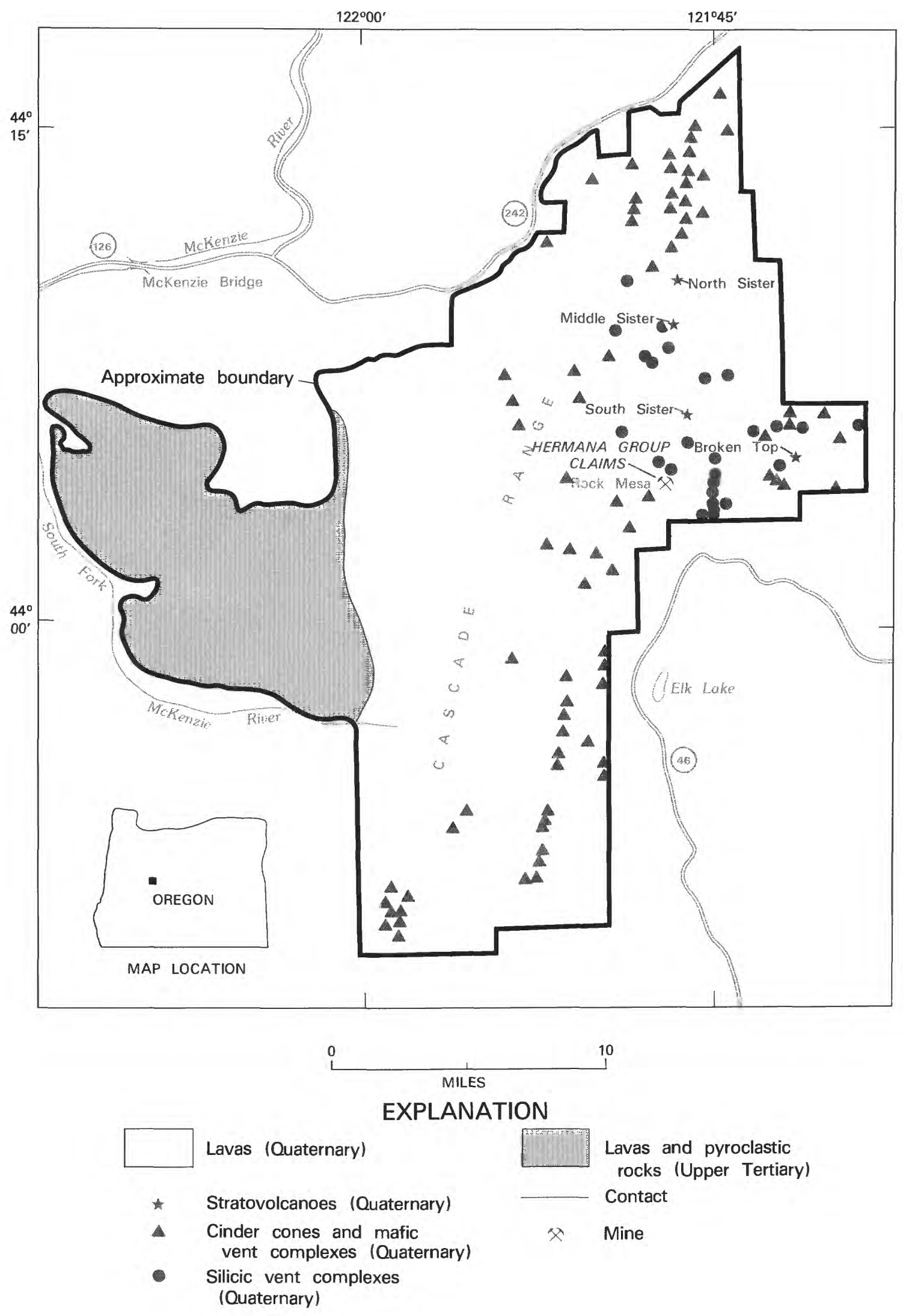

Figure 260.-Three Sisters Wilderness, Oregon. 
draining the wilderness show concentrations of metallic elements similar to those commonly found in volcanic rocks. Because the Cenozoic volcanic rocks are many thousands of feet thick in the wilderness, there is little promise for mineral occurrences, even at great depths.

Pumice deposits at the Hermana Group claims on Rock Mesa are the only industrial mineral resource identified in the wilderness. The pumice occurs as an irregular blocky capping of the glassy rhyodacite flow that forms Rock Mesa. This deposit has not been mined, but if developed, could yield 450,000 tons of potential commercial-grade pumice, primarily for use as decorative stone. Large amounts of cinders and stone in the wilderness have low value because numerous other sources are closer to markets.

The geology of the Three Sisters Wilderness suggests that parts of it have a higher geothermal potential than most other areas in the Cascade Range. Geothermal resources in the range are likely to be of two general types. The first is a possible regionally extensive deep resource related to influx of mafic magma into the upper crust during the development of the young mafic volcanic pile that forms the range. This resource may be deeply buried. Also, even if hot rocks are present at exploitable depths, permeability and porosity may be too low to yield adequate hydrothermal fluids for conventional methods of electric power generation. This type of deep resource may occur along the axial part of the High Cascade Range in the Three Sisters Wilderness, but may also be present in many other areas of the range outside the wilderness.

The second, and probably more important, geothermal resource type is related to large silicic magma bodies or still hot, but solidified, silicic intrusions. Silicic intrusive bodies commonly have a larger size in the shallow crust than do mafic bodies and they commonly are associated with developed geothermal resources in other areas in the world. The Three Sisters Wilderness contains relatively abundant silicic volcanic rocks. Dacite and rhyodacite domes and flows are more common in a broad area centered around South Sister volcano than in any other part of the Oregon Cascade Range, with the possible exception of the Crater Lake area. Furthermore, the Holocene rhyodacite flows and domes on the south to east sides of South Sister volcano are the youngest rhyodacites known in the Oregon Cascades.

Based on the distribution of silicic volcanic rocks, a broad area around South Sister is one of the most favorable targets for geothermal resources in the Cascade Range of Oregon. The most promising site for geothermal resources in this area is on the south and east sides of South Sister where Holocene rhyodacite vents are located. If high temperatures are present in this area at exploitable depths, development could be hampered by two factors. First, the porosity and permeability of the rocks at depth may be so low that fluids may be insufficient for direct hydrothermal power production. If so, techniques for transport of heat at depth to surface generating facilities would have to be different than in existing geothermal fields where electric power is generated by direct or indirect use of geothermal fluids. Second, this area has had numerous Holocene eruptions and future eruptions can be expected. Eruption of silicic magma is commonly explosive and capable of having devastating effects on nearby structures, such as power generation plants. Based on this evaluation and the fact that geothermal resources could exist outside the wilderness, no geothermal resource potential is identified.

\section{SUGGESTIONS FOR FURTHER STUDIES}

Deep exploration holes could be drilled in areas outside the wilderness south of South Sister to provide data on the subsurface thermal and hydrologic regimes in the southern part of the area most likely to contain geothermal resources. No further studies of mineral resources, other than geothermal resources, are warranted.

\section{REFERENCE}

MacLeod, N. S., Taylor, E. M., Sherrod, D. R., Walker, G. W., Causey, J. D., and Willett S. L., in press, Mineral resource potential map of the Three Sisters Wilderness, Deschutes, Lane, and Linn Counties, Oregon: U.S. Geological Survey Open-File Report 83-659. 

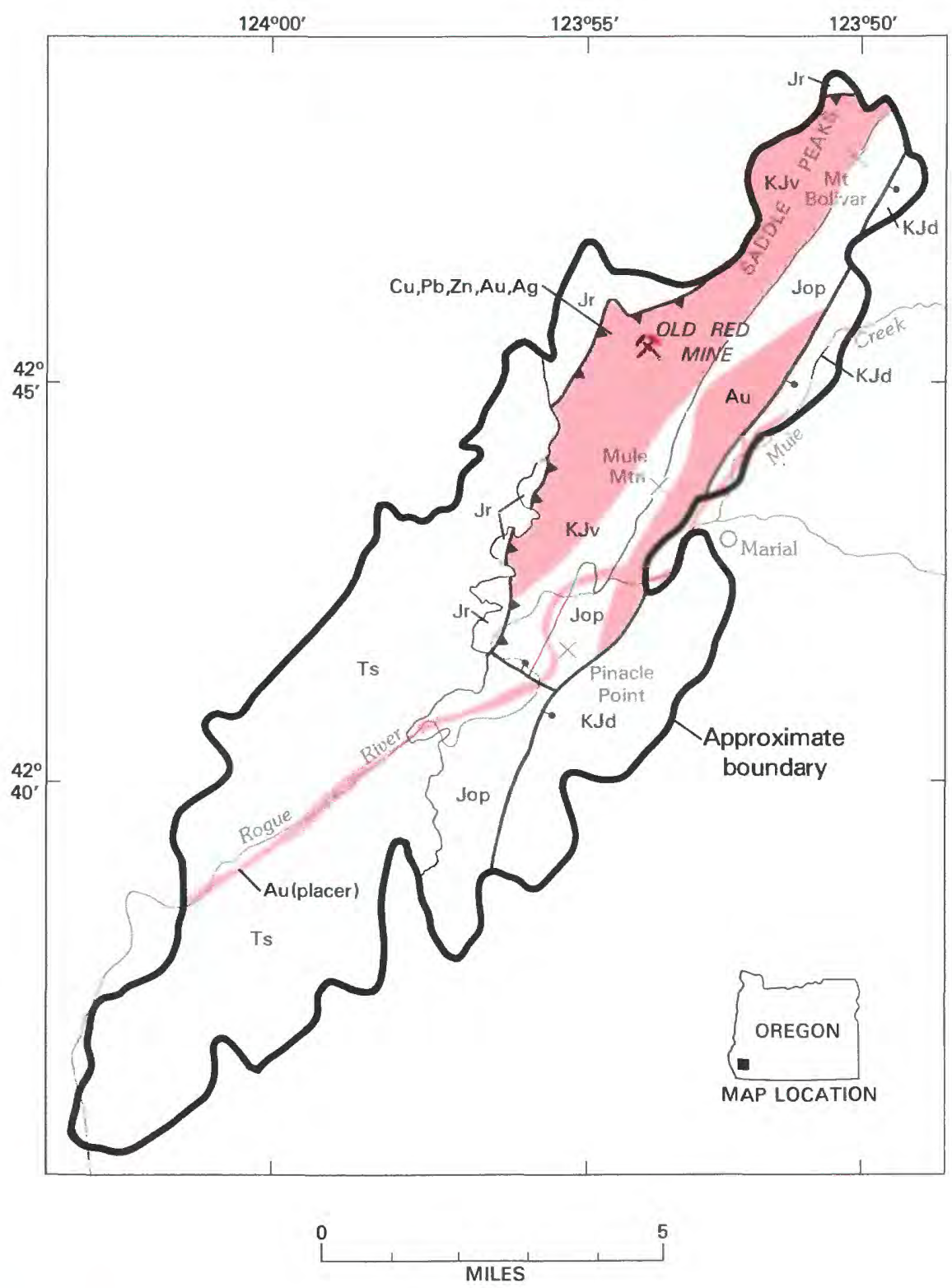

\section{EXPLANATION}

$\begin{array}{ll} & \begin{array}{c}\text { Geologic terrane } \\ \text { mineral-resour }\end{array} \\ \mathrm{Cu} & \text { Copper } \\ \mathrm{Au} & \text { Gold } \\ \mathrm{Pb} & \text { Lead } \\ \mathrm{Ag} & \text { Silver } \\ \mathrm{Zn} & \text { Zinc } \\ \mathrm{X} & \text { Mine or deposit }\end{array}$

\begin{tabular}{|c|c|}
\hline Ts & Sandstone and shale \\
\hline KJV & Igneous rocks \\
\hline KJd & Dothan Formation \\
\hline $\mathrm{Jr}$ & Riddle Formation (Jurassic) \\
\hline Jop & Ophiolite (Jurassic) \\
\hline & Contact \\
\hline - & $\begin{array}{l}\text { Fault--Bar and ball on } \\
\text { downthrown side }\end{array}$ \\
\hline A A & $\begin{array}{l}\text { Thrust fault--Sawteeth on } \\
\text { upper plate }\end{array}$ \\
\hline
\end{tabular}

Figure 261.-Wild Rogue Wilderness, Oregon. 


\title{
WILD ROGUE WILDERNESS, OREGON
}

\author{
By Floyd Gray, U.S. GeOlOGiCAL SURVEY, and
}

Michael S. MilleR, U.S. BUREAU OF MiNES

\begin{abstract}
SUMMARY
A geologic, geochemical, and geophysical investigation and a survey of mines, prospects, and quarries were conducted in 1972-80 to evaluate the mineralresource potential of the Wild Rogue Wilderness. Approximately 800 mining claims, one-third of which are placer gold locations, exist in or adjacent to the area. The Wild Rogue Wilderness has one area of probable resource potential for copper, lead, zinc, silver, and gold and two areas of probable resource potential for gold.
\end{abstract}

\section{CHARACTER AND SETTING}

The Wild Rogue Wilderness is located in Coos and Curry Counties, southwestern Oregon. It is an elongate area, $16 \mathrm{mi}$ long by 2-4 mi wide and includes about $40 \mathrm{sq}$ mi of Siskiyou National Forest land and about $16 \mathrm{sq} \mathrm{mi}$ of U.S. Bureau of Land Management territory extending from the town of Agness northeast to Mount Bolivar. The wilderness essentially borders the steep canyons and major tributaries of the wild and scenic stretch of the Rogue River. Although rock exposures are nearly continuous in this river-etched canyon, the wilderness is densely populated by manzanita, golden chinkapin, tan oak, and madrone as well as Douglas fir, sugar pine, Port Orford cedar, and others.

In the vicinity of the Wild Rogue Wilderness, the Rogue River has cut a path through a northeasttrending faulted and uplifted sequence of Jurassic to Upper Cretaceous igneous rocks, 155-122 million years old, that are bounded on the southeast by Upper Jurassic to Lower Cretaceous sedimentary rocks of the Dothan Formation and on the northwest by siltstones of the Riddle Formation of Late Jurassic age (Gray and others, 1981). The Riddle is unconformably overlain by Tertiary sandstone and shale approximately $\mathbf{4 0}$ million years old. In brief, the igneous complex consists of ophiolite (diorite to mafic gabbroic rocks, diabase dikes, and minor metabasalts) unconformably overlain by a thin sequence of younger, perhaps Cretaceous, andesite to rhyolite. The volcanism of the younger sequence was accompanied by distinctive explosive activity, as enduced by air-fall tuff, vent breccias, and agglomeratic flows.
The area was evaluated in 1972-80 and the results were published by Gray and others (1983). Streamsediment and whole-rock samples were collected and analyzed from the wilderness and adjacent areas. An aeromagnetic survey was flown and compiled in 1978 as part of a larger survey of the Medford $1^{\circ} \times 2^{\circ}$ quadrangle.

\section{MINERAL RESOURCES}

Earliest prospecting and mining in the Wild Rogue Wilderness postdate the 1850's but most mining occurred prior to 1940 . In the wilderness, small-scale lode and placer mining and prospecting were stimulated in 1979 by high gold prices. More than 800 claims have been staked in or adjacent to the Wild Rogue Wilderness. Approximately one-third of the claims are placer locations.

The most significant lode deposits in the wilderness occur in a northeast-trending zone approximately $0.5 \mathrm{~m}$ wide and $6 \mathrm{mi}$ long that has a probable gold resource potential. Mineralization in this zone is intimately associated with quartz veins which cut through the oldest rocks in the region. Quartz veins and quartz vein systems in this terrane are as thick as $12 \mathrm{ft}$ and as much as $2600 \mathrm{ft}$ long. Most of the quartz veins have been affected by tectonic motion in the form of faulting and minor folding. The effect of this tectonic "jostling" has been to create irregular, sheared and contorted veins. Gold content, especially if high, is generally unevenly distributed and appears to be directly proportional to the concentration of sulfide minerals, primarily pyrite 
and chalcopyrite. Gold values in mineralized quartz veins could range from 0.01 to $1 \mathrm{oz}$ gold per ton. Silver and minor copper are also associated with vein systems.

Base- and precious-metal mineralization of the younger volcanic rocks in the Wild Rogue Wilderness also commonly occurs as vein deposits but differs from mineralization of the older rocks in the general absence or paucity of primary quartz in the veins. Mineralized stringers in hydrothermally altered fracture zones containing little or no quartz are the principal sites of mining activity in the upper Mule Creek drainage area. These zones are as much as several hundred yards wide and several miles long. Pyrite is widely distributed in the area, but copper, lead, and minor zinc minerals can be found locally. These deposits contain gold and silver as well. The Old Red mine, one of the larger mines in this system, was sampled and gave values of $0.11 \mathrm{oz}$ gold/ton, $0.275 \mathrm{oz}$ silver/ton, and average base-metal content of 0.089 percent copper, 0.36 percent lead, and 0.52 percent zinc. The silicic upper portion of the volcanic sequence, in which rocks characteristic of nearvent activity are more common, contains several altered, mineralized zones. These apparently lenticular zones contain disseminated pyrite, chalcopyrite, and copper oxides and carbonates. Minor galena and sphalerite are also present. The host rocks usually exhibit complete alteration to clay minerals with or without iron oxide. The area of younger volcanic rocks has probable mineral-resource potential for base and precious metals.

Most placer gold deposits are in the Mule Creek mining district and in the adjacent Agness mining district. The placer gold was probably derived from lodes upstream along the Rogue River and from quartz veins at Mule Mountain, Saddle Peaks, Mule Creek, and Pinnacle Point. Placer gold was deposited in gravel along both Mule Creek and the Rogue River and narrow elongate areas along these drainages have probable mineralresource potential. Bench deposits may occur at or hundreds of yards above creek or river level. Most gravel contains 0.00001 to $0.005 \mathrm{oz}$ of fine gold per cubic yard.

Very thin seams of shaly coal crop out in the upper part of the Tertiary sandstone and shale unit which is exposed on the northwest boundary of the wilderness and which forms the outermost extremities of a coal field, one of the principal coal fields in the State of Oregon. Outcrops of significant coal beds, however, do not extend into the wilderness.

\section{SUGGESTIONS FOR FURTHER STUDIES}

Detailed studies, including drilling, along the northwest border of the igneous terrane would lead to a better understanding of the association of rocks and mineralization in this region. A geochemical anomaly along the Rogue River near Solitude bar has never been explained adequately. Therefore, there is some possibility that the igneous complex extends beneath the lower part of the Riddle Formation and Tertiary sandstone and shale, and consequently, the mineralized zones may continue beyond the borders of the wilderness.

\section{REFERENCES}

Gray, Floyd, and McKee, E. H., 1981, New K-Ar dates from the Wild Rogue Wilderness, southwestern Oregon: Isochron/West, no. 32, p. 27-29.

Gray, Floyd, Miller, M. S., Gaps, R. S., Peterson, J. A., Blakely, R. J., and Senior, Lisa, 1983, Mineral resource potential map of the Wild Rogue Wilderness, Coos and Curry Counties, Oregon: U.S. Geological Survey Miscellaneous Field Studies Map MF-1381-D, scale 1:48,000.

Gray, Floyd, and Peterson, J. A., 1982, Geochemical analyses of rock and stream-sediment samples from the Wild Rogue Wilderness area, Coos, Curry, and Douglas Counties, Oregon: U.S. Geological Survey Open-File Report 82-186, 21 p.

Gray, Floyd, Ramp, Len, Moring, B. C., Douglas, Ian, and Donahoe, J. L., 1981, Geologic map of the Wild Rogue Wilderness, Coos, Curry, and Douglas Counties, Oregon: U.S. Geological Survey Miscellaneous Field Studies Map MF-1381-A, scale 1:48,000.

Peterson, J. A., and Gray, Floyd, 1982, Geochemical map and rock and stream-sediment data from the Wild Rogue Wilderness, Coos and Curry Counties, southwestern Oregon: U.S. Geological Survey Miscellaneous Field Studies Map MF-1381-B, scale $1: 48,000$ (in press). 


\title{
WINDIGO-THIELSEN ROADLESS AREA, OREGON
}

\author{
By DAVId R. SHERrod, U.S. GeOlOGiCAl SURVEY, and \\ JOHN R. BENHAM, U.S. BUREAU OF MINES
}

\begin{abstract}
SUMMARY
The results of a mineral survey in 1981 and 1982 indicate that the WindigoThielsen Roadless Area has little promise for the occurrence of metallic mineral or fossil fuel resources. Abundant cinder deposits occur in the area, but numerous other large volume deposits are available in the region, closer to markets. Available data are insufficient to evaluate the geothermal resource potential of the roadless area.
\end{abstract}

\section{GHARACTER AND SETTING}

The Windigo-Thielsen Roadless Area occupies an area of $165 \mathrm{sq} \mathrm{mi}$ in the Cascade Range of central Oregon. The area straddles the crest of the Cascade Range and includes the Pacific Crest National Scenic Trail. Oregon State Highway 138 bounds the south and west sides of the roadless area and provides access to facilities at nearby Diamond Lake and Crater Lake National Park. The rugged spire of Mount Thielsen, $9182 \mathrm{ft}$, is the landmark geographic feature of the area; extensive glaciation affords an unsurpassed view into the core of this basaltic andesite stratovolcano.

The roadless area is in the the High Cascade Range of Oregon, a physiographic and geologic province of late Cenozoic volcanic landforms. West of the WindigoThielsen Roadless Area the young volcanic rocks of the High Cascade Range lie depositionally above, and bank against, the deeply dissected volcanic rocks of the Western Cascade Range. South of Mount Thielsen is Crater Lake National Park which includes the caldera of Mount Mazama.

The rocks of the Windigo-Thielsen Roadless Area are principally lavas of Pleistocene and late Pliocene age; older lavas of Pliocene or late Miocene age crop out only in the northern part of the area. The younger lavas are vesicular to massive olivine basalt and basaltic andesite. They were erupted from cinder cones and moderate-sized stratovolcanoes. Some of the cinder cones have youthful morphology including preservation of all or parts of the central crater depressions. Other vents, however, have experienced pronounced erosion during glacial intervals.

Mount Thielsen and Howlock Mountain are eroded stratovolcanoes. Lavas from Mount Thielsen have yielded a $0.29 \pm 0.05$ million years old potassium-argon age (J. G. Smith, written commun., 1983). The vents grew by eruptions of mafic pyroclastic rocks and coeval lava flows. Most of the lava was erupted from dike-fed sources surrounding the central pyroclastic cone. Magma congealed in the central conduit to form a large central plug. The resulting structure is a pyroclastic edifice laced with dikes and sills and armored by flow aprons.

Older, more silicic rocks crop out north of the North Fork of the Umpqua River, where the terrain is more deeply eroded and reduced outpourings of Quaternary lavas have failed to bury older strata. These rocks are probably late Miocene or Pliocene in age. Andesite and dacite are common and rhyodacite crops out locally.

Surficial deposits obscure most of the bedrock within the roadless area. Unconsolidated air-fall pumice deposits of Holocene age form a mantle that has been removed by erosion only along ridge crests and valley floors. The deposit varies from $6 \mathrm{ft}$ thick along the western margin to as much as $50 \mathrm{ft}$ thick on the eastern flanks of Mount Thielsen. These pumice depositsMazama ash-were erupted about 6845 years ago, based on carbon-14 dating methods, from a source now marked by the caldera at Crater Lake National Park, 16 mi south of Mount Thielsen. Subsequent eruptions produced ash flows that left deposits bordering the Windigo-Thielsen Roadless Area except on the north side.

Many of the High Cascade volcanoes have experienced multiple glaciations. U-shaped valleys and cirques heading on ridge crests attest to the severity of glacial erosion in the Windigo-Thielsen Roadless Area. The glacial drift is mostly buried beneath the younger pumice deposits. 


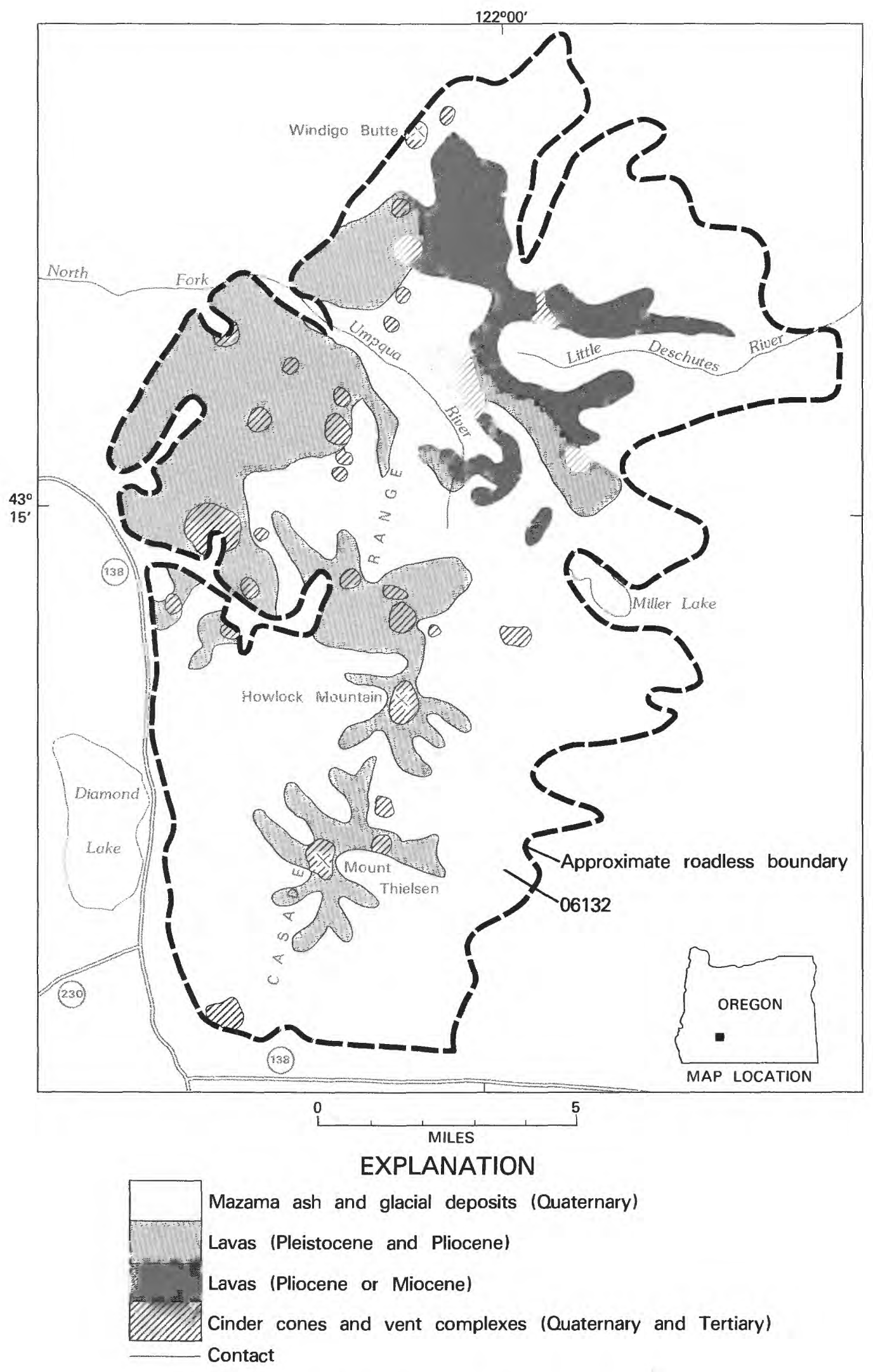

Figure 262.-Windigo-Thielsen Roadless Area, Oregon. 
Alteration in Pleistocene and upper Pliocene rocks of the Windigo-Thielsen Roadless Area is minor, and of the type expected in volcanic rocks. In contrast, pervasive clay alteration occurs in a circular area $2 \mathrm{mi}$ in diameter south and east of Tolo Mountain where upper Miocene or Pliocene rocks crop out. The rocks are altered to clay minerals, limonite, and hematite; finegrained pyrite is visible in the less oxidized rocks, commonly occurring as "paint" on fracture surfaces. Sericite is not present and there are no signs of potassium metasomatism. Analyses of the altered rocks indicates no abnormal concentrations of base or precious metals. The localization, geometry, and style of the alteration is consistent with leaching beneath an area of ancestral hot springs, perhaps the surface expression of an extinct hydrothermal system once driven by cooling intrusive magma.

\section{MINERAL RESOURCES}

Metallic mineral resources are not known within the High Cascade physiographic province of Oregon, of which the Windigo-Thielsen Roadless Area is a part. No mining districts exist in or around the roadless area. Samples of sediment from streams draining the roadless area contain only trace amounts of metallic elements, similar to those commonly found in unaltered volcanic rocks.

Cinder is the only industrial resource in the roadless area. Large volumes of cinders occur at several cinder cones, but sufficient sources exist outside the roadless area to supply regional needs.

The High Cascade physiographic province, formed of young volcanic rocks, may locally contain hightemperature geothermal energy resources capable of producing electric power; lower-temperature resources, which can be utilized for heating and other direct uses of hot water, are likely to be more abundant.

No thermal springs occur in or near the WindigoThielsen Roadless Area, although such springs are present in many other areas along the west margin of the High Cascades. Shallow holes that were drilled to test heat flow in older rocks of the Western Cascades 10 to $15 \mathrm{mi}$ west and northwest of the Windigo-Thielsen Roadless Area had only moderate temperature gradients. No deep holes have been drilled in the High Cascades near the Windigo-Thielsen Roadless Area so depth-temperature relationships are not known. On the basis of geology, there is no reason to suspect that geothermal resources are more likely in the WindigoThielsen Roadless Area than in other nearby parts of the High Cascades; they are much less likely than in the Crater Lake area immediately south of the WindigoThielsen Roadless Area.

\section{SUGGESTIONS FOR FURTHER STUDIES}

The geothermal potential of the High Cascades province cannot be realistically evaluated without data on the subsurface thermal and hydrologic regime that can only be provided by deep drill holes. Several deep holes could be drilled outside the roadless areas of the High Cascades from which extrapolations of the geothermal potential of the province could be made.

\section{REFERENCE}

Sherrod, D. R., Benham, J. R., and MacLeod, N. S., in press, Geology and mineral resource potential map of the Windigo-Thielsen Roadless Area, Douglas and Klamath Counties, Oregon: U.S. Geological Survey Open-File Report 83-660. 


\section{$\begin{array}{llllllllllll}P & E & N & N & S & Y & L & V & A & N & I & A\end{array}$}

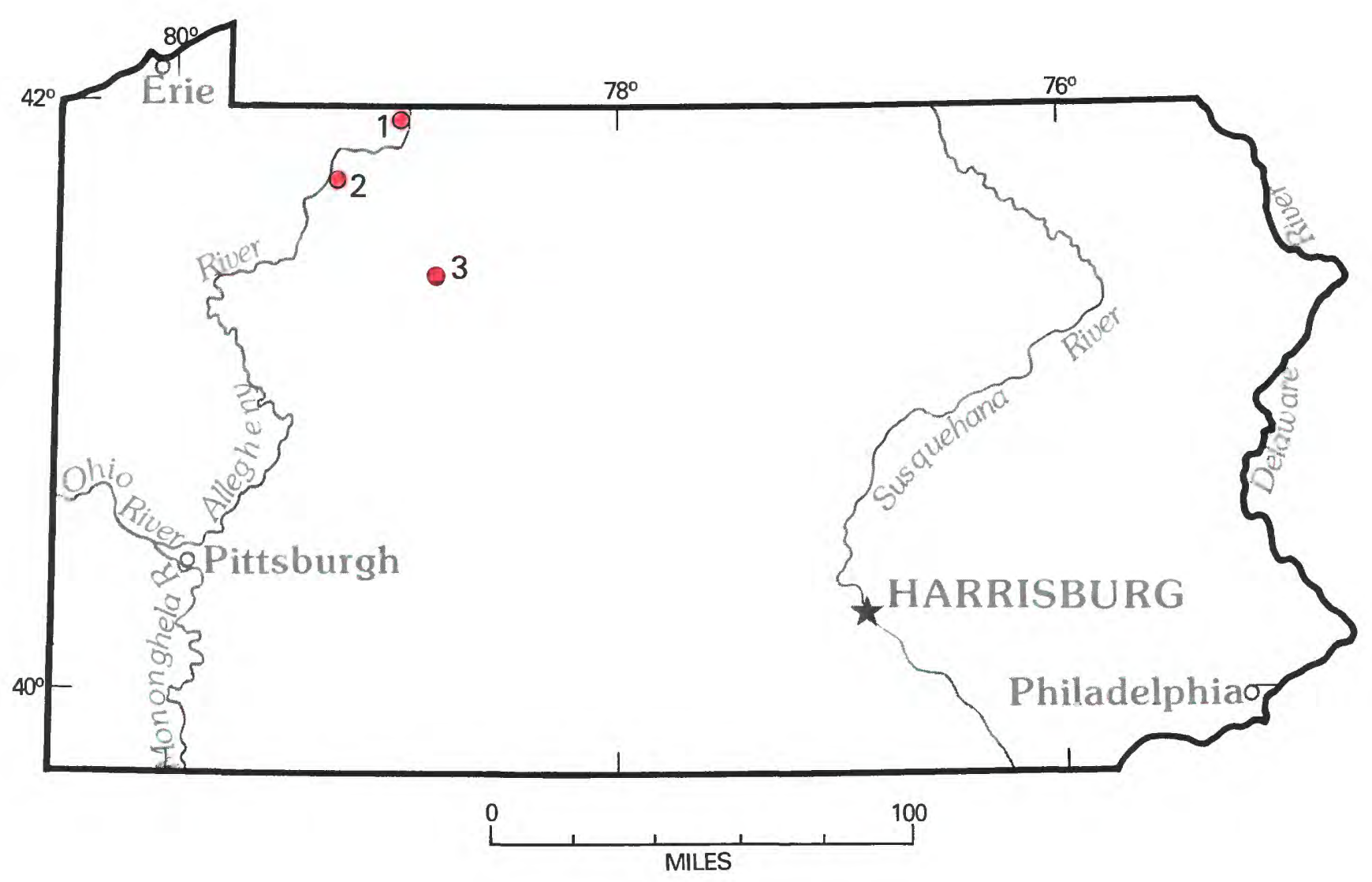

Location of areas studied. 


\title{
PENNSLYVANIA
}

\author{
Map \\ Name of Area \\ 2 Allegheny Front and Hickory Creek Roadless Areas \\ 3 Clarion River Roadless Area \\ 1 Cornplanter Roadless Area
}




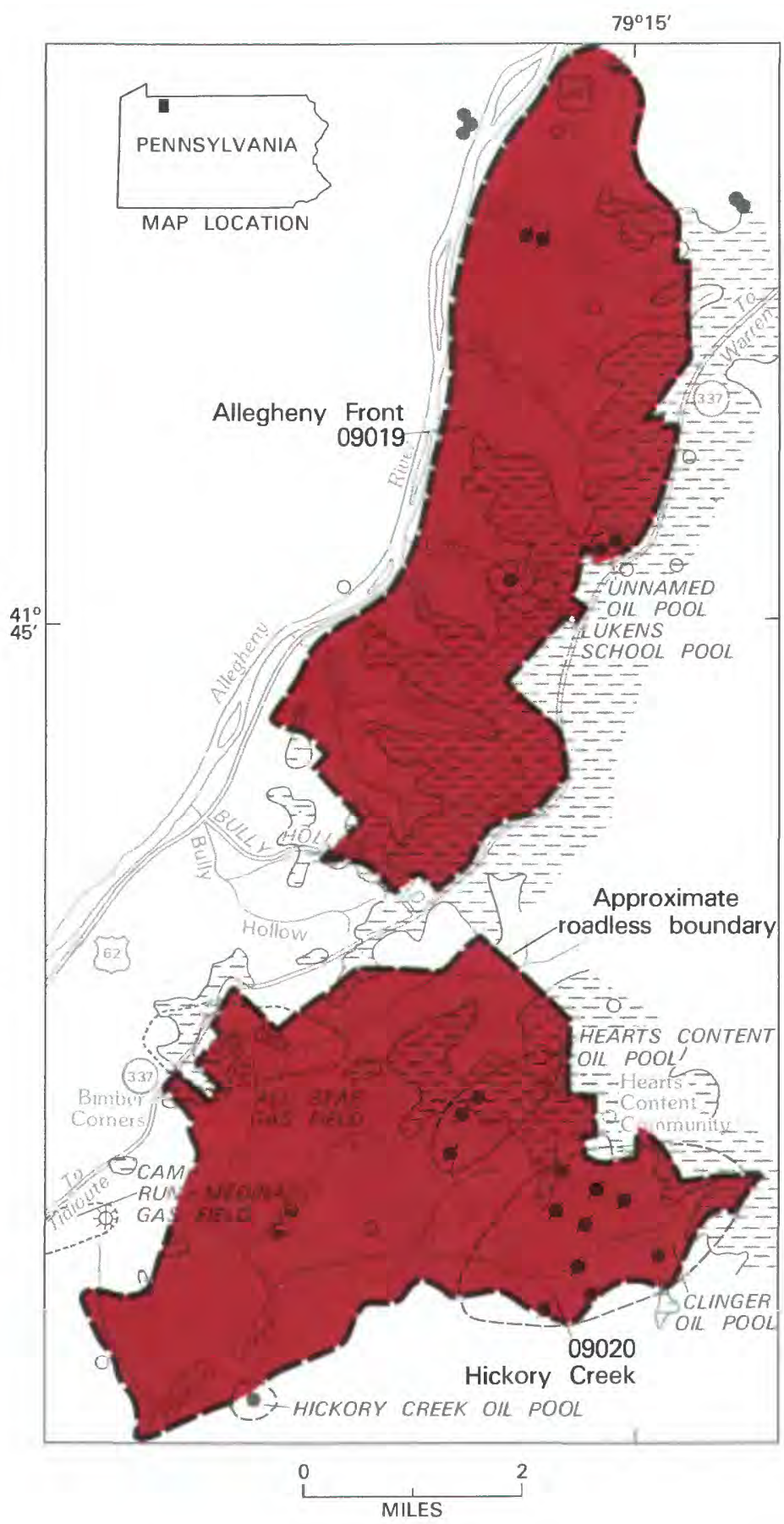

\section{EXPLANATION} Geologic terrane with substantiated oil $=-1$ Pennsylvanian sedimentary rocks
potential and probable gas potential $=-1$ -

- Oil well

to. Gas well

辛 Show of oil and gas

- Shut in or abandoned

决 Shut in or abandoned gas well

(.) Well, no information
Early Mississippian and Late Devonian sedimentary rocks

Contact

Figure 263.-Allegheny Front and Hickory Creek Roadless Areas, Pennsylvania. 


\title{
ALLEGHENY FRONT AND HICKORY CREEK ROADLESS AREAS, PENNSYLVANIA
}

\author{
By Stanley P. Schweinfurth, ${ }^{1}$ U.S. Geological Survey, and \\ VAUGhN P. GIROL, U.S. BUREAU OF MineS
}

\section{SUMMARY}

On the basis of a mineral-resource survey conducted in 1979-80, the Allegheny Front and Hickory Creek Roadless Areas, Pennsylvania, have a substantiated potential for oil resources, a probable potential for gas resources, and little likelihood for the occurrence of coal and metallic mineral resources. The Federal Government owns about 85 percent of the surface rights and 4 percent of the mineral rights in the Allegheny Front Roadless Area and 95 percent of the surface rights and none of the mineral rights in the Hickory Creek Roadless Area; the remaining surface and mineral rights are privately owned.

\section{CHARACTER AND SETTING}

The Allegheny Front and Hickory Creek Roadless Areas comprise $28 \mathrm{sq} \mathrm{mi}$ on the western side of the Allegheny National Forest, Warren County, Pennsylvania. The 13.5-sq-mi Allegheny Front Roadless Area lies along the high, deeply dissected, east bluff of the Allegheny River and the 14.5-sq-mi Hickory Creek Roadless Area lies just to the south of the Allegheny Front Roadless Area in an upland basin formed by the headwaters of Hickory Creek. The roadless areas are situated about $7 \mathrm{mi}$ and $12 \mathrm{mi}$ southwest of Warren, Pennsylvania and are accessible from Warren by Pennsylvania State Route 337.

The surface rights of 85 percent of the Allegheny Front Roadless Area and 95 percent of the Hickory Creek Roadless Area are owned by the Federal Government; the surface rights over the remaining area are privately owned. Ninety-six percent of the mineral rights in the Allegheny Front Roadless Area and 100 percent of the mineral rights in the Hickory Creek Roadless Area are privately owned. Subsurface rights are often subdivided, and individual formations underlying a given parcel of land may be held by different parties.

The roadless areas are within the Appalachian Plateau at the northern edge of the Appalachian coal region. The plateau surface in the roadless areas locally reaches an altitude of about $1900 \mathrm{ft}$. Topographic relief averages about $750 \mathrm{ft}$ in the Allegheny Front Roadless

\footnotetext{
${ }^{1}$ With a contribution by Wallace deWitt, Jr., USGS.
}

Area and about $630 \mathrm{ft}$ in the Hickory Creek Roadless Area.

About $900 \mathrm{ft}$ of sedimentary rocks of the Upper Devonian, Lower Mississippian, and Lower and Middle Pennsylvanian Series crop out in the roadless areas, and about 9000 to $10,000 \mathrm{ft}$ of lower Paleozoic sedimentary rocks may be in the subsurface (Schweinfurth and others, 1982). Colluvium mantles most valley slopes, and alluvium underlies many valley floors.

The structural configuration of the roadless areas is simple (Schweinfurth and others, 1982). The strata dip about $20 \mathrm{ft} / \mathrm{mi}$ to the south-southwest, and are gently warped into several low-amplitude, northeastsouthwest-trending folds.

\section{MINERAL RESOURCES}

Oil and gas are the most important mineral resources in the roadless areas (Girol, 1982; Schweinfurth and others, 1983). Oil-field development drilling to Upper Devonian sandstones is taking place near the boundaries of the Allegheny Front Roadless Area and some exploratory drilling has been done near both roadless areas. Recently, seismic surveys have been conducted in the general region of the roadless areas.

The Allegheny Front Roadless Area contains two oil pools producing from Upper Devonian sandstones. Two tests at the northern tip of the roadless area had shows of oil and gas, and there are two shut in or abandoned oil wells on Charley Run. 
The Hickory Creek Roadless Area has four shut in or abandoned oil and gas fields partially or totally contained within its boundaries; all had produced from Upper Devonian sandstones. Two tests on Jacks Run also had shows of oil and gas. The Camp Run field, located immediately to the west of the Hickory Creek Roadless Area, produced gas from the Lower Silurian "Medina" sandstone between 1961 and 1964 .

The roadless areas have a substantiated potential for oil resources in the Upper Devonian sandstones, but it is believed that there is only a probable potential for gas resources because oil has been the principal hydrocarbon discovered to the present. The oil and gas in the Upper Devonian rocks are found in stratigraphic traps, that commonly are not evident from surface indications. The only sure method to determine if the Upper Devonian sandstones contain oil or gas at a specific site is to drill through the sequence and test the more favorable zones.

Much of the Upper and Middle Devonian rock below the shallow oil- and gas-bearing sandstone sequence consists of marine shales which are rich in organic detritus and are moderate to good source beds for oil and gas. Where naturally fractured, black Middle and Upper Devonian shales may be both source and reservoir rock for natural gas. However, beds of Devonian black shale under the roadless areas do not appear to be attractive drilling targets because of the uncertainties of locating and stimulating fractured zones in the shales and because of the considerable drilling depths; but they are secondary targets to be considered when drilling to test the hydrocarbon resource potential of more deeply buried formations.

The Middle Devonian Onondaga Limestone and the Lower Devonian Oriskany Sandstone are gas productive in parts of the Appalachian basin, but there is little likelihood for gas production from these formations beneath the roadless areas because the best Onondaga production is in southern New York, because the Oriskany is very thin under the roadless areas, and because local tests of these formations have found only small amounts of gas or oil and large amounts of salt water.

The Upper Silurian Bass Islands Dolomite has produced hydrogen-sulfide bearing gas from the single-well Boot Jack pool in Elk County, Pennsylvania, and as much as 500 barrels of oil and 10 million cubic feet of gas per day from wells in Chautauqua County, New York. Consequently, the roadless areas have probable potential for gas resources in the Bass Islands Dolomite.

The Middle Silurian Lockport Dolomite has produced small amounts of gas elsewhere and had a show of gas in a test about $1.5 \mathrm{mi}$ west of the Hickory Creek Roadless Area (Schweinfurth and others, 1983). Consequently, the roadless areas may also have probable potential for gas resources in the Lockport.

The oil and gas productive "Medina" sandstones of western New York and northwestern Pennsylvania make up much of the Lower Silurian sequence under the roadless areas where they appear to be too thermally mature to contain oil but are well within the limits for natural gas. An active drilling program for gas from the "Medina" sandstones in the western half of Warren County, and the proximity of the Camp Run-Medina gas field to the western edge of the Hickory Creek Roadless Area indicate the roadless areas have a probable potential for gas resources in the "Medina."

A relatively small number of deep or ultra-deep wells and tests have penetrated into or through the dolomites and sandstones of the Lower Ordovician and Upper Cambrian sequence in western Pennsylvania and adjacent southwestern New York. Locally, the Upper Cambrian Gatesburg Formation yields gas, but evidence from tests near the roadless areas indicates that, although the roadless areas have potential for gas in the sandy dolomite of the Upper Cambrian sequence, no gas resources have been identified.

A bed of salt more than $50 \mathrm{ft}$ thick occurs in the Upper Silurian Salina Group under the southwestern part of the Hickory Creek Roadless Area. This bed is about $3400 \mathrm{ft}$ below sea level and more accessible salt deposits are available in northwestern Pennsylvania and in adjacent New York and Ohio.

Shale, sandstone, conglomerate, sand, and gravel suitable for construction materials occur in the roadless areas (Girol, 1982). All the commodities occur in abundance in other areas outside the roadless areas.

Coal beds were not observed within the roadless areas, and there is little promise for the occurrence of coal resources in the areas (Schweinfurth and others, 1983).

Metallic minerals were not observed during the field investigations and none have been reported in the literature. No major anomalies were found by a geochemical survey (Hickling and others, 1983) and there is little likelihood for the occurrence of metallic mineral resources.

\section{SUGGESTIONS FOR FURTHER STUDIES}

It is believed that further mineral-resource potential studies are not required in the Allegheny Front and Hickory Creek Roadless Areas. 


\section{REFERENCES}

Girol, V. P., 1982, Mineral resource investigation, Allegheny Front and Hickory Creek RARE-II Further Planning Areas, Warren County, Pennsylvania: U.S. Bureau of Mines Open-File Report MLA 28-82, 26 p.

Hickling, N. L, Schweinfurth, S. P., and Adrian, B. M., 1983, A reconnaissance geochemical survey of the Allegheny Front and Hickory Creek Roadless Areas, Allegheny National Forest, Warren County, Pennsylvania: U.S. Geological Survey, Open-File Report 83-5, 20 p.
Schweinfurth, S. P., Hickling, N. L., and Person, M. A., 1982 , Geologic map of the Allegheny Front and Hickory Creek Roadless Areas, Warren County, Pennsylvania: U.S. Geological Survey Miscellaneous Field Studies Map MF-1442-A, scale 1:50,000.

Schweinfurth, S. P., deWitt, Wallace, Jr., and Girol, V. P., 1983, Mineral resource potential map of the Allegheny Front and Hickory Creek Roadless Areas, Warren County, Pennsylvania: U.S. Geological Survey Miscellaneous Field Studies Map MF-1442-B, scale 1:50,000 (in press). 

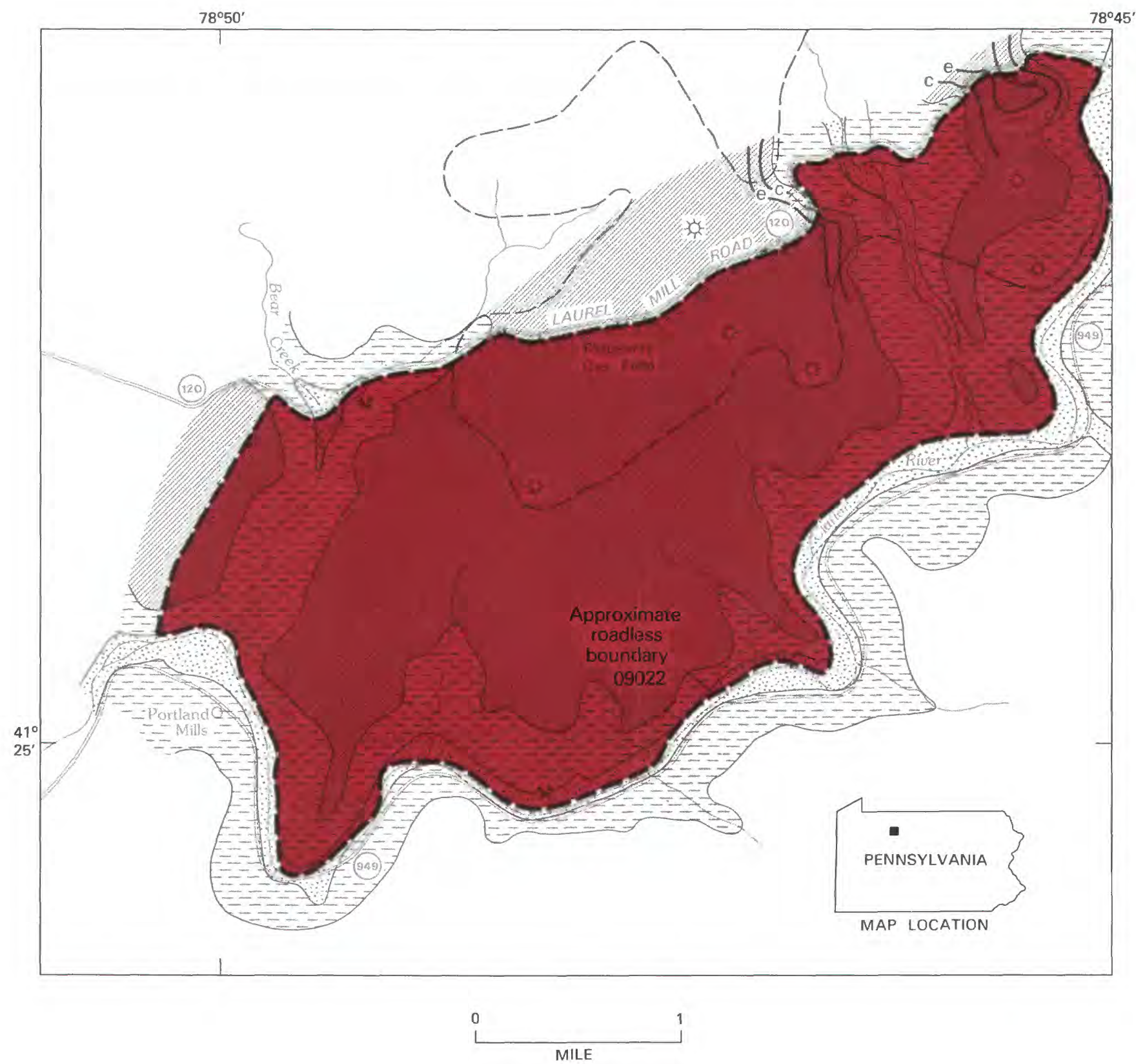

\section{EXPLANATION}

Geologic terrane with substantiated gas resource potential and probable oil resource potential

Gas well

* Abandoned mine

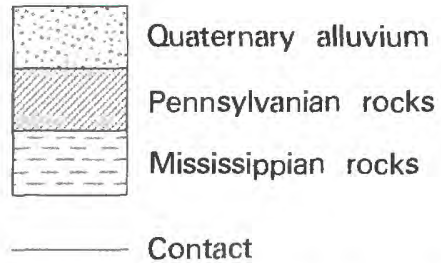

Contact

- $\mathrm{C}$ - Approximate outcrop of coal bed

Figure 264.-Clarion River Roadless Area, Pennsylvania. 


\title{
CLARION RIVER ROADLESS AREA, PENNSYLVANIA
}

\author{
By Stanley P. Schweinfurth, ${ }^{1}$ U.S. GeOlOGical SurVey, and \\ ROBERT A. WeLSh, JR., U.S. BUREAU OF MineS
}

\section{SUMMARY}

The Clarion River Roadless Area is a small tract of rough terrain situated at the southeastern corner of the Allegheny National Forest and bounded on the south by a bend in the Clarion River. The roadless area has a substantiated resource potential for gas and a probable potential for oil. About 1.3 million short tons of coal in beds between 14 and 28 in. thick have been identified in the area. Construction materials occur in the area, but no resource potential is identified; there is little promise for the occurrence of metallic mineral resources in the area. This assessment is based on a mineral-resource survey conducted in 1980 by the USGS and USBM.

\section{CHARACTER AND SETTING}

The Clarion River Roadless Area comprises $6.3 \mathrm{sq} \mathrm{mi}$ in the southeastern part of the Allegheny National Forest, Elk County, Pennsylvania. The roadless area is about $1 \mathrm{mi}$ west of Ridgway, Pennsylvania and is accessible from Ridgway by Pennsylvania State Routes 120 and 949. The Federal Government owns about 89 percent of the surface rights; the remaining surface rights and all mineral rights are privately owned. Thirdparty mineral rights of 99 percent of the roadless area are reserved by National Fuel Gas Supply Corporation.

The roadless area is within the slightly folded eastern part of the Kanawha section of the Appalachian Plateaus Province and is near the northern edge of the Appalachian coal region. The plateau surface in the roadless area locally reaches an altitude of about 1840 $\mathrm{ft}$. Topographic relief is as much as $510 \mathrm{ft}$ and averages about $\mathbf{4 0 0} \mathrm{ft}$.

About $540 \mathrm{ft}$ of sedimentary rocks of the Lower(?) Mississippian Series, the Cuyahoga(?) Group and Knapp(?) Formation, undivided, and of the Lower(?) and Middle(?) Pennsylvanian Series, crop out in the roadless area, and about 13,000 to $14,000 \mathrm{ft}$ of older Paleozoic sedimentary rocks may be in the subsurface (Schweinfurth and others, 1982). Quaternary deposits of colluvium mantle most valley slopes and unconsolidated alluvium underlies many valley floors. The roadless area is south of the limit of Pleistocene glaciation in this part of Pennsylvania.

\footnotetext{
${ }^{1}$ With a contribution by Wallace deWitt, Jr., USGS, and Paul T. Behum, USBM.
}

The roadless area is on the gently dipping, southeast limb of the Johnson Run syncline. The strata dip about 25 to $30 \mathrm{ft} / \mathrm{mi}$ to the northwest.

\section{MINERAL RESOURCES}

Natural gas is the most important mineral resource in the roadless area (Welsh and Behum, 1982; Schweinfurth and others, 1983). As of 1982, the National Fuel Gas Supply Corporation was operating five producing gas wells within the area and several more outside the area. These wells were producing gas from Upper Devonian sandstone beds in the Ridgway gas field. Although the Ridgway gas field is nearly depleted it may have future utility as a gas-storage field.

Of the approximately $13,500 \mathrm{ft}$ of Paleozoic sedimentary rock in the subsurface of the roadless area, the shallow sandstones of the Upper Devonian Series have a substantiated potential for natural gas as shown by wells in the Ridgway gas field in the eastern part of the area. These Upper Devonian reservoir sandstones are lenticular and irregular in shape, and are scattered throughout a thick sequence of shale so that drilling is the only method to confirm the existence of gas, or oil, at any specific site. The Upper Devonian sandstones have only a probable potential for oil, however, because they have been subjected to thermal-maturation temperatures near the upper limit for the generation and retention of oil. A few oil wells on the north side of the Ridgway gas field demonstrates that oil may be present 
in these sandstones. Thermal-maturation temperatures increase with depth of burial so there is little likelihood for oil in the older Devonian rocks and underlying lower Paleozoic strata but the rocks are well within the range for natural gas.

The potential for natural gas in formations of intermediate depth beneath the roadless area is considered as substantiated because the strata below the Upper Devonian rocks contain both source and reservoir beds as demonstrated by local gas production from these formations in central Pennsylvania and adjacent New York. For example, the Middle Devonian black Marcellus Shale is a source and a reservoir rock for natural gas in western Pennsylvania and adjacent New York. The Marcellus Shale is potentially productive for gas in fracture zones in the roadless area, but the difficulty of locating and stimulating gas production from the fracture zones in the shale, and drilling depths of 5000 to $6000 \mathrm{ft}$, may exclude it as a primary drilling target. However, the fractured shale is a good secondary target in wells drilled to test more deeply buried reservoir rocks.

The Upper Silurian Bass Islands Group equivalent has produced as much as 531 thousand cubic feet per day of hydrogen-sulfide bearing gas from the single-well Boot Jack pool about $2 \mathrm{mi}$ southeast of the roadless area. The Bass Islands also contained two small-volume zones of gas and some salt water in a deep test, which was drilled in 1928 about $13 \mathrm{mi}$ north of the roadless area. These data suggest the roadless area may have a probable potential for gas in the Bass Islands equivalent rocks.

Evidence from the few deep and ultra-deep tests in western Pennsylvania and adjacent New York suggests strongly that there is little likelihood for gas in the remainder of the sedimentary rock sequence underlying the Bass Islands equivalent.

At least seven thin, nonpersistent coal beds, referred to as coal beds a through g, were identified in strata of Pennsylvanian age near the roadless area (Schweinfurth and others, 1982). None of these coal beds were observed within the roadless area, but coal beds $c$ and e, which were observed adjacent to the northeastern part of the roadless area, are locally thick enough and persistent enough to warrant projection into the northeastern part of the roadless area. Coal bed $c$ was mined for local use at a small, now abandoned, adit adjacent to the northeast corner, but no mines were observed in bed e. The maximum thickness of coal bed $\mathrm{c}$ is estimated to be about 28 in. (Welsh and Behum, 1982) at the abandoned mine, and the average thickness is about 21 in. for that part of the bed within the roadless area having a thickness greater than 14 in. For coal bed e, thickness within the roadless area is estimated to be about 16 in.
The coal is tentatively ranked as high volatile $A$ bituminous, and has low sulfur but high ash content. In this report areas underlain by beds with coal between 14 and 28 in. thick are not shown on the map. The total tonnage of all coal beds in the area more than 14 in. thick is about 1.3 million short tons.

Clay, shale, sandstone, and sand and gravel are resources of construction materials identified in the roadless area. Preliminary evaluations of clay and shale units in and near the roadless area suggest potential uses as structural clay and building brick but not lightweight aggregate. Some underclays and one shale unit were found to contain as much as 38.5 percent alumina. An alumina content this high has been regarded as a possible future aluminum source; but at present, the area of alumina-bearing clay and shale in the roadless area is not considered as having resource potential. Sandstone has been quarried in the roadless area for construction, chemical, and foundry applications. Local use of Pennsylvanian-age sandstone for rough building stone is indicated by its presence in the abutments of a nearby abandoned railroad bridge over Big Mill Creek. However, because textural and bedding characteristics of these sandstones are generally irregular, their use would probably be confined to rough dimension stone rather than architectural stone. Iron oxide content of the sandstone is too high for it to be used as glass sand. Sand and gravel in alluvial deposits adjacent to the Clarion River have been exploited for construction material and molding sand for metal casting. However, extensive deposits of all of these rock types are present throughout the region closer to markets.

Metallic mineral deposits were not observed and no anomalies were found by geochemical analyses of bedrock and stream sediments during the study (Hickling and others, 1983), and there is little promise for the occurrence of metallic mineral resources.

\section{SUGGESTIONS FOR FURTHER STUDIES}

It is believed that further mineral-resource potential studies are not required in the Clarion River Roadless Area.

\section{REFERENCES}

Hickling, N. L., Schweinfurth, S. P. and Adrian, B. M., 1983, A reconnaisance geochemical survey of the Clarion River Roadless Area, Allegheny National Forest, Elk County, Pennsylvania: U.S. Geological Survey Open-File Report 83-22, 14 p.

Schweinfurth, S. P., Hickling, N. L., and Person, M. A., 1982, Geologic map of the Clarion River Roadless Area, Elk County, Pennsylvania: U.S. Geological Survey Miscellaneous Field Studies Map MF-1444-A, scale 1:50,000. 
Schweinfurth, S. P., deWitt, Wallace, Jr., Welsh, R. A., Jr., and Behum, P. T., 1983, Mineral resource potential maps of the Clarion River Roadless Area, Elk County, Pennsylvania: U.S. Geological Survey Miscellaneous Field Studies Map MF-1444-B, scale 1:50,000.
Welsh, R. A., Jr. and Behum, P. T., 1982, Mineral investigation of the Clarion River Rare II further planning area, Elk County, Pennsylvania: U.S. Bureau of Mines Open-File Report MLA 85-82, $32 \mathrm{p}$. 


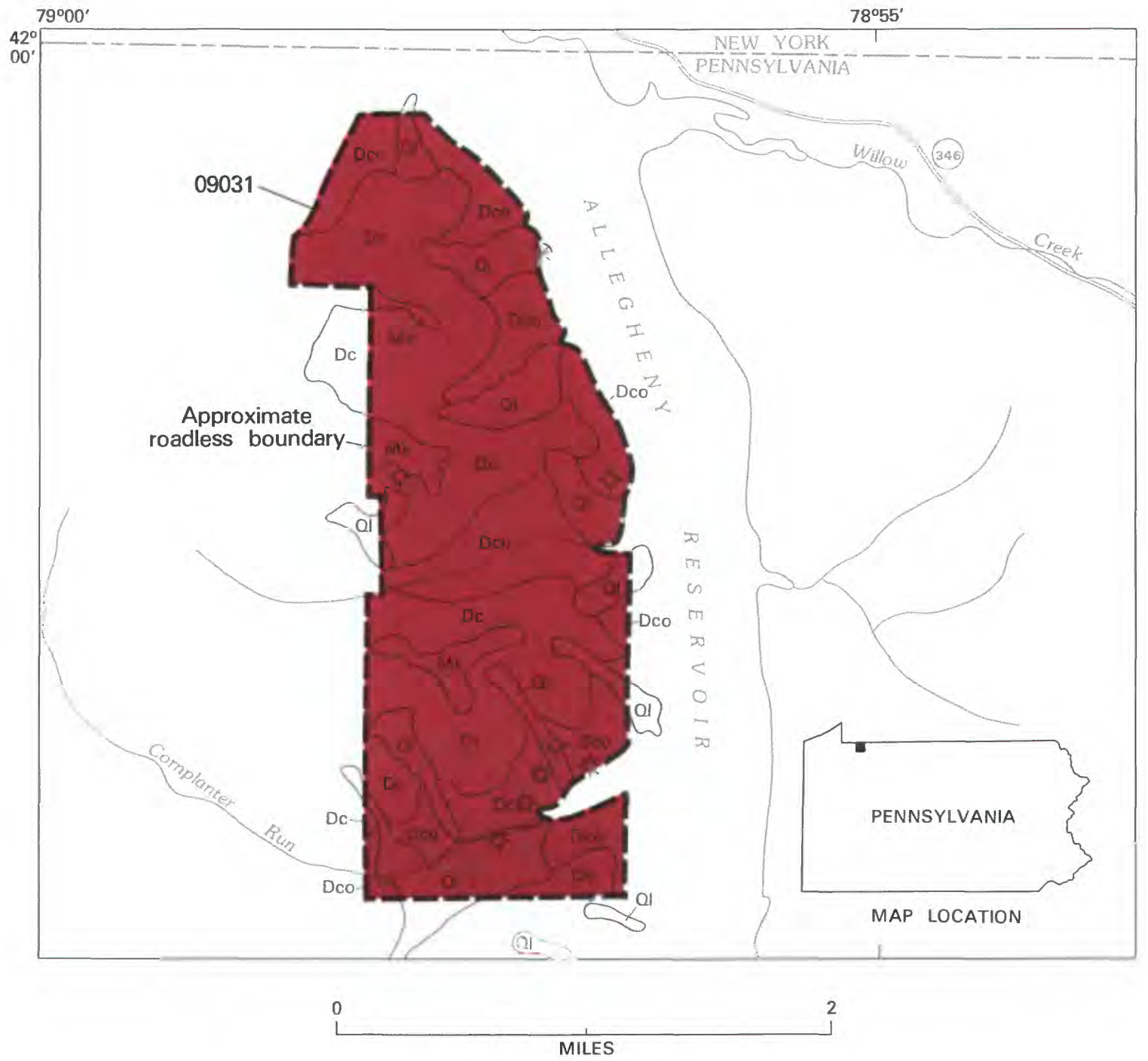

EXPLANATION

Geologic terrane with substantiated gas potential and probable oil potential

Well symbols

- $\phi$ Reported show of gas

Reported gas well

- $\phi$ Reported dry hole

a Gravel pit (abandoned) ol Landslides, contain boulders and finer material that conceal bedrock (Quaternary)

Mk Quartz sandstone and conglomerate of Knapp Formation (Mississippian)

DC Sandstone, siltstone, and shale of Conewango Formation (Devonian)

Deo

Siltstone, sandstone, and shale of Conneaut Group of Chadwick (1935) (Devonian)

Contact

Figure 265.-Cornplanter Roadless Area, Pennsylvania. 


\title{
CORNPLANTER ROADLESS AREA, PENNSYLVANIA
}

\author{
By Frank G. Lesure, ${ }^{1}$ U.S. GeOlogical SurVey, and \\ ROBERT A. WELSH, Jr., U.S. BUREAU OF MiNES
}

\begin{abstract}
SUMMARY
The Cornplanter Roadless Area is on the west shore of Allegheny Reservoir, Pennsylvania, in an area containing flat-lying sedimentary rocks of Devonian and Mississippian age. Based on mineral-resource studies made in 1980 by the USGS and USBM, these rocks have a substantiated potential for natural gas and a probable potential for oil in the roadless area. Other identified inineral resources include various rocks suitable for crushed rock, conglomeratic sandstone suitable for high silica uses, and shale suitable for production of clay products. All these rock types are abundant throughout the region. The Federal Government owns all of the surface rights to the area but only 23 percent of the mineral, oil, and gas rights.
\end{abstract}

\section{CHARACTER AND SETTING}

The Cornplanter Roadless Area contains about $4.5 \mathrm{sq}$ mi of the Allegheny National Forest on the west side of Allegheny Reservoir, Warren County, Pennsylvania. The north end of the area is $0.5 \mathrm{mi}$ south of the New York-Pennsylvania State line. This region is part of the Appalachian Plateau physiographic province. The higher altitudes are about $2100 \mathrm{ft}$ above sea level on narrow ridges that are remnants of the plateau; the lower altitudes are along Allegheny Reservoir where the normal pool level is $1328 \mathrm{ft}$. Access is good by woods roads and trails from paved and graveled county roads along the west and north sides and by boat along the east side.

The Federal Government owns all the surface rights in the roadless area, but owns oil, gas, and mineral rights to only a little more than $1 \mathrm{sq} \mathrm{mi}$. Oil, gas, and mineral rights on $2.5 \mathrm{sq} \mathrm{mi}$ are privately owned, but subordinated so that extraction is limited by Federal regulations.

About $800 \mathrm{ft}$ of nearly flat lying marine sedimentary rocks of Late Devonian and Early Mississippian age are well exposed along the lake shore but poorly exposed in the remainder of the area (Lesure, 1983). These rocks consist of interlayered gray and red shale, siltstone, and sandstone of the Upper Devonian that are overlain by a thick light-colored quartz-pebble conglomeratic sandstone of the Early Mississippian. Possibly as much as

${ }^{1}$ With contributions from Wallsce deWitt, Jr., USGS.
$9000 \mathrm{ft}$ of older Paleozoic sedimentary rocks are present in the subsurface. The rocks dip gently to the south at about $70 \mathrm{ft} / \mathrm{mi}$. No faulting was observed during field work, and none has been reported by previous workers.

A mineral-resource survey of the area made in the fall of 1980 consisted of geologic mapping (Lesure, 1983), a geochemical survey (Lesure and Day, 1983), and examination of well sites and drilling data (Welsh and Grau, 1982).

\section{MINERAL RESOURCES}

The Cornplanter Roadless Area contains a substantiated potential for natural gas, a probable potential for oil, and resources of shale and sandstone suitable for various construction materials (Lesure and others, 1983). Relatively small flows of oil and gas were extracted in the region from beds of Upper Devonian sandstone during the 1940's, but much of the roadless area has not been tested by drilling either for shallow or for deep oil and gas horizons. The Cornplanter Roadless Area lies within the main oil and gas producing region of western Pennsylvania and adjacent southwestern New York, where many thousands of wells have been drilled to the shallow Devonian sandstones during the past 123 years. Most of these shallow wells were drilled between 1860 and 1920 to the north and east of the roadless area in the vicinity of Bradford, Pennsylvania, and Olean, New York, or to the west and south near Warren and Kane, Pennsylvania. 
As of June 1981 no oil and gas lease applications had been filed on the land. The surrounding region contains numerous shallow gas and oil wells. Seven holes drilled within the roadless area include three gas wells, one hole with shows of gas, and three dry holes. The only other mineral production in the area is a small amount of sand and gravel from a pit on the lake shore.

The available subsurface data indicate that the roadless area is probably underlain by abundant source beds and reservoir rocks. The presence of both oil and gas fields in the broad region adjacent to the roadless area indicates that the source beds have been raised to a temperature high enough to have generated oil and gas and to have released the fluid hydrocarbons to adjacent reservoir rocks. The thermal history of the area suggests further that the Devonian rocks may contain both oil and gas whereas the older more deeply buried Cambrian, Ordovician, and Silurian rocks will more likely contain only dry gas. Improved drilling and recovery techniques developed since the early drilling make it likely that the area could produce gas and oil. Drilling exploratory holes is the only method to determine the presence, geometry, and hydrocarbon content of reservoir rocks beneath the Cornplanter Roadless Area.

Shale, sandstone, conglomerate, and sand and gravel in the roadless area could be used for construction materials. Preliminary ceramic evaluations of five shale samples indicates the shale is suitable for use in making building and floor brick but not suitable for making lightweight aggregate (Welsh and Grau, 1982, p. 22). Analysis of sandstone and conglomerate suggest that the contents of iron oxides and other impurities may be too high to permit use in glass manufacture without beneficiation (Welsh and Grau, 1982, p. 15; Lesure and Day, 1983). These rocks are suitable for use as common building stone and crushed rock. Deposits of sand and gravel are of limited extent along the larger streams and as isolated patches along the shore of the reservoir. Extensive deposits of all these rock types are present, however, throughout the region.

Analysis of geochemical samples, including rocks, soils, and stream sediments, did not identify any metallic mineral resources in the roadless area and no evidence of metallic resources was found during geologic mapping. The sedimentary sequence exposed at the surface does not normally host metallic resources.

\section{REFERENCES}

Chadwick, G. H., 1935, Chemung is Portage: Geological Society of America Bulletin, v. 46, no. 2, p. 343-354.

Lesure, F. G., 1983, Geologic map of the Cornplanter Roadless Area, Warren County, Pennsylvania: U.S. Geological Survey Miscellaneous Field Studies Map MF-1510-A, scale 1:24,000.

Lesure, F. G., and Day, G. W., 1983, Geochemical maps of the Cornplanter Roadless Area, Warren County, Pennsylvania: U.S. Geological Survey Miscellaneous Field Studies Map MF-1510-B, scale 1:24,000.

Lesure, F. G., deWitt, Wallace, Jr., and Welsh, R. A., Jr., 1983, Mineral resource potential map of the Cornplanter Roadless Area, Warrent County, Pennsylvania: U.S. Geological Survey Miscellaneous Field Studies Map MF-1510-C, scale 1:24,000.

Welsh, R. A., Jr., and Grau, R. H., III, 1982, Mineral resource investigations of Cornplanter RARE II Further Planning Area, Warren County, Pennsylvania: U.S. Bureau of Mines Open-File Report MLA 39-82, 24 p. 



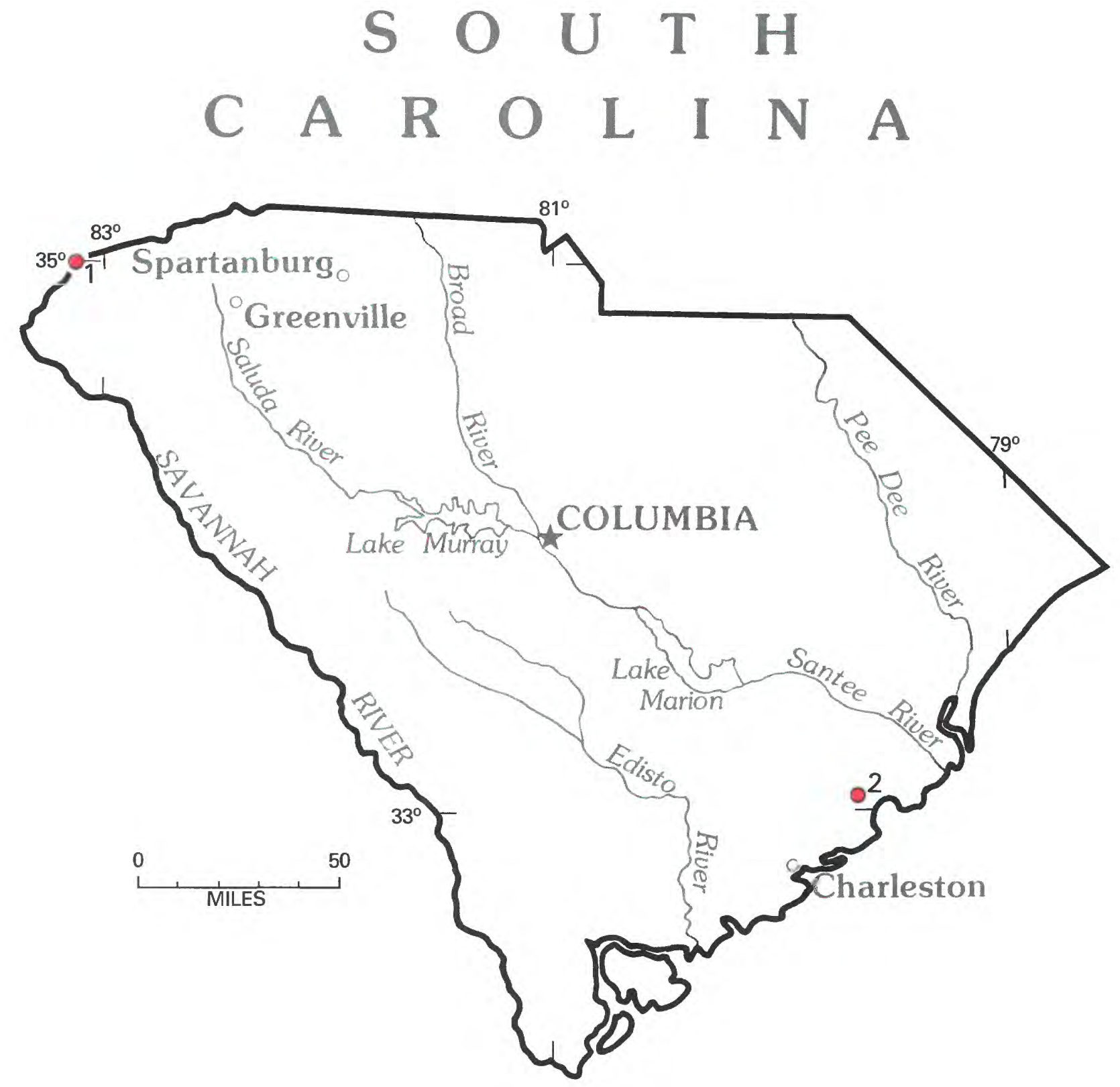

Location of areas studied. 


\section{SOUTH CAROLINA}

Map
No.

1 Ellicott Rock Wilderness and Additions, South Carolina, North Carolina, and Georgia

2 Hell Hole Bay, Wambaw Swamp, Little Wambaw Swamp, and Wambaw Creek Wildernesses 


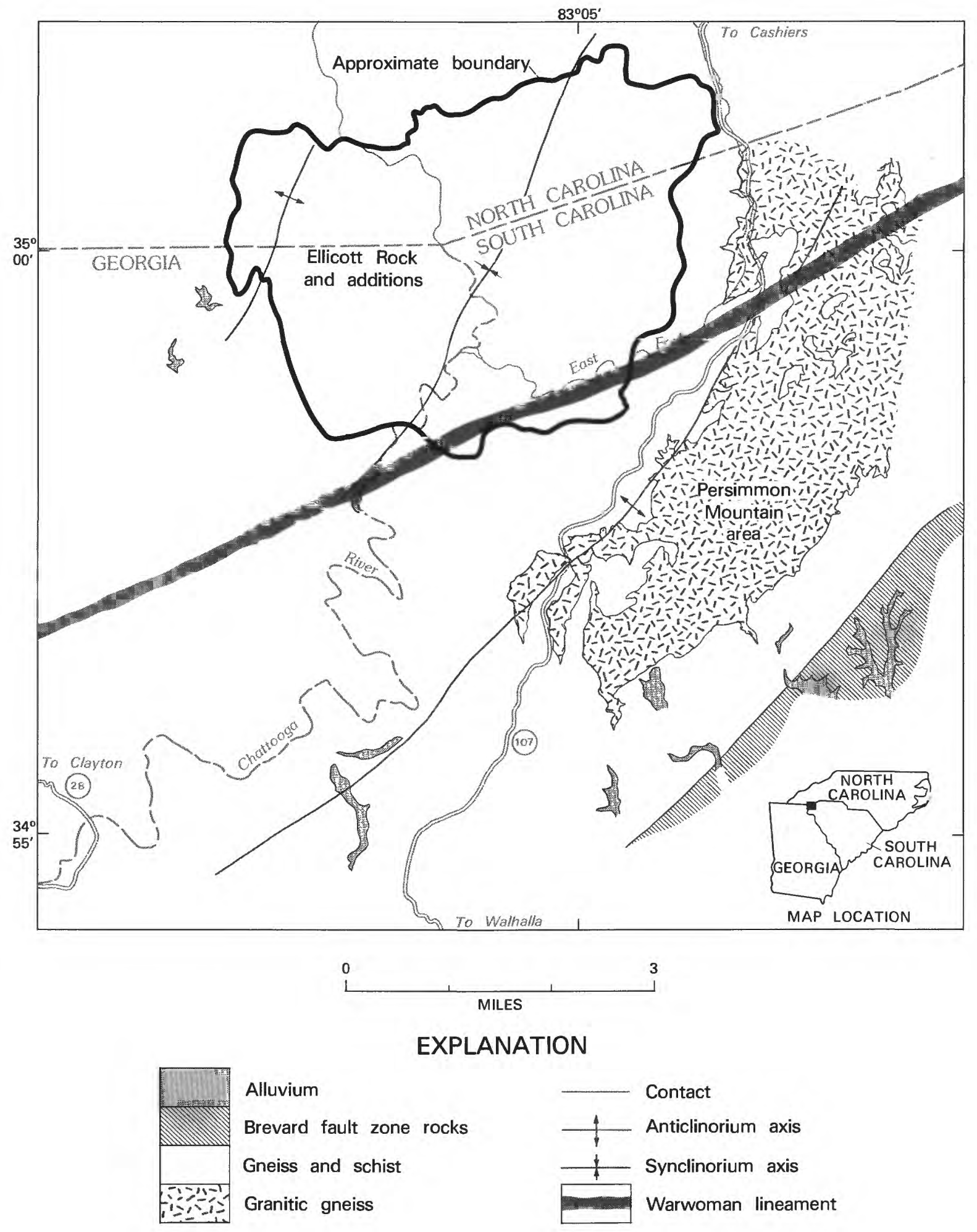

Figure 266.-Ellicott Rock Wilderness and Additions, South Carolina, North Carolina, and Georgia. 


\title{
ELLICOTT ROCK WILDERNESS AND ADDITIONS, SOUTH CAROLINA, NORTH CAROLINA, AND GEORGIA
}

\author{
By HENRY BELl III, ${ }^{1}$ U.S. GeOlOGICAl SURVEY, and \\ GerTRUde C. GAZDIK, U.S. BUREAU OF MiNES
}

\begin{abstract}
SUMMARY
A mineral survey was made in 1980 of the Ellicott Rock Wilderness and additions located in the common corner of South Carolina, North Carolina, and Georgia. Surveys along the rivers, streams, and ridges indicated that there is little promise for the occurrence of metallic mineral or energy resources.
\end{abstract}

\section{CHARACTER AND SETTING}

The Ellicott Rock Wilderness and its additions comprise about $33 \mathrm{sq} \mathrm{mi} \mathrm{of} \mathrm{rugged} \mathrm{rhododendron-covered}$ hills and forested mountains surrounding the common corner of the three states near Cashiers, North Carolina, Walhalla, South Carolina, and Clayton, Georgia. Nearly all of it is owned by the U.S. Government.

The rocks in the area are those common throughout much of the Blue Ridge, mainly intensely deformed mica-, kyanite-, and garnet-bearing schists interlayered with dark gneisses rich with mixtures of biotite and hornblende. Rivers flowing southward towards the piedmont across these rocks are deeply entrenched. A dome of Proterozoic granitic gneiss forming conspicuous outcrops at high altitudes is partly surrounded and overlain by these dissected schists and gneisses (Luce and Daniels, 1982). The Brevard fault zone of highly sheared rocks is topographically expressed in the southeast corner of the area by narrow alined stream valleys (Bell and Luce, 1982).

\section{MINERAL RESOURCES}

There has never been any substantial production of mineral resources in the area, only small-scale mining of short duration (Gazdik, 1982). Quartz veins, peginatites, and small bodies of altered ultramafic rock prospected for asbestos, vermiculite, and corundum occur widely scattered in the area. Gold occurs in some of the quartz veins and in small placers which have been intermittently mined during the last hundred and thirty

${ }^{1}$ With contributions from R. W. Luce, USGS. years producing altogether only a few hundred ounces of gold. The presence of a few small peginatites and coarse mica flakes similar to low-grade mica produced in nearby areas was noted. Chemical analyses of rocks and stream sediments, including panned concentrates, were used to test for indications of mineral resources (Siems and others, 1981). Surveys to test for indications of radioactive minerals were also made. The results showed nothing that would not have been expected from the known mineral occurrences, small mines, and placers (Luce and others, 1982a). There is little promise for the occurrence of metallic mineral or energy resources (Luce and others, 1982b).

\section{SUGGESTIONS FOR FURTHER STUDIES}

Recent seismic-reflection geophysical surveys in nearby parts of North Carolina and Georgia indicate that sedimentary rocks may be deeply buried as much as $45,000 \mathrm{ft}$ below the outcropping metamorphic rocks in the Ellicott Rock Wilderness (Cook and others, 1979). The deeply buried sedimentary rocks have an unknown potential for hydrocarbons, probably gas. Until some deep drilling is done to test these deep sedimentary rocks no reasonable estimate of gas potential can be made, but it cannot be totally discounted.

\section{REFERENCES}

Bell, Henry, III, and Luce, R. W., 1982, Geologic map of the Ellicott Rock Wilderness and additions, South Carolina, North Carolina, and Georgia: U.S. Geological Survey Miscellaneous Field Studies Map MF-1287-B, scale 1:48,000. 
Cook, F. A., Albaugh, D. S., Brown, L. D., Kaufman, Sidney, Oliver, J. E., and Hatcher, R. D., Jr., 1979, Thin-skinned tectonics in the crystalline southern Appalachians; COCORP seismic-reflection profiling of the Blue Ridge and Piedmont: Geology, v. 7, no. 12, p. $563-567$.

Gazdik, G. C., 1982, Map showing mines, prospects, and mineral sites in the Ellicott Rock Wilderness and additions, South Carolina, North Carolina, and Georgia: U.S. Geological Survey Miscellaneous Field Studies Map MF-1287-E.

Luce, R. W., Bell, Henry, III, and Gazdik, G. C., 1982a, Geochemical maps of the Ellicott Rock Wilderness and additions, South Carolina, North Carolina, and Georgia: U.S. Geological Survey Miscellaneous Field Studies Map MF-1287-A, scale 1:48,000. 1982b, Mineral resource potential map of the Ellicott Rock Wilderness and additions, South Carolina, North Carolina, and Georgia: U.S. Geological Survey Miscellaneous Field Studies Map MF-1287-D, scale 1:48,000.

Luce, R. W., and Daniels, D. L., 1982, Aeromagnetic map and selected aeroradiometric data for the Ellicott Rock Wilderness and additions, South Carolina, North Carolina, and Georgia: U.S. Geological Survey Miscellaneous Field Studies Map MF-1287-C, scale $1: 48,000$.

Siems, D. F., Meier, A. L., Luce, R. W., and Bell, Henry, III, 1981, Analyses and descriptions of geochemical samples, Ellicott Rock Wilderness and additions, South Carolina, North Carolina, and Georgia: U.S. Geological Survey Open-File Report 81-594, 37 p. 


\title{
HELL HOLE BAY, WAMBAW SWAMP, LITTLE WAMBAW SWAMP, AND WAMBAW CREEK WILDERNESSES, SOUTH CAROLINA
}

\author{
By Cornelia C. Cameron, ${ }^{1}$ U.S. GeOlogical Survey, and \\ Clay M. Martin, U.S. BUREAU OF Mines
}

\begin{abstract}
SUMMARY
A mineral survey in 1982 of four wildernesses within the Francis Marion National Forest, showed that one of the areas, Wambaw Swamp, had a peat resource potential. An estimated 810,000 tons of demonstrated peat resources on the dry basis occurs in an area of substantiated peat resource potential within easy access to a good road network. No mineral or other energy resources were identified in this study.
\end{abstract}

\section{CHARACTER AND SETTING}

Four wildernesses, including Hell Hole Bay about 10.6 sq mi, Wambaw Swamp about 8 sq mi, Little Wambaw Swamp about 4 sq mi, and Wambaw Creek about $2.5 \mathrm{sq} \mathrm{mi}$, are swamp lands in the Francis Marion National Forest on the lower Atlantic Coastal Plain of South Carolina, about $30 \mathrm{mi}$ northeast of Charleston. They lie between the Copper and Santee Rivers near the boundary of Berkeley and Charleston Counties. Hell Hole Bay, Wambaw Swamp, and Little Wambaw Swamp serve as collecting basins for the surrounding sandy uplands. Drainage of Hell Hole Bay is essentially subsurface. Wambaw Swamp lies at the head of Wambaw Creek flowing northeast to the Santee River, and Wambaw Creek Wilderness extends along the creek's floodplain. Little Wambaw Swamp is drained by Steed Creek, a branch of Awandaw Creek that empties into the Atlantic Ocean.

All surface and mineral rights in the wildernesses are owned by the Federal government. At the time of the survey there were no active or pending mineral leases in Francis Marion National Forest.

Vegetation of these wildernesses is generally similar, and patterns of contrasting trees and shrubs reflect environmental factors such as changes of microrelief, drainage, soil porosity, and acidity. These vegetation patterns are valuable in the study and mapping of the surficial geology, including peat deposits.

\footnotetext{
${ }^{1}$ With contributions from Andrew E. Grosz, USGS, and Gertrude C. Gazdik, USBM.
}

Unconsolidated deposits of Quaternary age conceal the somewhat more indurated rocks of the Santee Limestone and Cooper Formation of Tertiary age in and near the four wildernesses. These Tertiary sedimentary rocks probably rest on 2100-2400 ft of Upper Cretaceous and Paleocene sedimentary rocks. No deep drilling has been done in the wildernesses, but reasonable projections can be made from test holes 25 or $30 \mathrm{mi}$ to the west.

The oldest formation recognized in power auger drill holes is the Santee Limestone of Eocene age. It lies closest to the surface in the Hell Hole Bay and Wambaw Creek Wildernesses and is deepest in southern parts of the Wambaw Swamp and Little Wambaw Swamp Wildernesses.

The younger Cooper Formation consists of carbonate sand, clay, and phosphate. It lies unconformably on the Santee Limestone. Some phosphate nodules representing an old erosional surface at the base of the Cooper Formation extend across the Wambaw Swamp and Little Wambaw Swamp Wildernesses.

Deposits of clay, silt, sand, and gravel of Quaternary age rest unconformably on the Santee Limestone and Cooper Formation in and near the four wildernesses, and attain a thickness greater than $60 \mathrm{ft}$ at the southern borders of Wambaw Swamp and Little Wambaw Swamp. The oldest are beds of granular to shelly coarseto medium-grained feldspathic sand locally grading upward into silty clay, and reflect fluvial (at the base) to upper estuary environment (at the top). Therefore, beds of sand and clay may be of commerical quality at one site and not at another because the beds lack horizontal uniformity. The estuary deposits are in turn overlain by calcareous sandy muds and muddy fine sands typical of 


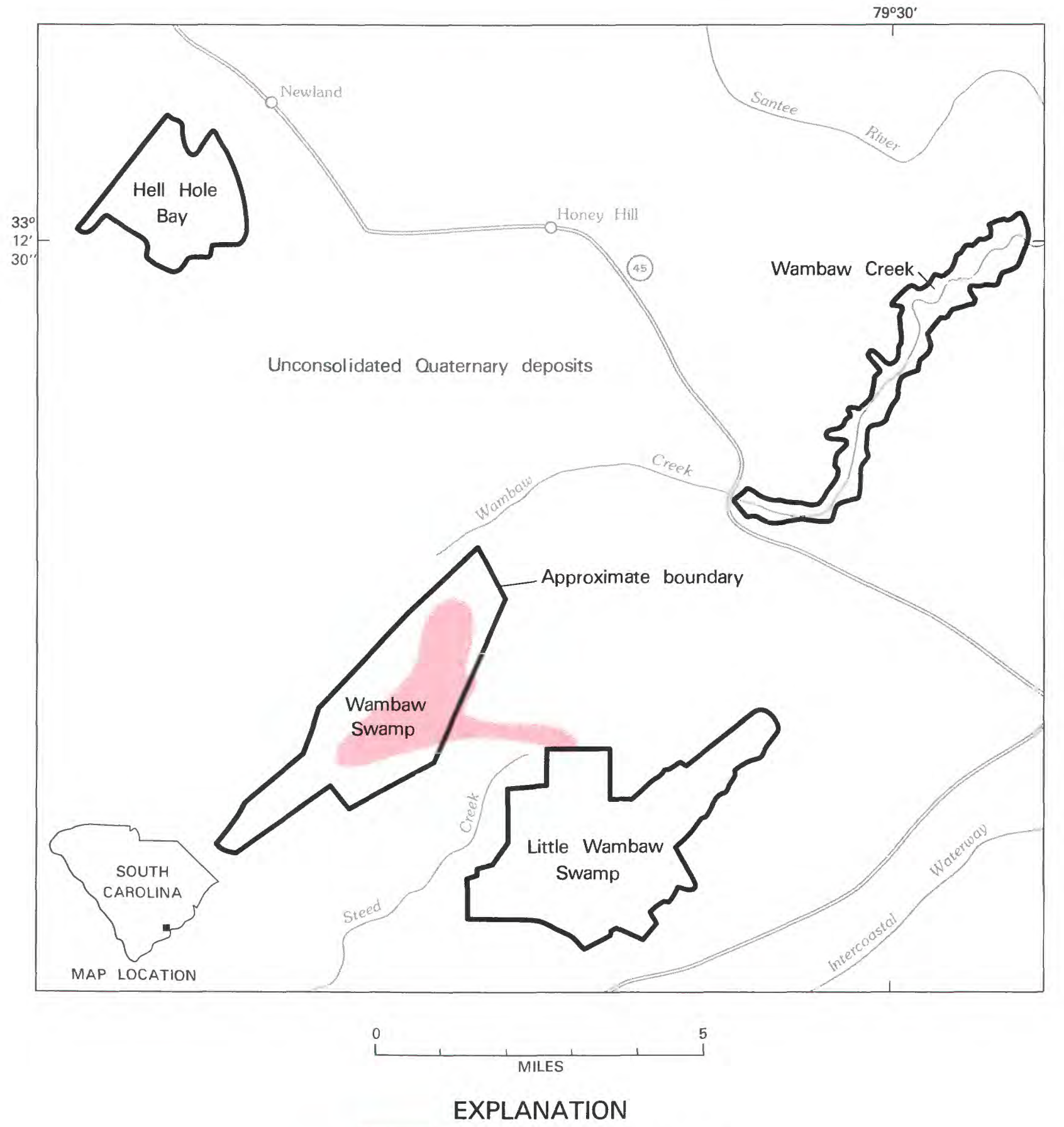

Geologic terrane with probable peat resource potential

Figure 267.-Hell Hole Bay, Wambaw Swamp, Little Wambaw Swamp, and Wambaw Creek Wildernesses, South Carolina. 
near-shore shelf, lagoon, and inlet environments. Next in the transgressive sequence are well-sorted sands that form the gentle rises of former barrier islands and sand spit deposits. Fine sand, silt, and organic clay fill channels associated with the regressing sea, cut into the older sediments. Peat and muck of Holocene age represent the final stage of sedimentation in fresh-water swamps of the wildernesses.

\section{MINERAL RESOURCES}

An area of substantiated peat resource potential is identified in the Wambaw Swamp Wilderness. A demonstrated resource of 810,000 tons of humus peat on the dry basis computed as 200 tons/acre $\mathrm{ft}$ at an average thickness of $5 \mathrm{ft}$ is available in the Wambaw Swamp Wilderness. Samples from a core in this deposit near the east border of Wambaw Swamp show that it is acceptable for agricultural and fuel use; these samples are comparable with those of the deposit near Creswell, North Carolina where peat is being mined for fuel use.

Clay suitable for structural clay products and expanded lightweight aggregate is present in small amounts in the Wambaw Creek and Hell Hole Bay Wildernesses. A power auger hole in Little Wambaw Swamp Wilderness showed a good-grade clay at a depth of 34 to $60 \mathrm{ft}$. It is noncalcareous, homogenous, sticky, blue-gray clay with detrital wood and a few foraminifera tests. X-ray diffraction indicated the primary clay mineral to be kaolinite. Clay from a power auger hole near the Hell Hole Bay Wilderness, is within $2 \mathrm{ft}$ of the surface and $18 \mathrm{ft}$ thick. These clays were laid down in fluvial, estuarene, and tidal environments which tend to form irregular deposits varying in thickness over short distances; they are often limited in extent. Similar resources of clay can be found outside the wildernesses.

Small amounts of phosphate and sand occur within the wildernesses, but other areas outside the wildernesses contain an abundance of these materials.

Oil and gas have never been produced in South Carolina. The areas studied lack adequate source beds, and suitable traps are unknown. There is little likelihood for the occurrence of oil and gas.

\section{SUGGESTION FOR FURTHER STUDIES}

Further study of the wildernesses themselves offers little promise for identification of hidden mineral deposits.

\section{REFERENCE}

Cameron, C. C., Grosz, A. E., Martin, C. M., and Gazdik, G. C., 1983, Mineral resource potential map of Hell Hole Bay, Wambaw Swamp, Little Wambaw Swamp, and Wambaw Creek Wildernesses, Berkeley and Charleston Counties, South Carolina: U.S. Geological Survey Miscellaneous Field Studies Map MF-1556-B, scale 1:48,000. 


\section{$\begin{array}{lllllllll}T & E & N & N & E & S & S & E & E\end{array}$}

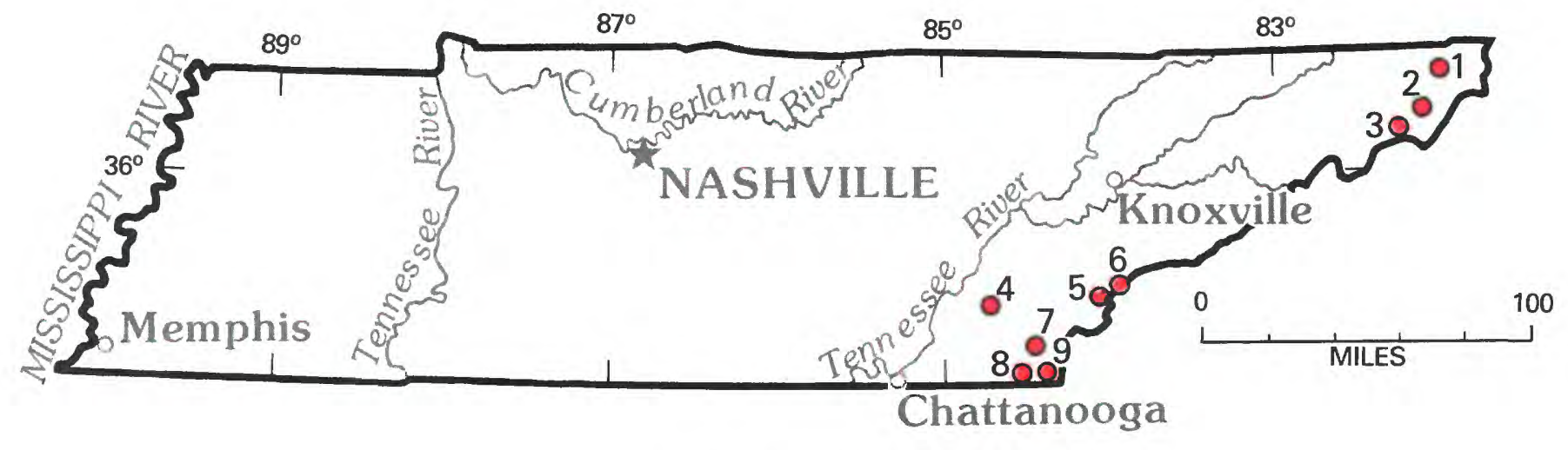

Location of areas studied. 


\section{TENNESSEE}

Map

No.

Name of Area

8 Big Frog Wilderness Study Area and Additions, Tennessee and Georgia

5 Citico Creek Wilderness Study Area

9 Cohutta Wilderness, Georgia and Tennessee, and Hemp Top Roadless Area, Georgia and Tennessee-See Georgia

1 Flint Mill Roadless Area

4 Gee Creek Wilderness

7 Little Frog Roadless Area

6 Joyce Kilmer-Slickrock Wilderness, North Carolina and Tennessee-See North Carolina

2 Pond Mountain and Pond Mountain Addition Roadless Areas

3 Unaka Mountain Roadless Area 


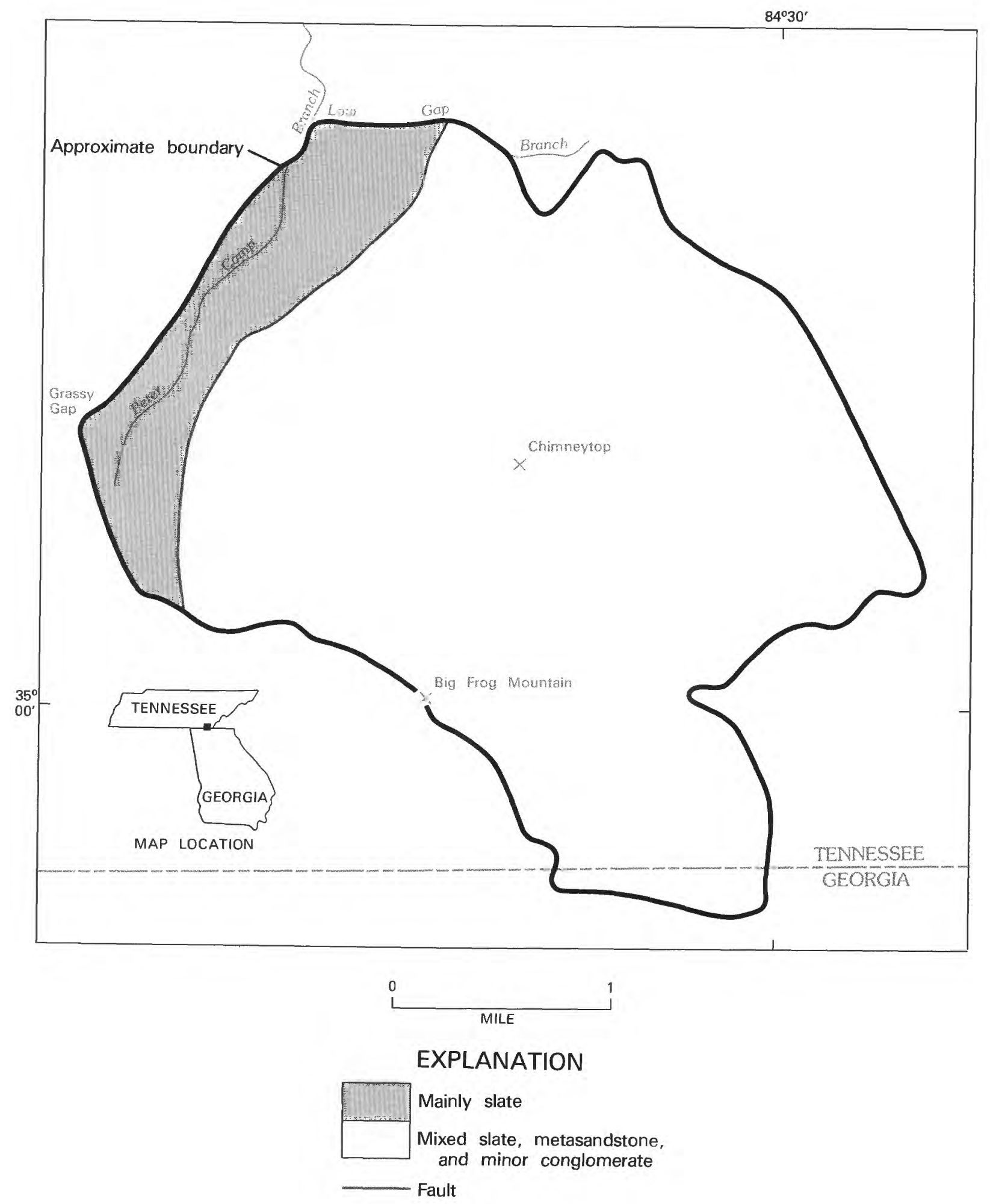

Figure 268,-Big Frog Wilderness Study Area and Additions, Tennessee and Georgia. 


\title{
BIG FROG WILDERNESS STUDY AREA AND ADDITIONS, TENNESSEE AND GEORGIA
}

\author{
By John F. Slack, U.S. GeOlogical SuRVey, and \\ GerTRUde C. GaZdiK, U.S. BUREaU OF MiNeS
}

\begin{abstract}
SUMMARY
In 1977 a mineral-resource survey was made by the USGS and USBM of the Big Frog Wilderness Study Area and additions, Tennessee-Georgia. Geochemical sampling found traces of gold, zinc, copper, and arsenic in rocks, stream sediments, and panned concentrates, but not in sufficient quantities to indicate the presence of deposits of these metals. The results of the survey indicate that there is little promise for the occurrence of metallic mineral deposits within the study area. The only apparent resources are nonmetallic commodities including rock suitable for construction materials, and small amounts of sand and gravel; however, these commodities are found in abundance outside the study area. A potential may exist for oil and natural gas at great depths, but this cannot be evaluated by the present study.
\end{abstract}

\section{CHARACTER AND SETTING}

The Big Frog Wilderness Study Area and additions comprise an area of $7.9 \mathrm{sq} \mathrm{mi}$ in southeastern Tennessee and northernmost Georgia. The study area consists of mountainous terrain in the Cherokee and Chattahoochee National Forests in part of the Blue Ridge Province, $8 \mathrm{mi}$ west of Ducktown, Tennessee. The topography is characteristic of much of the Blue Ridge, consisting of steep forested ridges and narrow valleys. Altitudes range from $1480 \mathrm{ft}$ at the confluence of Peter Camp and Low Gap Branches along the northwestern boundary of the area to the $4210 \mathrm{ft}$ summit of Big Frog Mountain. Drainages are developed in a radial pattern around this summit, the streams discharging into tributaries of the westward-flowing Ocoee River to the north. Principal access is from U.S. Highway 64 to the north and by secondary USFS roads 62 and 221 on the north and northwest; unnamed jeep roads provide entry along the northeastern side. The southern boundary of the study area, shared with the Cohutta Wilderness, has poor access except by foot trails. The entire area is owned by the U.S. Government and there are no privately owned mineral rights. The only mining in the region is in the Ducktown district east of the study area.

A mineral-resource survey of the proposed wilderness was made in 1977 and published in 1982 (Slack and others, 1982). The survey involved geologic mapping and geochemical sampling. Results of the geologic work indicate that the area contains mixtures of Precambrian metamorphic rocks, variously folded and broken by faults. Prior to metamorphism, the rocks consisted of clastic sediments including sandstone, siltstone, shale, and conglomerate, all deposited on an ancient ocean floor. Today these rocks show transformation by heat and pressure into hard metasandstone, slate, phyllite, and schist. Local pods and veins of quartz within these rocks are thought to be the result of this metamorphism.

The geochemical survey was conducted in an attempt to locate concentrations of metals that might signify the presence of nearby mineral deposits. Samples of rock, soil, and stream sediment were collected from throughout the study area; several samples of heavy minerals were panned from major creeks. All these materials were submitted for geochemical analysis. No concentrations of minerals were found, although slightly anomalous quantities of a few elements (copper, zinc, arsenic, barium, gold) are present locally.

\section{MINERAL RESOURCES}

The Big Frog Wilderness Study Area has no known mineral-resource potential except for certain nonmetallic commodities. Rock suitable for construction purposes is present in sufficient quantity to be considered useful for railroad ballast or highway materials. Local 
deposits of sand and gravel are also of potential interest for land fill and concrete. However, extensive amounts of these commodities of equal or better quality are common in surrounding areas closer to market destinations.

Although rocks exposed at the surface in the area are devoid of known hydrocarbons, it is possible that oil and natural gas exist at great depths. Recent seismic studies (Cook and others, 1979) indicate that the Blue Ridge of eastern Tennessee and western North Carolina contains at great depth a thick sequence of sedimentary rocks having a favorable hydrocarbon potential; these rocks lie beneath older metamorphic rocks at the surface. A resource potential for oil and gas may therefore exist in these deeper rocks, but it cannot be evaluated by the present investigation.

\section{SUGGESTIONS FOR FURTHER STUDIES}

Some of the rock units in the study area contain minor amounts (less than 10 percent) of sulfide minerals, chiefly the iron sulfides pyrite and pyrrhotite. In places these sulfide-bearing rocks also have traces of associated sphalerite (a zinc sulfide) and arsenopyrite (an arseniciron sulfide). The presence of these other sulfides explains the slightly anomalous concentrations of zinc and arsenic identified during the geochemical survey. The sulfide minerals could be studied in greater detail as an aid in searching for possible mineral deposits at depth or peripheral to the proposed wilderness.

Deep drilling would test the potential for hydrocarbon resources underlying the metamorphic rocks.

\section{REFERENCES}

Cook, F. A., Albaugh, D. S., Brown, L. D., Kaufman, S., Oliver, J. E., and Hatcher, R. D., Jr., 1979, Thin-skinned tectonics in the crystalline southern Appalachians-COCORP seismic-reflection profiling of the Blue Ridge and Piedmont: Geology, v. 7, no. 12, p. 563-567.

Slack, J. F., Gazdik, G. C., and Dunn, M. L., Jr., 1982, Mineral resources of the Big Frog Wilderness Study Area and additions, Polk County, Tennessee, and Fannin County, Georgia: U.S. Geological Survey Bulletin 1531, 25 p. 


\title{
CITICO CREEK WILDERNESS STUDY AREA, TENNESSEE
}

\author{
By John F. Slack, U.S. GeOlOGical Survey, and \\ Paul T. Behum, U.S. Bureau of Mines
}

\begin{abstract}
SUMMARY
A mineral-resource survey of the Citico Creek Wilderness Study Area, in easternmost Tennessee, in 1976 indicated that the area offers little promise for the occurrence of metallic mineral resources. Geochemical sampling found traces of gold, copper, cobalt, barium, arsenic, lead, zinc, and thorium in rocks, stream sediments, and panned concentrates, but not in sufficient quantities to indicate the presence of metallic mineral deposits. The only apparent resources are nonmetallic commodities including rock suitable for construction materials, and small amounts of sand and gravel; however, these commodities are found in abundance outside the study area. The potential for oil and natural gas at great depths could not be evaluated by this study.
\end{abstract}

\section{CHARACTER AND SETTING}

The Citico Creek Wilderness Study Area comprises about $22 \mathrm{sq} \mathrm{mi}$ in the Cherokee National Forest in easternmost Monroe County, Tennesee. The topography in the study area consists of steep ridges and narrow valleys, typical of much of the mountainous Blue Ridge Province in the southern Appalachians. Altitudes range from $1410 \mathrm{ft}$ at the confluence of Citico and Doublecamp Creeks along the western boundary of the area to 5160 $\mathrm{ft}$ south of Chestnut Knob astride the Tennessee-North Carolina border. Principal drainages are Doublecamp Creek and the headwaters of Citico Creek, both of which are tributaries of the main part of Citico Creek that empties into the westward-flowing Little Tennessee River to the north. Principal access is from the southwest along Tennessee State Route 68 from Madisonville and Tellico Plains. USFS Road 217-I, continuing from Route 68 to the northeast along Sassafrass Ridge, forms the southern border of the study area; USFS roads $217-\mathrm{H}$ and $217-\mathrm{G}$ extend into the southeastern interior. USFS Road 35 provides entry from Citico Beach and other northwest locations, with USFS Road 59 extending up Doublecamp Creek to Farr Gap and USFS Road 29 a short distance up Citico Creek. USFS Road 81, along Santeetlah Creek, allows access from the North Carolina (eastern) side of Beech Gap, from where a dirt road (217- H) heads north along the Tennessee-North Carolina border. The area has been logged heavily in the past and many hiking trails follow old railroad grades along stream valleys. With the exception of the 178-acre Falls Branch Scenic Area along the southern boundary, there are no privately owned mineral rights within the study area. The nearest areas of known mineralization are the inactive Fontana and Hazel Creek copper mines, 15-20 mi to the northeast, and the old Coker Creek gold district, about $10 \mathrm{mi}$ southwest of the study area.

A mineral-resource survey of the study area was made in 1976 (Slack and others, 1979). The geologic mapping part of the survey disclosed that the area contains mixtures of Precambrian metamorphic rocks, variously folded and broken by faults. Prior to metamorphism, these rocks were clastic sediments including sandstone, siltstone, shale, and conglomerate, which were deposited on an ancient ocean floor. Today these rocks show transformation by heat and pressure into hard metasandstone, slate, phyllite, and schist. Local pods and veins of quartz within these rocks are thought to be the result of this metamorphism.

A geochemical survey was conducted to evaluate possible concentrations of metals that might signify the presence of nearby mineral deposits. Samples of rock, soil, and stream sediment were collected from through out the study area; several samples of heavy minerals were panned from major creeks. All these materials were submitted for geochemical analysis. No concentrations of minerals were found, although slightly anomalous quantities of a few elements (copper, cobalt, barium, arsenic, lead, zinc, gold, and thorium) are present locally. 


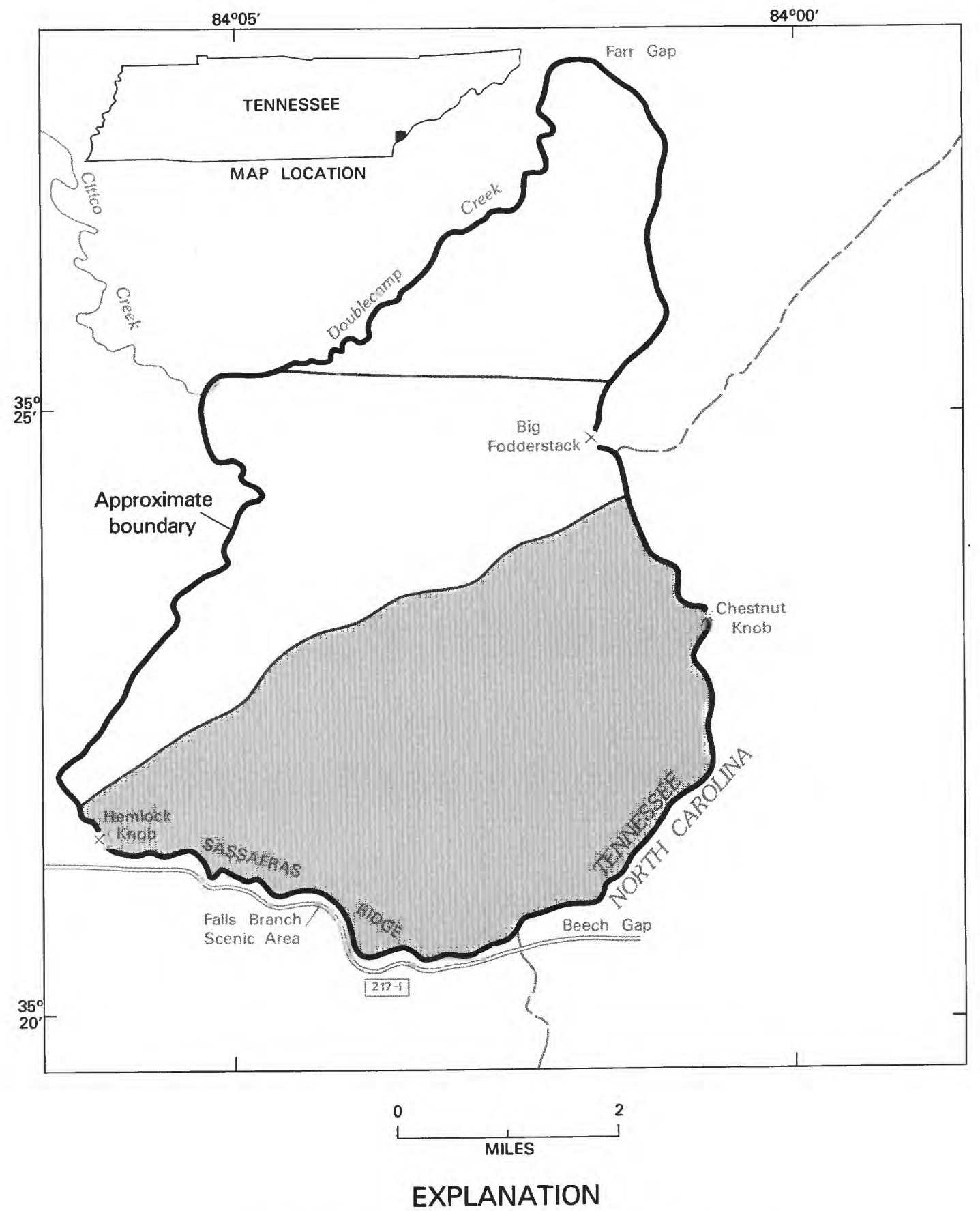

Slate, metasandstone, minor conglomerate

Graphite slate and metagraywacke

Fault

Figure 269.-Citico Creek Wilderness Study Area, Tennessee. 


\section{MINERAL RESOURCES}

The Citico Creek Wilderness Study Area has little promise for mineral resources except for certain nonmetallic commodities. Rock suitable for construction purposes is present in sufficient quantity to be considered useful for railroad ballast or highway materials. Local deposits of sand and gravel are of potential interest for land fill and concrete. Some slates may have marginal use for structural clay products such as brick and tile. Extensive amounts of all these commodities of equal or better quality are present in surrounding regions, however.

Although rocks exposed at the surface in the area are devoid of known hydrocarbons, it is possible that oil and natural gas exist at great depths. Recent seismic studies (Cook and others, 1979) indicate that the Blue Ridge of eastern Tennessee and western North Carolina contains at great depth a thick sequence of sedimentary rocks having a favorable hydrocarbon potential; these rocks lie beneath the older metamorphic rocks at the surface. A resource potential for oil and gas therefore may exist in these deeper rocks, but it cannot be evaluated by the present investigation.

\section{SUGGESTIONS FOR FURTHER STUDIES}

Some of the rocks in the study area contain minor amounts (less than 10 percent) of sulfide minerals, chief- ly the iron sulfides pyrite and pyrrhotite. These sulfidebearing rocks also have traces of associated chalcopyrite (a copper-iron sulfide), sphalerite (a zinc sulfide), and arsenopyrite (an arsenic-iron sulfide). The presence of these other sulfides explains the slightly anomalous concentrations of copper, zinc, and arsenic identified during the geochemical survey. These sulfide minerals could be studied in greater detail as an aid in searching for possible mineral deposits at depth or peripheral to the study area.

Deep drilling would test the potential for hydrocarbon resources underlying the metamorphic rocks.

\section{REFERENCES}

Cook, F. A., Albaugh, D. S., Brown, L. D., Kaufman, S., Oliver, J. E., and Hatcher, R. D., Jr., 1979, Thin-skinned tectonics in the crystalline southern Appalachians-COCORP seismic-reflection profiling of the Blue Ridge and Piedmont: Geology, v. 7, no. 12, p. 563-567.

Slack, J. F., Force, E. R., Behum, P. T., and Williams, B. B., 1979, Mineral resources of the Citico Creek Wilderness Study Area, Monroe County, Tennessee: U.S. Geological Survey Open-File Report 79-231, $33 \mathrm{p}$. 


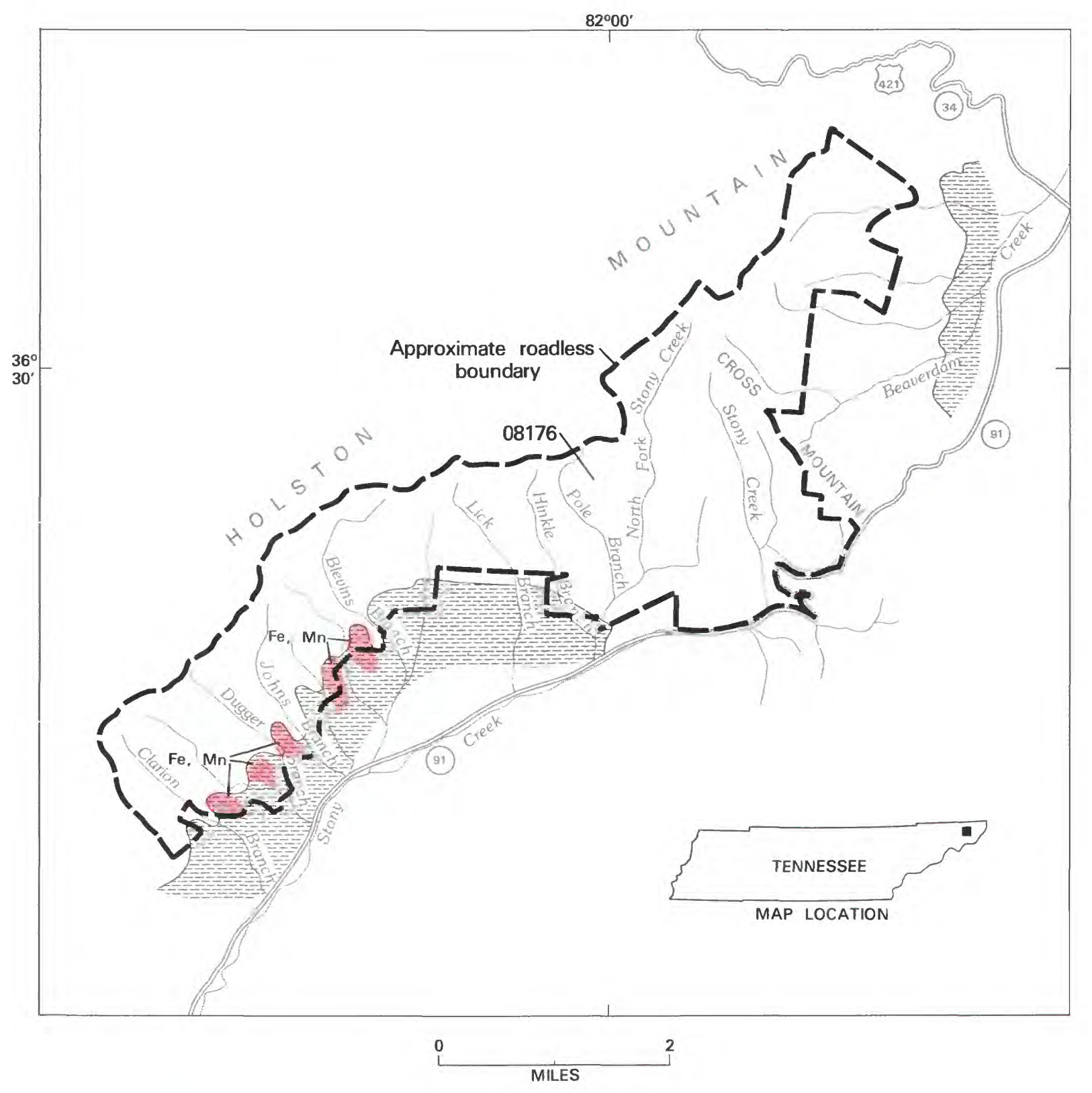

EXPLANATION

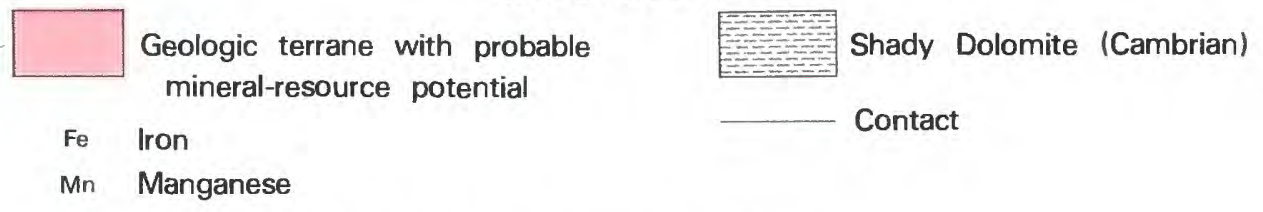

Figure 270.-Flint Mill Roadless Area, Tennessee. 


\title{
FLINT MILL ROADLESS AREA, TENNESSEE
}

\author{
By WALlace R. GRIFFitTS, U.S. GeOlOGICAL SURVEy, and \\ JAY G. JONES, U.S. BUREAU OF MINES
}

\begin{abstract}
SUMMARY
A mineral-resource survey was made of the Flint Mill Roadless Area in northeastern Tennessee by the USGS and USBM in 1980. Studies of known manganese deposits, most of which are small and mined out, evaluation of iron prospects, and the results of a geochemical survey for other metals in stream sediments indicate there is probable resource potential for the occurrence of small iron-manganese resources in the roadless area. Nonmetallic minerals such as clay, carbonate rock, and other industrial raw material are found in the area but, similar commodites are found outside the area. The remote possibility of deep oil or gas in the southern Appalachians, of which the roadless area is a part, cannot be evaluated with existing data.
\end{abstract}

\section{CHARACTER AND SETTING}

The Flint Mill Roadless Area comprises about 11 sq $\mathrm{mi}$ in Cherokee National Forest in northeastern Tennessee. The roadless area is in Carter and Johnson Counties, about $8 \mathrm{mi}$ northeast of Elizabethton, Tennessee. State Highway 91 parallels the southern boundary of the area and determines part of the southeastern boundary. USFS roads allow access to the western portion of the roadless area. Unimproved secondary roads and foot trails provide additional access.

The roadless area occupies the southern slope of Holston Mountain. Topography is rugged with high ridges and fairly steep slopes. Altitudes range from $4140 \mathrm{ft}$ at Holston High Knob at the western edge of the roadless area, to $2180 \mathrm{ft}$ in Dugger Branch. Cross Mountain, a ridge that extends southeast from Holston Mountain, separates the roadless area into two drainage basins. Tributaries to southwest-flowing Stony Creek drain the southwestern three-fourths of the area, and tributaries to northeast-flowing Beaverdam Creek drain the northeastern one-fourth. These streams and their tributaries have dissected an ancient land surface-the Harrisburg or Valley Floor Peneplain-leaving remnants on the divides between tributary valleys and around the heads of the main streams.

The Flint Mill Roadless Area is near the eastern edge of the folded Appalachian Mountains and is underlain by folded and faulted sedimentary rocks of Paleozoic age (King and Ferguson, 1960). The area is only $5 \mathrm{mi}$ west of the westernmost exposures of the Precambrian Cranberry Gneiss. The sedimentary rocks include the thick Chilhowee Group of clastic rocks of Early Cambrian age, stratigraphically overlain by the carbonate and shaly rocks of the Shady Dolomite, of Cambrian age.

The Shady Dolomite has been thoroughly weathered along the southeastern flank of Holston Mountain. In many places the carbonate minerals have been removed entirely to leave a mass of light-brown or tan sticky clay, locally sandy. Manganese and iron concentrations are parts of this residuum, occurring as concretionary lumps in the clay. At a few places, metal-bearing oxides are underlain by the Erwin Formation of the Chilhowee Group, but little or no ore has been produced from such places on Holston Mountain. The residuum is best developed on, and almost restricted to, remnants of the Harrisburg Peneplain. These remnants are on the divides between tributaries of Stony and Beaverdam Creeks and at the heads of those creeks. The total area of these remnants of the peneplain is rather small and many of the bodies of residuum under them have already been mined, so there is little unexploited terrane left to explore.

\section{MINERAL RESOURCES}

Studies of known manganese deposits, most of which have been mined out and now abandoned, evaluation of 
iron prospects (Jones, 1982), and a geochemical survey for other metals in stream sediments, including pan concentrates indicate that there is a probable potential for small iron and manganese resources in the roadless area.

Residual manganese deposits have yielded a little more than 300 tons of ore from mines on spurs from the eastern side of Holston Mountain at an altitude of about $2800 \mathrm{ft}$, where they underlie hills or gentle slopes. Additional deposits, if present, would be expected under flat areas along the flank of the mountain at about the altitude of the other remnants of the terraces. Only about 3 percent of the acreage inside the boundaries of the roadless area provide the proper setting for manganese mineralization, and much of that 3 percent has been explored. The Erwin Formation is reported to contain manganese as a cementing agent in parts of Stony Creek Valley (King and Ferguson, 1960), but no production from this formation has been reported.

Many of the manganese mines in the Stony Creek and Shady Valley mining districts originated as iron prospects. Iron deposition in the roadless area was coincident with that of manganese, and the iron occurs under the same topographic conditions. Small concentrations are in residual clays over the Shady Dolomite and, rarely, over the Erwin Formation. The iron content and tonnages of the known deposits were small and additional resources, if present, would be similar. Percentages of iron in the known deposits do not exceed 42 percent and phosphorous values are high.

Anomalously high contents of cobalt, lead, zinc, copper, and tin were determined in one or more geochemical samples collected near manganese mines. Copper and tin in samples may have come from trash dumped in the area or from the Precambrian metamorphic and igneous rocks to the east. Possibly they are recycled from sediment detritus from the Erwin Formation, with Precambrian rocks the ultimate source. Lead and zinc are widespread in lower Paleozoic carbonate sedimentary rocks of the region, and in places are mined from large ore deposits. Possibly small amounts of lead and zinc in the Shady Dolomite have been concentrated along with the manganese during weathering. Lithiophorite, a black lithium-aluminum-manganese oxide, reported from several places in the Appalachian Mountains, commonly contains cobalt as a major component, so it may be the host of the small amounts of cobalt in some samples. None of these base metals are likely to be present in large enough tonnage or in large enough concentrations to be resources.

High values of copper, zinc, lead, and barium found sporadically in this and other roadless areas in eastern Tennessee suggest that the rocks of the Chilhowee Group may contain red-bed-type copper deposits. The general types of rocks in the group are compatible with this inference, but data from this study do not define a resource potential for such deposits in the Flint Mill Roadless Area.

Analyses of clay and shale samples indicate suitability for use as structural clay products, but abundant sources occur elsewhere in the region. Bauxite, phosphate, pyrite, and barite have been noted in the region, but were not observed in the roadless area. Carbonate rock for possible cement or other products may be present under the eastern part of the roadless area, but is overlain by thick residual clay and would also occur outside the area. Recent structural studies, based mainly on seismic traverses (Cook and others, 1979), suggest that oil or gas may have accumulated at depth in this general region.

\section{SUGGESTIONS FOR FURTHER STUDIES}

No additional studies for metallic mineral resources are recommended, but further geophysical study and possibly drilling would be necessary to evaluate the resource potential for gas and oil in the roadless area.

\section{REFERENCES}

Cook, F. A., Albaugh, D. S., Brown, L. D., Kaufman, Sidney, Oliver, J. E., and Hatcher, R. D., Jr., 1979, Thin-skinned tectonics in the crystalline southern Appalachians-COCORP seismic-reflection profiling of the Blue Ridge and Piedmont: Geology, v. 7, p. 563-567.

Griffitts, W. R., and Jones, J. G., in press, Mineral resource potential of the Flint Mill Roadless Area, Johnson and Carter Counties, Tennessee: U.S. Geological Survey Open-File Report 83-509.

Jones, J. G., 1982, Mineral investigations of the Flint Mill Gap RARE II Further Planning Area, Carter and Johnson Counties, Tennessee: U.S. Bureau of Mines Open-File Report MLA-99-82, 24 p.

King, P. B., Ferguson, H. W., 1960, Geology of northeasternmost Tennesee: U.S. Geological Survey Professional Paper 311, 136 p. 


\title{
GEE CREEK WILDERNESS, TENNESSEE
}

\author{
By Jack B. Epstein, ${ }^{1}$ U.S. Geological Survey, and \\ Gertrude C. Gazdik, U.S. Bureau of Mines
}

\begin{abstract}
SUMMARY
On the basis of geologic, geochemical, and mine and prospect surveys made in 1979 it was determined that the Gee Creek Wilderness has little promise for the occurrence of inineral resources. Iron ore was formerly inined, but the deposits are small, have a high phosphorous content, and are inaccessible. Shale, suitable for brick or lightweight aggregate, and sandstone, which could be utilized for crushed stone or sand, are found in the area, but are also found in areas closer to potential markets. The geologic setting precludes the presence of oil and gas resources in the surface rocks, but the possibility of finding natural gas at depth below the rocks exposed in the area cannot be discounted.
\end{abstract}

\section{CHARACTER AND SETTING}

The Gee Creek Wilderness comprises nearly $4 \mathrm{sq} \mathrm{mi}$ in the Cherokee National Forest, Polk and Monroe Counties, Tennessee, about $4 \mathrm{mi}$ southeast of Etowah, and about 20 mi northeast of Cleveland, Tennessee. The area lies in the Blue Ridge physiographic province and is underlain by sandstone, shale, and conglomerate of the Chilhowee Group that was deposited more than 550 million years ago during the Cambrian Period. Erosion of these sedimentary rocks has produced mountains that reach $2570 \mathrm{ft}$ in altitude that are cut by deep gorges in places. The area is steep and rugged, especially in the southern portions. Gee Creek, which drains the wilderness, parallels Starr and Chestnut Mountains, and cuts through the deep gap at the southwest end of Starr Mountain.

Access to the wilderness is by USFS Road 297, a gravel road leading west from State Route 14, about $5 \mathrm{mi}$ north of Reliance. This road joins the wilderness boundary at Iron Gap on Chestnut Mountain and continues north along this boundary. The southern part of the wilderness can be reached by travelling south $2.3 \mathrm{mi}$ from Wetmore to a gravel road that terminates a few hundred yards from the wilderness boundary. Recent logging has left several haulage roads that serve as trails into the interior. From Iron Gap, one haulage road leads south along the crest of Chestnut Mountain; another leads west to the junction of Gee Creek and its western tributary, Poplar Springs Branch. Most other

${ }^{1}$ With contributions from Paul T. Behum, USBM. logging roads are overgrown. Steep hillsides, rhododendron thickets, slash from recent logging, and dense regrowth combine to make hiking rigorous through much of the area. Fishermen's trails provide access to most of Gee Creek, except for a short stretch in the interior of the wilderness.

The Chilhowee Group is about $2000 \mathrm{ft}$ thick and is divided into four formations, which are, from youngest to oldest, the Hesse Sandstone, Murray Shale, Nebo Sandstone, and Nichols Shale. Alluvium, comprised of mud, sand, and boulders that may be more than $10 \mathrm{ft}$ long, is found along many of the streams, and landslide deposits are found along several of the steeper slopes. Several landslides are still active.

The wilderness is in an open syncline that has been broken by the Gee Creek fault, a low-angle thrust with displacement of at least $2000 \mathrm{ft}$. Subsidiary folds and faults are common. The rocks of the Blue Ridge province have moved for many miles along the Great Smoky fault over folded and faulted rocks of the Valley and Ridge province. Further stratigraphic and structural information on the geology of the Gee Creek Wilderness is given in Epstein (1983a).

The reconnaissance geochemical survey of the Gee Creek Wilderness included the collection of bulk steamsediment, rock, and soil samples which were analyzed by a variety of analytical methods for from 36 to 40 elements (Epstein, 1983b; Gazdik and Behum, 1983). Two shale samples were evaluated for ceramic properties and lightweight aggregate potential (Gazdik and Behum, 1983).

Mining has not been of major importance in the Gee 

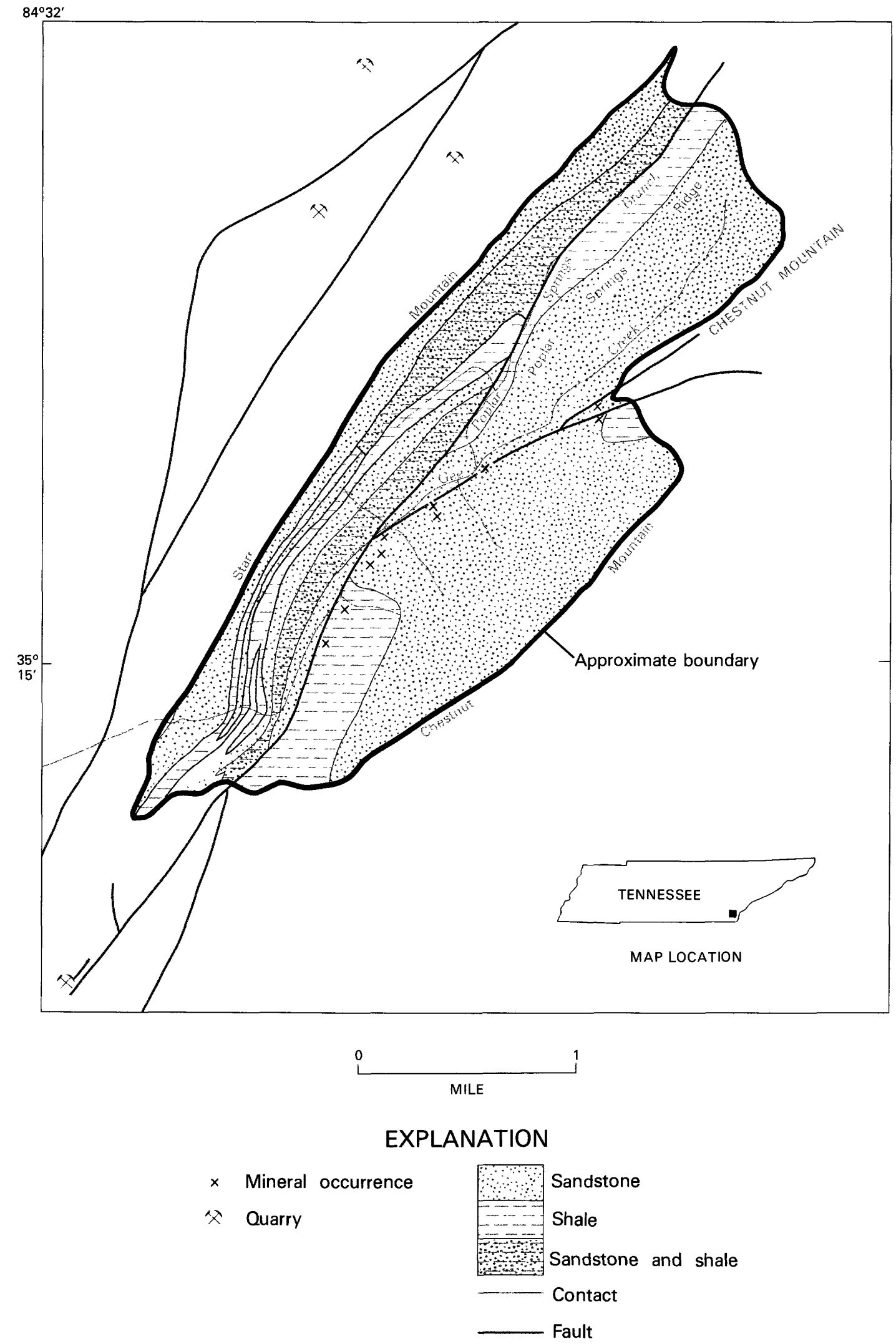

Figure 271.-Gee Creek Wilderness, Tennessee. 
Creek Wilderness. During the 19th and 20th centuries, brown iron ore was produced in small quantitites and smelted locally. There are no active iron mines at present. Limestone has been quarried on the western flank of Starr Mountain, and sandstone was once quarried near the Hiwassee River southwest of the wilderness. The abandoned prospects and mines are discussed by Gazdik and Behum (1983). The resource potential of the Gee Creek Wilderness is discussed by Epstein and others (1983).

\section{MINERAL RESOURCES}

Deposits of iron oxides have been mined immediately west of the wilderness boundary and other prospects and limonite occurrences are also common. The limonite occurs as hard and lumpy boulder-like masses with irregular red, yellow, and black mottling on fresh surfaces. It is surrounded by red and yellow clayey soil. Voids are filled with loose yellow sand material, or less commonly, manganese oxide. War Minerals studies by the USBM during World War II indicated little promise for these deposits because of small size, inaccessibility, and high phosphorous content; present field studies (Gazdik and Behum, 1983) corroborated these earlier findings. Analyses of random samples from one prospect, for example, indicate that the limonite, although high in iron, has a high phosphorous content. However, the abundance of limonite float suggest that iron concentrations may be common along the faults in the area and their thickness and areal extent has not been determined.

Sandstones are well exposed and hold up prominent ridges in the wilderness. Chemical analyses (Gazdik and Behum, 1983, table 2) and microscopic examination (Epstein, 1983b, fig. 5) indicates that, with a few exceptions, the silica content is low and impurities of iron, feldspar, and mica are too high to be acceptable for glass making without extensive beneficiation. Quartzite for fluxstone was quarried many years ago from a locality along the Hiwassee River southeast of the wilderness. This quarry is now abandoned. Much of the sandstone in the Gee Creek Wilderness could be crushed to produce sand, and the harder, better-cemented sand- stones could be processed for road metal. However, these rock types are common elsewhere in the region nearer potential markets.

The abundant shales within the Gee Creek Wilderness have ceramic properties and bloating characteristics that proved suitable for building and floor bricks and lightweight aggregate (Gazdik and Behum, 1983). Similar shales are found extensively outside the wilderness in areas closer to major markets.

The rocks of the Chilhowee Group exposed in the Gee Creek Wilderness appear to have reached too high a level of thermal maturity to have any oil and gas remaining. However, these rocks have been thrust along the Great Smoky fault over carbonate rocks of Cambrian and Ordovician age which have produced gas to the west in Tennessee. The potential for gas in the area underlain by these rocks has not been evaluated.

\section{SUGGESTIONS FOR FURTHER STUDY}

Geophysical exploration would be necessary to define the local structure in rocks at depth to properly evaluate the potential of the area for gas. This should be a regional study, however, and not be confined to the wilderness boundaries. Additional study within the Gee Creek Wilderness does not seem warranted because there appears to be little promise for the occurrence of hidden mineral resources.

\section{REFERENCES}

Epstein, J. B., 1983a, Geologic map of the Gee Creek Wilderness, Polk and Monroe Counties, Tennessee: U.S. Geological Survey Miscellaneous Field Studies Map MF-1474-A, scale 1:24,000.

Epstein, J. B., 1983b, Reconnaissance geochemical map of the Gee Creek Wilderness area, Polk and Monroe Counties, Tennessee: U.S. Geological Survey Miscellaneous Field Studies Map MF-1474-B.

Epstein, J. B., Gazdik, G. C., and Behum, P. T., 1983, Mineral resource potential of the Gee Creek Wilderness, Polk and Monroe Counties, Tennessee: U.S. Geological Survey Miscellaneous Field Studies Map MF-1474-D, scale 1:24,000.

Gazdik, G. C., and Behum, P. T., 1983, Map showing mines, quarries, prospects, and analyses of samples, Gee Creek Wilderness, Polk and Monroe Counties, Tennessee: U.S. Geological Survey Miscellaneous Field Studies Map MF-1747-C. 


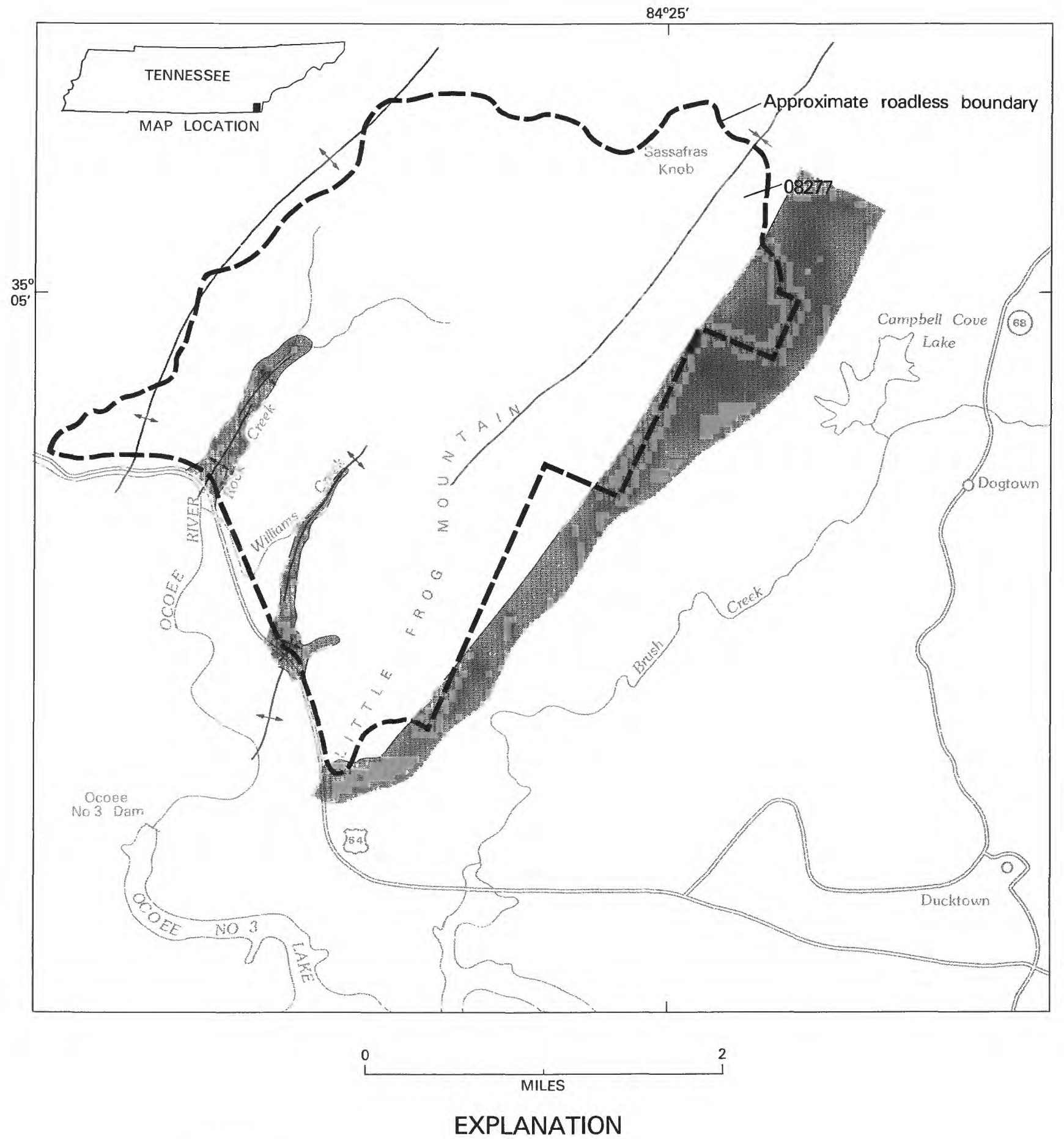

Meta-arkose, gray slate, and fine polymictic conglomerate (Proterozoic Z)

Black graphitic slate and dark sulfidic and graphitic graywacke

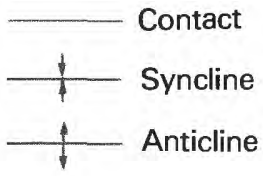
(Proterozoic Z)

Figure 272.-Little Frog Roadless Area, Tennessee. 


\title{
LITTLE FROG ROADLESS AREA, TENNESSEE
}

\author{
By ERIC R. Force, U.S. Geological SurVey, and \\ Gertrude C. GaZdik, U.S. BuREau of Mines
}

\begin{abstract}
SUMMARY
No mineral-resource potential was identified during studies of the Little Frog Roadless Area, during studies by the USGS and USBM in 1979-82. Possibilities exist, however, for the occurrence of massive sulfide-bearing rocks of the type mined in the adjacent Ducktown Basin at depth beneath the roadless area. A possibility also exists for the presence of natural gas in sedimentary rocks at great depth. Insufficient data to support these concepts precludes assessing any of the roadless area as having resource potential.
\end{abstract}

\section{CHARACTER AND SETTING}

The Little Frog Roadless Area, Polk County, Tennessee, is in a southern extension of the Great Smoky Mountains, and forms part of the northern side of the Ocoee River Gorge. The roadless area occupies $7 \mathrm{sq} \mathrm{mi}$ and ranges in altitude from 1230 to $3320 \mathrm{ft}$. It is entirely forested and locally has heavy underbrush. Natural rock exposures are sparse except in streambeds; good roadcut exposures exist on U.S. Highway 64 along the gorge. Immediately east is the intermontane Ducktown or Copper Basin, where massive sulfide deposits have been mined since the 19th century.

Exposed rocks in the roadless area are late Precambrian in age, are deformed into folds shaped like stairsteps, and are recrystallized to chlorite-bearing rocks. The lowermost unit of black slate and dark sandstone contains conspicuous graphite and iron sulfides. The overlying unit of gray slate, lighter-colored feldspathic sandstone (much of it coarse and containing small pebbles), and shale-cobble conglomerate, is at least $1350 \mathrm{ft}$ thick. Both units apparently formed as coarse debris, some deposited as turbidites, in an opening seaway of late Precambrian age, 600-900 million years ago.

Rock, soil, and stream-sediment samples were collected and analyzed for 31 elements, and compared with analyses of samples from areas of known massive sulfide deposits in similar rocks nearby. Only a few gold and silver values were considered anomalous.

\section{MINERAL RESOURCES}

No mineral-resource potential was identified during studies of the roadless area. A potential may exist, however, for metal deposits in underlying rocks.

The rocks of the roadless area appear to be separated from those of the Ducktown Basin by one or more thrust faults or unconformities. If these structures are roughly parallel to folded beds in the roadless area, massive sulfides of the Ducktown type could be present at depths of as little as $2000 \mathrm{ft}$ beneath the roadless area.

An even deeper thrust fault separates rocks of the Blue Ridge, including those present in both the Great Smoky Mountains and the Ducktown Basin, from underlying sedimentary rocks which may contain natural gas. There is not sufficient evidence to support either of these concepts consequently no resource potential was identified in the area.

\section{SUGGESTIONS FOR FURTHER STUDY}

A limited amount of geologic mapping coupled with seismic work in the Ocoee Gorge would be useful to test whether rocks of the Ducktown Basin are present at depth under the roadless area. Seismic work and drilling would be necessary also to test for the presence of gas at great depths. 


\section{REFERENCES}

Force, E. R., 1981, Geologic map of the Little Frog Roadless Area, Polk County, Tennessee: U.S. Geological Survey Miscellaneous Field Studies Map MF-1338-A, scale 1:24,000.

Force, E. R., and Siems, D. F., 1983, Geochemical survey of the Little Frog Roadless Area, Polk County, Tennessee: U.S. Geological Survey Miscellaneous Field Studies Map MF-1338-B, scale $1: 24,000$.

Force, E. R., and Gazdik, G. C., 1983, Mineral resource potential map of the Little Frog Roadless Area, Polk County, Tennessee: U.S. Geological Survey Miscellaneous Field Studies Map MF-1338-C, scale 1:24,000. 


\title{
POND MOUNTAIN AND POND MOUNTAIN ADDITION ROADLESS AREAS, TENNESSEE
}

\author{
W. R. GRIFFITTS, U.S. GEOLOGICAL SURVEY, and \\ RICHARD BITAR, U.S. BUREAU OF MINES
}

\begin{abstract}
SUMMARY
As a result of a mineral study of the Pond Mountain Roadless Areas, Tennessee, by the USGS and USBM in 1980-82 a probable potential for the occurrence of tin, niobium, and tungsten resources with associated beryllium, molybdenum, zinc, and fluorite was identified in rocks of Precambrian age particularly in the southeastern part of the area.
\end{abstract}

\section{GHARACTER AND SETTING}

The Pond Mountain and Pond Mountain Addition Roadless Areas encompass about $10 \mathrm{sq} \mathrm{mi}$ in the Cherokee National Forest in eastern Tennessee. The two roadless areas are in Carter County, about 7 mi southeast of Elizabethton, close to the Tennessee-North Carolina boundary. The heavily wooded area rises southward from an altitude of about $2000 \mathrm{ft}$ near Lake Wataunga to about $4000 \mathrm{ft}$ in the Blue Ridge Mountains. Roads near the northern, eastern, and southern boundaries provide access to the area; the Appalachian Trail crosses the roadless area.

The Pond Mountain and Pond Mountain Addition Roadless Areas are on the northwestern flank of the Blue Ridge in Carter County, Tennessee, and are underlain by crystalline rocks of Precambrian age and clastic rocks and dolomite of Cambrian age. The younger Precambrian rocks in the southeastern part of the roadless areas consist of rocks with granitic texture ranging in composition from quartz monzonite to granodiorite. Coarse, massive, pink granite is predominant, but small bands of finer-grained red granite and finegrained porphyritic granite are within the coarse granite, as are local steeply dipping phyllite layers.

Older Precambrian rocks are thrust over the younger Precambrian granitic rocks and are a complex of quartzmonzonite and granite that has been highly sheared and metamorphosed, resulting in flaser gneiss, phyllonite, and mylonite. These older rocks have been cut by pegmatites, quartz veins, and dikes.

The sedimentary rocks that lie unconformably on the basement rocks include at the base, the thick Chilhowee Group of clastic rocks of Early Cambrian age followed by the Shady Dolomite, of Early and Middle Cambrian age. Concretions or lumps of manganese and iron oxides in the residuum overlying the lower part of the Shady Dolomite have been mined locally as manganese ore.

A few prospects for radioactive materials were opened in the Precambrian rocks in and alongside the roadless areas in the 1950's and iron prospects were opened in veins in the same general areas many years earlier. Manganese and iron have been mined from residual deposits along the northern and northwestern edge of the area.

Geochemical field work by the USGS and examination of prospects and sampling of rocks and sediment by the USBM were undertaken in 1980-82 as part of a study to determine the resource potential of the area. Information about the geology of the area was taken from a report by King and others (1960).

\section{MINERAL RESOURCES}

Small manganese deposits have been known for many years in residuum of weathered Shady Dolomite that is restricted to remnants of the Harrisburg peneplain. Manganese and iron are found in lumps of hydrous oxides embedded in soft tan to light-brown clay. A little manganese was mined from such deposits in the Hampton district northwest of the area and a few prospects are located within the roadless areas, but no resource potential for manganese was identified in this study.

Many years ago iron ore prospects were located in the Precambrian rocks near the roadless areas and prospects were located in the 1950's for thorium in, and near, the area. No significant deposits were found. 

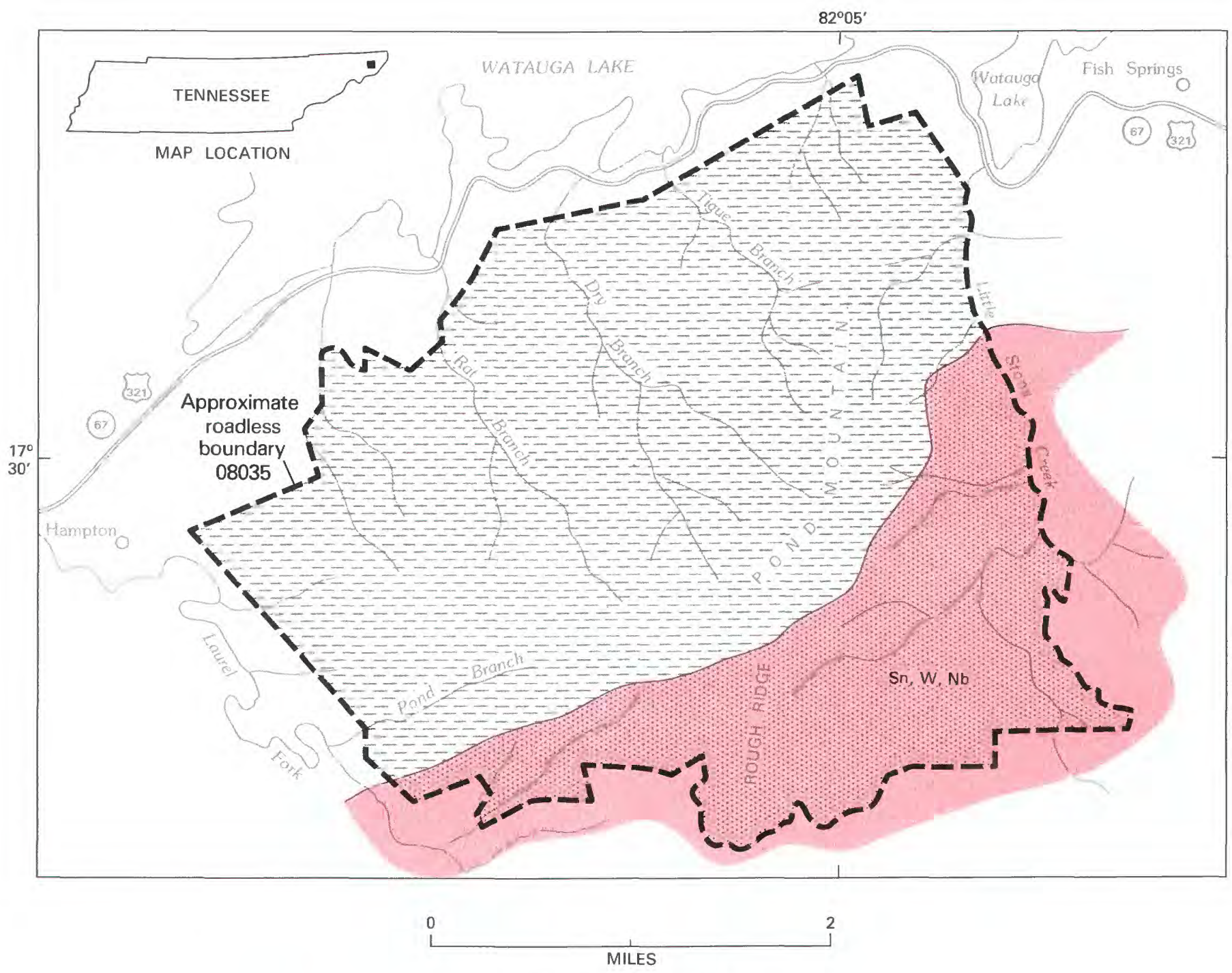

\section{EXPLANATION}

\begin{tabular}{|lll}
\hline & $\begin{array}{l}\text { Geologic terrane with probable } \\
\text { mineral-resource potential }\end{array}$ & Cambrian sedimentary rocks \\
Nb & Niobium & Precambrian rocks \\
Sn & Tin & Contact \\
W & Tungsten &
\end{tabular}

Figure 273.-Pond Mountain and Pond Mountain Addition Roadless Areas, Tennessee. 
Pan concentrates from each stream in or alongside the roadless areas were analyzed mineralogically and spectrographically. Most samples collected in the area of Precambrian rock contain fluorite and topaz and the following elements: tin in concentrations that exceed 1000 parts per million, niobium concentrations of 200 to 2000 parts per million, tungsten concentrations of 200 to 2000 parts per million, beryllium concentrations of 10 to 200 parts per million, and molybdenum concentrations of 10 to 20 parts per million. Most of these elements with fluorite and topaz are found in most of the world's leading tin districts (Taylor, 1979).

The abundance of tin, beryllium, niobium, and tungsten associated with small amounts of molybdenum and zinc provide clear evidence that the Precambrian rocks in the roadless area are mineralized. The metals are probably in the bedrock as hypothermal replacement deposits that are probably related to the magnetite and hematite veins reported by King and others $(1960$, p. 86). Cataclastic rocks along a shear zone in the headwaters of Firescald Branch and Big Branch average about 0.1 percent niobium. Minerals identified in the rocks include columbite, fergusonite, euxenite, pyrochlore, thorite, thalenite, bastnaesite, and cerianite (Bitar and others, 1983). Tungsten and beryllium contents are not high in these cataclastic rocks, but a vein on Walnut Mountain contains 6 parts per million tungsten, 26 parts per million beryllium, and 400 parts per million tin (Bitar and others, 1983). Sediment samples that are rich in niobium and tungsten are most abundant in the southeastern part of the roadless areas, including the sites at which topaz and fluorite were found. Columbite and wolframite, probably the main hosts of niobium and tungsten, respectively, do not survive transport over very long distances so they may have disappeared from the sediment as it was reworked into the western and northern streams. The more durable tin mineral, cassiterite, could persist for much longer distances, providing more widely dispersed geochemical anomalies. However, the entire southeastern area of Precambrian rocks in the Pond Mountain Addition Roadless Area has probable mineral-resource potential for tin and tungsten.

\section{SUGGESTIONS FOR FURTHER STUDIES}

Detailed geologic mapping and geochemical sampling of the soils and rocks in the area of Precambrian rocks is recommended to identify and delimit the areas of potential resources of tin, niobium, and tungsten.

\section{REFERENCES}

Bitar, R. F., Behum, P. T., and Hammack, R. W., 1983, Mineral investigation of Pond Mountain and Pond Mountain Addition RARE II Further Planning Areas, Carter County, Tennessee: U.S. Bureau of Mines Open-File Report.

Griffitts, W. R., and Bitar, Richard, in press, Mineral resource potential map of the Pond Mountain and Pond Mountain Addition Roadless Areas, Carter County, Tennessee: U.S. Geological Survey Miscellaneous Field Studies Map MF-1648-A, scale 1:24,000.

King, P. B., and Ferguson, H. W., 1960, Geology of northeasternmost Tennessee: U.S. Geological Survey Professional Paper 311, 136 p.

Taylor, R. G., 1979, Geology of tin deposits: Amsterdam, Elsevier, $543 \mathrm{p}$. 

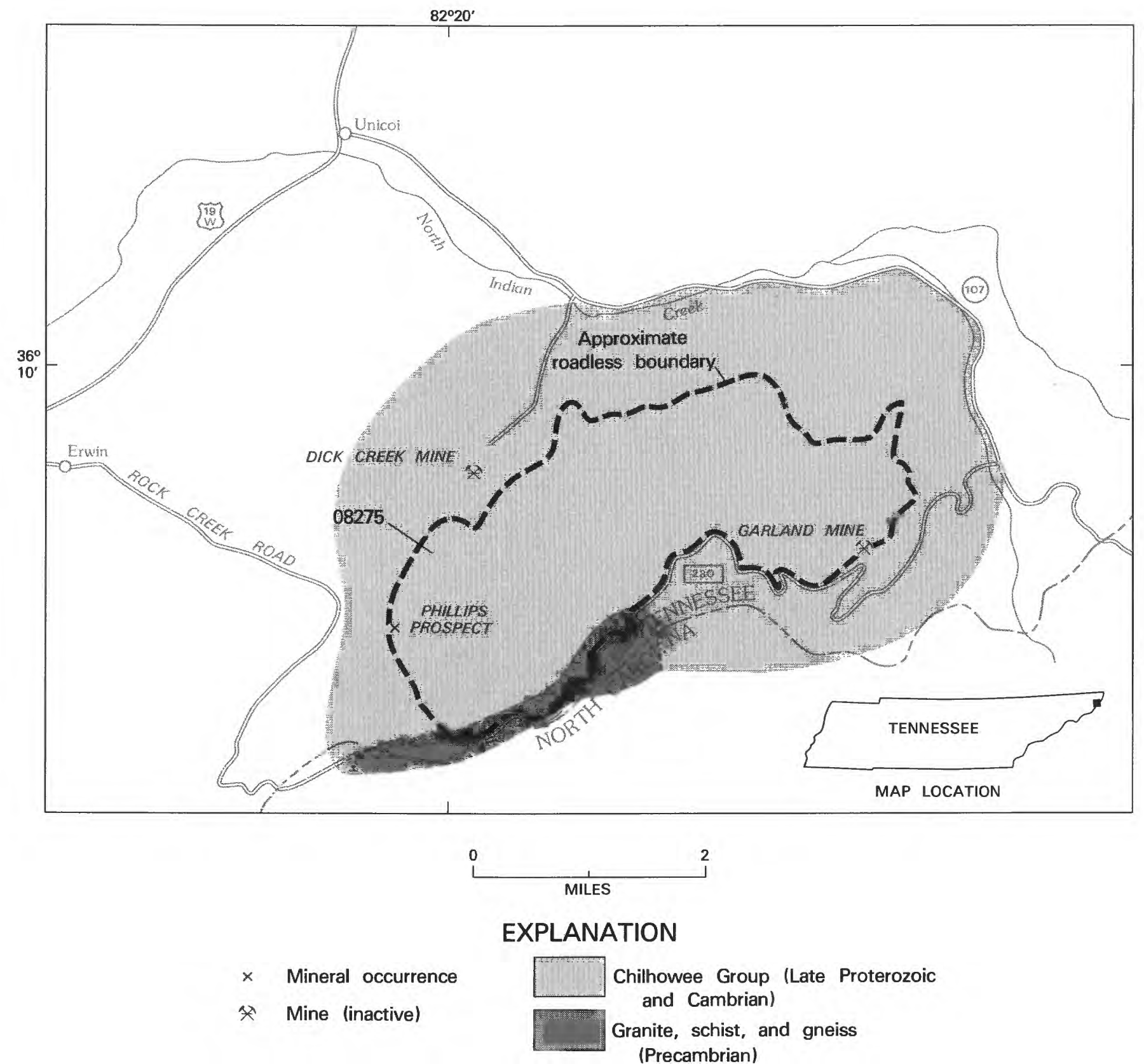

Chilhowee Group (Late Proterozoic and Cambrian)

Granite, schist, and gneiss (Precambrian)

Contact

Figure 274.-Unaka Mountain Roadless Area, Tennessee. 


\title{
UNAKA MOUNTAIN ROADLESS AREA, TENNESSEE
}

\author{
By WAllace R. GRIfFitTS, U.S. GeOlOGical SuRVEY, and \\ Mark ChatMan, U.S. BUREAU OF MiNeS
}

\section{SUMMARY}

No metallic mineral or energy resource potential was identified in the Unaka Mountain Roadless Area during mineral surveys made in 1981 by the USGS and USBM. Stone suitable for use as rough building stone and crushed rock is the only identified mineral resource in the roadless area. Abundant stone resources are readily available in the region outside the roadless area.

\section{CHARACTER AND SETTING}

The Unaka Mountain Roadless Area comprises $7.3 \mathrm{sq}$ mi on the north side of Unaka Mountain in the Cherokee National Forest in northeastern Tennessee. The area lies entirely in Unicoi County, about $2.5 \mathrm{mi}$ south of Stone Mountain. The Tennessee-North Carolina State line nearly parallels the southern border of the roadless area. Access to the area is primarily by dirt roads and trails. Relief is moderate to steep and vegetation thick in most places.

Clastic rocks of the Chilhowee Group of Late Proterozoic and Early Cambrian age underlie about 98 percent of the Unaka Mountain Roadless Area. Granite, schist, and gneiss of Precambrian age underlie the other 2 percent of the area.

The Chilhowee Group is composed of three formations in this area. The lowest, the Late Proterozoic Unicoi Formation, is largely quartzite, in part arkosic. The middle, the Late Proterozoic Hampton Formation, is predominantly shale with interlayered siltstone and quartzite. The uppermost formation in the group is the Lower Cambrian Erwin Formation, which is mainly quartzite with subordinate siltstone and shale.

Heavy-mineral concentrates from a few small streams show low to moderate concentrations of several ore metals. Of these, barium and zinc are most likely to occur in substantial concentrations. These two metals were found in only a few samples obtained from creeks that drain terrane of the Chilhowee Group and no resource potential was identified.

The Phillips manganese prospect is in the roadless area, and the Dick Creek iron mine is about 0.25 mi outside of it, but neither appears to contain resources. The roadless area borders the Unicoi manganese-iron mining district of Tennessee (King and others, 1944; Maher, 1964), but the residual ores of that district do not extend into the area. A third site of mineral activity in the roadless area, the Garland mine, was reported to have been worked earlier for silver.

\section{MINERAL RESOURCES}

No mineral-resource potential was identified in a mineral study of the Unaka Mountain Roadless Area in 1981. The known manganese and iron deposits are too small to be assessed as having resource potential and the reported silver mineralization was not confirmed. No oil, gas, uranium, or copper resources were identified although the evidence for deposits of those materials is permissive.

Seismic profiling interpretations suggest that hydrocarbons may exist under part of the Blue Ridge (Cook and others, 1979; 1980), but the Unaka Mountain Roadless Area has not been tested for oil and gas possibilities. It is unlikely that petroleum occurs in the small roadless area itself.

Middle Proterozoic Cranberry Gneiss, exposed over 2 percent of the roadless area, has a high background radioactivity, but analysis of samples showed only small amounts of uranium and no thorium.

Samples from some creeks in the region draining rocks of the Chilhowee Group contain moderate to high contents of barium, copper, and zinc, suggestive of possible sedimentary-type copper deposits. This is only a possibility, however, and no mineral-resource potential was identified in the area of the Chilhowee Group. Stone suitable for use as rough building stone and crushed rock is the only identified mineral resource in 
the roadless area. Abundant stone resources are readily available in the region outside the roadless area.

\section{REFERENCES}

Chatman, M. L., 1982, Mineral investigations of the Unaka Mountain RARE II Further Planning Area, Unicoi County,Tennessee: U.S. Bureau of Mines Open File Report MLA 87-82, 15 p.

Cook, F. A., Albauth, D. S., Brown, L. D., Kaufman, Sidney, Oliver, J. E., and Hatcher, R. D., Jr., 1979, Thin-skinned tectonics in the crystalline southern Appalachians; COCORP seismic-reflection profiling of the Blue Ridge and Piedmont: Geology, v. 7, December 1979 , p. 563-567.
Cook, F. A., Brown, L. D., and Oliver, J. E., 1980, The Southern Appalachians and the growth of continents: Scientific American, v. 243 , no. 4 , p. $156-168$.

Griffitts, W. R., and Chatman, Mark, 1983, Mineral resource potential of the Unaka Mountain Roadless Area, Unicoi County, Tennessee: U.S. Geological Survey Open-File Report 83-445.

King, P. B., and Ferguson, H. W., 1960, Geology of northeasternmost Tennessee: U.S. Geological Survey Professional Paper 311, 136 p.

King, P. B., Ferguson, H. W., Craig, L. C., and Rodgers, John, 1944, Geology and manganese deposits of northeastern Tennessee: Tennessee Division of Geology Bulletin 52, $275 \mathrm{p}$.

Maher, S. W., 1964, The brown iron ores of east Tennessee: Tennessee Division of Geology Report of Investigations 19,63 p. 



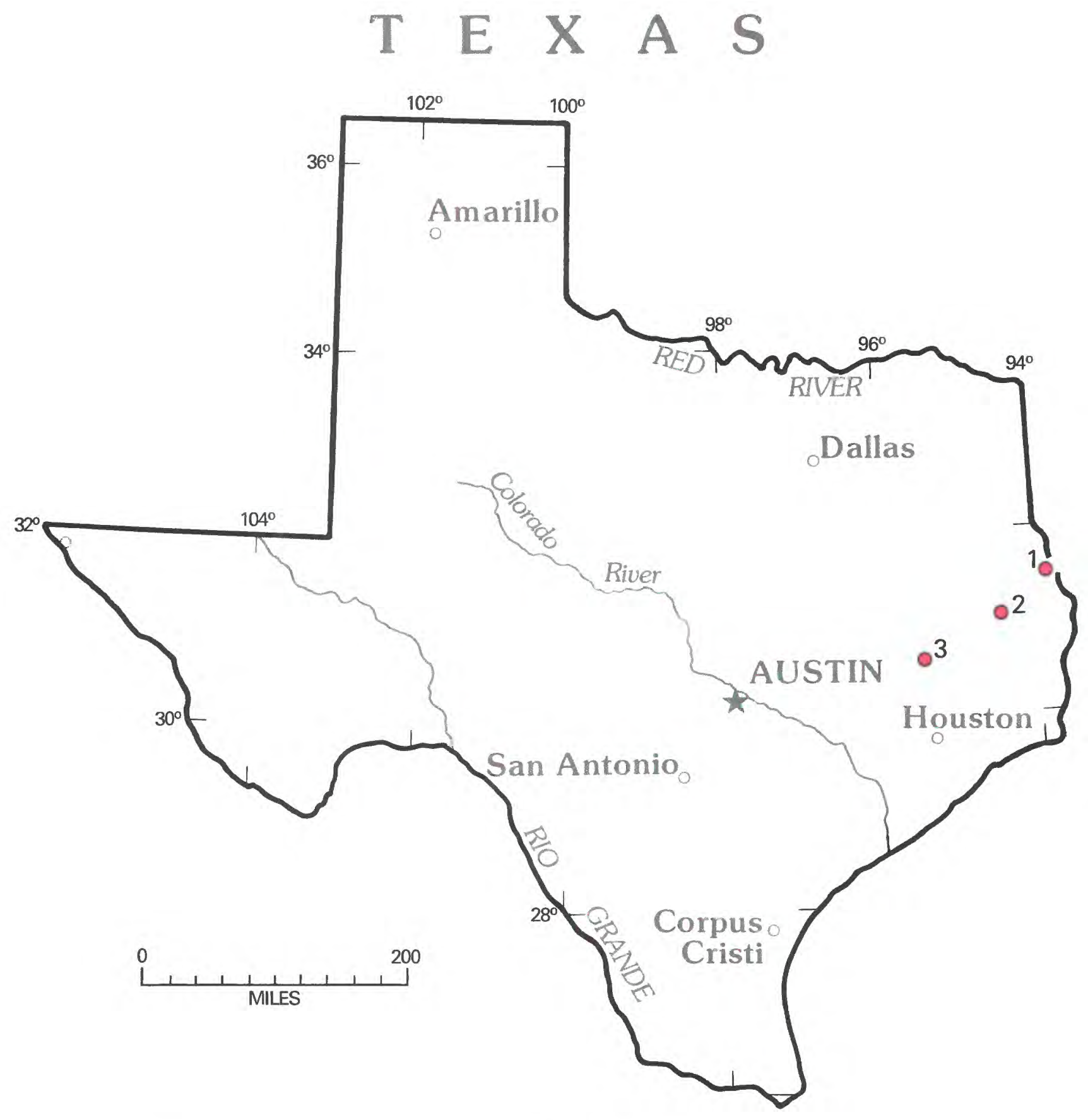

Location of areas studied. 


\title{
TEXAS
}

\author{
Map \\ No. Name of Area \\ 1 Chambers Ferry Roadless Area \\ 3 Four Notch Roadless Area \\ 2 Graham Creek Roadless Area
}



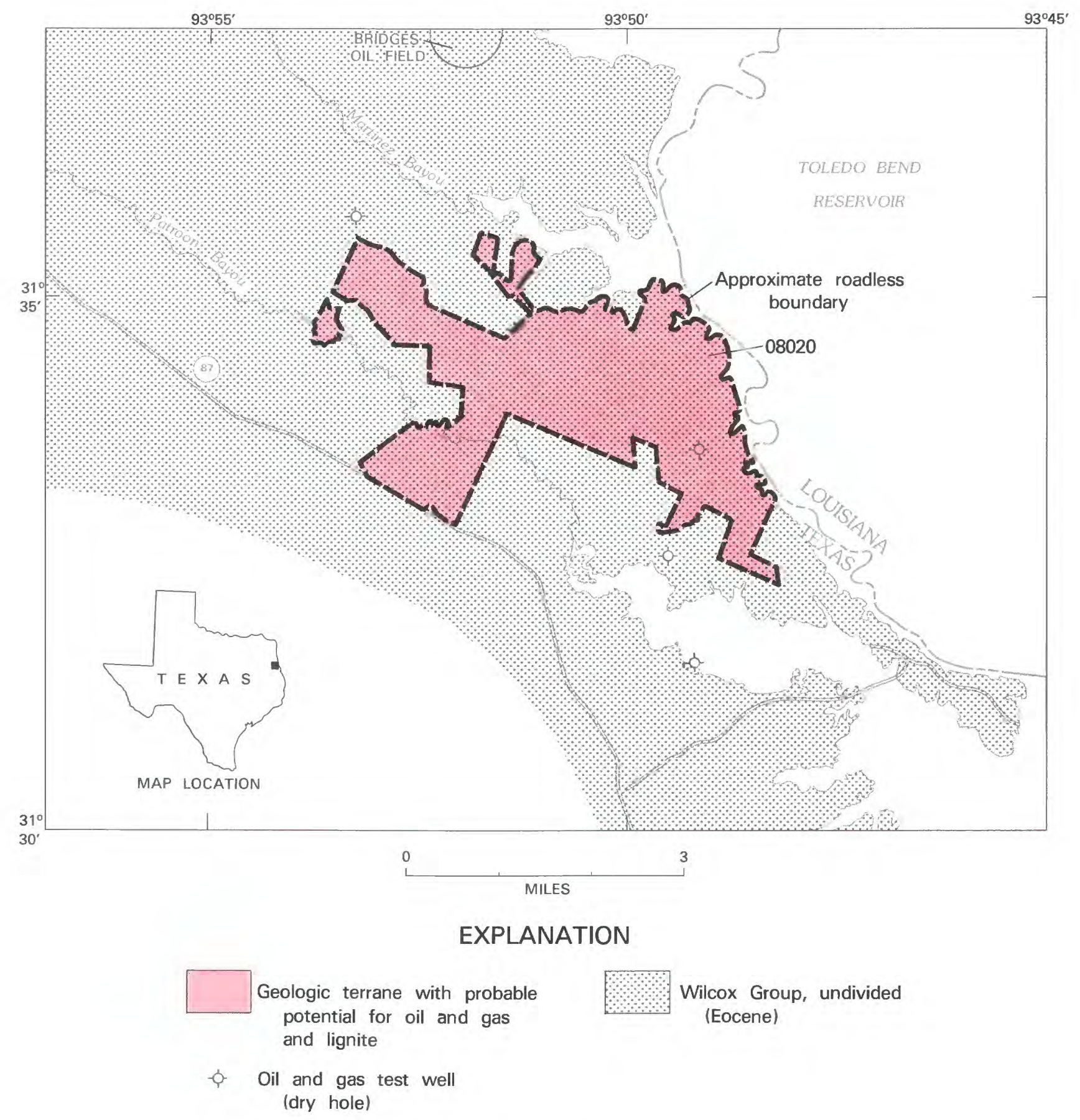

Figure 275.-Chambers Ferry Roadless Area, Texas. 


\title{
CHAMBERS FERRY ROADLESS AREA, TEXAS
}

\author{
By B. B. Houser, U.S. GeOlogical Survey, and \\ GeORGE S. RYAN, U.S. BUREAU OF Mines
}

\section{SUMMARY}

\begin{abstract}
A geologic and geochemical investigation of the Chambers Ferry Roadless Area, Texas was conducted in 1981-82. The area has probable mineral-resource potential for oil and gas and for lignite. No metallic or additional energy resources were identified in the investigation.
\end{abstract}

\section{CHARACTER AND SETTING}

The Chambers Ferry Roadless Area comprises 7.3 sq $\mathrm{mi}$ in the Sabine National Forest in Sabine County, Texas, adjacent to the Texas-Louisiana State line. The roadless area is in the Gulf of Mexico Coastal Plain and is characterized by low hills separated by numerous small drainages. The altitudes ranges from 160 to $285 \mathrm{ft}$. Drainage is by steep gradient intermittent streams and gullies tributary to Martinez Bayou on the northeast, Patroon Bayou on the southwest, and the Sabine River on the east (now Toledo Bend Reservoir). The climate is humid subtropical with an annual precipitation of about $52 \mathrm{in}$. and a mean annual temperature of about $66^{\circ} \mathrm{F}$. The area supports the vegetation of the Pine Woods belt of the Forested Coastal Plain.

A mineral survey of the Chambers Ferry Roadless Area was conducted in 1981 and 1982. The USBM investigation included a radiometric survey and analysis of surface sediment samples for uranium. The USGS conducted a geologic and geochemical survey of the region which included drilling and collecting samples from six auger holes ranging from 57 to $102 \mathrm{ft}$ deep for stratigraphic and geochemical anaylses. The oil and gas resource potential of the area was evaluated by Gordon L. Dolton of the USGS using readily available data only. The results of these surveys were published in 1983 (Houser and Ryan, 1983). Thirty-four percent of the mineral rights in the roadless area are privately owned.

Geologically, the roadless area is in the north-central part of the Western Gulf Basin which is filled with a sequence of seaward-thickening wedges of sand, silt, and clay. The sequence is relatively young (Cenozoic) and reaches thicknesses of tens of thousands of feet beneath the Gulf of Mexico. The sediments are deposits of rivers, deltas, shorelines, and continental shelves and slopes. Underlying this young sequence of sedimentary rocks is an older sequence of Mesozoic rocks which consists chiefly of limestone and sandstone with a basal evaporite unit in the subsurface called the Louann Salt.

Regionally, the sedimentary rocks of the Gulf Basin dip gently seaward or are broadly warped by large structures such as the East Texas Embayment and the Sabine uplift. Folding and faulting is confined chiefly to sediments in the vicinity of salt domes and in zones termed flexures. Flexures are discontinuous arcuate zones parallel to the modern shoreline where growth faults are concentrated. Growth faults constitute an important category of faults generally considered to be nontectonic in origin. They are gravity-induced faults (down on the coastward side) generated by sediment loading. Movement along the fault planes is more or less continuous for the duration of sediment deposition and, thus, the amount of displacement is greater with increasing sediment age. Both salt domes and growth faults are effective hydrocarbon traps and are targets for exploration.

Other zones of hydrocarbon accumulation in the Gulf Basin, not associated with faults, are called trends. These are zones parallel to the coastline where similarity of age, depositional environment, and depth of burial has resulted in packages of sedimentary rocks with similar characteristics regarding their favorability as hydrocarbon source or reservoir rocks. Only one geologic unit, the lower Eocene Wilcox Group, is present in the Chambers Ferry Roadless Area. The Wilcox Group is chiefly semiconsolidated mudstone with minor beds of fine-grained sandstone as thick as $20 \mathrm{ft}$ and locally common, thin, impure lignite seams. The rocks dip gently to the southwest because the area is on the south-southwest margin of the Sabine uplift, a broad structural dome about $100 \mathrm{mi}$ across, centered on the Texas-Lousiana State line. 


\section{MINERAL RESOURCES}

The Chambers Ferry Roadless Area has probable resource potential for oil and gas on the basis of its regional setting and nearby producing fields. Data show a history of exploration drilling in the vicinity. Most wells are shallow, on the order of 1500 to $3000 \mathrm{ft}$, and penetrate portions of the Eocene sequence, however, there are several deep wells in the general area, which test rocks as old as Cretaceous. A 9500-ft test well was drilled near the southeastern edge of the area (Santa Fe Energy, \#1 Chamber). Nearest production is about 2 to $3 \mathrm{mi}$ to the north and northwest in the Bridges and Patroon fields in Shelby County, Texas. These fields, discovered in 1950 and 1948, respectively, have produced only small amounts of high gravity oil to date (slightly more than 50,000 barrels altogether) from the Lower Cretaceous Fredericksburg Group. Gas production has also been established at Huxley field farther to the north, which produces from the Lower Cretaceous Paluxy, Rodessa, and Pettet Formations. Larger production has been established about $10 \mathrm{mi}$ to the east in Sabine Parish, Louisiana, at Zwolle, Pendleton-Many, and Converse fields, in addition to production at a number of small fields such as Blue Lake (now beneath Toledo Bend Reservoir). The significant plays there are from Upper and Lower Cretaceous reservoirs and producing depths are generally 1500-3000 ft. PendletonMany, the largest field, has produced about 20 million barrels of oil while Zwolle has produced over 16 million barrels (by end of 1976).

Seven lignitic seams were penetrated in the auger holes drilled in the Chambers Ferry Roadless Area. The seams range from 2 to $11 \mathrm{ft}$ thick with an average thickness of $4 \mathrm{ft}$. Proximate and ultimate analyses of six lignitic samples indicate high ash and sulfur content relative to lignite mined elsewhere in East Texas, and calculations of rank indicate that only one sample could be classified as high as lignite. Because the auger method of drilling can result in considerable sample contamination, the analyzed ash content of the samples and the calculated rank may be either too high or too low. Descriptions in other geologic reports of lignite in the general area, however, suggest that the lignite seams are typically impure, thin, and discontinuous. On this basis, the Chambers Ferry Roadless Area is classed as having probable resource potential for lignite, although it is unlikely that there are any laterally extensive lignite seams within the area.

Except for oil and gas and near-surface lignite, there are no other mineral resources in the Chambers Ferry Roadless Area. Specialty clays and sands are not present. No uranium mineralization was identified.

\section{SUGGESTIONS FOR FURTHER STUDIES}

Detailed analyses of well logs from the vicinity of the Chambers Ferry Roadless Area, in conjunction with seismic data, are necessary to determine if the subsurface stratigraphy and structure are favorable for the accumulation of oil and gas. These data may exist but are likely to be proprietary.

A shallow drilling program involving coring on a close-spaced grid is necessary for determination of the rank and continuity of seams of lignitic sediments in the area.

\section{REFERENCE}

Houser, B. B. and Ryan, G. S., 1983, Geologic and mineral resource potential map of the Chambers Ferry Roadless Area, Sabine County, Texas: U.S. Geological Survey, Miscellaneous Field Studies Map MF-1553, scale 1:50,000. 


\title{
FOUR NOTCH ROADLESS AREA, TEXAS
}

\author{
By B. B. Houser, U.S. Geological Survey, and \\ GeOrge S. RYAN, U.S. BUREAU OF MineS
}

\begin{abstract}
SUMMARY
A geologic and geochemical investigation of the Four Notch Roadless Area, Texas, was conducted in 1981-82. The area has a probable resource potential for oil and gas. There is, however, little promise for the occurrence of metallic mineral resources or other energy resources.
\end{abstract}

\section{CHARACTER AND SETTING}

The Four Notch Roadless Area comprises $8.8 \mathrm{sq} \mathrm{mi} \mathrm{in}$ the Sam Houston National Forest in Walker County, Texas, about 70 mi north of Houston. The roadless area is in the Gulf of Mexico Coastal Plain and is characterized by low rounded hills with a total relief of about $170 \mathrm{ft}$ and median altitude of about $350 \mathrm{ft}$. Drainage is by a dendritic network of southeast-flowing intermittent streams tributary to the East Fork of the San Jacinto River. The climate is humid subtropical with an annual precipitation of about $45 \mathrm{in}$. and a mean annual temperature of about $67^{\circ} \mathrm{F}$. The vegetation of the area is locally termed the East Texas Piney Woods. A segment of the Lone Star hiking trail crosses the area.

A mineral survey of the Four Notch Roadless Area was conducted in 1981 and 1982. The USBM investigation included a radiometric survey and analysis of surface sediment samples for uranium. The USGS conducted a geologic and geochemical survey of the region which included drilling and collecting samples from twelve auger holes ranging from 17 to $87 \mathrm{ft}$ deep for stratigraphic and geochemical analyses. The oil and gas resource potential of the area was evaluated by Gordon L. Dolton of the USGS using regional data. The results of these surveys were published in 1983 (Houser and Ryan, 1983). Ninety-nine percent of the mineral rights in the roadless area are privately owned.

Geologically, the area is in the north-central part of the Western Gulf Basin which is filled with a sequence of seaward thickening wedges of sand, silt, and clay. The sequence is relatively young (Cenozoic) and reaches thicknesses of tens of thousands of feet beneath the Gulf of Mexico. The sediments are deposits of rivers, deltas, shorelines, and continental shelves and slopes.
Underlying the sequence of sand, silt, and clay is an older sequence of rocks (Mesozoic) which consists chiefly of limestone and sandstone with a basal evaporite unit in the subsurface called the Louann Salt.

The sediments of the Gulf Basin dip gently seaward and are undeformed except in the vicinity of salt domes and in zones termed flexures. These are discontinuous arcuate zones parallel to the modern shoreline where growth faults are concentrated. Growth faults constitute an important category of faults generally considered to be nontectonic in origin. They are gravityinduced faults (down on the coastward side) generated by sediment loading. Movement along the fault planes is more or less continuous for the duration of sediment deposition and, thus, the amount of displacement is greater with increasing sediment age. Both salt domes and growth faults are effective hydrocarbon traps and are targets of exploration.

Other zones of hydrocarbon accumulation in the Gulf Basin, not associated with faults, are called trends. These are zones parallel to the coastline where similarity of age, depositional environments, and depth of burial has resulted in packages of sediments with similar characteristics regarding their favorability as hydrocarbon source and reservoir rocks.

The geologic formations present in the Four Notch Roadless Area are a lower, semiconsolidated, calcareous clay unit (Miocene Fleming Formation) separated from an overlying sand unit (Pleistocene Willis Formation) by a surface of weathering and erosion. Within the roadless area, both units are undeformed and the surface separating them dips coastward at $15-30 \mathrm{ft} / \mathrm{mi}$. One and three quarters of a mile north of the area, this surface is displaced downward about $100 \mathrm{ft}$, probably by a fault or fold. 


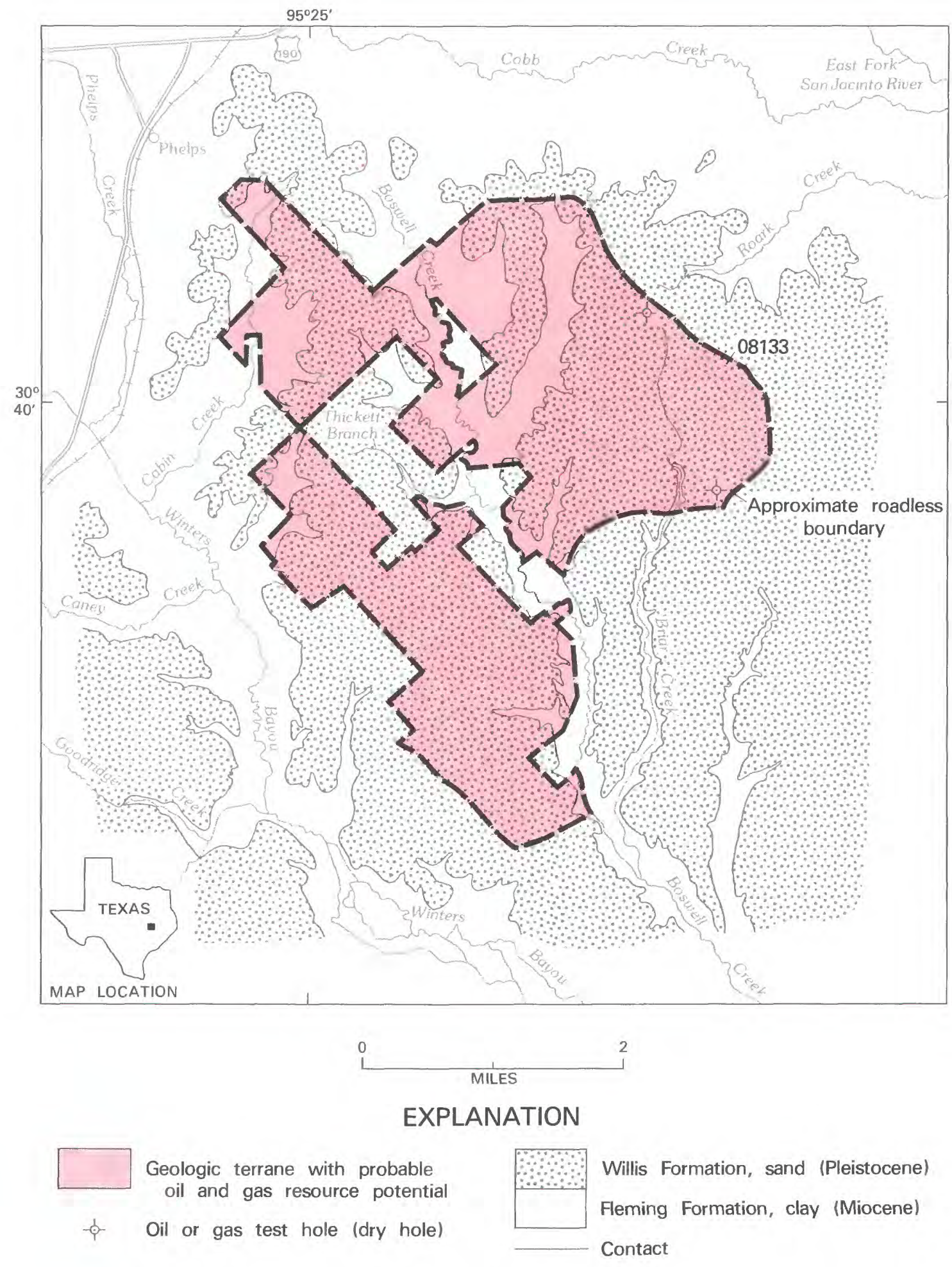

Figure 276.-Four Notch Roadless Area, Texas. 


\section{MINERAL RESOURCES}

The Four Notch Roadless Area has a probable resource potential for oil and gas on the basis of its regional setting, nearby producing fields, and the possibility that a structural trap may be present just north of the area.

Although the roadless area is not known to overlie any significant producing structures, projections of Cretaceous and Eocene structural trends indicate they may pass near the area. There is a history of exploration drilling in and around the roadless area, and some holes were drilled to depths greater than $15,000 \mathrm{ft}$, but no significant production has been established. Two dry holes were drilled within the roadless area and three on private land enclosed by the area. The closest production is $3 \mathrm{mi}$ northwest of the roadless area from the Morain-Sam Houston field, which has yielded approximately 150,000 barrels of oil from the Eocene Yegua Formation. This field appears associated with a major fault. Other small fields lie farther to the north and south and produce principally from Eocene and (or) Cretaceous rocks.

If the 100-ft displacement of the surface separating the Fleming and Willis Formations north of the Four
Notch Roadless Area is caused by a fault or fold, the probability that there might be significant hydrocarbon accumulation associated with a structural trap is increased for northern part of the area.

Except for oil and gas, there are no indications of mineral resources in the area. Specialty clays and sands are not present. No uranium mineralization was identified, and lignite beds are not known to be present at depths of less than $2000 \mathrm{ft}$.

\section{SUGGESTIONS FOR FURTHER STUDIES}

Acquisition of seismic data and detailed comparisons with logs from wells from the vicinity of the Four Notch Roadless Area is necessary to better determine if the subsurface stratigraphy and structure are favorable for the accumulation of oil or gas.

\section{REFERENCE}

Houser, B. B., and Ryan, George S., 1983, Mineral resource potential map of the Four Notch Roadless Area, Walker County, Texas: U.S. Geological Survey Miscellaneous Field Studies Map MF-1549, scale 1:50,000. 


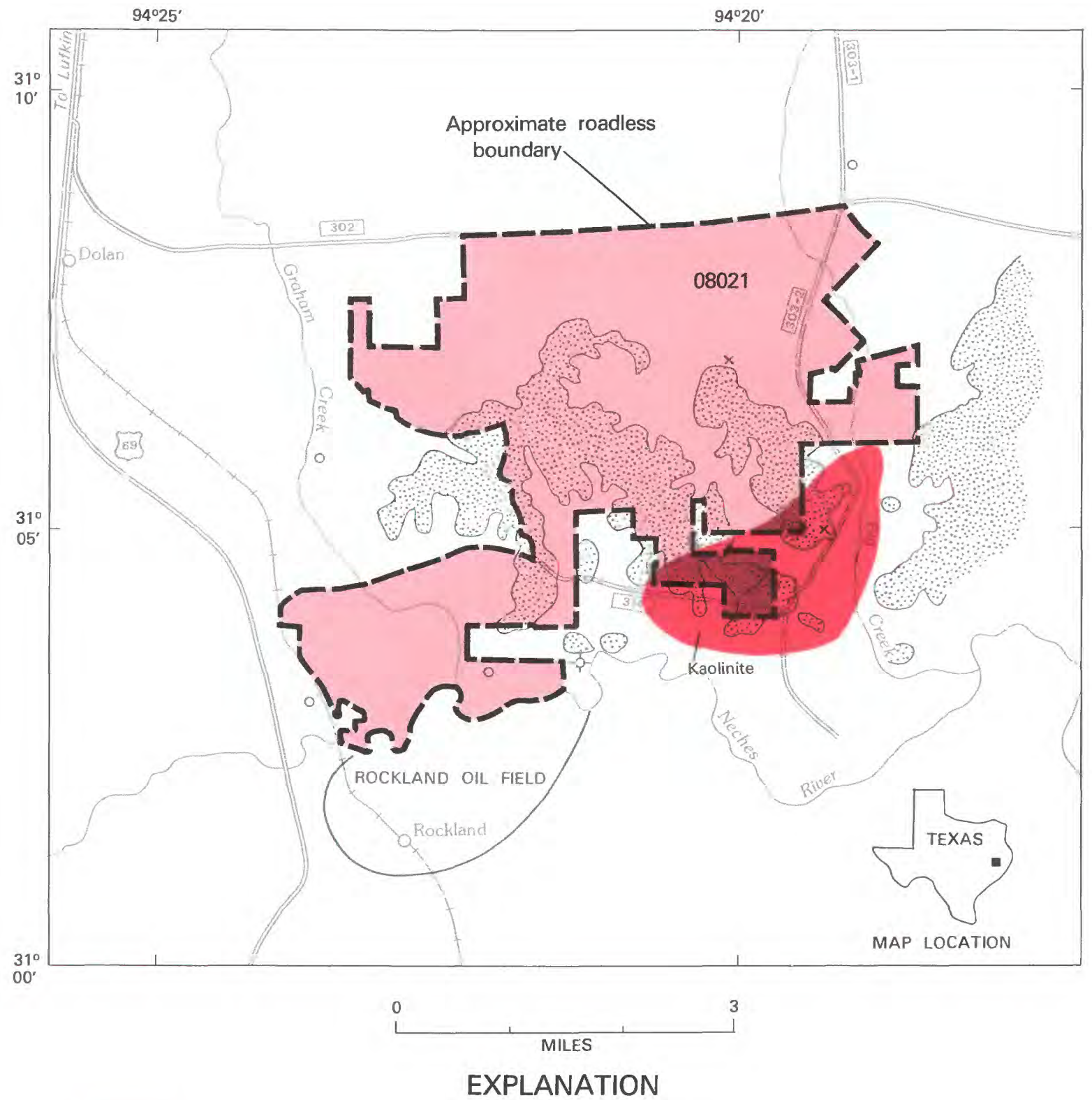

Geologic terrane with substantiated kaolinite resource potential and probable oil and gas resource potential

Geologic terrane with substantiated

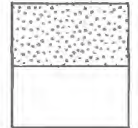

Catahoula Formation (Miocene)

Whitsett and Manning Formations, undifferentiated (Eocene) kaolinite resource potential

Geologic terrane with probable oil and gas resource potential

$\times \quad$ Mineral occurrence

Oil or gas well
Dry hole
$\quad-\quad$ Abandoned well

Figure 277,-Graham Creek Roadless Area, Texas. 


\title{
GRAHAM CREEK ROADLESS AREA, TEXAS
}

\author{
By B. B. Houser, U.S. Geological Survey, and \\ GEORGE S. RYAN, U.S. BUREAU OFMINES
}

\begin{abstract}
SUMMARY
A geologic and geochemical investigation of the Graham Creek Roadless Area, Texas was conducted in 1981-82. The area has a probable mineralresource potential for oil and gas. The roadless area contains a deposit of kaolinite clay similar to deposits being mined west of the area; the southeast part of the roadless area has a substantiated kaolinite clay resource potential. Smectite clay and sand deposits also are present in the area but these resources are relatively abundant throughout the region.
\end{abstract}

\section{GHARACTER AND SETTING}

The Graham Creek Roadless Area comprises $12.1 \mathrm{sq}$ $\mathrm{mi}$ in the Angelina National Forest in Angelina and Jasper Counties, Texas, about $30 \mathrm{mi}$ southeast of Lufkin and $50 \mathrm{mi}$ west of the Texas-Louisiana State Line. The roadless area is in the Gulf of Mexico Coastal Plain and can be divided into three topographic parts. The southwestern part consists of flood plains and terraces of Graham Creek and the Neches River and ranges in altitude from 90 to $120 \mathrm{ft}$. The central part is characterized by rolling hills and local outcroppings of sandstone ledges, at an altitude of as much as $300 \mathrm{ft}$. The northern part of the roadless area is relatively flat, ranging in altitude from about 130 to $240 \mathrm{ft}$. Drainage is by perennial and intermittent streams flowing in a southerly direction to the east-flowing Neches River. The climate is humid subtropical with an annual precipitation of about 51 in., and a mean annual temperature of about $67^{\circ} \mathrm{F}$. The area supports the vegetation of the pine woods belt of the forested Coastal Plain.

A mineral survey of the Graham Creek Roadless Area was conducted in 1981-82. The USGS conducted a geologic and geochemical survey of the region, which included drilling and collecting samples from twelve auger holes ranging from 17 to $107 \mathrm{ft}$ deep for stratigraphic and geochemical analyses. The USBM investigation included a radiometric survey and analysis of surface-sediment samples for uranium. The oil and gas resource potential of the area was evaluated by Gordon L. Dolton of the USGS using only readily available data. The results of this survey were published in 1983
(Houser and Ryan, 1983). Ninety percent of the mineral rights are privately owned.

Geologically, the area is in the north-central part of the Western Gulf Basin which is filled with a sequence of seaward thickening wedges of sand, silt, and clay. The sequence is relatively young (Cenozoic) and attains thicknesses of tens of thousands of feet beneath the Gulf of Mexico. The sediments are deposits of rivers, deltas, shorelines, and continental shelves and slopes. Underlying the sequence of sand, silt, and clay is an older sequence of rocks (Mesozoic), which consists chiefly of limestone and sandstone with a basal evaporite unit called the Jurassic Louann Salt.

The sediments of the Gulf Basin dip gently seaward and are undeformed except in the vicinity of salt domes and in zones termed flexures. These are discontinuous arcuate zones parallel to the modern shoreline where growth faults are concentrated. Growth faults constitute an important category of faults generally considered to be nontectonic in origin. They are gravity induced faults (down on the coastward side) generated by sediment loading. Movement along the fault planes is more or less continuous and thus the amount of displacement for older rock units is greater than for younger ones. Both salt domes and growth faults are effective hydrocarbon traps and are targets of exploration.

Three geologic formations crop out in the Graham Creek Roadless Area. The two older units, the Eocene Manning and Whitsett Formations of the Jackson Group, consist chiefly of dark greenish-gray, semiconsolidated, silty clay with sand and silt stringers. Plant 
fragments and lignitic beds are common in the Whitsett. The younger Catahoula Formation (Miocene) is separated from the underlying Whitsett Formation by a surface of erosion. The Catahoula consists mostly of fairly clean, loose sand, although pod-shaped bodies of opal-cemented sand are locally present, particularly at the base of the unit. Opalized palm wood is also locally present at the base. Beds of volcanic ash are relatively common in all three formations.

In general, the rocks in the region surrounding the area dip gently to the southeast at $1 / 2^{\circ}$ to $2^{\circ}$. Within the roadless area, however, the erosional surface separating the Catahoula and Whitsett Formations has the shape of one-third of a dome. Insufficient data are available to determine whether the dome is erosional or structural in origin.

\section{MINERAL RESOURCES}

The Graham Creek Roadless Area has a probable mineral-resource potential for oil and gas. Data show a history of scattered exploration drilling in and around the roadless area, especially at its southern and western edges, most of it very shallow. Immediately to the south, production has been established at Rockland and Sugar Creek fields in Jasper and Tyler Counties. Rockland produced a small amount of oil $(45,000$ barrels) from Eocene Yegua sandstones, whereas Sugar Creek is a small gas-condensate field producing from the Upper Cretaceous Woodbine Formation. Farther to the southeast, the Turpentine field in Jasper County also produces a small amount of oil and gas from the Upper Cretaceous (Austin Chalk and Woodbine Formation). Rockland, discovered in 1928, is the oldest of these fields. A new field, McGee Bend, was discovered in Angelina County in 1982.

The mineral-resource potential of the area for oil and gas would be increased if the domal shape of the Whitsett-Catahoula surface is structural and not erosional.

Southern Angelina County and northern Jasper County have a considerable history of clay production from relatively small pits (less than 25 acres), one of which (an abandoned smectite pit) is located within the roadless area. Most production has been from the Whitsett Formation $1.5 \mathrm{mi}$ west of the roadless area, although in January-February 1982 only one pit was being mined. Kaolinite clay and smectite clay resources of limited extent are present in the roadless area. The kaolinite clay resource consists of quartzose silt in a monomineralic matrix of kaolinite clay. This is essentially the same material currently being mined west of the roadless area. The kaolinite clay occurs in an area of substantiated kaolinite clay potential in the southeast part of the roadless area as a layer 5-20 ft thick, perhaps lenticular, in the top of the Whitsett Formation or in the base of the Catahoula. The smectite clay resource in the north-central part of the roadless area is greater than $15 \mathrm{ft}$ thick at one point and is probably a lenticular body. The deposit consists of silty smectite clay and occurs in the top of the Whitsett Formation.

The basal sandstone of the Catahoula Formation is presently being mined and crushed $0.25 \mathrm{mi}$ east of the roadless area by the Neches Stone Company. Sandstone from the Catahoula was also mined from an abandoned sand pit in the southeast corner of the roadless area. The sand consists of a mixture of loose, slightly clayey sand and sharp fragments of opal-cemented sandstone, and is used as road metal on the many graded roads of the region. Because of the local nature and lenticular shape of the opal-cemented sandstone bodies, it is not possible to predict their location or abundance; however, opal-cemented sandstone bodies undoubtedly exist at the base of the Catahoula within the roadless area because the lithology is widespread throughout the outcrop belt of the Catahoula Formation. Both sand and smectite clay commodities are abundant throughout the Gulf Coastal Plain.

No other metallic mineral or energy resources were identified in the Graham Creek Roadless Area. There is no uranium mineralization and lignite beds are not known to be present at depths of less than $2000 \mathrm{ft}$.

\section{SUGGESTIONS FOR FURTHER STUDIES}

Detailed analyses of well logs from the vicinity of the Graham Creek Roadless Area in conjunction with study of seismic data are necessary to determine if subsurface stratigraphy and structure are favorable for the accumulation of oil and gas. These data may already exist but are likely to be proprietary.

\section{REFERENCE}

Houser, B. B., and Ryan, G. S., 1983, Geologic and mineral resource potential map of the Graham Creek Roadless Area, Angelina and Jasper Counties, Texas: U.S. Geological Survey, Miscellaneous Field Studies Map, MF-1552, scale 1:50,000. 



\section{U T A H}

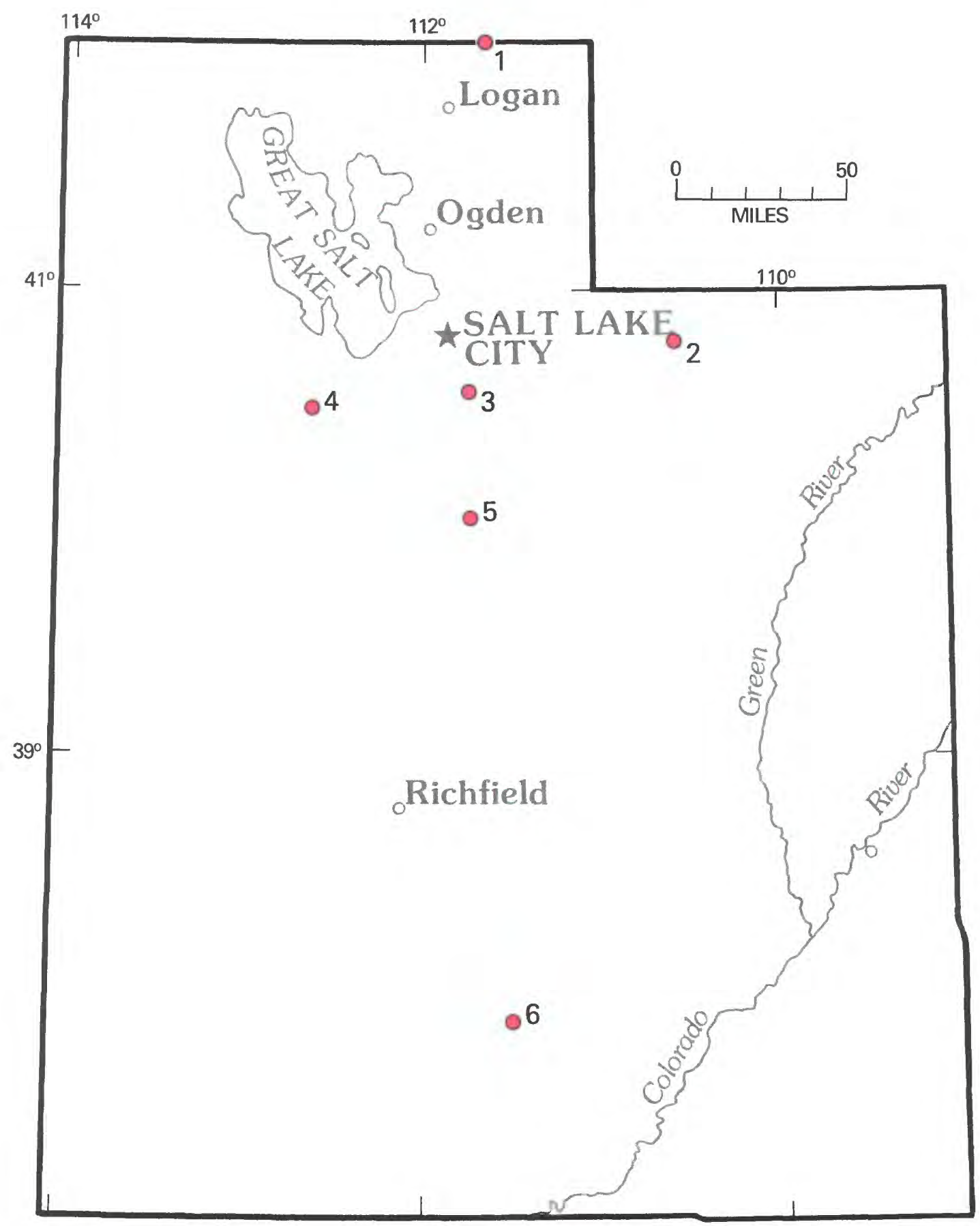

Location of areas studied. 


\section{UTAH}

Map
No.

5 Birdseye, Nephi, and Santaquin Roadless Areas

2 High Uintas Primitive Area

3 Lone Peak Wilderness study area

1 Mount Naomi Roadless Area, Utah and Idaho

4 Stansbury Roadless Areas

6 The Box-Death Hollow Roadless Area 


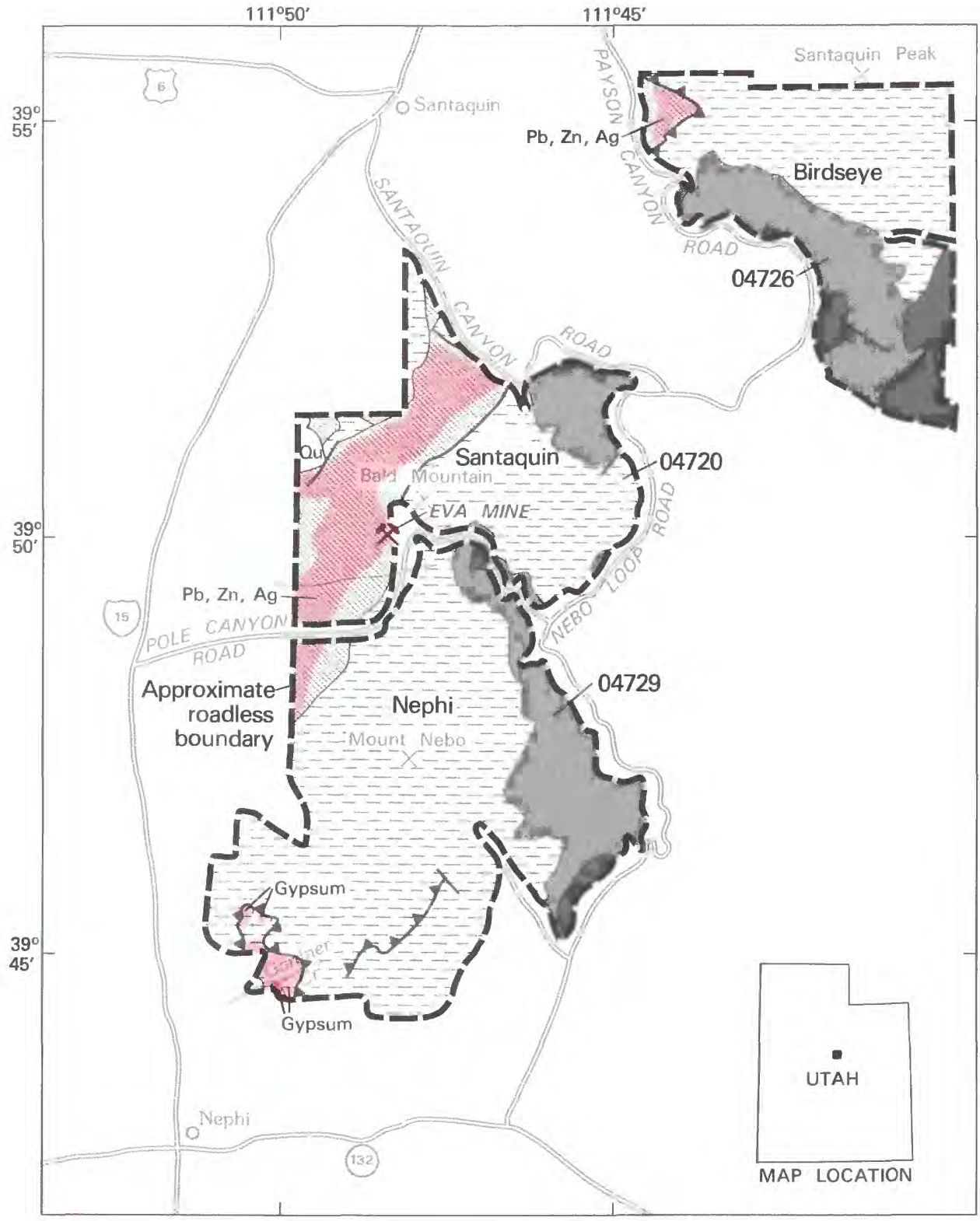

i

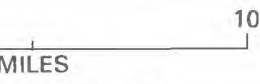

EXPLANATION

Geologic terrane with substantiated mineral-resource potential

Geologic terrane with probable mineral-resource potential

Lead

Silver

Zinc

3. Mine or deposit
Holocene and Quaternary surficial deposits, undivided

Tertiary volcanic rocks, undivided

Tertiary and Cretaceous sedimentary rocks, undivided

Jurassic, Triassic, Permian, and Pennsylvanian sedimentary rocks, undivided

Mississippian, Devonian, Cambrian, and

Proterozoic sedimentary rocks, undivided Contact

Fault

A_ Thrust fault--Sawteeth on upper plate

Figure 278.-Birdseye, Nephi, and Santaquin Roadless Areas, Utah. 


\title{
BIRDSEYE, NEPHI, AND SANTAQUIN ROADLESS AREAS, UTAH
}

\author{
By Martin L. SORENSEN, ${ }^{1}$ U.S. GeOlogical Survey, and \\ STANLEY L. KORZEB, U.S. BUREAU OF MiNeS
}

\begin{abstract}
SUMMARY
The results of a mineral-resource appraisal of the Birdseye, Nephi, and Santaquin Roadless Areas during 1981-82 indicate several areas with probable or substantiated mineral-resource potential. The Eva mine in the Santaquin Roadless Area contains small, demonstrated resources of lead-zinc-silver ore. A probable resource potential for lead, zinc, and silver deposits exists in the area around the Eva mine, and elsewhere in the Birdseye, Nephi, and Santaquin Roadless Areas where Mississippian and Cambrian carbonate rocks occur. A substantiated potential for gypsum is recognized in the southwest corner of the Nephi Roadless Area and a probable resource potential in adjacent areas underlain by the Jurassic Arapien Shale. There are limestone resources for use in cement and smelter flux in the Nephi and Santaquin Roadless Areas, but similar limestone occurs abundantly outside the area. The potential for oil and gas resources cannot be assessed from available data. There are no indications of coal or geothermal resources in the roadless areas.
\end{abstract}

\section{CHARACTER AND SETTING}

The Birdseye, Nephi, and Santaquin Roadless Areas are in the southern part of the Wasatch Mountains of central Utah where the Wasatch Mountains form the westernmost part of the Northern Rocky Mountains physiographic province and are separated from the Basin and Range province by the Wasatch fault. The roadless areas are located a few miles southeast of Santaquin, Utah, and $55 \mathrm{mi}$ south of Salt Lake City, Utah, where they occupy approximately $78 \mathrm{sq} \mathrm{mi}$ in the Uinta National Forest. The roadless areas are bounded by U.S. Highway 15 on the west, U.S. Highway 89 on the east, and Utah Highway 132 on the south, and are partially bordered by the paved Nebo Loop and Santaquin Canyon Roads and by an unpaved jeep trail in Pole Canyon.

The Wasatch Mountains in the roadless areas are underlain by approximately $26,000 \mathrm{ft}$ of sedimentary rocks and by discontinuous outcrops of Tertiary volcanic rocks. The lower part of the section consists of approximately $4000 \mathrm{ft}$ of dolomite, limestone, quartzite, and shale, and ranges in age from Proterozoic to Late Cambrian. Discontinuous outcrops of Upper Devonian dolomite and quartzite separate these rocks from the

\footnotetext{
${ }^{1}$ With contributions from Henry Pietropaoli, USGS, and John T. Neubert, USBM.
}

balance of the Paleozoic section which consists of approximately $14,500 \mathrm{ft}$ of limestone, limy sandstone, dolomite, quartzite, and shale. Mesozoic rocks in the roadless areas consist of approximately $7000 \mathrm{ft}$ of shale, sandstone, and limestone, with gypsum- and evaporitebearing shale common in the upper part of the section. The uppermost Mesozoic and lower Tertiary rocks include shale, sandstone, and conglomerate. The uppermost conglomerates are locally overlain by discontinuous outcrops of freshwater limestone and (or) andesitic volcanic rocks.

The surface geology in the roadless areas is generally uncomplicated. Rocks in the Birdseye and Santaquin Roadless Areas dip homoclinally to the east at moderate angles, but steepen southward and are near vertical to overturned throughout the southern part of the Nephi Roadless Area. The Birdseye, Nephi, and Santaquin Roadless Areas occupy part of the CharlestonNebo block (Roberts and others, 1965, p. 1946) and are underlain, with the exception of a few square miles of the Nephi Roadless Area, by the Nebo thrust fault. Thrust faults exposed in Santaquin and Payson Canyon are probably imbricate thrusts rising from an unexposed northern extension of the Nebo thrust fault.

A mineral-resource study of the Birdseye, Nephi, and Santaquin Roadless Areas (Sorensen and Korzeb, 1983) was conducted during 1981-82. Published geologic 
mapping was field checked and selected areas were remapped. Semiquantitative spectrographic analyses were made for altered or mineralized rock, streamsediment, and stream-sediment-concentrate samples from localities throughout the roadless areas (for results of analyses, see Sorensen and others, 1983). Water samples were collected from springs and streams and analyzed for 12 elements. Mines and prospects in and near the roadless areas were examined and samples collected from mineralized or altered areas and from waste dumps. All mine and prospect samples were analyzed for gold and silver by fire-assay methods and most were analyzed for 40 elements by semiquantitative spectrographic methods.

The Birdeye and northeast half of the Santaquin Roadless Areas are in the Santaquin mining district. The Santaquin district was organized in 1871 and during 1910-17 had a reported production of $208 \mathrm{lbs}$ of copper, 206,522 lbs of lead, and $3499 \mathrm{oz}$ of silver (Bullock, 1962, p. 90 ). The Nephi and southwest half of the Santaquin Roadless Areas are in the Mount Nebo mining district. The Mount Nebo district was organized in 1870 and during 1870-1917 had a reported production of $15.29 \mathrm{oz}$ of gold, $37,226 \mathrm{oz}$ of silver, 1526 lbs of copper, $1,932,683 \mathrm{lbs}$ of lead, and 788,679 lbs of zinc (Heikes, 1920 , p. 334).

\section{MINERAL RESOURCES}

A probable potential for lead, zinc, and silver deposits in the Santaquin and Birdseye Roadless Areas is recognized in areas underlain by Mississippian through Cambrian carbonate rocks. Deposits will probably be small, may be localized by faulting or intense folding, and may be spatially associated with lamprophyre dikes or sills. Although the upper part of the Mississippian Deseret Limestone is the most favorable host rock, such deposits may occur in any of the Middle Cambrian through Upper Mississippian limestones or dolomites. Near North Creek, at the Eva (Privateer) mine, approximately 1000 tons of demonstrated resources were identified as remaining from earlier mining activities.

An area of substantiated gypsum resource potential is recognized near the southwest corner of the Nephi Roadless Area, where approximately 270,000 tons of rock containing 80 percent gypsum are estimated to be present on three patented claims. A probable resource potential for gypsum deposits is assigned to other parts of the roadless area where the geology is similar.

Limestone occurs near Gardner Creek in the southwest corner of the Nephi Roadless Area, but there are abundant cement-grade limestone resources outside the area.

Although limestone and dolomite probably suitable for use as smelter flux occur in a 9 sq mi area south of Santaquin Canyon in the Nephi and Santaquin Roadless Areas, the area is inaccessible and abundant resources of limestone and dolomite with quarries already in operation closer to markets occur at West Mountain, $4 \mathrm{mi}$ northwest of Santaquin Canyon.

The resource potential for oil and gas cannot be determined from available information. Recent leasing and exploration activities by petroleum companies and the general nature of the geologic setting suggest the possibility of oil and gas in or near the roadless areas. Information and interpretation based on the geologic mapping of the roadless areas does not indicate the occurrence of these commodites, but assessment without seismic and drilling data would be misleading. Drilling has not taken place in or near the roadless areas and information is lacking on source rocks, reservoir rocks, and structure.

Secondary uranium mineralization occurs at one locality in the southwest corner of the Nephi Roadless Area. Drilling and sampling data indicate that the mineralization is low grade, confined to a narrow zone, and no resource potential was identified.

No coal or geothermal resouce potential was identified in the roadless areas.

\section{REFERENCES}

Bullock, K. C., 1962, Economic geology of north-central Utah, in Hintze, L. F., ed., Geology of the southern Wasatch Mountains and vicinity, Utah: Brigham Young University Geology Studies, v. 9., pt. 1, p. 85-94.

Heikes, V. C., 1920, History and production, in Butler, B. S., Loughlin, G. F., Heikes, V. C., and others, The ore deposits of Utah: U.S. Geological Survey Professional Paper 111, p. 333-335.

Roberts, R. J., Crittenden, M. D., Jr., Tooker, E. W., Morris, H. T., Hose, R. K., and Cheney, T. M., 1965, Pennsylvanian and Permian basins in northwestern Utah, northeastern Nevada, and south-central Idaho: American Association of Petroleum Geologists Bulletin, v. 49, p. 1926-1956.

Sorensen, M. L., Korzeb, S. L., and Neubert, J. T., 1983, Mineral resource potential map of the Birdseye, Nephi, and Santaquin Roadless Areas, Juab and Utah Counties, Utah: U.S. Geological Survey Miscellaneous Field Investigations Map MF-1574-A, scale 1:62,500

Sorensen, M. L., Pietropaoli, Henry, and Haley, S. M., 1983, Geochemical analyses of rock and stream-sediment samples from Birdseye, Nephi, and Santaquin Roadless Areas, Juab and Utah Counties, Utah: U.S. Geological Survey Open-File Report 83-175. 


\title{
HIGH UINTAS PRIMITIVE AREA, UTAH
}

\author{
By Max D. Grittenden JR., U.S. GeOlogical Survey, and \\ Michael J. Sheridan, U.S. BuREau OF MineS
}

\begin{abstract}
SUMMARY
Mineral surveys conducted in 1965 and 1966 in the High Uintas Primitive Area and the additions subsequently proposed concluded that the area has little promise for mineral resources. Of the areas around the fringes, a strip along the north flank fault can be classed as having probable energy-resource potential for oil and gas.
\end{abstract}

\section{CHARACTER AND SETTING}

The High Uintas Primitive Area is an area of about $505 \mathrm{sq} \mathrm{mi}$ in the western part of the Uinta Mountains, and extends from near Mirror Lake on the west to near Fox Lake on the east, a distance of more than $40 \mathrm{mi}$. The area includes Gilbert Peak (13,528 ft), the highest point in Utah, and the headwaters of the Provo, Weber, Duchesne, Uinta, and Bear Rivers, the sources of most of the surface water used in Utah.

The primitive area straddles the highest part of the range, and not only includes many of the highest peaks, but includes large areas of high meadows and cirque basins ranging in altitude from 10,000 to $12,000 \mathrm{ft}$. Virtually the entire area was glaciated, and the smoothbottomed valleys drain both north and south from the serrate peaks. The most significant feature of the area from the point of view of both recreation and water storage are myriad lakes which provide both prolonged runoff and well-renowned fishing. The easiest access by trail begins at Mirror Lake which can be reached by Utah State Highway 150 from either Kamas, Utah to the west or from Evanston, Wyoming to the north. Other trails ascend most of the stream canyons on both the north and south flanks. Because the difference in altitude between the road-ends and most of the primitive area amounts to several thousand feet, access to the area is difficult and the trails are commonly very rough; deep snowbanks may well impede travel across some of the higher passes until late summer.

Between 7000 and $10,000 \mathrm{ft}$ the forest cover is commonly very dense, and the dominant species are lodgepole pine and aspen, making cross-country travel laborious. Above $10,000 \mathrm{ft}$, spruce and fir are dominant. These form more open forest, and give way upward to scattered clumps of stunted trees at timberline, which is at an altitude of about $11,500 \mathrm{ft}$. Large areas of the cirque floors are virtually bare. Rock exposures are almost continuous in the upper part of the cirques and on the ridges and peaks. The effects of frost action are evident in many places, producing extensive areas of broken rock (felsenmeer) across which travel is difficult to almost impossible.

This part of the Uinta Mountains is carved almost exclusively from a thick sequence of reddish sedimentary rocks of middle Proterozoic age, the Uinta Mountain Group (Crittenden and others, 1967). These appear to have been deposited by streams that drained a steep and probably rugged landscape and deposited sand and mud to depths of tens of thousands of feet in the edge of a shallow sea. After millions of years the area was warped upward into the arch-like form it has today. This resulted in a broad arcuate structure having nearly flat lying rocks in the center and rocks that dip outward at moderate angles on the south and north flanks. Although the primtive area is underlain entirely by rocks of Precambrian age, younger rocks are present in places along the folded flanks, and are locally faulted against the rocks of the core. In most places the bounding faults appear to be steep and near the surface but seismic studies have shown that the faults at least locally flatten downward and bend inward beneath the margins of the range. In such areas, rocks of Paleozoic and Mesozoic age that have yielded oil and gas in adjoining areas are known to be preserved beneath at least one (the north flank) bounding fault.

\section{MINERAL RESOURCES}

Although there is little promise for the occurrence of mineral resources within the boundaries of the primitive 

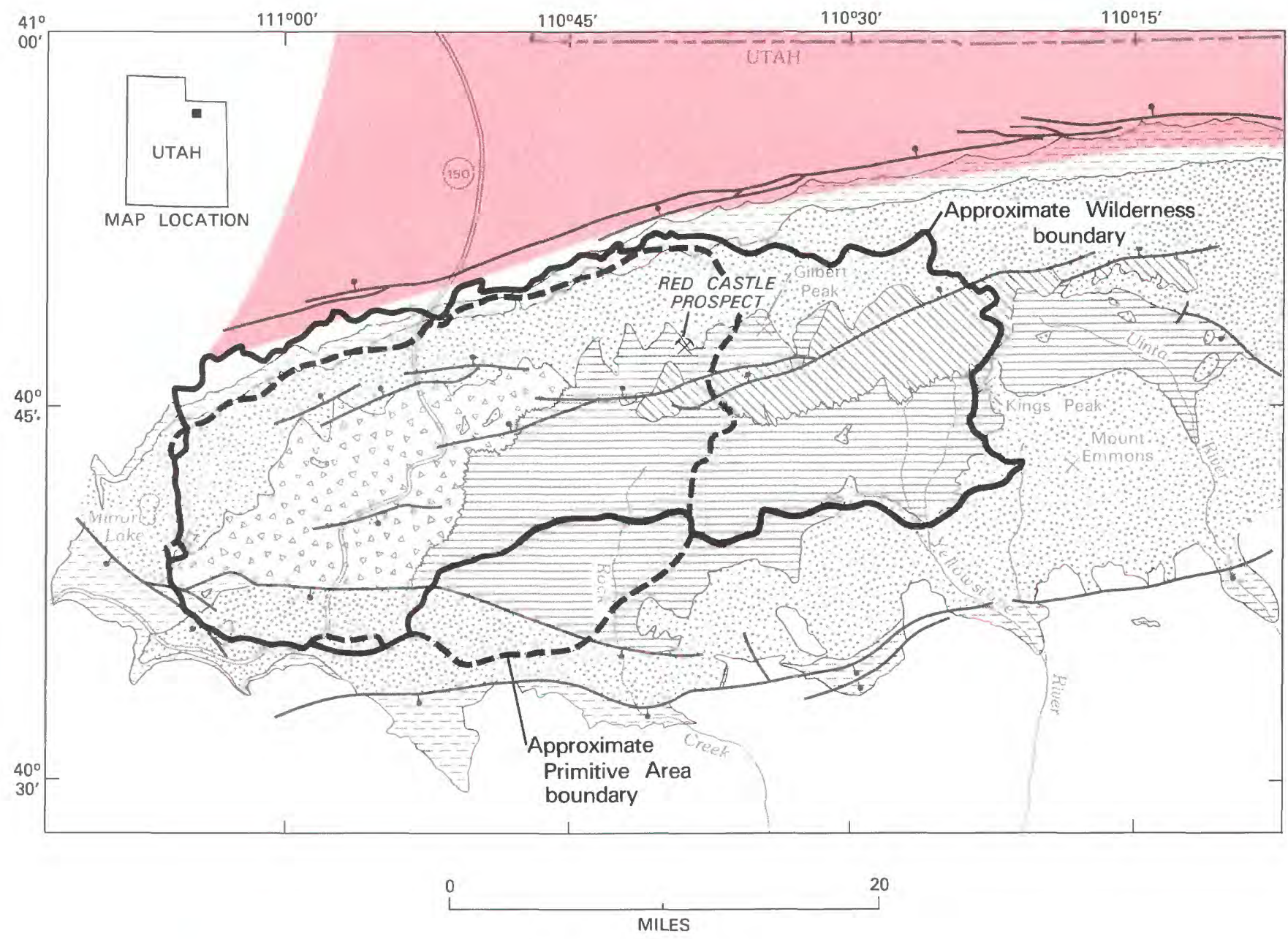

\section{EXPLANATION}

Geologic terrane with probable oil and gas resource potential

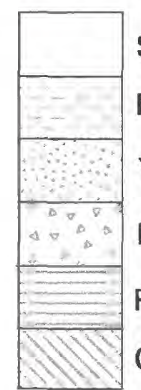

Sedimentary rocks

Red Pine Shale

Youngest fluvial-floodplain facies

Deltaic facies

Paralic-neritic facies

Oldest fluvial-floodplain facies

Contact

- Fault--Bar and ball on downthrown side

Figure 279.-High Uintas Primitive Area, Utah. 
area, a probable oil and gas resource potential has been identified in an area along the north flank fault.

A few small deposits of iron oxides have been found in the Uinta Mountains outside the primitive area, but none has yielded significant production. The only prospect within the primitive area is about $250 \mathrm{ft}$ northwest of the trail leading from Tungsten Pass into the upper basin of Yellowstone Creek, presumably the Red Castle prospect. Mineralization consists of quartzite breccia cemented by layers and crusts of specular hematite. The dark-red color and brilliant luster of this iron mineral is presumed to have been mistaken for one of the tungsten minerals which it resembles. A sample from this site contained only trace amounts of silica, alumina, and iron.

Inasmuch as rocks correlated with the Uinta Mountain Group are extensively exposed both here and in the Wasatch Mountains to the west, and have yielded no indication of bedded mineral deposits, no attempt was made to sample the rocks of the Uinta Mountain Group systematically. It was evident during our survey that the only visible mineral occurrences are related to the high-angle faults that cut the area; therefore, such faults were sampled in many places (Crittenden and others, 1967, table 1). Of the elements most commonly associated with ore deposits in the Western Statessilver, gold, and zinc-all analyses were below the limits of detectability. The only igneous rock encountered was a series of basalt dikes that was mapped for a total distance of nearly $5 \mathrm{mi}$ in the vicinity of Gilbert Peak (Crittenden and others, 1967, pl. 1). Samples of these dikes were reported by the Utah Geological and Mineral Survey (Ritzma, 1981, p. 13) to contain as much as 20 percent $\mathrm{TiO}_{2}$, but two samples of these dikes collected during the original survey and analysed by the USGS were found to contain only 3.89 and 4.55 percent $\mathrm{TiO}_{2}$, respectively, which is within the normal range of many igneous rocks.

The results of unpublished seismic data obtained by private companies since our mineral survey suggest that the bounding faults along the margins of the High Uinta Primitive Area dip inward, and that petroliferous rocks could extend a significant distance inward beneath the range. Thus, the north flank of the range has a probable potential for oil and gas. Only a few wells have been drilled to date on the north flank, in close prox- imity to the primitive area. The first of these to be drilled, the Shell, 21X-19 Government, Dahlgren Creek No. 1, followed the faults of the North Flank System downward through Precambrian shale and quartzite of the Uinta Mountain Group for nearly $10,000 \mathrm{ft}$, and showed this segment of the fault to have a southward dip of $65^{\circ}$ to $70^{\circ}$. Another well, nearer the west end of the range (American Quasar No. 1, Cow Hollow), is significant in that it showed that the thrust faults of the Wyoming thrust belt are folded and deformed by the faults at the margin of the Uinta Mountains. A third well was drilled by Champlin Petroleum in Moffatt County, Colorado. It also passed through several thousand feet of Precambrian rocks and encountered gently dipping rocks of Mesozoic age at depths in excess of $10,000 \mathrm{ft}$.

Because of the general arch-like character of the Uinta Mountains and its alinement with intrusive rocks of the Park City and Cottonwood, Utah areas, in the Wasatch Mountains to the west, an attempt was made to determine whether similar shallow intrusive rocks might be present in the core of the range. Examination of gravity and magnetic maps indicates the existence of a broad gravity high, which would be consistent with the presence of dense older Precambrian rocks at depth beneath the younger sedimentary rocks of the arched cover. The magnetic maps, however, lack the localized magnetic highs that characterize the mineralized stocks of the mining districts to the west.

\section{SUGGESTIONS FOR FURTHER STUDIES}

The oil and gas potential along the north flank of the primitive area could be tested by additional seismic studies followed by drilling. Much of the necessary information probably could be obtained without drilling within the primitive area itself.

\section{REFERENCES}

Crittenden, Max D., Wallace, C. A. and Sheridan, M. J., 1967, Mineral Resources of the High Uintas Primitive Area, Utah: U.S. Geological Survey Bulletin 1230-I, 27 p.

Ritzma, H. R., 1981, Dike investigation helped by chopper lift: Utah Geological and Mineral Survey, Survey Notes, v. 15, no. 4, 9 p. 

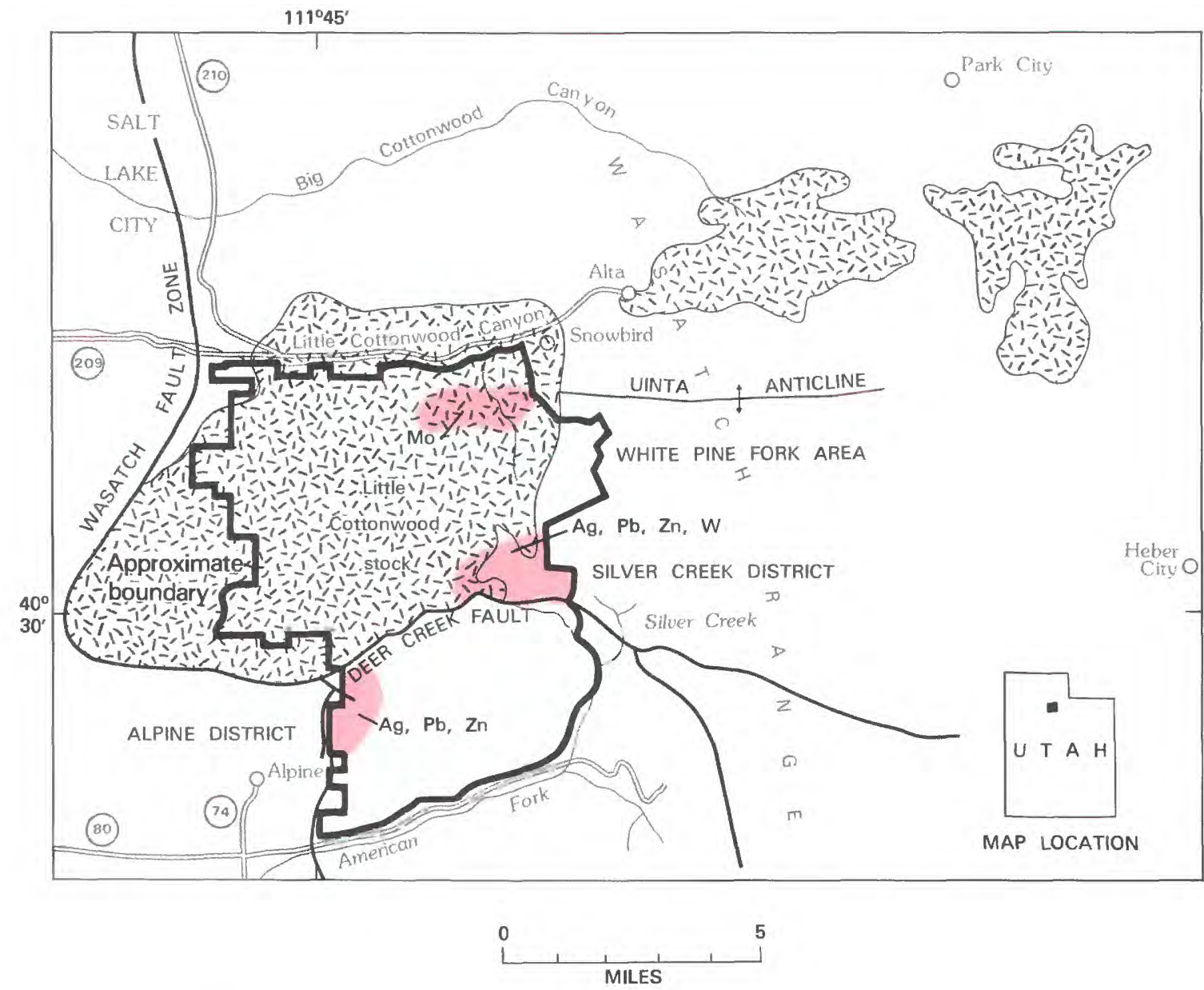

\section{EXPLANATION}

\begin{tabular}{|lll}
\hline & $\begin{array}{c}\text { Geologic terrane with probable } \\
\text { mineral-resource potential }\end{array}$ & \\
$\mathrm{Pb}$ & Lead & \\
$\mathrm{Mo} \quad$ Molybdenum & Contact \\
$\mathrm{Ag}$ & Silver & \\
$\mathrm{W}$ & Tungsten & \\
$\mathrm{Zn}$ & Zinc &
\end{tabular}

Figure 280.-Lone Peak Wilderness study area, Utah. 


\title{
LONE PEAK WILDERNESS STUDY AREA, UTAH
}

\author{
By Calvin S. BROMFIEld, U.S. GeOlOGICAL SuRVeY, and \\ Lowell L. Patten, U.S. Bureau of Mines
}

\begin{abstract}
SUMMARY
On the basis of a mineral survey completed in 1974, three areas in the Lone Peak Wilderness study area are classed as having mineral-resource potential. These include the Silver Creek district, near the east boundary of the area, the Alpine district near the southwest boundary, and the White Pine Fork area in the northeast part of the area. The Silver Creek and Alpine districts have probable potential for small deposits of silver, lead, and zinc and, in addition, the Silver Creek district has a probable potential for small tungsten deposits. Of more significance, the White Pine Fork area has a probable potential for porphyry-type molybdenum resources.
\end{abstract}

\section{CHARACTER AND SETTING}

The Lone Peak Wilderness study area comprises about $53 \mathrm{sq} \mathrm{mi}$ in the central Wasatch Range, Utah. The study area is unique in that it immediately adjoins metropolitan Salt Lake City. The Lone Peak Wilderness study area is centered on some of the most rugged and spectacular parts of the central Wasatch Range which have a maximum relief of about $6000 \mathrm{ft}$. The highest summits reach over $11,000 \mathrm{ft}$ in altitude. State Highway 210 , in Little Cottonwood Canyon, skirts the north boundary, and State Highway 80, in American Fork Canyon, skirts the south edge of the area.

A mineral survey of the Lone Peak Wilderness study area was made by the USGS and USBM in 1973 and 1974 and the results have been published (Bromfield and Patten, 1975; Bromfield and Patten, 1981).

Along its western front, the central Wasatch Range rises high above the valley in a bold escarpment. Its foot is bounded by the Wasatch Fault zone, along which the range was uplifted in relatively recent time. Erosion has etched rugged mountains that have a complex internal structure. The northern part of the Lone Peak Wilderness study area is chiefly underlain by a granitic intrusion, the Little Cottonwood stock, which has invaded a relatively thin sequence of sedimentary rocks (younger Precambrian and Paleozoic). South of the stock and separated from it by the Deer Creek fault is an area underlain by a much thicker section of sedimentary rocks of the same general age. The different sedimentary sections north and south of the Deer Creek fault are thought to have been brought together by a thrust fault, now concealed beneath the rocks south of the Deer Creek fault.

\section{MINERAL RESOURCES}

The Little Cottonwood stock lies at the west end of an east-northeast alinement of intrusive rocks in the central Wasatch. Associated with this intrusive belt east of the Lone Peak Wilderness study area are important ore deposits in the Park City district and the CottonwoodAmerican Fork district. Together, these districts have yielded over $\$ 600$ million in silver, lead, zinc, copper, and minor quantities of gold, chiefly from the Park City district. Most of the valuable metals have come from ore bodies that have replaced carbonate (limestone or dolomite) host rocks, or from veins. Some of these favorable carbonate beds are present in the Lone Peak Wilderness study area.

Because of its position within the intrusive belt, its close relation to the nearby Cottonwood-American Fork mining district, its complicated structure, and the presence in the study area of favorable carbonate host rocks, a careful study was made of the geology, known mines and prospects, and other mineralized localities in the area. Numerous stream-sediment and rock samples were taken.

Though early prospectors clearly prospected the study area in the latter half of the 19th century, no significantly productive silver-lead deposits of the type 
mined in the nearby Cottonwood-American Fork district or Park City district were found. However, evidence of mineralization was found in three areas: silverlead and tungsten occurrences in the Silver Creek district, which overlaps the east boundary of the area; silver, lead, and zinc occurrences in the Alpine district on the southwest boundary; and a disseminated molybdenum occurrence in the White Pine Fork area.

The Silver Creek district lies along and near the southeast margin of the Little Cottonwood stock where a thin skin of sedimentary rocks, including limestone and quartzite, dips away from the stock. A hundred years of prospecting in the Silver Creek district has failed to develop profitable ore bodies. Two narrow silver-lead-zinc veins just outside the study area apparently had a small but unknown production, and one very small occurrence of silver-lead mineralization in carbonate rocks just inside the boundary may have yielded a few tons. Silver-lead-zinc mineralization has apparently occurred in discontinuous and scattered zones and the area has a substantiated resource potential for small deposits. In this same general area, north of Deer Creek, small occurrences of tungsten minerals have been found disseminated in metamorphosed carbonate rocks near the Little Cottonwood stock. Further prospecting near the stock might disclose other similar occurrences; nevertheless, only a few of our samples were anomalous in tungsten, and these contained so little as to suggest that the possibility of finding tungsten in other than small occurrences is slight.

In the Alpine district, scattered prospect pits and shallow workings have disclosed small occurrences of silver-lead-zinc minerals in carbonate rocks, apparently in brecciated zones along flat faults. A few small ore shipments have been reported. Dumps now contain only sparse evidence of ore minerals. The results of analyses of stream sediments support the impression of meager mineralization seen on the dump and workings. There is no other evidence for the widespread circulation of ore solutions. Although the area is shown as having probable potential for small silver-lead-zinc deposits there is little likelihood of finding significant resources.

The presence of molybdenite in the White Pine Fork area has been known for many years. In that area the Little Cottonwood stock has been intruded by a small fine-grained granitic stock, which in turn is cut by dikes.
The rocks are stongly altered and have been sericitized, pyritized, and in places are laced with quartz veinlets. Iron staining, the most visible aspect of alteration, covers an area extending about $8000 \mathrm{ft}$ east-west, and perhaps half that much north-south. The most intensely altered and mineralized is in an oval area about 600 by $400 \mathrm{ft}$ in the middle part of White Pine Fork. Molybdenite occurs sparingly in quartz veins, as smears or coatings along fractures, and as disseminations in altered intrusive rocks. Our geochemical samples confirm widespread anomalous molybdenum values and low but anomalous copper, zinc, and silver. Limited exploration drilling by mining companies in the past confirm the occurrence of low-grade molybdenum mineralization at depth.

A consideration of the geologic, geochemical, and historical data mentioned above suggests that the Silver Creek and Alpine districts, and the White Pine Fork area have probable potential for mineral resources. In the case of the Silver Creek and Alpine districts, the potential is for small deposits of silver-lead-zinc type, and possibly also a probable resource potential for small tungsten deposits in the Silver Creek area. Exploration would be needed to find such deposits, and past empirical evidence suggests the size of the targets may discourage such exploration. Of considerably greater significance is the probable potential for porphyry-type molybdenum resources in the White Pine Fork area.

\section{SUGGESTIONS FOR FURTHER STUDIES}

A detailed study of the White Pine Fork area combining geologic mapping, with studies of the rock alteration pattern, mineralogy, and geochemistry, might suggest and guide additional drilling.

\section{REFERENCES}

Bromfield, C. S., and Patten, L. L., 1975, Mineral resources of the Lone Peak Wilderness study area, Utah and Salt Lake Counties, Utah: U.S. Geological Survey Open-File Report 75-382, 206 p.

Bromfield, C. S., and Patten, L. L., 1981, Mineral resources of the Lone Peak Wilderness study area, Utah and Salt Lake Counties, Utah: U.S. Geological Survey Bulletin 1491, 117 p. 


\title{
MOUNT NAOMI ROADLESS AREA, UTAH AND IDAHO
}

\author{
By James H. Dover, U.S. GeOlogical SuRVEY, and \\ PHILIP R. BigSBY, U.S. BUREAU OF Mines
}

\begin{abstract}
SUMMARY
Geologic, geophysical, and geochemical surveys, and an examination of mines and prospects were made in 1979 and 1980 in the Mount Naomi Roadless Area, Utah and Idaho. No significant precious-metal, base-metal, other trace-metal, or uranium anomalies are apparent in the geochemical data from the Mount Naomi Roadless Area, and no exploration targets were detected. However, a belt of probable resource potential for stratabound copper, lead, and zinc occurrences exists on the west side of the area in limestone and shale. The possibility that oil and gas concentrations lie deeply buried beneath the roadless area cannot be evaluated from available data. There is little promise for the occurrence of other mineral or energy resources in the Mount Naomi Roadless Area.
\end{abstract}

\section{CHARACTER AND SETTING}

The Mount Naomi Roadless Area occupies about 122 sq mi along the crest of the Bear River Range from near Logan, in Cache County, Utah, to a point east of Preston, in Franklin County, Idaho. Cache Valley lies along the west edge of the roadless area and Bear Lake is about $12 \mathrm{mi}$ to the east. U.S. Highway 91 connecting Logan and Preston is a few miles west of the roadless area in Cache Valley; U.S. Highway 89 through Logan Canyon bounds the roadless area on the south and east. The part of the Bear River Range within the roadless area rises to an altitude of nearly $10,000 \mathrm{ft}$ and features rugged box canyons with local relief of 2000 to $3000 \mathrm{ft}$.

The Bear River Range is carved from a tilted fault block and lies within the western part of the eastern Cordilleran fold and thrust belt commonly referred to as the Overthrust Belt. The bulk of the range is a sedimentary rock sequence at least $27,500 \mathrm{ft}$ thick, consisting mainly of quartzite, shale, and marine carbonate rocks of late Precambrian to Paleozoic age. Prior to the highangle faulting that blocked out the present range, these sedimentary rocks were emplaced into this area along a major system of deeply buried low-angle thrust faults, from an original site of deposition far to the west. The main thrust sheet is known as the Willard allochthon, and within the roadless area its rocks occur in a large fold-the Logan Peak syncline. The basal thrust zone that floors the Willard allochthon is not exposed within the roadless area but is inferred from regional geologic relationships to lie at a depth of $20,000-30,000 \mathrm{ft}$ under it. Available geophysical data do not adequately define the thickness of sedimentary rocks under the roadless area, but there is no evidence of shallow metamorphic basement, and the data are consistent with a thick layer of sediments underlying one or more thrust sheets. Tertiary sedimentary rocks unconformably overlie the Willard allochthon and are cut along with it by the highangle faults that blocked out the range after thrusting ceased.

The Richmond mining district, organized in 1894, includes a few mine workings and prospects within the Mount Naomi Roadless Area. Only three patented claims are located within its boundaries. Production from the Richmond district was small; production from specific properties inside the roadless area is unknown, except for the patented Fitzgerald lode, which shipped about 100 short tons of lead-silver ore, probably in the 1920 's or 1930 's. Other mining districts near the roadless area contain lead-silver-copper replacement deposits in carbonate rocks, a type of deposit resembling the smaller occurrences in the roadless area.

\section{MINERAL RESOURCES}

Old workings at five places in the roadless area contain disseminated lead-zinc and(or) copper minerals associated with barite in limestone country rocks. These, along with a few barren prospects are distributed 

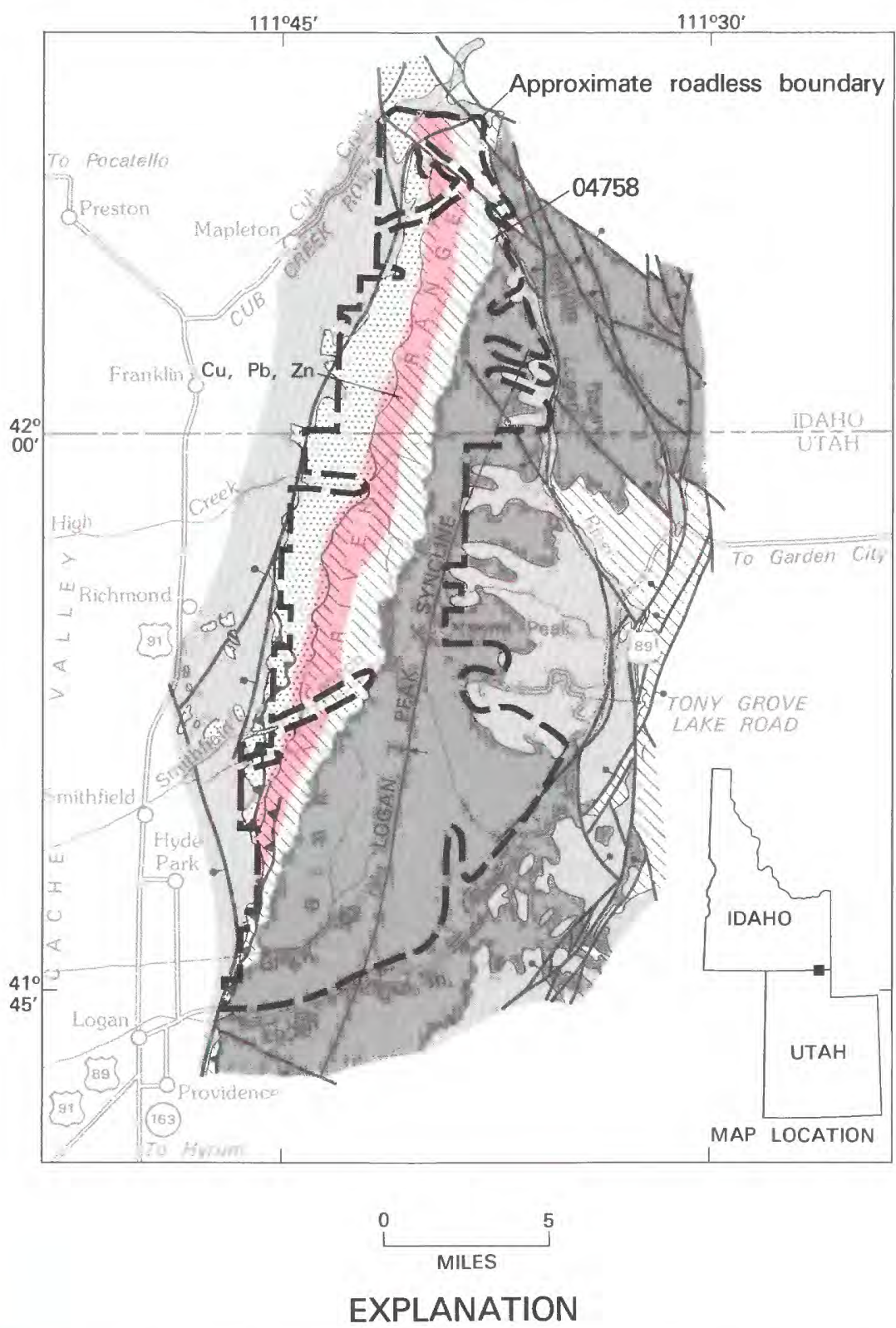

Geologic terrane with probable mineral-resource potential

$\begin{array}{ll}\mathrm{Cu} & \text { Copper } \\ \mathrm{Pb} & \text { Lead } \\ \mathrm{Zn} & \mathrm{Zinc}\end{array}$

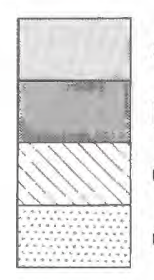

Quaternary and Tertiary rocks

Paleozoic rocks

Cambrian rocks

Cambrian and Precambrian rocks

Contact

Fault--Bar and ball on
downthrown side

- Thrust fault--Sawteeth on upper plate

+ Syncline

Figure 281.-Mount Naomi Roadless Area, Utah and Idaho. 
along a north-northeast-trending band coinciding with a belt of Middle Cambrian limestone and shale that crops out along the west limb of the Logan Peak syncline, on the west side of the roadless area. This belt of stratabound mineral occurrences is judged to have probable mineral-resource potential based on the discontinuous and disseminated distribution of the minerals, the relatively low concentrations of metals, and the near lack of past production.

No significant precious-metal, base-metal, other traceelement, or uranium anomalies are apparent in the geochemical data from the Mount Naomi Roadless Area, and no significant exploration targets have been detected. Barium, beryllium, copper, lead, and zinc values defined as high or anomalous are only relatively so for the data set considered, and may not represent significantly anomalous concentrations. Most rock samples with relatively high barium (200-1500 ppm (parts per million)), beryllium (1-5 ppm), copper (20-100 ppm), and zinc (40-120 ppm) values are from the belt of stratabound occurrences in upper Proterozoic and Cambrian siltstone and shale. These values may reflect concentrations of these elements established soon after deposition of the original sediments. Similarly, stream-sediment samples with relatively high barium (1000 ppm), beryllium (3 ppm), lead (70-100 ppm), and zinc (110-130 ppm) values, which occur mainly along the west side of the roadless area just north of the Idaho State line, have no recognized mineralized source and most likely reflect the relatively high background levels of the upper Proterozoic and Cambrian rocks drained by these streams. Stream sediments with relatively high copper values (70-100 ppm) also occur mainly in the northwest part of the roadless area underlain by upper Proterozoic and Cambrian rocks, near mine workings and prospects containing sparse disseminated copper sulfide minerals. The only two detectable precious-metal values found in the roadless area are comparatively low silver values (1.0-1.5 ppm) of questionable significance.

The roadless area is characterized by relatively featureless gravity and magnetic contour patterns of low relief. Geophysical data show no local anomalies within the Mount Naomi Roadless Area indicative of buried in- trusive rocks or other features that might be associated with metallic mineral deposits.

Potentially quarriable limestone and quartzite occur within the roadless area, but more accessible sources closer to markets are currently being utilized to the limit of present demand.

Phosphatic interbeds in Mississippian strata probably occur at high altitude within the roadless area but are likely to be thin and widely spaced. Richer and more extensive phosphate deposits are presently being mined from Permian rocks in nearby areas.

The oil and gas potential of the roadless area is unknown. Considering the nearby presence of potential petroleum source beds and the structure inferred for the roadless area, oil or gas concentrations could be present beneath the Willard allochthon. This possibility cannot be evaluated without seismic or drill-hole information. However, potential targets would probably be at depths comparable to the $20,000-30,000 \mathrm{ft}$ thickness estimated for the Willard allochthon, depths that may be prohibitive.

\section{SUGGESTIONS FOR FURTHER STUDIES}

Further study of the Mount Naomi Roadless Area would do little to refine the resource potential assessment for metallic minerals. However, Mississippian phosphate occurrences in the core of the Logan Peak syncline could be better delineated by more detailed mapping and sampling there than has been done to date. Refined seismic methods may eventually permit better evaluation of the subsurface oil and gas potential of the roadless area.

\section{REFERENCES}

Dover, J. H., and Bigsby, P. R., 1983, Mineral resource potential map of Mount Naomi Roadless Area, Cache County, Utah, and Franklin County, Idaho: U.S. Geological Survey Miscellaneous Field Studies Map MF-1566-A, scale 1:100,000.

McHugh, J. B., 1981, Analytical results for 60 water samples from Mount Naomi Wilderness study area, Utah-Idaho: U.S. Geological Survey Open-File Report 81-196. 

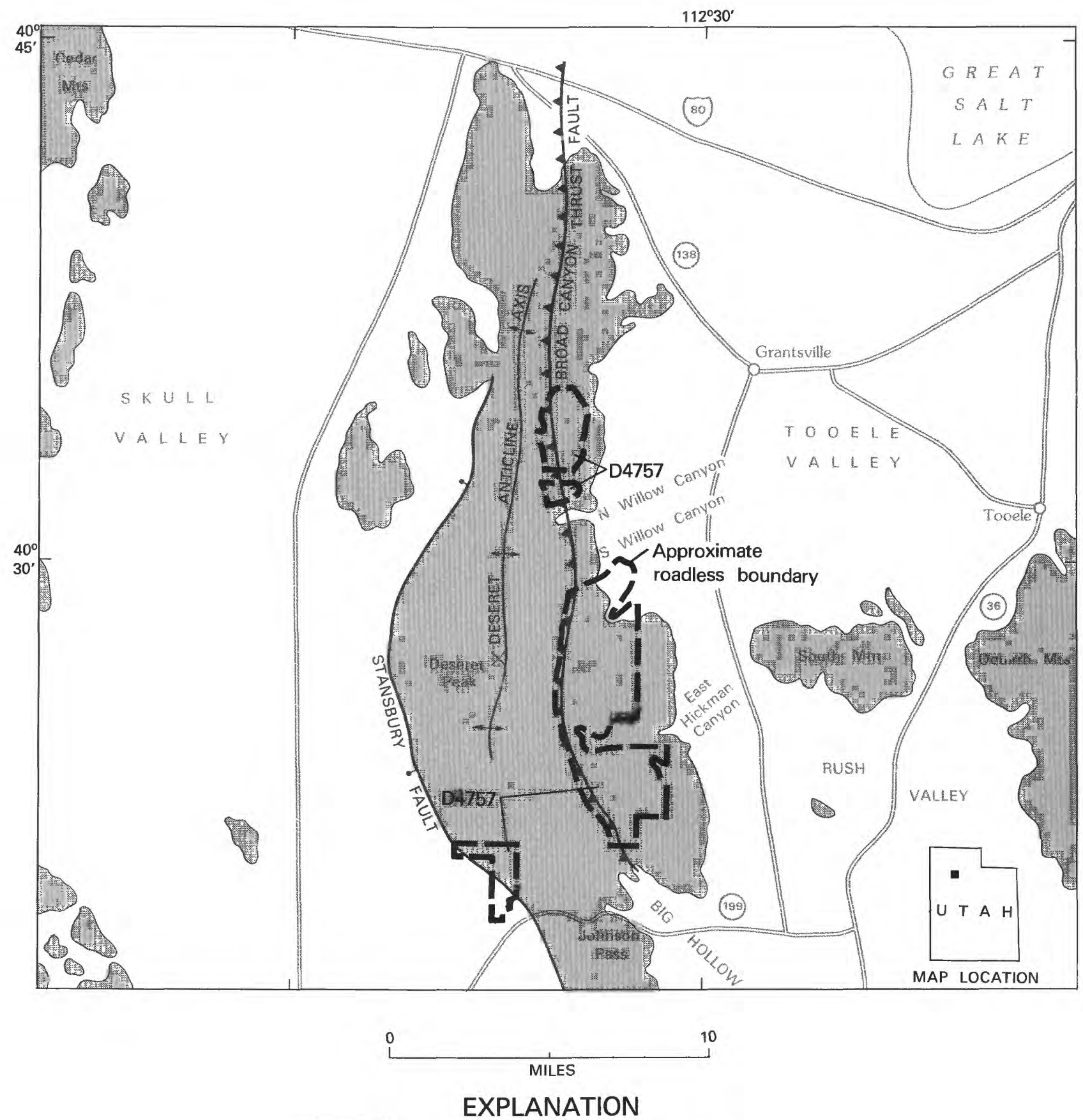

Upland areas, underlain principally by

Paleozoic sedimentary rocks

\section{Contact}

Fault--Bar and ball on downthrown
side

Figure 282.-Stansbury Roadless Areas, Utah. 


\title{
STANSBURY ROADLESS AREAS, UTAH
}

\author{
By Martin L. Sorensen, U.S. GeOlogical SurVey, and \\ RICHARD F. KNESS, U.S. BUREAU OF MINES
}

\begin{abstract}
SUMMARY
A mineral-resource survey of the Stansbury Roadless Areas was conducted in 1980 and 1981 and showed that there is little likelihood for the occurrence of metallic mineral resources in the areas. Limestone and dolomite underlie approximately 50 acres in the roadless areas and constitute a nonmetallic mineral resource of undetermined value. The oil and gas potential is not known and cannot be assessed without exploratory geophysical and drilling programs. There are no known geothermal resources.
\end{abstract}

\section{CHARACTER AND SETTING}

The Stansbury Roadless Areas are located in the Stansbury Mountains of north-central Utah, approximately $40 \mathrm{mi}$ west of Salt Lake City, and approximately $15 \mathrm{mi}$ west of Tooele, Utah. The range rises just south of Great Salt Lake, trends southward for approximately $28 \mathrm{mi}$, and has a maximum width of approximately 10 $\mathrm{mi}$. The roadless areas comprise $17.5 \mathrm{sq} \mathrm{mi}$ on the east flank and near the southern end of the range.

The Stansbury Mountains are underlain principally by rocks of Cambrian through Pennsylvanian age which have been folded into a large, south-trending anticline, the Deseret anticline. The west flank of the anticline is terminated by a recently active normal fault, the Stansbury fault. The east flank of the anticline terminates along the trace of the Broad Canyon thrust fault. A section of approximately $30,000 \mathrm{ft}$ of Paleozoic and Mesozoic sedimentary rocks and minor amounts of intrusive and extrusive igneous rocks are exposed in the Stansbury Mountains.

Many claims and prospects are present in the roadless areas, but there is no recorded production of any metals. Modest amounts of lead, silver, and zinc have been mined from several small mines east and north of the roadless areas. No mines are currently producing within or adjacent to the Stansbury Roadless Areas.

The mineral-resource study of 1980 and 1981 included analysis of heavy-mineral concentrates from stream sediments for 31 elements (Sorensen, 1982b). Samples collected from mines and prospects were assayed for metallic ore minerals (Sorensen and Kness, 1982). The resource evaluation was aided by interpretation of a 1971 regional aeromagnetic survey (U.S. Geological Survey, 1971).

\section{MINERAL RESOURCES}

Examination of the geology, geochemistry, mines, prospects, and claims in and near the roadless areas did not reveal any indications of previously unknown nearsurface metallic resources. Scattered occurrences containing copper, lead, or silver may be present in the roadless areas along the west side of the trace of the Broad Canyon thrust fault, but such occurrences, if present, are probably small and of low grade. Judging from the distribution of mines and prospects in adjacent parts of the Stansbury Mountains, the most favorable host rock for metal deposits is missing at the surface in these roadless areas. No significant anomalies of copper, lead, or silver were revealed by the analyses of streamsediment concentrates.

Rocks containing limestone and dolomite underlie approximately 50 acres in the roadless areas, but their value as industrial minerals is diminished by their inaccessibility, and by the presence of these commodities outside the roadless area.

A map of the geothermal resources of Utah (Utah Geological and Mineral Survey, 1980) does not identify any geothermal resources within the roadless areas. No oil and gas potential was identified in the Stansbury Roadless Areas during this study.

\section{SUGGESTIONS FOR FURTHER STUDIES}

Limestone and dolomite form the only identified mineral resource in the roadless areas. These rocks should be sampled and tested to determine their degree of purity, and hence, the value of these rocks for use as industrial minerals if needs cannot be met from more 
accessible deposits outside the area. An extensive program of geophysical exploration and exploratory drilling would be necessary to determine the potential for oil and gas in the Stansbury Roadless Areas.

\section{REFERENCES}

Sorensen, M. L., 1982a, Geologic map of the Stansbury Roadless Areas, Tooele County, Utah: U.S. Geological Survey Miscellaneous Field Studies Map MF-1353-A, scale 1:62,500.

$1982 \mathrm{~b}$, Map showing geochemical analyses of panned stream sediments, Stansbury Roadless Areas, Tooele County, Utah: U.S. Geological Survey Miscellaneous Field Studies Map MF-1353-B, scale 1:62,500.

Sorensen, M. L., and Kness, R. F., 1982, Mineral resource potential map of the Stansbury Roadless Areas, Tooele County, Utah: U.S. Geological Survey Miscellaneous Field Studies Map MF-1353-C, scale 1:62,500.

U.S. Geological Survey, 1971, Aeromagnetic map of part of westcentral Utah: U.S. Geological Survey Open-file report, scale $1: 250,000$.

Utah Geological and Mineral Survey, 1980, Geothermal resources of Utah 1980: Utah Geological and Mineral Survey, scale $1: 500,000$. 



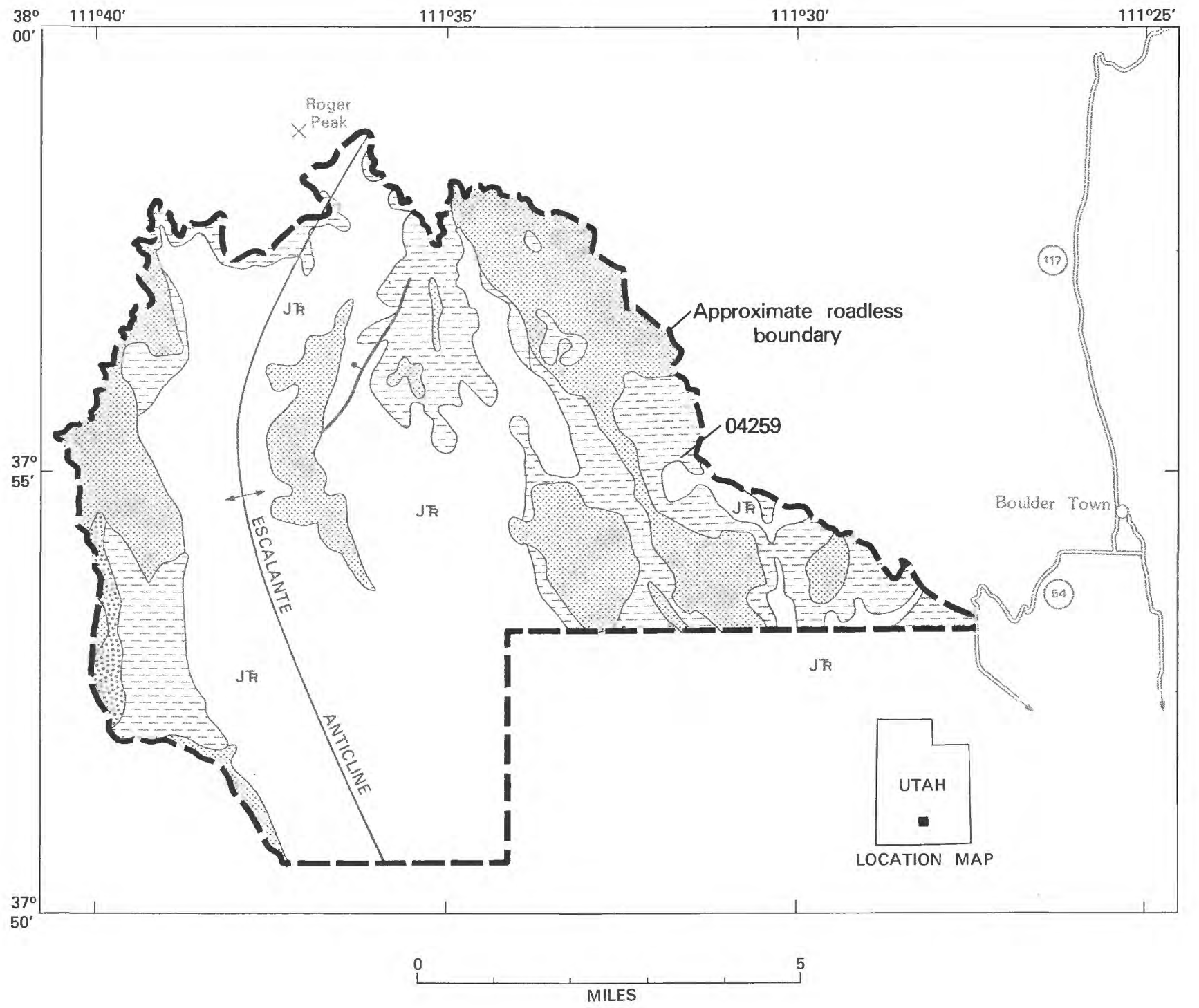

\section{EXPLANATION}

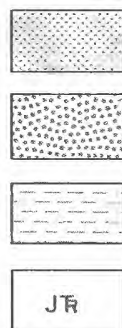

Alluvium, colluvium, and pediment deposits (Quaternary)

Shale, sandstone, and conglomerate (Cretaceous)

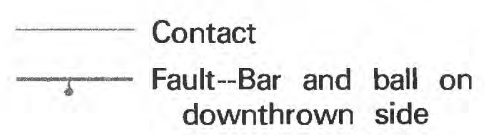

Shale, sandstone, and minor limestone and gypsum (Jurassic)

Sandstone (Jurassic and Triassic)

Figure 283.-The Box-Death Hollow Roadless Area, Utah. 


\title{
THE BOX-DEATH HOLLOW ROADLESS AREA, UTAH
}

\author{
By Gordon W. Weir, ${ }^{1}$ U.S. GeOlogical SURVEY, and \\ Michael E. LANE, U.S. BuREAU OF Mines
}

\begin{abstract}
SUMMARY
Geologic mapping, geochemical sampling, and a search for prospects and mineralized rock in The Box-Death Hollow Roadless Area conducted by the USGS and the USBM in 1970 and 1980 indicate that there is little promise for the occurrence of mineral or energy resources in the area.
\end{abstract}

\section{CHARACTER AND SETTING}

The Box-Death Hollow Roadless Area includes about $50 \mathrm{sq}$ mi of mesas and canyons in the Dixie National Forest in southern Utah. The southern boundary of the area is the forest boundary; elsewhere the periphery of the area is roughly defined by an improved dirt road which provides access from the nearest town, Escalante (population about 600), lying about $10 \mathrm{mi}$ to the south.

Rocks of Mesozoic age, chiefly sandstone and shale, totalling about $2000 \mathrm{ft}$ in thickness, and thin deposits of Quaternary age crop out in the area. Buried sedimentary rocks of Mesozoic and Paleozoic age, known from drill hole testing for oil and gas, are more than $4000 \mathrm{ft}$ thick. Over most of the area the rocks dip gently. The major structure is a broad fold known as the Escalante anticline. A high-angle normal fault, having a maximum displacement of about $200 \mathrm{ft}$, breaks the eastern flank of the anticline.

\section{MINERAL RESOURCES}

No metallic mineral deposits are known in The BoxDeath Hollow Roadless Area and there is little promise for the occurrence of metallic mineral resources. Analyses of samples of stream sediments, rocks, and water from springs and streams in and near the area do not suggest derivation from mineralized terranes. Slightly anomalous gold values detected in a few samples are not indicative of potential in this geologic setting.

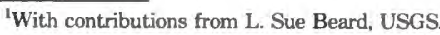

Although oil and gas may exist in the area data are insufficient to establish a resource potential. One well inside the roadless area and three wells near its margins have been drilled to test the Paleozoic rock in the Escalante anticline for oil and gas but without success.

A discontinuous seam of clayey coal, averaging less than 12 in. thick, crops out locally in Cretaceous shale along the west edge of the area. This seam has not been developed because thick seams of good quality coal crop out a few miles farther west outside the roadless area.

Potential construction materials within the area include stone for road metal in Cretaceous conglomerate and Tertiary basalt, gravel in Quaternary alluvial and colluvial deposits, and gypsum and limestone interbedded in Jurassic shale. However, thicker and more readily accessible deposits of these materials are available at nearby localities outside The Box-Death Hollow Roadless Area.

\section{SUGGESTIONS FOR FURTHER STUDIES}

Further study of this area in the search for mineral resources other than petroleum is unwarranted. Additional exploratory drilling by industry seems warranted if wells elsewhere in the region find oil or gas in strata as yet untested in The Box-Death Hollow Roadless Area.

\section{REFERENCE}

Weir, G. W., and Lane, M. E., 1983, Mineral resource potential map of The Box-Death Hollow Further Planning Area (RARE II), Garfield County. Utah: U.S. Geological Survey Miscellaneous Field Studies Map MF-1319-B, scale 1:48,000. 


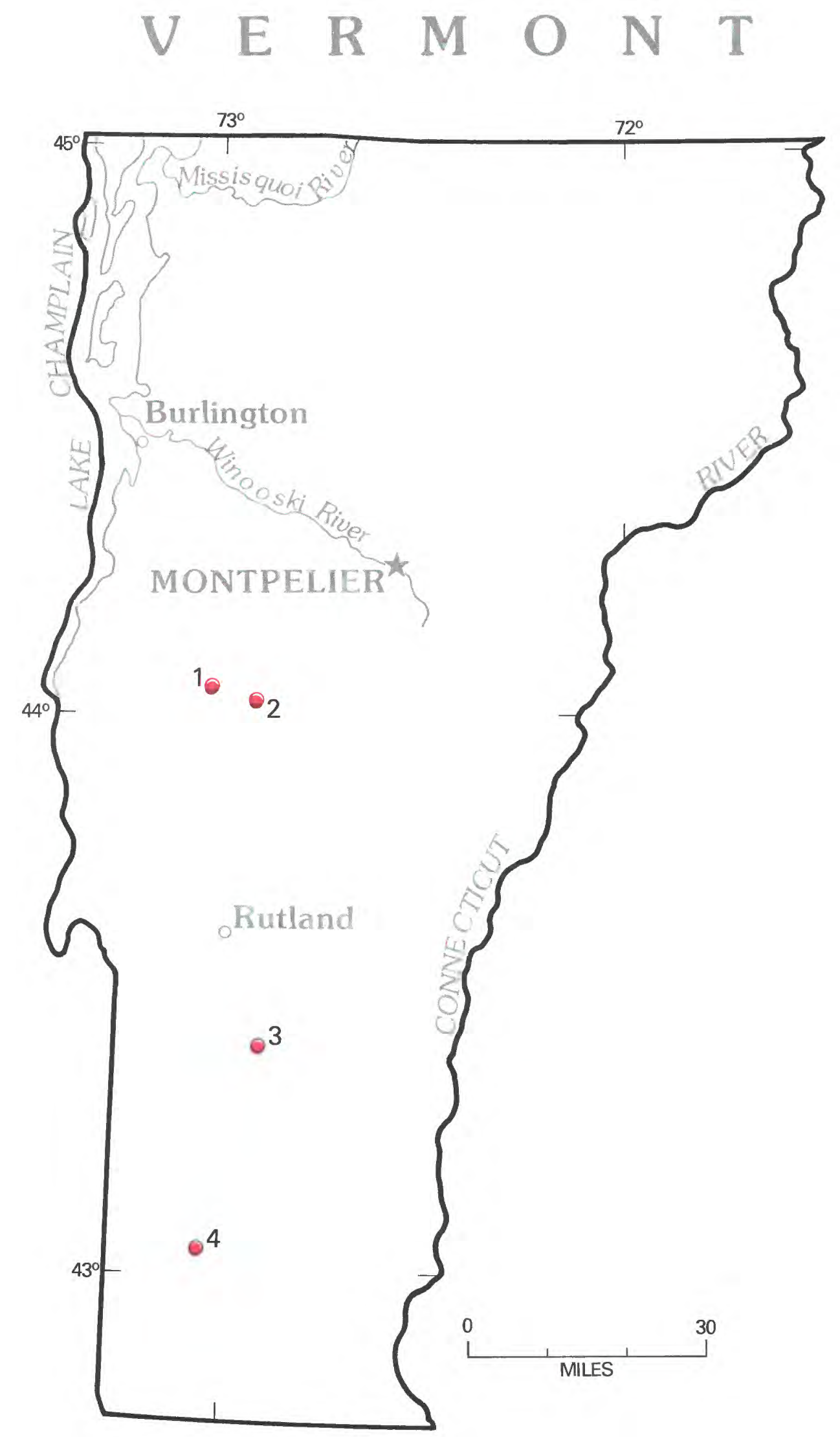

Location of areas studied. 


\title{
VERMONT
}

\author{
Map
No. \\ Name of Area \\ 2 Bread Loaf Roadless Area \\ 1 Bristol Cliffs Wilderness \\ 3 Devils Den Roadless Area \\ 4 Lye Brook Wilderness
}



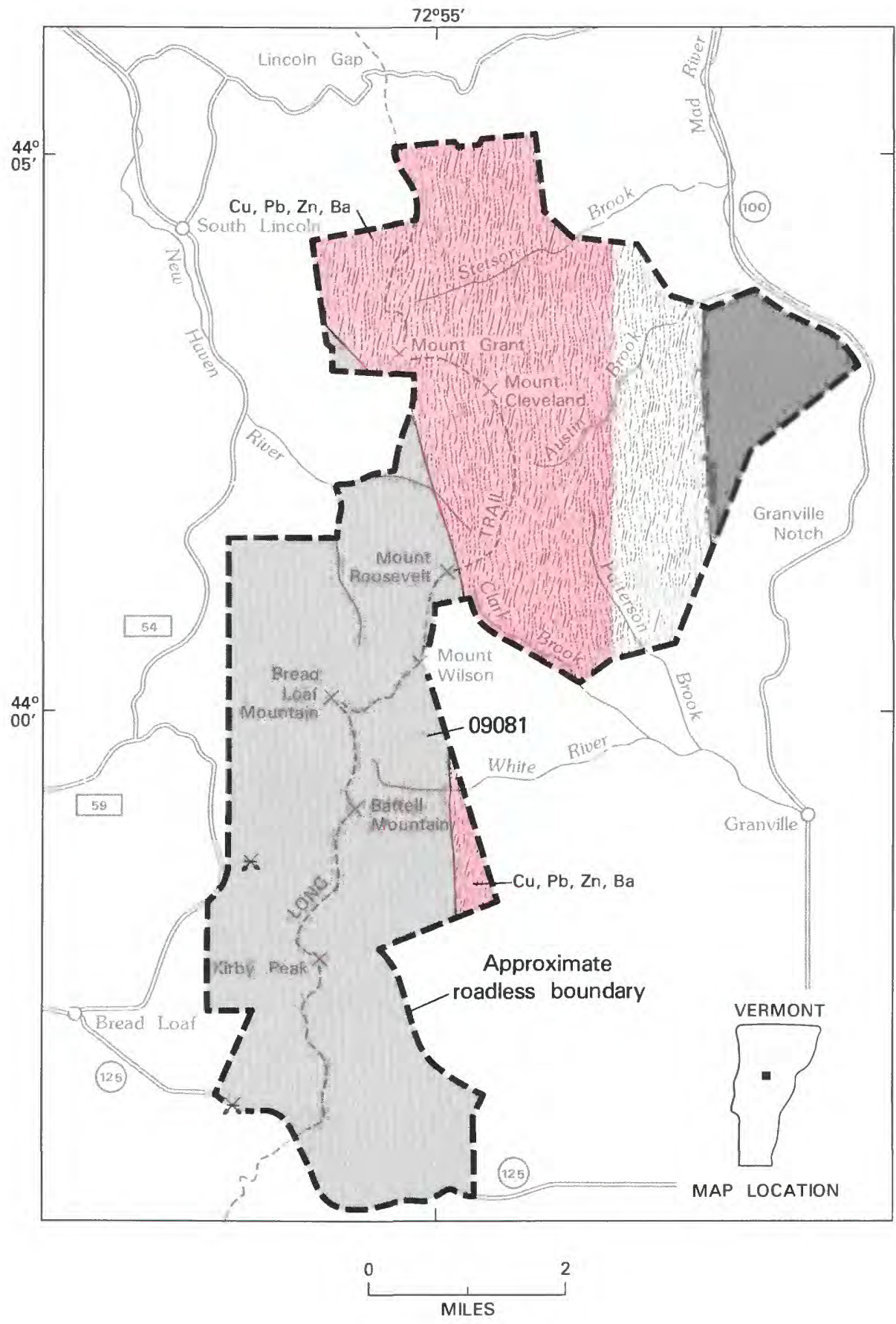

\section{EXPLANATION}

Geologic terrane with probable mineral-resource potential

$\begin{array}{ll}\mathrm{Ba} & \text { Barium } \\ \mathrm{Cu} & \text { Copper } \\ \mathrm{Pb} & \text { Lead } \\ \mathrm{Zn} & \text { Zinc } \\ * & \text { Sand and gravel pit (inactive) }\end{array}$

Noncarbonaceous schist and quartzite
Carbonaceous schist and minor volcanic rock
Mica schist and quartzite
Contact

Figure 284.-Bread Loaf Roadless Area, Vermont. 


\title{
BREAD LOAF ROADLESS AREA, VERMONT
}

\author{
By John F. Slack, U.S. Geological Survey, and \\ RICHARD F. BITAR, U.S. BUREAU OF MiNeS
}

\section{SUMMARY}

On the basis of a mineral-resource survey made in 1980-81, the Bread Loaf Roadless Area, Vermont, is considered to have probable resource potential for the occurrence of volcanogenic massive sulfide deposits of copper, zinc, and lead, particularly in the north and northeastern section of the roadless area. Nonmetallic commodities include minor deposits of sand and gravel, and abundant rock suitable for crushing. However, large amounts of these materials in more accessible locations are available outside the roadless area. A possibility exists that oil or natural gas resources may be present at great depth, but this possibility cannot be evaluated by the present investigation.

\section{CHARACTER AND SETTING}

The Bread Loaf Roadless Area comprises 31 sq mi in the Green Mountain National Forest in Addison and Washington Counties, central Vermont. The area is extremely rugged and contains some of the highest peaks in the State, including Bread Loaf Mountain (3835 ft), Mt. Wilson (3785 ft), Mt. Roosevelt $(3528 \mathrm{ft})$, Mt. Cleveland (3482 ft), and Mt. Grant (3623 ft). The nearest towns are Warren and Hancock, each a few miles to the northeast and southeast, respectively. The smaller villages of Granville, South Lincoln, and Ripton are nearby. The well-known Bread Loaf Writer's School is about $2 \mathrm{mi}$ from the southwestern boundary of the roadless area; the Middlebury College Ski Bowl is adjacent to the southern border. Total relief is nearly 2600 $\mathrm{ft}$, from a low altitude of $1240 \mathrm{ft}$ at the southeast corner, to a high point of $3835 \mathrm{ft}$ on the southern crest of Bread Loaf Mountan. Principal access is provided by Vermont State Route 100 along the east side of the roadless area, and by State Route 125 which forms the southern border; USFS roads 54 and 59 are near the western boundary. Old logging roads and several foot trails (including the Long Trail) provide access into the interior, and access to most of the high peaks. The north-south topographic divide provided by these peaks has developed many sizeable streams draining east and west from the divide. These streams, which include the headwaters of the New Haven, White, and Mad Rivers, ultimately discharge either west into Lake Champlain, or east into the Connecticut River.
Surface and mineral rights are owned entirely by the Federal Government and approximately half of the Bread Loaf Roadless Area is under lease application for oil and gas exploration. The applications cover slightly more than $15 \mathrm{sq} \mathrm{mi}$, mainly in the central and western part of the roadless area.

A mineral-resource survey of the Bread Loaf Roadless Area was made in the fall of 1980 , and briefly in 1981, by the USBM and the USGS. The investigations involved geologic mapping and several types of geochemical sampling programs (Bitar and Armstrong, 1981; Slack and Bitar, in press). Results of the geologic work indicate that the roadless area contains mixtures of relatively old rocks of late Precambrian and probably Early Cambrian age. These rocks show the effects of folding and metamorphism by heat and pressure deep within the Earth. Prior to this metamorphism the rocks consisted of sedimentary and volumetrically minor igneous rocks deposited on an ancient ocean floor. Originally these rocks included clastic sediments like sandstone, shale, and possibly graywacke; the igneous rocks formerly were mafic lava flows or tuffs erupted from volcanic centers under the sea. Today, all of these rocks show a transformation to hard schist and quartzite, and a structure in which most of the strata form part of a steeply dipping belt of schistose rocks, overlying older Precambrian basement gneisses to the west (Doll and others, 1961; Cady and others, 1962).

The occurrence in the roadless area of mixtures of marine sedimentary and volcanic rocks is an environment favorable for the occurrence of massive sulfide 
deposits. Deposits of this type are believed to form during submarine volcanic activity on the deep ocean floor (Hutchinson, 1973; Franklin and others, 1981). The ores typically consist of massive accumulations of sulfide minerals interlayered with volcanic and sedimentary rocks. The chief economically recoverable metals are copper and zinc, although some deposits yield significant amounts of lead and silver as well. Many massive sulfides are associated with rocks enriched in iron (as magnetite), barium, manganese, or boron. These rocks are important because they may be used as prospecting guides for massive sulfide deposits. Another characteristic of volcanogenic massive sulfides is for the ores to be conformable and stratabound within specific rock layers. As a result, the deposits tend to form rock units parallel to the trend of the surrounding strata.

\section{MINERAL RESOURCES}

The geologic setting and geochemical anomalies of the Bread Loaf Roadless Area suggest a probable potential for the occurrence of volcanogenic massive sulfide deposits. Analyses of rock, soil, streamsediment, and pan concentrate samples collected from throughout the roadless area show anomalously high concentrations of barium, cobalt, copper, lead, and zinc, especially in the north and northeastern part of the roadless area. Trace amounts of silver, gold, boron, chromium, molybdenum, and tin were also present. Because the high metal concentrations were found in all sample types, a local (non-glacial) source is postulated. In rocks, copper, lead, zinc, and barium are the most abundant elements of the anomalous suite which suggests a probable potential for the occurrence of resources of these commodities in massive sulfide deposits.

Nonmetallic commodities including sand and gravel, and abundant rocks suitable for crushing occur in the area; however, large amounts of these materials in more accessible locations are available outside the roadless area.

Rocks exposed at the surface lack any concentrations of hydrocarbons; however, a possibility does exist for oil and natural gas at depth. Recent seismic studies (Cook and others, 1979; Ando and others, 1982) indicate that the older metamorphosed rocks in the Blue Ridge of the southern Appalachians and the Green Mountains of Vermont overlie a thick sequence of young sedimentary rocks having a favorable hydrocarbon potential. The roadless area lies within the so-called Eastern Overthrust Belt which is currently being investigated
(McCaslin and Sumpter, 1981; Bigelow, 1982). Recently, large tracts of land in central and western Vermontincluding about half of the Bread Loaf Roadless Area-have been outlined by lease applications in the anticipation of a search for oil and gas (Oil and Gas Journal, 1982). A potential may exist for hydrocarbon resources in the deeper rocks of the roadless area, but it cannot be evaluated by the present investigation.

\section{SUGGESTIONS FOR FURTHER STUDIES}

The most geochemically anomalous samples in the roadless area appear to be restricted to one formation (the Hazens Notch Formation), mainly in the north and northeastern part of the roadless area near its western contact with the Mount Abraham Schist. Future efforts directed toward identifying deposits of economic interest in this region should therefore concentrate on this belt of rocks within and adjacent to the roadless area.

\section{REFERENCES}

Ando, C. J., Cook, F. A., Oliver, J. E., Brown, L. D., and Kaufman, S., 1982, Crustal geometry of the Appalachian orogen from seismic reflection studies: Geological Society of America, Abstracts with Programs, v. 14, nos. 1-2, p. 2.

Bigelow, T., 1982, Leasing in overthrust is becoming even more competitive: Northeast Oil Reporter, v. 2, no. 5, p. 94-98.

Bitar, R. F., and Armstrong, M. K., 1982, Mineral resources of Bread Loaf RARE II Further Planning Area, Addison and Washington Counties, Vermont: U.S. Bureau of Mines Open-File Report MLA $65-82,15 \mathrm{p}$.

Cady, W. M., Albee, A. L., and Murphy, J. F., 1962, Bedrock geology of the Lincoln Mountain quadrangle, Vermont: U.S. Geological Survey Geologic Quadrangle Map GQ-164, scale 1:62,500.

Cook, F. A., Albaugh, D. S., Brown, L. D., Kaufman, S., Oliver, J. E., and Hatcher, R. D., Jr., 1979, Thin-skinned tectonics in the crystalline southern Appalachians-COCORP seismic-reflection profiling of the Blue Ridge and Piedmont: Geology, v. 7, no. 12, p. 563-567.

Doll, C. G., Cady, W. M., Thompson, J. B., Jr., and Billings, M. P., 1961, Centennial Geologic Map of Vermont: Vermont Geological Survey, scale 1:250,000.

Franklin, J. M., Lydon, J. W., and Sangster, D. F., 1981, Volcanicassociated massive sulfide deposits: Economic Geology 75th Anniversary Volume, p. 485-627.

Hutchinson, R. W., 1973, Volcanogenic sulfide deposits and their metallogenic significance: Economic Geology, v. 68, p. 1223-1246.

McCaslin, J. C., and Sumpter, R., 1981, Eastern overthrust search picks up speed: Oil and Gas Journal, v. 79, no. 2, p. 173-180.

Oil and Gas Journal, 1982, Newsletter: Oil and Gas Journal, v. 80, no. 5.

Slack, J. F., and Bitar, R. F., in press, Mineral resource potential map of the Bread Loaf Roadless Area, Addison and Washington Counties, Vermont: U.S. Geological Survey Miscellaneous Field Studies Map MF-1625-A, scale 1:48,000. 


\title{
BRISTOL CLIFFS WILDERNESS, VERMONT
}

\author{
By John F. Slack, U.S. GeOlogical SurVey, and \\ Peter C. MORY, U.S. Bureau of Mines
}

\begin{abstract}
SUMMARY
A mineral-resource survey of the Bristol Cliffs Wilderness, Vermont, in 1977 and in 1981 indicates that there is little promise for the occurrence of metallic mineral resources within the wilderness. The only apparent resources are nonmetallic commodities including rocks suitable for construction materials and silica sand, and small amounts of peat and sand and gravel; however, these commodities are found in abundance outside the wilderness. A potential may exist for oil and natural gas at depth, but this cannot be evaluated by the present study.
\end{abstract}

\section{CHARACTER AND SETTING}

The Bristol Cliffs Wilderness comprises an area of about $6 \mathrm{sq} \mathrm{mi}$ in the Green Mountain National Forest, Addison County, in west-central Vermont. The area consists of mountainous terrain on the west flank of the Green Mountains, about $25 \mathrm{mi}$ southwest of Burlington and $8 \mathrm{mi}$ northeast of Middlebury. The terrain varies from gentle within the interior of the wilderness, to precipitous along the western boundary of the Bristol Cliffs, from which the wilderness obtains its name. Altitudes range from $520 \mathrm{ft}$ along the New Haven River near Bristol, to a high point of $2325 \mathrm{ft}$ on the crest of South Mountain in the center of the wilderness. Two small ponds (North and Gilmore Ponds) are located near South Mountain. Several unnamed streams drain radially away from the wilderness into the New Haven River, ultimately discharging into Lake Champlain to the west. Access is provided by U.S. Route 7 from Middlebury, and by State Highways 17 and 116. Paved and maintained gravel and dirt roads are also present near the western, southern, and eastern boundaries of the wilderness. With the exception of a small (12 acre) parcel of land in the northeast corner, surface and mineral rights of the wilderness are under the jurisdiction of the U.S. Government.

A mineral-resource survey of the wilderness was made in 1977 by personnel of the USBM and in 1981 by the USGS (Slack and Mory, 1983). The investigation involved both geologic mapping and geochemical sampling. Results of the geologic work indicate that the wilderness contains mixtures of relatively old rocks of late
Precambrian and Early Cambrian age (Slack and others, 1983). The rocks show the effects of folding and metamorphism, the latter by heat and pressure deep in the Earth. Prior to metamorphism the rocks consisted of clastic sediments including sandstone, siltstone, and shale, all deposited on an ancient ocean floor. Today these rocks show transformation to hard quartzite, phyllite, and schist. This metamorphism is in part responsible for the massive ledges of quartzite that make up the Bristol Cliffs.

The geochemical survey was conducted in an attempt to locate concentrations of metals that might indicate the presence of nearby mineral deposits. Samples of rock, soil, stream sediment, and pan concentrates from stream sediments were collected and analyzed from throughout the wilderness. No significant concentrations of metals were found, although slightly anomalous quantities of a few elements (copper, chromium, lead, nickel, tin, and zinc) are present locally.

\section{MINERAL RESOURGES}

The Bristol Cliffs Wilderness has no identified mineral-resource potential except for certain nonmetallic commodities. These include small deposits of sand and gravel, minor peat, and abundant rock suitable for construction purposes; a potential also may exist for oil or natural gas at depth. The deposits of sand and gravel occur along the New Haven River, on the northern edge of the wilderness, but they have minimal importance because of much larger resources of more accessible 

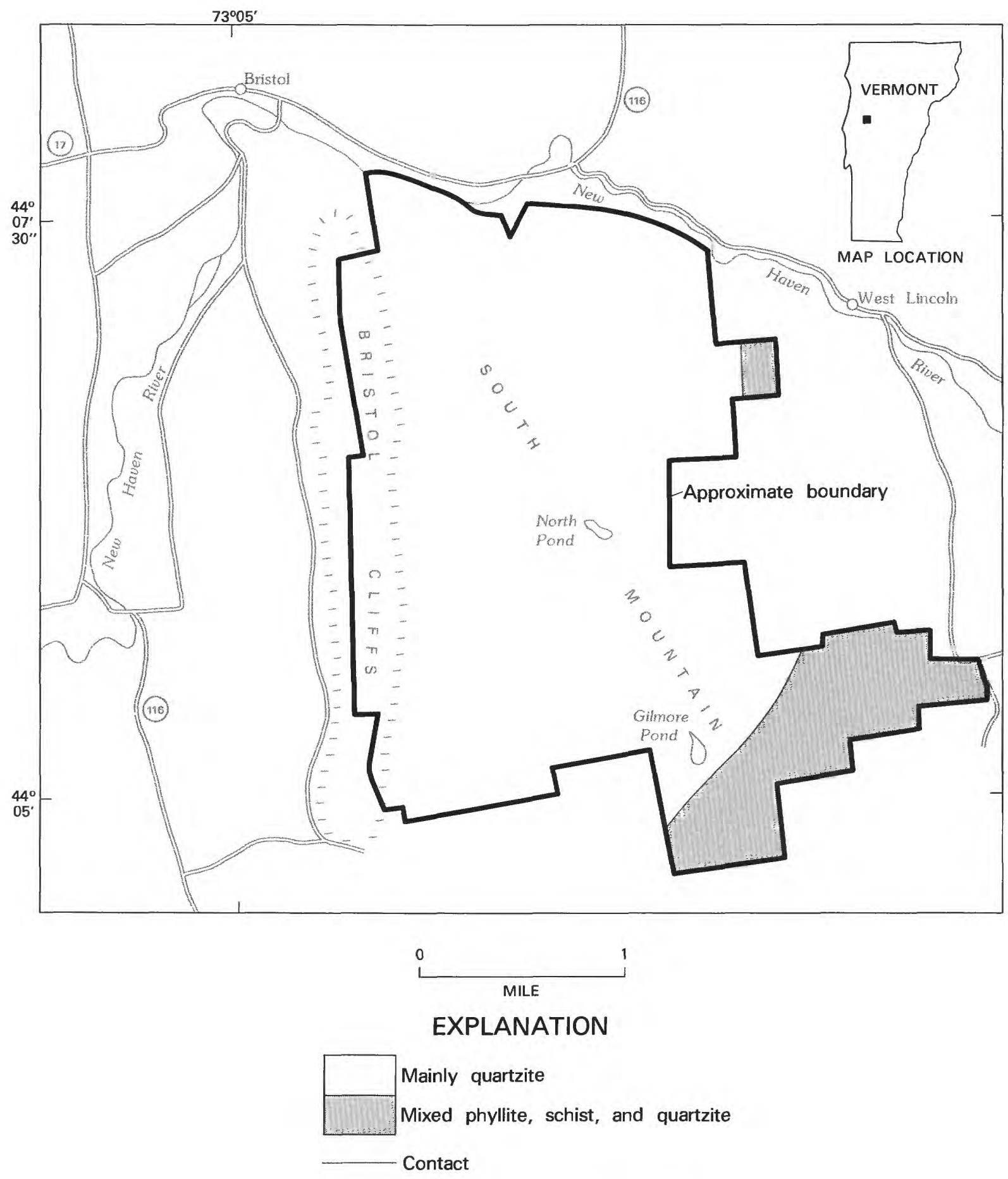

Figure 285.-Bristol Cliffs Wilderness, Vermont. 
deposits outside the area. A small peat bog on the east side of North Pond was found to have about $2 \mathrm{ft}$ of water-saturated sphagnum moss, but its size, inaccessibility, and contained debris limit its usefulness. Locally pure quartzite rocks along the western boundary of the wilderness-including the Bristol Cliffs-are a silica sand resource for glassmaking or chemical products. However, similar rock is available elsewhere in western Massachusetts and has been mined in the past for highsilica sand.

Although rocks exposed at the surface of the wilderness are devoid of any hydrocarbons, a possibility does exist for oil and natural gas at depth. Recent seismic studies (Cook and others, 1979; Ando and others, 1982) indicate that the old metamorphosed rocks of the Blue Ridge of the southern Appalachians and the Green Mountains of Vermont overlie a thick sequence of young sedimentary rocks having a favorable hydrocarbon potential. An oil and (or) gas resource may therefore exist in these deeper rocks, but this possibility cannot be evaluated by the present investigation.

\section{SUGGESTIONS FOR FURTHER STUDIES}

The geologic setting of the Bristol Cliffs Wilderness has many similarities to areas containing stratabound lead deposits. These types of deposits characteristically occur in basal quartzitic sandstone above feldspar-rich basement rocks. Comparable settings are found along much of the western front of the Green Mountains, including the Bristol Cliffs area. Sandstone lead deposits include the large (80 million ton) orebody at Laisvall, northern Sweden (Ricard and others, 1979), and others elsewhere in the world (Bjorlykke and Sangster, 1981). Although there is no evidence for such a deposit in the Bristol Cliffs area, more detailed geologic studies of the wilderness might find clues to concealed lead mineralization.

\section{REFERENCES}

Ando, C. J., Cook, F. A., Oliver, J. E., Brown, L. D., and Kaufman, S., 1982. Crustal geometry of the Appalachian orogen from seismic reflection studies [abs.]: Geological Society of America, Abstract with Programs, v. 14, nos. 1 and 2, p. 2.

Bjprlykke, A., and Sangster, D. F., 1981, An overview of sandstone lead deposits and their relation to red-bed copper and carbonatehosted lead-zinc deposits: Economic Geology 75th Anniversary Volume, p. 179-213.

Cook, F. A., Albaugh, D. S., Brown, L. D., Kaufman, S., Oliver, J. E., and Hatcher, R. D., Jr., 1979, Thin-skinned tectonics in the crystalline southern Appalachians-COCORP seismic-reflection profiling of the Blue Ridge and Piedmont: Geology, v. 7, no. 12, p. 563-567.

Ricard, D. T., Willdén, M. Y., Marinder, N. E., and Donnelly, T. H., 1979, Studies on the genesis of the Laisvall sandstone lead-zinc deposit, Sweden: Economic Geology, v. 74, p. 1255-1285.

Slack, J. F., Atelsek, P. J., and Grosz, A. E., 1983, Geologic and geochemical survey of the Bristol Cliffs Wilderness, Addison County, Vermont: U.S. Geological Survey Miscellaneous Field Studies Map MF-1593-A.

Slack, J. F., and Mory, P. C., 1983, Mineral resource potential map of the Bristol Cliffs Wilderness, Addison County, Vermont: U.S. Geological Survey Miscellaneous Field Studies Map MF-1593-B (in press). 

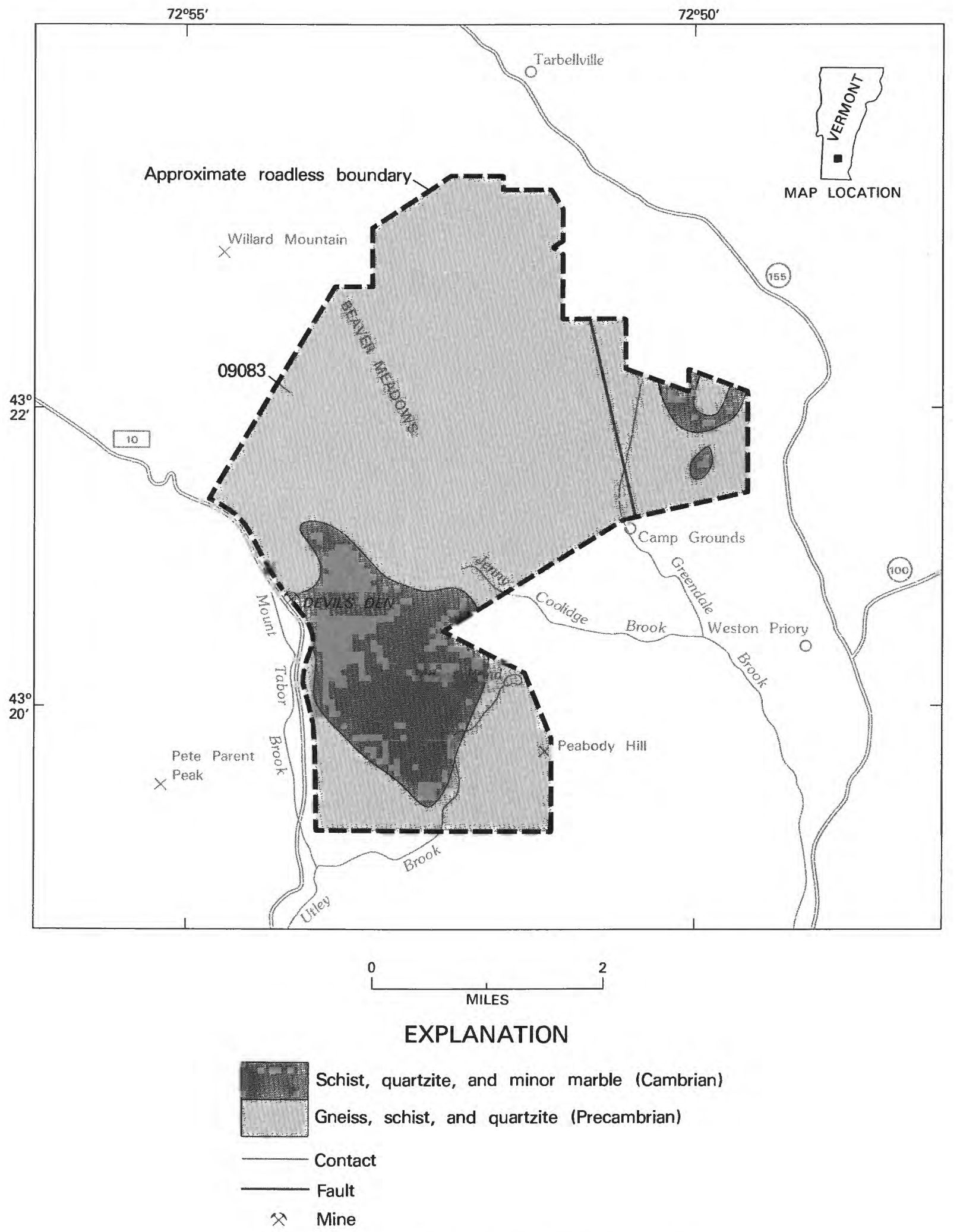

Figure 286.-Devils Den Roadless Area, Vermont. 


\title{
DEVILS DEN ROADLESS AREA, VERMONT
}

\author{
By JOHn F. Slack, U.S. GeOlOGical SuRVEY, and \\ ANDREW E. SABIN, U.S. BUREAU OF MINES
}

\begin{abstract}
SUMMARY
In 1980-81 a mineral-resource survey was made of the Devils Den Roadless Area, Vermont. Geochemical sampling found traces of gold, copper, barium, lead, molybdenum, silver, tin, and thorium in rocks, stream sediments, and panned concentrates, but not in sufficient quantities to identify any resource potential. The results of the survey indicate that there is little promise for the occurrence of metallic mineral resources within the roadless area. The only apparent resources are nonmetallic commodities including abundant rock suitable for crushing, and very small deposits of sand and gravel and marble; these also occur outside the roadless area. The area was also evaluated for bedrock uranium and thorium deposits, but no anomalously high radioactive bedrock was found. A potential may exist for oil or natural gas at great depth, but this cannot be evaluated by the present study.
\end{abstract}

\section{CHARACTER AND SETTING}

The Devils Den Roadless Area comprises an area of $13.8 \mathrm{sq} \mathrm{mi}$ in the Green Mountain National Forest in Rutland and Windsor Counties, south-central Vermont. The area consists of mountainous terrane in the heart of the Green Mountains, about 7 air miles southwest of Ludlow, the nearest large community. The small villages of Weston and East Wallingford are 3 and $5 \mathrm{mi}$ to the south and north, respectively. Total relief is nearly $1200 \mathrm{ft}$, from a low altitude of $1640 \mathrm{ft}$ along the southwestern edge of the area, to a high point of about $2860 \mathrm{ft}$ in the northwest portion. Principal access is provided by State Routes 100 and 155 on the southeast and northeast, and by USFS Road 10 along the western boundary. Old logging roads and foot trails allow entry to the interior of the roadless area. Several swamps and one small pond (Moses Pond) are located in topographically low areas. Drainage is principally to the south and southeast by tributaries of the south-flowing West River, ultimately discharging into the Connecticut River near Brattleboro.

The surface and mineral rights are owned by the Federal Government, and a large part of the roadless area is under lease application for oil and gas exploration. Three lease applications were filed in December, 1979 , on 15 tracts of land covering approximately 5600 acres.
A mineral-resource survey of the Devils Den area was made in 1980 by personnel of the USBM and in 1981 by the USGS (Slack and Sabin, in press; Sabin and Jones, 1981). The investigation involved both geologic mapping and geochemical sampling. Results of the geologic work indicate that the roadless area contains mixtures of relatively old rocks of late Precambrian and probable Early Cambrian age. The rocks show the effects of folding and metamorphism by heat and pressure deep within the Earth; in places the rocks have been melted to form granite pegmatites. Prior to this metamorphism and melting, the rocks consisted of sedimentary and igneous rocks deposited on an ancient ocean floor. Originally these rocks included clastic sediments such as sandstone and shale, and chemical sediments like dolomite. The igneous rocks formerly were mafic lava flows or tuffs erupted from volcanic centers under the sea. Today, all of these rocks show a transformation to hard quartzite, schist, marble, and gneiss, and a complex structure in which most of the strata of the roadless area are upside down, as a part of a large fold sequence.

The geochemical survey was conducted in an attempt to locate concentrations of metals that might suggest the presence of concealed mineral deposits. Samples of rock, soil, and stream sediment were collected from throughout the roadless area; several pan concentrate samples were also collected. All of these materials were 
processed in the laboratory and submitted for geochemical analysis. Slightly anomalous quantities of a few elements (barium, copper, gold, lead, molybdenum, silver, tin, and thorium) are present locally, but none of these elements occur in concentrations sufficient to identify any mineral-resource potential in the area.

\section{MINERAL RESOURCES}

The Devils Den Roadless Area has no recognized mineral resources except for certain nonmetallic commodities. These include small deposits of sand and gravel, and abundant rock suitable for construction purposes. The only evidence of past mining activity is a small artificial cave along the western border of the roadless area, made during early excavation of marble (Dale, 1915). Recent studies of the geologic and geochemical setting of this and other nearby marbles indicate that their limited size and vein-quartz inclusions reduce their potential for modern lime manufacturing. Exploration for uranium has been carried out in adjacent parts of the Green Mountains, including localities just 3 to 5 air miles east of the roadless area. However, airborne and ground radiometric surveys of the Devils Den Roadless Area have failed to indicate any anomalously radioactive bedrock. There is thus judged to be little promise for the occurrence of uranium (or thorium) resources in the roadless area.

Although rocks exposed at the surface near Devils Den are devoid of hydrocarbons, a possibility does exist for oil and natural gas at depth. Recent seismic studies (Cook and others, 1979; Ando and others, 1982) indicate that the older metamorphosed rocks in the Blue Ridge of the southern Appalachians and the Green Mountains of Vermont overlie a thick sequence of young sedimentary rocks having a favorable hydrocarbon potential. The roadless area lies within the so-called Eastern Overthrust Belt (McCaslin and Sumpter, 1981; Bigelow, 1982). Recently, large tracts of land in central and western Vermont-including most of the Devils Den Roadless Area-have been included in lease applications in the anticipation of a search for oil and gas (Oil and Gas Journal, 1982). A hydrocarbon resource may exist in the deeper rocks of the roadless area, but it cannot be evaluated by the present investigation.

Tourmaline-rich schists and gneisses occur along the extreme western and eastern margins of the roadless area. Tourmaline is noteworthy because it is a common mineral that contains large quantities of the element boron. Although tourmaline is found as a minor ac- cessory mineral in many rock types throughout the world, only rarely does it occur in concentrated amounts. The tourmaline-rich rocks near Devils Den are believed to have originally formed either as chemical precipitates from undersea hot springs, or as deposits related to shallow-water evaporites, and although they are not identified as resources they are of general exploration interest because of their close association with a variety of stratabound mineral deposits (Slack, 1982).

\section{SUGGESTIONS FOR FURTHER STUDIES}

Some of the older Precambrian rocks of the Devils Den Roadless Area contain unusual concentrations of minerals that are of broad geochemical interest. A more detailed study of the tourmaline-rich rocks might help in deciphering the geologic history of the roadless area, as well as in identifying the origin of some of the trace elements found by the geochemical survey. Further work in the roadless area could also help identify the potential for oil and gas resources.

\section{REFERENCES}

Ando, C. J., Cook, F. A., Oliver, J. E., Brown, L. D., and Kaufman, S., 1982, Crustal geometry of the Appalachian orogen from seismic reflection studies [abs.]: Geological Society of America, Abstracts with Programs, v. 14, nos. 1 and 2, p. 2.

Bigelow, T., 1982, Leasing in overthrust is becoming even more competitive: Northeast Oil Reporter, v. 2, no. 5, p. 94-98.

Cook, F. A., Albaugh, D. S., Brown, L. D., Kaufman, S., Oliver, J. E., and Hatcher, R. D., Jr., 1979, Thin-skinned tectonics in the crystalline southern Appalachians-COCORP seismic-reflection profiling of the Blue Ridge and Piedmont: Geology, v. 7, no. 12, p. 563-567.

Dale, T. N., 1915, The calcite marble and dolomite of eastern Vermont: U.S. Geological Survey Bulletin 589, 67 p.

McCaslin, J. C., and Sumpter, R., 1981, Eastern overthrust search picks up speed: Oil and Gas Journal, v. 79, no. 2, p. 173-180.

Oil and Gas Journal, 1982, OGJ Newsletter: Oil and Gas Journal, v. 80 , no. 5 .

Sabin, A. E., and Jones, J. G., 1981, Mineral resources of Devils Den RARE II Further Planning Area, Rutland and Windsor Counties, Vermont: U.S. Bureau of Mines Open-File Report MLA $34-82,16 \mathrm{p}$.

Slack, J. F., 1982, Tourmaline in Appalachian-Caledonian massive sulphide deposits and its exploration significance: Transactions of Institution of Mining and Metallurgy, v. 91, sec. B (Applied Earth Science), p. B81-B89.

Slack, J. F., and Sabin, A. E., in press, Mineral resource potential map of the Devils Den Roadless Area, Rutland and Windsor Counties, Vermont: U.S. Geological Survey Miscellaneous Field Studies Map MF-1626-A, scale 1:24,000. 


\title{
LYE BROOK WILDERNESS, VERMONT
}

\author{
By Robert A. Ayuso, U.S. GeOlogical SuRvey, and \\ D. K. HaRrison, U.S. BuREAU of Mines
}

\begin{abstract}
SUMMARY
The Lye Brook Wilderness, in the Green Mountains of Vermont is underlain by gneisses, quartzites, schists, and amphibolites of Precambrian to Ordovician age. A mineral-resource survey in 1981 determined that only one commodity, quartzite, is present in large quantities and could be a source of dimension stone or crushed stone. Although an anomalously high radioactive area occurs within the Precambrian basement, geochemical studies indicate little promise for the occurrence of significant uranium mineralization or for the occurrence of other mineral or energy resources within the wilderness.
\end{abstract}

\section{CHARACTER AND SETTING}

The Lye Brook Wilderness contains about $23 \mathrm{sq}$ mi in the Green Mountain National Forest of the Green Mountains in southern Vermont. The wilderness is in Bennington and Windham Counties, about 2 mi east of the village of Manchester, Vermont. The eastern boundary coincides generally with the Winhall River. Traces of the Appalachian and Long Trails are the northern boundaries, while U.S. Highway 7 parallels the western boundary. Access to the northern part of the wilderness is from the Lye Brook, Appalachian, and Long Trails. The central and southeastern portions of the wilderness are not easily accessible by trails. Streams in the southern half are not adequate avenues into the wilderness because they are generally not navigable. Altitudes range from about $700 \mathrm{ft}$ near Batten Kill just west of the wilderness boundary to $2900 \mathrm{ft}$ in a few hills of the northern half of the wilderness. Slopes are extremely steep along the deeply cut banks of Lye Brook, Bourn Brook, and Mill Brook. Other areas within the wilderness are much flatter, as in the southeastern part where marshy terrane is common.

A mineral-resource survey of the Lye Brook Wilderness was made in 1981 and 1982 . This survey included reconnaissance geologic mapping, (Ayuso and Robinson, in press) geochemical sampling and analysis, (Ayuso and Day, in press; Ayuso and Harrison, in press) and examination of mines and prospects (Harrison, 1981). The Federal Government owns 90 percent of the surface and mineral rights within the wilderness.

Bedrock in the Lye Brook Wilderness consists of Precambrian to Ordovician rocks. The Mount Holly
Complex is the Precambrian basement and consists of gneisses, quartzites, schists, and amphibolites (Hewitt, 1961). The gneisses are irregularly banded greenschist facies metamorphic rocks composed of quartz, microcline, and biotite. Quartzites of variable thickness are massive, highly contorted, and cut by thin pegmatitic veins. This basement is unconformably overlain by the Cambrian Mendon Formation which consists chiefly of conglomeratic quartz schist, gritty quartz-muscovite, and graphitic quartz-muscovite phyllite. The Cambrian Cheshire Quartzite overlies the Mendon Formation along a gradational contact and consists of massively bedded, gray to white, recrystallized sandstone. Another gradational contact consisting of interbedded dolomites and quartzites characterizes the transition from the Cheshire Quartzite to the Ordovician Dunham Dolomite. The cream-colored rocks of the Dunham Dolomite are only exposed along the northern boundary of the wilderness.

The bedrock in the Lye Brook Wilderness overlies the west flank of the Green Mountain anticlinorium forming a western-facing escarpment toward the synclinal Vermont valley. The rocks are characterized by isoclinal and recumbent folding superimposed on the Green Mountains anticlinorium. Lower Cambrian rocks also show west-facing folds, while in general, the rocks overlying the Precambrian basement show evidence of slip cleavage and plastic deformation.

\section{MINERAL RESOURCES}

No significant metallic mineral resources were found 


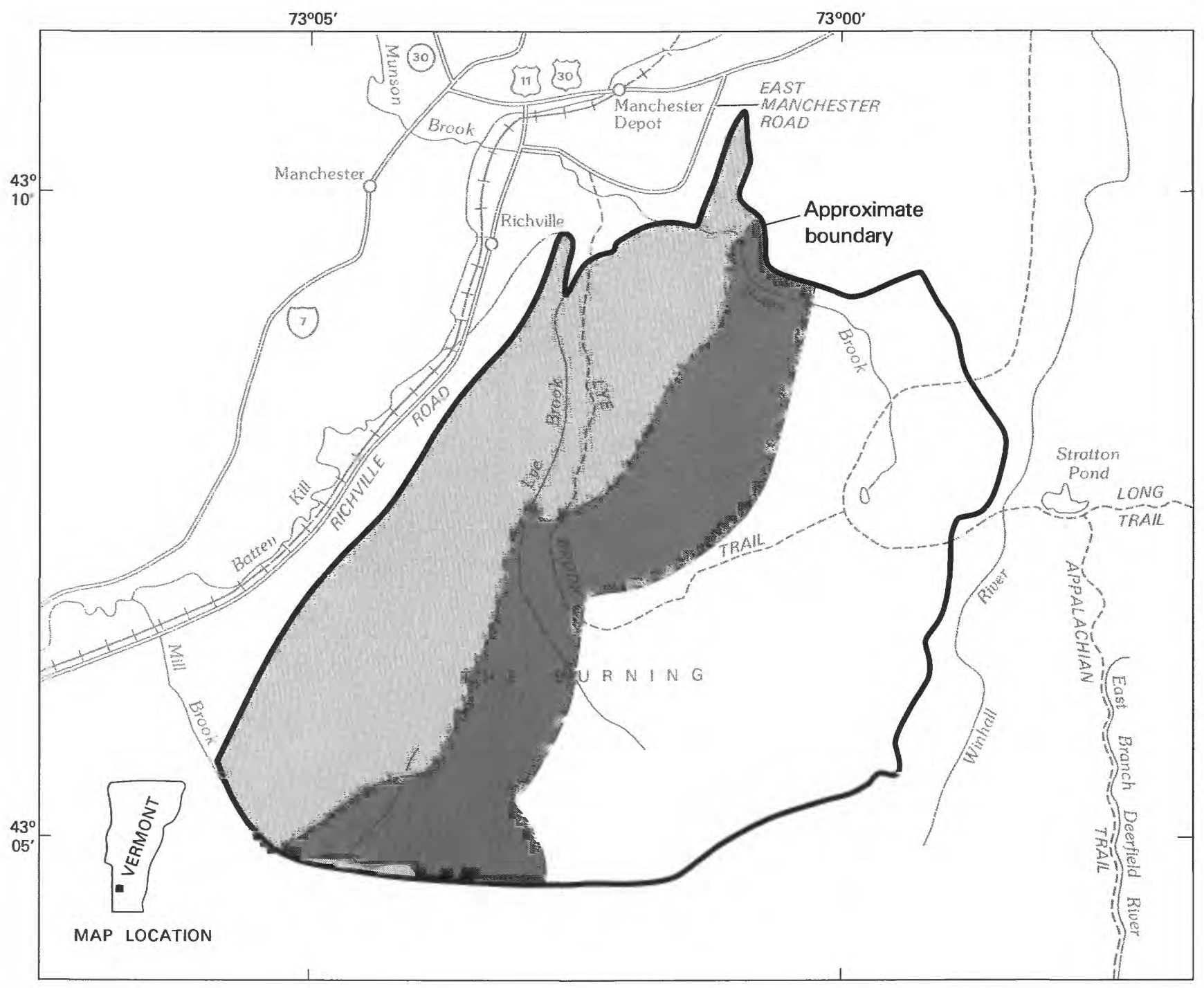

0

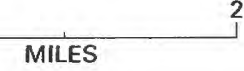

\section{EXPLANATION}

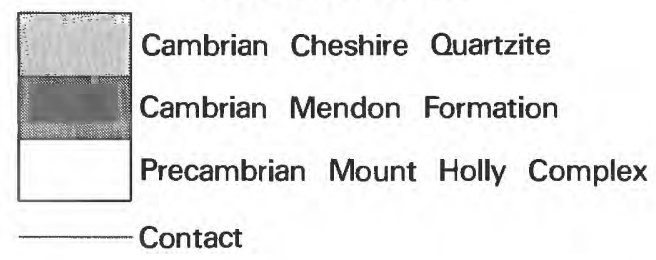

Figure 287.-Lye Brook Wilderness, Vermont. 
in the Lye Brook Wilderness and the results of analyses of stream-sediment, soil, and rock samples indicate little promise for the occurrence of metallic or energy resources in the area. The Cheshire Quartzite is a potential source of low-grade silica sand. Iron, mineral pigments, and kaolin deposits occur in the vicinity of the area but are not known to exist within the wilderness (Harrison, 1981).

Approximately one third of the area is underlain by the Cheshire Quartzite where it outcrops along cliffs and near the tops of the ridges. Quartzite beds and lenses also occur in the Mendon Formation and the Precambrian basement. However, abundant resources of the Cheshire Quartzite are available outside the wilderness.

As a result of the intense exploration for uranium in the vicinity (Preiss, 1979), the Precambrian basement was traversed in detail in order to delineate potentially mineralized pegmatitic bodies. Popenoe (1964) indicated that an area within the wilderness near Bourn Brook was anomalously radioactive. Rock types that are superficially similar to those in known mineralized areas in the vicinity of the town of Jamaica, Vermont, form a spotty outcrop distribution in the Mount Holly Complex, but the uranium concentrations in these rocks were disappointingly low ( $<5 \mathrm{ppm})$. A few samples had anomalously high thorium contents (as much as 51 $\mathrm{ppm}$ ) but most contained less than $10 \mathrm{ppm}$. No uranium resource potential was identified in the area.

\section{SUGGESTIONS FOR FURTHER STUDIES}

Although many of the metal abundances in the
Precambrian rocks are higher than the average highcalcium granitic rock (Turekian and Wedepohl, 1961), their regional distribution is spotty and restricted to the northeast quadrant of the wilderness. Thus, it is unlikely that these rocks would ever constitute a significant metal resource. Additional exploration for uranium within the wilderness is not warranted on the basis of geologic and geochemical results obtained in this study.

\section{REFERENCES}

Ayuso, R. A., and Day, G. W., 1983, Geochemical survey of the Lye Brook Wilderness, Bennington and Windham Counties, Vermont: U.S. Geological Survey Miscellaneous Field Studies MF-1609-B.

Ayuso, R. A., and Harrison, D. K., 1983, Mineral resource potential map of the Lye Brook Wilderness, Bennington and Windham Counties, Vermont: U.S. Geological Survey Miscellaneous Field Studies MF-1609-C.

Ayuso, R. A., and Robinson, G. R., Jr., 1983, Geologic map of the Lye Brook Wilderness, Bennington and Windham Counties, Vermont: U.S. Geological Survey Miscellaneous Field Studies MF-1609-A.

Harrison, D. K., 1981, Mineral resources of the Lye Brook Wilderness, Bennington and Windham Counties, Vermont: U.S. Bureau of Mines, Open-File Report MLA 17-81.

Hewitt, P. C., 1961, The geology of the Equinox quadrangle and vicinity, Vermont: Vermont Geological Survey Bulletin, 18, 83 p.

Popenoe, P., 1964, Aeroradioactivity of parts of east-central New York and west-central New England: U.S. Geological Survey Geophysical Investigation Map GP-358, scale 1:250,000

Preiss, R., 1979, Report on uranium mineralization in the College HillPinnacle Hill Area, Windham County, Vermont: Urangesellschaft U.S.A., Inc.

Turekian, K. K., and Wedepohl, K. H., 1961, Distribution of the elements in some major units of the Earth's crust: Geological Society of America Bulletin, v. 72, pp. 175-191. 


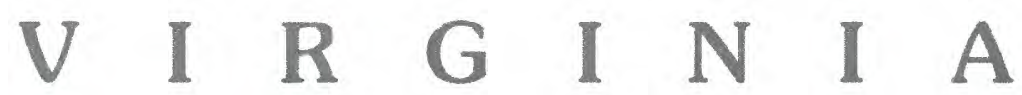

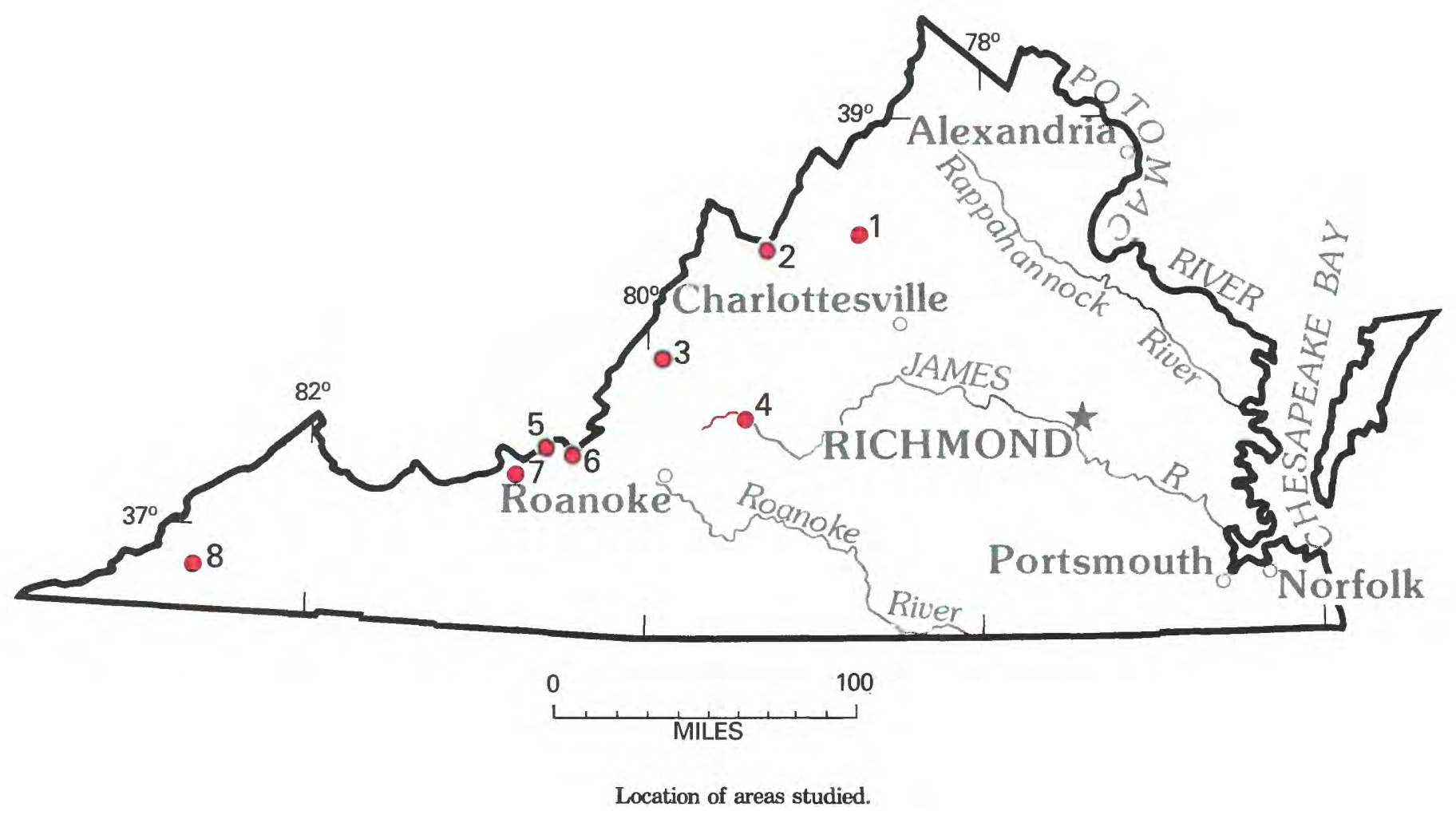




\section{VIRGINIA}

Map

Name of Area

8 Devils Fork Roadless Area

3 Dolly Ann Roadless Area

4 James River Face Wilderness

7 Mill Creek Wilderness Study Area

6 Mountain Lake Wilderness Study Area, Virginia and West Virginia

5 Peters Mountain Wilderness Study Area

2 Ramseys Draft Wilderness Study Area

1 Southern Massanutten Roadless Area 


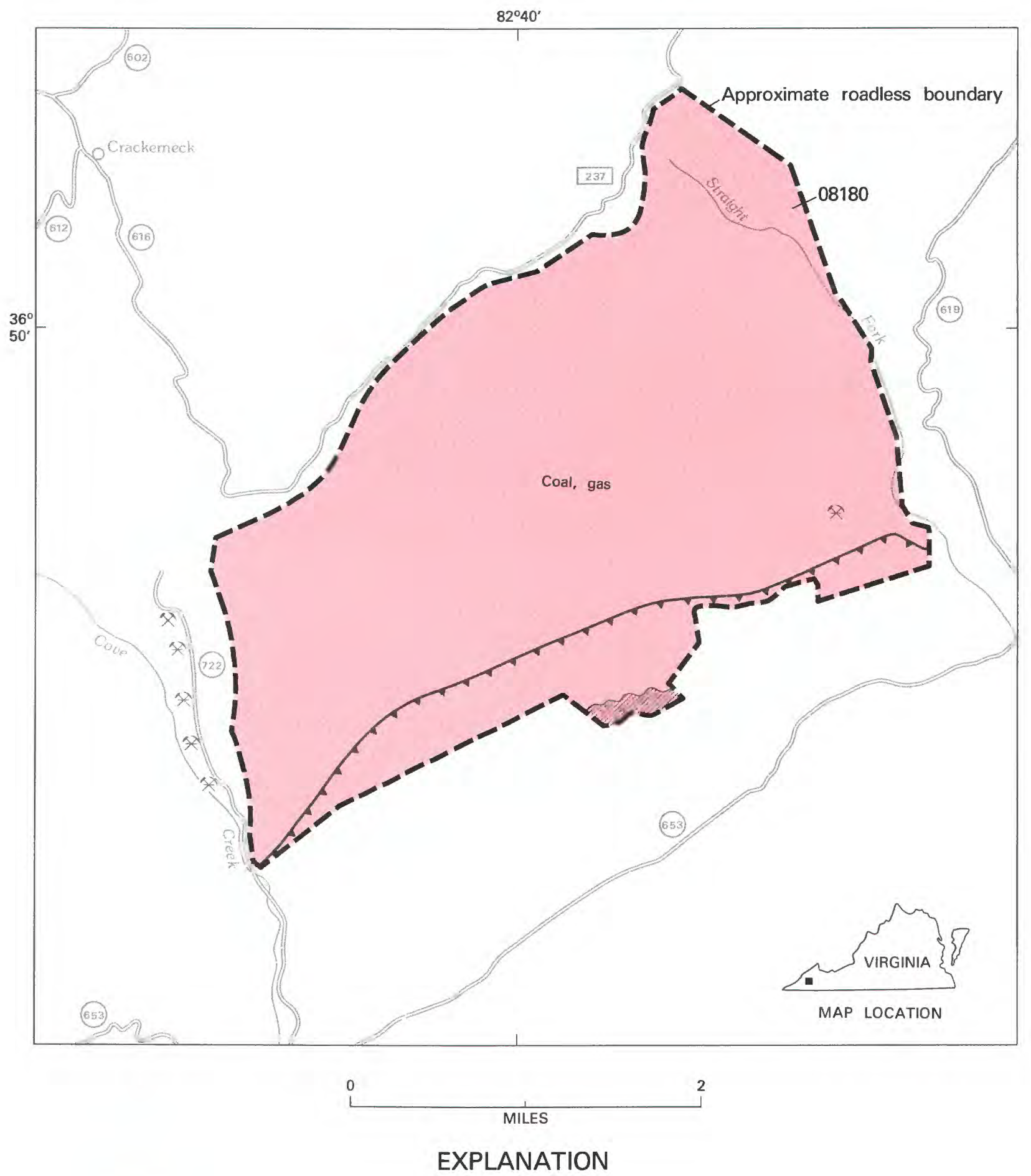

\begin{tabular}{ll|l}
\hline $\begin{array}{l}\text { Geologic terrane with probable } \\
\text { mineral-resource potential }\end{array}$ & Early Pennsylvanian rocks \\
a Mine & Late Mississippian rocks \\
A Abandoned mine & Contact \\
& - Thrust fault--Sawteeth on upper plate
\end{tabular}

Figure 288.-Devils Fork Roadless Area, Virginia. 


\title{
DEVILS FORK ROADLESS AREA, VIRGINIA
}

\author{
By Kenneth J. Englund, ${ }^{1}$ U.S. Geological SuRVey, and \\ Paul T. Behum, U.S. BUREAU of Mines
}

\begin{abstract}
SUMMARY
The Devils Fork Roadless Area occupies a tract of mountainous terrain in the Jefferson National Forest in southwestern Virginia. A mineral-resource survey in 1981 indicated that coal is the principal mineral resource of the area, but its distribution, thickness, quantity and quality are conjectural because of the lack of exploratory drilling in the roadless area. However, several coal beds observed in adjacent areas are thick enough and persistent enough to warrant projection into the roadless area. Therefore the area has a probable resource potential and preliminary estimates show 55 million tons of coal resources to be present. Rocks underlying the area have a probable resource potential for gas. There is little promise for the occurrence of metalhic mineral or oil resources.
\end{abstract}

\section{CHARACTER AND SETTING}

The Devils Fork Roadless Area comprises about 9 sq $\mathrm{mi}$ in the southwesternmost part of the Jefferson $\mathrm{Na}$ tional Forest, Scott County, Virginia. It is located $20 \mathrm{mi}$ northwest of Kingsport, Tenneseee and is accessible from there by U.S. Highways 23 and 58 and Virginia State Highways 653 and 722 . The Federal Government owns about 80 percent of the surface rights. The remaining surface rights, and all mineral rights are privately owned.

The area is in the Cumberland Mountain section of the Appalachian Plateaus physiographic province and is in the southwestern Virginia coal field of the Appalachian coal region. Altitudes range from slightly less than $1600 \mathrm{ft}$ on the lower part of Devils Fork to as much as $3500 \mathrm{ft}$ in the surrounding mountain tops. Most of the roadless area is drained by Devils Fork and its tributaries.

About $1700 \mathrm{ft}$ of sedimentary rocks of the Upper Mississippian Hinton and Bluestone Formations, the Lower Pennsylvanian Pocahontas Formation, and the Mississippian and Pennsylvanian Lee Formation crop out in the roadless area and as much as $13,000 \mathrm{ft}$ of older Paleozoic sedimentary rocks may be in the subsurface. Deposits of colluvium mantle most mountain slopes and alluvium underlies some stream beds and valley floors. Most of the roadless area is on the gently dipping south-

\footnotetext{
${ }^{\text {I}}$ With contributions from Wallace de Witt, Jr., and A. E. Grosz, USGS.
}

eastern flank of the Powell Valley anticline. The strata dip about $5^{\circ}$ to $20^{\circ}$ to the southeast. Faulted and overturned beds crop out along the southeastern boundary of the area. The dip of these beds is mostly from $35^{\circ}$ to $55^{\circ}$ to the southeast.

\section{MINERAL RESOURCES}

Coal is the most important mineral resource in the roadless area. It occurs in at least 8 beds, ranging from a few inches to about $4 \mathrm{ft}$ thick, in the Pocahontas and Lee Formations. The coal beds crop out principally along the southwestern and northeastern boundaries of the roadless area where several abandoned truck mines are located. In 1981, a truck mine was in operation on Cove Creek about $0.2 \mathrm{mi}$ southwest of the area; the mine face has been extended beneath the roadless area and the coal is about $4 \mathrm{ft}$ thick. The coal is tentatively ranked as high-volatile $\mathrm{A}$ bituminous and has low sulfur and ash contents. Observations of coal beds within the roadless area were limited to highly weathered coal and coal bloom cropping out along Straight Fork at the northeastern edge of the roadless area and to a prospect and an outcrop along Devils Fork. Several of the coal beds observed in adjacent areas are thick enough and persistant enough to warrant the projection of coal into the roadless area. Although no demonstrated coal resources were established because of the lack of adequate exploration, the preliminary estimates of coal in 
four coal beds projected beneath the roadless area are 55 million short tons of coal resources. The area has a probable coal resource potential.

The Devils Fork Roadless Area is underlain by strata having a potential for oil and gas. Middle and Upper Devonian shale and associated beds have a probable resource potential for gas, particularly where these rocks have been deformed and fractured. Older Paleozoic rocks, including the Middle Ordovician Trenton Limestone and underlying limestones have little promise for the occurrence of both oil and gas. A few deep tests of the Cambrian rocks in southwestern Virginia have not encountered petroleum.

Metallic mineral deposits were not observed and major chemical anomalies or anomalous concentrations of chemical elements related to mineralized bedrock were not found during the study. There is little likelihood for the occurrence of metallic mineral resources.

\section{SUGGESTIONS FOR FURTHER STUDIES}

Further study of the roadless area, including exploratory core drilling, could reveal coal beds with inineralresource potential.

\section{REFERENCE}

Englund, K. J., Sigleo, W. R., and Behum, P. T., in press, Mineral resource potential map of Devils Fork Roadless Area, Scott County, Virginia: U.S. Geological Survey Miscellaneous Field Studies Map MF-1611-C. 


\title{
DOLLY ANN ROADLESS AREA, VIRGINIA
}

\author{
By Frank G. Lesure, U.S. GeOlogical SurVey, and \\ Jay G. JONES, U.S. BUREAU OF Mines
}

\begin{abstract}
SUMMARY
Mineral-resource surveys made in 1979 and 1980 indicate that much of the Dolly Ann Roadless Area, in the George Washington National Forest, Alleghany County, Virginia, has substantiated iron resource potential. Inferred low-grade iron resources occur in folded sedimentary rocks of Paleozoic age. The area has an estimated 540 million long tons of contained iron in hematitic sandstone and 700,000 long tons contained iron in deposits of sandy limonite. Other mineral resources include various rocks suitable for crushed rock, quartzite suitable for high-silica uses, limestone suitable for agricultural uses, and clay and shale suitable for structural clay products, all of which can be readily obtained outside the wilderness. A potential for natural gas and geothermal energy may exist but cannot be quantified from present knowledge.
\end{abstract}

\section{CHARACTER AND SETTING}

The Dolly Ann Roadless Area includes about $12 \mathrm{sq} \mathrm{mi}$ of the George Washington National Forest, in the Valley and Ridge Province in west-central Virginia. The area is northeast of Covington, the county seat of Alleghany County. U.S. Highway 220 forms much of the western boundary and USFS Road 125, which parallels Pounding Mill Creek, forms the eastern boundary. The principal streams draining the area are Pounding Mill Creek on the east, Dry Run in the middle and south, and Roaring Run on the west; all are tributaries of the Jackson River. The highest point in the area is Big Knob at the north end, $4072 \mathrm{ft}$ above sea level; the lowest points, about $1400 \mathrm{ft}$, are along Dry Run and Pounding Mill Creek. Dolly Ann Hollow in the northeast part of the area is a picturesque steep-sided and boulder-strewn gorge. Access to the center of the area is by a trail up Dry Run, and access to the northern part of the area is by a trail from USFS Road 125 to Bald Knob, Big Knob, and on west to U.S. Highway 220.

The Federal Government owns all surface and mineral rights in the roadless area. Oil and gas leases have been issued on approximately $2.5 \mathrm{sq} \mathrm{mi}$, and applications for leases on the remainder of the area are pending.

About $3000 \mathrm{ft}$ of folded marine clastic sedimentary rocks of Paleozoic age are exposed in the Dolly Ann Roadless Area (Lesure, 1981). The oldest of these rocks, interbedded shale, siltstone, and limestone of Late Ordovician age, are present in Dolly Ann Hollow and along the northern edge of the roadless area. The overlying beds of sandstone, hematitic sandstone, and quartzite of Late Ordovician to Middle Silurian age are resistant to erosion and form much of the bedrock in the roadless area. Upper Silurian to Middle Devonian formations overlying the resistant rocks are poorly exposed; they include interlayered limestone, sandstone, and shale units. A Lower Devonian limestone locally contains surficial deposits of limonite along the eastern border of the roadless area. The rocks were folded in late Paleozoic time into upright to overturned folds forming the southwest-plunging end of the Hot Springs anticline. A zone of regional thrust faulting, part of the eastern overthrust belt, is buried at depths of several thousands of feet below the area.

Mineral surveys made in 1979 and 1980 (Lesure and Jones, 1983) included geologic mapping (Lesure, 1981), geochemical sampling (Lesure and others, 1981; Lesure, 1982), and mine and prospect examination (Jones and others, 1982; Jones, 1983).

\section{MINERAL RESOURCES}

The Dolly Ann Roadless Area, which is on the western edge of the Clifton Forge iron district, contains two types of low-grade iron deposits: (1) primary deposits of hematitic sandstone in the Rose Hill Formation, and (2) secondary deposits of limonite in limestone. In the primary deposits, the iron was precipitated from sea 

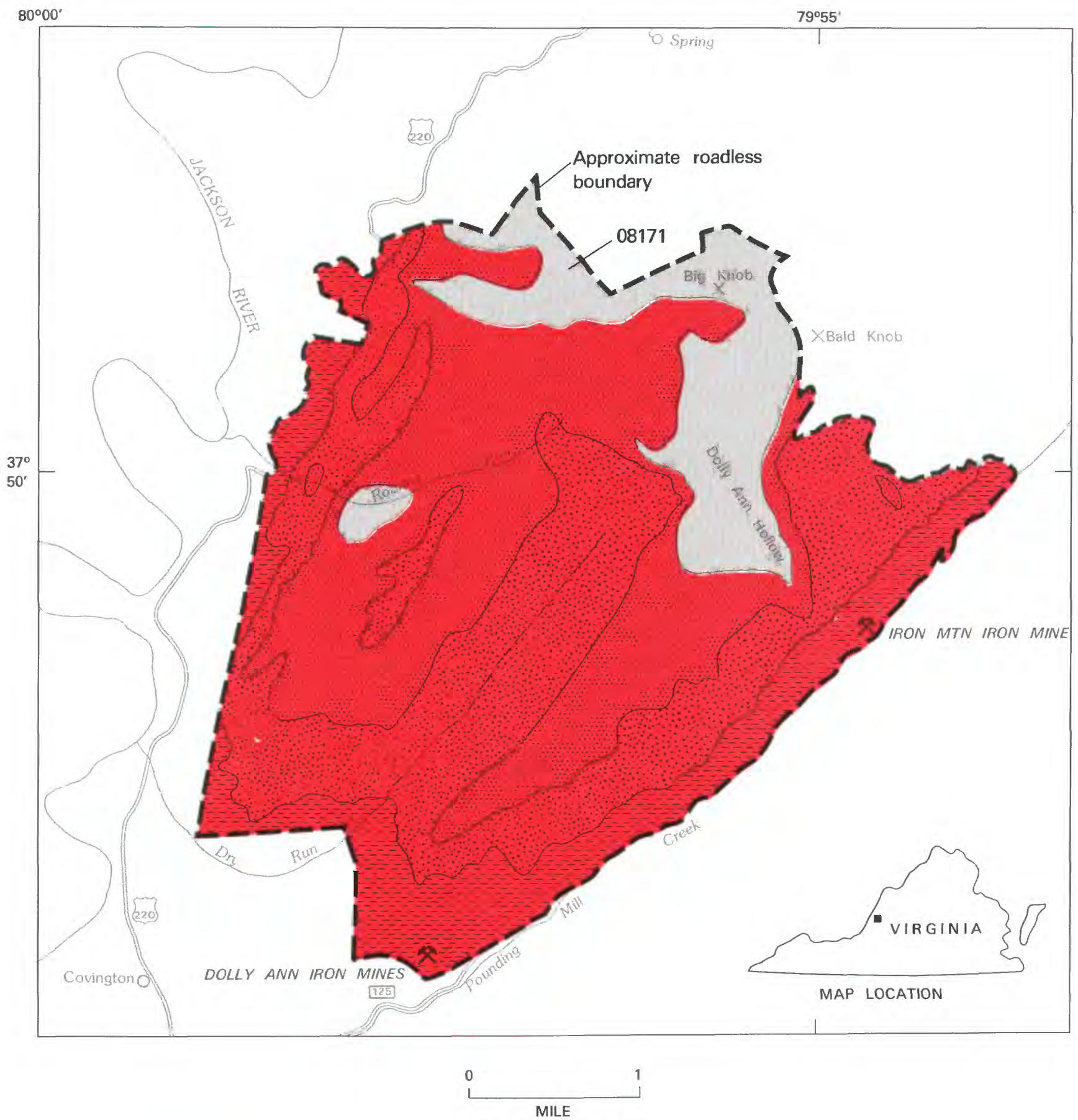

\section{EXPLANATION}

Geologic terrane with substantiated iron resource potential

R Mine or deposit

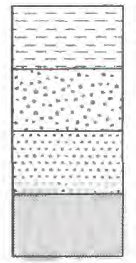

Sandstone, limestone, and shale

Keefer Sandstone

Rose Hill Formation

Quartzite, sandstone, and shale Contact

Figure 289.-Dolly Ann Roadless Area, Virginia. 
water and concentrated as the sediments were deposited. The iron content is fairly consistent throughout any one sandstone bed and will persist to depth. In the secondary deposits the iron minerals form discontinuous masses that cannot be projected for any extended distance. The deposits formed during weathering by acid, iron-rich ground water that dissolved the limestone host rock and precipitated mixtures of iron oxides and hydroxides called limonite. The deposits are nearsurface features and grade into unweathered limestone at depth. This type of deposit was mined earlier at the Dolly Ann and Iron Mountain iron mines along the eastern part of the roadless area.

Inferred low-grade iron resources in the hematitic sandstone of the Rose Hill Formation of Middle Silurian age may be as much as $150 \mathrm{ft}$ thick and contain an average of 18 percent iron over an area of nearly $11 \mathrm{sq}$ $\mathrm{mi}$ of the roadless area either as exposed rocks or covered by 5 to more than $200 \mathrm{ft}$ of younger rock. This area of substantiated low-grade iron resource potential could contain as much as 3 billion tons of hematitic sandstone or 540 million tons of contained iron. This iron-bearing formation is widely distributed in western Virginia and eastern West Virginia from Maryland southwest nearly to Tennessee. It is particularly well developed in Giles County, Virginia, where it was prospected for iron in the 1950's and 60's in what is now the Mill Creek Wilderness study area.

Two abandoned limonite iron mines in the Dolly Ann Roadless Area were worked in the 19th and early 20th centuries. Inferred iron resources at the Dolly Ann mine amount to 800,000 long tons of sandy and clayey limonite having an average grade of 44 percent iron or 350,000 long tons of contained iron. An 0.11-sq-mi area having substantiated iron resource potential exists around the Dolly Ann mine. Inferred resources at the Iron Mountain mine are estimated to be 800,000 long tons of sandy limonite averaging 43 percent iron. An area of about $0.08 \mathrm{sq}$ mi northeast of the mine is also underlain by the ore-bearing formation but contains little surface evidence of mineralized rock. There is little possibility of significant amounts of limonite in this additional area.

The roadless area also contains sandstone and quartzite suitable for specialty sands, crushed rock, and building stone; limestone suitable for crushed rock and agricultural lime; and shales suitable for use in structural clay products and lightweight aggregates (Jones and others, 1982, p. 31). All these commodities are abundant in the region, however, and they can be obtained more readily outside the roadless area.
Although the Dolly Ann Roadless Area contains both hydrocarbon source beds and reservoir rocks, these rocks have been heated to temperatures beyond the range for oil stability and are favorable only for the occurrence of dry natural gas. Inasmuch as the better reservoir rocks are exposed at the surface, any accumulation of gas would have escaped long ago. Extensive fracture porosity associated with the zone of buried thrust faults could have formed potential reservoirs for gas accumulation, but estimation for this potential would require drilling.

The Warm Springs valley northeast of Dolly Ann contains thermal springs, the nearest of which is less than a mile north of the roadless area. Studies to the north indicate that this region may constitute a geothermal resource for low-temperature applications (Costain, 1976), but additional data would be required to determine the geothermal energy potential for the roadless area.

The reconnaissance geochemical sampling in the roadless area did not indicate the presence of any other metallic mineral resources (Lesure, 1982). Minor amounts of zinc are present in the limonite deposits but are too low grade to be a resource.

\section{REFERENCES}

Costain, J. K., 1976, Geology and geophysical study of the origin of the Warm Springs in Bath County, Virginia: Virginia Polytechnic Institute and State University, Department of Geological Sciences, $44 \mathrm{p}$.

Jones, J. G., 1983, Maps showing mines, prospects, and mineral localities in and near the Dolly Ann Roadless Area, Alleghany County, Virginia: U.S. Geological Survey Miscellaneous Field Studies Map MF-1358-C.

Jones, J. G., Piros, M. E., and Hammack, R. W., 1982, Mineral resources of Dolly Ann RARE II Further Planning Area, Alleghany County, Virginia: U.S. Bureau of Mines Open-File Report MLA 61-82, 37 p.

Lesure, F. G., 1981, Geologic map of the Dolly Ann Roadless Area, Alleghany County, Virginia: U.S. Geological Survey Miscellaneous Field Studies Map MF-1358-A, scale 1:24,000.

Lesure, F. G., 1982, Geochemical survey of the Dolly Ann Roadless Area, Alleghany County, Virginia: U.S. Geological Survey Miscellaneous Field Studies Map MF-1358-B, scale 1:48,000.

Lesure, F. G., Arbogast, B. F., Meier, A. L., Motooka, J. M., and Siems, D. F., 1981, Analyses and descriptions of geochemical samples, Dolly Ann Roadless Area, Alleghany County, Virginia: U.S. Geological Survey Open-File Report 81-1126, 18 p.

Lesure, F. G., and Jones, J. G., 1983, Mineral resource potential map of the Dolly Ann Roadless Area, Alleghany County, Virginia: U.S. Geological Survey Miscellaneous Field Studies Map MF-1358-D, scale 1:24,000. 


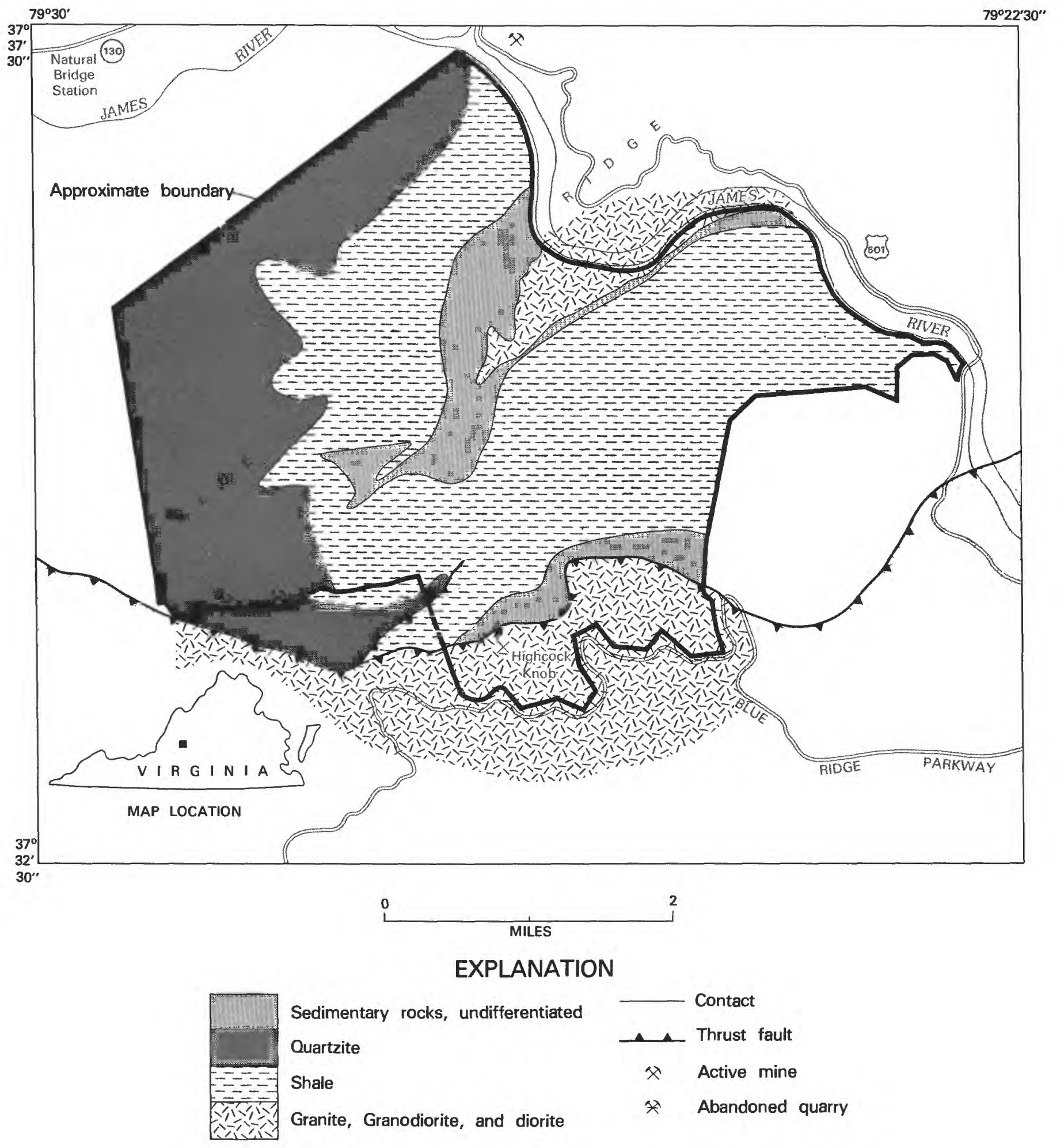

Figure 290.-James River Face Wilderness, Virginia. 


\title{
JAMES RIVER FACE WILDERNESS, VIRGINIA
}

\author{
By C. ERvin Brown, U.S. GeOlogical SurveY and \\ Gertrude C. GazdiK, U.S. BUREAU OF MiNeS
}

\begin{abstract}
SUMMARY
A mineral survey done in 1978 and 1979 concluded that the James River Face Wilderness, Virginia, had little promise for the occurrence of metallic mineral resources. Two major rock units in the area do contain large nonmetallic mineral resources of quartzite and shale that have been mined for silica products and for brick and expanded aggregate, respectively. Because large deposits of the same material are more easily available in nearby areas, demand for the deposits within the wilderness is highly unlikely. No energy resources were identified in the course of this study.
\end{abstract}

\section{CHARACTER AND SETTING}

The James River Face Wilderness is an area of about $14 \mathrm{sq} \mathrm{mi}$ of heavily forested land in the Blue Ridge of Virginia. The wilderness is $18 \mathrm{mi}$ west of Lynchburg and $16 \mathrm{mi}$ south of Lexington and is bounded by the right bank of the James River where it cuts through the Blue Ridge. Part of the southern wilderness boundary is coincident with the Blue Ridge Parkway right-of-way. The highest point in the wilderness is Highcock Knob with an altitude of $3073 \mathrm{ft}$. The low point, $640 \mathrm{ft}$, is the James River at the easternmost extremity of the area.

A mineral survey of the James River Face Wilderness was made in 1978 and 1979 and the results were published in 1981 and 1982 (Brown and Spencer, 1981; Brown and Siems, 1982; Brown and Gazdik, 1982; and Gazdik and Ross, 1982.

The rocks in the James River Face Wilderness include a thick sequence of sedimentary rocks, shales, and quartzites of Paleozoic age, that overlie igneous rocks, granite, diorite, and granodiorite of Precambrian age. The sedimentary rocks are folded into a broad arch that plunges to the southwest. An extensive thrust fault that extends across the south side of the wilderness raised the ancient rocks northwestward over the arch of sedimentary rocks. The highest part of the Blue Ridge in the wilderness consists of the igneous rocks carried upward by the faulting. These rocks also occur in the core of the arch beneath the mantle of sedimentary rocks in the north-central part of the area.

\section{MINERAL RESOURCES}

Except for iron, no metallic resources have been mined from the vicinity of the wilderness. The iron is contained in iron-cemented sandstone and was mined several miles to the southwest. The iron-cemented sandstone occurs in the wilderness but is less than $10 \mathrm{ft}$ thick, quite low grade, and is not shown on the map. Geochemical sampling for numerous other metals revealed no significantly mineralized areas.

Nonmetallic resources have been mined from the wilderness and several mines for shale products are located nearby. Metallurgical-grade quartzite was produced from 1945 to 1963 from three quarries in the wilderness. The quartzite was crushed at a plant at Natural Bridge Station and shipped to a plant in West Virginia for use in production of ferrosilicon. Byproducts from the crushing plant included crushed stone and sand which were used for concrete aggregate, road metal, railroad ballast, and mortar sand.

Shale is mined at quarries $3 \mathrm{mi}$ northeast of the wilderness for the production of lightweight aggregate, a valuable raw construction material. A mine in weathered shale $1500 \mathrm{ft}$ north of the wilderness on the north side of the James River supplies raw material for brick manufacture at kilns near Natural Bridge Station, and in 1880 to 1904 roofing slate was quarried about $3.5 \mathrm{mi}$ northeast of the wilderness. Large resources of both quartzite and shale useable for the aforementioned products are in the James River Face Wilderness, but 
more easily accessible resources of similar rocks are found to the northeast in the Blue Ridge; it is, therefore, unlikely that the resources in the wilderness will be needed in the foreseeable future.

\section{REFERENCES}

Brown, C. E. and Siems, D. F., 1982, Geochemical survey of the James River Face Wilderness, Bedford and Rockbridge Counties, Virginia: U.S. Geological Survey Miscellaneous Field Studies Map MF-1337-B, scale 1:32,000.
Brown, C. E. and Spencer, E. W., 1981, Geologic map of the James River Face Wilderness, Bedford and Rockbridge Counties, Virginia: U.S. Geological Survey Miscellaneous Field Studies Map MF-1337-A, scale 1:24,000.

Brown, C. E. and Gazdik, G. C., 1982, Mineral resource potential map of the James River Face Wilderness, Bedford and Rockbridge Counties, Virginia: U.S. Geological Survey Miscellaneous Field Studies Map MF-1337-D, scale 1:24,000.

Gazdik, G. C. and Ross, R. B.,Jr., 1982, Mines, prospects and sample data for the James River Face Wilderness, Bedford and Rockbridge Counties, Virginia: U.S. Geological Survey Miscellaneous Field Studies Map, MF-1337-C. 


\title{
MILL CREEK WILDERNESS STUDY AREA, VIRGINIA
}

\author{
By Frank G. Lesure, U.S. Geological Survey, and \\ BRADFORD B. Williams, U.S. BUREAU OF MinES
}

\begin{abstract}
SUMMARY
A mineral survey of the Mill Creek Wilderness Study Area, done in 1975, concluded that the area contains gently folded clastic sedimentary rocks of Paleozoic age that have a substantiated iron resource potential and abundant rock suitable for construction materials. The area has an estimated 360 million long tons of inferred low-grade iron resources in hematitic sandstone that may average as much as 20 percent iron, or 72 million long tons of contained iron. Additional inferred iron resources of limonitic sandstone occurring at the Chestnut Flat iron mines in the southwest end of the area probably amount to less than 100,000 long tons of rock containing 20 percent iron, or less than 20,000 long tons of contained iron. The sedimentary rocks have little promise for the occurrence of oil and structural conditions appear unfavorable for gas accumulation. No deep exploratory drilling for oil and gas has been done in or near the area.
\end{abstract}

\section{CHARACTER AND SETTING}

The Mill Creek Wilderness Study Area in Jefferson National Forest consists of about $6 \mathrm{sq} \mathrm{mi}$ of terrain folded into a shallow synclinal upland forming the upper drainage basin of Mill Creek and its tributary, Mercy Branch. The area is bordered by Wolf Creek Mountain on the northwest and Pearis Mountain on the southeast. The east end, called Angels Rest, is 0.5 mi southwest of the city limits of Pearisburg, the county seat of Giles County. The town of Narrows is $1 \mathrm{mi}$ northwest of the area. Altitudes range from a low of $2100 \mathrm{ft}$ above sea level near the Narrows Reservoir to $3947 \mathrm{ft}$ on Pearis Mountain. The Appalachian Trail follows the east side of the area along Pearis Mountain from the USFS road at the south end to Angels Rest at the northeast end. Two power lines with cutover right-of-ways cross the area. The Chestnut Flat iron mine was operated intermittently in the 19th century in several open cuts at the southwest end of the area near the USFS road.

The Federal Government owns both surface and mineral rights on 95 percent of the study area. A mineral survey was made in 1975 and the results were published in 1982 (Lesure and others, 1982). The survey consisted of geologic mapping, geochemical studies, and mine and prospect examination. The analytical data on streamsediment and rock samples were released in 1978 (Mei and Lesure, 1978).
Bedrock in the Mill Creek Wilderness Study Area consists of interlayered red and light-gray sandstone and minor amounts of shale and limestone that have a total thickness of more than $850 \mathrm{ft}$ and range in age from Late Ordovician to Early Devonian. These rocks have been folded into a broad syncline and are cut by minor faulting.

\section{MINERAL RESOURCES}

The Mill Creek Wilderness Study Area contains an estimated 360 million long tons of inferred low-grade iron resources in hematitic sandstone with an iron content of 20 percent iron, or 72 million long tons of iron. These iron-rich sandstone beds are primary deposits of iron in the Rose Hill Formation of Silurian age. The beds were deposited as iron-rich sediments, and the mineral hematite formed during or shortly after deposition. The iron content ranges from 10 to 28 percent and averages about 20 percent. Individual sandstone beds range in thickness from 1 to $25 \mathrm{ft}$ and may be as much as $1 \mathrm{mi}$ or more long. The iron-rich beds form a quarter to a third of the formation, which ranges in thickness from 150 to $250 \mathrm{ft}$. The area underlain by the Rose Hill Formation has substantiated potential for low-grade iron resources. The formation crops out over a $4 \mathrm{sq} \mathrm{mi}$ area in the Mill Creek Wilderness Study Area, and is 

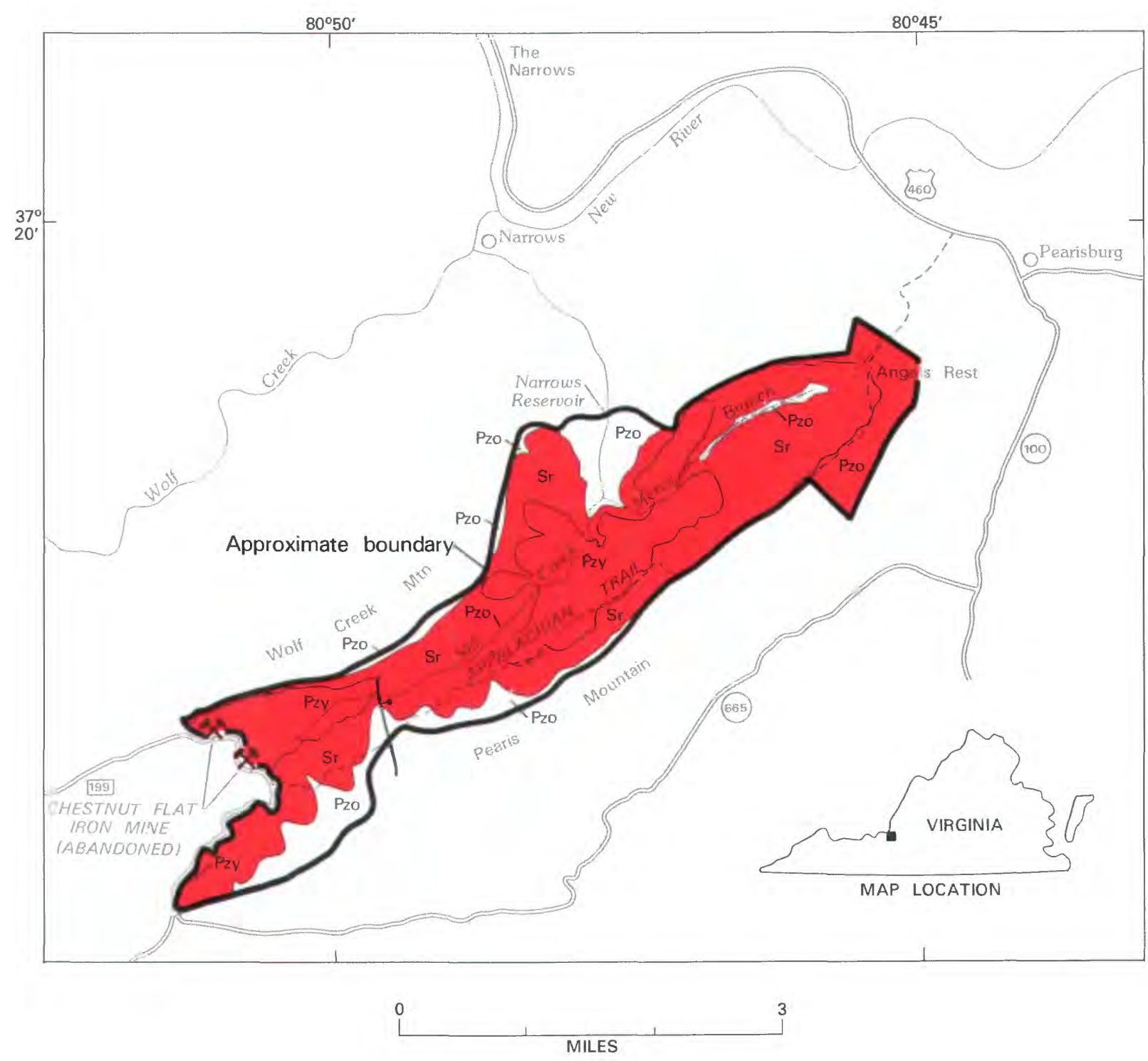

\section{EXPLANATION}

Geologic terrane with substantiated iron resource potential

x Mine or deposit

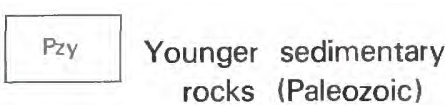

rocks (Paleozoic)

$\mathrm{Sr}$

Rose Hill Formation (Silurian)

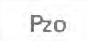

Older sedimentary rocks (Paleozoic)

\section{Contact}

Fault--Bar and ball on downthrown side

Figure 291.-Mill Creek Wilderness Study Area, Virginia. 
present but covered by 1 to $200 \mathrm{ft}$ of younger rocks in 2 sq mi.

The Minerals Development Corporation, Roanoke, Virginia, prospected the area in the 1960's and drilled 10 core holes within the wilderness study area boundary. The iron content of hematitic sandstone in the drill core averaged about 17 percent. Beneficiation tests conducted by the company suggested that 1 ton of iron concentrate can be produced from 3 tons of hematitic sandstone. Exploration was stopped because the formation contained a much greater proportion of shale waste material than had been expected.

The Rose Hill Formation is widely distributed in western Virginia and eastern West Virginia, and extends from Maryland southwest nearly to Tennessee, but the Mill Creek Wilderness Study Area contains one of the more promising deposits. The nearby Mountain Lake and Peters Mountain Wilderness Study Areas and Dolly Ann Roadless Area also contain similar low-grade iron resources in the Rose Hill Formation.

The Mill Creek Wilderness Study Area also contains, at the southwest end, an area of iron resources in the form of limonite-cemented sandstone in a younger formation, the Rocky Gap Sandstone of Devonian age, that is about $100 \mathrm{ft}$ or more stratigraphically above the Rose Hill Formation. These limonite deposits are variable in size and are, in general, near-surface features formed during the weathering of the rocks. Inferred iron resources at the Chestnut Flat iron mines probably amount to less than 100,000 long tons of rock containing 15,000 to 20,000 long tons of iron.

The area also has abundant sandstone suitable for construction materials, including rough building stone and crushed rock. Some of the sandstone beds are a high-silica resource suitable for silica refractory brick and abrasives, but contain too many impurities for use as glass sand without beneficiation. Similar rock is widely distributed throughout the region outside the wilderness study area.

No oil or gas has been discovered in or near Giles County, but the rocks are a potential resource of natural gas. Although a gas prospective area is postulated immediately southeast of Mill Creek, the possibility that gas accumulated below the study area appears to be poor.

\section{SUGGESTIONS FOR FURTHER STUDIES}

Additional drilling and detailed sampling would be needed to accurately determine the iron resources in the area. Continued studies of beneficiation methods to be used on this type of low-grade iron deposit could be done as technology advances.

\section{REFERENCES CITED}

Lesure, F. G., Williams, B. B., and Dunn, M. L., Jr., 1982, Mineral resources of the Mill Creek, Mountain Lake, and Peters Mountain Wilderness Study Areas, Craig and Giles Counties, Virginia, and Monroe County, West Virginia: U.S. Geological Survey Bulletin $1510,76 \mathrm{p}$.

Mei, Leung, and Lesure, F. G., 1978, Analyses and description of geochemical samples, Mill Creek Wilderness Study Area, Giles County, Virginia: U.S. Geological Survey Open-File Report 78-1077-D, 17 p. 

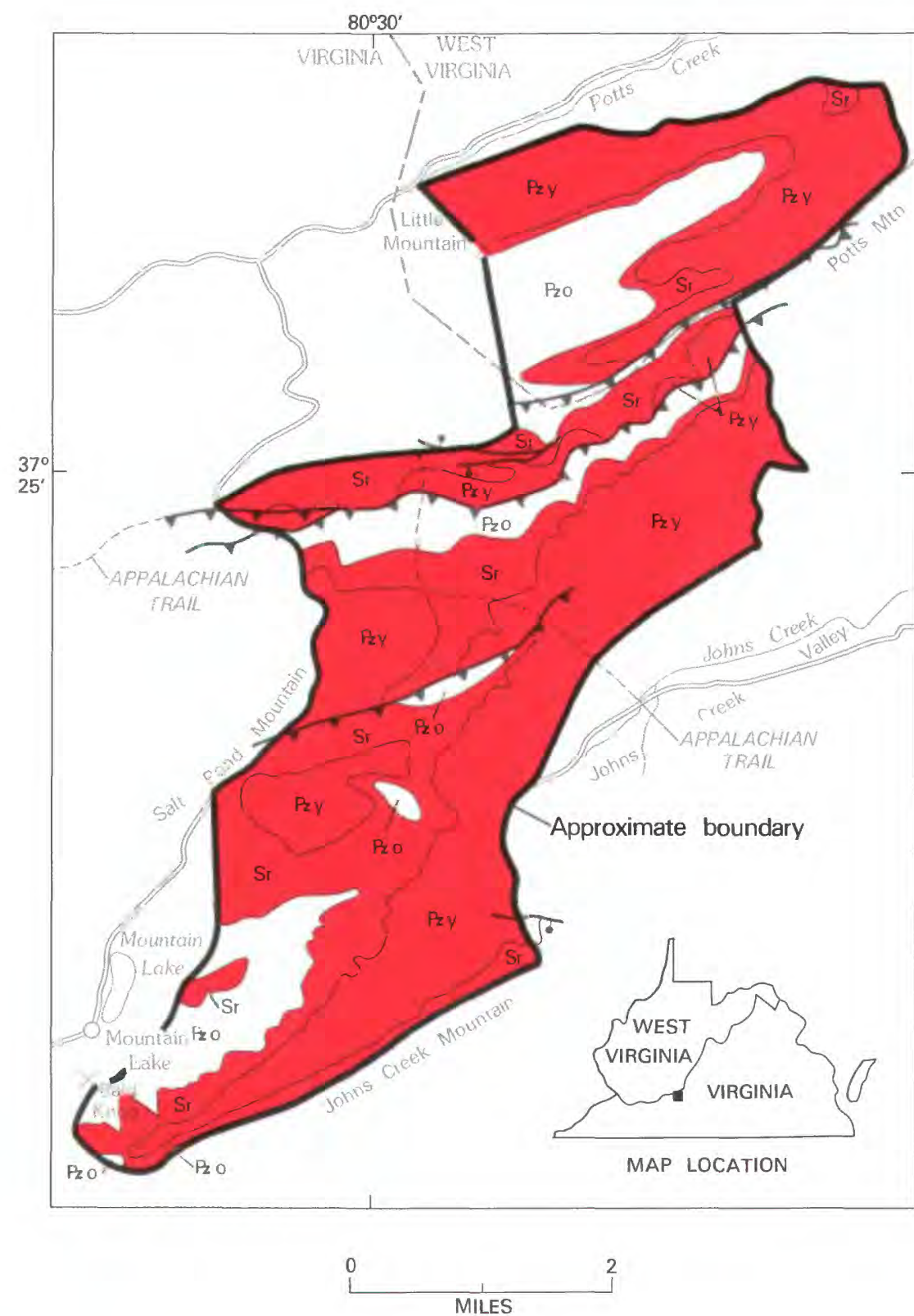

EXPLANATION

Geologic terrane with substantiated iron resource potential

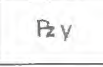

$\mathrm{Sr}$

Pzo Older sedimentary rocks (Paleozoic)

Contact

Fault--Bar and ball on downthrown side

A A Thrust fault

Figure 292.-Mountain Lake Wilderness Study Area, Virginia and West Virginia. 


\title{
MOUNTAIN LAKE WILDERNESS STUDY AREA, VIRGINIA AND WEST VIRGINIA
}

\author{
By FranK G. LeSURE, U.S. GeOlOGical SurVey, and \\ BRADFORD B. WILLIAMS, U.S. BUREAU OF MINES
}

\begin{abstract}
SUMMARY
A mineral survey of the Mountain Lake Wilderness Study Area made in 1974-75 concluded that the area contains folded and faulted clastic sedimentary rocks of Paleozoic age that have a substantiated iron resource potential and abundant rock suitable for construction materials. The area has an estimated 1000 million long tons of inferred low-grade iron resources in hematitic sandstone that may average as much as 20 percent iron, or 200 million long tons of contained iron. Minor deposits of limonitic sandstone and manganese oxides occur along the eastern part of the area but are not classified as having resource potential. The sedimentary rocks have some promise for the accumulation of natural gas but little promise for the occurrence of oil. No deep exploratory drilling for oil and gas has been done in or near the area.
\end{abstract}

\section{CHARACTER AND SETTING}

The Mountain Lake Wilderness Study Area consists of $18.5 \mathrm{sq}$ mi of Jefferson National Forest land extending from Johns Creek Mountain at the south to the old railroad grade along the South Fork of Potts Creek at the north. The area includes parts of Salt Pond, Potts, and Little Mountains and the upper end of Johns Creek valley. It lies along the divide between New River and James River drainage. Most of the area is in Giles County, Virginia, about $10 \mathrm{mi}$ northeast of Pearisburg, the county seat; about a quarter of the area is in Monroe County, West Virginia, and a small part is in Craig County, Virginia. Altitudes range from a low of $2000 \mathrm{ft}$ above sea level in Johns Creek valley to more than 4340 $\mathrm{ft}$ on Bald Knob. Mountain Lake, the highest natural lake in the eastern part of the country, is just west of the south end of the area. Access to the area is from Virginia State Road 613 which forms much of the western boundary of the area north of Mountain Lake, Virginia, from State Road 632 up Johns Creek valley, and from the road along Potts Creek valley. The Appalachian Trail crosses the northern part of the area. A power line crosses the southern end of the area along a cutover right-of-way.

The Federal Government owns the surface and mineral rights of about 80 percent of the study area; the rest is privately owned. A mineral-resource survey of the area was made in 1975 and 1976 and the results were published in 1982 (Lesure and others, 1982). The survey consisted of geologic mapping, geochemical sampling, and mine and prospect examination. Analytical data on rock, stream-sediment, and soil samples were released in 1978 (Mei and others, 1978; Matooka and others, 1978).

Bedrock in the Mountain Lake Wilderness Study Area consists of more than $850 \mathrm{ft}$ of interlayered red and light-gray sandstone and minor amounts of shale and limestone ranging in age from Ordovician to Devonian. These rocks have been folded and faulted. At least three thrust faults cross the area bringing older rocks on the southeast side of each fault up and over younger rocks on the northwest side of the fault.

\section{MINERAL RESOURCES}

The Mountain Lake Wilderness Study Area contains inferred low-grade iron resources in the Rose Hill Formation of an estimated 1000 million long tons of hematitic sandstone containing as much as 200 million long tons of iron. These iron-rich sandstone beds are primary deposits of iron in the Rose Hill Formation of Silurian age. The Rose Hill Formation, which has a substantiated potential for low-grade iron resources, is widely distributed in the wilderness study area; it crops out in $5 \mathrm{sq} \mathrm{mi}$, and is covered by younger rocks in $10 \mathrm{sq} \mathrm{mi}$. 
The beds were deposited as iron-rich sediments, and the mineral hematite formed during or shortly after deposition. The iron content ranges from 10 to 30 percent and averages about 20 percent. Individual sandstone beds range in thickness from 1 to $25 \mathrm{ft}$, and may be as much as $1 \mathrm{mi}$ or more long. The iron-rich beds form a quarter to a third of the Rose Hill Formation, which ranges in thickness from 150 to $250 \mathrm{ft}$. Faulting has repeated the outcrop pattern in the northern part of the area where the formation dips steeply to the southwest. On Salt Pond Mountain the hematitic sandstone is exposed over larger areas.

The iron resource has not been prospected within the boundaries of the area, but the USBM drilled nine core holes to test the Rose Hill Formation 2 to $5 \mathrm{mi}$ west of the area (Fish, 1967). Beneficiation tests made by the USBM suggest that 1 ton of iron concentrate can be produced from 3 tons of the hematitic sandstone.

The Rose Hill Formation is widely distributed in western Virginia and eastern West Virginia, and extends from Maryland southwest nearly to Tennessee. The Mill Creek and Peters Mountain Wilderness Study Areas and Dolly Ann Roadless Area also contain large outcrop areas of the iron-bearing Rose Hill Formation.

Limonitic sandstone in the Rocky Gap Sandstone of Devonian age is sporadically exposed along the lower southeast slopes of Salt Pond and Potts Mountains. Several prospect pits scattered along these slopes contain minor amounts of limonite and indicate a minor iron resource potential that is not shown on the map. Deposits of this type are near-surface features formed during weathering of the rocks; in this area they appear to be small.

A small deposit of manganese oxides in sandstone of Silurian age on Johns Creek Mountain was exposed in several prospect pits. The amounts of manganese oxides in the area are small and low grade, and indicate little promise for the occurrence of manganese resources.

The Mountain Lake Wilderness Study Area contains abundant sandstone suitable for rough building stone and crushed rock. Some of the sandstone beds are a good source for high-silica rock suitable for silica refractory brick and abrasives, but contain too many impurities to be used for glass sand without beneficiation. Shale suitable for the manufacture of structural clay products are present especially in Jolıns Creek valley. Both sandstone and shale are widespread in the general region and deposits of similar or better quality occur outside the Mountain Lake Wilderness Study Area nearer markets and transportation.

The sedimentary rocks of the Mountain Lake Wilderness Study Area have been subjected to too much heat and pressure for the preservation of oil but they are a potential source of natural gas. No gas has been discovered in commercial quantities in the surrounding area where the nearest exploratory drilling is more than 10 mi away. An anticline at the north end of the study area may provide structural conditions for the accumulation of natural gas in older rocks at depth, and additional trapping possibilities may be present below the deep thrust faults under the area. The lack of drilling precludes any detailed assessment of the gas potential.

\section{SUGGESTIONS FOR FURTHER STUDY}

Drilling and detailed sampling would be needed to determine accurately the iron resources in the area. Continued studies of beneficiation methods to be used on this type of low-grade iron deposit should be done as technology advances. The gas resources in the area can only be assessed by a drilling program.

\section{REFERENCES CITED}

Fish, G. E., 1967, Clinton hematitic sandstone deposits, Butt Mountain area, Giles County, Virginia: U.S. Bureau of Mines Report of Investigations RI-6966, $39 \mathrm{p}$.

Lesure, F. G., Williams, B.B., and Dunn, M. L., Jr., 1982, Mineral resources of the Mill Creek, Mountain Lake, and Peters Mountain Wilderness Study Areas, Craig and Giles Counties, Virginia, and Monroe County, West Virginia: U.S. Geological Survey Bulletin 1510, 76 p.

Mei, Leung, Fletcher, J. D., Rait, Norma, and Lesure, F. G., 1978, Analyses and description of geochemical samples, Mountain Lake Wilderness Study Area, Virginia-West Virginia: U.S. Geological Survey Open-File Report 78-1077-B, 24 p.

Motooka, J. M., Curtis, C. A., and Lesure, F. G., 1978, Analyses of soil samples from Mountain Lake and Peters Mountain Wilderness Study Areas, Virginia-West Virginia: U.S. Geological Survey Open-File Report 78-1077-A, 8 p. 


\title{
PETERS MOUNTAIN WILDERNESS STUDY AREA, VIRGINIA
}

\author{
By Frank G. LeSURE, U.S. GeOlOGiCAl SuRVEY, and \\ BRADFORD B. WILLIAMS, U.S. BUREAU OF MiNES
}

\section{SUMMARY}

\begin{abstract}
A mineral-resource survey of the Peters Mountain Wilderness Study Area done in 1975-76, concluded that the area contains steeply dipping and faulted clastic sedimentary rocks of Paleozoic age that have a substantiated iron resource potential and abundant rock suitable for construction materials. The area has an estimated 340 million long tons of inferred low-grade iron resources in hematitic sandstone that may average as much as 20 percent iron, or 68 million long tons of contained iron. Structural conditions favorable for hydrocarbon accumulation appear to be absent beneath the area.
\end{abstract}

\section{CHARACTER AND SETTING}

The Peters Mountain Wilderness Study Area consists of $6.5 \mathrm{sq} \mathrm{mi}$ of Jefferson National Forest lands on the southeast slope of Peters Mountain along the northern border of Giles County. The area is $6 \mathrm{mi}$ northeast of Pearisburg, the county seat. State Road 635 along Stony Creek is the southeast boundary, and the crest of Peters Mountain, which is the Virginia-West Virginia State line, is the northwestern boundary. The area also extends from Foster Knob at the southwest near Olean to Huckleberry Ridge north of Interior at the northeast end. Altitudes range from a high of $3956 \mathrm{ft}$ above sea level on Peters Mountain to a low of $1900 \mathrm{ft}$ on Stony Creek at the south end. Several trails lead from the road to the ridge top.

The Federal Government owns about 98 percent of the surface rights and 95 percent of the mineral rights in the Peters Mountain Wilderness Study Area. A mineralresource survey of the area, made in 1975 and 1976, consisted of geologic mapping, geochemical sampling, and mine and prospect examination, and the results were published in 1982 (Lesure and others, 1982). Analytical data on stream-sediment and rock samples were released in 1978 (Rait and Lesure, 1978; Motooka and others, 1978).

Bedrock in the Peters Mountain Wilderness Study Area consists of interbedded red and light-gray sandstone and minor amounts of shale and limestone of Late Ordovician to Early Devonian age. These rocks have been folded and faulted. At least three thrust faults cross the area bringing older rocks on the southeast side of each fault up and over younger rocks on the northwest side of the fault.

\section{MINERAL RESOURCES}

The Peters Mountain Wilderness Study Area contains an estimated 340 million long tons of hematitic sandstone containing an average of about 20 percent iron, or about 68 million long tons of iron in an area of substantiated iron resource potential. This resource, which is in the Rose Hill Formation of Silurian age, has not been prospected within the boundaries of the study area, but has been prospected in the Mill Creek Wilderness Study Area $8 \mathrm{mi}$ to the southwest. The iron-rich sandstone beds are primary iron deposits. The beds were deposited as iron-rich sediments, and the mineral hematite formed during or shortly after deposition. The iron content of samples from the area ranges from 10 to 23 percent and averages 18 percent. The Rose Hill Formation crops out in $3 \mathrm{sq} \mathrm{mi}$ and is present but covered by younger rocks in $2.5 \mathrm{sq} \mathrm{mi}$. Individual sandstone beds range in thickness from 1 to $25 \mathrm{ft}$ and may be as much as $1 \mathrm{mi}$ or more long. The iron-rich beds form a quarter to a third of the formation, which ranges in thickness from 150 to $250 \mathrm{ft}$. Thrust faults have repeated the outcrop areas of the hematitic beds, which generally dip steeply to the southeast.

The Rose Hill Formation is widely distributed in western Virginia and eastern West Virginia, and extends from Maryland southwest nearly to Tennessee. The Mill Creek and Mountain Lake Wilderness Study 


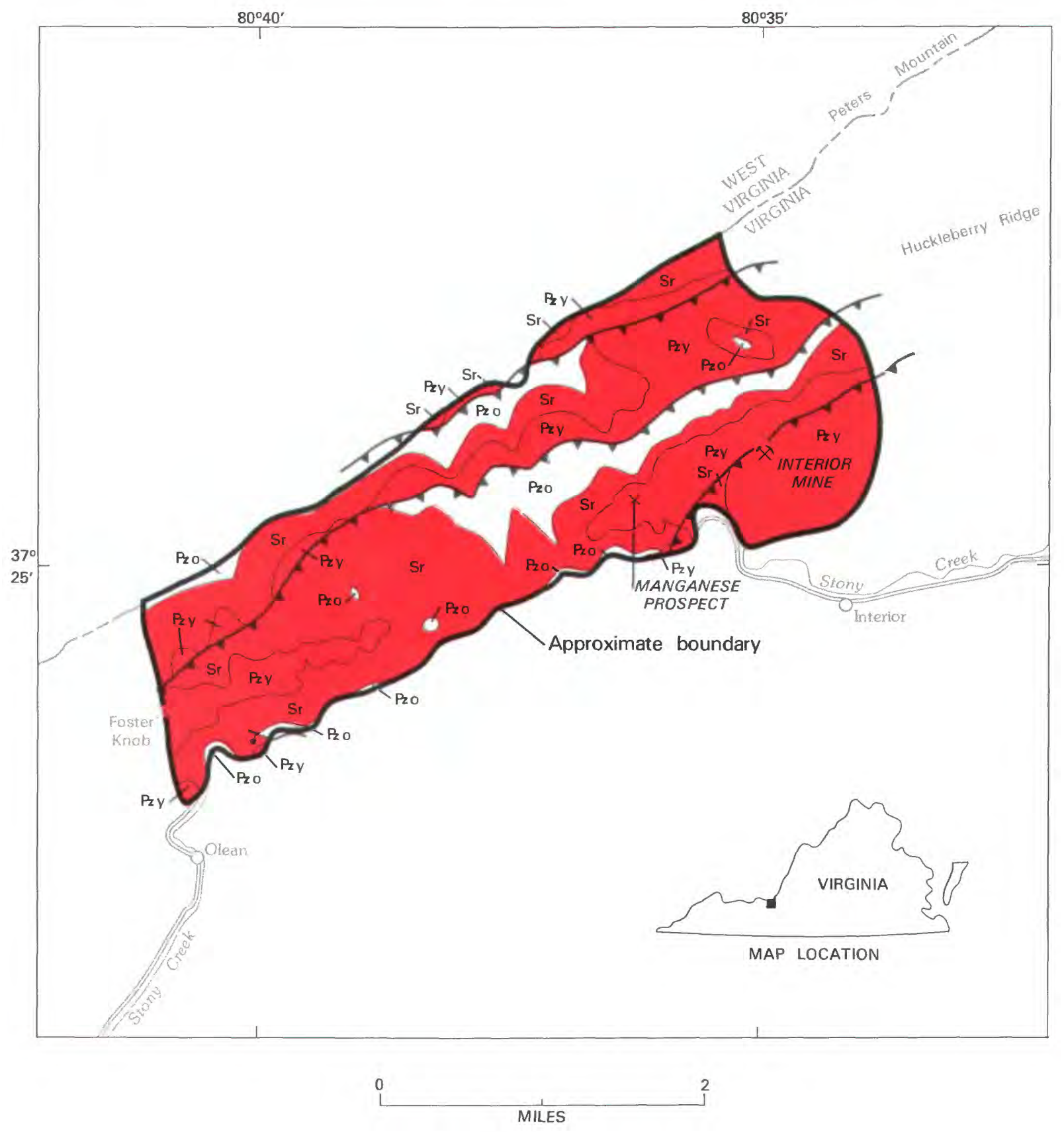

EXPLANATION

\begin{tabular}{|c|c|c|c|}
\hline & $\begin{array}{l}\text { Geologic terrane with substantiated } \\
\text { iron resource potential }\end{array}$ & $\mathrm{B} Y \mathrm{Y}$ & Younger sedimentary rocks (Paleozoic) \\
\hline $\begin{array}{l}x \\
x\end{array}$ & $\begin{array}{l}\text { Mineral occurrence } \\
\text { Mine }\end{array}$ & $\mathrm{P}_{2} \mathrm{O}$ & Older sedimentary rocks (Paleozoic) \\
\hline & & 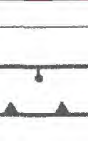 & $\begin{array}{l}\text { Contact } \\
\text { Fault--Bar and ball on downthrown side } \\
\text { Thrust fault--Sawteeth on upper plate }\end{array}$ \\
\hline
\end{tabular}

Figure 293.-Peters Mountain Wilderness Study Area, Virginia. 
Areas and the Dolly Ann Roadless Area also contain large outcrop areas of the formation.

Limonitic sandstone in the Rocky Gap Sandstone of Devonian age is exposed in the Interior mine at the eastern end of the Peters Mountain Wilderness Study Area and in several small isolated knobs at the west end, including Foster Knob. Deposits of this type are near-surface features formed during weathering of the rocks. In this area the deposits are small and low grade. Remaining resources are limited in extent and are not classified as having resource potential.

The Peters Mountain Wilderness Study Area contains one small manganese prospect in an area of Silurian-age sandstone cemented with manganese oxides. Material on the dump and in the pits is too low grade and the amounts in the prospect are too small to establish a mineral-resource potential. No other areas of manganese mineralization were seen in the study area.

The Peters Mountain Wilderness Study Area contains abundant sandstone suitable for rough building stone and crushed rock. Some of the sandstone beds are a good source of high-silica rock suitable for silica refractory brick or abrasives but contain too many impurities to be used for glass sand without beneficiation. Sandstone deposits of similar or better quality are widespread throughout the region and are closer to markets and transportation.
The study area is part of the southeast-tilted upper plate of a large thrust fault, and structural conditions favorable for the accumulation of oil or gas appear to be absent.

\section{SUGGESTIONS FOR FURTHER STUDY}

Drilling and detailed sampling would be necessary to determine more accurately the iron resources in the area. Additional beneficiation tests on the use of the low-grade hematitic sandstone for iron ore should be done as technology advances.

\section{REFERENCES}

Lesure, F. G., Williams, B. B., and Dunn, M. L., Jr., 1982, Mineral resources of the Mill Creek, Mountain Lake, and Peters Mountain Wilderness Study Areas, Craig and Giles Counties, Virginia, and Monroe County, West Virginia: U.S. Geological Survey Bulletin 1510, 76 p.

Motooka, J. M., Curtis, C. A., and Lesure, F. G., 1978, Analyses of soil samples from Mountain Lake and Peters Mountain Wilderness Study Areas, Virginia-West Virginia: U.S. Geological Survey Open-File Report 78-1077-A, 8 p.

Rait, Norma, and Lesure, F. G., 1978, Analyses and description of geochemical samples, Peters Mountain Wilderness Study Area, Giles County, Virginia: U.S. Geological Survey Open-File Report 78-1077-C, 15 p. 


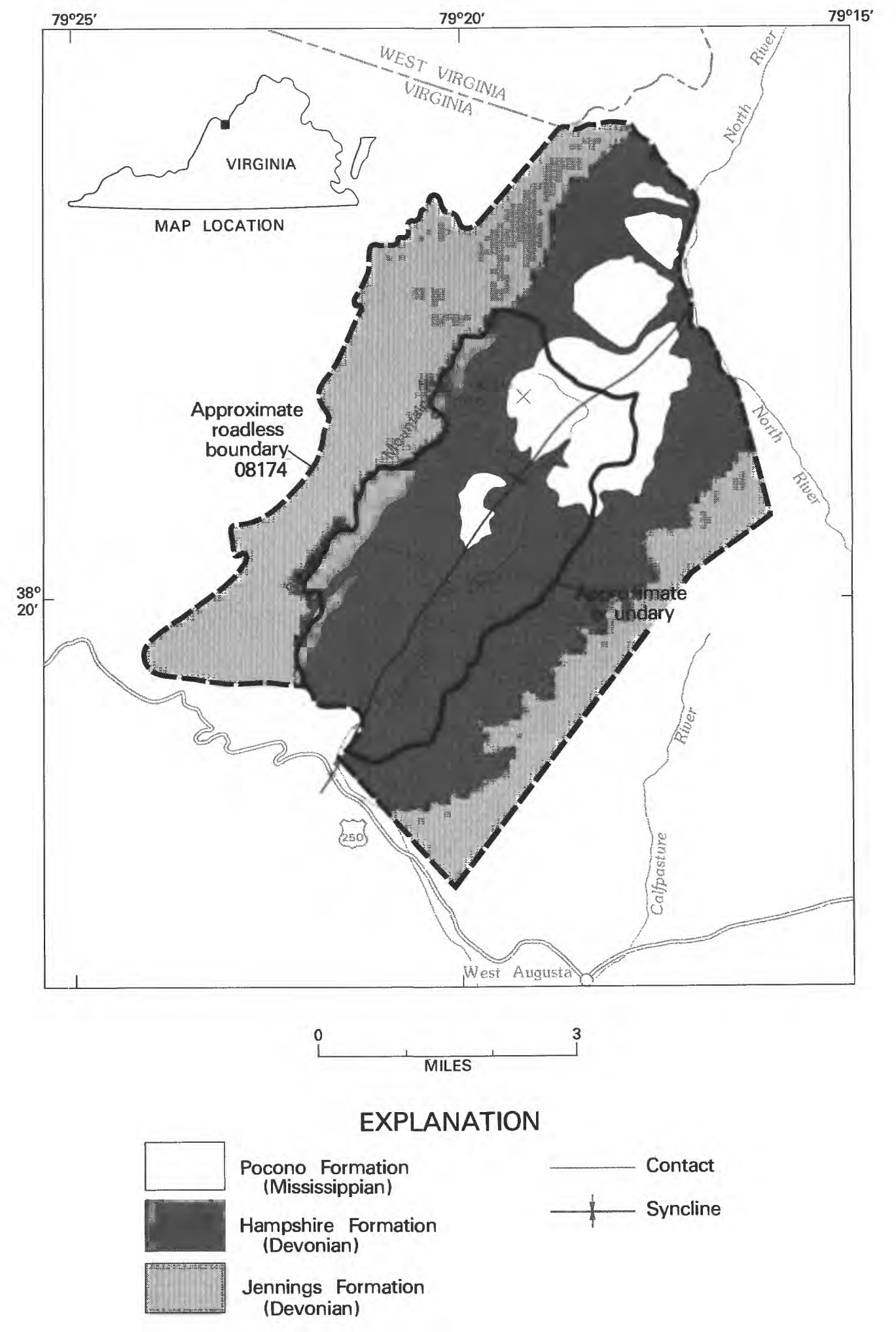

Figure 294.-Ramseys Draft Wilderness Study Area, Virginia. 


\title{
RAMSEYS DRAFT WILDERNESS STUDY AREA AND ADDITION, VIRGINIA
}

\author{
By Frank G. Lesure, U.S. GeOlogical Survey, and \\ PETER C. MORY, U.S. BUREAU OF MiNES
}

\begin{abstract}
SUMMARY
Mineral-resource surveys of the Ramseys Draft Wilderness Study Area and adjoining roadless area addition in George Washington National Forest in the western valley and ridge province, Augusta and Highland Counties, Viginia, were done intermittently between 1974 and 1979. The surveys outlined three small areas containing anomalous amounts of copper, lead, and zinc related to stratabound red-bed copper mineralization, but these occurrences are not large and are not considered as having mineral-resource potential. The area contaims abundant sandstone suitable for construction materials and shale suitable for making brick, tile, and other low-grade ceramic products, but these commodities occur in abundance outside the wilderness study area. Structural conditions are probably favorable for the accumulation of natural gas, but exploratory drilling has not been done sufficiently near the area to evaluate the gas potential.
\end{abstract}

\section{CHARACTER AND SETTING}

Ramseys Draft Wilderness Study Area, 18 mi northwest of Staunton, Augusta County, Virginia, consists of $10.5 \mathrm{sq} \mathrm{mi}$ of the steep-forested slopes of a northeasttrending valley forming the upper reaches of Ramseys Draft, a moderate-size clear-flowing stream. The roadless area addition of $21 \mathrm{sq}$ mi adjoins the study area on the west, north and east so that all of the adjacent part of Shenandoah Mountain to the west and north and the foothills to the east are included. Altitudes range from $2200 \mathrm{ft}$ above sea level along streams on the west and east sides to $4282 \mathrm{ft}$ on Hardscrabble Knob. Access to the area is by trails from U.S. Highway 250 along the southwest side and from USFS roads along the other sides. The Federal Government owns all the surface rights and about 75 percent of the mineral rights. The remaining mineral rights are privately owned.

A mineral-resource survey of the wilderness study area was made in the fall of 1974 (Lesure and others, 1977); additional geochemical studies in 1975 and 1976 resulted in the discovery of a small low-grade copper occurrence near the center of the area (Lesure and Motooka, 1980). Further field work in parts of the roadless area addition not visited during earlier work was done in 1979 (Lesure, 1982a, b; Lesure and Mory, 1982). The surveys included geologic mapping, geochemical prospecting, and mine and prospect examination.
Geochemical analyses for 30 elements by semiquantitative spectrographic methods and for several elements by atomic absorption methods were completed on stream-sediment, rock, soil, and forest-litter samples (Lesure and others, 1977; Motooka and others, 1981).

Bedrock in the combined areas is coarse- to finegramed marine and nonmarine clastic sedimentary rocks of Late Devonian and Early Mississippian age. These rocks, which are mostly shale and interbedded sandstone and conglomerate, are folded into a broad open syncline that plunges gently to the northeast. Several small, poorly exposed northwest-trending dikes of igneous rocks of Mesozoic age cut the sedimentary rocks in the northeastern half of the area.

\section{MINERAL RESOURCES}

Geochemical sampling outlined three areas having anomalous amounts of copper, lead, and zinc in sandstone related to strata-bound red-bed copper inineralization, but these occurrences are not large and are not considered as having mineral-resource potential. Additional sampling might find a few more such sites but there is little promise for the occurrence of copper, lead, and zinc resources in the area.

The area contaims abundant sandstone, suitable for crushed rock and possibly as a source of silica, and 
equally abundant shale, suitable for the manufacture of structural clay products including common brick, floor brick, sewer pipe, quarry tile, and possibly light-weight aggregate; but occurrences of sandstone and shale of similar quality are found throughout the general region.

The formations exposed at the surface within the study area have petroleum-bearing equivalents deeply buried under the Appalachian Plateau to the west in West Virginia. Structural traps are possible below the area in older formations and might contain gas. Test drilling for petroleum has not been done in the area and the potential for oil or gas under Ramseys Draft Wilderness Study Area and Addition cannot be evaluated adequately.

\section{SUGGESTIONS FOR FURTHER STUDIES}

The possible presence of structural traps, minor anticlines or high-angle faults, on the flanks of the syncline, especially under the roadless area addition, has been suggested by Perry (1978), and the oil and gas potential of this area can only be adequately determined by a carefully designed geophysical and drilling program.

\section{REFERENCES}

Lesure, F. G., 1982a, Geology of Ramseys Draft Addition, Augusta and Highland Counties, Virginia: U.S. Geological Survey Miscellaneous Field Studies Map MF 1369-A, scale 1:48,000.

1982b, Geochemical survey of Ramseys Draft Addition, Augusta and Highland Counties, Virginia: U.S. Geological Survey Miscellaneous Field Studies Map MF 1369-B, scale $1: 48,000$.

Lesure, F. G., Geraci, P. J., Mory, P. C., and Williams, B. B., 1977 Mineral resources of the Ramseys Draft Wilderness Study Area, Augusta County, Virginia: U.S. Geological Survey Bulletin $1397-\mathrm{C}, 42 \mathrm{p}$.

Lesure, F. G., and Motooka, J. M., 1980, Possible stratiform-copper occurrence, Ramseys Draft Wilderness Study Area, August County, Virginia: Southeast Geology, v. 21, no. 3, p. 227-238.

Lesure, F. G. and Mory, P. C., 1982, Mineral resource potential map of Ramseys Draft Addition, Augusta and Highland Counties, Virginia: U.S. Geological Survey Miscellaneous Field Studies Map MF 1369-C, scale 1:48,000.

Motooka, J. M., Forn, C.L., Lesure, F.G., Siems, D. F., and others, 1981, Analyses and descriptions of geochemical samples, Ramseys Draft Wilderness Study Area and Addition, Augusta and Highland Counties, Virginia: U.S. Geological Survey OpenFile Report 81-1319, 42 p.

Perry, W. J., Jr., 1978, Sequential deformation in the Central Appalachians: American Journal of Science, v. 278, p. 518-542. 


\title{
SOUTHERN MASSANUTTEN ROADLESS AREA, VIRGINIA
}

\author{
By Frank G. Lesure, U.S. GeOlogical Survey, and \\ Mark L. Chatman, U.S. BuREau OF Mines
}

\begin{abstract}
SUMMARY
The Southern Massanutten Roadless Area is in the George Washington National Forest in the Shenandoah Valley of Page and Rockingham Counties, Virginia. According to mineral surveys of the area made in 1979 and 1980, inferred resources of low-grade iron occur at two mines in folded Paleozoic sedimentary rocks. The iron resources consist of 120,000 long tons of clayey and sandy limonite. Other mineral resources occur in the area including extensive areas of high-silica sandstone, shale suitable for making brick, and limestone suitable for crushed stone and agricultural lime. The potential for the occurrence of oil or natural gas resources cannot be evaluated from the available data. The nonmetallic mineral resources are of limited importance because of relative inaccessibility as compared to large accessible resources outside the roadless area.
\end{abstract}

\section{CHARACTER AND SETTING}

The Southern Massanutten Roadless Area contains about $18 \mathrm{sq} \mathrm{mi}$ of the George Washington National Forest in the Valley and Ridge province of west-central Virginia. The area, which is $13 \mathrm{mi}$ long and 1 to $2 \mathrm{mi}$ wide, is in Page and Rockingham Counties on the eastern side of the Shenandoah Valley between the North and South Forks of the Shenandoah River. The north end is $11 \mathrm{mi}$ southwest of Luray and the south end is 7 mi east of Harrisonburg. The roadless area contains two to four steep-sided ridges whose altitudes are generally 2600 to $2800 \mathrm{ft}$ above sea level but locally reach $3200 \mathrm{ft}$. Low points are about $1100 \mathrm{ft}$ on Cub Run which drains the northern end and $1600 \mathrm{ft}$ on Boone Run which drains the southern end. Access is good from the Cub Run Road on the east side, Pitt Spring Run Road on the north, and several trails on the west. The Federal Government owns all the surface rights in the area but only about 30 percent of the mineral rights. Allegheny Ore and Iron Company, a subsidiary of Lukens Steel Company, Coatesville, Pennsylvania, holds the mineral rights in perpetuity on most of the northern two thirds of the area. The Shenandoah Iron, Lumber, Mining, and Manufacturing Company and its successor Allegheny Ore and Iron Company mined iron at the north end of the roadless area in the Pitt Spring mine and the New Ore Bed prospects in the 19th century. The ruins of
Catherine furnace are at the northeast end of the area; this was a charcoal iron furnace that used local limonite ores before the Civil War.

Southern Massanutten Mountain consists of two narrow asymmetric synclines and an intervening anticline in Middle Ordovician to Middle Devonian sedimentary rocks (Lesure, 1983). These rocks consist of older sequences of shaly limestone and interbedded shale, siltstone, and limestone along the flanks of the ridges and the anticlinal axis. Above these is a thick quartzitic sandstone very resistant to erosion, which forms the upper slopes and crests of all the ridges. The youngest rocks preserved along the synclinal axes consist of reddish sandstone overlain by several thin limestone units that are in turn overlain by dark shales. Much of the roadless area, however, is covered with coarse boulders and gravel eroded from the resistant sandstone. The younger limestone unit is locally the host for surficial deposits of limonite (hydrous iron oxides).

Although no major faults are exposed in the roadless area, a zone of major flat-lying thrust faults is present at a depth of 2 to $5 \mathrm{mi}$ below the roadless area.

Mineral surveys made in the fall of 1979 and spring and summer of 1980 (Lesure and others, 1983) consisted of geologic mapping (Lesure, 1983), geochemical studies (Lesure and Forn, 1983), and examination of mines and prospects in or near the area (Chatman and Behum, 1983). 

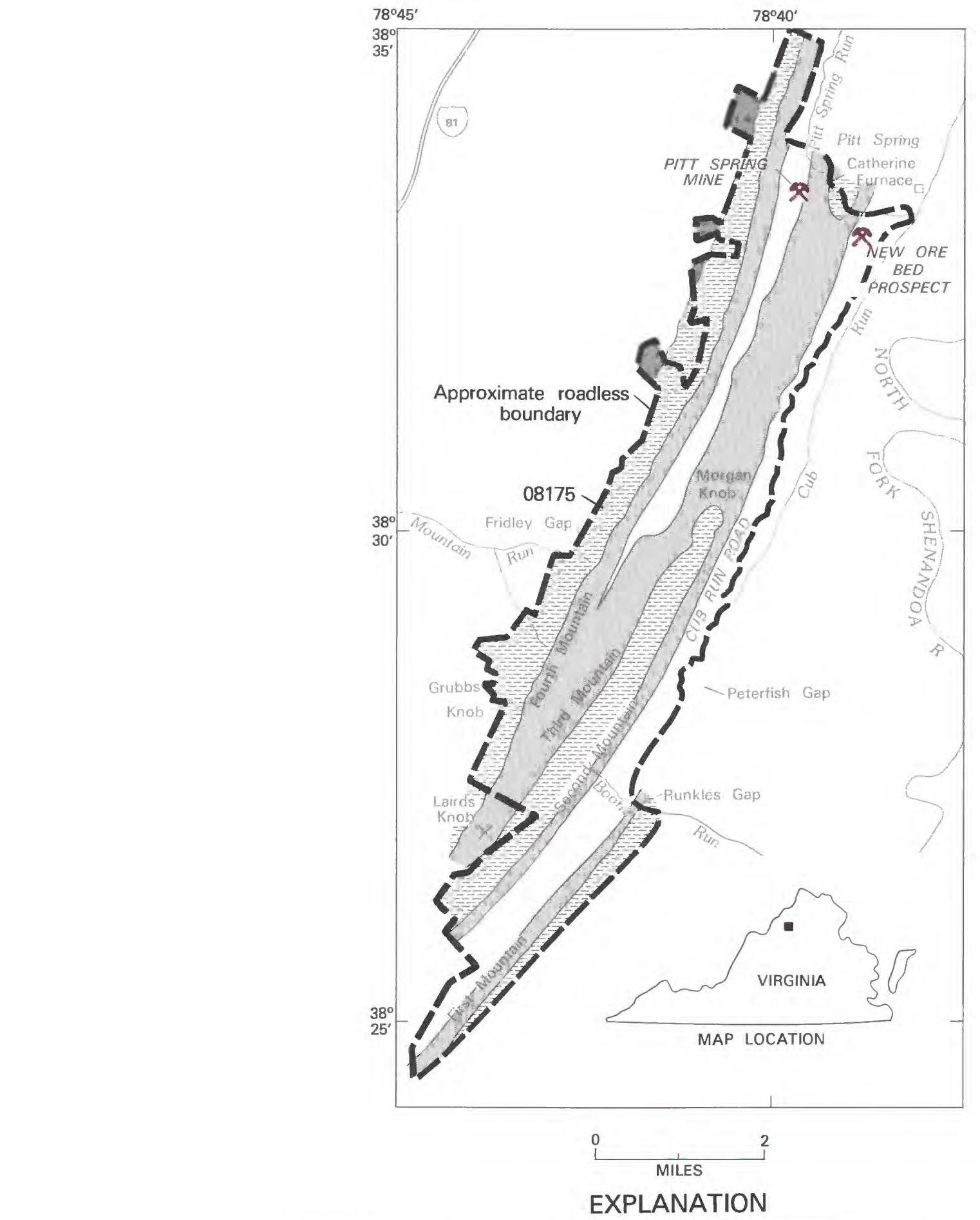

Shale, limestone, and red sandstone (Devonian and Upper Silurian)

Quartzite (Silurian)

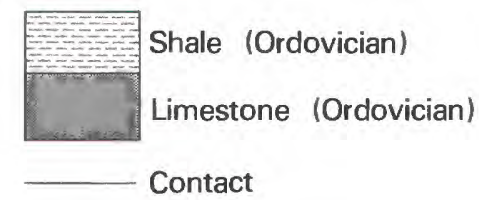

× Mine or deposit

Figure 295.-Southern Massanutten Roadless Area, Virginia. 


\section{MINERAL RESOURCES}

The deposits of clayey and sandy limonite are limited to two areas each about $1500 \mathrm{ft}$ long and a hundred or so feet wide at the northern end of the roadless area. The western deposit, the Pitt Spring mine, contains an estimated 80,000 long tons of inferred resources of lowgrade iron that may have an average of 40 percent iron or 32,000 long tons of contained iron; the eastern deposit, the New Ore Bed prospects, contains an estimated 40,000 long tons of similar material containing 16,000 tons of iron. These deposits, formed by the action of iron-bearing ground water, are in moderately dipping beds of sandy limestone. The deposits are shallow, tabular, or lenticular masses and are typical of deposits widespread in west-central Virginia. They are generally too small, discontinuous, nonuniform in grade, and too high in phosphorus content to be used in modern blast furnaces. The deposits in and near the roadless area have not been worked since the early 1900's and the larger and richer deposits of this type found near Clifton Forge, Virginia, about $70 \mathrm{mi}$ to the southwest of the roadless area, have not been worked since 1925 .

The white quartzite sandstone present in large amounts on the ridges in the roadless area is a potential source of stone suitable for common building stone, crushed rock, and high-silica sand. Analyses of representative samples (Wawro and others, 1982, p. 18; Lesure and Forn, 1983) suggest that the sandstone is made of nearly pure silica sand and is suitable for lowquality glass products. The sandstone could possibly be used for refractory sand, abrasive material, or as a source of silica for chemical and metallurgical uses. Massanutten Mountain north of the roadless area contains the same sandstone unit and has exposures along major roads more accessible than deposits in Southern Massanutten Mountain.

The various shale deposits on the flanks of the ridges are suitable for common brick, tile, and lightweight aggregate. The most accessible parts of the shale resources are along the flanks of the ridges generally outside the roadless area.

There is little promise for the occurrence of resources of oil and natural gas in the Southern Massanutten
Roadless Area above the zone of regional thrust faulting. The synclinal structures of the mountain are unfavorable for accumulation of oil and gas, and the rocks above the zone of thrust faulting have been heated to temperatures at which oil and natural gas break down (high thermal maturation). The thermal maturity of the sedimentary rocks below the zone of thrust faulting is unknown but these rocks are probably thin and are not likely sources for oil and gas.

The younger limestone sequence in the roadless area is a possible source of limited amounts of crushed rock and agricultural lime. The Shenandoah Valley surrounding Massanutten Mountain is, however, a major source of aggregate and lime from much more extensive and accessible deposits of limestone and dolomite.

Geochemical studies do not indicate the presence of metallic resources other than iron in the roadless area. Zinc deposits in older limestone formations are known in the Shenandoah Valley and similar deposits may occur in the roadless area in these same formations but at depths greater than $4000 \mathrm{ft}$. These deposits, if they occur, would be of small size and at great depth and would not be classified as resources.

\section{REFERENCES}

Chatman, M. L., and Behum, P. T., 1983, Maps showing mines and prospects in the Southern Massanutten Roadless Area, Page and Rockingham Counties, Virginia: U.S. Geological Survey Miscellaneous Field Studies Map MF-1527-C.

Lesure, F. G., 1983, Geology of the Southern Massanutten Roadless Area, Page and Rockingham Counties, Virginia: U.S. Geological Survey Miscellaneous Field Studies Map MF-1527-A.

Lesure, F. G., Chatman, M. L., Behum, P. T., and Wawro, T. J., 1983, Mineral resource potential map of the Southern Massanutten Roadless Area, Page and Rockingham Counties, Virginia: U.S. Geological Survey Miscellaneous Field Studies MF-1527-D.

Lesure, F. G., and Forn, C. L., 1983, Geochemical survey of the Southern Massanutten Roadless Area, Page and Rockingham Counties, Virginia: U.S. Geological Survey Miscellaneous Field Studies Map MF-1527-B

Wawro, T. J., Chatman, M. L., and Behum, P. T., 1982, Mineral investigation of the Southern Massanutten RARE II Further Planning Area, Page and Rockingham Counties, Virginia: U.S. Bureau of Mines Open-File Report MLA 73-82, 26 p. 
$\begin{array}{llllllllll}\text { W } & A & S & H & \text { I } & N & G & T & O & N\end{array}$

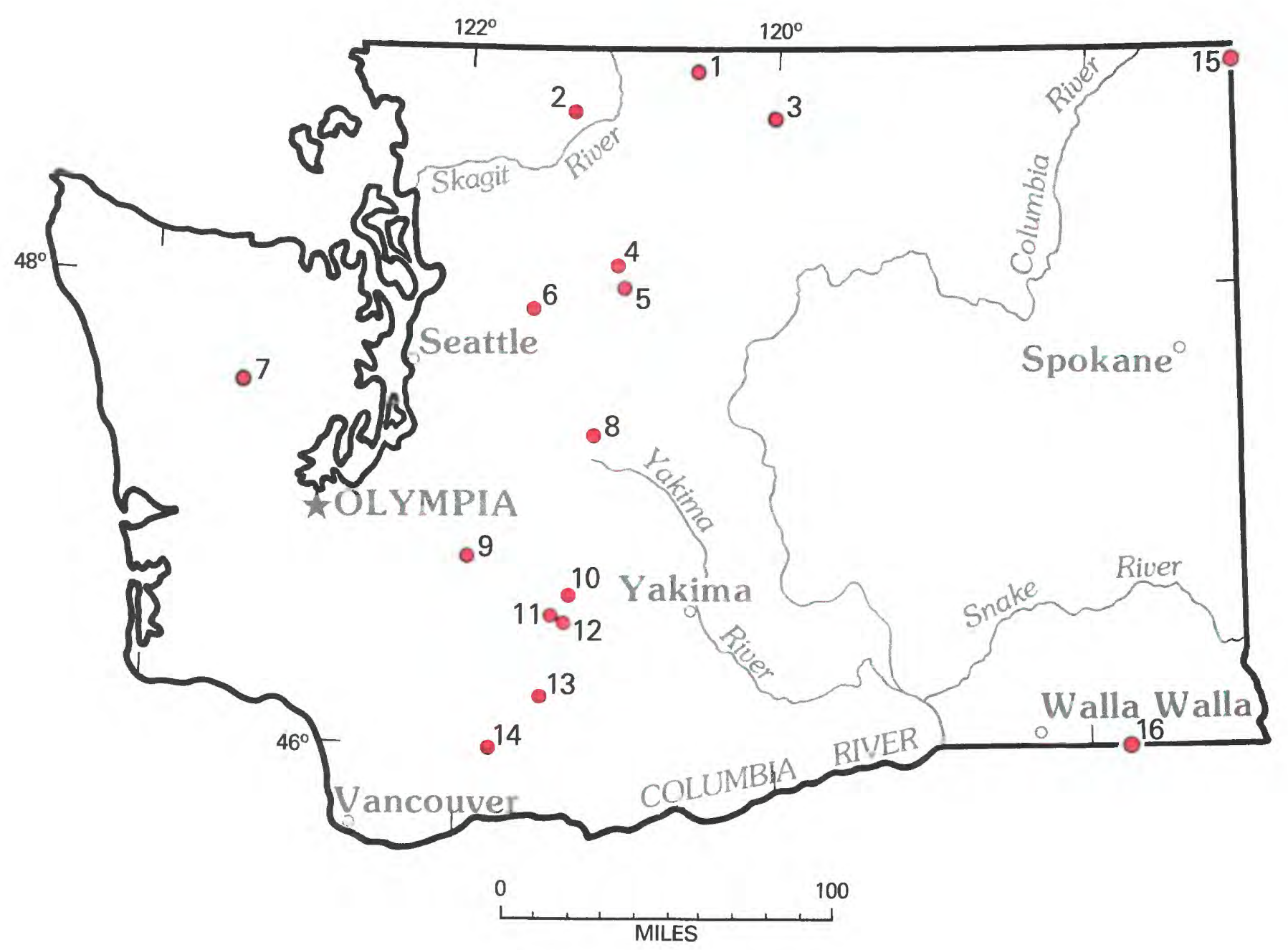

Location of areas studied. 


\section{WASHINGTON}

Map
No.

Name of Area

8 Alpine Lakes Wilderness study area

10 Cougar Lakes-Mount Aix Wilderness study area

6 Eagle Rock Roadless Area

5 Glacier Peak Roadless Area

4 Glacier Peak Wilderness study area

9 Glacier View Roadless Area

12 Goat Rocks Wilderness and adjacent roadless areas

14 Indian Heaven Roadless Area

3 Long Swamp Roadless Area

13 Mount Adams and contiguous roadless areas

2 Northern part of the North Cascades National Park

1 Pasayten Wilderness

15 Salmo Priest Wilderness study area, Washington and Idaho

11 Tatoosh Roadless Area

16 Wenaha Tucannon Wilderness, Washington and Oregon

7 Wonder Mountain Roadless Area 

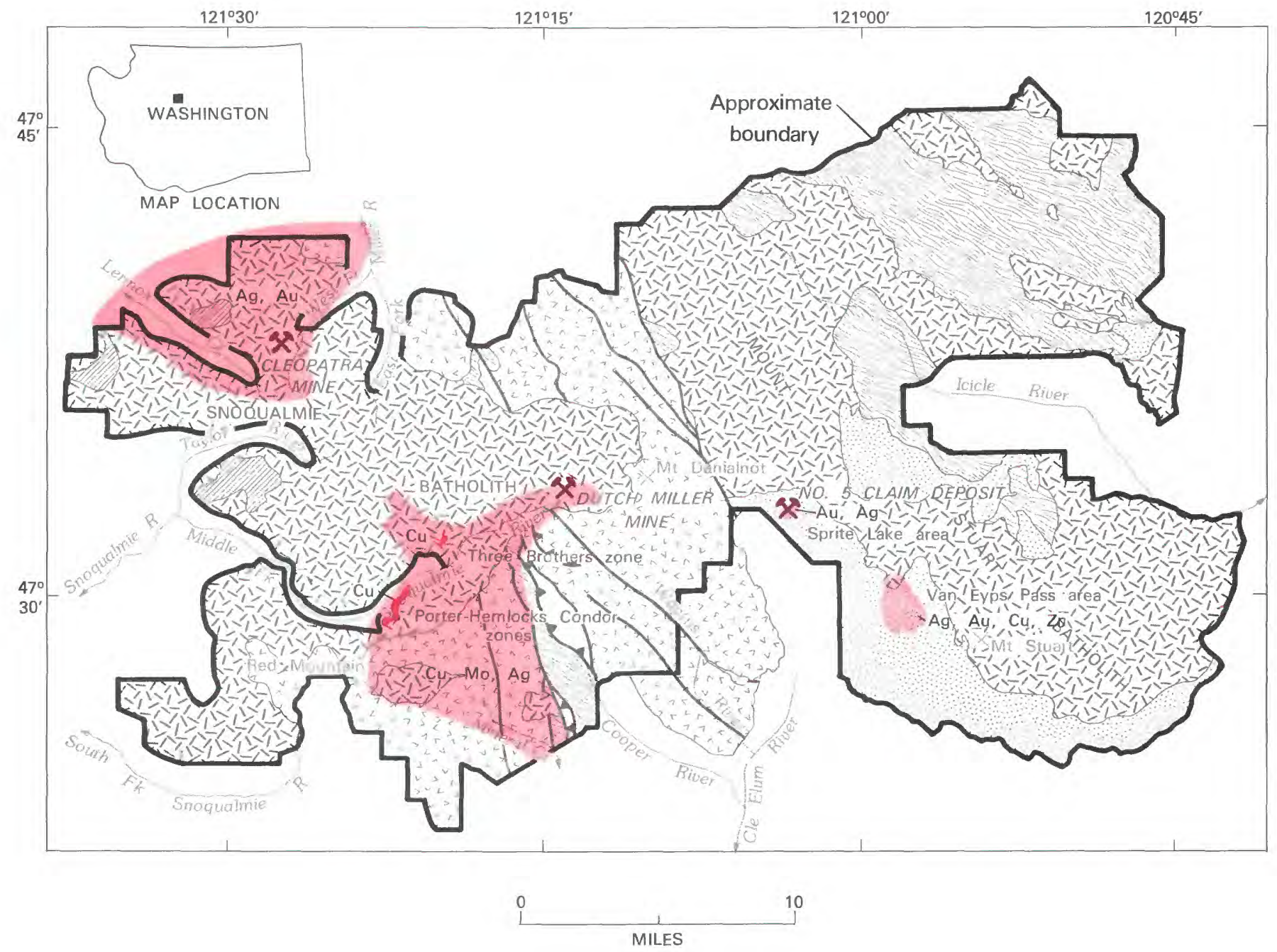

\section{EXPLANATION}

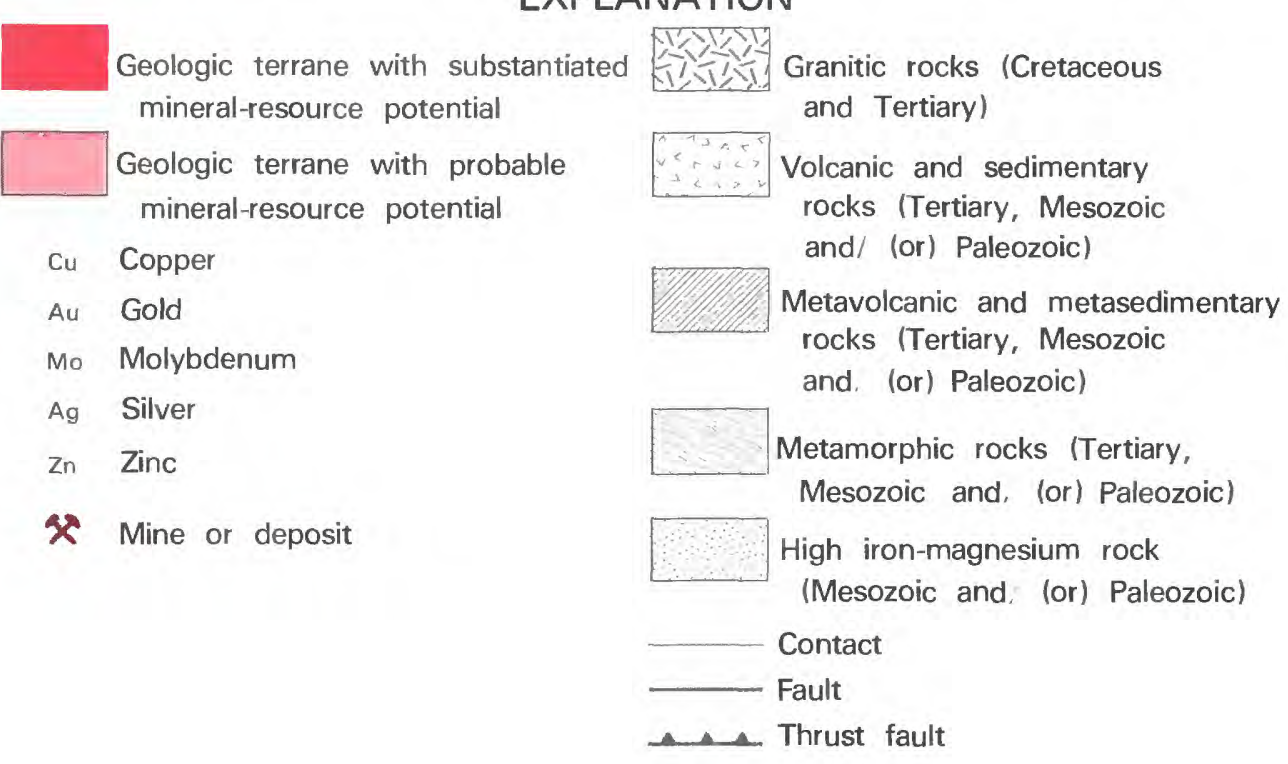

Figure 296.-Alpine Lakes Wilderness study area, Washington. 


\title{
ALPINE LAKES WILDERNESS STUDY AREA, WASHINGTON
}

\author{
By J. L. Gualtieri, U.S. Geological Survey, and \\ H. K. Thurber, U.S. BUREAU OF Mines
}

\section{SUMMARY}

\begin{abstract}
The Alpine Lakes Wilderness study area, located in the central part of the Cascade Mountains of Washington was examined for its mineral-resource potential during the period 1971-73. On the basis of that study the area was found to contain deposits of copper, other base metals, and gold and silver. Probable or substantiated mineral-resource potential exists for these commodities in the southwest-central, northwest, and southeast-central parts of the area. The geologic terrane precludes the occurrence of fossil fuel resources.
\end{abstract}

\section{CHARACTER AND SETTING}

The Alpine Lakes Wilderness study area, which covers about $600 \mathrm{sq} \mathrm{mi}$, is located about $45 \mathrm{mi}$ east of Seattle. It is roughly bounded by Interstate 90 on the southwest, U.S. Highway 2 on the northwest, and U.S. Highway 97 on the southeast. The western boundary lies along the South, Middle, and North Forks of the Snoqualmie River. On the west, south, and east the boundary lies well back from the main highways and follows such natural features as ridge crests and valley floors.

The area is rugged and is characterized by deeply glaciated canyons and serrate ridges. In only a few small highland areas does relatively flat rolling topography exist. Mount Stuart, in the southeastern part of the study area, has the highest summit, at an altitude of $9415 \mathrm{ft}$. In the western part of the area the highest peaks exceed $7000 \mathrm{ft}$ and in the northeastern part they reach almost $8000 \mathrm{ft}$.

The Alpine Lakes Wilderness study area is underlain by metamorphic, sedimentary, and volcanic rocks that have been intruded by large granitic bodies. A northwest-trending fault zone divides the area into two blocks of contrasting geology. The block to the east consists mostly of metamorphic rock, high iron-magnesium intrusive rock, similar volcanic rock with associated sedimentary rock, all intruded by granitic rock more than 63 million years ago. The block to the west mostly consists of moderate iron-magnesium volcanics, metamorphic, metavolcanic and metasedimentary, and sedi- mentary rocks, all intruded by granitic rock about 10 million years ago.

The principal structures of the Alpine Lakes Wilderness study area consist of thrust faults, low- and highangle faults, and folds, most of which are in the western part. The faults are part of a regional belt of faults that extends into the northern part of the Cascade Range. The continuity of the structures has been locally interrupted by granitic bodies that intruded the area after the structures formed. The fault zone that separates the study area into blocks of diverse geology resulted from the uplift of the eastern block. The oldest faults came into existence less than 60 million years ago and some may have been intermittently active since then. Major low-angle faults occurred before the formation of folds, but some lesser low-angle faults may have occurred concurrently. Most high-angle faults probably occurred after folding.

The survey of the Alpine Lakes Wilderness study area included reconnaissance geologic mapping, geochemical sampling and analysis of stream-sediment, soil, country, and mineralized rock, and examination, including mapping, of mines, prospects, and claims (Gualtieri and others, 1973, 1975). An aeromagnetic survey was made and interpreted to give some insight into the subsurface geology.

Mining activity near the Alpine Lakes Wilderness study area began as early as $\mathbf{1 8 6 0}$ with the discovery of placer gold. Later, in the period of the 1870's to the 1890 's, lode deposits of precious and base metals were prospected within the study area and work on these continued intermittently through the time of the study. 


\section{MINERAL RESOURCES}

The central part of the Cascade Mountains of Washington, which include the Alpine Lakes Wilderness study area, lies on the southern extension of a metallogenic belt that is traceable from British Columbia, Canada. The belt is characterized by copper and low-grade molybdenum deposits but contains deposits of other metals. The deposits are associated with certain types of granitic rock and with broad shear zones of regional extent. Four areas within or near the boundary of the study area are considered to have probable mineralresource potential and places within three of these areas have substantiated mineral-resource potential.

An area of altered granitic, volcanic, sedimentary, and metamorphic rock with numerous geochemical anomalies is in the southwest-central part of the Alpine Lakes Wilderness study area. The area lies along the Middle Fork Snoqualmie River and extends from the Dutch Miller mine southwest to Red Mountain and southeast to the study area boundary in the vicinity of Mineral Creek. It contains disseminated coppermolybdenum-silver deposits, and vein deposits of copper, other base metals, and precious metals. The disseminated copper deposits commonly occur in sheared and shattered granitic rock and were formed through a complex, multicyclic mineralizing process concurrent with host rock deformation and alteration. Vein deposits occur in relatively narrow zones of sheared or jointed rock.

Stream-sediment samples collected from the area contain anomalous amounts of copper, molybdenum, and silver, and less commonly lead and zinc. Rock samples from extensively altered and (or) mineralized areas contain metal content, similar to the anomalous streamsediment samples. Samples of veins or mineralized shear zones contain proportionately more lead and zinc and less copper than the extensively mineralized areas, and also contain other metals such as tin, tungsten, arsenic, antimony, bismuth, and cadmium.

The area has been prospected and explored through many workings, and mined in a few places. The area is regarded as having probable mineral-resource potential for the occurrence of disseminated copper deposits and vein deposits of base and precious metals. A mineralized area along the Middle Fork Snoqualmie River, known as the Porter, Hemlock, and Condor zones, was being explored at the time of the study by drilling and underground mining. The area has substantiated mineralresource potential and contains demonstrated resources of as much as 200 million tons of 0.7 percent copper. Another similarly mineralized area also along the Middle Fork Snoqualmie River, known as the Three Brothers zone and explored prior to the study, con- stitutes an area of substantiated mineral-resource potential containing demonstrated resources of as much as two million tons of 0.8 percent copper. The Dutch Miller mine, inactive at the time of the study, was developed along base metal-bearing veins. The deposit has demonstrated mineral resources of 3700 tons of 11 percent copper.

Veins and mineralized shear zones that contain values principally in silver, and in places also gold, occur in the northwestern part of the study area west of the Cleopatra mine. The mineralized structures mostly occur in granitic rock and are west to northwest trending. The deposits are commonly arsenic bearing and contain copper, lead, molybdenum, zinc, antimony, tin, and tungsten in addition to precious metals.

Stream-sediment samples collected from the area most commonly contain anomalous amounts of molybdenum, lead, silver, and arsenic, and rarely anomalous amounts of copper, tungsten, and zinc. Rock samples collected from or near mineralized sites contain a similar suite of metals but at much higher concentrations. Anomalous amounts of copper are more common in rock samples than in stream-sediment samples. Molybdenum occurs almost exclusively in the southwestern part of the area whereas antimony was found only in the northern part of the area. This may be indicative of zonation of metals during the mineralizing process.

Several mines and many workings and prospects are scattered over the area. The area is regarded as having probable mineral-resource potential for the occurrence of similar small vein and mineralized shear zonedeposits containing values in silver and gold. The Cleopatra mine, located on a 3-mi-long shear zone, is estimated to contain demonstrated resources of more than 100,000 tons of mineralized rock of $6-17 \mathrm{oz}$ silver/ton.

Veins, and mineralized shear or shatter zones of short extent containing values in silver and gold occur in the area of Sprite Lake. The mineralized structures are east to northeast trending. Mineralization appears to have occurred where small bodies of granitic rock that intrude the area and adjacent high iron-magnesium rock are sheared or shattered. The veins and mineralized rock contain sulfides of iron and arsenic.

Sediment samples collected from streams that drain the area surprisingly contain only small amounts of metal. Samples of veins and mineralized rock contain concentrations of silver, gold, copper, and arsenic, and a few also contain amounts of lead, molybdenum, antimony, tungsten, and zinc.

The deposits have been explored by pits and trenches, and some underground workings but none of the deposits have been explored at depth. The area is regarded as having a probable mineral-resource potential for the 
occurrence of similar deposits. One deposit, a vein on the No. 5 claim, is estimated to contain demonstrated resources of over 2000 tons of $1.78 \mathrm{oz}$ gold/ton.

Several base-metal vein deposits, mineralized shear zones, and small bodies of altered rock occur in the Van Epps Pass area. The deposits are in, or associated with, high iron-magnesium dike rock and in places the deposits occur along faults that form the contacts of these rocks. The mineralized structures are mostly northeast trending. The chief values are in silver and copper, and to a lesser extent gold.

Stream and soil samples collected from the area contain anomalous amounts of copper, molybdenum, zinc, and silver. Mineralized rock samples contain the same suite of metals at much higher concentrations, and some were found to contain arsenic and antimony in addition. The distribution of copper and zinc over the area, on the basis of the analyses, suggest a zonation from relatively high copper-low zinc in ground nearer the main body of granitic rock to relatively high zinc-low copper in ground farther from the body.

The area has been explored by many pits and trenches, and some underground workings. It is regarded as having a probable mineral-resource potential for the occurrence of similar deposits.

\section{SUGGESTIONS FOR FURTHER STUDIES}

If future study of the mineral-resource potential of the Alpine Lakes Wilderness study area is undertaken, a study of the precious metal-bearing veins and mineralized shear zones might be a worthy endeavor. These deposits appear to be structurally controlled but otherwise there is no comprehensive understanding of their occurrence: why some structures are mineralized and other similar structures in the same area are not; why only a part or parts of a structure are mineralized and other parts are not; or why the structures, where mineralized, contain relatively abundant precious metals whereas other mineralized parts do not. Some understanding might be obtained through detailed study and mapping of precious-metal deposits being actively mined. Mining is now precluded from most of the Alpine Lakes Wilderness study area, therefore such a study would have to be conducted on deposits being mined outside, but near the study area.

\section{REFERENCES}

Gualtieri, J. L., Simmons, G. C., Thurber, H. K., and Miller, M. S., 1973, Mineral resources of the Alpine Lakes study area, Chelan, King, and Kittitas Counties, Washington, with a section on Aeromagnetic interpretation by W. E. Davis: U.S. Geological Survey Open-file report, $132 \mathrm{p}$.

Gualtieri, J. L., Thurber, H. K., Miller, M. S., McMahan, A. B., and Federspiel, F. F., 1975, Mineral resources of additions to the Alpine Lakes study area, Chelan, King, and Kittitas Counties, Washington: U.S. Geological Survey Open-File Report 75-3, $161 \mathrm{p}$. 

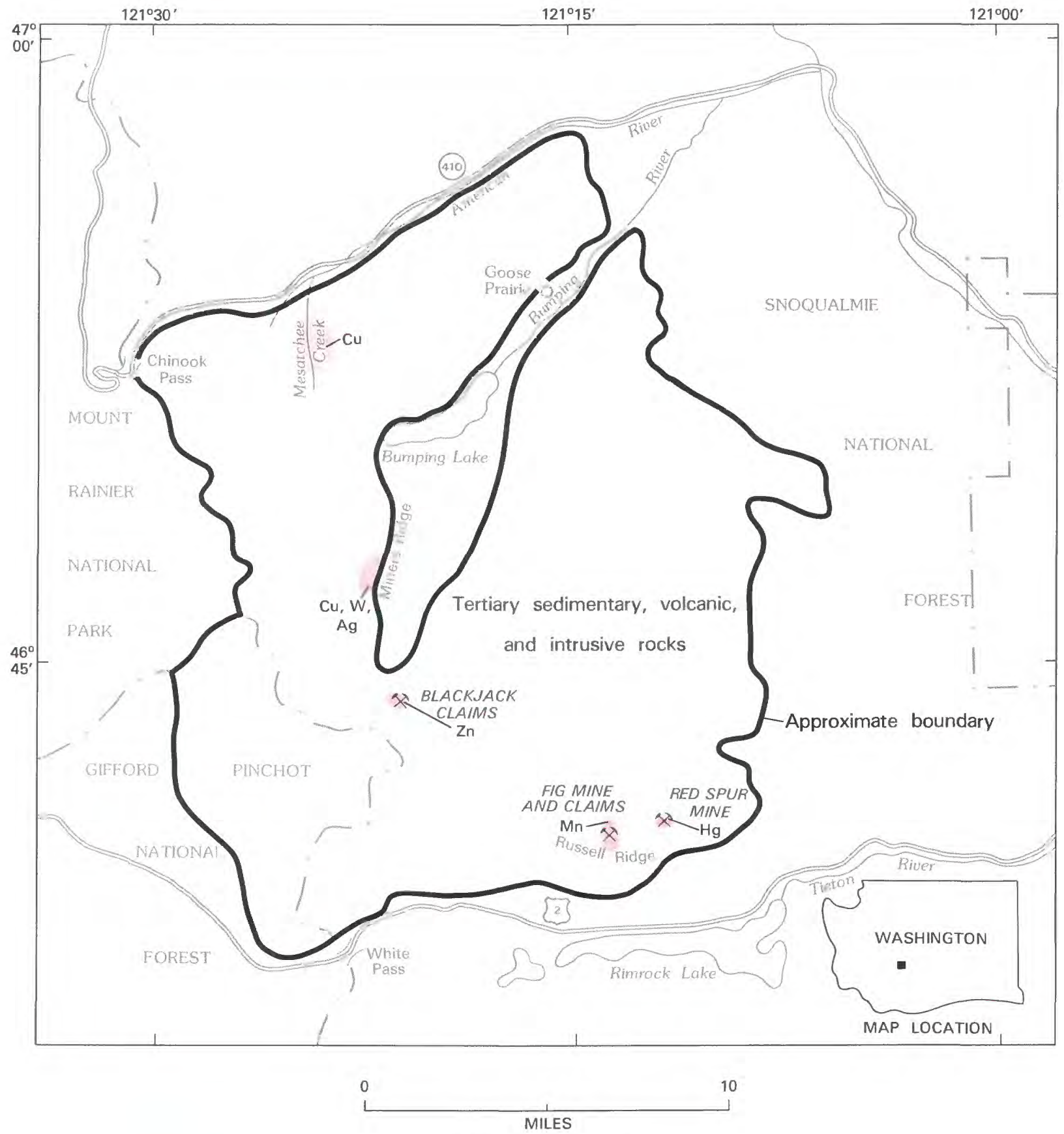

\section{EXPLANATION}

\begin{tabular}{llll}
\hline & $\begin{array}{l}\text { Geologic terrane with probable } \\
\text { mineral-resource potential }\end{array}$ & $\mathrm{Ag}$ & Silver \\
$\mathrm{Cu} \quad$ Copper & W & Tungsten \\
$\mathrm{Mn} \quad$ Manganese & $\mathrm{Zn}$ & Zinc \\
$\mathrm{Hg}$ Mercury & × & Mine \\
\hline
\end{tabular}

Figure 297.-Cougar Lakes-Mount Aix Wilderness study area, Washington, 


\title{
COUGAR LAKES-MOUNT AIX WILDERNESS STUDY AREA, WASHINGTON
}

\author{
By George C. Simmons, ${ }^{1}$ U.S. Geological Survey, and \\ RONALD M. VAN NOY, U.S. BUREAU OF MineS
}

\begin{abstract}
SUMMARY
A mineral survey of the Cougar Lakes-Mount Aix Wilderness study area was carried out in 1973 by the USGS and USBM to assess its mineral-resource potential. The study included reconnaissance geologic mapping and geochemical sampling, statistical analyses of samples, interpretation of an aeromagnetic survey, and an investigation of mining properties. These studies indicate that the Cougar Lakes-Mount Aix Wilderness study area has a probable mineralresource potential for silver, copper, manganese, mercury, tungsten, and zinc. This resource potential occurs in four small isolated areas in the southern half of the study area, and in a larger area which has a potential for porphyry copper, near the north boundary of the study area.
\end{abstract}

\section{CHARACTER AND SETTING}

The Cougar Lakes-Mount Aix Wilderness study area covers approximately $260 \mathrm{sq}$ mi near the crest of the Cascade Range, and includes parts of the Snoqualmie and Gifford Pinchot National Forests in Yakima and Lewis Counties, Washington, respectively. The area is south and west of the Chinook Pass Highway (Washington 410), north of the White Pass Highway (U.S. 12), and is bounded on the west by Mount Rainier National Park. Most of the terrain consists of steep, densely wooded mountains and valleys, but also includes alpine lakes, peaks and ridges above timberline, and a large plateau on the crest of the Cascade Range. A mineral survey was made by the USGS and the USBM during 1973 to assess the resource potential of the area (U.S. Geological Survey and U.S. Bureau of Mines, 1983; Simmons and others, 1974 [1975]).

The rocks of the Cougar Lakes-Mount Aix Wilderness study area consist of sedimentary, volcanic, and intrusive rocks; most are of Cenozoic age, but a few are of Mesozoic(?) age. The oldest rocks are argillite, graywacke, and basalt flows that were folded into a series of north-trending folds, slightly metamorphosed, and eroded prior to the deposition of the Puget Group of early Tertiary age. The Puget Group is made up of shale, arkose, sandstone, and carbonaceous shale. It is

\footnotetext{
${ }^{1}$ With contributions from Nicholas T. Zilka, USBM.
}

conformably overlain by, and the upper part is locally intercalated with, the Ohanapecosh Formation. The Ohanapecosh Formation is composed mostly of tuff, breccia, and flows, chiefly of andesitic composition.

The pre-Puget rocks, Puget Group, and Ohanapecosh Formation were uplifted and gently folded in a broad anticlinorium from which the Cascade Range was subsequently eroded. The uplift was accompanied first by the emplacement of a batholith of granite and granodiorite and the intrusion of plugs of diorite, and then by the intrusion of stocks, dikes, and sills of rhyodacite; all of the rocks were fractured along zones trending northwest to west-northwest.

Most of the mineral occurrences in the area are associated with or resulted from the intrusion of the granitic rocks and rhyodacite. Concentrations of metallic elements occur as disseminated bodies in and adjacent to the intrusive rocks and as veins in some of the northwest- to west-northwest-trending shear zones. Small amounts of copper, mercury, and tungsten have been mined from these deposits. A small amount of manganese has also been produced in the area.

After a period of erosion, the older rocks were partly covered by the Fifes Peak Formation (Oligocene and (or) Miocene) and were intruded by plugs, dikes, and sills of andesite porphyry. Then, during the Miocene and Pliocene, while the Yakima Basalt Subgroup was being extruded onto the Fifes Peak Formation to the east, the area was uplifted and eroded, and several large normal 
faults offset the Fifes Peak Formation and older strata. Probably during the Pliocene, when the present drainage pattern was partly developed, andesite flows were extruded from several centers and flowed into the drainage system. Later, during the Pleistocene, when the valleys had developed a configuration much like that of the present day, basalt flows accumulated to form a plateau on the crest of part of the Cascade Range, and flowed into adjacent valleys. The glaciated basalt plateau is capped by a postglacial basalt cinder cone.

Evaluation of the mineral potential was in part based on statistical analyses of geochemical sampling, and upon aeromagnetic data. Stream-sediment samples were collected from all major and most minor streams; some streams were panned to check their heavy-mineral content. Rock samples were collected from all major and most minor ridges, slopes, and valley bottoms. Waters from several springs were tested for indications of geothermal activity. An aeromagnetic survey of the region, made by Scintrex Surveys, Inc., was interpreted by W. E. Davis. Total-intensity magnetic data were obtained along north-south lines flown about $1 \mathrm{mi}$ apart at an average barometric elevation of $8000 \mathrm{ft}$. The data were contoured at intervals of 20 and 100 gammas relative to an arbitrary datum.

Records of Yakima and Lewis Counties indicate that about 450 claims have been located within or along the boundary of the study area since 1872; none of the claims are patented claims. Minor production of gold, silver, copper, and tungsten between 1938 and 1942 is recorded from part of the area, but most if not all of the production was from claims outside of the study area. More recently, small amounts of mercury and manganese ores were mined from the Red Spur and Fig claims respectively, on Russell Ridge.

\section{MINERAL RESOURCES}

The Cougar Lakes-Mount Aix Wilderness study area contains local concentrations of several metallic minerals. An area with probable resource potential for a large body of copper ore is in and adjacent to the granitic rocks near Mesatchee Creek in the north part of the study area. Identification of this resource is supported by anomalously high copper analyses from stream-sediment and rock samples collected in the Mesatchee Creek granitic area.

Small deposits of mercury and manganese are present in the Puget Group and Ohanapecosh Formation near Russell Ridge in the southern part of the study area and past production was from the Red Spur and Fig claims.
These claims are in discontinuous bodies of marginal grade, and future discoveries may be of the same type.

A small area with a probable zinc resource potential exists along a shear zone in silicified argillite on the Blackjack group of claims in the central part of the area. Surface sampling indicates 4.0 percent zinc across a $4.0 \mathrm{ft}$-wide zone exposed for a strike length of $160 \mathrm{ft}$. Flooded workings (1973) prevented the determination of the depth of mineralized rock.

A probable resource potential for copper, tungsten, and silver is present also in the central part of the study area on the west side of Miners Ridge. Small amounts of the metals were mined from northwest-striking shear zones adjacent to the study area on the east side of the ridge. If these mineralized zones do extend into the study area, and this seems very possible, only small amounts of metals would be expected near the surface in as much as anomalous amounts of metals were not detected in samples collected along Miners Ridge.

Although five limited areas containing probable metallic mineral-resource potential were found in this survey, no areas of energy-resource potential were identified. Although coal has been reported in the Puget Group in the study area, no coal was found during the present study.

\section{SUGGESTIONS FOR FURTHER STUDY}

The Cougar Lake-Mount Aix Wilderness study area may have a geothermal resource potential that warrants further investigations. No hot springs are known in the area, but it contains basaltic lava flows and a cinder cone of late Tertiary and Quaternary ages. Analyses of some cold spring water suggest that hot water at about $320^{\circ} \mathrm{F}\left(160^{\circ} \mathrm{C}\right)$ may be at depth diluting cold meteoric waters.

\section{REFERENCES}

Simmons, G. C., and others, 1974 [1975], Magnetic tape containing spectrographic and chemical analyses of mineralized ores and floats, mines and dumps, stream sediments and pan concentrates from the Cougar Lakes-Mount Aix study area, Yakima and Lewis Counties, Washington: U.S. Geological Survey Report USGS-GD-74-032; available only from the U.S. Department of Commerce, National Technical Information Service, Springfield, VA 22151, as Report PB-238-413/AS.

U.S. Geological Survey and U.S. Bureau of Mines, 1983, Mineral resources of the Cougar Lakes-Mount Aix study area, Yakima and Lewis Counties, Washington, with a section on Aeromagnetic interpretation by W. E. Davis (USGS): U.S. Geological Survey Bulletin 1504, in press. 


\title{
EAGLE ROCK ROADLESS AREA, WASHINGTON
}

\author{
By S. E. Church, ${ }^{1}$ U.S. GeOlogical Survey, and \\ F. L. JOHNSON, U.S. BUREAU OF MiNES
}

\begin{abstract}
SUMMARY
The results of geologic, geochemical, aeromagnetic, and mine and prospect investigations that were conducted in 1981-82 define the mineral-resource potential of the Eagle Rock Roadless Area of north-central Washington. The area has probable and substantiated resource potential for base and precious metals where the eastern part of the Index mining district extends into the roadless area; the Sunset mine, $400 \mathrm{ft}$ outside the area, has inferred copper resources, and 10 other properties in the roadless area have demonstrated resources for base and precious metals. The resource potential in the area is related to the Index batholith, which makes up the western part of the roadless area, and rocks to the east in the roadless area that are intruded by the Index batholith. There is little promise for the occurrence of energy resources in the roadless area.
\end{abstract}

\section{CHARACTER AND SETTING}

The Eagle Rock Roadless Area is located in the Northern Cascade Mountains and covers an area of about $54 \mathrm{sq} \mathrm{mi}$ in the Mt. Baker-Snoqualmie National Forest, Snohomish and King Counties, Washington. The roadless area consists of a mountainous terrain with glaciated valleys, mostly covered with a dense alpine forest; the area is bordered on the south, west, and north by the South and North Forks of the Skykomish River and on the east by the Beckler River. The roadless area may be reached by U.S. Highway 2 west from the town of Skykomish, Washington, or by county and USFS roads. Lower slopes of the roadless area are crisscrossed by numerous logging roads. Altitudes range from about $700 \mathrm{ft}$ along the Skykomish River to $6240 \mathrm{ft}$ at Gunn Peak, the highest promontory in the roadless area. The west side of the roadless area includes much of the Index mining district established in the late 1800's to mine copper, gold, and silver (Weaver, 1912).

The oldest rocks in the Eagle Rock Roadless Area are the highly deformed, faulted, and slightly metamorphosed rocks of Permian to Jurassic age. These rocks consist of ribbon chert, basalt, graywacke, shale, and minor limestone and have been complexly faulted to form a chaotic melange. The predominantly marine rocks are imbricated with mafic gneiss, probably of

${ }^{1}$ With contributions from R. W. Tabor, USGS, and D. K. Denton, R. B. McCulloch, and S. A. Stebbins, USBM.
Triassic age, and ultramafic rocks. The melange is preserved as a thick wedge between two major Tertiary plutons. Unconformably overlying the melange, and forming a part of the wedge, is the Eocene feldspathic sandstone of the Swauk Formation (Tabor and others, 1982).

Bordering the Eagle Rock Roadless Area on the east, and separated from the melange by a Tertiary batholith, are Cretaceous metamorphic rocks of the Tonga Formation, the Chiwaukum Schist, and related banded gneisses.

Two batholiths and associated volcanic rocks make up most of the roadless area. The Index batholith (Oligocene) is exposed west of the pre-Tertiary melange, and the Grotto batholith (Miocene) crops out to the east. In the southwest part of the roadless area, the dacitic Eagle Tuff is exposed in a downfaulted block. The Eagle Tuff consists of tuff and breccia and may represent the extrusive equivalent of the Grotto batholith (Tabor and others, 1982).

\section{MINERAL RESOURCES}

Two contiguous areas of base- and precious-metal resource potential in the roadless area have been identified, one substantiated and one probable. Analytical results from geochemical sampling of stream sediments, bedrock, and hydrothermally altered areas (Church and 

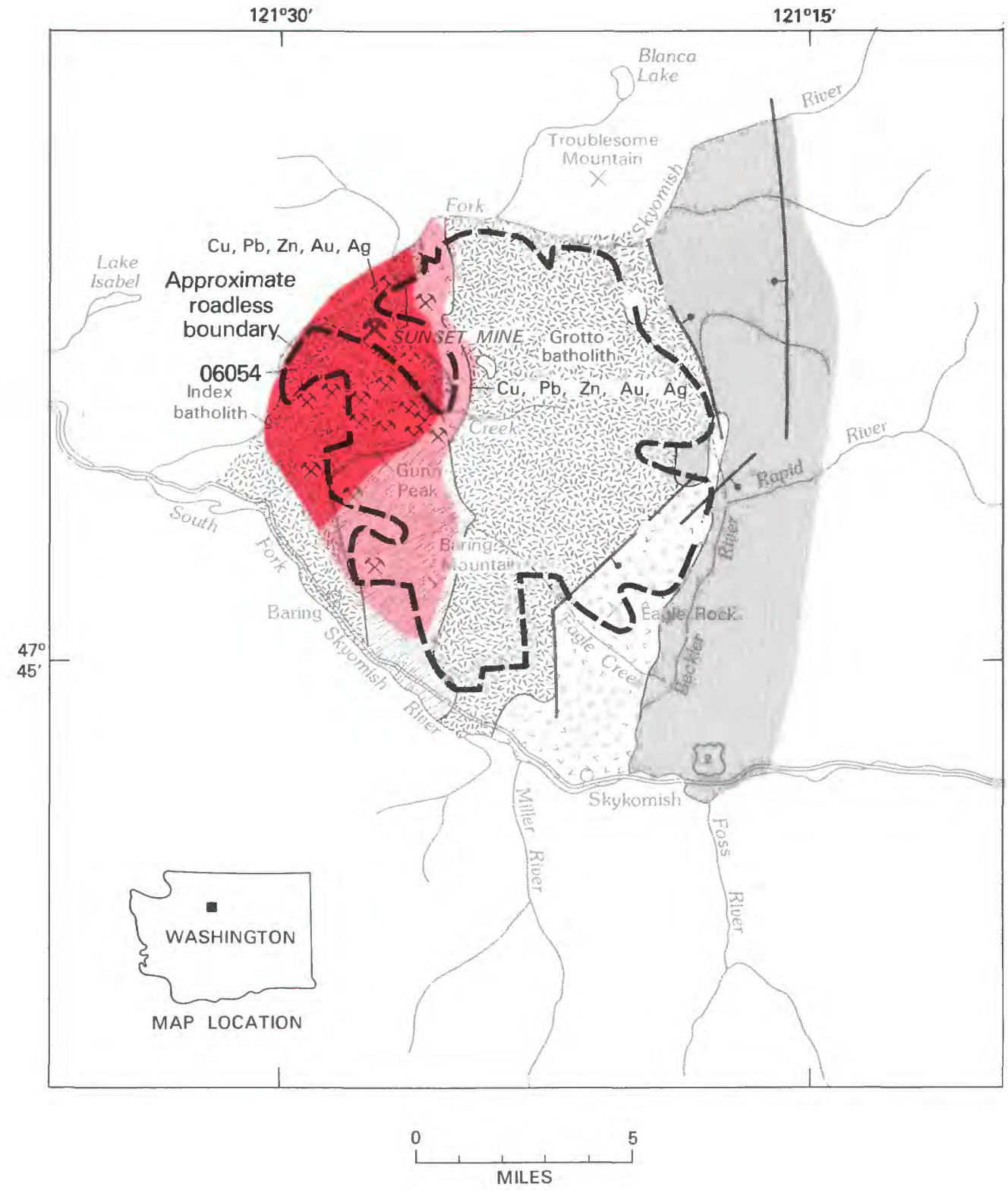

\section{EXPLANATION}

Geologic terrane with substantiated mineral-resource potential

Geologic terrane with probable mineral-resource potential

$\begin{array}{ll}\mathrm{Cu} & \text { Copper } \\ \mathrm{Au} & \text { Gold } \\ \mathrm{Pb} & \text { Lead } \\ \mathrm{Ag} & \text { Silver } \\ \mathrm{Zn} & \text { Zinc } \\ \mathrm{X} & \text { Mine or deposit } \\ \text { 爻 } & \text { Mine }\end{array}$

Volcanic and sedimentary rocks (Miocene to Eocene)

Plutonic rocks (Early Miocene to Oligocene)

Phyllite, schist, and gneiss (Cretaceous)

Metamorphosed marine sediments and volcanic rocks (Permian to Jurassic)

\section{Contact}

Fault--Bar and ball on downthrown side

Figure 298.-Eagle Rock Roadless Area, Washington. 
others, 1982), and a detailed interpretation of the geochemical data (Church, Frisken, and others, 1983) show many of the stream-sediment samples from drainage basins within the roadless area contain anomalous values for copper, cobalt, molybdenum, and lead. Samples from several of the basins contained anomalously high values of tungsten, silver, tin, and gold, and there are scattered anomalies of bismuth, zinc, and barium.

Aeromagnetic data that were evaluated along with the study of the Glacier Peak Wilderness (V. J. Flanigan and others, unpub. data, 1983) showed no particular magnetic signature that can be associated with the mineralization in the Index mining district.

Investigations of accessable mines and calculations of tonnage and grade were made to determine demonstrated and inferred mineral resources (Johnson and others, 1983). More than 950 mining claims had been located in or near the roadless area by 1980; 62 claims are patented and 42 underground and 5 surface workings were identified.

Mineral production from the roadless area has been small, but the Sunset mine, $400 \mathrm{ft}$ north of the roadless area boundary, was the State's second largest copper producer. Mining ceased in 1949 after production of 263,500 tons of ore, from which $156,000 \mathrm{oz}$ of silver, $1500 \mathrm{oz}$ of gold, and 12,912,000 lb of copper were recovered (Toepher, 1953). The Sunset mine contains 310,000 tons of inferred copper resources with an average content of 3.46 percent.

In addition to the Sunset mine, 10 mineral occurrences in and 6 near the roadless area have demonstrated resources. The grade at these occurrences ranges from 0.20 to 5.72 percent copper with as much as $4.2 \mathrm{oz}$ silver/ton, but most of the tonnage identified in the roadless area averages less than 0.5 percent copper. The 16 occurrences are considered to be in areas of probable or substantiated resource potential even through they are of small tonnage, low in grade, and difficult to access.

The east side of the Index mining district has been designated as an area with substantiated and probable mineral-resource potential. Veins containing sulfides $o c$ cur in the intrusive rocks. Weaver (1912) described veins containing quartz, chalcopyrite, bornite, galena, and sphalerite. Mineralization is associated with the intrusion of the Index batholith. Although the geochemical sampling was limited in the west side of the roadless area, the contents of lead, silver, molybdenum, copper, cobalt, and tungsten were anomalously high (Church, Frisken, and others, 1983).

The melange and Tertiary sandstone wedge intruded by the Index batholith has a probable mineral-resource potential. There are a few prospects in the zone, but anomalously high metal contents of zinc, molybdenum, copper, and tungsten were found in drainages from this area.

Sediment samples from almost all of the drainages from the Grotto batholith contain anomalously high values of many base metals. Lead, molybdenum, copper, and cobalt, are ubiquitous; silver, gold, and tungsten are common, and barium and manganese are each anomalously high in one drainage basin. Field investigations in the Monte Cristo and the Silver Creek mining districts less than $10 \mathrm{mi}$ to the north indicate that mineralization in these districts is associated with the Grotto batholith (Church and Johnson, this volume) and show the same geochemical signature (Church, Frisken, and others, 1983). However, erosion levels of the Grotto batholith in the Eagle Rock Roadless Area are apparently below the mineralized zones seen to the north and consequently no resource potential was identified. Field investigations of altered zones in the Grotto batholith revealed only low values for copper and silver.

\section{SUGGESTIONS FOR FURTHER STUDIES}

Further examination of the mineral system associated with the Grotto batholith where it may be overlain by volcanic strata in the southeast part of the roadless area is needed to determine if mineralization is present, and, if so, to further define the age, timing, and mode of emplacement of the mineralization. A more detailed investigation of mineralization suites and associated geochemical signatures, together with geologic mapping, is required to specify the exact nature and extent of mineralization within and adjacent to the entire roadless area.

\section{REFERENCES}

Church, S. E., Mosier, E. L., Frisken, J. G., Arbogast, B. F., and McDougal, C. M., 1982, Analytical results from stream sediments and panned concentrates from stream sediments collected from the Monte Cristo and Eagle Rock study areas, Washington: U.S. Geological Survey Open-File Report 82-303, $83 \mathrm{p}$.

Church, S. E., Frisken, J. G., Mosier, E. L., and Willson, W. R., 1983, Geochemical map of the Eagle Rock and Glacier Peak Roadless Areas, Snohomish and King Counties, Washington: U.S. Geological Survey Miscellaneous Field Studies Map MF-1380-D, scale $1: 100,000$.

Church, S. E., Tabor, R. W., and Johnson, F. L., in press, Mineral resource potential map of the Eagle Rock Roadless Area, Snohomish and King Counties, Washington: U.S. Geological Survey Miscellaneous Field Studies Map MF-1380-B, scale 1:50,000.

Johnson, F. L., Denton, D. K., McCulloch, R. B., and Stebbins, S. A., 1983, Mineral investigation of the Eagle Rock RARE II Area, Snohomish and King Counties, Washington: U.S. Bureau of Mines Open-File Report MLA 54-83, 20 p. 
Tabor, R. W., Frizzel, V. A., Jr., Yeats, R. S., and Whetten, J. T., 1982, Geologic map of the Eagle Rock and Glacier Peak Roadless Areas, Snohomish and King Counties, Washington: U.S. Geological Survey Miscellaneous Field Studies Map MF-1380-A, scale, $1: 100,000$.
Toepfer, P. H., 1953, Investigations of the Sunset copper mine, Snohomish County, Washington: U.S. Bureau of Mines Report of Investigations $4989,9 \mathrm{p}$.

Weaver, C. E., 1912, Geology and ore deposits of the Index mining distict: Washington Geological Survey Bulletin 7, 93 p. 


\title{
GLACIER PEAK ROADLESS AREA, WASHINGTON
}

\author{
By S. E. Church, ${ }^{1}$ U.S. GeOlogical Survey, and \\ F. L. JOHNSON, U.S. BUREAU OF MineS
}

\begin{abstract}
SUMMARY
A mineral survey by the USGS and the USBM from 1978 to 1982 outlined areas of mineral-resource potential in the Glacier Peak Roadless Area, Washington. Substantiated resource potential for base and precious metals has been identified in four mining districts included in whole or in part within the boundary of the roadless area. Several million tons of demonstrated base-and precious-metal resources occur in numerous mines in these districts. Probable resource potential for precious metals exists along a belt of fractured and locally mineralized rock extending northeast from Monte Cristo to the northeast edge of the roadless area.
\end{abstract}

\section{CHARACTER AND SETTING}

The Glacier Peak Roadless Area is a glaciated rugged mountainous terrain located in the Northern Cascade Mountains. It covers an area of about $90 \mathrm{sq} \mathrm{mi} \mathrm{in} \mathrm{the}$ Mount Baker-Snoqualmie National Forest, Snohomish County, Washington. The area is bounded on the south by the North Fork of the Skykomish River; the Eagle Rock Roadless Area lies just to the south. The Sauk River and the Glacier Peak Wilderness study area bound the area on the north and east. The relief is great; altitudes range from about $1500 \mathrm{ft}$ near the North and South Forks of the Sauk River to about $7800 \mathrm{ft}$ at Sloan Peak. Glacier-clad peaks rise 4000 to $4500 \mathrm{ft}$ above the site of the old mining town of Monte Cristo.

Access to the roadless area from the north is by gravel logging roads. Roads to Monte Cristo come east over Barlow Pass from Granite Falls and south from Darrington along the Sauk River. The access to the area from the south is along paved and gravel county roads from U.S. Highway 2.

The Glacier Peak Roadless Area is divided roughly into two geologic terranes by the Straight Creek fault, a major somewhat discontinuous north-south structure with probable major pre-Tertiary strike-slip movement (Vance and Miller, 1981). On the north, the fault separates low-grade melange terrane (Misch, 1966) on the west from higher-grade metamorphic rocks of the North Cascades crystalline core. The metamorphic

${ }^{1}$ With contributions from R. W. Tabor, USGS, and D. K. Denton, S. R. Iverson, R. B. McCulloch, S. A. Stebbins, and R. B. Stotelmeyer, USBM. rocks east of the Straight Creek fault consist of Chiwaukum Schist, banded garnet-biotite gneiss derived from it, and gneissic Upper Cretaceous Sloan Creek plutons (Tabor and others, 1982a, b).

Within the Glacier Peak Roadless Area, the Straight Creek fault has been intruded by the Miocene Grotto batholith, the associated Monte Cristo stock, and the Oligocene Goblin Creek stock (Tabor and others, 1982b). Upper Eocene volcanic rocks of Barlow Pass were intruded by the plutons and contain many of the mineralized zones. Miocene breccias of Kyes Peak unconformably overlie the folded Barlow Pass volcanic rocks and appear to be roughly equivalent to the Grotto batholith in age and composition. These volcanic breccias may represent a catastrophic filling of a caldera. Mineralization is mostly associated with the Grotto batholith and late Miocene tonalite stocks exposed in Silver Creek (Tabor and others, 1982a).

Analytical results from geochemical sampling of stream sediments, bedrock, and hydrothermally altered areas (Church and others, 1982), and a detailed interpretation of the geochemical data showed the presence of anomalous metal concentrations in stream sediments. These include gold, arsenic, mercury, cobalt, copper, molybdenum, tungsten, zinc, lead, silver, and in places, some antimony, manganese, bismuth, and tin. Effects of hydrothermal alteration are widespread.

Aeromagnetic data were analysed as a part of the study of the Glacier Peak Wilderness study area. No particular magnetic signature can be associated with mineralization except that a magnetic low appears to persist along the axis of mineralization. 

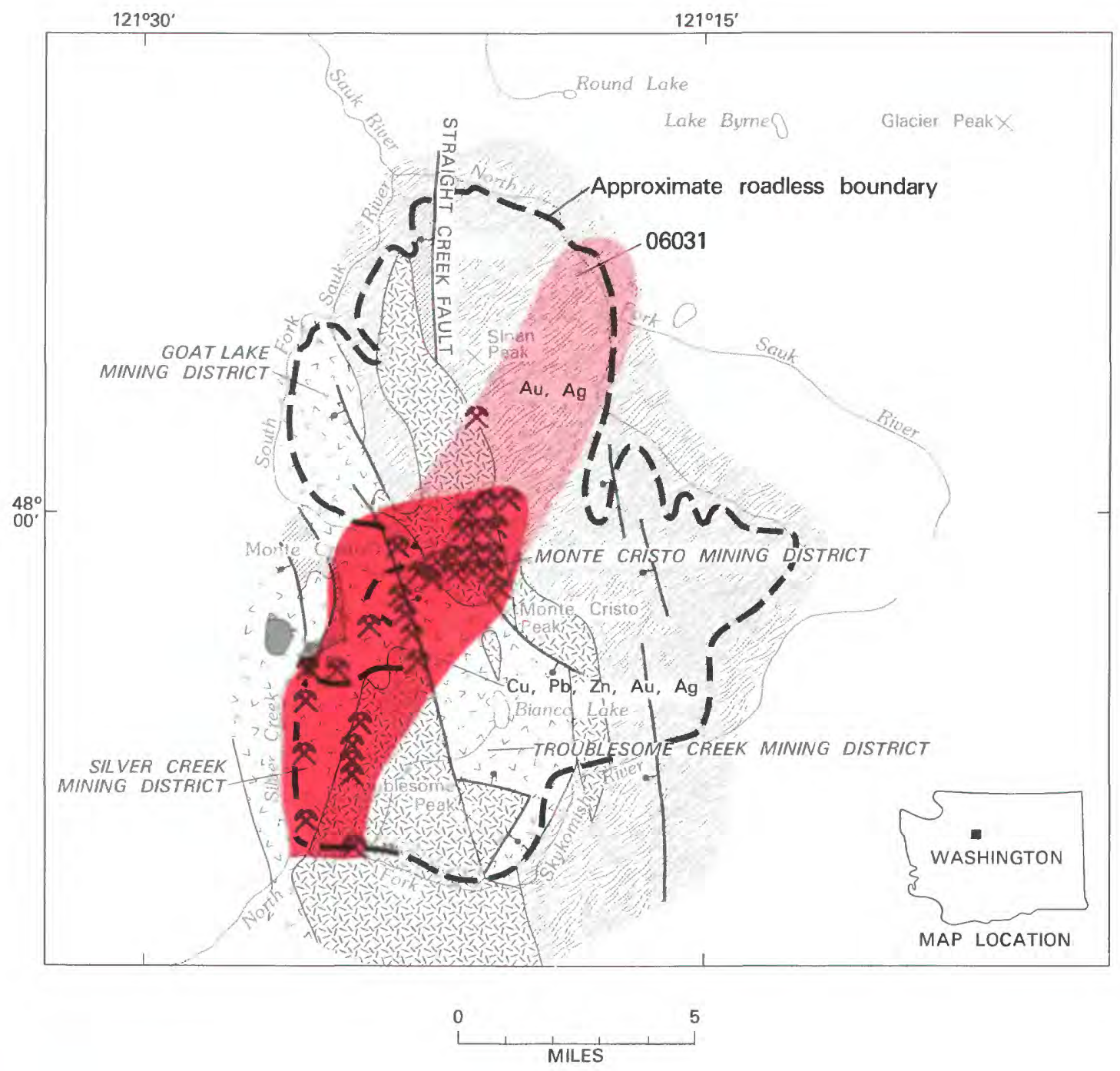

\section{EXPLANATION}

Geologic terrane with substantiated mineral-resource potential

Geologic terrane with probable mineral-resource potential

$\begin{array}{ll}\mathrm{Cu} & \text { Copper } \\ \mathrm{Au} & \text { Gold } \\ \mathrm{Pb} & \text { Lead } \\ \mathrm{Ag} & \text { Silver } \\ \mathrm{Zn} & \text { Zinc } \\ \mathrm{X} & \text { Mine or deposit }\end{array}$

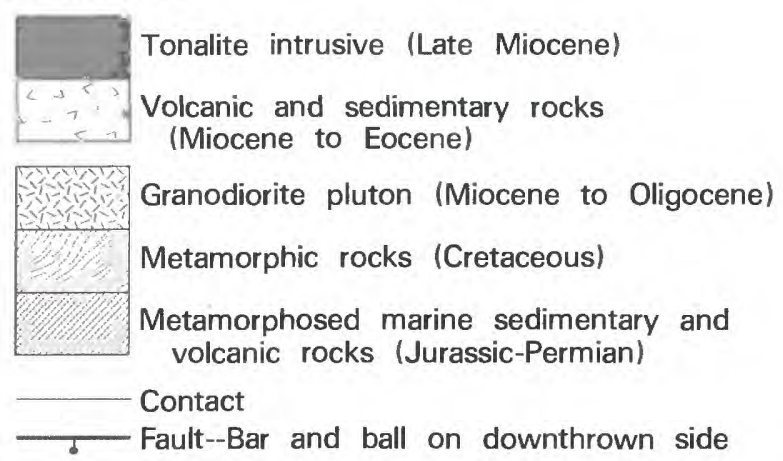

Figure 299.-Glacier Peak Roadless Area, Washington. 


\section{MINERAL RESOURCES}

Early mining activity in the Monte Cristo mining district began in 1874 and many claims were filed along Silver Creek, a tributary of the North Fork of the Skykoinish River. The ore contained gold, silver, lead, and arsenic, with lesser amounts of zinc and molybdenum. Most of the mining activity in the district was in the Glacier Creek drainage, a tributary of the South Fork of the Sauk River. Spurr (1901) made a classic study of the mineralization in the Monte Cristo mining district; he concluded that the ores were formed by downward percolating ground waters. $\mathrm{He}$ also argued that the precious metals did not persist at depth. His study, along with labor, transportation, and capital problems encountered shortly thereafter, caused the collapse of mining activity in the Monte Cristo district about 1903 (Woodhouse, 1979, p. 169-198).

More than 4000 mining claims had been located in the roadless area by the summer of 1979 , and 196 patented claims are in or within $1 \mathrm{mi}$ of the area. About 160 underground and 40 surface workings were identified. The workings are so numerous in the four districts, particularly in the Monte Cristo and Silver Creek districts, that only the mine workings with resources are shown (see Johnson and others, 1983 for detailed descriptions). More than $50,000 \mathrm{ft}$ of underground workings were mapped and sampled. Twenty-ight properties in the roadless area and five near it contain several million tons of demonstrated resources. The most significant deposit in the roadless area is developed by the Justice, Golden Cord, Mystery, Pride of the Woods, New Discovery, and Pride of the Mountains mines. Gold-andsilver-rich quartz veins and lenses containing varying amounts of pyrite, pyrrhotite, arsenopyrite (arsenic), sphalerite (zinc), galena (lead), chalcopyrite (copper), and stibnite (antimony) occur in a northeast-trending shear zone over an exposed strike length of $5800 \mathrm{ft}$. In addition, a large low-grade copper-molybdenum porphyry deposit may underlie part of the roadless area in the Silver Creek district. Production from the roadless area is estimated to have been in excess of 230,000 tons of ore, all from the above mines.

The Silver Creek, Troublesome Creek, Goat Lake, and Monte Cristo mining districts (Johnson and others, 1983) contain mines having demonstrated resources for both base and precious metals. Most of the resources occur in steeply dipping, northeast-trending shear zones. Gold, silver, copper, lead, zinc, arsenic, and antimony occur in many of the mineralized zones that roof the Grotto batholith and in zones that appear to be closely related to the Miocene Monte Cristo stock. Mineralization is controlled by a preexisting transverse fracture system (Spurr, 1901; Grant, 1969) that includes two mineralized breccia-pipe structures (Tabor and others, 1982a).

On the basis of the combined studies, the bulk of the roadless area that is included in the four mining districts, principally the Silver Creek and Monte Cristo, has substantiated resource potential for additional mineral resources for base and precious metals.

Studies of adits and prospect pits along the transverse structure east of Monte Cristo revealed only lowgrade demonstrated resources. However, gold, silver, and mercury anomalies indicate a potential for preciousmetal veins in the Sloan Peak area. This zone is shown on the map as having probable mineral resource potential.

\section{SUGGESTIONS FOR FURTHER STUDIES}

Several geologic, geocheunical, and geophysical trends intersect at the loci of major mineralization in the Monte Cristo and Silver Creek mining districts. A subtle change in character of the geocheinical suite from the Silver Creek to the Monte Cristo districts may reflect these structural controls, but alternative hypotheses are also viable. For example, the mineralization at Monte Cristo may be the result of several episodes of mineralization, or the differences may simply reflect a temperature gradient. Further examination of these trends is essential to document the nature of the control of mineralization.

\section{REFERENCES}

Church, S. E., Mosier, E. L., Frisken, J. G., Arbogast, B. F., and McDougal, C. M., 1982, Analytical results from stream sediments and panned concentrates from stream sediments collected from the Monte Cristo and Eagle Rock study areas, Washington: U.S. Geological Survey Open-File Report 82-303, 83 p.

Church, S. E., Tabor, R. W., and Johnson, F. L., in press, Mineral resource potential map of the Glacier Peak Roadless Area, Snokomish County, Washington: U.S. Geological Survey Miscellaneous Field Studies Map MF-1380-C, scale 1:50,000.

Grant, A. R., 1969, Chemical and physical controls for base-metal deposition in the Cascade Range of Washington: Washington Division of Mines and Geology Bulletin 58, $107 \mathrm{p}$.

Johnson, F. L., Denton, D. K., McCulloch, R. B., Stebbins, S. A. Iverson, S. K., and Stotelmeyer, R. B., 1983, Mineral investigation of the Glacier Peak RARE II Area (no. 6031), Snokomish County, Washington: U.S. Bureau of Mines Open-File Report MLA 75-83, 27 p.

Misch, Peter, 1966, Tectonic evolution of the Northern Cascades of Washington State-a west-cordilleran case history, in A symposium on the tectonic history and mineral deposits of the western Cordillera in British Columbia and in neighboring parts of the U.S.A.: Canadian Institute of Mining and Metallurgy Special Volume, v. 8, p. 101-148. 
Spurr, J. E., 1901, The ore deposits of Monte Cristo, Washington: U.S. Geological Survey Annual Report 22, pt. 2, p. 777-865.

Tabor, R. W., Frizzell, V. A., Jr., Yeats, R. S., and Whetten, J. T., 1982a, Geologic map of the Eagle Rock and Glacier Peak Roadless Areas, Snohomish and King Counties, Washington: U.S. Geological Survey Miscellaneous Field Studies Map MF-1380-A, scale 1:100,000.

Tabor, R. W., Zartman, R. E., and Frizzell, V. A., 1982b, Possible accreted terranes in the North Cascades Crystalline Core, Washington [abs.]: Geological Society of America Abstracts with Programs, v. 14, no. 4, p. 239.
Vance, J. A., and Miller, R. B., 1981, The movement history of the Straight Creek Fault in Washington State: The last 100 million years (mid-Cretaceous to Holocene) of geology and mineral deposits in the Canadian Cordillera: Cordillerean Section Geological Association of Canada, Programs with Abstracts, v. 6 , p. 39-41.

Woodhouse, P. R., 1979, Monte Cristo: The Mountaineers, Seattle, $307 \mathrm{p}$. 


\title{
GLACIER PEAK WILDERNESS STUDY AREA, WASHINGTON
}

\author{
By S. E. Church, ${ }^{1}$ U.S. GeOlogical Survey, and \\ R. B. Stotelmeyer, U.S. Bureau of Mines
}

\begin{abstract}
SUMMARY
Geologic, geochemical, gravity, aeromagnetic, and mine and prospect surveys were conducted in 1976-82 to evaluate the mineral-resource potential of the Glacier Peak Wilderness study area and proposed additions. In the study area, six areas containing several base and precious metals have been identified that have substantiated mineral-resource potential, two of which are in areas recommended for wilderness addition. An additional 10 areas have probable mineralresource potential. The most important demonstrated resource identified is the porphyry copper-molybdenum deposit at Glacier Peak mine near the center of the wilderness study area, where a deposit totaling 1.9 billion tons of mineralized rock has been delineated by drilling. A possible geothermal potential exists on the east side of the Glacier Peak volcano, and a possible 24-million-cu-yd cinder resource is identified at the White Chuck Cinder Cone in the wilderness study area, but both are remote and no resources were identified. No other energy resource potential was identified in this study.
\end{abstract}

\section{CHARACTER AND SETTING}

The Glacier Peak Wilderness study area encompasses $726 \mathrm{sq} \mathrm{mi}$ of the Mt. Baker-Snoqualmie and Wenatchee National Forests, Chelan, Skagit, and Snohomish Counties, north-central Washington. Adjoining recommended additions totaling $141 \mathrm{sq}$ mi are included in this study. The study area extends south about $40 \mathrm{mi}$ from the North Cascades National Park, along the crest of the northern Cascade Range. It consists of rugged highly varied alpine terrain cut by many deep river valleys. Dense Douglas fir dominate the western slopes and contrast with the more open larch and pine forests on the east side of the Cascade crest. Glaciers and permanent snow fields cover extensive areas west of the crest. The terrain is dominated by the volcanic cone of Glacier Peak, which has an altitude of $10,541 \mathrm{ft}$ and rises $3000-4000 \mathrm{ft}$ above most of the nearby summits.

Access to the study area is by generally well maintained and graded trails or gravel logging roads leading up major valleys from Darrington, Marblemount, Stehekin, Holden, Trinity, and Lake Wenatchee. Major trail routes in the study area cross the mountain passes, and many minor trails exist in the study area but are generally rough and infrequently maintained.

\footnotetext{
${ }^{1}$ With contributions from A. B. Ford and V. J. Flanigan, USGS, and F. L. Johnson, E. L. McHugh, F. E. Federspiel, D. K. Denton, and S. A. Stebbins, USBM.
}

The North Cascades crystalline core complex is composed of pre-Tertiary gneiss, schist, and foliated igneous rocks. The regional framework and evolution of the crystalline core complex and its complicated structural and metamorphic history have been described by Misch (1966). Many large intrusions of pre-Tertiary age were altered by metamorphism and accompanying intense deformation. Following metamorphism, a large fault trough, the Chiwaukum graben, developed in the early Tertiary just south of the study area and was filled with locally derived sediments. The Straight Creek fault, a major structural feature of the area, separates lowgrade metamorphic rocks to the west from the more metamorphosed crystalline core complex. Plutonic bodies of Cretaceous to Miocene age have intruded this complex. Mineralization appears to be associated primarily with igneous intrusions of Miocene age, and many of the mineralized areas are located along transverse zones of structural weakness (Grant, 1969). The Cascades were uplifted and deeply dissected by erosion prior to the building of andesitic volcanos, such as Glacier Peak, in Quaternary time.

\section{MINERAL RESOURCES}

To obtain data for the mineral-resource assessment of 


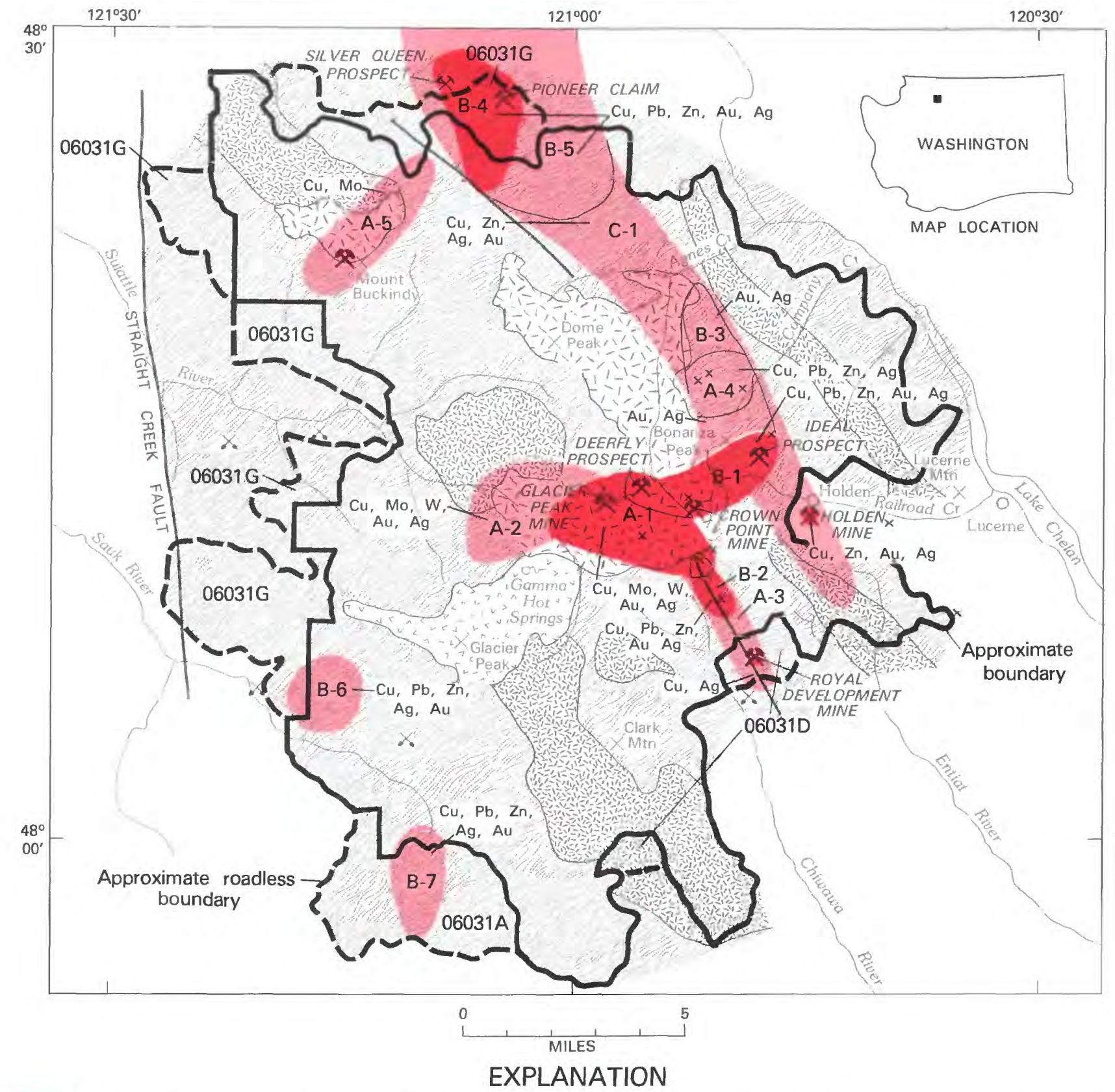

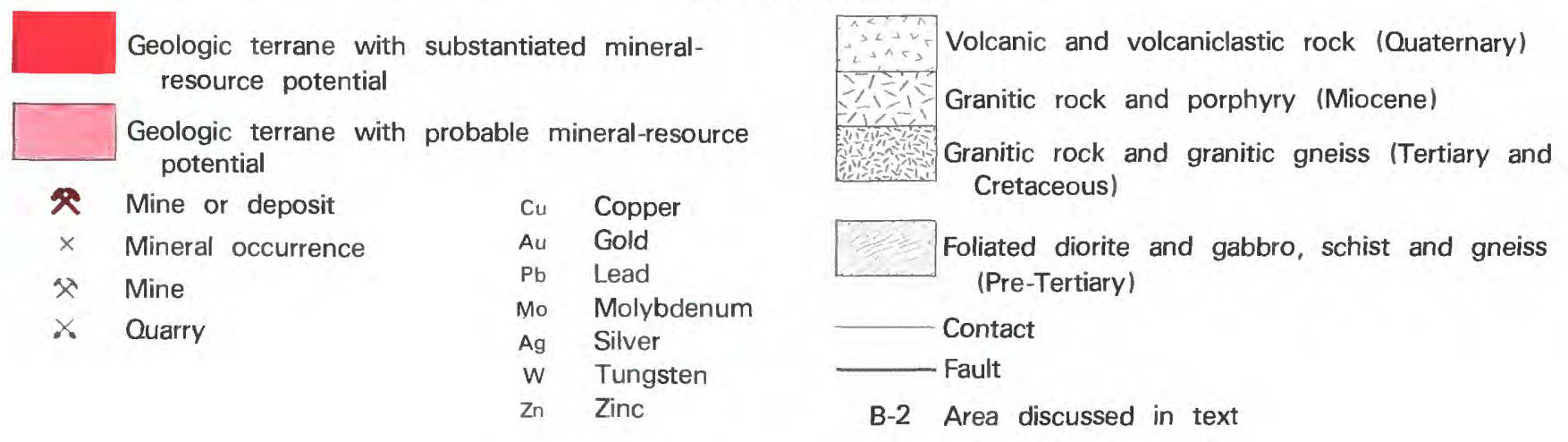

Figure 300.-Glacier Peak Wilderness study area, Washington. 
the study area, stream-sediment geochemistry surveys (Church and others, 1982), geochemical studies of the bedrock, gravity (V. J. Flanigan, unpub. data), aeromagnetic studies, and geologic mapping were conducted. Significant results of the many prior geologic investigations (Ford, 1983) and mineral-exploration studies (Grant, 1982) have been reviewed in a sunimary report (Church and others, in press). Mineral occurrence investigations of previously mined and prospected areas were conducted by Stotelmeyer and others (1982).

The principal mineral deposits in the Glacier Peak Wilderness study area are associated with porphyrycopper-molybdenum-type systems; the resources and reserves defined by subsurface drilling at the Glacier Peak mine are examples. The major area of substantiated resource potential (A-1, on map) is around Glacier Peak mine site, which has 1.9 billion tons of demonstrated resources containing 0.334 percent copper, with molybdenum, tungsten, gold, and silver as possible byproducts; the area contains 17 patented claims. The deposit is a late phase of the Cloudy Pass pluton that has disseminations and veinlets of sulfide minerals. The axis of the deposit trends east-west and is marked by a linear regional aeromagnetic low within the Cloudy Pass aeromagnetic anomaly. Nearby areas of probable mineral-resource potential A-2, A-3, and A-4 show similar geologic characteristics and geochemical suites of elements, but either do not contain demonstrated resources, or have less favorable indications of mineral potential. The Royal Development mine, located in the reconimended addition area to the south, is in a small area of substantiated resource potential in a breccia pipe containing inferred resources of 8.5 million tons of 0.4 percent copper and $0.9 \mathrm{oz}$ silver/ton. Similar breccia pipe structures are present at the north end of area A-3. Area A-4 also contains a relatively unexplored tactite zone having high-grade occurrences of silver, lead, and zinc associated with copper.

The area A-5, in the vicinity of Mt. Buckindy, has a probable resource potential for copper and molybdenum in porphyry-type deposits. Widespread geochemical anomalies and localized alteration are present; two breccia pipes are exposed on Mt. Buckindy. Five exploration holes in an area near Mt. Buckindy indicate demonstrated resources having 0.34 percent copper and 1.3 percent molybdenum content.

Peripheral to the major porphyry-copper systems are several areas having resource potential for silver and gold along with base metals. Area B-1 has substantiated mineral-resource potential and contains three known deposits with demonstrated resources. The Deerfly prospect, a finely dispersed vein deposit probably associated with the Glacier Peak mineralizing system, has demonstrated resources of $\mathbf{1 7 4 , 0 0 0}$ tons containing
$0.75 \mathrm{oz}$ silver/ton, with some gold and copper. The Crown Point mine has demonstrated resources of 1300 tons that contains $2.9 \mathrm{oz}$ silver/ton along shear zones in the Cloudy Pass pluton; other contained metals include copper ( 2.6 percent), lead ( 0.39 percent), and zinc ( 0.72 percent). The Ideal prospect is on a fissure vein containing demonstrated resources of 34,000 tons with $1.42 \mathrm{oz}$ silver/ton. Area B-2 also has a substantiated resource potential for base and precious metals. Area B-3 to the north of area B-1 has a probable potential for precious metals, based on geochemical anomalies as well as on examination of the prospect pits in this area.

Area B-4 has substantiated base and precious metal resource potential, in large part located in the recommended wilderness addition to the north, which contains a major sulfide vein at the Pioneer patented claims. Demonstrated and inferred resources are 734,000 tons of silver-lead-zinc ore at $6.46 \mathrm{oz}$ silver/ton, 6.4 percent lead, and 6.5 percent zinc. Copper $(0.52$ percent) and gold $(0.015 \mathrm{oz} /$ ton) are also present. This deposit lies adjacent to the Triplets, a very large breccia pipe. The Silver Queen prospect just outside the wilderness addition boundary, also located in this same zone, is on a sulfide vein in the Cascade River Schist of Misch (1966); an estimated 69 tons of material are in highgrade pods that contain silver ( $4.8 \mathrm{oz}$ silver/ton), lead (5.0 percent), zinc (2.0 percent), and associated copper, gold, and cadmium. An adjacent area, B-5, has similar geochemical, geophysical, and geologic features and is designated as a zone having probable mineral-resource potential.

Area B-6, near Red Mountain, is located in a regional transverse shear zone (Grant, 1969) and is associated with a granitic plug; it also has several base- and precious-metal geochemical anomalies, and has a probable mineral-resource potential.

Area B-7, located mainly in a reconumended addition south of the wilderness is based largely on geochemical anomalies associated with volcanic plugs. Company assay records from an adit in area B-7 indicate a silver vein having $13.85 \mathrm{oz}$ silver/ton and 8.3 percent copper, but there are no indications that this is anything other than a localized high-grade occurrence. This area has probable resource potential for base and precious metals.

Area C-1, delineated by the outcrop pattern of the pre-Tertiary schist belt, is marked by high geochemical anomalies of acid-soluble zinc, and has a probable mineral-resource potential. The Holden mine, which is about 1 mi east of the study area and is in a small area of substantiated mineral-resource potential, lies in this unit. Ores from the mine are not typical of a porphyrycopper system, and ages obtained from alteration zones in the mine indicate that these ores formed earlier than 
those associated with the Cloudy Pass pluton. From 1938 to 1957,10 million tons of copper-zinc-gold-silver ore were produced from the Holden, which was the largest copper mine in the State. Demonstrated resources of 3 million tons remain in the Holden mine; ores contain 1.1 percent copper, 0.3 percent zinc, $0.2 \mathrm{oz}$ silver/ton and $0.06 \mathrm{oz}$ gold/ton. The tailings pile at the Holden mine also contains resources of gold, silver, and zinc.

Several nonmetallic deposits occur in the study area; they include cinder at the White Chuck Cinder Cone, limestone, marble, pumice, and garnet. The occurrences are in remote areas, however, and substitute materials closer to markets are available elsewhere.

Investigations of the three hot springs in or near the study area indicate a reservoir temperature at Gamma Hot Springs between $350^{\circ}$ and $410^{\circ} \mathrm{F}$, but studies by Brook and others (1979) indicated a reservoir of limited size. Consistent with geologic information, gravity data suggest a thick pile of volcanic rock in the area (Tabor and Crowder, 1969), but the area is in rugged terrain, is remote, and no geothermal resources are identified.

\section{SUGGESTIONS FOR FURTHER STUDIES}

Additional, more detailed studies of the schist and gneiss belt (area C-1), and further work on the Holden mine are warranted to define the deposit type and outline areas for potential exploration. Detailed mapping, geochemical, isotopic, and geophysical studies, and exploration drilling are needed to establish the exact mineral-resource potential, particularly in areas $\mathrm{A}-1$, $\mathrm{A}-3, \mathrm{~A}-5, \mathrm{~B}-1, \mathrm{~B}-2$, and B-4. Further investigation of the geothermal potential may also be warranted.

\section{REFERENCES}

Brook, C. A., Mariner, R. H., Mabey, D. R., Swanson, J. R., Guffanti, Marianne, and Muffler, L.J.P., 1979, Hydrothermal convection systems with reservoir temperatures $>90^{\circ} \mathrm{C}$, in Muffler, L.J.P. ed., Assessment of geothermal resources of the United States-1978: U.S. Geological Survey Circular 790, p. 18-85.

Church, S. E., Mosier, E. L., Frisken, J. G., Arbogast, B. F., McDougal, C. M., and Evans, J. G., 1982, Analytical results for stream sediments and panned concentrates from stream sediments collected from the Glacier Peak Wilderness and adjacent areas: U.S. Geological Survey Open-File Report 82-780, 227 p.

Church, S. E., Ford, A. B., Flanigan, V. J., and Stotelmeyer, R. B., in press, Mineral resource potential map of the Glacier Peak Wilderness and adjacent areas, Chelan, Skagit, and Snohomish Counties, Washington: U.S. Geological Survey Miscellaneous Field Studies Map MF-1652-A.

Ford, A. B., 1983, Annotated guide to geologic reports and maps of the Glacier Peak Wilderness and adjacent areas, Northern Cascades, Washington: U.S. Geological Survey Open-File Report 83-97, 27 p.

Grant, A. R., 1969, Chemical and physical controls for base-metal deposition in the Cascade Range of Washington: Washington Division of Mines and Geology Bulletin 58, $107 \mathrm{p}$.

Grant, A. R., 1982, Summary of economic geology data for the Glacier Peak Wilderness, Chelan, Snohomish, and Skagit Counties, Washington: U.S. Geological Survey Open-File Report 82-408, $37 \mathrm{p}$.

Misch, Peter, 1966, Tectonic evolution of the Northern Cascades of Washington State-a west-cordilleran case history, in Symposium on the tectonic history and mineral deposits of the western Cordillera in British Columbia and in neighboring parts of the USA: Canadian Institute of Mining and Metallurgy Special Volume 8, p. 101-148.

Stotelmeyer, R. B., Johnson, F. L., McHugh, E. L. Federspiel, F. E., Denton, D. K., Jr., and Stebbins, S. A., 1982, Mineral investigation of the Glacier Peak Wilderness and adjacent areas, Chelan, Skagit, and Snohomish Counties, Washington: U.S. Bureau of Mines Open-File Report MLA 89-82, 36 p.

Tabor, R. W., and Crowder, D. F., 1969, On batholiths and volcanoes-intrusion and eruption of Late Cenozoic magmas in the Glacier Peak area, North Cascades, Washington: U.S. Geological Survey Professional Paper 604, 67 p. 


\title{
GLAGIER VIEW ROADLESS AREA, WASHINGTON
}

\author{
By Russell C. EVARTs, U.S. Geological SuRVey, and \\ DONALD J. BARNES, U.S. BUREAU OF MineS
}

\begin{abstract}
SUMMARY
Surveys conducted in 1980 and 1982 indicate little promise for the occurrence of metallic mineral resources in the Glacier View Roadless Area, Washington. Small, thin lenses of coal may be present at depth near the western edge of the area, but larger coal deposits occur at or near the surface outside the roadless area. Oil and gas may be in the subsurface, but the evaluation of the potential requires additional information obtainable only by drilling.
\end{abstract}

\section{CHARACTER AND SETTING}

The Glacier View Roadless Area is within the Snoqualmie National Forest on the heavily forested western slope of the Cascade Range about $\mathbf{4 0} \mathrm{mi}$ southeast of Tacoma, Washington. It is a north-south-elongated area bounded on the east by Mount Rainier National Park. The roadless area comprises $4.7 \mathrm{sq} \mathrm{mi}$ at altitudes between 3300 and $5500 \mathrm{ft}$, and offers spectacular vistas of the western flank of Mount Rainier and its glacial carapace. The roadless area is accessible by a USFSroad network originating at Washington State Highway 706, 3 mi east of Ashford.

The geology of the roadless area is dominated by a sequence of sedimentary rocks dipping steeply to the east, forming the eastern limb of a major anticline (Hammond, 1980). Most of the sedimentary rocks are Tertiary sandstone, conglomerate, and breccia derived from erosion of a volcanic source terrane. Volcanic rocks such as lava flows and ash-flow tuff are widespread but not abundant. Rocks similar to these make up much of Mount Rainier National Park to the east, and are described by Fiske and others (1963). Along the western margin of the roadless area, the volcanic sedimentary rocks overlie Eocene arkosic sandstone and siltstone which locally contain beds of impure bituminous coal. These lower beds evidently represent deposits in part of a Mississippi-type deltaic system that extended westward from a broad granitic highland during Eocene time (Buckovic, 1979). The overlying volcanic and sedimentary rocks represent the initial products of volcanic activity in the Cascade Range.

Many small dikes and sills of mafic composition occur throughout the sedimentary sequence. In addition, a larger body of granitic rock intrudes volcanic and sedimentary rocks in the northern part of the Glacier View Roadless Area. The granitic intrusion is similar to parts of the Tertiary Tatoosh pluton in Mount Rainier National Park (Fiske and others, 1963) and was probably emplaced during the same igneous episode.

All rocks in the roadless area have been affected by low-grade zeolite-facies metamorphism, and rocks immediately adjacent to the granitic intrusive body have been moderately altered to hornfels. However, there are no areas of extensive hydrothermal alteration, and sulfide minerals are uncommon.

Geologic mapping and geochemical sampling of stream sediments and altered bedrock were accomplished in 1980. Records of mining activity were searched in 1982. The detailed results of these studies were published by Evarts and others (1983).

\section{MINERAL RESOURCES}

The Glacier View Roadless Area offers little promise for the occurrence of metallic mineral deposits. No significant indications of hydrothermal alteration or concentrations of sulfide or other metallic minerals were encountered during the mapping. Analyses of streamsediment and bedrock samples revealed no geochemical anomalies attributable to mineralization. Although six coal claims were located in the roadless area between 1905 and 1907, no coal was found at the described locations or anywhere else in the roadless area. Coal beds are exposed immediately to the west, and the geologic structure indicates coal is probably present beneath the surface in the roadless area. However, the coal beds are 


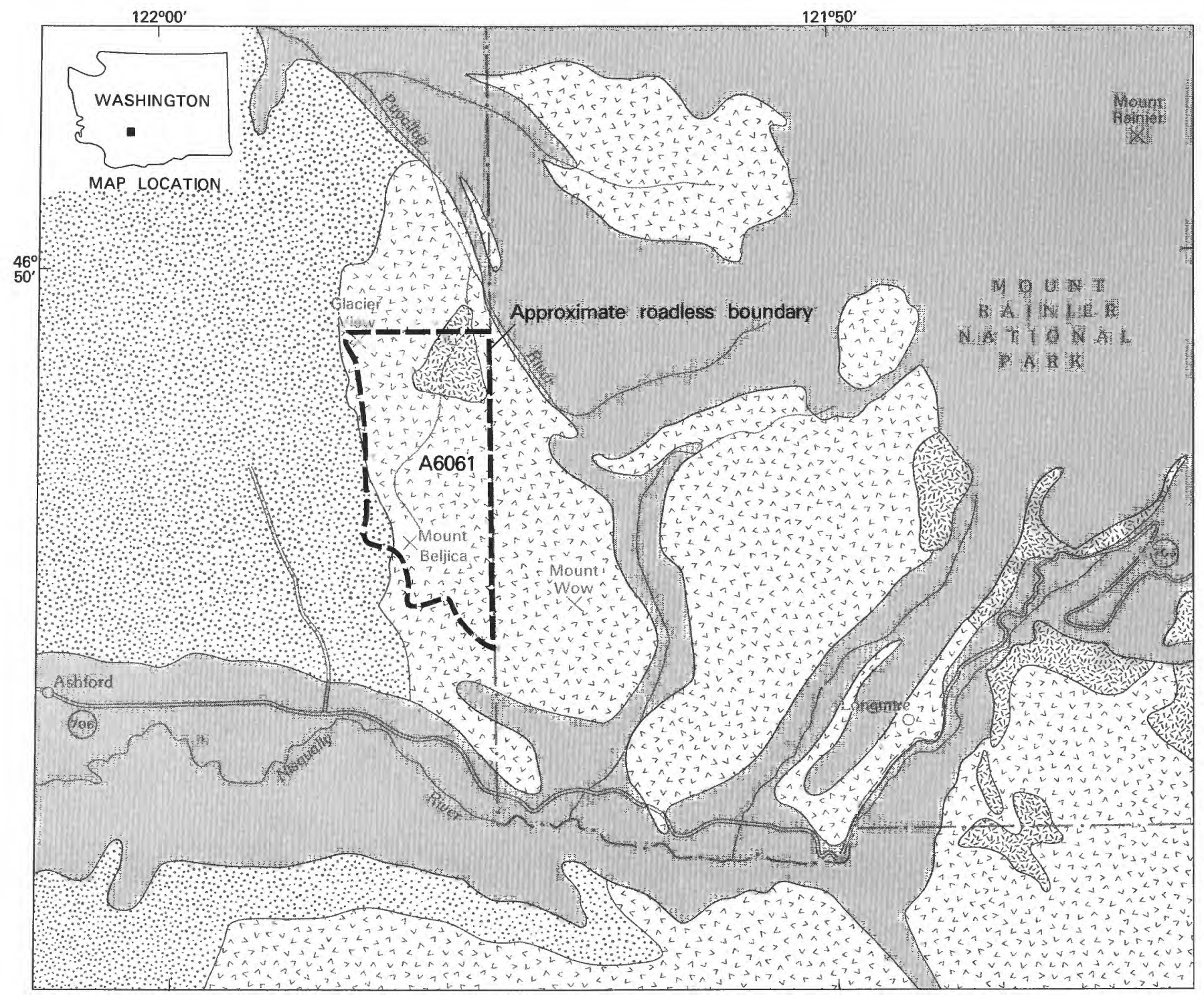

0 $\stackrel{5}{5}$

MILES

\section{EXPLANATION}

Volcanic and sedimentary deposits of Mount Rainier (Quaternary)

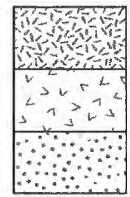

Granitic rocks (Tertiary)

Volcanic and sedimentary rocks (Tertiary)

Arkosic sandstone, thin coal layers (Eocene)

Contact

Figure 301.-Glacier View Roadless Area, Washington. 
relatively thin and of limited extent, and analyses of samples from the exposed beds show the coal to be an impure bituminous variety with a low heat value. Furthermore, recovery by conventional coal-mining techniques would be difficult because of intensive minor faulting. About half of the roadless area is covered by recent oil and gas leases; the geology is permissive for the occurrence of these commodities, but without additional supporting geophysical or drilling information, the resource potential cannot be adequately evaluated.

\section{SUGGESTIONS FOR FURTHER STUDIES}

Available data indicate little promise for the occurrence of mineral resources in the Glacier View Roadless Area. If further study and exploration for mineral deposits is contemplated, they should be concentrated in and adjacent to the granitic pluton in the northern part of the area, because most mineral deposits in the Cascades are associated with such rocks (Grant, 1969). Drilling might reveal coal deposits at depth, but is probably unjustified because larger and higher-grade coal deposits occur at or near the surface in the region to the west (Beikman and others, 1961). Geophysical studies and exploratory drilling are necessary, however, to determine the likelihood of oil and gas resources.

\section{REFERENCES}

Barnes, D. J., 1983, Mineral investigation of the Glacier View RARE II Area (No. A6061), Pierce County, Washington: U.S. Bureau of Mines Open-File Report MLA 16-83.

Beikman, H. M., Gower, H. D., and Dana, T. A. M., 1961, Coal reserves of Washington: Washington Divison of Mines and Geology Bulletin 47, 115 p.

Buckovic, W. A., 1979, The Eocene deltaic system of west-central Washington, in Armentrout, J. M., Cole, M. R., and Terbest, Harry, Jr., eds., Cenozoic paleogeography of the Western United States: Society of Economic Paleontologists and Mineralogists, Pacific Section, Pacific Coast Paleogeography Symposium 3, p. 147-163.

Evarts, R. C., Mosier, E. L., Church, S. E., and Barnes, D. J., 1983, Mineral resource potential of the Glacier View Roadless Area, Pierce County, Washington: U.S. Geological Survey Open-File Report 83-501, $16 \mathrm{p}$.

Fiske, R. S., Hopson, C. A., and Waters, A. C., 1963, Geology of Mount Rainier National Park, Washington: U.S. Geological Survey Professional Paper 444, 93 p.

Grant, A. R., 1969, Chemical and physical controls for base-metal deposition in the Cascade Range of Washington: Washington Division of Mines and Geology Bulletin 58, $107 \mathrm{p}$.

Hammond, P. E., 1980, Reconnaissance geologic map and cross sections of southern Washington Cascade Range: Portland, Oregon, Portland State University, Department of Earth Sciences, 31 p. 

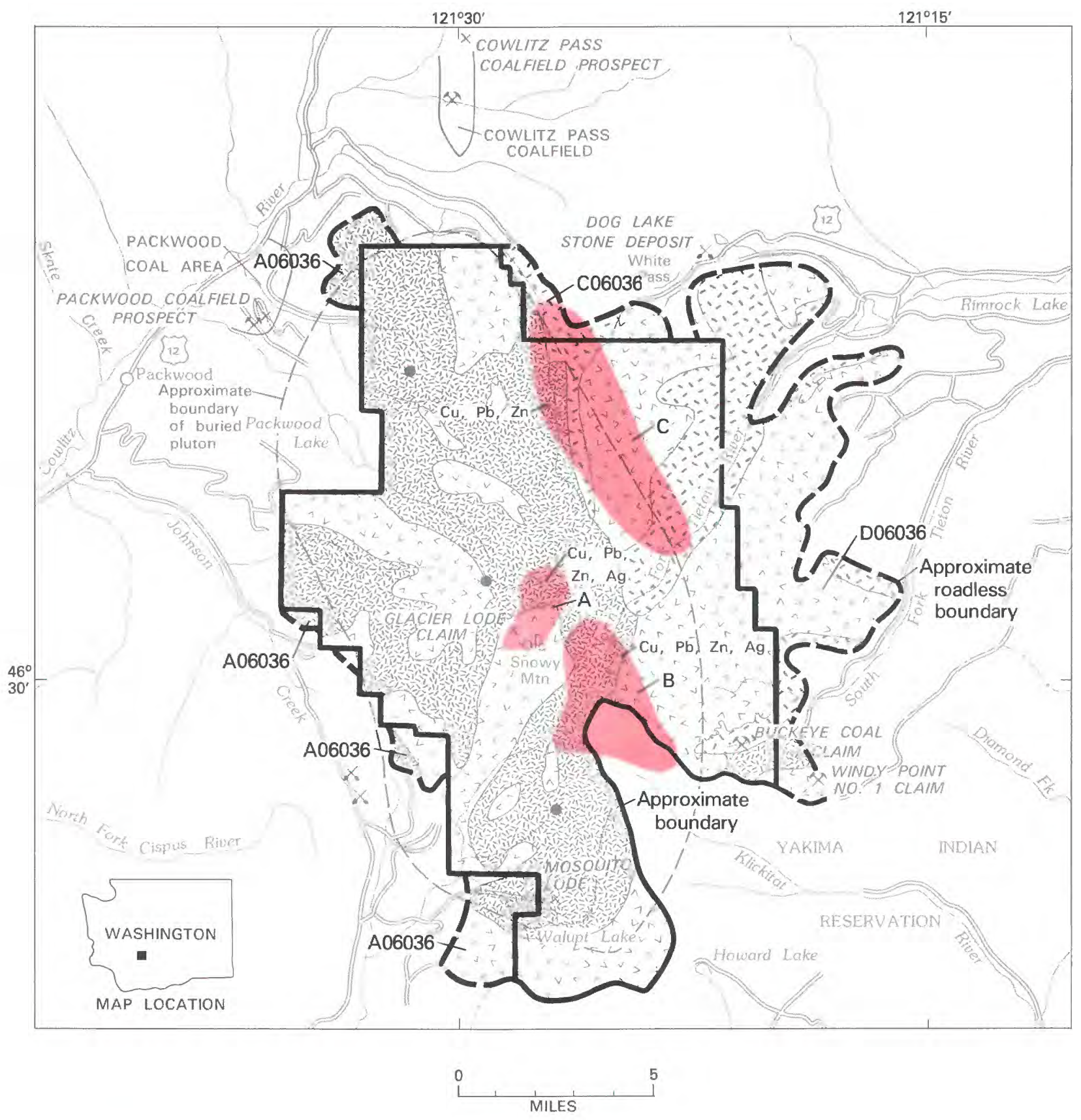

\section{EXPLANATION}

Geologic terrane with probable mineral-resource potential

$\begin{array}{rlrl}\mathrm{Cu} & \text { Copper } \quad \mathrm{Ag} & \text { Silver } \\ \mathrm{Pb} & \text { Lead } \quad \mathrm{Zn} & \mathrm{Zinc} \\ \times & \text { Mineral } & \text { occurrence } \\ \text { × } & \text { Mine } & \\ \times & \text { Quarry } & \end{array}$

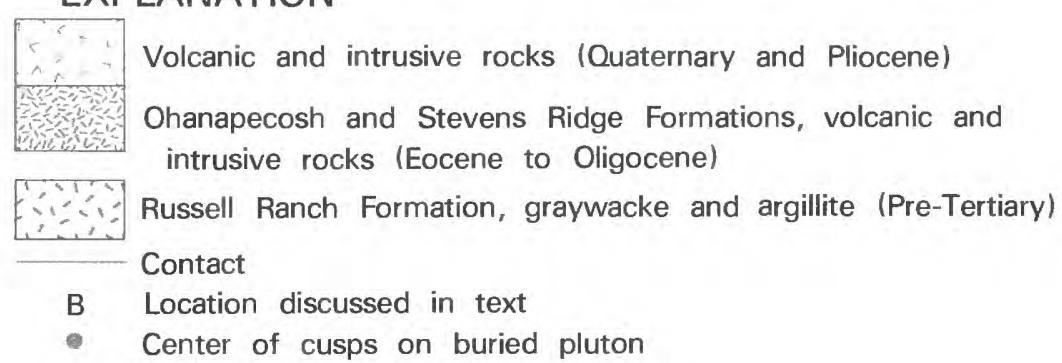

Figure 302.-Goat Rocks Wilderness and adjacent roadless areas, Washington. 


\title{
GOAT ROCKS WILDERNESS AND ADJACENT ROADLESS AREAS, WASHINGTON
}

\author{
By S. E. Church, ${ }^{1}$ U.S. Geological Survey, and \\ T. J. Close, U.S. BUREAU OF MineS
}

\begin{abstract}
SUMMARY
The Goat Rocks Wilderness and adjacent roadless areas are a rugged, highly forested, scenic area located on the crest of the Cascade Range in south-central Washington. Several mineral claims have been staked in the area. Mineral surveys were conducted in 1981. Geochemical, geophysical, and geologic investigations indicate that three areas have probable mineral-resource potential for base metals in porphyry-type deposits. Available data are not adequate to permit definition of the potential for oil and gas. There is little likelihood for the occurrence of other kinds of energy resources in the area.
\end{abstract}

\section{CHARACTER AND SETTING}

The Goat Rocks Wilderness and adjacent roadless areas, here referred to as study area, cover about $170 \mathrm{sq}$ $\mathrm{mi}$ in the Gifford Pinchot and Wenatchee National Forests, Lewis and Yakima Counties, Washington. The deeply eroded Goat Rocks volcano, located in the central part of the wilderness, is a part of the Cascades Range volcanic province. Mount Rainier is about $15 \mathrm{mi}$ to the north, and Mount Adams is about $15 \mathrm{mi}$ to the south. Access to the study area is provided by good unpaved roads from U.S. Highway 12. Travel within the study area is aided by the Pacific Crest National Scenic Trail and connecting USFS trails.

The wilderness and adjacent roadless areas are underlain by the pre-Tertiary marine graywacke and argillite of the Russell Ranch Formation, that comprise the southernmost known exposures of pre-Tertiary rocks in the Cascade Range of Washington and Oregon. The Russell Ranch is overlain by a thick sequence of Eocene to Oligocene volcanic rocks. The thickest and most extensive formation is the Eocene Ohanapecosh Formation, which consists of volcaniclastic rocks and lava flows dominantly of andesitic composition. The Ohanapecosh is overlain by silicic ash-flow tuff of the Oligocene Stevens Ridge Formation. A major erosional unconformity separates these early Tertiary rocks from a sequence of Pliocene and Quaternary volcanic rocks. The oldest unit occurs in the eastern part of the study

\footnotetext{
${ }^{1}$ With contributions from D. A. Swanson, D. L. Williams, and G. A. Clayton, USGS, and T. J. Peters, USBM.
}

area and consists of upper Pliocene silicic tuff and flows. A thick sequence of pyroxene andesite erupted in the late Pliocene and Pleistocene from the Goat Rocks volcano, centered in the core of the wilderness, and satellitic vents fed andesite and basalt flows. The youngest volcanism, of late Pleistocene age, produced hornblende andesite from vents in the central and northern part of the study area and olivine basalt from small volcanoes in the northern and southern part.

Intrusive bodies, particularly of intermediate composition are common. They range from narrow dikes to shallow plutonic bodies several miles in diameter. Ages are poorly constrained; it is likely that they were intruded throughout much of the Cenozoic. Many of the bodies and adjacent country rocks underwent quartzsericite-pyrite and propylitic alteration.

The Russell Ranch Formation is cut by major northtrending faults, but the Ohanapecosh and Stevens Ridge Formations are only broadly folded along northnorthwest trends and are not demonstrably deformed.

Geologic mapping, geochemical and geophysical studies, and detailed studies of hydrothermally altered areas within the study area were undertaken by the USGS; detailed chip sampling of the altered zones was done by the USBM.

A reconnaissance geochemical survey of the study area was undertaken during 1981. Stream-sediment samples, panned concentrate samples from stream sediments, and water samples were taken and analyzed using several analytical methods (Church and others, in press). 
Both gravity and aeromagnetic surveys were conducted. The gravity data are interpreted to show a buried pluton, trending approximately N. $10^{\circ} \mathrm{W}$, bounded on the east and west sides of the study area by thick piles of Russell Ranch and Ohanapecosh rocks. The aeromagnetic data primarily reflect the topographic relief, but one of the hydrothermally altered areas is underlain by a pronounced negative magnetic anoinaly interpreted to represent a large mass of hydrothermally altered rock at depth.

A search of county claims, and U.S. Bureau of Land Management and USBM records, shows that only five claims have been filed in the study area; field examination of these areas failed to produce any evidence of mining.

\section{MINERAL RESOURCES}

Within the study area, three areas having probable mineral-resource potential have been identified. Areas A and $B$ are very similar in their major characteristics. They are areas of pyritic-sericitic alteration, surrounded by argillic and propylitic alteration zones. These zones have geochemical anomalies for copper, molybdenum, cobalt, nickel, lead, and zinc with smaller and somewhat unore random anomalies in other metals. Both areas show sporadic high values for silver; no significant gold values were found. Pyrite is ubiquitous. Area A coincides with a magnetic low covering about $1 \mathrm{sq} \mathrm{mi}$. Both areas include, or are adjacent to old volcanic vents, and are inferred to lie above cusps on a larger pluton below. Both areas fit the environment in which porphyrycopper deposits form. Area B extends into the Yakima Indian Reservation, which is closed to public access; the boundary of the altered zone on the reservation has been inferred from color anomalies and mapped alteration zones in the study area. A hydrothermally altered system with ore-grade rock does not crop out in either area, but both areas have probable mineral-resource potential for base metals and silver in a buried system.

Area $\mathrm{C}$ is defined by a large geochemical anomaly located along the inferred contact between the Goat Rocks pluton and the older volcanics and sediments in the east. Anomalous amounts of copper, cobalt, manganese, and barium, with smaller amounts of lead, zinc, nickel, and molybdenum were found in the streamsediment samples. In the panned concentrates made from these samples, pyrite was ubiquitous, and cinnabar and barite were each identified from four sites. Boron, tin, and mercury were found in anomalous amounts in the panned concentrate samples. Altered rocks collected in this region contained high values of zinc, manganese, lead, molybdenum, and arsenic. Water samples contain high concentrations of chlorine, fluorine, unolybdenum, and copper. This area is regarded as having probable mineral-resource potential for base metals in buried deposits.

Outside the study area, coal resources have been identified in the Packwood and Cowlitz Pass coal fields (Beikman and others, 1961). The coal-bearing unit, the Eocene Spiketon Formation, does not crop out inside the study area; there seems to be little promise for the occurrence of coal resources in the study area.

Quantities of building stone and gravel are currently being quarried from deposits located north and west of the study area. Similar deposits of stone and gravel probably occur within the study area, however, current market needs can be met from existing quarries or froin deposits found closer to existing markets.

The potential for oil and gas in the area cannot be defined from current data. Recent drilling $5 \mathrm{mi}$ north of Yakima ( $30 \mathrm{mi}$ east of the study area), has shown the presence of sedimentary rocks beneath the lavas of the Columbia River Basalt Group. If the gravity model is correct, as much as 10,000 to $25,000 \mathrm{ft}$ of sedimentary rocks may be present on the east and west sides of the Goat Rocks pluton. Marine strata, if present and particularly if they represent an accreted terrain, could supply both the source beds as well as the structural and stratigraphic traps necessary for the accumulation of oil and gas (W. D. Stanley, written commun., 1983). Because we do not have the resources at hand for subsurface seismic reflection work in the study area, the potential for oil and gas resources cannot be assessed, but should not be dismissed without additional data.

There is no evidence to indicate the occurrence of geothermal resources in the study area. There are no hot springs in the study area, there is no recent silicic volcanism, and most of the andesitic volcanism occurred in the Pliocene and early Pleistocene. The most recent volcanism in the area is basaltic and occurred about 14,000 years ago. Even though the study area lies along the crest of the Cascade Range, an active volcanic chain, there is little promise for the occurrence of geothermal resources.

\section{SUGGESTIONS FOR FURTHER STUDIES}

Evaluation of resource potential in the three areas identified as having probable mineral-resource potential could be improved by more detailed geochemical studies and geologic mapping. Study of the southern part of the hydrothermal aureole on the Yakima Indian Reservation might significantly improve understanding of the 
mineral potential of area B. Detailed geologic mapping would help to resolve details of the structure of the host rocks and the associated hydrothermal alteration zones.

East-west seismic-reflection profiles crossing the center of the Goat Rocks pluton would be useful in deciphering the structure of the area and would assist interpretation of the gravity survey and magnetotelluric data (W. D. Stanley, written commun., 1983). Confirmation of an accreted, pre-Tertiary marine terrane in this area would add significantly to the understanding of tectonic models for the region and would help define the potential for oil and gas in the buried sedimentary rocks.

\section{REFERENCES}

Beikman, H. M., Gower, H. D., and Dana, T. A. M., 1961, Coal reserves of Washington: Washington Division of Mines and Geology Bulletin 47, 115 p.

Church, S. E., Swanson, D. A., Williams, D. L., Clayton, G. A., Close, T. J., and Peters, T. J., in press, Mineral resource potential map of the Goat Rocks Wilderness and adjacent roadless areas, Lewis and Yakima Counties, Washington: U.S. Geological Survey Miscellaneous Field Studies Map MF-1653-A, scale 1:48,000.

Fiske, R. S., Hopson, C. A., and Waters, A. C., 1963, Geology of Mount Rainier National Park, Washington: U.S. Geological Survey Professional Paper 444, 93 p. 


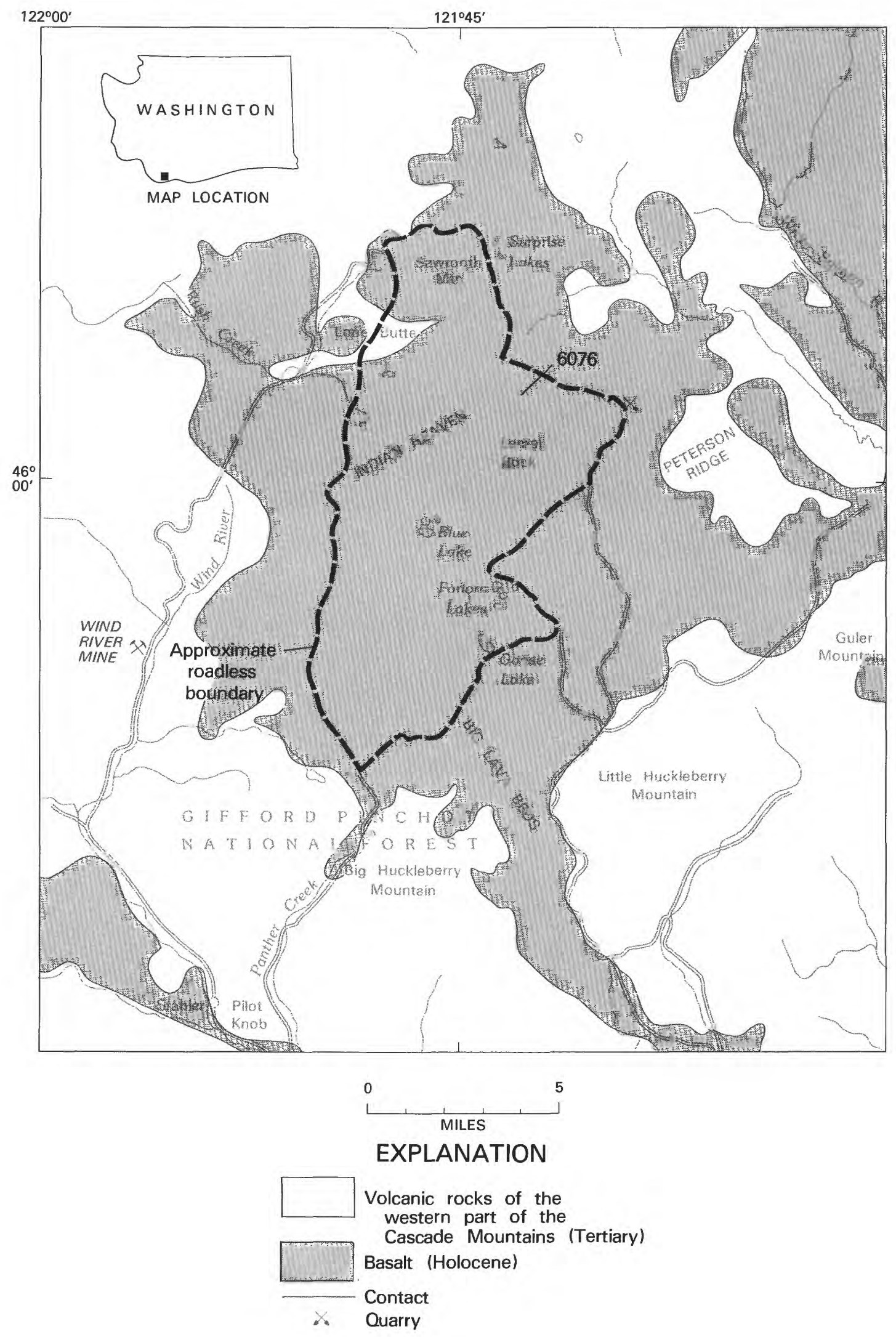

Figure 303.-Indian Heaven Roadless Area, Washington. 


\title{
INDIAN HEAVEN ROADLESS AREA, WASHINGTON
}

\author{
By S. E. Ghurch, U.S. GeOlogical SurVeY, and \\ D. J. BARnes, U.S. BUREAU OF MineS
}

\begin{abstract}
SUMMARY
On the basis of geologic, geochemical, and mining activity surveys in 1981 , the Indian Heaven Roadless Area offers little promise for the occurrence of metallic or nonmetallic mineral resources. Preliminary investigations of the geothermal potential of the area are inconclusive; however, a hot spring is located approximately $10 \mathrm{mi}$ south of the roadless area, and the data indicate an aquifer of unknown extent at a temperature of less than $212^{\circ} \mathrm{F}$. Geothermal lease applications were filed on about $23.5 \mathrm{sq} \mathrm{mi}$ of the roadless area in 1982 indicating potential interest in the development of a geothermal resource. In addition, about $39 \mathrm{sq} \mathrm{mi}$ of the roadless area have been leased for oil and gas exploration.
\end{abstract}

\section{CHARACTER AND SETTING}

The Indian Heaven Roadless Area is located in a basaltic field in Skamania County, Washington. It lies between Mount St. Helens on the west and Mount Adams on the east, and covers approximately $40 \mathrm{sq} \mathrm{mi}$. It is located $14 \mathrm{mi}$ north of the Columbia River and 40 mi east of Vancouver, Washington. Access to the area is by a county road that runs along the Wind River north from Washington State Highway 14 at the town of Carson. The roadless area is heavily wooded, although the surrounding area has been clearcut for timber. Camping facilities and existing trails are heavily used, especially during the late summer and fall. Altitudes range from $3200 \mathrm{ft}$ to $5925 \mathrm{ft}$ at the summit of Lemei Rock.

A mineral-resource study of the Indian Heaven Roadless Area was done by the USGS and the USBM in 1981 (Church and others, 1983). This report abstracts the results of that study and companion studies (U.S. Geological Survey, 1981).

The Indian Heaven Roadless Area is underlain by a young basaltic lava field. Ages of the lavas range from about 6 million years in the roadless area to 8200 years for the Big lava bed, an informal unit, just south of the Indian Heaven Roadless Area. The area consists chiefly of a north-south trending chain of shield volcanos, 3$7 \mathrm{mi}$ in diameter and 1500-2000 ft high, whose shapes have been modified by glaciation. Detailed geologic mapping of the volcanic field was done by D. E. Ham- mond (unpub. data). The accompanying map shows the contact between the basalts and the underlying Tertiary volcanic rocks of the western part of the Cascade Mountains in the vicinity of the Indian Heavens Roadless Area.

No producing mines, active claims, or mineral patents exist in the roadless area. The only commodity produced from the roadless area consisted of about 200,000 tons of basalt quarried from near Indian View Point and used for road construction. Geologic, geochemical, and geophysical investigations of the roadless area did not indicate any mineralization within the boundaries of the roadless area.

\section{MINERAL RESOURCES}

No metallic mineral-resource potential was identifed in the Indian Heaven Roadless Area. Volcanic cinder and basalt could be produced for local markets, but ample supplies of cinder and road material nearer potential markets exist outside the boundaries of the roadless area.

Because the roadless area is in a young volcanic field, the geothermal resource potential has been examined by drilling (Schuster and others, 1978). Results of the drilling indicate little promise for the occurrence of geothermal resources. Studies of water geochemistry from the 
St. Martins (Carson) hot springs located approximately $10 \mathrm{mi}$ south of the Indian Heaven Roadless Area indicate aquifer temperatures less than $212^{\circ} \mathrm{F}$ (Schuster and others, 1978, table 3, p. 20-21). The extent of this aquifer is not known, but the area is currently leased for geothermal exploration.

Oil and gas leases have been awarded on much of the roadless area. The nearest test well drilled $24 \mathrm{mi}$ southwest of the roadless area near an oil seep had an oil show at a depth of $250 \mathrm{ft}$. Structural traps for oil and gas may occur in the Tertiary section.

\section{REFERENCES}

Church, S. E., Hammond, P. E., and Barnes, D. J., 1983, Mineral resource potential of the Indian Heaven Roadless Area, Skamania County, Washington: U.S. Geological Survey OpenFile Report 83-473.

Schuster, J. E., Blackwell, D. D., Hammond, D. E., and Huntting, M. T., 1978, Heat flow studies in the Steamboat Mountain-Lemei Rock area, Skamania County, Washington: Washington Division of Geology and Earth Resources Information Circular 62, $56 \mathrm{pp}$.

U.S. Geological Survey, 1981, Aeromagnetic map of the Indian Heaven area, Washington: U.S. Geological Survey Open-File Report 81-928, scale 1:62,500. 


\title{
LONG SWAMP ROADLESS AREA, WASHINGTON
}

\author{
By Russell C. Evarts, U.S. Geological Survey, and \\ JOHN R. BENHAM, U.S. BUREAU OF Mines
}

\begin{abstract}
SUMMARY
Based on geologic and geochemical surveys conducted in 1982, the Long Swamp Roadless Area is considered to have a probable resource potential for metallic minerals in three separate areas. An area of hydrothermal alteration west of the Chewack River contains anomalous concentrations of copper, lead, zinc, molybdenum, and silver. Relatively high concentrations of gold and silver along Windy Creek and copper and lead along Basin Creek have been detected in stream sediments. The bedrock sources of these elements have not been located, but are probably rather small. There is little promise for the occurrence of energy and nonmetallic mineral resources in the roadless area.
\end{abstract}

\section{CHARACTER AND SETTING}

The Long Swamp Roadless Area comprises $15.9 \mathrm{sq} \mathrm{mi}$ in the Okanogan National Forest of northern Washington. The roadless area lies in the heart of the Okanogan Range about $6 \mathrm{mi}$ south of the Canadian border and is bounded on its northern and western sides by the Pasayten Wilderness. Access is provided by USFS roads from Winthrop to the south and Loomis to the east.

The roadless area is underlain largely by coarsegrained granite of the Cathedral batholith of Cretaceous age. This body intrudes gneissic granitic rocks that are exposed in the easternmost part of the roadless area.

The Okanogan Range was extensively glaciated during Pleistocene time (Staatz and others, 1971). Glacial activity was responsible for the relatively smooth and subdued topography of the eastern half of the roadless area, the steep-walled, U-shaped configuration of the Chewack River canyon, and a small terminal moraine on the Chewack River above Thirtymile campground.

A mineral-resource assessment of the Pasayten Wilderness was conducted by Staatz and others (1971) and a geologic and reconnaissance geochemical investigation of a large area to the east of the Long Swamp Roadless Area was published by Rinehart (1981). Neither of these studies, however, extended into the roadless area. Therefore, in 1982 the geology of the area was examined and rock, stream-sediment, and panned concentrate samples were collected for geochemical analysis (Evarts and others, 1983a,b).

\section{MINERAL RESOURCES}

A search of public records by the USBM and subsequent field studies revealed no claims, prospects, or mines in the Long Swamp Roadless Area. Nevertheless, the geologic and geochemical data indicate that the area has a probable resource potential for metallic minerals. The most interesting area is a zone of intensely altered rock in the Cathedral batholith west of the Chewack River. In addition to having abundant secondary quartz and sericite, this zone contains minor pyrite and traces of chalcopyrite. Analyses of rocks and stream sediments from the altered area show relatively high concentrations of copper, lead, zinc, molybdenum, and silver. These characteristics suggest affinities with porphyry-type copper-molybdenum deposits. However, other typical features of this kind of deposit, such as porphyritic igneous host rocks and mineral alteration zonation, are absent, so the significance of the altered zone is uncertain. A single vein of molybdenite found north of the area of altered rock is also suggestive of hydrothermal mineralization, but the host rock is not altered and no other veins were seen.

Geochemical anomalies in stream-sediment samples from two localities east of the Chewack River suggest 


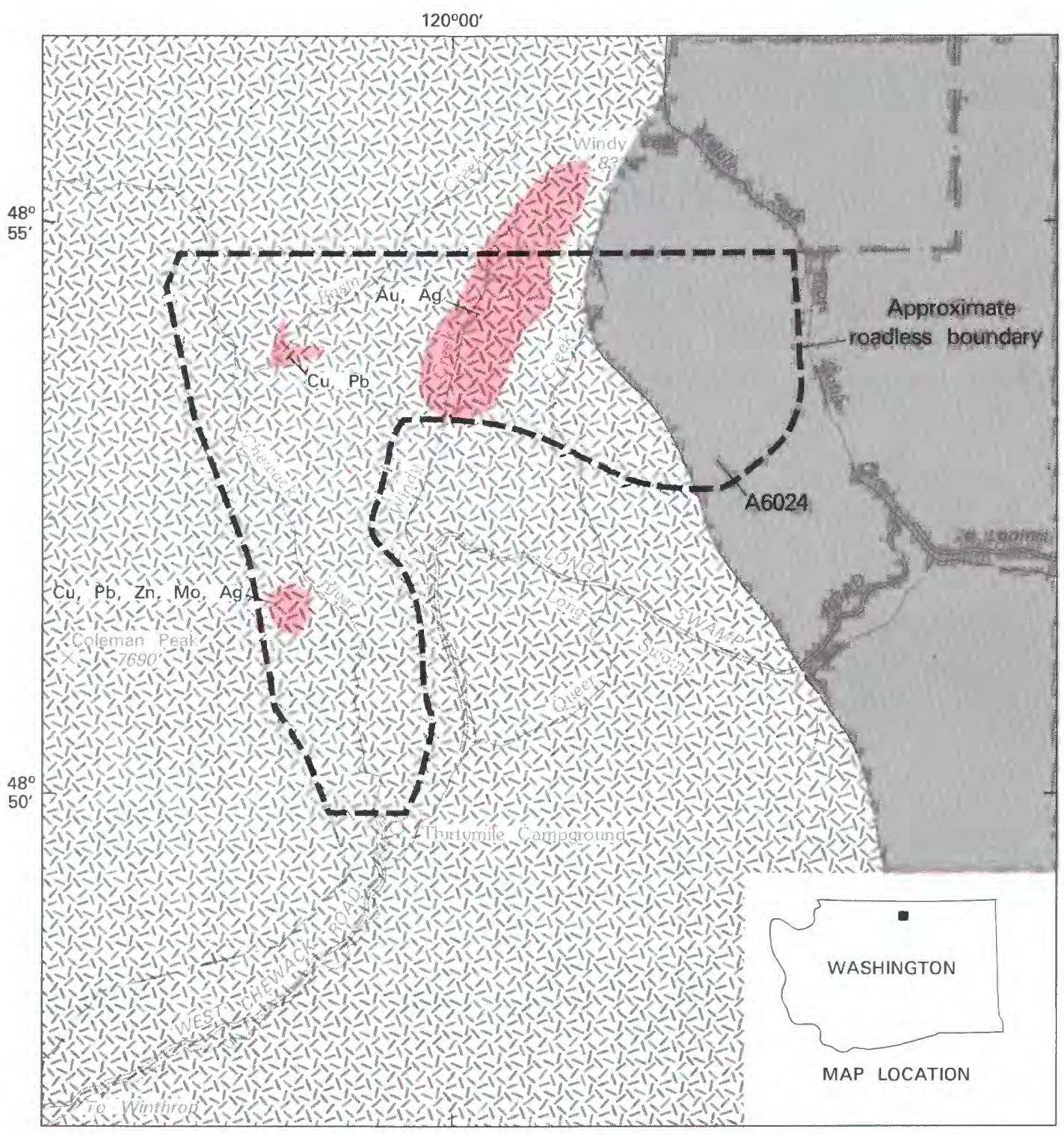

0

5

MILES

EXPLANATION

\begin{tabular}{lll}
\hline & $\begin{array}{l}\text { Geologic terrane with probable } \\
\text { mineral-resource potential }\end{array}$ & \\
$\mathrm{Cu} \quad$ Copper & Cneissic granitic rocks \\
$\mathrm{Au} \quad$ Gold & \\
$\mathrm{Pb} \quad$ Lead & \\
$\mathrm{Mo} \quad$ Molybdenum & \\
$\mathrm{Ag} \quad$ Silver & \\
$\mathrm{Zn} \quad$ Zinc &
\end{tabular}

Figure 304.-Long Swamp Roadless Area, Washington. 
the existence of small mineralized areas. At one locality in Windy Creek, gold flakes were visible in the pannedconcentrate sample, and analysis showed high contents of silver, as well as gold. Anomalous values for copper and lead were detected in a sample from Basin Creek. In neither of these drainages was the bedrock source of the anomalous elements located.

There are no mineral, geothermal, or oil and gas leases in the Long Swamp Roadless Area, and the lack of sedimentary or young volcanic rocks in the vicinity indicates little promise for such commodities.

\section{SUGGESTION FOR FURTHER STUDIES}

Additional detailed geologic mapping and geochemical sampling should be conducted near the hydrothermally altered area west of the Chewack River in order to delineate its extent. The bedrock sources for the mineralization detected in stream sediments from Basin and
Windy Creeks should be sought, and the sediments in Windy Creek should be further examined to evaluate the possibility of placer gold deposits.

\section{REFERENCES}

Evarts, R. C., Frisken, J. G., and Bishop, K. R., 1983a, Geochemical analyses of rock and stream-sediment samples from the Long Swamp Roadless Area, Okanogan County, Washington: U.S. Geological Survey Open-File Report 83-227, 13 p.

Evarts, R. C., Frisken, J. G., Bishop, K. R., and Benham, J. R., 1983b, Mineral resource potential of the Long Swamp Roadless Area, Okanogan County, Washington: U.S. Geological Survey Miscellaneous Field Studies Map MF-1550, scale 1:48,000.

Rinehart, C. D., 1981, Reconnaissance geochemical survey of gully and stream sediments, and geologic summary, in part of the Okanogan Range, Okanogan County, Washington: Washington Division of Geology and Earth Resources Bulletin 74, 24 p.

Staatz, M. H., Weis, P. L., Tabor, R. W., Robertson, J. R., Van Noy, R. M., Pattee, E. C., and Holt, D. C., 1971, Mineral resources of the Pasayten Wilderness area, Washington: U.S. Geological Survey Bulletin 1325, 255 p. 


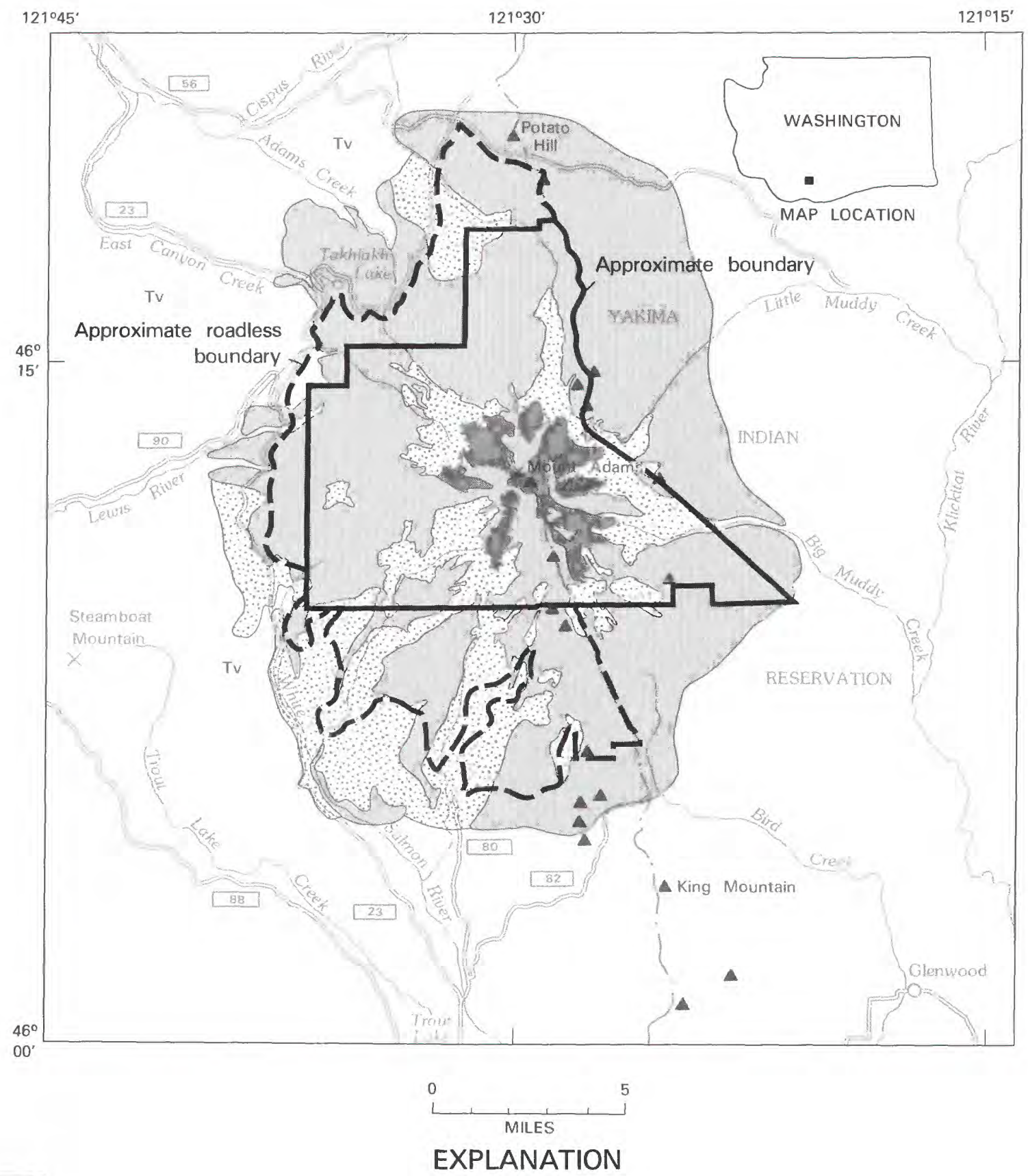

Glacial ice

Glacial and debris-flow deposits (Quaternary)

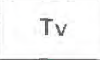

Basalts, andesites, and silicic volcanic and volcaniclastic sedimentary rocks older than Mount Adams volcano (Tertiary) Contact

$\times \quad$ Mineralized occurrence with no demonstrated resource

Andesites and basalts (Quaternary)

Eruptive centers (vents)

Figure 305.-Mount Adams and contiguous roadless areas, Washington. 


\title{
MOUNT ADAMS WILDERNESS AND CONTIGUOUS ROADLESS AREAS, WASHINGTON
}

\author{
WES Hildreth, ${ }^{1}$ U.S. GEOlOGICAL SURVEY, and \\ M. MiLler, U.S. BUREAU OF MineS
}

\begin{abstract}
SUMMARY
There is little likelihood for the occurrence of metallic mineral or energy resources based on a mineral survey in 1981-82 in the Mount Adams Wilderness and contiguous roadless areas. No mining claims exist in the study area, which is almost entirely a young andesitic stratovolcano. There is no indication of a shallow magma reservoir capable of supporting a convective geothermal system.
\end{abstract}

\section{CHARACTER AND SETTING}

Mount Adams is one of the dominant natural features of the Pacific Northwest, rising nearly $2 \mathrm{mi}$ above its surroundings to an altitude of $12,276 \mathrm{ft}$. An ice-capped stratovolcano, the mountain consists largely of andesitic lava and ejecta that total about $135 \mathrm{cu} \mathrm{mi}$ in volume, ranking it behind Mount Shasta as the second most voluminous volcano in the High Cascades. There have been no historical eruptions of Mount Adams and probably only one in the past 3500 years, but evidence for several eruptions during Holocene time and persistent sulfurous fumaroles on the summit indicate that the volcano remains potentially active.

The andesitic stratocone covers approximately $250 \mathrm{sq}$ $\mathrm{mi}$, its upper portion being the Mount Adams Wilderness, which consists of $50.6 \mathrm{sq} \mathrm{mi}$ of glaciers, rugged ridges, barren moraines, alpine meadows, huckleberry thickets, and, below the 6000- $\mathrm{ft}$ level, a densely forested periphery. The contiguous roadless area, an additional 44.1 sq mi under consideration for inclusion in the wilderness, would extend this forested peripheral zone outward to the existing system of USFS logging roads.

Mount Adams stands upon the Cascade crest and is drained radially by many tributaries of the Klickitat, Cispus, Lewis, and White Salmon Rivers. On USFS lands, easy access to the mountain is provided by several generally unpaved logging roads. The Yakima Indian Reservation on the east, however, is closed to all but enrolled members of the Yakima Nation and permittees approved by the Yakima Tribal Council. The south-

\footnotetext{
${ }^{1}$ With contributions by Judy Fierstein and E. L. Mosier, USGS.
}

easterly tract of the Mount Adams Wilderness, administered by the tribe since 1972 , remains open to the public and is accessible by graded dirt roads from Trout Lake and Glenwood during the summer months. Several foot trails penetrate the wilderness, which is itself roadless.

The main cone of Mount Adams consists of porphyritic pyroxene andesite and subordinate amounts of olivine andesite and basalt. A few dacitic lava flows erupted early in the evolution of the volcano but crop out only outside the wilderness. Potassium-argon dating suggests that the bulk of the main stratocone is younger than about 220,000 years, but two distal flows have been dated at 400,000 and 470,000 years (Hildreth and Fierstein, 1983).

Late Pleistocene glaciers covered more than 90 percent of the volcano's surface, compared to only 2.5 percent today. Seven or more eruptions of Mount Adams, however, have taken place during latest Pleistocene and Holocene time, roughly the 12,000 years since disappearance of the last extensive ice sheets. None of these eruptions issued from a vent near the summit, but all did come from flank vents higher in altitude than 6500 $\mathrm{ft}$, that is, well up on the stratocone.

The central part of the main cone is underlain largely by andesitic scoriae and breccias, which are extensively exposed on the headwalls of glaciers and high on several cleavers. Owing to their permeability and their focal position in a zone of persistent solfataric emission, these pyroclastic deposits have in most places undergone pervasive acid-sulfate leaching and precipitation of kaolinite, silica, alunite, gypsum, sulfur, iron-oxides, and iron-hydroxides. This altered pyroclastic core 
grades radially into stacks of thin and very rubbly lava flows that mostly dip outward at $15^{\circ}-35^{\circ}$.

Two groups of Tertiary rocks, the Columbia River Basalt Group on the east and mafic to silicic lavas and pyroclastic rocks typical of the western Cascades on the west, are presumed to extend well beneath Mount Adams, but within the wilderness they crop out only along the western fringe. All rocks exposed within the wilderness and contiguous roadless areas are therefore of igneous origin or consist of equivalent material that was reworked by avalanches, glacial ice, or running water. Moreover, all are of Quaternary age, apparently younger than 0.5 million years, except for about $1 \mathrm{sq} \mathrm{mi}$ of Oligocene and (or) Miocene lavas, breccias, tuffs, and associated volcaniclastic sedimentary rocks at the western edge of the wilderness.

The volcanic deposits erupted from Mount Adams and its contemporaneous peripheral centers are essentially undeformed. Compared to the other nearby stratovolcanoes (Mounts Hood, St. Helens, and Rainier), few fragmental deposits have been noted at Mount Adams outside of its highly brecciated and scoria-rich summit zone. No widespread ash layers are known to have erupted from Mount Adams. The only major debris flow documented from Mount Adams originated in the headwall of the White Salmon Glacier cirque about 5070 years ago and devastated the White Salmon River valley for at least $25 \mathrm{mi}$ downstream (Hopkins, 1976).

\section{MINERAL RESOURCES}

The mineral survey did not identify any metallic mineral or energy resource potential, nor is there any likelihood for the occurrence of resources in the wilderness or the contiguous roadless areas. There have been no major producers of base or precious metals in southwestern Washington (Moen, 1977), and not a single mine is now in production in the St. Helens and Washougal mining districts, west of Mount Adams. The only mining operations near the volcano have been quarries for rock, sand and gravel, or cinders.

A solfatarically altered summit region is the only mineralized zone that has been recognized at Mount Adams. Deposition of sulfur has taken place near fumarolic orifices immediately beneath the insulating cover of the summit icecap, but the deposits are not a significant resource.

Sulfur claims were filed on the summit of Mount Adams in 1929 and in 1931, under the name "Glacier Mining Company." Several pits were excavated into solfatarically altered rocks adjacent to the summit icefield. In 1934, as much as $305 \mathrm{ft}$ of ice and as much as
$38 \mathrm{ft}$ of altered rocks were penetrated with 16 drill holes. Although no coring was done, sulfates and sulfur were prominent in sludge from the holes that successfully penetrated through the ice. Fowler (1935) analyzed about 33 samples from outcrops, crevasses, and pits, obtaining values ranging between 11 and 79 percent sulfur. In remarking on the possible difficulties of mining sulfur on the summit of the second highest peak in the Northwest, an unpublished report recommended, perhaps tongue-in-cheek, that the operation should be conducted underground (beneath the protective icecap) and in the winter, when uninterrupted freezing might reduce caving of the soft altered rocks and stronger atmospheric convection might help to cool the hot ground and ventilate the noxious gases.

In 1981 and 1982, the late-summer meltdown on the summit of Mount Adams was inadequate to permit a thorough reevaluation of the sulfur and sulfate content of the altered rocks there. We collected a variety of texturally and mineralogically different kinds of altered rocks peripheral to the summit icecap and from debris that had avalanched from precipitous outcrops. More than 60 (Hildreth and Fierstein, 1983) of these were $\mathrm{X}$-rayed and contain assemblages dominated by alunite, kaolinite, and silica minerals; in a few samples gypsum is also important. Elemental sulfur is present in surprisingly few samples, mostly as yellow crusts and vesicle fillings in altered scoriae but also as fragments of white, massive, fine-grained material in which it is mixed with silica and alunite. Rare pyrite was the only sulfide mineral identified.

Nearly pure sulfur is largely restricted to irregular veins and vug fillings, whereas most of the elemental sulfur present appears to be mixed with alunite, silica, and altered andesite. Spectrographic analyses indicated trace amounts of $\mathrm{Hg}$ in some of the fumarolically altered summit rocks. Excavation beneath the summit icecap for sulfur, sulfates, or kaolinite would involve formidable risks of life, limb, and capital.

Lower on the volcano, the exposed Quaternary lavas are generally unaltered and certainly unmineralized. Some of the Tertiary lavas and pyroclastic rocks exposed along the western fringe of the wilderness are weakly propylitized and cut in a few places by veinletstypically fracture fillings of silica and iron oxides in breccias-but none appear to contain sulfides or unusual concentrations of metals.

Mount Adams also appears to be a poor target for geothermal-resource exploration. The only silicic lavas known to have been derived from Mount Adams erupted early in the evolution of the volcano. The many subsequent eruptions that have built the present cone appear to have been exclusively andesitic or basaltic, irrespective of whether their vents were on the flanks or 
at the summit. This virtually precludes the possibility of a silicic magma reservoir beneath Mount Adams during most of its history. Geophysical data for Mount Adams are sparse, but neither the aeromagnetic pattern (U.S. Geological Survey, 1975) nor the gravity map (Schuster and others, 1978) provide any indication of a magma body beneath the volcano. The high precipitation on the stratocone, estimated by Cline (1976) to be about 140 in., makes Mount Adams an important site of ground water recharge. The high permeability of its rubbly lava flows suggests that much of this ground water moves rapidly downward and outward from the stratocone, failing to remain in the warmer central region of the volcano long enough to develop a hydrothermal convection pattern but, instead, dispersing and dissipating whatever heat is supplied from depth to the fumarolically altered core. The weak and diffuse fumarolic emissions on the summit are the only manifestations of possible hydrothermal activity anywhere on the stratocone. There are ample exposures of permeable pyroclastic rocks on the steep cliffs all around the summit plateau, such that any significant hydrothermal system in the cone itself would be readily identifiable. The warmest spring that we have found anywhere in the contiguous roadless areas measured only $37^{\circ} \mathrm{F}$ on a summer day.

Because no faults of significance cut the gently dipping apron of Quaternary lavas around the central cone of Mount Adams, no structures have been identified that might control upward convection of ground water heated at great depth.

\section{SUGGESTIONS FOR FURTHER STUDY}

Further study of the wilderness offers little promise for identification of hidden mineral deposits. Drilling in the lowland periphery of the volcano might be technically difficult, but $150^{\circ}-200^{\circ} \mathrm{F}$ waters suitable for space heating would not be unexpected at depths of $5000-6000 \mathrm{ft}$.

\section{REFERENCES}

Cline, D. R., 1976, Reconnaissance of the water resources of the upper Klickitat River basin, Yakima Indian Reservation, Washington: U.S. Geological Survey Open-File Report 75-518, 54 p.

Fowler, C. S., 1935, The origin of the sulfur deposits of Mount Adams: M.S. thesis, State College of Washington, Pullman, $22 \mathrm{p}$.

Hildreth, W., and Fierstein, J., 1983, Mineral and geothermal resource potential of the Mount Adams Wilderness and contiguous roadless areas, Skamania and Yakima Counties, Washington: U.S. Geological Survey Open-File Report 83-474.

Hopkins, K. D., 1976, Geology of the south and east slopes of Mount Adams volcano, Cascade Range, Washington: Seattle, University of Washington, unpublished Ph.D. thesis, $143 \mathrm{p}$.

Moen, W. S., 1977, St. Helens and Washougal mining districts of the southern Cascades of Washington: Washington Division of Geology and Earth Resources, Information Circular 60, 71 p.

Schuster, J. E., Blackwell, D. D., Hammond, P. E., and Huntting, M. T., 1978, Heat flow studies in the Steamboat Mountain-Lemei Rock area, Skamania County, Washington: Washington Division of Geology and Earth Resources, Information Circular 62, 56 p.

U.S. Geological Survey, 1975, Aeromagnetic map for part of southwestern Washington: 4 sheets; scale 1:62,500: U.S. Geological Survey Open-File Report 75-648. 

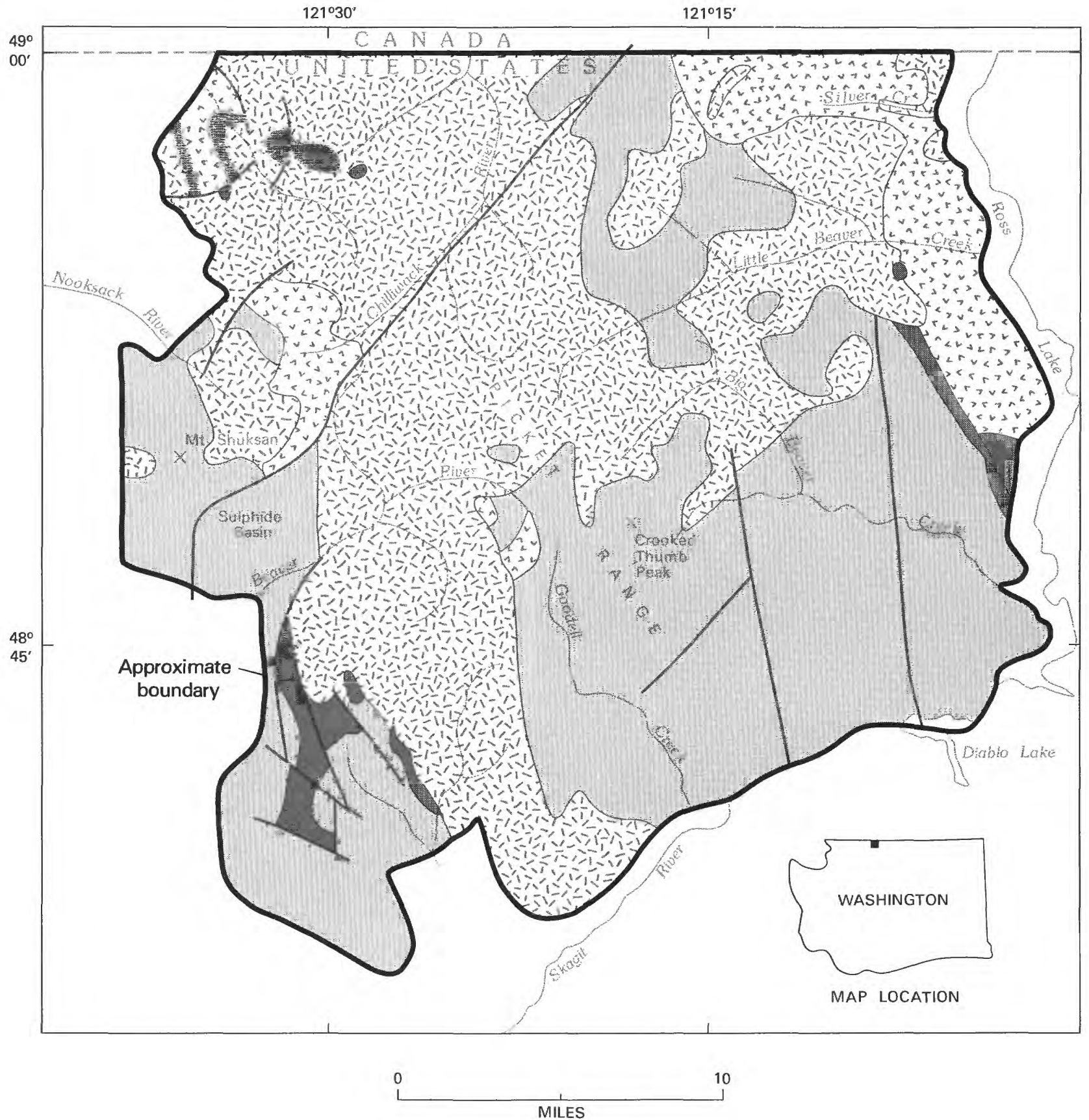

EXPLANATION

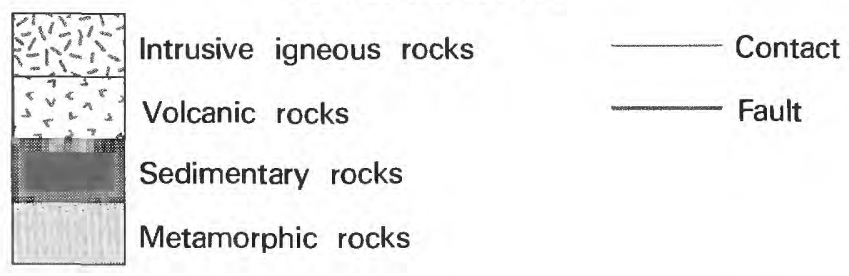

Figure 306.-Northern part of the North Cascades National Park, Washington. 


\title{
NORTHERN PART OF THE NORTH CASCADES NATIONAL PARK, WASHINGTON
}

\author{
By Mortimer H. StaAtz, ${ }^{1}$ U.S. GeOlogical SurVey, and \\ RONALD M. VAN NOY, U.S. BUREAU OF MINES
}

\begin{abstract}
SUMMARY
The mineral potential of the northern part of the North Cascades National Park was evaluated in 1966-67 by a detailed geochemical survey and by examination of all known mining claims in the area. It was concluded that this area offers little or no promise for the occurrence of mineral or energy resources.
\end{abstract}

\section{CHARACTER AND SETTING}

The northern part of the North Cascades National Park is separated from the southern part of the park by Skagit River. The northern part of the park occupies approximately $500 \mathrm{sq} \mathrm{mi}$ of steep mountains and densely forested valleys. It lies across the precipitous Picket Range and extends for about $22 \mathrm{mi}$ along the Canadian border from Ross Lake on the east to Mount Shuksan on the west. The highest peak is Mount Shuksan, whose ice-clad summit at $9127 \mathrm{ft}$ towers $7000 \mathrm{ft}$ above the broad forested Nooksack River valley to the north. Many other steep-faced peaks rise majestically above glacier-filled cirques to altitudes of more than $8000 \mathrm{ft}$. Many small glaciers occupy cirques along the north and east sides of the higher ridges. The upper parts of the streams course down steep narrow chutes. These coalesce to form larger streams that commonly occupy broad U-shaped valleys excavated by glaciers during the ice age. No roads have ever been built into this area, and the lack of pasture makes it difficult to use pack animals even along trails.

The northern part of the North Cascades National Park was formerly the western one third of the North Cascade Primitive area. A mineral study was made of this area in 1966-67, and the results have been published (Staatz and others, 1972). This study included sampling and analysis of stream-sediment samples, heavy-mineral concentrates panned from stream gravels, and rock samples from areas that contain visible sulfide minerals, iron oxide-stained rocks, or other types of altered rock. Congress reclassified the North Cascade

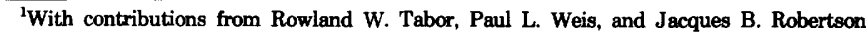
USGS, and Eldon C. Pattee, USBM.
Primitive Area and certain other national forest lands in the fall of 1968 and created the North Cascades National Park, the Ross Lake National Recreational Area, and the Pasayten Wilderness. The Ross Lake National Recreation Area forms a corridor 2 1/4-4 mi wide along the Skagit River and its dammed portions, Ross, Diablo, and Gorge Lakes, separating the park into two parts, as well as separating the northern part of the park from the Pasayten Wilderness to the east. This report covers mineral resources of the North Cascades National Park north of the Skagit River plus the parts of the Ross Lake Recreation Area that lie either west of Ross Lake or north of the Skagit River.

The rocks of the northern part of the North Cascades National Park are varied and include igneous, metamorphic and sedimentary rocks. By far the most abundant rocks are granitic ones of the Chilliwack composite batholith, which intrude the other rock types and form a medial belt separating one suite of metamorphic, sedimentary, and volcanic rocks in the eastern part of the area from a different suite of the same type of rocks in the western part of the area. The eastern part of the area is made up of a thick sequence of (1) thinly layered metamorphic biotite and hornblende gneisses and schists, (2) sheared phyllites and schists, (3) greenstones with lesser amounts of chert, (4) metagabbro, and (5) volcanic tuffs and flows. The oldest gneisses and schists are probably Precambrian in age and the volcanics are early Tertiary in age. In the western part of the area in addition to intrusive rocks of the Chilliwack batholith there are (1) metamorphic interbedded greenschist and phyllite, (2) a sedimentary unit consisting of sandstones with some conglomerate, and (3) volcanic tuffs and breccia. The age of the oldest rock in the western part is not known; the volcanic rocks are early Tertiary in age. 
Faulting of several ages and various trends occurs in this area. Older faults are cut off by the Chilliwack batholith, and younger faults of two ages cut the batholith.

\section{MINERAL RESOURCES}

The northern part of the North Cascades National Park has been prospected off and on, but, no mines have ever been established, mineral prospects are few, and those found are small. Disseminated sulfide deposits, veins, and placers occur in the area but no resource potential was identifed for areas containing these occurrences. Hundreds of zones of disseminated sulfides consisting chiefly of tiny grains of pyrite and pyrrhotite scattered through the country rock are known in the northern part of the area. They range in size from a few inches wide by a few feet long to one in Sulphide basin that is $2.5 \mathrm{mi}$ long by $0.3 \mathrm{mi}$ wide. Sparse and erratically distributed grains of copper and molybdenum sulfides are present in some of these zones but the copper and molybdenum contents are low. One exception is a property on Silver Creek, where an area 200 by $240 \mathrm{ft}$ contains much higher amounts of disseminated molybdenum and copper minerals than other disseminated sulfide zones; however, the deposit is small and no mineral-resource potential was identified.

Veins are relatively rare in the northern part of the North Cascades National Park. Those found are generally narrow, short, and low in metal content. The largest and highest grade veins seen were three veins near the crest of the Picket Range south of Crooked Thumb Peak. These veins contained base and precious metals, were traced 150 to $250 \mathrm{ft}$, and varied in thickness from $1 / 8$ to 5 in. Mineralization was not extensive enough to identify a mineral-resource potential for this area.

Placer deposits of gold are found in several areas in the North Cascades Mountains, but little gold has been reported from streams within the northern part of the park. Samples from 33 streams within the park were panned but only a few scattered concentrates contained more than $0.008 \mathrm{oz}$ of gold/ton. Additional concentrate samples taken along the same streams did not contain any measurable gold. Total heavy-mineral content of most samples was also small. Streams, although abundant, commonly are rapid as they flow down steep mountain sides, and hence there is little accumulation of sand along many of them. Furthermore, glaciation during the Pleistocene has scoured out many channels removing any gold that might have accumulated previous to the glaciation. Because of the small amount of gold found, as well as the overall small proportion of heavy minerals found in the stream sediments, it seems unlikely that resources of placer gold exist in the northern part of the North Cascades National Park.

\section{REFERENCE}

Staatz, M. H., Tabor, R. W., Weis, P. L., Robertson, J. F., Van Noy, R. M., and Pattee, E. C., 1972, Geology and mineral resources of the northern part of the North Cascades National Park, Washington: U.S. Geological Survey Bulletin 1359, 132 p. 


\title{
PASAYTEN WILDERNESS, WASHINGTON
}

\author{
By MORTimer H. StaAtz, ${ }^{1}$ U.S. GeOlogical SurVey, and \\ RONALD M. VAN NOY, U.S. BUREAU OF MINES
}

\begin{abstract}
SUMMARY
The resource potential of the Pasayten Wilderness was evaluated in 1965-66 by examining all known mining claims and by making a detailed geochemical survey. Four areas have either a probable or substantiated mineral-resource potential for small- to moderate-size deposits. These favorable areas and the types of deposit they contain include the following: (1) Monument Peak region for copper-molybdenum porphyries; (2) the northern edge of the Slate Creek mining district for gold-bearing veins; (3) the Tungsten Creek area for tungsten veins; and (4) the New Hope property for copper and silver veins.
\end{abstract}

\section{CHARACTER AND SETTING}

The Pasayten Wilderness occupies approximately $900 \mathrm{sq}$ mi of rugged mountanious terrain in northeastern Washington. It lies east of Ross Lake and extends for $55 \mathrm{mi}$ along the International Boundary. The Cascade Divide runs roughly north south across the area. Rugged mountains and deep, steep-walled canyons form most of the area. Ridge crests commonly have elevations of 7500 to $8500 \mathrm{ft}$ above sea level, and adjacent valley bottoms are commonly 4000 to $5000 \mathrm{ft}$ lower. The western part of the area is most rugged and the maximum relief is in the southwestern part of the area, where Jack Mountain towers $7328 \mathrm{ft}$ above Ross Lake, only $3 \mathrm{mi}$ away. The northeastern part of the Pasayten Wilderness, in marked contrast to the rugged relief elsewhere, is a gently rolling upland that lies between scattered peaks.

The Pasayten Wilderness makes up the eastern two thirds of what was the North Cascade Primitive Area. A mineral study was made of this area during the summers of 1965 and 1966, and the results published in 1971 (Staatz and others, 1971). Congress reclassified the North Cascade Primitive Area along with certain other national forest lands in the fall of 1968 and created the Pasayten Wilderness, the Ross Lake National Recreation Area, and the North Cascade National Park. The Ross Lake National Recreation Area, a corridor 3-4 mi wide along Ross Lake separates the Pasayten Wilder-

${ }^{1}$ With contributions from Paul L. Weis, Rowland W. Tabor and Jacques B. Robertson, USGS, and Eldon C. Pattee and Dean C. Holt, USBM. ness from the North Cascades National Park. The present report covers the mineral resources of all of the Pasayten Wilderness plus the part of the Ross Lake Recreation Area east of Ross Lake and some land adjacent to the south border of the wilderness area.

The rocks of the Pasayten Wilderness are diverse and include metamorphic, sedimentary, volcanic, and intrusive igneous rocks. Most are Cretaceous or Tertiary in age but some may be as old as Precambrian. The area is divided into geologically dissimilar areas by the Eightmile Creek fault. East of the fault, various types of metamorphic rocks underlie small areas, and have been largely engulfed by igneous intrusive rocks. In contrast, rocks to the west of the fault are principally sedimentary; these rocks form a thick sequence made up mainly of arkose and argillite, which are overlain by volcanic rocks and intruded by quartz diorite-quartz monzonite and granite plutons of Late Cretaceous and early Tertiary ages (Tabor and others, 1968). Old metamorphic rocks separated by a fault from the rest of this region occur in the southwest corner of the wilderness. Rocks west of the Eightmile Creek fault have a number of northward-trending folds and are broken by several large faults. Movement on the faults occurred in middle or late Tertiary time.

\section{MINERAL RESOURCES}

Although the Pasayten Wilderness is in an extremely rugged and rather inaccessible area, it has been examined by many prospectors, and some 605 claims have 

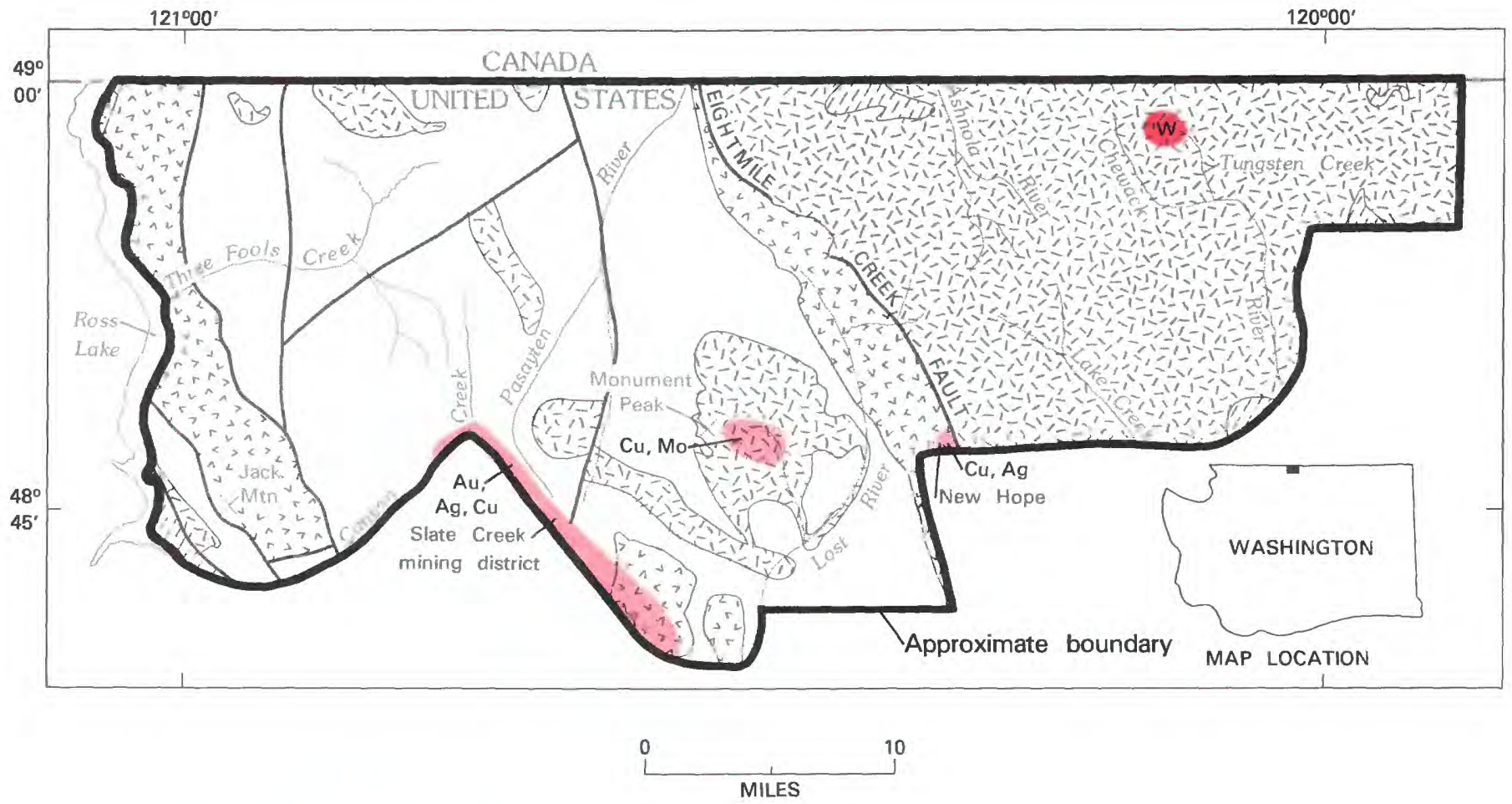

\section{EXPLANATION}

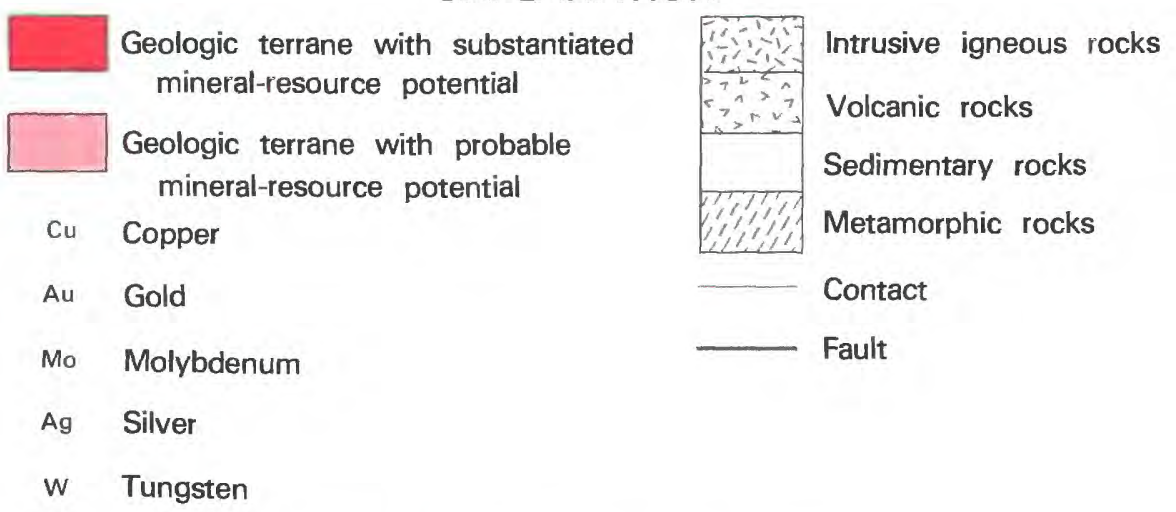

Figure 307.-Pasayten Wilderness, Washington. 
been located. Yet total production within the wilderness has amounted to only a few carloads of hand-sorted tungsten ore. Some production, however, has come from areas adjacent to the wilderness, and mines in the Slate Creek mining district, along the southern border of the wilderness have produced at least $\$ 1.5$ million in gold and silver. Gold from these veins also occurred im placers along Canyon Creek from which as much as $\$ 150,000$ in gold has been recovered (Staatz and others, 1971, p. 46).

Lode deposits are of two types: vem and porphyry. The veins attracted many early prospectors and most of the existing claims are on veins. Porphyry-type deposits were of generally too low a grade to attract the early prospectors, but they may have a greater promise for metals than the veims. Zones containing disseminated sulfides are scattered throughout the wilderness west of the Eightmile Creek fault. The sulfide minerals are principally pyrite and pyrrhotite, but some zones also contain chalcopyrite or molybdenite and rarely, other base metals. Most sulfide zones are small or contain only minor amounts of copper or molybdenum. These zones are most common in and around the Monument Peak stock, the only mtrusive body of granite in the wilderness and outline an area of probable mineral-resource potential for porphyry-type mineralization. This area of probable potential contains a zone southeast of Monument Peak where stream-sediment sampling identified highly anomalous amounts of copper and molybdenum for at least $1000 \mathrm{ft}$ along the stream. The anomalous samples came from a valley covered by glacial deposits. Other occurrences of porphyry-type mineralization in the Monument Peak area contain as much as 0.1 percent copper and 0.02 percent molybdenum. The sediment sample analyses for copper and molybdenum are higher southeast of Monument Peak than near the other occurrences. The Monument Peak area, however, is extremely steep and rugged, and extensive physical exploration would be needed to outline and determine the size and grade of any possible porphyry deposit.

Vem deposits can be found in many places in the wilderness, but most of them tend to be small, low grade, and difficult to reach. Three areas have the most promise for producing small amounts of valuable minerals. The first area has a probable mineral-resource potential and forms a broad band 1- to $21 / 2-$ mi wide around the northern margin of the Slate Creek mining district. Scattered through this area are many small vems, which are estimated to contain approximately 100,000 tons of vem material. Principal values are in gold, but there are some values in silver and copper. None of the known vems within this belt could be operated other than on a small scale for a short while. Further prospecting, however, might reveal larger or higher-grade deposits.
The second area has with a substantiated tungsten resource potential in vein deposits and lies in the eastern part of the wilderness along Tungsten Creek, a tributary of the Chewack River. Several narrow gently dipping tungsten-bearing quartz veins that have been developed by about $1900 \mathrm{ft}$ of workings occur in this area. The grade of the ore is low; the average grade on the two best-developed properties is estimated at 0.5 and 0.85 percent $\mathrm{WO}_{3}$. A total of six carloads of handpicked ore was packed out from one of the properties. The veims' flat dip, their narrow width, and the occurrence of tungsten mainly in widely scattered small pockets makes mining expensive. These veims cannot be mined successfully under most conditions. However, demonstrated tungsten resources in this district may well approach 1,000,000 tons, and in times of tungsten shortage and high prices, these veins could become significant.

The third area, which has a probable mineral-resource potential, is just mside the southern border of the Pasayten Wilderness on the west side of the Eightmile Creek fault. Numerous prospects containing copper and silver occur in this general area, but most lie just outside the wilderness. The principal deposit within the wilderness is on the New Hope property, high on a knifeedged ridge. Here a shear zone made up of branching shears $4 \mathrm{~m}$. to $2 \mathrm{ft}$ wide that contain calcite, barite, and copper minerals has been traced for about $200 \mathrm{ft}$. The property was explored by an adit-now caved. Four of five samples taken from shear zones near the adit mouth, and a sample from a small ore pile at the mouth of the adit contain from 0.33 to 10.2 percent copper and from 2.2 to $20.6 \mathrm{oz}$ of silver per ton. Further exploration might well lead to development of a small high-grade mineral resource in this area.

Placer deposits were thoroughly prospected in the late 1800's and early 1900's. Although 171 placer claims have been located $\mathrm{m}$ the wilderness and gold has been produced from placers along its southern border, there is little promise for the occurrence of gold placer resources within the wilderness. In most areas the steep gradients of the streams and narrow V-shaped valleys im which they flow will prevent the formation of all but very small placers. In the few wider valleys recent glaciation has removed nearly all the placer deposits. Furthermore, only a trace of gold was found in 1 of 85 samples panned during the examination of this wilderness.

\section{SUGGESTIONS FOR FURTHER STUDIES}

An imventory of known deposits within the wilderness and in adjacent areas indicate that any newly discovered deposits are likely to be small and low grade. Addi- 
tional exploratory work could best be spent on defining the size, shape, and grade of the porphyry deposit that is covered by glacial till near Monument Peak and the small copper-silver deposit on the New Hope property.

\section{REFERENCES}

Staatz, M. H., Weis, P. L., Tabor, R. W., Robertson, J. F., Van Noy,
R. M., Pattee, E. C., and Holt, D. C., 1971, Mineral resources of the Pasayten Wilderness Area, Washington: U.S. Geological Survey Bulletin 1325, 255 p.

Tabor, R. W., Engel, J. C., and Staatz, M. H., 1968, Quartz dioritequartz monzonite and granite plutons of the Pasayten River area, Washington-petrology, age, and emplacement: U.S. Geological Survey Professional Paper 600C, p. C45-C52. 


\title{
SALMO-PRIEST WILDERNESS STUDY AREA, WASHINGTON AND IDAHO
}

\author{
By F. K. Miller, ${ }^{1}$ U.S. GeOlOGical Survey, and \\ S. W. SCHMAUCH, U.S. BUREAU OF MineS
}

\begin{abstract}
SUMMARY
Geologic, geochemical, geophysical, and mines and prospects evaluation in 1976-78 of the Salmo-Priest Wilderness study area has yielded no evidence of significant mineral-resource potential. Although gold was detected in trace amounts to moderate anomalies in scattered stream-sediment concentrates it has probably been derived from small and localized occurrences and does not constitute a resource. As a result of this study the area appears to have little promise for the occurrence of metallic mineral resources, energy minerals, fossil fuels, and geothermal resources. Nonmetallic mineral resources, notably shale, are abundant, but adequate supplies exist outside the study area.
\end{abstract}

\section{CHARACTER AND SETTING}

The Salmo-Priest Wilderness study area consists of $62 \mathrm{sq} \mathrm{mi}$ and lies $85 \mathrm{mi}$ north of Spokane, Washington, in the rugged mountains east of Metaline Falls, Washington. The area is bounded by the United StatesCanadian border on the north. The northern part of the area is cut by the deep heavily timbered canyon of the South Salmo River. Southwest and east of the canyon are the high glaciated Crowell Ridge and Snowy Top Peak, respectively.

Geologic mapping and geochemical stream-sediment sampling of the Salmo-Priest area were done by the USGS in 1978 (Miller, 1982). The USBM searched for all known mining claims within the study area and took rock samples from prospects and mine workings in 1976 and 1978 (Miller and others, 1982). These studies were supplemented by aeromagnetic, airborne gamma-ray spectrometry and reconnaissance gravity surveys by the USGS (Pitkin and Duval, 1980).

Most of the area is underlain by recrystallized and sheared conglomerate, sandstone, and shale that make up the Windermere Group. These rocks are of Proterozoic $\mathrm{Z}$ age (560 to $800 \mathrm{~m}$.y. (million years) old), and appear to be at least $20,000 \mathrm{ft}$ thick. The eastern part of the area consists of recrystallized and sheared shale, limestone, and quartzite of the upper part of the Belt Supergroup, which is older than the Windermere Group, about 800 to $1600 \mathrm{~m}$.y. old. In the western part of the

${ }^{1}$ With contributions from E. A. Rodgriquez, J. A. Pitkin, and J. S. Duval, USGS. area, the Windermere Group is overlain by the Lower Cambrian Gypsy Quartzite and Maitlen Phyllite which are about 545 to 570 m.y. old.

The rocks are cut by a few faults of moderate displacement, but by and large, form a relatively undisturbed succession of strata that dips uniformly to the northwest. The study area appears to be an island of relatively unfaulted rocks that are surrounded by complexly faulted and folded rocks to the west, south, and east.

The Metaline mining district, a major producer of zinc and lead, is located a few miles west of the area. The Idaho Continental mine, located a few miles east of the area produced significant amounts of lead until the 1930's. About $7 \mathrm{mi}$ south of the area, significant indications of molybdenum are associated with a small granitic body, and about $3 \mathrm{mi}$ south of the area streamsediment samples from streams draining a separate granitic body of the same rock type contain anomalous amounts of tungsten.

\section{MINERAL RESOURCES}

The results of this study indicate that there is little promise for the occurrence of mineral or energy resources in the Salmo-Priest Wilderness study area. Due to its proximity to the Metaline mining district to the west and the Idaho Continental mine to the east, the area has been heavily prospected in the past by individuals and by exploration geologists, none of whom found any significant mineral resources. 

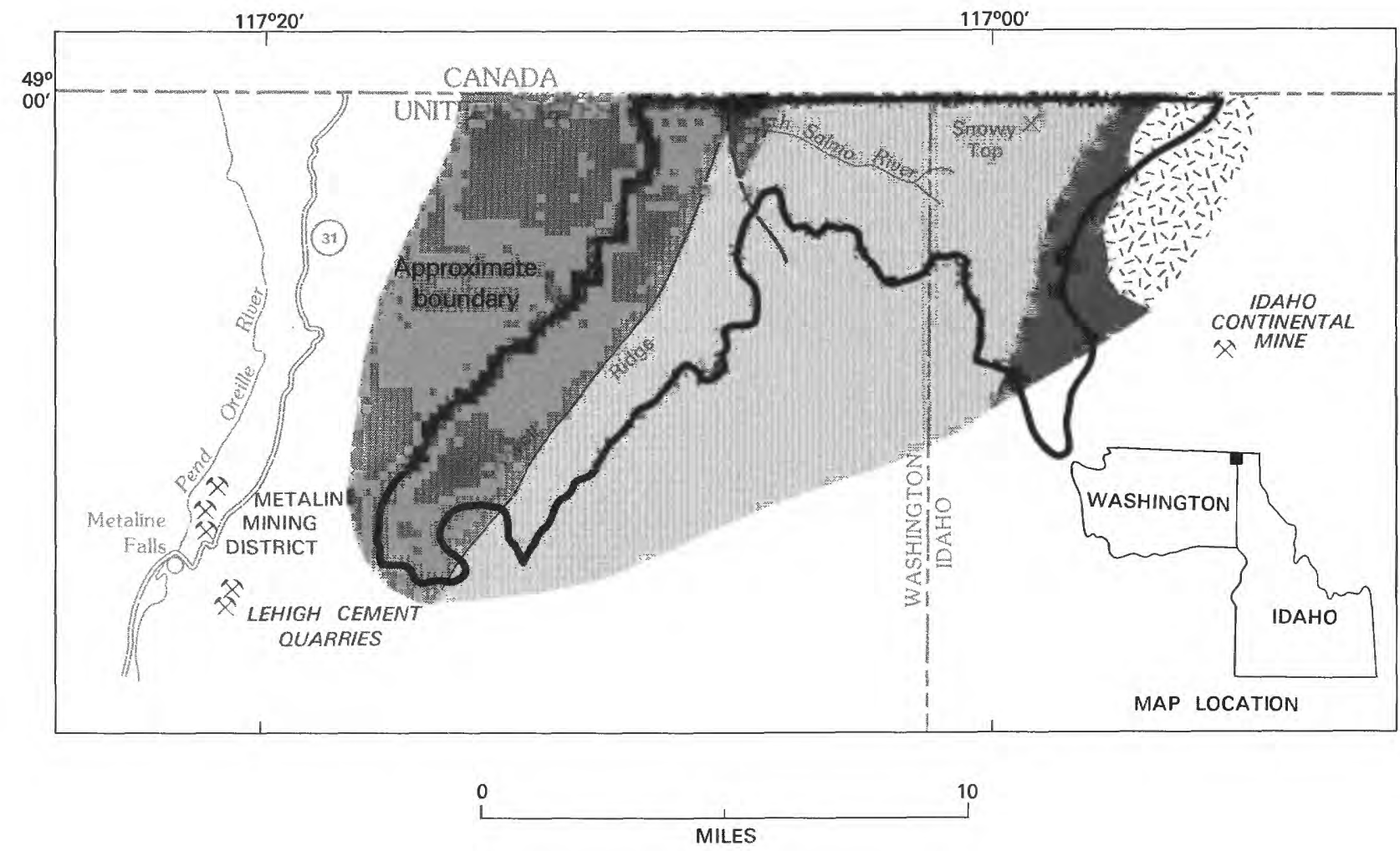

\section{EXPLANATION}

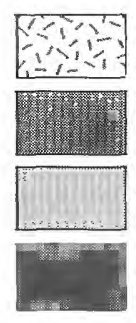

Granitic rock (Mesozoic)

Contact

Phyllite and quartzite (Cambrian)

Windermere Group (Proterozoic)

Belt Supergroup (Proterozoic)

Figure 308.-Salmo Priest Wilderness study area, Washington and Idaho. 
Gold anomalies in panned concentrates of streamsediment samples as much as $\mathbf{0 . 5}$ parts per million have been found at scattered localities, but appear to be derived from isolated small quartz veins. Analyses of panned concentrates from streams adjacent to those with gold anomalies showed no detectable gold, indicating that the source of the anomalies is localized. No concentration of gold or gold-bearing veins was found in outcrop.

Although the Metaline mining district is only a short distance west of the area, no significant zinc-lead mineralization was found within the study area. Most of the deposits of the Metaline mining district are in, or associated with, the Metaline Limestone, which does not occur in the study area.

The molybdenum-tungsten occurrences south of the study area (Miller and Theodore, 1982) were discovered after investigation of the Salmo-Priest area. The molybdenum and tungsten are associated with a distinctive granitic rock type that does not occur in the study area. No molybdenum or tungsten was detected in either the stream-sediment samples or panned-concentrate samples, so mineralization associated with the granitic rocks does not appear to extend into the study area.

The airborne geophysical data delineate the previously mapped geologic units within the study area, and appear to be within reasonable limits for the rock types involved and interpretation of the aerial radiometric data indicated no obvious evidence for any anomalous concentrations of radioactive elements.

One placer and about 20 lode claims have been located within the study area, but except for prospecting, there has been no known mining development. Only minor amounts of mineralization in small quartz veins were found on two of the claims.

\section{SUGGESTIONS FOR FURTHER STUDIES}

A detailed, careful search might locate the sources of the gold anomalies in panned concentrates, but the distribution and magnitude of the anomalies, suggest that their sources are small and dispersed. Further study for other commodities offers little promise for identification of hidden mineral resources.

\section{REFERENCES}

Miller, F. K., 1982, Geologic map of Salmo-Priest wilderness study area (RARE E6-981 Al-981), Pend Oreille County, Washington and Boundary County, Idaho: U.S. Geological Survey Miscellaneous Field Studies Map MF 1192-A, scale 1:48,000.

Miller, F. K., Schmauch, S. W., and Rodriquez, E. A., 1982, Mineral resource potential map of the Salmo-Priest Wilderness study area, Pend Oreille County, Washington and Boundary County, Idaho: U.S. Geological Survey Miscellaneous Field Studies Map MF 1192-C, scale 1:48,000.

Miller, F. K., and Theodore, T. G., 1982, Molybdenum and tungsten mineralization associated with two stocks in the Harvey Creek area, northeastern Washington: U.S. Geological Survey OpenFile Report 82-295, 24 p.

Pitkin, J. A., and Duval, J. S., 1980, Interpretation of an aerial radiometric and magnetic survey of the Salmo-Priest study area (RARE-E6-981 A1-981), Pend Oreille County, Washington and Boundary County, Idaho: U.S. Geological Survey Miscellaneous Field Studies Map MF 1192-B, scale 1:48,000. 

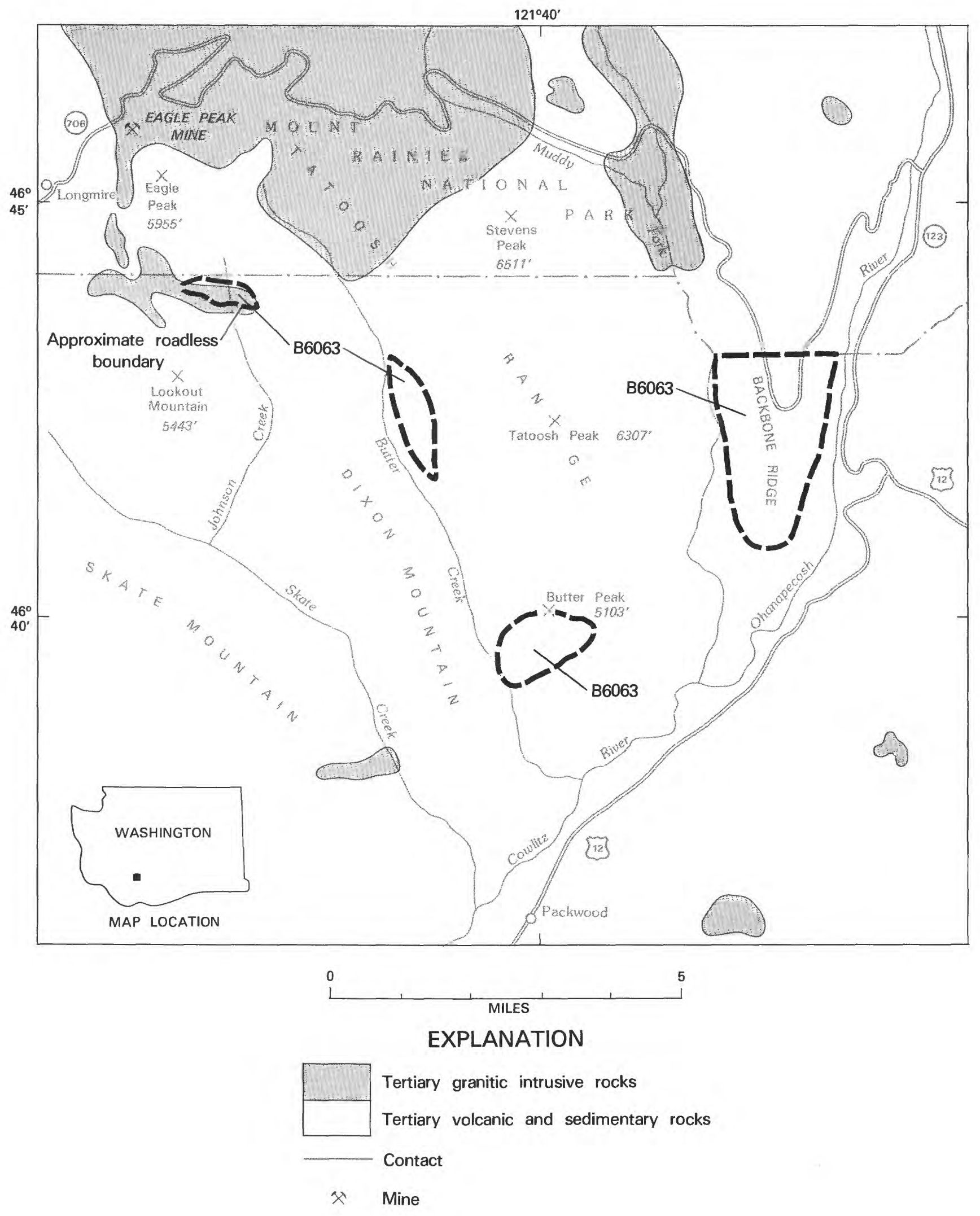

Figure 309.-Tatoosh Roadless Area, Washington. 


\title{
TATOOSH ROADLESS AREA, WASHINGTON
}

\author{
By Russell C. EVARTS, U.S. GEOlOgical SURVEY
}

\begin{abstract}
SUMMARY
Geologic and geochemical surveys of the Tatoosh Roadless Area were conducted in 1981-82. The results indicate that none of the four parts comprising the roadless area are likely to contain mineral or energy resources.
\end{abstract}

\section{CHARACTER AND SETTING}

The Tatoosh Roadless Area is within the Gifford Pinchot National Forest in the south-central Cascade Range of Washington. The roadless area consists of four separate parts, comprising $5.4 \mathrm{sq} \mathrm{mi}$, peripheral to the Tatoosh Wilderness. The Tatoosh Wilderness, located immediately south of Mount Rainier National Park, includes the core of the rugged and heavily forested Tatoosh Range. Access to the roadless area is via the USFS road network north of U.S. Highway 12; the easternmost part of the roadless area on Backbone Ridge is crossed by Washington State Route 706 which also traverses the southern part of the National Park.

All four parts of the Tatoosh Roadless Area are underlain by mid-Tertiary igneous and sedimentary rocks formed during the early stages of volcanic activity in the Cascade Range, about 25 to 40 million years ago (Fiske and others, 1963; Hammond, 1980). The volcanic rocks are predominantly andesitic lava flows and dacitic ash-flow tuffs, but basalt flows and rhyolite domes occur locally. These rocks have been intruded by dikes, sills, and irregular bodies of fine-grained rocks ranging from basalt and diabase to granite. The granitic rocks are generally the youngest and largest of the intrusive units and most of them are probably offshoots of the 14 to 26 million-year-old Tatoosh pluton in Mount Rainier National Park (Fiske and others, 1963; Mattinson, 1977). Virtually all of the volcanic, sedimentary, and intrusive rocks have been metamorphosed at low temperatures to zeolite-facies mineral assemblages, composed of chlorite, quartz, albite, calcite, and zeolites. Intense hydrothermal alteration of the kind associated with metallic mineral deposits, however, is rare, and although traces of pyrite are not uncominon, nowhere have concentrations of sulfide minerals been found.

The geology of the roadless area and vicinity was examined in 1981. Stream-sediment, panned concentrate, and bedrock samples were collected and analyzed in
1981-82. The detailed results of this work have been published by Evarts and others (1983).

\section{MINERAL RESOURCES}

Geologic and geochemical surveys indicate that there is little likelihood for the occurrence of metallic mineral resources in any of the four parts of the Tatoosh Roadless Area or, in fact, in the entire Tatoosh Range. No potential for nonmetallic or energy resources in the roadless area was identified. Minor geochemical anomalies possibly attributable to sulfide mineralization were detected only in panned concentrates from the central two parts of the roadless area. Analyses of altered bedrock from these two parts of the roadless area failed to reveal a source for the anomalies, suggesting that the sources are either small, sparsely disseminated, or located in parts of the drainage basins outside of the roadless area. No mining claims are known to exist in the Tatoosh Roadless Area. The nearest mining activity is at the Eagle Peak mine in Mount Rainier National Park, about $3 \mathrm{mi}$ north of the westernmost part of the roadless area. The Eagle Peak mine, which may be representative of the kind of deposit that might be found in the Tatoosh Range, produced less than 200 tons of copper ore. This deposit, however, occurs in a coarse-grained phase of the Tatoosh pluton which is unlike any intrusive rocks found in the roadless area.

\section{SUGGESTIONS FOR FURTHER STUDIES}

Further study restricted to the small areas encompassed by the Tatoosh Roadless Area is unlikely to reveal significant hidden mineral deposits. However, the geology of this part of the Cascade Range is poorly known, and a regionally focussed program of geologic mapping and geochemical sampling might discover 
areas of promising mineralization perhaps extending into the roadless area beneath the surface.

\section{REFERENCES}

Evarts, R. C., Church, S. E., and Mosier, E. L., 1983, Mineral resource potential of the Tatoosh Roadless Area, Lewis County, Washington: U.S. Geological Survey Open-File Report 83-471, 15 p.
Fiske, R. S., Hopson, C. A., and Waters, A. C., 1963, Geology of Mount Rainier National Park, Washington: U.S. Geological Survey Professional Paper 444, 93 p.

Hammond, P. E., 1980, Reconnaissance geologic map and cross sections of southern Washington Cascade Range: Portland, Oregon, Portland State University, Department of Earth Sciences, 31 p.

Mattinson, J. M., 1977, Emplacement history of the Tatoosh volcanic-plutonic complex, Washington: ages of zircons: Geological Society of America Bulletin, v. 88, p. 1509-1514. 


\title{
WENAHA TUCANNON WILDERNESS, WASHINGTON AND OREGON
}

\author{
By Donald A. SWanson, ${ }^{1}$ U.S. GeOlOGiCal Survey, and \\ STEVEN R. Munts, U.S. Bureau OF Mines
}

\section{SUMMARY}

A geologic and mineral survey conducted by the USGS and USBM in 1979-81 in the Wenaha Tucannon Wilderness, southeast Washington and northeast Oregon, indicates little promise for the occurrence of mineral or energy resources. Thin seams of low-grade coal possibly occur in the subsurface in the southeast corner of the wilderness.

\section{CHARACTER AND SETTING}

The Wenaha Tucannon Wilderness covers an area of about $277 \mathrm{sq} \mathrm{mi}$ in the Blue Mountains of southeast Washington and northeast Oregon, about 20 mi east of Walla Walla, Washington, and $30 \mathrm{mi}$ southwest of Lewiston, Idaho. The wilderness is in rugged terrain, with local relief of as much as $3300 \mathrm{ft}$; highest altitudes are about $6387 \mathrm{ft}$ (Oregon Butte) and $6379 \mathrm{ft}$ (Diamond Peak), and the lowest is about $1880 \mathrm{ft}$, along the Wenaha River. North-facing slopes are heavily forested, but south-facing slopes are moderately open and dry. Main access is provided by unpaved roads from Troy $(5 \mathrm{mi})$ and Elgin $(22 \mathrm{mi})$, Oregon, and Dayton (15 mi), Pomeroy (25 mi), and Walla Walla $(25 \mathrm{mi})$, Washington.

Most of the Wenaha Tucannon Wilderness is underlain by the Columbia River Basalt Group, a thick accumulation of lava flows that covers much of eastern Washington, northern Oregon, and western Idaho. The flows in the wilderness were produced during gigantic eruptions about 16.5 to 10.5 million years ago. Some of these eruptions took place within the confines of the wilderness, as attested by deposits of pumice and spatter and the presence of numerous feeder dikes from which the lava was extruded. The oldest flows covered a hilly to mountainous landscape. The only evidence in the wilderness for the nature of the prebasalt terrain is in the extreme northern tip, where low-grade metamorphic rocks (principally greenstone) of late Paleozoic or early Mesozoic age crop out.

The crest of the Blue Mountains uplift, a major structure extending from central Oregon to the tri-state area of Washington, Oregon, and Idaho, passes east-west

${ }^{1}$ With contributions from Thomas L. Wright, USGS. through the northern third of the Wenaha Tucannon Wilderness. The uplift may have begun to form in the area as early as 15 million years ago but was first prominent about 10.5 million years ago. Two systems of faults, one trending northwest, the other northnortheast, occur on the south limb of the uplift; the faults probably have strike-slip displacement.

For this study, samples of silt-sized stream sediment, rock samples, and heavy-mineral fractions of placer concentrates were analyzed for their mineral content.

There is no record of mining activity or of claims in the Wenaha Tucannon Wilderness. The Tucannon mining district extends into the northern part of the wilderness, but the principal part of the district is $4 \mathrm{mi}$ north of the wilderness. The Asotin mining district is $6 \mathrm{mi}$ northeast of the wilderness. Several of the older mines and prospects in these districts are currently being mined for precious metals, chiefly gold.

\section{MINERAL RESOURCES}

The Wenaha Tucannon Wilderness has little promise for the occurrence of metallic, nonmetallic, and energy resources.

Trace amounts of gold were found in three rock samples and three placer samples, most of which were collected from the northeastern part of the wilderness. Slightly anomalous concentrations of silver and copper were also noted in some samples of altered basalt and greenstone. Most of these anomalies are derived from the pre-Tertiary rocks in the northern tip of the wilderness, and no resources were identified. Two local occurrences of low-quality, semi-precious gemstones were found, one of chalcedony, the other of sunstone 

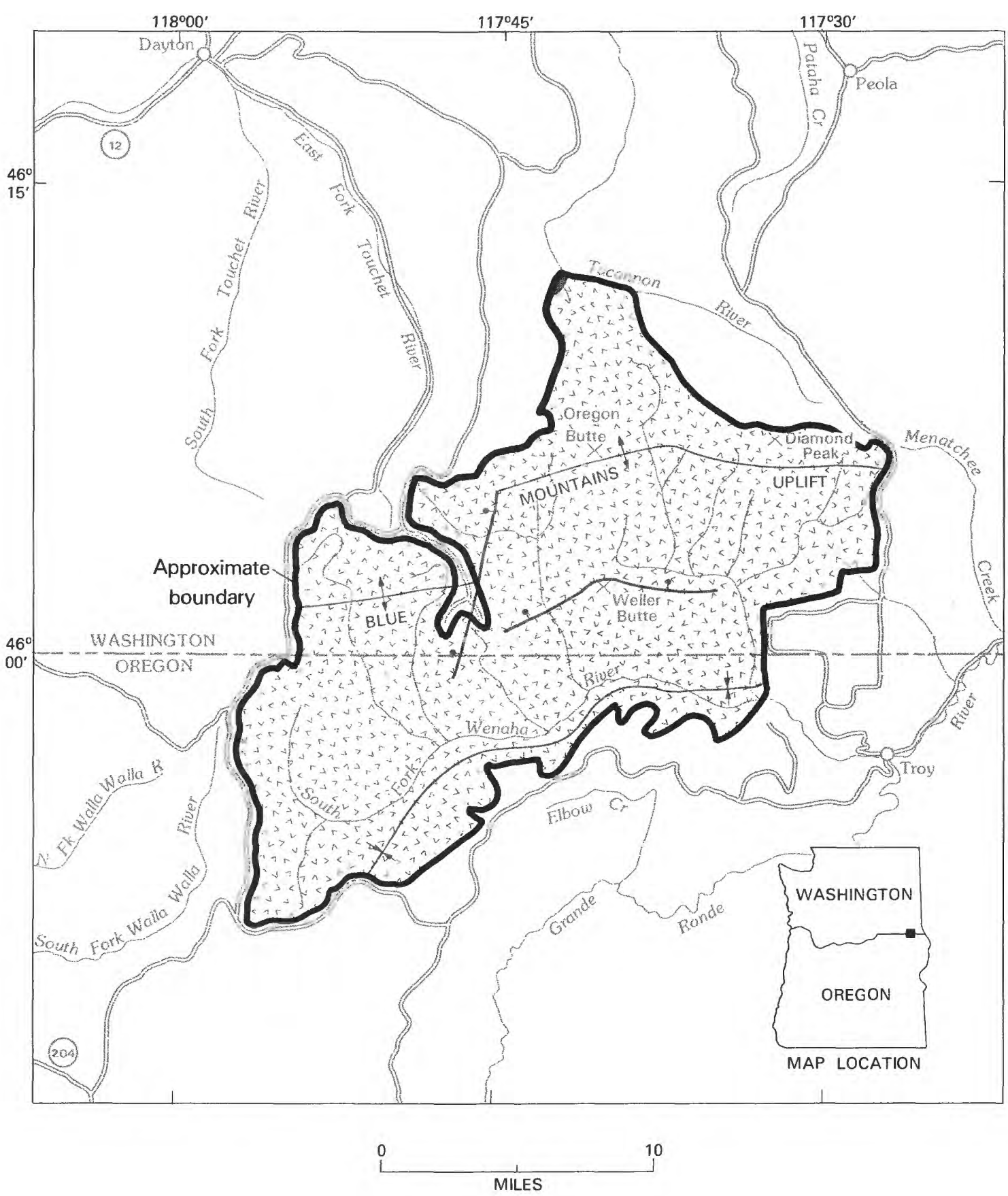

EXPLANATION

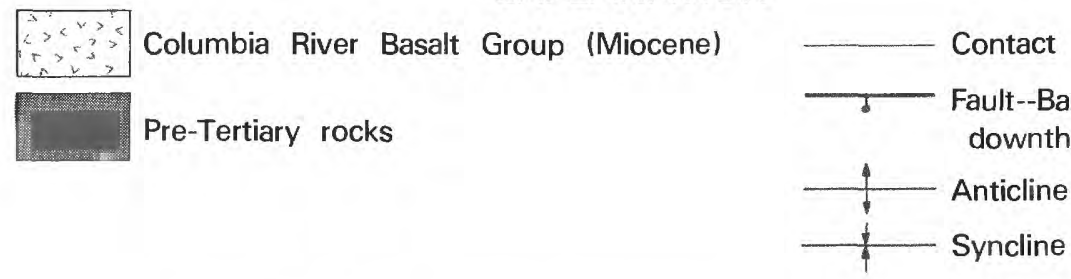

Figure 310.-Wenaha Tucannon Wilderness, Washington and Oregon. 
(plagioclase phenocrysts in one of the basalt flows); neither is assessed as having resource potential. No thermal springs or wells were found in the wilderness.

Thin seams of low-grade coal and beds of carbonaceous shale occur locally east of the wilderness, but none was found within the wilderness itself. Buried coal seams could occur in interbeds between basalt flows in the southeastern part of the wilderness, but they are unlikely. There is little likelihood for the occurrence of oil and natural gas resources.

\section{SUGGESTIONS FOR FURTHER STUDIES}

Further study of the Wenaha Tucannon Wilderness itself offers little promise for the identification of hidden mineral deposits or energy resources. Additional study of the pre-Tertiary rocks north of the wilderness might reveal important features to aid in further evaluating the pre-Tertiary rocks in the northern tip of the wilderness.

\section{REFERENCES}

Munts, S. R., 1982a, Mineral resources of the Wenaha-Tucannon Wilderness study area (FS), Asotin, Columbia, and Garfield Counties, Washington and Wallowa County, Oregon-Summary Report: U.S. Bureau Mines File Report, 17 p.

Munts, S. R., 1982b, Mineral resources of the Wenaha-Tucannon Wilderness, Asotin, Columbia, and Garfield Counties, Washington and Wallowa County, Oregon-File Report: U.S. Bureau Mines Open File Report.

Ross, M. E., 1978, Stratigraphy, structure, and petrology of Columbia River basalt in a portion of the Grande Ronde-Blue Mountains area of Oregon and Washington: Moscow, Idaho University, $\mathrm{Ph}$. D. thesis, $407 \mathrm{p}$.

Swanson, D. A., Wright, T. L., and Munts, S. R., 1983, Mineral resource potential of the Wenaha Tucannon Wilderness, Washington and Oregon: U.S. Geological Survey Open-File Report 83-374. 

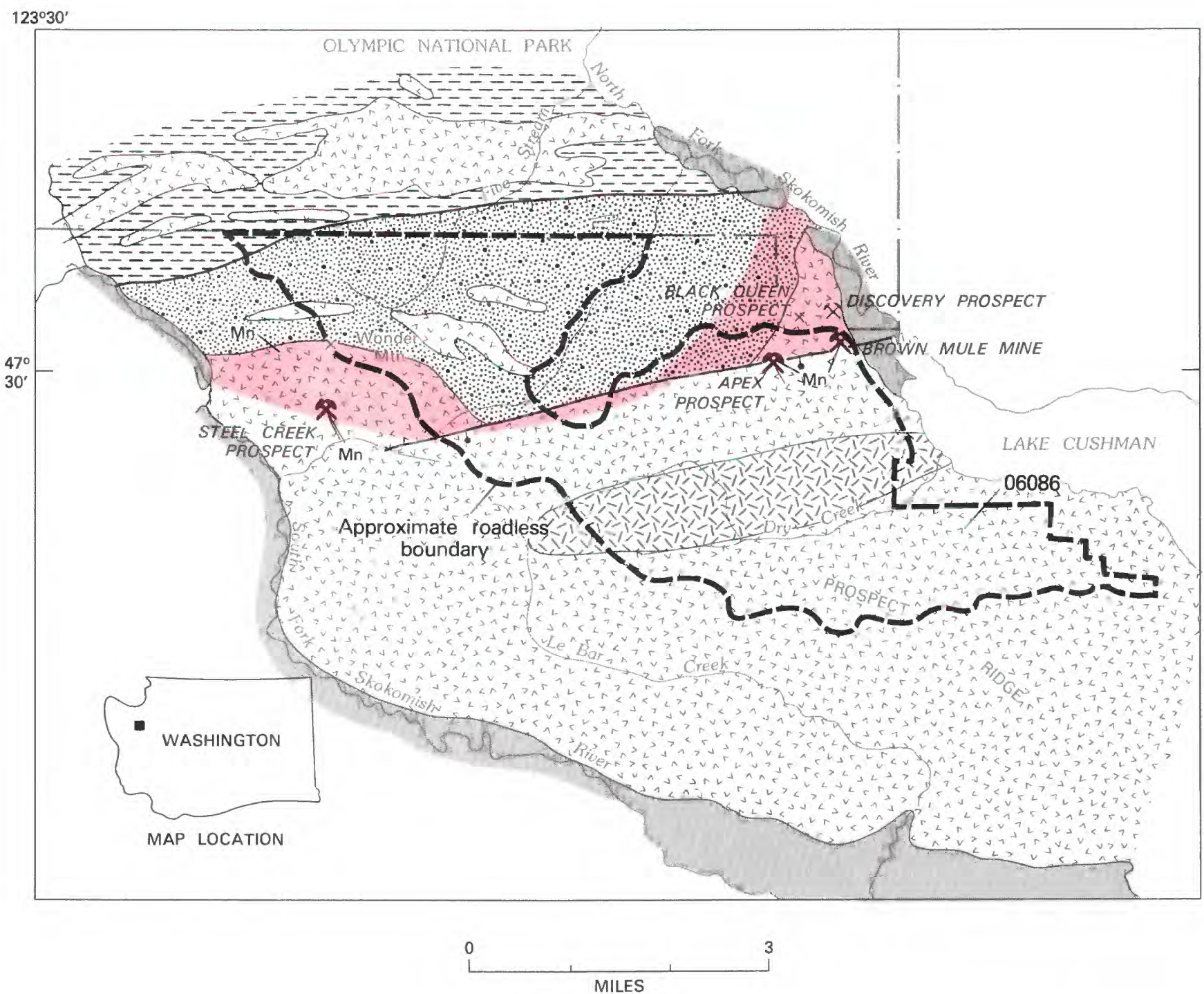

EXPLANATION

$\begin{aligned} & \text { Geologic terrane with probable } \\ & \text { mineral-resource potential }\end{aligned}$
$\mathrm{Mn} \quad$ Manganese
$\times \quad$ Mine or deposit
$\times \quad$ Mineral occurrence
$\times \quad$ Mine

Geologic terrane with probable

Manganese

Mine

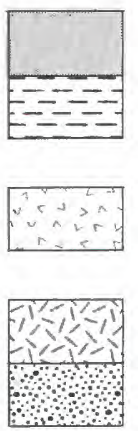

Alluvium (Quaternary)

Foliated sandstone, slate, and phyllite (Tertiary)

Basalt, basalt breccia, and greenstone (Tertiary)

Diabase and gabbro (Tertiary)

Argillite and sandstone (Tertiary)

\section{Contact}

Fault--Bar and ball on downthrown side

Folded thrust fault

Figure 311.-Wonder Mountain Roadless Area, Washington. 


\title{
WONDER MOUNTAIN ROADLESS AREA, WASHINGTON
}

\author{
By S. E. Church, ${ }^{1}$ U.S. GeOlogical Survey, and \\ S. R. IVERSON, U.S. BUREAU OF Mines
}

\begin{abstract}
SUMMARY
The results of geologic, geochemical, and mineral surveys in the Wonder Mountain Roadless Area done in 1982 indicate a probable resource potential for manganese. Deposits are small (less than 12,000 tons of demonstrated resources) and are primarily manganese silicate (bementite) which is difficult to refine. There is no indication of any resource potential for other metallic, nonmetallic or energy resources in the area.
\end{abstract}

\section{CHARACTER AND SETTING}

High mountain ridges with rugged outcrops of basalt characterize the Wonder Mountain Roadless Area in the southeastern Olympic Mountains. The roadless area adjoins Olympic National Park to the north, Lake Cushman Reservoir to the east, and heavily logged areas within Olympic National Forest to the south and west. Access to the roadless area is available from Hoodsport on U.S. Highway 101. A paved road leads northwest to Staircase in the Olympic National Park at the head of Lake Cushman. The south and west sides of the roadless area are accessible by logging roads along the south fork of the Skokomish River. The USGS and the USBM made a mineral-resource study of the area in 1982 (Church and others, 1983). This report abstracts the results of that study and companion studies (Tabor, 1982; Frisken and others, 1983).

The rocks exposed in the roadless area are Eocene in age. They consist of various basalts, diabase, unmetamorphosed sandstone and shale, and a metamorphosed sandstone and phyllite unit. Structurally, the basalts and underlying sandstones and shales have been folded and are in thrust contact with the metamorphosed sandstone, shale, and basalt terrain to the north. The basaltic rocks represent oceanic crust of Eocene age. They overlie and interfinger with the marine sandstone and shale unit which locally contains red limestone, shales, and some jasper. Manganese-rich zones are associated with these sedimentary rocks. Local, small deposits of manganese-rich sediments accumulated in

${ }^{1}$ With contributions from R. W. Tabor, USGS. small sediment traps away from zones of active sedimentation or volcanic activity, where chemical precipitates, along with pelagic ooze, settled on the ocean floor and were swept into the topographic lows. A period of active volcanism on the ocean floor terminated this sedimentation process and is presumed responsible for the small size and local nature of these bedded manganese deposits. There are approximately 150 known deposits of manganese-bearing rocks in the $125 \mathrm{mi}$ belt around the north, east, and south sides of the Olympic Mountains.

The Wonder Mountain Roadless Area is within the indefinite boundaries of the Lake Cushman, Mount Tebo, and Wonder Mountain mining districts. Prospecting for manganese and copper ore began in the late 1800's; in 1890, James McReavy organized the Mason County Mining and Development Company to prospect for iron and copper in the area of Lake Cushman. In 1895, the Discovery claims on Copper Creek were located. Manganese was discovered in the Lake Cushman area in 1903. Sporadic activity occurred in the area through World War I and several small shipments of ore were made. The Crescent mine, located approximately $35 \mathrm{mi}$ northwest of the roadless area in Clallam County, produced approximately 46,000 tons of manganese ore. This single mine accounted for 98 percent of the manganese production from the Olympic Peninsula.

\section{MINERAL RESOURCES}

Examination of the five mines and prospects in the Wonder Mountain Roadless Area has shown that three of these prospects (Steel Creek, Apex, and Brown Mule) 
have aggregate demonstrated resources of about 12,000 tons of manganese-bearing rock. Two other prospects investigated may have resource potential, but currently available data preclude calculation of manganese resources.

The Steel Creek prospect consists of three small deposits: (1), a lens approximately $4 \mathrm{ft}$ by $25 \mathrm{ft}$ averaging 13.2 percent manganese; (2), a lens $7 \mathrm{ft}$ by $85 \mathrm{ft}$ averaging 32.4 percent manganese; and (3), a small series of stratigraphically discontinuous lenses averaging 32.4 percent manganese. Wiebelt (1942) estimated 948 tons of manganese resources averaging 27.0 percent manganese and the geologic conditions appear favorable for locating additional resources.

The Apex prospect consists of a manganese-rich lens approximately $200 \mathrm{ft}$ long with a maximum thickness of $28 \mathrm{ft}$. It has been extensively drilled and the samples range from 1.0 to 47.0 percent manganese with measurable gold values. Wiebelt (1942) estimated 10,662 tons of manganese resource averaging 24.8 percent manganese. Geologic conditions are favorable for locating additional resources.

The Brown Mule mine has several pits and adits in a tabular but discontinuous body of rock containing manganese-rich lenses. Ore zones are as much as $1.5 \mathrm{ft}$ wide and manganese contents range from 20.8-31.0 percent. Wiebelt (1942) estimated 294 tons of manganese resources averaging 24.8 percent manganese. Geologic conditions appear favorable for locating additional resources.

The Black Queen prospect consists of several small pits exposing a manganese-rich lens $2 \mathrm{ft}$ by $20 \mathrm{ft}$; no assay data are available and exposures are insufficient to evaluate mineral-resource potential.

The Discovery prospect is in an iron- and manganesestained shear zone bounded by red limestone beds. The average thickness is about $4 \mathrm{ft}$; assay data indicate manganese values ranging from 1.0 to 5.0 percent manganese with a trace of copper. Exposures are insufficient to judge mineral-resource potential.
Geochemical investigations and geologic mapping (Frisken and others, 1983; Tabor, 1982) suggest that the area containing the red shale, limestone, and jasper has a probable mineral-resource potential. Geologic conditions are favorable for the occurrence of mineralized horizons only in the sedimentary rocks. The manganese occurs predominantly as manganese silicate (bementite) which is difficult to refine. Deposits in the roadless area, although they contain resources of manganese, are small, especially when compared with the large deposits of manganese oxide ores being mined today.

The only nonmetallic resource in the area is basalt, quarried locally for road base. There is an ample supply of basalt available outside the roadless area for this purpose.

Exploration for oil and gas has not been carried out in the immediate vicinity of the Wonder Mountain Roadless Area, but no production has been obtained from wells drilled elsewhere on the Olympic Peninsula in rocks of similar age, type, and structural setting.

There is no indication of potential for any geothermal resource.

\section{REFERENCES}

Church, S. E., Frisken, J. G., Tabor, R. W., and Iverson, S. R., 1983, Mineral resource potential map of the Wonder Mountain Roadless Area, Mason County, Washington: U.S. Geological Survey Miscellaneous Field Studies Map MF-1418-B, scale 1:62,500.

Frisken, J. G., Chruch, S. E., Mosier, E. L., and McCollaum, A. D., 1983, Geochemical map of the Wonder Mountain Roadless Area, Mason County, Washington: U.S. Geological Survey Miscellaneous Field Studies Map MF-1418-C, scale 1:62,500.

Tabor, R. W., 1982, Geologic map of the Wonder Mountain Roadless Area, Mason County, Washington: U.S. Geological Survey Miscellaneous Field Studies Map MF-1418-A, scale 1:62,500.

Wiebelt, F. J., 1942, Final report for the Olympic Peninsula manganese project no. 301, Port Angeles, Washington: U.S. Bureau of Mines, unpublished report, p. 164. 



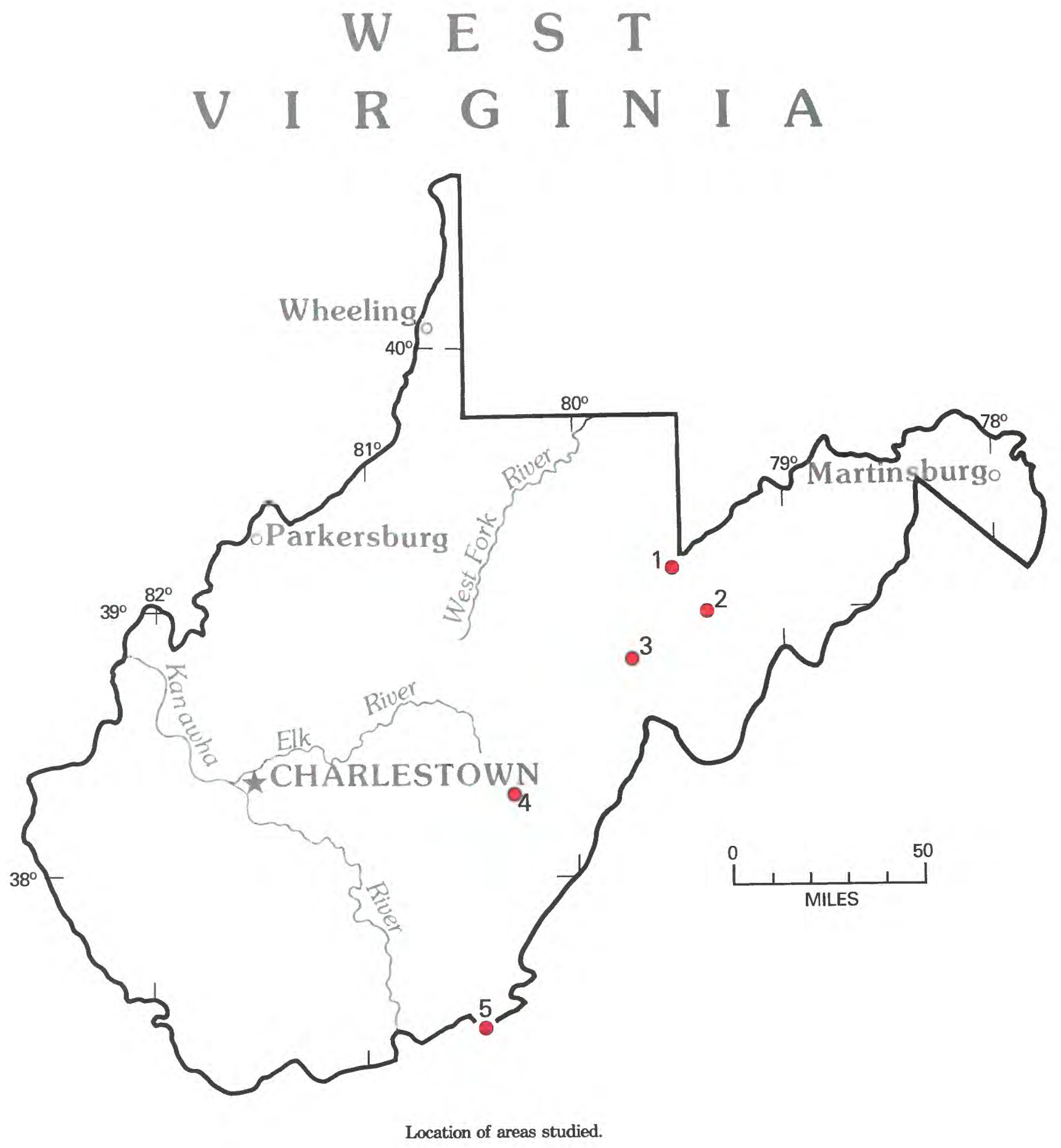




\section{WEST VIRGINIA}

Map

Name of Area

3 Cheat Mountain Roadless Area

4 Cranberry Wilderness Study Area

2 Dolly Sods Wilderness

5 Mountain Lake Wilderness Study Area, Virginia and West Virginia-See Virginia

1 Otter Creek Wilderness 

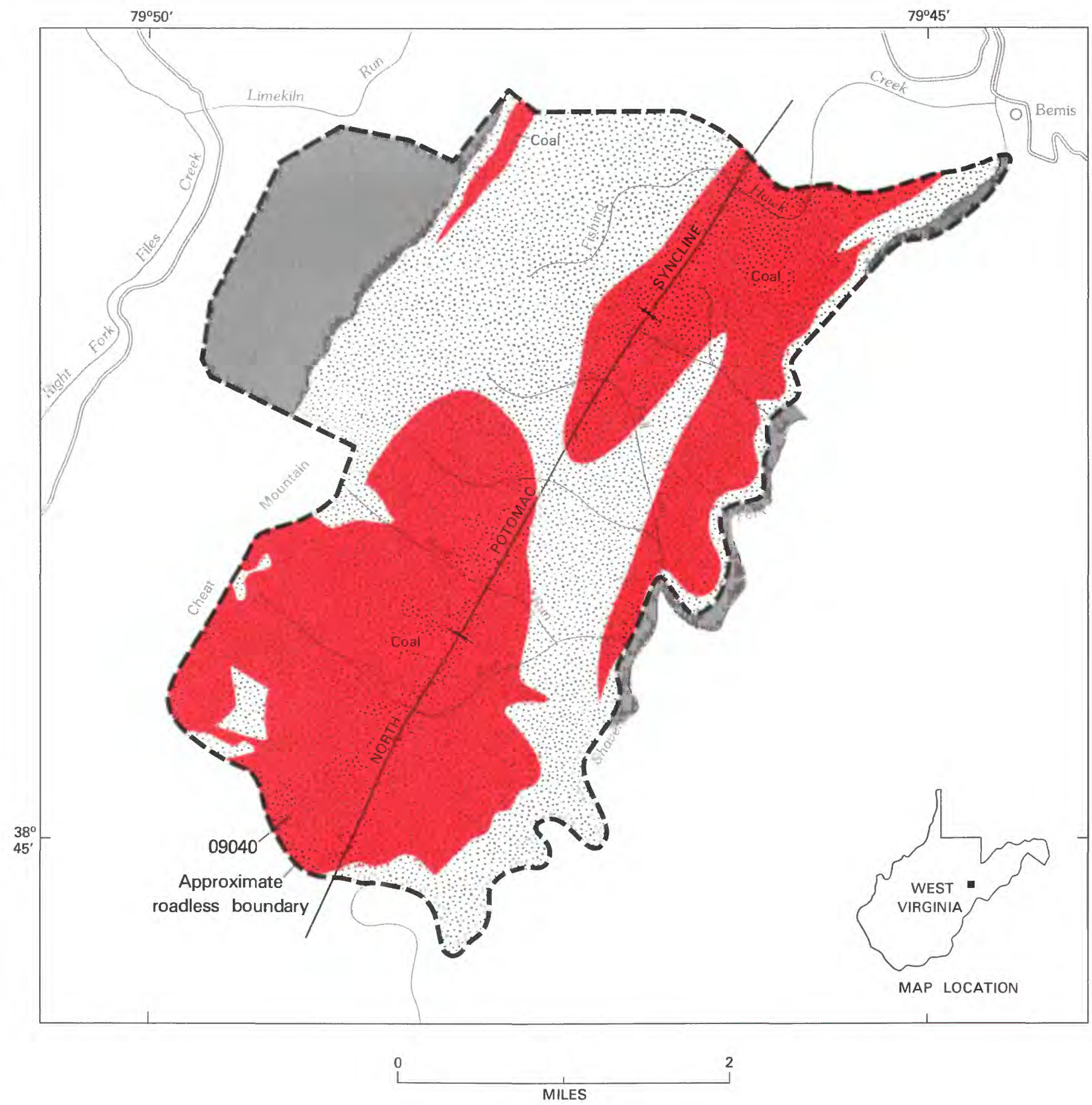

EXPLANATION

Geologic terrane with substantiated coal resource potential

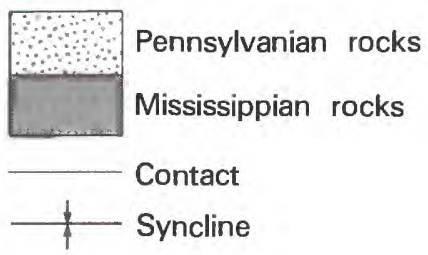

Figure 312.-Cheat Mountain Roadless Area, West Virginia. 


\title{
CHEAT MOUNTAIN ROADLESS AREA, WEST VIRGINIA
}

\author{
By K. J. Englund, U.S. GeOlogical Survey, and \\ P. T. BEHUM, U.S. BUREAU OF MINES
}

\begin{abstract}
SUMMARY
A mineral-resource survey by the USGS and USBM in 1980 determined that coal is the most important mineral resource in the Cheat Mountain Roadless Area, West Virginia. It is tentatively ranked as high-volatile A to mediumvolatile bituminous similar to coal in nearby mining areas, and is primarily of coking quality. Demonstrated coal resources are estimated to total about 11.6 million short tons in beds more than 28 in. thick in areas of substantiated resource potential and an additional 32.7 million short tons in beds between 14 and 28 in. thick have been identified. Limestone, shale, clay, and sandstone occur in the area but these commodities are readily available outside the roadless area. Available information suggests little promise for the occurrence of metallic mineral or other energy resources in the area.
\end{abstract}

\section{CHARACTER AND SETTING}

The Cheat Mountain Roadless Area contains about 12 sq $\mathrm{mi}$ in the Monongahela National Forest, Randolph County, West Virginia. The area is located about $10 \mathrm{mi}$ southeast of Elkins, West Virginia, and is accessible from there by U.S. Highway 219-250 to Beverly, West Virginia, and then southwestward along an improved country road. Unimproved USFS roads, abandoned logging railroad grades, and primitive trails provide access by foot or horseback into the interior of the roadless area.

Cheat Mountain Roadless Area comprises portions of seven large surface land tracts acquired in 1936 under the authority of the Weeks Act of 1911. The U.S. Government owns all of the surface rights and 35 percent of the mineral rights in the roadless area; the remaining 65 percent of the mineral rights is in private ownership.

Physiographically, the Cheat Mountain Roadless Area is in the Allegheny Mountain section of the Appalachian Plateaus province and is situated at the eastern edge of the Appalachian coal region. Cheat Mountain, a northeast-trending linear ridge, is bordered on the west by the Right Fork of Files Creek and on the east by Shavers Fork and its tributaries. Altitudes range from about $2320 \mathrm{ft}$ on Lime Kiln Run to more than 3900 feet on Cheat Mountain. The topography ranges from relatively flat in the uplands to very steep in the canyons along tributaries of Shavers Fork. Most of the area occupies an elevated plateau capped by resistant sandstone and conglomerate.

About $2600 \mathrm{ft}$ of sedimentary rocks of Late Devonian to Middle Pennsylvanian age crop out in the roadless area (Englund and others, 1981), and as much as 30,000 $\mathrm{ft}$ of older Paleozoic sediments may be in the subsurface. The basal part of the exposed section consists of continental and marine rocks assigned to the Hampshire Formation, Pocono Sandstone, and Greenbrier and Mauch Chunk Formations of Late Devonian to Late Mississippian age. Overlying rocks of the New River and Kanawha Formations (Early to Middle Pennsylvanian age) are mostly continental and coal bearing, but the sequence also contains a few deposits of marine origin. Quaternary deposits consist mostly of sandstone and conglomeratic sandstone debris that occurs as colluvium in unmapped slope deposits, or as alluvium in locally mapped deposits on the valley floor.

The Cheat Mountain Roadless Area is a part of the much larger North Potomac syncline, the major structural feature in central Randolph County. The trough of the syncline in the eastern part of the roadless area strikes generally N. $25^{\circ}$ E. and plunges gently in that direction. Structure contour lines drawn on the base of the Sewell(?) coal bed indicate that the rocks have a low to moderate dip, ranging from about $3^{\circ}$ near the trough of the syncline to as much as $17^{\circ}$ on the limbs which parallel the eastern and western boundaries. Evidence of faulting was not observed in the roadless area. 


\section{MINERAL RESOURCES}

Coal of high-volatile A to medium-volatile bituminous rank is the principal mineral resource in the Cheat Mountain Roadless Area (Englund and others, 1983). Exploitation of the coal resources has been limited to several small underground and surface mines located south and northeast of the area. In this report, coal resources are separately estimated for coal beds more than 28 in. thick, and for coal beds 14 to 28 in. thick. Areas underlain by coal beds more than 28 in. thick are shown on the map as areas of substantiated coal resource potential. Areas underlain by beds less than 28 in. but more than 14 in. are not shown.

Seven coal beds (Little Raleigh(?), Sewell(?), Sewell A(?), Sewell B(?), Hughes Ferry(?), C, C-1) are thick enough to be classified as demonstrated coal resources. Several less important coal beds were identified and mapped during the investigation. Most of these are less than 14 in. thick and are not identified as resources.

The Sewell(?) coal bed, the most important in the roadless area, contains an estimated total resource of about 22 million short tons. The $\mathrm{C}$ coal bed is too thin in the northern part of the roadless area to constitute a resource, but thickens in the southern part where about 4.9 million short tons are estimated. The C-1 coal bed contains an estimated 2.4 million short tons of coal, and the Hughes Ferry(?) coal bed is estimated to contaim about 4.9 million short tons. The total coal resource tonnage of all coal beds in the roadless area more than 14 in. thick is about $\mathbf{4 4 . 3}$ million short tons; 11.6 million short tons of this total are in beds more than 28 in. thick.

Limestone, high-silica sandstone, clay, and shale occur in the roadless area, but these commodities are abundant in other more favorably located areas outside of the roadless area.

Metallic mineral deposits have not been reported in the area and none were observed during the field investigations. The rock units exposed in the roadless area do not normally host metallic deposits in the nearby region, and a geochemical survey revealed no areas that contamed anomalously high concentrations of metals (Grosz and Cooley, 1981).
The Cheat Mountam Roadless Area shows little promise for the occurrence of oil and gas resources (Weed, 1983). Analysis of local structural features suggests the presence of splay and fracture zones with favorable fracture porosity. Recent exploratory drilling in similar structural settings in Pennsylvania has proven successful. However, two recent exploration wells in a neighboring syncline were dry. Source and reservoir rocks appear to be present; however, maturation levels are high.

\section{SUGGESTIONS FOR FURTHER STUDIES}

Adequate subsurface data are not available within Cheat Mountam Roadless Area and data from nearby wells are insufficient to determine if structural traps suitable for petroleum accumulation exist at depth or if gas is present. Seismic studies and exploration drilling are needed to determine the existence of structural traps for hydrocarbon accumulation.

\section{REFERENCES}

Behum, P. T., and Hammack, R. W., 1983, Mines, quarries, prospects, and exposures, Cheat Mountain Roadless Area, Randolph County, West Virginia: U.S. Geological Survey, Miscellaneous Field Studies Map MF-1271-D.

Englund, K. J., Sigleo, W. R., Behum, P. T., and Hammack, R. W., 1983, Mineral resource potential map of the Cheat Mountain Roadless Area, Randolph County, West Virginia: U.S. Geological Survey Miscellaneous Field Studies Map MF-1271-E, scale 1:48,000.

Englund, K. J., Sigleo, W. R., and Teaford, N. K., 1981, Geologic map of the Cheat Mountain Further Planning Area, Randolph County, West Virginia: U.S. Geological Survey Miscellaneous Field Studies Map MF-1271-A.

Grosz, A. E., and Cooley, E. F., 1983, Geochemical survey of the Cheat Mountain Roadless Area, Randolph County, West Virginia: U.S. Geological Survey Miscellaneous Field Studies Map MF-1271-C.

Weed, E.G.A., 1983, Oil and gas resources of the Cheat Mountain Roadless Area, Randolph County, West Virginia: U.S. Geological Survey Miscellaneous Field Studies Map MF-1271-B. 


\title{
CRANBERRY WILDERNESS STUDY AREA, WEST VIRGINIA
}

\author{
By Charles R. Meissner, JR., U.S. GeOlogical Survey, and \\ P. C. MORY, U.S. BuREAU of Mines
}

\begin{abstract}
SUMMARY
The Cranberry Wilderness Study Area contains a large demonstrated resource of bituminous coal of coking quality according to studies made in 1977 . Demonstrated coal resources in beds more than 14 in. thick are about 110 million short tons of which 56.5 million tons are in beds more than $28 \mathrm{in}$. thick in areas of substantiated coal resource potential. Other mineral resources in the study area include peat, shale and clay suitable for building brick and lightweight aggregate, sandstone suitable for low-quality glass sand, and sandstone suitable for construction material. These commodities are found in abundance in other areas throughout the State. Study of the drill-hole data did not reveal indications of a potential for oil and gas resources in the study area. Evidence of metallic mineral potential was not found during this investigation.
\end{abstract}

\section{CHARACTER AND SETTING}

The Cranberry Wilderness Study Area comprises $57 \mathrm{sq} \mathrm{mi}$ in the Monongahela National Forest, eastcentral West Virginia. The area is in parts of Webster and Pocahontas Counties about 8 mi west of Marlinton, West Virginia, and can be reached by several improved roads. Access to the northeastern corner is by State Highway 17 to USFS Route 86 . Route 86 , a graded gravel road, parallels the Williams River and forms the northern and northeastern boundary. State Highway 39 abuts the southern part of the area and connects to State Scenic Highway 150 which follows the mountain crest along the southern and eastern boundaries. USFS Route 102, which extends from State Highway 39, parallels the Cranberry River and provides access for restricted vehicular traffic along the southwestern boundary.

Nearly 86 percent of the mineral rights in the study area are owned by a mining company. The remainder of the mineral rights either are owned outright by the Federal Government (10 percent) or are subordinate to the surface rights ( 4 percent).

The wilderness study area is dominated topographically by the Yew Mountains of the Appalachian Plateaus and is at the east-central edge of the Appalachian coal region. Altitudes range from about $2395 \mathrm{ft}$ above sea level in the Middle Fork of the Williams River valley to $4559 \mathrm{ft}$ above sea level on Black Mountain. Principal streams are the Williams River, Middle Fork of the Williams River, Cranberry River, and the North Fork of the Cranberry River.

A major tourist attraction is the Cranberry Glades Botanical Area, which comprises about $1.2 \mathrm{sq} \mathrm{mi}$ at the southern end of the study area. These glades are likened to the tundra country of Alaska, containing peat, reindeer moss, sedge, high bush cranberry (Vibernum) and other shrubs, as well as birds and animals native to more northern parts of the United States. All mineral rights of the Glades are owned by the Federal Government.

Sedimentary rocks of Mississippian and Pennsylvanian age are exposed throughout the study area and have a gentle regional dip to the northwest (Meissner and others, 1981). The oldest exposed rocks are of Late Mississippian age and are composed predominantly of red shale, siltstone, and sandstone containing a few lenticular coal beds. They crop out in the lower slopes of the more deeply incised valleys in the central and northern parts of the study area and underlie a high plateau along the headwaters of the Cranberry River in the southern part of the area where the peat-bearing Cranberry Glades are located. The overlying Lower Pennsylvanian rocks contain more sandstone beds than the Mississippian rocks and contain important coal beds. Sandstone beds of Pennsylvanian age form prominant ledges and cliffs on the higher slopes and cap ridges in the central and northern part of the area. 


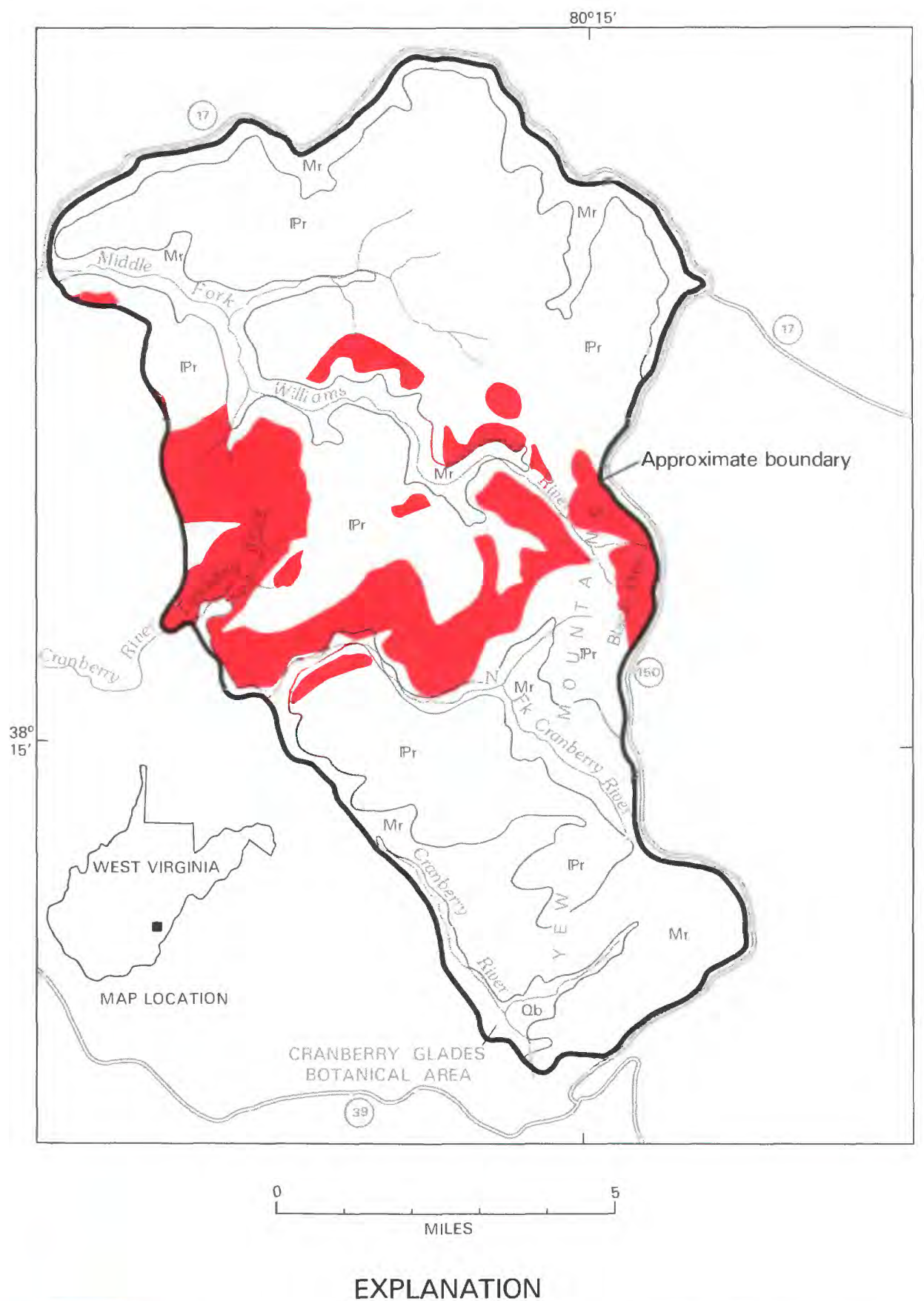

Geologic terrane with substantiated coal resource potential

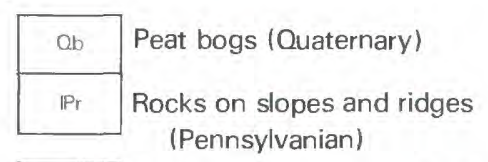

Mr Rocks in deeply incised valleys (Upper Mississippian)

\section{Contact}

Figure 313.-Cranberry Wilderness Study Area, West Virginia. 


\section{MINERAL RESOURCES}

Coal, the most important resource in the study area, has been prospected extensively by 65 known drill holes, 54 prospect trenches, and 10 adits. Several inactive surface and underground coal mines have operated about $1.2 \mathrm{mi}$ north of the northern border of the study area. Commercial production from the study area has not been recorded, although several small mines may have furnished coal for the locomotives used in logging operations.

Coal beds that have been mined elsewhere in northern West Virginia have been tentatively correlated into the study area. These are the Pocahontas No. 3, Pocahontas No. 3 rider, Little Fire Creek, Fire Creek, Beckley, Little Raleigh, Little Raleigh rider, Sewell, and Hughes Ferry coal beds (Meissner and others, 1981). Identification of Pocahontas coal beds in the Cranberry Wilderness study area has extended the Pocahontas coal field $20 \mathrm{mi}$ farther north then previously mapped. All of the identified beds except the Sewell and Hughes Ferry are known to contain coal of minable thickness. Areally, the more extensive beds are the Pocahontas No. 3, Fire Creek, Beckley, Little Raleigh and Sewell. Demonstrated coal resources in beds more than 14 in. thick and under less than $6000 \mathrm{ft}$ of overburden are about 110 million short tons. The estimated demonstrated resources of coal in beds more than 28 in. thick, under less than $1000 \mathrm{ft}$ of overburden, and less than $3 / 4 \mathrm{mi}$ from a point of measurement, is about 56.5 million tons and are shown on the map as areas of substantiated coal resource potential (Meissner and others, 1981, p. 15). The remaining 53.5 million tons of demonstrated coal resources are in areas containing beds less than 28 in. thick and are not shown on the map, despite their contained coal, because their development is considered unlikely. Coal resources underlie most of the northern three-quarters of the study area.

The drainage area and water table of the Cranberry Glades are isolated from the area of coal resources. The peat bogs lie upstream and updip on older rocks from the coal resources. Thus, the streams and aquifers draining the coal-bearing area do not drain across or into the Cranberry Glades. The peat deposits of the Cranberry Wilderness Study Area are restricted to an area of approximately $1.2 \mathrm{sq} \mathrm{mi}$ in the Cranberry Glades, along Cranberry River and its principal tributary, Charles Creek (Cameron and Grosz, 1981). The Glades consist of four peat bogs totalling about $0.2 \mathrm{sq}$ $\mathrm{mi}$. The peat in the four bogs ranges in thickness from about 2 to $4 \mathrm{ft}$ but the quantity of peat is too small and the beds too thin to be considered a resource at the present. The USBM collected and analyzed six sainples from the bogs that showed it to be of fuel quality with low ash and sulfur contents and adequate heating value (Caineron and Grosz, 1981).

The Cranberry Wilderness Study Area contains shale, underclay, sandstone, and conglomerate that are suitable for a variety of industrial uses. Laboratory tests by the USBM on shale and underclay sainples from the area suggest that most are suitable for use in making building brick (Meissner and others, 1981, p. 44-51). Analyses of sandstone and conglomerate by the USBM indicate that some beds have a silica content greater than 95 percent and may qualify for use as low-quality glass sand (Meissner and others, 1981, p. 45). Most of the sandstone and conglomerate is suitable for use as common building stone and crushed rock. These commodities are found in abundance in more readily accessible deposits throughout the State.

Exploration drilling suggests a remote chance for discovering gas, but little promise for the discovery of oil in and near the Cranberry Wilderness Study Area (Perry, 1981). The Pocahontas No. 8 exploratory well in the study area, was drilled to a depth of $4556 \mathrm{ft}$ and bottomed in Upper Devonian beds. No shows of oil or gas were reported. In exploratory wells drilled outside the study area, shows of gas were reported at several horizons in rocks of Mississippian and Early Devonian age. Apparently these gas shows did not indicate sufficient quantitites of gas to warrant production. A very old well, Pocahontas Land Company No. 1, drilled 1.2 mi east of the study area, had a questionable show of oil. However, no shows of oil have been subsequently reported in wells drilled in the surrounding region during 40 years of oil and gas exploration, and furthermore, no oil is expected in the study area because of the high thermal maturity of the rocks.

Reconnaissance geochemical sampling of the Cranberry Wilderness Study Area was done to find indistinct or unexposed mineral deposits that might be recognized by their geochemical halos. No metallic deposits have been reported in the literature of the study area, and none were found during the reconnaissance geologic mapping. Only normal background values of elements searched for were found in the rock and stream-sediment sainples (Lesure, 1981).

\section{SUGGESTIONS FOR FURTHER STUDIES}

No further studies are recommended for the Cranberry Wilderness Study Area.

\section{REFERENGES}

Cameron, C. C. and Grosz, A. E., 1981, Peat resources, in Meissner, C. R., Jr. and others, 1981, Mineral Resources of the Cranberry 
Wilderness Study Area, Webster and Pocahontas Counties, West Virginia: U.S. Geological Survey Bulletin 1494, p. 40-54.

Lesure, F. G., 1981, Geochemical survey, in Meissner, C. R., Jr., and others, 1981, Mineral resources of the Cranberry Wilderness Study Area, Webster and Pocahontas Counties, West Virginia: U.S. Geological Survey Bulletin 1494, p. 58-60.

Meissner, C. R., Jr., Windolph, J. F., Jr., Mory, P. C. and Harrison, D. K., 1981, Mineral resources of the Cranberry Wilderness Study Area, Webster and Pocahontas Counties, West Virginia with sections on Peat resources by C. C. Cameron and A. E.
Grosz; Oil and gas potential by W. J. Perry, Jr.; and Geochemical survey by F. G. Lesure: U.S. Geological Survey Bulletin 1494, $61 \mathrm{p}$.

Perry, W. J., 1981, Oil and gas potential in Meissner, C. R., Jr. and others, Mineral resources of the Cranberry Wilderness Study Area, Webster and Pocahontas Counties, West Virginia: U.S. Geological Survey Bulletin 1494, p. 54-58.

U.S. Bureau of Mines and U.S. Geological Survey, 1976, Coal resource classification system of the U.S. Bureau of Mines and U.S. Geological Survey: U.S. Geological Survey Bulletin 1450-B, $7 \mathrm{p}$. 


\title{
DOLLY SODS WILDERNESS, WEST VIRGINIA
}

\author{
By Kenneth J. Englund, U.S. Geological Survey, and \\ James J. Hill, U.S. BuREau of Mines
}

\begin{abstract}
SUMMARY
Coal, the principal mineral resource of the Dolly Sods Wilderness, is in at least seven beds of low- to medium-volatile bituminous rank according to studies made in 1975. Of these beds, four are of sufficient thickness, quality, and extent to contain demonstrated coal resources which are estimated to total about 15.5 million short tons in areas of substantiated coal resource potential. Small-scale development of the coal resources of the Dolly Sods Wilderness has been by several shallow adits which provided fuel for locomotives during early logging operations and by a one truck mine. All mine entries are now abandoned. Peat, shale, clay, and sandstone, occur in the area but because of remoteness of markets and inaccessability they are not classified as resources in this report. Natural gas may occur in rocks underlying the area, but because of a lack of subsurface information an estimate of resource potential has not been made. No evidence of metallic-mineral resources was found during this investigation.
\end{abstract}

\section{CHARACTER AND SETTING}

The Dolly Sods Wilderness comprises approximately $16 \mathrm{sq} \mathrm{mi}$ in the Monongahela National Forest, Tucker, Grant, and Randolph Counties, West Virginia. It is about 11 mi west of Petersburg, West Virginia, and can be reached by several improved roads; USFS Route 19 provides access from the south, USFS Route 75 parallels the eastern boundary, and the northwestern corner is accessible by State Routes 32 and 37 and by USFS Route 80 . From the USFS roads, well-marked trails extend into the interior.

The area is in the Allegheny Mountain section of the Appalachian Plateaus physiographic province and at the eastern edge of the Appalachian coal region. Altitudes range from about $2590 \mathrm{ft}$ on the lower part of Red Creek to more than $4100 \mathrm{ft}$ on the mountain tops. The topography is varied and includes highland bogs, canyons deeply incised by Red Creek and its tributaries, and broad upland plateaus fringed by cliffs of conglomeratic sandstone. Picturesque waterfalls along Red Creek and its tributaries are formed by resistant sandstone beds.

Under authority of the Weeks Act of 1911, the USFS purchased the four tracts of land that make up the Dolly Sods Wilderness and by 1929 all surface rights in the area were in Federal ownership. The Nature Conserv- ancy of Arlington, Virginia, optioned and later purchased (deed dated September 1, 1972) mineral and mining rights under $24.3 \mathrm{sq} \mathrm{mi}$ in Tucker and Randolph Counties from the West Virginia Coal and Timber Company, Inc. Mineral rights were purchased and conveyed to the Federal government in a deed dated December 19,1972 . A mineral survey was made in the fall of 1975 , and the results were published in 1980 (Englund and others, 1980).

About $1600 \mathrm{ft}$ of sedimentary rocks of Late Mississippian to Late Pennsylvanian age crop out in the Dolly Sods Wilderness and 25,000-30,000 ft of older Paleozoic sedimentary rocks may be in the subsurface. The basal $700 \mathrm{ft}$ of the exposed beds, representing either intertidal or fluvial mud-flat deposits, are assigned to the Mauch Chunk Formation of Late Mississippian age. This formation crops out along the lower valley slopes bordering Red Creek and its tributaries in the southwestern part of the area. The rest of the exposed stratigraphic section consists of continental coal-bearing rocks of the New River, Kanawha, Allegheny, and Conemaugh Formations of Early to Late Pennsylvanian age. These formations, preserved in the trough of the Stoney River syncline, are an isolated remnant of a sequence that was once laterally continous with Pennsylvanian rocks in the Appalachian Plateaus to the west and the folded and faulted Appalachian Mountains to the east. 


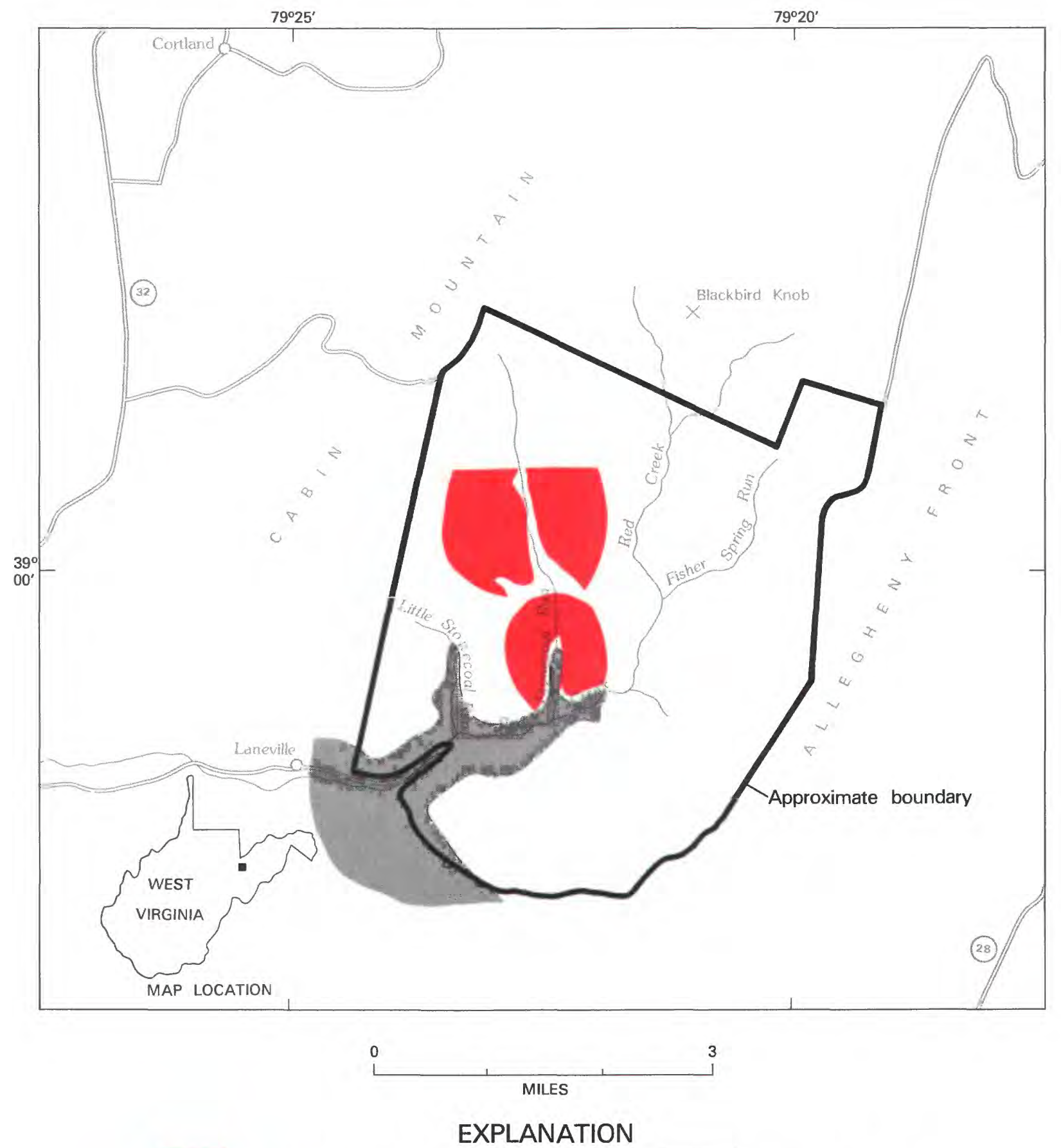

Geologic terrane with substantiated coal resource potential

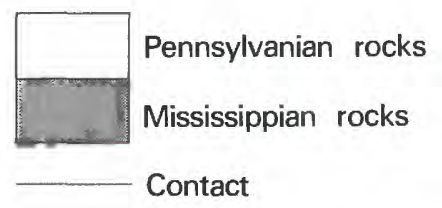

Figure 314.-Dolly Sods Wilderness, West Virginia. 
Quaternary deposits in the Dolly Sods Wilderness consist of alluvium in the flood plain of Red Creek and colluvium and talus accumulations on hill slopes, ridge tops, and along the steeper tributaries of Red Creek. This locally derived material is mostly subrounded to angular boulders and gravel. An extensive mantle of large angular blocks of conglomeratic sandstone that may have originated as the result of frost action on parent sandstone beds is abundant on ridge tops and slopes along Allegheny and Cabin Mountains.

Dolly Sods is situated in the west-central part of the Appalachian folded belt in the broad Stoney River syncline, a southwest-trending extension of the larger Georges Creek syncline. The trough line of the Stoney River syncline strikes irregularly N. $30^{\circ} \mathrm{E}$. and also plunges slightly to the northeast. Structure contour lines drawn on top of the Roaring Creek Sandstone Member of the Pottsville Formation (Pennsylvanian) of White (1903), a term supplanted by the Homewood Member of the Pottsville, show that the rocks dip gently from about $2^{\circ}-3^{\circ}$ near the trough line of the syncline to as much as $7^{\circ}$ on the east limb and $20^{\circ}$ on the west limb. The west limb is deformed by two subsidiary folds, a shallow syncline and an anticline that parallel the trough of the Stoney River syncline. Strata in the Dolly Sods Wilderness were folded during the Appalachian orogeny in late Paleozoic time; folding possibly continued into early Mesozoic time. Initial deformation that may have begun as early as the Pennsylvanian Period, is suggested by slight troughward thickening of Pennsylvanian strata in the Stone River syncline.

\section{MINERAL RESOURCES}

Coal in the Dolly Sods Wilderness is of low- to medium-volatile bituminous rank and is in at least seven beds in the New River, Kanawha, Allegheny, and Conemaugh Formations. Partings of impure coal, shale, and underclay are common in most beds and finely disseminated pyrite is sparse in some beds.

Coal resources have been estimated for the Sewell(?) and two unnamed coal beds in the New River and Kanawha Formations, undivided, and for the Kittanning coal zone in the Allegheny Formation (Englund and others, 1980, p. A16). The lack of physical connection between these coal beds and correlative beds in the Appalachian coal region to the west results in some uncertainty in coal-bed identifications. For this reason, only tentative correlations have been postulated with the Roaring Creek area (Englund, 1969) on the basis of the stratigraphic position of beds.

The Sewell(?) coal bed is widely distributed along the lower valley slopes of the wilderness. Resources in this bed are located principally along tributaries of Red Creek in the central part of the area where measurements made at abandoned adits and at outcrops indicate that the coal ranges from 10 to $34 \mathrm{in}$. in thickness, excluding one or two partings that aggregate as much as 6 in. in thickness. The bed thins toward the margins of the wilderness and may be absent locally.

Two unnamed coal beds at approximately 100 and $200 \mathrm{ft}$ above the Sewell(?) coal bed contain resources locally along Red Creek above the mouth of Stonecoal Run. These beds attain maximum thicknesses of 26 and 17 in., respectively, and may be of limited areal distribution.

Locally, one to three coal beds near the base of the Allegheny Formation comprise the Kittanning coal zone. Other names-Upper Kittanning and Lower and Upper Freeport-have applied previously to these coal beds (Reger and others, 1923). Regardless of their correlation, these coal beds are principally in an easttrending belt across the central part of the wilderness, where they total as much as $8 \mathrm{ft}$ in thickness. Because of the lenticular character of the individual beds, their combined thickness of coal is used for convenience in coal-resource calculations where the thickness of each bed is $14 \mathrm{in}$. or more. Before the inception of this study two thin coal beds of undetermined extent were cored in the Conemaugh Formation (Reger and others, 1923, p. 143).

The coal beds in the report area contain estimated original and remaining resources totalling about 40 million short tons of coal. Of this total: 66 percent is in the 14-28 in., or thin, category of thickness; 18 percent is in the 28-42 in., or intermediate, category; and 16 percent is in the greater than 42 in., or thick category. Areas underlain by coal beds more than 28 in. thick are shown on the map as areas of substantiated coal resource potential. Areas containing beds less than 28 in. thick are not shown, despite their contained coal, as development is considered unlikely. The areas of substantiated coal resource potential are largely located in the west-central part of the wilderness.

Demonstrated coal resources, estimated for coal beds that are $28 \mathrm{in}$. or more in thickness are reported only for the Sewell(?) coal bed and the Kittannning coal zone. The area of demonstrated coal resources for the Sewell(?) coal bed borders lower Stonecoal Run where the bed contains an estimated 2,640,000 short tons of coal. The Kittanning coal zone contains an area of demonstrated coal resources in beds along upper Stonecoal Run where an estimated 12,900,000 short tons of coal are present. Resources have not been estimated for the other coal beds because data on the areal extent and thickness of the coal is insufficient, or where observed, the coal was less than 28 in. thick. 
Deposits of clay, shale, sandstone, and peat were also identified in the Dolly Sods Wilderness; however, because of the remoteness of markets and the lack of accessibility they are not classified as resources in this report. Natural gas may occur in rocks underlying the area but, because of the lack of subsurface information, an estimate of the potential for the occurrence of natural-gas resources has not been made.

Metallic deposits have not been reported in the wilderness and reconnaissance geochemical sampling of stream sediments and bedrock did not reveal any anomalous values related to obviously mineralized rocks. There is little promise for the occurrence of metallic-mineral resources in the area.

\section{SUGGESTIONS FOR FURTHER STUDIES}

Aside from coal, there is little likelihood that further study of the wilderness would disclose any hidden min- eral deposits. Additional exploration, particularly core drilling, would possibly increase the area of substantiated coal resource potential.

\section{REFERENCES}

Englund, K. J., 1969, Geologic map of the Roaring Creek area, Randolph County, West Virginia: U.S. Geological Survey Miscellaneous Geologic Investigation Map I-577, scale 1:12,000.

Englund, K. J., Warlow, R. C., Hill, J. J., Mory, P. C., Williams, B. B., and Dunn, M. L., Jr., 1980, Mineral resources of the Dolly Sods Wilderness Area, Grant, Randolph, and Tucker Counties, West Virginia: U.S. Geological Survey Bulletin 1483-A, 52 p.

Reger, D. B., Price, W. A., and Tucker, R. C., 1923, Tucker County: West Virginia Geological Survey (County Report), 542 p.

White, I. C., 1903, The Appalachian coal field: West Virginia Geological Survey Reports, v. 2, pt. 2, p. 81-725. 


\title{
OTTER CREEK WILDERNESS, WEST VIRGINIA
}

\author{
By Ralph C. WARlow, U.S. GeOlogical SurVey, and \\ PAUl T. BEHUM, U.S. BUREAU OF Mines
}

\begin{abstract}
SUMMARY
A mineral-resource survey of the Otter Creek Wilderness conducted in 1978 resulted in the determination of demonstrated coal resources estimated to total about 24 million short tons in beds more than 28 in. thick and an additional 62 million short tons of coal in beds between 14 and 28 in. thick. There is little promise for the occurrence of mineral or other energy resources in the area.
\end{abstract}

\section{CHARACTER AND SETTING}

The Otter Creek Wilderness is an area of approximately $31 \mathrm{sq} \mathrm{mi}$ in the Monongahela National Forest, Randolph and Tucker Counties, West Virginia, about $8 \mathrm{mi}$ east of Elkins, West Virginia. The Otter Creek Wilderness occupies all of the Otter Creek drainage basin and most of the Shavers Lick Run drainage basin, both of which flow into the Cheat River. The topography varies from nearly flat, poorly drained, upland areas to steep, canyon-like slopes. The altitudes within the wilderness range from $1790 \mathrm{ft}$ at the lowest point to $3920 \mathrm{ft}$ at the highest point. About 90 percent of the land is owned by the U.S. Government but 96 percent of the mineral rights are in private ownership.

Rocks of Early Mississippian to Middle Pennsylvanian age crop out in the wilderness and are about $1750 \mathrm{ft}$ thick. More than 20,000 ft of older Paleozoic sedimentary rocks may be present in the subsurface of the wilderness. The coal-bearing Pennsylvanian rocks are preserved in the trough of the North Potomac syncline as a remnant of a sequence once continuous with Pennsylvanian rocks of similar age to the west in the Appalachian Plateaus.

The North Potomac syncline is a large flexure in the west-central part of the Appalachian folded belt. The trough of the syncline strikes generally N. $25^{\circ}$ E. across the central part of the wilderness and plunges gently northeastward. The rocks dip about $3^{\circ}$ to $4^{\circ}$ near the trough of the syncline to as much as $13^{\circ}$ on the east and west limbs (Warlow, 1981). Evidence of faulting was not found within the wilderness although smallscale faults are exposed adjacent to the western edge of the wilderness.

\section{MINERAL RESOURCES}

Coal of medium-volatile bituminous rank is the only resource identified within the wilderness (Warlow and others, 1981). Bituminous coal has been mined and prospected in and near the wilderness (Behum and Mory, 1981). In this report, demonstrated coal resources are separately estimated for coal beds more than 28 in. thick and for coal in beds between 14 and 28 in. thick. Areas underlain by coal beds more than 28 in. thick are shown on the map as areas of substantiated coal resource potential. Areas underlain by beds less than 28 in. but more than 14 in. thick are not shown, despite their contained coal, as development is considered unlikely. Five coal beds or coal zones, the Sewell(?), Sewell(?) rider, and C-1 coal beds, and the C-2 coal zone, contain coal beds thick enough to be classed as demonstrated coal resources. Several other coal beds of less importance were identified and mapped during the investigation. Data indicate that most of the latter beds are less than $14 \mathrm{in.} \mathrm{thick} \mathrm{and} \mathrm{do} \mathrm{not} \mathrm{constitute} \mathrm{a}$ resource; therefore, only the resources contained in thicker (greater than 14 in. thick) and more extensive coal beds were estimated.

The Sewell(?) coal bed, the most important in the wilderness, contains an estimated total resource of about 37 million short tons. The Sewell(?) rider coal bed is too thin in the northern part of the wilderness to constitute a resource, but thickens in the southern part and there is estimated to contain about 6 million short tons of coal. The C-1 coal bed has been mined at two locations in the wilderness, and is estimated to contain about 15.5 million short tons of coal. The $\mathrm{C}-2$ coal zone consists of at least four generally lenticular coal beds. 


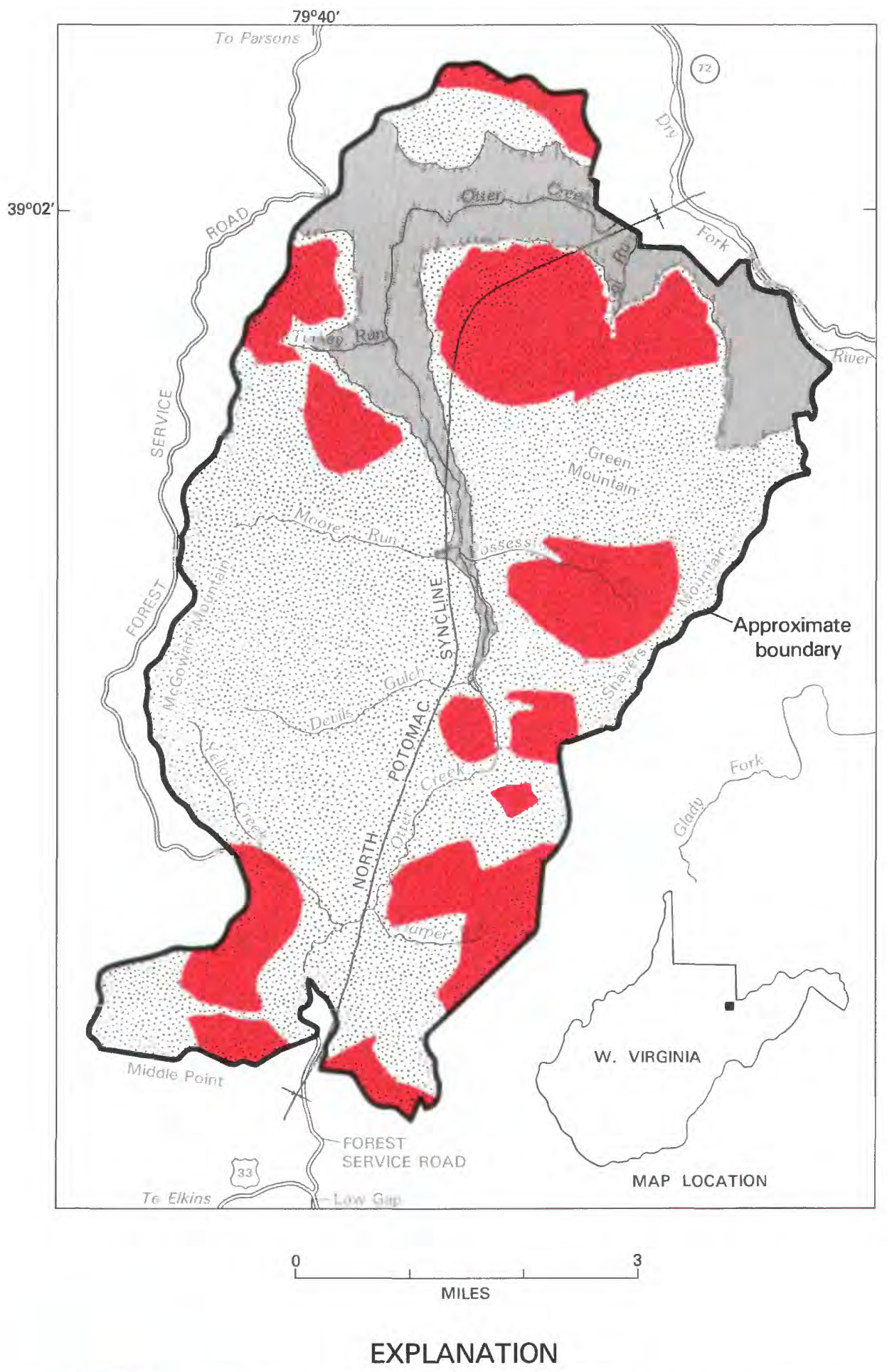

Geologic terrane with substantiated coal resource potential

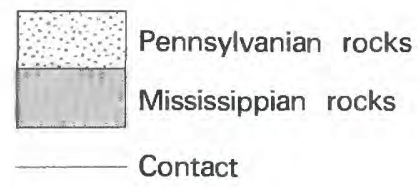

Figure 315.-Otter Creek Wilderness, West Virginia. 
Only one of these appears to be persistent throughout the wilderness and contains an estimated coal resource of about 26 million short tons. The Kittanning coal zone is $580 \mathrm{ft}$ above the Sewell(?) coal bed and is estimated to contain 1.3 million short tons of coal. The total demonstrated coal resource tonnage of all coal beds in the wilderness more than 14 in. thick is about 86 million short tons; 24 million short tons of this total is contained in beds more than 28 in. thick.

Nonmetallic minerals present in the wilderness include limestone, high-silica sandstone, clay, and shale; these resources are abundant in other more favorably located areas, outside of the wilderness.

The stratigraphic units exposed in the wilderness do not normally host metallic deposits, and no significant metal anomalies were identified in this area as a result of the geochemical survey.

Although petroleum source and reservoir rocks may underlie the wilderness, the rocks have a high thermal maturity and any oil that may have been present probably has been destroyed. Natural gas, which can exist under these thermal conditions, is produced in the vicinity of the Otter Creek Wilderness. Subsurface data are not available from within the wilderness and data from nearby wells are insufficient to determine if structural traps exist at depth in the wilderness and if gas might be present in the traps. Geophysical exploration is necessary to determine if there are structural traps for hydrocarbon accumulations in the Otter Creek Wilderness; presently available information suggests little potential for oil and gas.

\section{SUGGESTIONS FOR FURTHER STUDIES}

Further core drilling would aid in better determining the extent of minable coal deposits in the wilderness, and might aid in identifying unknown coal deposits. Seismic studies and exploration drilling would be required to refine assessments of oil and gas potential in this area.

\section{REFERENCES}

Behum, P. T., and Mory, P. C., 1981, Mines, quarries, prospects, and exposures in the Otter Creek Wilderness, Randolph and Tucker Counties, West Virginia: U.S. Geological Survey Miscellaneous Field Studies Map MF-1267-C.

Siems, D. M., Meier, A. L., and Wright, N. A., 1981, Analyses and descriptions of geochemical samples, Otter Creek Wilderness, Randolph and Tucker Counties, West Virginia: U.S. Geological Survey Open-File Report 81-352, 13 p.

Warlow, R. C., 1981, Geologic map, cross sections, generalized columnar section and structure contour map of the Otter Creek Wilderness, Randolph and Tucker Counties, West Virginia: U.S. Geological Survey Miscellaneous Field Studies Map MF-1267-A, scale 1:48,000.

Warlow, R. C., Behum, P. T., Mory, P. C., 1981, Map showing mineral resource potential of the Otter Creek Wilderness, Randolph and Tucker Counties, West Virginia: U.S. Geological Survey Miscellaneous Field Studies Map MF-1267-E.

Warlow, R. C., Oman, C. L., and Brooks, A. E., 1981, Chemical analysis and evaluation of 22 coal samples from the Otter Creek Wilderness and adjacent area, Randolph and Tucker Counties, West Virginia: U.S. Geological Survey Open-File Report 81-351, $34 \mathrm{p}$.

Weed, E.G.A., Oil and gas resources of the Otter Creek Wilderness, Randolph and Tucker Counties, W. Va: U.S. Geological Survey Miscellaneous Field Studies Map MF-1267-B.

Wright, N. A., 1981, Reconnaissance geochemical map of the Otter Creek Wilderness, Randolph and Tucker Counties, West Virginia: U.S. Geological Survey Miscellaneous Field Studies Map MF-1267-B. 
$\begin{array}{lllllllll}\text { W } & \text { I } & S & C & O & N & S & \text { I } & N\end{array}$

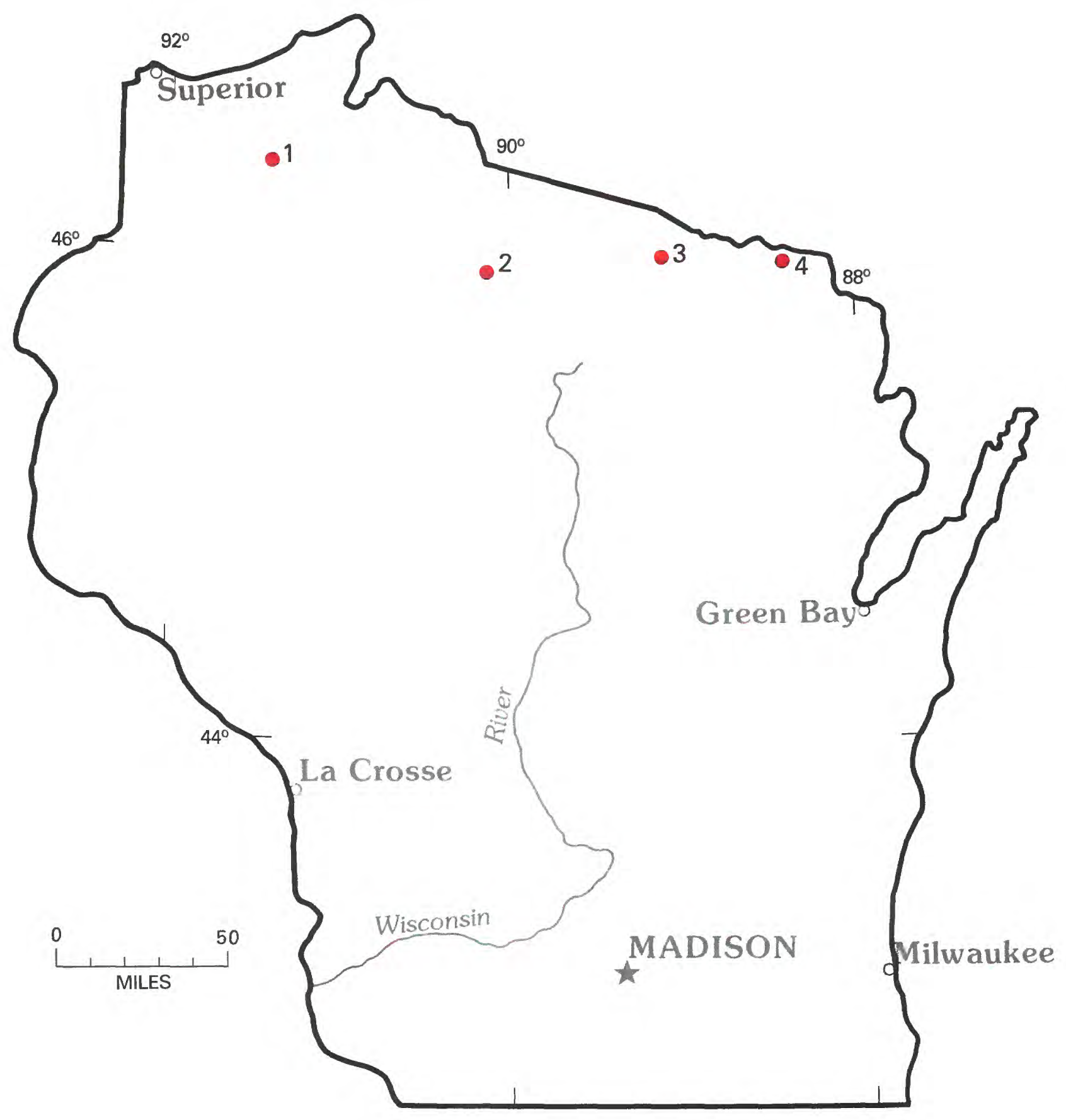

Location of areas studied. 


\title{
WISCONSIN
}

\author{
Map \\ Name of Area \\ 3 Blackjack Springs Wilderness \\ 1 Rainbow Lake Wilderness and Flynn Lake Wilderness Study Area \\ 2 Round Lake Wilderness Study Area \\ 4 Whisker Lake Wilderness
}




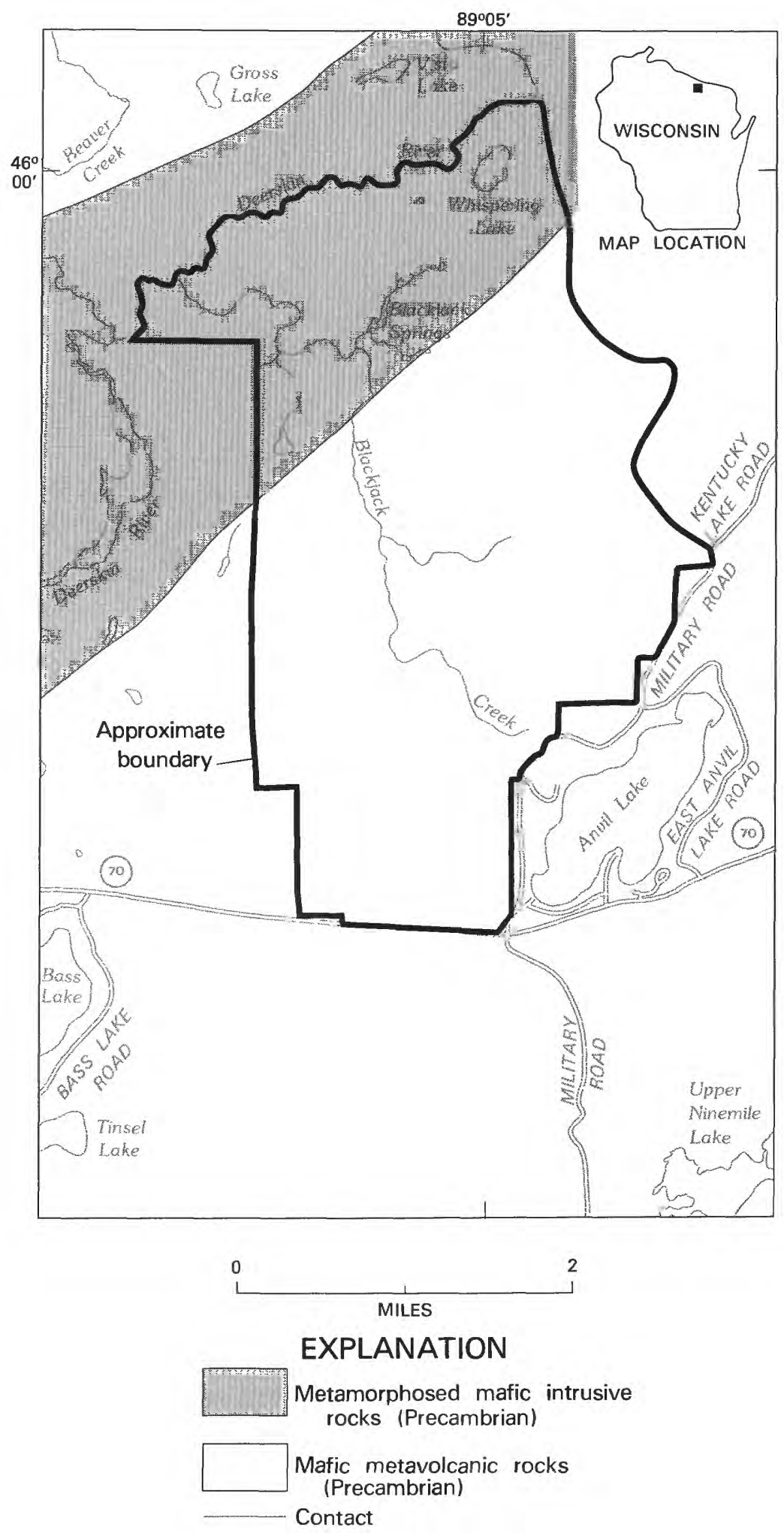

Figure 316.-Blackjack Springs Wilderness, Wisconsin. 


\title{
BLACKJACK SPRINGS WILDERNESS, WISCONSIN
}

\author{
By Klaus J. Schulz, U.S. Geological Survey
}

\begin{abstract}
SUMMARY
The mineral-resource potential of the Blackjack Springs Wilderness in northern Wisconsin was evaluated in 1982. The lack of bedrock exposures in or near the wilderness and the thick mantle of glacial sediments precludes a detailed assessment of the mineral potential of the wilderness. However, based on presently available data, the area is concluded to offer little promise for the occurrence of mineral resources. If mineral deposits exist in the area, they would be under thick glacial cover and probably be of the massive sulfide type in association with metavolcanic rocks or be magmatic copper-nickel in association with metamorphosed mafic intrusive rocks. Sand and gravel resources occur in the wilderness, but they are abundant regionally, outside the wilderness. No other metalhic or energy resources were identified in this study.
\end{abstract}

\section{CHARACTER AND SETTING}

The Blackjack Springs Wilderness is located in Vilas County in northern Wisconsin, about $8 \mathrm{mi}$ eastnortheast of the town of Eagle River. It occupies an area of about $9 \mathrm{sq} \mathrm{mi}$, and is bounded on the south by State Highway 70, on the east by Military Road (USFS Road 2178), and on the north by the Deerskin River.

The wilderness is in the lake country of northern Wisconsin and numerous lakes surround the wilderness. The topography is controlled by glacial drift deposits which form a hummocky terrane with a maximum relief of about $150 \mathrm{ft}$. The drift deposits are from 100 to $200 \mathrm{ft}$ thick (Borman, 1971).

The wilderness was examined in the summer of 1982 and the results published (Schulz, 1983). No bedrock exposures are known within or near the boundaries of the wilderness. The geologic assessment and mineralresource evaluation of the area are largely based on the data of Morey and others (1982), Zietz and others (1977), and Dutton and Bradley (1970).

Most of the wilderness is believed to be underlain by recrystallized and deformed mafic volcanic rocks of Precambrian age, that are part of an extensive east-west belt of volcanic rocks in northern Wisconsin. The compilation of aeromagentic data by Zietz and others (1977) shows a prominent positive magnetic anomaly trending northeast-southwest across the northern part of the wilderness. This is interpreted to reflect a metamorphosed mafic intrusive body probably similar to those exposed to the southwest and to the east in Wisconsin. North of the wilderness is a terrane of mostly metasedi- mentary rocks that also form an elongate east-west belt. These rocks, consisting mostly of slates, are not inferred to extend into the wilderness. The rocks of the area were deformed and recrystallized about 1800 million years ago in an event which effected much of northern Wisconsin and upper Michigan. Following repeated cycles of erosion and inundation by seas, the area was sculptured by glacial erosion and covered by outwash sediments derived from melting glacial ice about 10,000 years ago.

The Blackjack Springs Wilderness is just south of the Conover district, an area explored for iron ore in the early 1900's; fifteen holes were drilled along an eastwest trending belt of positive magnetic anomalies. Although ferrugineous cherts were encountered, no ore grade material was found. The available aeromagnetic data (Zietz and others, 1977) suggest that these ferruginous units do not extend south into the wilderness.

\section{MINERAL RESOURCES}

The only identified resources of the Blackjack Springs Wilderness are sand and gravel. These commodities are abundant regionally, outside the wilderness.

No resources of metalkic minerals are known in the Blackjack Springs Wilderness or adjacent areas. However, the inferred geologic relationships suggest that it could be favorable for the occurrence of certain types of ore deposits. The volcanic rocks, which are inferred to underlie most the wilderness, are part of the volcanic terrane in which four massive sulfide deposits 
of copper, zinc, lead, and precious metals have been identified in the last 10 years. These deposits, lenses rich in sulfide minerals, are associated with mostly felsic volcanic rocks; similar felsic volcanic rocks are not presently known to underlie the wilderness although available information does not preclude their existence. Exploratory drilling has been conducted recently within the volcanic terrane about $30 \mathrm{mi}$ to the west of the wilderness, in the Lac du Flambeau area, and also about $35 \mathrm{mi}$ to the east, in the Florence area; no drilling has been undertaken in the wilderness to date.

The northern portion of the wilderness is inferred to be underlain by a metamorphosed mafic intrusive body. While such bodies are known to host disseminated to massive deposits of copper and (or) nickel sulfides, no such deposits are known to be associated with the other exposed mafic intrusive bodies within this volcanic terrane.

On the basis of presently available information, it is concluded that although the occurrence of certain types of mineral resources are possible in the Blackjack Springs Wilderness their occurrence is not considered probable. However, further physical exploration would be required to fully establish the existence or nonexistence of ore deposits in the area. If mineral deposits do exist, they probably are of the massive sulfide type, consisting of copper and zinc with variable amounts of lead, and are found in association with felsic volcanic rocks; and (or) magmatic sulfides that contain copper with variable amounts of nickel and are found in association with mafic intrusive bodies.

\section{SUGGESTIONS FOR FURTHER STUDIES}

Further study of the wilderness would be required to fully assess its mineral potential. Such study would require detailed geophysical surveys with subsequent test drilling.

\section{REFERENCES}

Borman, R. G., 1971, Generalized thickness of glacial deposits in Wisconsin: Wisconsin Geologic and Natural History Survey Open-File Map.

Dutton, C. E., and Bradley, R. E., 1970, Lithologic, geophysical, and mineral commodity maps of Precambrian rocks in Wisconsin: U.S. Geological Survey Miscellaneous Investigation Series I-631.

Morey, G. B., Sims, P. K., Cannon, W. F., Mudrey, M. G., Jr., and Southwick, D. L., 1982, Geologic map of the Lake Superior region: Minnesota, Wisconsin, and Northern Michigan: Minnesota Geological Survey Map S-13, scale 1:1,000,000.

Schulz, K. J., 1983, Geologic and aeromagnetic maps and mineral resource potential survey of the Blackjack Springs Wilderness, Vilas County, Wisconsin: U.S. Geological Survey Miscellaneous Field Studies Map MF-1592, scale 1:24,000.

Zietz, I., Karl, J. H., and Ostrom, M. E., 1977, Preliminary aeromagnetic map covering the exposed Precambrian terrane in Wisconsin: U.S. Geological Survey Miscellaneous Field Studies Map MF-888, scale 1:250,000. 


\title{
RAINBOW LAKE WILDERNESS AND FLYNN LAKE WILDERNESS STUDY AREA, WISCONSIN
}

\author{
By W. F. Cannon, U.S. Geological Survey, and \\ Maynard L. DunN, U.S. BuREAu of Mines
}

\begin{abstract}
SUMMARY
The Rainbow Lake Wilderness and Flynn Lake Wilderness study area are contiguous and were studied as a unit in 1976 and 1977. The Rainbow Lake Wilderness contains a demonstrated resource of about 210,000 tons of commercial-quality peat in an area of substantiated peat resource potential. The Flynn Lake Wilderness study area contains a demonstrated resource of about 300,000 tons of commercial-quality peat in an area of substantiated peat resource potential. These deposits, however, are of limited importance because larger deposits of similar material are abundant outside the areas, closer to present markets. Rocks in the subsurface contain a low-grade copper resource identified by mining company exploration drilling. Although this is an area of substantiated copper resource potential, it is a low-grade resource, thin and generally at great depth.
\end{abstract}

\section{CHARACTER AND SETTING}

The contiguous Rainbow Lake Wilderness and Flynn Lake Wilderness study area encompass about $10 \mathrm{sq} \mathrm{mi}$ each in the Chequamegon National Forest, Bayfield County, Wisconsin. Ashland, the nearest major town, is about $30 \mathrm{mi}$ northeast of the areas and the village of Drummond lies at the southeast corner of the Flynn Lake Wilderness study area. Old logging trails and the North Country hiking trail provide access to much of the areas.

Deposits of sand and gravel blanket the entire area so that bedrock is nowhere exposed. Depth to bedrock ranges from a few tens to several hundred feet. The nature of the bedrock is inferred from geophysical measurements, a few drill holes for which logs were provided by a mining company, and a few bedrock exposures near the study area (Cannon and others, 1981).

Bedrock consists of Proterozoic volcanic and sedimentary rocks about 1.1 billion years old. All are in layers inclined gently to the north. The oldest rocks are basalt and andesite flows which occupy the southernmost part of the area. These are overlain northwestward by the Copper Harbor Conglomerate, Nonesuch Shale, and Freda Sandstone of the Keweenawan Supergroup.

\section{MINERAL RESOURCES}

The rocks in the wilderness and wilderness study area are westward extensions of rocks that contain important copper deposits in northern Michigan, about $100 \mathrm{mi}$ to the east. Native copper has been extensively mined from basalt and conglomerate in the Keweenaw Peninsula in Michigan that is equivalent to the basalt underlying the southern part of the study area. The study area and surroundings were judged to be broadly favorable for native copper deposits (White, 1978) but no direct indications of such deposits were found in our study.

An extensive deposit of copper-sulfide minerals and native copper is mined at White Pine, Michigan, from a shale equivalent to the Nonesuch Shale underlying about 80 percent of the Rainbow Lake Wilderness. Between 1955 and 1960 Bear Creek Mining Company drilled about 50 exploration holes near or within the study area and an area of substantiated copper resource potential was found in the Nonesuch Shale. The base of the shale was found to contain copper over most of the area drilled, but concentrations are low, only a few tenths of a percent at most, and the mineralized beds are thin, no more that $1.5 \mathrm{ft}$ thick. A probable copper 


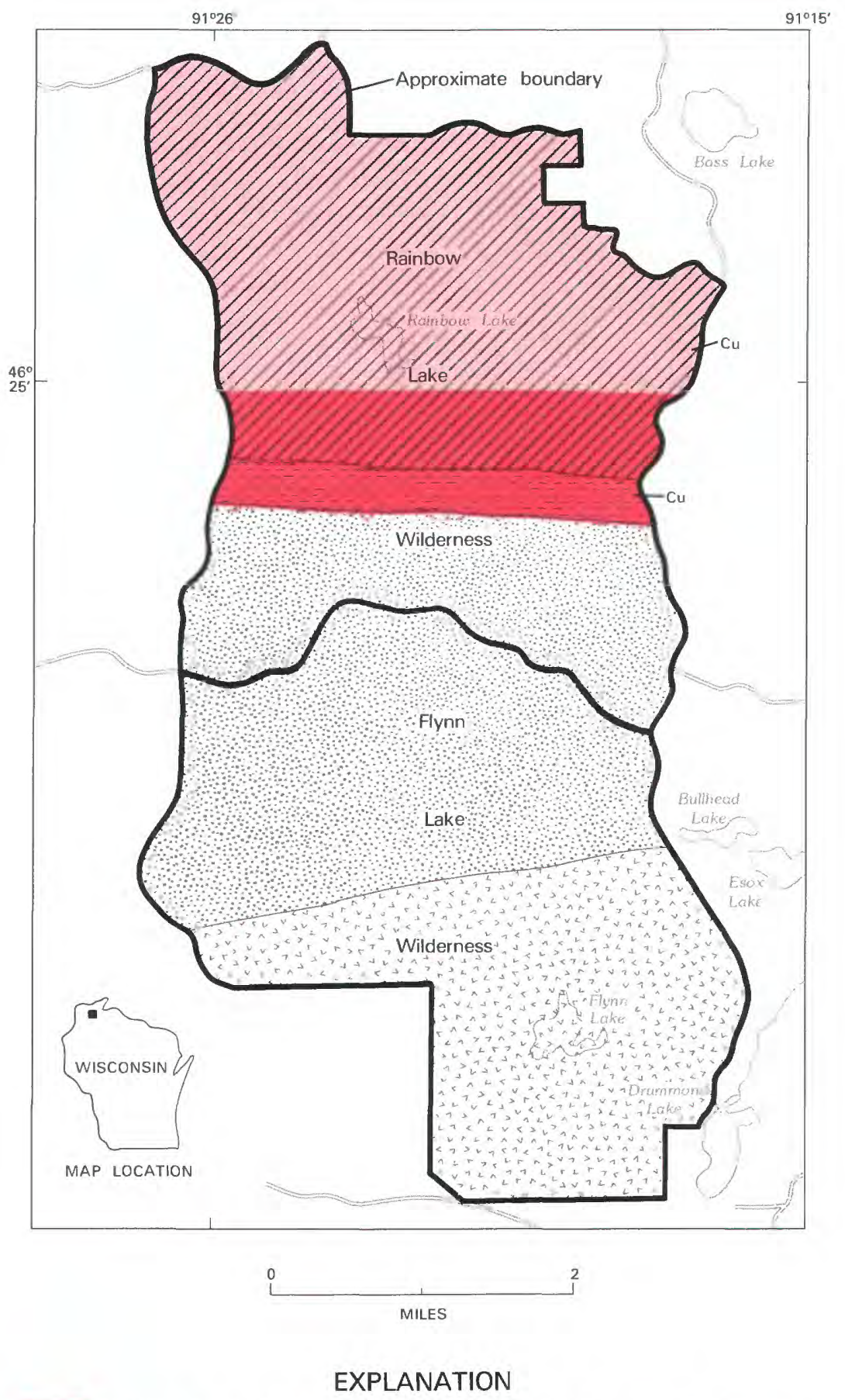

Geologic terrane with substantiated mineral-resource potential

Geologic terrane with probable mineral-resource potential

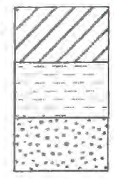

Freda Sandstone IProterozoic Nonesuch Shale (Proterozoic) Copper Harbor Conglomerate (Proterozoic)

cu Copper

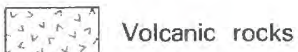

Contact

Figure 317.-Rainbow Lake Wilderness and Flynn Lake Wilderness Study Area, Wisconsin. 
resource potential may also occur in the Nonesuch Shale projected at depth to the north in the Rainbow Lake Wilderness.

Areas of substantiated peat resource potential of commercial quality identified by an augering and testing program are widespread in numerous depressions in the surficial sand and gravel deposits. Demonstrated peat resources of about 210,000 tons in the Rainbow Lake Wilderness and about 300,000 tons in the Flynn Lake Wilderness study area have been identified. Similar material is abundant, however, in larger deposits outside the area, closer to markets.

\section{SUGGESTIONS FOR FURTHER STUDIES}

Further drilling in the Rainbow Lake Wilderness would be needed to establish any additional copper resource potential in the Nonesuch Shale.

\section{REFERENCES}

Cannon, W. F., Cameron, C. C., Grosz, A. E., Dunn, M. L., Gazdik, G. C., and Hill, J. J., 1981, Mineral Resources of the Rainbow Lake Wilderness Area and the Flynn Lake Wilderness Study Area, Bayfield County, Wisconsin: U.S. Geological Survey Bulletin 1511, 19 p.

White, W. S., 1978, A theoretical basis for exploration for native copper in northern Wisconsin: U.S. Geological Survey Circular 769,19 p. 

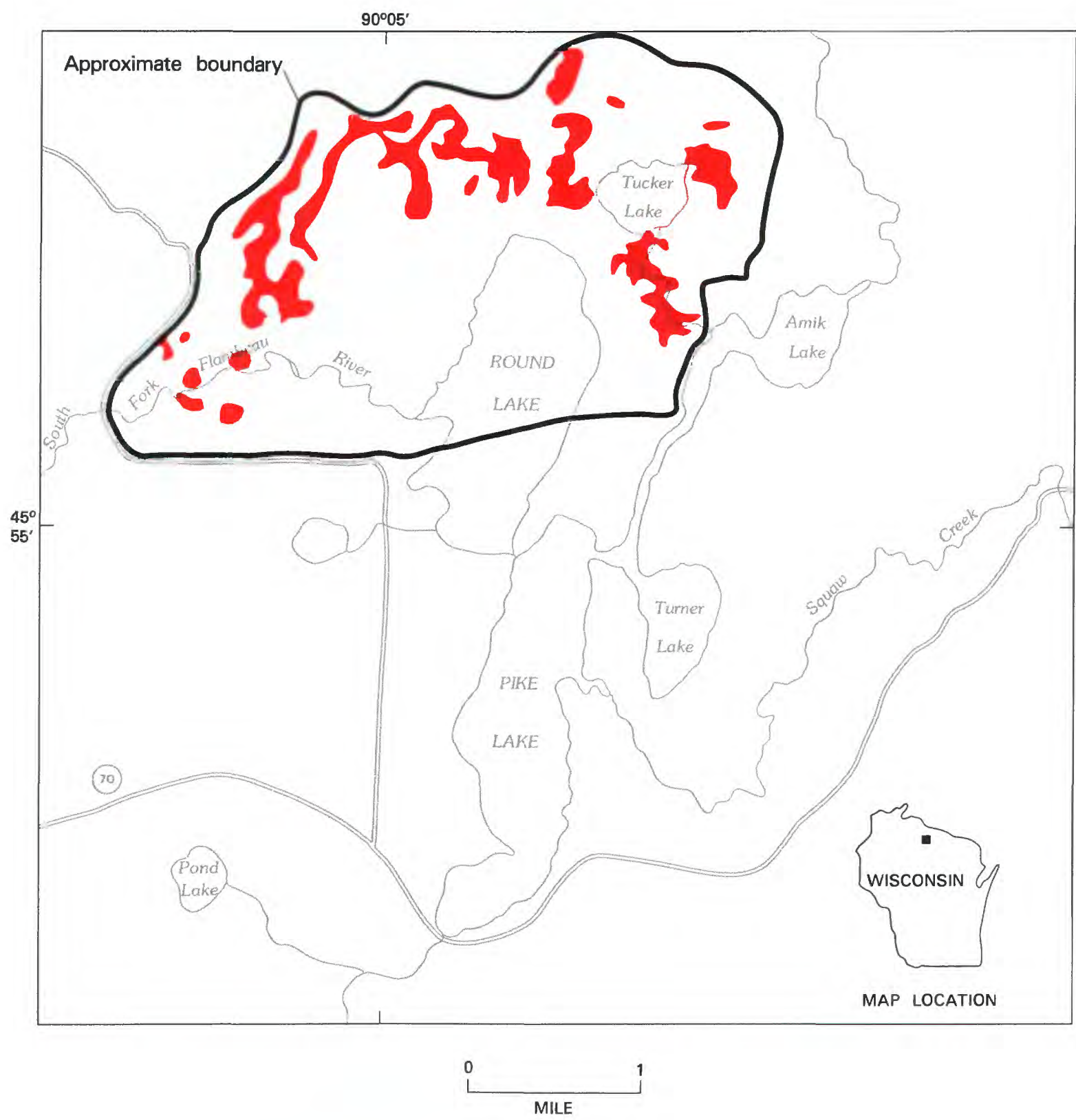

\section{EXPLANATION}

Geologic terrane with substantiated peat resource potential

Figure 318.-Round Lake Wilderness Study Area, Wisconsin. 


\title{
ROUND LAKE WILDERNESS STUDY AREA, WISCONSIN
}

\author{
By W. F. Gannon, U.S. Geological Survey, and \\ BRADFORD B. WILLIAMS, U.S. BUREAU OF MiNES
}

\section{SUMMARY}

The Round Lake Wilderness study area was studied by the USGS and USBM in 1976 and 1977 using geophysical and geochemical surveys, examination of a few bedrock exposures near the area (none are known within the area) and augering and testing of peat deposits. The only direct indication of potential mineral resource is about 760,000 tons of commercial quality peat contained in several bogs. Larger deposits of similar material are abundant closer to markets and although the peat in this area is classified as a demonstrated resource within an area of substantiated peat resource potential, it is considered to be of little importance. The study area lies within a belt of ancient volcanic rocks extending across northern Wisconsin in which several important copper, zinc, and lead deposits were discovered in the 1960's and 1970's but no indication of such deposits was found within the area by our study.

\section{CHARACTER AND SETTING}

The Round Lake area has low, rolling topography with widespread bogs and small lakes. Topography mostly reflects the shape of sand, gravel, and clay deposits left as glaciers receded from the area about 10,000 years ago. These glacial deposits completely cover bedrock within the area so our understanding of the geology of the area is indirect, derived from geophysical studies that reflect the character of the bedrock in subsurface, and from examination of a few bedrock exposures near the study area (Cannon and others, 1981).

Bedrock is believed to be mostly volcanic rocks, probably about 1.8 billion years old, part of an extensive belt of such rocks that extend east-west across northern Wisconsin. The western part of the area is believed to contain granitic rocks of undetermined age.

\section{MINERAL RESOURCES}

Peat of commercial quality and from 5 to $15 \mathrm{ft}$ thick is estimated to total 760,000 tons. These deposits, although a demonstrated resource, are of little importance because larger deposits of similar material are abundant closer to markets.
The Round Lake area lies within a belt of volcanic rocks that extends across much of northern Wisconsin. In the late 1960's and 1970's the belt received intensive mineral exploration. Several important discoveries of copper, zinc, and lead deposits have been made. An area of volcanic rocks, such as the Round Lake area, within that belt must be considered to have some potential for similar deposits. Our studies found no direct indications of deposits but results must be considered tentative because of the thick cover of glacial deposits and lack of bedrock exposures.

\section{SUGGESTIONS FOR FURTHER STUDIES}

In order to evaluate the mineral-resource potential for copper, zinc, and lead deposits in volcanic rocks in this area additional studies using more sensitive geochemical and geophysical techniques and more closely spaced survey points would have to be carried out.

\section{REFERENCE}

Cannon, W. F., Cameron, C. C., Klasner, J. S., Grosz, A. E., Williams, B. B., 1981, Mineral resource evaluation of the Round Lake Wilderness Study Area, Price and Vilas Counties, Wisconsin: U.S. Geological Survey Bulletin 1512, 23 p. 

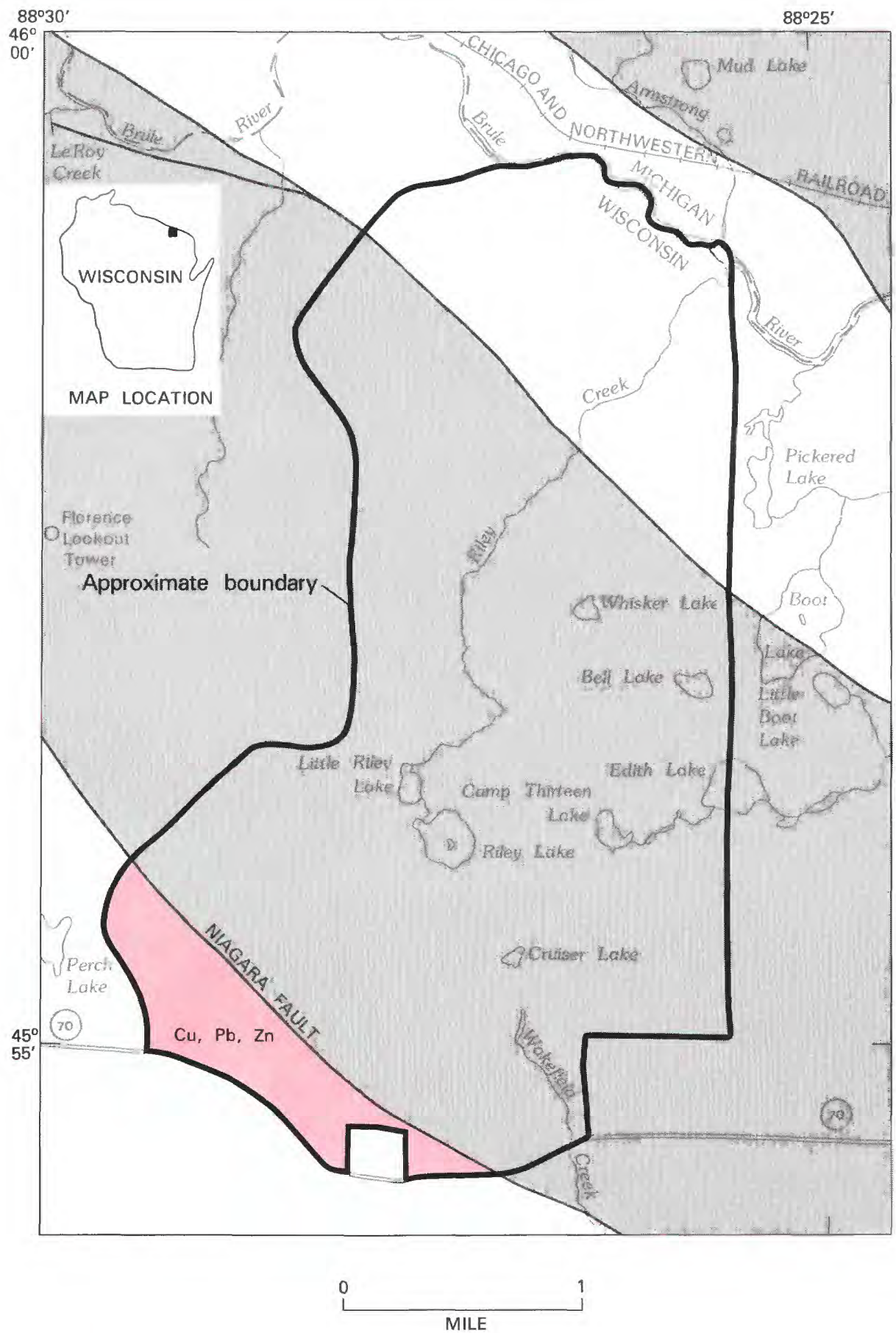

EXPLANATION

Geologic terrane with probable mineral-resource potential
Cu Copper
$\mathrm{Pb} \quad$ Lead
Zn Zinc

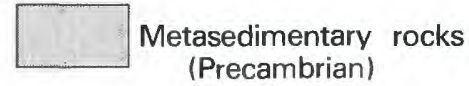

Mafic metavolcanic rocks (Precambrian)

Fault

Figure 319.-Whisker Lake Wilderness, Wisconsin. 


\title{
WHISKER LAKE WILDERNESS, WISCONSIN
}

\author{
By Klaus J. Schulz, U.S. GeOlOGical SurveY
}

\begin{abstract}
SUMMARY
The mineral-resource potential of the Whisker Lake Wilderness in northeastern Wisconsin was evaluated in 1982. Only a strip along the southwest corner of the wilderness is assessed as having probable mineral-resource potential. If mineral deposits exist, they probably are of the massive sulfide type. The geologic terrain precludes the presence of fossil fuel resources.
\end{abstract}

\section{CHARACTER AND SETTING}

The Whisker Lake Wilderness occupies an area of about $12 \mathrm{sq} \mathrm{mi}$ in the Nicolet National Forest of northeastern Wisconsin, about 6 mi west of Florence, Wiscon$\sin$. State Highway 70 passes along the southern border of the wilderness, USFS road 2150 along the western border, and the Brule River along the north.

The wilderness lies on the edge of the lake country of northern Wisconsin and contains several small lakes. The topography is hummocky with a maximum relief of about $220 \mathrm{ft}$ and represents pitted outwash formed during retreat of the last glacial cover.

The wilderness was examined in the summer of 1982 and the results published in Schulz (1983). No rock outcrops are known within the boundaries of the wilderness; however, outcrops occurring to the north, east, and south were examined. This information, in conjunction with data from Dutton and Bradley (1970), Dutton (1971), and the magnetic data compilation of King and others (1966), were used for the geologic assessment and mineral-resource evaluation of the wilderness.

The bedrock of the Whisker Lake Wilderness is believed to consist of recrystallized and deformed volcanic and sedimentary rocks which form part of a major volcanic-sedimentary terrane of Precambrian age in northern Wisconsin. A northwest-trending belt of sedimentary rocks, consisting of recrystallized sandstones, shales, and lesser iron formation and conglomerates such as are found in outcrops to the southeast, is thought to underlie the central portion of the wilderness. This metasedimentary belt is inferred from the magnetic data to be separated from adjacent volcanic rocks, both to the northeast and southwest, by steeply dipping faults. The volcanic rocks consist largely of recrystallized mafic lavas, though some felsic volcanic material may also be present. The volcanic rocks are slightly older in age than the sediments. The rocks of the area were deformed and recrystallized about 1800 million years ago in an event which effected much of northern Wisconsin and upper Michigan. Subsequent to repeated cycles of erosion and inundation by seas during at least the last 500 million years, the area was sculptured by glacial erosion and covered by sediments deposited by melt waters from the retreat of the last glacial ice.

The Whisker Lake Wilderness is on the edge of the Menominee iron-bearing district. To the east of the wilderness, iron was mined until 1932 and briefly again from 1953 to 1960 from several open pits and underground mines near the communities of Florence and Commonwealth. No significant iron-bearing units are known in the area of wilderness, however.

\section{MINERAL RESOURCES}

Sand and gravel and peat in swampy lowlands are the only resources of the Whisker Lake Wilderness. The area has not been identified as having resource potential for these commodities because they are abundant regionally.

No resources of metallic minerals are known in the Whisker Lake Wilderness but the geologic relationships indicate it is a favorable area for the occurrence of ore deposits. The volcanic rocks of the area are part of a volcanic terrane in which four massive sulfide deposits of copper, zinc, lead, and precious metals have been identified in the last 10 years. These deposits occur as lenses of rock rich in sulfide minerals that are parallel to the primary layering of the enclosing, mostly felsic volcanic rocks. While similar felsic volcanic rocks are not known to be present in the wilderness, present information does not preclude their existence particularly in 
the southwest part of the area where an area of probable mineral-resource potential has been identified.

In the last five years two areas adjacent to the wilderness and within the volcanic belt thought to underlie the southwest corner of the wilderness have been examined by mining companies. Geophysical surveys with follow up drilling were carried out in both areas. The results of these exploration efforts are not presently available. Massive sulfide mineralization consisting largely of iron sulfides is also known from outcrops about $7 \mathrm{mi}$ southeast of the wilderness. These features suggest that the volcanic rocks of the area have a probable potential for the occurrence of massive sulfide deposits of copper, zinc, and lead.

The sedimentary belt thought to underlie the central part of the wilderness has little promise for the occurrence of mineral resources. Thin iron-formation units that occur within the belt to the southeast were examined in the early 1900's (Dutton, 1970). Iron sulfide mineralization has been observed at scattered localities within the sedimentary belt southeast of the wilderness, particularly in the units just northeast of the Niagara fault. While it appears likely that these units continue to the northwest into the wilderness, there is no evidence to suggest that mineral resources are associated with them. To date, no mineral deposits have been identified within this sedimentary sequence in Wisconsin or upper Michigan.

On the basis of the features noted above, only the strip southwest of the Niagara fault, thought to be underlain by volcanic rocks, has probable mineralresource potential. No known deposits exist within the area and physical exploration would be required to either prove or disprove the existence of deposits. If deposits do exist, they probably would be of the massive sulfide type consisting of copper and zinc with variable amounts of lead.

\section{SUGGESTIONS FOR FURTHER STUDIES}

Further study of the wilderness would be required to identify any hidden mineral deposits. Such study would require detailed geophysical surveys with subsequent test drilling.

\section{REFERENCES}

Dutton, C. E., 1971, Geology of the Florence area, Wisconsin and Michigan: U.S. Geological Survey Professional Paper 633, 54 p.

Dutton, C. E., and Bradley, R. E., 1970, Lithologic, geophysical, and mineral commodity maps of Precambrian rocks in Wisconsin: U.S. Geological Survey Miscellaneous Geologic Investigations Series I-631.

King, E. R., Henderson, J. R., and Vargo, J. L., 1966, Aeromagnetic map of Florence-Goodman area, Florence, Forest, and Marinette Counties, Wisconsin: U.S. Geological Survey Geophysical Investigations Map GP-576, scale 1:62,500.

Schulz, K. J., 1983, Geologic, aeromagnetic, and mineral resource potential maps of the Whisker Lake Wilderness, Florence County, Wisconsin: U.S. Geological Survey Miscellaneous Field Studies Map MF-1583, scale 1:24,000. 



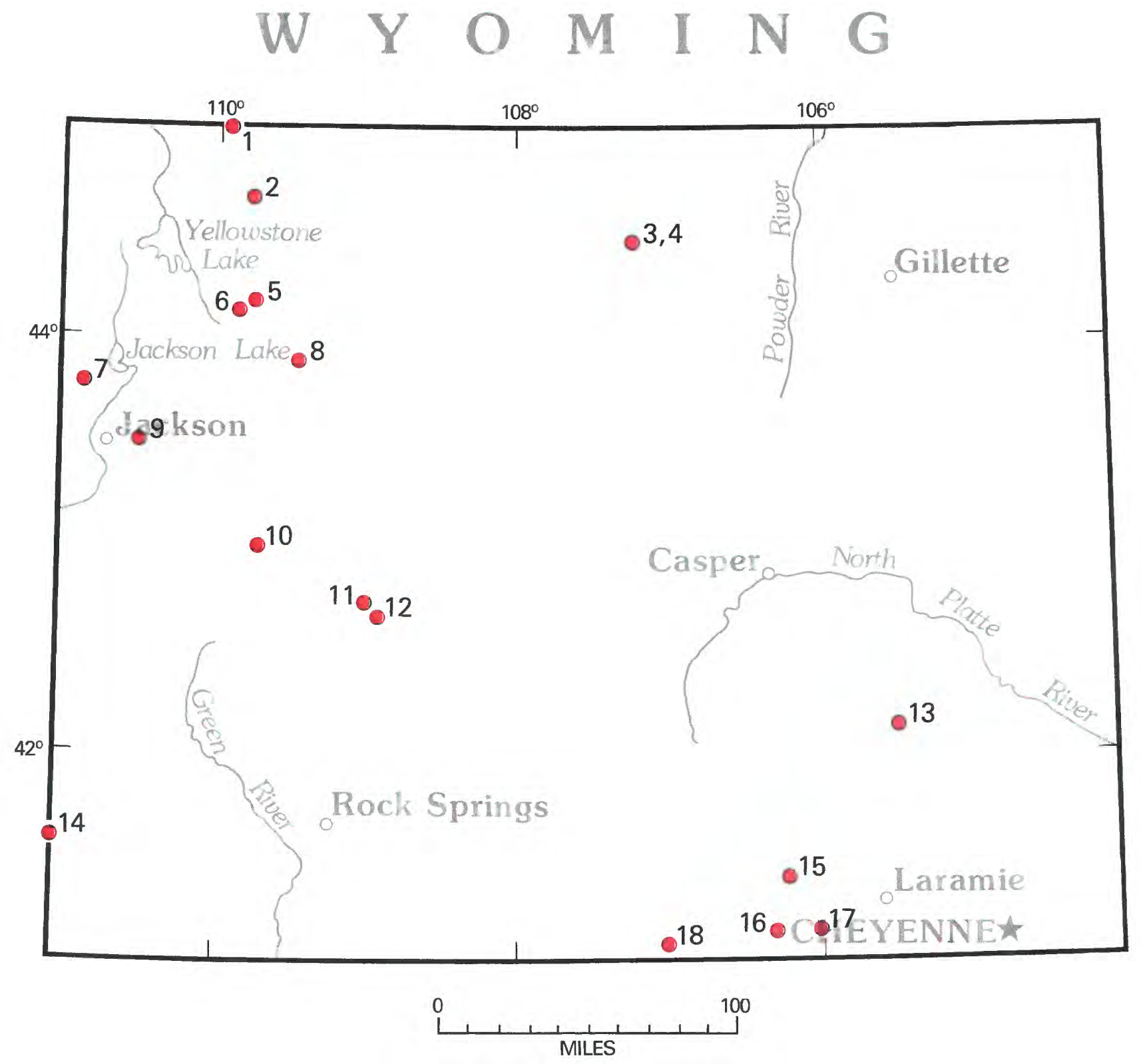

Location of areas studied. 


\section{WYOMING}

Map

No.

1 Beartooth Primitive Area and vicinity, Montana and Wyoming-See Montana

12 Bridger Wilderness and Green-Sweetwater Roadless Area

3 Cloud Peak Primitive Area and adjacent areas

4 Cloud Peak Contiguous, Rock Creek, Piney Creek, and Little Goose Roadless Areas

10 Glacier Primitive Area

9 Gros Ventre Wilderness study area

18 Huston Park Roadless Area

13 Laramie Peak Wilderness study area

2 North Absaroka Wilderness

11 Popo Agie Primitive Area

16 Savage Run Wilderness

17 Sheep Mountain Wilderness study area

15 Snowy Range Wilderness

8 Stratified Primitive Area

6 Teton Wilderness, Teton Corridor, and Du Noir Addition to Washakie Wilderness

5 Washakie Wilderness (northern part) and nearby roadless areas

7 West Slope Tetons Roadless Area

14 West and East Palisades Roadless Areas, Idaho and Wyoming-See Idaho 


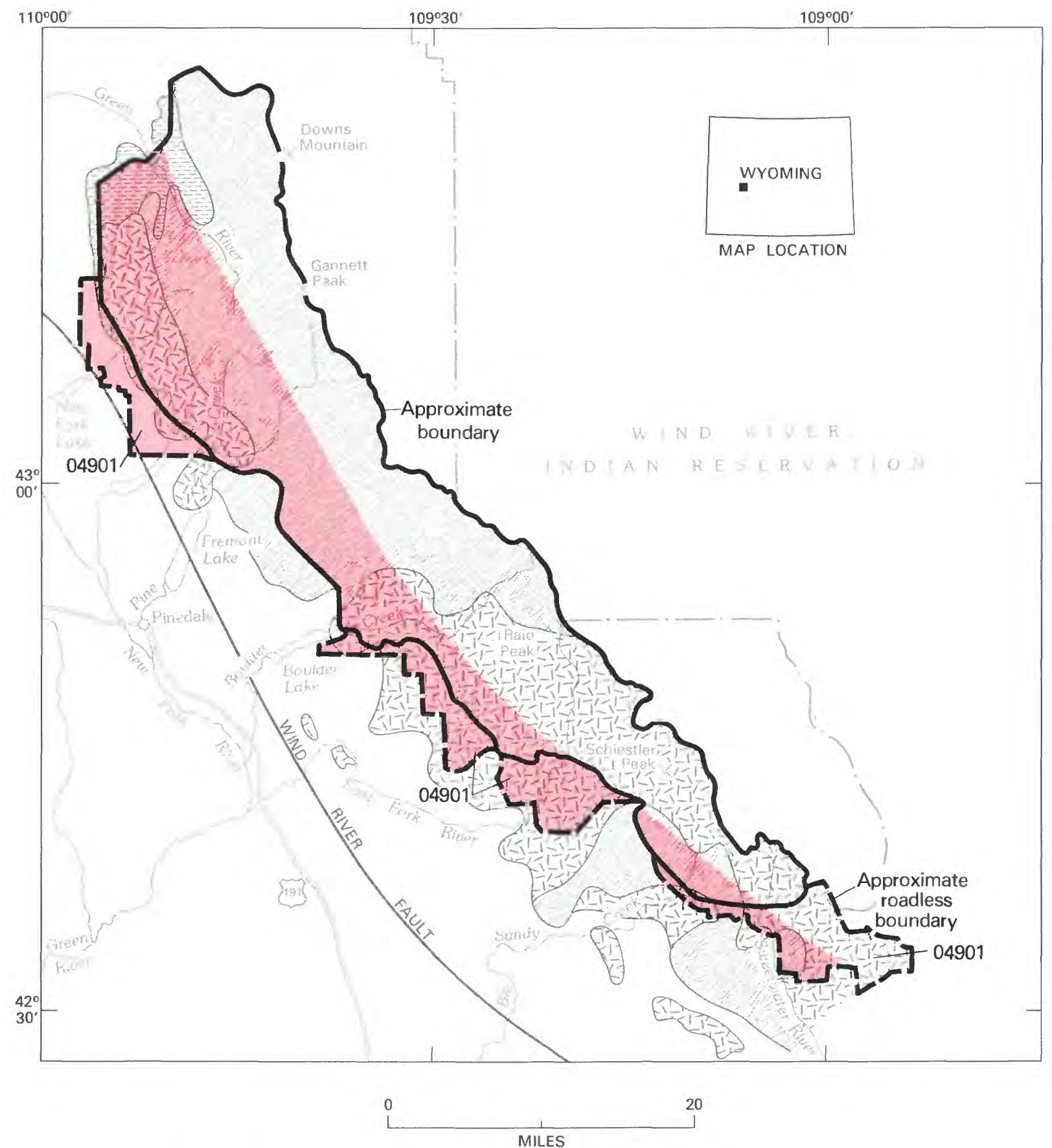

\section{EXPLANATION}

Geologic terrane with probable oil and gas resource potential

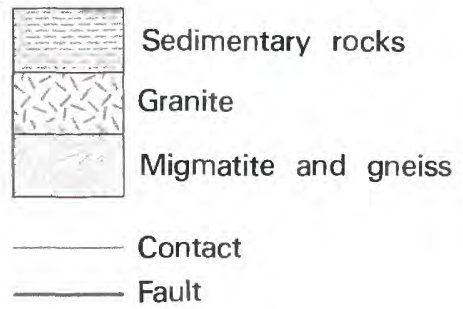

Figure 320.-Bridger Wilderness and Green-Sweetwater Roadless Area, Wyoming. 


\title{
BRIDGER WILDERNESS AND GREEN-SWEETWATER ROADLESS AREA, WYOMING
}

\author{
By RONALD G. WORL, U.S. GEOLOGICAL SURVEY, and \\ GeOrge S. Ryan, U.S. Bureau of MineS
}

\begin{abstract}
SUMMARY
A mineral-resource appraisal of the Bridger Wilderness and contiguous Green-Sweetwater Roadless Area was made by the USGS and USBM in 1980-82. This rugged and remote region along the west slope of the Wind River Range, Wyoming is mostly Precambrian crystalline granitic rocks that contain only small and discontinuous areas of mineralization. The area is considered to have little promise for metallic mineral deposits. Sedimentary rocks in the area have minor coal seams and beds of phosphate rock, but the coal beds are thin and of limited extent, and the phosphate rock is low-grade compared to similar rocks elsewhere in the region. A probable potential for oil and gas at depth, assigned to part of the area, is based on the assumption that oil- and gas-bearing rocks exist at depth below a low-angle thrust fault and a wedge of Precambrian crystalline rock.
\end{abstract}

\section{CHARACTER AND SETTING}

The Bridger Wilderness and contiguous GreenSweetwater Roadless Area were studied in 1980-82 to determine mineral-resource potential (Worl and others, in press). The combined areas, hereafter to be referred to as the study area, comprise about $1090 \mathrm{sq} \mathrm{mi}$ along the west slope of the Wind River Range in Sublette and Fremont Counties, west-central Wyoming. The study area is bounded on the east, from north to south, by the Fitzpatrick Wilderness, the Wind River Indian Reservation, and the Popo Agie Primitive Area. Pinedale, Wyoming, on U.S. Highway 191, is a few miles to the west. Access to the study area is from trail heads at the ends of several secondary roads leading from U.S. Highway 191 and from Wyoming State Highway 28, which crosses historic South Pass a few miles to the southwest. Horse and walking trails lace much of the region, but large tracts along the crest of the range and in the north are inaccessible.

The crest of the range, the Continental Divide, is a spectacularly rugged, glacially sculptured alpine mountain terrain with altitudes ranging from $10,500 \mathrm{ft}$ to $13,804 \mathrm{ft}$ on top of Gannett Peak, the highest point in the State of Wyoming. This area is all above timberline, and is dominated by bare rock, glacial blue lakes, block fields, talus, snowfields, and glaciers. West of the alpine peaks and extending to the edge of the range is an upland, a remnant of an old gently rolling erosional surface, now deeply dissected by steep-walled glacially scoured canyons. The upland area is below timberline and is characterized by bare rock, sparse and sporadic timber growth, lush marshes in potholes and along areas of poor drainage, and an abundance of lakes formed by glacial scouring.

The Wind River Range is a large $(40 \times 125 \mathrm{mi})$ asymmetrical structural arch flanked on the east by the Wind River Basin and on the west by the Green River Basin. A complex of ancient (2.5 billion years old) crystalline rocks forms the core of the range. In the study area, the crystalline rocks are chiefly granites of several types and migmatite, a mixed rock that is part igneous and part metamorphic. Migmatites of the study area formed from preexisting sedimentary and igneous rocks that partially melted from heat and pressure of deep burial. The portion that melted became the igneous part of the migmatite; the portion that did not melt, but was plastically deformed, became the metamorphic part. Small pods of the preexisting rocks occur as remnants in the migmatite. Large diabasic dikes, commonly many miles long, intrude the granites and migmatite. Sedimentary rocks of Paleozoic and Mesozoic ages dip gently into the Wind River Basin off the east flank of the range, and are in fault contact with the crystalline 
rocks in the northern part of the study area. Along the west flank, a major eastward-dipping fault has placed crystalline rocks over Paleozoic and Mesozoic sedimentary rocks of the Green River Basin. Younger sedimentary rocks (Tertiary) and glacial debris cover this fault along its entire length, but its trace is delineated by gravity and seismic data.

Geochemical and geophysical surveys were integrated with the geologic mapping. Analytical results from stream-sediment, pan-concentrate, rock, and soil samples reflect the rock type present at the sample site. Aeromagnetic anomalies and trends correspond to rock units. Gravity data indicate a positive Bouguer anomaly parallel to the structural trend of the Wind River Range.

\section{MINERAL RESOURCES}

The only mining activity within the study area was for an insignificant amount of coal many years ago. Exploration has been limited to the Schiestler Peak molybdenum prospect and consisted of diamond drilling, bulk sampling, and the driving of a short adit. Elsewhere in the study area there are a few prospect diggings along pegmatites, dikes, and mafic pods. Mineral lode claims in the study area are centered on the Schiestler Peak prospect, and a few gold placer claims extend into the most southern part of the study area.

Precambrian crystalline rocks of the study area contain little mineralization. The Wind River Range has none of the Tertiary intrusive rocks that are associated with the base- and precious-metal deposits of the $\mathrm{Ab}$ saroka Mountains in northwestern Wyoming. Gold and iron-ore mines southeast of the study area are in a different sequence of Precambrian rocks that do not extend into the study area. Iron ore near Downs Mountain in the study area is similar to that mined to the southeast, but during metamorphism the iron-rich beds were pulled apart and injected with granite, thus reducing the average iron content. The molybdenum prospect at Shiestler Peak has been thoroughly investigated and consists of two small pods of mineralization with no associated hydrothermal alteration. Numerous rock and stream-sediment samples from throughout the study area contain anomalous amounts of one or more metals. These anomalies are related to small mafic pods of preexisting rock, relics in the granite and migmatite. The metals were part of the original rock and were not introduced by a hydrothermal system. A detailed investigation gave no indication of concentration of radioactive minerals in the study area. Sedimentary rocks in the study area contain coal and phosphate rock.
The coal beds are thin and of himited extent and no resources were identified. The phosphate-bearing beds underlie large areas in the northern part of the study area, but are low-grade as compared to similar rocks elsewhere in the region.

The geologic, geochemical, and geophysical surveys of the study area do not indicate any significant areas of mineralization or alteration. Mineralization that is present is low grade, in small isolated pods, or dispersed over a large area. The study area is considered to have little promise for the occurrence of mineral resources.

A probable potential for oil and gas at depth is assigned to some of the western part of the study area. This potential is based on a currently accepted geologic model that assumes a low angle of dip for the fault along the west flank of the Wind River Range. The gentler the dip of the fault, the farther the sedimentary rocks of the Green River Basin extend eastward under the range and the study area. The sedimentary rocks of the Green River Basin are known to be oil and gas bearing. A deep seismic line south of the study area suggests a low eastward dip for the fault at this point. However, data are not available to adequately define the dip of the fault along most of the range. Some lines of evidence suggest that the fault may, in fact, dip at a steep angle along the northern part of the range. Because the dip of the fault is not exactly known, the areas of potential for oil and gas at depth are difficult to assign. The areas shown on the map are those covered by oil and gas leases as of 1982.

\section{SUGGESTIONS FOR FURTHER STUDIES}

Deep seismic-reflection profiles along at least two lines across the Wind River Range are needed to help resolve the nature of faulting along the west flank of the range. Other investigations such as detailed field exauninations along the flank of the range, testing for hydrocarbon migration along fractures in the crystalline rocks, stratigraphic studies and projections, evaluations of environment in hydrocarbon migration, and seismic and gravity modeling would have to accompany the deep seismic-reflection studies, in order to begin an evaluation of the oil and gas potential.

The crystalline rocks of the core of the range offer little promise for mineral deposits, but they are a geologic treasure house. This is one of the largest exposures of basement crystalline rock in the Western United States and the rocks in the study area represent a geologic environment exposed in very few places in the world. This geologic environment is the high-temperature boundary between metamorphic and igneous rocks in a zone of 
deep burial, partial melting, and metasomatism (a zone that is probably the source of many hydrothermal metal-bearing solutions). Although mineral deposits are not to be found in these rocks, further studies would certainly broaden knowledge and help find them elsewhere.

\section{REFERENCE}

Worl, R. G., Lee, G. K., Long, C. L., and Ryan, G. S., in press, Mineral resource potential map of the Bridger Wilderness and GreenSweetwater Roadless Area, Wyoming: U.S. Geological Survey Miscellanoues Field Studies Map MF-1636-A. 


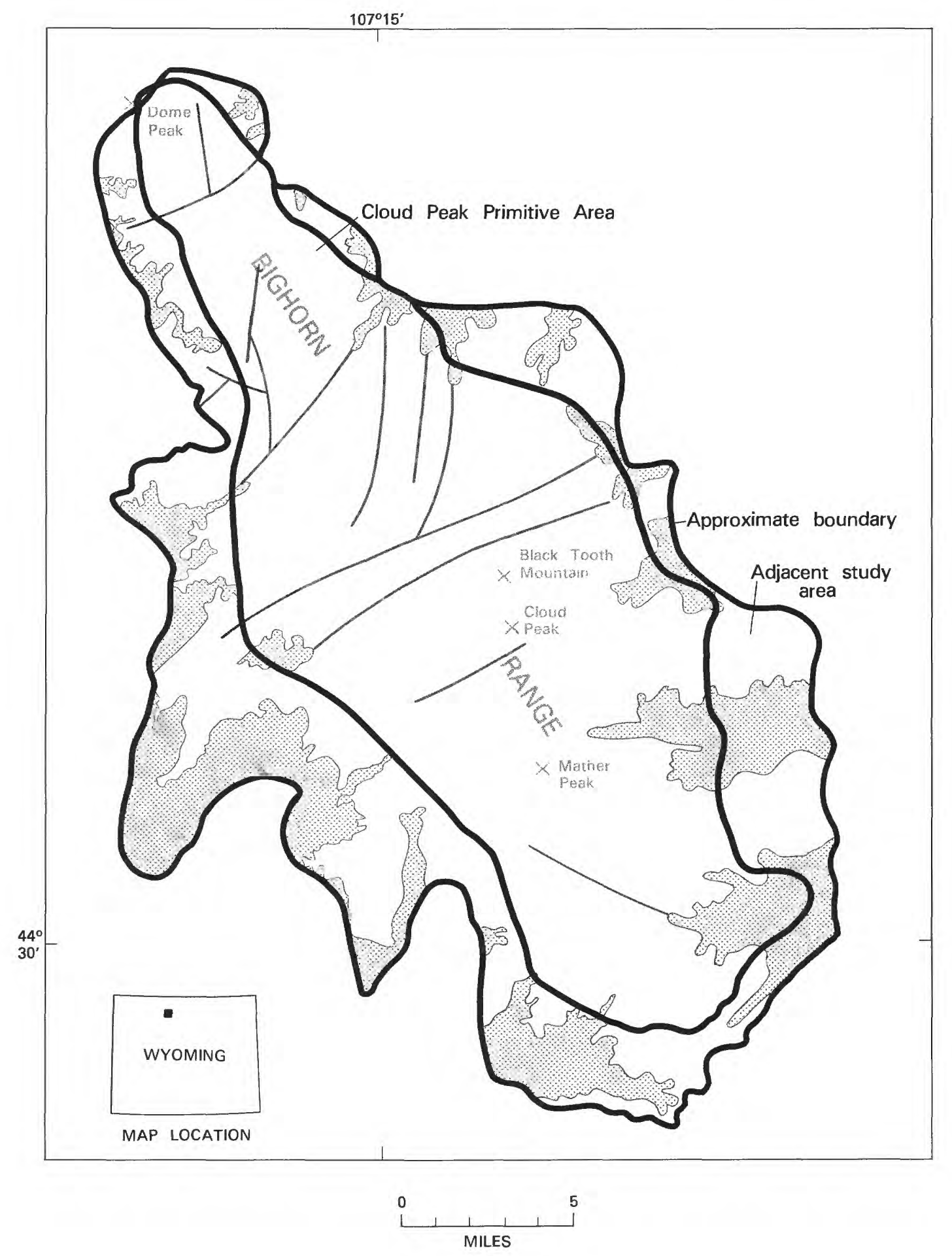

\section{EXPLANATION}

Sedimentary rocks, chiefly Contact glacial moraine Fault

Gneiss, schist and granitic rock

Figure 321.-Cloud Peak Primitive Area and adjacent areas, Wyoming. 


\title{
CLOUD PEAK PRIMITIVE AREA AND ADJACENT AREAS, WYOMING
}

\author{
By ThOr H. KiIlsgaARd, U.S. GeOlOGical SuRVeY, and
}

LOWELL L. PATTEN, U.S. BUREAU OF Mines

\begin{abstract}
SUMMARY
The results of a mineral survey of the Cloud Peak Primitive Area and adjacent areas conducted in 1970 by the USGS and USBM indicated little promise for the occurrence of mineral resources. There are some prospect workings, particularly in the northern part of the area, but in none of them were there indications that ore had been mined. Samples from the workings, from nearby rocks and sediments from streams that drain the area did not yield any metal values of significance. The crystalline rocks that underlie the area do not contain oil and gas or coal, products that are extracted from the younger rocks that underlie basins on both sides of the study area.
\end{abstract}

\section{CHARACTER AND SETTING}

This report summarizes the findings of a mineral survey made of the Cloud Peak Primitive Area, which contains $214 \mathrm{sq} \mathrm{mi}$, plus contiguous tracts that contain an additional $148 \mathrm{sq} \mathrm{mi}$, the total area studied aggregating $362 \mathrm{sq} \mathrm{mi}$. The combined areas are referred to as the Cloud Peak study area in this report. The mineral survey was made in 1970 and the results of the study were published in 1972 (Kiilsgaard and others, 1972).

The Cloud Peak study area lies along the crest of the Bighorn Range, within the Bighorn National Forest, in Bighorn, Jolunson, and Sheridan Counties, Wyoming. The Bighorn Mountains are a major, north-trending, scenic range, of which the highest peaks, Cloud Peak and Blacktooth Mountain, reach altitudes of 13,176 and $13,005 \mathrm{ft}$, respectively. Higher parts of the range have been glaciated extensively, leaving U-shaped valleys that drain eastward and westward. Deep cirques with precipitous headwalls have been scoured at the heads of the glaciated valleys, particularly on the east side of the range. A small glacier remains on the east side of Cloud Peak, and a few small snow fields persist from one season to another. All stream valleys leading east from the core of the range contain glacial moraines, some of which are extensive. Glacial deposits also exist in the headwater areas of streams that drain northwest. The many lakes in the study area are either small lakes in hummocky glacial moraine, are in cirques where glaciers have gouged basins in the bedrock, or have formed where glacial moraines have dammed streams.
The core of the Bighorn Range consists of gneissic or granitic rocks of Precambrian age, the gneissic rocks being more common in the southern part of the study area and the granitic rocks more common in the northern part. Formations of younger and softer sedimentary rocks lap onto the flanks of the Bighorn Range, but within the study area are exposed only in the southwestern part. The crystalline gneissic and granitic rocks have been faulted extensively, primarily in two fault patterns, one of which trends northeast and the other northwest. Prospect workings have been dug along some of the faults, in the northern part of the area. Dark mafic dikes, chiefly of quartz dolerite composition, cut the crystalline rocks along northeast and northwest trends. Some of the dikes have also been prospected.

\section{MINERAL RESOURCES}

No evidence for metallic resources was found in the study area and the Precambrian gneiss and granite of the core of the range do not contain coal or petroleum products.

All prospect workings found in the study area were sainpled, as were rocks that showed evidence of alteration. Saunples of stream sediments were collected from most streains draining the area but none of the rock or streain-sediment samples contained significant quantities of metals. Rocks at some of the prospect workings evidenced small quantities of pyrite and a few of the sainples analyzed contained trace aunounts of gold, 
silver, or copper but neither the sample analysis nor the field evidence indicated the presence of mineral deposits worthy of exploration.

\section{SUGGESTIONS FOR FURTHER STUDIES}

Further studies of the Cloud Peak study area would contribute information on regional geology and geologic structure but would not aid in identifying hidden mineral deposits, which are considered unlikely to exist in the area.

\section{REFERENCE}

Kiilsgaard, T. H., Ericksen, G. E., Patten, L. L., and Bieniewski, C. L., 1972, Mineral survey of the Cloud Peak Primitive Area, Wyoming: U.S. Geological Survey Bulletin 1371-C, 60 p. 


\title{
CLOUD PEAK CONTIGUOUS, ROCK CREEK, PINEY CREEK, AND LITTLE GOOSE ROADLESS AREAS, WYOMING
}

\author{
By Kenneth Segerstrom, U.S. Geological Survey, and \\ DON S. BROWN, U.S. BUREAU OF MineS
}

\begin{abstract}
SUMMARY
On the basis of mineral surveys in 1972 and 1980, study areas surrounding the Cloud Peak Primitive Area in northern Wyoming offer little promise for the occurrence of mineral or energy resources.
\end{abstract}

\section{CHARACTER AND SETTING}

The central core of the Bighorn Mountains comprises the Cloud Peak Primitive Area. This area and some adjacent lands were studied by Kiilsgaard and others (1972) and are the subject of a separate article in this volume. Additional tracts were subsequently added and were studied by Segerstrom and Weisner (1976). Transfers of land in 1980 from the study areas to the primitive area and from outlying roadless tracts to the study areas changed and expanded the boundaries and finally resulted in the four roadless areas discussed in this report. These are named Cloud Peak Contiguous, which is located northwest, west, and south of the primitive area; the Rock Creek and Piney Creek located east of the primitive area; and Little Goose north of the primitive area. The sizes of the four roadless areas are about 236, 80,37 , and $59 \mathrm{sq} \mathrm{mi}$, respectively. These additional tracts were studied by Segerstrom and Hladky (1983). The accompanying figure reflects the changes in the boundaries outlined above, and thus in part differs from the boundaries of the Cloud Peak Primitive Area shown in Kiilsgaard and others (1972). These areas fringe the highest part of the Bighorn Mountains, which culminate in Cloud Peak, 13,167 ft above sea level, located $23 \mathrm{mi}$ west of Buffalo, Wyoming.

The fringes of the Bighorns included in the roadless areas consist mostly of Precambrian gneiss, granite, mafic dikes, and Paleozoic sedimentary rocks that overlie the Precambrian basement rocks. Glacial debris covers the bedrock in places. The Bighorn Mountains were formed during the Laramide orogeny 80-70 million years ago, during Late Cretaceous to Eocene time.

\section{MINERAL RESOURCES}

Field investigations designed to detect metal occurrences concentrated on geochemical studies, sampling stream sediments and rock outcrops. None of the samples contained concentrations of metallic elements sufficently high to indicate that a metallic mineral resource potential exists. Indeed, the entire Bighorn Mountains are singularly lacking in evidence of mineral occurrences, in contrast to the extensive areas of altered rock that characterize mineralized areas elsewhere in the Rocky Mountains. Results of analyses of USGS and USBM samples from the four roadless areas have been tabulated (Segerstrom and Weissner, 1976; Segerstrom and Hladky, 1983).

Although determination of such metals as chromium, copper, nickel, scandium, and vanadium vary, the results reflect the composition of the different rock types that make up the areas, rather than indicating anomalous concentrations.

Gold and silver were found at or near the lower limit of analytical detection $(0.05$ parts per million gold and 0.5 parts per million silver) in certain stream-sediment samples, but the deposits sampled are too small and too low grade to constitute a resource.

Ferruginous beds about $3 \mathrm{ft}$ thick that average about 20 percent or less in elemental iron are present in the Cambrian Flathead Sandstone and the Mississippian Madison Limestone, but no resource potential for iron was identified in this study. Glauconitic beds, which in other areas accompany phosphate minerals, are present in the Gros Ventre Formation (Cambrian) and Madison Limestone, but no potential for phosphate was identified in the roadless areas. 

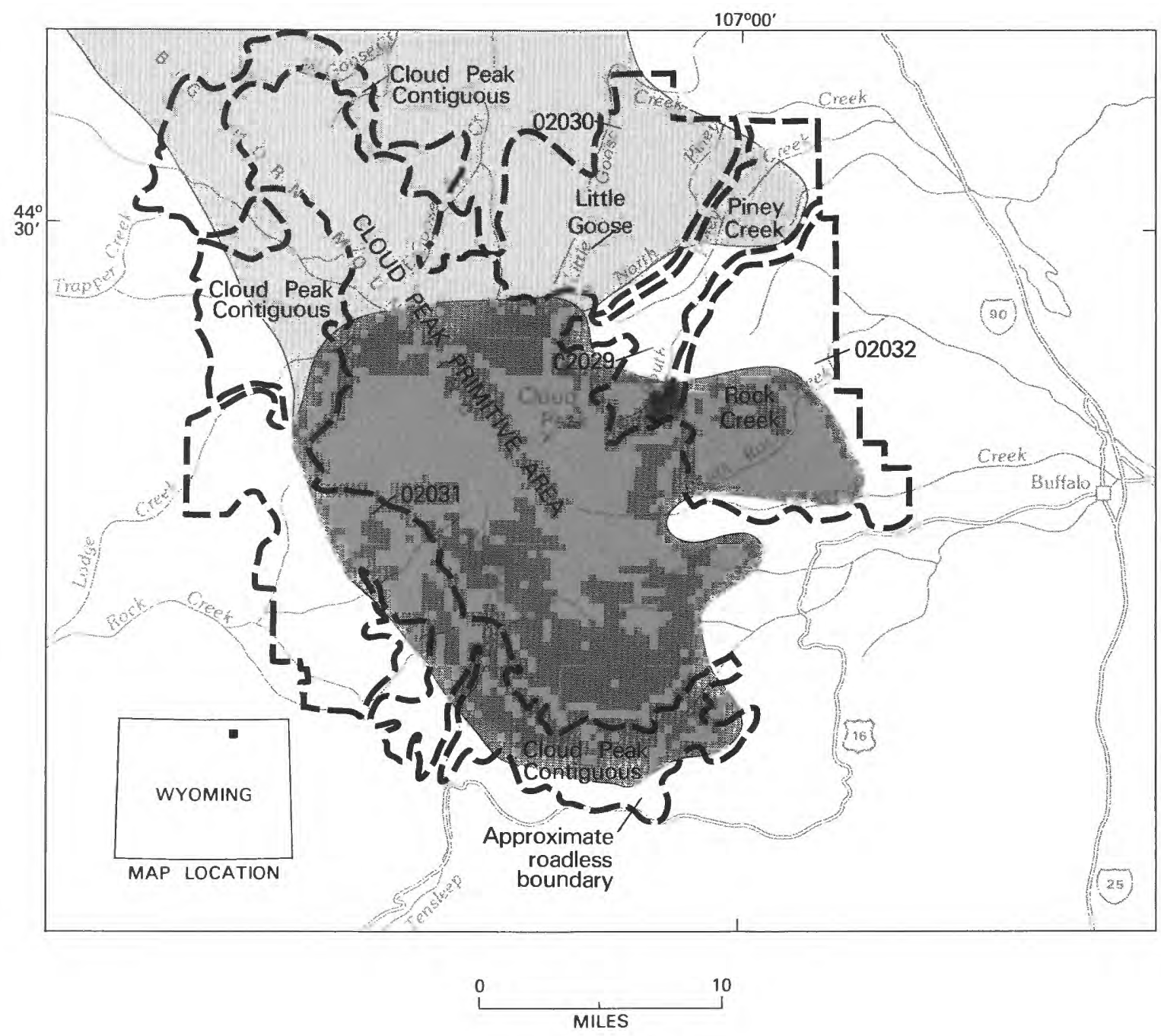

\section{EXPLANATION}

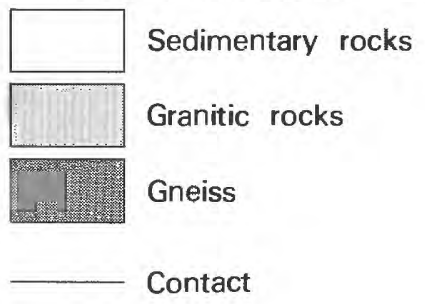

Figure 322.-Cloud Peak Contiguous, Rock Creek, Piney Creek, and Little Goose Roadless Areas, Wyoming. 
The geologic setting precludes the existence of deposits of organic fuels. Nonmetallic commodities, such as feldspar, limestone, building stone, clay, sand, and gravel are present, but these materials are readily available nearby in large quantities in more accessible areas.

\section{REFERENCES}

Kiilsgaard, T. H., Ericksen, G. E., Patten, L. L., and Bieniewski, C. L., 1972, Mineral survey of the Cloud Peak Primitive Area, Wyoming: U.S. Geological Survey Bulletin 1371-C, 60 p.
Segerstrom, Kenneth, and Weisner, R. C., 1976, Mineral resources of areas adjacent to the Cloud Peak Primitive Area, Wyoming: U.S. Geological Survey Bulletin 1391-D, 37 p.

Segerstrom, Kenneth, and Hladky, F. R., 1983, Mineral resource potential of parts of the Cloud Peak Contiguous, Little Goose, and Rock Creek Roadless Areas, Big Horn, Johnson, and Sheridan Counties, Wyoming: U.S. Geological Survey Open-File Report 83-469. 


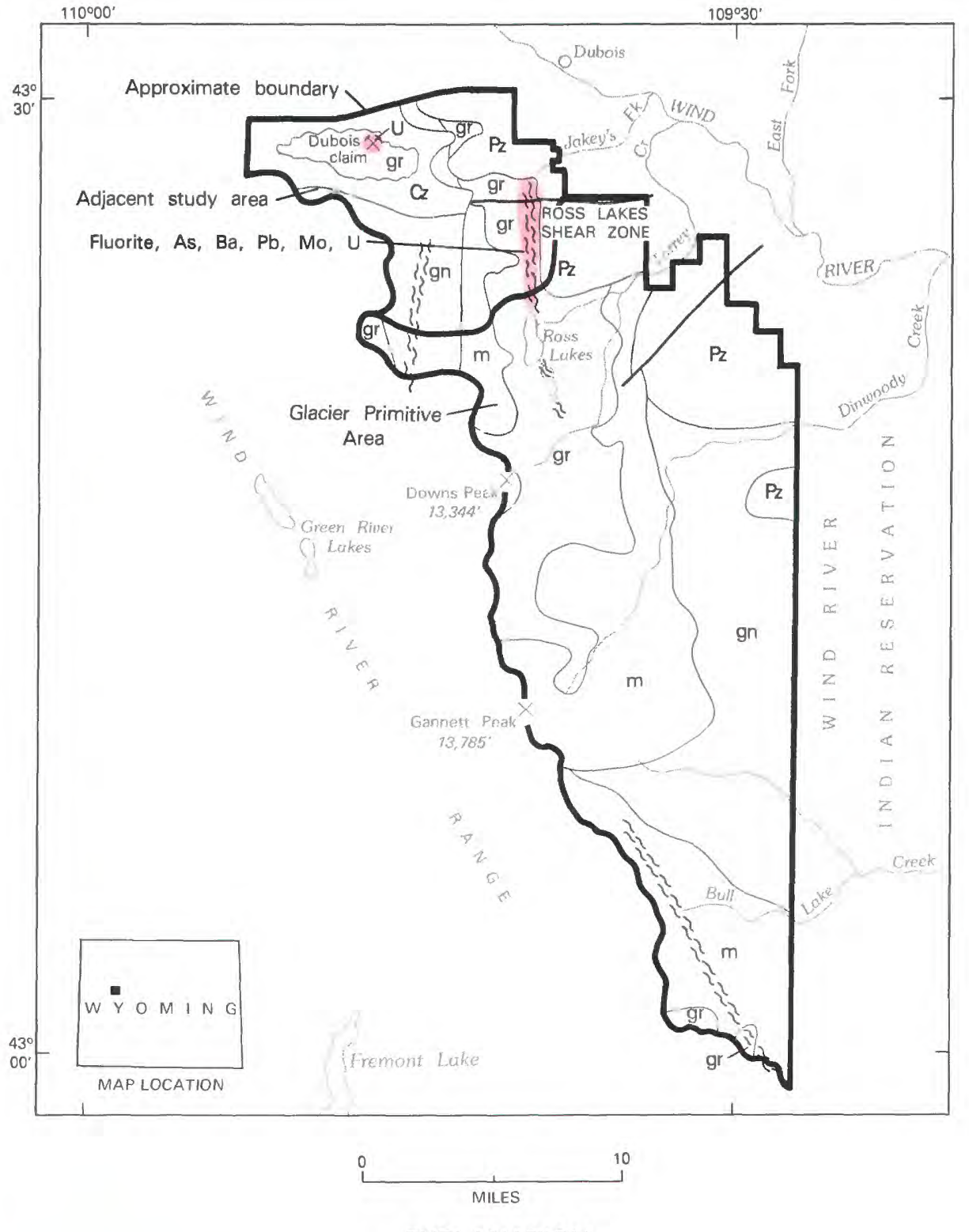

EXPLANATION

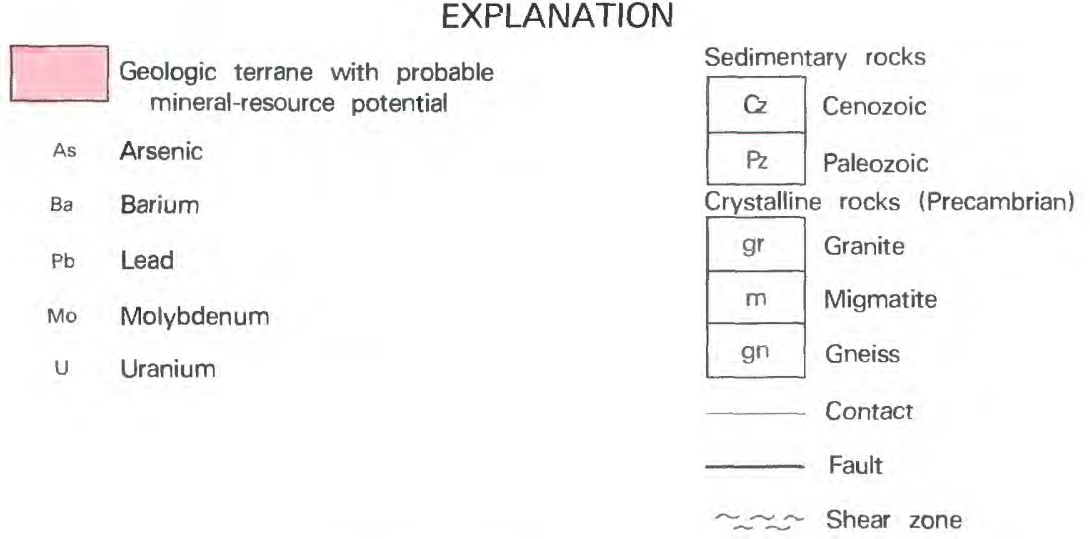

Figure 323.-Glacier Primitive Area, Wyoming. 


\title{
GLACIER PRIMITIVE AREA, WYOMING
}

\author{
By HARry C. Granger, U.S. GeOlogical SuRVey and
}

LOWell L. Patten, U.S. BUREaU of Mines

\begin{abstract}
SUMMARY
A mineral survey of the Glacier Primitive Area and an adjoining area to the northwest was made in 1968 and 1969. The study area was mapped geologically, an aeromagnetic survey was made, a geochemical study was done, and known mineralized occurrences and claims were examined. Two localities were found to contain small concentrations of uranium and several samples displayed minor anomalies in base and precious metals. A probable resource potential for lead, molybdenum, arsenic, barium, fluorite, and uranium exists in the area near the Ross Lakes shear zone and a small area of probable uranium resource potential exists around the Dubois claims. The study area, in general, is believed to have little promise for the occurrence of additional mineral or energy resources.
\end{abstract}

\section{CHARACTER AND SETTING}

The area studied is along the northeast flank of the Wind River Range in western Wyoming and includes the Glacier Primitive Area, about 277 sq mi in size, and an adjacent area of about $65 \mathrm{sq}$ mi. It contains some of the most spectacular alpine scenery in the Western United States. From the high, craggy, glacierdominated spine of the Continental Divide, the terrain drops toward the east and north onto an intricately incised series of peneplaned uplands and rounded hills. Much of the area is dotted with glacially carved lakes connected and drained by cascading mountain streams. Elevations range from $13,785 \mathrm{ft}$ at the crest of Gannett Peak, the highest in Wyoming, to about $6790 \mathrm{ft}$ in the valley of Dinwoody Creek, whose source is partly in glaciers on the flanks of Gannett Peak. A large part of the area is above the timberline, but the lower elevations are partly covered with spruce, pine, grasses, and low-growing flowering plants.

Dubois, the nearest town, is a few miles north of the study area on U.S. Highway 287. The northern edges of the area are accessible by umimproved roads, but the eastern edge abuts the Wind River Indian Reservation, and the west boundary is marked by the crest of the Wind River Range and the east border of the Bridger Wilderness.

The study area is largely underlain by Precambrian crystalline rocks but is flanked along the northeast edge by a sequence of Paleozoic marine sedimentary rocks which once also mantled the crystalline core of the Wind River Range. The north-central part of the study area is occupied by a north-trending granitic mass, which is about $5 \mathrm{mi}$ wide and $25 \mathrm{mi}$ long. This body grades outward into migmatites which, in turn, grade outward into paragneisses that form the framework of the core of the range. These rocks terminate rather abruptly on the south at a northwest-trending zone that probably represents a very old metamorphosed fault zone. South of this zone a different migmatite unit appears to border another granitic batholith whose northern parts are represented by lobes of porphyritic granite which project only short distances into the primitive area.

The Paleozoic marine sediments that dip northeasterly off the northeast flank of the Wind River Range total about $3000 \mathrm{ft}$ in thickness. They consist of quartzites, shales, limestone, dolomites, and a little oolitic iron.

Unlike many other ranges in the Rocky Mountains, no intrusive rocks of either Mesozoic or Cenozoic age were identified in the Wind River Range.

The present-day Wind River Range was initiated by a broad uplift of the northwestward-trending elongate crystalline core. After the earliest uplift, which occurred mostly in Laramide time (Late Cretaceous and early Tertiary), erosion exposed the crystalline core of the mountains and carved a topographically rugged forerunner of the present Wind River Range. Deep canyons were cut into the flanks of the range, and the lower reaches of these canyons were filled in Paleocene(?) and 
Eocene time with alluvial material derived, in large part, from erosion of older rocks at higher elevations. This period of erosion was followed by mid-Tertiary or later peneplanation that must have reduced much of the range to a region of low relief.

Renewed uplift of the range occurred during one or more episodes after peneplanation; broad arching of the peneplaned surface was accompanied by faulting which differentially uplifted some parts of the peneplaned surface near the crest of the range relative to other parts. Pleistocene glaciers then covered most of the crest of the range and scoured much of the Tertiary filling from the old canyons that emerged from the mountain front.

Since late Pleistocene time, the glaciers have retreated to their present sites high in the cirques and alpine valleys near the crest of the range. About 30 glaciers can now be found in the primitive area.

\section{MINERAL RESOURCES}

The Wind River Range has never been a significant producer of minerals. A little gold has been produced from placer deposits near Atlantic City in the southern part of the range and from localities just east of the primitive area and within the adjacent study area to the northwest. Taconitic iron ore has been produced from Precambrian rocks near Atlantic City and a similar body is present in the adjacent Bridger Wilderness. A little uranium was produced from a small mine at the north edge of the contiguous study area. No mineral production, however, has been recorded from the primitive area.

During the study samples of fresh, iron-stained, or altered rock and exposed veins were collected and analyzed. Stream-sediment samples and heavy-mineral separates were also collected from the stream valleys. Although many samples were found to contain slightly anomalous amounts of copper, lead, molybdenum, chromium, nickel, and (or) tin, none of them seems to indicate much promise for discovery of mineral resources.

Narrow, widely scattered veins of short strike length and negligible marginal alteration are present in the area. The exposures are commonly iron-stained and contain disseminated pyrite a few inches below the surface. Some of the veins contain base metals (lead, copper) with tin, and molybdenum but none indicate much promise for the discovery of mineral resources.

Small bodies of ultramafic rocks contain more nickel and chromium than the more silicic rocks but the concentrations are not abnormally high for these rock types. Fine placer gold occurs in sediments from streams that cut Tertiary sedimentary rocks in the adja- cent study area but none of the collected samples or panned concentrates indicate any promise for gold deposits.

Uranium occurs associated with a hematite-magnetitebearing vein in Precambrian gneiss at the Dubois claims in the adjacent study area. About 6 tons of uranium ore was produced from the magnetite-hematite vein at the Dubois claims and there is a probable potential that other small deposits could occur in the area. Uranium also occurs in brecciated dolomite and claystone in lower Paleozoic rocks, adjacent to the north-trending Ross Lakes shear zone. Along the shear zone were found some old mine workings, iron staining and gossan, and several samples that were anomalous in fluorite, arsenic, barium, lead, and molybdenum. The mineralization appears generally to have been weak, but its character at depth is not known and the area has a probable mineral-resource potential for base metals, molybdenum, and uranium.

Oolitic iron ores in the Paleozoic sedimentary rocks are of too low grade and insufficient size within the primitive area to constitute an identified resource on the map. Paleozoic rocks, which may be oil- or gas-bearing elsewhere, dip sharply off of the northeast flank of the Wind River Range and provide little chance of either structural or stratigraphic traps within the primitive area. Although overthrusting has placed blocks of Paleozoic sedimentary rocks beneath plates of Precambrian rocks on the west side of the range, there is no evidence that these relationships exist beneath the Precambrian rocks exposed on the east side of the range.

Neither the known occurrences of minerals nor the various geochemically anomalous samples collected during the sampling program seem to provide much hope for discovery of mineral resources. The various types of geologic settings usually associated with mineral deposits of the Western United States are not present here.

\section{SUGGESTIONS FOR FURTHER STUDIES}

It is not believed that further studies will significantly change the evaluation of the mineral potential of the study area. The Ross Lakes shear zone, which has not been explored at depth, offers the most promise.

\section{REFERENCE}

Granger, H. C., McKay E. J., Mattick R. E., Patten, L. L., and McIlroy, Paul, 1971, Mineral resources of the Glacier Primitive Area, Wyoming: U.S. Geological Survey Bulletin 1319-F, 113p. 


\title{
GROS VENTRE WILDERNESS STUDY AREA, WYOMING
}

\author{
By Frank S. Simons, ${ }^{1}$ U.S. Geological Survey, and \\ Carl L. Bieniewski, U.S. BuREaU of MineS
}

\begin{abstract}
SUMMARY
A mineral-resource survey of the Gros Ventre Wilderness study area in the Gros Ventre Mountains of northwestern Wyoming was carried out in 1976 . The area was found to have demonstrated phosphate resources in areas of substantiated phosphate resource potential. A probable oil and gas resource potential in the southwestern part of the study area was also identified. Oil and gas may occur in various possible reservoir rocks beneath the Cache Creek thrust fault, which is believed to extend beneath this part of the study area. There is little promise for the occurrence of other mineral or energy resources in the area.
\end{abstract}

\section{CHARACTER AND SETTING}

The Gros Ventre Wilderness study area consists of about $230 \mathrm{sq} \mathrm{mi}$ in the central part of the Gros Ventre Mountains in northwestern Wyoming. The Gros Ventre range is just east of Jackson and forms part of the east border of Jackson Hole. The range trends northwest, and its southwest front rises steeply from less than $7000 \mathrm{ft}$ altitude along the Hoback River to more than $11,000 \mathrm{ft}$ along the crest of the range. From the crest, the nearly flat lying to gently folded stratified rocks that make up most of the range slope in a generally northeastward direction and are deeply incised by the canyons of Granite and Crystal Creeks and the upper reaches of the Gros Ventre River.

Access into the study area is only by foot or stock trails, and although the Gros Ventre range is very rugged and has 20 peaks exceeding $11,000 \mathrm{ft}$ in altitude, few of the peaks and almost none of the beautiful alpine scenery they dominate can be seen from any road. This area was studied by the USGS and USBM in 1976 and results were published in 1981 (Simons and others, 1981).

More than 90 percent of the study area is underlain by sedimentary rocks which comprise Paleozoic rocks, mostly limestone and dolomite, $3500-4000 \mathrm{ft}$ thick; Mesozoic rocks, mainly sandstone and shale, 13,000$15,000 \mathrm{ft}$ thick; and Cenozoic rocks, mostly sandstone, conglomerate, and mudstone, perhaps $13,000 \mathrm{ft}$ thick.

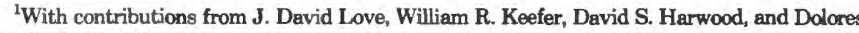
M. Kulik, USGS.
Near the crest of the range, small areas of metamorphic rocks of Precambrian age, mostly gneiss and granite, are exposed beneath the sedimentary sequence. No intrusive igneous rocks other than the ancient granites occur in the study area, and volcanic rocks also are lacking; the Gros Ventre range thus differs from most of those that make up the Rocky Mountains.

The geologic structure of the Gros Ventre range is essentially a northwest-trending broad arch that has a gently dipping, structurally simple northeast flank and a steeply dipping, thrust-faulted and structurally complex southwest flank. Superimposed on the northeast flank are several north- to northwest-trending folds and faults, some of which are 10-12 mi long.

Rocks along the crest of the Gros Ventre range are now $30,000-35,000 \mathrm{ft}$ above corresponding rocks in the Hoback River basin to the southwest; this uplift took place when the mountain block moved southwestward and upward along the northeast-dipping Cache Creek thrust fault in early Tertiary time, perhaps 50-55 million years ago. Movement along the Cache Creek fault occurred shortly after the formation of the Little Granite anticline and the Jackson thrust fault, which overrode the anticline from the southwest. The latest uplift of the Gros Ventre range took place during the Pleistocene, only 1-2 million years ago, when the range was raised about $4000 \mathrm{ft}$ relative to Jackson Hole to the west. With this uplift began the period of erosion by water and ice during which the present rugged alpine topography was formed. The higher parts of the range have been extensively glaciated as evidenced by the many deep steep-walled canyons floored by widespread deposits of glacial debris. 

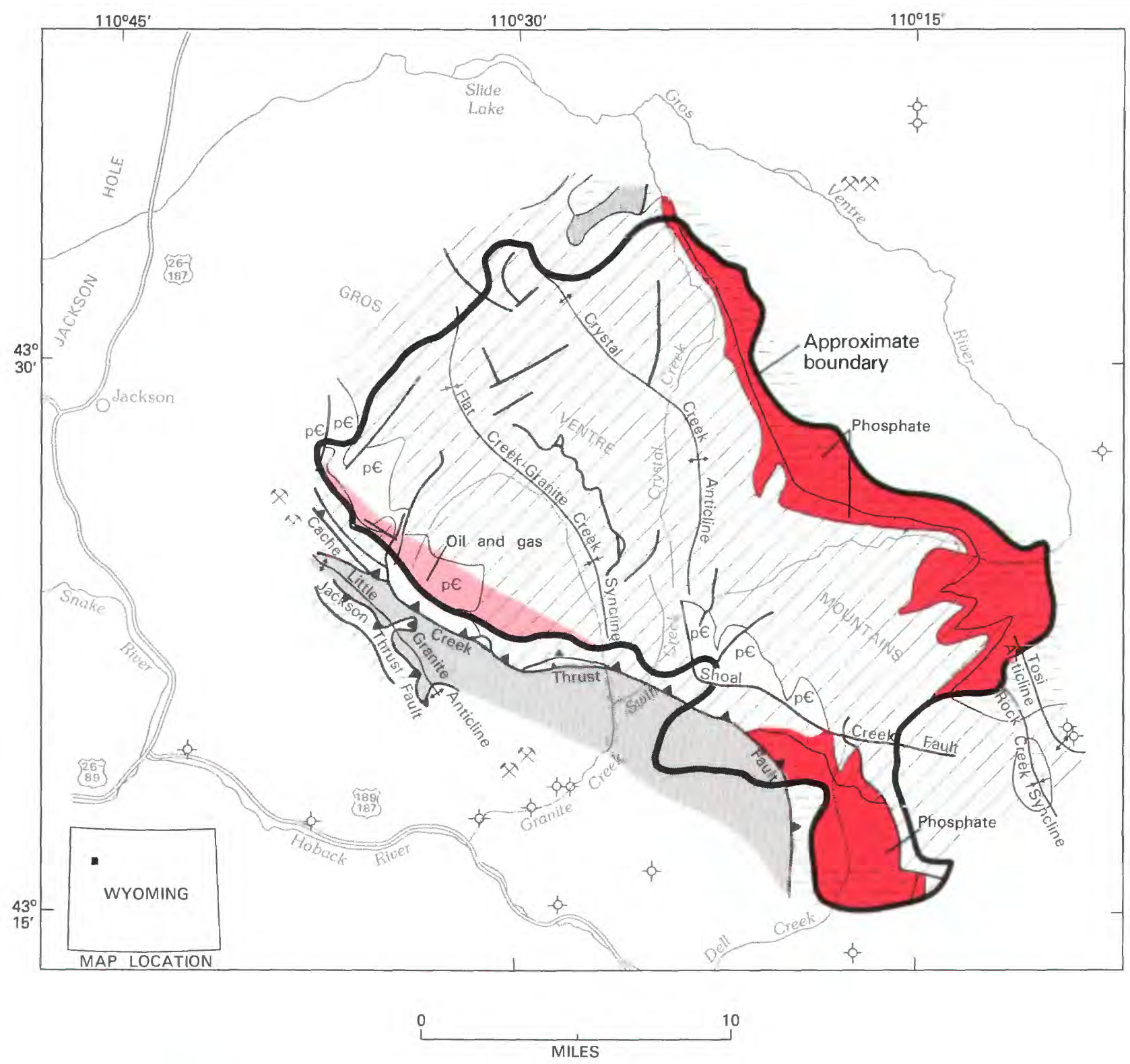

\section{EXPLANATION}

Geologic terrane with substantiated mineral-resource potential

Geologic terrane with probable oil and gas potential

a Coal mine

\& Oil-gas exploratory drill hole
Cenozoic sedimentary rocks Mesozoic sedimentary rocks Paleozoic sedimentary rocks

$p €$ Precambrian metamorphic rocks Contact Fault

- Thrust fault--Sawteeth on upper plate

Figure 324.-Gros Ventre Wilderness study area, Wyoming. 
The geochemical survey of the Gros Ventre area consisted of collection and analysis of rock samples, stream-sediment samples including panned concentrates, and one sample of water. Geophysical surveys, both aeromagnetic and gravity, were done to aid in interpretation of geologic structure and mineralresource potential.

No mining has been done in the study area, and the only mining nearby has been a small production of coal from the Little Granite coal mine, $3 \mathrm{mi}$ south of the study area. Prospecting for minerals has been done in Precambrian rocks of upper Swift and Dell Creeks, in phosphatic rocks of the Phosphoria Formation at several places, in iron-rich shale, and in limestone in West Dell Creek. A few mining claims have been staked, mainly in areas underlain by phosphatic rocks of the Phosphoria Formation.

No exploratory drilling for oil or gas has been done within the study area. A well drilled recently on Granite Creek about $5 \mathrm{mi}$ southwest of the area had numerous shows of gas, but other wells within a few miles southwest, south, or southeast of the area have been dry.

\section{MINERAL RESOURCES}

Phosphate rock in the Phosphoria Formation of Permian age is the principal mineral resource of the study area. This formation underlies about $30 \mathrm{sq} \mathrm{mi}$ on the northeast side of the area and another $8 \mathrm{sq} \mathrm{mi}$ in the southeast part. The formation within the study area is estimated to contain a total of at least 500 million tons of demonstrated phosphate resources in two areas of substantiated phosphate resource potential. The phosphate occurs in zones more than $3 \mathrm{ft}$ thick and containing more than 18 percent phosphorous pentoxide $\left(\mathrm{P}_{2} \mathrm{O}_{5}\right)$; the rock also contains traces of chromium, fluorine, silver, uranium, vanadium, and zinc.

Suitable source and reservoir rocks for oil and gas occur in several formations in the Little Granite anticline and the possible extension of its northeast flank beneath the Cache Creek thrust fault inside the southwest border of the study area. This area is considered to have a probable oil and gas resource potential. No exploratory drilling has been done on the anticline or its flanks near the study area.

Red shale of the Amsden Formation, of Mississippian and Pennsylvanian age, locally contains abundant nodules and grains of hematite (iron oxide). In the study area, the proportion of nodules to shale usually is low and the amount of iron-rich shale is too small to constitute a mineral resource.

Prospects in Precambrian rocks at the head of Swift Creek contain a little jade, small amounts of chromium and nickel, and traces of cobalt, copper, lead, silver, and tin. Prospects in upper Dell Creek are on veinlets of quartz and iron oxide in granite and have traces of lead and vanadium. None of these occurrences constitute a resource potential.

In the southeast part of the study area, formations of Late Cretaceous age contain several beds of coal that are inferred to underlie an area of about $2 \mathrm{sq} \mathrm{mi}$. The coal beds are thin and shaly, and no resource potential was identified.

Many samples of rocks and stream sediments contain anomalous amounts of one or more elements; in particular, several samples of Precambrian rocks contain anomalous amounts of chromium, cobalt, copper, molybdenum, nickel, and vanadium; hematite-rich shale commonly shows anomalous amounts of molybdenum and vanadium. One sample of soft black material from a small vein of calcite in limestone contains a peculiar combination of cobalt, nickel, vanadium, molybdenum, and copper, and another sample of siltstone has anomalous quantities of lead, molybdenum, nickel, silver, vanadium, and zinc. However, most samples with anomalous concentrations of metals are representative of only a small amount of rock, and none of the elements noted is present in sufficient quantity to constitute a mineral resource.

The Gros Ventre study area is singularly devoid of igneous rocks, including intrusive igneous rocks which commonly are associated with mineral deposits in the Rocky Mountains. Except for small patches of Precambrian rocks, none of which contains any significant mineral resource, no altered rocks were seen and no mineralization was noted along any of the faults that cut the layered rocks. Except as noted above, the stratified rocks themselves contain no recognized mineral resource.

\section{SUGGESTIONS FOR FURTHER STUDY}

Further investigation of the study area itself is unlikely to identify concealed or otherwise unrecognized mineral resources. Additional detailed study of the Cache Creek thrust fault might refine the geologic interpretation of this fault, the estimate of its extent at accessible depth beneath the study area, and hence the estimate of oil and gas potential.

\section{REFERENCE}

Simons, F. S., Love, J. D., Keefer, W. R., Harwood, D. S., and Bieniewski, C. L., 1981, Mineral resources of the Gros Ventre Wilderness study area, Teton and Sublette Counties, Wyoming: U.S. Geological Survey Open-File Report 81-510, 93 p. 

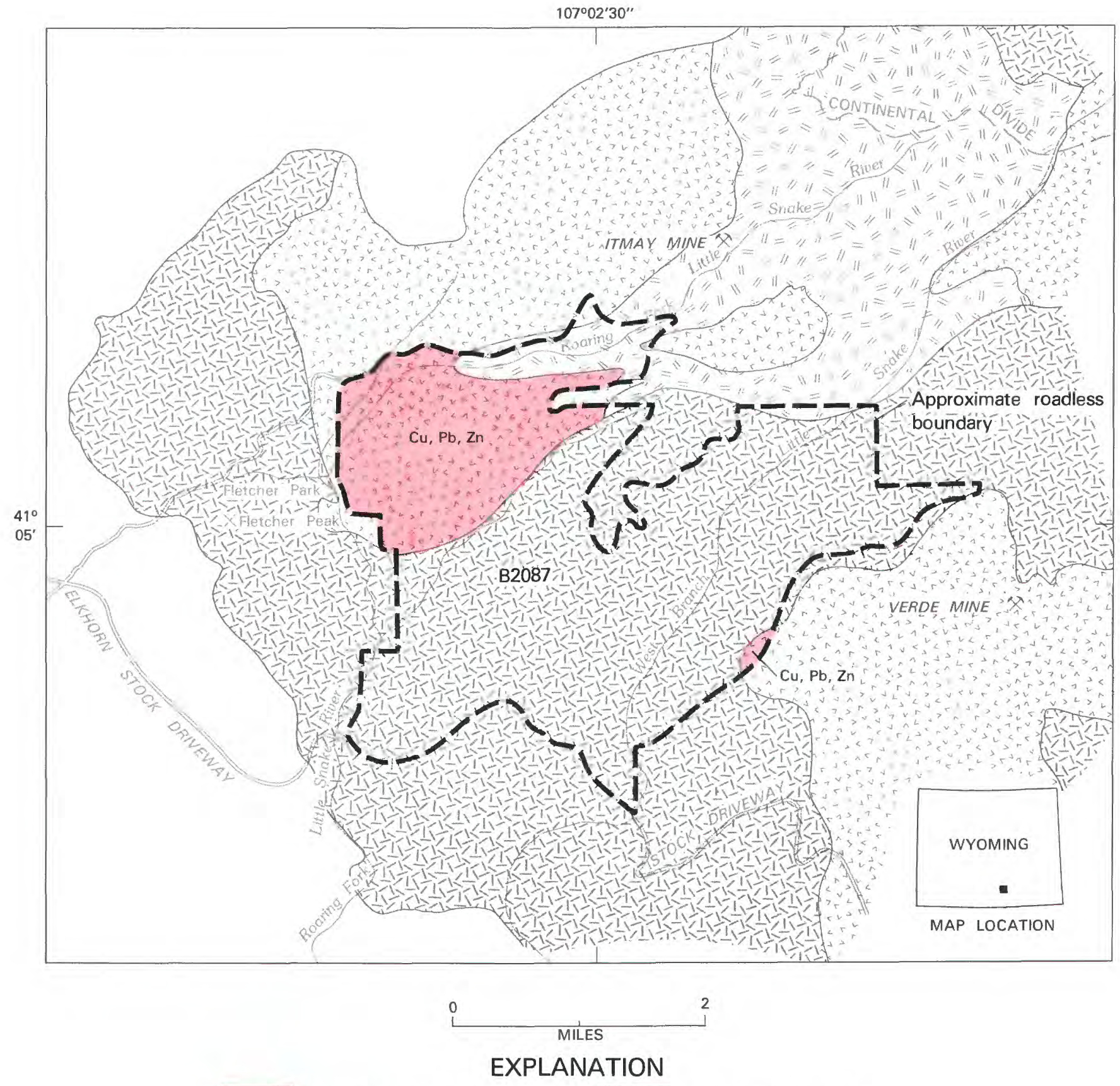

Geologic terrane with probable mineral-resource potential

$\begin{array}{cl}\mathrm{Cu} & \text { Copper } \\ \mathrm{Pb} & \text { Lead } \\ \mathrm{Zn} & \text { Zinc }\end{array}$

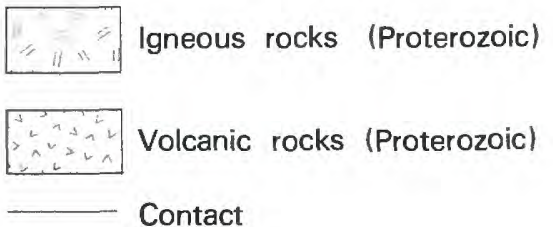

Figure 325.-Huston Park Roadless Area, Wyoming. 


\title{
HUSTON PARK ROADLESS AREA, WYOMING
}

\author{
By ROBERT S. Houston,${ }^{1}$ U.S. GeOlOGiCal Survey, and \\ Michael E. Lane, U.S. BuREaU OF Mines
}

\begin{abstract}
SUMMARY
A probable resource potential for the occurrence of metallic mineral resources in stratiform sulfide deposits is assigned to areas in the northern and southeastern parts of the Huston Park Roadless Area. These areas are underlain by volcanic rock successions favorable for stratiform sulfide deposits. However, no indication of mineralized rock was identified during a mineral survey by the USGS and USBM in 1981-1982.
\end{abstract}

\section{CHARACTER AND SETTING}

The Huston Park Roadless Area is approximately $10.5 \mathrm{sq} \mathrm{mi}$ located on the southwestern flank of the Sierra Madre of southern Wyoming, about $27 \mathrm{mi}$ west of the town of Encampment, Wyoming. It is an addition to the Huston Park Wilderness study area of the Southern Sierra Madre. The Huston Park Roadless Area includes portions of the drainage areas of the Roaring Fork Branch of the Little Snake River and the West Branch of the North Fork of the Little Snake River. The area is accessible by use of dirt roads that connect with Wyoming Road 70 between Encampment and Baggs; accessibility is limited to summer and early fall months and to dry periods because these dirt roads are extremely hazardous after significant precipitation. Altitude in the roadless area ranges from 8000 to $9700 \mathrm{ft}$; the lower altitudes are characterized by open parks and meadows and the higher altitudes are well timbered.

The Huston Park Roadless Area is south of and within about $3 \mathrm{mi}$ of a major geologic boundary that divides the Sierra Madre into two parts. North of the east-trending boundary are some of the most ancient rocks in the United States with ages ranging from over 3 billion years to about 2 billion years. These very old rocks are believed to have been located near the margin of an ancient continent about 2 billion years ago. South of the east-trending boundary are somewhat younger rocks ranging in age from about 1.9 billion years to about 1.7 billion years. The rocks south of the boundary, which includes the Huston Park Roadless Area, are primarily volcanic rocks deposited in the sea and were

\footnotetext{
${ }^{1}$ With contributions from T. G. Smith, USGS.
}

intruded by a variety of igneous rocks (chiefly granite). These ancient volcanic rocks have features like those of modern volcanic islands such as Japan and the Phillipines. Geologists have suggested (Hills and Houston, 1979) that about 1.7 billion years ago volcanic islands that were located in what is now Colorado were attached to an ancient continent located in what is now southeastern Wyoming. The major geologic boundary located north of the Huston Park Roadless Area is thought to be the site of the attachment or of suturing so that the boundary is referred to by geologists as a suture.

Geologic concepts concerning the origin of the rocks of a given area are important because if the concept on origin is correct, it is possible to search for mineral resources that are known to occur in such an area. In geologic mapping, geochemical sampling, and during the examination of mines and prospects of this area, particular attention was given to the search for mineral deposits of the type found in volcanic islands such as Japan, and for deposits found near major geologic boundaries or sutures.

\section{MINERAL RESOURCES}

Along with the standard procedures of geologic mapping, geochemical sampling, and the search for mineralized areas, the Huston Park Roadless Area was examined in somewhat more detail than usual because geologic reasoning suggested that the area had greater than average potential for two types of mineral deposits: (1) volcanogenic stratiform sulphide deposits and (2) tin and tungsten in granite. Volcanogenic stratiform sulphide deposits are formed where volcanic 
rocks are deposited beneath the sea. One concept on the formation of these deposits is that hot magma intruded beneath the sea floor sets sea water into circulation and this results in the development of local convective cells that drive hot sea water down into porous volcanic rocks deposited on the sea floor. As sea water circulates through porous volcanic rocks, metals are leached from the volcanics and are ultimately transported to the sea floor-sea water interface where they erupt as a metalbearing hot water plume. Chemical reactions near the interface cause precipitation of metal-bearing sulphide as a blanket layer (stratiform in geologic terms) near the plume (Franklin and others, 1981). These stratiform sulphide deposits are thus found in specific geologic settings that can be recognized in the field. They are usually sandwiched between rhyolite breccia and iron-rich chemical sediments.

Geologic mapping and geochemical study did not reveal mineral occurrences in the Huston Park Roadless Area nor were stratiform mineral deposits detected. Three prospects were located in areas adjacent to the Huston Park Roadless Area, two to the north and one to the southeast. In prospects near the old Itmay mine north of the Huston Park Roadless Area and the old Verde mine southeast of the roadless area, iron and copper sulphides were identified near a contact between rhyolite breccia and iron-rich chemical sediment. Some of these same occurrences were investigated prior to and during this study. A limited diamond drilling program was undertaken on prospects north of the Huston Park Roadless Area. A probable potential for mineral resources in strataform sulfide deposits is assigned to the northern and southeastern parts of the roadless area where underlain by volcanic rocks.

The second proposal based on geologic reasoning is that this general area of the southern Sierra Madre has potential for tin and tungsten deposits in granite. As suggested above, this area may be one where volcanic islands have collided with an ancient continent (Hills and Houston, 1979). If this interpretation is correct, it is reasonable to compare this area with younger geologic terranes such as southeast Asia where similar collisions between volcanic islands and continents are believed to have taken place. In southeast Asia granites thought to have formed during collisions are notably rich in tin and tungsten (Beckinsale, 1979). The search for these metals in the Huston Park Roadless Area was unsuccessful; ten of eleven granite samples did not contain either metal. Some higher than average values for tin and tungsten have been found in granites in other parts of the Sierra Madre, however, so it may be worthwhile to continue study of the granitic rocks until the concept is tested fully.

\section{SUGGESTIONS FOR FURTHER STUDIES}

It is unlikely that further surface examination of the roadless area would identify mineral deposits, but the general area of the southern Sierra Madre and several specific prospects located north and south of the roadless area deserve further examination to verify or disprove the presence of stratiform sulphide deposits. In addition, study of granites of the southern Sierra Madre are needed to determine whether or not they have promise as a source of tin and tungsten.

\section{REFERENCES}

Beckinsale, R. D., 1979, Granite magmatism in the tin belt of southeast Asia, in Atherton, M. P. and Tarney, J., editors, Origin of granite batholiths; geochemical evidence: Kent, U. K., Shiva Publishing Ltd., p. 34-44.

Franklin, J. M., Lydon, J. W., and Sangster, D. M., 1981, Volcanicassociated massive sulphide deposits, in Skinner, B., editor, Economic geology; Seventy-fifth anniversary volume: Lancaster Press, Pa., Economic Geology Publishing Company, p. 485-627.

Hills, F. A., and Houston, R. S., 1979, Early Proterozoic tectonics of the central Rocky Mountains, North America: University of Wyoming, Contributions to Geology, v. 17, p. 89-109.

Houston, R. S., Smith, T. G., and Lane, M. E., in press, Mineral resource potential map of the Huston Park Roadless Area, Carbon County, Wyoming: U.S. Geological Survey Miscellaneous Field Studies Map MF-1637-A. 


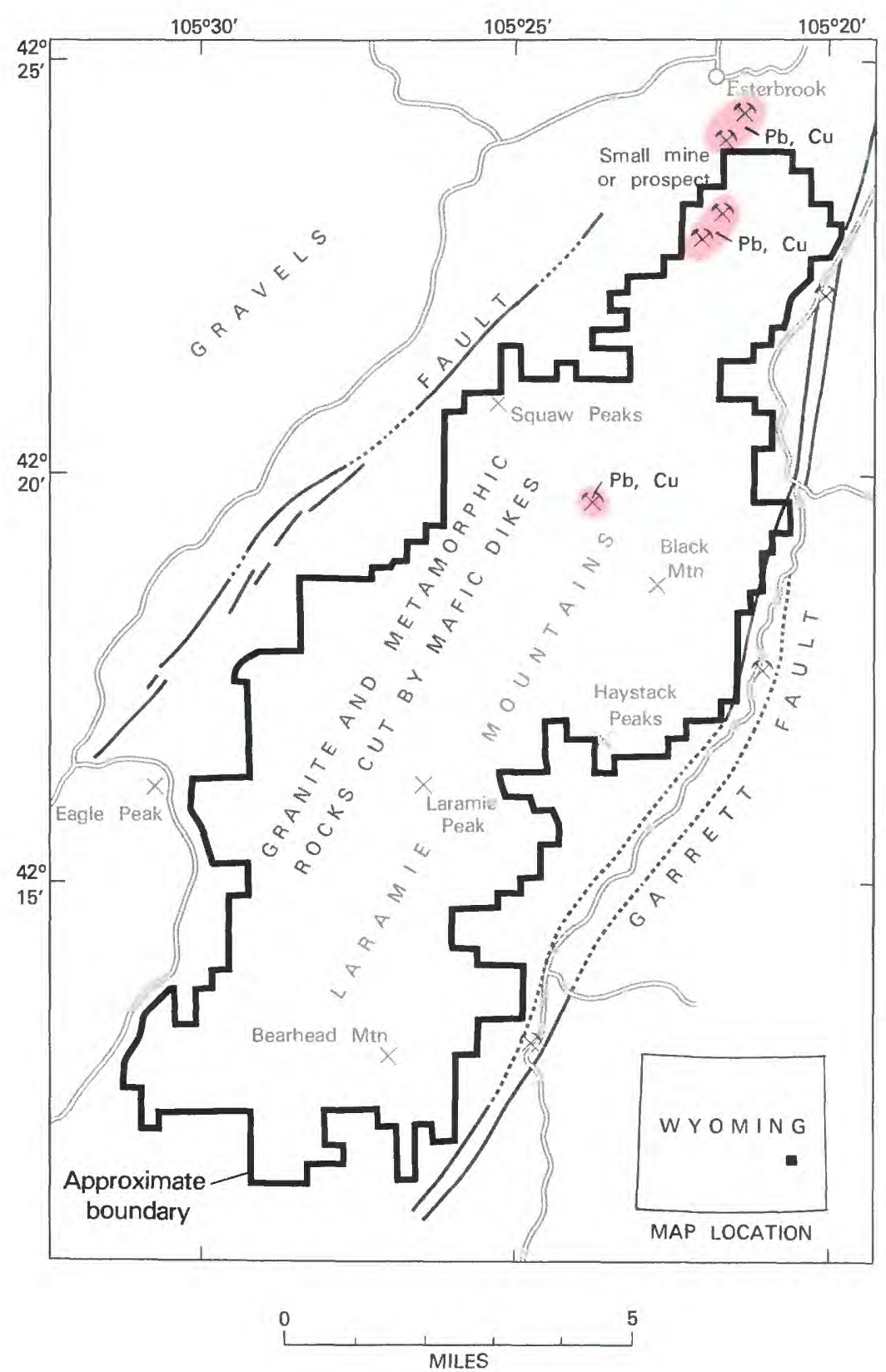

\section{EXPLANATION}

Geologic terrane with probable mineral-resource potential
$\mathrm{Cu} \quad$ Copper
$\mathrm{Pb} \quad$ Lead
父 Mine

Figure 326.-Laramie Peak Wilderness study area, Wyoming. 


\title{
LARAMIE PEAK WILDERNESS STUDY AREA, WYOMING
}

\author{
By Kenneth Segerstrom, U.S. GeOlogical Survey, and \\ R. G. Weisner, U.S. BUREAU OF MineS
}

\section{SUMMARY}

On the basis of a mineral survey conducted in 1973, most of the Laramie Peak Wilderness study area was concluded to have little promise for the occurrence of mineral or energy resources. Only three small areas in the northern part, one extending outside the study area to Esterbrook, were found to have probable mineral-resource potential for copper and lead.

\section{CHARACTER AND SETTING}

The Laramie Peak study area occupies about $54 \mathrm{sq} \mathrm{mi}$ of the Laramie Mountains, southeastern Wyoming, about 25 mi south of Douglas. Laramie Peak is the principle landmark of southeastern Wyoming and westernmost Nebraska, towering to $10,272 \mathrm{ft}$ above sea level. Imposing views of the peak are seen by the traveler as he follows Interstate 25 from Wheatland to Douglas. Agriculture was the chief industry of the region, and the towns were founded as marketing centers for farm products. The North Platte River and its tributaries supply water for irrigation. In more recent years oil and gas have become increasingly important, especially north of the study area, in the vicinity of Douglas.

A mineral survey of the area was made in 1973 and the results were published in 1977 (Segerstrom and Weisner, 1977).

The part of the Laramie Mountains included in the study area consists principally of granite, but roof pendants of metamorphic rock remain in a few places. The rocks are cut by a myriad of mafic dikes, and the whole assemblage is of Precambrian age. These mountains were uplifted in a giant block that is bounded on the southeast and northwest sides by faults. The Garrett fault, on the southeast side, is a continuous shear zone, whereas the fault system on the northwest side is made up of relatively discontinuous fractures.

\section{MINERAL RESOURCES}

Few traces of the early prospector are found in and around the Laramie Peak Wilderness study area, unlike most mountainous regions of the Western United States. Small mines and prospects are scattered in and around the north end, along but outside of the southeast side of the area, and a lone prospect was found in the north-central part of the area. In the workings and prospects within the study area pyrrhotite (iron) is by far the most abundant sulfide mineral, copper as chalcopyrite is locally present in some of the pyrrhotite, and there are traces of the secondary copper minerals malachite and chrysocolla along veinlets in the old mine workings. Galena (lead) is only rarely found. No production is recorded from within the study area boundaries; near the study area the only known metal production came from a small now abandoned lead mine at Esterbrook, about $1 \mathrm{mi}$ to the north.

Analytical results from selected samples of veins and mine-dump material show a few high values for copper; such samples contain megascopically visible sulfides. A few vein and mine dump samples also contained silver, platinum, and palladium; all of these mineralized samples apparently represent small volumes of material.

Although mineralized areas defined by old mine workings, veins, and geochemical anomalies are assigned a probable mineral-resource potential, known mineralized occurrences are small and the presence of a large deposit is considered unlikely.

Radiometric readings were taken with a scintillometer but nothing significant was found at any of the prospects visited or from any of the samples. The geologic setting precludes the presence of fossil-fuel resources in the study area. There are no surface indications that geothermal energy could be developed within or near the study area.

\section{REFERENGE}

Segerstrom, Kenneth, and Weisner, R. C., 1977, Mineral resources of the Laramie Peak study area, Albany and Converse Counties, Wyoming: U.S. Geological Survey Bulletin 1397-B, 35 p. 


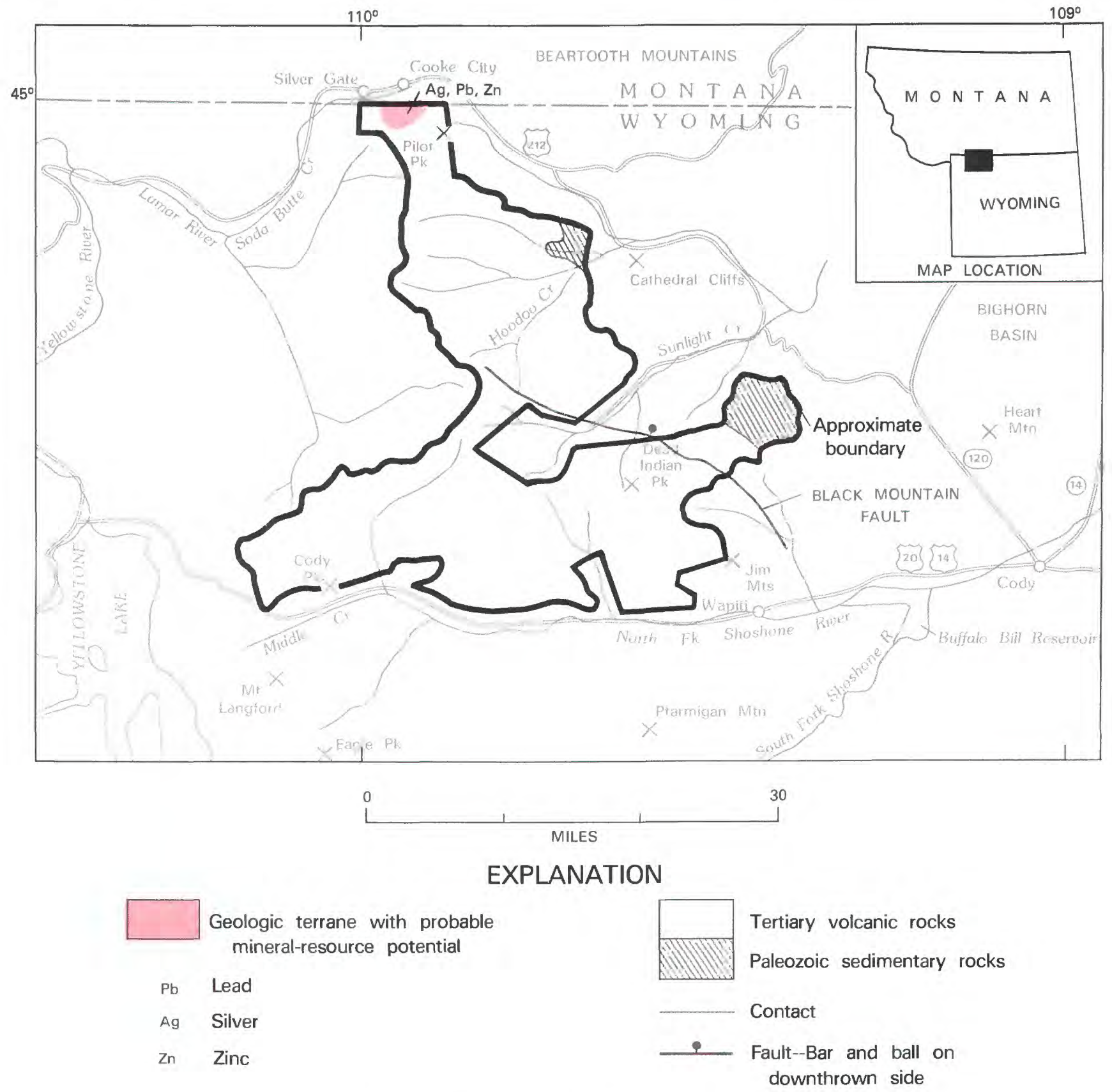

Figure 327.-North Absaroka Wilderness, Wyoming. 


\title{
NORTH ABSAROKA WILDERNESS, WYOMING
}

\author{
By Willis H. NELSON, U.S. GEOLOGICAL SURVEY, and \\ FRANK E. WILliams, U.S. BUREAU OF MiNeS
}

\begin{abstract}
SUMMARY
The North Absaroka Wilderness was studied during 1970-72 to evaluate the resource potential of the area. The results of geologic field mapping, field inspection of claims and prospects, analyses of bedrock and stream-sediment samples, and an aeromagnetic survey indicate that a small area of geologic terrane with probable mineral-resource potential for silver, lead, and zinc is present on the northern edge of the wilderness. Bentonite, low-quality coal, and localized deposits of uranium and chromite have been produced from surrounding areas; but such deposits, if present in the wilderness, are probably too deeply buried, too small, or too sporadically distributed to be classed as resources. Copper and gold mines and prospects are present on the fringes of the wilderness, but otherwise the area seems to be devoid of concentrations of metallic minerals. No surface evidence of geothermal energy resources was found.
\end{abstract}

\section{CHARACTER AND SETTING}

The area comprises about $560 \mathrm{sq}$ mi of very rugged scenic mountainous terrain that adjoins the eastern boundary of Yellowstone National Park in northwestern Wyoming. Volcanic rocks of intermediate composition comprise the upper few thousand feet of rock over nearly the entire wilderness area. These rocks were originally parts of several steep-sided volcanic mountains, whose rocks overlap in age and interfinger along their flanks. These volcanoes were active about 50 million years ago and their original forms have since been greatly modified by erosion. The location of eruptive centers of the ancient volcanoes can be identified by dikes which radiate from the centers, and from the distribution of flow rocks (near the centers) and reworked fragmental rocks (on the flanks of the volcanoes). Intrusive rocks related to the volcanic rocks are exposed at some of these volcanic centers.

The volcanic rocks rest on older sedimentary rocks that are exposed locally along the northern and eastern edges of the wilderness. Soon after deposition of some of the oldest volcanic rocks, they, along with some of the underlying sedimentary rocks, were broken into steep-sided flat-bottomed blocks which moved and separated from one another along a nearly horizontal plane, the Heart Mountain detachment fault. Ancient crystalline rocks, mostly granitic, occur north and east of the wilderness and probably extend deep beneath the wilderness.

\section{MINERAL RESOURCES}

Known deposits, principally of gold, copper, silver, and lead in the vicinity of the North Absaroka Wilderness are associated with intrusive rocks at some of the volcanic centers. In the Sunlight mining region, an enclave nearly surrounded by the wilderness, mineralization occurs in veins and is disseminated in volcanic and intrusive igneous rocks. At deeper levels replacement deposits may occur in Paleozoic carbonate rocks but these are deeply buried beneath volcanic rocks and would be difficult and costly to locate and exploit. Silver-lead-zinc replacement deposits in the Upper Cambrian carbonate rocks in the Cooke City mining district, just north of the wilderness, probably extend an undetermined distance underground into the north part of the wilderness, thereby defining an area of probable mineral-resource potential for deposits of silver, lead, and zinc.

Chromite has been mined from the very old crystalline rocks about $20 \mathrm{mi}$ north of the North Absaroka Wilderness. The rocks containing the chromite make up only a very small part of the older rocks and there is no evidence that similar rocks are buried beneath younger 
sedimentary and volcanic rocks in the wilderness. Even if such rocks are present in the wilderness they are so sporadically distributed and so deeply buried that they would be very difficult to locate. High iron content makes this chromite difficult and expensive to refine.

\section{REFERENCE}

Nelson, W. H., Prostka, H. J., and Williams, F. E., 1980, Geology and mineral resources of the North Absaroka Wilderness and vicinity, Park County, Wyoming, with sections on Mineralization of the Sunlight mining region and Geology and mineralization of the Cooke City mining district by J. E. Elliott, and a section on Aeromagnetic survey by D. L. Peterson: U.S. Geological Survey Bulletin 147, $101 \mathrm{p}$. 


\title{
POPO AGIE PRIMITIVE AREA, WYOMING
}

\author{
By Robert C. Pearson, ${ }^{1}$ U.S. Geological Survey, and \\ L. L. Patten, U.S. Bureau of Mines
}

\begin{abstract}
SUMMARY
A mineral-resource appraisal was made of the Popo Agie Primitive Area and some adjoining lands in 1969-70 and 1972. This scenic mountainous region of the Wind River Range in west-central Wyoming is composed largely of ancient granitic rocks in which virtually no evidence of mineral deposits was found. The area is considered to have little promise for the occurrence of mineral or energy resources.
\end{abstract}

\section{CHARACTER AND SETTING}

The Popo Agie (pronounced "po-PO-zhah") Primitive Area and some adjacent National Forest lands, which later were designated as roadless areas 02062, 02063, and part of 04901, were studied in 1969, 1970, and 1972 to determine their mineral-resource potential. These combined areas comprise about $240 \mathrm{sq}$ mi located along the southeast flank of the Wind River Range in Fremont and Sublette Counties, Wyoming. The area is bounded on the southwest by the Bridger Wilderness, from which it is separated by the Continental Divide, and on the north by the Wind River Indian Reservation. The town of Lander, Wyoming, is about $10 \mathrm{mi}$ to the east. Several roads to and along the east side of the Popo Agie Primitive Area provide access from U.S. Highway 287, which passes through Lander, and from Wyoming Highway 28, which crosses historic South Pass a few miles to the southeast.

The higher parts of the area are a rather gently rolling upland, a remnant of an old erosion surface that has been all but destroyed by later erosion of spectacular canyons, first by streams flowing off the rising mountain range and later by glaciers that modified the stream valleys to produce bare rock walls and huge cirques at their heads. Much of the area is above timberline where bare rock, block fields, talus, lakes, and snowfields dominate the landscape. Below timberline, bare rock and thin soil support sporadic and sparse forest growth.

The Wind River Range is typical of Rocky Mountain

${ }^{\text {I}}$ With contributions from T. H. Kiilsgaard and D. L. Gaskill, USGS. ranges in age and structure, though not in size, as it is the largest ( 40 by $125 \mathrm{mi})$. It is an asymmetric structural arch broken by low-dipping faults on its southwest flank and by numerous steep faults throughout. Sandstone, limestone, and shale strata formerly continued in unbroken layers across the area but were eroded rapidly as the arch began to rise some 70 million years ago. Ancient crystalline rocks were gradually exposed in the core of the range as the sedimentary rocks were removed. In the Popo Agie Primitive Area the crystalline rocks are chiefly granites of several types, all apparently over 2,500 million years old. The granites were intruded by several large dikes of diabase commonly many miles long.

Remnants of the sedimentary rocks dip about $10^{\circ}$ $15^{\circ}$ off the northeast flank of the range throughout its length; these are preserved in the primitive area only as a narrow fringe occupying a few square miles. Valley glaciers that were responsible for much of the outstanding scenery also distributed bouldery moraines over much of the lower terrain on the flank of the range.

In addition to geologic studies, an aeromagnetic map was prepared, and geochemical samples were collected and analyzed.

\section{MINERAL RESOURCES}

The old crystalline rocks of the Wind River Range contain few mines and prospects although gold and iron ore have been mined and uranium and molybdenum are known to occur in the range, outside the Popo Agie Primitive Area. Unlike the mountainous areas in surrounding states and in the Absaroka Mountains in 


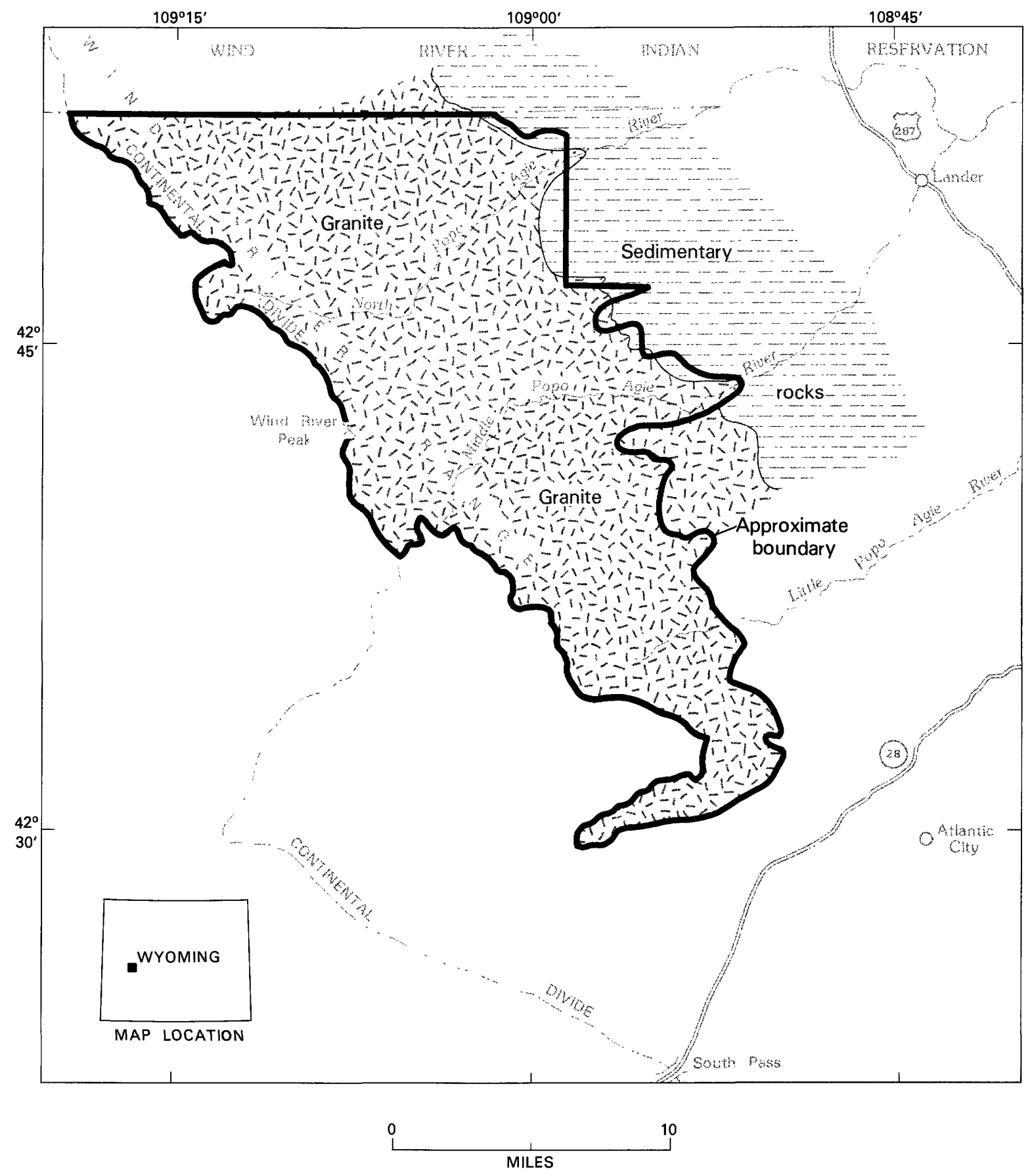

Figure 328.-Popo Agie Primitive Area, Wyoming. 
northwestern Wyoming, the Wind River Range contains none of the young intrusive rocks that are associated with base- and precious-metal deposits.

Iron ore in recrystallized sedimentary and volcanic rocks near Atlantic City, a few miles southeast of the primitive area, has been exploited by a large open-pit mine. The rocks that contain the iron deposits do not extend into the primitive area and in their absence no iron ore is to be expected. Gold has been produced from quartz veins, also near Atlantic City and also in the same recrystallized sedimentary and volcanic sequence as the iron ore. No gold-bearing quartz veins have been found in the Popo Agie Primitive Area nor has placer gold been found that would suggest a lode source. Uranium in fracture zones in the northern part of the range is in small low-grade, near-surface accumulations that seem unimportant. Though similar fracture zones are abundant in the Popo Agie area, no uranium was found in them. A molybdenum occurrence a few miles west of the primitive area has not proven to be significant. Though granites similar to those in which the molybdenum occurs are widespread in the Popo Agie area, no molybdenum was found in them.

The geochemical and aeromagnetic surveys did not identify any part of the area as sufficiently anomalous to warrant additional study.

Several groups of mining claims-none patentedhave been located, mostly along the periphery of the area. Prospect diggings were found on only one of these groups. Two small pits on Rennecker Peak were dug adjacent to a diabase dike; they exposed only traces of copper minerals, the only metallic minerals found in the entire area.

The general lack of visible indications of mineralization, the lack of rocks commonly associated with metallic-mineral deposits, and the lack of anomalous geochemical samples indicate that the Popo Agie Primitive Area has little promise for the occurrence of metallic or energy resources.

\section{SUGGESTIONS FOR FURTHER STUDIES}

Deep crustal seismic-reflection profiles obtained in 1976 and 1977 across the southern Wind River Range suggest the possibility that young sedimentary rocks, similar to those at the surface along the northeast flank of the range, are present at depth beneath the granite in the Popo Agie Primitive Area. If present, such buried sedimentary rocks could be petroleum bearing. Earlier, when the mineral survey of the Popo Agie area was made, the low-dipping fault on the southwest flank of the range, which places granite over sedimentary rocks, was recognized, but no evidence was available then to suggest that the sedimentary rocks extended back beneath the range the several miles necessary for them to be beneath the primitive area. Additional seismic and gravity studies would probably add valuable information, but ultimately very expensive, very deep drilling will be necessary to test this possiblity.

\section{REFERENCES}

Pearson, R. C., Kiilsgaard, T. H., and Patten, L. L., 1971, Mineral resources of the Popo Agie Primitive Area, Fremont and Sublette Counties, Wyoming: U.S. Geological Survey Bulletin 1353-B, $55 \mathrm{p}$.

Pearson, R. C., Patten, L. L., and Gaskill, D. L., 1973, Mineral resources of an area near the Popo Agie Primitive Area, Fremont County, Wyoming: U.S. Geological Survey Bulletin 1391-A, $18 \mathrm{p}$. 

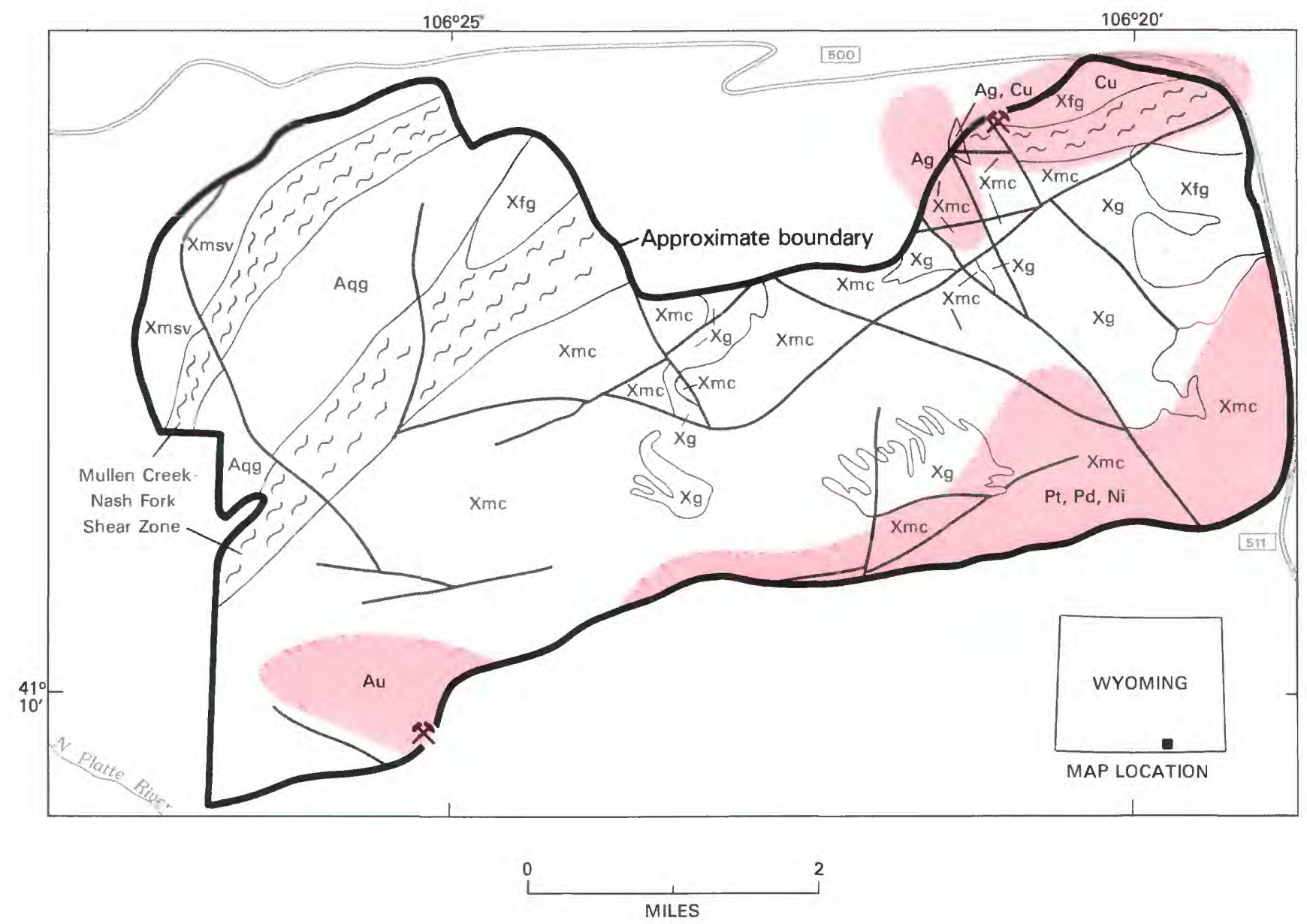

\section{EXPLANATION}

\begin{tabular}{|ll}
\hline & $\begin{array}{c}\text { Geologic terrane with probable } \\
\text { mineral-resource potential }\end{array}$ \\
$\mathrm{Cu}$ & Copper \\
$\mathrm{Au}$ & Gold \\
$\mathrm{Ni}$ & Nickel \\
$\mathrm{Pd}$ & Palladium \\
$\mathrm{Pt}$ & Platinum \\
$\mathrm{Ag}$ & Silver \\
$\mathrm{X}$ & Mine or deposit
\end{tabular}

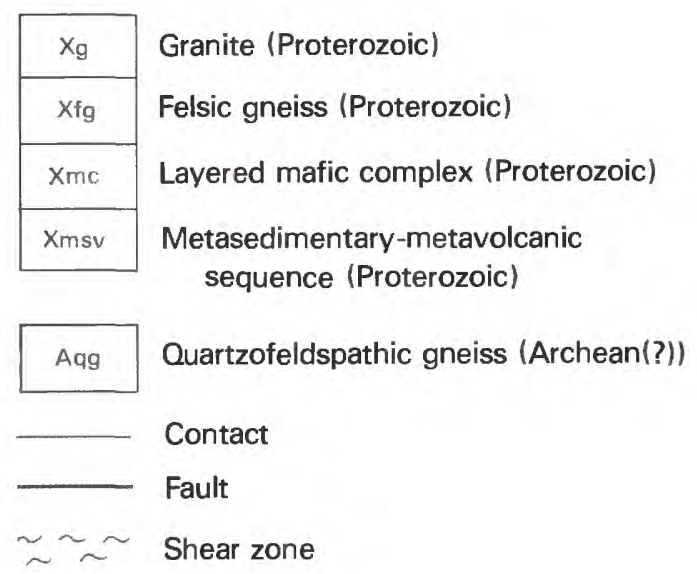

Figure 329.-Savage Run Wilderness, Wyoming. 


\title{
SAVAGE RUN WILDERNESS, WYOMING
}

\author{
M. E. MaCallum, U.S. Geological Survey, and \\ STEVEN E. KLUENDER, U.S. BUREAU OF Mines
}

\section{SUMMARY}

Mineral evaluation and related surveys were conducted in the Savage Run Wilderness in 1980-81 and results of these studies indicate probable mineralresource potential in four areas. Gold and (or) silver mineralization in veins associated with faults was found in two areas; all known occurrences inside the wilderness are very small in size. Slightly anomalous values of platinum, palladium, and nickel were recorded from rock-chip and stream- sediment samples from the southeast portion of the wilderness where layered mafic rocks predominate, and a probable resource potential exists for platinum, palladium, and nickel. An area of sheared rocks in the northeastern corner of the wilderness has a probable resource potential for copper. The nature of the geologic terrane precludes the occurrence of organic fuels.

\section{CHARACTER AND SETTING}

The Savage Run Wilderness encompasses approximately $23 \mathrm{sq} \mathrm{mi}$ of the Medicine Bow National Forest in south-central Wyoming about $40 \mathrm{mi}$ west of Laramie. It is situated on the west flank of the Medicine Bow Range and overlooks the North Platte River and Saratoga valley. Altitudes range from about 7500 to $9900 \mathrm{ft}$. The area is roughly bounded on the north, east, and south sides by unimproved USFS roads which can be reached via Wyoming State Highways 130 and 230.

Except for local Tertiary and Quaternary alluvial and colluvial deposits, all rocks in the Savage Run Wilderness are Precambrian in age. The northwestern portion of the wilderness is traversed by the northeasttrending Mullen Creek-Nash Fork shear zone, which is interpreted as a major Precambrian structure that has been reactivated many times (Houston and others, 1968). Rocks northwest of and locally included within the shear zone are predominantly metasedimentary and metavolcanic units of Early Proterozoic and Archean(?) age. The rocks south of the shear zone are Proterozoic in age and consist predominantly of metamorphosed gabbro of the mafic complex on Mullen Creek, with a lesser quantity made up by sills, dikes, and small irregular bodies of granite and a local felsic mylonite gneiss.

Faults are numerous; most trend northwest or northeast, and commonly show evidence of multistage movements. The northwest-trending structures have the greatest late stage movements and tend to be the most mineralized, especially where they cut across the shear zones.

Rock-chip and stream-sediment surveys were conducted in the wilderness and immediately adjacent areas, and the analytical results mainly reflect the composition of the rock types sampled, rather than superimposed mineralization. Aeromagnetic (U.S. Geological Survey, 1976) and gravity (D. M. Kulik, written commun., 1982) surveys reflect the distribution of the principal rock units and outline major structural trends.

\section{MINERAL RESOURCES}

There is no evidence of mineral production from the Savage Run Wilderness. Numerous small gold and copper operations were active for a number of years beginning at the turn of the century in the Holmes-Keystone, New Rambler, and Douglas placer districts, immediately to the east of the wilderness (McCallum and Kluender, in press).

A limited number of prospect pits and small workings were found in the wilderness, but none exhibit extensive mineralization. Other than small amounts of copper at several workings, base and precious metals were recorded at anomalous levels in only one prospect within the wilderness. Samples from a small pit in a gossan 
zone at the sheared contact between quartzite and metagabbro in the North Mullen Creek valley assayed 1000 ppm (parts per million) cobalt, $300 \mathrm{ppm}$ molybdenum, $15 \mathrm{ppm}$ bismuth, and $10 \mathrm{ppm}$ silver. Several workings immediately adjacent to the wilderness on the southwest and northeast contain gold and (or) silver values in fault-controlled vein systems that apparently continue into the wilderness. Free gold, argentiferous galena, bournonite, freibergite, sphalerite, and (or) chalcopyrite have been recognized in some of the veins along with local siderite, specular hematite, goethite, and (or) pyrite. Although demonstrated resources exist, the tonnage of mineralized material appears low. Samples that assay as much as $800 \mathrm{ppm}$ gold (25 oz/ton) and 1600 ppm silver $(51.2 \mathrm{oz} / \mathrm{ton})$ were obtained from two veins (McCallum and Kluender, in press). Copper values in excess of 2 percent were obtained from samples from a group of pits, trenches and shallow shafts in the easttrending shear zone located along the north-northeast wilderness boundary. Analyses indicate that the amounts of other metals are low at these sites.

Slightly anomalous values of platinum, palladium, and (or) nickel (as much as $0.03 \mathrm{ppm}, 0.016 \mathrm{ppm}$, and $3000 \mathrm{ppm}$, respectively) were obtained from rock-chip and stream-sediment concentrates from an area in the southeast portion of the wilderness underlain primarily by layered gabbroic rocks of the mafic complex on Mullen Creek (McCallum and Kluender, in press). Although these values are not appreciably above normal background levels for certain kinds of mafic rocks, they clearly exceed values for most mafic rocks in other parts of the layered complex within the wilderness, and may reflect a zone of enrichinent in platinum-group elements. Anomalous nickel values are associated almost exclusively with metapyroxenitic rocks, and commonly are accompanied by anomalous amounts of platinum and palladium.

Based on geologic mapping and geochemical surveys a probable mineral-resource potential is believed to exist in the Savage Run Wilderness for several metals: gold in the southwest, silver and copper in the northnortheast, and platinum-group elements and nickel in the south-southeast. The nature of the known occurrences suggests that large deposits are not to be expected.

\section{SUGGESTIONS FOR FURTHER STUDIES}

Little additional work in the veins in the wilderness seems warranted because of the limited amount of mineralized rock present. Additional study of areas in the mafic complex on Mullen Creek that exhibit anomalous platinum, palladium, and nickel is recommended to better evaluate the possibility of concentrations of these metals. More detailed geologic mapping should be conducted, and rock-chip samples should be collected and analyzed for tighter geochemical control. At least two magnetite-rich horizons are present in the sequence, and these should be traced by a magnetometer survey in order to better define the structure of the complex.

\section{REFERENCES}

Houston, R. S., and others, 1968, A regional study of rocks of Precambrian age in that part of the Medicine Bow Mountains lying in southeastern Wyoming, with a chapter on the relationship between Precambrian and Laramide structure: Wyoming Geological Survey Memoir 1, 167 p.

McCallum, M. E., and Kluender, S. E., in press, Mineral resource potential map of the Savage Run Wilderness, Albany and Carbon Counties, Wyoming: U.S. Geological Survey Miscellaneous Field Studies Map MF-1638-A.

U.S. Bureau of Mines, 1942, Rambler Mine, Albany County, Wyoming: War Minerals Report 17, $7 \mathrm{p}$.

U.S. Geological Survey, 1976, Aeromagnetic map of Keystone and vicinity, Wyoming: U.S. Geological Survey Open-File Report $76-687$, scale $1: 62,500$ 


\title{
SHEEP MOUNTAIN WILDERNESS STUDY AREA, WYOMING
}

\author{
By Robert S. Houston, U.S. GeOlogiCal SuRvey, and \\ Lowell L. Patten, U.S. Bureau of Mines
}

\begin{abstract}
SUMMARY
On the basis of a mineral survey completed in 1975 and 1976, the Sheep Mountain Wilderness study area, was determined to offer little promise for metallic mineral resources. There is a probable potential for oil and gas resources in a small part of the study area along its northeast margin.
\end{abstract}

\section{CHARACTER AND SETTING}

The Sheep Mountain Wilderness study area is a small mountain uplift of about $23 \mathrm{sq}$ mi area, located about 20 mi east of the main Medicine Bow Mountains of southern Wyoming. The Sheep Mountain uplift is isolated from the main mass of the Medicine Bow Mountains on three sides but is attached to the mountains at its southern extremity. Sheep Mountain rises abruptly from the Laramie Plains to the east from an altitude of about $7400 \mathrm{ft}$ at its eastern base to $9500 \mathrm{ft}$, the highest point. Sheep Mountain is flat-topped and although it stands above the surrounding areas, its relief is less abrupt on the south and west. Visitors to Sheep Mountain have spectacular views of the surrounding countryside; on clear days features over $100 \mathrm{mi}$ away are visible. Like many western mountains, Sheep Mountain is timbered, whereas surrounding plains are grasslands. Sheep Mountain is drained by a number of small streams that radiate from the mountain highland. The study area is readily accessible from a dirt road, the Fence Creek road, that crosses the southern boundary, and from Wyoming State Highways 130 and 11 on the north and west, respectively.

The greater part of the Sheep Mountain Wilderness study area consists of ancient (Precambrian) crystalline rocks which are more resistant to erosion than the sedimentary rocks that surround the mountain on the north, west, and east; this accounts, in part, for the relief discussed above. The crystalline core of Sheep Mountain consists of very old (about 1800 million years) volcanic and sedimentary rocks which have been folded and metamorphosed to gneisses during a geologic event that took place about 1700 million years ago. These metamorphosed volcanic and sedimentary rocks have been invaded by a variety of igneous rocks, the most important being a granite that underlies about threefourths of the crystalline core of the mountain, all but the northern and southernmost parts.

The northern, western, and eastern margins of Sheep Mountain are underlain by relatively young sedimentary rocks; the oldest being about 300 million years old. On the west flank of Sheep Mountain, these sedimentary rocks lie on the crystalline core and dip westward making a series of north-trending hogbacks that parallel the western margin. The eastern margin of Sheep Mountain is marked by a major fault that trends north parallel to the mountain front and dips about $45^{\circ}$ west. The mountain has moved from west to east on this fault bringing older crystalline core rocks over younger sedimentary rocks. The sedimentary rocks east of and beneath the fault have been folded and faulted in response to movement on this thrust fault.

The younger sedimentary rocks are primarily marine sediments deposited in shallow seas. The sedimentary succession is approximately $10,000 \mathrm{ft}$ thick and contains black shales that may be sources of oil and gas and sandstones that can act as reservoir rocks for oil and gas accumulations in structural or stratigraphic traps. Oil and gas is present in structural traps located north and east of Sheep Mountain.

The examination of the rocks of the Sheep Mountain Wilderness study area included both geophysical and geochemical surveys, but these surveys did not reveal areas favorable for metallic resources. There is no organized mining district in the Sheep Mountain area; and past activity has been limited to prospects and small shafts near the granite-metamorphic rock contact. 


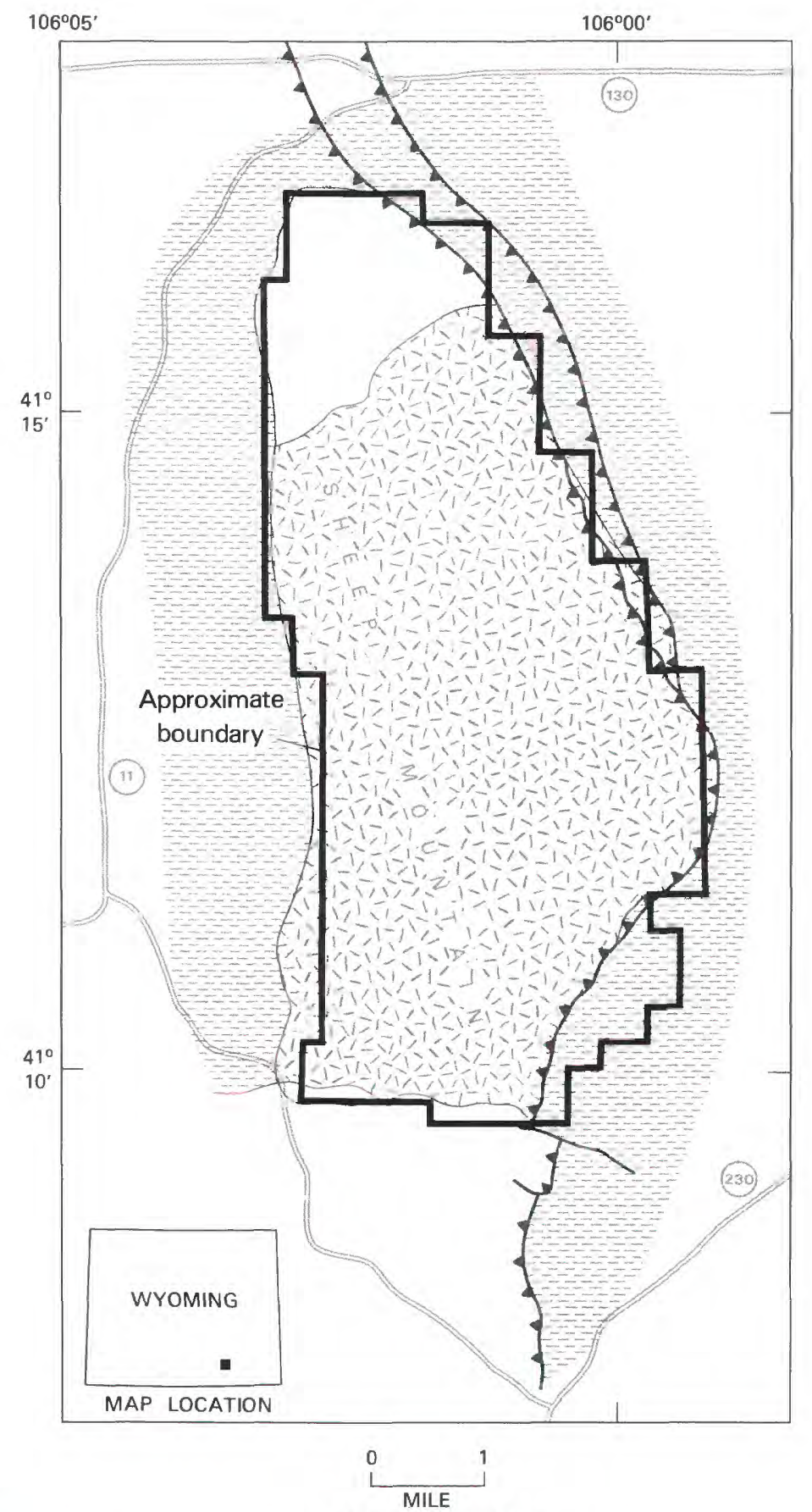

EXPLANATION

Geologic terrane with probable oil and gas resource potential

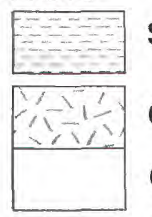

Sedimentary rocks (Paleozoic)

Granite (Early Proterozoic)

Gneiss (Early Proterozoic)

Contact

Thrust fault--Sawteeth

on upper plate

Figure 330.--Sheep Mountain Wilderness study area, Wyoming. 


\section{MINERAL RESOURCES}

The crystalline core of the Sheep Mountain Wilderness study area contains no known metallic or nonmetallic mineral resources. A geologic environment possibly favorable for mineralization would be near the contact between the younger granite and country rock (old metamorphosed volcanic and sedimentary rocks, now gneiss) and this is indeed the site of most of the prospects and workings. Most of these prospects explore small discontinuous quartz veinlets and skarns (impure marble) but none are large. The majority of these prospects were developed at the turn of the century and were probably explored for gold, but no significant gold values were detected during this study. Based on geologic reasoning, we suspect that the granite of Sheep Mountain is too deeply eroded to be the host of mineral deposits (Houston and others, 1983).

At the northeast margin of the Sheep Mountain Wilderness study area and largely outside of the wilderness study area, black sandstone occurs in a bed of sedimentary rocks. This black sand was formed on a beach during storms that took place about 100,000 years ago, and iron-, titanium- and zirconium-bearing minerals were concentrated by storm waves. Deposits of this type are mined in Australia and India and from time to time in Florida, but this study and earlier studies of this black sand deposit suggests that it is too small to constitute a resource (Houston and Murphy, 1962).

Oil and gas accumulations are present in anticlines north and east of Sheep Mountain (Glass and others, 1975). The Rex Lake oil field is located approximately 3.5 mi northeast of Sheep Mountain and the Big Hollow oil field about $7 \mathrm{mi}$ east of Sheep Mountain. Both of these fields produce petroleum and natural gas localized by the crests of anticlines. No stratigraphic traps have been found near Sheep Mountain, but it has been suggested that some traps that appear to be anticlinal are actually combined structural-stratigraphic traps (Stone, 1966).

In the Sheep Mountain Wilderness study area, there are probably only two types of petroleum and natural gas traps; a fault trap on the footwall of the main thrust on the northeast side of the area or an anticlinal trap developed either through crowding between thrusts or by some type of deformation under the thrust sheet. Study of limited outcrops of sedimentary rocks near the northeast border of the Sheep Mountain Wilderness study area suggest that a small anticline is present that may be a structural trap. Detailed evidence for this structure is given in Houston and others (1983) and the area is assessed as having a probable resource potential for oil and gas. There is not enough subsurface information to evaluate the potential for fault traps at this time.

An important consideration in exploration for oil and gas in faulted areas is the angle of inclination of the faults. Thrust faults that border uplifts like Sheep Mountain have been interpreted as steeply inclined by some geologists and gently inclined by others. Until recently, geophysical investigations such as deep seismic profiling necessary to define the angle of inclination of faults bounding Sheep Mountain-type uplifts, were not reported, but a seismic study of the fault system on the west flank of the Wind River uplift of northwestern Wyoming has shown that these faults have a dip of about $30^{\circ}$ and may extend to great depth (Smithson and others, 1979).

It is possible to measure the dip of thrust faults located on the southeastern margin of Sheep Mountain. These faults dip from $30^{\circ}$ to $45^{\circ}$ west. If low dips of this type extend to depth, an extensive section of sedimentary rocks might underlie Sheep Mountain, and the possibility of traps for oil and gas may exist.

\section{SUGGESTIONS FOR FURTHER STUDY}

It is unlikely that further study of the crystalline core of the Sheep Mountain Wilderness study area would identify hidden metallic mineral deposits. Geophysical studies, such as reflection seismic profiling would help define the oil and gas potential in fault-controlled structures, such as those beneath the thrust fault that crops out along the east flank of Sheep Mountain.

\section{REFERENCES}

Glass, G. B.; Wendell, W. G.; Root, F. H., and Breckenridge, R. M., 1975, Energy resources map of Wyoming: Wyoming Geological Survey.

Houston, R. S., and Murphy, J. F., 1962, Titaniferous black sandstone deposits of Wyoming: Wyoming Geological Survey Bulletin, 49, 120 p.

Houston, R. S, Patten, L. L., and Gersic, J., 1983, Mineral resources of the Sheep Mountain Wilderness study area, Albany County, Wyoming: U.S. Geological Survey Open-File Report 83-468.

Smithson, S. B., Brewer, J., Kaufman, S., Oliver, J., and Hurich, C., 1979, Nature of the Wind River thrust, Wyoming, from COCORP deep reflection data and gravity data: Geology, v. 6, p. 648-652.

Stone, D. S., 1966, Geologic and economic evaluation of the LaramieEastern Hanna Bassin area, Wyoming: Mountain Geologist, v. 3, p. 53-73. 

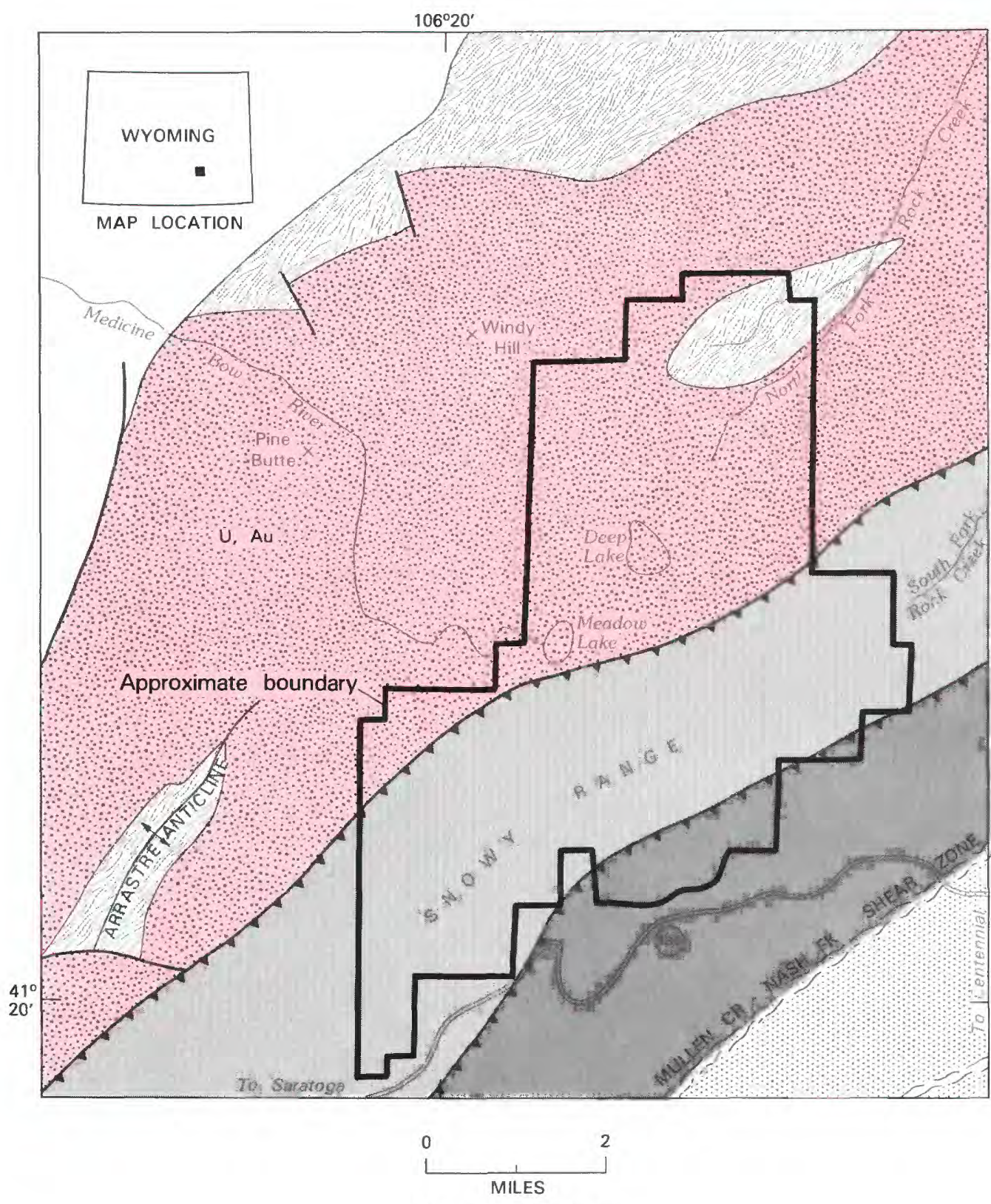

\section{EXPLANATION}

Geologic terrane with probable mineral-resource potential
Au Gold
u Uranium

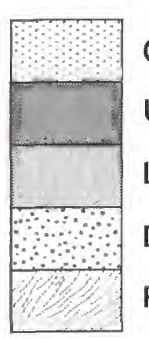

Gneisses (Proterozoic)

Upper Part Libby Creek Group (Proterozoic) Lower Part Libby Creek Group (Proterozoic)

Deep Lake Group (Proterozoic)

Phantom Lake Metamorphic Suite (Archean)

Contact

Fault

Thrust fault--Sawteeth on upper plate

Figure 331.-Snowy Range Wilderness, Wyoming. 


\title{
SNOWY RANGE WILDERNESS, WYOMING
}

\author{
By RoberT S. HOUSTON, ${ }^{1}$ U.S. GeOlOGICAL SURVEY, and \\ PhiliP R. Bigsby, U.S. BUREAU OF MiNES
}

\begin{abstract}
SUMMARY
A mineral survey of the Snowy Range Wilderness was undertaken by the USGS and USBM in 1976-78 and was followed up with more detailed geologic and geochemical surveys, culminating in diamond drilling of one hole in the Snowy Range Wilderness. No mineral deposits were identified in the Snowy Range Wilderness, but inasmuch as low-grade uranium and associated gold resources were identified in rocks similar to those of the northern Snowy Range Wilderness in an area about 5 mi northeast of the wilderness boundary, we conclude that the northern half of the wilderness has a probable-resource potential for uranium and gold. Closely spaced drilling would be required to completely evaluate this mineral potential. The geologic terrane precludes the occurrence of fossil fuels.
\end{abstract}

\section{CHARACTER AND SETTING}

The Snowy Range Wilderness is located at the crest of the central Medicine Bow Mountains of Wyoming at altitudes ranging from 10,000 to over $12,000 \mathrm{ft}$. The 53 sq $\mathrm{mi}$ area is readily accessible; the southern boundary is less than $1 \mathrm{mi}$ north of Wyoming State Highway 130. The area in general is a surface of modest relief, but it includes an escarpment at its southern border that rises abruptly from 10,600 to $12,000 \mathrm{ft}$. The escarpment is one of the most spectacular scenic areas in Wyoming and it results from differential erosion of resistant white quartzite and nonresistant gray schist. The Snowy Range Wilderness was glaciated and is characterized by numerous small lakes scattered within treeless alpine meadows.

The Snowy Range Wilderness and surrounding area has been investigated by geologic, geochemical, and mineral surveys by the USGS and USBM (Houston and others, 1983). Uranium resource potential of the region was further investigated by detailed geologic studies and diamond drilling sponsored by the U.S. Department of Energy (Borgman and others, 1981; Karlstrom and others, 1981a,b). The rocks of the wilderness consist of a thick succession over $30,000 \mathrm{ft}$ of Precambrian sedimentary rocks that have been folded and recrystallized during a geologic event that took place about 1700

${ }^{1}$ With contributions by K. E. Karlstrom, L. R. Lanthier, and W. R. Miller, USGS. million years ago. A major earth movement about 65 million years ago caused the general area of the Medicine Bow Mountains to rise well above sea level where continued erosion eventually exposed the ancient sedimentary rocks.

The lower succession (Deep Lake Group) of sedimentary rocks exposed in the northern half of the wilderness has beds of river gravels containing pebbles of quartz and other minerals where it lies on older rocks. This succession is overlain by sedimentary rocks (Libby Creek Group) deposited in ancient seas, perhaps along the margin of a continent somewhat like the Atlantic coast of today.

The sedimentary succession has been telescoped by movement on great faults that have brought rocks deposited well southeast of the present wilderness to this location. Some of these faults have been filled with basalt to form dikes and sills like the Palisades Sill of New Jersey.

\section{MINERAL RESOURCES}

The wilderness, and especially its northern part, is a particularly promising area for mineral exploration because of the presence of river gravels at the base of the lower succession of sedimentary rocks. This type of river gravel, known as quartz pebble conglomerate, has been formed many times during the Earth's past and is 
forming today, but geologic conditions were especially favorable for its formation from about 2500 million years ago to about 2000 million years ago. Quartz pebble conglomerate of this age is found in all parts of the world and two of the world's most important mineral deposits are in this type of conglomerate: the Witwatersrand gold-uranium deposits of South Africa and the uranium deposits of the Blind River area of Canada. In fact the quartz pebble conglomerate of the Snowy Range area (Deep Lake Group) strongly resembles the uranium-bearing conglomerate of Canada.

In South Africa, Canada, and elsewhere the minerals of economic interest in quartz pebble conglomerates are gold and uraninite $\left(\mathrm{U}_{3} \mathrm{O}_{8}\right)$ which were weathered from nearby highlands, transported, and deposited in ancient stream and river systems. For reasons still debated by geologists, no major uranium- and gold-bearing conglomerates are younger than 2000 million years. Geochemists of the USGS, using dating methods based on the decay of radioactive elements in minerals, determined that the lower succession of sedimentary rocks of the Snowy Range were deposited between 2700 million and 2000 million years (Hedge, in Karlstrom and others, 1981a). Thus the Snowy Range Wilderness contains conglomerates of the proper geologic setting and age to be of interest.

The quartz pebble conglomerate which underlies the northern half of the Snowy Range Wilderness is not everywhere exposed on the surface. There are modest exposures in the northern part of the Snowy Range Wilderness (North Fork Rock Creek) and larger areas of exposure in the Arrastre anticline area west of the Snowy Range, and on Threemile and Onemile Creeks, 3 to $5 \mathrm{mi}$ northeast of the Snowy Range Wilderness. All of these exposures proved to be radioactive, suggesting that radioactive minerals such as uraninite were present in the conglomerate. Geochemical exploration using radon in water indicated the presence of uranium mineralization at depth in both the Arrastre anticline and northern Snowy Range Wilderness. This was very encouraging and resulted in detailed geologic mapping, geochemical sampling, and diamond drilling (Karlstrom and others, 1981a, b; Borgman and others, 1981). The result of this extended effort, which lasted from about 1977 through 1981, was the discovery of low-grade uranium resources in conglomerate of the Onemile Creek area of the Medicine Bow Mountains and of thorium resources in conglomerate of the Sierra Madre (Karlstrom and others, 1981a). No significant gold resources were found in the Snowy Range or Medicine Bow Mountains, but modest gold values were reported in the Sierra Madre (Karlstrom and others, 1981a). No uranium or gold resources were found in the Snowy Range Wilderness or in the Arrastre anticline area, but the conglomerate of the Arrastre anticline was tested by only two drill holes and the conglomerate of the Snowy Range Wilderness was tested by only one drill hole. On the basis of all available information the Deep Lake Group in the Snowy Range Wilderness and adjacent areas constitute a terrane with probable resource potenital, for uranium and gold.

No other types of mineral resources were identified in the Snowy Range Wilderness and adjacent areas in this study. Uranium was detected in discontinuous veintype occurrences in faults and igneous rocks at the southern margin of the wilderness, but it was not considered as having resource potential.

\section{SUGGESTIONS FOR FURTHER STUDIES}

Additional geologic mapping and geochemical sampling in the Snowy Range Wilderness is not warranted. However, drilling programs undertaken in the northern half of the Snowy Range Wilderness and Arrastre anticline area were inadequate to test the quartz pebble conglomerate, and if there is a critical need for uranium in the future, closely spaced drilling will be required in both areas to evaluate the potential.

\section{REFERENCES}

Borgman, L. E., Sever, C. K., Quimby, W. F., Angrew, M. E., Houston, R. S., and Karlstrom, K. E., 1981, Uranium assessment for the Precambrian pebble conglomerates in southeastern Wyoming: Grand Junction, Colorado, U.S. Department of Energy, Report GJBX-139-81, Vol. 3, 159 p.

Houston, R. S., Karlstrom, K. E., Lanthier, L. R., Miller, W. R., and Bigsby, P. R., 1983, Mineral resource potential map of the Snowy Range Wilderness study area, Albany and Carbon Counties, Wyoming: U.S. Geological Survey Miscellaneous Field Studies Map MF-1596-A, scale 1:50,000.

Karlstrom, K. E., Houston, R. S., Flurkey, A. J., Coolidge, C. M., Kratochvil, A. L., and Sever, C. K., 1981a, A summary of geology and uranium potential of Precambrian conglomerates in south eastern Wyoming: Grand Junction, Colorado, U.S. Department of Energy, Report GJBX-139-81, Vol. 1,541 p.

Karlstrom, K. E., Houston, R. S., Schmidt, T. G, Inlow, David, Flurkey, A. S., Kratochvil, A. L, Coolidge, C. M., Sever, C. K. and Quimby, W. F., 1981b, Drill-hole data, drill-site geology, and geochemical data from the study of Precambrian uraniferous conglomerates of the Medicine Bow Mountains and the Sierra Madre of southeastern Wyoming: Grand Junction, Colorado, U.S. Department of Energy, Report GJBX-139-81, Vol. 2,682 p. 


\title{
STRATIFIED PRIMITIVE AREA, WYOMING
}

\author{
By C. S. Bromfield, U.S. Geological Survey, and \\ R. G. RAabe, U.S. Bureau OF Mines
}

\begin{abstract}
SUMMARY
A geologic and mineral survey of the Stratified Primitive Area in northwestern Wyoming was completed in 1965 . The mineral-resource potential was evaluated by geologic and geochemical studies and by examination of mining claims. On the basis of this study, a small area along the northeastern boundary of the area, adjacent to the Kirwin mining district, has probable resource potential for base and precious metals. No potential was identified in the primitive area for nonmetallic minerals, hydrocarbons, or coal.
\end{abstract}

\section{CHARACTER AND SETTING}

The Stratified Primitive Area, now a part of the Washakie Wilderness, consists of about $250 \mathrm{sq}$ mi along the south edge of the Absaroka Mountains, about $20 \mathrm{mi}$ southeast of Yellowstone Park. The area is characterized by extremely rugged topography, with altitudes ranging from 8000 to $12,000 \mathrm{ft}$. The area may be reached over gravel and unimproved roads from Meeteetse, $33 \mathrm{mi}$ to the northeast, and Du Bois, $28 \mathrm{mi}$ to the south.

The southern Absaroka Mountains contain two contrasting rock sequences. The older sequence is composed of rocks of Precambrian, Paleozoic, and Mesozoic age, which were folded and dissected at the end of the Cretaceous, 70 million years ago. The older rocks are exposed only in two small areas in the deeper valleys along the south boundary of the area where they consist of Paleozoic sandstone, limestone, and shale. A large uplifted block of Paleozoic rock is exposed near the north boundary of the area, southwest of the Kirwin district. The younger and more widespread sequence of rocks consists of generally flat lying to gently arched volcanic rocks and volcanic sandstones and conglomerates of Tertiary age; they form a thick blanket over an uneven erosion surface carved on the older rocks. Magma intruded the mid-Tertiary and older rocks and formed small stocks and dikes of intermediate to silicic composition. A few thin remnants of late Tertiary basalt flows and Quaternary ash beds are found.

\section{MINERAL RESOURCES}

On the basis of an anomalous geochemical sample, the presence of small intrusions and minor alteration, and proximity to the Kirwin district, an area totalling about $10 \mathrm{sq}$ mi along the north border of the primitive area has a probable resource potential for lead, zinc, copper, silver, and molybdenum. Although no significant metallic resources have been discovered in the southern $\mathrm{Ab}$ saroka Mountains in over 80 years of prospecting, a single small shipment of base and precious metal ore is reported prior to 1900 from the Kirwin district. The district, which borders the Stratified Primitive Area on the northwest, contains minor copper, lead, zinc, silver, and gold mineralization in narrow veins as scattered bunches or small ore shoots that trend southerly in the study area. At least 49 patented claims lie wholly or partly in the primitive area. More recently the Kirwin district was partially explored by diamond drilling for disseminated molybdenite.

Bedded deposits of nonmetallic minerals such as coal, bentonite, and phosphate occur in Paleozoic and Mesozoic formations that are exposed around the east and south edges of the Stratified Primitive Area. Because deposits of this type are rather widespread and common, it is possible that some underlie the primitive area. The coal, which is found in Cretaceous strata in nearby areas, is of rather low quality. Phosphorite, where it crops out south of the primitive area, is thin. The cover of Tertiary rocks, which is $4000 \mathrm{ft}$ thick in some parts of the area, prevents direct observation, and would make exploration for such common deposits unlikely.

Folded Paleozic and Mesozoic formations which contain structural traps that have produced oil and gas elsewhere in Wyoming extend under the primitive area. Although the possibility for oil and gas may exist, data from this study are insufficient to evaluate the oil and gas potential of the primitive area. 

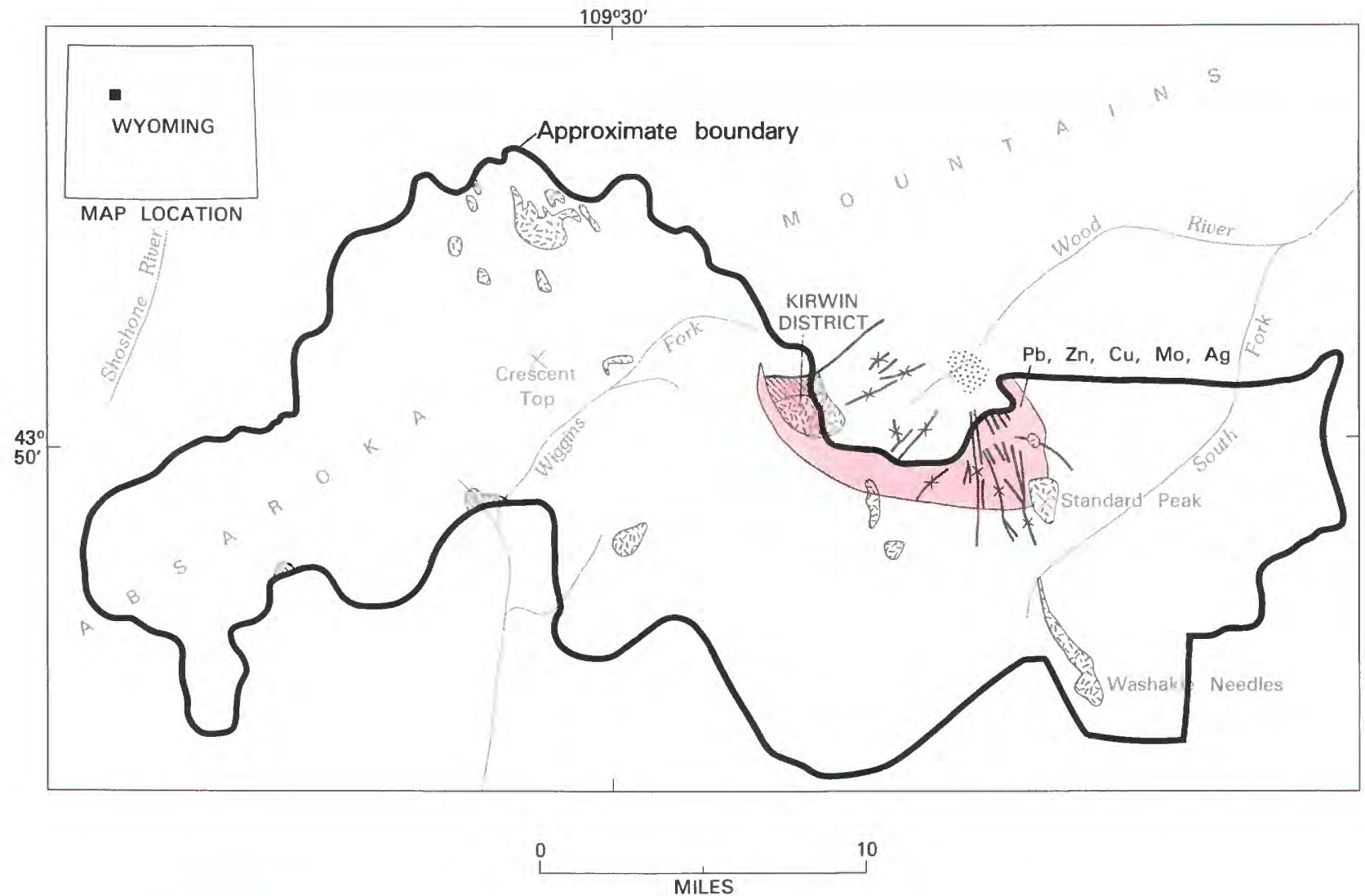

EXPLANATION

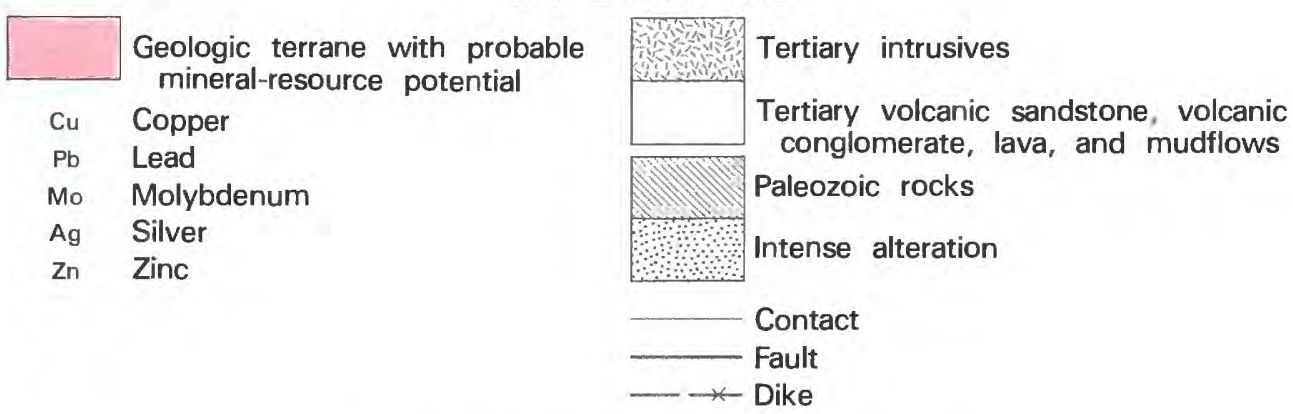

Figure 332.-Stratified Primitive Area, Wyoming. 


\section{REFERENCE}

Ketner, K. B., Keefer, W. R., Fisher, F. S., Smith, D. L., and Raabe, R. G., 1966, Mineral resources of the Stratified Primitive Area, Wyoming: U.S. Geological Survey Bulletin 1230-E, 56 p. 


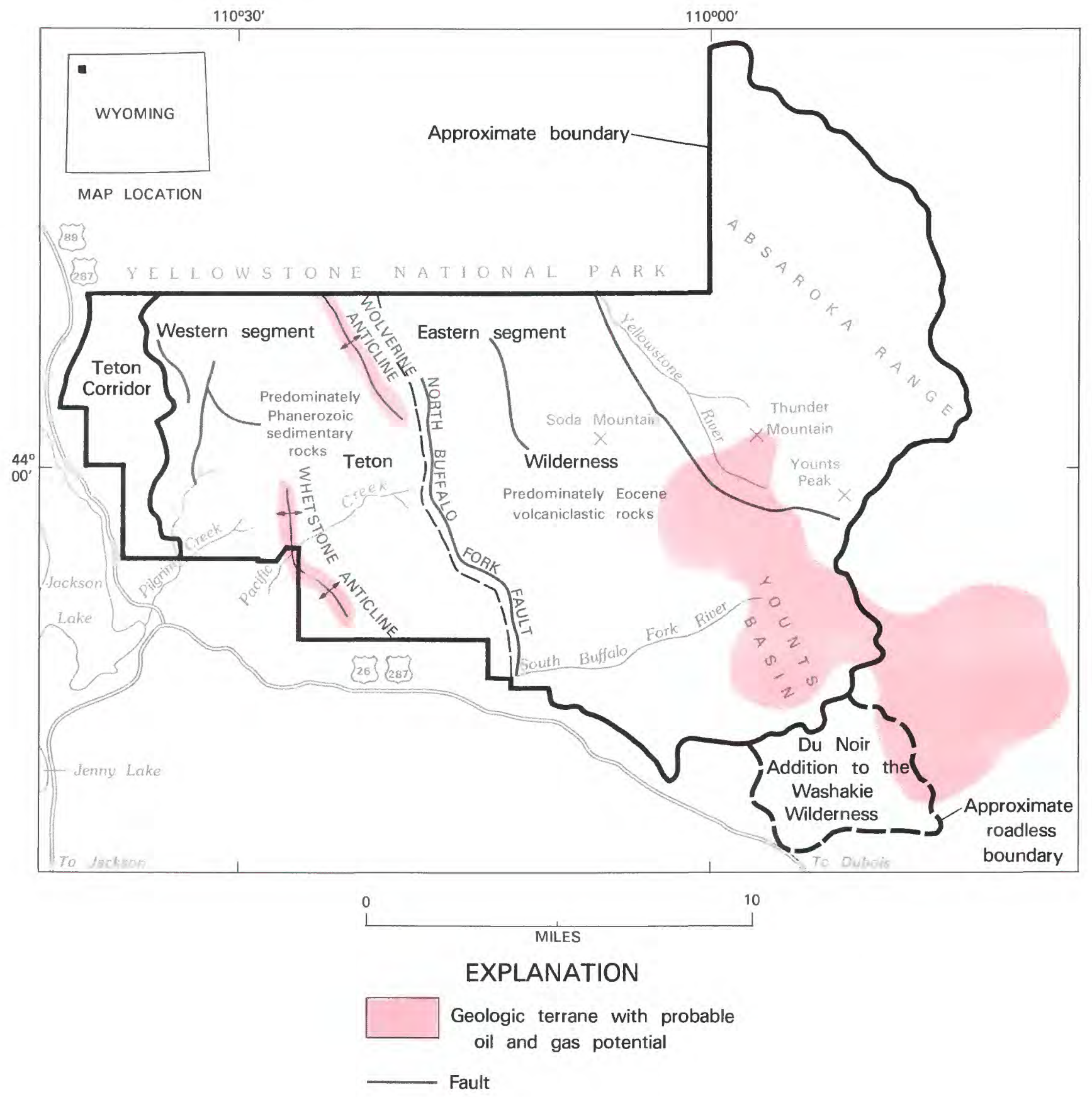

Figure 333.-Teton Wilderness, Teton Corridor, and Du Noir Addition to Washakie Wilderness, Wyoming. 


\title{
TETON WILDERNESS, TETON CORRIDOR, AND DU NOIR ADDITION TO WASHAKIE WILDERNESS, WYOMING
}

\author{
By J. C. Antweiler, ${ }^{1}$ U.S. Geological Survey, and \\ F. E. Williams, U.S. BUREAU OF Mines
}

\begin{abstract}
SUMMARY
Field investigations were conducted during the summers of 1972,1973 , and 1974 by the USGS and the USBM to evaluate the mineral-resource potential of the Teton Wilderness, the Teton Corridor, and the Du Noir Addition to the Washakie Wilderness. As a result of this study it was determined that there is little promise for the occurrence of metallic mineral resources, but there is probable potential for oil and gas resources in two anticlines in the western part of the Teton Wilderness and in the postulated Younts Basin in the eastern part of the wilderness and the eastern part of the Du Noir Addition. The Whetstone anticline is the largest.
\end{abstract}

\section{CHARACTER AND SETTING}

The Teton Wilderness consists of $880 \mathrm{sq} \mathrm{mi}$ in Teton, Fremont, and Park Counties, Wyoming. It lies directly south and southeast of Yellowstone National Park, and east of the Teton Corridor and Grand Teton National Park. The Teton Corridor, directly west of the wilderness, consists of $44 \mathrm{sq} \mathrm{mi}$ in Teton County, Wyoming. Both are entirely within the Teton-Bridger National Forest. The Du Noir Addition to the Washakie Wilderness, contiguous with the southeastern boundary of the Teton Wilderness, consists of $53.5 \mathrm{sq} \mathrm{mi}$, and lies within the Shoshone National Forest. The three areas are mountainous, with maximum relief of more than 5000 ft. U.S. Highway 26-287 skirts the southern margin. There are no roads within the wilderness and the two contiguous study areas. Except for one small gold placer mine, there has been no exploitation of minerals.

The rocks in the Teton Wilderness and contiguous study areas consist of a variety of crystalline, sedimentary, and igneous rocks ranging in age from Precambrian to Quaternary, but they are predominantly sedimentary in nature. The wilderness comprises two very different geologic segments. The eastern segment and the Du Noir Addition consist of great thicknesses of stratified volcanogenic rocks of Eocene age that originated mainly from volcanic centers outside the wilderness. The western segment of the wilderness and

${ }^{1}$ With contributions from J. D. Love, H. J. Prostka, D. M. Kulik, and L. A. Anderson, USGS, and J. E. Jinks, C. L. Bieniewski, and T. D. Light, USBM.
Teton Corridor consist chiefly of Mesozoic sedimentary rocks folded into northwest-trending anticlines that were subsequently overlapped by middle and upper Cenozoic rocks. These were then tilted westward and faulted in late Cenozoic time.

All but the highest parts of the Teton Wilderness were glaciated one or more times, and as a result, bedrock is, in places, covered with extensive deposits of glacial debris, especially along the major drainage systems. Meltwater saturated thick sequences of plastic shale and caused enormous landslides that further obscure the bedrock.

In the eastern segment, the Eocene volcanoclastic rocks that comprise the Absaroka Range buried the Precambrian and Paleozoic core of the Washakie Range of Laramide age. Subsequent erosion has exposed some of that range. The exposed Precambrian rocks are gneisses and schists, and the Paleozoic rocks are of marine sedimentary origin.

Because the Teton Wilderness and the contiguous study areas are underlain mainly by various kinds of sedimentary rocks, mineral resources are most likely to be associated with processes involving sedimentation rather than igneous activity. Although a slight possibility exists for other types of ore deposits, this investigation has shown that mineral commodities most likely to be found are oil and gas, gold in placers related to conglomerates deposited in Laramide time, phosphate, metals in black shales, coal, gypsum, building stone, sand, and gravel.

Major tectonic movements have involved even the 
youngest rocks. These tectonic movements are of two very different types, separated by about 65 million years of geologic time. During the first episode, near the end of Cretaceous time, a series of northwest-trending anticlines and synclines, broken and overriden in places by thrust or reverse faults, developed in Cretaceous and underlying rocks. In addition, along the northwest border of the Teton Wilderness, and extending into it for several miles is the southern flank of the Basin Creek uplift, a major upfold that developed in Late Cretaceous time, largely in southern Yellowstone National Park.

During the second tectonic event, about two million years ago, two episodes of igneous activity occurred, one involving the northern and western parts of the Teton Wilderness, and the other the north-central part. Rhyolitic tuffs, later welded, flowed southward, downhill, from one or more hugh calderas in Yellowstone National Park, completely across the western margin of the Teton Wilderness, partially burying some of the older anticlines and conglomerate beds. The other igenous event was the intrusion of pyroxene andesite and basalt along the one major thrust fault (later reactivated by normal faulting) in the north-central part of the Teton Wilderness. After emplacement of these igneous rocks, the western part of the Teton Wilderness was tilted westward and downward several thousand feet. During and perhaps following the westward tilting, the welded tuff and underlying rocks were broken by a series of northwest-trending normal faults which have a few tens to a few hundreds of feet displacement.

The USGS collected bedrock, stream-sediment, and panned concentrate samples derived from stream sediments and bedrocks for chemical and spectrographic analyses. Nearly all samples were analyzed for gold, mercury, and cold extractable heavy metals, and a few were analyzed for platinum. Standard coal analyses were made on coal samples collected from various parts of the area. Samples from the Permian Phosphoria Formation were analyzed for phosphate and uranium. Delayed neutron activation analyses for uranium and thorium were made on about one-fifth of the samples selected on a random basis. Samples of black shale of Mississippian age collected at the base of the Amsden Formation of Mississippian and Pennsylvanian age, and from lake beds in the Aycross(?) Formation of Eocene age were analyzed for organic content and trace metals.

The USBM searched County, State, and Federal records for information on mining claims, mineral leases, mineral occurrences, and mineral production, and conducted field work that included looking for evidence of mineral deposits and signs of activities related to mineral exploitation. The USBM also took samples of Quaternary gravels to evaluate their gold content, and examined prospects on the South Buffalo Fork River, and the placering operation by Mr. Frank Allen on unpatented mining claims on Pacific Creek.

\section{MINERAL RESOURCES}

There are no currently active mines that produce metallic or nonmetallic minerals from the rock units cropping out in the Teton Wilderness and the contiguous study areas. Two copper mines operated during the early 1900's near the southeast margin of the area and gold placer prospects have been worked from time to time along major drainages in the southwestern part.

Gold in significant quantities was found in alluvial deposits along several major streams that drain goldbearing conglomerates in the Upper Cretaceous Harebell Formation and Upper Cretaceous and Paleocene Pinyon Conglomerate. The USBM collected streamsediment samples within the wilderness for the economic appraisal of gold resources. The gold content of these samples ranged from not detected to $0.007 \mathrm{oz}$ gold/cu yd. Of those samples, 44 assayed $0.0004 \mathrm{oz}$ gold or more/cu yd, and averaged $(0.0014 \mathrm{oz} / \mathrm{cu}$ yd. Assuming a market price of $\$ 450 /$ troy oz for gold and a fineness of 950 for the flour gold, the $0.0014 \mathrm{oz}$ would be worth 60 cents/cu yd. The USBM also collected samples of bank gravels in the vicinity where those 44 samples with the highest values were obtained. Gold values obtained ranged from $0.00001 \mathrm{oz} / \mathrm{cu}$ yd to $0.002 \mathrm{oz}$ gold/cu yd. The highest value for 3 vertical feet occurred where the gravel from 4-7 ft beneath the surface averaged 0.001 oz gold/cu yd. At $\$ 450$ per troy ounce and 950 fine, the $0.001 \mathrm{oz}$ gold would be worth 43 cents.

Although flour gold is consistently present in the Quaternary gravels and in the parent Harebell Formation and Pinyon Conglomerate, the distribution of the gold and the values obtained do not warrant classifying these areas as having gold resources.

Copper prospects are present on the South Buffalo Fork River. Mineral values found in two small adits driven by early prospectors in Precambrian crystalline rocks showing malachite and chalcopyrite are not sufficient to assess the area as having copper resources.

Except for gold in the conglomerates and associated alluvium, and copper prospects in the Precambrian rocks, no indication of metallic mineralization was observed in the Teton Wilderness or in the contiguous study areas.

A portion of the Jackson Hole coalfield lies within the Teton Wilderness. Although coal beds occur at several localities in the Cretaceous Meeteetse and Mesaverde Formations, in the Sohare sequence, Bacon Ridge Sandstone, and Frontier Formation, they are generally thin 
and are not classified as coal resources. An unknown amount of coal was produced about 1910 by the U.S. Bureau of Reclamation from a mine on Pilgrim Creek which is now within the wilderness.

An aeromagnetic survey was made by the USGS in 1967 and a gravity survey in 1974 . These aeromagnetic and gravity studies showed several geophysical anomalies. Aeromagnetic positive anomalies (highs) in the vicinity of Thunder Mountain and Younts Peak appear to be related to granodiorite intrusions that are exposed at the surface in only very small outcrops. Another positive magnetic anomaly that may be related to a basic intrusion without surface expression occurs on Soda Mountain. Two anomalies with negative polarity located near the headwaters of the Yellowstone River may be related to silicic intrusions that also do not have surface expression. Major gravity low anomalies are associated with the intrusive granodiorite bodies on Thunder Mountain and Younts Peak. A gravity anomaly also occurs near the headwaters of the Yellowstone River, and coincides with the aeromagentic low there. Interpretations of the gravity data infer that thick sections of Cretaceous strata, including source and reservoir rocks which produce hydrocarbons in other areas of Wyoming are present in the Box Creek downwarp in the western segment of the Teton Wilderness and the eastern part of the Du Noir Addition in a postulated basin (Younts Basin?) in the eastern segment. The Younts Basin(?) has a probable potential for oil and gas resources.

Anticlines, fault trap structures, and stratigraphic traps occur in the western segment of the wilderness and could contain oil and gas resources. Most of the anticlines and fault trap structures have at least seven possible producing horizons within a depth range of $1000-10,000 \mathrm{ft}$. The Whetstone anticline in the southwestern part of the area and the Wolverine anticline in the north-central part of the area are the largest of these and have probable potential for oil and gas resources.

Bentonite, gypsum, pumicite, phosphate, glauconite, building stone, and sand and gravel deposits are present in the wilderness, but are remote and low grade compared to other deposits that are more accessible, of higher grade, or nearer to markets.

\section{SUGGESTIONS FOR FURTHER STUDIES}

If oil and gas are produced from anticlines southeast of the Teton Wilderness, the potential should be evaluated in more detail for those within the wilderness. Also, if gold is produced from placer deposits near the wilderness, placer deposits within the wilderness might warrant further studies.

\section{REFERENCES}

Antweiler, J. C., Love, J. D., Prostka, H. J., Williams, F. E., Jinks, J. E., and Light, T. D., 1983, Preliminary report on mineral resource potential of the Teton Wilderness, Teton, Fremont, and Park Counties, Wyoming: U.S. Geological Survey Open-File Report 83-470.

Love, J. D., Antweiler, J. C., and Williams, F. E., 1975, Mineral resources of the Teton Corridor, Teton County, Wyoming: U.S. Geological Survey Bulletin 1397-A, 51 p.

Prostka, H. J., Antweiler, J. C., and Bieniewski, C. L., 1979, Mineral resources of the Du Noir Addition, Washakie Wilderness, Fremont County, Wyoming: U.S. Geological Survey Bulletin 1472, $35 \mathrm{p}$. 


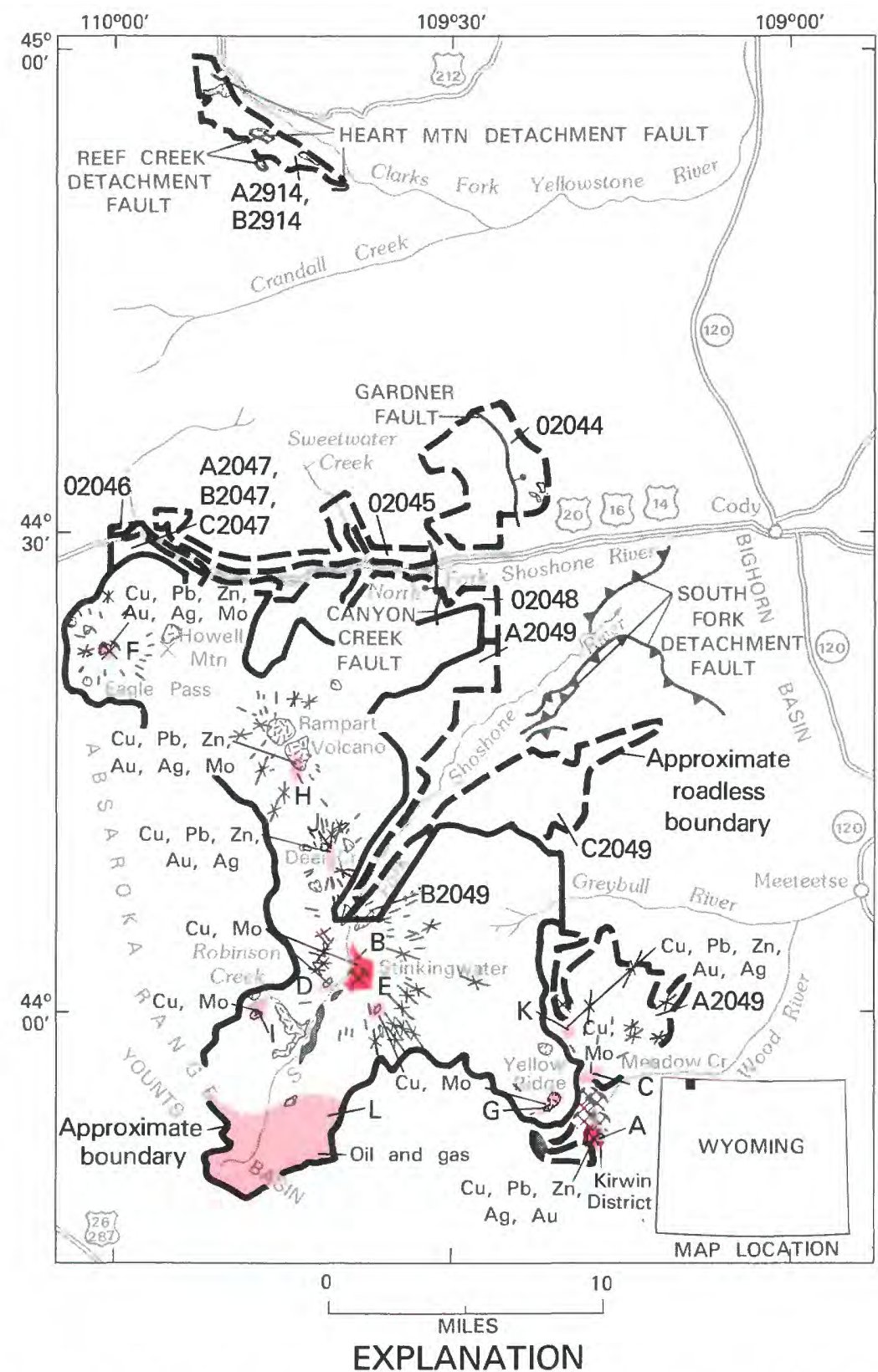

Geologic terrane with substantiated mineral-resource potential

Quaternary surficial deposits and stratified rocks of the Eocene Absaroka Volcanic Supergroup

Geologic terrane with probable mineral-resource potential

Paleozoic rocks

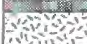

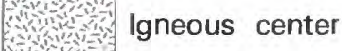

$\begin{array}{llll}\mathrm{Cu} & \text { Copper } & \text { Mo } & \text { Molybdenum } \\ \mathrm{Au} & \text { Gold } & \mathrm{Ag} & \text { Silver } \\ \mathrm{Pb} & \text { Lead } & \mathrm{Zn} & \text { Zinc } \\ \mathrm{A} & \text { Mine } & & \end{array}$

Figure 334.-Northern part of the Washakie Wilderness and nearby roadless areas, Wyoming. 


\title{
NORTHERN PART OF THE WASHAKIE WILDERNESS AND NEARBY ROADLESS AREAS, WYOMING
}

\author{
By JOHN C. ANTWEILER, ${ }^{1}$ U.S. GEOLOGICAL SURVEY, and \\ CARL L. Bieniewski, U.S. BureaU OF MineS
}

\begin{abstract}
SUMMARY
The northern part of the Washakie Wilderness and nearby roadless areas, Wyoming were found to contain areas with probable and substantiated resource potential for base and precious metals, and probable resource potential for natural gas and oil on the basis of a mineral survey conducted by the USGS and USBM in 1975-77. Geologic and geochemical evidence was found in many of the areas indicating copper-molybdenum porphyry systems, with associated veins of base and precious metals. Resources of oil and gas may exist in the sedimentary rocks that lie below the volcaniclastic rocks that cover nearly all of the wilderness, except for areas in the vicinity of the intrusive igneous centers. Data to distinguish favorable areas from those lacking favorable structures are not presently available. Based on gravity studies, the Younts Basin in the southwest corner of the area has a probable oil and gas resource potential.
\end{abstract}

\section{CHARACTER AND SETTING}

The Washakie Wilderness consists of about 1226 sq mi, of which $756 \mathrm{sq} \mathrm{mi}$ is the former South Absaroka Wilderness, originally established by the USFS in 1932. The South Absaroka Wilderness was combined with the Stratified Primitive Area in 1972 and the combined area was named the Washakie Wilderness. This report describes the area of the former South Absaroka Wilderness, referred to here as the northern part of the Washakie Wilderness. It also describes nearby roadless areas adjacent to the North Absaroka Wilderness and the former South Absaroka Wilderness as follows: Reef (2914 A, B) $26.2 \mathrm{sq} \mathrm{mi}$; Trout Creek (2044) $54.8 \mathrm{sq} \mathrm{mi}$; Wapiti Valley North (2045) 30.4 sq mi; Wapiti Valley East (2046) $0.8 \mathrm{sq} \mathrm{mi}$; Sleeping Giant (2047 A, B, C) 9.2 sq mi; Wapiti Valley South (2048) $66.5 \mathrm{sq} \mathrm{mi}$; South Fork (2049 A, B, C) 118 sq mi; and Francs Peak (2051) $103 \mathrm{sq} \mathrm{mi}$ ). The lands studied are east and southeast of Yellowstone National Park and west of the Bighorn Basin. Cody and Meeteetse, Wyoming, the nearest towns, are about $20 \mathrm{mi}$ east of the area, and Cooke City, Montana, is about $5 \mathrm{mi}$ north of the Reef study area. U.S. Highway 14-16-20 (one road) follows the North

\footnotetext{
${ }^{1}$ With contributions by D. W. Rankin, F. S. Fisher, C. W. Long, and J. D. Love, USGS, and C. S. Smith, USBM
}

Fork Shoshone River from Cody west to the East Entrance of Yellowstone National Park, and roughly marks the dividing line between the North Absaroka Wilderness and the Washakie Wilderness. The lands studied are in rugged mountainous terrain in the Absaroka Mountains, and all lie within the nation's first national forest, the Shoshone. The total relief is more than $7000 \mathrm{ft}$, and local relief along some of the canyons is as much as $6000 \mathrm{ft}$. Francs Peak, 13,153 ft in altitude, the highest mountain in the Absaroka Range, is in the southeastern part of the study area. Much of the area is underlain by relatively flat lying stratified rocks. Deep dissection of the layered sequence and subsequent glaciation of the peaks and valleys has created a topography of horns, cirques, and aretes as well as high rolling plateaus, benches, and steep-walled canyons.

Nearly all the exposed rocks had their source in volcanoes that erupted over a 5-million year span some 45 million years ago (Eocene Epoch). As much as $10,000 \mathrm{ft}$ of nearly flat lying stratified rocks, predominantly andesitic in composition, rest on terranes that were presumably mostly made up of sedimentary rocks. Collectively, the volcanic rocks are known as the Absaroka Volcanic Supergroup. This vast volcanic field is composed of coalescing stratovolcanoes, lava flows, breccias, flow breccias, mudflows, avalanche debris, and tuffs. The volcanic vents are the loci of many intrusive 
rock bodies, some of which were accompanied by mineralization. Dike swarms are abundant in most of the vent and intrusive centers, and occur in nearly all parts of the area except on Carter Mountain. Erosion subsequent to the cessation of volcanic activity has cut deeply into the volcanic pile, cutting steep-sided canyons and exposing in places some of the intrusive rocks. The volcanic rocks were deposited on a sequence of sedimentary rocks, that, based upon regional studies includes older Cenozoic, Mesozoic, and Paleozoic rocks, which, in turn are underlain by Precambrian crystalline rocks (as much as 2.6 billion years old).

The sedimentary rocks under the Absaroka Volcanic Supergroup are of particular interest because they are very likely similar to those that have produced oil and gas from favorable structures in the Bighorn Basin east of the volcanic field. Roof pendants consisting of blocks of Paleozoic rocks were pushed up near the headwaters of Wood River in the southern part of the area, and along the South Fork Shoshone River. Paleozoic rocks crop out also in the northern and northeastern part of the area, and in a narrow belt near the Reef study area. Mesozoic sedimentary rocks presumably occur in the subsurface beneath most of the volcanic rocks, but they are exposed in only a few small areas. Paleocene and Eocene rocks also presumably underlie the volcanic cover, but are exposed only along the eastern edge of the study area and in the deep valleys of the North and South Forks of the Shoshone River and the Greybull River.

The close of the Mesozoic Era, and the beginning of the Cenozoic Era was characterized by major tectonic movements that lasted several million years and are collectively termed the Laramide orogeny. Most of the structural features in the region date from the Laramide orogeny or are younger. Laramide structures in this region trend northwest. Precambrian and Mesozoic rocks southwest of the study area were deformed by a series of northwest-trending folds and faults (both nor$\mathrm{mal}$ and reverse) and were deeply eroded prior to the onset of Absaroka volcanism. Major uplift of the Beartooth Plateau north and northwest of the area began at this time. The Bighorn Basin to the east subsided and many of the anticlines which have been productive of oil and gas were formed. During the waning stages of the orogeny, several low-angle detachment faults developed. Deformation of parts of the study area continued after outpouring of the volcanic rocks. The Canyon Creek fault downdropped part of the volcanic field more than $1000 \mathrm{ft}$ near Canyon Creek.

\section{MINERAL RESOURCES}

The mineral-resource survey included geologic mapping, studies of past mining activity, geochemical sam1174 pling, geophysical studies (aeromagnetic and gravity surveys), and interpretation of all available information pertaining to possibilities for the occurrence of oil and gas. Several mineralized areas in or near the study area were known prior to the mineral-resource investigations of the USGS and the USBM and our studies have contributed new information, particularly in a regional sense, to those areas. Several unknown mineralized areas were identified as a result of the studies. In addition geologic mapping, clustered geochemical anomalies, or geophysical anomalies suggest other areas that may warrant further study.

The Kirwin district in an area of substantiated mineral-resource potential (area A, on map), outside but adjacent to the Francs Peak study area contains a porphyry-type orebody estimated to contain inferred resources of 70,000,000 tons of ore averaging 0.75 percent copper; other base and precious metals accompany the copper. The Kirwin district was vigorously prospected from about 1890 to 1915 , but its production of metals was small, and it was inactive until the 1960's when Amax Corporation commenced a drilling program that culminated in delineation of a large orebody. The Stinkingwater mining region is an area of substantiated mineral-resource potential (area B) within the Washakie Wilderness and was also prospected as early as 1895 , but has had no recorded production. Major companies became interested in the area in 1962, and conducted exploration activities including diamond-drill holes that resulted in outlining a low-grade copper-molybdenum porphyry deposit containing many millions of tons of demonstrated resources as of 1983 .

The Meadow Creek area (C), in the Francs Peak study area, has probable resource potential for copper and molybdenum in porphyry-type deposits. The area was prospected in the 1890's, and several small prospect pits and adits dating from that time can be found in Meadow Creek Basin. Two diamond-drill holes by Exxon Corporation in 1976-77 reportedly encountered low-grade copper mineralization at depth. The Silver Creek area (D), which is entirely within the Washakie Wilderness has probable resource potential for copper and molybdenum in a porphyry-type deposit. The Lost Ranger Top area (Birthday Basin) (E), south of the Stinkingwater region, and entirely within the Washakie Wilderness, also has probable resource potential for copper and molybdenum in a porphyry-type environment. Claims were located as early as 1911 in the Eagle Creek mineralized area (F) which is entirely within the Washakie Wilderness. The area has a probable resource potential for base and precious metals in quartz veins and also copper and molybdenum in a porphyry-type setting. A probable resource potential for copper and molybdenum in porphyry-type deposits also occurs at Yellow Ridge (G), Clouds Home Peak (H), and Robinson 
Creek (I) within the wilderness; Clouds Home Peak also has a probable resource potential for other base and precious metals. The Deer Creek area $(\mathrm{J})$ within the wilderness, and the Gold Reef area $(\mathrm{K})$ in the Francs Peak study area have probable resource potential for base and precious metals.

The study area includes a westward extension of the Bighorn Basin. Within the basin there are Paleozoic, Mesozoic, and lowest Tertiary sedimentary strata. The study area is overlapped by gently dipping to flat volcaniclastic rocks of the Absaroka Range. The trends of anticlines and synclines in the western part of the Bighorn Basin and the distribution of oil seeps suggest that Mesozoic and older sedimentary rocks extend northwestward into Yellowstone National Park beneath the cover of volcanic rocks. Twenty-one oil fields located on anticlines involving Mesozoic strata are present in the Bighorn Basin within $15 \mathrm{mi}$ of the east margin of the study area and several anticlines project into it. Seven dry holes were drilled within $2 \mathrm{mi}$ of the boundary of the study area. These, and data from the adjacent oil fields indicate that the thickness of sedimentary rocks inferred to underlie volcaniclastic cover in the study area is from 7600 to $10,000 \mathrm{ft}$. Resources of oil and gas may well exist in these buried sedimentry strata, except for those areas too close to the igneous centers and intrusives, but data delineating favorable structures is not available, and areas with resource potential cannot be distinguished from unfavorable areas. A probable oil and gas resource potential exists for that part of the Younts Basin (L) that extends into the southwest part of the study area.

\section{SUGGESTIONS FOR FURTHER STUDIES}

Further work is needed to define the areas with oil and gas potential in the study area. Seismic-reflection surveys are needed to define areas of favorable structure below the volcaniclastic rocks. The surveys might help determine the western margin of the Bighorn Basin, and would provide information on the existence and configuration of the postulated Younts Basin. Subsurface exploration is needed to evaluate the resource potential more completely of most of the mineralized areas, and to determine the resource potential of several areas where geologic evidence and geochemical or geophysical anomalies suggest the proximity of buried plutons that may be associated with concealed mineralized systems.

\section{REFERENGE}

Antweiler, J. C., Rankin, D. W., Fisher, F. S., Long, C. W., Love, J. D., Bieniewski, C. L., and Smith, C. S., 1983, Mineral resource potential of the northern part of the Washakie Wilderness and nearby roadless areas, Park County, Wyoming: U.S. Geological Survey Miscellaneous Field Studies Map MF-1597-A, scale 1:125,000. 


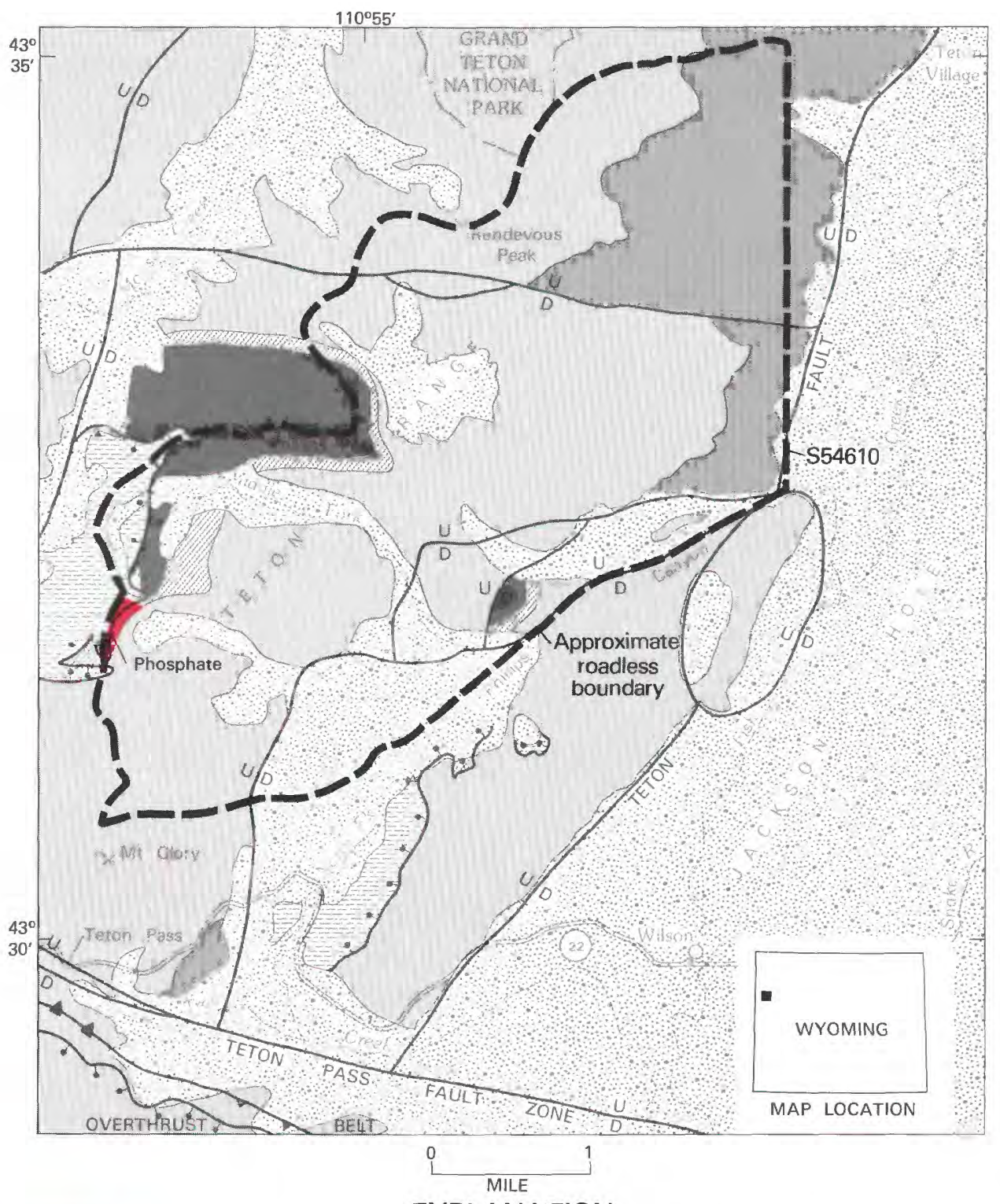

\section{EXPLANATION}

Geologic terrane with substantiated phosphate resource potential

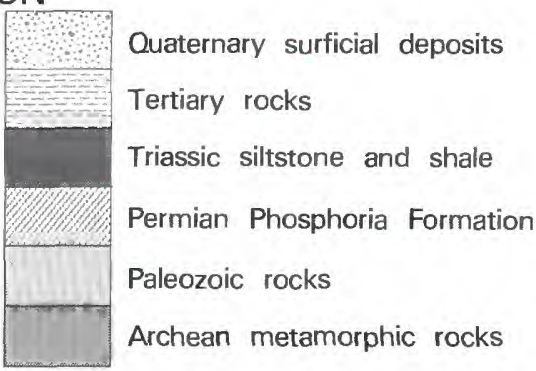
inverted symbols show Tertiary overturning

Figure 335.-West Slope Tetons Roadless Area, Wyoming. 


\title{
WEST SLOPE TETONS ROADLESS AREA, WYOMING
}

\author{
By W. BRADley Myers, U.S. GeOlOGiCAl SuRVEY, and \\ STEVEN E. KLUENDER, U.S. BUREAU OF Mines
}

\begin{abstract}
SUMMARY
On the basis of geologic, geochemical, and mines and prospects surveys in 1980-82 the West Slope Tetons Roadless Area, Wyoming, offers little or no promise for the occurrence of metallic mineral resources. A block estimated to contain about 2.5 million short tons of high-grade phosphate rock, lies along the western boundary; about 430,000 tons of this resource lie in an area of substantiated phosphate potential within the roadless area. Although adjacent to the Overthrust Belt, reassessment of the structural setting suggests that the roadless area has little promise for the occurrence of oil and gas resources.
\end{abstract}

\section{CHARACTER AND SETTING}

The West Slope Tetons Roadless Area comprises about $13 \mathrm{sq} \mathrm{mi}$ along the western boundary of the Teton National Forest, Teton County, Wyoming, north of Wyoming State Highway 22 across Teton Pass.

Despite the name, the roadless area is entirely on the eastern slope of the Teton Range draining into Jackson Hole and the Snake River. Centered about $14 \mathrm{mi}$ south of the Grand Teton, the roadless area is only moderately rugged. The maximum relief of more than $4500 \mathrm{ft}$ ranges from the floor of Jackson Hole to the crest of Rendezvous Peak at 10,927 ft above sea level. Northeast of the peak along the drainage divide the roadless area has a $0.4 \mathrm{mi}$ common boundary with the southern limit of the Grand Teton National Park.

Pack trails extend up Coal Creek from the west slope of the Teton Pass highway, across Coal Creek Pass to Phillips Pass, and hence back to the highway at the North Fork of Trail Creek. The Teton Crest Trail extends north from Phillips Pass and the Phillips Canyon Trail eastward from the pass to the floor of Jackson Hole.

Higher reaches of the roadless area have been lightly sculpted by Pinedale alpine glaciation; nearly formless vestiges of older glacial deposits occur on some lower slopes. Roughly half of the area is timbered at lower altitudes; few timber patches are found above $10,000 \mathrm{ft}$.

The West Slope Tetons Roadless Area lies completely within the Teton Range block of the Wyoming craton. Geologically young westward tilting of this coherent fault block has formed the precipitous eastern face of the Tetons, exposing the massive crystalline Precambrian basement. More than $4800 \mathrm{ft}$ of Paleozoic and lower Mesozoic shelf sediments are exposed above a basal Cambrian unconformity. Three Tertiary formations, a nonmarine conglomerate and two volcanic units, a sequence about $800 \mathrm{ft}$ thick, lie with mild discordance across the truncated upper portion of the preTertiary sedimentary succession. The Tertiary units, each somewhat discordant, are believed to be exotic glide sheets, rather than successive depositional units, each laid down on an erosional surface.

The recently uplifted Teton Range block is separated by a major steep fault (Teton fault) from the downdropped Jackson Hole terrane to the east and is also bounded on the southwest by the Teton Pass fault zone which separates it from the Overthrust Belt. The Teton block and the allied Gros Ventre Range were uplifted along the Teton Pass fault zone revealing the passive floor beneath the transported thrust sheets of the Overthrust Belt. The Teton Pass fault zone is crudely paralleled by lesser faults of like displacement within the region around the roadless area. Their effect is to diminish the structural relief of the southeastern corner of the block, and thus its altitude, in relation to the culmination of the range at the Grand Teton.

Mineral-resource investigations in and near the roadless area have been principally directed to the bedded phosphate of the Phosphoria Formation. These regionally distributed deposits of Permian age have been studied within the West Slope Tetons Roadless Area by Schroeder (1972); to the west by Pampeyan and others (1967); and to the south by Schroeder (1969). Gere and 
others (1966) report on a regional investigation of the Phosphoria in both the roadless area and in nearby portions of Idaho and Wyoming. The geology of the easternmost part of the roadless area and of the adjacent portions of Jackson Hole was mapped by Love and Reed (1975).

A geologic and geochemical investigation and a survey of prospects have been conducted to evaluate the mineral-resource potential of the roadless area (Myers and Kluender, in press). The USBM investigation was centered on the assessment of phosphate rock prospects. The USGS conducted a geochemical survey of the roadless area and adjacent localities. Field checking and additional geologic mapping was done to better delineate Tertiary rock units and their structural relationships.

\section{MINERAL RESOURCES}

Phosphate deposits occur in the Permian Phosphoria Formation within the roadless area. Gere and others (1966, p. 38-41) dug and sampled two trenches $0.48 \mathrm{mi}$ apart in the Phosphoria Formation on the high, watershed ridge forming the west boundary of the roadless area north of Mount Glory. The southern trench intersected $9.35 \mathrm{ft}$ of phosphate rock averaging 31.74 percent $\mathrm{P}_{2} \mathrm{O}_{5}$. This uncommon thickness of high-grade rock dwindled to about $1.5 \mathrm{ft}$ in the northern trench but details of thinning are unknown as the phosphatic interval is covered between trenched exposures. The structural environment of the southern trench and the complex succession of the phosphate layers suggest that the thick accumulation may be due to duplication by unrecognized faulting. If the thick exposure is unfaulted a total of 2.5 million short tons of 31 or more percent $\mathrm{P}_{2} \mathrm{O}_{5}$ phosphate rock may reasonably be estimated. However, most of this block is in the Targee National Forest; only about 430,000 tons is estimated to lie within the roadless area in a small area of substantiated phosphate resource potential.

No evidence was found of metallic minerals, hydrothermal alteration, or metallic mineral prospecting within the roadless area; no claims have been loated within or near the area. However, to further check the mineral potential the USGS conducted a geochemical survey of the West Slope Tetons Roadless Area. This reconnaissance survey involved the collection, analysis, and interpretation of analytical results of a geochemical sampling study at a density of about 5 samples per square mile. Two samples contained a distinctive suite of five metallic elements at anomalous concentrations. These samples, located downstream from mapped expo- sures of the Phosphoria Formation, which contains subeconomic amounts of numerous metals (U.S. Geological Survey, 1977), doubtless received their trace-metal suite from that source.

The results of the mineral survey indicate that the roadless area has little promise for the occurrence of base-metal resources.

The exposed section of sedimentary rocks in the roadless area has little promise for the occurrence of oil and gas resources. Deep erosion and unfavorable geometry of the known faults make the promise of hydrocarbon accumulation in the sediments above the metamorphic basement highly unlikely. This study also indicates that the presence of sedimentary rocks beneath the metamorphic basement is unlikely in the roadless area.

\section{SUGGESTIONS FOR FURTHER STUDIES}

The most significant resource potential of the West Slope Tetons Roadless Area may be oil and gas beneath the metamorphic basement, although such possibility is discounted in this survey. Helicopter-supported seismic-reflection surveys would likely determine whether potentially petroliferous sediments and structures underlie the Precambrian metamorphic rocks of the roadless area.

\section{REFERENCES}

Gere, W. C., Schell, E. M., and Moore, K. P., 1966, Stratigraphic sections and phosphate analyses of Permian rocks in the Teton Range and parts of the Snake River and Gros Ventre Ranges, Idaho and Wyoming: U.S. Geological Survey Open-file report, $71 \mathrm{p}$.

Love, J. D., and Reed, J. C., Jr., 1975, Geologic map of the Teton Village quadrangle, Teton County, Wyoming: U.S. Geological Survey Open-File Report 75-335, scale 1:24,000.

Myers, W. B., and Kluender, S. E., in press, Mineral resource potential map of West Slope Tetons Roadless Area, Teton County, Wyoming: U.S. Geological Survey Miscellaneous Field Studies Map MF-1654-A, scale 1:24,000.

Pampeyan, E. H., Schroeder, M. L., Schell, E. M., and Cressman, E. R., 1967, Geologic map of the Driggs quadrangle, Bonneville and Teton Counties, Idaho, and Teton County, Wyoming: U.S. Geological Survey Mineral Investigation Field Studies Map MF-300, scale 1:31,680.

Schroeder, M. L., 1969, Geologic map of the Teton Pass quadrangle, Teton County, Wyoming: U.S. Geological Survey Geologic Quadrangle Map GQ-793, scale 1:24,000.

1972 , Geologic map of the Rendezvous Peak quadrangle, Teton County, Wyouning: U.S. Geological Survey Geologic Quadrangle Map GQ-980, scale 1:24,000.

U.S. Geological Survey, 1977, Development of phosphate resources in southeastern Idaho: U.S. Geological Survey Final Impact Statement Report 77-37, volume 1. 

Volume 1 Pages 1-551 Volume 2 Pages 552-1179

\section{INDEX}

Absaroka Primitive Area and vicinity, Montana . . . . . . 659

Adams Gap Roadless Area, Alabama . . . . . . . . . . . . . . . $\quad 15$

Agnew Roadless Area, California . . . . . . . . . . . . . . 273

Agua Tibia Primitive Area, California . . . . . . . . . . . 165

Allegheny Front Roadless Area, Pennsylvania . . . . . . . . . . . . 923

Alpine Lakes Wilderness study area, Washington . . . . . . . . 1041

Anaconda-Pintlar Wilderness, Montana . . . . . . . . . . . . 661

Andrews Mountain Roadless Area, California . . . . . . . . . 167

Antimony Roadless Area, California . . . . . . . . . . . . . . 363

Arnold Mesa Roadless Area, Arizona . . . . . . . . . . . . . . . $\quad 49$

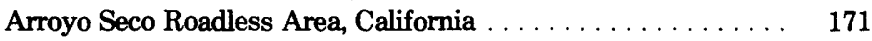

Bald Rock Roadless Area, California . . . . . . . . . . . . . . . 175

Bear Canyon Roadless Area, California . . . . . . . . . . 405

Bear Mountain Roadless Area, California . . . . . . . . . . . . . 405

Beartooth Primitive Area and vicinity, Montana and Wyoming

Beaver Creek Wilderness, Kentucky

Bell Mountain Wilderness Study Area, Missouri . . . . . . . . .

Bell Star East and West Roadless Areas, Arkansas

Belle Starr Cave Wilderness Study Area, Arkansas . . . . . . . . .

Benton Range Roadless Area, California ...............

Big Butte-Shinbone Roadless Area, California . . . . . . . . . . . .

Big Frog Wilderness Study Area and Additions, Tennessee and Georgia

Big Rocks Roadless Area, California .

Big Sandy Roadless Area, Alabama

Big Snowies Wilderness Study Area and contiguous roadless areas, Montana ........................

Birch Creek Roadless Areas, California and Nevada . . . . . . . . .

Birdseye Roadless Area, Utah . . . . . . . . . . . . . . . . . .

Black Butte Roadless Area, California . . . . . . . . . . . .

Black Butte Roadless Area, California . . . . . . . . . . . . . .

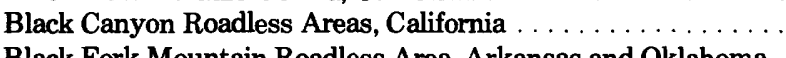

Black Fork Mountain Roadless Area, Arkansas and Oklahoma

Black Mountain Roadless Area, California . . . . . . . . . .

Black Range Primitive Area, New Mexico . . .

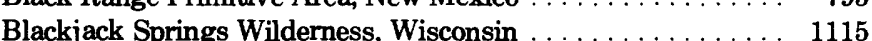

Blanco Mountain Roadless Area, California . . . . . . . . . 185

Blood Mountain Roadless Area, Georgia . . . . . . . . . . . 533

Blue Joint Roadless Area, Idaho . . . . . . . . . . . . . . . 673

Blue Joint Wilderness Study Area, Montana . . . . . . . . . . . 673

Blue Range Wilderness, Arizona and New Mexico . . . . . . . . 53

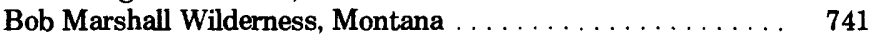

Boulder-Pioneer Wilderness study area, Idaho . . . . . . . . . 555

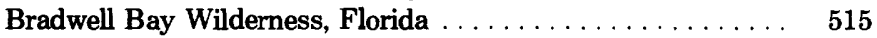

Bread Loaf Roadless Area, Vermont . . . . . . . . . . . . . . . 1001

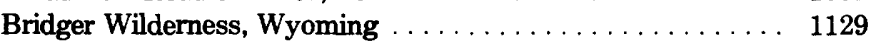

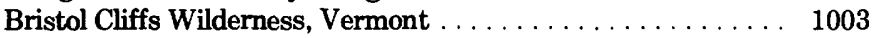

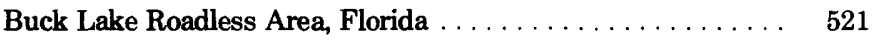

Bucks Lake Roadless Area, California . . . . . . . . . . . . . 189

Buffalo Addition Roadless Area, Arkansas . . . . . . . . . . . 159

Buffalo Peaks Wilderness Study Area, Colorado . . . . . . . . . 425

Bunk Robinson Peak Roadless Area, New Mexico and Arizona . $\quad 799$

Burden Falls Roadless Area, Illinois ................ 605

Butt Mountain Roadless Area, California . . . . . . . . . . . 263

Buttermilk Roadless Area, California . . . . . . . . . . . . . . . . 193

Caballo Roadless Area, New Mexico . . . . . . . . . . . . . . . . 801

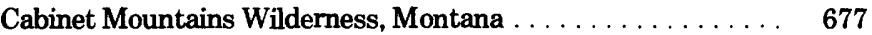

Cactus Spring Roadless Area, California $\ldots \ldots \ldots \ldots \ldots \ldots \ldots \quad 195$

Caliente Roadless Area, California . . . . . . . . . . . . . . . 371

Caney Creek Wilderness, Arkansas . . . . . . . . . . . . 145

Cannibal Plateau Roadless Area, Colorado . . . . . . . . . . . 427

Caribou Wilderness, California . . . . . . . . . . . . . . . . . 199

Carson-Iceberg Roadless Areas, California . . . . . . . . . . 203

Castle Crags Roadless Area, California . . . . . . . . . . . . . . 303

Centennial Mountains Wilderness study area, Montana and Idaho

Chama River Canyon Wilderness and contiguous roadless area, New Mexico .......................

Chama-Southern San Juan Mountains Wilderness study area, Colorado . . . . . . . . . . . . . . . . . . . . .

Chambers Ferry Roadless Area, Texas . . . . . . . . . . . .

Chanchelulla Roadless Area, California . . . . . . . . . . . . .

Charles M. Russell Wildlife Refuge, Montana ...........

Charles Sheldon Antelope Range, Nevada and Oregon . . . . . . .

Chattahoochee Roadless Area, Georgia . . . . . . . . . . . 535

Cheat Mountain Roadless Area, West Virginia . . . . . . . . . 1099

Chips Creek Roadless Area, California . . . . . . . . . . . . . . 189

Chiricahua Wilderness, Arizona . . . . . . . . . . . . . 55

Chugach National Forest, Alaska . . . . . . . . . . . . . $\quad 29$

Citico Creek Wilderness Study Area, Tennessee . . . . . . . . . 947

Clarion River Roadless Area, Pennsylvania . . . . . . . . . . 927

Clear Lake Roadless Area, Florida . . . . . . . . . . . . . . . . . . 517

Cloud Peak Contiguous Roadless Area, Wyoming . . . . . . 1135

Cloud Peak Primitive Area and adjacent areas, Wyoming . . . . 1133

Cohutta Wilderness, Georgia and Tennessee . . . . . . . . . 539

Columbine-Hondo Wilderness study area, New Mexico . . . . . . 807

Comanche-Big South wilderness study area, Colorado . . . . . . 433

Condrey Mountain Roadless Area, California . . . . . . . . . . 209

Cornplanter Roadless Area, Pennsylvania . . . . . . . . . . . 931

Cougar Lakes-Mount Aix Wilderness study area, Washington . 1045

Coyote Southeast Roadless Area, California . . . . . . . . . . 211

Craggy Mountain Wilderness study area and Extension, North Carolina ........................... 843

Cranberry Wilderness Study Area, West Virginia . . . . . . . . 1101

Cucamonga Roadless Areas, California . . . . . . . . . . . 215

Cucamonga Wilderness and Additions, California . . . . . . . 367

Cuyama Roadless Area, California . . . . . . . . . . . . . . 363

Cypress Roadless Area, California . . . . . . . . . . . . . . 217

Dardanelles Roadless Areas, California . . . . . . . . . . . . 249

Dennison Peak Roadless Area, California . . . . . . . . . . . . . 301

Deschutes Canyon Roadless Area, Oregon . . . . . . . . . . . 863

Desolation Valley Wilderness, California . . . . . . . . . 221

Devil Canyon-Bear Canyon Primitive Area, California . . . . . . 225

Devils Den Roadless Area, Vermont . . . . . . . . . . . . . . . . . . 1007

Devils Fork Roadless Area, Virginia . . . . . . . . . . . . . 1015

Diablo Roadless Area, California . . . . . . . . . . . . . . . . . . . 363

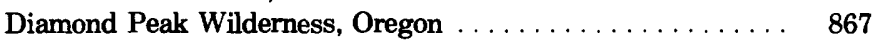

Dinkey Lakes Roadless Area, California . . . . . . . . . . . . . . . . 227

Dolly Ann Roadless Area, Virginia . . . . . . . . . . . . . . . . 1017

Dolly Sods Wilderness, West Virginia . . . . . . . . . . . . 1106

Dolus Lakes Roadless Area, Montana . . . . . . . . . . . . . . . . 687

Domeland Addition Roadless Area, California . . . . . . . . . . 231

Domeland Wilderness, California . . . . . . . . . . . . . . 231

Dragoon Mountains Roadless Area, Arizona . . . . . . . . . . . $\quad 59$

Dry Creek Wilderness Study Area, Arkansas . . . . . . . . . . 149 
Dry Lakes Roadless Area, California . . . . . . . . . . . . 363

Du Noir Addition to Washakie Wilderness, Wyoming . . . . . . 1169

Eagle Cap Wilderness and adjacent areas, Oregon . . . . . . . . 869

Eagle Rock Roadless Area, Washington . . . . . . . . . . . 1047

Eagles Nest Wilderness, Colorado . . . . . . . . . . . . . . $\quad 437$

East Fork Roadless Area, California . . . . . . . . . . . . . . $\quad 419$

East Palisades Roadless Area, Idaho and Wyoming . . . . . 595

East Yuba Roadless Area, California ............... 237

East part of the Raymond Peak Roadless Area, California . . . . . 235

Eastern Pioneer Mountains, Montana . . . . . . . . . . . . . . . 691

Elk Creek Roadless Area, California . . . . . . . . . . . . . . . . 181

Elkhorn Wilderness Study Area, Montana ... . . . . . . . 695

Ellicott Rock Wilderness and Additions, South Carolina,

North Carolina, and Georgia

Emigrant Basin Wilderness, California $\ldots \ldots \ldots \ldots \ldots \ldots, 937$

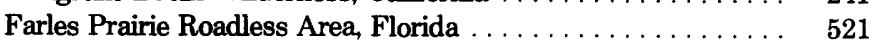

Fisher Gulch Roadless Area, California . . . . . . . . . . 245

Flat Tops Primitive Area, Colorado . . . . . . . . . . . 439

Flint Creek Range Wilderness study area, Montana . . . . . . . . 697

Flint Mill Roadless Area, Tennessee . . . . . . . . . . . . . . . . 951

Flynn Lake Wilderness Study Area, Wisconsin . . . . . . . . 1117

Fossil Ridge Wilderness Study Area, Colorado . . . . . . . . 443

Fossil Springs Roadless Area, Arizona . . . . . . . . . . . . 63

Four Notch Roadless Area, Texas . . . . . . . . . . . . . 971

Fox Mountain Roadless Area, California . . . . . . . . . . . . . 293

Freel Roadless Area, California . . . . . . . . . . . . . . . . . . 249

Galiuro Wilderness and contiguous roadless areas, Arizona ... . 65

Gallatin Divide Roadless Area, Montana . . . . . . . . . . . 701

Garcia Mountain Roadless Area, California . . . . . . . . . . 357

Gates of the Mountains Wilderness and additions, Montana . . . 705

Gearhart Mountain Wilderness and contiguous roadless area,

Oregon

Gee Creek Wilderness, Tennessee $\ldots \ldots \ldots \ldots \ldots \ldots$

Gila Wilderness, New Mexico . . . . . . . . . . . . . . . 811

Glacier Bay National Monument Wilderness study area, Alaska

Glacier Peak Roadless Area, Washington

Glacier Peak Wilderness study area, Washington . . . . . . . . .

Glacier Primitive Area, Wyoming .

Glacier View Roadless Area, Washington . . . . . . . . . . . . . 1059

Goat Rocks Wilderness and adjacent roadless areas, Washington

Golden Trout Wilderness, California . . . . . . . . . . .

Graham Creek Roadless Area Texas . ...................... 975

Granite Chief Wilderness study area, California . . . . . . . . $\quad 255$

Granite Fiords Wilderness study area, Alaska . . . . . . . . 35

Granite Peak Roadless Area, California . . . . . . . . . . . . . . $\quad 259$

Great Bear Wilderness, Montana . . . . . . . . . . . . . . 741

Green-Sweetwater Roadless Area, Wyoming . . . . . . . . . . 1129

Greenhorn Mountain Wilderness Study Area, Colorado . . . . . . 447

Gros Ventre Wilderness study area, Wyoming . . . . . . . . . 1141

Guadalupe Escarpment Wilderness Study Area, New Mexico . . 815

Hall Natural Area Roadless Area, California . . . . . . . . . . . 393

Harper Creek Roadless Area, North Carolina . . . . . . . . . . 851

Hauser Roadless Area, California . . . . . . . . . . . . . . . . 371

Heart Lake Roadless Area, California . . . . . . . . . . . . . . . 44

Hell Hole Bay Wilderness, South Carolina . . . . . . . . . . . . . 939

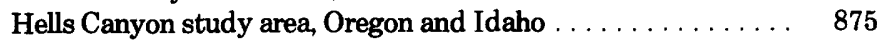

Hells Gate Roadless Area, Arizona . . . . . . . . . . . . . . . . . $\quad 69$

Hells Hole Roadless Area, Arizona and New Mexico . . . . . . . 73

Hemp Top Roadless Area, Georgia . . . . . . . . . . . . . . . . $\quad \mathbf{5 3 9}$

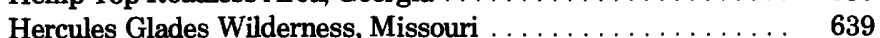

Hickory Creek Roadless Area, Pennsylvania . . . . . . . . . . 923

High Sierra Primitive Area, California $\ldots \ldots \ldots \ldots \ldots \ldots \ldots .261$

High Uintas Primitive Area, Utah $\ldots \ldots \ldots \ldots \ldots \ldots \ldots .983$
Highland Ridge Roadless Area, Nevada . . . . . . . . . . . . 769

Homestead Roadless Area, Oregon . . . . . . . . . . . . . . . $\quad 879$

Hoover Wilderness, California . . . . . . . . . . . . . 241

Horse Meadows Roadless Area, California . . . . . . . . . . 393

Horseshoe Springs Roadless Area, California . . . . . . . . . . 293

Hunter-Fryingpan Wilderness, Colorado . . . . . . . . . . 451

Huston Park Roadless Area, Wyoming . . . . . . . . . . . . . 1145

Idaho Wilderness, Idaho . . . . . . . . . . . . . . . . $\quad 559$

Indian Heaven Roadless Area, Washington . . . . . . . . . 1067

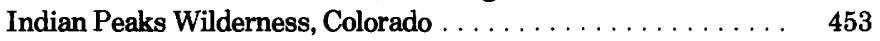

Irish Wilderness Roadless Area, Missouri . . . . . . . . . . . . . 643

Ishi Roadless Area, California . . . . . . . . . . . . . . 263

Italian Peak Middle Roadless Area, Idaho and Montana . . . . . 563

Italian Peak Roadless Area, Idaho . . . . . . . . . . . . . . 563

Jack Creek basin, Montana . . . . . . . . . . . . . . . $\quad 709$

James River Face Wilderness, Virginia . . . . . . . . . . . . . . . 1021

Jarbidge Wilderness, Nevada . . . . . . . . . . . . . . . 771

John Muir Wilderness, California . . . . . . . . . . . . 267

Joyce Kilmer-Slickrock Wilderness, North Carolina and Tennessee

Kaiser Wilderness, California ........................... 271

Kalmiopsis Wilderness, Oregon . . . . . . . . . . . . 883

Kanab Creek Roadless Area, Arizona . . . . . . . . . . . . . . . $\quad 77$

Kings River Roadless Area, California . . . . . . . . . . . . . . . . . 273

Kisatchie Hills Wilderness, Louisiana . . . . . . . . . . . . 621

La Brea Roadless Area, California . . . . . . . . . . . . . . . . 293

La Garita Wilderness, Colorado . . . . . . . . . . . . . . . . 455

La Panza Roadless Area, California . . . . . . . . . . . . . . 357

Lake Eleanor Roadless Area, California . . . . . . . . . . . . . . $\quad 279$

Lake Fork Roadless Area, Oregon . . . . . . . . . . . $\quad 879$

Laramie Peak Wilderness study area, Wyoming . . . . . . . . . 1149

Laurel-McGee Roadless Area, California . . . . . . . . . . . . 281

Lick Creek Roadless Area, Oregon . . . . . . . . . . . . . . . . . . 879

Lincoln Creek Roadless Area, Nevada . . . . . . . . . . . . . . . 775

Linville Gorge Wilderness and Additions, North Carolina . . . . 849

Little Blakely Roadless Area, Arkansas . . . . . . . . . . . . 151

Little Dog and Pup Canyons Roadless Area, New Mexico ... . . 817

Little Frog Roadless Area, Tennessee . . . . . . . . . . . . . . . . . . 957

Little Goose Roadless Area, Wyoming . . . . . . . . . . . . . . . 1135

Little Pine Roadless Area, California . . . . . . . . . . . . . 293

Little Wambaw Swamp Wilderness, South Carolina . . . . . . . . 939

Log Cabin-Saddlebag Roadless Area, California . . . . . . . . . 393

Lone Peak Wilderness study area, Utah . . . . . . . . . . . . 987

Long Swamp Roadless Area, Washington . . . . . . . . . . . . 1069

Los Machos Hills Roadless Area, California . . . . . . . . . 357

Lost Cove Roadless Area, North Carolina . . . . . . . . . . . . . . 8851

Lost Creek Roadless Area, California . . . . . . . . . . . . 283

Lower San Francisco Wilderness study area and contiguous roadless areas, Arizona and New Mexico . . . . . . . . . . $\quad 79$

Lusk Creek Roadless Area, Illinois . . . . . . . . . . . . . . 607

Lye Brook Wilderness, Vermont . . . . . . . . . . . . . . . . . . . 1009

Machesna Mountain Roadless Area, California . . . . . . . . . 357

Madison Roadless Area, Montana . . . . . . . . . . . . . . . . . . 713

Manzano Wilderness, New Mexico . . . . . . . . . . . . . . . . 821

Marble Mountain Wilderness, California . . . . . . . . . . 287

Maroon Bells-Snowmass Wilderness and additions, Colorado . . 459

Matilija Roadless Area, California . . . . . . . . . . . . .. 363

Mazatzal Wilderness and contiguous roadless areas, Arizona . . 83

Mazourka Roadless Area, California . . . . . . . . . . . . . . . 167

Middle Fork Feather River Roadless Area, California . . . . . . 175

Middle Fork of the Judith River Wilderness Study Area, Montana

$\begin{array}{ll}\text { Middle Mountain-Tobacco Root Roadless Area, Montana . . . . . } & 721\end{array}$

Mill Creek Roadless Area, California . . . . . . . . . . . . . . . 263

Mill Creek Wilderness Study Area, Virginia . . . . . . . . . . . 1023 
Minarets Wilderness and adjacent areas, California

Miranda Pine Roadless Area, California . . . . . . . . . . . . . .

Mission Mountains Wilderness, Montana

Mokelumne Wilderness and adjacent roadless areas, Califor-

nia

Moses Roadless Area Califormia

Mount Adams and contiguous roadless areas, Washington .....

Mount Baldy Wilderness, Arizona . . . . . . . . . . . . . $\quad 89$

Mount Eddy Roadless Area, California . . . . . . . . . . . . 303

Mount Henry Roadless Area, Montana . . . . . . . . . . . . . 727

Mount Hood Wilderness and adjacent areas, Oregon . . . . . . . 885

Mount Jefferson Primitive Area, Oregon . . . . . . . . . . . 889

Mount Moriah Roadless Area, Nevada . . . . . . . . . . . . . . . 777

Mount Naomi Roadless Area, Utah and Idaho . . . . . . . . . . . 989

Mount Raymond Roadless Area, California . . . . . . . . . . . 307

Mount Shasta Wilderness study area, California . . . . . . . . . . 309

Mount Washington Wilderness, Oregon . . . . . . . . . . . . . . 8

Mount Zirkel Wilderness and vicinity, Colorado . . . . . . 463

Mountain Lake Wilderness Study Area, Virginia and West Virginia

Mountain Lakes Wilderness, Oregon

Murphy Glade Roadless Area, California $\ldots \ldots \ldots \ldots \ldots \ldots \ldots$

Natural Area Roadless Area, Florida

Neota-Flat Top wilderness study area, Colorado

Nephi Roadless Area, Utah

Never Summer wilderness study area, Colorado

North Absaroka Wilderness, Wyoming .

North Absaroka study area, Montana .

North Cascades National Park (northern part), Washington . . . 1077

North End Roadless Area, Arizona . . . . . . . . . . . . . . . . 91

North Fork John Day River Roadless Area, Oregon

North Fork Smith River Roadless Area, California and Oregon

North Fork of the American River Wilderness study area, California

Oat Mountain Roadless Area, California

Oh-Be-Joyful Wilderness Study Area, Colorado . . . . . . . . .

Olallie Roadless Area, Oregon . . . . . . . . . . . . . . .

Orleans Mountain Roadless Area (B5079), California . . . . . . . .

Orleans Mountain Roadless Area (C5079, B5079), California . .

Otter Creek Wilderness, West Virginia

Overflow Roadless Area, Georgia and North Carolina . . . . . . . .

Paddy Creek Wilderness Study Area, Missouri . . . . . . . . .

Paiute Roadless Area, California . . . . . . . . . . . . . .

Pasayten Wilderness, Washington . . . . . . . . . . . 1079

Pecos Wilderness, New Mexico . . . . . . . . . . . . . . . . . . 823

Peters Mountain Wilderness Study Area, Virginia . . . . . . . . 1029

Piedra Wilderness Study Area, Colorado . . . . . . . . . . . 469

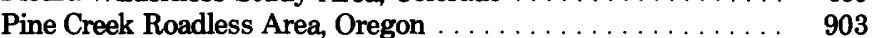

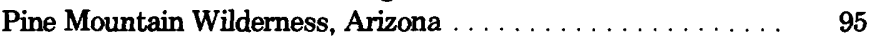

Piney Creek Roadless Area, Wyoming . . . . . . . . . . . . . 1135

Piney Creek Wilderness, Missouri . . . . . . . . . . . . . $\quad 649$

Pleasant View Roadless Area, California . . . . . . . . . . . . . 327

Polk Springs Roadless Area, California . . . . . . . . . . . . . . . 263

Polvadera Roadless Area, New Mexico . . . . . . . . . . . . . . . . 801

Pond Mountain Addition Roadless Area, Tennessee . . . . . . . 959

Pond Mountain Roadless Area, Tennessee . . . . . . . . . . 959

Popo Agie Primitive Area, Wyoming . . . . . . . . . . . . . . 1153

Porphyry Mountain Wilderness study area, Colorado . . . . . . $4 \mathbf{4 5 1}$

Powderhorn Wilderness study area, Colorado . . . . . . . . . . . 427

Pusch Ridge Wilderness, Arizona . . . . . . . . . . . . . . . . . $\quad 97$

Pyramid Roadless Area, California . . . . . . . . . . . . . 331

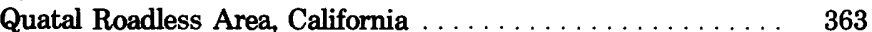

Rainbow Lake Wilderness, Wisconsin . . . . . . . . . . 1117

Ramseys Draft Wilderness Study Area, Virginia
Rancheria Roadless Area, California $\ldots \ldots \ldots \ldots \ldots \ldots \ldots \ldots, 273$

Rattlesnake Roadless Area, Arizona . . . . . . . . . . . . . . . . 101

Rattlesnake Roadless Area, Montana . . . . . . . . . . . . . $\quad 735$

Rawah Wilderness, Colorado . . . . . . . . . . . . . . . 473

Raywood Flat Roadless Areas, California . . . . . . . . . . 333

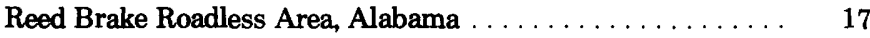

Rich Mountain Roadless Area, Georgia . . . . . . . . . . . . . $\mathbf{5 4 5}$

Richland Creek Roadless Area, Arkansas . . . . . . . . . . . . . 153

Richland Creek Wilderness Study Area, Arkansas . . . . . . . . 157

Rincon Wilderness Study Area, Arizona . . . . . . . . . . . . . . 103

Rock Creek Roadless Area, Wyoming . . . . . . . . . . . . 1135

Rock Pile Mountain Wilderness Study Area, Missouri . . . . . . . 653

Rock River Canyon Wilderness Study Area, Michigan . . . . . . 625

Round Lake Wilderness Study Area, Wisconsin . . . . . . . . . 1121

Rubicon Roadless Area, California $\ldots \ldots \ldots \ldots \ldots \ldots \ldots \ldots . .339$

Ryan Hill Roadless Area, New Mexico . . . . . . . . . . . . . . 827

Salmo-Priest Wilderness study area, Washington and Idaho . . . 1083

Salmon River Breaks Primitive Area and vicinity, Idaho . . . . . 567

Salmon-Trinity Alps Wilderness, California . . . . . . . . . $\quad 341$

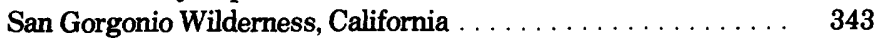

San Jacinto Wilderness, California . . . . . . . . . . . . . . . . 347

San Joaquin Roadless Area, California . . . . . . . . . . . . . . . $\quad 351$

San Pedro Parks Wilderness, New Mexico . . . . . . . . . . . . 831

San Rafael Primitive Area, California . . . . . . . . . . . . . . . . . 353

Sandia Mountain Wilderness, New Mexico . . . . . . . . . 833

Sandy Creek Roadless Area, Mississippi . . . . . . . . . . . . 631

Sangre de Cristo Wilderness Study Area, Colorado . . . . . . . . $\mathbf{4 7 5}$

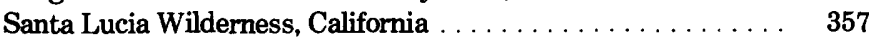

Santaquin Roadless Area, Utah . . . . . . . . . . . . . . . 981

Sapphire Wilderness Study Area and contiguous roadless

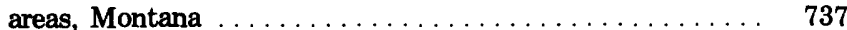

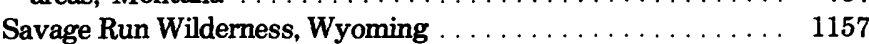

Savannah Roadless Area, Florida . . . . . . . . . . . . . . $\quad \mathbf{5 2 7}$

Sawmill-Badlands Roadless Area, California . . . . . . . . . . . 363

Sawtooth National Recreation Area, eastern part, Idaho . . . . . 569

Sawtooth Wilderness, Idaho . . . . . . . . . . . . . . . . . . . 573

Scapegoat Wilderness and additions, Montana . . . . . . . 741

Scodies Roadless Area, California . . . . . . . . . . . . . . . . 361

Scotchman Peak Wilderness study area, Montana and Idaho . . 745

Selkirk Roadless Area, Idaho . . . . . . . . . . . . . . $\quad 577$

Selway-Bitterroot Wilderness, Idaho and Montana . . . . . . . 581

Service Creek Roadless Area, Colorado . . . . . . . . . . . . . . . . 479

Sespe-Frazier Roadless Area, California . . . . . . . . . . . 363

Sheep Mountain Wilderness Study Area, California . . . . . . . . $\quad 367$

Sheep Mountain Wilderness study area, Wyoming . . . . . . 1159

Sheldon National Antelope Refuge, Nevada and Oregon . . . . . 765

Shinbone Creek Roadless Area, Alabama . . . . . . . . . . . . . 15

Shining Rock Wilderness, North Carolina . . . . . . . . . . . . $\quad 855$

Sierra Ancha Wilderness, Arizona . . . . . . . . . . . . . . . 107

Sill Hill Roadless Area, California . . . . . . . . . . . . . . . . . 371

Sipsey Wilderness and Additions, Alabama . . . . . . . . . . $\quad 21$

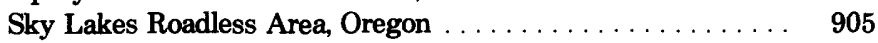

Snow Mountain Wilderness Study Area, California . . . . . . . 373

Snowbird Roadless Area, North Carolina . . . . . . . . . . . $\quad 857$

Snowy Range Wilderness, Wyoming . . . . . . . . . . . 1163

Sopchoppy River Wilderness study area, Florida . . . . . . . . 515

South Warner Wilderness, California . . . . . . . . . . . . 377

Southern Massanutten Roadless Area, Virginia . . . . . . . . . . 1035

Spanish Peaks Primitive Area, Montana ............ $\quad \mathbf{7 4 7}$

Spanish Peaks Wilderness Study Area, Colorado . . . . . . . . 483

Special Mining Management Zone-Clear Creek, Idaho . . . . . 583

Spoor Canyon Roadless Area, California . . . . . . . . . . . . 293

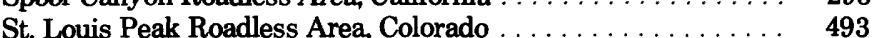

Stanley Mountain Roadless Area, California . . . . . . . . . 357

Stansbury Roadless Areas, Utah . . . . . . . . . . . . . . . . . . 993 
Stratified Primitive Area, Wyoming

Strawberry Crater Roadless Areas, Arizona

111

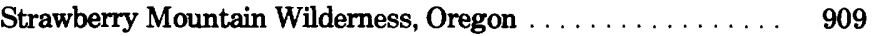

Sturgeon River Wilderness Study Area, Michigan . . . . . . . $\quad 627$

Sugarloaf Roadless Area, California . . . . . . . . . . . . . . 379

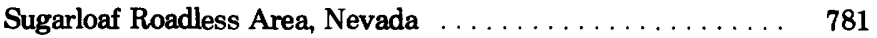

Superstition Wilderness, Arizona . . . . . . . . . . . . . . 113

Sweetwater Roadless Area, California and Nevada . . . . . . . . 383

Sycamore Canyon Primitive Area, Arizona . . . . . . . . . . . . 117

Table Mountain Roadless Area, California . . . . . . . . . . 211

Tatoosh Roadless Area, Washington . . . . . . . . . . . 1087

Ten Lakes Wilderness Study Area, Montana . . . . . . . . . . $\quad \mathbf{7 5 1}$

Ten Mile West Roadless Area, Idaho . . . . . . . . . . . . 587

Tepusquet Peak Roadless Area, California . . . . . . . . . . 293

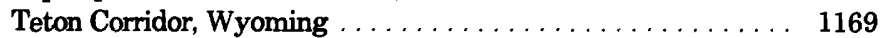

Teton Wilderness, Wyoming . . . . . . . . . . . . . . 1169

The Box-Death Hollow Roadless Area, Utah . . . . . . . . . . 997

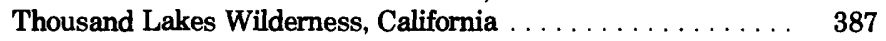

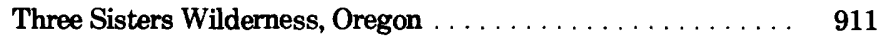

Timbered Crater Roadless Area, California . . . . . . . . . . 391

Tioga Lake Roadless Area, California . . . . . . . . . . . . 393

Tracy Arm-Fords Terror Wilderness study area and vicinity,

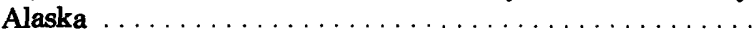

Trail Lake Roadless Area, California $\ldots \ldots \ldots \ldots \ldots \ldots \ldots$

Tray Mountain Roadless Area, Georgia . . . . . . . . . . . . . .

Troublesome Roadless Area, Kentucky . . . . . . . . . . . . .

Tuolumne River Roadless Area, California . . . . . . . . . . . . .

Unaka Mountain Roadless Area, Tennessee . . . . . . . . . . .

Uncompahgre Primitive Area, Colorado

Uncompahgre Primitive Area, contiguous study areas, Colorado

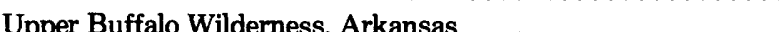

Upper Priest Roadless Area, Idaho . . . . . . . . . . . . . . .

Vasquez Peak Wilderness study area, Colorado . . . . . . . . . . .

Ventana Wilderness Additions, California . . . . . . . . . . . .

Ventana Wilderness, California . . . . . . . . . . . . . .

Wambaw Creek Wilderness, South Carolina . . . . . . . . . . . . .

Wambaw Swamp Wilderness, South Carolina . . . . . . . . . . .
Washakie Wilderness (northern part), Wyoming . . . . . . 1173

Weaver Bally Roadless Area, California . . . . . . . . . . . . . 407

Welcome Creek Wilderness, Montana . . . . . . . . . . . $\quad \mathbf{7 5 5}$

Weminuche Wilderness, Colorado . . . . . . . . . . . . . . 497

Wenaha Tucannon Wilderness, Washington and Oregon . . . . . 1089

West Clear Creek Roadless Area, Arizona . . . . . . . . . . . . . 121

West Elk Wilderness, Colorado . . . . . . . . . . . . . . . . 499

West Elliotts Creek Roadless Area, Alabama . . . . . . . . . . . . 17

West Needle Wilderness Study Area, Colorado ... . . . . . . . 503

West Palisades Roadless Area, Idaho and Wyoming . . . . . . . $\quad \mathbf{5 9 5}$

West Pioneer Wilderness Study Area, Montana . . . . . . . . . . 757

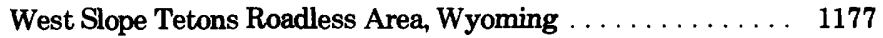

West Yuba Roadless Area, California . . . . . . . . . . . . . . 237

Western Chichagof and Yakobi Islands Wilderness study area,

Alaska .......................... 43

Wet Beaver Roadless Area, Arizona . . . . . . . . . . . . . . 123

Wheeler Peak Roadless Area, Nevada . . . . . . . . . . . . . . 783

Wheeler Peak Wilderness, New Mexico . . . . . . . . . . . . 807

Wheeler Ridge Roadless Area, California . . . . . . . . . . . . . 281

Wheeler Wilderness Study Area, Colorado . . . . . . . . . . . 507

Whetstone Roadless Area, Arizona . . . . . . . . . . . . 127

Whisker Lake Wilderness, Wisconsin . . . . . . . . . . . . . 1123

39 White Cloud-Boulder Roadless Area, Idaho . . . . . . . . . . . . 599

199 White Mountain National Forest, New Hampshire . . . . . . . 789

549 White Mountain Wilderness, New Mexico . . . . . . . . . . . . . 837

615 White Mountains Roadless Area, California and Nevada ..... 411

397 Whitmire Canyon Roadless Area, New Mexico and Arizona ... 799

963 Wild Cattle Mountain Roadless Area, California . . . . . . . . 415

485 Wild Rogue Wilderness, Oregon . . . . . . . . . . . . 915

Wilderness Contiguous Roadless Area, California . . . . . . . 419

489 Williams Fork Roadless Area, Colorado . . . . . . . . . . . . . 493

159 Wilson Mountains Wilderness, Colorado . . . . . . . . . . . 509

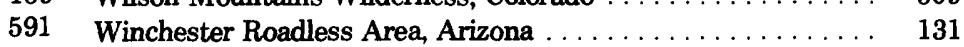

493 Windigo-Thielsen Roadless Area, Oregon . . . . . . . . . . 917

405 Wonder Mountain Roadless Area, Washington . . . . . . . . . . 1093

401 Woodpecker Roadless Area, California ................ 231

939 Yolla Bolly-Middle Eel Wilderness, California . . . . . . . . . . 419 
